\title{
ASPECTOS DE UMA TRADIÇÃO JURÍDICA ROMANO- PENINSULAR: \\ DELINEAMENTOS SOBRE A HISTÓRIA DO MANDATO NO \\ DIREITO LUSO-BRASILEIRO
}

Tese de Doutorado realizada sob a orientação do Professor

Titular IGNACIO MARIA POVEDA VELASCO,

do Departamento de Direito Civil - Área de História do Direito da Faculdade de Direito da Universidade de São Paulo. 
À coragem de Secundino Pousada; e à fé de Felice Lo Ré. 


\section{ÍNDICE}

Apresentação p. 5

Introdução .p. 12

\section{PARTE PRIMEIRA: \\ HistoRIOGRAFIA GERAL}

(Quatro aspectos peculiares da evolução do contrato de mandato e da representação negocial).

Capítulo I. "Procuratio", contrato de mandato e admissibilidade excepcional da representação direta pelo direito romano .p. 45

Capítulo II. O direito canônico e o desenvolvimento medieval da representação direta p. 87

Capítulo III. A atividade notarial e o robustecimento da representação direta no âmbito do direito comum .p. 97

Capítulo IV. O influxo iluminista e a "essencialização" da representação direta no contexto do contrato de mandato p. 104

\section{PARTE SEGUNDA: \\ HISTORIOGRAFIA LUSO-BRASILEIRA \\ (A evolução do contrato de mandato no direito luso-brasileiro).}

Capítulo V. O contrato de mandato (e sua relação com a representação negocial direta) consoante as fontes do direito visigótico p. 122

Capítulo VI. A primeira etapa do renascimento do direito romano (justinianeu) e o contrato de mandato segundo as fontes castelhanas .p. 145

Capítulo VII. Lineamentos sobre a eficácia da "procuração" segundo as fontes do direito lusitano p. 182

Capítulo VIII. A ascensão e o declínio do direito justinianeu no panorama das fontes jurídicas lusitanas: notas sobre a transição rumo a um mandato de contornos liberais p. 219

Capítulo IX. Uma historiografia interna exclusivamente portuguesa: instauração e reformulação de um contrato de "mandato" de contornos liberais .p. 257

Capítulo X. Historiografia exclusivamente brasileira: os contornos eficaciais do contrato de mandato anterior ao código civil de 2002 p. 296 


\section{PARTE TERCEIRA: \\ CONCLUSÃo.}

Capítulo final. Considerações conclusivas p. 403

Bibliografia .p. 410

Relação das fontes utilizadas p. 451

Anexo I - Tábua cronológica de diplomas legais (sistema diploma/data) p. 502

Anexo II - Tabela de correspondência $n^{\circ}$ I - Direito castelhano p. 503

Anexo III - Tabela de correspondência $\mathrm{n}^{\circ}$ II - Direito lusitano (períodos medieval e moderno) p. 510

Anexo IV - Tabela de correspondência n ${ }^{\circ}$ III - Direito português contemporâneo .....p. 524 Anexo V - Tabela de correspondência $\mathrm{n}^{\circ}$ IV - Direito brasileiro contemporâneo ........p. 531 Anexo VI - Documento: “Anteprojeto de Parte Geral do Código Civil” (1970) - de José Carlos Moreira Alves (extrato) .p. 551

Resumo .p. 554

Riassunto p. 555

Abstract p. 556 


\section{APRESENTAÇÃO.}

Esta apresentação corresponde ao elemento mais pessoal de todo este trabalho. Nela estão contidas algumas informações que podem contribuir para tornar mais claras ao leitor algumas obscuridades do texto que se segue; nela, igualmente, pode ser entrevista a ponta de um novelo que evidencia as próprias fraquezas estruturais deste estudo. No entanto, não nos pareceria adequado compartilhar com o leitor o resultado final, sem que se fizesse - preliminarmente - um breve apontamento sobre a trajetória da pesquisa que nele redundou.

Tudo se inicia com a admissão de nosso fracasso: buscávamos - ao início de nossos trabalhos - produzir um ensaio de natureza dogmática. À vista da linha de pesquisa adotada pelo autor, por seu orientador e pelo grupo a que orgulhosamente pertence, a investigação haveria de apresentar um "viés" histórico: o próprio tema abordado o propiciava, uma vez que nos manuais mais elementares se afirmava que em Roma, a despeito da existência do "mandatum”, não se admitia a representação direta. Tratava-se tão somente - de desenvolver tal assertiva, se possível coordenando-a com o direito contemporâneo; pois que, de início, o pesquisador pretendia abordar a distinção entre os institutos do "mandato" e da "representação" - para tanto lançando mão, sobretudo, das fontes contemporâneas brasileiras e alienígenas.

No entanto, a primeira pedra que surgiu em nosso caminho foi aquela sobre a qual erigimos todo o nosso trabalho: imagine-se que o cientista, pretendendo separar duas substâncias que integram uma mistura miscível, se convence da existência de uma terceira. Em lugar da destilação antes pretendida, sua atenção se volta, então, à descoberta acidentalmente realizada. Por mais que toda a comunidade científica conhecesse tal substância, aquela "novidade" - tão somente relativa - acabaria por tomar algumas noites de sono do referido pesquisador.

E foi exatamente isso o que aconteceu com este autor. Algumas pessoas "bolam" teses. Outras as "escrevem". Este investigador, no entanto, a "viveu" durante os últimos mil dias - e certamente durante as últimas mil noites.

Ao nos depararmos com o direito romano, buscávamos ali o fundamento histórico "elegante" - ou mesmo o argumento de autoridade - para uma dissociação entre o "contrato de mandato" e a "representação negocial". Ora, conhecedores - razoáveis - que éramos do direito contemporâneo, esperávamos encontrar o "mandatum"; e pretendíamos 
nos deparar com a ausência de uma eficácia representativa direta. Até aí, tudo andou conforme o planejado. No entanto, eis que - como fantasma - nos exsurgiu a "procuratio".

“Mas procuração não corresponde ao negócio jurídico unilateral de outorga de poderes representativos?". De fato, aquele instituto romano - por sua simples existência - acabou por tumultuar todo o projeto de pesquisa que tínhamos em mente.

Nossos estudos prosseguiram. Até o ponto em que não se podia mais procrastinar uma escolha metodológica fundamental. Usualmente, esta é uma opção que se faz de início, antes que se comecem as pesquisas mais acuradas; em nosso caso, assumiu uma feição francamente superveniente.

Em reunião com nosso "pai acadêmico", tínhamos duas opções fundamentais: ou se abria mão da investigação histórica; ou se punha de lado a parte dogmática do estudo. Com alegria dele recebemos a confirmação de que este segundo objeto poderia ser analisado em uma oportunidade futura.

De fato, os aspectos gerais da relação mantida entre os institutos da "procuração", do "mandato" e da "representação" já haviam sido analisados por inúmeros autores - inclusive em sua perspectiva histórica. No entanto, a gestação do mandato lusobrasileiro não havia merecido semelhante "devoção". Certamente, muitos investigadores mais preparados poderiam ter se voltado a este tema. No entanto, este autor não tem conhecimento de nenhum que tenha dedicado uma pesquisa de mais largo fôlego a uma investigação historiográfica sobre o tipo contratual objeto de nossas pesquisas.

O panorama com que nos deparamos era muito amplo. Graças a Deus não sabíamos quanto haveríamos de caminhar quando iniciamos nossa tarefa; pois se soubéssemos, acreditamos que nossa fraqueza de caráter haveria de preponderar sobre a missão a ser desenvolvida. De todo modo - por razões de ordem metodológica - buscamos nos concentrar em algumas premissas fundamentais. Exponhamo-las.

O cerne de nossa pesquisa haveria de corresponder a uma investigação lusobrasileira; assim, a historiografia geral deveria atender a um propósito bastante específico: evidenciar a relação mantida entre os institutos da "procuração", do "mandato" e da "representação" - pondo em relevo a "essencialização" moderna desta última na arquitetura do tipo contratual investigado.

Além disso, precisávamos eleger - escrupulosamente - as fontes do direito luso-brasileiro a serem pesquisadas. Assim, optamos pelo estudo das fontes primárias de nosso direito; em primeiro lugar porque, em tempos mais remotos, foram elas que - além 
dos costumes - chegaram inarredavelmente à prática quotidiana. Ademais, fomos impelidos a esta alternativa porque - pareceu-nos que - somente ela nos permitiria concatenar a tarefa "abrangente" a que nos havíamos comprometido.

Aliás, se por um lado nossos objetivos nos impeliam a uma abordagem das fontes primárias, de outra banda não nos pudemos desvencilhar de um compromisso metodológico fundamental: nossa investigação pretende contribuir à História do Direito. Assim, o direito romano abordado pelo romanista não é o mesmo que é estudado pelo historiador: aquele pretende ter acesso às fontes e àquilo que o direito romano "foi" em seu respectivo contexto histórico de produção; este, todavia, não pode se afastar de uma investigação que tenha em mira a maneira segundo a qual suas fontes foram transmitidas à posteridade.

Em termos práticos: dificilmente um romanista dedicado à investigação de um específico instituto lançaria mão, durante os seus trabalhos mais acurados, de manuais; ao contrário, pretenderia se debruçar - quase que exclusivamente - sobre monografias específicas. No entanto, ao historiador parece importante compreender a razão por que a obra de Ferdinand Mackeldey, por exemplo, destoa consideravelmente dos demais manuais de direito romano de sua época. Observação semelhante, aliás, deve ser feita quanto à utilização de obras contemporâneas por parte do jurista dogmático; da mesma forma, dele tivemos de nos distanciar - metodologicamente - em virtude dos estritos objetivos a que nos tínhamos proposto.

Por tais razões, considerações dogmáticas mais profundas - e o próprio estudo do direito comparado - somente poderiam ser realizadas "incidentalmente"; caso contrário, o desfecho de todo o trabalho poderia restar comprometido.

A fim de que pudéssemos cumprir nossos propósitos, elaboramos diversos quadros e tabelas, alguns dos quais se incorporam, nesta ocasião, sob a forma de anexos a este trabalho. $\mathrm{Na}$ verdade, os quadros comparativos se entrelaçam, intimamente, com outros dois assuntos: o método de exposição adotado e as notas de rodapé que instruem o texto principal.

Antes de iniciar a leitura do estudo, o leitor deve ter em mente uma premissa indispensável ao "seu" próprio êxito: toda a historiografia interna luso-brasileira - à exceção do "fragmentário" direito visigótico - foi fundada na "prévia" elaboração de tais quadros esquemáticos. Eles corresponderam ao principal instrumento de trabalho deste autor. Por isso, ocupam uma posição importantíssima em nossa investigação, pois 
correspondem, em verdade, à própria tese em uma versão "sintética". Coube-nos, tão somente, vertê-los, cuidadosamente, em um texto dissertativo.

Para tanto, lançamos mão de uma rigorosa estruturação da ordem expositiva. Podemos garantir ao leitor que nenhuma assertiva lançada no corpo do texto se repete noutra linha subseqüente. Aliás, também podemos assegurar que todas as afirmações contidas no texto contam com respaldo comprobatório em notas de rodapé.

Ciosos da boa metodologia de pesquisa, não pudemos, todavia, nos furtar a longas - e por vezes fatigantes - notas de rodapé: certamente o esforço do leitor em lê-las não é menor do que aquele despendido - pelo autor - em sua confecção. No entanto, os objetivos da obra não nos permitiam articulá-la - metodologicamente - noutra forma.

Observe-se que - excetuados esta "apresentação" e o capítulo derradeiro, dedicado às "considerações conclusivas" - todos os parágrafos do texto são numerados e acompanhados de uma breve epígrafe denunciadora de seu conteúdo. A numeração atende ao propósito de tornar mais fácil o acesso aos diversos conteúdos abordados. Já as epígrafes se voltam ao leitor que pretende efetuar uma segunda abordagem do estudo: delas lançando mão, será possível localizar qualquer assunto abordado no texto de maneira "relativamente" rápida. Além disso, da coordenação entre ambos - numeração e epígrafes - deflui uma linha expositiva que talvez não se tornasse perceptível ao leitor se não nos tivéssemos utilizado de tais expedientes.

Os quadros comparativos que integram este estudo - sob a forma de anexos - contêm referências a diversas fontes que guardam similitude quanto a alguns aspectos. Assim, quando desdobradas em nota de rodapé, transcreveu-se tão somente a mais antiga (dentro de cada um dos períodos analisados); as demais foram tão somente referidas quando não implicassem mudança significativa de orientação (hipótese que nos compeliu, por vezes, à transcrição destas outras).

Aliás, não foram poucas as transcrições: as palavras de censura daquele que mais nos influenciou quanto a questões metodológicas - o Professor Titular Eduardo César Silveira Vita Marchi - permanecem ecoando em nossa mente. No entanto, ao estimado mestre, temos apenas uma resposta: tentamos delas nos servir apenas quando isso nos pareceu estritamente necessário.

É neste ponto, pois, que se encerra a apresentação deste estudo - e se iniciam algumas palavras de agradecimento àqueles que tornaram possível este trabalho. 
Em primeiro lugar, devemos agradecer à nossa família. Por sua compreensão, por seu carinho, por sua paciência e - sobretudo - por sua confiança irrestrita. Em uma palavra, por todo o seu amor.

Em segundo lugar, a Elaine Lavaissiere de Melo. Nenhuma pessoa no mundo consegue entender melhor do que ela como este pesquisador "viveu" esta tese durante estes últimos anos de sua vida. A ela fica o reconhecimento por seu estímulo constante; por sua carinhosa palavra - dura ou afável - nos momentos em que este autor quis fraquejar; e por sua "inesgotável" paciência quando de nossas freqüentes instabilidades "súbitas".

Além disso, devemos agradecer a diversos amigos que, uns mais próximos, outros mais distantes, contribuíram com palavras e atos de estímulo dirigidos a este pesquisador.

Assim, somos gratos ao Centro de Extensão Universitária (CEU) e à Fundação Escola de Comércio Álvares Penteado (FECAP). Por intermédio destas instituições pudemos estreitar nossa amizade com os Professores Antonio Jorge Pereira Júnior, Paulo Restiffe Neto, Gilberto Haddad Jabur, José Osório de Azevedo Júnior, Marcelo Vieira von Adamek, André L. Costa-Corrêa, Ana Paula Savóia Bergamasco Diniz, Alexandre Multini Mihich, Fábio Pinheiro Gazzi, Rodrigo Fernandes Rebouças, Glauco Peres da Silva, Décio Azevedo Marques de Saes e Pedro Proscurcin. Foi nestas instituições que tivemos o "privilégio" de conviver com Fabiana Rodrigues da Fonseca, Vera Lúcia Viegas Liquidato, Alexandre Gaetano Nicola Liquidato e Marco Fábio Morsello.

Agradecemos, ainda, à Coordenadoria Geral de Especialização, Aperfeiçoamento e Extensão da Pontifícia Universidade Católica de São Paulo (COGEAEPUC/SP) e à Escola de Direito de São Paulo da Fundação Getúlio Vargas particularmente pela confiança demonstrada ao longo dos últimos anos.

Aliás, sem o concurso destas últimas quatro instituições não teria o pesquisador realizado sua tarefa tal como o pôde fazer. Razão pela qual os agradecimentos, mais do que tudo, correspondem a um dever deste autor.

Mas como nem só de pão vive o pesquisador, agradecemos ainda aos Professores João Baptista Villela, António Manuel Hespanha e Sandro Schipani pelo reconhecimento emprestado à seriedade de nossas investigações. 
Palavras de carinho - e de profunda admiração - também devem ser dirigidas aos seguintes Professores da Faculdade de Direito da Universidade de São Paulo, os quais nos incentivaram, constantemente, em nossas pesquisas: Antonio Junqueira de Azevedo (“in memoriam”), Luiz Carlos de Azevedo, João Alberto Schützer Del Nero, José Luiz Gavião de Almeida, Álvaro Villaça Azevedo, Hélcio Maciel França Madeira e Bernardo Bissoto Queiroz de Moraes.

Além deles, outros professores e amigos tiveram conosco contato mais próximo, à custa das constantes reuniões do Grupo de Monitoria e Pesquisa da Cadeira de História do Direito: aos Professores Maria Cristina da Silva Carmignani, Eduardo Tomasevicius Filho, Ivan Nogueira Pinheiro, Ivan Jacopetti do Lago e Júlia Rosseti Picinin Arruda Vieira - e aos amigos Renato Sedano Onofri e Rodrigo Sérgio Meirelles Marchini - nossa imensa gratidão por toda a paciência neste período turbulento de nossa vida.

Somos muito gratos ao Serviço de Biblioteca e Documentação da Faculdade de Direito da Universidade de São Paulo; pois foi graças ao seu acervo que esta pesquisa se fez - seja ela, afinal, bem ou mal-sucedida.

Agradecemos, ainda, aos funcionários desta Casa, dos quais nos despedimos - após quatorze anos de convivência - por meio de uma saudação especial à querida Lúcia Aparecida Alves de Menezes.

Pela amizade sólida, agradecemos a Luciano de Camargo Penteado, Marcos Takaoka, Jaime Meira do Nascimento Júnior, Ângelo Rigon Filho, Alessandra Maria Bosco e André Rebouças (“in memoriam”) - além da Dra. Lilian de Melo Silveira.

Pela presença constante nestes últimos tempos - e pela palavra amiga que sempre nos dispensaram - não temos palavras para agradecer a Alaor Dionisio da Silva, Raphael Blanco Cabello, Celso Bocatto e Manuel do Couto Fial. Suas imagens - tão queridas - jamais se apagarão de nossa memória.

Pela confiança depositada no jovem investigador, agradecemos - novamente - ao Ministro do Supremo Tribunal Federal e Professor Titular da Faculdade de Direito da Universidade de São Paulo José Carlos Moreira Alves. Este autor espera, sinceramente, ter honrado o seu voto.

Pela presença metodológica permanente em meio a nossas investigações, agradecimento especial é dirigido ao já referido Professor Emérito da Faculdade de Direito da Universidade Federal de Minas Gerais João Baptista Villela. No entanto, agradecemos 
mais por sua amizade, demonstrada em várias das ocasiões em que compareceu à capital do Estado de São Paulo.

Palavra de respeito e admiração sincera é dirigida ainda ao Professor Doutor Alcides Tomasetti Júnior, nosso orientador durante o Curso de Graduação na Faculdade de Direito do Largo de São Francisco. Sua figura - assim como a do Professor Titular Eduardo César Silveira Vita Marchi - nos guiou, direta e indiretamente, durante toda a trajetória desta investigação.

Finalmente, queremos - e devemos - agradecer a nosso orientador, Professor Titular Ignacio Maria Poveda Velasco. Um Mestre sereno, erudito, discreto, perspicaz e - acima de tudo - absolutamente íntegro. A um só tempo soube cobrar de seu discípulo toda a seriedade que nós pretendemos demontrar com este estudo; porém, se mostrou uma das poucas pessoas que, afora algumas das acima citadas, se preocuparam com o estado - de saúde e de espírito - deste amigo. Extremamente ocupado, teve de constantemente ouvir os nossos "choramingos", uma vez que sua missão de construir uma nova "Facvldade de Direito" tornou mais espaçados os nossos contatos "presenciais".

Assim, que a única oportunidade em que nos utilizamos da primeira pessoa do singular sirva para destacar: "querido Professor Poveda, espero ter podido honrá-lo, cumprindo adequadamente este mandato". 


\section{INTRODUÇÃO*.}

$\S 1^{\circ}$. A repercussão diversificada da Lei $n^{\circ} 10.406 / 02$ sobre os diversos meandros do sistema jurídico civil. O advento da Lei $\mathrm{n}^{\circ}$ 10.406/02 surtiu diferenciados efeitos quanto aos variados aspectos da vida civil de seus destinatários: enquanto algumas matérias foram objeto de uma atuação acentuadamente "inovadora" do legislador, outras não experimentaram qualquer descontinuidade significativa. No entanto, a despeito de serem sempre mais evidentes ao intérprete a introdução e a revogação de dispositivos legais pontuais, propomo-nos nesta oportunidade a abordar, incidentalmente, uma "eventual” reformulação sistemática da relação mantida entre dois institutos civis específicos: o contrato de mandato e a representação negocial. Aliás, essa nossa investigação será deliberadamente incidental; de fato, como teremos oportunidade de justificar mais adiante, nossos estudos - necessariamente orientados pelo propósito de defender o presente trabalho sob a forma de uma tese de doutoramento - estiveram sempre comprometidos - metodologicamente - tão somente com a evolução histórica daquele tipo contratual em meio às fontes primárias do direito luso-brasileiro ${ }^{1}$.

\footnotetext{
${ }^{*}$ Nota prévia: em cada uma das notas de rodapé utilizadas neste estudo, toda alusão a obra anteriormente referida será acompanhada de identificação quanto ao local em que foi pela primeira vez mencionada, então acompanhada dos dados usuais de uma referência bibliográfica exaustiva. A menção aos autores, no corpo do texto e nas notas de rodapé, será feita mediante o emprego da inicial do prenome e do último sobrenome, ressalvados os casos relacionados aos juristas espanhóis (que ostentam regra de patronímico própria) e lusobrasileiros, sendo estes últimos referidos de acordo com a forma segundo a qual se mostram conhecidos pela comunidade acadêmica brasileira. Assim - embora conhecido por FREITAS em toda a América Espanhola - a referência a Augusto TEIXEIRA DE FREITAS envolverá seu sobrenome completo, uma vez que assim referido pela comunidade acadêmica nacional.

Os nomes serão grafados, no corpo do texto e nas notas de rodapé, em sua forma moderna: Pascoal (e não Paschoal) José de Mello Freire dos Reis; em caso de dissenso sobre a grafia de prenomes ou sobrenomes (Mello Freire em lugar de Melo Freire), será adotada a forma utilizada pelo próprio titular (ou predominantemente empregada pela doutrina). Caso a dúvida persista, lançaremos mão da alusão nas obras de referência respectivas; desta forma, quanto aos portugueses dos séculos XVIII e XIX - por exemplo tomaremos por base a forma adotada pelo Dicionário de História de Portugal de Joel Serrão.

Tendo em vista as finalidades e princípios específicos das regras metodológicas adotadas neste estudo, necessário observar que na bibliografia os nomes serão empregados na forma constante do frontispício da obra respectiva, facilitando-se assim ao leitor o confronto direto com o exemplar referido no curso da presente exposição. Mencione-se, ainda, que a referência a personagens históricas, inclusive juristas, será feita em letras normais. Por sua vez, o emprego de maiúsculas pequenas (caixa alta ou versalete) será feito somente quando se tratar de citações de autores utilizados como tais. Por tal ordem de raciocínio, ora se terá Pascoal José de Mello Freire dos Reis, ora P. J. de Mello Freire dos Reis; em algumas vezes José Carlos Moreira Alves, e em outras J. C. MoREIRA ALvES. Finalmente, em se tratando de personagem histórica notória, será feita alusão ao modo como conhecida a partir da segunda menção no corpo do texto: Marquês de Pombal, por exemplo, em lugar de Sebastião José de Carvalho e Melo.

A respeito das principais regras de metodologia científica adotadas neste trabalho, cf. E. C. SILVEIRA MARCHI, Guia de Metodologia Científica (Teses, Monografias e Artigos), Lecce, Edizioni del Grifo, 2002, passim.

${ }^{1}$ A respeito do significado do termo destinatário - no contexto da teoria da norma jurídica - utilizamos a expressão, no texto, para nos referirmos aos sujeitos de direito que desenvolvem suas atividades sob a égide de uma determinada ordem jurídica; por tal ordem de idéias, não nos referimos tão somente aos órgãos
} 
$\S 2^{\circ}$. As alterações pouco expressivas quanto à disciplina pontual do contrato de mandato. Uma análise textual dos dispositivos do Código Civil especificamente voltados à disciplina do contrato de mandato nos revela que grande parte do acervo técnico anteriormente disponível foi aproveitada pelo legislador de 2002: dentre os quarenta artigos que atualmente disciplinam a matéria, três quintos correspondem, em larga medida, ao direito anterior - seja literalmente, seja mediante singelas adaptações (estilístico-redacionais ou de cunho sistemático evidente). Necessário destacar que pouco mais de quinze artigos revelam autêntica reformulação de regras de fundo - em meio aos quais tão somente três consagram regras que não encontram qualquer correspondência no diploma de $1916^{2}$.

jurisdicionais, tal qual preconizado por um significativo setor da teoria imperativista do direito. Sobre as origens e manifestações mais significativas deste último modelo metodológico, cf. R. von JHERING, Der Zweck im Recht I, $2^{\mathrm{a}}$ ed., Leipzig, Breitkopf \& Härtel, 1884, p. 336; H. KELSEN, Allgemeine Theorie der Normen, trad. it. de Mirella Torre, Teoria generale delle norme, Torino, Giulio Einaudi, 1985, pp. 11-22. Por um panorama relacionado à teoria imperativista do direito e seu estágio ao início da segunda metade do século XX, cf. N. BoвBio, Teoria della norma giuridica, Torino, G. Giappichelli, 1958, pp. 142-149; U. RocCO, Su la esistenza del problema dei destinatari delle norme giuridiche in Studi in onore di Enrico Redenti nel suo XL anno d'insegnamento II, Milano, Dott. A. Giuffrè, 1951, pp. 281-303.

Como pretendemos desenvolver uma análise histórica, necessário observar que toda a cautela parece oportuna quando se alude a alguma inovação introduzida por meio do Código Civil de 2002; assim, por exemplo, nos parece historicamente questionável uma atuação "inovadora" do legislador quanto à regra estabelecida no art. 157 do Código Civil - que dispõe a respeito da lesão (defeito do negócio jurídico) - a qual, embora sem correspondente no direito nacional imediatamente anterior, encontra antecedente histórico não apenas no direito das Ordenações do Reino de Portugal (Ord. Af. IV, 45 pr.; Ord. Man. IV, 30 pr.; Ord. Fil. IV, 13 pr.), como no próprio direito romano (clássico e pós-clássico) [Diocl. et Max. C. 4, 44, 2 (285) e Diocl. et. Max. C. 4, 44, 8 (294-305)] em que as fontes portuguesas por reiteradas vezes se fundaram. A respeito desta específica questão, quanto ao direito luso-brasileiro anterior à codificação civil, cf. M. A. CoElho da Rocha, Instituições de Direito Civil Portuguez - para uso dos seus discípulos, s. i. ed., Rio de Janeiro, H. Garnier, 1907, pp. 266-267 e 427-429; e quanto ao direito romano respectivo - com específica apreciação da atuação inovadora do legislador civil brasileiro - cf. E. M. A. MADEIRA, Laesio enormis, Tese (Doutorado) - Faculdade de Direito da U.S.P., São Paulo, 1998, pp. 129-135 (esp. p. 129).

Por outro lado, tomando-se ainda em consideração o iter de construção de nosso direito civil atual, uma autêntica atividade criadora do codificador deste início de século XXI - no âmbito legislativo - pode ser entrevista, por exemplo, na disciplina concernente aos direitos da personalidade, os quais, até o advento do Código Civil de 2002, tinham suas linhas gerais estabelecidas exclusivamente pela doutrina e pela jurisprudência. Nesse sentido, a disciplina estabelecida entre os arts. 11 e 21 (52) do Código Civil vigente realmente parece não encontrar correspondência em nosso direito positivo anterior.

Conforme afirmamos no corpo do texto, algumas matérias foram objeto de uma disciplina que em nada se distingue daquela em vigor até o final de 2002, como se pode observar naquilo que concerne à confusão (arts. 381 a 384). Em contrapartida, uma análise dos títulos que integram o livro vigente sobre o Direito das Coisas - comparados à estruturação correspondente do Código Civil anterior - nos revela que o direito de propriedade perdeu a primazia sistemática de que dispunha durante a vigência do paradigma positivo anterior. Teremos oportunidade de destacar que um fenômeno semelhante - embora menos evidente - afetou de modo significativo o tema que constitui nosso objeto específico de estudo.

${ }^{2}$ A partir de uma abordagem meramente textual dos dispositivos legais que atualmente disciplinam o contrato de mandato, podemos perceber que guardam exata correspondência com regras do Código Civil de 1916 os seguintes preceitos: art. 653 (art. 1.288); art. 656 (art. 1.290); art. 659 (art. 1.292); art. 660 (art. 1.294); art. 661 (art. 1.295); art. 668 (art. 1.301); art. 669 (art. 1.302); art. 674 (art. 1.308); art. 675 (art. 1.309); art. 677 (art. 1.311); art. 680 (art. 1.314); art. 687 (art. 1.319); art. 690 (art. 1.322) e art. 691 (art. 1.323). Por sua vez, observou-se mera adaptação redacional (sem qualquer reformulação de fundo) quanto 


\section{$\S 3^{\circ}$. A inserção - na Parte Geral do Código Civil - de um capítulo}

especificamente voltado à disciplina da representação. Situação diversa se verifica naquilo que concerne à disciplina da representação, com relação à qual se observou a introdução de um tratamento sistemático autônomo (completamente distinto daquele que lhe era atribuído pelo Código Civil revogado); e para demonstrar o alegado basta observar que dentre os seis artigos do Código Civil vigente que regulam a matéria, tão somente um encontra antecedente na legislação civil anterior: justamente o art. 118, correspondente ao art. 1.305 do diploma de 1916 - situado este, por sua vez, em meio aos dispositivos voltados ao contrato de mandato ${ }^{3}$.

aos seguintes dispositivos: art. 655 (art. 1.289, § 2 $2^{\circ}$ ); art. 665 (art. 1.297); art. 670 (art. 1.303); art. 676 (art. 1.310); art. 678 (art. 1.312); art. 679 (art. 1.313); art. 682 (art. 1.316) e art. 689 (art. 1.321). Finalmente, destacam-se como adaptações sistemáticas evidentes os arts. 666 (art. 1.298) e 673 (art. 1.306) respectivamente voltados à compatibilização do texto antigo com a redução da maioridade civil e com o acolhimento legislativo da teoria do negócio jurídico.

Sob a forma de alteração quanto à orientação anteriormente adotada, inovações relativas podem ser vislumbradas nos seguintes dispositivos: art. 654 (art. 1.289); art. 657 (art. 1.291); art. 658 (art. 1.290, § único); art. 662 (art. 1.296); art. 663 (art. 1.307); art. 664 (art. 1.315); art. 667 (art. 1.300); art. 672 (art. 1.304); art. 681 (art. 1.315); art. 684 (art. 1.317, II); art. 685 (art. 1.317, I); art. 686 (arts. 1.318 e 1317, III) e art. 688 (art. 1.320). Por fim, diante da ausência de qualquer correspondência com os dispositivos do Código Civil de 1916, merecem destaque as inovações promovidas pelos arts. 671, 683 e 692 - feita a devida ressalva quanto ao teor do art. 152 do Código Comercial derrogado.

Pelas abordagens mais genéricas dedicadas ao estudo do contrato de mandato segundo o Código Civil de 2002, cf. WASHINGTON De BARros MonteIRo, Curso de Direito Civil - Direito das Obrigações (2 ${ }^{a}$ parte) dos contratos em geral, das várias espécies de contrato, dos atos unilaterais, da responsabilidade civil $V, 34^{\mathrm{a}}$ ed. (revista e atualizada por Carlos Alberto Dabus Maluf e Regina Beatriz Tavares da Silva, de acordo com o novo Código Civil, Lei no 10.406, de 10-1-2002), São Paulo, Saraiva, 2003, pp. 260-299; SILVIO RodRIGUES, Direito Civil - Dos Contratos e das Declarações Unilaterais da Vontade III, 29a ed., São Paulo, Saraiva, 2003, pp. 285-307; CAIO MÁRIO da Silva Pereira, Instituições de Direito Civil - Contratos, Declaração unilateral de vontade, Responsabilidade civil III, $12^{\text {a }}$ ed. (revista e atualizada por Regis Fichtner, de acordo com o Código Civil de 2002), Rio de Janeiro, Forense, 2006, pp. 397-420; MARIA HELENA DinIZ, Curso de Direito Civil Brasileiro - Teoria das Obrigações Contratuais e Extracontratuais, $20^{\text {a }}$ ed., São Paulo, Saraiva, 2004, pp. 351-382; S. de S. VenosA, Direito Civil - Contratos em Espécie III, São Paulo, Atlas, 2007, pp. 249-278; N. G. B. Dower, Curso Moderno de Direito Civil-Contratos e Responsabilidade Civil, $3^{a}$ ed., São Paulo, Nelpa, 2007, pp. 281-303; S. L. F. da RochA, Curso Avançado de Direito Civil Contratos III, São Paulo, Revista dos Tribunais, 2002, pp. 295-316; FÁBIO UlHoA Coelho, Curso de Direito Civil III, São Paulo, Saraiva, 2005, pp. 311-328; C. A. BitTAR Filho - M. S. BitTar, Código Civil 2002 - Inovações, São Paulo, IOB Thomson, 2005, pp. 56-57; N. NERY JUNIOR - R. M. de ANDRADE NERY, Código Civil Anotado e legislação extravagante, $2^{\mathrm{a}}$ ed., São Paulo, Revista dos Tribunais, 2003, pp. 419-433; C. E. N. Camillo - G. M. Talavera - J. S. Fujita - L. A. Scavone JR. (coords.), Comentários ao Código Civil - artigo por artigo, São Paulo, Revista dos Tribunais, 2006, pp. 584-601; R. FIUZA (coord.), Novo Código Civil Comentado, $5^{\mathrm{a}}$ ed., São Paulo, Saraiva, 2006, pp. 533-570; A. VillaçA AzEVEdo - S. de S. Venosa, Código Civil Anotado e Legislação Complementar, São Paulo, Atlas, 2004, pp. 353-370; A. C. da Costa Machado - JuArez de Oliveira - Z. BARreto, Código Civil de 2002 Comparado e Anotado, $2^{\mathrm{a}}$ ed., São Paulo, Juarez de Oliveira, 2003, pp. 156-165; R. Lotufo, Código Civil Comentado I - Parte Geral: arts. $1^{o}$ a 232, São Paulo, Saraiva, 2003, pp. 319-340 (a propósito de sua distinção em relação à representação negocial). Ressalte-se que teremos ocasião de efetuar - em momento mais apropriado - uma abordagem mais cuidadosa dos textos legais acima referidos, bem como da doutrina mencionada nesta oportunidade.

${ }^{3}$ Dos seis dispositivos voltados à disciplina da representação, um deles concerne às suas fontes (art. 115), dois aos seus efeitos (arts. 116 e 118), dois a hipóteses de anulabilidade do negócio concluído pelo representante (arts. 117 e 119) e um estabelece uma norma de reenvio (art. 120). Em estudo futuro, que 


\section{$\S 4^{\circ}$. Uma regulamentação da representação - na Parte Geral do Código}

Civil de 2002 - concernente à suas variantes legal $e$ negocial. Não se pode esquecer, no entanto, que a referida disciplina da representação - articulada entre os artigos 115 e 120 do Código Civil - não se resume àquele modelo já familiar aos estudiosos do contrato de mandato; não apenas se estabeleceu uma disciplina sobranceira (a abranger a um só tempo as suas variantes legal e negocial), como ainda se estendeu o âmbito de aplicação da representação ex voluntate - que passou a abarcar hipóteses em que se verifica uma autêntica representação sem mandato ${ }^{4}$.

extrapola os limites metodológicos da presente investigação, teremos oportunidade de observar que, à exceção do disposto no art. 120, todas as demais regras revelam influência dos direitos alemão (1896), italiano (1942) e português (1966); aliás, especificamente no que concerne ao Código Civil português, cumpre assinalar que muito clara se mostra sua influência quanto à disciplina pontual da representação; entretanto, no que toca à conformação sistemática eleita pelo legislador lusitano, houve como que uma espécie de adesão parcial ao modelo referido, fato esse que não passou despercebido à oportuna crítica de J. C. Moreira Alves: "o Projeto, suprindo lacuna do Código Civil brasileiro em vigor, reservou, na Parte Geral, um capítulo para os preceitos gerais sobre a representação legal e a negocial. Ao contrário, porém, do que ocorre no Código Civil português de 1967 - que regula a representação negocial na Parte Geral (arts. $262^{\circ}$ a $269^{\circ}$ ) - o Projeto, seguindo a orientação do Código Civil brasileiro atual, disciplina essa matéria no capítulo concernente ao mandato, uma vez que, em nosso sistema jurídico, a representação é da essência desse contrato" (A Parte Geral do Projeto de Código Civil Brasileiro - com análise do texto aprovado pela Câmara dos Deputados, São Paulo, Saraiva, 1986, p. 105).

Por ora, mencione-se apenas que a razão desta "adesão parcial" será posta em evidência logo adiante. De fato, observaremos que a promulgação do Código Civil de 2002 parece denunciar uma reformulação sistemática da relação mantida entre os institutos do contrato de mandato e da representação negocial; todavia, desde logo podemos assinalar que a terminologia empregada pelo legislador no art. 118 do Código Civil vigente evidencia - de modo singular - uma situação de desconforto quanto à relação promíscua até então mantida entre os referidos institutos: de fato, em lugar das expressões mandante, mandatário e instrumento do mandato, encontramos uma terminologia diversa: "art. 118. o representante é obrigado a provar às pessoas, com quem tratar em nome do representado, a sua qualidade e a extensão de seus poderes, sob pena de, não o fazendo, responder pelos atos que a estes excederem”. Pergunta-se: o que se poderia depreender de uma tal substituição? É uma das questões incidentais que pretendemos analisar neste trabalho.

${ }^{4}$ A dissociação sistemática entre a representação negocial e o contrato de mandato abriu espaço para a produção de dois resultados potenciais: a representação (negocial) sem mandato e o mandato sem representação; embora, por razões metodológicas, este último seja abordado com maior freqüência neste trabalho, não podemos deixar de lembrar que a própria representação sem mandato já encontrava acolhimento por parte da doutrina anterior ao Código Civil vigente, a propósito, por exemplo, da hipótese de procuração em causa própria - em que o "representante" atua em nome alheio (embora em seu próprio interesse e sem acatar quaisquer instruções provenientes do mandante). A respeito da procuração em causa própria no direito brasileiro anterior ao advento do Código Civil de 2002, cf. D. R. FLORES, Notas sobre o Mandato em Causa Própria - o que é tal mandato e como faze-lo, São Paulo, Revista dos Tribunais, 1933 ; J. Miró Junior, A procuração em causa própria e seus efeitos, Curitiba, Tese (Livre-Docência) - Faculdade de Ciências Econômicas da Universidade do Paraná, Curitiba, 1952; M. FERREIRA, Do mandato em causa própria no direito civil brasileiro, São Paulo, Saraiva, 1933; M. M. da C. CRUZ, A procuração em causa própria definida e aplicada pela jurisprudência, São Paulo, Typ. Univeral, s.d.; D. S. B. de LiMA, Origem e evolução da procuração em causa própria, São Paulo, DIP, 1977.

Com a representação (negocial) sem mandato não deve ser confundida a atuação orgânica - que F. C. PONTES DE MIRANDA designa por "presentação" -, típica da hipótese de ação do órgão da pessoa jurídica, em que aquele manifesta a vontade desta, aplicando-se ao primeiro, por exemplo, a disciplina concernente aos defeitos do negócio jurídico (arts. 138 e seguintes do Código Civil). Neste sentido, pois, a advertência de F. C. PONTES DE MiRANDA: "há podêres de representação e de ação jurídica, desde o de praticar atos jurídicos unilaterais e de concluir contratos até o de administrar, que permitem que os atos de alguém tenham eficácia 


\title{
$\S 5^{\circ}$. A remissão operada pelo art. 120 do Código Civil. Haveria uma
}

\author{
vinculação entre a disciplina concernente ao contrato de mandato e aquela afeta à
}

representação (negocial)? A despeito das diversas vicissitudes extra-jurídicas inerentes a

uma fenomenologia da representação (que em princípio não serão por nós abordadas neste

trabalho), cremos que incorreria em equívoco metodológico grave o estudioso que se

propusesse a analisá-la sob uma perspectiva completamente apartada de suas respectivas

na esfera jurídica de outrem, como se fôssem atos dêsse, ou, até, como atos dêsse. Quem representa pratica atos que não são do representado, mas perfazem relações jurídicas em que o representado figura. Não é o que se passa, certamente, com os órgãos das pessoas jurídicas: êsses presentam, não representam" (F. C. Pontes De Miranda, Tratado de Direito Privado - Parte Especial - Direito das Obrigações: Mandato. Gestão de negócios alheios sem outorga. Mediação. Comissão. Corretagem XLIII, $3^{\text {a }}$ ed., Rio de Janeiro, Borsoi, 1972, p. 11, itálicos nossos); em idêntico sentido, cf. E. BETTI, Teoria generale del negozio giuridico, $2^{\mathrm{a}}$ ed., Torino, Unione Tiprografico-Editrice Torinese, 1960, p. 572. Entre nós, cf. M. G. MAIA JÚNIOR, $A$ Representação no Negócio Jurídico, São Paulo, Revista dos Tribunais, 2001, pp. 55-56; bem como A. Villaça AZEVEdo, Código Civil Comentado II - Negócio Jurídico, Atos Jurídicos Lícitos, Atos Ilícitos, São Paulo, Atlas, 2003, pp. 86-87.

É necessário destacar que - da mesma forma como não se devem confundir representação e a "presentação" - é defeso baralhar representação e nunciatura: na primeira hipótese o representante declara, por si, em nome do representado; em outras palavras, por declaração negocial própria percute a esfera jurídica do representado. Já na nunciatura as coisas se dão de modo diverso: o porta-voz não representa (declara por si em nome de outrem), mas simplesmente reproduz a declaração (que de outrem é e sempre foi). Por tal ordem de idéias é que não se há de investigar jamais - na pessoa do núncio - a ocorrência de vícios quanto à manifestação de vontade; deve-se perquiri-los na esfera da pessoa que se utiliza do mensageiro. No mesmo sentido a manifestação de F. C. PONTES DE MIRANDA: "se o mensageiro transmite outra manifestação de vontade que aquela de que foi incumbido, transmite a vontade do manifestante, erradamente. Daí ter êsse de anulá-la. Tem, todavia, de reparar o interêsse negativo. Tudo isso é assaz diferente do que se passa com os procuradores. Daí a necessidade de se saber de que figura se trata, - se de representante, ou se de mensageiro. Se nenhuma liberdade tem no que transmite, trata-se de mensageiro (...) se recebe procuração escrita, ou pode assinar, ou verificar papéis, impostos ou outros dados, é procurador. Quanto ao êrro, é que mais ressalta, nos resultados, a diferença. Se B diz que A manda dizer, B é mensageiro, porém, aí, mais importam as circunstâncias que as palavras; se entra em ajustes, exames de ofertas ou contra-ofertas, se toma parte em tratos preliminares, é de procurador que se trata. São circunstâncias que pesam: se B é criado ou empregado doméstico de A, e atua como comprador de objetos de uso pessoal, ou da casa, é mensageiro; se B é administrador e trata de assuntos de sua profissão, é mandatário" (Tratado de Direito Privado - Parte Geral - Negócios Jurídicos. Representação. Conteúdo. Forma. Prova III, Rio de Janeiro, Borsoi, 1954, pp. 316317). Perceba-se, pela expressão final por nós destacada, que ao próprio autor ora referido as questões concernentes ao mandato e à representação negocial parecem, por vezes, confusas. No mesmo sentido da diferenciação proposta, cf. M. A. D. de AndRADE, Teoria Geral da Relação Jurídica - Facto Jurídico, em especial Negócio Jurídico II, Coimbra, Almedina, pp. 291-292; M. G. MAIA JÚNIOR, A Representação cit. (nota 04), São Paulo, Revista dos Tribunais, 2001, pp. 47-50; E. BETTI, Teoria generale cit. (nota 04), p. 572; L. ENNERCCERUS - T. KIPP - M. WOLFF, Lehrbuch des Bürgerlichen Rechts - Einleitung - Allgemeiner Teil, trad. esp. de Blas Pérez González e José Alguer, Tratado de Derecho Civil - Parte General - nacimiento, extinción y modificación de los derechos subjetivos, pretensiones y excepciones, ejercicio y aseguramiento de los derechos, Barcelona, Casa Editorial Bosch, 1935, pp. 231-234; F. GALGANO, Il negozio giuridico, Milano, Dott. A. Giuffrè, 1988, pp. 352-354; A. GIOVENE, Negozio giuridico rispetto ai terzi, Torino, Unione Tipografico-Editrice Torinese, 1917, pp. 27-32; L. CARIOTA FERRARA, Il negozio giuridico nel diritto privato italiano, Napoli, Morano, 1956, pp. 678-679; V. SCIALOJA, Negozi giuridici-corso di diritto romano nella $r$. Università di Roma nell'anno accademico 1892-1893 raccolto dai dottori Mapei e Giannini, pp. 216-219.

Observe-se, finalmente, que embora as hipóteses de representação sem mandato não tivessem a consagração do Código Civil anterior, já havia previsão implícita de mandato sem representação - a qual se pode depreender dos arts. 1.307, 1.297, 1.301 e 1.309 do aludido diploma legal (e que merecerão, oportunamente, nossa específica atenção). 
manifestações especiais; assim, é nosso dever ressaltar que em nenhum momento consideramos inoportuna uma abordagem em que estivessem funcionalmente conjugados a representação negocial e o contrato de mandato (e por meio da qual se compreenda a primeira como instrumento indispensável ao adimplemento de uma das figuras relacionadas ao segundo instituto). Bem ao contrário, tão somente preocupamo-nos em esclarecer, desde logo, nossa posição (no sentido de que uma eventual coordenação funcional não pode obscurecer a autonomia estrutural existente entre os dois institutos jurídicos); e de fato - tendo-se em vista que o art. 120 do Código Civil estabelece que "os requisitos e os efeitos da representação legal são os estabelecidos nas normas respectivas; os da representação voluntária são os da Parte Especial deste Código" - parece-nos que a vinculação funcional apontada foi expressamente determinada pelo próprio legislador redirecionando a atenção do intérprete para outros destinos (os quais serão abordados ao longo da exposição) ${ }^{5}$.

\footnotetext{
${ }^{5}$ Perceba-se, pois, que não negamos a existência de um "vínculo" entre o instituto do contrato de mandato e a figura da representação negocial. Apenas afirmamos que nos parece imprescindível realizar uma espécie de "destilação" jurídica - por meio da qual se separem os elementos integrantes dessa mistura (levada a efeito pela realidade jurídica e corroborada pelo ordenamento jurídico positivo nacional) - a fim de que se chegue àquilo que poderíamos designar por "nota típica" do contrato de mandato - por reiteradas vezes mencionada no presente estudo e que será objeto de consideração mais detida no contexto de uma outra investigação, também filiada à linha de pesquisa adotada por este investigador.

Ora, como desde logo nos declaramos partidários da possibilidade de dissociação entre mandato e representação (dotados de eficácias jurídicas inteiramente distintas), acreditamos que esta última não corresponde, pois, àquilo que usualmente se tem designado por "essência" do contrato de mandato; mesmo porque, como veremos ao longo da primeira parte da pesquisa, embora entre os romanos o mandatum fosse um contrato típico, a representação direta não era admitida - inicialmente - pelo sistema. Certamente alguém cogitará que, a despeito da identidade quanto ao nomen juris, não haveria uma maior correspondência entre o mandatum romano e o seu correspondente moderno (e que o sistema jurídico brasileiro, aliás, adotara um mandato "essencialmente" representativo). Nesse sentido preleciona F. C. de SAN TIAGO DANTAS: "a característica principal desse contrato [o mandato] é essa incumbência para celebrar um certo negócio, que o mandante confere ao mandatário. Esta característica (...) implica em que uma pessoa (representante), emitindo uma declaração de vontade, dê vida a um negócio jurídico, que surge diretamente com referência a uma outra pessoa (representado), de modo que a primeira só no interesse deste age (...) a representação é, portanto, a idéia suprema do mandato, além de só a ele pertencer entre todas as espécies de contrato (...) o mandato é a maneira de fazer-se a representação direta negocial. É esta representação que distingue o instituto em estudo de todas aquelas figuras que lhes são afins" (Programa de Direito Civil II - aulas proferidas na Faculdade Nacional de Direito (fim de 1943- 1945) - Os Contratos, Rio de Janeiro, Editora Rio, 1978, pp. 369-370). Note-se que essa posição já podia ser entrevista em ClóVIS BEVILÁQUA ("o que caracteriza o mandato é a representação", Codigo Civil dos Estados Unidos do Brasil Commentado V-2, $5^{\mathrm{a}}$ ed., Rio de Janeiro, Livraria Francisco Alves, 1943, p. 29), J. M. de CARVAlHo SAntos ("o mandato, como se vê, justamente por envolver sempre uma representação, apresenta-se como uma figura inconfundivel, mesmo em face de outros contractos que com elle apresentam semelhanças", Codigo Civil Brasileiro Interpretado principalmente do ponto de vista pratico - Direito das Obrigações (arts. 1265-1362) XVIII, $2^{\mathrm{a}}$ ed., Rio de Janeiro, Livraria Editora Freitas Bastos, 1938, p. 109) e em Jỗo LuIZ Alves: "o que o caracteriza e distingue [contrato de mandato] de outros contractos é a representação" (Código Civil da República dos Estados Unidos do Brasil promulgado pela Lei n. 3.071, de 1 de janeiro de 1916 annotado II, $2^{a}$ ed., São Paulo, Saraiva, 1935, p. 348). No mesmo sentido, R. LimONGI FrANÇA: "a essência do mandato está na idéia de representação, de tal forma que, aquêle que recebeu os podêres, é como se fôsse o contraente que os outorgou" (Manual de Direito Civil IV-2 - Doutrina das obrigações contratuais, Doutrina das
} 


\section{$\S 6^{\circ}$. Sobre a necessidade de uma definição quanto aos limites da remissão}

à Parte Especial operada pelo art. 120 do Código Civil. Tais premissas ensejam, pois, algumas indagações: qual seria o alcance hermenêutico dos termos "requisitos" e "efeitos", empregados pelo art. 120 do Código Civil? Quais os obstáculos que a estrutura peculiar ao contrato de mandato poderia oferecer a uma indiscriminada comutação de regras com a heterogênea disciplina da representação negocial? Pretendemos, assim, oferecer as respectivas respostas ao longo do presente estudo - para tanto lançando mão, freqüientemente, da variante não representativa do tipo contratual mencionado ${ }^{6}$.

obrigaçães extracontratuais, São Paulo, Revista dos Tribunais, 1969, p. 184); J. F. DE LIMA: "tendo por conteúdo essencial o poder dado ao mandatário de agir em nome do mandante, o caráter do contrato de mandato é a representação" (Curso de Direito Civil Brasileiro II-2 - Direito das Obrigações - Dos contratos e das Obrigações por Declaração Unilateral de Vontade, $3^{\mathrm{a}}$ ed., Rio de Janeiro, Forense, 1979, p. 565); e F. R. Leite Filho (Curso de Direito Civil - Parte Geral, Direito das Obrigações, São Paulo, Edições Lael, 1973). O próprio M. M. de SERPA LOPES não afasta a representação da essência do contrato de mandato, conquanto já divisasse a necessidade sistemática de uma consideração autônoma de tais institutos: "embora, em nosso direito, a representação constitua elemento essencial do mandato, diferentemente do direito alemão, impõe-se, contudo, manterem-se inconfundíveis as duas figuras" (Curso de Direito Civil - Fontes das Obrigações: Contratos IV, Rio de Janeiro-São Paulo, Livraria Freitas Bastos, 1958, p. 240).

Já sob o contexto do Código Civil de 2002, G. TEPEDINo observa que "embora configurem institutos jurídicos autônomos, no direito brasileiro, por expressa opção legislativa, a representação compõe a causa do contrato de mandato não cabendo, por isso mesmo, falar em mandato sem representação, ainda que ontologicamente seja possível tal figura contratual (...) repugnava o espírito do Direito Romano a idéia de que uma pessoa pudesse agir em nome de outra, uma vez que o caráter personalíssimo e solene dos atos era incompatível com a idéia de representação. Mas o Direito Canônico reagiu a isso, acolhendo o conceito de representação e posicionando-o ao lado do mandato, fazendo com que a representação passasse a ser elemento essencial do referido contrato" (A técnica da representação e os novos princípios contratuais in Direito Civil - Direito Patrimonial e Direito Existencial: Estudo em homenagem à professora Giselda Maria Fernandes Novaes Hironaka, São Paulo, Método, 2006, pp. 79-80).

De fato, os exemplos acima reproduzidos - que nos parecem suficientes para evidenciar a concepção da maior parte da doutrina brasileira - desconsideram a figura do mandato sem representação. Mas algumas considerações nos parecem inevitáveis: se o Código Civil brasileiro alude à possibilidade de que o mandatário aja em seu próprio nome, devendo transferir ao mandante todas as vantagens provenientes do mandato, o qual tem não apenas uma ação adjudicatória específica, como também o dever de satisfazer as obrigações assumidas pelo mandatário (arts. 663, 668, 671 e 675), nos parece - com toda a honestidade científica possível - inteiramente inviável sustentar, no Brasil, o caráter "essencialmente" representativo do contrato de mandato. Aludisse-se a um caráter "naturalmente" representativo e nosso trabalho já estaria reduzido em grande parte; não teríamos que provar que são dois aquilo que é considerado pela doutrina como sendo um só. É contra a "essencialidade" do elemento representativo que lutaremos na primeira parte deste estudo. E para tanto será imprescindível uma historiografia geral a respeito da relação entre o instituto do contrato de mandato e a figura da representação negocial.

${ }^{6}$ Observe-se que a redação conferida ao art. 120 do Código Civil brasileiro (supra transcrito, $\S 5^{\circ}$ ) é induvidosamente clara; no entanto, não se pode afirmar o mesmo quanto ao alcance do referido dispositivo jurídico; de fato, uma vez admitida a essência representativa do contrato de mandato, pouco resta ao intérprete senão efetuar uma simples adição entre as regras sobre representação estabelecidas na Parte Geral (arts. 115 a 120) e as disposições referentes ao contrato de mandato, constantes da Parte Especial (arts. 653 a 692) - como se tudo concernisse a uma simples relação entre gênero (representação) e espécie (representação negocial = eficácia do contrato de mandato).

Contudo, com isso não concordamos. Pergunta-se: quais assinaturas constam da procuração, "instrumento do mandato", na terminologia adotada pelo legislador no art. 653 do CC/2002? Se na resposta oferecida se prescinde da menção ao mandatário - leia-se "outorgado" - é porque, em verdade, de contrato não estamos a tratar. Ou, à margem de inequívoca disposição legislativa, pode haver contrato defluente - unicamente - de 
um negócio jurídico unilateral? Não nos parece razoável sustentá-lo. Estaria a prática a negar a realidade constante do Código Civil, em uma manifestação de rebeldia ao caráter "contratual" do ato jurídico consubstanciado no instrumento de procuração? Ou seria forçoso reconhecer que na procuração estaria instrumentado outro negócio jurídico (unilateral), vizinho ao contrato de mandato, mas que com ele não se confunde? Aderimos, pois, a esta última posição. A este respeito, cf. E. A. SANCHEZ URITE, Mandato y representacion, Buenos Aires, Abeledo Perrot, 1986, p. 25 (trecho que será transcrito e melhor explorado em nota de rodapé posterior).

Dito isso, contudo, deparamo-nos com outras questões: ora, tudo que existe na Parte Geral do Código Civil concerne exclusivamente à representação (ainda que negocial)? Por sua volta, tudo o que existe em meio à Parte Especial do Código Civil respeita exclusivamente ao contrato de mandato? Parece-nos que às duas perguntas se deve responder negativamente. Com efeito, acreditamos que muito existe na Parte Especial, sob a rubrica do contrato de mandato, que em verdade respeita à representação (negocial); da mesma forma, em alguns pontos do disposto entre os arts. 115 e 120 do Código Civil, sentimos que estamos diante de preceitos que afetam, ainda que reflexamente, a disciplina do contrato de mandato. É exatamente este, pois, um dos principais objetivos de nossa tarefa: para segregarmos da disciplina do contrato de mandato a matéria concernente à representação, teremos de avaliar aquilo que sobre a representação se diz quando se empregam na legislação civil codificada as expressões mandato, mandante, mandatário, instruções e congêneres. Por essa razão reputamos, portanto, "indiscriminada" a comutação - promovida pela via do art. 120 do Código Civil - de regras entre institutos que, a despeito de sua vinculação funcional, guardam uma autonomia estrutural que será decisiva para a delimitação da eficácia jurídica de cada negócio decorrente.

Um exemplo, pois, dessa comutação indiscriminada pode ser depreendido da obra de WASHINGTON DE BARROS MONTEIRO: “convencionais são os representantes munidos de mandato, expresso ou tácito, verbal ou escrito, do representado, como os procuradores (no contrato de mandato) e o comissário (no contrato de comissão mercantil)" [Curso de Direito Civil - Parte Geral I, 40 a ed. (revista e atualizada por Ana Cristina de Barros Monteiro França Pinto), São Paulo, Saraiva, 2005, p. 220]; note-se que não entraremos, por ora, no mérito de uma análise do art. 693 do Código Civil, à custa de cuja redação parece insustentável a tese do "comissário representante", a menos que se empreste um sentido consideravelmente amplo a esta última expressão (para abranger a chamada representação indireta). No mesmo sentido por nós ora condenado - não advertindo, portanto, quanto aos limites à comutação entre as disposições legais referidas - cf. SILVIO Rodrigues, Direito Civil - Parte Geral I, 34ª ed., São Paulo, Saraiva, 2003, pp. 165-167; CAIO MÁRIO da Silva Pereira, Instituições de Direito Civil - Introdução ao Direito Civil, Teoria Geral do Direito Civil I, 21 ed. (revista e atualizada de acordo com o Código Civil de 2002 por Maria Celina Bodin de Moraes), Rio de Janeiro, Forense, 2006, p. 625; MARIA Helena DinIZ, Curso de Direito Civil Brasileiro - Teoria Geral do Direito Civil I, $23^{\mathrm{a}}$ ed., São Paulo, Saraiva, 2006, pp. 445-447; S. de S. VENOSA, Direito Civil - Parte Geral I, $7^{\text {a }}$ ed., São Paulo, Atlas, 2007, pp. 335-342 (de onde extraímos o trecho seguinte: "o mandato é a forma pela qual se torna conhecida a representação por vontade dos interessados (...) por isso se diz que o mandato, um contrato, que se instrumentaliza pela procuração", p. 338); N. G. B. DowER, Curso Moderno de Direito Civil - Parte Geral I, 4a ed., São Paulo, Nelpa, 2007, pp. 297-301; S. L. F. da RocHA, Curso Avançado de Direito Civil - Contratos III, São Paulo, Revista dos Tribunais, 2002, p. 295 (que em verdade nos pareceu pouco claro quanto às suas próprias conclusões a respeito da questão); FÁBIO UlHOA COELHO, Curso de Direito Civil I, 2a ed., São Paulo, Saraiva, 2006, pp. 297-303 [de onde extraímos que "o negócio jurídico de outorga de poderes de representação pelo próprio representado é o contrato de mandato, que se instrumentaliza na procuração (...) desse modo, o que recebe os poderes de representação (chamado mandatário ou procurador) é o representante investido nos seus poderes por vontade do próprio interessado", p. 299]; C. A. BitTAR Filho - M. S. BitTAR, Código Civil cit. (nota 02), p. 24; N. NerY JuniOR - R. M. de Andrade Nery, Código Civil cit. (nota 02), p. 66; C. E. N. CAmillo - G. M. TAlavera - J. S. Fujita - L. A. SCAVONE JR. (coords.), Comentários cit. (nota 02), p. 228; R. FIUZA (coord.), Novo Código cit. (nota 02), p. 109; A. Villaça Azevedo - S. de S. Venosa, Código Civil cit. (nota 02), pp. 111-112; A. C. da Costa Machado - Juarez de Oliveira - Z. BArreto, Código Civil cit. (nota 02), p. 44; F. TARTuCE, Direito Civil - Teoria Geral dos Contratos e Contratos em Espécie III, $2^{\mathrm{a}}$ ed., São Paulo, Método, 2007, p. 465; P. S. Gagliano - R. Pamplona Filho, Novo Curso de Direito Civil Brasileiro - Parte Geral I, $8^{\mathrm{a}}$ ed., São Paulo, Saraiva, 2006, p. 342; G. R. NiCOLAU, Direito Civil-Parte Geral, 2a ed., São Paulo, Atlas, 2006, p. 124.

Em abono da posição por nós defendida, encontramos, no Brasil, as manifestações de F. C. PONTES DE Miranda, Tratado III cit. (nota 04), pp. 235-236; F. M. DE MATTIA, Aparência de Representação, São Paulo, CID, 1999, pp. 3-5; A. VillaçA AZEVEDo, Código Civil cit. (nota 04), pp. 85-112; R. LOTUFO, Código Civil cit. (nota 02), pp. 319-340; e M. G. MAIA JÚNIOR, A Representação cit. (nota 04), pp. 153-155 dentre outros autores mais adiante devidamente referidos.

Ou seja, como não negamos que exista um vínculo funcional entre os institutos jurídicos referidos, não seremos jamais contrários - naturalmente - a um estudo que aborde "conjugadamente" as duas matérias. 


\title{
$\S 7^{\circ}$. O advento do Código Civil de 2002 e a discrepância entre as posições
}

\author{
do relator do Anteprojeto parcial de 1970 e da Comissão Elaboradora e Revisora.
}

Especificamente no que concerne à representação negocial, devemos observar desde logo que a versão promulgada do Código Civil de 2002 destoa consideravelmente do Anteprojeto da Parte Geral do Código Civil de 1970; com efeito, este retomava uma premissa que, quase trinta anos antes, havia sido salientada por Orosimbo Nonato, Philadelpho Azevedo e Hahnemann Guimarães, os quais - na Exposição de Motivos do Anteprojeto da Parte Geral do Código das Obrigações de 1941 - postulavam uma "libertação" do instituto da representação quanto à sua subserviência ao contrato de mandato. Não tendo sido integralmente acolhida pela Comissão Elaboradora e Revisora a proposta do autor do referido Anteprojeto parcial (José Carlos Moreira Alves), restou malograda a tentativa de se promover uma separação metodológica "plena" entre os institutos; ainda assim - impelidos pela dissociação pretendida pelo próprio legislador temos a convicção de que são perfeitamente definíveis os limites entre esses, cabendo à doutrina a tarefa de precisá-los, a partir de critérios que proporcionem suficiente segurança ao intérprete ${ }^{7}$.

Nosso principal óbice ao tratamento pretendido por grande parte da doutrina reside numa corriqueira mistura entre as respectivas estruturas jurídicas; o que acabará por produzir resultados significativos (ao ensejo da apreciação da eficácia concernente a cada uma delas).

${ }^{7}$ A respeito da tentativa de um apartamento pleno entre o instituto do contrato de mandato e a figura da representação negocial, oportuna se mostra a manifestação do próprio autor do Anteprojeto parcial (da Parte Geral), José Carlos Moreira Alves: “ocupa-se o Capítulo II com a representação. Nesse ponto, orientou-se o Anteprojeto no sentido de incluir, na Parte Geral, as regras referentes à representação legal e convencional. E, quanto a esta última - a fim de que não se fracionasse sua disciplina - regulou-a sob todos os aspectos que, no Código vigente, vêm tratados no instituto do mandato. Se acolhida a idéia, o futuro Código Civil, em sua Parte Especial, ao tratar do mandato, deverá estabelecer apenas as normas relativas ao contrato de mandato, não se ocupando com a representação" (J. C. MOREIRA ALVES, A parte geral cit. (nota 03), p. 79).

Como dissemos, a proposta articulada pelo relator do Anteprojeto reconduzia a uma iniciativa que já havia sido prestigiada pelo Anteprojeto de Parte Geral do Código das Obrigaçães de 1941 (elaborado por Orosimbo Nonato, Philadelpho Azevedo e Hahnemann Guimarães). Com efeito, em sua exposição de motivos a Comissão responsável pela obra anterior foi categórica ao asseverar a imprescindibilidade de uma autêntica libertação do instituto da representação (inclusive a sua variante negocial): "o instituto da representação foi libertado da sua condição servil ao mandato, deixando-se à disciplina deste contrato apenas as relações entre as próprias partes contratantes. A representação, seja qual for a sua origem, legal ou convencional, obedecerá a preceitos uniformes, que devem resguardar a boa-fé de terceiros, obrigados a tratar com interposta pessoa" (Exposição de motivos do Anteprojeto de Código das Obrigações - Parte Geral (1941) in Código Civil - Anteprojetos I, Brasília, Senado Federal - Subsecretaria de Edições Técnicas, 1989, p. 59).

Todavia, é mister efetuar desde logo um imprescindível reparo à terminologia empregada em ambas as ocasiões: alude-se à representação convencional, quando cremos que seria adequada referência à representação voluntária (ou mais precisamente negocial). De fato, como teremos a oportunidade de evidenciar mais adiante, a representação é manifestação da eficácia decorrente da celebração de um negócio jurídico unilateral de outorga de poderes (dispensada a aceitação do outorgado para que produza seus respectivos efeitos perante este); assim, não nos parece possível, portanto, sustentar a existência de uma representação convencional, eis que despicienda a "aceitação" do representante para que a outorga pretendida 


\section{$\S 8^{\circ}$. A atuação da Comissão Elaboradora e Revisora do Anteprojeto de}

Código Civil. A Comissão Elaboradora e Revisora do Anteprojeto de Código Civil deliberou - por maioria - no sentido da reformulação parcial do capítulo da Parte Geral dedicado à representação; entrevendo acertadamente uma unidade cimeira entre suas variantes legal e negocial, concluiu, todavia, pela oportunidade da manutenção da disciplina desta última em meio à regulamentação do contrato de mandato. Ou seja, em lugar de se promover uma separação entre as modalidades representativas por meio de uma natural tripartição em seções (disposições gerais, da representação legal e da representação negocial), optou o legislador por uma "cômoda" remissão que acaba por turvar os limites entre as categorias acima referidas; e com isso, ficou-se a meio caminho da completa reestruturação sistemática da matéria ${ }^{8}$.

surta efeitos. Nesse sentido, bastante elucidativa a manifestação de E. A. SANCHEZ URITE: "la representación, conforme a su origen, se la clasifica en voluntaria y en legal o necesaria. La representación voluntaria ha sido también denominada erróneamente convencional; debemos alertar sobre esta última denominación, ya que la representación, si bien en algunos casos puede nacer de una relación contractual, la mayoría de las veces ella tendrá por origen el poder, que es un acto jurídico unilateral, que para configurarse no necesita de ninguna aceptación de la persona a la que se lo ha conferido, de modo que de ninguna manera puede llamársela convencional" (Mandato y representacion, Buenos Aires, Abeledo Perrot, 1986, p. 25). Não podemos deixar de notar, ainda, que tal "equívoco" terminológico nos parece, enfim, um resquício daquela profunda imbricação estabelecida, no direito brasileiro, entre a outorga de poderes de representação e o contrato de mandato. Contudo, mesmo a expressão representação voluntária não nos parece imune a críticas - uma vez que os efeitos representativos não derivarão da "vontade" do sujeito de direito representado, mas sim do "negócio jurídico" de outorga de poderes de representação (e daí nossa predileção pela expressão representação negocial).

Finalmente, observe-se que não nos parece que a posição adotada nas duas oportunidades - Anteprojeto da Parte Geral do Código das Obrigações e Anteprojeto da Parte Geral do Código Civil - explicite uma consagração do mandato sem representação entre nós. A bem da verdade, podemos depreender, tão somente, um intuito evidente de destacar a autonomia técnica da relação jurídica decorrente do negócio de outorga de poderes representativos (suscetível de produzir efeitos perante terceiros) - em relação à relação jurídica afeta ao contrato de mandato (propriamente dito). Todavia, como teremos ocasião de abordar oportunamente, é da própria disciplina articulada pelo legislador (no que concerne ao contrato de mandato) que pretendemos depreender o acolhimento - ainda que inconsciente - daquela variante que corresponde a uma de nossas principais ferramentas de trabalho.

${ }^{8}$ Com efeito, pode-se depreender da própria manifestação do relator do Anteprojeto - de Parte Geral do Código Civil - que a maioria da Comissão Elaboradora e Revisora optou por trilhar um caminho diferente, como que a exato meio passo de um completo apartamento sistemático entre os institutos jurídicos envolvidos (contrato de mandato e representação). Nas palavras do referido autor: "a sugestão não foi acolhida pela maioria da Comissão Elaboradora e Revisora. Por isso, no capítulo do Anteprojeto de 1972 relativo à representação, só se disciplinam alguns aspectos gerais da representação legal e da representação convencional, dispondo-se, no art. 120, que 'os requisitos e os efeitos da representação legal são os estabelecidos nas normas respectivas; e os da representação convencional, os da parte especial deste Código"” (J. C. MoReIRA Alves, A parte geral cit. (nota 03), p. 79).

Assim, inicialmente, parece-nos existir quatro graus possíveis de relação entre o instituto do contrato de mandato e a figura da representação negocial: a) junção metodológica, tal qual pretendido pela doutrina que reputa a representação essencial ao contrato de mandato; b) autonomia parcial entre o contrato de mandato e a representação negocial (admitida apenas para que se abra caminho a um tratamento único das representações legal e negocial); c) apartamento pleno sem autonomia sistemática da figura do mandato sem representação (embora se reconheça que o contrato de mandato e a representação negocial não se confundem, não se admite, expressa ou implicitamente, o mandato não representativo); e d) apartamento 
$\S 9^{\circ}$. A existência de um vínculo indissociável entre o contrato de mandato $e$ a representação negocial: as experiências jurídicas estrangeiras. Tomando-se por base o panorama legislativo prevalecente no sistema jurídico de tradição romano-germanocanônica, podemos afirmar que preponderam duas orientações a respeito da relação entre a representação negocial e o contrato de mandato: de um lado, filiados à "tradição" derivada do Code Civil, posicionam-se os adeptos da indissociabilidade entre uma e outro; de outra banda, restam os partidários da corrente germânica - que defendem, por sua vez, a completa autonomia entre os dois institutos jurídicos ora considerados. Desta forma, ainda que a análise do direito comparado não corresponda ao objeto deste estudo, parece-nos de todo evidente que tal dado há de ser levado em consideração - ao menos como elemento informativo de nossa investigação ${ }^{9}$.

pleno com autonomia sistemática da figura do mandato sem representação (reconhece-se a independência metodológica entre o contrato de mandato e a representação negocial, com a admissão da figura do mandato sem representação). Acreditamos que as posições do autor do Anteprojeto Parcial (de Parte Geral) e da Comissão Elaboradora e Revisora correspondam, respectivamente, àquilo que acima mencionamos sob os itens $c$ e $b$. Defendemos, todavia, que a reformulação sistemática promovida pelo legislador de 2002 dá ensejo a uma conclusão consentânea com o item $d$ - sem que se faça necessário um esgarçamento sistemático por meio do apelo à categoria dos contratos inominados (art. 425 do CC/2002).

De todo modo, a se admitir a mais conservadora das hipóteses - a de que o intuito do legislador foi tão somente o de abrir caminho a um tratamento único das representações legal e negocial (b) - já resulta claro que se mostraria de todo conveniente uma divisão entre os preceitos comuns, os afetos à representação legal e os concernentes à representação negocial, sob a forma de seções autônomas - tal como expressamente preceituado pela Lei Complementar nº 95/98 (art. 10, V). Não foi essa, todavia, a orientação adotada pelo legislador, que reputou adequado disciplinar de maneira idêntica as duas modalidades representativas dominadas, no entanto, por princípios peculiares.

9 Observe-se que o emprego da expressão "tradição derivada do Code Civil" revela o papel de extrema relevância deste diploma, em particular no que respeita à difusão de um paradigma estribado em uma autêntica junção metodológica entre os institutos do contrato de mandato e da representação - como mencionamos na nota de rodapé imediatamente anterior. Pelo acolhimento, em geral, do Código Civil francês pelo mundo, cf. F. WIEACKER, Privatrechtgeschichte der neuzeit, trad. port. de António Manuel Botelho Hespanha, História do Direito Privado Moderno, $2^{a}$ ed., Lisboa, Fundação Calouste Gulbenkian, 1993, pp. 385-395; J. GiLISSEN, Introduction Historique au Droit, 1979, trad. port. de António Manuel Botelho Hespanha, Introdução Histórica ao Direito, Lisboa, Fundação Calouste Gulbenkian, 1988, pp. 448-460 (especialmente pp. 456-457); R. DAVID, Les grands systèmes de droit contemporains, $7^{\mathrm{a}}$ ed., Paris, Dalloz, 1978, pp. 62-76; A. M. Hespanha, Panorama histórico da cultura jurídica européia, $2^{\mathrm{a}}$ ed., Mira-Sintra, Publicações Europa-América, 1998, pp. 176-180; Cultura jurídica européia - síntese de um milênio, Florianópolis, Fundação Boiteux, 2005, pp. 376-383; M. J. de AlmEIDA CostA, História do Direito Português, $3^{\text {a }}$ ed., Coimbra, Almedina, 2000, pp. 394-396; A. CASTANHEIRA Neves, Digesta - Escritos acerca do direito, do pensamento jurídico, da sua metodologia e outros, Coimbra, Coimbra Editora, 1995, pp. 181-191; M. R. MARQUES, Codificação e paradigmas da modernidade, Coimbra, Coimbra Editora, 2003, passim; J. BONNECASE, La pensée juridique française de 1804 a l'heure présente - ses variations et ses traits essentiels I, Bordeaux, Delmas, 1933, passim.

Como já observado, o mandato sem representação desempenhou, sob a perspectiva dogmática, um papel de indiscutível importância no processo de dissociação entre o negócio jurídico unilateral de outorga de poderes representativos (procuração) e o contrato de mandato. Por tal razão, a bibliografia ao mesmo concernente nos parece extremamente elucidativa quanto às orientações noticiadas no corpo do texto. A respeito, cf. F. de $S$. L. PessoA Jorge, O mandato sem representação, Lisboa, Edições Ática, 1961, pp. 89-95; F. A. P. LANDIN FILHO, O mandato civil sem representação, Campinas, Agá Juris, 2000, pp. 36-37; C. P. M. CRUZ E TUCCI, 


\section{$\S 10$. A proposta de análise dogmática inerente ao presente estudo:}

afastamento preliminar da representação legal; necessidade de abordagem da relação entre o contrato de mandato $e$ a representação negocial à luz das imbricações desta no regime jurídico daquele. $\mathrm{O}$ que pretendemos com este estudo? Obviamente que, em primeiro lugar, segregar os elementos indispensáveis à definição dos contornos históricos assumidos pelo mandato luso-brasileiro. No entanto, para que possamos nos desincumbir deste compromisso historiográfico central, mostra-se oportuna uma análise dogmática - de feição instrumental e circunscrita às mesmas fontes primárias - voltada ao estudo da relação mantida entre o contrato de mandato e a representação negocial. Desta forma, afastamo-nos desde já - e expressamente - da temática afeta à representação legal (que poderá ser tangenciada, excepcionalmente, em notas de rodapé). Ora, feito este primeiro grande corte quanto ao objeto dogmático de estudo, ainda outro se afigura necessário: pois à vista das grandes proporções dos institutos a serem cotejados, parece-nos adequado evitar um enfrentamento direto de ambos os termos da relação em questão. Assim, em lugar de contemplar ex professo a representação negocial, pretenderemos analisá-la unicamente em suas imbricações sobre a disciplina do contrato de mandato ${ }^{10}$.

Interposição de pessoa nos negócios jurídicos, Tese (Doutoramento) - Faculdade de Direito da Universidade de São Paulo, São Paulo, 2004, pp. 127-146.

Como teremos oportunidade de ressaltar mais adiante, a despeito do reconhecimento conferido ao contrato de mandato (típico), os romanos não admitiam, inicialmente, a representação direta tal qual se verifica atualmente. Ao contrário, em virtude de alguns fatores específicos (dentre os quais se destaca o caráter personalíssimo das obrigações assumidas), havia uma completa dissociação entre estes dois institutos - a ser analisada incidentalmente em meio à parte primeira deste trabalho. Por uma apreciação geral da questão, entre nós, cf. A. CoRREIA-G. SCIASCIA, Manual de Direito Romano e textos em correspondência com os artigos do Código Civil brasileiro I, $2^{\text {a }}$ ed., São Paulo, Saraiva, 1953, pp. 292-294 (especialmente p. 293); J. C. MoReIRA Alves, Direito romano I (História do direito romano - instituições do direito romano: a) Parte Geral; b) Parte Especial: Direito das Coisas), Rio de Janeiro, Forense, 2001, pp. 158-160; T. MARKY, Curso elementar de direito romano, $8^{a}$ ed., São Paulo, Saraiva, 1995, pp. 60-62.

Oportunamente, teremos ocasião de observar de que forma esta originária autonomia entre os institutos do mandato e da representação se obscureceu, dando lugar a uma verdadeira "contaminação" estrutural - tal como aparentemente cristalizada nos Códigos Civis de 1916 e 2002.

${ }^{10}$ A proximidade funcional entre o instituto do contrato de mandato e a figura da representação negocial é tamanha que sobreleva a importância metodológica da variante do mandato desprovida de efeitos representativos diretos (mandato sem representação), pois nela não há sobreposição entre as respectivas eficácias jurídicas. Explicamo-nos: como pretendemos segregar aquilo que de específico existe no contrato de mandato (abrangente a um só tempo de sua variante provida e daquela outra desprovida de representação), um considerável destaque haverá de ser conferido às hipóteses de representação sem mandato e de mandato sem representação.

Ora, como pretendemos evidenciar as peculiaridades da relação entre mandante e mandatário - e que independem da existência de um vínculo de representação por meio do qual este declare em nome daquele resulta evidente a atenção que deveríamos dispensar a tais hipóteses, ainda que empiricamente pareçam menos expressivas do que o paradigma representativo (do tipo contratual).

Pelos sentidos em que se empregam, neste trabalho, os termos sistema, instituição, instituto jurídico, figura e categoria, cf. M. REALE, Lições preliminares de direito, $27^{\mathrm{a}}$ ed., São Paulo, Saraiva, 2002, pp. 190-192. Especificamente no que concerne aos termos instituto e figura, eis a distinção efetuada pelo autor: "as 
$\S 11$. Necessidade de abordagem da relação entre o contrato de mandato e a representação negocial à luz das imbricações desta no regime jurídico daquele: a importância metodológica do mandato sem representação e seu papel como instrumento decisivo de nossa pesquisa. Assim delimitado o objeto dogmático de nosso estudo, para que depuremos a evolução dos contornos eficaciais do mandato luso-brasileiro, será necessário - ainda - considerar com especial atenção a variante do instituto desprovida de efeitos representativos diretos; pois esta, ao lado da "representação sem mandato", parecenos ostentar uma importância metodológica indisfarçável - uma vez que ambas contribuem à discriminação entre os efeitos do negócio jurídico unilateral de outorga de poderes representativos e aqueles derivados do tipo contratual objeto de nossa análise. Mas em que consistiria este instrumento tão importante para nossas investigações, designado pela expressão "mandato sem representação"11?

normas da mesma natureza, em virtude de uma comunhão de fins, articulam-se em modelos que se denominam institutos, como, por exemplo, os institutos do penhor, da hipoteca, da letra de câmbio, da falência, da apropriação indébita. Os institutos representam, por conseguinte, estruturas normativas complexas, mas homogêneas, formadas pela subordinação de uma pluralidade de normas ou modelos jurídicos menores a determinadas exigências comuns de ordem ou a certos princípios superiores, relativos a uma dada esfera da experiência jurídica (...) já o termo figura indica as várias modalidades que pode assumir um instituto (a posse, por exemplo, pode ser de boa ou de má fé etc.)” (pp. 191-192).

11 Dentre os diversos fatores que despertam a atenção do intérprete para o estudo do mandato sem representação, importa-nos - sobretudo - uma razão histórico-metodológica, uma vez que - em razão do caráter secundário da análise dogmática promovida neste estudo - ainda que nos desperte interesse o cenário atual da relação entre o instituto do contrato de mandato e a figura da representação negocial, deflagra-se uma oportunidade sem igual para que se delimite um quadro evolutivo evidenciador da maneira segundo a qual tal relação foi acentuadamente pervertida, ensejando-se, enfim, a transformação da representação negocial em "essência" do contrato de mandato - quando, em verdade, essa não teria sido sua missão em momentos diversificados do evolver histórico.

Observe-se, no entanto, que não se confere neste trabalho a mesma atenção à chamada representação (negocial) sem mandato: pois embora ostente aspectos importantes face à autonomia sistemática preconizada pelo Código Civil de 2002, a delimitação de suas linhas gerais não pode prescindir - à vista do disposto no art. 120 do $\mathrm{CC} / 2002$ - de um prévio exame da disciplina destinada ao tipo contratual objeto de nossas investigações.

Ademais, especificamente quanto à representação sem mandato adstrita a uma causa-função de alienação, farto material de análise pode ser obtido a partir de uma generalização dos princípios da procuração em causa própria, já bastante estudada pela doutrina nacional. Além das referências constantes de notas anteriores (nota 04), cf., por todos, V. de SÁ PEREIRA, Da cláusula 'in rem propriam' nas procurações in Questões de Direito Civil, Criminal e Processual, $2^{\mathrm{a}}$ ed., Rio de Janeiro - São Paulo, Livraria Freitas Bastos, 1958, pp. 102-116; LINO DE MORAES LEME, Mandato em causa própria: da procuração in rem propria como título hábil para a transmissão de direitos reais sobre imóveis. Controvérsia na doutrina e na jurisprudência. Aquisição de domínio pelo próprio mandatário, mediante intervenção em ação divisória. Inadmissibilidade, mormente tendo-se apoiado em instrumento público não levado a registro, sem perfeita individualização do imóvel e sem assinatura de testemunhas. Prevalência do título de quem adquiriu o mesmo bem diretamente do mandante, por meio de escritura pública devidamente formalizada in Revista dos Tribunais 182/40.

Deste modo, consideramos importante ter o mandato sem representação sempre à nossa volta, a fim de que nos auxilie em nosso intento de obter, diretamente, o arcabouço afeto ao contrato de mandato; e indiretamente - pela via negativa - o material normativo concernente à representação negocial. 
$\S$ 12. A segregação estrutural entre o contrato de mandato $e$ a representação negocial à custa da análise do "mandato sem representação": um ganho de perspectiva inarredavelmente atrelado a um custo especulativo diretamente proporcional. Por ora, poderíamos definir o mandato sem representação como o contrato por meio do qual uma das partes incumbe a outra da gestão de seus interesses, sem a outorga de quaisquer poderes de representação; vale dizer, hipótese em que o mandatário age no interesse alheio e à custa do mandante (atuando, todavia, em nome próprio). Pergunta-se: os negócios jurídicos praticados pelo mandatário vinculam a esfera jurídica do mandante? Em relação a terceiros? Em relação àquele? Qual a repercussão de um descumprimento das instruções recebidas quanto aos negócios jurídicos ultimados pelo mandatário? Quais os efeitos da revogação do mandato sobre a esfera jurídica de terceiros de boa-fé? Observese, neste ponto, que as respostas a tais questões dependem fundamentalmente de uma única premissa: a ausência de uma representação (negocial) a imbuir a execução escorreita do contrato de mandato. Assim, a admissão da variante do instituto desprovida de efeitos representativos (diretos) apresenta reflexos dogmáticos bastante significativos. No entanto, há que se observar que a segregação estrutural entre o contrato de mandato e a representação negocial pode resolver algumas questões, substituindo-as, todavia, por uma única outra (de dificílima solução): apartadas as estruturas jurídicas referidas, qual seria, enfim, a "nota típica" do contrato de mandato? Em outras palavras: que impacto a admissão da figura do mandato sem representação teria na definição da "essência" deste instituto jurídico? É exatamente este um ponto a que o presente estudo não pretende oferecer resposta definitiva - conquanto a questão venha a ser abordada, incidentalmente, em alguns momentos de nossa incursão historiográfica ${ }^{12}$.

\footnotetext{
${ }^{12} \mathrm{Na}$ definição apresentada por um dos maiores especialistas no tema: "podemos definir o contrato de mandato sem representação como aquele pelo qual uma pessoa (mandante) confia a outra (mandatário) a realização, em nome desta mas no interesse e por conta daquela, de um acto jurídico relativo a interesses pertencentes à primeira, assumindo a segunda a obrigação de praticar esse acto" (F. de S. L. PESSOA JORGE, $O$ mandato cit. (nota 09), p. 411). Em sentido similar, cf. F. A. P. LANDIN FILHO, O mandato cit. (nota 09), pp. 18-19; C. P. M. CRUZ E TUCCI, Interposição cit. (nota 09), pp. 117-123.

Como observado no corpo do texto, aos reflexos dissociativos da admissão do "mandato sem representação" está atrelado um inarredável problema subseqüente: ora, se a representação deixa de ser a nota típica do contrato de mandato, qual passará a ser o elemento caracterizador de sua essência? Seria a gratuidade, tal qual pretendem os alemães? Teremos oportunidade de opinar em sentido negativo, uma vez que entre nós não causa qualquer repulsa a figura do mandato oneroso (art. 658 do CC/2002). Seria o objeto (tão somente a prática de atos jurídicos pelo mandatário), como pretendem os portugueses? Ao contrário da doutrina especializada a respeito do tema - F. de S. L. PeSSOA JORGE, $O$ mandato cit. (nota 09), p. 411; F. A. P. LANDIN FILHO, O mandato cit. (nota 09), p. 113; C. P. M. CRUZ E TUCCI, Interposição cit. (nota 09), pp. 117 (nota 210) - acreditamos que não. E para repelir tal solução tanto bastaria a referência ao gerente empregado - que pratica atos jurídicos no interesse da empresa, sem que eventual contrato de trabalho se descaracterize (para permitir uma qualificação orientada à hipótese de um contrato de mandato) - quanto o argumento de
} 
autoridade constante da lição de E. EsPíNOLA: “mandato é o contrato pelo qual uma pessoa (mandatário) se obriga a realizar um ou mais atos jurídicos por conta de outra (mandante). No direito romano, no direito comum e em vários códigos modernos, o mandato não se limita à incumbência de praticar atos jurídicos, podendo ter por objeto a realização de qualquer ato material (...) o nosso Código fala em praticar atos, de modo geral, sem precisar que devem ser atos jurídicos, como o direito romano e vários códigos modernos (...) [como] o francês, o alemão, o suíço das Obrigações, o polonês das Obrigações e alguns outros" (Dos contratos nominados no direito civil brasileiro, Rio de Janeiro, Gazeta Judiciária Editora, 1953, pp. 322323).

Aqui se faz necessário observar que a investigação sintetizada neste estudo se insere em um contexto mais amplo, relacionado à própria linha de pesquisa adotada por seu autor; com efeito, somente em outra oportunidade poderemos nos defrontar - "ex professo" - com a questão da "nota típica" do contrato de mandato. De fato, tal investigação subseqüente demandará - efetivamente - a utilização do material apresentado nesta ocasião; no entanto, seu objeto de investigação será substancialmente outro, transcendendo a análise puramente estrutural do contrato de mandato, a fim de que se contemple aquela parcela de realidade subjacente ao tipo contratual referido. Neste sentido, fazemos nossas, pois, as seguintes palavras de $T$. ASCARELLI: "è forse un residuo giusnaturalistico quello che trattiene e ha trattenuto i giuristi da uno studio di questa realtà, come che sdegnosi dell'atteggiamento che la pratica assumerà rispetto al sistema normativo disegnato, che, in quella che se ne pretende una interna logica, dovrebbe trovare una giustificazione che renderebbe inutile l'umile indagine della realtà. Ed invero concependo, con un suo giusnaturalismo a sua volta grossolano, il sistema come mero dispiegamento logico di principî e ravvisando allora il processo del diritto sotto il profilo di un affinamento che si vuole affidato alla migliore identificazione di questi e a un miglior sviluppo logico delle conseguenze, è inevitabile che si passi a trascurare un'indagine dell'attuale realtà, chè il diritto viene allora sostanzialmente posto fuori dalla storia" (Per uno studio della realtà giuridica effetuale in Problemi giuridici II, Milano, Casa Editrice Dott. A. Giuffrè, 1959, p. 803).

De todo modo, não nos parece inconveniente adiantar algumas observações a respeito deste estudo posterior, uma vez que intimamente relacionado - como que um seu natural desdobramento - à presente pesquisa. Assim, haveremos de perquirir sobre a prestabilidade do contrato de mandato no comércio jurídico: "afinal, para quê serve o contrato de mandato?". Note-se que essa indagação subjaz mesmo a este estudo, uma vez que acreditamos que a manutenção de um simples nomen juris ao longo de tantos séculos só se tenha dado em razão da força daquela intuição jurídica cristalizada no espírito do povo (Volksgeist) - o qual deve ser objeto, por sua vez, de uma maior atenção por parte dos intérpretes.

Neste sentido, uma ampliação de perspectiva - por meio da qual se transcenda da estrutura à função - se fará necessária, tal qual advertiram T. ASCARELLI e E. BETTI, em meio à dogmática jurídica aplicada e à teoria geral do negócio jurídico [respectivamente em suas obras Negócio jurídico indirecto (Lisboa, Jornal do Fôro, 1965, pp. 9-10) e Teoria generale cit. (nota 04), pp. 171-211)]. No âmbito da teoria geral do direito - na segunda metade da década de setenta do século passado - N. BoBBio destacava a importância de uma análise jurídica que levasse em consideração não apenas a conformação dos institutos jurídicos, mas inclusive sua contextualização; assim o referido autor sintetiza a aludida necessidade de uma análise funcional do direito (a extrapolar a consideração das simples estruturas jurídicas): "se si applica alla teoria del diritto la distinzione tra approccio strutturalistico e approccio funzionalistico, di cui fanno grande uso gli scienziati sociali per differenziare e classificare le loro teorie, non sembra dubbio che nello studio del diritto in generale (di cui si occupa la teoria generale del diritto) abbia prevalso in questi ultimi cinquant'anni il primo sul secondo. Senza indulgere alle etichette, sempre pericolose per quanto utili, credo si possa dire con una certa tranquilità che nel suo sviluppo dopo la svolta kelseniana la teoria del diritto abbia ubbidito assai più a suggestioni strutturalistiche che non a suggestioni funzionalistiche. In parole povere, coloro che si sono dedicati alla teoria generale del diritto si sono preoccupati molto di più di sapere 'come il diritto sai fatto' che 'a che cosa serva'. La conseguenza è stata che l'analisi strutturale è stata condotta molto più a fondo dell'analisi funzionale" (Dalla struttura alla funzione - nuovi studi di teoria del diritto, Milano, Edizioni di Comunità, 1977, p. 63). Necessário destacar que enquanto os dois últimos autores se preocuparam em efetuar estudos à luz de abordagens eminentemente abstratas, o primeiro voltou sua atenção aos desafios oferecidos por uma realidade penetrante - parecendo-nos que sua análise funcional seja um tanto mais "aplicada". Por tal razão, sua influência nos será decisiva quando viermos a investigar a "nota típica" do contrato de mandato - já libertos dos limites metodológicos que nos atrelam à presente incursão historiográfica (de cunho, inclusive, preparatório).

Destaque-se que, conquanto já tenhamos uma intuição sobre aquela que nos parece ser a "essência" (não representativa) do contrato de mandato, para que possamos bem articulá-la necessitaremos de submetê-la ao crivo de uma análise mais comprometida com a realidade jurídica por nós tão enaltecida: será necessário efetuar uma investigação (ainda que superficial) sobre a causa dos contratos (e em particular acerca da causa-função), a fim de que possamos aplicar o resultado de nossas pesquisas - inclusive aquele que se 


\section{$\S$ 13. Estabelecimento do pressuposto metodológico fundamental e}

articulação do iter de pesquisa; definição dos resultados a serem obtidos através da análise. Ora, para que possamos oferecer uma resposta satisfatória a cada uma das indagações acima apresentadas, faz-se necessário destacar que nosso trabalho somente poderá ser bem-sucedido se lançarmos mão adequadamente do principal instrumento dogmático de nossa investigação historiográfica - vale dizer, o "mandato sem representação". Por tal razão, o emprego desta ferramenta não se poderá converter em elemento panfletário de um discurso difamatório contra a variante representativa do

depreende do presente estudo - à específica diagnose da "nota típica" do contrato de mandato. Para isso, será imprescindível lançar mão de alguns textos elementares, dentre os quais podemos citar - além dos já referidos nesta nota de rodapé - os seguintes: L. CARIOTA FERRARA, Il negozio cit. (nota 04), pp. 592-634; M. AlbaladeJo, El negocio juridico, Barcelona, Librería Bosch, 1958, pp. 195-226; J. A. DORAL - M. A DEL ARCO, El negocio juridico, s.l., Trivium, 1982, pp. 187-234; J. L. DE LOS MozOS, El negocio juridico (estudios de derecho civil), Madrid, Editorial Montecorvo, 1987, pp. 155-298/433-459/517-553; F. GALGANO, Il negozio cit. (nota 04), pp. 85-102; V. SCIALOJA, Negozi cit. (nota 04), pp. 89-95; P. FEDELE, Causa (diritto canonico), in ED 6 (1974), pp. 577-580; E. CORTESE, Causa (diritto intermedio), in ED 6 (1974), pp. 535-547; G. GRosso, Causa (diritto romano), in ED 6 (1974), pp. 532-535; M. GIORGIANNI, Causa (diritto privato), in ED 6 (1974), pp. 547-576. Entre nós, cf. J. ABREU, O negócio jurídico e sua teoria geral, São Paulo, Saraiva, 1984, pp. 126-157; C. da P. U. MiRAndA, Teoria geral do negócio jurídico, São Paulo, Atlas, 1991, pp. 155-164; M. C. BodIN DE MORAES, A causa dos contratos, in Revista Trimestral de Direito Civil 21 (2005), pp. 95-119; A. JUNQUEIRA DE AZEVEDO, Negócio jurídico e declaração negocial (noções gerais e formação da declaração negocial), Tese (Titularidade) - Faculdade de Direito da Universidade de São Paulo, São Paulo, 1986, pp. 121-129. Por uma abordagem monográfica, cf. V. TABORDA FERREIRA, Do conceito de causa dos actos jurídicos, Tese (Doutoramento) - Universidade de Lisboa, Lisboa, 1946, passim.

Embora - por óbvio - não nos pareça oportuno declinar aqui qual seja (em nossa opinião) a "nota típica" do contrato de mandato, podemos desde já aguçar o espírito crítico do interessado: o que poderia haver em comum entre dois tipos contratuais tão distintos como a sociedade e o mandato? Haveria possibilidade de se aplicar - indiscriminadamente - a "exceptio non adimpleti contractus" a ambas as hipóteses? Note-se que voltaremos ao tema constantemente - ainda durante o curso deste estudo - em meio à investigação de seus reflexos em meio às fontes primárias do mandato luso-brasileiro.

Para o momento, resta-nos tão somente advertir para o fato de que não nos parece existir qualquer contradição entre a segregação - estrutural - que pretendemos empreender nesta obra e uma análise funcional a ser desenvolvida noutra oportunidade.

Da mesma forma, parece inexistir também qualquer contradição entre aquela dissociação estrutural e a junção funcional das resultantes do processo de "destilação" jurídica a que nos referimos em nota de rodapé anterior (nota 05). Apenas pretendemos ratificar que a miscibilidade funcional entre os mesmos não pode obscurecer sua autonomia estrutural.

Deste modo, nossa linha de pesquisa - em função da investigação sobre a nota típica do contrato de mandato - haverá de se desenvolver em duas etapas distintas: em um primeiro momento, buscaremos desenvolver uma análise estrutural da eficácia jurídica do contrato de mandato - dele afastando a matéria concernente à representação negocial sob a mesma rubrica situada -; é este, pois, o objeto dogmático desta obra. Em estudo vindouro, sob um enfoque distinto, teremos de abordar a perspectiva funcional do instituto, com o fito de evidenciar as especificidades do tipo contratual referido. Para que somente então possamos, finalmente, retornar ao estudo da estrutura do contrato de mandato, a fim de que seja efetuada uma nova apreciação de sua conformação própria, já orientada pelos resultados decorrentes de sua análise funcional. Como podemos ver, tal abordagem se fará em estágios bastante distintos, em meio aos quais se buscará promover um estudo comprometido com a teoria geral do direito, com a história do direito e com a dogmática jurídica (mais afeta ao direito privado); pois acreditamos que somente a partir de uma investigação norteada por tais balizas poderemos trilhar um caminho seguro, que nos conduza, enfim, à nota típica do contrato de mandato - e à eficácia jurídica dele decorrente. 
instituto. Assim, ao final desta análise, pretenderemos averiguar quais sejam os dispositivos da Parte Especial do Código Civil que, em verdade, concernem à representação negocial; para que - somente a partir de tais conclusões - possamos definir o repertório normativo atrelado à eficácia jurídica do tipo contratual objeto de nossa análise - relegando, então, a uma ocasião futura sua respectiva coordenação em estrutura "funcionalmente" comprometida com a "nota típica" do contrato de mandato ${ }^{13}$.

\section{$\S$ 14. Imprescindibilidade do presente estudo histórico: a vinculação entre} os esquemas jurídicos e os contextos culturais em que são aplicados. Ocorre que não bastassem as dificuldades de uma abordagem dogmática do tema, já pudemos enunciar que as orientações adotadas pelos ordenamentos estrangeiros não são uniformes. E a um panorama de tal modo intrincado se soma outro fator de complicação: a importância de um tratamento histórico específico - capaz de evidenciar a evolução experimentada pelo instituto estudado ao longo dos séculos. Como pretendemos demonstrar ao longo deste trabalho, se é notório um significativo engastamento entre determinados institutos jurídicos e a realidade social que lhes é subjacente, tal se evidencia de um modo sobremaneira particular no que respeita ao contrato de mandato - inclusive no contexto luso-brasileiro ${ }^{14}$.

\footnotetext{
${ }^{13}$ Destacando a oportunidade de um estudo sobre as peculiaridades concernentes à eficácia do mandato sem representação, eis a manifestação de F. de S. L. PESSOA JORGE (constante do prefácio à sua obra referida ao longo do presente trabalho): "a presente monografia restringe-se aos aspectos fundamentais do mandato sem representação. Às duas partes em que se encontra dividida, seguia-se, no plano inicial, uma terceira, dedicada ao estudo descritivo e sistemático do regime legal deste contrato, com especial referência aos desvios que resultam da inexistência de representação. Sucedeu, porém, que as matérias compreendidas nas duas primeiras partes exigiram um tratamento muito mais alongado do que havíamos previsto, forçando-nos a deixar para outro volume aquela terceira parte. Não obstante tratar-se de um estudo inacabado, cremos que os problemas versados neste volume apresentam interesse teórico e prático suficiente para justificar a sua publicação" ( $O$ mandato cit. (nota 09$)$, p. 11).

Conquanto a análise do autor se circunscreva ao mandato sem representação, devemos observar que, mesmo quanto à referida variante, dele divergimos em pontos substanciais; quanto a alguns aspectos, aliás, consideramos necessários reparos técnicos extremamente profundos - como naquilo que concerne à temática da "causa-função" do contrato de mandato (a respeito da qual somente nos debruçaremos noutra oportunidade, conforme referido em nota imediatamente anterior).

No entanto, o que - por ora - mais nos interessa é que da leitura da monografia citada pode-se depreender que seu autor lança mão da história do direito para desestruturar o mandato representativo, viabilizando-se, de modo eloqüente, a dissociação entre o contrato de mandato e a representação negocial.

Contudo, acreditamos que a evolução histórica deste instituto deva ser utilizada não como mera forma de apresentação do tema dogmático, mas sim como poderoso fator de contribuição para o deslinde da questão mais complicada que nossa linha de pesquisa pretende solver - vale dizer, a diagnose da "nota típica" do instituto em referência.

${ }^{14}$ Note-se que este engastamento a que fazemos referência não erige o instituto jurídico ao patamar de uma instituição. Na definição de M. REALE, "quando um instituto jurídico corresponde, de maneira mais acentuada, a uma estrutura social que não oferece apenas uma configuração jurídica, mas põe também como realidade distinta, de natureza ética, biológica, econômica etc., tal como ocorre com a família, a propriedade, os sindicatos etc., costuma-se empregar a palavra instituição" (Lições cit. (nota 10), p. 191).
} 
$\S 15$. A separação conceitual entre o contrato de mandato $e$ a representação negocial no direito romano. Entre os romanos, por exemplo, a representação negocial não fora conhecida desde cedo, entrevendo-se suas primeiras manifestações em uma atividade (dos pretores, da jurisprudência e inclusive dos imperadores) progressivamente desenvolvida durante todo o período clássico (sécs. II a.C. a III d.C.); mas a despeito de um surgimento tardio desta última, já podemos entrever algum tempo antes um contrato típico de mandato (séc. III a.C.). Ora, tal observação poderia nos servir tão somente como corroboração empírica do pressuposto dogmático aqui adotado (a "viabilidade" da dissociação entre os institutos envolvidos em nossa investigação); mas em realidade ela parece apresentar uma utilidade oblíqua muito maior do que esta (e de vital importância no contexto de nossa linha de pesquisa): ora, em que medida as fontes romanas poderiam nos ser úteis, portanto, para a revelação daquela "essência" do contrato de mandato ${ }^{15}$ ?

De todo modo, a história do direito demonstra, de modo bastante eloqüente, quão necessário se faz o estudo da realidade social subjacente (à qual há de se aplicar um instituto jurídico qualquer). Tome-se como exemplo a implantação do sistema de sesmarias no Brasil: originalmente concebido para solucionar uma crise de abastecimento que assolava Portugal no último quartel do século XIV, o instituto das sesmarias foi posteriormente utilizado por D. João III para a concatenação de finalidades consideravelmente distintas vale dizer, a colonização do Brasil. Ocorre que o cenário ao qual haveria de se aplicar o instrumento jurídico (já consagrado pela tradição reinícola) era distinto daquele para o qual havia sido forjado; e é possível que a diversidade de circunstâncias tenha sido um fator decisivo quanto aos resultados obtidos - por meio da aplicação do mesmo instrumento jurídico - no Brasil. A respeito, cf. M. CAETANO, As sesmarias no direito luso-brasileiro in M. CAetano, J. C. Moreira Alves, Clóvis do Couto E Silva, M. J. de Almeida Costa, Estudos de direito civil luso-brasileiro (I Jornada Luso-Brasileira de Direito Civil), São Paulo, Revista dos Tribunais, 1980, pp. 9-28; J. R. de LIMA LOPES, O Direito na História - lições introdutórias, São Paulo, Max Limonad, 2000, pp. 353-356; R. CIRNE LIMA, Pequena história territorial do Brasil - sesmarias e terras devolutas, $4^{\text {a }}$ ed., Brasília, Escola de Administração Fazendária, 1988, pp. 15-32.

Ora, o que se diz a respeito da implantação do sistema sesmarial no Brasil se aplica a tantas outras experiências em que o legislador dá de ombros às demandas ostentadas pela própria realidade social. Assim, acreditamos que todo e qualquer estudo histórico - principalmente aquele afeto à historiografia interna deva se pautar por um compromisso com as necessidades concretas ostentadas pelo contexto social subjacente. Voltaremos a tal ponto logo adiante.

${ }^{15}$ No sentido da inadmissibilidade de uma representação direta (imediata) pelo direito romano clássico, cf. S. PEROZZI, Istituzioni di diritto romano: obbligazioni ed azioni - diritto ereditario - donazioni II, Firenze, G. Barbera Editore, 1908, pp. 246-247; V. ARANGIO-RUIZ, Corso di istituzioni di diritto romano (diritti reali e di obbligazione), Napoli, Nicola Jovene E. C. Editore, 1921, p. 243; Istituzioni di diritto romano, 14 ${ }^{\mathrm{a}}$ ed., Napoli, Casa Editrice Dott. Eugenio Jovene, 1978, p. 94; P. F. GIRARD, Manuel élémentaire de droit romain, $4^{\mathrm{a}}$ ed., Paris, Arthur Rousseau Éditeur, 1906, p. 583; F. SERAFINI, Istituzioni di diritto romano comparato al diritto civile patrio: Delle obbligazioni - diritti di famiglia - diritto di eredità, $7^{\mathrm{a}}$ ed., Modena, Archivio Giuridico, 1899, p. 152; R. de FRESQUET, Traité élémentaire de droit romain II, Paris, A. Maresq et Dujardin Librairies, s.d., p. 192; E. CosTA, Storia del diritto romano privato - dalle origini alle compilazioni giustinianee, Milano-Torino-Roma, Fratelli Bocca Editori, 1911, pp. 449-456; S. DI MARzO, Istituzioni di diritto romano, Milano, Dott. A. Giuffrè, 1938, pp. 66-67; G. LEPOINTE, Les obligations en droit romain, Paris, Editions Domat Montchrestien, 1955, p. 105; J. CRETELlA JÚNIOR, Curso de direito romano - o direito romano e o direito civil brasileiro, $24^{a}$ ed., Rio de Janeiro, Forense, 2000, p. 197; P. VocI, Manuale di diritto romano - Parte generale II, Milano, Dott. A. Giuffrè, 1998, p. 364; Piccolo manuale di diritto romano I Parte generale, Milano, Dott. A. Giuffrè Editore, 1979, p. 321; A. D'ORS, Elementos de derecho privado romano, $2^{a}$ ed., Pamplona, Ediciones Universidad de Navarra, 1975, pp. 239-240; A. BuRdESE, Manuale di diritto privato romano, Torino, Unione Tipografico-Editrice Torinese, 1964, p. 559; M. KASER, Römisches 
Privatrecht, trad. port. de Samuel Rodrigues e Ferdinand Hämmerle, Direito Privado Romano, Lisboa, Fundação Calouste Gulbenkian, 1999, pp. 88-89; E. PETIT, Tratado elemental de derecho romano, Buenos Aires, Editorial Albratros, 1958, p. 521; A. E. GIFFARD, Droit romain et ancien droit français, $3^{\mathrm{a}}$ ed., Paris, Dalloz, 1970, p. 82; A. GuARINO, Profilo del diritto romano, $8^{\mathrm{a}}$ ed., Napoli, Jovene, 1994, pp. 181-182; Diritto privato romano, $12^{\mathrm{a}}$ ed., Napoli, Editore Jovene, 2001, pp. 403-404; J. C. de MATOS PeIXOTO, Curso de Direito Romano I - Partes introdutória e geral, Rio de Janeiro, Companhia Editora Fortaleza, 1950, pp. 346-347; E. Chamoun, Instituições de direito romano, $3^{\mathrm{a}}$ ed., Rio de Janeiro, Forense, 1957, p. 386; G. SCIASCIA, Sinopse de direito romano com tábuas e textos traduzidos, $3^{\mathrm{a}}$ ed., São Paulo, Saraiva, 1972, pp. 35-36; P. Bonfante, Istituzioni di diritto romano, $10^{\mathrm{a}}$ ed., Torino, G. Giappichelli, 1946, p. 78; Diritto romano, Milano, Dott. A. Giuffrè Editore, 1976, pp. 292-293; E. VOLTERRA, Istituzioni di diritto privato romano, trad. esp. de Jesús Daza Martínez, Instituciones de derecho privado romano, Madrid, Editorial Civitas, 1986, p. 170; F. Schulz, Classical roman law, trad. esp. de José Santa Cruz Teigeiro, Derecho romano clásico, Barcelona, Bosch, 1960, pp. 529-534; G. PUGLIESE, Istituzioni di diritto romano, $2^{\mathrm{a}}$ ed., Torino, G. Giappichelli, 1990, pp. 247-248; A. SANTOS Justo, Direito privado romano I - Parte Geral (introdução, relação jurídica, defesa dos direitos), Coimbra, Coimbra Editora, 2000, p. 202; F. Betancourt, Derecho romano clásico, Sevilla, Universidad de Sevilla, 2001, p. 624; B. NichOLAS, An introduction to roman law, Oxford, Clarendon Press, 1962, p. 189; U. AlvarEZ SuAREZ, Instituciones de derecho romano I (introducción histórica, conceptos fundamentales, hechos y negocios jurídicos), Madrid, UNED, 1973, p. 216; A. DOVERI, Istituzioni di diritto romano - acresciuta per note di confronto col codice civile italiano II, $2^{\mathrm{a}}$ ed., Firenze, Le Monier, 1866, p. 229 (nota 1); É. CUQ, Institutions juridiques des romains, Paris, Librairie Plon, 1917, p. 403; A. SAliVAS - A. BELlan, Éléments de droit romain II, Paris, A. Giard \& E. Brière, 1884, p. 293; C. DEMANGEAT, Cours élémentaire de droit romain II, $3^{\mathrm{a}}$ ed., Paris, 1876, p. 383; L. ARNDTS, Lehrbuch der Pandekten, trad. it de Filippo Serafini, Trattato delle pandette I, $3^{\mathrm{a}}$ ed., Bologna, Tipi Fava e Garagnani, 1877, pp. 145-148; G. PACCHIONI, Corso di diritto romano II, Innsbruck, Libreria Accademica Wagner, 1905, pp. 182-183 (entrevendo, antes mesmo de S. RICCOBONO, uma regra no sentido da admissão da representação direta em períodos mais adiantados da evolução histórica do direito romano); G. RongA, Corso di istituzioni di diritto romano: teoria delle obbligazioni II, $2^{\mathrm{a}}$ ed., Torino, Unione Tipografico-Editrice, 1899, p. 129; V. SCIALOJA, Corso di istituzioni di diritto romano, Roma, Off. Tip. di G. Bolognesi, 1912, p. 358; E. LAGRANGE, Manuel de droit romain ou explication des institutes de Justinien par demandes et réponses, $8^{\mathrm{a}}$ ed., Paris, J.-B. Mulot, 1861, p. 459; C. MAYNZ, Cours de droit romain II, Bruxelles, Librairie Polytechnique d'Aug. Decq, 1870, pp. 235-236; H. DERnBURG, Obligationenrecht, trad. it. de Francesco Bernardino Cicala, Diritto delle obbligazioni, Torino, Fratelli Bocca, 1903, p. 507-509, G. AmAzonAs DE FigueIREDO, Tratado de Direito Romano, Rio de Janeiro, Freitas Bastos, 1930, pp. 235-236; C. FERrINI, Manuale di Pandette, $3^{\text {a }}$ ed., Milano, Società Editrice Libraria, 1917 , pp. 154-156; J. P. MolitoR, Les obligations en droit romain avec l'indication des rapports entre la législation romaine et le droit français II, $2^{\mathrm{a}}$ ed., Paris, Auguste Durand, 1867, p. 141; R. von MAYR, Römische Rechsgeschichte, trad. esp. de Wenceslao Roces, Historia del derecho romano, Barcelona, Editorial Labor, 1926, pp. 215-218; W. W. BuCKLAND - A. D. MCNAIR, Roman law \& common law - a comparison in outline, Cambridge, Cambridge University Press, 1936, p. 168; G. BONJEAN, Explication méthodique des Institutes de Justinien II, Paris, A. Durand et Pedone-Lauriel, 1880, p. 488; F. K. von SAVIGNY, System des heutigen römischen Rechts, trad. it. de Vittorio Scialoja, Sistema del diritto romano attuale III, Torino, Unione Tipografico-Editrice Torinese, 1900, p. 116; Das Obligationenrecht, trad. it. de Giovanni Pacchioni, Le obbligazioni II, Torino, Unione Tipografico-Editrice Torinese, 1915, p. 21; R. von JHERING, Études complémentaires de l'esprit du droit romain V-IX, Paris, Librairie A. Marescq, 1903, pp. 123-132. Em sentido diverso, S. RICCOBONO observa que enquanto o direito quiritário vedava terminantemente a representação direta, já no direito clássico esta passou a ser admitida, sobretudo à custa da atuação dos pretores, dos jurisconsultos e mesmo de uma série de provisões imperiais (Lineamenti della dottrina della rappresentanza diretta in diritto romano, in Studi di diritto commerciale in onore di Cesare Vivante II, Roma, Società Editrice del Foro Italiano, 1931, pp. 127-157, especialmente pp. 131, 140, 144 e 146). Ainda em sentido (aparentemente) diverso, merece destaque a singular posição de F. MACKELDEY, a qual será objeto de análise mais detida em meio às notas seguintes - às quais se remete o interessado.

Neste cenário desponta a indagação: o que é que existe em comum entre o mandato romano e a sua variante atual? Pode-se entrever alguma similitude que determine a conservação (sob um mesmo nomen juris) de estruturas jurídicas tão distintas? Cremos, sinceramente, que sim. Em verdade, acreditamos que somente uma investigação histórica a respeito da "nota típica" do contrato de mandato poderá explicar o traço peculiar que afeta a sua eficácia, dominada por três elementos que nos parecem cruciais: a confiança (entre as partes) que lhe serve de fundamento; o escopo de viabilizar uma gestão colaborativa; e a instrumentalidade (da avença em relação à própria gestão confiada). 


\section{$\S 16$. A orientação adotada pelo direito lusitano medieval e pelas sucessivas}

Ordenações do Reino de Portugal. E qual não seria a surpresa do pesquisador ao descobrir que o direito lusitano muito pouco dispôs a respeito da variante extrajudicial do mandato? Ora, não fosse suficientemente notável a oportunidade de um aproveitamento de toda a experiência jurídica romana a respeito do instituto, o direito das Ordenações do Reino de Portugal foi ainda mais longe, não perdendo a oportunidade de referendar o direito imperial naquilo que pudesse ser útil aos interesses de uma monarquia em contínua construção; de fato, teremos a oportunidade de perceber de que maneira - especificamente no que toca ao contrato de mandato - o direito castelhano intermediou a transmissão de um legado romano aos praxistas da época imediatamente anterior ao advento do iluminismo jurídico português ${ }^{16}$.

No entanto, não pode confundir o estudo do direito romano que se fará neste trabalho com outro que pretendemos empreender na segunda etapa das investigações que informam nossa linha de pesquisa: nesta obra, a abordagem que se fará do direito romano tenciona exclusivamente divisar a relação mantida entre o "mandatum" e a eficácia representativa direta - eventualmente - admitida em meio às fontes romanas. Todavia, na segunda etapa de nossas pesquisas - já no contexto de um outro trabalho - buscaremos estudar, de modo mais exauriente, a eficácia do tipo contratual acima referido; pois estamos convictos de que mais do que um simples elemento informativo, esta abordagem posterior consistirá no único instrumento de orientação (suficientemente seguro) em nossa investigação sobre a "essência" do referido instituto jurídico.

${ }^{16} \mathrm{O}$ caráter lacunoso das sucessivas Ordenações do Reino de Portugal, bem como a importância do direito subsidiário como mecanismo de "colmatação" das lacunas ostentadas pelo sistema, foram ambos assunto de diversas manifestações doutrinárias, dentre as quais, para o momento, podemos citar: M. J. de ALMEIDA Costa, História cit. (nota 09), pp. 308-317; Fundamentos Históricos do Direito Brasileiro in M. CAETANO J. C. Moreira Alves - C. do Couto e Silva - M. J. de Almeida Costa, Estudos de Direito Civil Brasileiro e Português (I Jornada Luso-Brasileira de Direito Civil), São Paulo, Revista dos Tribunais, 1980, pp. 103125; La présence d'Accurse dans L'Histoire du Droit Portugais in Boletim da Faculdade de Direito da Universidade de Coimbra 41 (1965), p. 57; M. CAetano, História do Direito Português (sécs. XII - XVI) seguida de Subsídios para a história das fontes do direito em Portugal no séc. XVI, $4^{\mathrm{a}}$ ed., Lisboa, Verbo, 2000, p. 547-551; B. Antunes, Apontamentos para a cadeira de História do Direito Português, Coimbra, Livraria Neves Editora, s.d., pp. 137-138; CÂNDIDo MENDES DE AlMEIDA, Código Philippino ou Ordenações e Leis no Reino de Portugal recopiladas por mandado d'El-Rey D. Philippe I, 14 ${ }^{\mathrm{a}}$ ed., Rio de Janeiro, Typographia do Instituto Philomathico, 1870, p. XXVI; L. C. de AZEVEDO, O Reinado de D. Manuel e as Ordenações Manuelinas in Revista da Faculdade de Direito da Universidade de São Paulo 95(2000), pp. 24 e 26; J. C. MoreIRA Alves, Panorama do Direito Civil Brasileiro: das Origens aos Dias Atuais in Revista da Faculdade de Direito da Universidade de São Paulo 88 (1993), pp. 188-189; I. M. PovEDA VELASCO, Ordenações do Reino de Portugal in Revista da Faculdade de Direito da Universidade de São Paulo 89 (1994), pp. 11-67; F. C. Pontes De Miranda, Fontes e Evolução do Direito Civil Brasileiro, Rio de Janeiro, Pimenta de Mello \& C., 1928, p. 62; O. GoMES, Raízes Históricas e Sociológicas do Código Civil Brasileiro, Salvador, Publicações da Universidade da Bahia, 1958, pp. 9-13; A. SAntos Justo, O Direito Brasileiro: Raízes Históricas in Revista Brasileira de Direito Comparado s/ref., pp. 4-6; A. A. VIEIRA CURA, Direito Romano e História do Direito Português: Casos Práticos Resolvidos e Textos, Coimbra, Coimbra Editora, 1995, pp. 232-238; N. E. Gomes DA Silva, História do Direito Português - Fontes de Direito, $3^{\mathrm{a}}$ ed., Lisboa, Fundação Calouste Gulbenkian, 2000, pp. 479-492; O sistema de fontes nas Ordenações Afonsinas in Scientia Iuridica 29 (1980), pp. 429-455; G. BRAGA DA CRUZ, Formação Histórica do Moderno Direito Privado Português e Brasileiro in Obras Esparsas II - Estudos de História do Direito - Direito Moderno $1^{a}$ parte, Coimbra, Imprensa da Universidade, 1981, pp. 25-75; O Direito Subsidiário na História do Direito Português in Obras Esparsas II - Estudos de História do Direito - Direito Moderno - $2^{a}$ parte, Coimbra, Imprensa da Universidade, 1981, pp. 245-436; P. J. de MELlo FrEIRE dos Reis, Historiae Juris civilis lusitani liber singularis, trad. port. de Miguel Pinto de Menezes, História do Direito Civil Português in 


\section{$\S 17$. A origem iluminista da junção metodológica entre a representação}

negocial $e$ o contrato de mandato. A despeito dos méritos de qualquer estudo histórico consciencioso, não podemos negar a inestimável valia que uma tal espécie de investigação tem quando aplicada à evolução do contrato de mandato na Europa e na América Latina; sua importância, aliás, é sobrelevada pela "ruptura" (moderna) operada quanto à disciplina

Boletim do Ministério da Justiça 174 (1968); M. PAUlO MERÊA, Resumo das Lições de História do Direito Português, Coimbra, Coimbra Editora, 1925, pp. 147-148; R. R. NoGUEIRA, Prelecções de direito pátrio in O Instituto 12 (1865), pp. 125-126; M. A. COELHO DA RoCHA, Ensaio sôbre a História do Governo e da Legislação de Portugal para servir de introducção ao estudo do direito pátrio, $4^{\mathrm{a}} \mathrm{ed}$., Coimbra, Imprensa da Universidade, 1861, pp. 125-126, 129, 191; H. da GAMA BARros, História da Administração Pública em Portugal nos séculos XII a XV I, 2a ed., Lisboa, Livraria Sá da Costa - Editora, 1945, pp. 134-135; A. M. HESPANHA, História das Instituições - Épocas Medieval e Moderna, Coimbra, Almedina, 1982, pp. 526-527; J. G. B. CÂMARA, Subsídios para a História do Direito Pátrio, Rio de Janeiro, Livraria Brasiliana Editora, 1966, pp. 77-88.

Uma análise objetiva a respeito da questão - no que concerne às Ordenações do Reino de Portugal em geral - é efetuada por M. J. de ALMEIDA COSTA: "embora compreendendo cinco livros, as Ordenações estavam longe de constituir um sistema completo: sobretudo no âmbito do direito privado, há institutos que são de todo omitidos e muitos outros só excepcionalmente lembrados. Os próprios compiladores [terminologia adequada aos responsáveis pelas Ordenações Afonsinas] fixaram, no título $9^{\circ}$ do livro II, o critério para o preenchimento das lacunas" (M. J. de ALMEIDA CostA, Ordenações in Boletim da Faculdade de Direito da Universidade de Coimbra 44 (1968), p. 263).

Especificamente no que concerne às Ordenações Filipinas, observe-se que A. TEIXEIRA DE FREITAS - logo no início da Introdução à Consolidação das Leis Civis - faz uma observação importante acerca da insuficiência de suas disposições expressas para a regulamentação da vida civil em Portugal: "nunca tivemos Codigo Civil, e se por tal reputassemos o corpo das ordenações Fillipinas, ou antes o $4^{\circ}$ livro dellas, que mais se dedicou aos contractos e sucessões, estariamos ainda assim envolvidos na immensa teia das leis extravagentes, que se tem accumulado no decurso de mais de dois seculos e meio. Tambem não existe um só escriptor, antigo ou moderno, que puramente se limitasse a colligir e ordenar o Direito Patrio. Aquellas Ordenações, que são pobrissimas, reclamavam copioso supplemento. Seus collaboradores, ou pela escassez de luzes de que têm sido accusados, ou por fugirem á maior trabalho, reportárão-se muitas vezes ao Direito Romano, e mesmo geralmente o autorisárão mandando até guardar as glosas de Accursio, e as opiniões de Bartolo e mais Doutores. Essa franqueza, que a Ord. L. $3^{\circ}$ T. 64 igualmente estendêra ao Direito Canonico; a famosa Lei de 18 de Agosto de 1769, que deu largas ao arbitrio com o titulo de - boa razão -; o outro subsídio dos - estilos, e costumes -; tudo concorreu para que os nossos Juristas carregassem suas Obras de materiaes estranhos, ultrapassando mesmo as raias dos casos omissos. As coisas têm chegado á tal ponto, que menos se conhece, e estuda, nosso Direito pelas leis, que o constituem; do que pelos Praxistas que as invadirão. Outras causas ainda contribúem para tão desgradavel situação" (Consolidação das Leis Civis, $3^{\mathrm{a}}$ ed., Rio de Janeiro, B. L. Garnier, 1876, pp. XXXII-XXXIII).

Quanto à orientação assumida pelo direito português, percebemos a existência de uma forte preponderância do elemento romano no que concerne à disciplina do mandato extrajudicial, como nos denuncia P. J. de Mello FreIRE dos Reis (Institutiones Juris Civilis Lusitani cum Publici tum Privati - Liber IV: De obligationibus et actionibus, $2^{\mathrm{a}}$ ed., Conimbricae, Ex Typis Academicis, 1845, p. 22). No mesmo sentido, cf. J. H. CORReIA Telles, Digesto Portuguez ou Tratado dos modos de adquirir a propriedade; de a gozar e administrar; e de a transferir por derradeira vontade; para servir de subsidio ao 'Novo Codigo Civil', Lisboa, Livraria Classica Editora, 1909, pp. 86-96; bem como M. A. COELHO DA RoCHA, Instituições cit. (nota 01), pp. 303-309. Note-se, todavia, que em virtude do advento da Lei de 18 de Agosto de 1769 (Lei da Boa Razão), os textos romanos - em princípio plenamente aplicáveis em matéria civil diante da expressa disciplina do direito subsidiário - passam a se submeter ao crivo da doutrina das nações iluminadas, consoante um critério conhecido por usus modernus pandectarum - instituído pelos Estatutos da Universidade de Coimbra (1772) e acerca do qual teremos oportunidade de tratar posteriormente.

Note-se, todavia, que a respeito do mandato judicial as "Ordenações do Reino de Portugal" foram bastante minudentes - mantendo-se, aliás, uma orientação derivada das fontes medievais do direito lusíada, tal como se pode depreender dos diversos textos normativos reunidos no "Livro das Leis e Posturas" e nas "Ordenações de D. Duarte". 
do instituto até então prevalecente. Com efeito, haverá oportunidade para uma abordagem que se concentre no fato de que embora os romanos tivessem conhecido o mandato sem representação, o Code Civil acabou por consagrar expressamente o mandato representativo (art. 1.984); de maneira que o impacto das influências jusracionalistas na disciplina de tal tipo contratual será objeto de uma investigação específica, que buscará demonstrar o surgimento de uma nova conformação sistemática do instituto - ao mesmo tempo em que tenderá a evidenciar a manutenção, por alguns sistemas jurídicos, de uma linha de continuidade que reconduza, em última análise, às origens romanas do instituto objeto de nossa atenção específica ${ }^{17}$.

$\S 18$. O surgimento de novas demandas sociais e o correspondente “desvirtuamento” funcional das estruturas jurídicas tradicionais. Para além das utilidades acima apontadas, a análise histórica pode nos proporcionar uma oportunidade de que carecem muitos estudos jurídicos puramente dogmáticos: a de evidenciar as necessidades que - em um determinado contexto social - são atendidas pelas estruturas jurídicas postas à disposição dos particulares. De fato, poderíamos perguntar: "haveria a causa típica do

\footnotetext{
${ }^{17}$ No âmbito da evolução experimentada pelo instituto no direito luso-brasileiro, abordaremos (em momento posterior deste estudo) as definições de contrato de mandato oferecidas por diferentes jurisconsultos dos séculos XVIII e XIX, sob o influxo daquilo que se convencionou designar por usus modernus pandectarum português. Por ora, seja-nos permitido tão somente reproduzir uma das consagrações legislativas mais notáveis do mandato representativo (referida no próprio corpo do texto): "le mandat ou procuration est un acte par lequel une personne donne à une autre le pouvoir de faire quelque chose pour le mandant et en son nom. Le contrat ne se forme que par l'acceptation du mandataire" (Code Civil, art. 1.984).

Aproveitemos a oportunidade, enfim, para explicar uma observação lançada ao final de uma das notas de rodapé anteriores (nota 15): de fato, para a elaboração deste trabalho, lançamos mão da tradução belga da obra Lehrbuch des heutigen Römischen Rechts (de F. MACKELDEY); ocorre que a primeira tradução ao francês da obra foi publicada sob o título Manuel des Institutes du droit romain moderne. Como analisaremos adiante, percebemos aí um influxo do supra mencionado usus modernus pandectarum, com a utilização do direito romano - desde que conformado aos ditames da recta ratio jusnaturalista. Não podemos deixar de observar que tal título reflete, de modo muito mais claro, a razão pela qual se verifica um distanciamento entre as doutrinas de F. MACKELDEY e de outros romanistas ali relacionados: aquele autor desenvolve um estudo de direito romano moderno (modernizado ou acomodado). Todo o problema reside no fato de que a tradução de que lançamos mão não é provida de um título tão claro quanto a sua antecessora (Manuel de droit romain, contenant la théorie des Institutes, précédée d'une introduction a l'étude du droit romain); com isso, a primeira análise que fizemos deste texto revelou-se bastante surpreendente, uma vez que destoava por completo das orientações correntes - posta de parte a posição de S. RICCOBONO já destacada.

Mas qual a importância de um comentário como o que se faz na presente nota? A resposta é muito simples: foram tais estudos de direito romano adaptado que forjaram os nossos juristas dos séculos XVIII (segunda metade) e XIX. E por tal razão não deverá causar espanto a utilização, neste estudo, dos compêndios (de direito romano) empregados pelos nossos juristas do século XIX. Como pretendemos estudar a evolução do mandato luso-brasileiro, não nos basta saber tão somente $o$ que o direito romano dispunha a respeito do contrato de mandato (e da eficácia representativa direta); faz-se necessário compreender de que forma tais dados foram reproduzidos ao longo do tempo - e até que ponto foram "ajustados" às diretrizes principais do iluminismo jurídico europeu. Para que se possa efetuar diretamente o cotejo aqui referido, cf. F. MACKELDEY, Lehrbuch des heutigen Römischen Rechts, trad. fr. de J. Beving, Manuel de droit romain, contenant la théorie des Institutes, précédée d'une introduction a l'étude du droit romain, $3^{\mathrm{a}}$ ed., Bruxelles, Société Typographique Belge, 1846, pp. 212-213.
} 
contrato de depósito na sua variante irregular?"; ou então, "que dificuldade específica a cláusula de retrovenda (atualmente tão pouco usada entre nós) permitiu superar durante a Idade Média?"; ou finalmente: “que espécie de representação pode ser entrevista na procuração em causa própria?”. A resposta a cada uma dessas indagações pressupõe um confronto atento entre as estruturas estabelecidas pelo ordenamento jurídico e as finalidades práticas que os interessados buscam superar quando delas, respectivamente, lançam mão ${ }^{18}$.

\title{
§ 19. A atenção do intérprete quanto às novas funções dos institutos
}

\author{
jurídicos (diálogo com a realidade concreta) e o apego às circunstâncias fáticas que
}

${ }^{18}$ Não pretendemos, pois, investigar os motivos que inspiram as partes à celebração das mais variadas espécies de negócios jurídicos, mas sim a abertura proporcionada pela estrutura jurídica a um desdobramento das potencialidades de um instituto em especial (o contrato de mandato). De fato, não podemos negar que entre o negócio simulado e o modelo legal existe uma categoria intermediária, dotada de peculiaridades que recomendam seu estudo mais detido: a dos chamados negócios jurídicos indiretos. Com efeito, as partes querem exatamente aquilo que a lei prevê para a hipótese, mas as suas finalidades práticas estão para além da causa típica do negócio. As partes têm um problema concreto, uma operação econômica - no mais das vezes - a resolver. Se o intuito último não é lícito, caminha-se em direção a uma fraude (vedada pelo sistema jurídico); entretanto, se a intenção das partes não é ilícita, por que razão elas não poderiam utilizar expedientes que tornem a operação mais eficiente - reduzindo-se, assim, seus respectivos custos (de transação)? Por que razão proibir que alguém pratique uma operação econômica que implique alienação, sob as vestes de uma representação (artificial e com existência exclusivamente jurídica)?

Note-se que ao contrário da compra e venda celebrada com cláusula de retrovenda - empregada já durante a Idade Média com o intuito de "burlar" a interdição de empréstimos a juros - nem sempre se está diante de uma ameaça de fraude à lei. Por vezes as partes querem exatamente aquilo que declaram, mas o querem por uma finalidade outra, que ultrapassa os limites da eficácia jurídica regular do ato ou negócio: os romanos freqüentemente praticavam a acceptilatio a fim de que a parte devedora ficasse desde logo liberada do vínculo; ocorre que nem sempre o pagamento (que este ato pressupunha) havia sido feito. Não se tenha dúvida quanto à existência de uma íntima relação entre este processo de paulatina "potencialização" dos atos jurídicos - para que se atinjam finalidades outras que ultrapassam a eficácia jurídica deles imediatamente decorrente - e o desenvolvimento da categoria dos negócios jurídicos abstratos.

Ora, a outorga de uma procuração em causa própria reflete a constituição de um representante negocial; o qual, por mais que (sob a perspectiva jurídica) tão somente "represente" o outorgante, em verdade atua no interesse próprio (em "causa" própria). Embora o direito nos informe que, em princípio, ali só se tem representação, a realidade fática (sobretudo econômica) nos revela que por detrás da roupagem jurídica repousa uma autêntica operação de alienação; e no momento em que o Direito dá a atenção devida à sua própria criação pela realidade - pelo interesse das partes contratantes (e não de seus respectivos advogados) percebe-se que, neste caso, o procurador não é um mero representante. Na verdade, a representação parece ser tão somente um instrumento para a circulação de direitos. Nesse cenário torna-se cada vez mais importante uma investigação a respeito das novas funções desempenhadas pelos institutos jurídicos tradicionais, compreendidos, pois, como meros instrumentos para sua concatenação. A respeito do quanto dito até aqui, eis a manifestação de T. ASCARELLI: "em substancia, todo negocio é caracterizado por um escopo tipico que se destina a realizar e no qual se identifica precisamente a sua causa economica e jurídica (...) mas nada impede, no entanto, seja ele, embora dentro de determinados limites, disciplinado pelas partes de modo tal que não só possa realizar, imediatamente, o escopo que lhe é tipico, mas tambem, mediatamente, outros objetivos que até adquirem importancia predominante na vontade das partes. Perante a fixidez da finalidade tipica de cada negocio, é a variabilidade dos motivos que permite a diversidade de configuração dele, e, por conseguinte, a consecução de finalidades ulteriores. Tal consecução pode prender-se à vontade de apenas uma parte, constituindo então um motivo juridicamente irrelevante; pode, porém, prender-se à vontade consensual de todas as partes que participam do negocio e é nesta hipotese que se apresenta o problema do negocio com fins indiretos" (Problemas das sociedades anônimas e direito comparado, São Paulo, Saraiva, 1945, pp. 101-125, especialmente p. 115). 
ensejam a sua aplicação. Daí, portanto, a necessidade de uma revisão da análise histórica que tenha em vista tão somente uma justaposição cronológica das estruturas postas à disposição dos interessados; parece preciso efetuar uma conciliação entre uma abordagem estrutural dos diversos institutos jurídicos e uma sua investigação funcional (que leve em consideração, assim, a finalidade prática visada pelos sujeitos de direito). Especialmente no que concerne ao contrato de mandato, mostra-se oportuna uma perquirição a respeito das demandas sociais atualmente satisfeitas pelo referido instituto jurídico - investigação tal que considere, aliás, a distinção entre o negócio jurídico indireto e a simulação (no específico contexto da variante do instituto ordinariamente desprovida de efeitos representativos diretos) ${ }^{19}$.

\section{$\S$ 20. Investigação incidental: necessidades atendidas pelo mandato sem} representação. Surge, então, a inevitável indagação: as necessidades atendidas pelo mandato sem representação são as mesmas a que se reporta a variante representativa do instituto? Que vantagens imediatas ele pode apresentar? Que dificuldades de ordem prática não poderiam ser superadas por outro meio - ou se mostram mais adequadamente transpostas mediante o emprego da figura ora referida ${ }^{20}$ ?

\footnotetext{
${ }^{19}$ Retomando a linha de raciocínio desenvolvida na nota imediatamente anterior, devemos observar que uma abordagem funcional - tal qual pretendemos desenvolver na segunda etapa de nossa linha de pesquisa acaba por concluir que alguns institutos jurídicos não têm uma razão de ser em si mesmos: para quê serve a sociedade comercial, senão como instrumento para o desenvolvimento da empresa? De que serve o negócio jurídico de outorga de poderes de representação, senão para que estes sejam exercidos no contexto de uma outra relação jurídica, tal como - por exemplo - um mandato (quanto ao mandato representativo)? E o próprio mandato, a que serve senão à prática de atos ou à administração de interesses? Embora todo negócio jurídico seja um instrumento de viabilização de sua respectiva eficácia (algo que poderíamos designar por instrumentalidade ordinária), não se pode perder de vista que o mandato em muitas vezes - embora não em todas - se volta à prática de atos jurídicos (do que se depreende uma espécie de metainstrumentalidade). Ou seja - quanto ao mandato representativo - confere-se poderes de representação (instrumentais) para que o outorgado possa bem se desincumbir do mandato (instrumental); e celebra-se o mandato (instrumental) para que o mandatário possa praticar em nome do mandante um determinado ato (final).

Não fosse suficiente esta "instrumentalidade" para singularizar a eficácia jurídica do contrato de mandato, a "confiança" a ele subjacente - evidenciada pela sua própria matriz etimológica ("manus dare") - e o escopo de "gestão colaborativa" influenciarão, de modo decisivo, na conformação de um liame jurídico obrigacional consideravelmente complexo (o qual será objeto de nossa abordagem no estudo que remata, ulteriormente, o nosso esforço de pesquisa).

De fato, teremos a oportunidade de perceber, por exemplo, que a alguns contratos parece não se aplicar - ao menos em seus moldes tradicionais - a "exceptio non adimpleti contractus". O próprio T. ASCARELLI observa de modo sintético: "por isso podemos distinguir um aspecto externo (quando as partes entram, como grupo, em relação com terceiros) e um outro interno (nas relações entre as partes) (...) esse fenomeno (...) verificase, tambem, no mandato, por ter este contrato um carater 'instrumental' em relação à conclusão de negocios ulteriores. Justamente esta circunstancia constitue o ponto de partida dos problemas especiais do mandato" (Problemas cit. (nota 18), p. 310); no mesmo sentido, cf. A. WeILler, Corte d'Appello di Milano (28 febbraio 1933) - Sui caratteri differenziali tra i consorzi e le società commerciali, in Il Foro Italiano 58 (1933), pp. 1607-1624.
}

${ }^{20}$ Pense-se, pois, nas seguintes hipóteses: 


\section{$\S 21$. Investigação incidental (cont.): enumeração de algumas utilidades do}

mandato sem representação. Limitemo-nos, por ora, à simples enumeração de algumas vantagens ostentadas pelo mandato sem representação: a) ocultamento do mandante: podese empregá-lo a fim de que se evite demasiada exposição à sanha especulativa de terceiros; b) limitação de responsabilidade: o mandante pode dele se servir como mecanismo de contingenciamento de suas responsabilidades (que restariam, pois, a cargo do mandatário), reduzindo-se, assim, os seus respectivos "custos de transação"; c) expansão "econômica" da atividade empresarial: potencializa o alcance econômico da empresa sem a

a) após longos anos de afastamento, dois amigos se reencontram pelos corredores das bibliotecas departamentais da Faculdade de Direito da Universidade de São Paulo; em meio aos estudos, surge a idéia de uma incursão aos "sebos" do centro da cidade. Antes de entrarem em um dos mais importantes, Caio declara a seu amigo Tício que ali se encontrava uma das obras por ele mais cobiçadas; no entanto, o livreiro que sempre o atendia tinha uma curiosa mania: não marcava os preços nos livros mais valiosos. Ciente de que Caio era o único interessado na aquisição daquele exemplar, por pilhéria, o livreiro insistia em estabelecer preços bastante elevados sempre que aquele lhe fazia uma oferta. Diante da angústia do amigo, Tício se propõe a comprar o exemplar em lugar de Caio, fazendo uma única ressalva: teria que receber uma provisão para a negociação, eis que estava completamente desprovido de dinheiro. Algum tempo depois, da mesma porta por que saiu Caio tantas vezes desolado, surge o alegre Tício, com um pacote de livros em meio aos quais o exemplar de Caio havia the sido entregue como "brinde";

b) depois de receber a notícia de que sua futura nora estava grávida (de seu filho desempregado), Mévio descobre que ambos tinham a pretensão de se casar, sem que dispusessem, contudo, dos indispensáveis recursos financeiros para tanto. Surge-lhe a idéia de alojar o casal em sua casa; mas para resguardar a intimidade dos recém-casados, considera mais conveniente instalá-los em um terreno vazio (alheio) que existe nos fundos de seu imóvel. O problema é que tinha a impressão de que seu proprietário não se compadeceria da situação dos noivos (e dela muito se aproveitaria, por sinal). Recebendo em sua casa Públio (pai da futura nora), Mévio lhe pede que interceda em favor do casal, procurando o proprietário vizinho e propondo-lhe a aquisição do referido imóvel; Mévio destaca a Públio que - qualquer que fosse o valor estabelecido pelo vizinho - deveria ele celebrar o contrato tão logo possível, eis que a situação era urgente e sua intenção era apenas a de escapar aos abusos do proprietário. Públio aceita a incumbência, e poucos dias depois, bem-sucedido, promove o registro da transmissão de propriedade sobre o imóvel - que a partir de então não mais pertenceria ao vendedor;

c) o empresário do setor de comunicações Rufus resolve se associar a Paulus - ilustre professor de História da Arte - com o intuito de que juntos possam viabilizar a construção de um museu; entretanto, para que o objetivo fosse alcançado, tanto Rufus quanto Paulus não poderiam adquirir pessoalmente as obras de arte que integrariam seu acervo: o primeiro porque sua falta de familiaridade com o mercado artístico certamente despertaria a atenção dos prováveis vendedores; o segundo porque seu interesse manifesto por qualquer das obras implicaria em uma natural sobrevalorização dos objetos cobiçados. Então, ambos solicitam a Claudius que procure os potenciais vendedores e adquira, uma a uma, todas peças que comporiam a universalidade de fato. Plena de êxito a atuação de Claudius, estava "virtualmente" formada a coleção pretendida por Rufus e Paulus;

Pergunta-se: o que há de comum nas três situações referidas? Os "bons ofícios" de um amigo? A "confiança" que só se deposita em alguém que nos seja verdadeiramente próximo? A "gestão" dos interesses próprios por um terceiro desinteressado? A “instrumentalidade" da avença prévia (em relação aos atos de gestão ultimados)? Sem dúvida, todos esses componentes estão presentes. Mas, além disso, um outro elemento desponta: a ausência de representação (jurídica) direta. Em todos os casos, os efeitos contratuais repercutem diretamente sobre a esfera jurídica do "benemerente" intercessor. De operações econômicas de pouca expressão a realidades de indisfarçável relevo social, a figura do mandato sem representação resiste às digressões conceituais dos homens, atendendo mais às finalidades práticas (dos que dela se utilizam) do que aos apelos da doutrina jurídica que sobre ela se debruça. Eis aí, pois, a repercussão prática do instrumento que nos permitirá propor - sob uma perspectiva historiográfica luso-brasileira - a revisão da "nota típica" do contrato de mandato (a ser promovida a partir dos materiais coligidos nesta ocasião). 
correspondente extensão de sua responsabilidade jurídica (conseqüência esta que ordinariamente acompanha o incremento do estabelecimento empresarial); d) cooperação mais estreita entre as partes: como a responsabilidade perante terceiros incumbe ao mandatário, via de regra, sua "eventual" remuneração acaba sendo mais elevada do que a gratificação atrelada ao mandato representativo; e) eliminação da investigação sobre os limites dos poderes de representação: dispensa-se o terceiro, assim, da regular investigação quanto aos limites dos poderes de representação do mandatário, o que acaba por repercutir, diretamente, na redução dos “custos de transação" daquele - e indiretamente pode tornar mais atraentes as ofertas de contratação levadas a efeito por este último ${ }^{21}$.

${ }^{21}$ Quanto às utilidades do mandato sem representação cf., dentre outros, os posicionamentos de F. A. P. LANDIN FILHO, O mandato cit. (nota 09), p. 15; C. P. M. CRUZ E TUCCI, Interposição cit. (nota 09), pp. 0912; F. de S. L. PeSSOA Jorge (O mandato cit. (nota 09), pp. 101-102). Aliás, este último autor destaca que os próprios terceiros (envolvidos na gestão operada pelo mandatário) podem ter interesse em contratar diretamente com o agente - dispensando-se, assim, uma vinculação direta com o principal - exatamente em decorrência de sua específica (e favorável) reputação: "outras vezes, a pessoa com quem o mandatário contrata, tem conhecimento de que ele actua no interesse de outrem, sobre quem depois se hão-de projectar os resultados económicos do negócio; mas, porque sabe que o mandatário é honesto e solvente e desconhece o mandante, não tem interesse em ficar credora deste, preferindo realizar o contrato directamente com o mandatário e só com ele" (F. de S. L. PESSOA JORGE, O mandato cit. (nota 09), p. 102).

Desta forma, resultam interessados na conclusão de um mandato sem representação não apenas o mandante (potencialmente beneficiado pela ocultação, pela limitação de responsabilidade, pela possibilidade de expansão da atividade econômica e pelo crédito ostentado pelo agente em sua respectiva praça), mas também o mandatário (diante de uma eventual remuneração) e os próprios terceiros (os quais, fundados na confiabilidade do agente, estariam dispensados de um exame da extensão dos poderes de representação do procurador).

Note-se que ao contrário do que se verifica no contrato com pessoa a declarar (arts. 467 a 471 do Código Civil), no mandato sem representação a ocultação do principal se dá de modo muito menos ostensivo; ora, como tal circunstância acaba por influenciar o próprio valor da operação, os dois instrumentos jurídicos, conquanto próximos, evidenciam-se inconfundíveis.

No que concerne à proximidade entre o mandato sem representação e a comissão, cumpre destacar que a existência de pontos de contato entre os mecanismos não é tamanha que se possa vislumbrar uma autêntica sobreposição; aliás, consideramos que dois obstáculos impedem que se entreveja uma adequação perfeita: em primeiro lugar, a existência de uma nítida atividade (do comissário) implícita na disciplina articulada entre os arts. 693 e 709 do Código Civil (o que impediria a subsunção de atuações esporádicas à hipótese); além disso, a restrição material que integra o tipo referido ("comprar" ou "vender") elimina uma série de atos outros que um mandatário poderia praticar em prol dos interesses do mandante. Assim, adiantamos que neste estudo se defenderá a autonomia do mandato sem representação diante do contrato de comissão.

Observe-se ainda que o intuito de ocultação poderia sugerir uma aproximação em relação à sociedade em conta de participação; todavia, parece-nos que uma eventual remuneração do mandatário, por si só, jamais poderia converter o interesse do mandante em um interesse social - não havendo, ademais, qualquer espécie de previsão quanto à partilha de proveitos e prejuízos entre as partes.

Antecipando uma consideração que será desenvolvida mais à frente, parece-nos que a simples estipulação de uma gratificação ao mandatário não implica em um interesse deste último quanto à execução das incumbências que lhe foram confiadas; com efeito, para justificar essa nossa posição uma investigação histórica sobre a eficácia do contrato de mandato será profundamente elucidativa. Pergunta-se: a vinculação entre as partes envolvidas (mandante e mandatário) é sinalagmática? Eis aí uma outra indagação a que pretendemos oferecer resposta - incidentalmente - por meio deste nosso estudo.

Por fim, importa destacar que a possibilidade de um contingenciamento de responsabilidades - acompanhado de um incremento da potencialidade espacial da atividade empresarial desenvolvida pelo mandante - revela que o contrato de mandato sem representação pode ser uma alternativa extremamente interessante (sob o prisma empresarial), uma vez que por meio dela são reduzidos os custos de transação que seriam 
$\S$ 22. Investigação incidental (cont.): do mandato sem representação como tipo contratual autônomo: dissociação quanto a esquemas teóricos próximos (investigação de sua respectiva causa-função); distinção quanto a figuras jurídicas vizinhas (depuração de sua eficácia jurídica peculiar). Uma vez apresentadas algumas das utilidades do mandato sem representação, resta-nos a tarefa de declinar a questão mais difícil a que pretendemos oferecer resposta por meio da "linha de pesquisa" apresentada nesta introdução: qual seria a "causa-função" do instituto por nós analisado? Cumpre observar que a solução a esta indagação pressupõe que tenhamos previamente depurado toda a eficácia típica do instituto, apartando dos dispositivos do Código Civil que tratam a respeito do contrato de mandato aquilo que concerne tão somente à representação negocial. Feito isso - e realizada uma conexão eficiente entre a realidade subjacente e a superestrutura jurídica (o que somente poderemos empreender em meio a esforço investigativo de caráter complementar) - teremos por concluída a nossa tarefa, restando claras a essência do contrato de mandato e a sua correspondente "nota típica"22.

experimentados pelo empresário (mandante). A respeito da questão concernente aos custos de transação, cf. R. COASE, The problem of the social cost in The firm, the market and the law, Chicago-London, The University of Chicago Press, 1988, pp. 95-156. Quanto às possibilidades proporcionadas pela macro-estrutura empresarial (e que reputamos eventualmente obviadas por meio do mandato sem representação), cf. F. K. Comparato, Aspectos jurídicos da Macro-emprêsa, São Paulo, Revista dos Tribunais, 1970, p. 1-10.

Desta forma, percebe-se que a variante do mandato desprovida de efeitos representativos diretos - além de interesse metodológico evidente - ostenta peculiaridades práticas que justificam um esforço especulativo que não lhe dê as costas; mais uma razão, portanto, para que o conservemos sempre por perto em meio às investigações relacionadas ao tipo contratual objeto de nossa análise.

${ }^{22}$ A respeito do conceito de "causa-função", cf. as referências enumeradas em nota de rodapé anterior (nota 12). Note-se que um dos principais objetivos de nossa "linha de pesquisa" corresponde à identificação da "nota típica" do contrato de mandato; e para que consigamos chegar a uma sua definição, será necessário percorrer uma longa trajetória, da qual este estudo corresponde - simplesmente - a um primeiro estágio. Todavia, é aqui que colheremos os materiais indispensáveis para que - posteriormente - possamos reconstruir o modelo ora dissecado. E para tanto, uma das tarefas mais importantes corresponde à "realocação" da eficácia representativa direta no contexto do espectro eficacial do mandato: eis aí o papel importante a ser desempenhado pelo "mandato sem representação" - instrumento indispensável no processo de recondução deste elemento ao espaço exterior à chamada "essência" do instituto objeto de nossas investigações.

Especificamente quanto à "causa-função" da variante do mandato desprovida de efeitos representativos diretos, cf. F. A. P. LANDin FILHO, O mandato cit. (nota 09), p. 39; C. P. M. CRUZ E TuCCI, Interposição cit. (nota 09), pp. 121-123; F. de S. L. PeSSOA Jorge ( $O$ mandato cit. (nota 09), pp. 101-102). A título exemplificativo, eis a manifestação deste último autor a respeito da causa específica do mandato sem representação: "o mandato sem representação tem, pois, por objectivo típico fundamental a interposição de pessoa; por outras palavras, a realização de um acto ou negócio jurídico por interposta pessoa constitui a causa do mandato sem representação" (F. de S. L. PESSOA JORGE, O mandato cit. (nota 09), p. 158); note-se, aliás, que aí se admite a existência de dois elementos a integrar o referido conceito: um elemento constante (a interposição de pessoa) e um elemento variável (de acordo com o ato a ser praticado pelo mandatário) (pp. 159-160). Conquanto não seja este o momento adequado para que apresentemos nossa posição a respeito da questão, não podemos deixar de destacar que nossa discordância em relação aos referidos autores - no que toca à própria variante desprovida de efeitos representativos diretos - implicará um completo redimensionamento da eficácia do tipo contratual aludido. 


\section{$\S 23$. Reiteração do objetivo da pesquisa e prévia definição de questões} prejudiciais a serem abordadas: os artigos 119 e 671 do Código Civil (bem como algumas inovações pontuais). Entre esta proposta de trabalho e o objetivo final a ser alcançado medeia um considerável trabalho de pesquisa. Buscando um sentido que somente uma orientação histórica da investigação pode nos oferecer - e atentos aos "trilhos" representados pelos limites objetivos emprestados ao presente trabalho - teremos de realizar uma prévia tentativa de "desconstrução" do contrato de mandato; para que depois, a partir de seus próprios materiais possamos reconstruir, em bases quiçá mais sólidas, a eficácia do tipo contratual referido (já à luz da "causa-função" correspondente). Nesse interregno, aproveitaremos a ocasião para efetuar uma análise dos artigos 119 e 671 do Código Civil (dentre outros) - ambos resultantes da atuação inovadora do legislador civil deste início de século $\mathrm{XXI}^{23}$.

\section{$\S$ 24. Justificativa da pesquisa e originalidade do tema (contribuição} original ao estado da arte do tema tratado). Finalmente, podemos destacar algumas circunstâncias que demonstram a oportunidade do estudo ora sugerido: a) a raridade de análises do contrato de mandato que o tomem como estrutura independente da representação negocial; b) a escassez de monografias dedicadas à questão segundo o Código Civil vigente; c) a ausência de abordagens histórico-críticas nacionais sobre a relação estabelecida entre os dois referidos institutos; d) a necessidade de um exame que priorize uma coordenação entre as perspectivas estrutural e funcional da questão; e) a ausência de uma demonstração da "retomada" - pelo Código Civil vigente - das diretrizes romanas fundamentais sobre a relação entre os aludidos institutos jurídicos; f) a ausência

\footnotetext{
${ }^{23}$ Como teremos oportunidade de destacar, os artigos 119 e 671 do Código Civil vigente (que não encontram correspondentes no Código Civil ab-rogado) são consideravelmente relevantes para a demonstração de nossa hipótese de trabalho. O primeiro parece viabilizar, em caráter excepcional, uma repercussão da eficácia (interna) do contrato de mandato (representativo) sobre terceiros - justamente em uma consagração do princípio da boa-fé objetiva (e em acatamento à doutrina do terceiro cúmplice). De fato, poderemos compreender de que forma o legislador brasileiro soube mitigar o clássico princípio da relatividade dos efeitos do contrato na hipótese de um "conflito de interesses" entre representante e representado; pela comparação com o sistema anterior, cf. O. GOMES, Contratos, $18^{a}$ ed., Rio de Janeiro, Forense, 1999, p. 351. Especificamente quanto à figura do mandato sem representação, será oportuno analisar o impacto do art. 671 em nosso sistema jurídico. Em verdade, poderemos explorar a relação mantida entre esse dispositivo material (oriundo de um Projeto de Código Civil apresentado ao Congresso Nacional durante a década de 70 do século passado) e as principais regras processuais concernentes à execução das obrigações.

Necessário observar que nesta trajetória seremos compelidos a tomar partido quanto à tipicidade da variante utilizada como nosso principal instrumento de análise. No sentido da atipicidade, cf., exemplificativamente, F. A. P. LANDIN FILHO, $O$ mandato cit. (nota 09), p. 112; em sentido contrário - concebendo a figura do mandato sem representação como contrato típico - cf. O. GoMES, Contratos cit. (nota 23), p. 347. Seja-nos permitido observar, desde logo, que consideramos o contrato de mandato sem representação uma figura provida de tipicidade própria; aliás - pelas razões evidenciadas no bojo do presente estudo -, compreendemos que os artigos 662, 663, 665, 668, 671 e 675 do Código Civil bem ilustram esta assertiva.
} 
de uma demonstração da "conservação latente" do mandato sem representação no direito civil brasileiro à custa do trabalho de Augusto Teixeira de Freitas; g) a conveniência de uma avaliação em que se apontem os dispositivos que atualmente integram o capítulo específico (da Parte Especial) sobre o contrato de mandato e que em realidade melhor se situariam em meio à disciplina da representação negocial (Parte Geral); h) a necessidade de um juízo crítico a respeito das limitações experimentadas pelo legislador de 2002 quanto à reformulação sistemática por ele empreendida - e por meio do qual se possa responder a seguinte indagação: poderíamos ter avançado mais ${ }^{24}$ ?

\footnotetext{
${ }^{24}$ Quanto a tais aspectos, cabe mencionar o fato de que nossa pesquisa pretende contribuir - ainda - por meio da divulgação ao público do trecho do Anteprojeto de Parte Geral do Código Civil de 1970 (cf. nota 08 supra) em que se propõe o deslocamento de uma copiosa parcela da disciplina referente à representação negocial (então alocada em meio aos dispositivos afetos ao contrato de mandato), a fim de que constituísse um capítulo próprio da Parte Geral do Código Civil. Em virtude da confiança depositada em nossa investigação, desde logo dedicamos este trabalho ao Professor e Ministro José Carlos Moreira Alves - cujas perspicácia, inteligência e erudição são diretamente proporcionais à cordialidade e ao respeito dispensados, continuamente, a este pesquisador.
} 


\section{PARTE PRIMEIRA: HISTORIOGRAFIA GERAL (QUATRO ASPECTOS PECULIARES DA EVOLUÇÃO DO CONTRATO DE MANDATO E DA REPRESENTAÇÃO NEGOCIAL).}

$\S$ 25. Justificativa da presente investigação histórica. A despeito do evidente caráter "preambular" da investigação histórica majoritariamente dedicada aos mais diversos aspectos do direito privado, consideramos que uma análise da evolução do contrato de mandato - com particular ênfase quanto à relação mantida entre este e a representação negocial - é absolutamente imprescindível à compreensão da diversidade de objetos promiscuamente referidos por meio deste único termo técnico: "mandato"; com efeito, pretenderemos evidenciar ao cabo deste estudo que, conquanto "atualmente" inexista uniformidade de entendimento a respeito do alcance desta expressão, também sob a perspectiva histórica não existe a homogeneidade pretendida por aqueles que tendem a conceber o "mandatum" romano como um simples antecedente histórico de seu homônimo contemporâneo. De fato, diante de uma "crise" quanto à definição da "essência" do mandato, é sobrelevado o estudo histórico deste tipo contratual, ao qual o direito romano dedicara mais de uma centena de intrincadas regras; aliás, é exatamente nelas que pretenderemos buscar - em um estudo ulterior - a unidade manancial que se pode, porventura, estabelecer entre sistemas jurídicos contemporâneos vizinhos - os quais, quanto ao objeto de nosso trabalho, se tornam ora mais distantes, ora mais próximos.

§ 26. Advertência. Feita tal observação preliminar, cumpre ainda apartar a análise histórica que se tencionará empreender neste estudo (que tem por fim específico evidenciar a existência de uma linha condutora que une o mandato romano ao seu correspondente moderno) daquela que se fará noutro momento de nossa linha de pesquisa, quando, em contrapartida, o direito romano (em particular) será tomado como base de uma investigação voltada à depuração da "nota típica" do contrato de mandato (e, consequientemente, de seus respectivos efeitos). Ou seja: enquanto nesta primeira oportunidade interessa-nos o "movimento" experimentado pelo tipo contratual ao longo do tempo (especificamente no que tange à relação entre o contrato de mandato e a representação negocial), mais à frente, contudo (e por razões que só poderão ser compreendidas após o desenvolvimento desta análise primeira), voltaremos nossa atenção à compleição própria do "mandatum" romano, elegendo-o como termo de comparação, tomadas em consideração algumas de suas variantes modernas e contemporâneas. Façamos, assim, um sintético apanhado daquilo que constituirá o objeto da primeira parte do presente trabalho. 
$\S$ 27. Itinerário da historiografia geral a ser promovida. Nossa análise histórica terá início por uma abordagem que privilegiará aspectos gerais da evolução da relação entre o contrato de mandato e a representação negocial, abstraindo-se, em um primeiro momento, do particular contexto da península ibérica e do Brasil. Pretenderemos, assim, compreender em linhas gerais apenas alguns aspectos relevantes deste longo itinerário, elegendo, pois, como marcos obrigatórios: a) a dissociação sistemática promovida pelo direito romano entre a "procuratio", o "mandatum" e a representação direta (admitida em caráter excepcionalíssimo); b) o papel do direito canônico no paulatino desenvolvimento da representação direta (em um movimento de passagem de simples exceção a verdadeira regra); c) a contribuição da atividade notarial desenvolvida durante a Idade Média, por meio de cuja praxe se instituiu iterada inserção da chamada cláusula "de rato" nos instrumentos de procuração; e por fim, d) a influência do jusracionalismo para a implementação da representação direta como regra, ao evidenciar a incompatibilidade entre alguns dogmas romanos e os avanços experimentados pela sociedade moderna.

\section{$\S 28$. Justificativa dos marcos obrigatórios eleitos a pretexto de uma análise}

geral. Assim, nossa análise histórica pretenderá abranger "alguns" aspectos da evolução do contrato de mandato fora do específico contexto ibero-brasileiro; e de fato, diante da imensidão de fontes a serem perscrutadas, pareceu-nos não apenas interessante, mas sim verdadeiramente imprescindível, observar quatro momentos decisivos para o desenvolvimento histórico do contrato de mandato. Cabe destacar, pois, que todos eles estarão envolvidos, em maior ou menor medida, na descrição da própria história do contrato de mandato luso-brasileiro; observemos, assim, como cada um deles se vinculará ao contexto específico que constituirá o pano de fundo de nossa investigação.

\section{$\S 29$. Justificativa dos marcos obrigatórios eleitos a pretexto de uma análise}

geral: sobre o direito romano. O estudo do contrato de mandato no direito romano constituiria, certamente, material suficiente ao desenvolvimento de uma análise especificamente a ele devotada; e decerto aquele que observar os desdobramentos de nossa linha de pesquisa tenderá - em um primeiro momento - a compreender nossa abordagem como um autêntico elogio ao "mandatum" romano. Todavia, não se pode negar que, não apenas em virtude do imenso valor teórico do material cristalizado nos livros terceiro e décimo-sétimo do Digesto (sobretudo), mas inclusive em decorrência da adoção do direito romano como fonte subsidiária do direito português tal qual estabelecido nas Ordenações do Reino, seu estudo é não apenas a contemplação de um notável arcabouço da história da 
civilização ocidental, mas também - e principalmente, para os nossos fins específicos - um elemento de interpretação daquilo que foi (ou deveria ter sido) o mandato português até o ano de 1867 (data de promulgação do Código Seabra).

$\S 30$. Justificativa dos marcos obrigatórios eleitos a pretexto de uma análise geral: sobre o desenvolvimento canônico da representação direta. De sua parte, a teoria da representação direta é resultado do aprimoramento canônico de dogmas romanos dos quais se serviu este peculiar sistema jurídico em meio ao seu paulatino desenvolvimento histórico. Ora, na medida em que, como veremos, o direito canônico serviu ao Estado português como direito subsidiário em matéria que envolvesse "pecado", não há que causar estranheza a influência do material desenvolvido pelos canonistas (e pelos juristas medievais em geral) na construção de uma autêntica "teoria" da representação direta, em virtude da qual se verificará o comprometimento dos alicerces do dogma romano que, de modo genérico, terminantemente a vedava; eis aí o papel do direito canônico que, de maneira indireta e lateral, repercutirá a longo prazo na compleição própria do mandato europeu - e inclusive, portanto, do contrato de mandato lusitano.

§ 31. Justificativa dos marcos obrigatórios eleitos a pretexto de uma análise geral: sobre a atividade notarial e a cláusula "de rato". Abstraindo-se da questão concernente à natureza da ratificação (concebida por certos setores da doutrina como uma espécie de procuração superveniente), perceberemos o papel decisivo que teve o emprego iterado da chamada cláusula "de rato" (inserida no texto das procurações) no processo de progressiva incrustação da representação direta no âmbito dos efeitos ordinários do contrato de mandato. Veremos como, à semelhança do impacto de diversas outras cláusulas utilizadas freqüentemente pelos práticos (juristas) de então, a promessa solene de apropriação dos efeitos por parte do "representado" surtiu um significativo efeito no processo de gestação do mandato "essencialmente" representativo; e de que maneira essa influência foi sentida, com um peculiar vigor, no cenário português de então.

\section{$\S 32$. Justificativa dos marcos obrigatórios eleitos a pretexto de uma análise} geral: acerca do advento do jusracionalismo e da consagração da representação direta como nova regra. Finalmente, compreenderemos de que modo o desenvolvimento do ideário racionalista aplicado ao direito se constituiu em um fator de particular incremento à doutrina da representação direta, concebida - a partir de então - não mais como uma exceção sistemática (ainda que já bastante generalizada), mas sim como um autêntico 
imperativo conceitual, tão forte quanto diversos outros que constituíram as bases do direito privado moderno. E assim, tomada como decorrência da "recta ratio" racionalista, perceber-se-á como a representação negocial vai encontrar a sua morada provisória exatamente naquele que se constituiu em seu hospedeiro por excelência: o contrato de mandato; fato esse que, em virtude de específicas vicissitudes da história do direito português (as reformas pombalinas da aplicação e do ensino do direito, em particular), redundará em uma viragem quanto às linhas gerais do mandato reinícola. Passemos, pois, ao estudo ora prometido. 


\title{
CAPÍTULO I.
}

\section{"PROCURATIO", CONTRATO DE MANDATO E ADMISSIBILIDADE EXCEPCIONAL DA REPRESENTAÇÃO DIRETA PELO DIREITO ROMANO.}

\author{
$\S 33$. A pluralidade de instrumentos de gestão no direito romano e a
} progressiva proeminência do contrato de mandato em meio a uma terminologia pouco propícia a pretensões sistematizantes. A tentativa de conceber o "mandatum" romano como um simples antecedente histórico do mandato contemporâneo nos pareceria fadada ao fracasso, desde que não fossem feitas, ab initio, algumas indispensáveis reservas: em primeiro lugar, deve-se ter em mente que - conforme veremos mais adiante - o surgimento do referido tipo contratual somente se dera por volta do século III a.C., ocasião em que se verificou a grande expansão comercial sobre o Mediterrâneo; no entanto, mesmo antes desta época, já se vislumbrava uma gestão de negócios alheios satisfeita pelos instrumentos jurídicos disponíveis no âmbito do "ius civile" (notadamente a "procuratio"). Em segundo lugar, não se pode descurar que a afeição do espírito romano pelo método casuístico não permite que a terminologia encontrada nas fontes seja tomada como um dogma, sobretudo à vista da posição secundária ocupada pelas preocupações sistemáticas no panorama da jurisprudência clássica, muito mais comprometida com a solução de casos concretos do que com construções de caráter teórico. Finalmente, é preciso destacar que durante o intervalo de tempo compreendido entre a produção dos principais jurisconsultos clássicos e a compilação justinianéia (por meio da qual temos, preponderantemente, um efetivo acesso às suas obras), novas necessidades sociais surgiram e novas concepções jurídicas despontaram: exatamente por isso, muitas das atribuições feitas no Digesto não reproduzem, com a devida fidelidade, o pensamento dos jurisconsultos de outrora; de fato, não raras vezes representam uma deliberada manipulação de excertos, a fim de que se construísse uma artificial harmonia entre obras oriundas de fases distintas de um longo processo evolutivo - pretendendo-se dissolver, assim, uma heterogeneidade natural a todo e qualquer sistema em contínuo aprimoramento ${ }^{25}$.

\footnotetext{
${ }^{25}$ Como ressalta V. ARANGiO-RUIZ, uma das questões mais discutidas a respeito do "mandatum" concerne ao seu enquadramento em um sistema mais amplo, compreensivo de todos os mecanismos jurídicos de gestão dos interesses alheios. Nesse cenário, percebe-se que com o passar do tempo, gradualmente o contrato de mandato passa a assumir uma posição central, pondo de parte outros institutos - de origens diversas - que atendiam (genericamente) à mesma função; por exemplo, teremos a oportunidade de tratar, mais adiante, do consórcio doméstico ("ercto non cito"), da "mancipatio familiae" e da "procuratio". Contudo, é importante que tenhamos em mente, desde logo, que na maior parte do tempo houve uma convivência relativamente harmoniosa entre estes instrumentos; e com isso, perceberemos que assim como o "ius gentium" desempenhou um papel decisivo na origem do contrato de mandato, o "ius civile" teve uma importância extraordinária na conformação das linhas gerais da "procuratio" - assim como o "ius honorarium" foi o
} 


\title{
$\S 34$. As hipóteses mais remotas de gestão por meio da atuação de outrem:
}

\author{
o consórcio doméstico ("ercto non cito"), a tutela e a curatela. Feitas tais ressalvas, há
}

que se notar que o contrato de mandato não se encontra entre as formas mais antigas de

gestão de interesses alheios: sendo menor, nos tempos mais longínquos, a necessidade de

principal responsável pela flexibilização do instituto, já durante o período clássico. A respeito do assunto, em linhas gerais, cf. V. ARANGIO-RUIZ, Il mandato in diritto romano - Corso di lezioni svolto nell'Università di Roma (anno 1948-1949), Napoli, Casa Editrice Dott. Eugenio Jovene, 1965, pp. 1-2; sobre a utilização de mecanismos oferecidos pelo direito quiritário para suprir necessidades que não poderiam ser satisfeitas por um "mandatum" ainda inexistente, eis a manifestação do autor: "ora è comune a tutti i contratti consensuali l'essere venuti in essere quando già, nei rapporti fra i romani, qualche parte dei risultati pratici ai quali essi hanno mirato era realizzabile coi mezzi tecnici apprestati dal diritto civile (...) la stessa esperienza si ripete, anche più laragamente, per il mandato: se si voleva affidare a taluno l'amministrazione di un patrimonio o di una sua branca, la figura del procurator omnium rerum vi si prestava appieno; se si voleva sostituire a sè medesimi altra persona nella condotta di un processo, soccorrevano gli istituti del cognitor e del procurator ad litem; se bastava ricorrere all'opera del proprio figlio o schiavo, i congegni (...) davano pieno rendimento" (p. 47). A respeito da atuação dos filhos e escravos em prol do "paterfamilias", do "cognitor" e das principais figuras que integram o instituto da "procuratio", cf. os parágrafos posteriores deste trecho do estudo.

Não se pode deixar de reiterar, pois, as considerações lançadas em nota ao $\S 18$ do presente trabalho (nota 18), na qual aludimos ao negócio jurídico indireto como instrumento utilizado para o atingimento de finalidades que extrapolam a própria função ordinária do objeto. Remetemos o leitor, assim, ao referido ponto do texto.

A respeito do emprego do método casuístico pelos jurisconsultos romanos clássicos - em uma interessante comparação com o sistema do "Common Law", aliás - cf., por todos, L. VACCA, Contributo allo studio del metodo casistico nel diritto romano, Milano, Dott. A. Giuffrè Editore, 1976, pp. 140-144. No entanto, cabe ressalvar que, conquanto consubstanciasse o direito romano um sistema casuístico, não poderia ser considerado um autêntico "case law", à vista da ausência de uma maior vinculatividade dos posicionamentos estabelecidos (nesse sentido, cf. F. HoRAK, Dogmatica e casuística no direito romano e nos direitos modernos, in Revista de Direito Civil, Imobiliário, Agrário e Empresarial 28 (1984), pp. 82-83); e tal ressalva há de prevalecer durante praticamente toda a evolução do sistema jurídico romano, encontrando significativa mitigação, contudo, em uma Constituição dos Imperadores Teodósio II e Valentiniano III (426 d.C.), por meio da qual se instituiu o famigerado "tribunal dos mortos" [Theod. et Valent. C. Th. 1, 4, 3 (426)]. Por tal razão, as aproximações entre o direito romano clássico e o método casuístico empregado no sistema do "Common Law" podem ser feitas, mas circundadas de indispensável cautela. A respeito do assunto, cf. os estudos de G. GoRla ('Ratio decidendi', principio di diritto (e 'obiter dictum') in Studi in onore di Antonio Segni II, Milano, Giuffrè, 1967, pp. 387-ss; e Interessi e problemi della comparazione fra il diritto nostro e la 'common law' in Studi in memoria di Tullio Ascarelli II, Milano, Casa Editrice Dott. A. Giuffrè, 1969, pp. 937-955); a análise de H. F. JOLOWICZ (Roman regulae and english maxims in L'Europa e il diritto romano - studi in memoria di Paolo Koschaker I, Milano, Dott. A. Giuffrè, 1954, pp. 211-ss) ; e o instigante ensaio de F. TREGGIARI em que o tenciona aproximar os métodos sistemático e casuístico de trabalho (Sistematica e metodo del caso come tecniche complementari d'istruzione giuridica: maestri tedeschi ed epigoni italiani dell'Ottocento in Diritto e processo - studi in memoria di Alessandro Giuliani, Napoli, Edizioni Scientifiche Italiane, 2001, pp. 431-457).

Finalmente, por uma definição singela (porém precisa) de "interpolação", eis a manifestação de A. CORREIA e G. SCIASCIA (amparada nas lições de S. RiCCOBONO): "faculdade, que lhes foi dada [às comissões] pelo Imperador, de modificar e alterar os textos dos juristas clássicos” (Manual cit. (nota 09), p. 473). Note-se que a caçada às interpolações ensejou um grande desenvolvimento da ciência jurídica especializada, podendo-se entrever, por exemplo, na produção de E. ALBERTARIO, mais de uma dezena de escritos exclusivamente dedicados ao tema; dentre eles - em virtude de sua importância histórica no futuro desenvolvimento dos estudos romanísticos - cf., por todos, La cosidetta crisi del metodo interpolazionistico, in Studi di diritto romano V-Storia, Metodologia, Esegesi, Milano, Antonino Giuffrè Editore, 1937, pp. 67-145. Voltaremos ao tema das interpolações mais adiante, quando analisarmos algumas passagens do livro terceiro do Digesto concernentes ao "procurator" e à "actio negotiorum gestorum"; de todo modo, a respeito deste tema aplicado a tal específico objeto de estudo, cf. G. PACCHIONI, Di alcuni probabili interpolazioni nel titolo 'De negotiis gestis' in Scritti giuridici dedicati e offerti a Giampietro Chironi nel XXXIII anno del suo insegnamento I, Milano-Torino-Roma, Fratelli Bocca, 1915, pp. 211-220. 
intervenção estranha em prol da gestão do patrimônio familiar (de regra, a cargo do "pater familias"), nas ocasiões excepcionais em que se fazia necessário o concurso da atuação de terceiros, este se dava, sobretudo, à custa da participação de parentes próximos, sob a roupagem jurídica do chamado consórcio doméstico (“ercto non cito"). Todavia, verificando-se que da morte do "pater" poderia decorrer a vulnerabilidade do próprio acervo gentílico - de que então restava titular, por exemplo, um menor impúbere -, apressou-se o direito romano em conceber o instituto da tutela, permitindo-se ao tutor a gestão dos negócios familiares no interesse do incapaz (ainda que para tanto se lhe tenha atribuído, de início, a própria titularidade do patrimônio administrando); semelhante tratamento jurídico foi conferido, por extensão, às hipóteses mais antigas de curatela (envolvendo loucos e pródigos) ${ }^{26}$.

${ }^{26}$ O consórcio doméstico ("ercto non cito") é assim referido nas Institutas de Gaio (G. 3, 154a e 154b): "154a. Est autem aliud genus societatis proprium civium Romanorum. Olim enim mortuo patre familias inter suos heres quaedam erat legitima simul et naturalis societas, quae appellabatur ercto non cito, id est dominio non diviso: rectum enim dominium est, unde erus dominus dicitur: ciere autem dividere est, unde caedere et secare [et dividere] dicimus. Alii quoque, qui volebant eandem habere societatem, poterant id consequi apud praetorem certa legis actione. 154b. Alii quoque, qui volebant eandem habere societatem, poterant id consequi certa legis actione. In hac autem societate fratrum ceterorumve, qui ad exemplum fratrum suorum societatem coierint, illud proprium erat, quod vel unus ex sociis communem servum manumittendo liberum faciebat et omnibus libertum adquirebat: item unus rem communem mancipando eius faciebat, qui mancipio accipiebat" ("154a. Existe porém outra espécie de sociedade, própria aos cidadãos romanos. Assim antigamente, morrendo o paterfamilias, estabelecia-se entre os herdeiros seus uma sociedade, ao mesmo tempo legal e natural, chamada erctum non cito, quer dizer, domínio indiviso. Pois erctum é domínio; daí erus significar dono; ciere é dividir; daí empregarmos caedere e secare para significar dividir. Também outras pessoas que quisessem participar da mesma sociedade podiam consegui-lo, por uma acção da lei, proposta perante o pretor. 154b. Esta sociedade de irmãos e outras pessoas, membros de uma sociedade semelhante à dos irmãos herdeiros seus, tinha a seguinte peculiaridade: um dos sócios, alforriando escravo comum, o tornava livre, adquirindo o liberto para todos, também um dêles, mancipando uma coisa comum, tornava-a de quem a recebia em mancípio"). Note-se que a tradução das Institutas de Gaio utilizada neste trabalho é aquela produzida por A. A. de CASTRO CORREIA, incorporada ao Manual de A. CORREIA e G. SCIASCIA referido anteriormente (nota 09); aliás, os trechos em itálico na versão latina não correspondem a destaques, mas sim a omissões verificadas no palimpsesto veronense, preenchidas de uma maneira mais ou menos uniforme pela doutrina especializada - a despeito da existência de alguns pontos controversos, como aquele que cerca o trecho final do passo G. 2, 95, a respeito do qual trataremos mais adiante.

Sobre o consórcio doméstico ("ercto non cito") no direito romano, cf., por todos, V. ARANGIO-RUIZ, Società in diritto romano - Corso di lezioni svolto nell'Università di Roma: anno 1949-50, Napoli, Eugenio Jovene, 1950, pp. 1-ss.

A respeito das origens da tutela e da curatela, cf. V. ARANGIO-RuIZ, Il mandato cit. (nota 25), pp. 3-4, de onde se extrai o interessante trecho em que se alude à diversidade entre os regimes jurídicos aplicáveis ao tutor nas diferentes fases da evolução do sistema jurídico romano: "anche qui le cose non sono sempre andate come, dal diritto romano più evoluto in qua, siamo abituati a vederle: vi è stato un tempo nel quale il tutore, fosse il parente più vicino di linea maschile (adgnatus proximus) o la persona designata dal testatore, era considerado lui stesso come titolare dei beni, salvo l'obbligo di restituirli quando il pupillo raggiungesse la pubertà; ed anche successivamente, e per molto tempo ancora, almeno il tutore legittimo ha rappresentato piuttosto gli interessi della famiglia, di cui era il membro più vicino all'eredità nell'ipotesi che il pupillo venisse meno, anzichè l'interese del pupillo medesimo. Comunque, già di buon'ora la fides cui il rapporto s'ispirava ha fatto sì che nello spirito di ogni buon tutore avesse grande rilevanza l'interesse del pupillo; e ben presto, specialmente attraverso l'istituzione della tutela dativa, l'idea del tutore che gerisce gli affari 


\title{
$\S 35$. As hipóteses mais remotas de gestão por meio da atuação de outrem:
}

\author{
a figura do "cognitor" e a chamada "fiducia cum amico". Com o passar do tempo, outras
}

formas de gestão de interesses alheios foram concebidas: já se admitia que, diante da impossibilidade de comparecimento a todos os atos e termos do processo, o interessado (demandante ou demandado) lançasse mão da atuação de outrem em seu específico interesse; de modo que a condução da causa ficasse, pois, a cargo de um "cognitor" que,

dell'impubere venne prendendo sempre maggiore consistenza" (p. 4). Em sentido análogo, cf. A. WATSON, Contract of mandate in roman law, Oxford, Clarendon Press, 1961, p. 9.

Como ressalta F. BRIGUGLIO, aliás - com apoio em pesquisas lexicográficas levadas a efeito por meio da utilização dos manuais de H. E. DIRKSEN (Manuale Latinitatis fontium iuris civilis Romanorum), H. HEUMANN e E. SECKEL (Handlexikon zu den Quellen des römischen Rechts), A. BERGER (Encyclopedic Dictionary of Roman Law) e do Vocabularium Iurisprudentiae Romanae - o termo "procurator" é freqüentemente aproximado da figura do "curator", como que a aludir à idéia de que aquele "agisce in luogo di un curatore" (Studi sul procurator I - L'aquisto del possesso e della proprietà, Milano, Dott. A. Giuffrè Editore, 2007, pp. 34-35). Tal conexão não deve causar maior estranheza ao estudioso, uma vez que, conforme veremos mais adiante, ambas as situações eram objeto de tutela à custa da mesma actio, a chamada "actio negotiorum gestorum" (V. ARANGIO-RUIZ, Il mandato cit. (nota 09), pp. 28-29).

Pela falta de necessidade de um mecanismo de gestão em prol de terceiros - à luz da simplicidade da vida romana dos primeiros tempos e da utilização freqüente de expedientes recobertos pela figura do consórcio doméstico - cf. A. GUARINO, Diritto privato cit. (nota 15), p. 929; bem como R. LOTUFO, Questões relativas a Mandato, Representação e Procuração, São Paulo, Saraiva, 2001, pp. 1-2.

Entrevendo - a nosso ver equivocamente - no consórcio doméstico ("ercto non cito") uma espécie de pessoa jurídica, cf. E. PETIT, Tratado cit. (nota 15), p. 521 (nota 392.1).

Pela proximidade entre a "procuratio" e o consórcio doméstico, oriundos ambos do antigo "ius civile", cf. A. E. GIFFARD, Droit romain cit. (nota 15), p. 84.

A respeito da "nunciatura" (em geral) e de sua importância no sistema jurídico romano, cf. V. SCIALOJA, Corso cit. (nota 15), p. 357; J. C. de Matos Peixoto, Curso cit. (nota 15), pp. 346-346; P. Voci, Piccolo manuale cit. (nota 15), p. 320; Manuale cit. (nota 15), pp. 384-386 (com cuidadosa descrição do regime jurídico a que estava sujeito o "nuntius" romano); E. VolTerRA, Istituzioni cit. (nota 15), p. 169; M. CARBONI, Sul concetto di 'nuntius', in Scritti giuridici dedicati e offerti a Giampietro Chironi nel XXXIII anno del suo insegnamento I, Milano-Torino-Roma, Fratelli Bocca, 1915, pp. 45-48. U. ALVAREZ SUAREZ destaca, aliás, a extrema frequiência com que era empregado o mensageiro para a celebração de negócios nãoformais entre os romanos (Instituciones cit. (nota 15), p. 216).

Pela distinção entre o "núncio" (mensageiro) e o representante, eis a manifestação de V. ARANGiO-RuIZ: "bisogna nettamente distinguere dalla rappresentanza l'ipotesi in cui ad un estraneo sia affidata la semplice comunicazione di una volontà già formatasi nell'interessato. È il caso del nuncius, che - come bene intesero i romani - è soltanto un veicolo di manifestazione della volontà, alla pari del discorso della scrittura. Ciò importa che non in qualsiasi negozio possa intervenire un nuncius: anzi dovunque si richieda per la manifestazione della volontà una forma determinata, chi adempie le formalità nell'interesse di un altro ha funzione di rappresentante: ammettono un nuncio i soli atti esenti di forme, come i contratti consensuali e il divorzio"(Istituzioni cit. (nota 15), p. 93); no mesmo sentido, aliás, H. M. F. MADEIRA, História da Advocacia - origens da profissão de advogado no direito romano, São Paulo, Revista dos Tribunais, 2002, p. 63. Note-se que A. SANTOS JUSTO utiliza a expressão "agente de comunicação" (ou "porta-voz do dominus negotii") para aludir a tal personagem (Direito privado cit. (nota 15), p. 199).

Por uma interessante definição sobre o "núncio" romano - estribada na sua comparação face à atuação do órgão das pessoas juridicas (no direito contemporâneo) - eis a posição de M. KASER: "a concepção da 'organicidade' não foi formulada pelos Romanos; provém da doutrina moderna das pessoas jurídicas (...) mas manifesta-se como uma forma útil de pensar para ilustrar as situações jurídicas romanas aqui em questão. Nela se baseia a ideia de que alguém, para actuar juridicamente, se serve de uma pessoa dela dependente, de modo semelhante ao indivíduo que se serve dos membros do seu corpo. O órgão é um 'instrumento animado', um 'braço prolongado', como, na concepção romana e também na actual, o mensageiro (nuntius), que transmite uma declaração de vontade alheia. Mas a concepção romana vai muito além do caso do mensageiro, incluindo também casos em que o dependente tem a faculdade de actuar por decisão de vontade mais ou menos autónoma" (Direito Privado cit. (nota 15), p. 89). 
nomeado de forma solene na presença do adversário, se tornava, por força do "ius civile", o próprio “dominus litis". De toda forma, não foi apenas a estrita impossibilidade de gestão dos próprios afazeres que ensejou a utilização de tais expedientes; razões de simples conveniência, por vezes, suscitaram a administração em prol de terceiros: isso se deu, por exemplo, em hipóteses de perseguição política, nas quais, diante do perigo de confisco, o titular do patrimônio alienava todos os seus bens a alguém de sua irrestrita confiança praticando para tanto uma "fiducia cum amico" - a fim de que, passado o período de hostilidades, se lhe fosse restituído tudo quanto de início lhe cabia ${ }^{27}$.

${ }^{27}$ A previsão do "cognitor" e as linhas gerais do regime jurídico a que estava submetido podem ser depreendidas, fundamentalmente, de dois passos da obra de Gaio (G. 4, 82 e G. 4, 83): "82. Nunc admonendi sumus agere nos aut nostro nomine aut alieno, veluti cognitorio procuratorio tutorio curatorio, cum olim, quo tempore legis actionis in usu fuissent, alieno nomine agere non liceret, praeterquam ex certis causis. 83. Cognitor aute certis verbis in litem coram adversario substituitur. Nam actor ita cognitorem dat: QUOD $e$ g $o$ $a t e$ verbi gratia FUNDUM PETO, IN EAM REM LUCIUM TITIUM TIBI COGNITOREM DO; adversarius ita: QUIA TU A ME FUNDUM PETIS, IN EAM REM TIBI PUBLIUM MEVIUM COGNITOREM DO. Potest ut actor ita dicat: QUOD EGO TECUM AGERE VOLO, IN EAM REM COGNITOREM DO, adversarius ita: QUIA TU MECUM AGERE VIS, IN EAM REM COGNITOREM DO. Nec interest, praesens an absens cognitor detur; sed si absens datus fuerit, cognitor ita erit, si cognoverit et susceperit officium cognitoris" ("82. Devemos agora advertir que podemos agir, quer em nosso próprio nome, quer em nome de outrem, como quando agimos na qualidade de cognitor, procurador, tutor ou curador de alguém, enquanto antigamente, no tempo das acções da lei, não era permitido agir em nome de outrem, exceptuados certos casos. 83. O cognitor é substituído mediante certas palavras proferidas em presença do adversário. Pois o autor dá um cognitor assim: DESDE QUE EU RECLAMO DE TI, POR EXEMPLO, UM FUNDO, DOU-TE L. TÍCIO COMO COGNITOR NESTA CAUSA. O adversário por sua vez diz: DESDE QUE ME RECLAMAS O FUNDO, EU TE DOU P. MÉVIO POR COGNITOR NESTA CAUSA. O autor pode também dizer: QUERENDO AGIR CONTRA TI, DOU-TE UM COGNITOR NESTA CAUSA. Pouco importa esteja o cognitor dado presente ou não; mas se estiver ausente, a pessoa designada sòmente será cognitor se tiver conhecimento do ofício e o aceitar"). Com efeito, teremos a oportunidade de mais adiante - a propósito de uma comparação com o "procurator ad litem" - tecer alguns comentários a respeito do regime jurídico (rígido) a que estava submetida a utilização do "cognitor" em uma demanda judicial.

Além da atuação do "cognitor" em prol dos interesses da parte processual originária (demandante ou demandado), também em algumas hipóteses de negócio fiduciário ("fiducia cum amico") podem ser vislumbradas situações nas quais se caracteriza a gestão em prol de terceiro; em tal sentido se manifesta $\mathrm{V}$. ARANGIO-RUIZ, respaldando sua posição em passagem antiga de Boécio: "fuori del processo, una gestione di altri poteva essere il risultato di quell'istituto che porta il nome di fiducia, e che consiste nel trasferire ad un altro, mediante mancipatio o in iure cessio, la proprietà di una cosa, da restituirsi in determinate circostanze (...) da un passo di Boezio, [ad Cicer. Top. 10] attinto senza dubbio a buona fonte antica, si ricava che a questo istituto si ricorreva in periodi di persecuzione politica, quando il partito al potere avesse disposto la proscrizione dei beni degli avversarii (...) colui che si vedeva minacciato di perdita del patrimonio, trasferiva quel che poteva ad amici non esposti allo stesso pericolo, e questi lo restituivano quando la ventata passasse. E chiaro che nell'affidamento che così veniva fatto, per esempio, di case o di fondi, era comrpeso anche l'incarico di riparare, coltivare, impiegare il denaro delle pigioni, vendere i frutti etc., in una parola amministrare" (Il mandato cit. (nota 25), p. 5). No mesmo sentido, aludindo às hipóteses de perseguição política, cf. A. WATSON, Contract cit. (nota 26), pp. 10-11. Note-se, contudo, que se do ponto de vista "social" o fiduciário agia em prol do proprietário original, sob a perspectiva estritamente jurídica, administrava interesses próprios; essa espécie de descompasso assinala um período de transição em que as expectativas sociais são, pouco a pouco, recebidas pelo sistema jurídico - a fim de se lhe revestirem da indispensável proteção respectiva. Logo a seguir teremos a oportunidade de analisar o emprego, por exemplo, da antiga "mancipatio" para a obtenção dos efeitos típicos de um negócio jurídico de transmissão "causa mortis".

De todo modo, fique claro desde logo que, freqüentemente, premidos por razões - não mais de estrita necessidade, mas sim - de simples conveniência, os romanos admitiram que fossem postos de lado alguns pressupostos da aplicação de determinados institutos jurídicos, eis que presente, acima de tudo, a mesma 
$\S 36$. As hipóteses mais remotas de gestão por meio da atuação de outrem: a "mancipatio familiae" e a gradual incrustação de uma noção de "mandare”. Assim como se dava quanto à "fiducia cum amico", também na hipótese da chamada "mancipatio familiae" ocorria uma transferência da titularidade do acervo doméstico, em caráter precário, a alguém de inteira confiança do titular predecessor; neste último caso (considerado uma espécie de "testamentum per aes et libram"), tinha-se em vista a distribuição do patrimônio familiar entre os herdeiros, por meio de uma sua atribuição ficta, em caráter provisório, ao "adquirente" ("familiae emptor") - ao qual se conferiam, diga-se de passagem, as incumbências de o gerir e de o partilhar, tudo de conformidade com instruções estabelecidas em ato (conexo) celebrado imediatamente após a "transferência" simbólica dos bens. De qualquer maneira, deve-se destacar, pois, que em todas as hipóteses de gestão de interesses alheios nas quais há prévia atribuição de encargo, prevalece a idéia de "incumbência", suscetível de uma síntese aproximada sob o termo "mandare",28.

"ratio iuris" que justificara a tutela tradicionalmente prevista (e à quais se outorgava uma proteção ostensiva). Com isso, ocorria uma espécie de "alargamento" da hipótese de cabimento de um ou outro remédio, tal como se verificou, por exemplo, quanto à "procuratio", que paulatinamente passou a prescindir da generalidade da incumbência (que lhe caracterizou de início) e da "abstentia domini" (eis que socialmente conveniente um desdobramento da administração do patrimônio mesmo em caso de presença física de seu titular); a respeito, cf. F. BRIGUGLIO, Studi cit. (nota 26), pp. 11-13.

${ }^{28}$ Os contornos gerais da "mancipatio familiae" podem ser extraídos de G. 2, 102 e G. 2, 104: "102. Accessit deinde tertium genus testamenti, quod per aes et libram agitur. Qui enim neque calatis comitiis neque in procinctu testamentum fecerat, is si subita morte urguebatur, amico familiam suam id est patrimonium suum, mancipio dabat, eumque rogabat qui cuique post mortem suam dari vellet. Quod testamentum dicitur per aes et libram, scilicet quia per mancipationem peragitur (...) 104. Eaque res ita agitur: qui facit testamentum, adhibitis, sicut in ceteris mancipationibus, $\mathrm{V}$ testibus civibus Romanis puberibus et libripende, postquam tabulas testamenti scripserit, mancipat alicui dicis gratia familiam suam; in qua re his verbis familiae emptor utitur: FAMILIAM PECUNIAMQUE TUM ENDO MANDATELA TUA COSTODELAQUE MEA ESSE AIO ET EA, QUO TU IURE TESTAMENTUM FACERE POSSIS SECUNDUM LEGEM PUBLICAM, HOC AERE, et, ut quidam adiciunt, AENEAQUE LIBRA, ESTO MIHI EMPTA; deinde aere percutit libram, idque aes dat testatori veluti pretii loco; deinde testator tabulas testamenti tenens ita dicit: HAEC ITA, UT IN HIS TABULIS CERISQUE SCRIPTA SUNT, ITA DO ITA LEGO ITA TESTOR ITAQUE VOS, QUIRITES, TESTIMONIUM MIHI PERHIBETOTE; et hoc dicitur muncupatio: nuncupare est enim palam nominare; et sane quae testator specialiter in tabulis testamenti scripserit, ea videtur generali sermone nominare atque confirmare" ("102. Depois, surgiu uma terceira espécie de testamento, feito per aes et libram. Quem não tinha feito testamento nem calatis comitiis nem in procinctu e temesse morte repentina, dava sua família, isto é, seu patrimônio em mancipação a um amigo, dizendo-lhe o que queria dar a cada um, depois de sua morte. Chama-se per aes et libram a êste testamento, por se fazer por mancipação (...) 104. E isto se faz assim: o testador, presentes, como nas outras manicipações, cinco testemunhas, cidadãos romanos púberes e o libripende, mancipa ficticiamente sua família a alguém, depois de escrever as tábuas do testamento. Neste acto o familiae emptor diz: EU DECLARO TUA A FAMílIA E O PATRIMÔNIO , SENDO TEU O MANDATO E MINHA A CUSTÓDIA, E ASSIM OS COMPRO COM ÊSTE BRONZE- e segundo o que alguns acrescentam, COM ESTA BALANÇA DE BRONZE - PARA QUE TU POSSAS FAZER UM TESTAMENTO VÁLIDO SEGUNDO A LEI PÚBLICA. Toca em seguida a balança com o bronze, dado como preço ao testador; depois êste, segurando as tábuas do testamento, diz: EU ASSIM DOU, ASSIM LEGO E TESTO OS MEUS BENS COMO ESCREVI NESTAS TÁBUAS E NESTA CERA E ASSIM VÓS, QUIRITES, SOIS TESTEMUNHAS; chama-se a 


\title{
§37. O papel específico do "filius" e do escravo no auxílio à administração
}

\author{
dos bens integrantes do acervo familiar. Neste passo, o paulatino desenvolvimento de
} contratações à distância conduziu, para além dos estritos casos de ausência, à progressiva admissão da atuação de filhos e escravos em prol do patrimônio doméstico encabeçado pelo "pater familias"; conquanto em um primeiro momento somente se vislumbrasse a

isto nuncupação, nuncupar por significar nomear em público, pois sem duvida o testador declara e confirma com palavras gerais o que escreveu especìficamente nas tábuas do testamento").

Observe-se que, no penúltimo período do primeiro passo citado de Gaio (G. 2, 102), o jurisconsulto alude ao emprego usual do termo "família" no sentido de patrimônio familiar; além disso, percebe-se ainda do mesmo trecho que, conforme mencionado ao final da nota de rodapé imediatamente anterior, esta forma de testamento nuncupativo foi admitida em uma fase já desenvolvida do direito romano (ainda que muito anterior a Gaio), eis que nas origens, somente se a concebia se celebrado em comício ("calatis comitiis") ou em preparação à guerra, diante da tropa ("in procinctu"). Note-se, além disso, que de conformidade com o estabelecido nestes passos, o "familiae emptor" era concebido como verdadeiro herdeiro do testador; com o passar do tempo, contudo, foi tomado como autêntico testamenteiro, entrevendo-se já a designação dos herdeiros naquele mesmo ato (a respeito, cf. G. 2, 103).

Aqui podemos entrever, pois, uma utilização da antiga figura da "mancipatio" para a obtenção de fins diversos daqueles naturalmente decorrentes do instrumento jurídico empregado; conquanto não se possa esconder - à semelhança do que se verifica de conformidade com a teoria do negócio jurídico indireto - o efetivo intuito de que redunde a eficácia ordinária do negócio, deve-se observar que esta consiste em simples etapa - intermediária, pois - de um contexto mais amplo, delineado pelo intento das partes. Voltaremos ao tema mais adiante: por ora, contudo, remete-se o leitor ao conteúdo das notas de rodapé (anteriores) em que o tema é abordado (notas 18 e 25).

A respeito da "mancipatio familiae" entre os romanos, cf. G. LEPOINTE, Les obligations cit. (nota 15), p. 104; M. KASER, Direito Privado cit. (nota 15), p. 89 (destacando a importância dos negócios fiduciários entre os romanos, como mecanismo de concatenação dos efeitos de uma espécie de representação indireta); V. ARANGIO-RUIZ, Il mandato cit. (nota 25), pp. 5-6; e A. WATSON, Contract cit. (nota 26), pp. 4-5.

Finalmente, observe-se que no trecho transcrito (de G. 2, 104) consta a expressão "mandatela", sugerindo uma idéia de incumbência que era corrente entre os romanos e que estará ligada de maneira profunda aos negócios jurídicos "causa mortis" - e particularmente ao chamado "mandatum post mortem". De toda forma, a idéia de "incumbir" atrelada ao termo "mandare" permanecerá preservada não apenas durante a evolução do sistema romano, mas inclusive em meio ao direito hispânico medieval. Neste sentido - e destacando as diferenças entre as acepções romana e lusitana da expressão "mandare" - eis a preciosa lição de M. PAULO MERÊA: “'mandare signifie mettre en main' (...) a mesma idea se contém na expressão in manu commitere, bem como nas palavras manufidelis (...) manumissor, usadas em documentos medievais para designar o executor testamentário (também chamado mandatarius) (...) mandare (= manus dare) significou primitivamente colocar-se na dependência de alguém pelo oferecimento das mãos; daqui se teria passado para o sentido transitivo de confiar alguma coisa (...) é, com efeito, vulgar nos testamentos (...) o emprêgo de mandare e adcomendare, êste último verbo no duplo sentido de 'recomendar $=$ determinar' e 'recomendar $=$ confiar (encomendar)'. No sentido de 'dispor', 'estatuir', e em circunstâncias perfeitamente idênticas às de mandare, se adopta o verbo 'iubere', o que bem denota estarem de todo obliteradas as diferenças que o direito romano estabelecia entre as fórmulas imperativas e precativas. Finalmente, ainda nos mesmos casos é empregado freqüentemente o têrmo ordinare, cujo sentido se observa ter evolucionado para a moderna acepção de 'mandar', 'prescrever' (iubere) (...) é por isso também que até ao século XI o verbo mandare sòmente aparece nos nossos documentos como sinónimo de iubere, podendo sempre traduzir-se por 'mandar' no sentido que a palavra tem entre nós actualmente (...) esta curiosa evolução semântica está ligada, a meu ver, ao aperfeiçoamento da própria instituição do testamento e ao facto de o intermediário, o mandatário, deixar de desempenhar uma função técnica preponderante, de ocupar, digamos assim, o centro do acto jurídico, para se ir tornando um testamenteiro, isto é, um executor testamentário (...) de aí tornarem-se vulgares as disposições de última vontade em que os bens são, não já confiados (encomendados) a Fulano, para que dêles faça isto ou aquilo, mas sim deixados a êste e àquêle 'por mão' de Fulano (o executor). Esta última parte pode, mesmo, faltar, porque nem sempre se afigurava indispensável a nomeação expressa dum testamenteiro" (Sôbre a origem da palavra 'manda', in Novos Estudos de História do Direito, Barcelos, Minho, 1937, pp. 110-116). 
percussão da esfera jurídica familiar por posições jurídicas subjetivas ativas (oriundas da atuação do "alieni iuris" ou do escravo), com o decurso do tempo esboçou-se uma tendência a entrever sua vinculação também quando fossem contraídas obrigações. Por sua vez, a expansão romana sobre o Mediterrâneo expôs, de maneira singular, a necessidade de uma redefinição do conceito de esfera jurídica (bem como dos instrumentos de sua respectiva atuação), a fim de que, compreendido de uma maneira mais abrangente, fossem alcançados não apenas os atos ultimados pelo próprio "pater", como também todos aqueles que se cumprissem em atendimento a uma sua prévia incumbência (e presumível supervisão subseqüente); neste cenário, robusteceu-se a prática de incumbir um escravo da administração de todo um patrimônio (ou ao menos de um certo setor considerável do espectro de atuação econômica do principal): e assim surge, pois, a figura do "servus actor" - por vezes designado pela doutrina especializada sob a expressão "schiavo manager",29.

${ }^{29}$ Como teremos a oportunidade de observar mais adiante, esta atuação dos filhos e escravos em prol do "pater" estava em consonância com a regra romana que proibia - de maneira geral - a representação direta, tal como a compreendemos atualmente. O princípio encontra-se articulado em G. 2, 95: “ex his apparet perliberos homines, quos neque iuri nostro subiectos habemus neque bona fide possidemus, item per alienus servos, in quibus neque usumfructum habemus neque iustam possessionem, nulla ex causa nobis adquiri posse. Et hoc est quod vulgo dicitur per extraneam personam nobis adquiri non posse. Tantum de possessionem quaeritur, an per extraneam personam nobis adquiratur" ("daí resulta o não podermos em caso algum adquirir por intermédio de homens livres, nem sujeitos ao nosso poder, nem possuidos de boa fé, assim como não podemos adquirir por meio de escravos alheios, de que não temos o usufruto nem a posse justa. Tal o sentido do dito vulgar, não podemos adquirir por pessoa estranha. Apenas quanto à posse, pergunta-se se podemos adquiri-la por pessoa estranha").

Conquanto vedada, assim, a representação direta, do referido passo de Gaio podem ser extraídas duas exceções: a) a aquisição por meio de agentes que estejam sob o poder do "pater" (filhos e escravos); e b) a aquisição de posse por meio de pessoas não sujeitas ao poder do "pater" - e ainda assim, dada a redação conferida ao trecho de Gaio, tal exceção se revela, possivelmente, controvertida (à época).

Com isso, percebemos que era comum a prática de o "pater" investir subordinados seus (filhos e escravos) em funções administrativas mais ou menos determinadas, em virtude das quais produziam eficácia ativa (aquisições) em prol do patrimônio familiar; somente em um período posterior, graças à atuação do pretor, é que se viabilizou a percussão da esfera jurídica familiar também na hipótese de débitos; para a conformação de um tal sistema, foram de grande importância as chamadas "actiones adiecticiae qualitatis".

Sobre o cometimento de funções administrativas e a respeito da atuação dos filhos e escravos em prol do "pater", em geral, cf. A. SAlivas, A. BEllan, Éléments cit. (nota 15), p. 293 (nota 1); F. K. von SAVIGNY, Sistema II cit. (nota 15), pp. 411-424; Sistema III cit. (nota 15), pp. 111-112; S. DI MARZO, Istituzioni cit. (nota 15), p. 67; J. C. de Matos PeiXoto, Curso cit. (nota 15), p. 347; V. ARANGio-Ruiz, Istituzioni cit. (nota 15), p. 95; L. DíEZ-PICAZO, La representacion en el derecho privado, Madrid, Editorial Civitas, 1979, pp. 27-28; F. CReSPo Allue, La Revocacion del Mandato, Madrid, Editorial Montecorvo, 1984, pp. 51-52; E. Volterra, Istituzioni cit. (nota 15), p. 170; P. VocI, Piccolo manuale cit. (nota 15), p. 320 ; R. QUADRATO, Rappresentanza (diritto romano) in Enciclopedia del diritto 38 (1987), pp. 420-421; M. KASER, Direito Privado cit. (nota 15), p. 90; A. GuARINO, Diritto privato cit. (nota 15), pp. 403-404; V. ARANGIORuIZ, Il mandato cit. (nota 25), pp. 7-8; A. WATSOn, Contract cit. (nota 26), pp. 5-6; F. BrigugliO, Studi cit. (nota 26), pp. 6-8.

Considerando os filhos e escravos como autênticos "órgãos" da empresa doméstica (aptos ao atendimento de funções que, em estruturas sociais mais evoluídas, haveriam de ser cometidas à representação direta), cf. S. RICCOBONO, Lineamenti cit. (nota 15), p. 130. E diferenciando a atuação destes órgãos daquela reprodução 
mecânica (da manifestação de vontade) viabilizada pelo emprego do núncio, cf. A. SANTOS JUSTO, Direito privado cit. (nota 15), p. 200.

Tomando a atuação dos filhos e escravos como uma espécie de representação, cf. A. D'ORS, Elementos cit. (nota 15), pp. 239-240; bem como F. BETANCOURT, Derecho romano cit. (nota 15), p. 624. Em sentido diametralmente oposto - apartando a atuação dos filhos e escravos da idéia de representação (em sentido técnico) - eis a precisa manifestação de U. ALVAREZ SUAREZ: "esta responsabilidad adyecticia del pater no supone una verdadera representación, sino un caso especial de actuación de los efectos del negocio, derivado de la peculiar organización de la familia romana" (Instituciones cit. (nota 15), p. 216).

Aliás, este último autor observa que é exatamente em função de recaírem os efeitos diretamente sobre o patrimônio familiar que a ausência da representação entre os romanos não se fará sentir com maior prejuízo (p. 216); e neste exato sentido, aliás, é a posição de G. PUGLIESE: "si ritiene anzi che lo scarso sviluppo della rappresentanza nel diritto romano, nonostante l'intensità degli affari e la capacità di quei giuristi di trovare la soluzione adatta per molti problemi socio-economici, sia dovuto al larghissimo ricorso che si fece nel periodo preclassico e classico all'attività negoziale degli schiavi e delle persone alieni iuris, specie dei filii familias, e alla maggiore facilità di riconoscere che i loro negozi producessero direttamente effetti (per ius civilis o ius honorarium) in capo al dominus o pater" (Istituzioni cit. (nota 15), p. 248).

A respeito da atuação do "servus actor" em meio à estrutura empresarial familiar, eis a manifestação de A. DI PORTO: "il fenomeno dell'exercere negotiationes per servos communes, emergente dalle fonti (...) è espressione del più generale e unitario fenomeno organizzativo dell'attività impreditoriale (delle negotiationes), sia individuale che collettiva, imperniata sull'impiego manageriale degli schiavi: schiavi di un solo padrone (o figli) nel caso di impresa individuale, servi communes nel caso di impresa collettiva. Tale fenomeno può assumere forme e regimi giuridici diversi a seconda della posizione giuridica assunta dal servus. Fondamentalmente: lo schiavo (o il figlio) potrà essere preposto como magister $\mathrm{o}$ institor dal suo dominus (o dai suoi domini, se trattasi di esercizio collettivo) alla conduzione, rispettivamente, di un'impresa di navigazione (exercitio navis) o di un'impresa commerciale (ad es., exercitio tabernae), ovvero potrà essere fornito dal dominus stesso (o dai domini) di un peculio per l'esercizio di un'attività imprenditoriale (sia essa un'impresa di navigazione o una qualsiasi impresa commerciale). In ogni caso costituirà il cardine intorno a cui ruota l'organismo imprenditoriale", (Impresa coletiva e schiavo 'manager' in Roma antica (II sec. a.C. II sec. d.C), Milano, Dott. A. Giuffrè, 1984, pp. 19-20). No mesmo sentido, cf. F. BriGUGLIO, Studi cit. (nota 26), p. 7; P. ANGELINI, Il 'procurator', Milano, Dott. A. Giuffrè Editore, 1971, pp. 67-74.

Conquanto tratemos mais adiante da vedação à representação direta (como princípio prevalecente entre os romanos), cumpre desde já destacarmos - à vista de sua vinculação direta à atuação dos filhos e escravos "incumbidos" diretamente pelo "pater" - o papel das "actiones adiecticiae qualitatis", as quais, forjadas progressivamente pelo direito pretoriano, tiveram por missão precípua permitir uma extensão (ao patrimônio familiar) da eficácia passiva dos atos ultimados pelos referidos prepostos. Inspirada por razões eminentemente práticas - diante da ameaça à estabilidade das relações comerciais - exsurge a proteção honorária na hipótese de investidura de um subordinado pelo "pater familias" ("actio institoria", "actio exercitoria", "actio de peculio", "actio quod iussu", "actio tributoria" e a "actio de in rem verso"), ou mesmo quando da intercessão de um terceiro estranho ao núcleo familiar ("actio quasi institoria", de origem provavelmente justinianéia). Neste sentido, a manifestação de V. ARANGiO-RUIZ: "all'esclusione della rappresentanza diretta non mancarono compensi e temperamenti tali da evitare le conseguenze dannose che altrimenti avrebbe avute nelle relazioni commerciali (...) un sistema di azioni, dette adiecticiae qualitatis, faceva sì che il padre di famiglia rimanesse obligato tutte le volte che il debito derivava da negozi ch'egli aveva autorizzati o da cui traeva vantaggio. Egli rispondeva per l'intero debito si aveva autorizzato il terzo a contrattare col suo sottoposto (actio quod iussu) o se aveva preposto il figlio o servo all'azienda commerciale marittima (a. exercitoria) o terrestre (a. institoria) pei bisogni della quale il debito era stato contratto; rispondeva nei limiti del peculio se il sottoposto contraente ne era provveduto (a. de peculio), e con qualche maggiore asprezza si gli aveva consentito di farne oggeto di speculazione commerciale (a. tributoria); rispondeva, infine, nei limiti in cui il ricavato del negozio onde il debito derivava era stato destinato a spese necessarie per la sua azienda domestica ( $a$. de in rem verso). In qualche caso, le azioni adiecticiae qualitatis vennero estese a rapporti di preposizione intercedenti, anzichè fra pater familias e sottoposti, fra estranei (...) più controversa (...) è la classicità dell'azione quasi institoria, data contro l'interessato in base al contratto del procurator omnium bonorum" (Istituzioni cit. (nota 15), pp. 95-97).

Pelas "actiones adiecticiae qualitatis" (em geral), cf. A. DOVERI, Istituzioni cit. (nota 15), pp. 216-218; J. P. Molitor, Les obligations cit. (nota 15), pp. 141-150; A. SAlivas, A. Bellan, Éléments cit. (nota 15), pp. 293-294; E. FoucAult, Droit romain: de la representation dans le mandat et gestion d'affaires, Paris, G. Pedone-Lauriel, 1893, pp. 58-83; H. DernburG, Diritto cit. (nota 15), pp. 48-54; É. CuQ, Institutions cit. (nota 15), pp. 403-409; G. Russo, La costruzione giuridica della rappresentanza volontaria ed il nuovo diritto in Studi in onore di Mariano D'Amelio III, Roma, Società Editrice del Foro Italiano, 1933, pp. 272- 


\section{$\S$ 38. A atuação do liberto em prol dos interesses do patrono e a}

excepcional admissão da outorga de incumbências administrativas a pessoas livres não sujeitas ao poder do "pater familias". O desenvolvimento da figura do "servus actor" se mostra profundamente influenciado pela estrutura fática (subjacente à relação) à qual está adstrito: enquanto originariamente o escravo manumisso atuava em prol de uma família ("lato sensu") de que ainda fazia parte (e à qual permanecia ligado por meio de um vínculo sustentado pelo "patronato"), com o passar do tempo, verifica-se um progressivo esvaziamento do fundamento econômico-social que lastreava a sua atuação; com isso, passa a se revestir de um inegável contorno jurídico aquilo que, até então, se compreendia como uma relação pertinente a um dos diversos outros setores do (imenso) cenário da normatividade genérica. Ora, considerando-se que a tal fato se adiciona uma gradativa admissão da gestão de interesses alheios por terceiros ingênuos, logo se compreende que o vínculo orgânico que unia o "liberto" ao "patrono" vai aos poucos se degenerando, cedendo espaço a uma autêntica relação jurídica, em que são partes o "procurator" e o principal; eis aí, pois, a origem e a explicação para o alcance do excerto constante de G. 2 , $95^{30}$.

273; W. W. BuCKLAND, A. D. MCNAIR, Roman law cit. (nota 15), pp. 168-169; P. BONFANTE, Istituzioni cit. (nota 15), p. 79, nota 1 (com o reconhecimento de que necessidades comerciais levaram à mitigação do excessivo rigor do princípio proibitivo da representação direta); R. MONIER, Manuel Élémentaire de Droit Romain II - deuxième année de licence: diplômes d'études supérieures de droit romain et de droit privé (les obligations), $4^{\mathrm{a}}$ ed., Paris, Éditions Domat Montchrestien, 1948, pp. 258-261; E. PETIT, Tratado cit. (nota 15), pp. 521-524; G. SCIASCIA, Sinopse cit. (nota 15), p. 35; A. WATSON, Contract cit. (nota 26), pp. 5-6; U. ALVAREZ SUAREZ, Instituciones cit. (nota 15), p. 217 (sobre a atuação do "institor" e do "exercitor"); J. ITURRIAGA ROMERO, La representacion en el derecho privado, Lima, Universidad Nacional Mayor de San Marcos, 1974, pp. 34-36; A. D’ORS, Elementos cit. (nota 15), pp. 239-240; F. CRESPO AlLUE, La Revocacion cit. (nota 29), pp. 52-53; E. VOLTERRA, Istituzioni cit. (nota 15), p. 171; R. QUADRATO, Rappresentanza cit. (nota 29), pp. 426-431; G. PUGLIESE, Istituzioni cit. (nota 15), pp. 250-252 (com observações sobre a gênese, a evolução e o papel de relevo das ações "adiecticiae qualitatis"); A. SANTOS Justo, Direito privado cit. (nota 15), pp. 200-201 (com indicação das fontes respectivas); M. KASER, Direito Privado cit. (nota 15), pp. 90-91; A. GUARINO, Diritto privato cit. (nota 15), pp. 409-413 (por uma análise minudente das "actiones adiecticiae qualitatis" e com a indicação das respectivas fontes).

${ }^{30}$ A respeito da origem familiar do instituto da "procuratio" (estribado na freqüente atuação de um liberto em prol dos interesses do "patrono"), cf. E. Costa, Storia cit. (nota 15), pp. 374-375; P. BONFANTE, Diritto cit. (nota 15), p. 293; Istituzioni cit. (nota 15), p. 79; P. VocI, Piccolo manuale cit. (nota 15), p. 321; M. KASER, Direito Privado cit. (nota 15), p. 90.

Com efeito, a doutrina destaca que o instituto apresentava, em suas origens, contornos mais propriamente sociais do que jurídicos, verificando-se uma progressiva "juridicização" à custa da degeneração do vínculo que o sustentava ("patronato"), bem como de uma progressiva admissão da atuação (em prol do "pater") de terceiros ingênuos; neste sentido, cf. P. BONFANTE, Diritto cit. (nota 15), p. 293; Istituzioni cit. (nota 15), p. 79; P. Voci, Piccolo manuale cit. (nota 15), p. 321; Manuale cit. (nota 15), p. 366. Eis a precisa síntese de F. BRIGUGLIO: "l'originario inquadramento di questa figura (...) sembra da individuare nel particolare legame economico-sociale che se instaurava tra il dominus e lo schiavo liberato (...) il rapporto fra loro esistente, pur non essendo del tutto privo di una qualificazione giuridica, trovava probabilmente una tutela (...) sull'aspettativa che una persona ripone nell'altrui comportamento. Si tratta (...) del rispetto di quei doveri di reciproca lealtà e correttezza negoziale che (...) in Roma (...) hanno trovato una tutela processuale. Questa 


\section{$\S 39$. A gestão (geral) de interesses alheios (em prol do principal) e o}

conceito de "procurator": pluralidade terminológica e o emprego isolado do termo. Em sua oração pro Caecina $(20,57)$, Cícero define o termo "procurator" por meio de uma alusão àquela que é a sua modalidade mais antiga (e ao mesmo tempo a mais distante do "mandato" em sua configuração original): vale dizer, o "procurator omnium rerum", o qual, de uma maneira sintética, poderia ser conceituado como sendo aquele que gere os negócios alheios de modo prolongado (e não por um único instante); conquanto tal enunciado não se mostre imune a críticas - tome-se em conta a sua evidente omissão a respeito da "investidura" que, no período justinianeu servirá de sumo critério para a distinção entre o "mandato" e a "gestão de negócios" - tem a virtude de evidenciar, todavia, o caráter duradouro da atuação do agente, característica que corresponde justamente ao fator de discriminação entre esta variante da "procuratio" e suas correlatas (afetas, por sua vez, a atuações pontuais do encarregado). De todo modo, não se pode deixar de assinalar que nas fontes tal espectro semântico é referido não apenas por meio da expressão acima mencionada, mas também por suas variações “procurator rerum suarum”,

particolare connotazione economico-sociale, propria dell'originaria procuratio, ha ricoperto probabilmente un ruolo non marginale fino al momento in cui si è sentita l'esigenza di regolare giuridicamente tali doveri sociali e d'amicizia. Fintanto che il procurator resta, in un certo senso, una figura confinata entro l'ambito della famiglia, essendo considerato una sorta di 'organo della comunità domestica', il rapporto conserva quella natura potestativa e autoritativa che aveva caratterizzato l'istituto fin dal principio. In origine (...) l'investitura del procurator omnium rerum consisteva in un atto unilaterale del patronus e l'ordine ('iussum') dato da quest'ultimo si poneva a fondamento dei negozi giuridici conclusi coi terzi da parte del procurator. Col passare del tempo (...) sia per il mutare dei rapporti tra patrono e liberto, che diventano rapporti giuridici suscettibili di essere fatti valere processualmente, sia per il fatto che probabilmente cominciano a diventare sempre più frequenti i casi di procuratori scelti tra persone libere e ingenue, si avverte la necessità di regolare giuridicamente il rapporto intercorrente tra il procurator e il principale, non potendo più bastare la sanzione che derivava dalla violazione del vincolo di patronato e, sul piano sociale, il pericolo di emarginazione che gravava sul procuratore che avesse tradito la fiducia del dominus. La necessità di una regolamentazione giuridica dei rapporti intercorrenti tra il dominus e il procurator, tuttavia, non venne soddisfatta riconducendo immediatamente la procura nell'area consensualistica del contratto di mandato" (Studi cit. (nota 26), pp. 13-16).

A utilização progressiva de terceiros ingênuos (estranhos à família) é destacada por R. QUADRATO, o qual admite que embora de início se pudesse entrever "una linea di tendenza, ancora operante nella tarda età repubblicana, a individuare nel liberto, se non la sola, la persona più adatta ad assumere la funzione, l'officium (...) di procurator (...) sono disarmonie, incertezze, aporie legate alla 'storia' complessa di questa istituzione che, 'derivata dalla struttura assolutistica della famiglia romana', si è andata via via trasformando per varie cause, non tutte chiaramente decifrabili tra le quali il progressivo accentuarsi dell' indipendenza del liberto e l'affermarsi della prassi di nominare procurator 'anche un uomo del tutto estraneo alla famiglia"" (Rappresentanza cit. (nota 29), pp. 424-425); no mesmo sentido, cf. V. ARANGIO-RUIZ, Il mandato cit. (nota 25), p. 9.

Sobre a absorção (pelo direito) de parte do "mundo fático" - até então abrangida por outros ramos da normatização social - cf. F. C. PONTES DE MIRANDA, Tratado de Direito Privado I - Parte Geral: Introdução. Pessoas físicas e jurídicas, $4^{\mathrm{a}}$ ed., São Paulo, Revista dos Tribunais, 1983, pp. 9-10.

A respeito do texto de G. 2, 95 (bem como de sua tradução), cf. nota 29; pelas considerações expendidas no corpo do texto a respeito de sua origem (e de seu respectivo alcance), cf. V. ARANGIO-RUIZ, Il mandato cit. (nota 25), p. 7. 


\title{
"procurator totorum bonorum" e "procurator omnium bonorum" - quando não pela \\ simples alusão a "procurator" (desprovida tal menção de qualquer elemento complementar,
} a sugerir uma tendência especificante) $)^{31}$.

\begin{abstract}
${ }^{31}$ Eis a definição de "procurator" constante da obra de Cícero: "57. de liberis autem quisquis est, procuratoris nomine appelletur ; non quo omnes sint aut appellentur procuratores qui negoti nostri aliquid gerant, sed in hac re cognita sententia interdicti verba subtiliter exquiri omnia noluerunt. non enim alia causa est aequitatis in uno servo et in pluribus, non alia ratio iuris in hoc genere dumtaxat, utrum me tuus procurator deiecerit, is qui legitime procurator dicitur, omnium rerum eius, qui in Italia non sit absitve rei publicae causa, quasi quidam paene dominus, hoc est alieni iuris vicarius, an tuus colonus aut vicinus aut cliens aut libertus aut quivis, qui illam vim deiectionemque tuo rogatu aut tuo nomine fecerit" (Pro Caecina, 20, 57). Dentre todos os elementos integrantes de tal definição - como ressaltado no corpo do texto - ressalta o caráter duradouro da gestão que, qualificado pela ausência do dominus negotii ("absentia domini"), conforma a atuação do "procurator omnium rerum" e o distingue das demais modalidades de "procurator" ("ad litem" e "unius rei"), caracterizadas pela especificidade da administração confiada.
\end{abstract}

Tal definição de Cícero é tão difundida que, além de ser referência constante na bibliografia especializada - a respeito cf., por todos, R. QUADRATO, Rappresentanza cit. (nota 29), p. 423; bem como A. WATSON, Contract cit. (nota 26), pp. 6-7 - mereceu uma posição de destaque, por exemplo, no estudo de F. SERRAO, onde foi tomada com a mesma autoridade do fragmento de Ulpiano constante de Ulp. 9 ad Ed. D. 3, 3, 1 (Il procurator, Milano, Antonino Giuffrè Editore, 1947, pp. 11-19). Por sinal, eis o conteúdo do "principium" do referido passo do jurisconsulto: "procurator est, qui aliena negotia mandatu domini administrat" ("procurador es el que administra negocios ajenos por mandato del dueño"). Como se pode ver, há uma alusão genérica à incumbência de administrar em decorrência de um mandato do dominus; teremos a oportunidade de voltar a este assunto mais adiante, cabendo-nos, por ora, destacar que todas as referências ao Digesto (bem como às demais coleções integrantes do Corpus Iuris Civilis) contidas neste trabalho, serão acompanhadas da tradução de I. L. GARCÍA DEL CORRAL (in casu, Cuerpo de Derecho Civil Romano (a doble texto, traducido al castellano del latino) - Primeira Parte: Instituta-Digesto, Barcelona, Jaime Molinas Editor, 1889, p. 307). A doutrina especializada, por sua vez, apresenta diversas definições a respeito do "procurator omnium rerum"; dentre as quais, exemplificativamente, nos parecem imprescíndiveis as referências a F. SERRAO ("il procurator romano era l'amministratore stabile e generale, munito di pieni poteri, di tutti gli affari compresi quelli giudiziali, di un terzo, per lo più assente. Esse veniva costituito per preposizione unilaterale del principale o per sua spontanea ingerenza al fine di prendere cura degli affari del terzo assente. Egli non aveva rappresentanza diretta, ecceto che nell'acquisto del possesso, e i suoi rapporti col dominus erano regolati dall'actio negotiorum gestorum", Il procurator cit. (nota 31), pp. 19-20), V. SCIALOJA ["il concetto romano del procurator (comune al procurator litis, omnium bonorum e unius rei, e al negotiorum gestor) sia quello di persona che cura i negozi altrui non per uno solo momento, ma prolungatamente. Perciò il mandato relativo ad un atto unico e non prolungato non costituisce procurator il mandatario; mentre invece così vien chiamato il mandatario, il quale debba compiere diversi negozii, o un negozio che richieda una prolungata amministrazione, come la lite e come la ritenzione del possesso", L'acquisto del possesso per mezzo dei terzi secondo il diritto romano e l'attuale di S. Schlossmann, in Studi giuridici I - diritto romano, Roma, Anonima Romana Editoriale, 1933, p. 103], P. BONFANTE ("il procurator è distinto essenzialmente dal mandatario, sovratutto per la sua base sociale. Non è un semplice incaricato, ma una specie di factotum ai servigi del principale, di solito un liberto, il quale poteva esser munito di mandato, e allora dicevasi cum administratione o cum libera administratione, ma il più delle volte era anche senza mandato. Insomma sua base essenziale non è il vincolo contrattuale e giuridico del mandato, bensì la fiducia del principale, il carattere e il rapporto sociale della persona col principale: suo tipo è il procurator omnium bonorum, non il mandatario unius negotii", Facoltà e decadenza del procuratore romano, in Studii giuridici dedicati e offerti a Francesco Schupfer nella ricorrenza del XXXV anno del suo insegnamento I - diritto romano, Torino, Fratelli Bocca Editori, 1898, p. 10) e R. QUADRATO ("il ricorso a questa forma di intermediazione segna un momento di passaggio nell'assetto della vita sociale, da una fase ad'una altra, da una cultura ad un'altra: un elemento di transito, e di raccordo, tra tradizione e modernità. È 'una figura sociale, prima che giuridica' (...) la parola, che nell'etimo richiama l'immagine del curator, sta a signiicare colui che amministra, 'cura', appunto, gli interessi altrui: un'accezione che, dall'iniziale generecità (...) tende ad assumere sempre di più un carattere tecnico (...)", Rappresentanza cit. (nota 29), p. 423).

Com efeito, da definição de F. SERRAO se extraem o caráter duradouro da gestão e o requisito da "absentia domini"; admitindo-se, ademais, a intervenção espontânea do gestor e a produção de efeitos (consideravelmente limitados) de uma representação direta (Il procurator cit. (nota 31), pp. 19-20); por sua 


\title{
$\S 40$. A gestão (especial) de um processo alheio (em prol do principal) e a
}

\author{
figura do "procurator ad litem"; a coexistência face ao "cognitor" e a criação pretoriana
}

vez, da conceituação de V. SCIALOJA se obtém, como elemento indissociável da noção de "procurator", a idéia de administração (continuada), que se protrai no tempo (p. 103). Note-se que o autor, em comentário a trabalho de S. SCHLOSSMANN (Der Besitzerwerb durch Dritte nach römischen und heutigem Recht - Ein Beitrag zur Lehre von der Stellvertretung, Leipzig, Druck und Verlag von Breitkopf und Härtel, 1881, pp. X175), nos fornece uma paráfrase da definição oferecida por este (em obra à qual infelizmente não tivemos acesso): "il procurator è colui che ha cura dei negozii altrui, è un factotum, per lo più un liberto, che si trova in un puro rapporto di fatto col patrimonio, pel quale egli si adopera. Egli gode la fiducia del principale, ma non è ad esso legato da un vincolo giuridico, e i terzi facilmente s'inducono a contrattare col procurator conoscendo quella fiducia. Il principale talora dava al suo procuratore il mandato generale di amministrare il suo patrimonio, e in tal caso il procurator omnium bonorum prendeva il nome di procurator cum administratione, o cum libera administratione" (L'acquisto cit. (nota 31), p. 99).

De sua parte, a definição de P. BONFANTE nos fornece a perenidade da administração como nota distintiva da atuação do "procurator" ("omnium bonorum") em relação ao simples "mandatário", posta em destaque, ainda, a influência do elemento social sobre o vínculo estabelecido entre o agente e o principal (Facoltà cit. (nota 31), p. 10); finalmente, do excerto de R. QUADRATO se extrai a preponderância (inicial) do elemento social e a proximidade da noção de "curador", à custa de um progressivo processo de "juridicização" do vínculo (Rappresentanza cit. (nota 29), p. 423).

Em virtude, portanto, das peculiaridades de tais definições, foram então por nós recopiladas para uma ulterior comparação direta (por parte do leitor). Todavia, outras tantas podem ser extraídas dos estudos de S. SoLAZZI [La definizione del procuratore in Scritti di diritto romano II (1913-1924), Napoli, Casa Editrice Dott. Eugenio Jovene, 1957, pp. 557-567, especialmente p. 567 (pela adoção da definição contida em Ulp. 9 ad Ed. D. 3, 3, 1, considerada perfeita, após delicado estudo sobre a autenticidade do fragmento); Le facoltà del 'procurator bonorum' nel diritto romano-ellenico in Scritti di diritto romano II (1913-1924), Napoli, Casa Editrice Dott. Eugenio Jovene, 1957, pp. 579-592, especialmente p. 579 (com destaque à equiparação entre o "procurator" e o administrador legal de coisas alheias)]; H. DERNBURG [Diritto cit. (nota 15), pp. 500 (nota 02) e 524-525 (pela polissemia do termo "procurator" e sobre o conceito amplo de "negotiorum gestio" prevalecente antes da reformulação promovida pelo direito justinianeu, p. 500, nota 2 e pp. 524-525)]; A. D'ORS (Elementos cit. (nota 15), p. 240); V. ARANGIO-RUIZ (Istituzioni cit. (nota 15), p. 351) e P. VOCI [Manuale cit. (nota 15), pp. 365-367 (caracterizando a atividade do "procurator omnium rerum" mais como uma gestão provida de poderes genéricos do que como uma administração geral do patrimônio do principal)]. Como referido no corpo do texto, o encarregado da administração geral de um patrimônio alheio é designado por expressões diversas (suscetíveis de um agrupamento em virtude do emprego constante do termo "procurator"): por exemplo, pelo "procurator omnium rerum" temos: Ulp. 4 ad Ed. D. 2, 14, 12; Ulp. 9 ad Ed. D. 3, 3, 1, 1; Ulp. 76 ad Ed. D. 44, 4, 4; Ulp. 57 ad Ed. D. 47, 10, 17, 16; Iul. 4 ad Urs. Fer. D. 3, 3, 47; Paul. 10 ad Ed. D. 3, 6, 7; Paul. 30 ad Ed. D. 14, 3, 6; Cels. 20 Dig. D. 46, 3, 87; já sobre o "procurator omnium bonorum" temos: Gai. lib. sing. ad form. hyp. D. 20, 6, 7, 1; Paul. 72 ad Ed. D. 46, 2, 20, 1; Ulp. 77 ad Ed. D. 46, 7, 3, 2. Por sua vez, como designações esporádicas, temos - exemplificativamente - as alusões ao "procurator rerum suarum" (Iul. 4 ad Urs. Fer. D. 3, 3, 47 e Paul. 3 ad Sab. D. 12, 6, 6 pr.) e ao "procurator totorum bonorum" (Mod. 6 diff. D. 3, 3, 63). Finalmente, pelo emprego isolado do termo "procurator", cf. G. 1, 19 ("procuratoris") e G. 2, 64 ("procurator").

Sobre o caráter mais antigo da "procuratio omnium rerum" em relação às outras modalidades de "procuratio" ("ad litem" e "unius rei”), cf. F. SERRAO, Il procurator cit. (nota 31), pp. 41-46; B. FrESE, Defensio, Solutio Expromissio des unberufenen Dritten, in Studi in onore di Pietro Bonfante nel XL anno d'insegnamento IV, Milano, Fratelli Treves Editori, 1930, pp. 400-402; E. Albertario, Procurator unius rei, in Studi di diritto romano III - Obbligazioni, Milano, Antonino Giuffrè Editore, 1936, pp. 497-500; V. ARANGIO-RUIZ, Il mandato cit. (nota 25), pp. 8-19.

Sem querer antecipar maiores digressões a respeito da relação entre a "procuratio omnium rerum" e o "mandatum", cabe destacar que aquela é a modalidade de "procuratio" mais distante do contrato de mandato, uma vez que este, na origem, era tomado como incumbência "específica", sendo aquela a modalidade de administração "genérica" por excelência no direito romano clássico; como teremos a oportunidade de destacar mais adiante, a existência de variantes da "procuratio" caracterizadas por uma atuação pontual do agente, ao mesmo tempo em que a aproxima do mandato, se depara com este instituto em trajetória exatamente contrária, na medida em que se passa a admitir, com o decurso do tempo, a existência de uma modalidade de "mandatum" geral - a par daquela variante originária de cunho tradicionalmente pontual. 
de um mecanismo de representação processual: polêmica quanto à sua existência no direito clássico. Tomada a "procuratio omnium rerum" como ponto de partida, a evolução do sistema jurídico romano (principalmente à custa da criação pretoriana) se deu no sentido da admissão de outras modalidades de gestão de interesses alheios (caracterizadas, sobretudo, pela especificidade da atuação do agente). Assim, no âmbito processual (em razão da impossibilidade de intervenção de um escravo ou de um "alieni iuris" em prol do "paterfamilias"), ao largo da tradicional figura do "cognitor" exsurge o "procurator ad litem", cuja investidura se dava sem maiores solenidades (uma vez que nem era mesmo necessária a presença do adversário) e sem qualquer prejuízo quanto ao domínio do processo (que permanecia sob o controle último do principal); posto de parte o intenso debate acerca da época precisa de introdução de tal personagem no direito romano (alguns esposando a tese de ser uma modalidade clássica, enquanto outros a consideram uma degeneração pós-clássica da "procuratio omnium rerum"), a disparidade entre as circunstâncias que cercam a atuação do "cognitor" e do "procurator ad litem" parece sugerir ter havido - durante um intervalo de tempo mais ou menos dilargado - uma coexistência entre os referidos modelos de intervenção processual, sobretudo à vista de uma consagração simultânea de ambos em determinadas passagens das fontes ${ }^{32}$.

\footnotetext{
${ }^{32}$ A origem pretoriana da figura do "procurator ad litem" é atestada pelo fato de que as principais menções a tal personagem, como veremos, podem ser encontradas no título "dei procuratoribus et defensoribus" ("sobre os procuradores e sobre os defensores"), constante de D. 3, 3: ocorre que dentre os 78 (setenta e oito) fragmentos que o compõem, 54 (cinqüenta e quatro) remontam a comentários ao edito (atribuídos a Ulpiano, Paulo e Gaio): cf. Ulp. $9 a d$ Ed. D. 3, 3, 1; Paul. 8 ad Ed. D. 3, 3, 2; Ulp. 9 ad Ed. D. 3, 3, 3; Paul. 8 ad Ed. D. 3, 3, 4; Ulp. 7 ad Ed. D. 3, 3, 5; Paul. 6 ad Ed. D. 3, 3, 6; Ulp. 7 ad Ed. D. 3, 3, 7; Ulp. 8 ad Ed. D. 3, 3, 8; Gai. 3 ad Ed. prov. D. 3, 3, 9; Ulp. 8 ad Ed. D. 3, 3, 10; Paul. 8 ad Ed. D. 3, 3, 11; Gai. 3 ad Ed. prov. D. 3, 3, 12; Ulp. 8 ad Ed. D. 3, 3, 13; Paul. 8 ad Ed. D. 3, 3, 14; Ulp. 8 ad Ed. D. 3, 3, 15; Paul. 8 ad Ed. D. 3, 3, 16; Ulp. 9 ad Ed. D. 3, 3, 17; Ulp. 9 ad Ed. D. 3, 3, 19; Paul. 8 ad Ed. D. 3, 3, 20; Gai. 3 ad Ed. prov. D. 3, 3, 21; Paul. 8 ad Ed. D. 3, 3, 22; Ulp. 9 ad Ed. D. 3, 3, 23; Paul. 8 ad Ed. D. 3, 3, 24; Ulp. 9 ad Ed. D. 3, 3, 25; Paul. 8 ad Ed. D. 3, 3, 26; Ulp. 9 ad Ed. D. 3, 3, 27; Ulp. 9 ad Ed. D. 3, 3, 29; Ulp. 9 ad Ed. D. 3, 3, 31; Paul. 8 ad Ed. D. 3, 3, 32; Ulp. 9 ad Ed. D. 3, 3, 33; Gai. 3 ad Ed. prov. D. 3, 3, 34; Ulp. 9 ad Ed. D. 3, 3, 35; Paul. 8 ad Ed. D. 3, 3, 36; Ulp. 9 ad Ed. D. 3, 3, 37; Ulp. 40 ad Ed. D. 3, 3, 38; Ulp. 9 ad Ed. D. 3, 3, 39; Ulp. 9 ad $E d$. D. 3, 3, 40; Paul. 9 ad Ed. D. 3, 3, 41; Paul. 8 ad Ed. D. 3, 3, 42; Paul. 9 ad Ed. D. 3, 3, 43; Paul. 9 ad Ed. D. 3, 3, 45; Gai. 3 ad Ed. prov. D. 3, 3, 46; Gai. 3 ad Ed. prov. D. 3, 3, 48; Paul. 54 ad Ed. D. 3, 3, 49; Gai. 22 ad Ed. prov. D. 3, 3, 50; Ulp. 60 ad Ed. D. 3, 3, 51; Paul. 57 ad Ed. D. 3, 3, 52; Ulp. 60 ad Ed. D. 3, 3, 53; Paul. 50 ad Ed. D. 3, 3, 54; Ulp. 65 ad Ed. D. 3, 3, 55; Ulp. 66 ad Ed. D. 3, 3, 56; Ulp. 74 ad Ed. D. 3, 3, 57; Paul. $71 \mathrm{ad} E d$. D. 3, 3, 58; Paul. $57 \mathrm{ad} E d$. D. 3, 3, 77. Nesse sentido, aliás, defendendo a origem pretoriana do "procurator ad litem", cf. V. ARANGIO-RUIZ, Istituzioni cit. (nota 15), p. 351; bem como P. VocI, Piccolo cit. (nota 15), p. 332.

Conquanto à época de surgimento do "procurator ad litem" já existisse a figura do "cognitor", seus regimes jurídicos não se confundiam, à vista da menor solenidade que cercava a instituição de um "procurator", bem como dos poderes mais restritos que se atribuía a esta espécie de agente. Enquanto o "cognitor" haveria de ser investido em suas funções na presença do adversário, tamanha rigidez não se aplicava ao "procurator ad litem" (o qual, aliás, não se tornava titular da posição judicialmente defendida, tal como se verificava em relação àquele). Nas palavras de A. SANTOS JUSTO: "o processo do agere per formulas veio permitir, na sequiência duma evolução, a prática de actos típicos da representação directa através da dactio cognitoris: a
} 
substituição processual do demandante ou do demandado feita em forma solene e verbal na presença do adversário. Inicialmente, o cognitor ocupava o lugar do demandante ou do demandado e sofria, na sua esfera jurídica, os efeitos da sentença. Mais tarde, provavelmente na época dos Severos e por obra da iurisprudentia, esta representação indirecta transformou-se numa verdadeira representação, agindo o representante (procurator, tutor ou curator) em nome e no interesse do representado, a quem pertencia a legitimidade (activa e passiva) da correspondente actio, e da eventual e subsequente actio iudicati" (Direito privado cit. (nota 15), p. 202). Pelas linhas gerais sobre a diferenciação entre tais personagens, cf. P. WILLEMS, Le droit public romain ou les institutions politiques de Rome depouis l'origine de la ville jusqu'a Justinien, $5^{\mathrm{a}}$ ed., Paris, Ernest Thorin, 1884, pp. 346-347; F. BONIFACIO, Cognitor, procurator e rapporto processuale, in Studi in onore di Pietro de Francisci, Milano, Giuffrè, 1956, pp.535-548; V. SCIALOJA, Cognitur und Procuratvr di F. Eisele in Studi giuridici I - diritto romano, Roma, Anonima Romana Editoriale, 1933, pp. 170-173; F. BuONAMICI, Storia della procedura civile romana, Pisa, Nistri, 1886, pp.540-553; C. BeRTOLINI, Appunti didattici di diritto romano II - Il processo civile, Torino, Unione Tipografico-Editrice Torinese, 1914, pp. 293-294; R. MONIER, Manuel cit. (nota 29), pp. 262-263; A. H. J. GREENIDGE, The legal procedure of Cicero's time, New York, Augustus M. Kelley, 1971, pp. 235-243; P. VoCI, Piccolo cit. (nota 15), p. 332; Manuale cit. (nota 15), pp. 377-383; J. A. CROOK, Legal Advocacy in the Roman World, London, Gerald Duckworth \& Co. Ltd., 1995, pp. 158-163; A. GUARINO, Diritto privato (nota 15), pp. 408-409. Distinguindo de ambas as figuras, ainda, a atuação do "advocatus", cf. A. DovERI, Istituzioni cit. (nota 15), p. 233; R. TAUBENSCHLAG, The law of Greco-Roman Egypt in the light of the Papyri, 332 B.C.-640 A.D., New York, Herald Square Press, 1944, pp. 386-388; A. WATSON, Contract cit. (nota 26), pp. 56-60; bem como H. M. F. MADEIRA, História cit. (nota 26), pp. 64-66 e 68.

No que concerne à época de surgimento do "procurator ad litem", devem ser ressaltadas as posições de F. SERRAO (Il procurator cit. (nota 31), pp. 42-46) e B. FRESE (Defensio cit. (nota 31), pp. 400-402), os quais defendem que tal figura somente despontou no período pós-clássico (correspondendo a uma degeneração do "procurator omnium rerum"). Em contrapartida - e parece-nos que acertadamente - V. ARANGIO-RUIZ defende que tal modalidade de "procurator" já poderia ser entrevista durante o período clássico, eis que assim o atestam quatro passos das Institutas de Gaio (Il mandato cit. (nota 25), pp. 12-17, especialmente pp. 13-15). Com efeito, em G. 4, 55, trata-se do "cognitor" e do "procurator" promiscuamente, em meio ao livro em que Gaio trata das ações, parecendo-nos acertado que o jurisconsulto se referia à modalidade "ad litem" ("item palam est, si quis aliud pro alio inten incertae partis actio data sit, veluti talis: QUANTAM PARTEM PARET IN EO FUNDO, QUO DE AGITUR, actoris ESSE; quod genus actionis in pauderit, nihil eum periclitari eumque ex integro agere posse, quia nihil ante videtur egisse: veluti si is, quis hominem Stichum petere debet, Erotem petierit; aut si quis EX TESTAMENTO DARI sibi OPORTERE intenderit, cui ex stipulatu debebatur; aut si cognitor aut procurator intenderit sibi DARI OPORTERE"; "é também manifesto que quem pedir uma coisa por outra nada sofre, podendo agir uma segunda vez; pois, se entende não ter antes havido acção alguma. Tal o caso de quem, devendo pedir o escravo Stico, reclamar Erotes; ou o de quem na intentio pretenda dever ser-lhe dado por testamento, o que se lhe deve por estipulação; ou ainda o caso do cognitor ou procurator, pretendendo que se lhes deva dar a êles"); já em G. 4, 84, tratando-se de uma administração de interesses alheios de índole eminentemente processual, parece acertado concebê-la como característica da atuação da aludida modalidade específica de "procurator" ("procurator vero nullis certis verbis in litem substituitur, sed ex solo mandato et absente et ignorante adversario constituitur"; "o procurador, ao contrário, é substituído, na causa, sem palavras especiais, mas por simples mandato, podendo constituir-se na ausência e ignorância do adversário"). Por sua vez, em G. 4, 98-101, trata-se da atuação processual do "procurator", sendo aplicáveis as mesmas considerações expendidas quanto ao excerto anterior, corroboradas pela comparação constante com a figura do "cognitor" ("98. Procurator vero si agat, satisdare iubetur ratam rem dominum habiturum; periculum enim est, ne iterum dominus de eadem re experiatur. Quod periculum non intervenit, si per cognitorem actum fuerit, quia de qua re quisque per cognitorem egerit. 99. Tutores et curatores eo modo, quo et procuratores, satisdare deber verba edicti faciunt; sed aliquando illis satisdatio remittitur. 100. Haec ita, si in rem agatur: si vero in personam, ab actoris quidem parte quando satisdari debeat quarentes, eadem repetemus, quae diximus in actione que in rem agitur. 101. Ab eius vero parte cum quo agitur, si quidem alieno nomine aliquis interveniat, omni modo satisdari debet, quia nemo alienae rei sine satisdatione defensor idoneus intellegitur. Sed si quidem cum cognitore agatur, dominus satisdare iubetur; si vero cum procuratore, ipse procurator. Idem et de tutore et de curatore iuris est"; "98. Mas o procurador, se agir, deve dar caução pela futura ratificação de seus actos pelo mandante, por haver perigo de êste renovar a demanda sôbre a mesma questão. Tal perigo não existirá se tivesse agido por intermédio de um cognitor, pois qualquer acção movida mediante o cognitor não pode ser renovada pelo mandante, como não o poderia se êle mesmo tivesse agido. 99. Os tutores e curadores devem, segundo as palavras do edito, prestar caução de modo idêntico aos procuradores; mas às vezes são dispensados da caução. 100. Assim se procede nas acções in rem; quanto às in personam, tratando-se de caução a ser prestada pelo autor, repetiremos o mesmo já dito sobre a acção in rem. 101. Mas 


\section{$\S$ 41. A extensão da administração especial ao âmbito extrajudicial: o}

"procurator unius rei" e a polêmica sobre o momento de sua origem. Contudo, não foi apenas no âmbito processual que se passou a admitir uma gestão de interesses alheios um tanto mais "específica"; também na órbita negocial ganhou espaço uma nova modalidade de atuação, por meio da qual o agente se incumbia de uma atribuição isolada: trata-se da chamada "procuratio unius rei" (excluída, por óbvio, a peculiar variante "ad litem"). Conquanto também exista larga polêmica sobre a época do aparecimento desta nova espécie de "procurator", a nota que nos desperta maior interesse é outra: trata-se do progressivo trânsito em direção a um modelo mais suscetível de uma aproximação efetiva com o "mandatum"; como teremos a oportunidade de destacar logo adiante, enquanto com relação ao contrato de mandato se verificará um movimento rumo à admissão da assunção de incumbências cada vez mais genéricas, no que toca à "procuratio" verifica-se a tendência exatamente inversa - despontando variantes específicas de um instituto que, em suas origens ("procuratio omnium rerum"), tinha na amplitude (material e temporal) de atribuições a sua nota característica ${ }^{33}$.

por parte do réu, se alguém intervier em seu nome, deve necessàriamente prestar caução, porque não se admite um defensor idóneo de causas alheias sem dar caução. Porém, pleiteando-se com um cognitor, a caução incumbe ao mandante; com um procurador, êste mesmo deve prestá-la. Igual direito se aplica ao tutor e ao curador"); finalmente, em G. 4, 182, existe vedação (decorrente da pena de infâmia) à própria "substituição" processual - ou mesmo à atuação no interesse de outrem - por meio do emprego do "cognitor" ou do "procurator" - neste último caso, em uma referência oblíqua à modalidade "ad litem" ("(...) nec tamen ulla parte edicti id ipsum nominatim exprimitur, ut aliquis ignominiosus sit; sed qui prohibetur et pro alio postulare et cognitorem dare procuratoremve habere, item procuratorio aut cognitorio nomine iudicio intervenire, ignominiosus esse dicitur"; "em nenhum lugar do edito se declara de modo expresso seja alguém notado de infâmia; porém, como se diz vulgarmente, é infame aquêle ao qual se proíbe postular em nome de outrem, dar cognitor ou ter procurador, intervir em juízo, na qualidade de procurador ou cognitor"). Adotando a conclusão de V. ARANGiO-RUIZ, cf. A. WATSON, Contract cit. (nota 26), p. 9.

De qualquer forma, por uma análise minudente da questão concernente à época de introdução do "procurator ad litem" no sistema processual romano, cf. P. ANGELINI, Il 'procurator' cit. (nota 29), pp. 175-192; O. PAPERI, Considerazioni sull'origine del 'procurator ad litem' in Labeo - Rassegna di Diritto Romano 48 (2002), pp. 37-71 (especialmente pp. 66-71).

Note-se, ainda, que em decorrência da rigidez do sistema processual durante o período das "legis actiones", não se admitia, de início, a representação processual; tal situação se modificou, substancialmente, já no período do processo formular. Neste sentido, cf. R. MonIER, Manuel cit. (nota 29), pp. 262-263; L. C. de Azevedo - J. R. Cruz e TuCCI, Lições de História do Processo Civil Romano, São Paulo, Revista dos Tribunais, 2001, pp. 55 e 82.

A "procuratio ad litem" foi mesmo utilizada como mecanismo oblíquo para a obtenção dos efeitos práticos de uma cessão de crédito (em princípio vedada pelo direito romano). Nesse sentido, largo foi o emprego da "procuratio in rem suam", adotada desde cedo como mecanismo de circulação de "direitos" (por meio da manipulação das ações respectivas); a propósito, aliás, cf. G. 2, 38-39 e G. 2, 252.

Especificamente a respeito da manipulação operada nos textos justinianeus com o fito de parificar o "procurator ad litem" ao "cognitor", cf. F. BRIGUGLIO, Studi cit. (nota 26), p. 36, nota 68 (e p. 38, nota 81).

${ }^{33}$ É necessário que se faça um esclarecimento a respeito da extensão semântica da expressão "procuratio unius rei": conquanto corresponda a uma incumbência específica, contraposta à generalidade característica da "procuratio omnium rerum" - e à qual poderia ser reconduzida, inclusive, a "procuratio ad litem" - o emprego da expressão referida se tem voltado, exclusivamente, à atuação do agente em matéria negocial. 
$\S$ 42. A gestão de negócios alheios, sua tutela por meio da "actio negotiorum gestorum" e a demonstração da autonomia da "procuratio" diante de um "mandatum" ainda em expansão; a dissociação clássica entre os "iudicia bonae fidei" gerais e especiais como fator de discriminação entre a "procuratio" e o contrato de mandato; a aplicação excepcional da "actio negotiorum gestorum" a hipóteses de administração oficiosa do patrimônio alheio; conseqüiências (aplicação do instituto da "semetipso exigere”). O fato de se poder vislumbrar uma gradativa aproximação entre os suportes fáticos ensejadores tanto da "procuratio" como do "mandatum" não implica, por si só, uma imediata eliminação das consideráveis diferenças entre os regimes jurídicos dos institutos mencionados; com efeito, a despeito do franco desenvolvimento do contrato de mandato após a expansão de Roma sobre o Mediterrâneo, a tutela por meio da "actio mandati" não se estendeu automaticamente às hipóteses de atuação do "procurator": ao

Com isso, deve-se ter em conta o contexto em que a "procuratio unius rei" é analisada; sempre que a ela se alude por oposição à "procuratio omnium bonorum", tem-se em vista o gênero (e não a específica atuação extrajudicial); contudo, quando é tomada como termo de contraste com a "procuratio ad litem", obviamente que a utilização da expressão se dá em outra acepção, relativamente distinta da primeira. A respeito desta distinção e por uma delimitação das atribuições específicas do "procurator unius rei", cf. F. SERRAO, Il procurator cit. (nota 31), pp. 41-46; bem como E. ALBERTARIO, Procurator cit. (nota 31), pp. 497-521. Como destaca V. ARANGIO-RUIZ, aliás, a despeito da proximidade genérica entre o "procurator ad litem" e o "procurator unius rei", as duas personagens estavam submetidas a regimes jurídicos diversos: "le due figure di procuratori (...) sarebbero già così profondamente diverse l'una dall'altra, da scoraggiare in anticipo chi volesse rappresentarle come soggette in tutto e per tutto allo stesso regolamento giuridico" (Il mandato cit. (nota 25), p. 19). Em sentido similar, cf. A. WATSON, Contract cit. (nota 26), pp. 51-56.

Por uma apreciação geral da figura, cf. R. MONIER, Manuel cit. (nota 29), pp. 181-182; A. E. GIFFARD, Droit romain cit. (nota 15), p. 82; P. VOCI, Piccolo manuale cit. (nota 15), p. 331; A. GUARINO, Diritto privato cit. (nota 15), p. 408; P. ANGELINI, Il 'procurator'cit. (nota 29), pp. 167-175.

A respeito da polêmica sobre a pertinência do "procurator unius rei" ao período clássico, cf. as manifestações negativas de E. AlBerTARIO, Procurator cit. (nota 31), pp. 500-501 (de modo categórico, inclusive, à p. 506: "io mi ci ribello (...) ciò che mi importa di far rilevare è che il procurator unius rei (...) è una figura postclassica"); B. FRESE, Defensio cit. (nota 31), pp. 401-402; e F. SERRAO, Il procurator cit. (nota 31), pp. 41-46. Em contrapartida, pela sua admissão, de se destacar a posição de V. ARANGIO-RUIZ (Il mandato cit. (nota 25), pp. 17-19).

Pela menção, nas fontes, aos contornos de uma "procuratio unius rei”, cf. Ulp. 9 ad Ed. D. 3, 3, 1, 1; Ulp. 9 ad Ed. D. 3, 3, 33 pr. (sobre o encargo da administração do pecúlio de um escravo); Ulp. 77 ad Ed. D. 46, 7, 3, 2; Ulp. 57 ad Ed. D. 47, 10, 17, 16.

Conforme se assinalou no corpo do texto, a admissão de uma "procuratio unius rei" apresenta um significado "sistemático" muito grande, na medida em que se permite, desta forma, uma maior aproximação em relação ao "mandatum" (originariamente distinto da "procuratio omnium rerum", inclusive, em decorrência da especificidade da incumbência), em uma linha evolutiva contrária àquela assumida por este instituto. Neste sentido, percuciente é a análise de P. VOCI (sobre o impacto do surgimento da variante "unius rei" no universo da "procuratio"): "l'ammisione del procurator unius rei è l'indice di un chiarimento definitivo nella nozione giuridica della procura. L'esperienza della vita aveva creato la figura del procurator: la familiarità del dominus ne faceva un amministratore generale con ampi poteri. Ma col passar del tempo si doveva distinguere dalla configurazione etico-sociale l'essenza giuridica dell'istituto; e questa non poteva essere vista se non nel conferimento, per volontà del dominus, di poteri che un comune mandatario non aveva: la familiarità, la dipendenza, la generalità dell'amministrazione diventavano elementi accidentali. La nozione si affinava, e diveniva meramente formale: solo questo era essenziale alla procura, che ci fosse il conferimento di poteri speciali, per la gestione di un numero indefinito di negozi o di un negozio solo"(Manuale cit. (nota 15), p. 375); em sentido semelhante, aliás, se posiciona E. AlBERTARIO (Procurator cit. (nota 31), p. 519). 
contrário, em um primeiro momento permaneceu a primitiva via (exclusiva) da "actio negotiorum gestorum". Deste modo, devem ser completamente estremadas a relação gestória (inerente à "procuratio") e a eficácia defluente do ajuste de incumbência (vale dizer, o mandato); ora, ainda que deixemos de lado a contribuição oferecida pelas fontes literárias para a distinção entre as hipóteses (o que por si só demonstraria o seu caráter generalizado), cabe observar que das próprias fontes estritamente jurídicas se pode depreender que a "procuratio" apresentava uma contextura "sui generis": conclusão que se pode extrair não apenas da existência de um mecanismo de tutela específico (distinto da "actio mandati"), como também da submissão a um regramento peculiar - o qual, afeto aos “iudicia bona fidei” gerais, não se estendia, indiscriminadamente, aos juízos de boa-fé especiais (dentre os quais se enquadrava o "mandatum") ${ }^{34}$.

${ }^{34}$ Em primeiro lugar, deve-se observar que a noção de "gestão de negócios" clássica é peculiar, sendo de se
repelir qualquer aproximação apressada entre esta idéia e a "negotiorum gestio" justinianéia: enquanto o
direito dos compiladores conceberá a "negotiorum gestio" como assunção espontânea de incumbência por
parte do agente, os jurisconsultos clássicos propenderão a considerar como "gestão de negócios" a realidade
recoberta pelo espectro da "procuratio"; e desta forma, nesse período a "actio negotiorum gestorum" haverá
de tutelar a gestão incumbida (e não a espontânea como se verificará no período justinianeu). A respeito, cf.
S. SolAZZI, Sulla gestione per conto d'altri in Scritti di diritto romano II (1913-1924), Napoli, Casa Editrice
Dott. Eugenio Jovene, 1957, pp. 527-535 (sobre a "procuratio" compreendida como instrumento de gestão
dos interesses alheios, pp. 527-535); e R. MonIER, Manuel cit. (nota 29), pp. 207-208. M. KASER assim
evidencia o peculiar alcance da "gestão de negócios" clássica: "a negotiorum gestio (os Romanos diziam
negotia gesta), em sentido amplo qualquer gestão de negócios (alheios), abrange no direito pré-clássico e
clássico todas as gestões de negócios fora das relações jurídicas especificamente reguladas, sobretudo as de mandato e tutela" (Direito Privado cit. (nota 15), pp. 261-262).

Por sua vez, a distinção entre a "procuratio" e o "mandatum" era corrente entre os clássicos, sendo que mesmo em fontes literárias pode-se supreender passagens nas quais os dois institutos são postos lado a lado em meio a diversos outros tantos - sem que haja uma mínima preocupação do autor em diferenciá-los; assim, em dois momentos distintos de sua Topica $(10,42$ e 17, 66), Cícero aborda os institutos de uma maneira tão natural que se pode depreender a completa autonomia sistemática entre os mesmos. Neste sentido, as conclusões de V. ARANGIO-RUIZ, Il mandato cit. (nota 25), pp. 19-23 - com a peculiaridade de que este autor vislumbra em trecho de Sêneca o próprio reconhecimento do cabimento da "actio negotiorum gestorum" ao "procurator" (De Beneficiis 4, 27, 3) - e P. BONFANTE, Istituzioni cit. (nota 15), p. 497.

Sobre a autonomia entre os dois institutos, em geral, cf. S. SolazzI, Procuratori senza mandato in Scritti di diritto romano II (1913-1924), Napoli, Casa Editrice Dott. Eugenio Jovene, 1957, pp. 569-578; Ancora procuratori senza mandato in Scritti di diritto romano II (1913-1924), Napoli, Casa Editrice Dott. Eugenio Jovene, 1957, pp. 609-621; A. WATSON, Contract cit. (nota 26), pp. 36-51; A. BURDESE, Manuale cit. (nota 15), pp. 241-246 e 554; E. VolTerRA, Instituciones cit. (nota 15), p. 526; R. MARTINI, Mandato nel diritto romano in Digesto IV: Discipline Privatistiche (sezione civile) 11(1996), pp. 199-200. É de se ressaltar que V. SCIALOJA distingue as duas hipóteses segundo o critério da "continuidade" gestória, que só se encontraria presente na "procuratio": "tuttavia bisogna convenire che di questa distinzione fra mandatario e procuratore una diretta traccia nei testi non si trova (...) noi crediamo che la soluzione della questione stia in ciò: tanto is qui mandatum accepit, quanto il procurator (...) sono persone che hanno ricevuto un mandato; is qui mandatum accepit, poi, in quei testi dove di lui si parla, è un mandatario anch'esso, ma differisce dal procuratore in questo, che il procuratore è un mandatario ad administrandum, ha l'incarico, cioè, di una continuata amministrazione; is qui mandatum accepit, invece, è uno incaricat semplicemente di compiere un determinato atto giuridico, p. es. di fare un contratto" (Negozi giuridici - corso di diritto romano nell'Università di Roma nell'anno accademico 1892-1893, Roma, Società Editrice del Foro Italiano, 1933, p. 223). A. WATSON enumera, ainda, seis diferenças básicas entre o regime da "procuratio" e o "mandatum": a) a generalidade da gestão do "procurator" (comparada à estreita atuação do mandatário); b) a aplicabilidade 


\section{$\S$ 43. Particularidades e questionamentos sobre a evolução da "actio}

negotiorum gestorum": as fórmulas (concebidas "in ius" e "in factum”) e a gradativa extensão da tutela às hipóteses de gestão específica e assunção espontânea; uma contradição aparente entre Ulp. 10 ad Ed. D. 3, 5, 3 pr. e G. 4, 62. Tomando-se por ponto de partida o fato de que a expressão "gestão de negócios" abrange fenômenos diversos (consoante se considere o direito clássico ou o paradigma justinianeu), recobertos ambos pela "actio negotiorum gestorum", pode-se afirmar que toda a sua evolução - desde a

exclusiva da pena de "infamia" ao mandatário (não se estendendo ao "procurator"); c) a responsabilidade do "mandatário" unicamente por dolo (havendo controvérsia doutrinária sobre a responsabilidade do "procurator" pela simples culpa); d) o dever de prestação de contas que incumbia unicamente ao "procurator"; e) gratuidade essencial ao "mandatum" (mas não à "procuratio"); f) a representação direta na aquisição de posse somente poderia se verificar na hipótese de "procuratio" (Contract cit. (nota 26), pp. 7-9). No sentido do cabimento da "actio negotiorum gestorum" nas hipóteses de "procuratio" (durante o período clássico), são de importância significativa dois fragmentos atribuídos a Pompônio: Pomp. 5 ad Sab. D. 27, 3, 3 ("si tutelae aut negotiorum gestorum agatur, incerto hoc, quantum ab adversariis debetur tutori procuratorive, arbitratu iudicis cavendum est, quod eo nomine iis absit"; "si se ejercitase la acción de tutela ó de la gestión de negocios, siendo incierto cuánto se debe por los adversarios al tutor ó al procurador, se ha de dar caución por arbitrio del juez por cuanto por este concepto les falte") e Pomp. 6 ad Sab. D. 34, 3, 8, 6 ("si heres vetitus sit agere cum eo, qui negotia defuncti gesserit, non videtur obligatio ei praelegata, quae dolo, vel ex fraude eius, qui negotia gesserit, commissa sit; et testator id videtur sensisse; ideo si heres negotiorum gestorum egisset, agens procurator ex testamento incerti, doli mali exceptione excludi potest"; "si al heredero se le hubiera vedado ejercitar la acción contra aquel que hubiere gestionado negocios del difunto, no se considera que se lo prelegó la obligación que se haya contraído por dolo, ó por fraude del que hubiere gestionado los negocios; y parece que esta fué la intención del testador; por lo tanto, si el heredero hubiese ejercitado la acción de gestión de negocios, ejercitando el procurador en virtud del testamento la de cosa incierta, puede ser rechazado con la excepción de dolo malo"). Assim, se reconhece em ambos os passos a possibilidade de emprego da "actio negotiorum gestorum" em caso de "procuratio"; aliás - contra a opinião daqueles que consideram esta uma concepção primitiva - cabe observar que o jurisconsulto Pompônio atuou durante o séc. II d.C.. O emprego da referida ação era tão largamente admitido na hipótese de "procuratio" que se pretendeu estendê-lo, ainda, a situações caracterizadas por uma administração "oficiosa" (Ulp. 35 ad $E d$. D. 27, 3, 13). Opinando pela aptidão da "actio negotiorum gestorum" à tutela das relações estabelecidas em virtude da "procuratio", cf. V. ARANGIO-RUIZ, Istituzioni cit. (nota 15), p. 351; bem como J. MOSSET ItURRASPE, Mandatos, Buenos Aires, Ediar S.A., 1979, pp. 18-19. E pela aplicação da "actio negotiorum gestorum" às hipóteses de administração oficiosa, cf. A. AsCOLI, $L$ ' actio negotiorum gestorum directa contro il pupillo, in Studi in onore di Pietro Bonfante nel suo XL anno d'insegnamento II, Milano, Fratelli Treves, 1930, pp. 681-ss.

De sua parte, a distinção entre os "iudicia bona fidei" gerais e especiais remonta a um passo de Paulo (Paul. 6 $a d$ Sab. D. 17, 2, 38 pr.), no qual este jurisconsulto, por sua vez, alude à opinião de Sabino (séc. I d.C.): "pro socio arbiter prospicere debet cautionibus in futuro damno vel lucro pendente ex ea societate. Quod Sabinus in omnibus bonae fidei iudiciis existimavit, sive generalia sunt, veluti pro socio, negotiorum gestorum, tutelae, sive specialia, veluti mandati, commodati, depositi" ("en la acción de sociedad debe procurar el árbitro cauciones respecto á pérdida futura ó á lucro pendiente de la sociedad. Lo que estimó Sabino en todos los juicios de buena fé, ya si son generales, como el da sociedad, el de gestión de negocios, y el de tutela, ya si especiales, como el de mandato, el de comodato, y el de depósito"). Com efeito, uma das principais decorrências da observância do regime jurídico dos "iudicia bona fidei" gerais é a aplicação do princípio romano da "semetipso exigere", consagrado em algumas passagens do Digesto (Ulp. 10 ad Ed. D. 3, 5, 5, 14 e Ulp. $10 \mathrm{ad} \mathrm{Ed}$. D. 3, 5, 7) sobre as quais nos deteremos mais adiante ( 52 e nota 44). Por ora, interessa-nos apenas deixar claro que inexistem razões substanciais para que se rejeite a autenticidade do fragmento transcrito: de fato, levando-se em consideração que Sabino era contemporâneo de Cícero e Sêneca, não é de se estranhar a naturalidade com que entrevia a distinção entre os referidos institutos; além disso, tratasse-se de texto interpolado e certamente a generalidade da "procuratio" - bem como a especificidade do "mandatum" - haveria sido suprimida, a fim de que fossem incluídos em seu âmbito as variantes "ad litem" e "unius rei". Neste sentido, cf. V. ARANGIO-RUIZ, Il mandato cit. (nota 25), pp. 25-26 e p. 29 (nota 2). 
configuração original genérica da "procuratio" (“omnium rerum”), perpassando a paulatina incorporação das modalidades específicas "ad litem" e "unius rei”, para enfim absorver a gestão espontaneamente assumida pelo agente no período pós-clássico - encontra-se envolta por uma atmosfera bastante nebulosa, viabilizadora de uma profícua atividade especulativa da doutrina, notadamente dedicada a avaliar a contribuição pretoriana para o aprimoramento do sistema, mediante o desenvolvimento de fórmulas concebidas "in factum" (complementadoras, pois, daquelas "in ius conceptae", por sua vez derivadas do "ius civile"); de sua parte, a organização interna do Livro III do Digesto pouco contribui para o desenlace da questão, visto que ao mesmo tempo em que se estende a "actio negotiorum gestorum" à hipótese de atuação do "procurator ad litem" (previamente incumbido, D. 3, 3), assinala-se o cabimento da mesma tutela no caso de administração voluntariamente assumida pelo agente (D. 3, 5). Observe-se que tal cenário se torna ainda mais intrincado quando se comparam os passos constantes de Ulp. 10 ad Ed. D. 3, 5, 3 pr. (em que se atribui ao "ius honorarium" a origem da aludida "actio") e de G. 4, 62 (onde se afirma que a tutela defluiria naturalmente do "ius civile", consubstanciada, pois, em uma fórmula "in ius concepta"): e de fato, esta específica contradição só pode ser superada por meio de uma análise consciente do caráter complementar da atividade do magistrado (em relação ao sistema de fórmulas decorrentes do direito quiritário); assim sendo, exponhamos de maneira breve a orientação adotada - bem como as razões pelas quais são refutadas as principais teses concorrentes ${ }^{35}$.

\footnotetext{
${ }^{35}$ Durante o período clássico, a "actio negotiorum gestorum" foi utilizada para a tutela não apenas dos casos de "procuratio omnium rerum", mas também de variantes específicas da "procuratio" ("ad litem" e "unius rei"). Não é por acaso, pois, que as principais disposições relativas à "actio negotiorum gestorum" se encontram no Livro III do Digesto: conquanto não fosse inflexível, o Edito do pretor obedecia a uma respectiva ordem, em meio à qual se articulavam as disposições do "ius civile" e do "ius honorarium"; ocorre que, quando da compilação justinianéia, grande parte do material produzido pelo magistrado foi posto de lado - remanescendo unicamente a "cláusula" edital (eis que considerada uma manifestação da produção jurídica pretoriana). Assim, embora não encontremos as fórmulas desenvolvidas pelo pretor em aperfeiçoamento ao direito quiritário (fórmulas "in factum conceptae"), a simples presença da "cláusula" edital atesta que o direito honorário dispôs a respeito do tema.

A previsão da "actio negotiorum gestorum" se insere em uma perspectiva processual; e basta que tomemos em consideração os títulos que integram o Livro III do Digesto para possamos afirmá-lo com relativa segurança: D. 3, 1 ("de postulando"; "sobre o postular em juízo"); D. 3, 2 ("de his qui notantur infamia"; "sobre aqueles que são atingidos com a nota de infâmia"); D. 3, 3 ("de procuratoribus et defensoribus"; "sobre os procuradores e sobre os defensores"); D. 3, 4 ("quod cuiuscumque universitatis nomine vel contra eam agatur"; "quanto ao fato de se agir em nome de uma coletividade qualquer"); D. 3, 5 ("de negotiis gestis"; "sobre a gestão de negócios"); D. 3, 6 ("de calumniatoribus"; "sobre os caluniadores"). Ora, diante de tal específico enquadramento, V. ARANGIO-RUIZ compreende que tal ação competia ao "procurator ad litem" (Il mandato cit. (nota 25), pp. 29-32). Contudo, como explicar que em meio ao mesmo Livro III encontramos disposições a respeito do "procurator omnium rerum" e do agente que assume espontaneamente a gestão dos interesses alheios ("negotiorum gestor" justinianeu)?
} 


\section{$\S$ 44. Particularidades e questionamentos sobre a evolução da "actio}

negotiorum gestorum": pluralidade de teses sobre a gênese e a aplicação das fórmulas concebidas "in ius" e "in factum". Embora uma determinação precisa do momento de surgimento de cada uma das fórmulas envolvidas na evolução da "actio negotiorum gestorum" não constitua nosso objeto específico de pesquisa (e o mesmo se diga quanto a uma delimitação peremptória do âmbito de aplicação dos provimentos pretorianos desenvolvidos, respectivamente, à base do "ius civile" e do "ius honorarium"), podemos nos servir dos principais argumentos utilizados pela doutrina para a refutação das principais teses desenvolvidas a pretexto da solução do problema acima enunciado; deste modo, devem ser rechaçadas de plano tanto a teoria que concebe a fórmula "in factum" como expediente criado pelo pretor para a proteção ao "procurator" (por oposição à fórmula "in ius", destinada a resguardar o principal) - uma vez que, consoante fundadas pesquisas realizadas para reconstituição da produção pretoriana, chega-se à conclusão de que a atuação de magistrado esteve voltada, inclusive, à tutela do principal - como aquela que - estribada na frágil premissa da existência tão somente do "procurator omnium rerum" durante o período clássico - de maneira excessivamente simplificadora, atribui aos compiladores justinianeus quase toda a atividade de reformulação do instituto. De sua parte, conquanto um pouco mais rebuscada, a tese que pretende a aplicação da fórmula "in ius concepta" a praticamente todos os casos de gestão (incumbida ou espontânea) excetuada a assunção voluntária nas hipóteses de ausência ou herança jacente (para as

A dúvida se agrava quando tomamos em consideração uma "aparente" contradição entre Ulp. 10 ad Ed. D. 3, 5, 3 pr. ("ait Praetor: SI QUIS NEGOTIA ALTERIUS, SIVE QUIS NEGOTIA, QUAE CUIUSQUE, CUM IS MORITUR, FUERINT, GESSERIT, IUDICIUM EO NOMINE DARO"; "dice el Pretor: "si alguno hubiere administrado los negocios de otro, ó los negocios que hubieren sido de cualquiera al morir, daré acción por esta causa"”) e G. 4, 62 ("sunt autem bonae fidei iudicia haec: ex empto vendito, locato conducto, negotiorum gestorum (...)"; "as acções de boa fé são as seguintes: de compra e venda, locação e condução, gestão de negócios (...)"): enquanto o primeiro jurisconsulto parece atribuir a ação ao "ius honorarium", Gaio a considera uma ação de boa-fé (concebida "in ius" e decorrente do "ius civile"). Ora, considerando-se que a atividade criativa do pretor se desenvolvia sob limites bem definidos, resulta claro que a fórmula concebida "in factum" sobreveio como uma espécie de "aperfeiçoamento" a um sistema que, em suas origens, decorria exclusivamente do direito quiritário. Assim, o "ius honorarium" ampliou aquela proteção (anteriormente circunscrita a uma "actio negotiorum gestorum" concebida "in ius"). Nesse sentido, cf. V. ARANGIO-RUIZ, Il mandato cit. (nota 15), pp. 33-34; bem como F. BetancourT, Derecho cit. (nota 15), pp. 626-628. A respeito da temática das fórmulas relacionadas à "gestão de negócios", cf. G. SEGRÈ, Sulle formole relative alla negotiorum gestio e sull'editto e il iudicium de operis libertorum, in Studi senesi - Scritti giuridici e di scienze economiche pubblicati in onore di Luigi Moriani nel XXXV anno del suo nascimento II, Torino, Fratelli Bocca, 1906, pp. 289-346.

Por uma apreciação geral sobre este papel criativo do direito preteoriano, cf. M. LAURIA, Ius civile - Ius honorarium in Scritti di diritto romano in onore di Contardo Ferrini pubblicati dalla R. Università di Pavia, Milano, Ulrico Hoepli, 1946, pp. 595-657. Já quanto ao seu declínio, cf. A. GuARINO, L'esaurimento del ius honorarium e la pretesa codificazione dell'editto in Studi in memoria di Emilio Albertario I, Milano, Dott. A. Giuffrè, 1953, pp. 623-ss. 
quais caberia a fórmula estruturada "in factum", de origem honorária) - também deve ser afastada, não apenas porque admite, de modo contraditório, uma efetiva atuação pretoriana em matéria expressamente abrangida (ou abrangível) pelo "ius civile"; mas também porque, ao mesmo tempo em que pretende expandir, injustificadamente, para o âmbito negocial uma fórmula "in factum concepta" (desenvolvida, ao que tudo indica, exclusivamente para a aplicação na seara judicial), renega toda a produção dos jurisconsultos clássicos dos séculos II e III d.C. (os quais também contribuíram de maneira decisiva para o incremento de tal cenário) ${ }^{36}$.

${ }^{36}$ Como ressalta V. ARANGIO-RUIZ, a questão concernente ao desenvolvimento histórico da "actio negotiorum gestorum" corresponde a um dos mais intrincados capítulos do estudo das diversas ações que compunham o sistema jurídico romano (Il mandato cit. (nota 25), p. 33). Assim, dedicaremos a presente nota de rodapé a uma síntese sobre as três principais teses (não acolhidas) sobre a relação entre o direito quiritário e a produção pretoriana no âmbito específico desta "actio".

A primeira tese - estribada em Ulp. $10 a d E d$. D. 3, 5, 3 pr. (reproduzido em nota 35) - considera que o direito honorário esteve voltado à criação de uma fórmula ("in factum concepta") voltada à proteção do "procurator", eis que do direito quiritário decorreria, assim, a tutela conferida ao principal. Embora tal posição pareça suficiente à superação da contradição há pouco referida (estabelecida entre Ulp. $10 \mathrm{ad} \mathrm{Ed}$. D. $3,5,3$ pr. e G. 4, 62), conduz ao "duvidoso" entendimento de que o pretor não teria dispensado maior esforço em relação ao principal. Parece-nos, no entanto, que o magistrado tomou a "gestão" (em si mesma considerada) como causa eficiente da proteção conferida (e não como simples pressuposto para amparar somente o procurador), eis que a mesma, sendo "socialmente útil" - Ulp. 10 ad Ed. D. 3, 5, 1 ("hoc edictum necessarium est, quoniam magna utilitas absentium versatur, ne indefensi rerum possessionem, aut venditionem patiantur, vel pignoris distractionem, vel poenae committendae actionem, vel iniuria rem suam amittant"; "este Edicto es necesario, porque reunda en grande utilidad de los ausentes, á fin de que, indefensos, no sufran la posesión de sus bienes, ó su venta, ó no pierdan la enagenación de la prenda, ó la acción de la pena en que se haya incurrido, ó con la injusticia su propia cosa") -, redundava em benefício e proveito do principal.

Aliás - como nota V. ARANGIO-RUIZ - os recentes e judiciosos esforços em prol da reconstituição do edito têm reconduzido ao "ius honorarium" alguns fragmentos em que se reconhece proteção ao principal (tais como Ulp. $10 \mathrm{ad} E d$. D. 3, 5, 3, 8 e Ulp. 10 ad Ed. D. 3, 5, 3, 9) (Il mandato cit. (nota 25), p. 36).

De se observar, ainda, que sendo os "iudicia bona fidei" campo fértil para o reconhecimento de ações dúplices, parece pouco razoável a tentativa de estruturar o sistema à custa de um critério pautado na titularidade da "actio" referida.

Já a segunda tese pode ser identificada no esforço de B. FRESE (Defensio cit. (nota 31), pp. 400-402) - como uma decorrência necessária, diga-se de passagem, do trabalho de E. AlBERTARIO, Procurator cit. (nota 31), pp. 497-ss - e assim sintetizada: como o direito romano clássico somente conheceu o "procurator omnium rerum" (e não o "procurator ad litem"), a "actio negotiorum gestorum" (clássica) somente se aplicava a esta espécie de gestor (previamente investido em suas funções por meio de um ato de incumbência oriundo do principal); deste modo, não se poderia estender tal "actio" à assunção espontânea da gestão de interesses alheios, eis que a "negotiorum gestio" (em sua acepção justinianéia) só foi concebida muito tempo depois.

Ora, como tivemos a oportunidade de analisar em nota de rodapé anterior (nota 32), existem vários passos da obra de Gaio (G. 4, 55; G. 4, 84; G. 4, 98-101; G. 4, 182) que parecem demonstrar a existência de uma variante específica da "procuratio" ("ad litem") durante o próprio período clássico; e ainda que tal ordem de idéias não fosse suficiente para desestabilizar a tese de B. FRESE, há que se ressaltar que o referido autor não oferece qualquer justificativa razoável para a posição ocupada pela "actio negotiorum gestorum", em meio à disciplina da "substituição" processual. Nesse sentido, há que se acolher as críticas formuladas por V. ARANGIO-RUIZ (Il mandato cit. (nota 25), pp. 37-38).

A derradeira tese refutada - atribuída a H. KRELLER - foi articulada em trabalho que infelizmente não tivemos em mãos (Das Edikt de negotiis gestis in der klassischen Praxis, in Festschirift Paul Koschaker II, Weimar, 1939, pp. 193-ss); desta forma, observadas as naturais limitações de uma tal utilização, servimo-nos da paráfrase do trabalho realizada por V. ARANGIO-RUIZ. Eis a tese de H. KRELLER: todos os casos de gestão de negócios alheios - precedida de prévia incumbência ou não - eram tutelados por meio da "actio 


\section{$\S$ 45. Particularidades e questionamentos sobre a evolução da "actio}

negotiorum gestorum": a tese adotada como uma tentativa de harmonização quanto à progressiva aplicação das fórmulas concebidas "in ius" e "in factum". Deste modo, sendo por nós adotada a tese de V. ARANGIO-RUIZ, assim pretendemos sintetizá-la: conquanto de início se vislumbrasse uma "actio negotiorum gestorum" ("in ius concepta") para tutelar unicamente os casos de gestão confiada - e neste sentido a ausência de uma previsão clássica no sentido da aplicação da "procuratio" à gestão espontaneamente assumida

negotiorum gestorum" concebida "in ius" (exceto nas hipóteses de mandato e de tutela); contudo, diante da ausência de previsão específica, a gestão da herança jacente e dos bens do ausente somente recebeu proteção por meio de uma fórmula "in factum concepta" (pretoriana). Embora tal distinção tenha sido preservada durante todo o período clássico, a superveniência de Justiniano assinalou uma reformulação sistemática: ao mesmo tempo em que este atrelou todas as gestões incumbidas ao mandato (e, por via de consequiência, à "actio mandati"), relegou as gestões desprovidas de prévia incumbência (antes tuteladas pela "actio negotiorum gestorum" concebida "in ius") à área de abrangência da "actio negotiorum gestorum" estruturada "in factum" - a qual, como visto, anteriormente só se aplicava às heranças e aos ausentes. Com isso criou-se um novo critério (a prévia incumbência pelo principal) e se aboliu o sistema original da "actio negotiorum gestorum".

A tese de H. KRELLER não nos parece, contudo, imune a críticas: em primeiro lugar, se o "ius civile" já admitia a tutela das gestões não incumbidas (como ensina o autor), por sua própria expansão deveria alcançar a hipótese da herança jacente e do ausente, descabendo o exercício do poder criativo do pretor em matéria já regulada; neste sentido, pertinente é o ataque de V. ARANGIO-RUIZ, para quem a tutela oriunda do "ius civile" (pela "actio negotiorum gestorum" concebida "in ius") somente haveria de alcançar a gestão incumbida ("omnium rerum" e "ad litem"), mas não a assunção espontânea dos negócios alheios, espaço este ocupado pelo direito pretoriano, à custa de uma "actio negotiorum gestorum" estruturada "in factum" (Il mandato cit. (nota 25), pp. 39-40).

Em segundo lugar, a tese de H. KRELLER parece estender, desde a sua origem, a "actio negotiorum gestorum" concebida "in factum" às assunções (espontâneas) judiciais e extrajudiciais. Ora, a localização da "cláusula" edital em meio a previsões de natureza eminentemente processual parece conduzir ao entendimento de que a fórmula concebida "in factum" somente se aplicava à assunção espontânea de uma gestão "judicial". Neste sentido, aliás, parece-nos que deve ser interpretado o passo de Gaio transcrito em nota de rodapé anterior (G. 4, 84, constante de nota 32), no qual se afirma que "alguns" - por que não os pretores? - entendiam haver procurador ("ad litem") sem prévia incumbência (adotando-se, assim, a "actio negotiorum gestorum" estruturada "in factum"). Neste sentido, opinando por uma fórmula "in factum concepta" aplicável exclusivamente à atuação "processual" do gestor espontâneo (em prol do ausente e do defunto), cf. A. D'Ors, Elementos cit. (nota 15), p. 242; M. KASER, Direito Privado cit. (nota 15), pp. 262-263; F. BetANCOURT, Derecho cit. (nota 15), p. 626; V. ARANGIO-RuIZ, Il mandato cit. (nota 25), pp. 40-41.

Finalmente, a tese de H. KRELLER há de ser reparada em virtude de uma sensível omissão quanto ao papel dos jurisconsultos dos séculos II e III d.C.: considerando como último estágio da evolução do direito clássico as obras de Quintus Mucius (Scaevola), Servius (Sulpicius Rufus), Labeão e Sabino - e compreendendo a posição de tais juristas como um panorama "definitivo" a que se contrapôs a orientação justinianéia - o autor parece descurar por completo a produção dos jurisconsultos dos séculos II d. C. (tais como Celso e Juliano) e III d.C. (tais como Ulpiano e Paulo). De fato, a significativa contribuição dos sucessivos "comentários" ao direito pretoriano - a título exemplificativo, tome-se em consideração simplesmente o papel de Gaio, Ulpiano e Paulo, de conformidade com a menção constante do início da nota de rodapé de $\mathrm{n}^{\circ} 32$ - parece recomendar uma apreciação mais acurada do esforço destes juristas posteriores, os quais, ainda que não se tenham demonstrado grandes inovadores, auxiliaram no trabalho de adaptar o sistema às novas necessidades, fundindo - com primazia da "actio negotiorum gestorum" concebida "in ius" - as fórmulas quiritária e pretoriana de tutela. Neste sentido, cf. V. ARANGIO-RUIZ, Il mandato cit. (nota 25), pp. 41-42. E quanto ao papel decisivo da jurisprudência clássica no processo de evolução do sistema romano, cf. o alentado estudo de S. Riccobono (La giurisprudenza classica come fattore di evoluzione nel diritto romano in Scritti di diritto romano in onore di Contardo Ferrini pubblicati dalla R. Università di Pavia, Milano, Ulrico Hoepli, 1946, pp. 17-80). 
configura um silêncio bastante eloqüente -, posteriormente a situação se alterou: a fim de que se resguardasse a utilidade da gestão não-incumbida (Ulp. $10 a d E d$. D. 3, 5, 1), foi então estruturada (para a proteção daquele que assumisse a defesa de interesses alheios em um processo) uma fórmula pretoriana (que naturalmente haveria de estar situada em meio à disciplina contida no Livro III do Digesto, de natureza eminentemente processual); o que aliás seria corroborado - à vista do fato de que na confecção do Edito do pretor não se observava um maior rigor sistemático - pela justaposição entre a tradicional disciplina da fórmula "in ius concepta" e a previsão, imediatamente seguinte, de uma variante desenvolvida "in factum” (e daí a razão da cláusula constante de Ulp. 10 ad Ed. D. 3, 5, 3 pr.). Todavia, ocorre que a jurisprudência clássica dos séculos II e III d.C. reuniu (eis aí o seu papel decisivo), sob a modalidade "in ius", todas as hipóteses de gestão de interesses alheios (precedidas de prévia incumbência ou não); com isso, aquela proteção "honorária" da assunção processual espontânea, que ostentava até então um caráter excepcional, erigese em regra abrangida pelo sistema: delineia-se, assim, um ambiente francamente propício à completa reformulação do âmbito de aplicação da "actio negotiorum gestorum" - fato esse que se dará quando da atuação dos compiladores justinianeus, os quais, operando uma irrestrita "revisão" do conceito de "negotiorum gestio", a partir de então vincularam-na a uma gestão de interesses alheios desprovida de prévia incumbência por parte do principal $^{37}$.

\footnotetext{
37 Assim, conclui-se que a compilação justinianéia - conquanto não seja a única responsável - subverte a gestão de negócios em sua acepção clássica, espoliando da "procuratio" a "actio negotiorum gestorum" que a caracterizava desde as suas origens mais remotas (com a "procuratio omnium rerum"); a fim de atribuir esta última a um seu titular que, durante todo o período clássico, granjeou progressivamente tal proteção - única e exclusivamente - à custa de uma atividade pretoriana de caráter eminentemente excepcional. A respeito, cf. G. PACCHIONI, Trattato della gestione degli affari altrui secondo il diritto romano e civile, $2^{\mathrm{a}}$ ed., Milano, Casa Editrice Dottor Eugenio Vallardi, 1915, pp. 1-31; F. BETANCOURT, Derecho cit. (nota 15), p. 628. Com isso, a "gestão de negócios" (em sua acepção clássica) restou completamente esvaziada, em detrimento da consagração de um critério sistemático simplificador que - em lugar de outorgar a "actio negotiorum gestorum" na hipótese de (efetiva) gestão - se curvou, equivocadamente, à aferição da existência (ou não) de uma prévia incumbência por parte do principal.

Assim - como teremos a oportunidade de destacar mais à frente -, verificou-se uma junção indevida entre a "procuratio" e o "mandatum", como se a riqueza da relação gestória pudesse ser reduzida à simples existência de uma prévia incumbência: quando se fala em vedação à representação direta no direito romano, tem-se em vista unicamente os efeitos da atuação do "agente" sobre a esfera jurídica do "principal"; contudo, descura-se daquilo que entre os modernos se costuma designar pela expressão "representação indireta" e que, conquanto não se confunda com sua correlata direta, na mesma medida não se reduz ao simples mandato. Pela distinção entre a representação direta e a gestão instituída por meio da "procuratio", cf. P. BONFANTE, Istituzioni cit. (nota 15), pp. 78-79. E com a costumeira acuidade, assim se manifesta P. VocI: "secondo la nozione moderna, l'essenza della procura sta nel conferimento, al mandatario, di un potere che lo rende rappresentante diretto del principale. Alla procura romana sono essenziali, da un lato, l'estensione generale e la discrezionalità, dall'altro il carattere familiare del rapporto tra dominus e procurator. Questa seconda qualità rende naturale l'estensione delle norme che valgono per le gestione dei figli e degli schiavi muniti di peculio. In questa situazione si rimane a lungo, perchè solo Papiniano estenderà al procurator la norma che
} 
$\S$ 46. A origem do contrato de mandato no "ius gentium" e a progressiva incorporação dos juízos de boa-fé ("ex fide bona") ao direito quiritário. Assim como a "procuratio" deita suas raízes no direito quiritário (e mais remotamente em um direito familiar, que aos poucos vai ganhando a nota de juridicidade típica do "ius civile") - e, da mesma forma, a "negotiorum gestio" vai encontrar sua justificativa histórica no paulatino desenvolvimento do âmbito de aplicação da "actio negotiorum gestorum" (abrangendo no período justinianeu a própria gestão de negócios alheios não incumbida) -, o "mandatum" tem sua origem no direito das gentes ("ius gentium"), como o resultado da expansão da atividade mercantil romana sobre o Mediterrâneo (verificada, sobretudo, a partir do séc. III a.C.); em um sistema infenso a maiores formalidades (características dos atos jurídicos que integravam o direito citadino), a nota típica que reunia sob um único gênero a compra e venda, a locação, a sociedade e o mandato era a consensualidade (que constituía, assim, a "causa civilis" comum ao grupo). Desta forma, ainda que remanesçam algumas dúvidas quanto à ordem de seu reconhecimento pelas demais esferas da produção jurídica romana (se tal se teria dado primeiro em relação ao "ius civile" ou ao "ius honorarium”), não existe qualquer polêmica quanto ao fato de que tal tipo contratual exsurge do contato comercial entre romanos e peregrinos (e daí a acepção específica por nós emprestada à expressão “ius gentium”); estribando-se sua eficácia, portanto, não em um sistema de intrincadas fórmulas solenes, mas sim nas exigências de lealdade sem cujo atendimento não poderia subsistir um tráfico jurídico entre povos regidos por sistemas normativos diferenciados ${ }^{38}$.

vale per i contratti conclusi dall'institor. Per analogia, dunque, si forma il regime della procura: un regime cui manca la relazione necessaria con la rappresentanza diretta", (Manuale cit. (nota 15), p. 371).

Em suma: o direito justinianeu, ao assinalar o rearranjo sistemático do conceito de "gestão de negócios" - e o declínio do âmbito originário de aplicação da "actio negotiorum gestorum" - demarca o ocaso do instituto da "procuratio", chave imprescindível para a compreensão daquilo que não se confunde nem com a produção direta de efeitos gestórios sob o patrimônio do principal (representação direta), nem com a simples execução de uma incumbência por parte do encarregado (mandato); toda a chave da compreensão do fenômeno gestório se traduz exatamente nesta noção que, como um barco a naufragar tão só parcialmente, permanecerá a assombrar mesmo após o advento da consolidação justinianéia - sob as famigeradas expressões "falsus" e "verus procurator".

38 Assim como dissemos a respeito da origem da "procuratio" (e da evolução de seu respectivo sistema de ações), cabe-nos destacar que a "filiação" do contrato de mandato ao "ius gentium" nos interessa sobretudo à vista dos elementos peculiares que, constatada tal "ascendência", parecem influir diretamente em seu espectro eficacial. Com efeito, posteriormente teremos a oportunidade de evidenciar - em estudo a ser desenvolvido ulteriormente (ainda sob a mesma linha de pesquisa) - o papel de relevo desempenhado pela boa-fé (bem como pela lealdade) na conformação da específica eficácia do "mandatum" romano; por ora, todavia, cumpre-nos apenas destacar que a ausência de tais elementos comprometeria gravemente o comércio jurídico, uma vez que os povos (então em contato) não se mostravam regulados por um sistema normativo comum. Note-se, ainda, que quando empregamos a expressão "ius gentium" aproximada de tipos contratuais que lhe pretendemos vincular, não a tomamos no sentido de os considerar inspirados em uma "ratio naturalis", mas sim em uma acepção mais concreta, que remonta à idéia de negócios jurídicos celebrados entre cidadãos romanos e estrangeiros; a respeito, cf. V. ARANGIO-RUIZ, Il mandato cit. (nota 25), pp. 44-47. 
Como tivemos a oportunidade de expor há pouco, a "procuratio" corresponde a um instituto jurídico forjado à luz das peculiaridades da estrutura doméstica romana; por sua vez, a "negotiorum gestio" justinianéia é o resultado da evolução experimentada por aquela, à vista de uma intensa atividade pretoriana e de uma profícua produção da jurisprudência. Já o "mandatum" deita suas raízes nas necessidades específicas de uma atividade comercial em expansão, resultante dos avanços experimentados em decorrência da expansão romana sobre o Mediterrâneo, sobretudo a partir do século III a. C; neste sentido, cf. J.-J. CLAMAGERAN, Du louage d'industrie, du mandat et de la comission en droit romain, dans l'ancien droit français et dans le droit actuel, Paris, Auguste Durand, 1856, pp. 26-27; E. A. SANCHEZ URITE, Mandato cit. (nota 06), pp. 127129; G. LONGO, Mandato (diritto romano), in NNDI 10 (1964), pp. 105-108; G. PROVERA, Mandato (storia), in ED 25 (1975), pp. 312-313; G. DonATUTI, Mandato, in NDI 8 (1939), pp. 51-53; G. PUGLIESE, Istituzioni cit. (nota 15), p. 577; D. NÖRR, Sulla specificità del mandato romano, in SDHI 60 (1994), pp. 373-380; F. LANDIN, $O$ mandato cit. (nota 09), pp. 24-25; A. GUARINO, Diritto cit. (nota 15), p. 929. De sua parte, A. BURDESE manifesta sua dúvida quanto ao influxo da praxe comercial na difusão do tipo contratual referido: "non è possibile dire in qual misura esso, che è contratto iuris gentium, abbia tratto impulso dai rapporti tra Romani e peregrini" (Manuale cit. (nota 15), p. 554); curiosa, todavia, é a posição adotada por E. CHAMOUN (Instituições cit. (nota 15), p. 384) e A. E. GIFFARD (Droit romain cit. (nota 15), p. 81), os quais defendem uma origem bastante diversa deste tipo contratual: "o mandato surgiu por volta do século VI, quando as guerras de conquista provocaram grandes ausências na cidade" (E. CHAMOUN, Instituições cit. (nota 15), p. 384).

Deve-se observar que - ao contrário do que se verifica com relação à compra e venda (Paul. $30 a d$ Ed. D. 18, 1, 1, 2), à locação (Paul. $34 a d E d$. D. 19, 2, 1) e à sociedade (G. 3, 154) - inexiste uma consagração expressa nas fontes sobre a origem do contrato de mandato no "ius gentium". Contudo, se esta não pode ser depreendida diretamente, há de ser concebida de maneira oblíqua, por duas razões fundamentais: em primeiro lugar à vista do fato de que a "consensualidade" (que caracteriza os contratos filiados a este sistema) é expressamente reconhecida a propósito do "mandatum" (G. 3, 135): "consensu fiunt obligationes in emptionibus et venditionibus, locationibus conductionibus, societatibus, mandatis" ("as obrigações se constituem por consenso na compra e venda, locação e condução, sociedade e mandato"). Além disso, como destaca V. ARANGIO-RUIZ, o emprego nas fórmulas processuais das expressões "dare facere oportere ex fide bona" - em lugar do "dare facere oportere" puro e simples (típico do direito quiritário) - denota que os contratos consensuais em geral (e o mandato em particular) apresentam exatamente a origem acima apontada. Nessa linha de raciocínio, o contrato de mandato teria sido apreciado primeiro pelo pretor peregrino, sendo em seguida reconhecido pelo pretor urbano (em um movimento de absorção do "ius gentium" pelo "ius civile"); a respeito, cf. V. ARANGIO-RUIZ, Il mandato cit. (nota 25), pp. 44-46; bem como A. WATSON, Contract cit. (nota 26), pp. 16-23 (especialmente p. 18).

Ainda quanto aos desdobramentos da origem do contrato de mandato, cumpre-nos destacar que há quem sustente que os juízos de boa-fé ("ex fide bona") - típicos do "ius civile" - foram precedidos de fórmulas estruturadas "in factum" pelo pretor (assim P. BONFANTE, Diritto cit. (nota 15), pp. 292-293). Mas se é provável que isso se tenha verificado quanto aos contratos de comodato (cf. Ulp. 28 ad Ed. D. 13, 6, 1 pr. e G. 4, 47) e de depósito (cf. Ulp. 30 ad Ed. D. 16, 3, 1, 1 e G. 4, 47), não há razões suficientes para que se lance afirmação semelhante quanto ao "mandatum"; não apenas em decorrência de inexistir qualquer menção expressa neste sentido, como também em razão de não se encontrar "cláusula" edital que nos permita concluir de maneira diversa. Assim, parece-nos muito mais provável que os juízos de boa-fé tenham precedido qualquer desenvolvimento de fórmulas "in factum conceptae"; neste sentido, cf. V. ARANGIORUIZ, Il mandato cit. (nota 25), pp. 45-46.

Finalmente, deve-se ressaltar - conforme já acenado em nota anterior deste trabalho (nota 25) - que a ausência de um contrato de mandato não comprometeu o atendimento às necessidades imediatas dos cidadãos romanos, os quais se utilizaram, pois, do instituto da "procuratio" (oriundo do direito quiritário). Ora, assim como é natural o desenvolvimento do "mandatum" para o atendimento das necessidades de um intercâmbio em larga escala (via comércio internacional mediterrâneo de então), da mesma forma, não se pode negar que os juristas romanos concebiam o emprego dos instrumentos tradicionais para a concatenção de objetivos novos: isso se verificou a respeito da compra e venda - estruturada inicialmente à custa da "mancipatio", de duas tradições sucessivas ou mesmo da "stipulatio" (na venda à crédito) -, da locação (vide o emprego do tradicional "precarium") e da sociedade (sob a forma do antigo consórcio "ercto non cito"). Para suprir a ausência de um "mandatum" ainda inexistente, lançava-se mão do "procurator omnium rerum", do "procurator ad litem" ou do "cognitor" (quando não fosse suficiente a atuação do filho ou do escravo); a respeito, cf. V. ARANGIO-RuIZ, Il mandato cit. (nota 25), p. 47. Especificamente sobre o emprego da "mancipatio" para o atendimento de necessidades diversas daquela a que originariamente esteve adstrita, cf. R. Ambrosino, Le applicazioni innovative della mancipatio, in Studi in memoria di Emilio Albertario II, Milano, Dott. A. Giuffrè, 1953, pp. 573-618. 


\section{$\S 47$. Amizade e assistência recíproca no contexto da origem do contrato de} mandato: da aplicação especial à admissão de seu emprego para a administração de interesses em geral; sobre uma eventual sobreposição entre a "procuratio omnium rerum" e o "mandatum". Ora, como tivemos a oportunidade de destacar há pouco, com o passar do tempo a estrutura da "procuratio" sofreu duas ordens significativas de modificações: em primeiro lugar, passou a admitir, em contraposição à configuração primígena da "procuratio omnium rerum”, modalidades mais específicas, de aplicação judicial (“procuratio ad litem") e extrajudicial (“procuratio unius rei”); além disso, forjou-se um sistema em que a sua ação típica (a "actio negotiorum gestorum") foi compreendida como mecanismo hábil à tutela de gestões desprovidas de uma incumbência prévia. Ocorre que fenômeno similar se verificou, só que em sentido contrário, com relação ao contrato de mandato: conquanto de certa forma remanescessem elementos originais do tipo - tais como os fundamentos da amizade e do dever de assistência recíproca, ou mesmo a sanção de "ignominia" (precursora da infâmia) -, sua estrutura não se conservou intacta durante toda a evolução do sistema jurídico romano; deste modo, embora a maioria das fontes se refira ao "mandatum" como a veste jurídica adequada à hipótese de incumbências específicas, a sua gradual admissão para o cometimento de atribuições genéricas contribuiu - tanto quanto a degeneração da estrutura original da "procuratio" - para a formação de uma extensa zona de intersecção entre os espectros de incidência dos referidos institutos jurídicos. Sem querer incomodar, por ora, o problemático e polissêmico termo "causa", poderíamos dizer que exsurgiu um ambiente favorável à sobreposição de tais estruturas; parecendo-nos oportuna, pois, uma rápida menção à hipótese de cumulação de mecanismos de tutela à disposição do interessado ("actio negotiorum gestorum" e "actio mandati”) precedida de uma avaliação sobre o espaço próprio que afinal restou reservado à “procuratio" (progressivamente espoliada, assim, de seu âmbito de aplicação exclusivo) ${ }^{39}$.

\footnotetext{
39 Assim como o mútuo desinteressado, o "mandatum" foi concebido entre os romanos como uma decorrência natural da amizade e dos deveres de assistência recíproca; dele decorriam obrigações que ultrapassavam os limites da simples cortesia - tal como se depreende das manifestações de Cícero (Pro Rosc. Amer. 38-39, 111-113) bem destacadas por V. ARANGIO-RUIZ (Il mandato cit. (nota 25), pp. 47-48) alcançando, por vezes, conseqüências bastante severas, tais como a pena de "ignominia" (precedente da "infamia"). A respeito de tais considerações, cf. G. BONJEAn, Explication cit. (nota 15), p. 481; G. LEPOINTE, Les obligations cit. (nota 15), p. 104; J.-L. GAZZANIGA, Mandat et représentation dans l'ancien droit in Droits: Revue Française de Théorie Juridique 6 (1987), pp. 22-25; A. GUARINO, Diritto privato cit. (nota 15), pp. 929-930;

Segundo alguns autores - à semelhança do que se verificara quanto à "procuratio" - o "mandatum" também teve primeiro uma base eminentemente "social", para que tão somente depois alcançasse uma autêntica relevância jurídica; neste sentido, cf. G. AMAZONAS DE FIGUEIREDO, Tratado cit. (nota 15), p. 235; F. SCHUlZ, Principles of Roman Law, Oxford, Clarendon Press, 1936, p. 149; M. KASER, Direito Privado cit.
} 
(nota 15), pp. 259-260. A. GUARINO destaca o momento e a razão da referida transição: “fu forse la crisi sociale ed economica dei sec. II-I a.C. a rendere vivo il problema, nella dissoluzione dei vecchi valori dell'amicitia e della fides, di costringere il mandatarius a riitenersi strettamente impegnato, sul piano del diritto e non più su quello della cortesia, attraverso dunque l'esperibilità di un'actio mandati, al compimento di una attività che avesse liberamente accettato di compiere" (Diritto privato cit. (nota 15), p. 930).

Conquanto as fontes revelem, em geral, um "mandatum" afeto a atribuições específicas - cf. D. 17, 1 (passim) e G. 3, 155 (passim) - por vezes se surpreendem exceções, nas quais se admite uma incumbência geral ao mandatário (mandato geral), viabilizando-se, assim uma autêntica sobreposição "sistemática" entre este instituto (oriundo do "ius gentium") e a "procuratio omnium rerum" (radicada no direito quiritário). Elucidativos desta tendência são alguns fragmentos ora coligidos: Paul. 71 ad Ed. D. 3, 3, 58 ("procurator, cui generaliter libera administratio rerum comissa est, potest exigere aliud pro alio permutare"; "el procurador, á quien en general se encomendó la libre administración de bienes, puede reclamar y permutar una cosa por otra"); Paul. 4 resp. D. 3, 3, 60 ("mandato generali non contineri etiam transactionem decidendi causa interpositam; et ideo, si postea is, qui mandavit, transactionem ratam non habuit, non posse eum repelli ab actionibus exercendis"; "en el mandato general no se contiene también la transacción que se interpuso para decidir una cuestión; y así, si el que dió el mandato no ratificó después la transacción, no puede ser repelido del ejercicio de sus acciones") e Mod. 6 diff. D. 3, 3, 63 ("procurator totorum bonorum, cui res administrandae mandatae sunt, res domini neque mobiles vel immobiles, neque servus sine speciali domini mandatu alienare potest, nisi fructus aut alias res, quae facile corrumpi possunt"; "ni el procurador de todos los bienes, á quien se encomendaron las cosas para administrarlas, ni el esclavo, pueden enajenar, sin especial mandato de su principal, los bienes muebles ó los inmuebles, sino los fructos ú otras cosas que facilmente pueden deteriorarse"). Desta forma, parece ser útil um estudo dedicado às zonas de contato entre os dois institutos, buscando entrever até que medida os mesmos se imbricaram.

Contudo, não podemos deixar de destacar que esta mútua influência em nenhum momento pode redundar em uma fusão precipitada entre a "procuratio" e o "mandatum": como ressalta V. ARANGIO-RUIZ, "questo movimento non poteva mai portare, peraltro, a far considerare mandato e procura come sinonimi. In fondo, per i romani come pure per noi (...) procuratio e mandatum erano, più che due istituti omogenei, due diverse posizioni della volontà del principale: che taluno sia procuratore di un altro, significa che gli altri sono autorizzati a contrattare con lui, sicuri che il principale ne riconoscerà l'operato (pur facendo i conti col normale divieto romano della rappresentanza diretta); che taluno sia mandatario di un altro, vuol dire che si è impegnato verso quest'altro a gerire gli affari affidatogli, con correlativo impegno del mandante di prendere su di sè le conseguenze dlla gestione e d'indennizzarlo di ogni pregiudizio. Il problema specificamente romano nasce da ciò che il primo fenomeno giuridico è stato avvertito quando i lineamenti del secondo non erano ancora stati definiti: onde la collocazione, almeno originaria, sotto una diversa insegna" (Il mandato cit. (nota 25), p. 48, nota 2). Assim, não parece ensejar uma "promiscuidade" a simples sobreposição do espectro de aplicação que se verifica entre tais institutos jurídicos.

Compreender o contrato de mandato romano em todas as suas peculiaridades é um desafio para todo e qualquer jurista, sobretudo quando forjado em uma tradição jurídica diversa, tal qual se verifica no sistema do "Common Law"; a propósito, assim se pronuncia B. NICHOLAS: "to the English lawyer, accustomed to the idea of contract as necessarily a bargain, the surprising feature of mandate is its gratuitous character (...) the origins of the contract are hidden, but they lie perhaps in the extra-legal relationship between friends, which could make far greater demands in Rome than it does in the modern world. It is still surprising that such social obligations should have acquired legal force, but the transformation was no doubt made easier by the importance of the transaction which the agreement might embrace, and also by the existence of the intermediate concept, part social or moral and part legal, of good faith" (An introduction cit. (nota 15), pp. 187-188). No entanto, mesmo um estudioso radicado no "Civil Law" se depara com uma série de dificuldades, inerentes à distância que separa a sociedade contemporânea do contexto social em que tal tipo contratual foi construído: "la génesis de este contrato necesita una explicación (...) en los tiempos modernos, incluso en el Derecho continental, cuyos codificadores adoptaron el mandatum romano, este contrato, desempeña una función muy modesta. El mandato de hacer algo en favor del mandator sin compensación alguna, queda en realidad fuera dal ámbito jurídico, ya que las partes no sienten, por causa de la gratuidad, el deseo de obligarse jurídicamente. En Roma, y especialmente en aquellos estratos sociales a que pertenecían los juristas, ciertas reglas y costumbres sociales fueron en realidad las que sugirieron este contrato. La amistad (amicitia) imponía serios y hasta penosos deberes. El amigo romano tiene exigencias que en la actualidad serían inconcebibles. En la Roma republicana, no se titubea en acudir a un amigo en damanda de la ayuda precisa para salir de una situación penosa. Al amigo podía exigírsele hospitalidad, patrocinio, despliegue de actividades e incluso préstamos. Era parte muy principal del officium de una persona, ayudar al amigo en lo posible (...) estas ideas fueron generalmente aceptadas y la persona que realizaba una comisión o 


\section{$\S 48$. A vitalidade da "procuratio omnium rerum" quanto à aquisição da}

posse por meio de terceiro e a excepcionalidade da representação direta no direito romano. A análise da questão da aquisição de posse por meio de outrem é bastante proveitosa, visto que revela, a um só tempo, a vitalidade remanescente da figura do "procurator" (em crise quanto à sua respectiva identidade) e o alcance da regra romana "per extraneam personam nobis adquiri non potest" (ou "per liberam personam nobis adquiri non potest”); observe-se, pois, que tal capítulo específico do regramento possessório romano indica não apenas que a interdição à representação direta era uma realidade, mas também que uma determinada exceção havia, expressamente conformada quanto aos seus aspectos material (aquisição de posse) e subjetivo (por meio do “procurator"). Com efeito, conquanto exista controvérsia doutrinária sobre o alcance do preceito excepcionante - pendendo debate sobre os seus limites subjetivos (a envolver o "mandatário" e o "gestor de negócios", no sentido justinianeu) e objetivos (a abarcar a aquisição do próprio "domínio" pelo terceiro) -, parece-nos adequado concluir que, considerada uma autêntica mitigação ao aludido princípio geral, a exceção da aquisição de posse por meio do "procurator" não poderia ser objeto de uma interpretação extensiva (que pudesse, em última análise, subverter a regra então ressalvada): ou seja, a admissão de sua aplicação em hipóteses outras (como na atuação do "mandatário" ou do "gestor de negócios", ou mesmo para efeito da aquisição de propriedade), implicaria não uma simples restrição, mas um autêntico esvaziamento do princípio; e de fato, no sentido de uma interpretação restritiva caminham as mais recentes abordagens de G. 2, 95, pondo em dúvida o "consenso" a que parece aludir Nerácio em Ner. 7 membr. D. 41, 3, 41".

encargo per cuenta del amigo, no esperaba de éste remuneración alguna, pero a pesar de ello, atendía al negocio ajeno por lo común, muy concienzudamente" (F. SCHULZ, Classical cit. (nota 15), pp. 530-531).

40 Assim, a questão pode ser sintetizada nos seguintes termos: de acordo com a doutrina dominante, prevaleceu no direito romano o princípio segundo o qual era vedada a representação direta, à vista do caráter personalíssimo dos atos jurídicos inerentes ao "ius civile" [nesse sentido, cf. A. Doveri, Istituzioni cit. (nota 15), pp. 216-218; C. MAYNZ, Cours cit. (nota 15), pp. 236-237; H. ADAM, Droit romain: rapports du mandant et du mandataire avec les tiers, Paris, Typographie et lithographie Ves Renou, Maulde et Cock, 1874, pp. 32-36; A. SAlivas - A. Bellan, Éléments cit. (nota 15), pp. 293-294; G. Ronga, Corso cit. (nota 15), pp. 129-131; R. de FRESQUeT, Traité cit. (nota15), pp. 191-192; E. FouCAULT, Droit cit. (nota 29), pp. 14; H. Dernburg, Diritto cit. (nota15), pp. 48-54 e 507-509; C. FERRINI, Manuale cit. (nota 15), pp. 154-159; É. CUQ, Institutions cit. (nota 15), pp. 403-409; B. WINDSCHEID, Pandektenrecht, trad. it. de Carlo Fadda e Paolo Emilio Bensa, Diritto delle pandette - con note e riferimenti al Diritto Civile Italiano I, Torino, Unione Tipografico-Editrice Torinese, 1925, pp. 219-220; M. de ANDRADE, Teoria Geral cit. (nota 04), pp. 300-301; V. ScIAlOJA, Negozi cit. (nota 34), pp. 216-219 e pp. 220-221; G. RuSSO, La costruzione cit. (nota 29), pp. 272-273; E. BETTI, L'attuazione di due rapporti causali attraverso un unico atto di tradizione (contributo alla teoria della delegazine a dare) in Bullettino dell' Istituto di Diritto Romano 41 (1933), pp. 178-184; E. A. SANCHEZ URITE, Mandato cit. (nota 06), pp. 13-15; L. DíEZ-PICAZO, La representacion cit. (nota 29), pp. 25-26; G. Pugliese, Istituzioni cit. (nota 15), pp. 247, 250-252; M. G. MaIA JÚnIOR, A 
representação cit. (nota 04), pp. 23-24; H. M. F. MADEIRA, História cit. (nota 26), p. 62]; contudo, em decorrência de exigências de eqüidade, foram desenvolvidos (principalmente pelo direito pretoriano) mecanismos excepcionantes da regra geral, os quais consistiram, em síntese, nas "actiones adiecticiae qualitatis" (cf. nota 29), no referendo à gestão oficiosa (dos tutores e curadores) e na aquisição de posse por meio da atuação do "procurator". Assim, quanto às duas últimas mitigações, eis a posição de V. ARANGIORUIZ: "la deroga all'esclusione della rappresentanza diretta ha la sua ragion d'essere in una potestà personale riconosciuta ai rappresentanti sugli incapaci (...) altre volte ancora, la brecia viene aperta in relazione ad istituti speciali, che, pur non essendo negozi giuridici, producono conseguenze nel mondo del diritto. ̇̀ questo il caso dell'acquisto del possesso (...) un ulteriore svolgimento ha portato ad applicare la rappresentanza a negozi giuridici veri e propri, che nella struttura materiale coincidono coi modi di acquisto del possesso (...) è tuttavia assai incerto per quanta parte l'illazione dall'acquisto del possesso a quello della proprietà appartenga al diritto classico, per quanta parte sia frutto di rielaborazione postclassica e giustinianea" (Istituzioni cit. (nota 15), pp. 94-97). Note-se que este autor defende que o preceito excepcionante - desenvolvido durante o período clássico - atinente à atuação do "procurator" não atingia as hipóteses de aquisição de domínio, mas tão somente de aquisição de posse. Em idêntico sentido as posições de S. SolazzI, Di alcuni punti controversi nella dottrina dell'acquisto del possesso in Scritti di diritto romano I (1899-1913), Napoli, Casa Editrice Dott. Eugeinio Jovene, 1955, pp. 295-360; F. SERRAO, Il procurator cit. (nota 31), p. 187; R. MONIER, Manuel cit. (nota 29), p. 390; R. QUADRATO, Rappresentanza cit. (nota 29), pp. 418-421 e 426-431; A. WATSON, Contract cit. (nota 26), p. 9.

Posta de parte a extensão dos efeitos de uma representação direta às hipóteses de gestão oficiosa, especificamente quanto à atuação do "procurator" duas tendências expansivas do preceito excepcionante surgiram: de um lado, propensas a fazer incluir em seu suporte fático as atuações do mandatário e do gestor espontâneo ("negotiorum gestor" justinianeu); de outro, estendendo materialmente o âmbito de incidência deste preceito, para abranger também a aquisição de propriedade. Neste sentido, cf. E. PETIT, Tratado cit. (nota 15), pp. 521-524; M. KASER, Direito Privado cit. (nota 15), p. 90; U. AlvareZ SuAREZ, Instituciones cit. (nota 15), pp. 216-217.

Com efeito, o confronto de um antigo fragmento atribuído a Nerácio (Ner. 7 membr. D. 41, 3, 41) poderia nos levar ao equivocado entendimento de que tal preceito excepcionante (aquisição de posse pelo "procurator") fosse de admissão pacífica entre os romanos: "si rem surreptam mihi procurator meus apprehendit, quamvis per procuratorem possessionem adispisci nos iam fere conveniat, nihilo magis eam in potestatem meam rediisse, usuque capi posse existimandum est, quia contra statui captiosum erit" ("si mi procurador se apoderó de la cosa que me había sido hurtada, aunque de ordinario esté ya convenido que adquirimos la posesión por medio de procurador, no por eso se ha de estimar que volvio ella á mi poder, y que se puede usucapir, porque sería capcioso que se estableciera lo contrario"). Contudo, este entendimento assentado a que parece aludir Nerácio (séc. I d.C.) não é corroborado por Gaio (séc. II d.C.) em G. 2, 95: "ex his apparet per liberos homines, quos neque iuri nostro subiectos habemus neque bona fide possidemus, item per alienos servos, in quibus neque usumfructum habemus neque iustam possessionem, nulla ex causa nobis adquiri posse. Et hoc est quod vulgo dicitur per extraneam personam nobis adquiri non posse. Tantum de possessione quaeritur, an per extraneam personam nobis adquiratur" ("daí resulta o não podermos em caso algum adquirir por intermédio de homens livres, nem sujeitos ao nosso poder, nem possuídos de boa fé, assim como não podemos adquirir por meio de escravos alheios, de que não temos o usufruto nem a posse justa. Tal o sentido do dito vulgar, não podemos adquirir por pessoa estranha. Apenas quanto à posse, pergunta-se se podemos adquiri-la por pessoa estranha").

Ora, se ainda se indagava a respeito da aquisição de posse por meio de "procurator" à época de Gaio, é sinal de que o consenso a que alude Nerácio - um século antes - não era tão grande assim (havendo a possibilidade de que se tivesse estabelecido entre os proculianos, restando divergente a posição dos sabinianos). E isso fica ainda mais acentuado quando se tem vista que - como noticia V. ARANGIO-RUIZ - em algumas edições mais recentes das Institutas de Gaio consta o encerramento do passo acima referido por meio do período "tantum de possessione quaeritur, an per procuratorem nobis adquiratur"; com efeito, a expressão "per procuratorem" (mais sintética que a tradicional "per extraneam personam") se conformaria melhor à brevidade da lacuna existente no palimpsesto de Verona (Il mandato cit. (nota 25), p. 50). Por precisas considerações sobre a fórmula originária do princípio, cf. P. BONFANTE, Istituzioni cit. (nota 15), p. 79 (nota 01).

De toda forma, parece razoável a tese de que ainda havia polêmica quanto à admissibilidade do preceito excepcionante: razão pela qual, em lugar de uma sua admissão generalizada - ensejadora de interpretações extensivas e mais arrojados impulsos analógicos - deve ter sido instalada uma gradual mitigação ao princípio geral de vedação à representação direta, inviabilizando-se, assim, o entendimento que estende o alcance do preceito excepcionante à aquisição da propriedade pelo "procurator" - o mesmo se podendo afirmar acerca da atuação do mandatário e do gestor espontâneo. 


\section{$\S$ 49. Sobre uma aproximação sistemático-funcional e acerca da}

degeneração dos elementos de discriminação entre a "procuratio" e o "mandatum": aspectos de uma progressiva absorção e considerações sobre o direito romano compreendido como sistema em (constante) evolução. Desta forma, parece-nos que uma historiografia interna consciente deve tomar a "procuratio" e o "mandatum" como

Aliás, tal conclusão é corroborada pelo fato de que uma tal orientação restritiva foi sintetizada em uma Sentença de Paulo na qual se destaca que, como regra, por meio de outras pessoas livres (que não estão sob nosso poder), nós não podemos adquirir, ressalvada a aquisição de posse pelo "procurator" (PS. 5, 2, 2: "per liberas personas, quae in potestate nostra non sunt, adquiri nobis nihil potest. Sed per procuratorem adquiri nobis possessionem posse utilitatis causa receptum est. Absente autem domino comparata non aliter ai, quam si rata sit, quaeritur"). Assim, ao que tudo indica, o consenso a que alude Nerácio deve ser tomado com muita cautela pelo pesquisador.

Desta forma, se se conferir ao termo "procurator" um alcance demasiadamente amplo, ter-se-á de admitir que todo e qualquer mandatário (e eventualmente todo e qualquer gestor de negócios alheios) se subtrairia à regra "per extraneam personam nobis adquiri non potest"; com o que o próprio princípio restaria, pois, completamente esvaziado (e não somente mitigado). A mesma ordem de raciocínio deve ser empregada, aliás, para a compreensão da possibilidade de aquisição de propriedade por meio da entrega da coisa alienada. Esse tipo de interpretação extensiva é condenado, aliás, por V. ARANGIO-RUIZ, o qual destaca que tal tipo de questão restava ainda muito controversa entre os proculianos e sabinianos (aqui representados, respectivamente, por Nerácio e Gaio), a propósito de uma hipótese assaz limitada subjetiva ("procurator") e objetivamente (posse) (Il mandato cit. (nota 25), pp. 49-52). De todo modo, por uma apreciação geral da questão, em profundidade, cf. F. BRIGUGLIO, Studi cit. (nota 26), pp.46-267 e 538-551.

Não se pode deixar de aludir, todavia, à destoante posição de S. RiCCOBONO que, em estudo monográfico criterioso, chega a uma conclusão contrária àquela adotada pela doutrina dominante (conquanto tal antagonismo pareça ser muito mais um esforço retórico do que uma contrariedade autêntica). Observando que o direito quiritário vedava peremptoriamente a representação direta, o autor chega à conclusão de que o direito romano admitiu, sim, a representação direta, tendo-se em vista o fato de que tantas foram as exceções forjadas pelo direito pretoriano e imperial, que o próprio sistema tradicional, embora não pudesse ser revogado, mostrava-se cada vez mais limitado; dentre as várias passagens do estudo com observações categóricas a respeito, observe-se: "il diritto classico offre nel campo della rappresentanza due sistemi contradittori: da una parte l'esclusione assoluta di essa secondo il 'ius civile'; e dall'altra parte provvedimenti varii, escogitati dal Pretore, dalla Giurisprudenza, dagl'Imperatori, per conseguire sia i vantaggi dalla rappresentanza diretta, sia l'efficacia del contratto a favore di terzi. Le esigenze del commercio nel vasto impero, e la provvida tutela d'interessi familiari, in una società progredita, dovevano necessariamente imporsi nella pratica applicazione del diritto, determinando quella nuova direzione in aperto contrasto con la tradizione dell' 'ius civile'. Nella prassi quotidiana si vien così formando il nuovo diritto; con l'opera illuminata da tutti gli organi e dei dirigenti dell'amministrazione della giustizia" (Lineamenti cit. (nota 15), pp. 127-157, especilamente p. 140). No mesmo sentido, algumas décadas antes - conquanto com menor ênfase - cf. G. PACCHIONI, Corso cit. (nota 15), pp. 182-183. E adotando os termos de S. RicCOBONO como sua própria conclusão, cf. R. ORESTANO, Rappresentanza (diritto romano), in NDI 10 (1939), p. 1096 (e posteriomente em Rappresentanza (diritto romano), in NNDI 14 (1967), p. 800).

Finalmente, merece destaque a radical posição de J. HUPKA - repelindo a representação direta entre os romanos em qualquer hipótese - que nos oferece uma oportunidade especulativa sem igual, quando correlacionada às observações de U. ALVAREZ SUAREZ e G. PUGLIESE anteriormente referidas neste trabalho (nota 29): "los nombres de tutor, curator, procurator, nada dan a entender sobre la actividad exterior de estas personas, presentándolas, no como representantes, sino como gestores o administradores de los negocios de otro (...) la opinión (...) que afirma que especialmente la palabra procurator se emplea en las fuentes para designar al que obra en nombre de otro, ha sido fundadamente objeto de general repulsa. Ni siqueira es exacta con respecto a los modos de adquirir la posesión y la propiedad, y mucho menos aún en el campo de los derechos de obligación, en los que la actuación en nombre ajeno sólo por excepción es admitida (...) si el derecho romano hubiera prestado reconocimiento a la representación en general, la mano maestra de los jurisconsultos romanos nos hubiera transmitido con toda seguridad una teoría de la representación tan cuidadosa como finamente elaborada" (La representación voluntaria en los negocios jurídicos, Madrid, Revista de Derecho Privado, 1930, pp. 15-17). 
elementos em contínua evolução, os quais, a partir de um dado momento, passam a revelar uma recíproca imbricação; neste sentido, a gradativa juridicização do vínculo estabelecido entre o principal e o "procurator" - aliada ao distanciamento cada vez maior deste último em relação ao círculo da "potestas" familiar - torna cada vez mais evidente uma atmosfera contratual, em detrimento da unilateralidade que caracterizava o negócio jurídico de investidura em sua feição originária. Com isso, desta relação entre a "procuratio" e o contrato de mandato parece defluir a contemplação, sob diferentes enfoques, de um fenômeno único: enquanto de um lado se toma em consideração o poder decorrente do negócio jurídico de outorga ("procura”), de outro se enfatiza a incumbência cometida ao agente ("mandato"); ora, embora estejamos cientes dos potenciais efeitos nocivos de uma análise histórica indevidamente comprometida com os modelos de trabalho atuais - bem como do diverso grau de compromisso de cada instituto jurídico com o conjunto de valores nele sintetizados - parece viável a tentativa de se extrair dessa aproximação uma eventual dissociação entre os aspectos externo ("procuratio") e interno ("incumbência") da relação entre o principal e o agente - sobretudo à vista de uma tendência harmonizadora freqüentemente adotada pela jurisprudência romana ${ }^{41}$.

\footnotetext{
${ }^{41}$ Parece-nos oportuno destacar - particularmente no que concerne à evolução experimentada pelos institutos da "procuratio" e do "mandatum" - que o direito romano não pode ser tomado como uma unidade desprovida de quaisquer contradições internas (e mesmo de uma dinâmica peculiar); ao contrário, a pluralidade de sistemas que o informam (voltados, em suas linhas gerais, a prioridades diversas) recomenda ao intérprete uma atenção constante quanto à "possibilidade" de graduais rupturas - operadas ao longo de um intervalo tão dilargado quanto foi aquele em que este paradigma vigorou por sua autoridade própria.

Ora, como advertido no $\S 33$ deste estudo, a despeito de uma clara autonomia estrutural - mantida durante grande parte desse período - a "procuratio" e o "mandatum" passaram a ostentar uma proximidade lógica e sistemática diretamente proporcional à afinidade prática que ligava tais institutos. Como vimos no $\S 40$, a gestão de um processo não poderia ser incumbida a um "alieni iuris" (menos ainda a um escravo); neste passo, o surgimento do "procurator ad litem" tem reflexos sistemáticos mais amplos do que se poderia pensar, pois implica não só a admissão de uma "procuratio" com fins mais específicos, mas também a utilização desta estrutura (originariamente familiar) para viabilizar um vínculo que se estabelece entre iguais - pertencentes, ademais, a núcleos familiares diversos.

Pois bem: quando se adiciona a tal cenário uma progressiva admissão de terceiros (estranhos à família) para o exercício da função de "procurator omnium rerum", resta bastante mais difícil sustentar não apenas o caráter "extra-jurídico" do vínculo, mas também - e principalmente - a sua origem unilateral. Do ato "autorizativo" unilateral (proveniente do principal), transita-se a uma "contratualidade" que torna, sob a perspectiva analítica e sistemática, inevitável a aproximação em relação ao "mandatum". Assim, percebe-se uma tendência à "absorção" da "procuratio" por este tipo contratual, tal como sugerido pela doutrina; a respeito, cf. S. PEROZZI, Istituzioni cit. (nota 15), pp. 246-249; P. BonfANTE, Istituzioni cit. (nota 15), p. 79; E. ChAmoun, Instituições cit. (nota 15), pp. 384-385; A. CoRreIA - G. SCIASCIA, Manual cit. (nota 09), p. 293; A. Burdese, Manuale cit. (nota 15), p. 554; S. A. de B. MeIRA, Instituições de Direito Romano, $3^{\mathrm{a}}$ ed., São Paulo, Max Limonad, 1968, pp. 376-377; G. GRosso, Schemi giuridici e società nella storia del diritto privato romano - dall'epoca arcaica alla giurisprudenza classica: diritti reali e obbligazioni, Torino, G. Giappichelli, 1970, pp. 408-409; E. VOLTERRA, Istituzioni cit. (nota 15), p. 172 (nota 186); H. CoING, Europäisches Privatrecht, trad. esp. de Antonio Pérez Martín, Derecho Privado Europeo I - derecho común mas antiguo (1500-1800), Madrid, Fundação Cultural del Notariado, 1996, p. 583; A. SANTOS Justo, Direito privado cit. (nota 15), p. 203; A. GuARINO, Diritto privato cit. (nota 15), p. 414; M. C. do A. KroETZ, A
} 


\title{
$\S 50$. O progressivo entrelaçamento entre os institutos da "procuratio" e do
}

\author{
"mandatum" consoante alguns excertos do período clássico. Embora se possa extrair das
}

fontes que informam o direito romano clássico um considerável número de alusões genéricas à relação mantida entre a "procuratio" e o "mandatum" (v.g., Ulp. 9 ad ed. D. 3, 3, 1 pr. e Ulp. 57 ad ed. D. 47, 10, 17, 16), bem mais escassas são as oportunidades em que se efetua um cotejo direto entre os institutos jurídicos referidos, por meio de uma sua evocação segundo a precisa acepção técnica que lhes é peculiar; por sua vez, certos fragmentos devem ser analisados com reservas, diante das fundadas suspeitas de

representação voluntária no direito privado, São Paulo, Revista dos Tribunais, 1998, pp. 30-31. Merecem especial menção os estudos de G. PUGLIESE [que conclui pela referida absorção tão somente durante o período pós-clássico (Istituzioni cit. (nota 15), p. 581)] e de F. BETANCOURT, o qual alude expressamente à "contratualização" anunciada, esclarecendo que, em virtude de uma tendência republicana "se introdujo una actio (ex fide bona) negotiorum gestorum que contractualiza la gestión de negocios aproximándola al contrato de mandato" (Derecho cit. (nota 15), p. 626).

Como já asserverado em nota específica deste trabalho (nota 39), tal aproximação em nenhum momento pode ser compreendida como uma simples fusão entre os institutos considerados; contudo, os jurisconsultos romanos estavam, segundo V. ARANGIO-RUIZ, diante de uma realidade muito próxima daquela com que se depararam os estudiosos da segunda metade do século XIX que se ocuparam da questão: "non sembra, per vero, che i giurisconsulti abbiano potuto essere fermati su questa strada da considerazioni analoghe a quelle per le quali gran parte della dottrina pandettistica e civilistica tiene distinta la procura dal mandato (...) mentre il nome della procura fa convergere l'attenzione sul potere attribuito a qualcuno di agire in rappresentanza di un'altro (...) quello del mandato mette piuttosto in luce il dovere assunto dal rappresentante verso il suo principale. Il mandato è perciò (...) la causa della procura, il rapporto sottostante ad essa, altrimenti detto rapporto interno di cui la procura è l'esplicazione all'esterno" (Il mandato cit. (nota 25), p. 53).

No entanto, parece-nos que as considerações de V. ARANGIO-RUIZ, neste particular, são sensivelmente equivocadas: em um esforço de transposição metodologicamente questionável, o autor critica o posicionamento da doutrina que entrevê no negócio jurídico de outorga de poderes um ato unilateral, considerando-o, assim, um contrato (Il mandato cit. (nota 25), p. 53); voltaremos a tal questão, com a minudência devida, mais adiante. Contudo, por ora é necessário destacar que o autor ressalta muito bem a existência de uma incumbência suportada pelo contrato de mandato; não nos parece que anda tão bem, todavia, ao considerar a "procuratio" um poder. Se a aptidão a percutir a esfera jurídica alheia pode ser considerada um poder, esta questão concerne à temática da "representação direta", mas jamais da "procuratio" que - como instrumento de "gestão" - conservava entre os romanos uma irrestrita autonomia conceitual em relação àquela. Neste sentido, é clara a lição de P. BONFANTE: "nel diritto romano la facoltà di amministrare, cioè di agire nell'interesse altrui (che si suol dire anche rappresentanza indireta o impropria) non implica in via di principio la facoltà di rappresentare, cioè di agire veramente nel nome altrui, che è la vera o diretta rappresentanza" (Istituzioni cit. (nota 15), pp. 78-79). Com isso, surge o problema de se distinguir a incumbência geradora de um "dever" (mandato), a percussão da esfera jurídica alheia consubstanciadora de um "poder" (representação direta) e a relação gestória ("procuratio") que, por sua vez, não se reduz a qualquer das referidas situações. Feitas tais ressalvas, todavia, parece-nos acertada a posição do autor ao defender que os institutos jurídicos analisados tenham sido progressivamente aproximados, à vista de uma tendência "definidora e amalgamadora" da jurisprudência romana (cf. V. ARANGIO-RUIZ, Il mandato cit. (nota 25), p. 55).

Finalmente, deve-se observar o impacto que tal aproximação teve na historiografia jurídica posterior, posto em relevo por E. AlBERTARIO ao aludir à origem "pós-clássica" do art. 1.984 do Code Civil (que por um lapso o autor refere como 1.894): “e, se il C. N. nell' art. 1894 per definire il mandato adopera la formula: 'Le mandat ou procuration est un act etc.', conservando, insomma, la promiscua termonologia postclassica, il nostro Cod. civ. nell'art. 1737 adopera invece la formula: 'il mandato è un contratto etc.', sopprimendo nella definizione del mandato ogni traccia, sia pur anche terminologica, della fusione dei due istituti avvenuta nelle due parti dell'impero nell'età postclassica" (Procurator cit. (nota 31), p. 521). 
interpolação que se lhes dirigem. Desta forma, justificado o afastamento de alguns excertos, restam outros, porém, nos quais a menção simultânea aos institutos é feita de maneira precisa, conquanto indireta (v. g., G. 3, 155). De todo modo, mesmo que postas de parte tais referências oblíquas, restam ainda alguns textos clássicos nos quais se enfrenta a questão de maneira direta: por exemplo, (a) quando se reconhece a pertinência da "actio mandati" à relação mantida entre o "procurator" e o principal (Paul. 8 ad ed. D. 3, 3, 42, 2 e Papin. 1 resp. D. 17, 1, 55); (b) ao se declarar que é exatamente esse o remédio adequado à tutela daquele que fora prejudicado por seu respectivo procurador [Dioc. et Max. C. 4, 35, 9 (285-304)]; (c) quando se informa que o "procurator" (“ad litem”) é constituído "ex solo mandato" (G. 4, 84); (d) ou mesmo quando se surpreende uma disciplina pormenorizada da "procuratio" sob a cláusula editalícia da "actio mandati” (Ulp. 31 ad ed. D. 17, 1, 10). Assim - não obstante ressalvas individuais que se possa fazer a um ou outro passo -, tomadas em conjunto, essas manifestações parecem demonstrar a extensão da disciplina do contrato de mandato à "procuratio", ainda durante o período clássico ${ }^{42}$.

${ }^{42}$ Quanto às duas referências à obra de Gaio, cabem as seguintes observações: no que concerne a G. 4,84 ("procurator vero nullis certis verbis in litem substituitur, sed ex solo mandato et absente et ignortante adversario constituitur. Quin etiam sunt qui putant eum quoque procuratorem videri, cui non sit mandatum, si modo bona fide accedat ad negotium et caveat ratam rem dominum habiturum; quamquam et ille, cui mandatum est, plerumque satisdare debet, quia saepe mandatum initio litis in obscuro est et postea apud iudicem ostenditur"; “o procurador, ao contrário, é substituído, na causa, sem palavras especiais, mas por simples mandato, podendo constituir-se na ausência e ignorância do adversário. Na verdade, alguns pensam ser também procurador quem não tenha mandato, contanto que assuma a causa de boa fé e apresente caução pela futura ratificação de seus actos pelo mandante; embora também o próprio mandatário deva muitas vezes dar caução, porque freqüentemente, no comêço da lide, o mandato é incerto, manifestando-se só mais tarde, perante o juiz") resulta infundada a posição de B. FRESE, que sustenta - de modo "simplista" e incorrendo em uma petição de princípio - a não-autenticidade do passo em decorrência da inexistência de um "procurator ad litem" durante o período clássico (Defensio cit. (nota 31), pp. 400-402). De sua parte, em uma manifestação de clara hostilidade ao "procurator ad litem" clássico, F. SERRAO retoma as mesmas considerações já analisadas e repelidas neste estudo (cf. § 40 e nota 32) ( $I l$ procurator cit. (nota 31), pp. 41-46). Ora, postas de parte tais posições, resulta clara a vinculação de uma causa estranha ("mandato") ao efeito da investidura de um "procurator" - em evidente imbricação da disciplina do tipo contratual sobre a "procuratio".

Por sua vez, no que concerne a G. 3, 155 ("mandatum consistit, sive nostra gratia mandemus sive aliena. Itaque sive ut mea negotia geras, sive ut alterius, mandaverim, contrahitur mandati obligatio, et invicem alter alteri tenebimur in id, quod vel me tibi vel te mihi bona fide praestare oportet"; "existe mandato quer mandemos em nosso próprio interêsse quer no de outrem. Contrai-se portanto a obrigação de mandato se eu te encarregar de administrares, quer os meus negócios, quer os de outrem, e nós nos obrigamos recìprocamente por aquilo que devemos, em boa fé, prestar um ao outro") a influência é tão somente mediata (ou indireta): com efeito, sabendo que o jurisconsulto tinha ciência da noção corrente de "procuratio omnium rerum" a que aludiam Cícero e Sêneca (cf. nota 34), abrangente de uma gestão de negócios alheios, não é difícil concluir que admitisse, ainda que inconscientemente, o "procurator omnium rerum" como uma espécie de mandatário.

Já no que concerne ao direito justinianeu, deve-se destacar que algumas fontes remontam aos institutos referidos por meio da utilização imprecisa das expressões pelas quais normalmente haveriam de ser evocados: assim, por exemplo, em Ulp. 9 ad Ed. D. 3, 3, 1 pr. ("procurator est, qui aliena negotia mandatu domini administrat"; "procurador es el que administra negocios ajenos por mandato del dueño") e Ulp. $57 \mathrm{ad}$ $E d$. D. 47, 10, 17, 16 ("procuratorem autem accipere debemus non utique eum, cui specialiter mandata est procuratio actionis iniurarum, verum sufficit eum esse, cui omnium rerum administratio mandata est"; "pero 
debemos entender por procurador no solamente aquel á quien en especial se le encomendó la procuración de la acción de injurias, sino que basta que sea uno á quien se le haya encomendado la adminsitración de todos los bienes"), os termos "mandato" e "mandata", respectivamente, acenam para a idéia de "incumbir" (encarregar), traduzida no segundo caso pela expressão "encomendado" - mas não necessariamente se referem ao "confiar" a que aludimos em outra oportunidade (nota 28). Assim, tal emprego não é suficientemente preciso para que possamos entrever no contrato de mandato a causa eficiente do surgimento de uma relação jurídica típica da "procuratio". Aliás, mesmo quando os termos são aproximados não existe garantia de uma efetiva utilização das expressões em seu sentido técnico; comprobatório de tal assertiva é o fragmento constante de Iul. 54 ad Dig. D. 46, 3, 34, 3: "si Titium omnibus negotiis meis praeposuero, deinde vetuero, eum ignorantibus debitoribus administrare negotia mea, debitores ei solvendo liberabuntur; nam is, qui omnibus negotiis suis aliquem proponit, intelligitur etiam debitoribus mandare, ut procuratori solvant" ("si yo hubiere puesto á Ticio al frente de todos mis negocios, y después hubiere vedado, ignorándolo los deudores, que él administrara mis negocios, los deudores quedarán libres pagándole á él; porque se entiende que el que pone á alguien al frente de todos sus negocios les manda también á los deudores que le paguen al procurador"). Ora, resta evidente a aplicação imprecisa do termo "mandare", ainda que tratando de um tema relativamente próximo - a envolver justamente a "procuratio". Assim, a advertência de A. GUARINO exsurge em momento bastante oportuno: “il termine 'mandatum' non sta letteralmente a significare il contratto, ma solo l'incarico dato dal mandante al mandatario: pertanto non sempre i mandata di cui parlano le fonti sono espressioni del contratto consensuale di mandatum, il quale piú esattamente dovrebbe chiamarsi 'mandatum susceptum' ('mandato accettato'), o meglio ancora 'mandatum consensu contractum' ('mandato consensuale')" (Diritto privato cit. (nota 15), p. 929). Em sentido contrário, tomando as utilizações de "mandatum" e "mandare" - constantemente - em sentido técnico, cf. F. SERRAO, Il procurator cit. (nota 31), p. 111.

No que tange às fontes em que as expressões são empregadas em seu respectivo sentido técnico, pode-se iniciar a análise por Paul. 8 ad Ed. D. 3, 3, 42, 2: "ea obligatio, quae inter dominum et procuratorem consistere solet, mandati actionem parit. Aliquando tamen non contrahitur obligatio mandati, sicut evenit, quum in rem suam procuratorem praestamus, eoque nomine iudicatum solvi promittimus; nam si ex ea promissione aliquid praestiterimus, non mandati, sed ex vendito, si hereditatem vendidimus, vel ex pristina causa mandati agere debemus, ut fit, quum fideiussor reum procuratorem dedit" ("la obligación que suele mediar entre el principal y su procurador produce la acción de mandato, como sucede cuando nombramos procurador para negocio suyo, y en su nombre prometemos que se pagará lo juzgado; porque si por esta promesa hubiéremos pagado algo, no debemos reclamarlo por la acción de mandato, sino por la de venta, si vendimos la herencia, ó por la primitiva causa del mandato, como sucede cuando el fiador nombró por procurador al demandado"); com efeito, a parte inicial do passo denuncia, de modo categórico, o emprego da "actio mandati" em situação na qual se estabelecem induvidosamente os contornos de uma "procuratio". Contudo, o caráter "excessivamente" didático da exposição - aliado à posição do fragmento na obra de Paulo (Livro oitavo dos Comentários ao Edito) cotejado com o seu conteúdo - levam a crer que o texto não seja autêntico, uma vez que o jurisconsulto, provavelmente, se referia ao "cognitor" (e não ao "procurator"). De toda forma, o emprego da "actio mandati", em qualquer dos casos, denunciaria uma aproximação entre os institutos. Neste sentido, cf. V. ARANGiO-RUIZ, Il mandato cit. (nota 25), pp. 59-60.

Bastante eloqüente, todavia, é o passo de Papiniano contido em Pap. 1 resp. D. 17, 1, 55: "procurator, qui non res inclusas subtraxit, sed traditas non reddidit, iudicio mandati, non furti tenetur" ("el procurador que no sustrajo las cosas encerradas, pero que no devolvió las entregadas, está obligado por la acción de mandato, no por la de hurto"); em passo sintético, o jurisconsulto esclarece que aquele que recebeu coisa lacrada há de ser demandado não por meio da ação de furto, mas sim por meio da "actio mandati". Daí podermos depreender uma miscigenação entre as referidas disciplinas. Por uma análise cuidadosa deste passo, cf. G. DONATUTI, Sul fr. 55, Dig. 17, 1 mandati (vel contra), in Studi di diritto romano I, Milano, Dott. A. Giuffrè, 1976, pp. 135158.

Por sua vez, os três primeiros parágrafos que compõem o fragmento constante de Ulp. 31 ad Ed. D. 17, 1, 10 encerram uma casuística bastante minudente a respeito da atuação do "procurator"; entretanto, ainda que não se mencione diretamente a "actio mandati", podemos considerá-la vinculada à hipótese, eis que o trecho da obra de Ulpiano referido corresponde à continuação daquele constante de Ulp. 31 ad Ed. D. 17, 1, 8. Ocorre que em Ulp. 31 ad Ed. D. 17, 1, 8 pr. temos: "si procuratorem dedero, nec instrumenta mihi causae reddat, qua actione mihi teneatur? Et Labeo putat, mandati eum teneri, nec esse probabilem sententiam existimantium, ex hac causa agi posse depositi; uniuscuiusque enim contractus initium specttandum et causam" ("si yo hubiere nombrado un procurador, y no me devolviera los instrumentos de la causa, por qué acción me quedará obligado? Y opina Labeon, que queda él obligado por la acción de mandato, y que no es admisible la opinión de los que juzgan que por esta causa puede ejercitarse la acción de depósito; porque se ha de atender al principio y á la causa de cada contrato"); e aí temos uma articulação que evidencia, pois, o 
$\S 51$. O concurso entre a "actio negotiorum gestorum" e a "actio mandati" a respeito da tutela à gestão de negócios alheios: uma controvérsia oriunda do confronto entre fragmentos atribuídos a Pompônio, Africano e Ulpiano. Evidenciada a extensão do regime jurídico do "mandatum" à "procuratio", cumpre indagar sobre a sobrevivência da "actio negotiorum gestorum" como mecanismo de tutela do "procurator" (a concorrer com a "actio mandati"): a despeito da existência de excertos de Pompônio nos quais se admite expressamente o emprego do remédio tradicional (Pomp. 5 ad Sab. D. 27, 3 , 3 e Pomp. 6 ad Sab. D. 34, 3, 8, 6), o principal argumento em favor da tese da exclusividade da "actio mandati" é um dos principais fragmentos do título "Mandati vel contra" - atribuído a Ulpiano (Ulp. 31 ad ed. D. 17, 1, 6, 1) - no qual a "actio negotiorum gestorum" é rechaçada de modo veemente. Contudo, parece-nos que a força persuasiva deste passo deva ser mitigada, à vista não apenas da exigüidade do período compreendido entre a produção dos referidos jurisconsultos (inferior a um século), como também das fundadas razões pelas quais se considera interpolado um trecho similar em que Ulpiano alude ao mesmo tema (Ulp. 29 ad ed. D. 15, 3, 3, 2). Além disso, diante da existência de passos de Africano nos quais se reconhece a concorrência entre tais ações (Afric. 8 quaest. D. 15, 3, 17 pr., e Afric. 8 quaest. D. 21, 1, 51, 1) - bem como de outros trechos dos "Comentários ao Edito" nos quais Ulpiano admite que o "procurator omnium bonorum" atue (Ulp. $74 \mathrm{ad}$ ed. D. 44, 2, 5) ou seja demandado com fundamento em qualquer delas (Ulp. 35 ad ed. D. $3,5,16)$ - parece razoável a tese que levanta suspeitas quanto à autenticidade de Ulp. 31 ad ed. D. 17, 1, 6, 1, a fim de se concluir, portanto, pelo concurso de ambas as ações nas

emprego da ação de mandato para hipóteses de "procuratio", recomendado por Ulpiano ainda durante o período clássico. Aliás, como observa V. ARANGIO-RUIZ, a falta de uma menção direta à "actio mandati" somente corrobora a incolumidade do texto, ao que tudo indica preservado em suas feições originais ( $I l$ mandato cit. (nota 25), pp. 60-61).

Finalmente, da constituição imperial inscrita em Dioc. et Max. C. 4, 35, 9 (285-304) pode-se depreender que aquele que fosse prejudicado por seu procurador poderia demandá-lo por meio da ação de mandato, em uma clara demonstração de entrelaçamento entre as disciplinas respectivamente vinculadas aos referidos institutos: "quum per procuratorem causam tuam laesam esse dicas, mandati actio adversus eum tibi competit" ("puesto que dices que tu causa fué perjudicada por el procurador, te compete contra él la acción de mandato"). O que corrobora, ainda, a tese de um entrelaçamento entre os institutos mesmo durante o período clássico.

A respeito da mútua imbricação entre a "procuratio" e o "mandatum", cf. V. ARANGIO-RUIZ, Il mandato cit. (nota 25), pp. 55-62. Repelindo a miscigenação durante o período clássico, F. SERRAO assim descreve o panorama durante o período clássico: "la procura era completamente indipendente dal mandato, il quale ultimo consisteva invece nell'incarico di una missione isolata e definita (...) il procurator poteva intervenire volontariamente a curare gli affari del dominus o essere preposto da quest'ultimo mediante atto unilaterale di praepositio (...) nel diritto postclassico giustinianeo le cose cambiano profondamente. Il procurator deve essere costituito col mandato; i suoi rapporti col dominus sono regolati dall'actio mandati, la prcoura viene assorbita dal mandato" (Il procurator cit. (nota 31), p. 113 e pp. 187-188). Percebe-se, pois, a concordância entre os autores a respeito da referida "absorção"; a polêmica se cinge, assim, à sua respectiva periodização. 
hipóteses de "procuratio": de fato, se as alusões a uma tal concorrência são exíguas (tomando-se em consideração o número de vezes em que o termo "procurator" pode ser encontrado no Digesto), isso se deve ao fato de que a coletânea não representa um retrato "desinteressado" da obra dos jurisconsultos clássicos, mas sim uma "reconstrução" (por vezes adaptada) da produção destes últimos, orientada pelas novas concepções dos compiladores justinianeus; e desta forma, as escassas menções ao referido concurso tanto podem ser imputadas a lapsos destes últimos, como também - e talvez principalmente - à sua firme convicção de que a "actio mandati" caberia ao "procurator" incumbido, enquanto a "actio negotiorum gestorum" competiria às hipóteses de atuação do "falsus procurator" (“gestor de negócios" na acepção justinianéia da expressão) ${ }^{43}$.

\footnotetext{
${ }^{43}$ Pelos fragmentos em que Pompônio (séc. II. d.C.) admite a tutela das hipóteses de "procuratio" por meio da "actio negotiorum gestorum": cf. Pomp. 6 ad Sab. D. 34, 3, 8, 6 (transcrito em nota 34) e Pomp. 5 ad Sab. D. 27, 3, 3 ("si tutelae aut negotiorum gestorum agatur, incerto hoc, quantum ab adversariis debetur tutori procuratorive, arbitratu iudicis cavendum est, quod eo nomine iis absit"; "si se ejercitase la acción de tutela ó la de gestión de negocios, siendo incierto cuánto se debe por los adversarios al tutor ó al procurador, se ha de dar caución por arbitrio del juez por cuanto por este concepto les falte"). Com efeito, de tais excertos se pode depreender a viabilidade da utilização da "actio negotiorum gestorum" nos casos de "procuratio"; contudo, de tais manifestações deste jurisconsulto não se pode extrair sua posição a respeito do emprego da "actio mandati".
}

Todavia, em um dos mais importantes fragmentos sobre o contrato de mandato existe expressa previsão atribuída a Ulpiano - a rechaçar o emprego da "actio negotiorum gestorum" (Ulp. 31 ad ed. D. 17, 1, 6, 1): "si cui fuerit mandatum, ut negotia administraret, hac actione erit conveniendus; nec recte negotiorum gestorum cum eo agetur, nec enim ideo est obligatus, quod negotia gessit, verum idcirco, quod mandatum susceperit; denique tenetur, etsi non gessisset" ("si se hubiere mandado á alguno, que administrase negocios, deberá ser demandado por esta acción; y no se ejercitará derechamente contra él la acción de gestión de negocios, porque no se obligó por haber administrado los negocios, sino por haber aceptado el mandato; y finalmente, se obliga, aunque no los hubiese administrado"). Ora, o caráter peremptório de tal fragmento deixaria - em tese - pouco espaço a divagações por parte do intérprete; não fosse a hipótese concreta de interpolação, que pode ser construída a partir de quatro razões fundamentais.

Em primeiro lugar, o caráter excessivamente didático da exposição compromete a sua autenticidade, uma vez que os jurisconsultos clássicos não eram afeitos a esclarecimentos dotados da minudência que se pode entrever no excerto - em que não só se admite a ação de mandato como cabível, como também se repele a aplicação da "actio negotiorum gestorum".

Em segundo lugar, deve-se ter em mente que acurados estudos voltados a outro fragmento de Ulpiano - em que o jurisconsulto trata do mesmo tema - concluíram pela sua adulteração (a cargo dos compiladores justinianeus); com efeito, eis o teor de Ulp. 29 ad Ed. D. 15, 3, 3, 2: "et regulariter dicimus, toties de in rem verso esse actionem, quibus casibus procurator mandati, vel qui negotia gessit, negotiorum gestorum haberet actionem, quotiesque aliquid consumsit servus, ut aut meliorem rem dominus habuerit, aut non deteriorem" ("y por via de regla decimos, que hay la acción de lo que se convertió en provecho de otro en todos los casos en que el procurador tendría la acción de mandato, ó el que fué gestor de negocios de la gestión de negocios, y siempre que el esclavo consumió algo, para que el señor tuviere ó mejorada, ó no deteriorada, una cosa"). Ora, sendo a "gestão de negócios" - com a sua configuração mais próxima daquilo que modernamente se compreende por meio da expressão técnica - uma criação do direito justinianeu (eis que até então se compreendia por tal a administração do patrimônio alheio, inclusive mediante incumbência), tudo nos leva a crer que tenha sido o fragmento objeto de manipulação por parte dos compiladores: a compulsão pela atividade definidora, a constatação de erros gramaticais e deflagração de incoerências no período haveria de conduzir o intérprete à conclusão de que o trecho corresponderia "mais à dicção de um pós-clássico (debruçado sobre a obra de Ulpiano)" do que ao resultado direto da atuação do jurisconsulto referido (cf. V. ARANGIO-RUIZ, Il mandato cit. (nota 25), p. 63-65). 
Em terceiro lugar, deve-se levar em conta a existência de dois fragmentos de Africano nos quais se admite a concorrência de ambas as ações na hipótese de "procuratio": Afric. 8 quaest. D. 15, 3, 17 pr. ("servus in rem domini pecuniam mutuatus sine culpa eam perdidit: nihilominus posse cum domino de im rem verso agi existimavit, nam et si procurator meus in negotia mea impensurus pecuniam mutuatus, sine culpa eam perdiderat, recte eum hoc nomine mandati vel negotiorum gestorum acturum"; "habiendo un esclavo tomado en mútuo dinero para cosa de su señor, lo perdió sin culpa suya; esto no obstante juzgó que podia ejercitarse contra el señor la acción de lo convertido en su utilidad, porque también si mi procurador, habiendo tomado en mútuo dinero para gastarlo en negocios mios, lo habia perdido sin culpa, con razón ejercitará por este motivo la acción de mandato ó la de gestión de negocios") e Afric. 8 quaest. D. 21, 1, 51, 1 ("circa procuratoris personam, quum quidem ipse scierit, morbosum, vitiosum esse, non dubitandum, quin, quamvis ipse domino mandati vel negotiorum gestorum actione sit obstrictus, nihilo magis eo nomine agere possit: at quum ipse ignorans, esse vitiosum, mandatu domini, qui id sciret, emerit, et redhibitoria agat, ex persona domini utilem exceptionem ei non putabat opponendam"; "respecto á la persona del procurador, habiendo sabido ciertamente este que aquel tenia enfermedad ó vício, no se ha de dudar que aún cuando él quede obligato á su principal por la acción de mandato, ó por la de gestion de negocios, no puede, sin embargo, ejercitar la acción por tal motivo; mas cuando ignorando el que tenia vicio, lo hibiere comprado por mandato de su principal, que lo supiese, y ejercitara la acción redhibitoria, no opinaba que le hubiera de oponer excepción útil derivada de la persona de su principal"). Perceba-se que, ao contrário do que se verificava a partir dos textos de Pompônio - por meio dos quais tão somente se admitia a utilização da "actio negotiorum gestorum" -, tais fragmentos de Africano são categóricos quanto ao reconhecimento da possibilidade de emprego de quaisquer dos remédios materiais citados ("actio mandati" ou "actio negotiorum gestorum"). Com isso, dúvida exsurge quanto à posição da doutrina à época em que elaborado Ulp. 31 ad ed. D. 17, 1, 6, 1.

No entanto, tal estado de dúvida parece debelável por meio de uma consulta a Ulp. 74 ad ed. D. 44, 2, 5 e Ulp. 35 ad ed. D. 3, 5, 16. No primeiro fragmento, em meio a uma discussão sobre o conceito de "eadem res" - a pretexto exemplificativo - admite-se a utilização tanto da "actio negotiorum gestorum" quanto da "actio mandati": "de eadem re agere videtur, et qui non eadem actione agat, qua ab initio agebat, sed etiamsi alia experiatur, de eadem tamne re. Utputa si quis mandati acturus, quum si adversarius iudicio sisfendi causa promisisset, propter eandem rem agat negotiorum gestorum, vel condicat, de eadem re agit. Recteque ita definietur, eum deinum de re non agere, qui prorsus rem ipsam non persequitur; ceterum quum quis actionem mutat et experitur, dummodo de eademre experiatur, etsi diverso genere actionis, quam instituit, videtur de ea re agere" ("se considera que litiga sobre la misma cosa también el que no ejercita la misma acción que al principio ejercitaba, sino que ejercita otra, pero sobre el mismo objeto. Por ejemplo, si alguno, que hubiera de ejercitar la acción de mandato, habiéndole prometido su adversario comparecer en juicio, ejercitar por causa del mismo negocio la acción de gestión de negocios, ó la condicción, litiga sobre la misma cosa. Y con razón se definirá esto así, que solamente no litiga sobre el mismo negocio el que no persigue en absoluto la misma cosa; pero cuando aluno cambia la acción e ejercita otra, si la ejercita sobre la misma cosa, se considera que litiga sobre la misma cosa, aunque con diversa clase de acción que la que entabló"). Ja no segundo excerto, por sua vez, admite-se que o liberto possa ser demandado (quanto àquilo que geriu enquanto cativo) por meio da ação de gestão de negócios ou da ação de mandato: "eum actum, quem quis in servitute egit, manumissus non cogitur redder. Planesi quid connexum fuit, ut separari ratio eius, quod in servitute gestum est, ab eo, quod in libertate gessit, non possit, constat venire in iudicium vel mandati, vel negotiorum gestorum et quod in servitute gestum est. Denique si tempore servitutis aream emerit et in ea insulam aedificaverit, eaque corruerit, deinde manumissus fundum locaverit, sola locatio fundorum in iudicio negotiorum gestorum deducetur; quia ex superioris temporis administratione nihil amplius iudicio deduci potest, quam id, sine quo ratio libertatis tempore administratorum negotiorum expediri non potest" ("de la administración que cualquiera llevó en esclavitud, no está obligado á rendir cuentas, una vez manumitido. Mas si algún negocio fué conexo, de suerte que la cuenta de lo que aquel gestionó en libertad, es constante que va á la acción ó de mandato, ó de gestión de negocios, también lo que se hizo durante la esclavitud. Finalmente, si en el tiempo de la esclavitud hubiere comprado un solar y edificado en él una casa, y ésta se hubiere arruinado, y después de manumitido hubiere dado en arrendamiento el fundo, solamente se comprenderá en la acción de gestión de negocios el arrendamiento de los fundos; porque de la administración del tiempo anterior no puede deducirse en juicio nada más que aquello sin lo que no puede liquidarse la cuenta de los negocios administrados en el tiempo de la libertad").

Ora, desta forma, percebe-se que não há apenas um reconhecimento, por meio de dois fragmentos de Pompônio, quanto à possibilidade da emprego da "actio negotiorum gestorum" em relação à hipótese de "procuratio"; fosse isso e o caráter categórico da assertiva contida em Ulp. 31 ad Ed. D. 17, 1, 6, 1 comprometeria as intenções do intérprete. Todavia, o caráter excessivamente didático da exposição ali articulada - aliado à suspeita fundada de interpolação de Ulp. 29 ad Ed. D. 15, 3, 3, 2 - despertam a atenção 
$\S 52$. A extensão ao "mandatum" de regras originariamente destinadas aos "iudicia bonae fidei” gerais: observações sobre o influxo do regime jurídico da "procuratio" sobre a estrutura do contrato de mandato. Antes de encerrarmos nossas considerações sobre a relação entre a "procuratio" e o contrato de mandato durante o período clássico, é necessário mencionar que, não obstante a posição do "mandatum" entre os "iudicia bona fidei" especiais (Paul. 6 ad Sab. D. 17, 2, 38 pr.), com o passar do tempo lhe foram progressivamente estendidas algumas regras que, de início, cabiam unicamente aos juízos gerais de boa-fé (dentre os quais se encontrava a "procuratio", compreendida como "negotiorum gestorum" em sua acepção clássica): assim, por exemplo, de Iul. 14 dig. D. 17, 1, 31 se extrai a aplicação ao mandato do princípio da "semetipso exigere"; da mesma forma, em fragmento atribuído a Ulpiano (Ulp. 31 ad Ed. D. 17, 1, 6, 6) há uma consagração expressa da prevalência do interesse do beneficiário da gestão (mandante); ainda no mesmo sentido, de um excerto de Papiniano se depreende que o mandatário não se exonerava "ipso iure" quando - premido por motivos de interesse público - o mandante não lhe pudesse tomar as respectivas contas (Papin. 3 respons. D. 17, 1, 56, 2). Ora, ainda que não seja esta a ocasião propícia a uma análise pormenorizada do contrato de mandato romano, cumpre destacar desde já que, para além da simples absorção da "procuratio" pelo "mandatum", se verifica, do mesmo modo, uma considerável dose de influência do material "absorvido" sobre o arcabouço jurídico "absorvente": de maneira que, mesmo após o seu declínio, a "procuratio" subsistirá, latente, no sistema jurídico romano; senão como um instituto autônomo, ao menos como uma influência decisiva sobre os contornos gerais da eficácia do tipo - imantando as diversas posições jurídicas subjetivas (ativas e passivas) correspondentes ${ }^{44}$.

do estudioso para a autenticidade do texto em questão. Neste cenário, a conclusão se inverte quando nos deparamos com dois excertos de Africano em que se admite tal cumulação de tutelas (Afric. 8 quaest. D. 15, 3, 17 pr. e Afric. 8 quaest. D. 21, 1, 51,1) - corroborados, por sua vez, por duas outras manifestações do mesmo Ulpiano (Ulp. 74 ad ed. D. 44, 2, 5 e Ulp. 35 ad ed. D. 3, 5, 16).

Como observa V. ARANGIO-RUIZ, tais incongruências - reveladoras do verdadeiro regime jurídico que recobre a tutela à hipótese de "procuratio" - resultam não apenas de eventuais lapsos por parte dos compiladores, como também da robusta crença que tinham no fato de que a "actio mandati" haveria de ser atribuída nas hipóteses de gestão incumbida, restando a "actio negotiorum gestorum" para os casos de intervenção espontânea do gestor: "se qualche ricordo ne è rimasto, ciò è dovuto o a la trascuratezza nel correggere i testi classici ai fini della compilazzione, o all'opinione che il testo si prestasse ad essere inteso come concedente l' 'a. mandati nei riguradi del procuratore costituito, e l'a. negotiorum gestorum nei riguardi dello spontaneo interveniente" (Il mandato cit. (nota 25), pp. 74-75).

44 A posição do "mandatum" em meio aos "iudicia bona fidei" especiais pode ser depreendida de Paul. 6 ad Sab. D. 17, 2, 38 pr. (transcrito em nota 34). Com efeito, aos "iudicia bona fidei" gerais se aplicavam algumas regras que, em princípio, não poderiam ser estendidas às variantes especiais, eis que fundadas, pois, na "duração" do exercício da posição jurídica respectiva. 
§53. A reforma justinianéia e a redefinição dos contornos do "mandatum" e da "negotiorum gestio": o estabelecimento de um novo critério distintivo e o surgimento da dicotomia entre os conceitos de "verus" e "falsus procurator". Durante o período justinianeu se verifica uma completa reformulação da relação entre a "procuratio" e o "mandatum": ao mesmo tempo em que se passa a admitir uma variante geral do contrato (em uma superação da antiga restrição do instituto a incumbências específicas), vislumbrase neste o fundamento único para a investidura de um autêntico "procurator omnium

Contudo, como temos visto, aos poucos se verifica que o "mandatum" passa a assumir - também - a função de viabilizar uma gestão mais genérica, em um movimento de absorção da "procuratio", com a necessária repercussão em seu espectro eficacial daquelas regras que, em princípio, se mostravam incompatíveis com a pontualidade da incumbência outorgada ao "mandatário". Neste cenário, algumas regras - que então se aplicavam à "procuratio" - passam a influir sobre o novo "mandatum".

Um dos exemplos desta influência está na regra romana da "semetipso exigere" (dever de exigir de si próprio aquilo que, como gestor, deveria exigir de outrem), aplicável ao contrato de mandato consoante Iul. 14 dig. D. 17, 1, 31: "si negotia mea mandavero gerenda ei, qui mihi actione in quadruplum tenebatur, post annum vero in simplum, etsi post annum cum eo mandati agam, praestare mihi quadruplum debebit; nam qui alterius negotia administranda suscipit, id praestare debet in sua persona, quod in aliorum" ("si yo le hubiere encomendado la gestión de mis negocios á quien me estaba obligado por acción en el cráduplo, pero después de un año en el simples importe, aunque después del año ejercite yo contra él la acción de mandato, deberá pagarme el cráduplo: porque el que para administrarlos toma á su cargo los negocios de otro, debe responder respecto á sua persona de lo que respecto á la de otros").

Outro exemplo pode ser depreendido de Ulp. 31 ad ed. D. 17, 1, 6, 6: "apud Iulianum libro tertio decimo Digestorum quaeritur, si dominus iusserit procuratorem suum certam pecuniam sumere et foenerare periculo suo, ita ut certas usuras domino penderet duntaxat, si pluris foenerare potuisset, ipse lucraretur, in creditam pecuniam videtur, inquit, accepisse. Plane si omnium negotiorum erat ei administratio mandata, mandati quoque eum teneri, quemadmodum solet mandati teneri debitor, qui creditoris sui negotia gessit" ("pregúntase Juliano al libro décimo tercero, del Digesto, que si el señor hubiere mandado á su procurador, que tomase cierta cantidad de dinero, ya á su propio riesgo la prestase á interés, de suerte que pagára al señor solamente ciertos intereses, y que si pudiese prestarla á mayor interés, él mismo con ello se lucrase, dice, que se entiende que recebió el dinero como prestado. Pero que si se le había encomendado la administración de todos los negocios, queda él obligado también por la acción de mandato, á la manera que suele quedar obligado de mandato el deudor, que fué gestor de los negocios de su acreedor"). Com efeito, podemos constatar que se atribuem ao mandatário deveres especiais, adstritos à distribuição do proveito de empréstimo realizado em cumprimento a instruções do mandante; contudo, o que por ora nos interessa é a expressa equiparação do mandatário ao "gestor de negócios" (em sua acepção clássica) - tal qual se verifica da parte final do excerto.

Por fim, de Papin. 3 respons. D. 17, 1, 56, 2 podemos extrair que o "mandatário" não se eximia da responsabilidade pela gestão em decorrência da impossibilidade do "mandante" de lhe tomar as contas respectivas; em uma evidente extensão ao "mandatum" daquela idéia de "curatio" que imanta a atividade daquele que age em lugar de um curador. A respeito, cf. F. BRIGUGLIO, Studi sul procurator I - L'aquisto del possesso e della proprietà, Milano, Dott. A. Giuffrè Editore, 2007, pp. 34-35. Eis o texto do jurisconsulto: "non ideo minus omnis temporis bonam fidem explorari oportet, quod dominus post annos quinque provincia reversus, mox reipublicae causa profecturus, non acceptis rationibus mandatum instauraverit; quum igitur ad officium procuratoris pertinuerit, quidquid ex prima negotiorum gestorum administratione debuit, ad secundam rationem transferre, secundi temporis causa priorem litem suscipiet" ("no porque el señor, habiendo vuelto de provincia después de cinco años, ya habiendo de partir luego por causa de la república, no haya renovado el mandato sin haber tomado las cuentas, conviene menos que se examine la buenafé de todo el tiempo; así pues, como que correspondió al cargo de procurador comprender en la segunda cuenta cualquiera cosa que debió por la primera administración de la gestión de negocios, aceptará el litigio anterior por causa del segundo tiempo").

No sentido das considerações articuladas no corpo do texto e desenvolvidas na presente nota, cf. V. ARANGIO-RUIZ, Il mandato cit. (nota 25), p. 76 (inclusive nota 3). 
rerum"; neste mesmo compasso, o "iudicium mandati" passa a integrar o rol dos "iudicia generalia", afetado por uma série de regras que, no panorama anterior, lhe pareciam (de início) estranhas. Por sua vez, a "actio negotiorum gestorum" é apartada da "procuratio", de maneira que "procurator" ("verus") passa a ser o agente previamente constituído pelo principal (mediante contrato de mandato, e sujeito à "actio mandati"); aquela ação tradicional passa a ser reservada, então, a uma nova "negotiorum gestio", a qual - imbuída de um significado técnico completamente distinto daquele que caracterizara a antiga "procuratio" - finca suas raízes na ausência de prévia incumbência por parte do interessado: eis aí, portanto, o critério justinianeu de distinção entre o "mandatário" e o "gestor de negócios" ("falsus procurator") 45 .

\footnotetext{
${ }^{45}$ Com a reforma justinianéia, opera-se uma redefinição dos contornos do "mandatum" e da "procuratio"; da absorção (pelo primeiro) do regime jurídico desta última decorre uma nova extensão semântica conferida às referidas expressões, as quais se descortinam, então, como perspectivas distintas (interna e externa) de um mesmo fenômeno gestório. Pela fusão entre o "mandatum" e a "procuratio" operada no período justinianeu, cf. R. MONIER: Manuel cit. (nota 29), pp. 181-182; E. CHAMOUN, Instituições cit. (nota 15), p. 385; V. ARAngIo-Ruiz, Istituzioni cit. (nota 15), pp. 93-94 e 351; J. C. MoreIRA Alves, Direito Romano II Instituições de Direito Romano: B) Parte Especial: Direito das obrigações; direito de família; direito das sucessões, $6^{\mathrm{a}}$ ed., Rio de Janeiro, Forense, 1997, p. 169; A. VilLAÇA AZEVEdo, Código Civil cit. (nota 04), p. 87.
}

Neste contexto, estende-se ao mandatário "especial" a disciplina anteriormente concernente ao "procurator unius rei" (por sua vez derivada do estatuído a propósito do "procurator ad litem"); inclusive, diga-se de passagem, a única hipótese de representação direta admitida pelo direito romano clássico, vale dizer, a aquisição de posse pelo agente. Com isso, o emprego da expressão "procurator" sofre uma alteração semântica significativa: passa a designar o gestor incumbido, tomando-se em consideração o aspecto externo da gestão - bastando a expressão "mandatário" para aludir à compleição interna da relação (entre principal e gestor). Deste modo, o "procurator" ("verus") não é mais o gestor em perspectiva de longa duração - posição ocupada pelo longínquo "procurator omnium rerum" (nota 31) - mas sim aquele previamente incumbido por meio de um "mandatum"; neste sentido, cf. P. BonfanTe, Diritto cit. (nota 15), p. 293; Istituzioni cit. (nota 15), p. 79; A. D’ORS, Elementos cit. (nota 15), p. 240; F. SERRAO, Il procurator cit. (nota 31), p. 188.

Em sentido contrário, exsurge um "falsus procurator", que corresponde ao gestor espontâneo, "gestor de negócios" na acepção justinianéia da expressão; a respeito da dicotomia estabelecida entre o "verus" e o "falsus procurator", cf. G. DONATUTI, Studi sul procurator II - Verus et falsus procurator, in Studi di diritto romano I, Milano, Dott. A. Giuffrè, 1976, pp. 135-158; Studi sul procurator I - Dell'obbligo a dare la cautio ratam rem dominum habiturum, in Studi di diritto romano I, Milano, Dott. A. Giuffrè, 1976, pp. 103-133 (especialmente pp. 127-133); E. ALBERTARIO, Ancora "verus" e "falsus procurator" in SDHI 2 (1936), pp. 167-170; A. CORREIA - G. SCIASCIA, Manual cit. (nota 09), p. 294; E. VOLTERRA, Istituzioni cit. (nota 15), p. 527; P. ANGelinI, Il 'procurator' cit. (nota 29), pp. 192-212; G. Provera, Mandato cit. (nota 38); J. A. C. THOMAS, A note on a 'falsus procurator', in Studi in onore di Giuseppe Grosso II, Torino, G. Giappichelli, 1968, pp. 407-420; R. LotUFo, Questões cit. (nota 26), p. 2.

Assim, desponta o fundamento para a tomada do "procurador" como agente do principal, "em perspectiva de atuação perante terceiros" (V. ARANGIO-RUIZ, Il mandato cit. (nota 25), p. 77); ainda que em referência a um mesmo sujeito de direito, por sua vez, o termo "mandatário" é reservado para uma perspectiva diversa, eis que tangencia uma realidade jurídica própria - interna e prévia ao desempenho da incumbência atribuída pelo mandante. De qualquer modo, ainda que o termo "mandatum" guarde uma correspondência com a sua acepção clássica, a expressão "procurator" assume um sentido completamente novo (gestor incumbido). Paralelamente - e por via de conseqüência - a "negotiorum gestio" assume contornos novos, muito distintos daqueles que possuía durante o período clássico. Aliás, a respeito da acepção justinianéia de "negotiorum gestio", cf. M. KASER, Direito privado cit. (nota 15), p. 262; F. BETANCOURT, Derecho romano cit. (nota 15), p. 624 . 
$\S 54$. Encerramento do capítulo e apresentação do tema sucessivo. Se este era o panorama da relação entre o "contrato de mandato" e a "representação negocial" de acordo com o sistema decorrente do "Corpus Iuris Civilis", exsurge a questão: qual foi o papel do direito medieval - e particularmente do direito canônico - nos desdobramentos do tema ora discutido? É exatamente a respeito deste assunto que versará o próximo capítulo de nossa abordagem.

Desta forma, se nos parece correto que do próprio direito romano (inclusive de sua versão acabada no "Corpus Iuris Civilis") podemos extrair a distinção entre "mandatum" e "procuratio", não podemos deixar de reiterar, todavia, que esta última não implicava - senão em hipótese excepcional - qualquer mecanismo de representação direta, hoje tão familiar e natural ao estudioso do direito civil. Ora, podemos afirmar desde já que na "procuratio" - com seu conjunto de intrincadas regras concernentes à relação de gestão (dotada de duração) - repousam aspectos extremamente importantes que, descurados pelos estudiosos do direito civil contemporâneo, não se confundem nem com a "representação direta", nem com o cumprimento de incumbência realizado sob a veste jurídica de um "mandatum". 


\section{CAPÍTULO II. \\ O DIREITO CANÔNICO E O DESENVOLVIMENTO MEDIEVAL DA REPRESENTAÇÃO DIRETA.}

$\S 55$. O distanciamento do regime do mandato medieval em relação ao "mandatum" romano: "amicitia", honestidade do objeto e a questão da remuneração. Tomando-se como ponto de partida o panorama justinianeu concernente ao contrato de mandato (bem como à sua relação com a chamada representação negocial), deve-se destacar que o período medieval assinalou um progressivo distancimento face ao referido paradigma romano, sobretudo à custa de uma influência decisiva do direito canônico; postos de parte alguns aspectos peculiares concernentes à eficácia do referido tipo contratual (os quais serão objeto de análise nos parágrafos seguintes), percebe-se que a "amicitia" à qual remontava o modelo romano não mais ostenta toda a sua vitalidade (uma vez que prevalecentes fatores outros a determinar o emprego do instituto em um contexto social e econômico diverso daquele em que o "mandatum" teve sua origem), ao mesmo tempo em que se questiona a gratuidade "essencial" ao tipo e a possibilidade de se reconduzir a este a gestão de negócios ilícitos. Todavia, importa destacar desde logo que, conquanto o direito comum tenha submetido o "mandatum" a substanciais "ajustes", foi quanto à admissão da representação direta como regra geral que o direito canônico ofereceu sua mais profunda contribuição; assim, ainda que com relação ao contrato de mandato em alguns aspectos o modelo justinianeu tenha sido objeto de uma "oportuna" revisão, é no âmbito da representação negocial que o programa romano será posto em xeque: em lugar da antiga regra "per extraneam personam nobis adquiri non potest", as fontes canônicas hão de consagrar máximas como "potest quis per alium quod potest facere per se ipsum" e "qui facit per alium est perinde ac si faciat per se ipsum" 46.

\footnotetext{
46 Ao mesmo tempo em que se observa o declínio da "amicitia" como fundamento do contrato de mandato (uma vez que se admite a sua celebração entre estranhos), reconhece-se que mesmo um negócio ilícito poderia ser objeto de incumbência: "si può avere mandato - per quanto non obbligatorio - anche in un affare disonesto, e poi perchè può ricevere un mandato anche chi non è amico nostro" (E. BuSSI, La formazione dei dogmi di diritto privato nel diritto comune (contratti, successioni, diritti di famiglia), Padova, Casa Editrice Dott. Antonio Milani, 1971, p. 97). Contudo, dentre os diversos elementos caracterizadores do "mandatum" romano, nenhum se mostrou tão inconveniente (ao direito comum) como a "gratuidade"; com efeito, amparado nas lições de Azo e Hugolino, E. BUSSI destaca que a resistência à admissão de um mandato remunerado poderia representar, em última análise, o declínio do referido tipo contratual, em detrimento de um incremento da "locatio operarum" (p. 98). A respeito, aliás, da gratuidade do mandato romano, cf. o estudo específico de F. DuMONT (La gratuité du mandat en droit romain, in Studi in onore di Vincenzo Arangio-Ruiz nel XLV anno del suo insegnamento II, Napoli, Editore Jovene, 1953, pp. 307-ss); e por uma perspectiva mais ampla, cf. J. MicHEL, Gratuité en droit romain, Bruxelles, Université Libre de Bruxelles, 1962, passim.

De fato, a diferença entre as circunstâncias que caracterizaram a origem do contrato de mandato e o seu respectivo aproveitamento pelos glosadores (e comentadores) ressaltava a insustentabilidade de uma teoria
} 
intransigente a respeito da questão; desta forma, a saída menos radical foi a admissão de uma remuneração ao mandatário, sem que com isso se descaracterizasse a "gratuidade" da avença. Assim, não se deve apressadamente concluir pela admissibilidade medieval de uma correspectividade entre as obrigações das partes envolvidas no ajuste; reportando-se às obras de Azo e Acúrsio, bem observa G. PrOVERA que "i glossatori rispettarono, nell'insieme, le linee maestre dell'istituto quali emergono dai testi della compilazione, anche se, per quanto concerne il requisito della gratuità, non riuscirono sempre a districarsi dalle dificoltà conseguenti all'applicazione di un principio che riusciva sempre meno convincente. Azzone (...) nonostante dubbi ed incertezze, vi resta sostanzialmente legato, pur ammettendo che la gratuità non è affatto incompatibile con la promessa di una rimunerazione che testimoni concretamente al mandatario la riconoscenza del mandante (...) anzi il mandato resta tale anche se è stato convenuto un salario, purchè il mandatario (o procuratore) non sia persona solita a mettere a disposizione di altri la propria attività e purché questa non sia promessa a condizione di avere in cambio un corrispettivo (...) secondo Accursio, il mandato è solitamente concluso fra amici, ma può esserlo anche fra estranei, nel qual caso la promessa di una rimunerazione non risulta in contrasto con la natura dell'istituto (purché non si tratti di opere che sogliono essere prestate solo dietro corrispettivo)" (Mandato cit. (nota 38), p. 318). Como ressaltado por G. PROVERA, as linhas gerais desta espécie de mandato podem ser entrevistas já na obra dos glosadores, vislumbrando-se na atuação dos comentadores tão somente um aprimoramento das soluções divisadas; assim, em lugar da pluralidade de alternativas para a exigência da "retribuição" - "actio certi", "actio mandati”, "actio locati", "actio praescriptis verbis" ou "cognitio extraordinaria" - que se depreende da obra de Acúrsio, Bártolo assinala a licitude da estipulação de honorários, conquanto somente pudessem ser utilizadas a "actio locaticonducti" ou a "actio praescriptis verbis" (Mandato cit. (nota 38), pp. 318-319). Neste sentido - ao mesmo tempo em que prevêm a possibilidade de remuneração do mandatário - as obras de Cujácio (Opervm Postvmorvm quae de ivre reliqvit tomvs secvndvs sive Ivlivs Pavlvs, id est, ad Ivlii Pavli libros ad edictvm; et libros quaestionvm recitationes exactissimae, Lvtetiae Parisiorvm, Impensis Societatis Typographicae Librorum Oficij Ecclesiastici, 1658, pp. 483-485) e Donellus (Opera Omnia, Commentariorum de iure civili III, Lucae, Typis Joannis Riccomini, 1763, pp. 857-859) admitem um contrato de mandato gratuito, completamente isento de uma idéia de correspectividade obrigacional.

Todavia, a despeito da importância da contribuição do direito comum no que concerne aos mais diversificados aspectos da eficácia jurídica do contrato de mandato, não se pode negar que seu principal legado foi o desenvolvimento da representação negocial direta como regra: "il grande merito di Bartolo è di avere affermato che, se il mandatario agiva nell'àmbito dei suoi poteri, gli effetti degli atti da lui compiuti ricadevano automaticamente sulla persona del mandante: è l'affermazione del principio della rappresentanza diretta, destinata ad esercitare un ruolo di primo piano nella disciplina normativa dell'istituto" (G. PROVERA, Mandato cit. (nota 38), p. 319); no mesmo sentido, e destacando a subversão das fontes romanas pelo direito intermédio, cf. P. CAPPELLINI, Rapprezentanza (diritto intermedio), in ED 38 (1987), pp. 442-443. Pela obra de Bártolo, cf. comentário à lei XIII ( $§$ "si alieno") do título "de damno infecto et de sugrundis et protectionibus" (Ulp. 53 ad Ed. D. 39, 2, 13, 13) contida em Bartoli commentaria in priman Digesti novi partem doctiss. viri Do. Petri Pauli Parisij Cardinalis admodum reuerendi non paucis additionibus nuper illustrata, accuratéque castigata, Lvgdvni, Petrus Fradin, 1555, p. 35: “in his quae adeo sunt personalia, q ex persona procuratoris non possunt transire in dominum procurator repraesentat personam domini directo sicut nuncius (...) et ideo, si aliquis desponsat vxorem procuratorio nomine meo, non est dubium q illa non est vxor procuratoris, non est opus q per procuratorem cedatur mihi, sed mea directa vxor efficitur". Dedicaremo-nos, mais adiante, à questão concernente aos limites dos poderes do agente (bem como à importância do direito comum na construção de uma teoria relativa ao seu eventual exercício excessivo); de qualquer modo, já podemos entrever (no direito comum ora analisado) uma aproximação entre o contrato de mandato e a representação negocial direta. E para tanto, a contribuição do direito canônico foi fundamental: não apenas por meio da simples recomendação de que o clérigo contasse com a assistência de um "procurador" para a administração dos assuntos terrenos (cf. c. 3, C. 5, qu. 3: "quia episcopus universique sacerdotes ad solam laudem Dei bonorumque operum actiones constituuntur, debet unusquisque eorum, tam pro ecclesiasticis, quam etiam pro suis actionibus (excepto publico videlicet crimine) habere advocatum non malae famae suspectum sed bonae opinionis et laudabilis artis inventum: ne dum humana lucra attendunt, aeterna praemia perdant"; ou, em tradução livre: "porque o bispo e todos os sacerdotes são constituídos só para o louvor de Deus e para a prática de boas ações, cada um deles deve ter, tanto na esfera eclesiástica, quanto no âmbito particular (exceto em caso de crime público), um advogado não suspeito de má fama, mas que seja de boa opinião e de arte louvável: para que (bispo e padres) não percam os prêmios eternos enquanto cuidam de lucros humanos"), mas também por meio do próprio reconhecimento de que aquilo que se podia fazer por si próprio haveria de ser admitido quando ultimado à custa da contribuição de um representante [cf. reg. 68, in $\mathrm{VI}^{\mathrm{o}}$, De regulis juris: "potest quis per alium quod potest facere per se ipsum" ("alguém pode fazer através de 
outro aquilo que pode por si próprio") e reg. 72 , in $\mathrm{VI}^{\circ}$, De regulis iuris: "qui facit per alium est perinde ac si faciat per se ipsum" ("quem faz por outrem é como se fizesse por si próprio")].

No entanto, a admissão da representação negocial direta não se fez sem que se divisasse também a necessidade de mecanismos jurídicos voltados à proteção - simultânea - da vontade do principal e do interesse dos terceiros (que com o agente contratavam); com isso, ao mesmo tempo em que se reduziam as formalidades no sentido das sucessivas transferências do terceiro ao mandatário e do mandatário ao principal (por meio da admissão da representação direta), passou a ser exigida a celebração de um negócio jurídico formal, por meio do qual eram outorgados ao "mandatário" os necessários poderes de representação. Assim G. PROVERA descreve o surgimento do negócio de outorga de poderes (escrito), contrapondo-o à consensualidade ordinária do contrato de mandato: "ma il mandatario impegnava il mandante nei confronti dei terzi solo se risultava investito del potere corrispondente. Diventava perciò attuale l'esigenza di provare in modo rigoroso il conferimento di tale potere, non solo nei rapporti fra mandante e mandatario, ma anche in quelli fra mandatario e terzi, $i$ quali debbono essere messi in grado di conoscere quali siano esattamente le facoltà che il mandante ha attribuito al mandatario. E siccome la prova testimoniale non sembrava offrire sufficiente garanzie a questo riguardo, venne acquistando importanza sempre maggiore la scrittura, contenente l'attribuzione del potere di rappresentanza (...) queste formalità, tuttavia, erano richieste solo $a d$ probationem e non apparivano perciò in contrasto con la concezione tradizionale del mandato come contratto consensuale" (Mandato cit. (nota 38), p. 319); no mesmo sentido, cf. J. MOSSET ITURRASPE, Mandatos cit. (nota 34), pp. 20-21. A única ressalva que lançamos às considerações de G. PROVERA - adotadas, em geral, por J. MOSSET ITURRASPE - ora destacadas limitam-se à natureza da formalidade entrevista no negócio de outorga de poderes: em lugar de uma simples forma ad probationem, parece-nos que se está diante daquela forma ad regularitatem comprometida com a projeção dos efeitos de um ato jurídico perante terceiros (estranhos à sua celebração).

De todo modo, tem-se que do paradigma romano do "mandatum" (ajustado às novas necessidades sociais a que esteve atento o direito comum) se aproxima a representação negocial direta - em um movimento de justaposição funcional inevitável, uma vez que, ainda que sob a veste de uma eficácia jurídica distinta, destinava-se o arcabouço (como um todo) à mesma espécie de operação que ensejou o surgimento do tipo no âmbito do "ius gentium" - sem que se verifique, no entanto, uma "essencialização" da representação (ou mesmo que esta última se tornasse a "nota típica" do contrato de mandato). Assim, mesmo durante o direito comum o "contrato de mandato" e a "representação negocial direta" mantêm sua respectiva autonomia, como precisamente destaca E. EsPíNOLA: "os romanos eram contrários ao próprio conceito de representação porque se lhe opunham os princípios do direito quiritário, que proibiam estipular por outrem ou em nome de outrem. No direito comum também se excluía do mandato a idéia de representação; mas, os princípios jurídicos foram pouco a pouco se adaptando às novas necessidades e modificando-se por influência da doutrina, até o ponto de se aceitar a representação como elemento natural. Finalmente, os tratadistas entenderam que havia ela adquirido tal importância na prática dos negócios, que a admitiram como elemento essencial e característico do mandato. Foi êste o conceito que prevaleceu nas legislações do século XIX" (Dos contratos cit. (nota 12), p. 358). O que não impediu, todavia, uma futura "confusão" conceitual, estribada na falta de um tratamento técnico adequado à questão; neste sentido, cf. J. HUPKA, La representación cit. (nota 40), pp. 17-18; J. ItURRIAGA ROMERO, La representacion cit. (nota 29), p. 44; L. DíEZ-PICAZO, La representacion cit. (nota 29), pp. 29-30. Por isso, paracem-nos equivocadas as conclusões de E. A. SANCHEZ URITE (Mandato cit. (nota 06), p. 16), J. Mosset ItURRaspe (Mandatos cit. (nota 34), p. 20), C. P. M. CRUZ E TuCCI (Interposição cit. (nota 09), p. 48) e M. G. MAIA JÚNIOR no sentido de que o direito canônico foi o responsável pela tomada da representação "como elemento essencial do contrato de mandato" (A representação cit. (nota 04), p. 25). Em contrapartida, considerando o direito canônico um dos artífices de tal evolução, cf. F. CResPo Allue, La revocacion cit. (nota 29), p. 54; bem como F. de S. L. PeSSOA Jorge, $O$ Mandato cit. (nota 09), pp. 58-61.

De fato, tal aproximação funcional proporcionou, em um momento posterior, um ambiente favorável a que se desse maior relevo ao papel da representação no contexto do tipo contratual referido, culminando-se na essencialização que se vislumbrou, por exemplo, no Code Civil de 1804 (art. 1.984); todavia, antes de se chegar a esse ponto, passou-se pela influência da praxe notarial e do jusracionalismo. Sem pretender antecipar argumentos que serão desenvolvidos ao longo de todo este estudo, parece-nos que enquanto o direito romano não admitia, como regra, a representação direta, a contribuição do direito canônico se deu, principalmente, no sentido de admiti-la; e com isso, removeu-se o principal obstáculo que impedia a "confusão" conceitual entre os dois institutos. No entanto, a (indevida) junção entre os aspectos interno e externo da realidade jurídica ora analisada será resultado, por sua vez, da atuação de dois outros elementos: um primeiro, de natureza prática, que foi a composição do negócio de outorga de poderes (provido da cláusula "de rato" e designado "instrumento do mandato"); e um segundo, de natureza ideológica, que foi o advento do iluminismo jurídico e da generalizada repulsa por toda e qualquer espécie de formalidade (que 


\section{$\S$ 56. Peculiaridades do mandato comum em relação ao "mandatum"}

romano: a) a composição do instrumento; b) mandato geral e mandato especial; c) a obrigação cambiária e o duplo mandato; d) a responsabilidade do mandatário e o critério da “diligentia quam suis". Dentre as várias contribuições oferecidas pelo direito comum à disciplina do contrato de mandato podem ser citadas, por exemplo: a) o reforço à distinção romana entre as suas variantes "geral" e "especial" (ainda que à custa de certas imprecisões conceituais); b) a teoria do duplo mandato na hipótese de obrigação cambiária; c) ou mesmo a definição de um rígido regime de responsabilidades a afetar a atuação do mandatário. Contudo, a despeito da importância de tais aspectos da eficácia do tipo contratual referido, no que concerne especificamente à relação entre o contrato de mandato e a representação negocial, cumpre destacar a previsão - dentre os elementos indispensáveis ao "instrumento" (do "mandato") - da chamada cláusula "de rato", por meio da qual se expressava a promessa solene do "mandante" de haver por rato e válido o objeto da gestão do "mandatário". Exsurge assim, pois, a acepção usual do termo "procuração": de um lado, adequadamente comprometida com a promessa formal de assunção (pelo principal) dos efeitos dos atos de gestão praticados pelo representante; de outra banda, todavia, indevidamente vinculada à idéia de "instrumento do mandato" - tal qual difundida, aliás, entre diversas legislações modernas (dentre as quais a nacional) ${ }^{47}$.

parecia remontar à ignorância da gente romana), a respeito dos quais trataremos mais adiante. Não se deve esquecer, todavia, que o surgimento da "representação" como nota típica do contrato de mandato esteve vinculado ao declínio da gratuidade como elemento distintivo entre o "mandatum" e a "locatio operarum": "le ideologie portate avante dalla Rivoluzione francese erano in un certo senso incompatibili con la nozione tradizionale del mandato gratuito: l'altruismo non è sentimento che giovi all'iniziativa privata ed all'ordinato sviluppo delle attività economiche (...) ma se il mandato poteva essere oneroso restava la dificoltà di distinrguerlo dalla locazione d'opere (...) si spiega così perché il codice Napoleone (art. 1894) [art. 1984] consideri la rappresentanza come elemento inseparabile dal mandato, per cui il mandatario è sempre un rappresentante del mandante" (G. ProverA, Mandato cit. (nota 38), pp. 319-320). Conquanto tenha sido essa a posição afinal adotada pelo legislador francês, não é a orientação que se depreende da obra de Robert Joseph Pothier - o qual, a meio caminho entre a solução romana e a repulsa à gratuidade, distinguia um tipo contratual do outro à vista do objeto e da eficácia jurídica de cada um dos institutos.

${ }^{47}$ No que concerne à análise da influência do direito comum sobre a eficácia específica do contrato de mandato, consideramos apropriada a expressa ressalva metodológica de E. BuSSI, no sentido de que somente são abordados os aspectos em relação aos quais houve mudança quanto à orientação estabelecida pelo direito justinianeu (La formazione cit. (nota 46), p. 98). Observe-se, pois, que o arcabouço romano sobre o contrato de mandato será objeto de estudo específico - a ser desenvolvido em etapa ulterior de nossa linha de pesquisa.

No que toca à distinção entre mandato geral e mandato especial, percebe-se uma baralhada entre "mandato geral" (abrangente de uma atuação mais dilargada) e "mandato em termos gerais" (caracterizado pela outorga de simples poderes de administração); e da mesma forma, entrevê-se uma mistura entre "mandato especial" (de atuação específica) e "mandato com poderes especiais" (para gestões consideravelmente gravosas ao patrimônio do mandante). Ocorre, todavia, que tais conceitos são tratados indistintamente pela própria doutrina que sobre as fontes se debruça: "il mandato può essere generale e speciale (...) non solo infatti (...) [a jurisprudência canônica] richiama esplicitamente questa distinzione, ma fa esplicito riferimento alla autorià 
dei canoni per dar fondamento alle sue decisioni. La cosa non avrebbe, in fondo, che bene scarso rilievo se si tratasse della RoTA ROMANA, ma poichè essa si verifica anche presso quei Tribunali, come ad esempio quello di Genova, che sono assolutamente indipendenti dalla autorità dalla autorità politica della Chiesa e che, per di più, sono chiamati a decidere su materie, come ad esempio quella di commercio, che è quasi completamente svincolata dai suoi precetti, bisogna pur convenire che il diritto canonico ebbe nello svolgimento del diritto una efficacia quanto mai grande sino a tempi relativamente assai recenti. Per tornare alla differenza fra mandato generale e speciale, diremo che si riteneva occorrere quest'ultimo per il compimento di affari particolarmente gravi od implicanti più serie conseguenze economiche" (E. BUSSI, La formazione cit. (nota 46), pp. 102-103). De fato, conquanto tratasse da distinção entre perdoar expressa e tacitamente - reputando inaplicável a regra canônica "cui licet quod est plus, licet utique quod est minus" ("a quem é lícito o que é mais, é lícito também o que é menos", reg. 53 , in $\mathrm{VI}^{\circ}$, De regulis juris) - a Rota de Gênova reconheceu a distinção entre mandato geral e mandato especial, para considerar necessário, em certas circunstâncias, a concessão de "peculiares" poderes não compreendidos na primeira variante: "si procurator non potest expresse remittere debitum suo principali sine eius speciali mandato (...) molto minus debet posse tacite id facere (...)" (De. CC, n. 4, in Decisiones Rotae Genvae de Mercatvra et ad eam Pertinentibvs collectae a D. Marco Antonio Bellonio Iuriscontulto Praestantissimo; omnibus tam in foro versantibus, quam de Iure respondentibus caeterisq. Iuris studiosis perutiles, \& quam maxime necessariae, cum Argumentis, Sumarijs, \& rerum ac verborum Indice hac postrema editione locupletissime illustratae, Venetiis, Haeredem Damiani Zenarij, 1606, pp. 262 verso).

O regime jurídico canônico a distinguir o mandato geral de sua variante especial se limitara a exigir, para a prática de certos atos, poderes especiais: assim, se não era necessária a outorga de poderes especiais para a representação processual (cf. c. 5, in $\mathrm{VI}^{\circ}, 1$, 19: "qui generaliter constituitur ad negotia procurator agere, ac experiri potest: exceptis his casibus qui mandatum exigunt speciale"; "aquele que geralmente é constituído procurador para gerir negócios, pode contender em juízo, exceto nos casos que exigem um mandato especial"), o era nas hipóteses de transação (cf. c. 11, in X, 1, 38, glosa "generalis": "potest ergo quis constituere generalem procuratorem ad omnia tam ad iudicia quam ad negotia (...) tamen talis procurator transigere non potest nec alienare"; "alguém pode constituir um procurador geral para tudo, tanto para julgamentos, como para negócios (...) todavia, tal procurador não pode transigir nem alienar"), juramento (cf. c. 28 , in $\mathrm{X}, 1,3$, glosa "sine speciali mandato") e matrimônio (cf. c. reg. 68 , in $\mathrm{VI}^{\circ}$, de regulis iuris, glosa "potest"). A respeito, cf. E. BUSSI, La formazione dei dogmi di diritto privato nel diritto comune (diritti reali e diritti di obbligazione), Padova, Casa Editrice Dott. Antonio Milani, 1937, pp. 298-299 (inclusive notas 6, $1,2$ e 3$)$.

A teoria do duplo mandato na hipótese de obrigação cambiária foi construída por Paulo de Castro - a pretexto da análise de Ulp. 30 ad Sab. D. 46, 3, 12, pr.: "vero procuratori recte solvitur. Verum autem accipere debemus eum, cui mandatum est vel specialiter, vel cui omnium negotiorum administratio mandata est" ("al verdadero procurador se le paga bien. Pero debemos tener por verdadero aquel á quien se le dió especialmente mandato, ó á quien le fué encomendada la administración de todos los negocios") - e posteriormente consagrada pela doutrina, tal como podemos depreender da seguinte decisão da Rota de Gênova: "ex litera cambii oritur duplex mandatum, alterum, erga personam quae debet solvere, alterum vero erga illum qui debet pecuniam recipere" ("da letra de câmbio nasce um duplo mandato: um, junto à pessoa que deve pagar; outro, junto àquele que deve receber o dinheiro", De. LXXXXIII, n. 9, in Decisiones cit. (nota 47), p. 167 verso). Já no que respeita ao grau de responsabilidade a envolver a atuação do mandatário, eis a menção de E. Bussı à polêmica estabelecida entre Búlgaro e Martinho: "fu aggeto di viva disputa, fra i glossatori, il grado della colpa di cui il mandatario deve rispondere. BULGARO, contrariamente a MARTINO, riteneva che il mandatario dovesse rispondere anche della colpa lievissima e la sua opinione venne pure seguita da AZONE. Senonché, più avanti, sulla scorta di quanto si riteneva di poter dedurre da taluni passi delle opere dei dottori, fra i quali BARTOLO, BARTOLOMEO SALiceto e Giason DEl Maino, la Rota venne nello avviso che "mandatarius non tenetur plus facere quam in re sua fecit etiamsi (...) diligenter fecisset" (La formazione cit. (nota 46), pp. 103-104; o trecho latino que encerra o período poderia ser assim traduzido: "o mandatário não está obrigado a fazer mais do que aquilo que se verifica quanto ao que é seu (...) tendo-o feito diligentemente"). Como teremos a oportunidade de observar mais adiante, tal critério influenciou decisivamente algumas das principais legislações européias que a respeito dispuseram (tendo seguido no mesmo sentido a legislação brasileira). Observe-se que tal critério, oriundo da polêmica acima referida, foi logo em seguida acolhido pela mencionada Rota de Gênova, que o referendou em mais de uma oportunidade (cf. De. CLXXX, n. 5, in Decisiones cit. (nota 47), p. 242 e LXXVI, n. 6 e 9, in Decisiones cit. (nota 47), pp. 148 verso-149).

Finalmente, no que concerne aos elementos que deveriam integrar, obrigatoriamente, o "instrumento do mandato", temos: a) os nomes do "mandante" e do "mandatário"; b) o "objeto" da incumbência; c) a promessa de tomar por rato e válido o operado pelo agente. É o que se depreende da glosa "mandato" ao c. 1, 


\section{$\S$ 57. Excesso em "quantidade" e excesso em "qualidade" no quadro do}

adimplemento contratual: nota sobre uma harmonização (das fontes do direito comum) promovida pela praxe medieval. Diversamente do que poderia sugerir uma primeira impressão, a singeleza do "instrumento" de outorga de poderes não implica, necessariamente, uma perfeita compreensão quanto ao alcance da promessa formalizada por meio da cláusula "de rato" respectiva; ao contrário, a obscuridade do objeto ali definido deu ensejo a uma série de elucubrações dos expoentes do direito comum medieval, as quais conduziram à diferenciação escolástica entre quantidade e qualidade a propósito do excesso no exercício dos poderes de representação. Conquanto estribada em

in $\mathrm{X}, 1,38$ : "tria debet continere mãdatum, s. nomen eius qui pcuratorem eum constituit, \& causam ad quam constituitur, \& q ratum habebit qd cu eo factum fuerit" ("três coisas deve conter o mandato, ou seja, o nome daquele que o constitui procurador, a causa para a qual foi constituído e o que será tido por ratificado quando for executado com ele") (com a observação de que "haec glossula nõ est Bernardi, nec habet in vetustis exeplarib"; "esta glosa não é de Bernardo, nem consta dos exemplares mais antigos"). A respeito, cf. E. BUSSI, La formazione cit. (nota 46), p. 98; bem como La formazione cit. (nota 47), p. 299; F. de S. L. PESSOA JORGE, $O$ Mandato cit. (nota 09), pp. 62-63.

O mesmo se pode extrair da glosa "mandato procuratoris" ao c. 13, in X, 1, 38: "de mandato procuratoris actoris dictu est s. eod. c. i. in mãdato enim procuratorio debet contineri precipue nome eius q constituit procuratorem, \& nomen procuratoris, \& in qua causa, \& qd ratum habebit quod cum eo actuerit, sicut in litteris de rato, \& coram quibus iudicibus, maxime si sunt delegati" ("a respeito do mandato do procurador do autor, está dito no mesmo cânone que no mandato procuratório deve constar o nome daquele que constituiu o procurador, e o nome do procurador, e em qual causa, e quando terá por ratificado aquilo que for praticado pelo que com ele atuar (assim como nas cartas de rato) e na presença de quais juízes, principalmente se são delegados"). Conquanto não mencione a fonte a que se refere, talvez se tenha aí a origem da manifestação mais minudente de P. J. de MELlo FreIRE dos Reis, que alude ainda aos nomes do juiz e do adversário, ao ano, ao dia, à causa, aos atos que demandam outorga especial e à cláusula "de rato et indemnitate" (de ratificação e indenização) (cf. Institutiones (nota 16), p. 20). Pelo reconhecimento da importância da cláusula "de rato", cf. G. M. CAMINHA, Tractado da Fórma dos Libellos, das Allegações Judiciaes, do Processo do Juizo Secular e Ecclesiastico, e dos Contractos, com suas Glossas, Coimbra, Real Collegio das Artes, 1731, p. 241; J. H. CoRreia Telles, Manual do Tabellião, Lisboa, Imprensa Nacional, 1859, § 272; O. J. DE PlÁcIDO E Silva, Tratado do Mandato e Prática das Procurações II, $3^{\mathrm{a}}$ ed., Rio de Janeiro, Forense, 1959 , p. 401; E. PESSÔA, Da procuração, Rio de Janeiro, Editora Idéia Jurídica, 2001, pp. 65-66. Ora, depreende-se daí uma nova acepção para o termo "procuração", compreendido (tal qual se faz atualmente) como instrumento no qual se formaliza a outorga dos poderes pelo principal ao seu representante; neste contexto como já referido em nota anterior (nota 46) - a inserção da cláusula "de rato" é, de fato, importante garantia aos terceiros que contratarem com este último. Contudo, esse não é um aspecto inerente ao mandato, mas sim à representação negocial (direta).

Com isso, não só nos parece inapropriada a terminologia irrestritamente acolhida por E. BUSSI - que alude a todo momento a "mandante" e "mandatário", em lugar de "procurador" e "constituinte" (La formazione cit. (nota 46), pp. 98-99), embora empregue adequadamente "representante" e "representado" em La formazione cit. (nota 47), p. 299 - como também se pode entrever aí a oportunidade para que, em um momento posterior, se reconhecesse no mandato uma essência representativa que lhe era, $a b$ initio, estranha (cf. a respeito nota 46, alusiva ao declínio da "gratuidade" como nota típica do contrato de mandato e o surgimento da representação "essencial" ao tipo contratual referido). Em síntese: o direito canônico admitiu a representação direta; dentre os instrumentos necessários à atuação do representante (que também era mandatário), previu um documento, impropriamente designado "mandato", no qual havia a cláusula "de rato", viabilizadora da trasladação direta de efeitos à esfera jurídica do representado. Não se pode negar que, em um ambiente assim favorável, pouca dificuldade teve a doutrina posterior para fundir "representação direta" e "mandato", principalmente à custa da "problemática" compreensão do papel deste documento, legado à posteridade sob o nomen iuris "procuração"; tornaremos ao tema mais adiante, ao tratarmos do influxo da racionalidade iluminista sobre a obra de alguns autores jusracionalistas. 
uma "sutil" distinção, verificou-se, neste passo - ao contrário de um aparente antagonismo - uma fusão harmonizadora das contribuições dos canonistas e dos comentadores: enquanto aqueles propendiam à rejeição do excesso em "qualidade" (evidenciado, por exemplo, na prática de ato diverso daquele compreendido no objeto da "procuração"), estes defendiam a validade dos atos que refletissem um simples excesso em "quantidade" por parte do agente (em virtude do qual não se vislumbrasse, pois, uma afronta direta à vontade do principal); de qualquer forma, aí já se pode entrever uma evidência da indevida abordagem de uma questão concernente aos limites da representação negocial, por meio do recurso (impróprio) a um instituto jurídico "estruturalmente" autônomo - vale dizer, o contrato de mandato ${ }^{48}$.

${ }^{48} \mathrm{O}$ impasse sistemático a que alude o corpo do texto remonta à coordenação entre a regra principal segundo a qual os atos praticados pelo representante percutem direta (e imediatamente) a esfera jurídica do representado - e a exceção reconhecida e pacificamente acolhida pelo direito comum (no sentido de que os atos praticados em excesso pelo representante não surtiriam efeitos sobre o patrimônio do principal).

Ocorre que a simples coordenação entre regras jurídicas abstratas não oferece maiores obstáculos ao estudioso; no entanto - práticos que eram - os juristas do direito comum responsáveis pelo desenvolvimento do "mos italicus" se depararam com a seguinte indagação (de ordem empírica): se por um lado não parecia adequado vincular o representado em decorrência de atos praticados pelo representante contrariamente à sua vontade (ainda que presumida), seria correto, por sua vez, denegar a respectiva proteção na hipótese de ato excessivo praticado pelo agente, quando de sua omissão pudesse redundar um prejuízo ao principal, pelo qual seria aquele responsabilizado (sob o fundamento de um inadimplemento do contrato de mandato)? Ou, nas palavras de E. BuSSI: "la questione si pone così: poichè nell'atto di conferimento del mandato, il mandante si impegna di avere per rato e valido l'operato del mandatario, cosa è a dirsi per la attività di quest'ultimo che ecceda i limiti dell'incarico? La risposta a questa domanda non è dubbia: per quanto sia certo che il fatto del mandatario, nel diritto comune, si debba considerare come un fatto del mandante, pur tuttavia è fuori di ogni possibile discussione che quest'ultimo non si debba ritenere vincolato da atti che abbiano oltrepassato i limiti entro i quali egli intendeva obbligarsi. Ora, se la questione fosse tutta qui, non vi sarebbe nulla di veramente meritevole di attenzione particolare. Senonchè il diritto comune ha profilato la questione stessa sotto un altro e diverso punto di vista poichè si è preoccupato del caso in cui equivoca fosse la lettera del mandato, e dubbia la volontà del mandante. In questa ipotesi, quali poteri si devono riconoscere al mandatario che sa di essere tenuto ai danni se non esegue il mandato, ma sa anche che compirà un atto nullo se, eventualmente, dovesse eccedere i limiti del medesimo?" (La formazione cit. (nota 46), p. 99). Pelo compromisso dos juristas do direito comum para com as necessidades práticas enfrentadas pela sociedade (particularmente no que concerne à representação negocial direta), cf. L. DíEZ-PICAZO, La representancion cit. (nota 29), p. 30.

Os efeitos práticos de uma representação direta - vale dizer, a percussão imediata da esfera jurídica do representado por meio de um ato praticado pelo agente - foram reconhecidos pelo direito comum, sendo elucidativas, neste sentido, algumas sentenças proferidas pela Rota de Gênova (cf. De. LXVII, n. 2, in Decisiones cit. (nota 47), p. 141 verso e De. CLXXVIII, n. 3, in Decisiones cit. (nota 47), p. 238).

Em outros termos, a referida situação de impasse em que se encontrava o mandatário decorria: de um lado, da sua virtual responsabilização, na hipótese de inércia, por prejuízos afinal experimentados pelo mandante, à vista de um inadimplemento contratual (cf. De. CXLVII, n. 10, in Decisiones cit. (nota 47), pp. 206 verso207); de outra banda, porém, era pacífica a posição do direito comum no sentido da nulidade daqueles atos praticados eventualmente pelo agente - que excedessem os limites da outorga efetuada pelo principal. Neste sentido, os comentários de Bártolo ao § "si decurionis" do título "quod cuiuscumque universitatis nomine vel contra eam agatur" (Paul. 9 ad Ed. D. 3, 4, 6, 1), onde se diz que "actor universitatis non potest constitui ad lites futuras, sed as plures praesentes sic" (Bartoli prima in Digestum vetus, Alexandre Imolaei, Andreae Barbatiae, Celsi Hugonis ac Petri Pauli Parisii adnotamentis rerumque summis ornata fidelissimisque typis excusa, Lvgdvni, Petrus Fradin, 1555, p. 136); bem como os de Baldo à regra contida em C. 8, 41, 7. Aliás, fundando-se expressamente no capítulo "cum dilecta" (do Título "de rescriptis") das Decretais - c. 22, in X, 1, 3: "cum dilecta in Christo filia r. custos Hesien. ecclesiae, ac procurator g. Monialis, super electionibus in 
eadem ecclesia celebratis, litigauerint aliquandiu coram nobis: \& infra. Deprehendimus litteras ad abbate de Remech \& suos coniudices impetratas, fuisse per subreptionem obtetas, cu in eis illius articuli, videlicet, de subtractorum resignatione, fuerit praeter conscientiam nostra cognitio demandata, qui in prioribus litteris ad scholasticum Hildesen \& coniudices suos obtentis, insertus fuerat: de quibus in secundis litteris mentio no fiebat: \& ideo quod ipsarum litterarum occasione dignoscitur attentatum, duximus irritandum. Dictur insuper scholasticum \& coiudices suos inuenimos minus prouide processisse cum enim in litteris nostris eisdem principaliter mandaretur, ut ad praedictam ecclesiam personaliter accedentes, personae idonae administrationem committerent abbatie, cui ad opus eius fieret hincinde resignatio subtractorum, ipsi formam mandati apostolici transponentes, illo capitulo praetermisso: de alijs articulis inordinate plurimum cognouerat: propter quod processum ipsorum contra nostri formam rescripti, ac iuris ordinem attentatum, irritum decernimus \& inanem. Ideoque mandamus quatenus G. \& quibusdam alijs sororibus ecclesiae (sicut iustum fuerit) restitutis, \& forma mãdati nostra exacta diligentia obseruata, in negotio ipso ratione praevia procedatis" - a Rota de Gênova declarou que nenhuma obrigação exsurge ao principal quando decorrente da atuação do agente contra o mandato ("contra mandatem"), não exsurgindo qualquer obrigação em tais circunstâncias ("et tunc nulla obligatio oritur contra mandatem" in R. G. De. CLXXIIII, n. 6, in Decisiones cit. (nota 47), p. 231 verso).

Dado tal panorama, a construção da teoria responsável pela distinção entre o "excesso em qualidade" e o "excesso em quantidade" se deu à custa da coordenação entre a vedação canônica àquele - tome-se, por exemplo, o conteúdo da glosa "casus" ao c. 19, in X, 2, 13: "forma mandati diligenter seruanda est: \& qui contra facit, irritus est processus" ("a forma do mandato deve ser observada cuidadosamente: e aquele que faz contra, torna nulo o processo") - e a aceitação pelos comentadores deste último [neste sentido os comentários de Bártolo à 1 . III do título "mandati vel contra" (Paul. 32 ad Ed. D. 17, 1, 3, 2): "praetera in mandato indeterminato sufficit negotium vtiliter esse gestum: sed si fuit determinatum in excessu vel deterioratione vel diminutione quantitatis in praeiudicium mandantis non datur actio mandati, nisi ad forma debita reducat: si in alia specie excedat, mandatum non implet: si vero ad comodum mandantis quantitatis diminutio fiat, mandati actionem non impedit. h. d. vsque ad 1. diligenter" (Bartoli commentaria in secvundam Digesti veteris partem, Doctis. viri Do. Petri pauli Parisii Cardinalis admodum reuerendi non paucis additionibus nuper illustrata, accuratéque castigata, Lvgdvni, Petrus Fradin, 1555, pp. 119 verso120)]. A conciliação entre as posições foi realizada pela praxe jurisdicional de então, encontrando-se em algumas decisões da Rota de Gênova não apenas a condenação genérica ao excesso em qualidade - sob a forma de uma declaração de que o agente deveria observar escrupulosamente os limites de sua gestão, ainda que relativamente obscuros (De. IX, n. 13, in Decisiones cit. (nota 47), p. 40: "mandatarius tenetur qualitates mandati omnes servare (...) etiam si tales qualitates in modico consisterent"; "o mandatário tem de conservar todas as qualidades do mandato (...) mesmo que tais qualidades consistam em pouca coisa") - mas também uma previsão daquilo que caracterizaria uma inobservância a ser reprimida: assim, prometer em lugar de pagar (De. II, n. 15, in Decisiones cit. (nota 47), p. 12 verso) - ou mesmo trocar, em lugar de vender (De. IX, n. 4, in Decisiones cit. (nota 47), p. 39 e De. LIII, n. 1, in Decisiones cit. (nota 47), p. 127 verso).

Em suma, deveria o mandatário interpretar a vontade do mandante, em uma espécie de gestão colaborativa (De. VIII, n. 5, in Decisiones cit. (nota 47), p. 36). Ora, diante da pouca objetividade deste critério, assim foi resolvido - pragmaticamente - o problema, consoante anota E. BUSSI: "poichè la interpretazione può riuscire difficoltosa, mentre il tempo può mancare, il diritto comune, al fine di evitare tardivi pentimenti di dubbia fede da parte del mandante, dispose che costui non possa rifiutarsi di ratificare l'opera del mandatario ogni qualvolta quest'ultimo non solo avesse fatto uso delle facoltà comprese nel mandato, ma avesse altresì esplicato quei poteri che ragionevolmente vi sembravano compresi" (La formazione cit. (nota 46), p. 102).

Não nos cabe, por ora, tecer maiores comentários a respeito da repercussão desta espécie de distinção sobre o direito moderno (e contemporâneo). Todavia, não podemos deixar de assinalar quão lamentável é a presunção do jurista atual que, ao analisar a questão concernente à interpretação dos limites dos poderes conferidos ao agente, aborda dispositivos "modernos" - como o Cap. IX (do Livro IV) do Código bávaro, o art. 2969 do Código Civil da Louisiana, o art. 1029 do Código Civil austríaco, o art. 2134 do Código Civil chileno, o art. 2065 do Código Civil equatoriano, os arts. 1704, 1705 e 1709 do Código Civil de Quebec, o art. 2077 do Código Civil uruguaio, o art. 2160 do Código Civil colombiano, o art. 396 do Código das Obrigações suíço, o art. 400 do Código Civil montenegrino, o art. 103 do Código Civil japonês, o art. 533 do Código Civil chinês, o art. 1708 ( $1^{\mathrm{a}}$ parte) do Código Civil italiano, ou o art. $1159^{\circ}, 2$ do Código Civil português - sem que se faça uma única alusão ao legado do direito comum que pende sobre tal disciplina.

Por fim, devemos ressaltar que toda a adjetivação empregada na parte final do corpo do texto a que se refere esta nota de rodapé ("indevida", "impróprio", "autônomo") é produto da considerações modernas a respeito da questão; assim, estivéssemos imersos no contexto histórico criticado, certamente não teríamos adotado postura diferente daquela que é alvo de nossas críticas. Contudo, ainda que se possa considerar a abordagem sistemática autônoma dos institutos do "contrato de mandato" e da "representação negocial" (direta) o 


\section{$\S 58$. Um novo pressuposto e a admissibilidade da representação (negocial)}

direta pelo direito canônico. Como se teve a oportunidade de analisar há pouco, o contexto social romano - propenso a uma estrutura familiar centralizada na pessoa do "pater" contribuiu decisivamente para a atrofia de uma "representação direta" que, mais cedo ou mais tarde, haveria de se desenvolver; podendo o chefe da família se servir da atuação de núncios, dos filhos e de escravos para a prática de uma série de atos jurídicos, pode-se dizer que as finalidades a serem atingidas pelo instituto da representação negocial (direta) se viram concatenadas por meio do emprego de outros expedientes (dentro dos limites estabelecidos pelo direito quiritário). Ocorre que o contexto sócio-econômico do renascimento medieval é substancialmente diverso: a atuação do escravo administrador não se mostra mais suficiente à superação dos grandes desafios das empresas comerciais da Baixa Idade Média; com isso, a realidade social passa a exigir das jurisdições (e particularmente da canônica) respostas mais "eficientes", reduzindo-se, assim, os "riscos" operacionais inerentes à circulação em larga escala. À vista de tais fatores, desenvolve-se entre os canonistas a representação negocial direta: concebendo o próprio Sumo Pontífice como "representante" de Deus, estes não se depararam com os obstáculos enfrentados pelos jurisconsultos romanos; e assim, o instituto encontrou nas "Decretais" (Gregório IX) e no "Sexto" (Bonifácio VIII) sua consagração como autêntica regra - em conformidade, aliás, com a recomendação contida no "Decretum" (Graciano) de que os clérigos confiassem, sempre que possível, a gestão das coisas terrenas que lhes afetassem à atuação de "procuradores" 49 .

resultado de um desenvolvimento científico operado nos dois últimos séculos, não nos parece adequado considerar aquela mistura anterior o estado originário do problema: eis que, como vimos, se houve uma aproximação entre ambos operada durante o período do direito comum, este não era o cenário que se divisava durante o período romano clássico - tão criticado pelos sequazes do iluminismo jurídico no proêmio da Lei da Boa Razão (sobre a qual oportunamente teceremos maiores comentários).

${ }^{49}$ A respeito da atrofia da representação negocial direta entre os romanos, compreendida como resultado da profícua atuação dos filhos e escravos em prol do "pater" (e do patrimônio familiar por este encabeçado), cf. as passagens de U. AlvareZ SuAREZ e G. PACCHIONI referidas em nota anterior da presente exposição ( 37 e nota 29); e no mesmo sentido, correlacionando o advento da representação direta ao declínio da escravidão antiga, cf. W. HEYD, Geschichte des Levantehandels im Mittelalter, trad. fr. de Pauteur, Histoire du commerce du levant au moyen-âge II, Amsterdam, Adolf M. Hakkert Éditeur, 1967, pp. 555-563.

Por sua vez, atrelando o desenvolvimento da representação direta canônica a uma "concepção cristã de representação divina imputada aos membros do clero" cf. C. P. M. CRUZ E TuCCI, Interposição cit. (nota 09), p. 48; F. de S. L. PESSOA JORGE, Mandato cit. (nota 09), p. 59.

Destacando a insuficiência do modelo romano fundado nas atuações do "procurator" e do "institor" (e também ressaltando, assim, a vinculação entre o instituto da representação direta e as necessidades "comerciais" que então exsurgiam), cf. F. CRESPO Allue, La revocacion cit. (nota 29), p. 54; E. BESTA, Obbligazioni nella storia del diritto italiano - appunti di lezioni, Padova, Litotipo, 1926, pp. 180-181; F. de S. L. PeSSOA Jorge, Mandato cit. (nota 09), pp. 58-61; M. A. D. de ANDRADE, Teoria geral cit. (nota 04), p. 301; J. Mosset ItURRASPe, Mandatos cit. (nota 34), pp. 23-24; L. DÍEZ-PicAZO, La representancion cit. 
$\S 59$. Encerramento do capítulo e apresentação do tema sucessivo. Tendose em vista a contribuição do "ius commune" (e particularmente do direito canônico) em prol do desenvolvimento da representação negocial (direta), cumpre-nos analisar, então, de que forma a atividade notarial também participou do processo de robustecimento da atuação "em nome" alheio. É exatamente sobre este tema que nos debruçaremos no próximo capítulo do presente estudo.

(nota 29), p. 28; F. CALASSO, Il negozio giuridico - lezioni di storia del diritto italiano, $2^{\mathrm{a}}$ ed., Milano, Giuffrè, 1959, p. 319; F. BONET RAMON, Naturaleza jurídica del contrato de mandato, Barcelona, Bosch, 1941, pp. 81-82; F. A. P. LANDIN FILHO, O mandato cit. (nota 09), pp. 28-29.

Pelas principais fontes do direito canônico responsáveis pela admissão do princípio da representação direta, cf. aquelas referidas em notas anteriores do presente estudo (notas 46 e 48). E a respeito do juízo que se fez, já durante a Idade Moderna, sobre a proibição romana da representação direta, tornaremos a tratar mais adiante. 


\section{CAPÍTULO III.}

\section{A ATIVIDADE NOTARIAL E O ROBUSTECIMENTO DA REPRESENTAÇÃO DIRETA NO ÂMBITO DO DIREITO COMUM.}

$\S$ 60. A função notarial e o desenvolvimento da representação direta: a atuação do "servus" como ponto de partida para a elaboração da teoria da representação direta pelos doutores do direito comum. Como tivemos a oportunidade de observar há pouco, embora vedada a representação direta entre os romanos (cf. Paul. 12 ad Sab. D. 44, 7, 11; Q. Muc. def. D. 50, 17, 73, 4; Paul. 3 quaest. D. 45, 1, 126, 2), admitiu-se, em caráter excepcional, a percussão imediata da esfera jurídica do "pater" por meio da atuação de seu escravo (Ulp. 28 ad Sab. D. 50, 17, 22 pr.; G. 2, 87); mais especificamente no que concerne à herança jacente, havia a expressa previsão das fontes quanto à atuação do "servus" em prol do próprio patrimônio por ele integrado - ou mesmo em favor do herdeiro futuro (inominado) a quem o acervo pudesse ser eventualmente reconduzido (Mod. 7 reg. D. 45, 3, 35). Ora, conquanto o termo "notário" outrora tivesse designado o mero assistente do "tabelião" (voltado à compilação material dos atos jurídicos), tal figura foi utilizada pelos doutores do direito comum no processo de paulatina construção da teoria da representação direta; explorado noutro contexto - e para o atingimento de finalidades diversas daquelas que tinham inspirado os jurisconsultos romanos - , o arcabouço justinianeu foi habilmente coordenado com os preceitos basilares do direito canônico (referidos no capítulo anterior), daí resultando uma fusão na qual o "produto" não ostentava as mesmas limitações que poderiam ser apontadas quanto a cada um dos reagentes que lhe deram origem ${ }^{50}$.

\footnotetext{
50 Além das fontes já referidas a propósito da vedação à representação direta entre os romanos, podemos destacar os seguintes passos contidos na compilação justinianéia: Paul 12 ad Sab. D. 44, 7, 11 ("quaecunque gerimus, quum ex nostro contractu originem trahunt, nisi ex nostra persona obligationis initium sumant, inanem actum nostrum efficiunt; et ideo neque stipulari, neque emere, vendere, contrahere, ut alter suo nomine recte agat, possumus"; "cualesquiera cosas que hayamos hecho, como quiera que traen su origen de un contrato nuestro, si no tomaran de nuestra persona el principio de la obligación, hacen baldío nuestro acto; y por lo mismo no podemos ni estipular, ni comprar, ni vender, ni contratar, de modo que otro litigue con derecho en su propio nombre"), Q. Muc. def. D. 50, 17, 73, 4 ("nec paciscendo, nec legem dicendo, nec stipulando quisquam alteri cavere potest"; "ni pactando, ni imponiendo condición, ni estipulando puede uno obligar para otro"); Paul. 3 quaest. D. 45, 1, 126, 2 [“"Chrysogonus, Flavii Candidi servus actor, scripsi coram subscribente et assignante domino meo, accepisse eum a Iulio Zosa, rem agente Iulii Quintiliani absentis, mutua denaria mille; quae dari Quintiliano, heredive eius, ad quem ea res pertinebit, kalendis Novembribus, quae proximae sunt futurae, stipulatus est Zosas libertus, et rem agens Quintiliani; spopondit Candidus, dominus meus; sub die suprascripta si satis eo nomine factum non erit, tunc, quo post solvetur, usurarum nomine denarios octo praestare, stipulatus est Iulius Zosas, spopondit Flavius Candidus, dominus meus subscripsit et dominus'; respondi: per liberam personam, quae neque iuri nostro subiecta est, neque bona fide nobis servit, obligationem nullam acquirere possumus (...)"; "Yo, Crisógono, esclavo administrador de Flavio Candido, escribi ante mi señor, que lo suscribió y signó, que éste recibió de Julio Zosas, gestor de negocios de Julio Quintiliano, ausente, mil denarios en mútuo; los cuales estipuló el liberto
} 


\section{$\S$ 61. A articulação da teoria da representação direta à custa da}

equiparação do notário ao "servus publicus" romano. Partindo da premissa de que a atividade do notário produzia, em última análise, efeitos jurídicos “erga omnes" - e tomando em consideração o fato de que este não poderia se recusar a exercer seu ofício em favor de quem quer que dele o demandasse -, não demoraram os doutores do direito comum em considerá-lo detentor de um autêntico "munus publicum"; e assim, forjou-se um ambiente propício à sua equiparação ao "servus publicus" romano, como denunciam as

Zosas, gestor de negocios de Quintiliano, que serían dados à Quintiliano, ó al heredero de éste, á quién el negocio perteneciere, en las calendas de Noviembre próximas venideras; lo prometió Candido mi señor; si en el día susudicho no se hubiere satisfecho por tal motivo, para este caso estipuló Julio Zosas que por pagarse después se satisfarian ocho denarios á titulo de intereses, y lo prometió mi señor Flavio Candido, y lo suscribió también mi señor'; respondí: por medio de una persona libre, que ní está sujeta á nuestra potestad, ni de buena fe nos presta servidumbre, no podemos adquirir obligación alguna (...)"]. Perceba-se, neste último caso, que o "gestor" dos negócios do ausente (Júlio Quintiliano) não era um seu escravo, mas sim um liberto, de nome Júlio Zosas; daí não se ter admitido, no caso, a percussão direta do patrimônio do ausente à custa da atuação do gestor.

Com efeito, no sentido da admissão de uma percussão do acervo doméstico por meio da atuação de escravos, eis o teor de Ulp. 28 ad Sab. D. 50, 17, 22 pr.: "in personam servilem nulla cadit obligatio" ("en persona de condición servil no recae ninguna obligación"), coordenado com G. 2, 87: "igitur quod liberi nostri, quos in potestate habemus, item quod servi nostri mancipio accipiunt vel ex traditione nanciscuntur, sive quid stipulentur, vel ex aliqualibet causa adquirunt, id nobis adquiritur; ipse enim, qui in potestate nostra est nihil suum habere potest. Et ideo si heres institutus sit, nisi nostro iussu haereditatem adire non potest; et si iubentibus nobis adierit, hereditas nobis adquiritur proinde atque si nos ipsi heredes instituti essemus; et convenienter scilicet legatum per eos nobis adquiritur" ("por conseguinte, adquirimos o que os filhos em nosso poder ou nossos escravos recebem por mancipação, obtêm por tradição, estipulação ou qualquer outra causa; porque quem se acha em nosso poder nada pode ter para si. Por isso, sendo instituído herdeiro, não pode adir a herança sem nossa ordem, e aceitando-a por ordem nossa, adquire-a para nós, como se nós mesmos fôssemos nomeados herdeiros; e da mesma forma adquirimos um legado, por intermédio dêles").

Para os específicos fins deste parágrafo, todavia, destaca-se um fragmento específico de Modestino (Mod. 7 reg. D. $45,3,35)$ no qual se alude à atuação do escravo em prol da herança ou de um herdeiro eventual (em caso de herança jacente): "servus hereditarius et heredi futuro, et hereditati recte stipulatur" ("un esclavo de la herencia estipula validamente tanto para el futuro heredero, como para la herencia"). Tal fragmento não alude, pois, ao "servus publicus", na medida em que se reporta à atuação de um escravo integrante do patrimônio familiar pendente de transmissão "mortis causa". Teremos a oportunidade de examinar, mais adiante - a propósito do tratamento conferido à "satisdatio rem pupilli salvam fore" - a solução forjada pelos jurisconsultos (voltada à proteção do incapaz) para a hipótese de patrimônio não integrado por um único escravo sequer. De qualquer forma, podemos desde logo adiantar que, não havendo a possibilidade de se adquirir um escravo às expensas do patrimônio do menor impúbere, a manifestação de vontade decorreria da atuação de um escravo "público" ("servus publicus") - tendo-se em vista, sempre, a proeminência dos interesses do absolutamente incapaz.

Como observa E. BUSSI, o notário era compreendido, de início, como uma espécie de assistente do tabelião para a compilação material dos atos praticados por este último (La formazione cit. (nota 47), p. 303). Teremos a oportunidade de observar mais à frente que, assim como já se podia entrever uma menção à atividade do tabelião nas próprias Institutas, destas não se depreendia sua atuação em prol de um sujeito determinado, podendo-se vislumbrar - como, aliás, se fez em momento posterior - na eficácia "erga omnes" de seus atos (e na irrecusabilidade do exercício do ofício) uma justificativa para sua equiparação ao "servus publicus" romano. Pela atuação do notário, em geral, cf., por todos, E. DURANDO, Il tabellionato: o, notariato nelle leggi romane, nelle leggi medioevali italiane e nelle posteriori specialmente piemontesi, Torino, Fratelli Bocca, 1897, passim.

Pelo tratamento minudente do processo de desenvolvimento da representação notarial, cf. E. BUSSI, La rappresentanza negli atti 'inter vivos' dei nascituri non concepiti e delle persone assenti secondo il diritto comune, in Rivista di diritto privato 3 (1933), pp. 3-ss; La rappresentanza notarile del diritto intermedio, in Rivista di diritto privato 3 (1933), pp. 315-ss. 
seguintes passagens de Andrea ab Exea: "nec obstat quod omnes leges quae loquuntur de notario alteri acquirenti appellant eum servum publicum (...) sicut servus etiam absque ratificatione acquirit domino, ita etiam notarius debet adquirere". Ocorre que com essa aproximação não apenas se robusteceu a representação direta, mas também (à semelhança do que se verificara em Roma) se viabilizou a atuação deste novo agente em prol de terceiros indeterminados - aos quais, por vezes, as fontes do direito comum se reportam, laconicamente, por meio de uma alusão genérica à "ausência"51.

\section{$\S$ 62. O papel de Bártolo e o fundamento romano utilizado para o} desenvolvimento da representação "notarial". Tomando por fundamento principal três passos referentes à "satisdatio rem pupilli salvam fore" (Pap. $79 a d E d$. D. 46, 6, 2; Ulp. 35 ad Ed. D. 46, 6, 3; Ulp. 79 ad Ed. D. 46, 6, 4 pr.), Bártolo observa que o impúbere não poderia praticar a "stipulatio" por si próprio, sendo necessário que a manifestação se desse por meio de um "servus" integrante de seu patrimônio (ou adquirido às suas expensas); se

${ }^{51}$ Pelos trechos da obra de Andrea ab Exea (De pactis, n. 189, in Tractatus illustrium in utraque tum pontificii tum caesarei, juris facultate iuris consultorum VI, Venetiis, s.e., 1584, p. 7) à qual não tivemos infelizmente - acesso efetivo, cf. E. BUSSI, La formazione cit. (nota 47), pp. 304-305.

Já no que concerne à alusão ao notário como uma espécie de "servus publicus", assim se pronunciam os humanistas: "notarii est seruile nomen, est munus serui priuati hominis (...) tabularii sunt serui publici (...) quia huic conditioni addicti \& mancipati sunt, vt tabulario ciuitatis seruiant" (Iacobi Cviacii, Opervm Postvmorvm quae de ivre reliqvit tomvs quintvs sive Codex Ivstinianvs, id est, ad Codicem Ivstinianvm recitationes solemnes, Lvtetiae Parisiorvm, Impensis Societatis Typographicae Librorum Oficij Ecclesiastici, 1658, p. 1259, D e E); "dicent inservire eos publico, quia est eorum publicum munus" (Hugonis Donelli, Opera Omnia, Tomus Undecimus et commentariorum in selectos quosdam titulos digestorum volumen secundum, Lucae, Typis Joannis Riccomini, 1767, p. 795).

F. CRESPO ALluE assim sintetiza a importância da atuação dos notários para o desenvolvimento da representação direta no sistema do direito comum: "los doctores del Derecho común observaron que los notarios cumplían un 'munus publicum', en cuanto a ellos les era pedida la redacción de documentos, públicos o privados, que tenían valor 'erga omnes' respecto a los hechos en ellos atestiguados. Como tales, no pudiendo rehusar un oficio a quien lo solicitaba, vinieron llamados siervos públicos" (La revocacion cit. (nota 29), p. 55). Aludindo ao dever de "omnibus inservere", cf. L. DíEZ-PICAZO, La representacion cit. (nota 29), p. 30. No mesmo sentido, cf. F. de S. L. PESSOA JORGE, $O$ mandato cit. (nota 09), pp. 61-64. Por sua vez, como destaca E. BUSSI, ao contrário do que se verificava no direito canônico (segundo o qual o representante somente poderia atuar em nome de um representado determinado), as fontes romanas permitiam que o "servus publicus" atuasse em prol de terceiros simplesmente determináveis, viabilizando-se, assim, a representação do ausente: "e si noti: il notaio, qui si dichiara, non solo può stipulare per un terzo determinato, ma, ben di più, per delle persone incerte, poichè egli stipula 'nomine omnium quorum interest'. Quindi, non solo per gli assenti, ma anche per i nascituri (...) bisogna tener presente come, parlando di negozio concluso per l'assente alla presenza del notaio, la parola assenza non sia usata dagli stessi secondo quel ristretto significato tecnico che noi oggidì le attribuiamo" (La formazione cit. (nota 47), pp. 307-310). Mas como bem observa o referido autor, o termo ausência tem aí uma acepção bastante ampla, a ponto de abranger não apenas o seu significado técnico estrito, como também as hipóteses de afastamento material do domicílio, nascituro e prole eventual: "si ponga ora mente a questo punto: che cioè, quando nelle opere dei dottori del diritto comune si parla di stipulazione fatta per l'assente, ci si intende riferire anche ai nascituri ed ai non concepiti; sia perchè, come vedremmo, la parola assenza ha per essi un significato vastissimo, sia perchè, essendo più rari i casi di negozi stipulati pei non concepiti o pei nascituri, essi, quando si occupano della rappresentanza notarile, si riferiscono prevalentemente al caso che più si verificava nella pratica, quello cioè dell'assenza" (La formazione cit. (nota 47), pp. 308-309, especialmente p. 308). 
não fosse possível tal solução, caberia ao "servus publicus" estipular em proveito do menor - operando-se, apenas em último caso, a "satisdatio" por meio da atuação do próprio magistrado (Ulp. 36 ad Ed. D. 27, 8, 1, 15). No entanto, ao contrário dos jurisconsultos romanos, os doutores do direito comum não entreviam nos efeitos da atuação do escravo hipótese redutível à simples acessão; considerando-o uma autêntica pessoa, foi então removido o principal obstáculo à equiparação do notário ao "servus publicus", estendendose-lhe o regramento romano ao ponto de se admitir os efeitos da representação direta: "actio utilis acquiritur pupillo ex stipulatione notarii sine cessione in stipulationibus praetoriis". Contudo, se a partir de tais fragmentos se podia entrever a atuação do oficial tão somente em prol de um sujeito determinado, do aproveitamento de outras fontes (Marcell. 26 dig. D. 1, 7, 18 e I. 1, 11, 3) se pôde extrair o seu concurso para a tutela de terceiros indeterminados - e por vezes indetermináveis ${ }^{52}$.

\footnotetext{
${ }^{52}$ A respeito da "satisdatio rem pupilli salvam fore" e da atuação do escravo em prol do menor impúbere, eis os principais fragmentos referidos pela doutrina: Pap. 79 ad Ed. D. 46, 6, 2 ("si pupillus absens sit, vel fari non possit, servus eius stipulabitur; si servum non habeat, emendus ei servus est; sed si non sit, unde ematur, aut non sit expedita emtio, profecto dicemus, servum publicum apud Praetorem stipulari debere"; "si el pupilo estuviera ausente, ó no pudiera hablar, estipulará su esclavo; si no tuviera esclavo, se ha de comprar para él un esclavo; pero si no hubiera con qué comprarlo, ó no fuera fácil la compra, diremos ciertamente que debe estipular ante el Pretor el esclavo público"); Ulp. 35 ad Ed. D. 46, 6, 3 ("aut dare aliquem Praetor debet, cui caveatur"; "ó el Pretor debe nombrar alguien á quien se le dé caución"); Ulp. 79 ad Ed. D. 46, 6, 4 pr. ("non quasi ipso iure pupillo acquirat, neque enim acquirit, sed ut utilis actio ex stipulatupupillo detur"; "no para que de derecho adquiera para el pupilo, porque no adquiere, sino para que no se le dé al pupilo la acción útil derivada de lo estipulado"); Ulp. 36 ad Ed. D. 27, 8, 1, 15 ("exigere autem cautionem magistratus sic oportet, ut pupilli servus aut ipse pupillus, si fari potest et in praesentiarum est stipuletur a tutoribus, item fideiussoribus eorum rem salvam fore: aut, si nemo est qui stipuletur, servus publicus stipulari debet ren salvam fore pupillo aut certe ipse magistratus"; "pero el magistrado debe exigir la caución de modo que el esclavo del pupilo, ó el mismo pupilo, si puede hablar, y está presente, estipule de los tutores, y también de sus fiadores, que quedarán a salvo los bienes; ó si no hay nadie que estipule, debe estipular el esclavo público, que le quedarán á salvo al pupilo los bienes, ó ciertamente el mismo magistrado”). Perceba-se, pois, que nas hipóteses aventadas nos fragmentos ora referidos, a atuação do escravo do impúbere - ou do "servus publicus" - se volta sobretudo à proteção dos interesses de um sujeito específico: vale dizer, o incapaz.

Entretanto, quando abordado um passo específico de Marcelo (Marcell. 26 dig. D. 1, 7, 18) - onde se estabelece que "non aliter enim voluntati eius, qui arrogare pupillum volet, si causam eius ob alia probabit, subscribendum erit, quam si caveritservo publico, se restituturum ea, quae ex bonis eius consecutus fuerit, illis, ad quos res perventura esset, si arrogatus permansisset in suo statu" ("no se deberá, pues, asentir á la pretensión del que quiera arrogar á un pupilo, aun cuando por otros motivos probare su intención, de otro modo que si hubiere dado caución al esclavo público, de que habrá de restituir lo que de los bienes del pupilo hubiere percibido, á aquellos á quienes habria correspondido la hacienda, si el arrogado hubiese permanecido en su estado") - percebe-se que a atuação do "servus publicus" se voltava, nesta hipótese, à tutela dos interesses de terceiros que pudessem ser prejudicados pela adrogação do pupilo. Nesta situação, o "servus publicus" como que corporificava um intesse geral (ou ao menos de terceiros indeterminados), evidenciandose uma atuação que transcendia os interesses individuais das partes imediatamente afetadas pelo negócio jurídico aludido.

Note-se que tal orientação (adotada no passo de Marcelo acima referido) também encontra consagração nas Institutas (I. 1, 11, 3): “cum autem impubes per principalem rescriptum adrogatur, causa cognita adrogatio permittitur et exquiritur causa adrogationis, an honesta sit expediatque pupillo, et cum quibusdam condicionibus adrogatio fit, id est ut caveat adrogator personae publicae, hoc est tabulario, si intra pubertatem pupillus decessit, restituturum se bona illis, qui, siadptio facta non esset ad successionem eius venturi esset.
} 


\section{$\S$ 63. A atuação dos juristas do direito comum voltada à conformação do}

direito romano às novas necessidades sociais. Os juristas do direito comum exploraram as fontes romanas imbuídos de um profundo comprometimento com o significado prático de sua produção: preocupado, pois, com a possibilidade de extensão da representação direta a outras categorias de oficiais públicos, Bártolo confere um sentido peculiar à regra contida em Ulp. 36 ad Ed. D. 27, 8, 1, 15, ao asseverar que "actio utilis nobis quaeritur sine cessione in stipulationibus, conventionalibus per notarium vel alium ufficialem publicum"; da mesma forma, ao atribuir ao notário o dever de utilização da fórmula da "stipulatio", o comentador observa que este poderia estipular não apenas em proveito de um sujeito determinado, mas também "nomine omnium quorum interest". Deste modo, ao lado do direito canônico, esta nova feição da atividade notarial também contribuiu para o desenvolvimento da representação direta; enquanto o primeiro viabilizou uma generalização da figura do representante (eis que qualquer pessoa poderia atuar em prol de

Item non alias emancipare eos potest adrogator, nisi causa cognita digni emancipatione fuerint et tunc sua bona eis reddat. Sed et si decendens pater eum exheredaverit vel vivus sine iusta causa eum emancipaverit, iubetur quartam partem ei suorum bonorum relinquere, videlicet praeter bona, quae ad patrem adoptivum transtulit et quorum commodum ei adquisivit postea" ("quando porém um impúbere é arrogado por um rescrito do príncipe, é permitida a arrogação depois de conhecida a causa, indagando-se se a causa da adrogação é honesta e convenha ao pupilo. E a arrogação se faz sob certas condições, quando dá o arrogante fiança a uma pessoa pública, i. é., ao tabelião, que se morrer o pupilo dentro da puberdade, há-de êle restituir os bens àquêles que teriam vindo à sua sucessão, se não tivesse sido feita a adopção. Semelhantemente, não pode o adrogante emancipá-lo senão fôr êle, depois de conhecida a causa, digno de emancipação, e então deve entregar-lhe os seus bens. Mas embora o pai (adopativo), ao morrer, o haja deserdado, ou, ainda vivo, emancipado sem justa causa, é obrigado a deixar-lhe a quarta parte dos seus bens, i. é., além dos que transferir para o pai adoptivo e dos lucros que com êles posteriormente êste adquiriu"). Observe-se que a tradução das Institutas de Justiniano utilizada neste trabalho é aquela produzida por A. CORREIA, incorporada ao Manual de A. CoRREIA e G. SCIASCIA referido em nota de rodapé anterior (nota 09). Merece destaque o fato de que já nas Institutas de Justiniano há menção explícita à figura do tabelião, compreendido, pois, como uma pessoa pública ("personae publicae"). A produção de efeitos "erga omnes" e a indeclinabilidade da função hão de erigi-la à categoria de "munus publicum" - e o agente, por sua vez, ao patamar de "servus publicus" (já em uma nova acepção para a expressão).

A respeito da "satisdatio rem pupilli salvam fore" no âmbito da doutrina especializada, cf. G. ROTONDI, Appunti sulla stipulatio rem pupilli salvam fore, in Scritti giuridici II - Studii sul diritto romano delle obbligazioni (a cura di Emilio Albertario), Milano, Ulrico Hoepli, 1922, pp. 268-289.

No que tange à compreensão do escravo como pessoa, ensejador de representação (mas não de acessão), eis a manifestação clara de E. BUSSI: "per lo storico del diritto (...) quello che importa è che tale frammento [Ulp. 36 ad Ed. D. 27, 8, 1, 15] servì a Bartolo come punto, sia pure lontano, di partenza per porre la massima secondo la quale 'actio utilis acquiritur pupillo ex stipulatione notarii sine cessione in stipulationibus praetoriis'. Era venuto meno infatti, e da un pezzo, il rigido concetto della schiavitù romana. Per questa, l'acquisto del servo valeva come acquisto del padrone, giacchè detto acquisto non era, in fondo, che una accesione della cosa rappresentata dal servo. Ma i commentatori, i quali nel servo vedevano non la cosa ma la persona, per quanto consci dei principii romani, consideravano ormai il negozio posto in essere dal servo per il pupillo, null'altro che come il negozio di una persona in favore di altra persona" (La formazione cit. (nota 47), p. 306). Considerando "arriscadíssima” a analogia divisada por E. BUSSI na obra de Bártolo, cf. P. CAPPELlini, Rappresentanza cit. (nota 46), p. 444. 
seu semelhante), esta última possibilitou a extensão do instituto à tutela dos interesses de sujeitos indeterminados (ou mesmo indetermináveis) ${ }^{53}$.

${ }^{53}$ Após o renascimento do direito justinianeu, sua utilização não se deu de modo uniforme em todo o continente europeu. Ao contrário, de maneira bastante sintética pode-se circunscrever a utilização do direito romano a duas linhas principais de trabalho: de um lado, um estudo voltado ao atendimento de necessidades preponderantemente práticas (mos italicus); de outro, sob forte inspiração humanista, uma vertente menos comprometida com tal ordem de preocupações (mos gallicus), na medida em que mais devotada à compreensão das vicissitudes históricas por que passaram as diversas instituições do direito romano. Nas palavras de J. C. MOREIRA ALves “o estudo do Corpus Iuris Ciuilis pelos glosadores tinha, também, sentido prático, porque consideravam eles que o direito romano justinianeu era direito aplicável, mas não levaram em conta a dificuldade da sua aplicação pela vigência de outras fontes jurídicas como o costume, o direito estatutário fundado no direito germânico e o direito canônico. Para vencer essa dificuldade, os pós-glosadores adotaram outra orientação de estudo - o mos italicus, por ter sido a Itália onde surgiu e mais se desenvolveu, para daí propagar-se por outros países (...) dessa atividade criadora dos pós-glosadores resultou um direito romano ajustado às necessidades econômico-sociais da vida medieval (...) no século XVI, em decorrência do renascimento dos estudos clássicos, nova orientação se imprime ao estudo do direito romano pelos juristas que integram o que se denominou Escola Culta (...) [escola] que deixa de lado a interpretação da Glosa e o método dos comentaristas, e se dedica ao estudo das fontes romanas, com o auxílio da filologia e história (...) em oposição à orientação italiana - o mos italicus - surge, como vertente do humanismo, o mos gallicus" (Universidade, cultura e direito romano, in Revista da Faculdade de Direito da Universidade de São Paulo 87 (1992), pp. 48-50). A bibliografia devotada ao tema é bastante vasta. Por uma comparação entre os referidos métodos de abordagem do direito justinianeu cf., em geral, F. WIEACKER, História cit. (nota 09), pp. 228-232; e no âmbito luso-brasileiro, M. R. MARQUES, Codificação cit. (nota 09), pp. 79-81.

A respeito da regra contida em Ulp. 36 ad Ed. D. 27, 8, 1, 15, cf. sua transcrição e análise realizadas em nota anterior (nota 52).

Como referido no corpo do texto, Bártolo assevera que o notário deveria proferir a fórmula da "stipulatio": "quaero quando notarius stipulat, utrum est necesse quod dicat "promittis mihi notario tamquam publicae personae recipienti nomine omnium quorum interest?' et fateor quod, si non stipularet tamquam publica persona, non possit alii quaerere" (cf. comentário a D. 47, 6, 2 contido em Bartoli commentaria in secvndam Digesti novi partem, Do. Petri Pauli Paris. Andreae Barb. Alexan. Lofaei additionibus, multisque emendationibus illustrata accuratè, \& multa cum diligentia castigata, Lvgdvni, Petrus Fradin, 1555). Aliás, a respeito da participação de Bártolo no processo de desenvolvimento da representação direta (à custa da atividade notarial), bem como do acolhimento generalizado de sua posição entre os comentadores que lhe sucederam, cf. E. BUSSI, La formazione cit. (nota 47), pp. 307 e 311. Observe-se que tal autor destaca, ainda, ter sido Bártolo o maior responsável pelo surgimento da presunção de estipulação notarial em prol de terceiros indeterminados: "perchè il notaio, quando stipulava come tale, si riteneva che avesse stipulato per tutti gli interessati senza che dovesse ciò dire expressis verbis: 'sed ergo praesumo - scrive Bartolo - quod si stipulaverit tamquam notarius, praesumitur stipulari tamquam publica persona et nomine omnium quorum interest"” (p. 309).

Mesmo quanto à necessidade de ratificação (por parte do beneficiário da gestão) não havia maiores dificuldades (ou mesmo discrepâncias em relação à orientação consagrada nos textos justinianeus): em se tratando de doação pura - tal como se podia depreender dos próprios textos romanos (cf. Paul. 15 ad Sab. D. 39, 5, 10; Ulp. 46 ad Sab. D. 46, 2, 8, 5 (parte final); Pomp. 24 ad Sab. D. 46, 3, 23; Lab. 6 pith. D. 46, 3, 91; Iav. 13 epistul. D. 44, 1, 50 pr.) - era desnecessária qualquer ratificação por parte do donatário. Já em matéria de doação com encargo (ou de negócio jurídico oneroso, em geral), era necessária "l'accettazione dell'assente e del nascituro" (La formazione cit. (nota 47), p. 314).

Cabe destacar, finalmente, a complementaridade entre os preceitos do direito canônico voltados à representação direta e o paradigma da representação notarial acima referido. Com efeito, enquanto o direito canônico permitiu a representação "por quem quer que seja" - estendendo, assim, o rol de possíveis "representantes" - estava limitado, por sua vez, quanto ao beneficiário da atuação do agente; o representante canônico somente poderia atuar em prol de um sujeito "determinado". Assim, ao mesmo tempo em que suplantou o direito romano ao permitir o exercício da representação por alguém que não se enquadrava no conceito de órgão público, mostrava-se imperfeito por não abranger a atuação em favor de sujeitos indeterminados, tais como o nascituro e a prole eventual.

Já o direito romano (habilmente utilizado pelos comentadores medievais) passava a viabilizar a representação desta última espécie de sujeitos, conquanto não admitisse a atuação de representantes quaisquer. Assim, de 
$\S$ 64. Encerramento do capítulo e apresentação do tema sucessivo. Como visto, o direito comum contribuiu decisivamente para o desenvolvimento da representação direta; paralelamente, foram promovidos alguns ajustes com relação à eficácia do contrato de mandato (cujos reflexos podem ser entrevistos mesmo no direito contemporâneo). Todavia, o passo decisivo em direção à admissão de um mandato "essencialmente" representativo ainda não havia sido dado; teremos a oportunidade de analisar no capítulo subseqüente de que maneira o influxo iluminista contribuiu não apenas para a consagração da representação direta como regra, como também para a sua incorporação ao referido tipo contratual - em relação ao qual, ao longo de todo o período do direito comum, conservou uma significativa autonomia estrutural.

uma coordenação entre o direito canônico e o direito romano - levada a efeito pelos doutores do direito comum - exsurgiu uma representação direta bastante robustecida quanto às suas potencialidades, eis que cada um dos ramos aludidos the legou aquilo que o outro denegara: "la dottrina di Bartolo, invero, ripeteva le origini, o quanto meno la sua giustificazione, direttamente dai principi di diritto romano, pur se di questi travisava il contenuto od il significato; mentre la dottrina canonica ripeteva le origini più dall'equità e dalle consuetudini. Ne conseguiva che, mentre la prima riteneva che solo una persona publica, potesse 'alteri stipulari', la seconda opinava che qualsiasi cittadino potesse, in favor d'altri, compiere un negozio giuridico in virtù di quella equità che formava l'elemento sostanziale della sua costituzione (...) il curioso si è tuttavia questo: che, mentre ambedue miravano ad annullare od a scavalcare il principio per cui non si può stipulare in favor d'altri, accade che la teoria bartolista, che essendo fondata sui testi romani, avrebbe dovuto avere per tendenza di limitare la estensione della rappresentanza, valse invece ad ampliarla a casi in cui il diritto canonico non poteva giungere, cioè ai casi dei non concepiti e degli assenti" (La formazione cit. (nota 47), pp. 309-310). Eis uma manifestação evidente da coordenação entre direito justinianeu e direito canônico levada a efeito pelos doutores do direito comum.

Por uma profunda análise sobre a repercussão de tais desdobramentos na praxe judiciária - abordada a partir de diversas decisões, sobretudo da Rota Romana, coligidas em coleções às quais, lamentavelmente, não tivemos efetivo acesso (Rotae Romanae Decisiones coram Coccino ab anno 1600 ad annum 1640, Romae, 1672; Rotae Romanae Decisiones coram Merlino, ab anno 1621 ad annum 1642, Genevae, 1662; Sacrae Rotae Romanae Decisiones recentiores in compendium redactae, Mediolani, 1731; Decisiones Rotae Lucanae collectae per Hieronymum Palma, Venetiis, 1718; Rotae Romanae Decisiones ab anno 1623 ad annum 1637 collectae a Paulo Rubeo, Venetiis, 1642; Rotae Maceratensis Decisiones novissimae auctore Marco Antonio Thomato, Macerata, 1669; Decisiones Rotae Provinciae Marchiae auctore Stephano Gratiano, Venetiis, 1621; Decisiones Sacri Regni Senatus Cathaloniae auctore G. P. Fontanella, Venetiis, 1640 ) - cf. E. BUSSI, La formazione cit. (nota 47), pp. 315-320.

E por uma análise sobre o papel "adaptador" dos doutores do direito comum, cf. dois estudos de F. CALASSO (Citramontani, ultramontani e il problema storico del diritto commune, in L'Europa e il diritto romano studi in memoria di Paolo Koschaker II, Milano, Dott. A. Giuffrè, 1954, pp. 33-ss; e Il problema storico del diritto comune, in Studi di storia e diritto in onore di Enrico Besta per il XL anno del suo insegnamento II, Milano, Giuffrè, s.d., pp. 459-513); bem como o ensaio de C. GuIDO MOR (I giudici della Contessa Matilde e la rinascita del diritto romano in Studi in onore di Benvenuto Donati, Modena, Premiata Cooperativa Tipografi, 1954, pp. 43-60). 


\section{CAPÍTULO IV.}

\section{O INFLUXO ILUMINISTA E A "ESSENCIALIZAÇÃO" DA REPRESENTAÇÃO DIRETA NO CONTEXTO DO CONTRATO DE MANDATO.}

$\S 65$. A relação entre o contrato de mandato e a representação (direta) no período imediatamente anterior ao influxo iluminista: o Código Civil francês, seu art. 1.984 e a perplexidade decorrente da confrontação de seus trabalhos preparatórios. Como tivemos a oportunidade de observar há pouco, o simples desenvolvimento da representação negocial (direta) não foi suficiente para que fosse comprometida a autonomia estrutural do contrato de mandato (até então não representativo); de sua parte, a menção à procuração como "instrumento do mandato" deu ensejo a uma promiscuidade quanto aos efeitos das atuações do "procurador" e do "mandatário", daí decorrendo um modelo que seria posteriormente referendado (em termos científicos) pela obra de Jean Domat. De toda forma, a conjugação entre os trabalhos preparatórios do "Code Civil" e a redação de seu art. 1.984 conduzem o estudioso a um estado de autêntica perplexidade: enquanto no "Discurso Preliminar" - pronunciado quando da apresentação do Projeto elaborado pela comissão integrada por Jean Portalis, Félix Bigot-Préameneu, François Tronchet e Jacques de Malleville - se afirma que, em relação aos contratos, foram observadas os princípios transmitidos pela própria antigüidade (e nascidos com o próprio gênero humano), no que concerne ao mandato se estabelece que "le mandat ou procuration est un acte par lequel une personne donne à une autre le pouvoir de faire quelque chose pour le mandant et en son nom"; ora, posto de parte qualquer juízo que se possa fazer a respeito do acerto de uma tal definição, parece inegável que - ao contrário do afirmado na exposição de motivos - tal concepção do tipo contratual aludido não guardava uma exata correspondência com os paradigmas tradicionais então referidos ${ }^{54}$.

\footnotetext{
${ }^{54}$ Teremos a oportunidade de nos manifestar mais adiante com relação à obra de Jean Domat, bem como a respeito de seu papel decisivo no contexto de uma fusão entre os conceitos de "procurador" e "mandatário". No mesmo sentido, aliás, a observação a ser feita quanto aos trabalhos preparatórios do "Code Civil", os quais serão objeto de uma análise específica logo a seguir. De toda forma, pela documentação coligida a pretexto da tramitação do "Code Civil", cf. P. A. FENET, Recueil complet des travaux préparatoires du Code Civil, suivi d'une édition de ce Code, a laquelle sont ajoutés les lois, décrets et ordonnances formant le complément de la législation civile de la France, et ou se trouvent indiqués, sous chaque article séparément, tous les passages du recueil qui s'y rattachent, Paris, Imprimerie de Ducessois, 1827, passim (a obra completa é composta de 15 tomos); F. EWALD, Naissance du Code civil: la raisón du législateur, Paris, Flammarion, 1989, passim (a obra é composta de alguns extratos selecionados, obtidos a partir da versão de P. A. FenteT); J. RAY, Essai sur la structure logique du Code Civil Français, Paris, Librairie Félix Alcan, 1926, pp. 261-263. E quanto à resistência ao processo de codificação, cf. J. van KAN, L'unification du droit et les résistences des jurisconsultes sous l'ancien regime in Mélanges Paul Fournier, Paris, Sirey, 1929, pp. 363-374.
} 
$\S 66$. O período do jusnaturalismo racionalista como resultante de uma série de correntes do pensamento jurídico europeu: Escola Racionalista do Direito Natural, Jurisprudência Elegante e “usus modernus pandectarum”. O advento do iluminismo produziu uma série de repercussões no âmbito jurídico, ensejando uma atuação (experimental) da "recta ratio" tanto no que concerne à organização política do Estado (onde se destacaram, por exemplo, as obras de Thomas Hobbes e John Locke), como também no âmbito do direito privado; considerando o Direito um objeto suscetível de revelação por meio do emprego da razão, a Escola Racionalista do Direito Natural questionou a viabilidade de uma utilização "moderna" do direito justinianeu (produzido no já longínquo séc. VI d.C.). Desta forma, conquanto persistissem alguns estudos do direito romano estribados no método histórico-crítico (levados a efeito sobretudo nos Países Baixos, pela Escola dos Jurisconsultos Elegantes), difundiu-se uma tendência lastreada em uma análise contemporânea do "Corpus Iuris Civilis", voltada à depuração daquilo que fosse efetivamente compatível com as necessidades ostentadas pela sociedade dos novos tempos; daí o surgimento de um "usus modernus pandectarum" que - no que concerne à temática da representação negocial (direta) - tomava a vedação indiscriminada constante de G. 2, 95 como uma manifestação exemplar daquela excessiva sutileza dos textos romanos - a qual, mostrando-se incompatível com um contexto social diverso daquele em que havia sido originalmente produzida, havia de ser submetida a um necessário e conseqüente expurgo (sobretudo à custa da atuação dos novos intérpretes, comprometidos com os valores sociais já então prevalecentes) ${ }^{55}$.

\footnotetext{
${ }^{55}$ A bibliografia voltada ao estudo do iluminismo (e seus influxos sobre os mais diversos ramos da ciência) é vastíssima, remetendo-se o leitor, por um panorama geral, à obra de E. CASSIRER (Die Philosophie der Aufklärung, trad. it. de Ervino Pocar, Filosofia dell'illuminismo, Firenze, Nuova Italia, 1952). No entanto, como teremos a oportunidade de reiterar posteriormente, tal movimento ideológico se propagou em momentos distintos por toda a Europa, ostentando particularidades que impedem uma generalização irrestrita mesmo de suas diretrizes mais amplas; assim, por exemplo, enquanto o iluminismo francês é laico, seu correspondente ibérico mostra-se profundamente comprometido com a preservação da fé católica. Deste modo, por uma análise específica do iluminismo português, cf. L. S. CABRAL DE MONCADA, Filosofia do Direito e do Estado I, Coimbra, Arménio Amado, 1947-1966, pp. ; Um 'iluminista' português do século XVIII: Luís António Verney, in Estudos de História do Direito III: Século XVIII - Iluminismo Católico; Verney: Muratori, Coimbra, Imprensa da Universidade, 1950, pp. 3-9.

Pelo "jusracionalismo" - compreendido como projeção do movimento iluminista sobre o âmbito jurídico cf. F. WIEACKER, História cit. (nota 09), pp. 279-300 (especialmente pp. 297-300); N. BOBBIO, Il positivismo giuridico - lezioni di Filosofia del diritto raccolte dal Dott. Nello Morra, Torino, G. Giappichelli, 1979, pp. 11-13 e 38-41; L. S. CABRAL DE MoncadA, O 'século XVIII' na legislação de Pombal, in Estudos de História do Direito I, Coimbra, Imprensa da Universidade, 1948, pp. 86-92; M. R. MARQUES, Codificação cit. (nota 09), pp. 355-434 (especialmente pp. 372-421); e M. de AlBUQUERQUE, O século XVIII na legislação de Pombal in Pensamiento juridico y sociedad internacional - Libro-homenaje al profesor D. Antonio Truyol Serra I, Madrid, Universidad Complutense, 1986 (pp. 59-ss).
} 


\section{$\S 67$. Um hiato entre a admissibilidade generalizada da representação} direta e a sua incorporação à "essência" do contrato de mandato: uma abordagem das principais manifestações da doutrina jusracionalista dedicada ao tema. Ora, entre a admissibilidade generalizada da representação negocial direta e a sua incorporação à essência do contrato de mandato medeia uma distância significativa; de sua parte, o simples juízo de reprovação a respeito da vedação romana àquela não é suficiente para justificar, por si só, a concepção do mandato que se depreende do art. 1.984 do "Code Civil". Assim, faz-se necessário abordar algumas das principais manifestações doutrinárias que viabilizaram a transição do paradigma não representativo ao modelo francês, no qual a representação (direta) passou a constituir a própria "nota típica" do "mandat" - em substituição à "gratuidade", tendo-se em vista a admissibilidade de uma variante onerosa (em posição francamente contrária à orientação adotada nas fontes romanas). Desta forma, a despeito da importância da obra de diversos outros juristas dos séculos XVI e XVII, nossa atenção estará voltada, sobretudo, à produção de sete jurisconsultos específicos: Hugo Grotius (1583-1645), Georg Adam Struvi (1619-1692), Samuel Pufendorf (16321694), Jean Domat (1625-1696), Johaniss Voet (1647-1713), Johann Gottlieb Heineccii

\footnotetext{
Ainda que dedicadas àquilo que usualmente designamos por direito público, as obras de T. HOBBES e J. LOCKE denunciam, de modo claro, a importância da "razão natural" como meio indispensável à obtenção de uma "verdade" jurídica; deste modo, assim como o primeiro pretendia reduzir sua doutrina "to the rules and infallibility of reason" (The epistle dedicatory, in The elements of law natural and politic, London, SimpkinMarshall and Co., 1889, p. XV), este último estruturou toda a sua produção em uma "natural reason" que deveria conduzi-lo a resultados de proporções universais (cf. Essai sur l'entendement humain, in Oeuvres de Locke et Leibnitz, Paris, Firmin Didot Frères, 1839, pp. 427-450 e 466-469; The second treatise of Government: an Essay concerning the true original, extent, and end of Civil Government, in Two Treatises of Government, Cambridge, Cambridge University Press, 1996, pp. 79-92 e 285-302).

Por sua vez, a respeito da "jurisprudência elegante" dos países baixos - assim designada em função do rigor de seus representantes quanto à precisão conceitual e sua respectiva expressão escrita - cf. A. CAVANNA, Storia del diritto moderno in Europa I - le fonti e il pensiero giuridico, Milano, A. Giuffrè, 1979, pp. 434-ss. Não obstante a importância de seus diversos outros membros, voltaremos nossa atenção, oportunamente, sobretudo à atuação de dois de seus expoentes: Gerard Noodt e Johaniss Voet (especialmente este último). Especificamente no que tange ao "usus modernus pandectarum" compreendido como método, remetemos o leitor, desde logo, a momento posterior do presente estudo, no qual se pretenderá desenvolver uma análise voltada à sua vertente lusitana (então acompanhada de um levantamento bibliográfico pretensamente mais exaustivo). Por ora, limitemo-nos a destacar que a vedação romana à representação negocial direta fora compreendida por um de seus adeptos - J. BRUNNEMANN - como uma "mera juris civilis subtilitate" (Commentarius in Codicem Justinianeum quo singulae leges et authenticae breviter et succincte explicantur; quaestiones in academis, et foro frequentatae resolvuntur; axiomata ab interpretibus subinde proposita examinantur, et alia ex ipsis textibus notabilia eruuntur; quaeque alias ad analysin pertinent per compendium quasi dilucide traduntur; inserto hinc inde quid de jure tam communi novissimo, quam etc. etc. opus theoretico-practicum cui praeter indicem rerum et verborum locupletissimum accessit ex ejusdem auctoris commentario ad Pandectas, notabilium, quae circa leges affines inibi commentatus est II, Laureti, Ex Typis Fratrum Rossi Editorum, 1843, p. 245). Contudo, observaremos em seguida que também quanto a outros temas - inclusive acerca de uma eventual eficácia representativa (direta) do "mandatum" - a concorrência do "usus modernus pandectarum" foi fator decisivo na reformulação de princípios tradicionais do direito romano, paulatinamente postos em xeque.
} 
(1681-1741) e Christian Wolff (1679-1754); em alguns casos, em virtude da conservação da orientação romana a respeito do "mandatum"; noutros, em decorrência da mútua imbricação entre "mandato" e "procuração" (a qual, por sua vez, acarretará uma série de conseqüências para o próprio direito contemporâneo); alguns ainda, finalmente, em razão do desenvolvimento gradual da matriz responsável pela compreensão da representação (direta) como "causa-função" afeta ao tipo contratual aludido ${ }^{56}$.

\section{§ 68. A clareza da doutrina de Hugo Grotius: uma distinção meridiana} entre as duas perspectivas (interna e externa) de um mesmo fenômeno. A posição de $\mathrm{H}$. GROTIUS a respeito da relação entre o contrato de mandato e a representação negocial (direta) somente pode ser obtida a partir da conjugação entre o conteúdo de duas de suas

${ }^{56}$ Cabe aqui esclarecer, preliminarmente, que não se pretendeu desenvolver um estudo pormenorizado a respeito da definição do contrato de mandato segundo cada um dos expoentes do cenário jurídico durante os séculos XVI e XVII. Não fosse em virtude das feições hercúleas de um tal esforço - uma vez que seria então indispensável confrontar, por exemplo, os estudos de Andrea Alciato (Giovanni Andrea Alciati ou Andreas Alciatus), Martín de Azpilcueta (Doctor Navarro ou Doctor Navarrus), Charles Dumoulin (Charles du Moulin ou Molinaeus), Giovanni Paolo Lancelotti (Johannes Paulus Lancelottus), François Hotman (Francisco Hotomano ou Franciscus Hotomanus), Pedro Barbosa, Jacopo Menochio, Luis de Molina, Denis Godefroy (Dionysius Gothofredus, Dionisio Godofredo ou Godofredo el Viejo), Alberico Gentili, Hermann Wöhl (Vulteius), Antoine Favre (Antonius Faber ou Antonio Fabro), Johaness Althusius, Jacques Godefroy (Jacobus Gothofredus ou Jacobo Godofredo), Arnold Vinnen (Arnoldus Vinnius), Benedikt Carpzov, Giovanni Battista De Luca, Ulrich Huber, Samuel Stryk, Gottfried Wilhelm Leibniz, Christian Thomasius, Justus Henning Böhmer, Samuel von Cocceji, entre diversos outros - os próprios objetivos deste item específico do trabalho apontam para uma solução diversa do exame exaustivo de cada um desses posicionamentos.

Com efeito, nosso estudo está comprometido com a abordagem de sete grandes juristas dos séculos XVI e XVII, que por meio de suas obras assinalam a existência de uma trajetória que conduzirá o estudioso de um ponto de partida (a admissibilidade generalizada da representação negocial tal qual decorrente do direito comum) a um termo de chegada (a junção estrutural entre "mandato" e "procuração" acompanhada da recondução da representação negocial direta à posição de "causa-função" do tipo contratual aludido). Entre os extremos (representados pelo direito comum e pelo "Code Civil") se desenvolveu um significativo esforço no sentido do impulsionamento da representação negocial; e este empenho será aqui representado pela obra de cada um dos juristas ora invocados.

Iniciaremos, pois, pela análise da obra de Hugo Grotius: e teremos a oportunidade de nela entrever muito mais romanismo do que aquele sentido inovador que comumente se lhe costuma atribuir; em seguida, depararemo-nos com um peculiar conservadorismo de Samuel Pufendorf (aberto à transigência terminológica que servirá de mola mestra ao esforço unificador de Jean Domat). Após a análise das "loix civiles", deteremo-nos na introjeção da representação (direta) na estrutura do próprio mandato, à custa dos trabalhos de Georg Adam Struve e Christian Wolff; finalmente, debruçaremo-nos sobre a consciência de "usus modernus pandectarum" latente na obra de Johaniss Voet, na qual se faz um cotejo entre aquilo que "outrora fora" e o que "era" (e mesmo "deveria ser") dali em diante. Confrontados os estudos destes seis autores, restará uma menção à obra de Johann Gottlieb Heinecke (Heineccius, Heinecio ou Heineccii); ainda que não seja perfeitamente enquadrável na trajetória que pretendemos divisar, sua produção merecerá uma consideração especial, sobretudo à luz da substancial influência que desempenhou no cenário luso-brasileiro imediatamente posterior às reformas pombalinas da aplicação e do ensino jurídicos.

Alguns outros juristas - como Gerard Noodt e o já referido Johannes Brunnemann - poderão ser utilizados ao longo da presente análise. Contudo, a exposição será desenvolvida à custa dos sete autores acima mencionados.

Por um estudo bio-bibliográfico voltado a cada uma das personagens referidas na presente nota de rodapé, cf. a monumental obra coordenada por R. DoMINGo (Juristas universales, Madrid-Barcelona, Ediciones Jurídicas y Sociales Marcial Pons, 2004, passim). 
obras: em seu "De iure belli ac pacis libri tres, in quibus ius naturae et gentium item ius publici praecipua explicantur" - voltando sua atenção ao direito internacional público - o autor evidencia uma clara distinção entre as perspectivas interna e externa da dinâmica representativa; contudo, sem uma posição clara a respeito do "mandatum", simplesmente observa que as fontes romanas (no que toca aos contratos em espécie) revelaram princípios decorrentes de uma "justiça natural", referendados, no mais das vezes, por diversas outras ordens jurídicas da mais variada origem. Em contrapartida, em "Inleydinge tot de Hollandsche Rechts-geleerdheyt", o jurisconsulto oferece uma definição do mandato bastante comprometida com o paradigma romano, não apenas em virtude da posição de destaque conferida à "gratuidade", mas também em razão da inadmissão (implícita) de efeitos representativos imediatamente decorrentes do tipo contratual aludido; aliás, tal aspecto da eficácia típica deste contrato deve ser ponderado pelo estudioso com uma atenção ainda maior, uma vez que H. GROTIUS não faz nenhuma espécie de ressalva à ampla utilização da figura do representante - seja no âmbito do direito público, seja ainda em meio ao direito privado ${ }^{57}$.

\footnotetext{
${ }^{57}$ Toda a doutrina contratual de H. GROTIUS está estribada na contraposição entre os contratos benéficos (ou gratuitos) e os contratos permutatórios, cuidadosamente articulada nos parágrafos $2^{\circ}$ e $3^{\circ}$ do capítulo "de contractibus" (L. II, cap. XII, II e III) da obra "De Jure Belli ac Pacis Libri Tres, in quibus Jus Naturae \& Gentium, item Juris Publici praecipua explicantur" (Washington, Carnegie Institution, 1913, pp. 228-230; observe-se que existe tradução espanhola a cargo de Jaime Torrubiano Ripoll, Del derecho de la guerra y de la paz, Madrid, Editorial Reus, 1925, da qual serão extraídas as traduções que acompanham as transcrições latinas). Esta observação é bastante importante, uma vez que tal dicotomia será tomada como ponto de partida de uma série de trabalhos de juristas que lhe foram posteriores - como é o caso de Samuel Pufendorf. Aliás, como referido no corpo do texto, em seu "De Jure Belli ac Pacis" H. Grotius não aborda especificamente o contrato de mandato; todavia, em L. II, cap. XII, XIII consta uma observação que evidencia o acolhimento genérico do paradigma romano do referido tipo contratual: "quae omnia Romanis quidem congruunt legibus, sed non ex illis primitus, sed ex aequitate naturali veniunt. Quaere eadem apud alias quoque gentes reperire est" (p. 232); "lo cual todo está seguramente conforme a las leyes Romanas, pero no se proviene de ellas primordialmente, sino de la justicia natural. Por lo cual se encontra lo mismo también en otras gentes" (pp. 205-206).

Além disso, da mesma obra (L. II, XI, XII) se extrai uma perfeita dissociação entre as perspectivas interna e externa da fenomenologia representativa: "XII. Sed \& per hominem alterum obligamur, si constet de voluntate nostra qua illum elegerimus, ut instrumentum nostrum ad hoc speciatim, aut sub generali notione. Et in generali praepositione accidere potest, ut nos obliget qui praepositus est agendo contra voluntatem nostram sibi soli significatam: quia hic distinct sunt actus volendi unus quo nos obligamus ratum habituros quicquid ille in tali negotiorum genere fecerit; alter, quo illum nobis obligamus, ut non agat nisi ex Praescripto, sibi non aliis cognito. Quod notandum est ad ea, quae legati promittunt pro regibus ex vi instrumenti procuratorii excedendo arcana mandata" (p. 224); "mas también nos obligamos por medio de otro hombre, si consta de la voluntad nuestra por la cual le elegimos como instrumento nuestro, o para algo especial, o de una manera general. $\mathrm{Y}$ en un nombramiento general puede acaecer que el nombrado para representarnos nos obligue contra nuestra voluntad, sólo de él conocida; porque aquí hay distintos actos de la voluntad: uno por el cual nos obligamos a tener por válido cuanto él hiciere en una determinada clase de negocios, y outro por el cual le atamos a nosotros para que no obre sino conforme a lo stipulado, conocido de él y no de los otros. Lo cual se ha de notar respecto de aquello que prometen los enviados en nombre de los reyes, en virtud del documento de procuración, traspasando los mandatos ocultos" (pp. 184-185).
} 
§ 69. O romanismo de Samuel Pufendorf: a "gratuidade" como essência de um contrato de mandato (ainda) não representativo. De sua parte, S. PUFENDORF oferece uma definição do contrato de mandato construída a partir de materiais recolhidos do direito justinianeu; tomando por base a distinção cimeira entre contratos benéficos (gratuitos) e onerosos, reúne sob a primeira categoria as hipóteses de "mandatum, commodatum, \& depositum". Atribuindo àquele a nota específica da "gratuidade", o autor permanece fiel à estrutura romana não representativa, assim definindo o instituto: "mandatum est, quando quis gratis alterius negotia, ipso requirente, \& committente expedienda suscipit". Referindo-se (indiscriminadamente) ao modelo por meio dos termos "mandement" ou "procuration", já em outra oportunidade - em meio à análise da dicotomia entre "contratos de boa-fé" e "contratos de direito estrito" - o jurisconsulto reitera a importância da amizade e da afeição como fundamentos do tipo contratual mencionado, na medida em que ao mandatário caberia "se charger, sans intérét, \& de pure bonne volonté, des affaires de quelcun, qui nous en prie"; assim, ao mesmo tempo em que preserva a estrutura fundamental do "mandatum" (romano), abre espaço - por meio de uma sutil aproximação

Por sua vez, em sua "Inleydinge tot de Hollandsche Rechts-geleerdheyt" o autor oferece uma definição do contrato de mandato flagrantemente influenciada pelo paradigma romano, não apenas em razão da importância conferida à "gratuidade", mas também em decorrência da atribuição ao mandatário de uma obrigação de transferir o objeto adquirido em cumprimento à incumbência (o que descaracteriza, por si só, uma eficácia representativa direta "ordinária"): "2. Lastgeving ofte last-aenvaerding is een overkoming waer door den eene den andere vertrouwt iet dat gheoorloft is voor hem ofte voor een andré te verrichten, ende den ander om niet zulcks aenneemt (...) is oock ghehouden alle vruchten, winsten ende baten, die hem ter zake van sijne belastinghe eenigsins aenkomen, den lastgever over te gheven, ende de inschulden die hy mag bekomen hebben op hem te verlijden"; "the giving or acceptance of a mandate is an agreement whereby on person confides to another some lawful thing to accomplish for him, or for another, and the other accepts the burden gratuitously (...) he [mandatário] is also bound to make over to the mandator all fruits, profits and advantages which in any way come to him in connexion with his mandate, and to transfer to him all personal claims to which he may have become entitled" (The jurisprudence of Holland I - text translation and notes, Oxford, Clarendon Press, 1938, pp. 353-355).

Com isso, percebe-se que a concepção de H. GROTIUs a respeito do contrato de mandato é toda extraída do "mandatum" romano; a única distinção em relação às suas fontes - e aí já se pode entrever uma espécie de "usus modernus pandectarum" - consiste na ampla admissão da representação direta como regra (e não mais como uma simples exceção). Todavia, mesmo tal peculiaridade não impediu que o jurista exibisse toda a sua perspicácia ao distinguir duas esferas de atuação absolutamente inconfundíveis - vale dizer, a relação jurídica "interna" e a eficácia "erga omnes" decorrente do exercício dos poderes de representação.

Pela importância da obra de H. GrotiUs, em termos gerais, cf. J. A. CoRRIENTE, Hugo Grocio (Huig de Groot, Grotius, Hugo el Grande), in R. Domingo (ed.), Juristas universales II - Juristas modernos (siglos XVI al XVIII: de Zasio a Savigny), Madrid-Barcelona, Ediciones Jurídicas y Sociales Marcial Pons, 2004, pp. 334-342; M. PAulo MerÊA, Suáres, Grócio, Hobbes: lições de história das doutrinas políticas, Coimbra, Armênio Amado, 1941; A. CAUMONT, Étude sur le vie et les travaux de Grotius, ou, le droit naturel et le droit international, Paris, Durand, 1862; Van EYSINGA, Gothofredus e Grotius in La tecnique et les principes du droit public - études em l'honneur de Georges Scelle I, Paris, Libreirie Générale de Droit et de Jurisprudence, 1950, pp. 241-252. 
terminológica - àquela fusão que, algum tempo depois, será promovida por meio da obra de Jean Domat ${ }^{58}$.

${ }^{58}$ A definição transcrita no corpo do texto - fortemente carregada de um elemento tradicional romanístico foi extraída da obra "De officio hominis, et civis secundum legem naturalem libri duo" ( $5^{\mathrm{a}}$ ed., FrancofurtiLipsie, Impensis Henr. Lud. Broenneri, 1758, pp. 250-251). Note-se que este trabalho corresponde a uma espécie de síntese da obra mais ampla de S. PUFENDORF ("De iure naturae et gentium libri octo"), da qual lançamos mão por meio da edição suíça de 1771 (Le droit de la nature et des gens, ou systeme general des principes les plus importants de la morale, de la jurisprudence, et de la politique, Basle, Emanuel Thourneisen, 1771).

Como referido em nota imediatamente anterior, observa-se que a exposição a respeito do contrato de mandato se faz, em ambas as oportunidades, logo após o imediato enquadramento do tipo contratual em meio à categoria dos contratos benéficos (ao lado do depósito e do comodato); assim, a dicotomia estabelecida entre os "contratos onerosos" e os "contratos gratuitos" não é de pouca importância na conformação sistemática de toda a contratualística jusracionalista. Para além desta contraposição, o método dialético também é empregado na construção de uma outra dicotomia (por sua vez derivada daquela primeira), voltada, pois, à distinção entre os "contratos de direito estrito" e os "contratos de boa-fé": "cette distinction semble être le fondement d'une autre, par laquelle on divise les Contracts en Contracts de bonne foi, e Contracts de droit rigoureux: dont les premiers avoient cet effet, par le Droit Romain, qu'ils donnoient action de bonne foi, c'est-à-dire, que le Juge avoit pleine liberté de prononcer selon les maximes de l'Equité; au lieu que les autres ne donnoient qu'action de droit rigoureux, en sorte que le Juge étoit tenu de suivre invariablement certaines formules, \& de se régler sur ce qui avoit été dit ou écrit" (Le droit de la nature et des gens, ou systeme general des principes les plus importants de la morale, de la jurisprudence, et de la politique II, Basle, Emanuel Thourneisen, 1771, pp. 25-26).

Assim, poderia o estudioso ser tomado pela impressão de um comportamento um tanto servil em relação ao direito romano; no entanto, a confrontação do trecho imediatamente seguinte o dissuade imediatamente: "par le Droit même Naturél, les Contracts Onéreux sont manifestement des Contracts de bonne foi, c'est-à-dire, susceptibles d'une interprétation plus étendue, selon les régles de l'Equité; parce que renferment une Obligation égale de part \& d'autre, aucun des Contractans ne se trouve par là surchargé. Au contraire, les Contracts Bienfaisans ou gratuits, n'admettent pas une interprétation si étendue, \& l'on ne peut rien exiger ici de celui qui donne ou qui fait, au delà de ce à quoi il s'est expressément engagé; autrement il en coûteroit trop, pour rendre service aux autres" (p. 26).

Por sua vez, a definição em língua francesa transcrita no corpo do texto - por se situar em obra um tanto mais prolixa - pôde remontar à própria origem do "mandatum"; estribado na amizade e na afeição, quanto a este aspecto particular, tal conceito - que pode causar um certo mal-estar entre alguns juristas contemporâneos (cf. observações de F. ScHULZ transcritas em nota 39, in fine) - permanecia íntegro entre os jusracionalistas, que não vão colocar em xeque a gratuidade como elemento "natural" do tipo contratual mencionado. A respeito, cf. S. PUFENDORF, Le droit de la nature II cit. (nota 58), p. 43.

Por uma análise da personalidade, da metodologia de trabalho e da importância da obra de S. PUFENDORF para o direito que se lhe seguiu, cf. as importantes observações de M. I. RUIZ GALLARDóN: "hombre de extraordinaria voluntad sistemática y espíritu cartesiano, Samuel Pufendorf aplicó en todas sus obras la geometría al estudio de las ciencias morales. Gran parte de su éxito se debió al desarollo metódico de los principios formulados por sus predecesores iusnaturalistas, especialmente Grocio. De este modo, aclaró las tendencias de la llamada Escuela de Derecho natural cuya doctrina básica se contenía en la afirmación de que el único fundamento del Derecho es la razón humana (...) tomó el principio de que el método matemático debe hacerse extensivo a la Ética y al Derecho natural, reivindicando así para las verdades morales aquella certeza que es propria de la geometría (...) su doctrina del Derecho natural recibe un carácter abstracto e antihistórico, propios del iusnaturalismo de la Ilustración (...) la extraordinaria voluntad sistemática de Pufendorf le llevó a considerar en ocho libros los principios generales del Derecho civil, penal, político e internacional, deduciéndolos del principio dominante de la sociabilidad, y partiendo del hombre singular, de sus propiedades y cualidades, sus derechos y obligaciones, pasando por las comunidades más restringidas de la familia, el matrimonio, la sociedad heril, hasta llegar al Estado y la comunidad de los pueblos. Esta sistemática de estructura objetiva iba a servir de modelo a las teorías posteriores del derecho natural ya a los códigos surgidos de ellas, como el derecho general prusiano, y su influencia en la intensa sistemática del Derecho alemán" (Samuel Pufendorf, in R. DoMINGo (ed.), Juristas universales II - Juristas modernos (siglos XVI al XVIII: de Zasio a Savigny), Madrid-Barcelona, Ediciones Jurídicas y Sociales Marcial Pons, 2004, pp. 424-428). 


\section{$\S 70$. A fusão entre o mandato e a procuração operada por Jean Domat: de}

uma simples proximidade funcional a uma autêntica junção estrutural. Diferentemente do que se extrai da obra de S. PufENDORF, a análise de J. DOMAT é caracterizada por algo mais do que uma simples promiscuidade terminológica (decorrente da abordagem simultânea de institutos jurídicos funcionalmente afins); para muito além disso, de sua obra "Les loix civiles dans leur ordre naturel" se pode depreender uma autêntica fusão entre os conceitos de "mandato", "procuração" e "comissão" (considerando-se a primeira expressão uma simples reminiscência denunciativa da noção romana de "incumbência”). Além disso, as definições emprestadas aos termos "procuração" ("la procuration est un acte, par lequel celui qui ne peut vaquer lui-même à ses affaires, donne pouvoir à un autre de le faire pour lui, comme s'il étoit lui-même présent") e "procurador" (“le procureur constitué est celui qui fait l'affaire d'un autre ayant pouvoir de lui") denunciam a plena adoção de um sistema de representação negocial direta; assim, tomado em devida conta o contributo individual de J. DOMAT (no contexto de transição rumo a um direito civil codificado), não resta dúvida quanto ao papel desta sua obra - bem como do "Legum Delectus ex libris Digestorum et Codicis" - na conformação de uma nova concepção sobre o tipo contratual aludido, a qual certamente haveria de influenciar o legislador do "Code Civil" - seja de modo direto, seja por meio dos escritos de Robert Joseph Pothier"

Com efeito, no que concerne ao legado específico de S. PUFENDORF quanto ao contrato de mandato, sua obra ocupa uma posição de destaque por conciliar tradição (quanto aos aspectos estruturais) e inovação (quanto ao perfil funcional do instituto); por meio de sua ligeira abertura terminológica a uma promiscuidade entre "mandement" e "procuration" (cf. Le droit de la nature II cit. (nota 58), p. 25), o autor efetivamente abriu espaço à fusão promovida, em um momento posterior, por Jean Domat, jurista de cuja obra nos ocuparemos a seguir.

${ }^{59}$ A fusão entre os conceitos de "procurador" e "mandatário" - tão distintos para o direito romano clássico pode ser depreendida não apenas da denominação conferida ao Título XV ("des procurations, mandemens \& commissions") do Livro I ("des engagemens volontaires \& mutuels par les conventions") da Primeira Parte ("des engagemens, \& de leurs suites") da obra "Les loix civiles dans leur ordre naturel; le droit public, et legum delectus"; também a própria apresentação do título feita por J. DOMAT é elucidativa do intuito de unificar a disciplina aplicável às procurações, mandatos e comissões: “c'est cette espece de convention, \& ces engagemens, qui seront la matiere de ce Titre (...) et comme les regles des procurations sont presque toutes communes aux commissions, \& aux autres manieres semblables de commettre \& préposer une personne à la place d'une autre; il sera facile d'appliquer à chacune ce qui sera dit des procurations" (Les Loix civiles dans leur ordre naturel; le droit public, et legum delectus I, Paris, Nyon ainé, 1777, pp. 221222).

Observe-se que é próprio autor que considera a utilização do termo "mandato" uma espécie de tributo ao legado jurídico romano (e à noção romana de "incumbência”): “on a ajouté dans l'intitulé de ce Titre, le mot de Mandement, parce que c'est le mot du Droit Romain, qui signifie les procurations, \& que dans notre usage il signifie aussi une maniere de donner quelque ordre (...) le Mandement en ce sens est une espece de convention de la nature de celles qui sont la matiere de ce Titre" (Les loix cit. (nota 59), p. 222). Por sinal, pelas definições de "procuração" e "procurador" transcritas no corpo do texto, cf. Les loix cit. (nota 59), p. 222 . 


\section{$\S$ 71. Georg Adam Struvi, Christian Wolff e uma (nova) definição}

"representativa" do contrato de mandato. A abordagem das obras de G. A. STRUVI e C. WOLFF é importante por denunciar um cenário de transição rumo àquela conformação do "mandat" assumida no "Code Civil"; com efeito, ainda que o primeiro autor tenha dedicado suas obras mais tardias ao estudo de algumas questões pontuais do sistema de direito civil (v. g., "Evolutiones controversiarum in Syntagmate iuris civilis comprehensarum"), de seu "Syntagma Iurisprudentiae Secundùm ordinem Pandectarum" se pode extrair uma definição do tipo contratual alusiva aos efeitos representativos (diretos) que ordinariamente haveriam de defluir da atuação do mandatário: "mandatum est contractus, quo rogante \& committente aliquo, negotium nomine ejus gerendum, quis gratis suscipit”. Por sua vez, C. WOLFF - após distinguir cuidadosamente os conceitos (e os respectivos efeitos) de "commendare", "rogare" e "mandare" - não se satisfaz com uma definição do instituto por meio da qual simplesmente se reconheça, de modo lânguido, sua eficácia representativa ordinária ("mandatum est contractus beneficus, quo alteri quid

Note-se que a obra de J. DOMAT corresponde a uma manifestação do "usus modernus pandectarum", na medida em que o sistema desenvolvido pelo autor (à custa do emprego da "razão natural") tem como material constitutivo o acervo consubstanciado no "Corpus Iuris Civilis"; neste sentido, é bastante proveitoso o contato direto com a referida obra, eivada de alusões a textos romanos, ainda que por vezes submetidos a uma interpretação relativamente tendenciosa. De toda forma, remete-se o leitor à análise direta do texto referido (Les loix cit. (nota 59), pp. 221-230). Aliás, cabe uma menção especial àquele extrato das fontes romanas (sobretudo do Digesto) providenciado pelo próprio autor, publicado postumamente sob o título "Legum delectus ex libris Digestorum et Codicis"; com efeito, não é por acaso que o subtítulo da obra alude ao emprego prático que se deveria fazer do material então coligido ("ad usum scholae et fori; accesserunt singulis legibus suae summae earum sententiam brevi complexae").

Por um apanhado bio-bibliográfico a respeito de J. DOMAT, cf. B. BAUDELOT, Un grand jurisconsulte du XVII siècle: Jean Domat, Paris, Universitè de Paris (Thèse de Droit), 1939; R.-F. VoElTZEL, Jean Domat (1625-1696): essai de reconstitution de sa philosophie juridique, précédé de la biographie du jurisconsulte, Paris, Sirey, 1936; F. TODESCAN, Il problema della secolarizzazione nel pensiero giuridico di Jean Domat, Milano, Giuffrè, 1987. Merece destaque, ainda, o estudo de M. Á. PÉREZ ÁlVAREZ, do qual se podem extrair as seguintes conclusões: "por lo que a su obra si rifiere, frente a la diversidad que caracteriza al derecho en el periodo histórico en que escribe - ordenanzas reales, Derecho romano, costumbres locales, jurisprudencia -, Domat realiza la primera sistematización doctrinal, de inspiración iusnaturalista y racionalista, del Derecho privado y público francés. Y es que para Domat la luz de la razón permite al hombre conocer las reglas comunes de la justicia y la equidad. Pero, a diferencia de otros autores de la época, el recurso a la razón no excluye el hecho de que el sistema que Domat construye tenga su asentamiento en el Derecho natural (...) por lo que respecta a les loix civiles dans leur ordre naturel, la construcción de Domat se fundamenta en el Derecho romano, ya que se considera que en éste se encuentran casi todas las reglas naturales del Derecho privado. Por ello, su exposición va acompañada de la cita a los textos correspondientes del derecho romano, dándoles 'toda su extensión por los principios sacados del Derecho natural' (...) además de su importancia para la ciencia jurídica, Les loix civiles dans leur ordre naturel - publicada en tres volúmenes entre 1689 y 1694 - será una de las obras que facilitarán notablemente las labores de codificación del Derecho civil francés - directa e indirectamente a través de la exposición del derecho romano en que se fundamenta y de la obra de Pothier. Por otra parte, en el libro preliminar se inspirará Portalis para realizar lo que sería el Titre Préliminaire del Code y se le considera un notable antecedente de lo que después constituiría la llamada 'Parte Geral' del derecho civil" (Jean Domat, in R. DoMINGo (ed.), Juristas universales II - Juristas modernos (siglos XVI al XVIII: de Zasio a Savigny), Madrid-Barcelona, Ediciones Jurídicas y Sociales Marcial Pons, 2004, pp. 409-411). 
nostro nomine faciendum committitur \& commissum ab eo gratuito suscipitur"); mais do que isso, o jurisconsulto ressalta - de maneira inequívoca - que "enimvero quicquid facit mandatarius, non suo nomine, sed mandantis unice nomine facit”. Assim, ainda que a ruptura com o modelo justinianeu não seja completa (à vista da preservação de uma "gratuidade" inerente ao tipo) - e nem mesmo acompanhada de um completo abandono da terminologia romana - percebe-se que aquela junção estrutural pretendida por J. DOMAT vai encontrar aqui um ambiente consideravelmente propício à mais ampla ressonância ${ }^{60}$.

${ }^{60}$ Observe-se que foi no "Syntagma Jvrisprvdentiae, Secundùm ordinem Pandectarum" que encontramos a
mais antiga definição do contrato de mandato alusiva a uma eficácia representativa ordinária. Aliás, pela
transcrição constante do corpo do texto, cf. G. A. STRUVE, Syntagma Jvrisprvdentiae Secundùm ordinem
Pandectarum concinnatvm qvo solida jvris fvndamenta tradvntvr Digestorvm, et affines Codicis, novellarvm
ac jvris canonici titvli methodice explicantvr, controversiae nervose resolvuntvr, qvid in foro vsvm habeat -
Pars Tertia Pandectarvm (Libro XII. usq ad Lib. XX), Francofvrti et Lipsiae, Ioannis Hoffmanni, 1692, p.
1427. Observe-se, ainda, que em outras oportunidades da mesma obra o autor reitera a posição assumida de
início: "forma hujus contractus consistit in consensu mutuo super negotio, quod quis gratis suô nomine
gerendum committit, \& alter ita commissum suscipit (...) dicimus nomine mandantis gerendum: sive quis
mandet suâ tantùm gratiâ" (Syntagma Jvrisprvdentiae cit. (nota 60), pp. 1431-1433) Com efeito, em obra posterior - "Evolvtiones Controversiarvm in Syntagmate Ivris Civilis" - G. A. STRUVE vai se voltar a alguns aspectos específicos sobre a disciplina do contrato de mandato, alguns dos quais terão repercussão, inclusive, no âmbito do direito moderno - vide, por exemplo, a questão "an si Dominus laesus fuerit per procuratorem, \& fortè procurator non sit solvendo, possit Dominus uti beneficio restitutionis in integrum?", como hipótese de extensão (excepcional) dos efeitos da relação interna (entre mandante e mandatário) ao adversário do representado litigante (Evolvtiones Controversiarvm in Syntagmate Ivris Civilis, ab ipso olim in Academia Ienensi adornato, comprehensarum, nec non Resolvtiones Dubiorum \& Textuum obstantium ibi allegatorum, Francofvrti et Lipsiae, Matthaevm Bircknervm, 1684, pp. 121-122). Teremos a oportunidade de observar que o direito brasileiro contemporâneo, por exemplo, contém uma disposição em sentido semelhante à doutrina preconizada pelo aludido jurisconsulto (art. 119).

No que toca a uma apreciação da obra de G. A. STRUVE em seu conjunto, eis a oportuna síntese de R. DOMINGO: "su grande aportación a la ciencia jurídica consistió en mostrar la jurisprudencia como un habitus practicus que requería en todo caso una constante accommodatio in civili societate, y no sólo como un mero reconoscimento de las reglas jurídicas aplicables. No es estraño, pues, que haya sido considerado como un precursor de la "jurisprudencia práctica"' (Georg Adam Struve, in R. DoMINGO (ed.), Juristas universales II Juristas modernos (siglos XVI al XVIII: de Zasio a Savigny), Madrid-Barcelona, Ediciones Jurídicas y Sociales Marcial Pons, 2004, p. 400).

Já no que concerne à obra de C. WOLFF, é necessário observar que o autor pretende distinguir, a propósito da análise do contrato de mandato, os efeitos diversos de "commendare", "rogare" e "mandare", uma vez que "quoniam qui commendat, vel rogat, non contrahit, qui vero mandat contrahit; qui commendat, vel rogat, non mandat" (Jus Naturae Methodo Scientifica per Tractatum - Pars Quarta: de actibus ad aliorum utilitatem tendentibus in specie, ubi agitur de donationibus, et de contractibus tam beneficis, quam onerosis praecipuis, et nunc primum cum viri Cl. de Vattel animadversionibus, Francofurti et Lipsiae, Aere Societatis Venetae, 1765, p. 205). Por oportuno, a respeito dos trechos da obra de C. WolfF transcritos no corpo do texto, cf. Jus Naturae cit. (nota 60), pp. 203 e 206 ( $\$ 640$ e 649).

Atribuindo-se-lhe a distinção entre os conceitos de "direito das gentes voluntário", "direito das gentes estipulativo" e "direito das gentes consuetudinário", no que tange ao legado geral de sua produção jurídica, eis a conclusão de F. CARPINTERO e J. J. MEGías QuiRós: "su modo de introduzir las teorías modernas a través de las premisas más clásicas parece haber seducido irresistiblemente. Todos los que habían leído a Spinoza, Descartes, Locke y Hobbes y no quedaron tranquilos, encontraron en la filosofia wolffiana el sosiego idel y cómodo a sus escrúpulos. La influencia y la difusión fulminante de la enseñanza wolffiana es una prueba de que el deseo de adaptar el edificio filosofico antiguo a la Modernidad estaba más difundido en la Europa protestante y católica del siglo XVIII de lo que se admite generalmente" (Christian Wolff, in R. DomINGO (ed.), Juristas universales II - Juristas modernos (siglos XVI al XVIII: de Zasio a Savigny), Madrid-Barcelona, Ediciones Jurídicas y Sociales Marcial Pons, 2004, pp. 517-518). 
$\S$ 72. A doutrina de Johaniss Voet e o reconhecimento de um "usus modernus pandectarum" aplicado ao contrato de mandato: aspectos de uma prática voltada à absorção de uma modalidade representativa do referido tipo contratual. Diferentemente do que se verifica nas obras de J. Domat, G. A. STRUvi e C. WolfF, a análise do contrato de mandato realizada por J. VOET é caracterizada por uma escrupulosa utilização das fontes romanas; não sendo de causar maior supresa, pois, uma definição naturalmente comprometida com a noção defluente do "Corpus Iuris Civilis": "est autem mandatum contractus bonae fidei consensu constans, qua negotium honestum alteri id suscipienti gratis gerendum committitur". No entanto, a obra do jurista holandês apresenta algumas peculiaridades que exigem uma cautela especial do estudioso que lhe é devotado. De fato, os "Commentariorum ad Pandectas" correspondem a uma das mais bem-acabadas manifestações do "usus modernus pandectarum" europeu; desta forma, ao mesmo tempo em que se reconhece a autoridade das fontes justinianéias, abre-se espaço para o influxo de (novas) práticas, mais comprometidas com as necessidades ostentadas pelo meio social circundante: "quas tamen nostris moribus cedi haud opus, quoties mandatarium non suo, sed mandantis nomine contraxisse, expressum est; quia procuratores hodie in negotiis contrahendis considerantur magis ut nuncii, et quisque nunc alteri aeque ac sibi actionem quaerit". Eis a explicação, portanto, para a coexistência de tão diferentes concepções a respeito de um mesmo instituto jurídico; viabilizando-se, assim, uma - "profícua" contraposição entre o "tradicional" e o "novo", em um "potencial” entrechoque que permeará o desenvolvimento dos trabalhos legislativos que redundarão na redação definitiva do art. 1.984 do "Code Civil"

\footnotetext{
${ }^{61}$ Como bem observa E. LÓPEZ-JACOISTE DíAZ: "los fallidos intentos por parte de las autoridades de Utrecht de contar (...) con el citado profesor entre su claustro, facilitaron a Voet la ampliación de sus funciones docentes en el ámbito del ius hodiernum, es decir, el estudio de los usos y costumbres propias del incipiente Derecho civil holandés (...) los resultados de su investigación y docencia se pueden apreciar en su obra maestra: Commentarius ad Pandectas (1698-1704), que fueron reeditados con posterioridad en La Haya en 1731. En cada uno de sus títulos no sólo se exponen las bases del Derecho romano desde la antigüedad hasta su época, sino que además se recoge la tradición del ius hodiernum" (Johannes Voet, in R. Domingo (ed.), Juristas universales II - Juristas modernos (siglos XVI al XVIII: de Zasio a Savigny), Madrid-Barcelona, Ediciones Jurídicas y Sociales Marcial Pons, 2004, pp. 465-466).

Com efeito, a obra de J. VOET consubstancia uma comparação efetiva e clara entre o direito tradicional (romano) e as tendências defluentes do evolver de novas necessidades oriundas do próprio seio social, articuladas por meio de práticas informantes de um "direito novo"; eis a tradução italiana dos trechos latinos transcritos no corpo do texto, obtidas à custa do trabalho de Leone Fortis: "il mandato è un contratto di buona fede e consensuale, mercè cui uno commette ad un'altra persona, che gratuitamente accetta, di assumere la gestione di affare onesto (...) queste azioni ["actio mandati directa"] per altro, secondo le nostre costumanze, non fa d'uopo sieno cedute qualora fu espresso che il mandatario contrattava non in nome suo ma in nome del mandante; conciossiachè oggigiorno $i$ procuratori nel fare $\mathrm{i}$ contratti vengono consideratti piuttosto quali messi, e chiunque ora può acquistare un'azione per altrui del pari che per sè" (Commentariorum ad
} 
$\S$ 73. Os projetos que redundaram no "Code Civil" e os trabalhos preparatórios da codificação: de uma generalização da variante representativa à "essencialização" da representação (direta) no contexto do mandato. No que concerne aos trabalhos legislativos que redundaram no "Code Civil" - especificamente no que tange à disciplina articulada quanto ao contrato de mandato - algumas observações, ainda que ligeiras, devem ser feitas: a) em primeiro lugar, cumpre destacar que o projeto submetido à apreciação parlamentar foi aquele oferecido em 24 thermidor do ano VIII (1800), no qual se articulara uma concepção de mandato "essencialmente" representativa, à semelhança da que propusera Jean-Jacques-Régis de Cambacérès no primeiro Projeto de Código Civil por este apresentado; b) todavia, malogrado em sua primeira tentativa, este jurisconsulto encaminhou duas outras versões (reformuladas) à Convenção Nacional, sendo que de ambas constava uma mesma definição de mandato, forjada sob a influência do modelo justinianeu; c) a análise dos trabalhos preparatórios revela que a aprovação do texto final se deu de maneira sumária - em sucessivas sessões do Conselho de Estado (23 de fevereiro de 1804) e do Corpo Legislativo (10 de março de 1804) - sem que tenham sido debatidos (ou sequer confrontados) o paradigma romano tradicional e a concepção representativa então proposta; d) em reiteradas oportunidades se observa que o mandato é o resultado social de uma necessidade "natural" de substituição do principal (decorrendo o instituto, portanto, da própria "natureza das coisas"). Assim, o “entrechoque" há pouco aludido restou, afinal, em um estado meramente "latente"; principalmente em decorrência do tortuoso processo legislativo que circundou a aprovação do texto final de cada dispositivo (inclusive o art. 1.984). De todo modo - ainda que se possa sustentar polêmica a respeito da maior conformidade à "recta ratio" de um modelo ou de outro - a consagração da estrutura romana pelos dois derradeiros projetos de Jean-Jacques-Régis de Cambacérès é suficiente, por si só, para que se possa infirmar a assertiva da Comissão Governamental no sentido de que - em matéria de contratos - seus trabalhos se tinham limitado à simples

Pandectas libri quinquaginta, in quibus, praeter romani juris principia c controversias illustriores, jus etiam hodiernum, et praecipuae fori quaestiones excutiuntur, trad. it. de Leone Fortis, Commento alle Pandette di Giovanni Voet, giureconsulto e professore nella Università di Leida, libri Cinquanta, ne'quali, oltre $i$ principii e le più insigni controversie del diritto romano, si disaminano il diritto moderno e le principali quistioni del foro II, Venezia, Pietro Naratovitch, 1847, pp. 741-750).

Observe-se, pois, que tal posicionamento de J. VOET se destaca em meio à produção dos próprios expoentes da "Jurisprudência Elegante"; em termos comparativos, por exemplo, é de se destacar que a definição de G. NOODT é bastante mais simples (e comprometida com as estritas bases do paradigma justinianeu): "est vero mandatum (...) contractus juris gentium, bonae fidei, consensu constans, de negotio, mandatoris periculo, gratis gerendo" (Opera omnia III, Neapoli, Fratres Terres, 1786, p. 57). Daí a importância da obra de J. VOET em um contexto de transição rumo à admissão de um novo modelo de contrato de mandato - provido de uma "nota típica" comprometida com a eficácia representativa (direta) da atuação do agente. 


\section{reprodução de diretrizes comuns; ou para adotarmos os termos utilizados pelo próprio}

Conselho: "sur cette matière, nous n'irons jamais au-delà des principes qui nous ont été transmis par l'antiquité, et qui sont nés avec le genre humain" ${ }^{\text {"62 }}$.

${ }^{62}$ Estruturado em quatro livros (I - do estado das pessoas; II - dos bens; III - dos contratos; IV - das ações), o
primeiro Projeto de Código Civil - apresentado por Jean-Jacques-Régis de Cambacérès - ostentava uma
definição do contrato de mandato bastante inovadora, na medida em que incorporava a representação direta
como efeito ordinário do tipo contratual, ao mesmo tempo em que expurgava a gratuidade do rol de seus
elementos essenciais: "le mandat ou procuration est un acte par lequel on constitue un mandataire ou
procureur pour gérer ou contracter en son nom" (cf. P. A. FENET, Recueil I cit. (nota 54), p. 91).
Posteriormente, Jean-Jacques-Régis de Cambacérès ofereceu dois novos projetos que, adaptados em alguns
aspectos - vide a abolição de um livro especificamente dedicado às ações - ostentavam as linhas gerais do
primeiro trabalho. No entanto, em matéria de "mandat", a concepção adotada era bastante mais conservadora,
uma vez que não mais se proclamava (ao menos expressamente) a atuação do mandatário em nome do
mandante: "le pouvoir de gérer les affaires d'autrui se confère par le mandat"; este era o teor dos artigos 261
(20 Projeto de Cambacérès) e 1063 ( $3^{\circ}$ Projeto de Cambacérès) (cf. P. A. FENET, Recueil I cit. (nota 54), pp.
135 e 319). Todavia, no Projeto definitivo (Projet de l'an VIII) - note-se que o Projeto de Jacqueminot não dispunha a respeito da questão - a concepção representativa do mandato novamente veio à tona, prevalecendo aquela definição do primeiro Projeto de Cambacérès, com ligeiras alterações redacionais (a destacar a conferência de poder pelo mandante): "le mandat ou procuration est un acte par lequel quelqu'un donne pouvoir à un autre de faire pour lui et en son nom, une ou plusiers affaires" (cf. P. A. FenET, Recueil II cit. (nota 54), p. 392). Conquanto não tenha sido esta a redação que prevaleceu afinal, desde logo se pode perceber a preponderância do elemento representativo em meio à estrutura geral do tipo contratual aludido.

É de se notar que nenhuma espécie de ressalva foi feita acerca da "revolução" operada quanto à eficácia ordinária (e quanto à definição da "causa-função") do referido contrato: nem a Corte de Cassação ofereceu qualquer observação a respeito do teor do art. 1.984 da versão afinal promulgada (cf. P. A. FENET, Recueil II cit. (nota 54), p. 740); nem mesmo em sede de discussão parlamentar se pronunciou uma única palavra a respeito do tema. Neste sentido, prevaleceu o absoluto silêncio: seja por ocasião da discussão do projeto no Conselho de Estado (5 pluviose an XII/26 de janeiro de 1804), seja ainda quando de sua apresentação ao Corpo Legislativo (19 ventose an XII/10 de março de 1804) - cf. a respeito P. A. FENET, Recueil XIV cit. (nota 54), pp. 572, 579, 584, 591 e 605.

Sobre a base natural em que se alicerça o contrato de mandato, eis a manifestação de Berlier: "s'il est dans les affections naturelles de l'homme et dans l'ordre commun de ses habitudes qu'il pourvoie lui-même à ses propres affaires, les maladies, l'absence, les obstacles de tout genre qui prennent leur source et dans la nature et dans l'état social l'obligent souvent à confier à autrui ce que tant de causes viennent l'empêcher de faire en personne. De là le mandat, objet du titre que nous venons vous présenter aujourd'hui” (cf. P. A. FENET, Recueil XIV cit. (nota 54), p. 584). Adotando a mesma linha de raciocínio, o tribuno Bertrand de Greuille acrescenta uma observação que nos permite considerar a representação direta - seja pela via da "procuração", seja mesmo pela via do "mandato" - plenamente difundida no ambiente francês imediatamente anterior à própria codificação: "l'acte qui contient cette transmission de pouvoirs s'appelle procuration ou mandat, et son usage très-habituel dans la société atteste toute son importance et son utilité" (cf. P. A. FENET, Recueil $X I V$ cit. (nota 54), p. 605).

Ora, o que merece destaque é a "completa" ausência de discussão a respeito de tão importante alteração; diante de tamanha omissão, somos compelidos a crer - com base no discurso de Bertrand de Greuille cotejado com a doutrina de J. DOMAT - que distinção entre "mandato" e "procuração" fosse simplesmente uma questão terminológica, já completamente desprovida de maior sentido prático. Se tal conjectura merecer acolhida, teremos que o "Code Civil" nada mais fez senão referendar, em termos legislativos, uma tendência que já poderia ser divisada na praxe de então.

De toda forma, em sentido contrário temos os dois derradeiros projetos de Cambacérès. E é exatamente este fato que - atrelado à "tranqüilidade" com que se pronunciaram os membros da comissão elaboradora do Projeto de Código (em seu "Discurso Preliminar") - deixa aberta ao estudioso a porta para uma ulterior investigação: se ainda pode restar dúvida legítima quanto às proporções inovadoras do "Code Civil" (a respeito da estrutura do contrato de mandato), por outro lado é absolutamente inconteste que especificamente quanto a este tipo contratual - não foram observadas as bases históricas a que os legisladores expressamente se reportaram no "Discours Préliminaire" (cf. P. A. FeNET, Recueil I cit. (nota 54), p. 517). 
$\S$ 74. A posição intermediária de Johann Gottlieb Heineccii: pela admissibilidade generalizada de uma representação negocial (ainda) extrínseca ao contrato de mandato; sua peculiar importância para o objeto de nossa análise. A obra de J. G. HEINECCII merece uma consideração específica ao cabo do presente capítulo, não somente em virtude de sua importância quanto à formação da mentalidade jurídica imediatamente posterior às reformas pombalinas do ensino do direito (as quais serão objeto de uma análise mais detida em capítulo apropriado do presente trabalho), como também em decorrência de sua singular posição, intermediária em relação aos dois modelos de mandato especificamente tomados em consideração neste item. Assim, se por um lado a "gratuidade" e a ausência de efeitos representativos imediatos parecem decorrer da definição e da conformação do instituto adotadas pelo autor (uma vez que este considera obrigação do mandatário transmitir a propriedade sobre a coisa adquirida durante o efetivo exercício da incumbência), de outra banda se surpreende não apenas uma admissão irrestrita da representação negocial (direta) - a envolver, a um só tempo, a aquisição de posse, domínio e obrigações - mas também uma sua origem atrelada ao próprio tipo contratual referido: "mandatum enim efficit, ut, quod per alium fecimus, id ipsi fecisse videamur"; e daí a evidência de uma contradição entre trechos distintos de uma mesma obra - na qual, segundo entendemos, parece inexistir uma firme tomada de posicionamento a respeito da questão ${ }^{63}$.

\footnotetext{
${ }^{63}$ Pela perspectiva tradicional quanto à definição e aos efeitos ordinários do contrato de mandato, eis a posição de J. G. HEINECCII: "quid sit mandatum, definitio ostendit. Est enim contractus consensualis, quo negotium honestum, ab alio ex fiducia commissum, gratis administrandum gerendumque suscipitur (...) illa agit mandans adversus mandatarium ad negotium perficiendum, rationes reddendas, rem ex mandato adquisitam tradendam, damnum praestandum, ut paucis dicamus, ad omne id, ad quod mandatarius ex contractu obligatus est" (Recitationes in Elementa Juris Civilis secundum ordinem Institutionum, Conimbricae, Typis Academicis, 1817, pp. 371 e 374); ou na tradução de Luis de Collantes y Bustamante: "que cosa sea mandato, lo manifiesta la definición. Es un contrato consensual por el cual uno se encarga de administrar y dirigir gratuitamente un negocio honesto que otro le encomienda por la confianza que en él tiene (...) por aquella [actio mandati directa] obra el mandante contra el mandatario para que se concluya y desempeñe el negocio, se den cuentas, se entregue la cosa adquirida por el mandato, se presten los daños, en una palabra, para todo aquello á que el mandatario está obligado por el contrato" (Recitationes in Elementa Juris Civilis secundum ordinem Institutionum, trad. cast. de Luis de Collantes y Bustamente, Recitaciones del derecho Civil Romano II, $8^{\mathrm{a}}$ ed., Valencia, Librería de Pascual Aguilar, 1888, pp. 125 e 128).

No entanto, ao se reportar à representação - em tópicos intitulados "por que pessoas podemos adquirir" e "por meio de que pessoas podemos adquirir uma obrigação" - o autor adota uma posição um tanto mais "moderna": "attamen cum alter alteri mandare possit, ut hoc vel illud faciat, merito recepta est regula, per procuratorem nostrum et dominium et possessio nobis adquiri potest, $\S 5$ Inst. h. t. Mandatum enim efficit, ut, quod per alium fecimus, id ipsi fecisse videamur (...) atqui per quas personas nobis aliae res adquiruntur, per easdem etiam adquiritur obligatio" (Recitationes in Elementa cit. (nota 63), pp. 226 e 381); "pudiendo uno mandar á otro que haga esto ó aquello, con razón se ha establecido la regla de que por medio de nuestro procurador y por nuestro mandato, podemos adquirir el dominio y la posesión, § 5 Inst. h. t. Pues el mandato es causa de que se entienda que hacemos nosotros mismos lo que hacemos por medio de otro" (Recitaciones del derecho cit. (nota 63), pp. 293 e 136).
} 
$\S 75$. Encerramento do capítulo e apresentação do tema sucessivo. Assim, tivemos a oportunidade de observar de que modo a doutrina jusracionalista possibilitou uma alteração quanto à conformação interna do contrato de mandato; em detrimento de outros elementos potencialmente atrelados à sua "nota típica", a eficácia representativa direta exsurge como "causa-função" deste tipo contratual, de conformidade com o sistema delineado pelos arts. 1.984 e seguintes do Código Civil francês. Esse foi o panorama que pudemos construir a partir de um quadro consideravelmente amplo (sobretudo quanto aos seus respectivos quadrantes espaço-temporais); de agora em diante, voltaremos nossa atenção às vicissitudes experimentadas pelo instituto em um contexto bastante mais específico, vale dizer, o direito luso-brasileiro.

Desta forma, parecem de difícil conciliação os dois trechos da obra de J. G. HEINECCII, uma vez que em um dos casos se admite uma eficácia representativa (direta) generalizada do contrato de mandato ( $\$ 482$ ), ao passo que não se o admite ao se tratar, minudentemente, dos efeitos do tipo contratual aludido ( $\$ 991$ e 992 ). Assim, consideramos que para superar tal contradição seria necessário um esforço hermenêutico considerável, que tomasse por ponto de partida uma referência de J. G. HEINECCII à idéia de entrega ("tradendam") em uma acepção extremamente ampla - de modo que de tal expressão se afastasse a idéia de transferência de propriedade.

Contudo, ainda que uma tal interpretação nos pareça sedutora - à vista da posição de conforto resultante de uma harmonização entre trechos destoantes de uma mesma obra - a ela não nos filiamos, não apenas em virtude da pertinência de tais excertos a partes "distintas" de uma mesma obra, como também da recusa que manifestamos a respeito de uma utilização larga do termo "tradendam" por J. G. HEINECCII; preferimos a companhia de V. ARANGIO-RUIZ que, pronunciando-se a respeito das contradições entre diversos trechos do "Corpus Iuris Civilis" (a respeito do contrato de mandato), observa que "a parte i numerosi casi nei quali, in confronto di compagni di lavoro che hanno voluto saper troppo, dovremo rassegnarci ad esercitare l'umile ma prudente ars ignorandi, dovremmo anche abituarci a fare i conti con cerchi le cui circonferenze s'intersecano, per modo che certi settori risultano appartenenti a più d'uno. È questo, d'altronde, un fenomeno che nel diritto romano classico, risultante dal reciproco aggiustamento di tanti e diversi sistemi di norme, è ben più frequente di quel che generalmente si creda" (Il mandato cit. (nota 25), p. 2).

Pela biografia de J. G. HEINECCII e a respeito de seu legado para os estudos de direito romano que lhe sucederam, cf. P. de P. CONTRERAS, Johann Gottlieb Heinecke (Heineccius, Heinecio), in R. DomingO (ed.), Juristas universales II - Juristas modernos (siglos XVI al XVIII: de Zasio a Savigny), Madrid-Barcelona, Ediciones Jurídicas y Sociales Marcial Pons, 2004, pp. 522-524. Acerca de sua importância no âmbito da ciência jurídica luso-brasileira, manifestaremo-nos oportunamente. 


\section{PARTE SEGUNDA: HISTORIOGRAFIA LUSO-BRASILEIRA (A EVOLUÇÃO DO CONTRATO DE MANDATO NO DIREITO LUSO- BRASILEIRO).}

$\S$ 76. Itinerário da abordagem histórica a ser promovida: aspectos especialmente vinculados ao contexto luso-brasileiro. Superada a análise panorâmica, passaremos a nos deter sobre a disciplina da relação entre o contrato de mandato e a representação negocial segundo as principais fontes do direito luso-brasileiro. Iniciaremos nossa incursão pela trilha adotada pelo direito romano vulgar, ao ensejo da dominação visigoda: pretenderemos abordar, assim, algumas disposições do Código de Eurico (476 d.C.), do Breviário de Alarico (506 d.C) - sobrelevando a influência nele contida do Código Teodosiano, da Epítome de Gaio, das Sentenças de Paulo, bem como de algumas constituições imperiais e manifestações esparsas da jurisprudência - e do "Código Visigótico" (654 d.C), com especial ênfase a este último diploma, considerada a sua posição de manifestação sintética e pretensamente última do direito visigótico (L. II, Tít. I, 1. 9).

$\S$ 77. Itinerário da abordagem histórica a ser promovida: aspectos especialmente vinculados ao contexto luso-brasileiro (cont.). Em seguida, abordaremos algumas das manifestações (sobre a relação entre o contrato de mandato e a representação negocial) constantes das fontes responsáveis pela primeira etapa da introdução do direito romano justinianeu (renascido) em Portugal; neste passo, serão examinadas algumas obras do Mestre Jácome das Leis (as "Flores de Derecho", o "Dotrinal” e a "Summa delos noue tienpos delos pleytos”) e certas disposições atribuídas a D. Afonso X (o Sábio), constantes do "Fuero Real", do "Espéculo" e das "Siete Partidas". Logo após, já tendo em vista um segundo estágio do processo de recepção do direito justinianeu em Portugal, analisaremos o impacto da Provisão de 13 de abril de 1361 (bem como de outros documentos sucessivos), que evidencia um movimento de repulsa às fontes castelhanas (como mecanismo de intermediação do acesso ao direito romano imperial); como teremos a oportunidade de demonstrar, é neste contexto de transição que o direito romano vulgar quedará substituído, em uma espécie de preparação à expressa adoção das fontes justinianéias como elemento subsidiário no âmbito do direito lusitano.

$\S$ 78. Itinerário da abordagem histórica a ser promovida: aspectos especialmente vinculados ao contexto luso-brasileiro (cont.). Em um terceiro estágio de nossa investigação sobre a evolução histórica do contrato de mandato luso-brasileiro, 
buscaremos analisar as disposições do direito lusitano medieval e moderno afetas à disciplina do tipo contratual referido; no que toca à variante extrajudicial do instituto, particular atenção será dedicada à temática do direito subsidiário, concebido como supedâneo nas hipóteses de omissão da legislação portuguesa a respeito de certa questão (inclusive de natureza civil). Constataremos, pois, que diante do silêncio das fontes lusitanas a respeito do mandato extrajudicial, haveriam de ser observadas as disposições romanas atinentes ao caso, eis que reputadas - à vista da "boa razão" na qual haviam sido inspiradas - o instrumento mais adequado à superação das deficiências do sistema então vigente.

$\S$ 79. Itinerário da abordagem histórica a ser promovida: aspectos especialmente vinculados ao contexto luso-brasileiro (cont.). Já na quarta etapa de nossa incursão pelo direito luso-brasileiro aplicável ao contrato de mandato, voltaremos nossa atenção ao estudo do impacto da Lei de 18 de agosto de 1769 (Lei da Boa Razão) sobre a aplicação do direito romano em caráter subsidiário ao sistema lusitano; teremos a oportunidade de compreender, então, de que forma aquele direito que outrora constituíra o manancial de uma tradição (introduzida desde há muito no ambiente lusitano), fora despojado de sua autoridade exatamente em função do anacronismo que, não inteiramente sem razão, se lhe atribuía de maneira genérica. De qualquer forma, perceberemos que as fontes de colmatação do sistema passam, gradativamente, a ser outras, em um movimento que culminará, logo adiante, na adoção de modelos especificamente influenciados pelo Código Civil francês - que a cada dia ampliava a sua esfera de influência na Europa e em outros contextos mundiais.

\section{$\S$ 80. Itinerário da abordagem histórica a ser promovida: aspectos} especialmente vinculados ao contexto luso-brasileiro (cont.). Paralelamente a esse quadro aplicável ao direito privado, observa-se que, paulatinamente, vai se forjando um ambiente propício à Independência do Brasil, afinal proclamada no ano de 1822. Contudo, antes que a separação política efetivamente se desse, houve tempo para a preparação de caminhos próprios a serem seguidos pela metrópole e pela colônia; teremos a oportunidade de verificar, pois, de que forma as obras dos principais jurisconsultos portugueses (posteriores às reformas pombalinas da aplicação e do ensino do direito) foram influenciadas pelo "mandat" francês, enquanto se preparava a edição de um Código Civil que, no ano de 1867, consagraria um mandato essencialmente representativo. 
$\S$ 81. Itinerário da abordagem histórica a ser promovida: aspectos especialmente vinculados ao contexto brasileiro (cont.). Entretanto, como demonstraremos na sexta parte de nossa incursão específica, a delonga na promulgação de nossa primeira codificação civil proporcionou um ambiente favorável à ampla discussão sobre a oportunidade da adoção de um modelo de mandato essencialmente representativo; após uma série de anteprojetos, ora mais comprometidos com o paradigma representado pelo "mandatum" romano, ora mais influenciados pelo clichê do "mandat" francês, foi promulgado um diploma no qual se consagrava, a um só tempo, um mandato "essencialmente" representativo, acompanhado de uma variante marginal desprovida de representação.

$\S$ 82. Itinerário da abordagem histórica a ser promovida: aspectos especialmente vinculados ao contexto brasileiro (cont.). Ao final de nossa análise histórica pretenderemos evidenciar como, por ocasião da tramitação dos diversos anteprojetos que redundaram no Código Civil brasileiro de 2002, houve uma preocupação constante e específica com a "autonomia" do fenômeno representativo (face ao instituto do contrato de mandato); tendo sido acolhida a doutrina que vislumbrara na representação negocial realidade distinta do contrato de mandato, perceberemos como se disciplinou em uma série de dispositivos projetados um contrato de mandato mais enxuto, e adstrito à relação estabelecida entre as suas respectivas partes. Contudo, a meio-termo entre a preservação do paradigma moderno e a variante contemporânea da relação entre os institutos referidos, perceberemos de que modo o legislador conseguiu comprometer a unidade sistemática da matéria, conservando regras concernentes à representação negocial em meio à disciplina do contrato de mandato; e mais do que isso, como ofereceu ensejo à rediscussão sobre a autonomia conceitual entre os temas, proporcionando um ambiente bastante favorável à avaliação dos eventuais progressos que se poderiam conceber, a partir de uma meditação consciente a respeito da "nota típica" do contrato de mandato. De toda sorte, ao cabo desta investigação histórica, poderemos nos reputar preparados para alçar outros vôos, diretamente comprometidos com a concatenação da linha de pesquisa apresentada na introdução deste trabalho. 


\section{CAPÍt́ULO V.}

\section{O CONTRATO DE MANDATO (E SUA RELAÇÃO COM A REPRESENTAÇÃO NEGOCIAL DIRETA) CONSOANTE AS FONTES DO DIREITO VISIGÓTICO.}

$\S$ 83. Apresentação das fontes do direito visigótico. Tomados em consideração os deliberados limites metodológicos impostos ao presente esforço investigativo, não nos cabe desenvolver aqui um estudo voltado à historiografia externa do direito visigótico; desta forma, a despeito da importância da "Lei de Teudis" (546 d.C.) no panorama da evolução das fontes do direito visigodo, a ela não dedicaremos, portanto, nossa atenção específica. Em contrapartida, quatro outras fontes germânicas revelam uma importância siginificativa quanto ao objeto de nosso estudo: o "Código de Eurico" (475476 d.C.), o "Breviário de Alarico" ("Lei Romana dos Visigodos" ou "Lex Romana Visigothorum”, de 506 d.C.), o "Código Revisto de Leovigildo" (“Codex Revisus”, editado entre 572-586 d.C.) e o "Código Visigótico" (“Lex Visigothorum Rescesvindiana", "Liber Iudiciorum", "Liber Iudicum", "Forum Iudicum" ou "Fuero Juzgo", de 654 d.C.). Conquanto uma reconstituição da penúltima só se possa fazer de maneira indireta - a partir das remissões às leis antigas ("antiquae") constantes do "Código Visigótico" -, tais elementos nos revelam, em seu conjunto, a concepção dos visigodos não apenas a respeito da "procuratio" e do "mandatum", mas inclusive com relação à atuação dos filhos (e dos escravos) em prol do patrimônio familiar; e como teremos a oportunidade de observar, aí se pode entrever, em estado latente, um influxo decisivo da jurisprudência clássica, sobretudo à custa daquilo que se convencionou designar por meio da expressão "direito romano vulgar" ${ }^{\circ 4}$.

\footnotetext{
${ }^{64}$ A despeito da inexistência de abordagens monográficas dedicadas à análise dos institutos da "procuratio", do "mandato" e da "representação" (direta ou indireta) no âmbito do direito visigótico, merecem destaque os seguintes estudos (devotados todos ao estudo das fontes componentes do referido sistema jurídico): M. J. de Almeida Costa, História cit. (nota 09), pp. 127-132; M. CAetANO, História cit. (nota 16), pp. 98-109; CÂNDido Mendes de AlmeIda, Código cit. (nota 16), pp. XIII-XVIII; L. C. de Azevedo, O direito visigótico, in Revista da Faculdade de Direito da Universidade de São Paulo 96(2001), pp. 5-9; J. C. Moreira Alves, Panorama cit. (nota 16), pp. 186-187; I. M. PovedA Velasco, Ordenações cit. (nota 16), pp. 11-15; N. E. Gomes DA Silva, História cit. (nota 16), pp. 68-72; P. J. de Mello Freire dos Reis, História cit. (nota 16), pp. 83-93; M. PAULo MerÊA, Resumo cit. (nota 16), pp. 22-32; M. A. CoELHO DA Rocha, Ensaio cit. (nota 16), pp. 21-28; J. G. B. CÂMARA, Código Filipino ou Ordenações do Reino, in Estudos Jurídicos e de História, Rio de Janeiro, Barrister's, 1987, pp. 224-230; S. MinguIJón AdRián, Historia del Derecho Español, $3^{\text {a }}$ ed., Barcelona - Madrid - Buenos Aires - Rio de Janeiro, 1943, pp. 46-51; A. GarCíA-GALlo, Curso de Historia del Derecho Español I - Introduccion e historia de las bases de la formacion del derecho, de las fuentes y del derecho publico, $5^{\text {a }}$ ed., Madrid, s. e., 1950, pp. 88-90; Consideracion critica de los estudios sobre la legislacion y la costumbre visigodas, in Anuario de Historia del Derecho Español 44 (1974), pp. 368-409; L. de EsTRADA, Manual de Historia del Derecho Argentino (Español - Indiano - Argentino), Buenos Aires, Abeledo-Perrot, 1978, pp. 16-19; V. LOBO DA CosTA, Contribuição ao estudo da história do direito brasileiro, in Revista da Faculdade de Direito da Universidade de São Paulo 50 (1955), pp. 354-357; L. de M. Leme, O direito na Península Ibérica, in Revista da
} 
Faculdade de Direito da Universidade de São Paulo 53 (1958), pp. 75-76; A. PÉREZ MARTín, El Fuero Real y Murcia, in Anuario de Historia del Derecho Espanol 54 (1984), pp. $63-65$ (especialmente sobre o "Liber Iudiciorum" e sua repercussão); C. PETIT, Consuetudo y mos en la Lex Visigothorum, in Anuario de Historia del Derecho Español 54 (1984), p. 240 (particularmente sobre o "Código Visigótico"); G. VISMARA, Le fonti del diritto romano nell'alto medioevo secondo la più recente storiografia (1955-1980), in Studia et Documenta Historiae et Iuris 47 (1981), pp. 7-13; G. AstuTI, Lezioni di storia del diritto italiano - Le fonti età romano-barbarica, Padova, CEDAM, 1968, pp. 29-34; L. C. AZEVEDO - J. R. CRUZ E TUCCI, Lições cit. (nota 32), pp. 31-32 e 35; M. R. MARQues, História do Direito Português Medieval e Moderno, $2^{\mathrm{a}}$ ed., Coimbra, Almedina, 2002, p. 9 (em trecho de proveito relativamente duvidoso). Tomando impropriamente por Código Visigótico (654 d.C.) a "Lex Romana Visigothorum" (506 d.C.), cf. M. KARAM, O processo de codificação do direito civil brasileiro (da Consolidação de T. de Freitas ao Projeto Beviláqua); o sistema do Esboço, in S. SCHIPANI (coord.), Augusto Teixeira de Freitas e il diritto latinoamericano, Padova, CEDAM, 1988, p. 320. A respeito do direito germânico - em geral - cf., ainda, os estudos de M. ScovAZZI, Scritti di storia del diritto germanico, Milano, A. Giuffrè, 1975; e H. BRUNNER, Historia del derecho germánico, Barcelona - Madrid - Buenos Aires - Rio de Janeiro, Editorial Labor, 1956.

Pela expressão "direito romano vulgar" e sua acepção, cf. G. BRAGA DA CRUZ, Direito romano vulgar ocidental, in Obras Esparsas I - Estudos de História do Direito - Direito Antigo ( $1^{a}$ parte), Coimbra, Imprensa da Universidade, 1979, pp. 317-ss. A respeito deste específico tema, parece-nos importante destacar alguns trechos do precioso prefácio de M. PAULO MerÊA aos seus Estudos de Direito Visigótico (Coimbra, Imprensa da Universidade, 1948, pp. VII-XIX), nos quais o autor define e explica a origem da expressão "direito romano vulgar": "o Ocidente não estivera inerte e improdutivo durante os últimos séculos da dominação romana (...) também aqui se operara, embora por outros processos e por vezes noutro sentido, uma autêntica transformação; numa palavra, que não houvera apenas um direito romano clássico e um direito romano oriental, mas sim também um direito post-clássico ocidental, com o qual era preciso entrar em linha de conta e que levava ao aproveitamento, em maior escala, de fontes até então consideradas secundárias (...) quebrou-se, efectivamente, o encanto que mantinha os medievistas, de um modo geral, alheados do direito romano e, em compensação, atraídos pela fascinação do direito germânico (...) o romanista preocupava-se quase exclusivamente com o direito clássico e com a 'caça às interpolações', ou então, se educado na escola de Mitteis, fechava-se na torre de marfim da investigação papirológica (...) é evidente, com efeito, o papel que a estas [fontes da época visigótica] cabe na transmissão do cabedal jurídico romano (...) as fontes visigóticas permitem-nos tomar contacto com o chamado 'direito romano vulgar' (...) o direito oficial não era a representação fiel da vida jurídica nesse período de crise (...) nem tudo no direito romano vulgar representa uma incompreensão dos tesouros da jurisprudência romana e um manuseamento grosseiro desse precioso cabedal (...) correspondiam [tais fontes visigóticas] à necessidade de simplificar o direito clássico, dando-lhe maior maleabilidade e uma feição mais consentânea com o novo estilo de vida (...) representam a adaptação de um sistema desenvolvido e intelectualizado às exigências de povos cuja visão mental não estava ao nível da vida metropolitana. Todavia, eles são também elos importantes da cadeia do progresso, porque as raças do Ocidente tiveram de desenvolver as regras do direito romano como sendo o seu próprio direito. $\mathrm{O}$ resultado deve ter sido um direito românico com certas analogias com o desenvolvimento das línguas e literaturas romances, as quais, como é sabido, tiveram como ponto de partida o latim vulgar" (pp. VIII-XII).

Por fim, deve ser feita aqui uma observação (de cunho metodológico) a respeito dos limites de nossa análise, tendo-se em consideração a específica evolução histórica do "mandatum" e da "procuratio" no cenário lusobrasileiro: tendo-se em vista o fato de ser este um estudo devotado à História do Direito neste específico âmbito, parece oportuno observar que, conquanto na parte geral de nossa análise histórica tenhamos nos dedicado exclusivamente à abordagem de alguns aspectos pontuais da relação entre "mandato" e "representação" (relegando expressamente para um momento ulterior a específica abordagem minudente da disciplina romana do "mandatum"), no panorama estreito de nossa investigação (luso-brasileiro) se faz necessária uma abordagem mais detelhada do espectro eficacial dos institutos envolvidos, uma vez que diferentemente do que se dará quanto ao direito justinianeu - não nos voltaremos mais à abordagem das fontes ora referidas (senão eventualmente). Assim, a fim de conciliar um tratamento mais detalhado da eficácia de tais institutos jurídicos e uma abordagem precisa (e pontual) da relação mantida entre mandato e representação, observamos que a partir de agora se desenvolverá, sempre que possível, um tratamento especial desta específica temática, sem prejuízo de uma análise mais ampla, devotada à compreensão dos referidos institutos em suas linhas gerais. Com isso, cremos que não se compromete a precisão metodológica indispensável a qualquer estudo científico consciencioso, ao mesmo tempo em que se evita a perda de perspectiva por parte do analista - decorrente de uma arbitrária (e por vezes limitadora) restrição excessiva quanto ao objeto estudado. 
§ 84. O “Código de Eurico" e a eficácia da atuação do escravo (CE. caps. 283, 284 e 287). Correspondendo à primeira coletânea sistemática do direito visigótico (articulada em cerca de trinta títulos), o "Código de Eurico" (promulgado entre os anos de 475 e 476 d.C.) pode ser enquadrado em meio às "leges barbarorum" ("leis dos bárbaros" ou "leis populares"); conquanto não disponha expressamente a respeito da "procuratio" e do "mandatum", sua relevância - considerados os específicos fins do presente estudo - se evidencia à vista de três disposições especificamente voltadas à disciplina dos efeitos da atuação do "servus" sobre o acervo doméstico. Assim, enquanto no cap. 283 se nega qualquer efeito ao depósito (ou mesmo ao comodato) em que tenha havido entrega ao escravo sem a ciência de seu proprietário, no cap. 284 se outorga tal eficácia quando o recebimento tenha sido precedido de uma incumbência conferida ao servo (ainda que este tenha posteriormente desatendido as instruções de seu senhor); por sua vez, no cap. 287 se observa que, em matéria de compra e venda, concluído o contrato com o escravo - sem que neste sentido tenha havido prévia determinação de seu amo - o negócio somente produzirá seus regulares efeitos se sobrevier ratificação do "dominus", uma vez que este poderá “desfazer" o ajuste por meio da simples restituição do preço ao comprador ${ }^{65}$.

${ }^{65}$ Por observações genéricas a respeito do Código Euriciano, cf. M. J. de ALMEIDA CostA, História cit. (nota 09), pp. 128-129; M. CAETANO, História cit. (nota 16), pp. 100-101; L. C. de AzEVEDO, O direito visigótico cit. (nota 64), p. 6; I. M. Poveda VElasco, Ordenações cit. (nota 16), pp. 11-12; N. E. GoMeS DA SILVA, História cit. (nota 16), p. 69; M. PAUlo MERÊA, Resumo cit. (nota 16), pp. 22-32; M. A. COELHO DA RoCHA, Ensaio cit. (nota 16), pp. 27-28; J. G. B. CÂMARA, Código Filipino ou Ordenações do Reino, in Estudos Jurídicos e de História, Rio de Janeiro, Barrister's, 1987, pp. 224-226; S. MingUIJÓN AdRIÁN, Historia cit. (nota 64), pp. 46-47; A. GARCÍA-GALlo, Curso cit. (nota 64), p. 88; Consideracion cit. (nota 64), pp. 368381; L. de ESTRADA, Manual cit. (nota 64), pp. 16-17; G. VISMARA, Le fonti cit. (nota 64), pp. 11-12.

Deve-se, pois, a A. D’ORS uma criteriosa reconstituição do conteúdo do Código de Eurico ("palingenesia"), acompanhada de uma tradução castelhana do palimpsesto parisiense (cf. El Codigo de Eurico - Edición, Palingenesia, Indices, in Estudios Visigoticos II, Roma-Madrid, Consejo Superior de Investigaciones Cientificas - Delegacion de Roma (Cuadernos del Instituto Juridico Español n. 12), 1960, pp. 15-19 e 47-55. Com efeito, em seu esforço "conjectural", o autor chega à conclusão de que o "Codex Euricianus" contava com trinta e um títulos, a saber: I) de iudiciis; II) de falsariis; III) de accusationibus; IV) de his qui ad ecclesiam confugiunt; V) de fugitivis; VI) de plagiatoribus; VII) de furtis; VIII) de caedibus; IX) de vulneribus; X) de veneficis; XI) de medicis; XII) de violatoribus sepulcrorum; XIII) de transmarinis negotiatoribus; XIV) de nuptiis inlicitis; XV) de raptu virginum et viduarum; XVI) de adulteriis; XVII) de expositis; XVIII) de incendiis; XIX) de damnis arborum; XX) de vitiatis animalibus; XXI) de vitiosis animalibus; XXII) de iter agentibus; XXIII) de divisionibus; XXIV) de porcis; XXV) de invasionibus; XXVI) de terminis; XXVII) de commendatis vel commodatis; XXVIII) de venditionibus; XXIX) de donationibus; XXX) de successionibus; XXXI) de liberatibus.

Observe-se, contudo, que de todos estes títulos tão somente três nos foram legados diretamente por intermédio do palimpsesto parisiense (XXVII, XXVIII e XXX); os demais, por sua vez, resultam do esforço reconstitutivo da doutrina, estribada em outras fontes do direito visigótico (sobretudo o "Liber Iudiciorum" $\mathrm{e}$ suas "antiquae"). Além disso, a despeito do inestimável valor historiográfico deste último contributo, seu teor especulativo impede uma utilização mais segura por parte do estudioso; por exemplo, conquanto haja uma espécie de consenso quanto à origem euriciana de LI II, 3, 6, não se pode afirmar o mesmo a respeito de LI II, 3, 7: fragmento do "Código Visigótico" importante para nossa análise, esta última lei é considerada euriciana por Ureña e Zeumer, enquanto A. D’ORS rejeita expressamente uma tal conclusão (El Codigo cit. 
§ 85. A "Lex Romana Visigothorum” e sua respectiva estrutura interna. Por sua vez, a "Lex Romana Visigothorum" ("Lei Romana dos Visigodos", "Código de Alarico", "Breviário de Alarico", "Breviarium Alarici", "Breviarium Alaricianum", "Breviário Alariciano" ou "Breviário de Aniano") - promulgada no ano de 506 d.C. por Alarico II - pode ser considerada um exemplar das chamadas "leges romanae barbarorum" ("leis romanas dos bárbaros"); correspondendo a uma obra de compilação, nela se mostram reunidas tanto "leges" - representadas pelo "Código Teodosiano" (438 d.C.) e pelas "novelas" pós-teodosianas - como "iura", de que são exemplo o "Epítome de Gaio", as "Sentenças de Paulo", os excertos dos Códigos Gregoriano (291 d.C.) e Hermogeniano (295 d.C.), bem como fragmentos isolados do "Responsorum" de Papiniano. É necessário observar que os visigodos não lançaram mão de tais fontes diretamente: em se tratando de textos afetos aos períodos clássico e pós-clássico, sua utilização foi mediatizada pelo

(nota 65), pp. 56-57). Desta forma, nossas perquirições haveriam de se cingir ao trechos induvidosamente pertencentes ao palimpsesto parisiense - ainda que assim obtivéssemos, afinal, conclusões muito mais limitadas do que as decorrentes de uma investigação mais arrojada.

Assim, eis os três capítulos do "Codex Euricianus" referidos no corpo do texto: "CCLXXXIII. Quod nesciente domino servis fuerit commendatum, si id perierit, dominus servi nullum damnum incurrat. Suae enim inpotet culpae qui servo alieno res suas commendaverit domino nesciente. 2. Similis et de commodatis forma servetur: 283. Por lo que sin conocimiento del amo fué depositado a los siervos, si pereció, no sufra ningún perjuicio el amo del siervo. Impútelo a su propia culpa el que depositó sus cosas en poder de un siervo ajeno sin conocimento del amo. 2. Obsérvese la misma norma para los préstamos" (El Codigo cit. (nota 65), pp. 24-25) (cf. LI V, 5, 6); “CCLXXXIIII. Si dominus per servum suum quodcumque sibi petierit commodandum, et servus cum rebus commodatis in fuga fuerit / elapsus, tunc dominus obligetur ut commodata restituat. 2. Si vero servus petisse dominum mentiatur et sic deportanda ad dominum susceperit, sed ea quae susceperit everterit aut forte perdederit, et fugitivus non potuerit inveniri, dominus servi praebeat sacramentum se eum ut susciperit non misisse, et cum id peteret ignorasse, et nihil calumniae pertimescat. 3 . Haec eadem de commendatis praecipimus; 284. Si un amo pidió por mediación de su siervo que se le prestara algo, y el siervo se hubiere dado a la fuga con las cosas prestadas, el amo entonces quede obligado a restituir lo prestado. 2. Si el siervo, fingiendo que ele amo lo había pedido, recibió como para llevar al amo, pero gastó lo que recebió o lo perdió y el fugitivo no pudiere ser hallado, preste juramento el amo del siervo de que él no lo había enviado para recibir nada, ni había sabido nada cuando lo pidió, y no tema inculpación alguna. 3. Eso mismo mandamos para los depósitos" (El Codigo cit. (nota 65), pp. 24-27) (cf. LI V, 5, 7); e "CCLXXXVII. Si quid a servo fuerit conparatum domino nesciente, si dominus firma(m) esse noluerit emptionem, praetium reddat emptori, et emptio nihil habeat firmitatis; 287 . Si se compró algo de un siervo, sin conocimiento del amo, si el amo no quisiere que la venta fuera válida, devuelva el precio al comprador y la compra no tenga validez alguna" (El Codigo cit. (nota 65), pp. 26-27) (cf. LI II, 5, 6; LI V, 4, 14; e LI X, 1, 10). Por um juízo crítico a respeito do teor de cada um dos capítulos referidos, cf. A. D’ORS, El Codigo cit. (nota 65), pp. 204 e 208 (CE. 283 e 284); e pp. 209 e 220 (CE. 287).

Note-se que empregamos no corpo do texto o termo "desfazer", diante das dúvidas que parecem cercar o alcance de CE. 287. Entretanto, cumpre-nos observar que A. D'ORS tem como induvidosa a prescrição de anulabilidade do ato: "En CE 287 (= LB 16, 3) se trata de la venta hecha por un siervo sin permiso del dueño: puede éste convalidar la venta con su ratificación, o no (si firman esse noluerit emptionem), y en caso negativo, débe devolver el precio al comprador con error de representación y la venta queda anulada: nihil habeat firmitatis; expresión que se aplica aquí a un supuesto de clara anulabilidad (comparable a la venta por representante deficiente). Chindasvinto LV 3, 4, 13, modificó este régimen (en el Fuero Juzgo: la ley 'antigua'), declarando la invalidez absoluta (por falta de capacidad) para la venta de los objetos valiosos, y la validez absoluta para las ventas menores (impugnables tan sólo mediante prueba de no pertenencia al peculio)" (El Codigo cit. (nota 65), p. 220). 
emprego freqüente das "interpretationes" que, conquanto preponderantemente voltadas à superação da obscuridade dos textos coligidos, em algumas ocasiões redundaram em uma completa subversão de seu teor original; desta forma, não deve causar maior estranheza ao intérprete o fato de que o "Epítome de Gaio" - embora desprovido de uma respectiva "interpretatio" - por vezes destoe completamente da obra parafraseada, em uma espécie de acomodação da doutrina de outrora às necessidades ostentadas pelos novos tempos ${ }^{66}$.

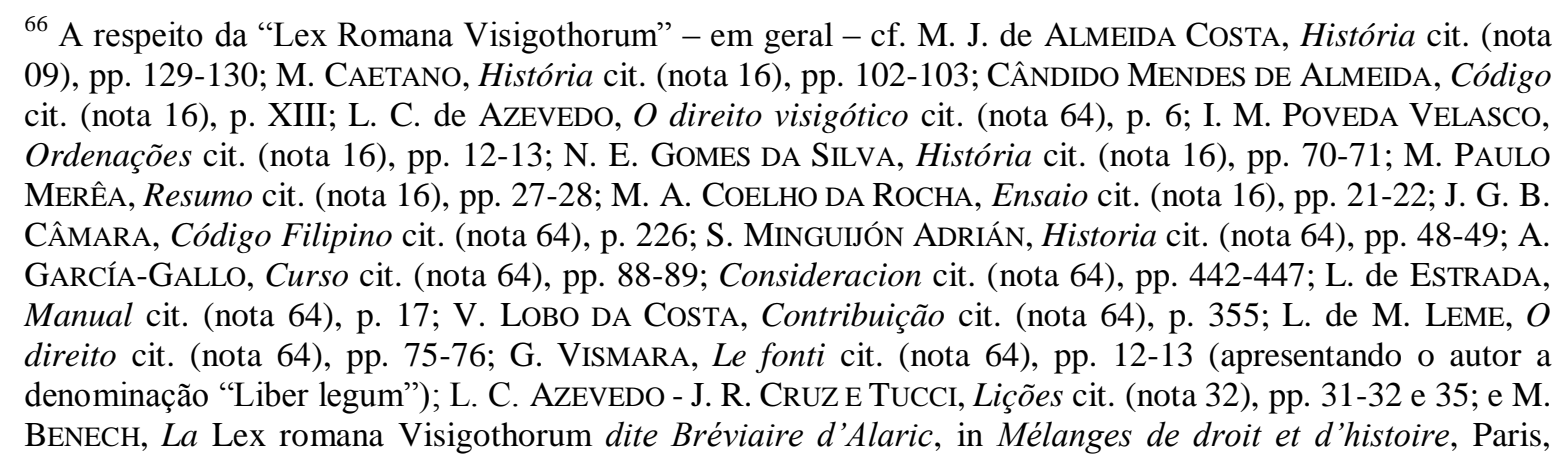
Cottilon, s.d..

Com efeito, o "Breviário de Alarico" pode ser considerado integrante das "leges romanae barbarorum", vale dizer, do grupo de "leis romanas dos (povos) bárbaros"; a respeito do sentido emprestado ao termo "bárbaro", cf. R. De MATTEI, Sul concetto di barbaro e barbarie nel Medio Evo, in Studi di storia e diritto in onore di Enrico Besta per il XL anno del suo insegnamento IV, Milano, Giuffrè, s.d., passim. Como observa M. J. de ALMEIDA COSTA, trata-se de uma coletânea de direito romano organizada pelos visigodos à custa da reunião de textos representativos de "iura" e de "leges": assim, como os fragmentos dos Códigos Gregoriano e Hermogeniano remontavam a períodos antigos, seus extratos devem ser inclú́dos em meio à primeira categoria (História cit. (nota 09), p. 130).

A utilização das "interpretationes" viabilizou não apenas o esclarecimento a respeito do respectivo alcance de algumas disposições recopiladas na "Lex Romana Visigothorum", como também a sua adaptação às necessidades do diverso contexto social em que tais fontes foram então aplicadas: "cifram-se em pequenos comentários destinados a esclarecer o conteúdo dos fragmentos transcritos, mas que, algumas vezes, chegam ao ponto de modificar completamente o preceito interpretado" (M. J. de ALMEIDA CosTA, História cit. (nota 09), p. 130). Conquanto desprovido de "interpretatio", o "Epítome de Gaio" corresponde - ele próprio - a uma "interpretatio simplificativa e sintetizadora, do texto gaiano, então em desuso nas escolas jurídicas do reino visigótico" (J. F. TEIXEIRA DE CARVALHO, Epitome das Instituições de Gaio e Introdução, in Revista de Direito Civil, Imobiliário, Agrário e Empresarial 5 (1978), p. 297). A respeito do epítome, ainda, cf. E. AlBertario, Sulla Epitome Gai in Studi di diritto romano V, Milano, Dott. A. Giuffrè, 1933.

Aliás, tomando-se por base as considerações de M. PAULO MERÊA transcritas em nota imediatemente anterior, são elucidativas da importância histórica da paráfrase de Gaio as seguintes palavras de G. G. ARCHI: "dobbiamo, infatti, inquadrare l'Ep. anche nel complesso panorama del suo tempo e dei tempi, che immediatamente la seguirono, tenendo presente non i soli elementi giuridici, ma anche quelli politici e sociali. A questa nuova luce l'Ep. assume altra importanza e appare come l'estrema, se pur debole, difesa dell'antica tradizione romana nel mondo, che ormai più non la comprende. Lo sforzo, con cui l'epitomatore cerca di salvare non nella scuola ma nella vita certi istituti, certe costruzioni, certi schemi antichi, potrà alle nostre esigenze moderne apparire inadeguato e a volte puerile, ma è uno sforzo che al lume della storia assume una grande importanza e, direi quasi si nobilita. Difensore di una tradizione, che di fronte alle nuove esigenze di un mondo giuridicamente ridiventato primitivo, sta per tramontare nella sue più felici elaborazioni, il tardo epitomatore di Gaio non può che riscuotere ancora tanta simpatia, quanta è necessaria per perdonargli glie errori a volte comessi e in generale le sue deficienze" (L'Epitome Gai' - studio sul tardo diritto romano in Occidente, Milano, Dott. Antonino Giuffrè, 1937, pp. 435-436). Ora, diante de tais observações, parece-nos inevitável a pergunta: estaríamos diante de uma modalidade de "uso moderno" das fontes romanas (do período clássico)? 
$\S$ 86. O "Código Teodosiano" como elemento representativo de uma transição rumo ao direito romano pós-clássico. Compilação oficial predecessora do "Codex" justinianeu - promulgada quase que simultaneamente nos Impérios do Oriente (Teodósio II) e do Ocidente (Valentiniano III) durante o ano de 438 d.C. -, o Código Teodosiano corresponde a uma recolha de constituições imperiais produzidas a partir do reinado de Constantino (306-307 d.C.); em virtude do peculiar momento histórico em que fora produzida, nesta obra se pode surpreender um estágio de transição entre o direito romano clássico e a etapa pós-clássica iniciada após a ascensão de Diocleciano (284 d.C.). Especificamente no que concerne ao tipo contratual objeto de nosso estudo, para além de um alargamento semântico da expressão "mandare" - que em lugar do simples "commitere" (incumbir), passa a implicar a idéia de ordenar ("iubere"), tal qual se depreende de CTh. X, 4, 1 (313 d.C.) (= Brev. X, 3, 1) - percebe-se uma junção entre as disciplinas voltadas à "procuratio" e ao "mandatum", compreendido este então como a fonte, por excelência, daquela espécie particular de eficácia - e daí a constante alusão (ainda que indireta) do CTh. II, 12 ("de cognitoribus et procuratoribus") (= Brev. II, 12) ao "procurator" constituído "ex mandato" - tudo como já diagnosticado, aliás, em outra oportunidade da presente exposição ( $\S 49$ e 50). Concomitantemente, no que toca aos fundamentos do "mandatum", podem ser vislumbrados sinais de um franco declínio da "amizade" e do dever de "assistência reciproca" que outrora o caracterizaram; sendo de se destacar, neste sentido, uma severa reprimenda imperial àqueles que (se aproveitando da momentânea fragilidade alheia) indevidamente se locupletavam durante o exercício de uma das mais nobres manifestações do contrato de mandato - a "advocacia" (cf. CTh. II, 10, 4 $=$ Brev. II, 10,1$)^{67}$.

\footnotetext{
${ }^{67}$ Tratando-se de uma compilação de caráter oficial, o Código Teodosiano nisso se diferencia das precedentes recopilações Gregoriana (291 d.C.) e Hermogeniana (295 d.C.), ambas promovidas à custa da iniciativa particular. Não obstante eventuais restrições quanto à autenticidade do extrato teodosiano contido na "Lex Romana Visigothorum" - em virtude das disparidades existentes entre o seu texto e a edição mais autorizada do "Codex Theodosianus" - utilizamo-nos da célebre edição Hänel para a obtenção dos excertos utilizados na presente nota de rodapé, tendo-se em vista o fato de que o direito coligido nesta consolidação somente nos interessa, por ora, exatamente em virtude de seu acatamento na forma em que fora adotado pelo legislador visigodo.

Assim, justificada a utilização do extrato visigodo à custa da edição da "Lex Romana Visigothorum" a cargo de G. F. HÄNEL (Leipzig, Sumptibus et Typis B. G. Teubneri, 1849), cumpre observar que, pela tradução respectiva, lançamos mão dos trabalhos de C. PHARR (The Teodosian Code, Princeton, University Press, 1952).

Pela ampliação do espectro semântico de "mandare" - que além da idéia de "incumbir" passa a admitir uma noção de "mandar" ou "ordenar" - eis o teor de Imp. Constantinvs A. Ad Filippvm vic(arivm) vrb(is) CTh. $\mathrm{X}, 4,1$ (313 d.C.) [= Brev. X, 3, 1 ("De actoribus et procuratoribus et conductoribus rei privatae, hoc est, qui causas ad se non pertinentes prosequuntur")]: " 1 . Si quis ab actore rerum privatarum nostrarum sive a procuratore fuerit vexatus, super eius calumniis vel depraedationibus deferre querimoniam non dubitet. Quae
} 
res quum fuerit comprobata, sancimus, ut idem, qui contra provincialem quicquam moliri fuerit ausus, publice concremetur, quoniam gravior poena constituenda est in hos, qui nostri iuris sunt et nostra debent custodire mandata. Interpretatio. Quicunque ab actore dominico vel procuratore fuerit alicuius iniuriae improbitate vexatus, de eorum calumniis vel depraedationibus ad principem convolare debebit. Quae res si potuerit approbari, eos, qui circa provinciales talia facere ausi sunt, placuit incendio concremari, quia graviorem poenam principes constitui voluerunt in eos, qui sui iuris sunt et sua debent custodire mandata" (Lex Romana Visigothorum cit. (nota 67), p. 212); "1. If any person should be harassed by an oversser or a procurator of Our privy purse, he shall not hesitate to lodge a complaint with respect to the chicanery and depredations of such overseer or procurator. If such complaint should be proved, We sanction that the person who dared to contrive anything against a provincial shall be publicity burned, since graver punishments must be established against those who are directly subject to Us and who ought to guard Our mandates. Interpretation. If any person should be harassed by the wicked wrongdoing of an imperial overseer or a procurator, he must hasten to the Emperor on account of their chicanery and depredation. If such crimes can be proved, it is the imperial pleasure that those persons shall be burned alive who have dared to commit such deeds against the provincials, because it is the will of the Emperors that a more severe penalty should be established in the case of those persons who are directly subject to the imperial power and whose duty it is to observe the imperial mandates" (C. PHARR, The Teodosian cit. (nota 67), p. 271). Percebe-se, pois, o emprego do termo "mandare" (e suas derivações) como alusivo ao sentido de ordem (ou incumbência) imperial. É a esta acepção que R. ORESTANO alude em seu verbete "Procurator (procuratores)" (in NNDI 13 (1966), pp. 1246-1247) (= o anterior “Procuratores”, in NDI 10 (1939), pp. 645-646).

Por sua vez, a respeito da junção entre os institutos da "procuratio" e do "mandatum", é indispensável a alusão a quatro excertos constantes do título "de cognitoribus et de procuratoribus, hoc est, ut qui mandatum et dominium rem susceperit, mandatum suum apud acta alleget; - hoc est, procurator, qui per mandatum causam suscipiat alienam, cognitor, qui sine mandato"; ei-los em sua respectiva ordem interna:

a) Imp. Ivlianvs A. Secvundo p(raefecto) p(raetori)o CTh. II, 12, 1 (368 d.C.) (= Brev. II, 12, 1): "1. Nulla dubitatio est, post causa in iudicio publicatam, utpote dominum litis procuratorem effectum, etiam post excessum eius, qui defensionem mandaverat, posse inchoatam litem iurgiumque finire: quippe quum et procuratorem posse eum instituere et ad heredes suos inchoata transmittere, veteres iuris voluerunt conditores. Interpretatio. Qui dominus et procurator de cuiuslibet rei petitione fuerit institutus et susceptam litem vivo mandatore per actionem repetendo fuerit contestatus, etiamsi ille, qui ei mandatum tale fecerat, de hac luce discedat, liceat ei rem, quam repetendam susceperat, sibimet ipsi defensare et alium procuratorem in hac causa, si voluerit, qui repetat, ut dominus ordinare atque actionem ad heredes suos successoresque transmittere: quia sicut in rebus, quae possidentur, procuratores tantum adversus pulsantes nec non et domini possunt firmiter ordinari, ita in rebus, quae repetuntur, dominus procuratoresque facere is, qui pulsat ac repetit, iure permittitur. Solum est, ut mandatum ad vicem donationes factum, actis habeatur insertum" (Lex Romana Visigothorum cit. (nota 67), pp. 46-48); “1. There is no doubt that after a case has been formally published in court, a procurator appointed as principal of the litigation may carry to a conclusion the litigation and the suit thus begun, even after the death of the person who gave him the mandate to conduct his defense, since, to be sure, the founders of the ancient law intended such procurator to have the power both to institute another as procurator and to transmit to his heirs a suit already begun. Interpretation. When any person has been instituted as principal and procurator of a suit for the recovery of anything whatever, and through action for recovery he has attested the suit which he has undertaken during the life of the mandator, even if the person who gave him such a mandate should depart from this light, the procurator shall be permitted to sue in his own name for the thing qhich he had undetaken to recover. If he should wish, he shall be permitted, as principal, to appoint another procurator in this case who shall have the right to sue, and he shall be allowed to transmit the action to heirs and his successors. Just as procurators only and not principals also of litigation can be validly appointed to defend against those persons suing for things which the mandator possesses, so, in the case os actions for the recovery of anything, a person who brings the action and seeks recovery is permitted by law to appoint procurators and principals of litigation. It is required only that the mandate, when made in the form of a gift, shall be entered in the public records" (C. PHARR, The Teodosian cit. (nota 67), p. 47). Do excerto depreeende-se a utilização dos termos "mandaverat" e "mandatum" (na "interpretatio"), em respaldo à atuação de um "procurator ad litem".

b) Imp. Grat(ianvs), Valentin(ianvs) et Theod(osivs) AAA. Pancratio p(raefecto) v(rbi) CTh. II, 12, 3 (382 d.C.) (= Brev. II, 12, 3): "3. In principio quaestionis persona debet inquiri, et utrum ad agendum negotium mandato utatur accepto. Quibus rite et soleniter constitutis, potest esse sententia: praeteritis autem his, nec dici controversiae solent, nec potest esse iudicium etc.. Interpretatio. Quum primum ad iudicem causa fuerit intormissa, personarum firmitas requiratur, ut is, qui causam alterius prosequitur, mandatum eius, cuius causam agendam susceperat, proferre procuret" (Lex Romana Visigothorum cit. (nota 67), p. 48); “3. At the beginning os a suit the person of the procurator must be investigated and whether he is exercising a mandate 
which he received for conducting the case. When these facts have been duly and frmally established, sentence can be pronounced. Moreover, cases are not customarily pleaded if such formalities are omitted, nor can there be a trial. Interpretation. When a case is first brought before the judge, the reliability of the persons must be investigated, so that who prosecutes the case of another must arrange to produce the mandate of the one whose case he has undertaken to conduct" (C. PHARR, The Teodosian cit. (nota 67), p. 47). Note-se que tal fragmento preconiza uma investigação dos poderes do "procurator ad litem" investido "ex mandato".

c) Imp. Theod(osivs), Arcad(ivs) et Honor(ivs) AAA. Victorio Procons(vli) Aslar CTh. II, 12, 4 (393 d.C) (= Brev. II, 12, 4): "4. Procurator, licet maritus sit, id solum exsequi debet, quod procuratio emissa praescripserit. Interpretatio. Qui uxoris suae negotium fuerit prosecutus, quamvis maritus sit, nihil aliud agat, nisi quod ei agendum per mandatum illa commiserit" (Lex Romana Visigothorum cit. (nota 67), p. 48); "4. A procurator, even though he be the husband of the principal, must execute only that which has been prescribed by the procuracy issued to him. Interpretation. If any man should prosecute a case of his own wife, although he is her husband, he shall do nothing other than that which she has commissioned him to do through a mandate" (C. PHARR, The Teodosian cit. (nota 67), p. 48). Este último fragmento é importante não apenas em virtude da consideração (na "interpretatio") do mandato como fundamento de atuação do "procurator", mas também em decorrência da menção (ainda que oblíqua) a uma espécie de documento onde estariam declinados os poderes outorgados ao agente - e talvez tenhamos aí uma manifestação remota da idéia de "procuração" como instrumento da outorga. Para além disso, deve ser cuidadosamente observada a alusão implícita a um conjunto de "instruções" do principal, a serem observadas pelo "procurator ad litem" tal qual se dera com o "mandatum" em suas origens.

d) Imp. Theodosivs A. et Valentin(ianvs) Caesar Ascleptodoto p(raefecto) p(raetori)o CTh. II, 12, 7 (424 d.C.) (= Brev. II, 12, 7): "7. Si lite contestata procuratorem vel cognitorem, qui litis minister est ordinatus, mori contigerit, minime eius quaerantur heredes, ne supervacua domino causae laboris occasio protendatur, sed statim ad eum migrent omnes, qui dominus causae fuerat, actiones. Et successoribus procuratoribus nulla super eo petitio relinquatur, nisi tantum expensarum nomine vel factorum litis causa sumtuum. Nec sane videtur incongruum cognitori, quum manifestum sit, si cognitor vel praesentis procurator usus fuerit in iudicio prosperiore fortuna, vel eadem non flante devictus, iudicati actionem sine ulla cunctatione in dominum dari vel domino. Et haec quidem in actoris persona de litis ministro edixisse sufficiat; ceterum in rei quoque idem licere, non dubium est, quamvis abunde legum veterum observatione munita sit, quae, si in rem quoque suam cognitor vel procurator quis fuerit ordinatus, simili modo nihil novi requirere patiuntur etc.. Interpretatio. Procurator est, qui per mandatum causa committitur. Cognitor est, cui sine mandato causam suam agendam praesens praesente iudice litigator iniungit. Si procurator aut cognitor tantummodo, non dominus et procurator effectus, post litem contestatam quolibet casu de hac luce discesserit, de mandato sibi negotio ad suum nihil transmittit heredem: nisi tantum sumtuum vel expensarum repetitionem, quam auctorem suum in suscepta causa fecisse probaverit: lis vero ad mandatorem redit. Si praesentis procurator vincatur aut vincat, in dominum vel domino, non in procuratorem vel procuratori actio tribuetur iudicati. Idem est et in pulsati possessoris procuratore servandum, si ipse pro sua utilitate iam fecerit, similiter existus rei iudicatae dominum respiciet, non actorem" (Lex Romana Visigothorum cit. (nota 67), pp. 48-50); "7. If, after a suit has been formally attested, either the procurator or the cognitor who has been appointed as agent for the litigation should happen to die, by no means shall his heirs be sought, so that an occasion of labor may not be extended for the principal of the case on account of a superfluous matter, but all rights os action shall immediately pass to the person who had been the principal of the case. To the successors of the procurator no claim about this matter shall be left except only in the name of expenses or outlays that the procurator had incurred on account of the litigation. 1. Indeed, this does not appear incongruous for the cognitor, sice it is manifest that action on the judgement is granted without any delay, either against the principal or to the principal, whether the cognitor or procurator of a party who is present experiences prosperous fortune in the suit or is defeated by an adverse fortune. 2. Indeed, it shall suffice to have said this about the agents of the suit who act in the role of plaintiff. But to those acting in the role of defendant there is no doubt that the same is permitted, although the legal position of the latter has been abundantly protected by the provisions of the ancient laws, which in like manner allow nothing new to be required if any person should be appointed as cognitor or procurator in his own case. Interpretation. A procurator is a person to whom a case is entrusted through a mandate. A cognitor is one whom the litigant who is present has enjoined in the presence of a judge to undertake his case without a mandate. If a man should be appointed only as procurator or cognitor and not as both principal and procurator and should depart from this light by any contingency whatsoever after the suit has been attested, from the litigation entrusted to him by mandate he transmits nothing to his heir except on ly the right to recover expenditures or outlays which the heir shall prove that the author of his right had incurred in the case that he had accepted, but the litigation indeed reverts to the mandator. Whether the procurator of a party who is present should be defeated of victorious, the action on the judgement shall be granted against the principal or to the principal, not against the procurator or to the 
procurator. The same rule shall be observed in the case of a procurator of a possessor who has been sued, according as he is defeated or victorious in the suit. If any person should be made principal and procurator in his own case and if he himself should then appoint a procurator for his own advantage, similarly the outcome of the judgement shall look to the principal, not to the agent" (C. PHARR, The Teodosian cit. (nota 67), p. 48). Quanto a este fragmento, observe-se a consagração - levada a efeito na "interpretatio" - de uma "procuratio" estribada em um mandato; além disso, merece destaque a ressalva expressa no sentido de uma admissão de efeitos representativos diretos - em favor ou contra o próprio principal (isento de todo efeito o agente).

Também alusiva - ainda que implicitamente - à investidura do "procurator ad litem" por meio do "mandatum" é a seguinte constituição imperial (atinente àqueles que demandam por conta de outrem sem mandato): Impp. Arcad(ivs) et Honor(ivs) AA. Victorio Proc(onsvli) Afric(ae) CTh. IX, 39, 3 (398 d.C.) (= Brev. IX, 29, 3): “3. Innocentes sub specie falsae criminationis non patimur callidorum impugnatione subverti: qui si tentaverint, intelligant, sibimet severitatem legum pro comissis facinoribus incumbere. Interpretatio. Calumniatores sunt, quicunque causas ad se non pertinentes sine mandato alterius proposuerunt. Calumniatores sunt, quicunque iusto iudicio victi causam iterare tentaverint. Calumniatores sunt, quicunque quod ad illos non pertinet, petunt aut in iudicio proponunt. Calumniatores sunt, qui sub nomine fisci facultates appetunt alienas et innocentes quietos esse non pemittunt. Calumniatores etiam sunt, qui falsa deferentes contra cuiuscunque innocentis personam principum animos ad iracundiam commovere praesumunt. Qui omnes infames effecti in exsilium detrudentur. Hic de Iure addendum, qui calumniatores esse possunt" (Lex Romana Visigothorum cit. (nota 67), p. 202); "3. We do not permit innocent persons to be ruined by the attacks of crafty men under the pretext of false criminal accusations. If any persons should attempt such attacks, they shall know that the severity of the law will overwhelm them for the commission of such crimes. Interpretation. Those persons are malicious accusers who prosecute cases not pertaining to themselves without the mandate of others. Those persons are malicious accusers who attempt to renew a case when they have been defeated in a fair trial. Those persons are malicious accusers who make a demand or bring into a court a matter which does not pertain to them. Those persons are malicious accusers who seek to obtain the property of others under the name of the fisc and do not permit innocent persons to remain undisturbed. Those persons are malicious accusers also who praesumptuously arouse the minds of the Emperors to anger by bringing false charges against some innocent person. All such persons shall be rendered infamous and driven into exile (Here must be added from the law what persons can be malicious accusers)" (C. PHARR, The Teodosian cit. (nota 67), p. 255).

Tendo sido considerada uma manifestação do "mandatum", o exercício da advocacia em Roma, perpassou por uma longa evolução, ao cabo da qual vislumbrava-se um franco declínio da "amizade" e do "dever de assistência reciproca" que outrora lhe serviram de fundamento. Assim, em lugar de encontrar em seu advogado um aliado, a parte - juridicamente fragilizada - por vezes se deparava com um autêntico aproveitador, o que ensejou uma rigorosa reprimenda, coligida no Código Teodosiano, e que não escapou ao extrato que deste restou no "Breviário de Alarico": Imp. Constant(invs) A. ad Bassvm p(raefectvm) v(rbi) CTh. II, 10, 4 (326 d.C.) (= Brev. II, 10, 1): “1. Advocatos, qui consceleratis depectionibus suae opis egentes spoliant atque denudant, non iure causae, sed fundorum, pecorum et mancipiorum qualitate rationeque tractata, dum eorum praecipua poscunt coacta sibi pactione transscribi, ab honestorum coetu iudiciorumque conspectu segregari praecipimus. Interpretatio. Advocati, id est causas agentes, qui per iniquam cupiditatem susceptos, quorum causas acturi sunt, prius cogunt de rebus suis taliter scriptura intercedente pacisci, ut omnia, quae meliora sunt in agris aut in mancipiis aut in pecoribus, ad eos sub promissa defensione perveniant, et ideo qui tam scelerati in eos, quibus patrocinium promittunt, fuerint deprehensi, et a conventu hosnestorum virorum et iudiciorum communione praecipimus segregari" (Lex Romana Visigothorum cit. (nota 67), pp. 44-46); "1. There are advocates who by means of criminally extortionate agreements rob and strip bare those persons who need their help, and who consider not the right of a client's case but the quality and quantity of his farms, herds, and slaves and demand that the best part of such property shall be signed over to them by a forced pact. We order that such advocates shal be excluded from the assembly of the honorable and from the sight of the courts. Interpretation. There are advocates, that is, pleaders of cases, who through wicked avarice, before they will undertake a case, first force clients whose cases they are going to conduct to make agreements in writing affecting their property in such a way that all their more valuable assets, in the form of fields or slaves or herds, shall be transferred to the said advocates under a promise of defense. Therefore We order that those persons who are apprehended in such crimes against those to whom they have promised protection shall be excluded from the assembly of honorable men and from the communion of the courts" (C. PHARR, The Teodosian cit. (nota 67), p. 46).

Por uma abordagem monográfica a respeito do Código Teodosiano, cf. G. G. ARCHI, Teodosio II e la sua codificazione, Napoli, Edizioni Scientifiche Italiane, 1976, passim. Por considerações relacionadas à sua estrutura interna - bem como a respeito de sua relação com as codificações gregoriana e hermogeniana - cf. 


\section{$\S$ 87. O "Epitome de Gaio" e a reprodução da doutrina clássica sobre o}

contrato de mandato; cautelas relacionadas à exegese de EG. 2, 9, 20. De autoria desconhecida e destinado ao ensino dos estudantes de direito, o "Epítome de Gaio" também conhecido por "Gaio Visigótico" - foi produzido, provavelmente, durante o séc. V d.C.; sendo a única fonte coligida desprovida de "interpretatio", o "Epítome" representa preponderantemente uma obra de síntese, na qual não raras vezes se verifica uma reformulação do pensamento jurídico clássico. No que tange especialmente ao contrato de mandato, três excertos particularmente interessam ao presente estudo: a) em EG. 2, 9, 18 pode-se vislumbrar uma estrita paráfrase do original clássico, em acolhida às diretrizes tradicionais que entreviam no "mandatum" um contrato consensual, escrupulosamente devotado tão somente a objetivos lícitos, por meio do qual se incumbia alguém da atuação em prol do mandante (ou de terceiros); b) por sua vez, em EG. 2, 9, 19 observa-se uma sucinta proposição a respeito da extinção da relação jurídica, seja em decorrência da morte de uma das partes, ou mesmo da "contraria illius voluntate" do mandante; c) já em EG. 2, 9, 20 existe previsão expressa quanto aos efeitos do excesso praticado pelo mandatário (durante a execução da incumbência confiada) - recusando-se-lhe, categoricamente, ação contra o mandante. Particularmente quanto a este último fragmento, diante da falta de subsídios indicativos de uma atuação "inovadora" do epitomador, parece-nos que o trecho final "et quod extra mandatum egit, non praeiudicet mandatori" - tomado em estrita correlação com o texto parafraseado (G. 3,161) - jamais poderia ser compreendido como uma espécie de exceção aos "conjeturais" efeitos (ordinários) de uma representação direta, mas tão somente como consagração explícita de uma específica hipótese de cabimento exclusivo da "actio mandati directa",68.

os preciosos escritos de G. SCHERILlo (Teodosiano, Gregoriano, Ermogeniano in Studi in memoria di Umberto Ratti a cura e con prefazione di Emilio Albertario, Milano, A. Giuffrè, 1934; e Il sistema del Codice Teodosiano in Studi in memoria di Aldo Albertoni I, Padova, CEDAM, 1935).

${ }^{68}$ Por considerações relativas à importância histórica do "Epítome de Gaio", permitimo-nos remeter o leitor às observações lançadas em nota específica do presente estudo (nota 66), na qual se alude, inclusive, à bibliografia concernente ao tema.

Já no que concerne ao contrato de mandato, eis os três excertos relacionados ao tema, extraídos todos do título "de obligationibus, hoc est, qualiter ex contractu nascuntur aut ex culpa; - hoc est, qualiter ex contractu nascuntur aut ex culpa et qualiter ab heredibus obligatio debiti exigatur" (“das obrigações"):

a) EG. 2, 9, 18: "18. Similiter et mandari verbo potest, et cum verbis mandatum fuerit, obligatio contrahitur. Possumus enim aut nostra negotia aut aliena cuicumque agenda mandare, dummodo honestum aliquid mandare voluerimus, hoc est, si cuidam mandemus, ut alicui furtum faciat, aut homicidium, aut adulterim admittat in his rebus mandati obligatio non contrahitur" (Lex Romana Visigothorum cit. (nota 67), p. 336); “18. Semelhantemente, também se pode dar mandato por palavras e quando por palavras for dado, contrai-se a obrigação. Na verdade, podemos mandar que alguém faça os nossos negócios ou os alheios, desde que aquilo que nós mandemos que se faça seja por uma coisa honesta. Pois, se quisermos mandar uma coisa 
$\S$ 88. A atuação dos filhos, escravos e libertos no âmbito das "Pauli Sententiae"; em particular, sobre a gestão do "procurator" ("ad litem”) e seus respectivos efeitos (representativos). Ainda que pendente controvérsia quanto à sua autenticidade, as "Pauli Sententiae" gozaram de elevado prestígio durante todo o período pós-clássico, merecendo expressa consagração (em termos "pretensamente" definitivos) por meio de uma provisão de 426 d.C. atribuída aos Imperadores Teodósio II e Valentiniano III (CTh. I, 4, 3); ainda que a "Lex Romana Visigothorum" nos tenha legado tão somente parte de seu conteúdo, o extrato coligido foi suficiente para influenciar, por exemplo, a eficácia (inclusive passiva) da atuação de filhos e escravos em prol do patrimônio familiar (cf. PS. 2, 6, 1; PS. 2, 8, 1; PS. 5, 8, 3; PS. 2, 8, 2 e PS. 2, 8, 3). Conquanto nos parágrafos seguintes venhamos a nos deter sobre a peculiar relação entre a "procuratio" e o "mandatum" (no específico panorama das "Sentenças de Paulo"), cumpre destacar, desde logo, que a respeito daquele instituto não houve um tratamento minudente, senão sob a forma de algumas disposições pontuais, voltadas à admissão excepcional da

contrária aos bons costumes, isto é, se mandarmos a alguém que pratique um furto, ou perpetre um homicídio ou cometa um adultério, neste caso não se contrai uma obrigação do mandato" (J. F. TEIXEIRA DE CARVAlHo, O Epítome cit. (nota 66), p. 323).

b) EG. 2, 9, 19: "19. Solvitur mandatum aut morte 'eius qui mandavit, aut eius' cui mandatum est, aut contraria illius voluntate, qui mandavit" (Lex Romana Visigothorum cit. (nota 67), p. 336); "19. Extingue-se o mandato quer por morte do mandante ou do mandatário, quer por vontade do mandante" (J. F. TEIXEIRA DE CARVAlHo, O Epítome cit. (nota 66), p. 323).

c) EG. 2, 19, 20: "20. Sed is, cui mandatur, mandati formam egredi non potest: aut si egressus fuerit, et mandatori teneatur obnoxius, et quod extra mandatum egit, non praeiudicet mandatori" (Lex Romana Visigothorum cit. (nota 67), p. 336); "20. Aquele a quem for confiado um mandato não poderá exceder os limites deste; se o fizer, ficará obrigado para com o mandante, o qual não ficará prejudicado pelos atos praticados além do mandato" (J. F. TEIXEIRA DE CARVALHO, O Epítome cit. (nota 66), p. 323).

Como tivemos a oportunidade de destacar no corpo do texto, a utilização exclusiva do trecho final de EG. 2 , 19, 20 ("non praeiudicet mandatori") poderia levar o leitor à compreensão de que, observados os limites do "mandatum", da gestão decorreriam efeitos representativos diretos. No entanto, quando o texto alude à ausência de "prejuízo" ao principal, refere-se à relação interna (defluente do contrato de mandato), e não a eventuais efeitos exercitáveis perante terceiros. A fim de afastar um precipitado entendimento neste sentido, é interessante o cotejo com o texto parafraseado pelo epitomador, constante de G. 3, 161: "cum autem is, cui recte mandaverim, egressus fuerit mandatum, ego quidem eatenus cum eo habeo mandati actionem, quatenus mea interest implesse eum mandatum, si modo implere potuerit; at ille mecum agere non potest. Itaque si mandaverim tibi, ut verbi gratia fundum mihi sestertiis C emeres, tu sestertiis CL emeris, non habebis mecum mandati actionem, etiamsi tanti velis mihi dare fundum, quanti tibi mandassem; idque maxime Sabino et Cassio placuit. Quod si minoris emeris, habebis mecum scilicet actionem, quia qui mandat, ut $\mathrm{C}$ milibus emeretur, is utique mandare intellegitur, ut minoris, si posset, emeretur" ("se a pessoasa quem eu vàlidamente constitui mandatário exceder os poderes do mandato, tenho acção de mandato, na medida do meu interesse em haver ela executado o mandato, desde que tal se pudesse cumprir; ela porém não pode agir contra mim. Portanto, se mandando eu, por exemplo, compres tu um fundo por cem sestércios e tu o comprares por cento e cinqüenta, não tens acção de mandato contra mim, embora estejas disposto à me dar o fundo pelo preço que eu determinei; tal é a opinião sobretudo de Sabino e Cássio. Porém, se o houveres comprado por menos, terás aç̧ão contra mim, pois quem manda comprar por cem mil entende-se por certo mandar comprar por menos, sendo possível a compra"). De maneira que, excedidos os limites do mandato, descaberia a "actio mandati contraria", sendo precisamente esta a conseqüência prejudicial a que aludira Gaio - e que decerto inspirou, da mesma forma, o epitomador de suas Instituições. 
atuação de "infames" e mulheres no âmbito da variante "ad litem" (PS. 1, 2, 1; PS. 1, 2, 2 e

PS. 1, 2, 3); e no que toca à eficácia dos atos praticados por esta modalidade específica de “procurator", merece destaque a explícita admissão de efeitos representativos (diretos)

decorrentes da gestão: ensejando-se, assim, a percussão imediata da esfera jurídica do principal - com a possibilidade, ainda, de uma sua eventual extensão ao patrimônio dos respectivos herdeiros (PS. 1, 2, 4) ${ }^{69}$.

${ }^{69}$ Assim como observado a respeito do Código Teodosiano, também as "Pauli Sententiae" foram obtidas a partir do extrato constante da "Lex Romana Visigothorum", tendo sido utilizada a edição de G. F. Hänel (Leipzig, Sumptibus et Typis B. G. Teubneri, 1849); no que concerne à sua tradução, lançamos mão do trabalho de Samuel Parsons Scott contido em sua obra The Civil Law - including The Twelve Tables, The Institutes of Gaius, The Rules of Ulpian, The Opinions of Paulus, The Enactments of Justinian, and The Constitutions of Leo: translated from the original Latin, edited, and compared with all accessible systems of Jurisprudence ancient and modern I (Cincinnati, The Central Trust Company Publishers, 1932). Note-se que, desprovida da tradução das "interpretationes", tem sido alvo da crítica de renomados especialistas.

No que toca à atuação dos "cognitores" e "procuratores" ("ad litem"), quatro fragmentos - constantes do título "de procuratoribus et cognitoribus" - merecem especial referência:

a) PS 1, 2, 1: "1. Omnes infames, qui postulare prohibentur, cognitores fierit non possunt, etiam volentibus adversariis. Interpretatio. Infames sunt, qui propter aliquam culpam notantur infamia. Et ideo tales personae ad agendas causas nec mandatum dare, nec suscipere ab altero possunt, etiamsi hoc eorum adversarii acquiescant" (Lex Romana Visigothorum cit. (nota 67), p. 340); "1. All infamous persons who are forbidden to bring actions at law cannot become attorneys, even with the consent of their adversaries" (S. P. SCOTT, The Civil Law cit. (nota 69), p. 259). Proíbe ao infame, em síntese, a atuação como "procurator".

b) PS 1, 2, 2: "2. Feminae in rem suam cognitoriam operam suscipere non prohibentur. Interpretatio. Feminae, licet procurationem suscipere prohibeantur, tamen, si dominae et procuratrices fiant, pro re iam sua agere possunt" (Lex Romana Visigothorum cit. (nota 67), p. 340); "2. Women are not forbidden to undertake the duties of attorneys where their own property is concerned" (S. P. SCOTT, The Civil Law cit. (nota 69), p. 259). Por sua volta, faculta às mulheres a defesa judicial de seus (e tão somente de seus próprios) bens.

c) PS 1, 2, 3: "3. In rem suam cognitor procuratorve ille fieri potest, qui pro omnibus postulat. Interpretatio. Nec procurator in causa aliena, nec procurator et dominus, ut pro re sua agat, infamis persona fieri potest" (Lex Romana Visigothorum cit. (nota 67), p. 340); "3. He can become an attorney or agent in his own behalf who sues for all parties" (S. P. ScotT, The Civil Law cit. (nota 69), p. 259). Admite-se, excepcionalmente, a atuação judicial do infame em seu próprio proveito.

d) PS 1, 2, 4: "4. Actio iudicati non solum in dominum aut domino, sed etiam heredi et in heredem datur. Interpretatio. Actio de executione iudicatarum rerum non solum ipsi auctori, qui egit, competit, sed et heredi similiter datur. Nam et heres victi ad solutionem iudicati nihilominus retinetur" (Lex Romana Visigothorum cit. (nota 67), p. 340); "4. The action to enforce a judgement is not only granted for and against a principal, but also for and against an heir" (S. P. SCOTT, The Civil Law cit. (nota 69), p. 259). Este fragmento consagra, portanto, a eficácia representativa direta da atuação do "procurator ad litem" em relação ao seu principal.

Por sua vez, no que concerne à atuação do "institor" e do "exercitor", desponta oportuna a alusão a quatro passos constantes do segundo livro das "Sentenças de Paulo":

a) PS 2, 6, 1: "1. Filiusfamilias, si voluntate patris navem exerceat, patrem in solidum ob ea, quae salva receperit, obligat. Interpretatione non eget" (Lex Romana Visigothorum cit. (nota 67), p. 358); "1. If a son under paternal control has charge of a ship with his father's consent, he will bind his father for the entire amount of the cargo which he received in good condition" (S. P. SCOTT, The Civil Law cit. (nota 69), p. 270). Deste fragmento se extrai a responsabilidade paterna pelos atos praticados pelo filho "instituído".

b) PS 2, 8, 1: "1. Sicut commoda sentimus ex actu praepositi institoris, ita et incommoda sentire debemus. Et ideo qui servum sive filium filiamve familias sive ancillam praeposuit negotiis vel mercibus exercendis, eorum nomine in solidum convenitur. Interpretatione non eget" (Lex Romana Visigothorum cit. (nota 67), p. 358); "1. As we derive advantages from the appointment of an agent so we should also suffer the inconvenience resulting therefrom; and therefore anyone who appoints a male or female slave, or a son or a daughter under paternal control, to transact his business, or to buy or sell merchandise, can be sued for the entire amount of any indebtedness contracted in his or her name" (S. P. SCOTT, The Civil Law cit. (nota 69), 
§ 89. As "Pauli Sententiae" e os contornos eficaciais do "mandatum”: de uma aproximação (sistemático-funcional) em relação à "procuratio" ao afastamento de efeitos representativos (diretos) decorrentes da atuação do agente. Como já tivemos a oportunidade de observar ( $\$ \$ 49$ e 50 ), durante o período pós-clássico se verificou uma aproximação sistemático-funcional entre a "procuratio" e o contrato de mandato; no que concerne especificamente às "Pauli Sententiae", dois excertos são elucidativos de uma tal

pp. 271-272). Provavelmente sob influência do direito pretoriano, admite-se aqui uma percussão não apenas ativa - como também passiva, pois - do patrimônio familiar.

c) PS 2, 8, 2: "2. Si quis pecuniae foenerandae agroque colendo, condendis vendendisque frugibus praepositus est, ex eo nomine, quod cum illo contractum est, in solidum fundi dominus obligatur: nec interest, servus an liber sit. Interpretatio. Quicunque quamlibet personam aut ad exercendum negotium aut pro ratione culturae aut condendis vendendisque fructibus praeposuisse cognoscitur, si quid damni per eius actum accesserit, ad eum, qui eum instituit, pertinebit, sive servus, sive liber est" (Lex Romana Visigothorum cit. (nota 67), p. 358); "2. If a slave is placed in charge of money to be lent, or a tract of land to be cultivated, and on which crops are to be planted and sold, the owner of the land or the money will be bound for the entire amount involved in the contract made by the agent; and it makes no difference whether he is a slave or a freeman" (S. P. SCOTT, The Civil Law cit. (nota 69), p. 272). Como se pode depreender da expressão "ex eo nomine", admite-se a percussão imediata do patrimônio doméstico em virtude da atuação de tais agentes, nos exatos moldes preconizados pelo direito pretoriano, à custa, inclusive, das "actiones adiecticiae qualitatis" (cf. nota 29).

d) PS 2, 8, 3: "3. Quod cum discipulis eorum, qui officinis vel tabernis praesunt, contractum est, in magistros vel institores tabernae in solidum actio dabitur. Interpretatio. Si quid cum discipulis vel mercenariis tabernariorum vel cuiuslibet officinae actum fuerit, ad magistrum officinae vel institorem tabernae damnum, quod accesserit, pertinebit" (Lex Romana Visigothorum cit. (nota 67), pp. 358-360); "3. Where a contract is made with the employness of those who have charge of factories or shops, an action is granted for the entire amount of the indebtedness against the masters or agents of said shops" (S. P. SCOTT, The Civil Law cit. (nota 69), p. 272). Observe-se que este fragmento destaca a vinculação tanto do principal como de seu agente, admitindo-se a percussão imediata do patrimônio do "pater", sem que com isso se eximisse, contudo, aquele que em seu proveito atuara.

Além de tais fragmentos, ainda quanto aos efeitos da atuação (genérica) do "servus" em prol do patrimônio familiar, eis o teor de PS 5, 8, 3: "3. Fructuarius servus si quid ex re fructuarii aut ex operis suis acquirit, ad fructuarium pertinet: quidquid autem aliunde vel ex re proprietarii acquirit, domino proprietatis acquirit. Interpretatione non eget" (Lex Romana Visigothorum cit. (nota 67), p. 424); "3. If a slave belonging to an usufructuary acquires anything by the property of the latter, or by his own labor, it will belong to the usufructuary; and, moreover, whatever he acquires from any other source, or from the property of the owner, he acquires for the owner" (S. P. SCOTT, The Civil Law cit. (nota 69), p. 317). Percebe-se, pois, que se tinham mantido, em linhas gerais, as diretrizes defluentes do direito romano clássico.

Finalmente, sobre o significado histórico das "Pauli Sententiae", eis a manifestação de A. CORREIA e G. SCIASCIA: "a obra teve no período pós-clássico muita autoridade e difusão. Com efeito, uma constituição de Constantino de 327 tira as dúvidas levantadas a respeito do seu valor prático, exatamente por que era uma reelaboração do original, e a lei de citações de 426 confirma expressamente a sua autoridade nos tribunais. Assim se explica o trazerem tôdas as coletâneas de direito dêste período fragmentos seus e porque às vêzes é citada sob o título de Sententiae Receptae. Dela chegaram até nós cerca de um sexto na Lex Romana Visigothorum, sob a forma de epítome feito pelos comissários da lei e do qual vários resumos foram feitos posteriormente, em alguns manuscritos, ou mediante confronto com obra mais antiga ou com acréscimos separados em apêndice (...) além das alterações que podem provir das mais antigas relações os comissários visigóticos fizeram não só mutilações, mas também freqüentes modificações. A obra destinada à prática dividia-se em cinco livros e títulos, com rubricas, e continha os princípios fundamentais do direito privado, penal, processual expostos segundo a ordem do edito perpétuo. A crítica negou que pertençam as Sententiae a Paulo e as atribuiu a um compilador do III século ou pós-clássico, o qual teria composto uma antologia extraída das obras de Paulo ou, segundo outros, dos escritos dos vários juristas Paulo, Ulpiano, Papiniano e talvez Modestino. É mais provável, porém, que a a obra tenha sido constantemente atualizada por desconhecidos professôres de direito posteriores a Paulo, como recentemente demonstrou Ernst Levy" (Manual cit. (nota 09), p. 441). 
imbricação: enquanto em PS. 1, 3, 1 o jurisconsulto afirma (ainda que implicitamente) ser a "procuratio" eficácia ordinária de um mandato ("mandari potest procuratio praesenti"), no fragmento imediato (PS. 1, 3, 2) admite-se um "procurator" encarregado da administração de interesses específicos (“ad litem (...) aut ad partem negotii”) diversamente do que se verificara quando das origens do instituto (atreladas à variante “omnium rerum"). Contudo, a despeito deste particular, os contornos eficaciais do tipo contratual permaneceram os mesmos do direito clássico; assim, enquanto de PS. 2, 15, 1 se pode extrair uma minuciosa disciplina a respeito das hipóteses de renúncia do mandatário, em PS. 2, 15, 3 se preconiza um escrupuloso acatamento deste último às instruções do mandante. Por sua vez, no que toca estritamente à representação (negocial) direta, percebese que ao mesmo tempo em que se admite a aquisição de posse por meio do "procurator" (PS. 5, 2, 2), se evita a sua incorporação à eficácia ordinária do "mandatum"; a esse respeito, é elucidativo o trecho de PS. 2, 15, 2 no qual se alude à possibilidade de que mudando de idéia - o mandante se recusasse a receber a coisa adquirida pelo seu mandatário ("et si rem postea accipere nolis"): de fato, tal passagem parece evidenciar a ausência de uma eficácia traslativa direta (imediata) - decorrente da simples aquisição levada a efeito pelo próprio agente ${ }^{70}$.

${ }^{70}$ É necessário destacar, preliminarmente, que a eficácia ordinária do "mandatum" será objeto de análise futura - em estudo ulterior que integra a "linha de pesquisa" apresentada na introdução deste estudo.

No Livro I das "Pauli Sententiae" está situado o título "de procuratoribus, hoc est, qualiter actio possit mandari et reliqua", em meio ao qual se pode surpreender duas proposições consideravelmente relevantes para os específicos fins deste estudo:

a) PS 1, 3, 1: "1. Mandari potest procuratio praesenti, et nudis verbis, et per literas, et per nuncium, et apud acta praesidis et magistratus. Interpretatione non eget" (Lex Romana Visigothorum cit. (nota 67), p. 340); "1. The appointment of an agent can be made either during his presence, or his absence; and it can be conferred either by mere words, or by a letter, os by a messenger, or in the presence of a Governor or a magistrate" (S. P. SCOTT, The Civil Law cit. (nota 69), p. 260). Tal fragmento se volta, portanto, à caracterização do "mandatum" como uma espécie de contrato consensual; assim, tendo-se em vista o modo de sua formação, depreende-se que a relação jurídica contratual exsurge a despeito da observância de quaisquer formalidades que extrapolem os limites do simples consenso. Além disso (como destacado no corpo do texto), o período "mandari potest procuratio praesenti" evidencia, com inquestionável eloqüência, a proximidade entre os institutos da "procuratio" e do "mandatum".

b) PS 1, 3, 2: "2. Procurator aut ad litem, aut ad omne negotium, aut ad partem negotii, aut ad res administrandas datur. Interpretatio. Procurator eas tantum res agere potest, quas ei evidenter constiterit fuisse commissas" (Lex Romana Visigothorum cit. (nota 67), p. 340); "2. An agent is appointed either for the purpose of conducting a suit, or to transact any business, wholly or in part, or for the general administration of affairs" (S. P. SCOTT, The Civil Law cit. (nota 69), p. 260). Este passo, por sua vez, é importante por denunciar a aproximação sistemático-funcional entre a "procuratio" e o "mandatum"; enquanto originalmente o "procurator" se identificava com o administrador geral ("omnium rerum"), com o passar do tempo passou a ser admitida a assunção de incumbências específicas por tal modalidade peculiar de agente ("procuratio ad litem" e "procuratio unius rei").

Já o Livro II das "Sentenças de Paulo" se volta à definição de algumas regras aplicáveis ao "mandatum" propriamente dito: 


\section{§ 90. O "Liber Iudiciorum” e a eficácia da atuação do escravo sobre o}

acervo doméstico. Promulgado no ano de 654 d.C., o "Código Visigótico" ("Lex Visigothorum Rescesvindiana", "Liber Iudiciorum", "Liber Iudicum”, "Forum Iudicum” ou "Fuero Juzgo") se caracteriza pela convergência de elementos germânicos, canônicos e romanos; contudo, a despeito de uma remota influência justinianéia quanto à sua estruturação interna (tenha-se em vista o fato de que o "Forum Iudicum" também está repartido em doze livros), é o direito romano pós-clássico (pré-justinianeu) que concorre para a sua conformação (sobretudo pela via do "direito vulgar"). No que respeita à

a) PS 2, 15, 1: "1. Ob subitam valetidinem, ob necessariam peregrinationem, ob inimicitiam et inanes rei actiones integra adhuc causa mandati negotio renuntiari potest. Interpretatio. Propter subitam infirmitatem, et necessitatem peregrinationis, vel propter inimicitias maioris personae ne cuiuscunque videatur actio vacillare, integra adhuc causa, is qui susceperit, susceptum negotium renuere potest" (Lex Romana Visigothorum cit. (nota 67), p. 364); "1. A mandate for the transaction of business can be refused on account of sudden illness, or a necessary journey, or enmity, or for the reason that there is no property, before anything has been done" (S. P. SCOTT, The Civil Law cit. (nota 69), p. 274). Trata-se de proposição denunciadora das estreitas hipóteses de cabimento da renúncia - por parte do mandatário.

b) PS 2, 15, 3: "3. Certo pretio rem iussus distrahere, si minoris vendiderit, mandati iudicio pretii summa poterit integrari. Venditionem enim dissolvi non placuit. Interpretatio. Si quis suilibet mandet, ut rem suam decem solidis vendat, et ille eam octo vendiderit, pretium, quod ei mandatum est, quic quid minus ab emtore percepit, mandatori complere compellitur. Venditio tamen rescindi non potest" (Lex Romana Visigothorum cit. (nota 67), p. 364); "3. If a person ordered to sell property for a certain price sells it for less, the entire sum can be recovered by an action of mandate, for it has been held that the sale cannot be set aside" (S. P. SCOTT, The Civil Law cit. (nota 69), p. 274). Este fragmento remonta, indiretamente, ao teor de G. 3, 161 (cf. nota 68 ); outorgando-se ao mandante, desatendido, a ação de mandato (direta) pelo preço constante das instruções confiadas ao mandatário (eis que frustrada a confiança outrora depositada).

No que concerne aos efeitos representativos (diretos) decorrentes da atuação do "procurator", eis o teor de PS 5, 2, 2: "2. Per liberas personas, quae in potestate nostra non sunt, acquiri nobis nihil potest. Sed per procuratorem acquiri nobis possessionem posse, utilitatis causa receptum est. Absente autem domino comparata non aliter ei, quam si rata sit, quaeritur. Interpretatio. Per liberas personas, quae nobis nulla conditione obligatae sunt, acquirere nihil possumus. Sed per procuratores acquiri nobis possessionem certum est. Nam si aliquid absente domino fuerit comparatum, non aliter ei acquiritur, nisi hanc ipsam venditionem sibi acceptam dominus esse consenserit" (Lex Romana Visigothorum cit. (nota 67), p. 414); "2. Nothing can be acquired for us by free persons who are under our control, but it has been decided that, for the sake of convenience, possession can be acquired for us by an agent. When the principal is absent, anything which is purchased is not acquired for him, unless he subsequently ratifies the act" (S. P. ScOTT, The Civil Law cit. (nota 69), p. 310). A respeito do teor da regra contida nesta passagem das "Sentenças de Paulo", cf. nota 40, supra. Contudo, a tradução de S. P. ScOTT, neste particular, nos parece equivocada - uma vez que, em lugar de "who are under our control", parece-nos que seria adequado constar "who are not under our control" (correspondente ao trecho latino "quae in potestate nostra non sunt").

Finalmente, de PS. 2, 15, 2 parece ser possível depreender uma inadmissão da representação direta no quadro da eficácia regular do contrato de mandato: "2. Si meis nummis mandato tuo aliquid tibi comparavero, et si rem postea accipere nolis, mandati actio mihi adversus te competit. Non enim tantum quod impensum est, sed et usuras eius consequi possum. Interpretatione non eget" (Lex Romana Visigothorum cit. (nota 67), p. $340)$; "2. If I purchase anything for you with my money under your direction, even if you afterwards should be unwilling to take the property, an action of mandate will lie against you in my favor, and I can not only recover what has been expended but also the interest on the same" (S. P. SCOTT, The Civil Law cit. (nota 69), p. 274). Com efeito, se o mandante se mostra relutante quanto ao recebimento da coisa adquirida durante a execução do "mandatum", a transferência da propriedade não se opera (senão à custa da "actio mandati contraria"); desta forma, sendo necessário o manejo da ação de mandato (pelo mandatário), parece-nos evidente a vedação - conquanto implícita - a efeitos representativos (diretos) ordinariamente decorrentes do exercício do mandato. 
historiografia interna pretendida neste trabalho, a contribuição do "Liber Iudiciorum" é notável, compreendendo não apenas a eficácia típica do contrato de mandato (§91), como também disposições precisas sobre aspectos peculiares do fenômeno representativo (§ 92) - algumas das quais particularmente ligadas à atuação do mandatário (§ 93). De todo modo, naquilo que concerne à eficácia da atuação do escravo sobre o patrimônio familiar, verifica-se não só uma reiteração de disposições já articuladas no "Código de Eurico" - cf. CE. 287 e LI. V, 4, 14 (venda sem autorização do "dominus"); CE. 283 e LI. V, 5, 6 (assunção de depósito sem a ciência do amo); e CE. 284 e LI. V, 5, 7 (particularidades da contração de empréstimo) - como também uma generalização expressa de seu respectivo alcance, podendo-se constatar uma irrestrita vedação à prática de quaisquer atos (não autorizados) pelo cativo (LI. X, 1, 10) - especificamente referendada, aliás, a respeito da contratação por meio do "servus" (LI. II, 5, 6) ${ }^{71}$.

\footnotetext{
${ }^{71}$ Antes de voltarmos nossa atenção aos fragmentos propriamente coligidos, cabe uma breve menção acerca da forma de citação do "Código Visigótico". Com efeito, diante da pluralidade de denominações que lhe tem sido emprestada, algumas delas se mostram preferíveis diante das demais; não fosse por razões de crítica historiográfica, ao menos a fim de que se evitem confusões graves. Assim, embora uma das mais difundidas designações seja "Lex Visigothorum Rescesvindiana" - por vezes abreviada ("Lex Visigothorum"), tal como faz A. D’ORs (El Codigo cit. (nota 65), p. 18) -, dela não nos utilizaremos, sobretudo à vista da (evidente) possibilidade de equívoco, quando correlacionada à "Lex Romana Visigothorum" (Breviário de Alarico).

Tendo sido por nós eleita, arbitrariamente, a denominação "Liber Iudiciorum" (como simples mecanismo operacional), resta-nos ainda a questão atinente à forma de citação dos fragmentos incorporados a esta coletânea de direito visigodo. Apenas para que possamos transmitir ao leitor o estado da própria doutrina especializada, trazemos à colação três formas distintas de referência ao aludido texto: 1) L. C. de AZEVEDO, por exemplo, lança mão de uma referência detalhada, bastante clara e inequívoca - v. g. "Liv. II, Tít. I, n. IX" - mas que por ora é afastada em virtude de seu caráter extremamente trabalhoso e pouco difundido na comunidade científica (L. C. de AZEVEDO, O direito visigótico cit. (nota 64), p. 8); 2) J. M. P.-P. MuÑOZ ARRACO, por sua vez, se utiliza de uma metodologia de referência excessivamente "romanizada" - v. g. "Liber Iudiciorum 4, 2, 18" - suscetível de ensejar confusões, por sua vez, com os textos romanos objeto de nossos estudos (Breviario de Derecho Germánico, Madrid, Servicio de Publicaciones Facultad Derecho Universidad Complutense Madrid, 1993, p. 102); 3) M. PAUlo MerÊA, enfim, emprega um método de citação que nos parece suficientemente distintivo, singelo e compacto - v. g. Código Visigótico "IV, 2, 13" além de referendado pela autoridade de um dos maiores expoentes da historiografia jurídica visigoda (Estudos cit. (nota 64), p. 15). Por tais razões, adotamos neste trabalho o estilo de referência constante das obras deste último autor.
}

No que toca aos fragmentos referidos no corpo do texto, declina-se aqui o seu respectivo teor - tomando-se por base, para o texto latino, a edição publicada pela Real Academia Espanhola (Fuero Juzgo en Latin e Castellano, cotejado con los mas antiguos y preciosos códices por la Real Academia Española, Madrid, Ibarra, 1815); já no que concerne à versão castelhana, utilizamos a coletânea produzida sob a supervisão de D. Alonso de Villadiego (El Libro de los Jueces ó Fuero Juzgo, segun el texto del Dr. Alonso de Villadiego, que desde su publicacion se ha seguido comunmente en los Juzgados del reino; emendadas muchas erratas, y cotejado con el de la edicion moderna de la Academia española, que ha servido para aclarar varios lugares obscuros de las leyes - precédele un discurso del editor sobre los godos, sus costumbres y su legislación en España, Madrid, Imprenta de D. Leon Amarita, 1841). Eis o teor dos excertos referidos:

a) LI. V, 4, 14: "De commvtationibvs et venditionibvs" ("De las cambias é de las vendezones"): "XIV. Antiqua. Si servus venditus in priorem dominum crimen obiiciat. Si quis servum suum vendiderit, et ipse servus priori domino aliquod crimen obiecerit, ille qui vendidit, recipiat, quem vendiderat, pretium redditurus emptori; ut ipse in servo suo crimen, quod sibi obiectum est, inquirere vel vindicare studeat. Id autem et de ancillis praecipimus custodiri. Idem tamen servus vel ancilla, seu venditi, sive donati, vel commutati in 
priorum dominorum capite non torqueantur, neque credatur eis, si prioribus dominis crimen obiecerint" (Fuero Juzgo en Latin cit. (nota 71), p. 68); "Ley XIV - No valga la venta hecha por el esclavo de las cosas de su señor (Cindasuinthi, ut in C. Latino): Las cosas que son ayenas, non las pode nengun vender sen voluntad de so senor: e por ende la ley antigua que mandaua desfazer las vendiciones de los sieruos ayenos, non era sen dano de sos senores: e porende aquela ley antigua queremos tornar a derecho, ca meyor es de emendarla por nos, que de errar con aquelos que la fizeron. E por esto estabelecemos, que si algun ome sabiendo del sieruo, o de la sierua ayena, recibir delos casa, o vina, o sieruo, o possession alguna, o emiendacion, o empenos, en alguna manera, tal fecho non vala: ante aquel que tomo el precio, nin aquel que tomo el precio, non sea tenudo de lo dar, e aquel que lo vendio sea dado por sieruo al senor del sieruo, o de la sierua: e el que lo compro pierda el sieruo, e pierda el precio: ca derecho es que pierda aquelo que dio, porque coydo de ganar el ayeno por cobiça: e si el sieruo, o la sierua vender alguna animalia, o dalgunos ornamentos, o otras cosas que eran de su peguyar, o le los diera so senor, o otro ome para vender, esta vendecion deue valer: assi que si el senor del sieruo, o de la sierua quisier desfazer la bendicion a minos de prouarel senor por bonas testimonias, o por so yuramiento, que aquelo non era peguyar del sieruo, e que lo vendio sen voluntat de so senor: e esto deuemos entender de las cosas viles e pequenas: ca las grandes cosas non se poden vender sen voluntat del senor" (El Libro de los Jueces cit. (nota 71), pp. 218-219). Trata-se de uma disposição correspondente ao capítulo 287 do "Código de Eurico", sobre o qual tivemos oportunidade de nos manifestar anteriormente (nota 65).

b) LI. V, 5, 6: "De commendatis, et commodatis" ("De las cosas encomendadas é emprestadas"): "VI. Antiqua. De rebus servo, nesciente domino, commendatis. Quod, nesciente domino, servo fuerit commendatum, si id perierit, nec dominus, nec servus ullum damnum incurrant. Suae enim imputet culpae, qui servo alieno res suas commendaverit, domino nesciente. Si vero alicuius rei animal sit, et per fraudem pastorum diminutum reperiatur, hoc reddere compellatur. Similis et de commodatis forma servetur, si fraude, aut malitia consumpta aut dissipata noscuntur" (Fuero Juzgo en Latin cit. (nota 71), p. 71); "Ley VI - El que dió alguna cosa en guarda al esclavo ageno sin saberlo el señor, aunque se pierda, ni el esclavo ni el señor sea obligado á pagarla (Eurici aut Leouigildi): La cosa que es comendada al sieruo, non lo sabiendo nen el senor, nen el sieruo, non son tenudos por pagar ende nada, mas deuese tornar assimismo a aquel que encomienda la cosa al sieruo non lo sabiendo el senor: e si fur alguna animalla e se perder por engano de los sieruos, el senor sea tenudo de lo pechar. Otrosi mandamos gardar de las cosas emprestadas, si se perdieren por engano, o por maldade" (El Libro de los Jueces cit. (nota 71), p. 229). Assim como afirmado com relação ao fragmento anterior, consiste este excerto em adaptação do capítulo 283 do Código Euriciano, a cujo comentário tomamos a liberdade de remeter o interessado (nota 65).

c) LI. V, 5, 7: Livro V: "De commendatis, et commodatis" ("De las cosas encomendadas é emprestadas"): "VII. Antiqua. Si servus mentiatur dominum petere commodanda. Si dominus per servum suum quodcumque sibi petierit commodandum, et servus cum rebus commodatis in fugam fuerit elapsus, tunc dominus obligetur, ut commodata restituat. Si vero servus petisse dominum mentiatur, et sic quasi deportanda ad dominum susceperit, et quae susceperit, aut evertat, aut forte perdiderit, et fugitivus non potuerit inveniri: dominus servi praebat sacramentum se eundem servum, ut susciperet non misissse, et quum id peteret ignorasse, et nihil calumniae pertimescat. Servum tamen tam dominus quam ille qui commodavit, quaerere sollicite procurabunt. Haec eadem et de commendatis praecipimus custodiri" (Fuero Juzgo en Latin cit. (nota 71), pp. 71-72); “Ley VII - Si el esclavo por mandado de su señor pidió alguna cosa emprestada, y se fue con ella, páguela el señor, y si la pidió sin su mandado, no (Eurici): Si el senor mando al sieruo que fusse demandar alguna cosa emprestada, e el sieruo fuir con aquelas cosas, el senor las deue pechar, mas si el sieruo demandaba las cosas emprestadas sen mandado del senor, e pedir aquelas, o fuir con ellas, el senor del sieruo jure que non embio pedirlas, e que lo non sobo quando las pidio, e non peche ende nada, e el senor, e el que las emprestara deuen a buscar el sieruo. Otrosi dizemos de las cosas encomendadas" (El Libro de los Jueces cit. (nota 71), pp. 229-230). Este fragmento corresponde ao capítulo 284 do "Código de Eurico", analisado em momento anterior do presente estudo (nota 65).

d) LI. X, 1, 10: "De divisionibus, et terris ad placitvm datis" ("De los departamientos de las terras que son dadas á plazos"): "X. Quod ea quae servus non iubente domino fecerit, excepto quod lex iubet, valere non poterit. Quidquid servus non iubente domino diviserit vel fecerit, excepto quod lex permittit, firmum non esse iubemus, si id dominus servi noluerit custodire" (Fuero Juzgo en Latin cit. (nota 71), p. 131); "Ley X - No valga lo que el esclavo hiciere sin mandado de su señor (Sisnandi): Lo que parte el seruo, o lo que faze sen mandado de so senor non deue ser estable, si el senor non quisier, si non quando manda la ley" (El Libro de los Jueces cit. (nota 71), pp. 384-385). Neste fragmento se tem uma generalização do alcance da regra extraída, indutivamente, dos capítulos 283, 284 e 287 do Código Euriciano, voltando-se a atenção do legislador não mais a hipóteses específicas de atuação do "servus" em prol do patrimônio doméstico, mas sim de um seu emprego em caráter generalizado (sobretudo no âmbito contratual). Por tal ordem de idéias, este 
§ 91. O "Liber Iudiciorum" e a relação entre "mandatum” e "procuratio"; peculiaridades sobre a eficácia do tipo contratual e notas a respeito do fenômeno representativo (no âmbito da "procuratio ad litem”). No que concerne à eficácia típica do contrato de mandato, temos que a aproximação sistemático-funcional entre a "procuratio" e o "mandatum" se evidencia também no "Liber Iudiciorum": em seu Livro II, deparamonos com o título "de mandatoribus et mandatis" (Tít. III), em cujo bojo se articula uma minuciosa disciplina voltada à atuação do "procurator ad litem". Todavia, para além da aludida junção entre os referidos institutos, especificamente no que concerne ao tipo contratual referido, merecem destaque três ordens de dispositivos reunidos no título mencionado: a) em primeiro lugar, uma série de provisões de fundo social, relacionadas à utilização compulsória de procurador (LI. II, 3, 1), ao seu excepcional emprego em caráter facultativo (LI. II, 3, 10) e à proibição - dirigida ao principal - quanto à constituição de um agente mais poderoso que o seu adversario (LI. II, 3, 9); b) além disso, a previsão da extinção dos efeitos da outorga de poderes em virtude da morte de um dos sujeitos envolvidos (LI. II, 3, 8), a evidenciar o caráter "intuitu personae" do negócio jurídico; c) finalmente, a possibilidade de remoção do gestor que - eivado de dolo ou culpa procrastina o encerramento da controvérsia judicial, acarretando prejuízo ao seu principal (LI. II, 3, 5). Por sua vez, no que concerne ao fenômeno representativo (e ainda no âmbito

preceito está intimamente ligado à disposição contida em LI. II, 5, 6, a que dedicaremos nossa atenção a seguir.

e) LI. II, 5, 6: "De Scriptvris valitvris et infirmandis, ac deffunctorvm volvntatibvs conscribendis" ("De los escriptos que deuen valer ó non, é de las mandas de los mortos"): "VI. Ne valeant definitiones vel pacta servorum, sine iussu dominorum. Honestas hoc habet, et iustitia hoc adfirmat, ut quae servi non iubentibus dominis suis, seu per scripturam paciscuntur, sive per testam definiunt, nullo firmo robore penitus habeantur" (Fuero Juzgo en Latin cit. (nota 71), p. 28); “Ley VI. El esclavo no puede hacer contrato alguno sin licencia de su señor (Cindasuinthi): "Iusticia e onestat, manda que lo que fazen los sieruos sin mandado de los senores, o lo que prometen por escripto, o por testimonias, que non deue valer" (El Libro de los Jueces cit. (nota 71), p. 109). Trata-se, como se vê, de uma aplicação mais restrita da regra contida em LI. X, 1, 10, voltada exclusivamente ao âmbito do direito contratual.

Ainda quanto à atuação do "servus", orienta-se o interessado a cf. LI. IV, 2, 16 - em que se estabelece que as aquisições operadas por meio dos escravos da esposa redundam em benefício de seu respectivo marido.

Por considerações historiográficas (amplas) a respeito do "Código Visigótico", cf. M. J. de ALMEIDA CosTA, História cit. (nota 09), pp. 131-132; M. CAETANO, História cit. (nota 16), pp. 104-107; CÂNDIDO MENDES DE AlmeIDA, Código cit. (nota 16), pp. XIII-XVIII; L. C. de AZEVEDo, O direito visigótico cit. (nota 64), pp. 710; J. C. MoReIRA Alves, Panorama cit. (nota 16), pp. 186-187; I. M. Poveda Velasco, Ordenações cit. (nota 16), pp. 11-15; N. E. GoMES DA Silva, História cit. (nota 16), pp. 71-72; P. J. de MELlo FreIRE dos Reis, História cit. (nota 16), pp. 86-87; M. PAUlo MERÊA, Resumo cit. (nota 16), pp. 28-30; M. A. COELHO DA RochA, Ensaio cit. (nota 16), pp. 22-24; J. G. B. CÂMARA, Código Filipino cit. (nota 64), pp. 226-230; S. MinguiJón AdRIÁn, Historia cit. (nota 64), pp. 49-51; A. GARCíA-GAllo, Curso de Historia cit. (nota 64), pp. 89-90; L. de ESTRADA, Manual cit. (nota 64), pp. 17-19; V. LOBO DA CosTA, Contribuição cit. (nota 64), pp. 355-356; L. de M. LEME, O direito cit. (nota 64), p. 76; A. PÉREZ MARTín, El Fuero Real cit. (nota 64), pp. 63-65; M. R. MARQUES, História cit. (nota 64), p. 9; e C. PETIT, Consuetudo y mos cit. (nota 64), p. 240 (aludindo a uma vigência generalizada do "Código Visigótico", sem maiores "luchas dramáticas" contra o fundo jurídico germânico até então prevalecente). 
estritamente processual), o estudioso se defronta com a provisão contante de LI. II, 3, 2, segundo a qual aquele que comparecer em juízo por outrem deve exibir o respectivo instrumento de outorga de poderes (à semelhança do preconizado pelo art. 118 do Código Civil vigente); e em se tratando de agente desprovido de poderes, o "Código Visigótico" admite, excepcionalmente, que o marido litigue por sua esposa, desde que prestada “caução" - destinada esta, em última análise, a proporcionar à parte contrária um mínimo de segurança (LI. II, 3, 6) ${ }^{72}$.

${ }^{72}$ Reproduzimos, em nota, os fragmentos referidos no corpo do texto:

a) LI. II, 3, 1: "De mandatoribvs et mandatis" ("De los mandadores, y de las cosas que mandan"): "I. Quod Principum et Episcoporum negotia non per eos, sed per subditos sint agenda. Maiorum culminum excellentia quanto negotiis rerum dare iudicium decet, tanto negotiorum molestiis sese implicare non debet. Si ergo Principem vel Episcopum cum aliquibus consisterit habere negotium, ipsi pro suis personis eligant, quibus negotia sua dicenda committant; quia tantis culminibus videri poterit contumelia inrogari, si contra eos vilior persona in contradictione causae videatur adsistere. caeterum, et si rex voluerit de re qualibet propositionem adsumere, quis erit qui ei audeat ullatenus resultare? Itaque ne magnitudo culminis huius evacuet veritatem, non per se, sed per subditos agat negotium actionis" (Fuero Juzgo en Latin cit. (nota 71), pp. 20-21); "Ley I. Los príncipes, los obispos, y prelados no pueden traer por si mismos los pleitos, sino por sus procuradores (Sisnandi, vel D. Isid.): "Los señores qnanto mas deuen judgar los pleytos, tanto mas se deuen guardar de los destoruar; onde quando el Obispo, o el Principe, han pleyto con algun ome, ellos deuen dar otros personeros que trayan el pleyto por ellos, ca desondra semeiarie a tan grandes omes si algun ome rafez les contradixiesse lo que dixiessen en el pleyto: e si el Rey quisiere traer el pleyto por si, quien le osara contradezir? Onde que por el miedo del poderio, non desfallezca la verdad, mandamos que non traten ellos el pleyto por si, mas por sus mandaderos" (El Libro de los Jueces cit. (nota 71), p. 87). Aqui temos uma disposição parecida com o teor de um passo do "Decreto" (de Graciano) já referido ao longo do presente trabalho (c. 3, C. 5, qu. 3; nota 46). Contudo, não fosse suficiente a precedência cronológica do "Código Visigótico" (de quase meio milênio), a própria teleologia dos dispositivos afastaria uma aproximação maior; enquanto a preocupação canônica estaria voltada à concentração do clero (em seus respectivos assuntos de natureza espiritual), o direito visigodo buscava evitar, então, a prevalência da força (ou mesmo do temor reverencial) em juízo. Afinal, "quem ousaria contradizer o rei?" - justifica o legislador visigótico.

b) LI. II, 3, 10: "De mandatoribvs et mandatis" ("De los mandadores, y de las cosas que mandan"): "X. Quod liceat his, quibus commissus est fiscus, pro re fisci quibus voluerit exsequendas iniungere actiones. Nullus quidem rerum fiscalium temerator debet existere. tamen quandoquidem si pro iure fisci contra quemlibet provenerit intentione moveri, ille cui commissa res est, apud comitem civitatis, vel iudicem habebit licentiam legaliter negotium prosequendi: quem si absentem a loco, ubi res agenda est, esse contingerit, vel occasio eum quaecumque suspenderit, aut etiam per se proponere fortasse noluerit, eandem utilitatis publice actionem per mandatum iniungere prosequendam cui elegerit, sui erit indubitanter arbitrii" (Fuero Juzgo en Latin cit. (nota 71), p. 22); "Ley X. Los mayordomos del rey puedan tratar los pleitos por si mismos, ó por la persona de quien quisieren (Sisnandi, vel D. Isid.): Ningun ome deue tener forçadas las cosas del Rey, e si por ventura auiene que el que guarda las cosas del Rey fiziere demanda contra alguno, este puede traer el pleyto por si, si quisiere: e si por ventura non pudiere ser en el pleyto, e ouiere de yr en otras partes, o non lo quisiere traer por si, puede meter por personero a quien quisiere. E esto mandamos por prouecho de todos, e de todo el pueblo" (El Libro de los Jueces cit. (nota 71), p. 94). Trata-se de provisão por meio da qual se estabelece uma espécie de privilégio processual, no sentido da admissão de uma atuação tão somente facultativa do "procurator ad litem".

c) LI. II, 3, 9: "De mandatoribvs et mandatis" ("De los mandadores, y de las cosas que mandan"): "IX. Qualibus personis potentes, et qualibus pauperes prosequendas actiones iniungant. Nulli liceta potentiori quam ipse est qui committit, causam suam ulla ratione committere, ut non aequalis sibi eius possit potentia opprimi vel terreri. Nam etiam si potens cum paupere causam habuerit, et per se adserere noluerit, non aliter quam aequali pauperi, aut fortasse inferiori a potente poterit causa committi. Pauper vero, si voluerit, tam potenti suam causam debeat committere, quam potens ille est, cum quo negotium videtur habere" (Fuero Juzgo en Latin cit. (nota 71), p. 22); "Ley IX. No sea procurador de otro el que es mas poderoso que su adversario (Reccesuinthi): Ningun ome non deue meter por personero de su pleyto ome mas poderoso de si, 
por querer apremiar su auersario por poder daquel: e si algun ome poderoso ha pleyto con algun ome pobre, e non quiere traer el pleyto por si mismo, non puede meter por personero si non ome que sea egual del pobre, o que sea menos poderoso del que lo mete: e si el pobre quisiere meter personero, pueda meter por personero ome que sea poderoso tanto como su auersario" (El Libro de los Jueces cit. (nota 71), p. 93). Aqui se tem uma previsão fundada na idéia de eqüidade (concebida como "suum cuique tribuere"), que já se podia divisar, sob outras circunstâncias, na própria "Lei das XII Tábuas" $(1,7)$, ao se admitir que do pobre (e não do rico) qualquer pessoa pudesse ser garante.

d) LI. II, 3, 8: "De mandatoribvs et mandatis" ("De los mandadores, y de las cosas que mandan"): "VIII. Vt si mortuus fuerit is qui mandatum accipit, commodum illi debitum haeredes eius accipiant. Qui mandatum fecit, si mortuus fuerit antequam causa dicatur, mandatum quod fecerat non valeat; et qui mandatum suscepit, si antequam causa dicatur, fuerit morte praeventus, mandatum nullam habeta firmitatem. Quod si antequam moreretur causam dixisse dinoscitur, atque per suam instantiam ad fines usque legitimos perduxerit, et tamen quocumque casu intercedente, nec dum perfinita res, aut exacta remansit, si ad hunc forte terminum fuerit causa deducta, quo eam ille qui per mandatum sequutus est, iam ante acceleraverat, omne lucrum quod ipse fuerat habiturus, haeredibus eius a mandatoris partibus exsolvatur" (Fuero Juzgo en Latin cit. (nota 71), p. 22); "Ley VIII. El poder espira con la muerte del señor ó de su procurador (Sisnandi, vel D. Isid.): El que tiene personero en el pleyto, si se muriere ante que el pleyto sea acabado, el mandado que fizo al personero non vala nada, e si el personero muere por ventura ante que el pleyto sea acabado, el mandado otrosi non vala nada: e si el pleyto era acabado antes que el muriese, e por algun embargo, por ventura el señor del pleyto non anie aun recebida la cosa que le era judgada, si la cosa auiniere a aquel plazo que el personero fiziera que fuesse pagada, sus herederos del personero deuen auer el precio quel fue prometido, daquel que lo metio por personero, o de sus herederos" (El Libro de los Jueces cit. (nota 71), pp. 92-93). Trata-se aqui de uma disposição evidenciadora do caráter "intuitu personae" da relação - ressalvando-se o direito adquirido dos herdeiros, em virtude das atividades desenvolvidas pelo "procurator" antes de sua morte.

e) LI. II, 3, 5: "De mandatoribvs et mandatis" ("De los mandadores, y de las cosas que mandan"): "V. Vt si dilationem in causa patitur qui mandatum fecit, liceat ei immutare mandatum. Qui causam alicuius ex mandato susceperit, ut negotium peragatur insistat: quod si protrahit tempus, et causa, quam forsitan celerius poterat expediri, occasionibus superfluis, aut fraudulenta dilatione suspenditur, mandator recurrat ad iudicem. Et qui mandatum acceperat, si malitiae alicuius aut cupiditatis, vel negligentiae vitio, adversario praesente, vel iudice, susceptum negotium ultra decem dies absque praecepto iudicis dilataverit, is qui mandaverat, aut per se proponere, aut alicui quem elegerit, suam liceat committere actionem" (Fuero Juzgo en Latin cit. (nota 71), p. 21); "Ley V. El procurador que maliciosamente y por su culpa alarga el pleito, puede ser removido (Eurici aut Leouigildi): Quien trae pleyto por mandado de otro, deue acabar el pleyto, quanto mas aina pudiere, e si por ventura prolongare el pleyto por engaño, que lo podie acabar mas ayna si quisiese, el que lo metio por personero venga ante el juez: e si por ventura prouare que el su personero por engaño, o por pereza prolongo el pleyto sobre diez dias sin voluntad del juez, e que podie auer el juez e su auersario, estonce el que lo metio por personero, puede traer el pleyto por si, o por otre quien quisiere" (El Libro de los Jueces cit. (nota 71), p. 90). Aqui se tem uma previsão especificamente devotada à "remoção" do "procurator" ("ad litem") negligente, facultando-se ao principal a retomada do curso da ação.

f) LI. II, 3, 2: "De mandatoribvs et mandatis" ("De los mandadores, y de las cosas que mandan"): "II. Vt iudex litigatore perquirat, utrum propria, an aliena sit causa prolata. Iudex primum a litigatore perquirat, utrum propriam causam dicat, an alienam fortasse susceperit. Interrogetur etiam cuius mandatum habeat, et postquam causam iudicaverit iudex, comprehendat in iudicio, quem aut ex cuius mandato audierit negotium prosequentem, ac praeterea mandati exemplar accipiat illius assertoris apud se cum iudicati exemplaribus reservandum. Liceat tamen illi qui pulsatus est, mandatum a petitore coram iudice petere, ut quam ob causam fuerit iudicio praesentatus, vel quid tenor mandati contineat, indubitanter possit agnoscere" (Fuero Juzgo en Latin cit. (nota 71), p. 21); "Ley II. Mande el juez exhibir y mostrar el poder al que pareciere en juicio en nombre de otro (Sisnandi, vel D. Isid.): El Iuez deue demandar primeiramient a aquel que se querella, si es el pleyto suyo, o ageno, e si dixere que es ayeno, muestre como mando que se querellase aquel cuyo era el pleyto, e pues que lo mostrare, el juez faga escriuir en la carta quien es aquel que se querella, e por cuyo mandado se querella, e tome el traslado, e guardelo con los otros escriptos del juycio: e aquel de quien se querella puede demandar, quel muestren el mandado que pueda saber, por que razon, o por qual cosa se querella del, e como mandaron al personero que se querellasse" (El Libro de los Jueces cit. (nota 71), pp. 8788). Trata-se de preceito de importância indiscutível, na medida em que aí se pode entrever um antecedente histórico significativo da regra constante do art. 118 do Código Civil; embora não se estabeleça a exibição do instrumento de outorga de poderes como incumbência do "procurator" ("ad litem"), determina-se ao juiz tal providência - conferindo-se, em último caso, à própria parte contrária o poder de assim o exigir.

g) LI. II, 3, 6: "De mandatoribvs et mandatis" ("De los mandadores, y de las cosas que mandan"): "VI. Antiqua. Ne causam suscipiat femina per mandatum, licite vero propria exsequatur. Femina per mandatum 


\section{§ 92. A eficácia da atuação do "procurator" ("ad litem") consoante dois}

fragmentos do "Liber Iudiciorum". Epigrafado "Vt sicut lucrum, ita et damnum revertatur ad mandatorem: de commodis etiam mandatum accipientis", o fragmento constante de LI. II, 3, 7 poderia, em um primeiro momento, conduzir ao equivocado entendimento de que fora admitida entre os visigodos, em caráter ordinário, a representação direta por efeito do próprio contrato de mandato; de fato, a uma conclusão como esta seria induzido o intérprete que - em consulta a uma edição castelhana - se deparasse com a tradução "que el daño y el provecho del pleito pertenece al señor del pleito, y no á su procurador". Todavia, o confronto do inteiro teor do excerto sugere ao estudioso um entendimento completamente diverso, quando tomado em consideração o período "quod si receptam rem prosecutor infra tres menses reddere neglexerit mandatori, quidquid de eadem causa per quamcumque definitionem conseque potuit, perdat, et mandator iudicis instantia rem sibi competentem accipiat"; ou seja, não havendo transmissão espontânea dos direitos adquiridos em virtude do exercício da "procuratio ad litem", tal providência seria determinada ao "procurator" pelo próprio juízo. Note-se que uma interpretação neste sentido é corroborada pela regra constante de LI. II, 3, 3, segundo a qual o dano causado pela desídia do agente deve ser por ele próprio suportado: entregando-se à contraparte "res" integrante do patrimônio do próprio "procurator" (e não do principal); ou seja, o

causam non suscipiat, sed suum proprium negotium in iudicio proponere non vetetur. Maritus sane non sine mandato causam dicat uxoris, aut certe ante iudicem se tali obliget cautione, quod uxor negotium eius non revolvat; et si revolverit, damnum quod cautio demonstrat, maritus excipiat, qui sine mandato causam dicere praesumpsit uxoris. Quod si maritus causam, quam sine mandato coniugis suae prosequebatur, amiserit, uxor nullum praeiudicium pertimescat; sed aut per se negotium prosequatur, aut qui voluerit ea quae ipsi competunt prosequenda commendet. Ita ut si marito per iudicium iuste superato, denuo ad causam dicendam adversarium illum, qui victor extiterat, pars mulieris crediderit convexandum, atque in iudicio secundo patuerit eundem eius maritum non indebite victum fuisse; noverit eadem mulier non solum se iudici, qui causam prius examinavit, sed et illi causidico, quem iteratim ad iudicium compulit, iuxta legis sententiam esse satisfacturum" (Fuero Juzgo en Latin cit. (nota 71), pp. 21-22); "Ley VI. Que la muger no pueda litigar en nombre de otro, sino en el suyo; y el marido no pueda tratar negocio de la muger sin su poder (Sisnandi, vel D. Isid.): Las mugeres non deuen traer el pleyto dotre ninguno, mas bien pueden razonar su pleyto si quisieren, e nin el marido non puede razonar el pleyto de la muger sin su mandado della, si non diere buen recabdo que la muger aya por firme lo que el fiziere, e si la muger lo quisiere despues desfacer, el marido deue perder la pena que prometio con el recabdo: e se el marido que tien el pleyto de la muger sin su mandado, lo perdiere por ventura, esto non deue empecer a la muger, que ella non lo pueda demandar de cabo por si, o por otre si quisiere: e si por ventura el marido fue vencido por derecho, e la muger se querella decabo, si ella o su personero fuere vencida otra vez, porque semeia que su marido fue vencido con tuerto, ella deue fazer enmienda al juez que judgo primeirament el pleyto, e a su aduersario, porquel fizo trabaiar con tuerto: asi como manda la ley" (El Libro de los Jueces cit. (nota 71), p. 91). Tal fragmento - ao mesmo tempo em que reitera o teor de PS. 1, 2,2 - prescreve a utilização de uma cláusula "de rato", à semelhança do que se pode depreender da parte final do art. 673 do Código Civil ("salvo se este [o mandatário] lhe prometeu ratificação do mandante ou se responsabilizou pessoalmente").

Note-se, finalmente, que segundo A. D'ORS, o título "de mandatoribvs et mandatis" é inteiramente novo - ao contrário das posições de Ureña e Zeumer, que compreendem como euricianas algumas de suas leis (El Codigo cit. (nota 65), pp. 52, 56-57. 
termo "revertatur" (constante da epígrafe de LI. II, 3, 7) não pode ser tomado como indicativo de uma representação direta (ordinariamente) decorrente do contrato de mandato

- mas tão somente como elemento informativo da pertinência mediata do resultado da demanda $^{73}$.

${ }^{73}$ Eis o teor dos fragmentos referidos no corpo do texto:

a) LI. II, 3, 3: "De mandatoribvs et mandatis" ("De los mandadores, y de las cosas que mandan"): "III. Vt qui per se causam non dicit, scriptis assertorem informet. Si quis per se causam dicere non potuerit, aut forte noluerit, assertorem per scripturam suae manus, vel testium signis, aut subscriptionibus roboratam dare debebit. Ita ut si idem assertor aliquod conludium fecerit qualiter ab adversario suo possit in iudicio superari, aliud tantum de facultate sua mandatori, restituat, quantum de rebus eius perdidit aut evertit, aut etiam quae ipse mandator obtinere, vel adquirere debuit exsolvat, Servo tamen non licebit per mandatum causas quorumlibet suscipere, nisi tantum Domini suae, Ecclesiarum quoque, vel pauperum, sive etiam negotiorum fiscalium de mandato. Quod si vero per tepriditatem, aut fraudulentiam iudicum, sive falsorum testimonium aliquid ex voce mea inutilitatum fuerit, tunc robore vocis meae adfuturum mihi reservetur, facto mandato" (Fuero Juzgo en Latin cit. (nota 71), p. 21); "Ley III. Daño que viniere á la parte por engaño y culpa del procurador, débele éste pagar (Reccesuinthi): Si algun ome non sabe, o non quiere dezir su querella por si, dela en escripto a su personero, e que aya testimonias, o sellos: e si aquel personero se dejare vencer por pleytesia, o por engaño, quanto perdio por el señor del pleyto, todo gelo deue entregar el personero de lo suyo, e quanto pudiera ganar, e non lo quiso ganar, otrosi todo lo deue pagar de lo suyo, e el sieruo non deue ser personero de ninguno en pleyto, si non de su señor, o de su señora, o por alguna Eglesia, o por algun pobre, o del Rey" (El Libro de los Jueces cit. (nota 71), pp. 88-89). A previsão de uma satisfação do crédito da parte contrária - à custa do próprio patrimônio do agente parece indicar a ausência de uma eficácia representativa (direta) decorrente do próprio mandato, eis que, se assim o fosse, restaria ao mandante a (natural) via regressiva; e assim não se verificando, abre-se ensejo para um confronto direto do teor de LI. II, 3,7 .

b) LI. II, 3, 7: "De mandatoribvs et mandatis" ("De los mandadores, y de las cosas que mandan"): "VII. Vt sicut lucrum, ita et damnum revertatur ad mandatorem: de commodis etiam mandatum accipientis. Sicut lucrum, ita et damnum iuxta conditionem mandati ad eum, qui causam mandaverit, revertatur; ita ut qui causam ex mandato dixerit, et fideliter, ut negotium peragatur, instituerit, ab eo mandator nec mandatum repetat, nec ipsam postea ad alium transferat actionem. Quia iniustum est, ut mercedem sui laboris amittat, qui pro suscepta causa fideliter elaborasse cognoscitur; ita ut is qui negotium prosecurutus est, ante causae principium cum mandatore definiat, quantum pro commodo sui laboris finito negotio ab eo sit accepturus. Quod si receptam rem prosecutor infra tres menses reddere neglexerit mandatori, quidquid de eadem causa per quamcumque definitionem conseque potuit, perdat, et mandator iudicis instantia rem sibi competentem accipiat" (Fuero Juzgo en Latin cit. (nota 71), p. 22); "Ley VII - El daño y el provecho del pleito pertenecen al señor del pleito, y no á su procurador (Sisnandi, vel D. Isid.): El daño e el prouecho del pleyto deuen pertenecer a aquel que metio el personero, e si el personero trae el pleyto fielment, e como deue el que lo metio por personero, non lo puede ende toller, e meter otro, ca tuerto serie, que aquel que fielmentse trabaya perdiesse el precio de su trabayo, e todauia el personero ante que entre el pleyto, deue poner con el señor del pleyto quantol de: e si lo que vencio el personero non entregar al señor del pleyto, fasta tres meses, deue perder el personero quantol prometio, y entregar aquella cosa a su señor por mandado del juez" (El Libro de los Jueces cit. (nota 71), p. 92). Este fragmento denuncia - desde que adequadamente traduzido o termo "revertatur" - uma eficácia representativa tão somente indireta, uma vez que, não efetuado o repasse do proveito da execução do mandato ao principal, caberia contra o agente a "actio mandati directa", com previsão específica de uma cominação judicial que constrangesse o mandatário a atender ao teor do ajuste, sem prejuízo da perda de sua remuneração; neste sentido, parece-nos que o intérprete deve tomar o termo "revertatur" como indicativo de uma pertinência mediata quanto ao resultado do litígio. Assim, parece-nos mais oportuna a tradução do trecho final do período realizada por S. P. ScotT (evidenciadora da ausência de quaisquer efeitos representativos inerentes à atuação do agente): "and if he who conducted the case shall neglect to deliver to his constituent, within three months, any property which came into his hands under the decree, he shall lose the compensation for his services which he would otherwise have received; and shall be compelled by order of court to deliver to his constituent, whatever he was entitled to under the decision" (The Visigotic Code (Forum Judicum), Boston, The Boston Book Company, 1910, p. 51).

Cabe destacar, ainda, uma informação latente neste último fragmento. Com efeito, seu teor evidencia o paulatino desenvolvimento de uma perspectiva sinalagmática do contrato de mandato, na medida em que, 
$\S$ 93. Encerramento do capítulo e apresentação do tema sucessivo. De acordo com as fontes coligidas, temos que a orientação visigótica a respeito do "mandatum" - bem como da "procuratio" - se aproxima, em larga medida, dos textos romanos em que este povo germânico se inspirou. Desta forma, enquanto no Oriente as feições pós-clássicas perduraram por pouco mais de um século - até o advento da reforma justinianéia (séc. VI d.C.) - no Ocidente acabaram por prevalecer durante um intervalo consideravelmente mais longo; havendo de coincidir, portanto, o desenvolvimento canônico da representação direta com o renascimento do direito justinianeu. Tendo-se em conta que este foi implementado em Portugal à custa das obras de Mestre Jácome das Leis e D. Afonso X (o Sábio), observamos que é exatamente ao exame de tais fontes castelhanas que se dedicará o capítulo seguinte de nossa análise.

posto de parte o ajuste prévio de "honorários" - já compreendidos como "salários" (e daí o emprego do termo "mercedem") - havia a previsão de perda da remuneração na hipótese de descumprimento da avença pelo mandatário. Com isso, a tão refinada estrutura eficacial construída pelos jurisconsultos romanos - para harmonizar um mandato "essencialmente" gratuito e aquela praxe (cada vez mais frequiente) de se admitir uma retribuição pela via dos honorários - parece ter sido aqui, efetivamente, posta em xeque. E talvez assim se justifique ainda mais aquela provisão recolhida no CTh. II, 10, 4 (326 d.C.) (= Brev. II, 10, 1) já referida em oportunidade anterior do presente estudo (nota 67). 


\title{
CAPÍTULO VI.
}

\section{A PRIMEIRA ETAPA DO RENASCIMENTO DO DIREITO ROMANO (JUSTINIANEU) E O CONTRATO DE MANDATO SEGUNDO AS FONTES CASTELHANAS.}

\author{
$\S 94.0$ direito castelhano como fator de intermediação do renascimento
} justinianeu na Península Ibérica: apresentação de suas principais fontes. Especificamente no que concerne à historiografia externa do direito português, enquanto o elemento visigótico ostenta elevada importância como fator de intermediação no contato com as fontes do direito romano pós-clássico, o direito castelhano viabilizou - durante os séculos XIII e XIV - um primeiro acesso dos juristas lusitanos ao legado justinianeu; neste cenário, desempenharam um papel relevante tanto os textos de Mestre Jácome das Leis ("Flores de Derecho", "Dotrinal" e "Los Noue Tienpos Delos Pleytos"), como as obras de D. Afonso X ("Fuero Real", "Espéculo" e "Siete Partidas"). A despeito de seu caráter originalmente doutrinário, os trabalhos de "Maestro Jacobo de las Leyes" influenciaram decisivamente a produção legislativa que se lhes seguiu (notadamente por meio da referida atuação legiferante de D. Afonso, o Sábio); assim, é mediante sua análise que iniciaremos nossas investigações a respeito dos contornos assumidos pelos institutos do "mandatum" e da "procuratio" segundo o direito castelhano ${ }^{74}$.

\footnotetext{
${ }^{74}$ Embora não tenhamos tido acesso a qualquer estudo monográfico dedicado à análise dos institutos da "procuratio", do "mandato" e da "representação" (direta ou indireta) no âmbito das fontes castelhanas, devem ser referidos os seguintes trabalhos (todos voltados a uma historiografia externa do direito castelhano): CÂndido Mendes de Almeida, Código cit. (nota 16), pp. XVI-XVIII; M. A. CoelHo da Rocha, Ensaio cit. (nota 16), pp. 78-79; M. PAUlO MERÊA, Resumo cit. (nota 16), pp. 124-125; Versão portuguesa das flores de las leys - contribuições para a história do direito português, Coimbra, Imprensa da Universidade, 1918, passim; G. BRAGA DA CRUZ, O direito subsidiário cit. (nota 16), pp. 269-282; M. J. de AlmEIDA CosTA, Fundamentos cit. (nota 16), p. 112; História cit. (nota 09), pp. 232-236; La présence cit. (nota 16), pp. 51-53; Para a história da cultura jurídica medieva em Portugal, in Boletim da Faculdade de Direito da Universidade de Coimbra 35 (1959), pp. 254-255; Romanismo e bartolismo no direito português, in Boletim da Faculdade de Direito da Universidade de Coimbra 36 (1960), pp. 25-26; J. VALLET DE GoYTISOLO, El derecho romano como buena razon en Cataluña, in Boletim da Faculdade de Direito da Universidade de Coimbra 58 (1982), p. 474; M. CAETANO, História cit. (nota 16), pp. 339-343; I. M. PovedA VELASCO, Ordenações cit. (nota 16), pp. 11-15; N. E. GOMES DA SILVA, História cit. (nota 16), pp. 227-232; A. M. HeSPANHA, História cit. (nota 16), pp. 492-495; J. G. B. CÂMARA, Código cit. (nota 64), pp. 230-231; S. MinguiJón AdRIÁn, Historia cit. (nota 64), pp. 88-94; A. GARCÍA-GALlo, Curso cit. (nota 64), pp. 257-262; La obra legislativa de Alfonso X - hechos e hipotesis, in Anuario de Historia del Derecho Español 54 (1984), pp. 97-161; L. de EsTRADA, Manual cit. (nota 64), pp. 32-35; L. de M. LEME, O direito cit. (nota 64), p. 78; A. PÉrez MARTín, El Fuero cit. (nota 64), pp. 77-80; M. R. MARQues, História cit. (nota 64), p. 69 (novamente em trecho de proveito relativamente duvidoso); R. de UREÑA Y SMENJAUD - A. BONILLA Y SAN MARTín, Obras del Maestro Jacobo de las leyes - jurisconsulto del siglo XIII, publicadas, en virtud de acuerdo del ilustre colegio de abogados de Murcia, Madrid, Talleres Tipográficos de la Editorial Reus, 1924, pp. V-XXV; e A. PIMENTA, Fuero Real de Afonso X, o Sábio - versão portuguesa do século XIII, Lisboa, Instituto para a Alta Cultura, 1946, passim. Cumpre destacar que uma das primeiras dificuldades com que se depara o pesquisador devotado ao estudo das fontes castelhanas diz respeito à sua respectiva periodização; conquanto existam dados mais precisos no que toca à produção legislativa de D. Afonso X (o Sábio), o mesmo não se pode afirmar com relação aos textos atribuídos ao "Maestro Jacobo de las Leyes". Neste
} 
§ 95. A produção doutrinária de "Maestro Jacobo de las Leyes": a "personeria" conforme as "Flores de Derecho". A partir de uma dissociação sistemática entre as figuras do "bozero" e do "personero", as "Flores de Derecho" admitiram expressamente uma atuação generalizada do "procurator ad litem", ressalvados unicamente os feitos criminais, nos quais não se admitia o seu respectivo concurso (FD. I, 3, 9); assim, sempre que as partes não pudessem (ou não quisessem) litigar por si próprias (FD. I, 3, 1), poderia ser constituído um "personero" para atuar individualmente ou em grupo (FD. I, 3, 2 e FD. I, 3, 3) - desde que observados os respectivos impedimentos processuais (FD. I, 3, 4). Embora compreendido o "mandatum" como fonte por excelência da "personeria" (e daí a feição justinianéia da orientação assumida), não se esqueceu "Maestro Jacobo de las Leyes" daqueles que, em virtude de um peculiar "status familiae", poderiam atuar em prol da parte "sin su mandado" (FD. I, 3, 5): no mesmo sentido, havendo mínimos indícios de uma atribuição de encargo, admitia-se sem maiores reservas o concurso do "procurator",

sentido, R. de UREÑA Y SMENJAUD e A. BONILlA Y SAN MARTín promovem uma tentativa de periodização da produção do jurisconsulto a partir das referências lançadas no corpo de seu respectivo texto (Obras cit. (nota 74), pp. XIII-XVII). De toda forma, mesmo que prosperando a alegação dos autores de que o "Dotrinal" é posterior às "Siete Partidas" - o que aliás se nos afigura bastante razoável - fato é que nos pareceu historicamente proveitoso reunir toda a obra do "Maestro Jacobo de las Leyes" em um esforço investigativo contínuo; assim, a ela nos dedicaremos em primeiro lugar - enfrentando em um segundo momento a produção legislativa de D. Afonso X.

Quanto ao método de trabalho utilizado no presente capítulo, faz-se necessário observar que, à falta de monografias dedicadas ao tema, o pesquisador foi "compelido" a efetuar uma consulta direta às fontes: e como aqui temos uma disciplina consideravelmente intrincada, optou-se por uma menção expressa aos textos em que as principais questões concernentes à eficácia da "personeria" e do "mandado" tivessem sido enfrentadas pela primeira vez; e sempre que possível, tais alusões foram acompanhadas de remissões aos dispositivos (correspondentes) situados nas demais fontes do direito castelhano. Assim, considerada a vastidão da disciplina de tais institutos nas "Siete Partidas", pareceu-nos oportuno aproveitar a análise das demais fontes para antecipar as principais provisões similares naquelas contidas; restando na parte final deste capítulo um tratamento tão somente residual, voltado às proposições sem qualquer correspondência com os demais textos que informaram nossa investigação.

Especificamente quanto à obra "Los noue tienpos delos pleytos", inexiste qualquer trecho em que haja uma abordagem, mesmo que superficial, da temática estudada neste trabalho. Contudo, como seu próprio título indica, há uma sumária exposição a respeito de cada uma das fases do trâmite de uma demanda judicial, tal qual se pode depreender de seu respectivo prólogo: “todo[s] los pleytos puedense partir en noue tienpos. El primero tienpo es quando el omne faz chamar a otro quele faga derecho. El segundo tienpo es quando uienen las partes antel iuyz. El tercero tienpo es quando el lamado dize algunas excepciones o defensiones por que se delonga el playto. El quarto tienpo es quando se comiença el pleyto. El quinto tienpo es quando deuen las partes aiurar de calunpnia, o de dizer uerdat. El sexto tienpo es quando las partes o la parte aduzen prouas. El septimo tienpo es quando las partes rrazonan sobre las prouas y sobre todo el pl[e]yto. El ochauo tienpo es quando las partes cierran el pleyto y pieden sentencia. El nono tienpo es el tienpo dela sentencia" (Obras cit. (nota 74), pp. 379-380).

Por fim, a propósito da projeção das "Siete Partidas" no âmbito do direito moderno - particularmente do direito espanhol anterior à promulgação do Código Civil de 1889, cf. F. SANCHEZ Román, Estudios de Derecho Civil segun los principios, los precedentes y cuerpos legales del antiguo derecho de Castilla, las leyes civiles generales, las especialidades de las legislaciones forales, la jurisprudencia del Tribunal Supremo y el Código Civil é Historia General de la legislacion española IV: Derechos de Obligaciones (derecho de la contratación), 2a ed, Madrid, Est. Tipográfico “Sucesores de Rivadeneyra”, 1899, p. 494. 
desde que oferecida a regular "cautio de rato" (FD. I, 3, 6 e FD. I, 3, 7); além disso, dado o manifesto proveito da atividade do gestor espontâneo, legitima-se a participação desta personagem, a resguardar o principal independentemente de prévia incumbência (FD. I, 3, 8). Conquanto inexista nas "Flores de las leys" um reconhecimento de efeitos representativos diretos defluentes da atuação do "personero", resta-nos observar, finalmente, o caráter "intuitu personae" da relação jurídica decorrente - a se extinguir em virtude de qualquer das razões indicadas em FD. I, 3, $10^{75}$.

${ }^{75}$ Preliminarmente, observe-se que para o acesso ao texto das "Flores de Derecho", lançamos mão da versão
contida na obra já referida de R. de UREÑA Y SMENJAUD e A. BONILLA Y SAN MARTín (Obras cit. (nota 74),
pp. 27-38). É oportuno destacar, aliás, que a numeração constante do índice da obra (pp. 7-10) não
corresponde, em várias oportunidades, àquela empregada no corpo do texto - mostrando-se jungidas sob a
epígrafe "commo deue[n] ser fechos", por exemplo, as leis primeira e segunda do Título "delos personeros". A respeito da inadmissibilidade da "personeria" no âmbito dos feitos criminais, assim dispõem as "Flores de Derecho" (FD. I, 3, 9): "viij. Que non puede ser dado personero en lo criminal. Ley VIIII. En todos los preytos pueden seer dados personeros senon fueren pleytos criminales; y pleytos crjmjnales son todos aquelles por que alguno es demandado o acusado pora muerte o a pena[s] algunas desos cuerpos" (Obras cit. (nota 74), p. 37); corroborando tal preceito - e evidenciando que, conquanto não se admitissem procuradores, caberia a assistência de advogado - eis o teor do fragmento contido em FD. I, 13, 3: "ij. Por quales non deuen ser rreçebidos fiadores nin personeros. Ley III. Sennor, quando estos pleitos tales uinieron ante uos, se el peccado es atal que [se] fuere prouado, deue amorir el acusado, o perder menbro, o perder el auer, o reçibir azotes, y non deuedes reçibir fiadores non perçoneros entales pleitos, ca guisada cosa es quela persona que deue reçibir ela pena, que tracte por si el pleyto. Pero, si uos demandare auogado que razone su pleyto, deuedes ielo dar" (Obras cit. (nota 74), pp. 86-87). No "Dotrinal" deparamo-nos com uma disposição (Dot. II, 1,7) que, conquanto semelhante, se revela um tanto mais abrangente, na medida em que se volta também à possibilidade de desterramento do demandado; além disso, é admitida a atuação de qualquer pessoa mesmo aqueles que ordinariamente não poderiam desempenhar a "personeria" - apenas com o intuito de comprovar a ocorrência de um impedimento legítimo, responsável pela ausência do réu. E o preceito ainda estabelece que o juiz, após prolatar sentença, deveria permanecer no território em que fora proferida pelo prazo de cinqüenta dias, a fim de eventualmente emendá-la, vedada a constituição de procurador para tais providências: "Cap. 7. En quales plejtos pueden ser dados personeros y en quales non. Pleytos y ha en que pueden ser dados personeros, y otros en que non. Onde dezjmos que en toda demanda que faga vno contra otro, quier sea sobre cosa mueble o rayz, que puede y ser dado personero, para demandarla en juyzjo. Mas sobre plejto sobre que pueda venjr sentencia de muerte, o perdimjento de mjembro, o desterramjento de tierra para sienpre, quier sea moujdo por acusacion, o en manera de rriepto, non deue ser dado personero; ante dezjmos, que todo omne es tenudo de demandar, o de defenderse ental plejto como este, por si mjsmo, y non por personero. Por quela justiçia non se podria fazer derecha mente en otro, sinon en aquel que faze el yerro, quando le fuere prouado, o enel acusador, quando acusase a tuerto. Pero sy algun omne fuese acusado, o rreptado sobre tal plejto, commo sobre dicho es, y non fuese el presente enel logar do lo acusasen; entonçe bien podria su personero, o otro omne que lo quisiese defender, rrazonar, o mostrar por el alguna escusanza derecha, si la oujere, porque non puede venjr el acusado. Y por esto deue el judgador sennalar plazo, aque pueda aueriguar la escusa que pone por el: y si la provare, deuele valer al acusado. Mas commo quier que pueda esto fazer, en rrazon de escusar al acusado, con todo eso non podria demandar, njn defender tal plejto por el en njnguna otra manera, asy commo personero. Y otrosi dezjmos, que maguer el menor de veynte y çinco annos, njn la muger, non pueden ser personeros por otrie,] pero ental rrazon como esta sobre dicha bien puede rrazonar por el acusado en juyzjo, mostrando [por] el alguna escusa derecha por queno pudo venjr al plazo, mas non para defenderlo enel plejto dela acusacion. Y avn dezjmos que si acaeçiese que algun judgador, acabase su ofiçio que oviese tenjdo en algun logar y oviese querellosos del por rrazon del ofiçio que y toviera, que enlos çinquenta dias que es tenjdo de fincar enel logar despues deso para fazer emjenda alos querellosos, por si mjsmo se deue defender y rresponder en juyzjo, y no puede dar personero por si alas demandas quel fizjeren enel tienpo de çinquenta dias y mjentra duraren" (Dotrinal de Maestre Jacobo delas Leyes, in Obras cit. (nota 74), pp. 226-227). A justificativa para a inadmissibilidade da "personeria" é exposta, portanto, nesta passagem do "Dotrinal", e consistiria na impossibilidade de se executar a pena noutra 
pessoa que não o próprio condenado. Preceitos similares podem ser entrevistos no "Fuero Real" (FR. I, 10, 2 e FR. I, 10, 7) e no "Especulo" (Esp. IV, 8, 12). Aliás, nesta última fonte encontra-se mais uma ressalva à regra da inadmissibilidade de "personeria" em feitos criminais: caso alguém demandasse um liberto pela prática de ato em virtude do qual pudesse ser reconduzido à servidão, tanto o acusador como o aforrado poderiam se servir de procurador, o mesmo se aplicando em algumas outras situações excepcionais (Esp. IV, $8,13)$; e aquele que tivesse demanda contra si proposta, em decorrência da qual pudesse perder todos os bens, retornar à escravidão ou ser privado de posto ou função, tinha a faculdade de constituir "personero" ou de se atuar por si próprio, salvo determinação real em contrário (Esp. IV, 8, 14). Nas "Siete Partidas", por sua vez, encontramos disposição que se cinge à reiteração do teor das disposições acima referidas (Part. III, 5, 12).

Sobre a utilidade dos procuradores, eis a disposição encontrada nas "Flores de Derecho" (FD. I, 3, 1): “j. Commo deue[n] ser fechos. Ley I. Porque el uso delos personeros es mucho prouechoso y es mucho menester, por que aquellos que non pueden onon quisieren ser presentes afazer suas demandas que an contra algunos o adefendesse contra sos con[ten]tores, puedenlo fazer por personeros, ta[n]bien en demandar como en defender. Porende quiero dizer destos personeros, que son dichos en latin procuratores" (Obras cit. (nota 74), pp. 27-28). No "Dotrinal" encontra-se disposição quase idêntica (Dot. II, 1, 1), na qual se destaca que o principal poderia lançar mão do procurador se não viesse a juízo "por algun embargo o enojo" (Obras cit. (nota 74), p. 219). Em sentido semelhante, cf. Esp. IV, 8 pr. e Part. III, 5 pr..

Em FD. I, 3, 2 encontramos a seguinte definição de "personero": “j. Commo deue[n] ser fechos. Ley II. Procurator es dicho aquel que tracta los pleytos e los fechos ayenos por mandado de so duenno" (Obras cit. (nota 74), p. 28). Desta definição podemos extrair não apenas a admissão de uma "personeria" voltada à prática de atos determinados (judiciais ou extrajudiciais), como também de uma sua origem "ex mandato"; tudo de conformidade, portanto, com a orientação justinianéia a respeito da relação entre "procuratio" e "mandatum". No mesmo sentido, cf. Dot. II, 1, 2 ( $1^{\text {a }}$ parte). No "Especulo" encontra-se uma definição curiosa, que de certa forma parace nos antecipar os efeitos da atuação do agente (Esp. IV, 8, 1): "personero dezimos, que es aquel que recibe pleito ageno para demandar o para defender a otri, por mandado daquel que es señor del pleito, asi como señor. E a nonbre personero, porque él recibe el pleito en vez de la persona daquel cuyo es. Ca pues que lo recibe por mandado del dueño, desde alli entra en voz de la persona dél, para razonarlo tan bien como él mismo farie, o meior si podiere" (Especulo, in Los Codigos Españoles concordados y anotados VI, Madrid, Imprenta de la Publicidad, 1849, p. 101); daí se pode depreender que o procurador atua "asi como señor", o que parece indicar uma eficácia representativa direta, defluente da atuação do agente. No mesmo sentido, cf. Part. III, $5,1$.

No entanto, neste mesmo fragmento das "Flores de Derecho" (FD. I, 3, 2) pode-se entrever uma regulamentação a respeito das formas de constituição do "personero": "e puedelo fazer procurador, el duen[n]o del pleyto por sua carta opor su mandado, pero que non sea presente. E puedelo fazer por un pleyto solo opor muchos, opor uno dia solo, opor tienpo asinalado, opor todo el pleyto, y su condicion, assi como [se] el duen[n]o del pleyto dize: 'fago mio personero adon fulan contra don fulan se dalguna cossa me quisier demandar'. Essi dissier: 'fago mio personero afulan, para demandar tal cossa, se naue uinier de françia', o otra cosa semeiabre" (Obras cit. (nota 74), pp. 28-29). No "Dotrinal”, por sua vez, a disposição correspondente é mais minudente, aludindo ao caráter solene do ato de constituição do procurador (Dot. II, 1 , 3): assim, ou se deveria lançar mão do escrivão público, ou se haveria de empregar selo de autenticidade (oficial ou particular). No mesmo sentido, cf. FR. I, 10, 1. Já no "Especulo" pode ser vislumbrada uma mitigação dos excessivos rigores relacionados à forma do ato de constituição da "personeria": ao mesmo tempo em que se admite, para os pleitos pequenos (até dez "maravedis"), uma investidura de procurador à base de testemunhas, ou mesmo "apud acta" (Esp. IV, 8, 7), permite-se, para as demandas maiores, a utilização - por certas pessoas, tais como arcebispos, bispos ou "ricos omes (...) que ayan escrivanos conoscidos" - da "carta de personeria" lavrada por escrivães privados (Esp. IV, 8, 8). No âmbito das "Siete Partidas" prevalecem regras semelhantes (Part. III, 5, 13 e Part. III, 5, 14), não obstante haja uma prescrição a exigir outorga de poderes expressos e específicos sempre que houvesse investidura de "personero" para demandar "restitutio" em benefício de incapaz (Part. III, 5, 15).

Nas "Flores de Derecho" é regulada, ainda, a "personeria" desempenhada por uma pluralidade de agentes constituídos (FD. I, 3, 3): “ij. Del que faze dos o munchos. Ley III. Se alguno faze dos personeros, o muchos en algun pleyto, todos de mancomun o cada uno por si, aquel que primiera mientre el pleyto conpeçare, esse es sennor del, y los otros non an poder en el pleyto. Mas se todos começaren el pleyto de consuno, cada uno dellos lo puede seguir por si, pero que nenguno delos otros no sean presentes. Ese alguno faz muchos personeros en algun pleyto y non dize sinalada mientre que cada uno delos sea personero o que razone el pleyto por si, nenguno delos puede razonar nen seguir el pleyto, senon quanto fuere por la sua parte da quel pleyto de que es personero" (Obras cit. (nota 74), pp. 29-30). No "Dotrinal” há disposição semelhante, conquanto haja limitação acerca da atuação de plúrimos procuradores, a fim de que não se tumultue o 
processamento da demanda (Dot. II, 1, 5): "pero si todos los personeros vinjeren en vno al plejto, y la otra parte se agrauiare en rrazonar con todos, deuen dar vno dellos que rrazone: y sy non se acorden, tome el juez qual dellos entendiere quelo fara mejor. Y si por aventura non dixese enla carta, de commo el duenno del plejto los fazia personeros, a cada vno en todo; estonçe non podria njinguno dellos demandar, njn defender, mas de quanto cupiese en la su parte. Pero sy tales personeros todos ayuntados en vno, lo quisiesen demandar, poderlo y an fazer, estando ellos delante, o fazjendo rrazonar a vno con consentimjento de todos" (Obras cit. (nota 74), pp. 224-225). No mesmo sentido, cf. FR. I, 10, 8, Esp. IV, 8, 10 (1 $1^{\text {a }}$ parte) e Part. III, 5, 18.

Já no que concerne à aptidão à "personeria", vislumbra-se nas "Flores de Derecho" uma admissão genérica à função, permeada por específicas restrições, fundadas em circunstâncias pessoais - temporárias ou permanentes - que envolvem cavaleiros, clérigos, mulheres, enfermos, menores, escravos e acusados da prática de crime (FD. I, 3, 4): "iij. Los que non lo pueden ser. Ley IIII. Todo omne puede seer personero en iuyzo ofuera de su casa por mandado del sennor del pleyto, se no fuere daquelos que defende la ley. E aquellos que defende la ley y el derecho son estos. Caualleros que estan en corte del Rey y que receben sollada del por le fazer seruicio, fueras en pleytos de caual[1]eros que fussen so su poderio en suas cosas. Clerigos, mugieres y contrechos que non pueden leuantar por algunas enfermedades. Elos que son menores de vinte y V annos. E los que son acusados de alguno malo fecho, mientre dura ela acusacion. Pero mugieres bien pueden ser personeros por padre, opor madre, o por auuelos, opor bisauuelos, se fueren flacos por uegez opor otra graue enfermedat. Otrossi, se alguno so pariente es iudgado pora muerte, pueden efiarle oda[r] fiadores por el, y aplazear y appellar y defe[nde]rle segundo que manda el derecho. Otrossi, si alguno demanda aqual quier desos parientes por sieruo, puede seer personero y seguir el pleyto porel, tanbien en demandar, como en defe[n]der, por liberdad desus pariente[s]. Otrossi, sieruos non pueden ser personeros. Pero el sieruo que diz que es libre y contiende en iuyzo con su sen[n]or sobre pleyto de sua liberdat, bien puede tal sieruo seer personero de otre fasta que el pleyto sea acabado" (Obras cit. (nota 74), pp. 31-33). No "Dotrinal" deparamo-nos com um fragmento correspondente (Dot. II, 1,4), no qual se amplia o rol dos inaptos à "personeria" (loucos, desmemoriados, mudos, surdos e emissários reais); contudo, nesta mesma disposição encontra-se uma restrição à atuação excepcional das mulheres (que somente poderiam exercer tal ofício em prol de seus parentes "quando non oviesen otrie em quese fiar y pidiesen que rrazonase por ellos"), contrabalançada pela admissão ao exercício excepcional da personeria por escravos ("fueras ende si fuese siervo del rrey; mas para rrecabdar otras cosas fuera de juyzjo que perteneçiese asu pegujar o asu sennor bien lo podria fazer") e cavaleiros (em prol do fidalgo indefeso, do menor e do enfermo). Mesmo aquele que estivesse sendo demandado como escravo, antes da condenação, poderia tanto atuar como "personero", como constituir alguém que nesta posição zelasse pelos seus interesses; tudo "porque el es en posesion de ljbertad, maguer le muevan plejto sobrella". Aliás, como destacaremos mais adiante, este fragmento do "Dotrinal" contém uma regra destinada a coibir a maliciosa utilização de um procurador excessivamente poderoso: "Y otro si dezjmos, que los adelantados, njn los judgadores, njn los escriuanos mayores dela corte del rrey, njn los otros oficiales, que son poderosos por rrazon de sus ofiçios, non pueden ser personeros por otrie en njngun plejto enla corte del rrey: y esto porque se non enmargue aquello que son tenudos de fazer desus ofiçios por ser ellos personeros de otrie, y porque pueden meter en grandes costas y trabajos alos omnes contra quien fuesen fechos personeros, alongandoles los plejtos, por rrazon del poder que han enla corte por los ofiçios que tienen" (Obras cit. (nota 74), pp. 222-224); no sentido de tais restrições, cf. FR. I, 10, 3, FR. I, 10, 4, FR. I, 10, 16 e Esp. IV, 8, 3 (parte final). Já em Esp. IV, 8, 2, ao mesmo tempo em que se presencia uma restrição à atuação do excomungado (e do traidor), reconhece-se a possibilidade do concurso do escravo na defesa do interesse "de ome o de mugier pobre"; além disso, cumpre destacar que se dispõe a respeito do "personero", por meio de uma expressa alusão ao "vozero", bem como ao regime estabelecido no Título IX ("de los vozeros") (Especulo cit. (nota 75), p. 101). Pelas disposições correspondentes das "Siete Partidas", cf. Part. III, 5, 5, Part. III, 5, 6, Part. III, 5, 8, Part. III, 5, 9 e Part. III, 5, 19; na Part. III, 5, 7 se preceituam outras hipóteses nas quais o cavaleiro poderia, excepcionalmente, ser "personero": a) para livrar seu parente de pleito que o pudesse reduzir à servidão; b) para defender aquele que tivesse sido injustamente condenado à morte; e c) quando iniciasse o pleito sem que houvesse oposição da parte contrária. E por força da Part. III, 5, 8 , tais hipóteses também se aplicavam aos agentes poderosos - em princípio afastados da "personeria" pelo legislador. Merece análise, nesse particular, a Part. III, 5, 11 (parte final), em que se estende o favor à tutela do rei, de viúva, de órfão e de qualquer "cuytada persona".

Nas "Flores de Derecho" existe ainda uma previsão quanto ao exercício da "personeria" - em caráter excepcional - sem qualquer incumbência prévia por parte do principal (FD. I, 3, 5): "iiij. Los que pueden ser por otros sin su mandado. Ley V. Maguer que es dicho enla ley de suso, que aquel es personero que tracta los pleytos por mandado de su duenno, personas son ciertas que pueden seer personeros por otros se[n] so mandado. Assi como padre por fiyo, o fiyo por padre opor madre, opor hermanos, opor hermanas, olos maridos por las mugieres, olos que son forros por aquellos sennores que los aforraron, ose son todos 
conpaneros enel pleyto y conmesçaren el pleyto todos de consunno por demanda opor respuesta. Cada una destas personas sobredichas puede seer personero por qual quier destas otras, dando buen fiador, so una pena guisada, segundo, qual for el pleyto, que el fara auer por firme y por estable quanto en aquel pleyto feziere orazonare daquel por quien se faz el personero, ca en otra guisa non deue seer recebido" (Obras cit. (nota 74), pp. 33-34). Trata-se de hipótese excepcional, na qual se reconhece a possibilidade do exercício da "personeria" sem que exista um "mandado" a lastreá-la, evidenciando-se, novamente, a feição justinianéia emprestada ao perfil da relação mantida entre "procuratio" e "mandatum"; contudo, não deve escapar ao estudioso a atribuição de uma contrapartida para a atuação destes "personeros" especiais: a prestação de uma garantia, consistente na fiança prestada por um terceiro. Por sua vez, no "Dotrinal" se amplia o rol daqueles que poderiam agir sem a imprescindível "carta de personeria", facultando-se tal favor a outros parentes consangüíneos (até o quarto grau) ou por afinidade -, co-herdeiros, parceiros ou mesmo devedores do principal (Dot. II, 1, 6): “Cap. 6. Quales pueden ser personeros syn carta de personeria. Njngun omne non puede tomar poder por sy mjsmo para ser personero de otrie, njn para fazer demanda por el en juyzjo, syn otoramjento de aquel cuyo es el plejto. Fueras ende por personas sennaladas, asy commo marido por muger, o pariente por pariente fasta el quarto grado, o por otros quel perteneciesen por rrazon de casamjento, asi commo por su suegro, o por su yerno, o por su cunnado. o por omne con quien oujese deudo, o por rrazon de aforramjento. Ca qualquier destos sobre dichos puede fazer demanda en juyzjo, vno por otro; maguer non toujese carta de personeria del. Fueras ende, si fuese cierta cosa, que el queria fazer demanda, contra voluntad de aquel en cuyo nome demandaua. Eso mjsmo dezjmos delos que fueren herederos o aparçeros de vna mjsma heredad, o de otra cosa queles pertenesca comunal mente. Pero cada vna destas personas de suso dichas, antes que entren en juyzjo, deuen dar rrecabdo por fiadores, so cierta pena, que fara, y guisara de manera, que aquel por quien faze la demanda, aura por firme quanto se rrazonare, o se fizjere, o se judgare en aquel plejto. Y si el otro non quisiese estar por ello, que el y los fiadores pechen al demandado la pena que y fuere puesta. Y dando este rrecabdo ala otra parte, demandogelo ante que el plejto fuese començado por rrespuesta, deue ser cabida su demanda. Ca si despues que fuese començado el plejto, le demandase tal rrecabdo, non sia tenudo de gelo dar. Y esto que de suso dezjmos auria logar, quando vno quisiese demandar por otro en juyzjo; mas para rresponder y defender por otro a quien oujesen enplazado, y non fuese adelante, todo omne lo puede fazer en juyzjo, maguer non sea su pariente, njn tenga carta de personeria del; dando rrecabdo, que el otro lo aura por firme lo que fuere fecho en juyzjo y pagara lo que fuere judgado" (Obras cit. (nota 74), pp. 225-226); em todas essas hipóteses, poderiam tais sujeitos demandar como "personeros" doutrem desde que oferecessem fiador. No mesmo sentido, cf. FR. I, 10, 5; observe-se apenas que neste fragmento se preconiza - na hipótese de não-ratificação pelo principal - a perda da fiança e o restabelecimento do "status quo ante": "si despues aquel por quien demandó o por quien respondió non lo quisiere otorgar, el fiador peche la fiadura, e torne el pleito a aquel estado em que era ante que fuese la fiadura" (Fuero Real del Rey Don Afonso el Sabio, copiado del Codice del Escorial, y cotejado con vários otros codices de diferentes archivos por la Real Academia de la Historia, Madrid, Imprenta Real, 1836, p. 25). Por disposições semelhantes constantes do "Especulo", cf. Esp. IV, 8, 11 (1 $1^{\text {a }}$ parte) e Esp. IV, 8, 15. Note-se que além da garantia representada pela fiança, neste último dispositivo se preceitua que o agente "deve aun dar seguranza que si el contendor quisiere demandar a él alguna cosa en razon de aquel por qui él se mete por personero, ante del juyzio finado, que responda por él, el defienda en aquel pleito. E si fuere vencido, que faga conprir lo que fuere judgado a aquel cuyo pleito defiende, o que lo cunpla él de lo suyo" (Especulo cit. (nota 75), p. 105); como teremos a oportunidade de observar mais adiante, tal regra excepciona o princípio geral de que da atuação do "personero" deveriam derivar efeitos exclusivamente ao principal. Finalmente, com relação às "Siete Partidas", o estudioso se depara com disposição na qual são reiterados os preceitos acima expostos (Part. III, 5, 10, em sua primeira parte); contudo, em caráter excepcional, se reconhece a possibilidade de que o filho demande sem a necessária outorga de poderes por seu pai, caso tenha sido por este enviado a lugar remoto (Part. IV, 17, 12): "porque si el fijo ouiesse auenir a demandar licencia a su padre, para demandar, o responder: por auentura podria entre tanto perder su derecho el o el otro que ouiesse a el ademandar" (Las Siete Partidas del Sabio Rey Don Alfonso El Nono II, Salamanca, Andrea de Portonariis, 1555 , p. 49).

Ora, em FD. I, 3, 6 temos a explicitação de uma regra que poderia ser depreendida de uma interpretação, "a contrario sensu", do preceito instituído em FD. I, 3, 5 (acima analisada); de fato, estabelece-se que, não havendo prévia incumbência - e nem se tratando de quaisquer das pessoas que excepcionalmente poderiam demandar sem "carta de personeria" - não poderia o sujeito atuar em prol de outrem: "v. commo demande vno por otro sin poder. Ley VI. "Se otra alguna persona que non sea destas sobredichas, quisier demandar por otro non auiendo nen mostrando mandado alguno daquel por quien demanda, assi como por cartas opor testigos, non deue seer recebido, maguer que disse tal fiador como sobredicho es" (Obras cit. (nota 74), p. 35). Ora, sendo tal dispositivo não faz mais do que explicitar algo que se pode depreender da simples interpretação da regra precedente, qual seria a sua razão de ser? Observe-se que tal dúvida se robustece, 


\section{§ 96. A produção doutrinária de "Maestro Jacobo de las Leyes" (cont.):}

"personeria" e "representação" (direta) segundo o "Dotrinal": Para além de uma reiteração de idéias já articuladas nas sucintas "Flores de Derecho", a análise do "Dotrinal" nos revela importantes aspectos relacionados ao esquadrinhamento da eficácia dos institutos da "procuratio" ("personeria") e do "mandatum" ("mandado"): ao mesmo tempo em que é vedada a constituição de um procurador "superpoderoso" (Dot. II, 1, 4), fortalece-se - por meio de uma incisiva menção à "carta de personeria" (Dot. II, 1, 6) - a acepção instrumental do termo "procuração" - provida esta da já referida "cláusula de rato" (Dot. II, 1, 3). Ao mesmo tempo em que desponta uma disciplina minudente a respeito daqueles que podem constituir um "procurator ad litem" (Dot. II, 1, 2), mitiga-se o excessivo rigor de alguns preceitos contidos nas "Flores de las leys", ao se admitir uma excepcional atuação do "personero" em hipóteses das quais este estava, em princípio, peremptoriamente afastado (Dot. II, 1, 7). Ao contrário da omissão que se depreende das "Flores", no "Dotrinal” há menção expressa à atuação extrajudicial do "procurator" (Dot.

quando se afirma que não encontramos qualquer disposição correspodente em meio às demais fontes do direito castelhano. Contudo, a resposta a tal indagação está intimamente relacionada com o fragmento imediatamente subseqüente das "Flores de Derecho" que, a despeito de sua indiscutível utilidade, também não encontra par em meio aos textos castelhanos posteriores por nós investigados.

De fato, assim dispõem as "Flores de Derecho" a respeito daqueles que pudessem demonstrar a incumbência de modo frágil, por meio de uma única testemunha ou de "carta de personeria" desprovida de selo de autenticidade: "vj. Dela cabçion. Ley VII. Quando alguno dize que es personero de otro y lo demostra por algunos endicios que recebio o que amandado pora seer personero, assi como selo demosstrasse por un testigo, opor carta en que [non] aya seelo autentico, deue seer recebido por personero, dando tal fiador como sobredicho es en la ley de suso que copiesça, 'Maguer que es dicho'. Etal fiadoria es dicha en [latin] caucio de rato" (Obras cit. (nota 74), pp. 35-36). Assim, por mais que a regra contida em FD. I, 3, 6 possa parecer desnecessária, apresenta utilidade na medida em que justifica a disposição contida em FD. I, 3, 7, por meio da qual se legitima a utilização da "cautio de rato".

Merece menção especial uma regra contida nas "Flores de Derecho" (FD. I, 3, 8) por força da qual se admite uma espécie de "gestão de negócios" - na acepção justinianéia da expressão - de natureza processual, estritamente comprometida com a atuação do "personero" em defesa dos interesses do réu (mas jamais do autor): "vij. Commo defiende vno a otro absente syn poder. Ley VIII. Todo omne puede defender aotro que non sea presente, maguer quenon demuestre que a su mandado, nen carta de personeria. Ca prol es de todos comunal mientre quelos que non son presentes poden seer defendudos por otros quellos quieran defender, assi como es sobredicho. E deue seer recebido aello se dier fiador que seguira el pleyto, y pagara, y conplira todo lo que fur iudgado, peroque nolo aya por firme, nen por estable aquel por quien defiende, y tal fiadoria es dicha en latin iudicatum solui" (Obras cit. (nota 74), pp. 36-37). No mesmo sentido, cf. Dot. II, 1, 6, FR. I, 10, 14, Esp. IV, 8, 11 (parte final) e Esp. IV, 8, 16. A respeito deste último fragmento do "Especulo" - e das exceções nele consagradas à vedação genérica de atuação do "gestor" contra a vontade manifesta do "dominus negotii" - manifestaremo-nos mais adiante. Pela regra geral acima referida, no contexto das "Siete Partidas", cf. Part. III, 5, 10 (parte final).

Finalmente, a respeito da extinção da "personeria", eis o trecho correspondente das "Flores de Derecho" (FD. I, 3, 10): "viiij. Quando se cumple el ofiçio del personero. Ley X. Se el duenno del pleyto oso personero morrire, o se el duenno del pleyto reuocar la personeria del personero ante que el pleyto sea copesçado por respuesta de si o de non, ose el pleyto fuere acabado por sentencia defenjtiua, conplido es el officio del personero" (Obras cit. (nota 74), pp. 37-38). No "Dotrinal" disposição semelhante pode ser encontrada, acrescida das hipóteses de renúncia e de constituição de novo "personero" (Dot. II, 1, 9). No mesmo sentido, cf. FR. I, 10, 18 e Part. III, 5, 23. 
II, 1, 8) - reconhecendo-se, aliás, uma disciplina minudente a respeito do eventual excesso de poderes por parte do agente - inclusive com a previsão de uma prorrogação "excepcional" dos efeitos da outorga, a fim de que a morte de um dos sujeitos não prejudicasse o alcance do objetivo principal da incumbência (Dot. II, 1, 9); além disso, é importante destacar que não apenas se evidencia uma consagração expressa de efeitos representativos diretos defluentes da atuação do "personero" - desobrigado este, de todo modo, conforme claramente se depreende de Dot. II, 1, 10 - como também uma refinada disciplina que, à semelhança do que se verifica na tecnologia jurídica mais moderna, preceitua expressamente a necessidade de uma inequívoca cientificação de terceiros a fim de que o negócio de revogação opere seus efeitos para além das esferas jurídicas do principal e do incumbido (Dot. II, 1, 9) ${ }^{76}$.

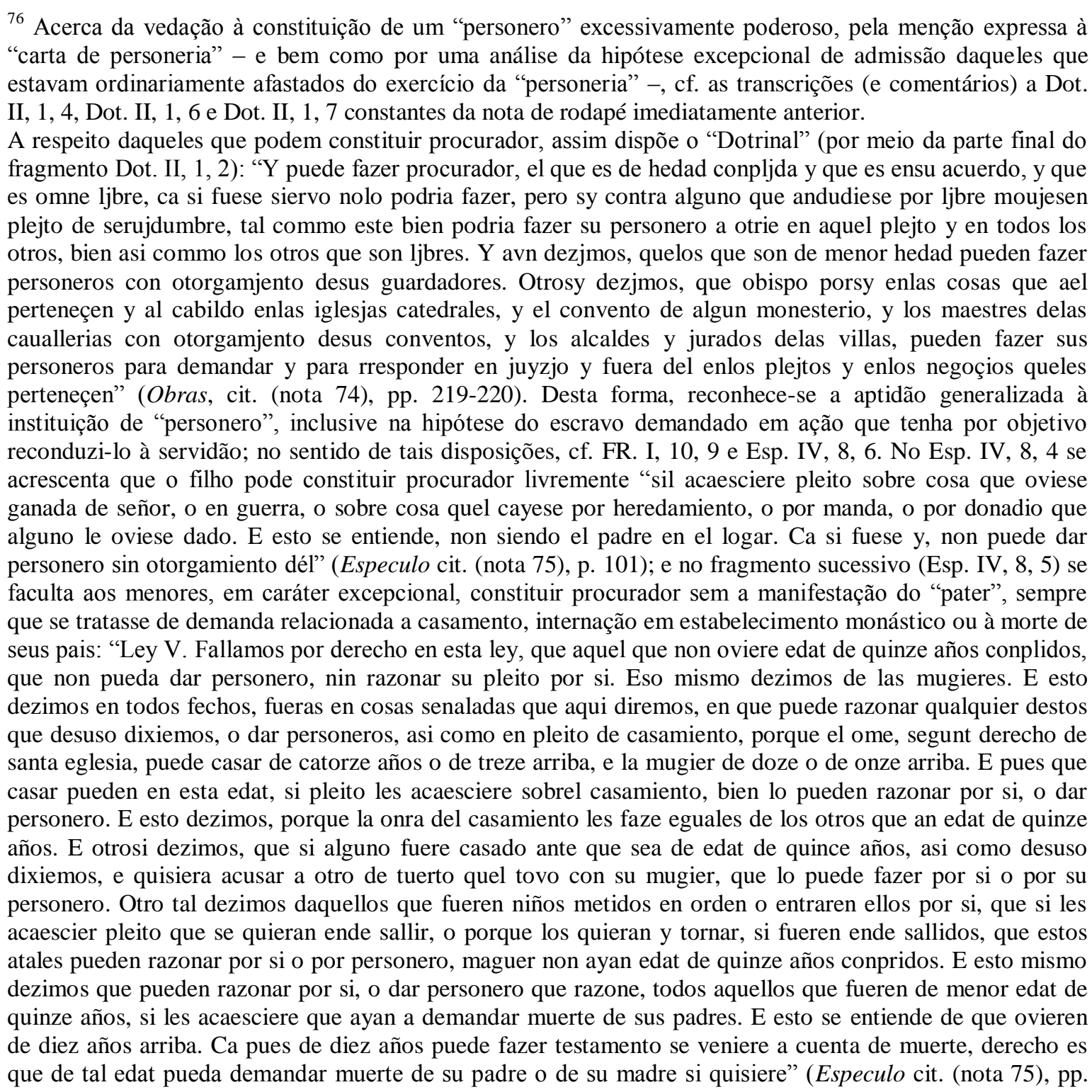


101-102). Aliás, no "Especulo" pode ainda ser encontrada uma previsão que - visando evitar a indevida prevalência dos poderosos sobre aqueles contra os quais litigam - estabelece a utilização compulsória de procurador (Esp. IV, 8, 3), à semelhança de disposição específica do Código Visigótico (LI. II, 3, 1): "pero algunos son que maguer puedan dar personeros, non deven por si mismos razonar en juyzio, asi como rey, o fijo de rey, o arzobispo, obispo, o noble ome señor de cavalleros que tenga tierra del rey, o otro ome onrado o poderoso, asi como maestre de alguna orden, o grant comendador, o abad, o prior, o otro ome onrado de villa que tenga logar señalado. Ca estos atales non deven entrar en pleito para razonar con menores que si. E esto por dos razones, la una porque podrie seer que razonando el otro menor para defender su pleito, que dirie alguna cosa contra el mayor que se le tornarie como en desonra. La otra porque por el poder del mayor, e por su miedo, non osarie el menor razonar complidamiente su pleito, e non fallarie quien lo razonase, e por aqui podrie perder o menoscabar su derecho. Mas estos mayorales que dixiemos, bien pueden razonar sus pleitos unos contra otros, fueras ende contra rey con qui non deve ninguno razonar en pleito sinon otro rey" (Especulo cit. (nota 75), p. 101). No âmbito das "Siete Partidas", disposições correspondentes podem ser surpreendidas em Part. III, 5, 4 e Part. III, 5, 11. Na Part. III, 5, 2 se reconhece ao filho, excepcionalmente, a possibilidade de constituir procurador independentemente da anuência paterna, nas mesmas circunstâncias em que poderia atuar por si próprio, sem a expressa incumbência do "pater" (cf. Part. IV, 17, 12). Finalmente, merece destaque uma regra das "Siete Partidas" na qual a validade da atuação do "personero" do menor está sujeita ao desfecho da lide, configurando uma espécie de nulidade "secundum eventum litis" (Part. III, 5, 3): "Ley. iij. como el menor de veynte cinco años puede fazer personero por si, con consejo del guardador (como el menor de xxv. años puede dar personero por si con consejo de su guardador). Menor de veynte e cinco años, puede dar personero por si, en juyzio, con otorgamiento de su guardador. E si por auentura, el mismo lo diesse por si, non gelo otorgando su guardador, si tal personero fiziere alguna cosa en juyzio, que sea a pro del huerfano, vale. Mas si diessen juyzio contra el, o fiziessen alguna cosa que fuesse a su daño, por razon de aquella personeria, non valdria. E otrosi dezimos, que el guardador, non puede dar por si, personero, para fazer demãda, o respuesta, en juyzio, por el huerfano, si el, primeramente por su persona, non comieça el pleyto, por demãda, e por respuesta. Mas despuesq lo quiere começado assi, bie lo puede fazer, si quisiere" (Las Siete Partidas II cit. (nota 75), p. 32).

Por sua vez, em Dot. II, 1, 3 é desenvolvida toda uma disciplina voltada à constituição do "personero"; ocorre que em meio ao fragmento é mencionada, conquanto de modo implícito, a chamada "cláusula de rato", constante da "carta de personeria" e em virtude da qual o principal se obriga em decorrência de tudo aquilo que for praticado pelo procurador: "Cap. 3. Enque manera deue ser fecho el personero. La manera enque deue ser fecho el personero y procurador es esta: quel duenno del plejto diga (...) y prometo de aver por firme todo quanto el fizjere eneste pleyto (...) pero siel personero fuer del demandado, deue ser escrito enfin dela carta esto ademas, que promete el quelo faze que conpljra y pagara todo quanto fuere judgado en aquel plejto y que para esto conpljr, que obljga asi y a todos sus bienes" (Obras cit. (nota 74), p. 220). Da mesma forma, no "Fuero Real" se reconhece a importância de tal cláusula (FR. I, 10, 6), tal qual se depreende da declaração - que deverá constar da "carta de personeria" - de que o principal "estará por cuanto aquel personero ficiere o razonare en aquel pleito" (Fuero Real cit. (nota 75), p. 25). No mesmo sentido, cf. Esp. IV, 8, 9.

Acerca dos limites da atuação do "personero", assim preceitua o "Dotrinal” (Dot. II, 1, 8): “Cap. 8. Que es loque puede fazer el personero, en juyzjo quele es acomendado. Rrazonar nj fazer no puede el personero mas cosas enel plejto, nj meter a juyzjo de quanto le fuese otorgado o demandado en rrazon dela personeria, y si a mas pasase no deue valer loque fizjere. Y por ende dezjmos, que si el personero quisiere abenjr consu contendor, o fazer alguna postura conel o quitar la demanda, o dar jura por quese destajese el plejto que lo no puede fazer, fueras ende si el duenno del plejto le oviese otorgado sennalada mente poderio de fazer estas cosas, o si enla carta dela personeria, le oviese otorgado ljbre y llenero poderio, para fazer conpljida mente todas las cosas enel plejto, quel mjsmo podria fazer. Ca entonçes, quando tales palabras fuesen y puestas, bien podria fazer qualqueira destas cosas sobre dichas. Otrosy dezjmos, quel personero no puede poner otro ensu lugar en aquel tienpo mjsmo sobre quel fuese dado, si primera mente non lo oviese començado por demanda o por rrespuesta. Pero sile fuese otorgado tal poderio enla carta dela personeria, entonçe bien lo podria fazer, antes y despues. Y esto a logar enlos personeros que son dados para seguir los plejtos en juyzjo, mas los otros que son fechos para rrecabdar y fazer otras cosas fuera de juyzjo, estos atales bien pueden dar otros personeros ensu logar, cada que quisieren, y valdra lo que fuere fecho conellos, tanbien como si lo fizjesen alguna cosa a danno del sennor, estonçe los primeros personeros quelos cogeron y los pusieron ensus logares, son tenjdos de se parar a ello. Y avn dezjmos quelos personeros que son dados para rrecabdar cosas fuera de juyzjo, que cunplen de hedad de diez y syete annos, como quier [quelos otros] que son puestos para demandar o para rresponder por otrie en juyzjo deue ser alo menos de veynte y çinco annos. Otrosy dezjmos, que si la carta dela personeria fuere menguada o dubdosa, quel personero no a poder en juyzjo de demandar o de rresponder, a menos de dar fiadores, que aquel que lo fizo personero avra por firme lo que fue fecho por el enel pleyto" (Obras cit. (nota 74), pp. 227-228). Conquanto extenso, tal fragmento pode ser dividido, 
analiticamente, em quatro partes principais: a) em primeiro lugar, há uma previsão a respeito da necessidade de um estabelecimento de limites claros para a atuação do "personero" (sobretudo no que concerne à conclusão de determinados atos dotados de maior relevância), invalidando-se os atos praticados em excesso pelo agente, à vista dos poderes conferidos por meio da "carta de personeria" (neste mesmo sentido, cf. FR. I, 10, 11; FR. I, 10, 12; Esp. IV, 8, 18 e Part. III, 5, 19); b) além disso, como a "carta de personeria" pode ensejar dúvidas quanto aos limites dos poderes conferidos ao procurador, caso não haja clareza a esse respeito, deve o agente oferecer fiadores (a este respeito, na Part. III, 5, 21 se admite que o próprio principal assuma a posição de garante); c) também existe menção expressa a respeito da possibilidade de emprego da "personeria" no âmbito extrajudicial (cf. Part. III, 5, 2 parte final); d) por fim, verifica-se uma vedação à substituição ordinária do "procurator ad litem", admitindo-se-a - sob responsabilidade solidária do "personero" nomeante, originariamente indicado - quanto ao procurador extrajudicial (cf. Part. III, 5, 19 parte final).

Diferentemente do que se verificou em meio às "Flores de Derecho" (FD. I, 3, 10), no âmbito do "Dotrinal" existe uma regulamentação muito mais desenvolvida a respeito das causas de cessação da "personeria" (bem como dos efeitos posteriores à morte de um dos sujeitos, com relação ao "alter" e aos herdeiros do "de cujus"). Eis o teor de Dot. II, 1, 9: "Cap. 9. Commo se acaba el ofiçio del personero. "Muriendose el sennor del plejto ante que su personero le començase por demanda y por rrepuesta, acabase por ende el ofiçio del personero, de guisa que no puede njn deue despues yr adelante por el plejto. Mas si muriese despues que fuese començado por demanda y por rrepuesta, no pierde por ende el personero su poderio, ante dezjmos que deue seguir el plejto, fasta que sea acabado, tanbien commo si fuese bivo el quelo fizo personero, maguera no rreçibiese mandado nueva mente delos herederos del finado. Otrosi dezjmos, que siel personero se muere ante que sea començado el plejto por rrepuesta, quese acaba el ofiçio del. Mas si muriese despues quelo oujese començado, sus herederos pueden acabarlo lo quel començo, sy fueren omnes para ello. Avn dezjmos, que se acaba el [ofiçio del] personero luego quel judgador da juyzjo afinado sobrel plejto en quel era otorgada la personeria. Pero quando el juyzjo diesen contra el o contra otro cuyo personero fuese, deuese alçar y puedelo fazer, maguer nole fuese otorgado poder para lo fazer enla carta dela personeria, mas no puede seguir el alçada sin otorgamjento del sennor del plejto. Otrosi acaba su ofiçio, quando el duenno del plejto lo rrevoca y pone ya el plejto començado porel o si el mjsmo por su grado dexala personeria, por algun enbargo o derecho que ha, tal por quelo non puede seguir. Otrosi dezjmos, que quando el duenno del plejto faze otro personero que tuelle el poderio al primero siel plejto no era ja començado conel, por demanda y rrepuesta, enpero luego quelo mudare deue fazer çierto al juez que oye el plejto, o dezjr asu contendor commo tollje el primero poder de personeria en aquel plejto y lo da al segundo, y syno lo fiziese asi, valdria quanto fizjese el primero enel plejto, bien asi como si nole oviese tolljdo el poder" (Obras cit. (nota 74), pp. 228-229). Posta de parte a matéria relacionada à extinção em decorrência da morte de um dos sujeitos e da extinção da "procuratio" em decorrência do julgamento da lide - matérias abordadas ao cabo da nota de rodapé imediatamente anterior - mostra-se oportuna a abordagem de três aspectos deste fragmento: a) primeiramente, há que se ressaltar a previsão da prorrogação dos efeitos da relação jurídica mantida entre o "procurator" e o principal, mesmo para depois da morte de um dos sujeitos, como uma espécie de consagração à confiança do principal e à instrumentalidade da incumbência (neste mesmo sentido, cf. FR. I, 10, 18; Esp. IV, 8, 10 parte final e Part. III, 5, 23 primeira parte); b) em segundo lugar - prestigiando-se tanto a confiança quanto a gestão colaborativa que informam a atuação do "personero" - há previsão quanto ao dever de interposição de recurso pelo procurador do sucumbente, mesmo que na ausência de poderes expressos na "carta de personeria", e ainda que a obrigação de interposição do recurso não abarque o acompanhamento de seu processamento perante a instância superior (cf. Esp. IV, 8, 17, $2^{\mathrm{a}}$ parte). Como assinalam o FR. I, 10, 11 e Part. III, 5, 23 (2 $2^{\text {a }}$ parte), caso o "personero" não pretenda interpor o recurso, deve tomar as providências necessárias no sentido de informá-lo ao principal, como maneira de retribuir a confiança deste último; c) finalmente, destaca-se a revogação como negócio jurídico de caráter receptício, suscetível de produzir efeitos tão somente quando de sua chegada à esfera de conhecimento do constituinte (em direção idêntica, cf. FR. I, 10, 12; Esp. IV, 8, 10, $3^{\text {a }}$ parte; Esp. IV, 8, 19, $2^{\text {a }}$ parte; Part. III, 5, 24, 2 parte).

Finalmente, no que concerne à eficácia decorrente da atuação do "personero" - diferentemente do que se verificara com relação às "Flores de Derecho" - há previsão expressa no "Dotrinal” (Dot. II, 1, 10): "Cap. 10. En quales bienes deue ser conpljdo el juyzjo que es dado contra el personero. "Contra el personero de aquel a quien demandasen, seyendo dado juyzjo sobre plejto en que fuese otorgada la personeria, dezjmos que tal juyzjo se deue conpljr enlos bienes de aquel tan sola mente que fizo su perrsonero, y si por aventura nose fallassen mas bienes delos suyos en quel juyzjo se pudiese conpljr, entonçe deue ser conpljdo enlos bienes delos fiadores quel personero del demandado dito, y no enlos del personero. Mas si algun omne se parase porsy mjsmo a defender plejto ageno sin carta de personeria y sin mandado del sennor del plejto, el juyzjo que fuese dado contra el, se deue conpljr enlos bienes de aquel defendedor y de sus fiadores enla manera que 
fiaron, y no enlos bienes del sennor del plejto; y sy este defendedor quisiere demandar despues, aquel cuyo plejto defendiera, alguna cosa que dixese que pechara por el, en aquel plejto de que fuera vençido, non seria el otro tenjdo de gelo dar; pero sy tal defendedor commo este vençiese el plejto, tenjdo seria el duenno del de pagar las costas y las mjsiones que oviese fecho derecha mente en defendiendolo, maguer no quiera, y no se puede escusar, dizjendo que no le encomendaran su plejto, njn le otorgara de ser su personero, pues que pro y rrecabdo le vino por su procuramjento" (Obras cit. (nota 74), pp. 229-230). Desse fragmento se extrai a atribuição de uma eficácia representativa direta nas hipóteses de prévia incumbência, eximindo-se expressamente o "procurator ad litem", uma vez que seriam objeto de excussão tão somente os bens do principal (e de seus fiadores); contudo, caso tivesse havido intervenção espontânea - caracterizando-se uma espécie de "gestão de negócios" processual (na acepção justinianéia da expressão) - a responsabilidade seria atribuída tão somente ao "falsus procurator", com eventual direito regressivo relacionado às despesas suportadas na condução do pleito, unicamente na hipótese de desfecho favorável ao "dominus negotii". O "Fuero Real", por sua vez, incrementa esta estrutura, por meio de uma previsão a respeito dos efeitos internos dos atos de gestão praticados pelo "personero" (FR. I, 10, 17): "otrosi mandamos, que asi como el dueño de la voz quier ganar por aquello que el personero gana o meiora en su pleito, asi mandamos que sufra el dano que por él le veniere, si por su razon el pleito le empeorare. Pero si el personero a sabiendas, o por algun engano, alguna cosa ficiere o manifestare en el pleito, o testigos que habia non quisiere dar, o cartas que tenia para pro de su pleito non quisiere mostrar, e el dueño de la voz por hi perdiese su pleito, el personero sea tenido del pechar cuanto por él perdió" (Fuero Real cit. (nota 75), p. 28). Observe-se que tal preceito contido no "Fuero Real" não ostenta qualquer espécie de conflito em relação ao excerto transcrito do "Dotrinal", mas tão somente o complementa. No âmbito do "Especulo" também encontramos uma consagração de tal sistema, tal qual se pode depreender de Esp. IV, 8, 17 (primeira parte), Esp. IV, 8, 19 (primeira parte) e Esp. IV, 8, 15 (que dispõe a respeito da responsabilidade do gestor processual espontâneo). Poderia suscitar dúvida o teor de Esp. IV, 8, 12, onde se proíbe a "personeria" em feitos criminais "porque la justicia non se podrie fazer derechamiente en otro, sinon en aquel que fizo el yerro" (Especulo cit. (nota 75), p. 104); contudo, cremos que uma alusão a efeitos representativos indiretos deformaria a teleologia do preceito - informado, sobretudo, por uma preocupação quanto à plenitude do exercício do direito de defesa pelo acusado. E neste mesmo sentido, cf. Part. III, 5, 27. Contudo (ainda quanto aos efeitos representativos defluentes da "personeria"), da parte final de Esp. IV, 8, 17 se pode inferir o contrário (no sentido da admissão de efeitos representativos tão somente indiretos): "dezimos que el personero, despues que el pleito oviere vencido, sil entregaren de alguna cosa daquello que venciere, que lo deve dar al dueno de la voz fasta tercer dia (...) e si asi non lo fezire, de aquel dia adelante mandamos que gelo dé doblado" (Especulo cit. (nota 75), p. 105); e por sua vez, das "Siete Partidas" podem ser extraídas outras disposições que contrariam a idéia de uma eficácia representativa direta; em sua maior parte, estão situadas na "Partida Quinta", que deverá ser objeto de estudo específico, a ser desenvolvido mais adiante. De todo modo, cabe destacar que na própria "Partida Tercera" pode ser encontrado um fragmento no qual - a propósito de uma menção ao dever de prestação de contas, por parte do "procurator ad litem" - se atribui ao agente não apenas a obrigação de entrega do resultado (favorável) do litígio, como também um dever de investir o principal em todo e qualquer direito que lhe tenha sido atribuído em virtude da demanda (Part. III, 5, 25): "Ley. xxv. como el personero deue dar cuenta, e entregar al dueño del pleyto, de todo lo que ganara en juyzio (como el personero deue dar cuenta, e entregar al dueño del pleyto de todo lo que ganara en juyzio por el). Bie assi como el personero, o el procurador, que es dado para racabdar algunas cosas, fuera de juyzio, es tenudo de dar cuenta dellas, a aquel cuyas son: assi el personero que es dado en juyzio, es tenudo de dar cuenta al señor del pleyto, de todas las cosas que recibiere, o ouiere por razon de aquel pleyto, en que es personero. Ca si la otra parte fuere condemnada enlas costas, o enlas missiones, o en algunas otras cosas, todo lo que el personero ende leuare, tenudo es de lo dar al Señor del pleyto. E aun dezimos, q desto es tenudo de dar le, e de otorgar le todo el derecho q ganasse en juyzio, por qual manera quier, por razõ de aql pleyto. Otrosi dezimos, q todas las despesas, q tal personero fiziere, en siguiedo aquel pleyto, que seã derechas, e co razon, q es tenudo el que fizo su personero, de gelas dar, fueras ende las que ouiesse fechas, o pechadas, por razõ de yerro, que el mismo fiziesse. Assi como si le condenassen enlas costas, o enlas missiones, o en otra pena por razõ de su rebeldia, o de su culpa. Ca derecha cosa es q sufre ome el daño, q le viene por su yerro, e que nõ demande porede emienda a otri. Pero si el personero, ouiesse fecha alguna postura, cõel señor del pleyto, en razõ delas despensas, o de daño que el sufriesse, en siguiendo el pleyto: dezimos, que le deue ser guardada" (Las Siete Partidas II cit. (nota 75), p. 38). Ora, do cotejo entre este último fragmento e as demais fontes do direito castelhano - ora referidas - parece defluir uma espécie de antagonismo, a respeito do qual nos pronunciaremos mais à frente. No entanto, deve-se desde logo destacar que, tomada em consideração a inadmissibilidade genérica da eficácia representativa direta no âmbito da "procuratio" romana (e mesmo visigótica), a disciplina defluente destas fontes castelhanas já revela uma considerável viragem, 


\section{$\S$ 97. A atividade legiferante de D. Afonso X: peculiaridades da}

"personeria" consoante o "Fuero Real". Conquanto seja, no plano legislativo, a fonte do direito castelhano mais sintética, o "Fuero Real" ostenta mais de duas dezenas de regras aplicáveis à "personeria"; todavia, tomada em consideração a orientação adotada pelas fontes doutrinárias atribuídas ao "Maestro Jácobo de las Leyes", restam algumas poucas disposições em que tal fonte legislativa revela um aprimoramento da disciplina articulada nestes textos. Isto posto, no âmbito da "personeria" propriamente dita, merecem destaque as disposições concernentes à sua prova (FR. I, 10, 2), revogação (FR. I, 10, 2 e FR. I, 10, 8) e excepcional obrigatoridade (FR. I, 10, 19); por sua vez, no que toca ao efetivo exercício da "procuratio ad litem", observa-se a existência de disposição expressa a respeito do conteúdo da "carta de personeria" (FR. I, 10,6), bem como de proibição à pluralidade de "personeros" responsáveis pela condução de uma única demanda (FR. I, 10, 15). Finalmente, no que toca à relação mantida entre os institutos da "procuratio" e do "mandatum" ("mandado"), percebe-se - a despeito de um tratamento sistemático autônomo, sob a forma de títulos distintos - uma promíscua alusão às figuras do "personero" e do "vocero": assim, ao proibir a súbita denúncia ("pues que (...) rescibiere la personería (...) non la pueda dejar (...) et si dotra guisa la dejare, pierda el galardon”) e ao preceituar a responsabilidade por culpa ("si por su culpa perdiere el dueño de la voz"), o legislador alude ao "personero", e não ao mandatário (FR. I, 10, 10); no entanto, em fragmento de difícil interpretação (FR. I, 10, 13), há uma referência indiscriminada a tais personagens, a pretexto da menção aos limites de atuação do agente: "non pueda facer ninguna avenencia, nin ninguna compustura en aquel pleito, fueras ende si el dueño de la voz gelo mandare nombradamientre en la personería"77.

evidenciadora daquela mesma tendência que se pode depreender das fontes canônicas produzidas durante $o$ mesmo período (séculos XIII e XIV).

${ }^{77}$ A respeito da prova e da revogação da "personeria", regulamentação expressa pode ser encontrada em FR. I, 10, 2: "todo ome que veniere ante el alcalle e dijiere que es personero de otro, quier en demandar, quier en responder, muestrese por personero por testigos o por carta que sea valedera. Et si lo asi mostrare, rescibanlo por personero, fuera si fuere pleito que caya en justicia de cuerpo o de miembro. Et en todo pleito pueda dar vocero el dueño de la voz o su personero. Et el dueño de la voz pueda camiar su personero o su vocero quando quisiere: et dé su galardon a aquel a qui tuelle la personeria o la voz, si por su culpa non la perdiere" (Fuero Real cit. (nota 75), p. 24); bem como em FR. I, 10, 8: "Si algun ome hoviere muchos pleitos pueda dar un personero para todos si quisiere, quier sean comenzados los pleitos, quier por comenzar. Otrosi pueda dar dos personeros o mas en un pleito si quisiere; et cualquier dellos que tomare el pleito ante el alcalle, aquel finque por personero, et non mas. Et si despues que el personero comenzare el pleito, el dueño de la voz veniere por sí al pleito, este non fique mas por personero, si el dueño de la voz non gela otorgare de cabo. Otrosi despues que diere un personero si despues diere otro, el primero sea tollido, maguer que el dueño de la voz non lo tuelga nombradamientre" (Fuero Real cit. (nota 75), p. 26). Observe-se que o legislador, conquanto aproxime as figuras do procurador e do advogado, ainda as mantém distintas, na medida em que 
se atribui ao primeiro a possibilidade de - assim como o principal - indicar "vocero". A despeito da inexistência de paralelo (em meio às fontes castelhanas) a respeito da prova legal da "personeria", deve-se destacar, quanto à possibilidade de sua revogação a líbito do principal, preceito constante de Esp. IV, 8, 10 ( $2^{\mathrm{a}}$ parte), no qual se alude às possibilidades de revogação "de fato" e "de direito": "dezimos aun, que en dos maneras se puede toller el personero, la una de fecho e la otra de dicho. De fecho, quando el dueño de la voz da otro personero en el pleito, o viene él a razonarlo por si mismo. Ca dali adelante non deve valer lo que el personero razonare, si nol otorgare la personeria otra vez. De dicho es quando abertamiente diz que non quiere que sea su personero" (Especulo cit. (nota 75), p. 103).

Disposição também sem paralelo parece ser a contida em FR. I, 10, 19, na qual se busca prevenir os efeitos nocivos da ausência e da contumácia: "mandamos que el que fuere aplazado sobre alguna demanda, quier de raiz, quier de mueble, e despues quisiere ir en romería o en hueste o en otro lugar, deje personero por sí que responda; e si lo non ficiere, el alcalle del pleito faga contra él, asi como manda la ley de los que son emplazados e non quieren venir facer derecho" (Fuero Real cit. (nota 75), p. 28).

Já no que concerne ao conteúdo da "carta de personeria", o "Fuero Real" estabelece um conjunto de elementos, posteriormente complementado pelas demais fontes do direito castelhano (FR. I, 10, 6): "si alguno diere a otro por su personero por carta sobre algun pleito, debe nombrar así en la carta, e el personero, e el pleito sobre quel da, e el alcalle para ante quel da, e que el estará por cuanto aquel personero ficiere o razonare en aquel pleito. Pero avenencia non pueda facer, nin quitar la demanda, si non gelo mandare el dueño de la voz señaladamientre por aquella personeria o por otra" (Fuero Real cit. (nota 75), p. 25). Ora, temos aqui não apenas o estabelecimento do rol de elementos mínimos da "carta de personeria", como também uma previsão a respeito dos limites a serem observados pelo agente. Tal disposição é complementada, assim, pelo fragmento constante de FR. I, 10, 13: "ningun personero que sea dado en algun pleito, quier para demandar, quier para defender e para juicio tomar, non pueda facer ninguna avenencia, nin ninguna compustura en aquel pleito, fueras ende si el dueño de la voz gelo mandare nombradamientre en la personería" (Fuero Real cit. (nota 75), p. 27). No que toca ao conteúdo da "carta de personeria", o "Especulo" é mais minudente, exigindo-se ali também a indicação do adversário, lugar e data em que é passada, além da outorga de poderes não só para que o "personero" demande, mas igualmente para que responda em caso de reconvenção (Esp. IV, 8, 9): "en la personeria que fuere fecha por carta deve dezir estas cosas que aqui mostraremos. Primeramiente deve y seer nonbrado el nonbre daquel que faze el personero. E desi aquel contra quien es dado, e el pleito sobre quel da, e el judgador ante quien se deve librar el pleito, e que tanbien le da por personero para demandar, como para responder. E deve y dezir que estará por quanto y fiziere e razonare el personero en aquel pleito. E sobre todo esto deve y seeer escriptoel lugar en que la fezieron, e el dia, e el mes, el el era del año en que fue fecha" (Especulo cit. (nota 75), p. 103). Nas "Siete Partidas", além de se demandar tais elementos - dispensados unicamente na hipótese de procuração "apud acta" (Part. III, 5, 14) - são exigidas testemunhas (nas "cartas de personeria" lavradas por escrivães públicos) e outorgas específicas de poder - como nos casos de demanda de filho próprio sob poder de outrem (Part. III, 5,16 ) e ações contra o administrador de bens do incapaz (Part. III, 5, 17). Já no que concerne ao influxo dos poderes outorgados na "carta de personeria" sobre os limites da atuação do "personero", o "Especulo" complementa a disposição do "Fuero Real" ao prescrever a necessidade de poderes expressos para que o agente possa prestar juramento e prometer o comparecimento do principal (Esp. IV, 8, 18). No âmbito das "Siete Partidas", o legislador acrescenta a possibilidade de utilização de uma fórmula geral (Part. III, 5, 19), em virtude da qual o procurador poderia "fazer cõplidamente todas las cosas, enel pleyto que el mismo podria fazer” (Las Siete Partidas II cit. (nota 75), p. 36); orientação esta que é reiterada a propósito do recebimento judicial de importâncias devidas ao principal (Part. V, 14, 7): "Ley. vij. Como deue ser fecha la paga, o non al personero que la demanda en juyzio por otri (Como deue ser fecha la paga o non al personero que la demanda en juyzio por otro). Personero fazendo vn ome a otro para demandar en juyzio alguna debda quel deuiessen, Maguer veciesse al debdor este personero, tal nõ gela deue a el pagar, fueras ende si el dueño en la carta de la personeria, le otorgasse poder tambien para recibir la paga, como para demandar el debdo. E si tal poder nõ le otorgasse en la carta de personeria, deue pagar e entregar el debdo al Señor, e non al personero. Otrosi dezimos q tal personero como este non puede fazer pleyto de quitamiento, con aquel a quien ha a demandar el debdo, que gelo nõ demande, nin gelo puede quitar. Pero si enla carta dela personeria le fuesse otorgado libre e llenero poder en demãdar, e en recabdar la debda, e fazer todas las otras cosas que el Señor podria fazer si fuesse presente, entonce bien podria recibir la paga, o quitar el debdo, tan bien como el Señor que lo fizo su personero" (Las Siete Partidas III cit. (nota 75), pp. 99-99verso). De toda forma, não se pode encerrar o presente comentário sem que se aluda ao fato de que, conquanto em FR. I, 10, 13 se disponha a respeito dos limites da atuação do "personero", utiliza-se - a evidenciar uma confusão terminológica (com graves repercussões dogmáticas) - a expressão "mandare".

Por sua vez, em FR. I, 10, 15 se estabelece que, ainda que sejam muitos os principais, devem todos lançar mão de um único "personero", a fim de que não se tumultue o processamento do feito: "se muchos han un 


\section{$\S$ 98. A atividade legiferante de D. Afonso $X$ (cont.): dois aspectos}

peculiares da "personeria" de conformidade com o "Especulo". Ainda que controvertido o seu respectivo enquadramento no panorama oferecido pela historiografia externa do direito castelhano, o "Especulo" de D. Afonso X apresenta uma indiscutível importância como elemento de síntese da disciplina articulada - de modo mais pormenorizado - nas "Siete Partidas". Conquanto de seus dispositivos deflua um maior incremento quanto à disciplina da atividade do "vozero" - e que será objeto de um tratamento mais detalhado (e unificado) logo adiante - dois dispositivos estritamente atinentes à "personeria" ostentam singular relevância: a) de um lado, em Esp. IV, 8, 10 o intérprete se depara com uma consagração expressa do direito à remuneração do agente que, não tendo incorrido em culpa, tem seus poderes revogados pelo principal (“dezimos que despues quel tolliere, quel deve dar su galardon, segunt lo oviere merecido, non faziendo porque perdiese la personeria por su culpa"); b) por sua vez, no fragmento constante de Esp. IV, 8, 16 deparamo-nos com uma disposição de caráter social, em virtude da qual são estabelecidas duas exceções - representadas pelos pleitos "de morte" e "de servidão" - à regra de que o

pleito de consuno, quier en demandar quier en responder, den todos un personero, ca non es razon que un pleito se razone por muchos" (Fuero Real cit. (nota 75), p. 27). A despeito do caráter profilático - e talvez pouco democrático - de tal disposição, deve-se considerar com especial atenção a razão para a proibição do exercício da "personeria" por múltiplos sujeitos: "ca non es razon que un pleito se razone por muchos"; com efeito, a justificação oferecida pelo legislador denuncia a promiscuidade entre os conceitos de "vocero" e "personero". De fato, o responsável por articular o feito - arrazoando-o - não é o "procurator", mas sim o advogado. De forma que, mesmo sintético, este fragmento demonstra uma importância sistemática bastante significativa.

Por fim, no que diz respeito aos efeitos internos da relação mantida entre o principal e seu "personero", mostra-se importante (e inovadora) a disposição contida em FR. I, 10, 10: "Pues que el personero rescibiere la personería de otro en algun pleito, non la pueda dejar fasta que aquel pleito sobre que rescibió la personeria sea acabado, fuera si ovier enfermedat o otro embargo derecho porque la non pueda tener: et si dotra guisa la dejare, pierda el galardon que dende hobo o debie haber. Et si por su culpa perdiere el dueño de la voz el pleito o alguna cosa dent, el personero sea tenudo de pecharle aquello que por él perdió. Et esto mismo establecemos de los voceros" (Fuero Real cit. (nota 75), p. 26). Para além da aproximação promovida entre a "personeria" e a advocacia, merece destaque a ligação existente entre este fragmento e a provisão contida no Código Visigótico (LI. II, 3, 7) em que se aludia à perda do salário por aquele "procurator ad litem" que não transferisse, tempestivamente, o resultado da demanda ao seu constituinte; pois bem, aqui também temos uma previsão de perda da remuneração - a robustecer a tendência a uma bilateralização do vínculo, mediante a gestação progressiva de uma espécie de sinalagma entre a atuação do gestor e a "contrapartida" que lhe é prestada pelo principal. Além disso, se estabelece a responsabilidade do agente (pela via regressiva) na hipótese de culpa manifestada no desempenho de suas funções. No mesmo sentido deste preceito, cf. Esp. IV, 8, 17 ( $1^{\mathrm{a}}$ parte $)$ e Part. III, 5, 26.

Em uma das raras análises do tema em meio às fontes castelhanas, A. PIMENTA observa que "havia grande confusão entre Procuradores e 'Voguados' (...) Pessoeiro, procurador, solicitador - são três nomes que indicam no fundo a mesma função" (Fuero Real cit. (nota 74), p. 408). Embora não concordemos com a fusão promovida por este autor, somos compelidos, por outro lado, a referendar a sua observação quanto à promiscuidade havida não apenas entre "personeros" e "vozeros", mas inclusive a afetar personagens outras como os "mesajeros" e "mandaderos". De todo modo, resta claro que ao mesmo tempo em que se robustece o dever de informação por parte do agente, se consagra, ademais, aquela orientação visigótica estabelecida em LI. II, 3, 3, no sentido da reponsabilidade do agente por culpa - inclusive com a perda de seus salários, conquanto em hipótese distinta daquela aventada em LI. II, 3, 7 . 
"personero" não pode atuar contra a manifesta vontade do principal: "pueden demandar o defender pleito ajeno sin personeria (...) enpero ninguno lo deve fazer contra su defendemiento sinon por dos cosas (...) la una es, si judgan alguno a muerte (...) e la outra es, si dan juyzio contra alguno que torne a servidumbre (...) ca asi como estas dos cosas, muerte e servidumbre son las mas graves del mundo, asi deven aver mayores conseios e maiores accoros de los omes". Enquanto no primeiro preceito pode ser entrevista uma influência da orientação visigótica (LI. II, 3, 7) a respeito do mandato (e sua eventual onerosidade), neste último excerto pode ser surpreendido um antecedente da “indisponibilidade" do direito de defesa técnica - tão cara aos contemporâneos estudiosos do direito processual penal ${ }^{78}$.

${ }^{78}$ No que concerne à revogação dos poderes outorgados ao "personero" - e seus efeitos estritamente relacionados à remuneração que the é devida - eis o teor de Esp. IV, 8, 10: "Ley X. Dado puede seer un personero en muchos pleitos, o muchos personeros en un pleitoasi como dixiemos en la ley ante desta. E esto dezimos quier sean comenzados los pleitos, quier por comenzar. Empero quando muchos personeros fueren dados en un pleito o en muchos, si aquel que lo dixiere, dixiere que da a cada uno dellos nonbradamiente por si, el que primero comenzare el pleito, es personero e non los otros. Pero si todos venieren en uno al pleito, e non se acordaren entre si qual dellos lo comenzará, deve el judgador recebir por personero al que viere que es mas guisado para razonarlo, e al que toviere que lo fará meior. Mas si dieren dos personeros, o mas de so uno, e non dixiere que faz señaladamiente a cada uno dellos por si, non puede ninguno dellos entrar en el pleito nin razonarlo, a menos del otro que fueren dados con él. E mas dezimos aun, que en dos maneras se puede toller el personero, la una de fecho e la otra de dicho. De fecho, quando el dueño de la voz da otro personero en el pleito, o viene él a razonarlo por si mismo. Ca dali adelante non deve valer lo que el personero razonare, si nol otorgare la personeria otra vez. De dicho es quando abertamiente diz que non quiere que sea su personero. Enpero quando asi lo quisiere toller, develo facer saber a aquel que a de judgar el pleito, e a su contendor. E si non lo feziere asi, deve valer quanto el personero razonare en aquel pleito, tan bien como si non lo oviesse tollido. Pero dezimos que despues quel tolliere, quel deve dar su aglardon, segunt lo oviere merecido, non faziendo porque perdisse la personeria por su culpa, o el galardon que devie aver por ella. Otrosi dezimos que si el dueno dela voz muriere ante que el pleito sea comenzado, que non vale la personeria. E se muriere despues que el pleito fuere comenzado, deve yr el personero adelante por el pleito, fasta que gelo tuelgan aquellos a quien pertenece aquella cosa sobre que es el pleito, e valer lo que y oviere fecho. E si el personero muriere ante que el pleito sea comenzado, non vale la personeria, mas si muriere despues, deve valer lo que y oviere fecho, e sus herederos deven haber galardon segunt que lo oviere el merecido" (Especulo cit. (nota 75), p. 103). Observe-se que a respeito de algumas regras contidas neste fragmento já tivemos a oportunidade de nos manifestar em oportunidades anteriores; contudo, há que se destacar o fato de que, na hipótese de substituição repentina do "personero", o procurador anterior tem resguardado o direito aos seus respectivos salários (proporcionais), a serem estimados de acordo com os critérios pertinentes - destaque-se que nas "Siete Partidas" encontraremos disposição expressa a respeito dos padrões envolvidos na apreciação da remuneração do advogado (Part. III, 6, 14). Assim, a par da proteção tradicionalmente conferida aos interesses do principal, começa a exsurgir em meio à própria "personeria" um sistema de tutela ao próprio "procurator", na medida em que - ainda que atuasse em benefício daquele - não poderia ser arbitrariamente despojado de sua remuneração, em caso de revogação ("de fato" ou "de direito") abrupta de seus poderes. Cumpre ressaltar que não encontramos, todavia, disposição similar em meio às demais fontes do direito castelhano.

Por sua vez, no que tange à vedação quanto ao exercício (espontâneo) da "personeria" contra a manifesta vontade do "dominus negotii", eis o teor do fragmento contido em Esp. IV, 8, 16: "Ley XVI. Esta misma seguranza que dixiemos en la ley ante desta, dezimos que deve dar otro qualquier que venga defender pleito ageno, non mostrando personeria. E si tal seguranza non quisiere dar, non deve seer recebido en el pleito. e como quier que estos de que dixiemos en esta ley, e en la otra ante della, que pueden demandar o defender pleito ajeno sin personeria de aquel cuyo es, enpero ninguno non lo deve fazer contra su defendemiento sinon por dos cosas. La una es, si judgan alguno a muerte, e non se quisiere alzar de aquel juyzio. E la otra es, si 


\section{§ 99. A atividade legiferante de D. Afonso X (cont.): organização familiar $e$}

efeitos dos atos jurídicos praticados por filhos e escravos segundo as "Siete Partidas". As "Siete Partidas" correspondem a um mecanismo de acomodação das disposições do direito justinianeu ao cenário ibérico de meados do século XIII. No que toca especificamente à organização familiar, verifica-se uma ampla adoção do paradigma representado pelo "Corpus Iuris Civilis": assim, todos os atos praticados pelo escravo (Part. IV, 21 pr.) mesmo que durante um efêmero estado de liberdade (Part. III, 2, 10) - repercutem diretamente na esfera jurídica do "dominus" (Part. IV, 21, 7); admitindo-se, em caráter excepcional, uma atuação judicial do "servus" - em defesa dos interesses do "pater" - em virtude da ausência ou da dignidade especial de seu senhor (Part. III, 2, 9). Por sua vez, no que concerne aos atos "benéficos" praticados pelos filhos, aplica-se, em linhas gerais, a disciplina romana do pátrio poder (Part. IV, 17 pr.): todas as aquisições promovidas pelos "alieni iuris" eram incorporadas ao patrimônio encabeçado pelo "pater" (Part. IV, 17, 5), observadas as peculiaridades atinentes à disciplina das diversas modalidades de pecúlios profectício, adventício, castrense e quase-castrense (Part. IV, 17, 5; Part. IV, 17, 6; Part. IV, 17, 7). Já no que diz respeito à percussão passiva, a regra era a de que os atos praticados de moto próprio pelo filho não obrigavam o acervo doméstico; todavia, esse princípio não tinha aplicação irrestrita: não apenas o adimplemento voluntariamente efetuado pelo incapaz era inatacável (Part. V, 1, 4), como também se considerava vinculado o patrimônio familiar se houvesse aquiescência - expressa ou tácita - por parte daquele "em cuyo poder" se encontrava o "filiusfamilias" (Part. V, 1, 6)

dan juyzio contra alguno que torne a servidumbre, e otrosi non se quiere alzar de aquel juyzio. Ca en estos dos pleitos dezimos que qualquier se puede alzar para defender al que fuere asi judgado, si entendiere quel judgan mal, maguer él lo contradiga. Ca asi como estas dos cosas, muerte e servidumbre son las mas graves del mundo, asi deven aver mayores conseios e maiores acorros de los omes, aquellos que fueren judgados para ellas, por estorcerlos ende con derecho se pudieren" (Especulo cit. (nota 75), p. 105). Assim, conquanto as demais fontes do direito castelhano permitam esta espécie de "gestão de negócios" de natureza processual (na acepção justinianéia da expressão), não encontramos preceito correspondente, no qual sejam ressalvadas as referidas exceções; a respeito, cf. FD. I, 3, 8, Dot. II, 1, 6, FR. I, 10, 14, Esp. IV, 8, 8, Esp. IV, 8, 11 e Part. III, 5, 10 (parte final).

${ }^{79}$ A situação do escravo em meados do século XIII - bem como a sua posição em meio ao núcleo familiar pode ser depreendida da disposição inaugural do título XXI da "Partida Quarta", intitulado "de los sieruos" (Part. IV, 21 pr.): "sieruos, son otra manera de omes, que hã debdos, con aquellos, cuyos son, por razon del señorio, que han sobre ellos, Onde, pues que enel titulo ante deste, fablamos de los criados, que ome cria en su casa, que son libres: queremos aqui dezir de los sieruos, porque son de casa" (Las Siete Partidas cit. (nota 75), p. 54verso). Deste fragmento, merece destaque a consideração do "servus" como alguém de casa: a quem se atribuia uma série de deveres, conquanto - curiosamente - não fosse considerado propriamente um sujeito de direitos (mas tão somente um objeto).

No que toca às aquisições promovidas pelo escravo, prevalecia um sistema muito parecido com aquele que se entrevira entre os romanos. A este respeito, são elucidativas as disposições contidas em Part. III, 2, 10 e Part. IV, 21, 7, ora transcritas: "Ley. x. que los religiosos no pueden estar en juyzio sin mandado de su mayoral 
(...) otrosi dezimos, que si alguno fuesse sieruo, e lo ouiesse aforrado su señor, e en aquel tiempo, qu estouiesse forro, fiziesse deuda con o otro ome, e despues ouiesse fecho cosa porque lo tornasse en seruidumbre come de primero, aquel cuyo era, que si alguno le quisiesse demandar aquella deuda, non lo puede fazer a el, mas al señor, en cuyo poder fuesse " (Las Siete Partidas II cit. (nota 75), p. 5verso); "Ley. vij. Como las ganancias que fazen los sieruos deuen ser de sus señores. Todas las cosas quel sieruo ganare por qual manera quier que las gane, deuen ser de su Señor. E aun dezimos, que las cosas quel fuessen mandadas en testamento al sieruo, que tambien las puede demandar el Señor, como si las ouiessen mandado a el mismo. Otro si dezimos, que si alguno pone su sieruo entienda, o naue, o en otro logar, mandando que vse de aql menester, o mercaduria, que todos los pleytos que tal sieruo fiziere con quienquier que los faga, por razon de aquel menester, o mercaduria en que lo pone: que es tenudo el Señor de los guardar, e de los complir: tambien como si el mismo los ouiesse fechos" (Las Siete Partidas II cit. (nota 75), p. 56). Enquanto no primeiro fragmento podemos entrever a repercussão sobre o patrimônio familiar dos atos praticados pelo escravo (aforrado e posteriormente reconduzido à servidão), no segundo vislumbramos uma consagração (medieval) da tendência romana (clássica) de utilizar o "servus" para o incremento de atividades comerciais, com o conseqüente desenvolvimento pretoriano das chamadas "actiones adiecticiae qualitatis" (cf. notas $29 \mathrm{e}$ 40).

Finalmente, no que concerne à atuação judicial do escravo em prol de seu senhor, eis o disposto nas Part. III, 2, 9: "Ley. ix. por quales cosas puede el sieruo fazer demãda a otros en juyzio. Viña, o casa, o eredamiento, o alguna cosa, que touiesse el sieruo, por su señor, si otro gelo embargasse, o lo desapoderasse della, non seyendo el señor en aquel logar, por que podiesse amparar su derecho: entõce, bien puede el sieruo, fazer demãda en juyzio, contra aquel que lo fiziesse. E otrosi quando acaesciesse, q matassen a su señor, e los parietes del, nin otro non quisiessen demandar la muerte alos matadores: entonce bien puede el sieruo estar en juyzio, para fazer tal demãda. E aun dezimos, q si el sieruo faziedo algu yerro, porque mereciesse perder miebro, o recibir muerte, si le fuesse prouado, bien gelo pueden a el mismo demandar, sin su señor. Otrosi dezimos, que todo sieruo de Emperador, o de Rey, puede fazer demanda en juyzio, sobre cosa que perteneciesse a su señor, o por razon de su persona misma. E esta mayoria fue otorgada atales sieruos como estos por honrra de los señores, cuyos son" (Las Siete Partidas II cit. (nota 75), pp. 5-5verso). Aqui temos uma consagração ao exercício - excepcional - da "personeria" pelo escravo, legitimado nas hipóteses de justo impedimento ou morte de seu senhor. No que concerne à demanda voltada à apuração de crime praticado pelo escravo, a disposição aqui coligida difere de sua correspondente situada no "Especulo" (Esp. IV, 8, 6): enquanto neste se determina que "el señor es tenudo de demandar o de responder por él, o de dar personero por él, o de desenpararle" (Especulo cit. (nota 75), p. 102), nas "Siete Partidas" se preceitua que o próprio escravo pode ser demandado ("sin su señor"). Finalmente, em razão da dignidade especial de seus senhores, os escravos imperiais tinham a prerrogativa atuar como autênticos "procuratores ad litem".

Já no que concerne à posição dos filhos na estrutura familiar, é elucidativo o proêmio do título XVII da "Partida Quarta", intitulado "del poder que han los padres sobre sus fijos, de qual natura quier que sean" (Part. IV, 17 pr.): "poder e señorio, han los padres sobre los fijos segud razon natural, e segud derecho. Lo vno, porq nasce dellos, lo al porque han de heredar lo suyo. Onde, pues que enel titulo ante deste fablamos de los hijos legitimos: e de todos los otros, de qual natura quier q seã: queremos aqui dezir deste poderio q han los padres, sobre ellos. E mostrar, q cosa es este poderio. E en quantas maneras se puede enteder esta palabra. e como deue ser establescida. E q fuerça ha." (Las Siete Partidas II cit. (nota 75), p. 46verso). Merecem destaque as duas justificativas utilizadas para fundamentar o pátrio poder: a razão natural (que será invocada em outras oportunidades do presente estudo) e o fato de que os filho tende a herdar o patrimônio que efemeramente cabe a seu pai. Daí a grande importância conferida (pelo legislador) ao direito sucessório no âmbito das "Siete Partidas".

No que toca às aquisições promovidas pelos filhos, a regra central do sistema há de ser depreendida da Part. IV, 17, 5 - sempre revertendo seus efeitos em favor do "pater" - onde se alude, inclusive, às mitigações representadas por algumas das modalidades integrantes do sistema de pecúlios (profectício, adventício, castrense e quase-castrense), disciplinado naquele fragmento e nas Part. IV, 17, 6 e Part. IV, 17, 7, ora transcritas: "Ley. v. Que fuerça ha este poder que ha el padre sobre sus fijos, en razõ delos bienes que ellos ganan (Que fuerça ha este poder, que el padre ha sobre sus fijos, en razon delos bienes que ellos ganan). En tres guisas se departe las ganãcias que faze los fijos, mietra estã en poder de sus padres. La primera es, de aquello que ganã los fijos con los bienes delos padres: e tal ganancia como esta, llaman en latin, profectitium peculium. Ca quanto quier que gaña desta manera: o por razon de sus padres: todo es de los padres, que los tienen en su poder. La seguda es, lo quel fijo de alguno ganasse por obra de sus manos, por algud menester, o por otra sabiduria q ouiesse: o por otra guisa: o por alguna donacion que le diesse alguno en su testamento, $o$ por herecia de su madre, o de alguno de los parientes della: o de otra manera: o si fallasse tesoro: o alguna otra cosa porauentura. Ca delas ganacias que fiziesse el fijo, por qual quier destas maneras, q non saliessen delos bienes del padre, nin de su abuelo: deue ser la propiedad del fijo, que las gano, e el vsofruto, del padre 
en su vida, por razon del poderio que ha sobre el fijo. E esta ganancia, llaman en latin aduentitia, porque viene de fuera, e non por los bienes del padre. Pero el padre dezimos, q deue defender, e guardar estos bienes adueticios de su fijo, en toda su vida, tambien en juyzio, como fuera de juyzio. La tercera manera de bienes e de ganancia es, la que dize en latin, castrense vel quasi castrense peculium. Assi como se muestra adelante" (Las Siete Partidas II cit. (nota 75), pp. 47-47verso); "Ley. vj. Que los fijos puede fazer lo que quisieren delas cosas que ganaren en castillo, o en hueste, o en corte, maguer sean en poder de su padre. Castra es vna palabra de latin, q se etiede en tres maneras. La primera e la mas comunal es, todo castillo e todo logar, q es cercado de muros, o de otra fortaleza. La seguda es, hueste o aluergada, do se ayuta muchas getes, q es fortaleza, e porede es llamada en latin castra. La tercera es, corte del rey: o de otro principe, do se allegã muchas getes, como a señor q es fortaleza, e amparamieto de justicia. E por esta razõ, las ganãcias q los omes faze en algunos destos lugares, tomarõ nomes desta palabra, q dize en latin, castra. E por esso sõ llamadas, castrese, vel qsi castrese peculiu. E a vn porq tales ganãcias como estas, faze los omes cõ grãd trabajo, e cõ grand peligro e porque las fazen en tan nobles lugares, porende son quitamete delos que las ganaron, e son mas, franqueadas que las otras ganãcias. ca los duenos dellas, pueden fazer destos bienes a tales, lo que quisieren: e non hã derecho en ellas, nin gelas puede embargar, padre nin hermano: nin otro pariente que ayan" (Las Siete Partidas II cit. (nota 75), pp. 47verso-48); “Ley. vij. Quales cosas que los fijos ganan son llamadas pegujar de aluergada (Que las cosas que los fijos ganan son llamadas pegujar de aluergada). Castrense peculium, llaman en latin, a las ganancias que los omes faze en algunos delos tres lugares que diximos en la ley ante desta, assi como las soldadas q dan los señores a los vassallos, qer sean caualleros, o otros qualesquier que los siruan de cauallo, e con armas. Otras ganancias y ha, a que llaman en latin, quasi castrense, que quier tanto dezir en romance, como ganancias que son semejãtes destas otras: e son assi como lo que dã alos maestros, de qual sciecia quier que sean, dela camara del rey: o de otro lugar publico, en razon de soldada: o de salario. E otrosi lo que dan ende alos juezes, e alos escriuanos del Rey: por razon de su officio: e lo que dan a otros quales quer desta manera. Esso mesmo dezimos, que es, quasi castrese todo donadio de heredad, o de otra cosa qualquier q da el rey, o otro señor qlquier destos sobre dichos. Ca tales ganancias como estas son quitamete de aquellos que las fizieron, assi como de suso diximos" (Las Siete Partidas II cit. (nota 75), p. 48). Desta forma, o regime jurídico atinente às aquisições promovidas pelos filhos pode ser assim sintetizado: a regra geral é de que tudo aquilo que é adquirido pelo filho pertence ao "pater", eis que os bens que se encontram sob o poder (fático) dos "alieni iuris" presumem-se integrantes do "profectitium peculium"; quanto aos bens adventícios, pertencem à propriedade do filho, mas o pai deles tem usufruto vitalicio (contrabalançado pelo dever de os defender da eventual investida de terceiros). A terceira modalidade corresponde ao pecúlio castrense: partindo-se dos significados do termo "castra" - castelo (fortaleza), exército, ou mesmo corte do rei - se conclui que em tais lugares, dada a magnitude da função neles desempenhada, é obtida uma espécie própria de pecúlio, submetida a regime jurídico singular, eis que o "filius" não somente é proprietário, como também administra livremente tais bens (diferentemente do que se verifica quanto aos pecúlios profectício e adventício); já no que toca ao pecúlio quase-castrense, tem-se uma extensão do regime jurídico da modalidade anterior (castrense) a hipóteses que nela não podiam ser ("ab initio") incluídas - mostrando-se necessária, então, a regra de efeito extensivo.

Por fim, assim como o direito pretoriano progressivamente admitiu a percussão passiva do acervo doméstico em virtude da atividade desempenhada pelo "filiusfamilias" (e para tanto foram decisivas as "actiones adiecticiae qualitatis"), duas disposições constantes do Título I da "Partida Quinta" ("que fabla de los emprestidos") merecem destaque, na medida em que, respectivamente, legitimam o adimplemento espontaneamente realizado pelo incapaz (Part. V, 1,4) e vinculam o próprio "pater" pela dívida contraída pelo filho em sua presença ou com a sua anuência (Part. V, 1, 6). Eis os textos dos referidos fragmentos: "Ley. iiij. Del prestamo q es fecho a los fijos q son n poder desu padre, o de su madre (Del prestamo que es fecho a los fijos que son en poder de su padre, o de su abuelo). Si demientra, que estouiere el fijo, o el nieto, en poder del padre, o de su abuelo, tomare prestado, de otro sin mãdado de aql e cuyo poder esta nõ es tenudo el fijo, nin el padre, de tornar tal emprestamo, ni el fiador del fijo, maguer lo ouiesse dado. pero si el fijo tornasse, aquella misma cosa, que le ouiesse emprestado, o otra tal que non fuesse delos bienes de su padre, o de su abuelo, valdra, si lo fiziere, e non gelo podria el padre vedar. otrosi dezimos, que si el fijo, o el nieto, estando en poder de su padre, o de su abuelo, si ala razon que tomasse la cosa emprestada, la preguntassen si auia padre, o abuelo, o alguno de los otros ascendietes, en cuyo poder estuuiesse, e lo negasse, diziendo que non, q por tal metira, que dixo, e nego la verdad, es tenudo de pechar aquello que tomo emprestado. Otrosi dezimos, que qualqueira q tuuiesse algund officio, publicamete del Rey, o de otro señor, o de algud concejo, o el q fuesse menestral, de qualqueier menester, que vsasse a labrar publicamete, o tuuiesse tieda de cambio, o de paños o de otra mercaduria, en que vsasse alabrar e mercar, bien assi como ome, que no esta en poder de otro porq creen los omes q este atal, q estaua sobre si, es tenudo de pagar lo que tomare emprestado, maguer que este, en poder de otro. Esso mismo dezimos, quãdo aquel que es en poder de otro, es cauallero, que si algo tomare emprestado tenudo es delo pagar. E esto es por que non deue ome sospechar, que lo que tomo 
$\S 100$. A atividade legiferante de D. Afonso X (cont.): peculiaridades do regime jurídico da "personeria" consoante as "Siete Partidas". No âmbito da "personeria", para além das disposições decorrentes das demais fontes do direito castelhano, depreende-se das "Siete Partidas" uma conjugação entre elementos defluentes da estrutura tradicional da "procuratio" - como é o caso da eficácia liberatória do pagamento efetuado ao "procurator omnium rerum" ou ao "mayordomo" (Part. V, 14, 5) e disposições voltadas ao atendimento das específicas necessidades da sociedade de meados do século XIII: é neste sentido que devem ser interpretadas algumas importantes disposições, tais como a que equipara o notário ao "servus publicus" (Part. V, 11, 7), a que determina que alguns entes especiais somente possam ser demandados por meio de seus procuradores (Part. III, 2, 13), ou mesmo a que estende a idéia de "personeria" a hipóteses de incumbência legal (Part. V, 11,8). Já no que concerne à "carta de personeria" visando-se coibir quaisquer excessos por parte do agente - preceitua-se que sejam expressamente declinados os poderes outorgados ao "personero", vedada qualquer espécie de substituição quando sua atuação se der no âmbito processual (Part. III, 5, 19); de toda forma, pairando quaisquer dúvidas a respeito da extensão dos poderes conferidos ao agente, determina-se que sejam oferecidas garantias pelo próprio “procurator ad litem",

prestado, q lo despendio en malos vsos, mas en las cosas que pertenescen a caualleria" (Las Siete Partidas cit. (nota 75), pp. 3-3verso); "Ley. vj. Del prestamo que es fecho al fijo, o al nieto que esta en poder de su padre, o de su abuelo, con otorgamiento de aquel en cuyo poder esta. Sacando emprestado el que esta en poder de otro, con sabiduria, o con mandamiento de aquel en cuyo poder es, o maguer non le mando sacar, si esta delante o lo consiente, o si lo saca a otra parte, e gelo embia a dezir por carta, o de otra guisa, o lo otorga, o si paga despues alguna partida dela debda, dezimos q tenudos son de pagar tal prestamo el que lo saca, o aquel en cuyo poder esta. Otro si dezimos, q el que tomasse, emprestado, estando en poder de otri, si despues que fuesse de edad complida, e saliesse de poder de aql que lo auia en guarda pagasse alguna partida del debdo, q tenudo es porede de pagar todo lo alq finca. Otrosi dezimos, que si alguno que esta en poder de otry, va en mãdaderia o en escuela, e saca alla algund emprestido, que tenudo es de lo pagar el. o aquel en cuyo poder esta, fasta en aquella quãtia a lo menos, que pudiera despender en comer, e en vestir, e enlas otras cosas que le serien menester, fincãdo en su poder, e en su casa. E aun de mas, quãto asmaren que le podria costar el loguero de la casa, en que morasse, e lo que aurien a dar a su maestro, e a despender en las otras cosas, que serien menester por razon de su estudio, o de aquella mandaderia en que fuesse" (Las Siete Partidas cit. (nota 75), pp. 3verso-4). Desta forma, de acordo com o primeiro fragmento, sendo realizado um empréstimo ao "filiusfamilias", inexiste vínculo que possa compeli-lo à restituição (ou mesmo o seu responsável); contudo, havendo restituição, esta é perfeitamente válida e eficaz, não ensejando qualquer espécie de repetição. Ademais, do mesmo fragmento (Part. V, 1, 4) se extraem duas disposições que despertam a atenção do estudioso: à semelhança do estabelecido pelo art. 180 do Código Civil em vigor, havendo ocultação proposital do menor a respeito de seu estado familiar, permaneceria adstrito ao pagamento da dívida, à vista do caráter malicioso de sua conduta; além disso, sob certas circunstâncias (vinculadas ao exercício de determinadas funções ou atividades), da aparente autonomia do sujeito poderia dimanar a presunção de sua capacidade plena - legitimando-se, assim, uma tutela específica (conferida pelo legislador em caráter extraordinário). Por sua vez, do segundo fragmento se extrai preceito que - resguardando a tão enaltecida boa-fé objetiva - determina a vinculação do "pater" sempre que a contratação se der em sua presença ou com o seu assentimento; mas para além disso, mantém jungido ao vínculo o próprio incapaz - ao menos até o limite da quantia que despenderia com a sua própria subsistência (quando se mostre efetivamente distante do domicílio paterno). 
sob a forma de fiança ou de caução (Part. III, 5, 21). Finalmente, no que tange à eficácia da atuação do "personero", vislumbra-se um acatamento à orientação romana a respeito da questão; neste sentido, ao mesmo tempo em que não se admite uma eficácia representativa direta decorrente da atuação do agente (Part. III, 5, 25; Part. V, 11, 8 e Part. V, 11, 9), observa-se uma consagração - ainda que implícita - da regra "ratihabitio mandato comparatur" (Part. III, 5, 20) ${ }^{80}$.

${ }^{80}$ Com relação ao efeito liberatório decorrente do pagamento realizado ao "procurator omnium rerum", eis o teor de Part. V, 14, 5: "Ley. v. Como es quito el ome dela debda, pagando la al señor que la deue auer, o a su mãdado (Como es quito el ome dela debda pagando la al Señor que la deue auer, o a su mandado). Debda deuiedo vn ome a otro, e pagãdola a otro tercero por su mandado de aquel aquie la deuia, o sin su mandado. Auiendo lo despues por firma, tambien es quito del debdo el q lo deuia como si lo ouiesse pagado, a el mismo. Esso mismo dezimos que seria si pagasse el debdo al mayordomo o al procurador que fuesse puesto señaladamente del Señor del debdo para recebirlo, e para recabdar e procurar todos sus bienes. Otrosi dezimos q si prestasse vn ome a otro dineros, e rescibiesse la promission del en esta guisa prometedes me q me dedes estos marauedis que vos presto a mi, o fulan nombrãdolo señaladamente. Si los marauedis paga al otro aquien señalo quel pagasse, tambie es quito del debdo como si los pagasse a el mismo" (Las Siete Partidas III cit. (nota 75), p. 98verso). Observe-se que a figura do "procurator omnium rerum" é referida de modo oblíquo, por meio da alusão ao "personero" encarregado da administração de todos os bens do principal; daí a nítida influência romana do fragmento. Além disso, é necessário destacar que tal excerto parece aludir, ainda que de maneira velada, a uma eficácia representativa direta da atuação do "personero", uma vez que se diz expressamente que o pagamento efetuado ao agente deve ser considerado como realizado ao próprio principal; de todo modo, voltaremos à questão da eficácia representativa direta (defluente da "personeria") ainda nesta nota de rodapé.

A respeito da equiparação do notário ao "servus publicus" (romano), tivemos a oportunidade de tecer maiores comentários ao longo da própria exposição realizada nos parágrafos 67 e seguintes deste estudo; por sua volta, no que concerne à sua consagração pelas "Siete Partidas", eis o teor do fragmento constante de Part. V, 11, 7: "Ley. vij. Como vn ome non puede recebir de otri promissiõ, en nombre de vna persona, so cuyo poder non estuuiesse (Como vn ome non puede rescebir de otri promission en nome de vna persona so cuyo poder non estouiesse). Vn ome non pode recibir promission de otro en nome de tercera persona, so cuyo poder non fuesse. E seria como si dixiesse el vno al otro, prometes me que des a fulã tal cosa, e el otro respondiesse prometo. Ca tal prometimiento, non fincaria obligado, el q lo faze, nin la tercera persona, en cuyo nome fue fecha la promission, nol puede apremiar, nin deue. Mas si el que fiziesse la promission: dixiesse assi: prometo, que de a vos, o a fulan tal cosa, si este que fizo la promission, el por si mismo, non seyedo apremiado, quisiesse complir la promission, dando al otro tercero, lo q prometyera a dar dende adelante, nõ podria demandar aquello, que ouiesse dado, nin el otro non seria tenudo de gelo tornar a el (...) Mas aql que estouiesse en poder de otri, assi como el fijo en nome de su padre. O el sieruo en nome de su Señor: o el religioso, en nome de su mayoral, bien puede rescebir promissiõ de otro. E valdra la promissiõ que cada vno destos sobredichos rescibiesse en nome de aquel, so cuyo poder estouiesse. E puede la demandar aql en cuyo nome fue fecha, al que la fizo tãbien como si el mismo la ouiesse rescebida. E aun dezimos que los judgadores e los escriuanos, de concejo, que escriuen cõ ellos, pueden rescebir promissiõ en nome de otro. E esto seria, si la rescebissen en nome de algund huerfano, prometiedole el guardador que lealmete guardasse, a la persona del huerfano, e a sus bienes. E si la rescebiesse en juyzio de la vna parte en nome de otro, sobre algun pleyto, que ouiesse entre ellos. O si la rescibiessen, tomando tregua de vno en nome de otro. O sobre otro pleyto semejante, destos. Ca maguer ninguno destos sobredichos, en cuyo nome fuesse rescebida la promission, non estouiesse delante, quando la rescibio, vale la promission, e puede la demandar, aquel en cuyo nome fue fecha, tãbien como si el mismo la ouiesse recebida. Porque estos, en cuyo nome toman estas promissiones, son como en poder. e en guarda destos officiales a tales. E aun por que estos officiales atales, son como sieruos publicos, del concejo do biuen, por razon de las cosas que han de fazer, que pertenescen a su oficio" (Las Siete Partidas III cit. (nota 75), pp. 63-63verso). Em primeiro lugar, cumpre esclarecer que parece haver no excerto uma certa confusão entre a "representação direta" (viabilizada pela atuação do "servus publicus") e a "estipulação em favor de terceiro"; entretanto, como observa E. Bussi (La formazione cit. (nota 47), pp. 305-315, especialmente pp. 309-310), este último instrumento (estipulação em favor de terceiro) foi um dos mecanismos utilizados (pelos doutores do direito comum), para obter os efeitos práticos 
de uma representação direta. Além disso, merece destaque o fato de que - tomada em consideração a repercussão generalizada do exercício de suas funções - os notários e julgadores foram considerados "servi publici" não apenas pelas fontes do direito comum europeu, mas também por suas manifestações - inclusive legislativas - no estrito âmbito do direito ibérico.

Com relação a algumas entidades específicas (tais como os concelhos, capítulos e conventos), as "Siete Partidas" estabelecem que sua atuação há de ser - forçosamente - promovida à custa da intermediação de "personeros" especiais; neste sentido, a previsão constante da Part. III, 2, 13 é clara: "Ley. xiij. como si alguno ha demanda contra concejo de algun lugar la deue fazer asu personero (como si alguno ha demanda contra concejo de algund lugar, o cabildo, o conuento la deue fazer a su personero). Concejo de ciudad, o de villa, o cabildo de eglesia, o conuento de religiosos, a quien quisiessen demandar en juyzio: tal demanda como esta, non puede ser fecha a todos comunalmente, porque son muchos; mas deuen la fazer al personero q fuesse puesto para reponder por ellos. Ca si de otra guisa lo fiziessen a otras personas señaladas, maguer de aquel logar fuessen, nõ valdria. Por quela cosa que todo el concejo, o el cabildo, o el cõuento, deuiesse, o fuesse tenudo de fazer, nõ pueden apremiar por ella, a personas ciertas, de aquel logar, que lo cuplan, como quier, que todos en vno, sean tenudos de lo cumplir, bie assi como la deuda, q deuiessen, a ciertas personas de algun lugar que non lo pueden todos en vno demandar: mas solamente aquellos, a quien pertesneciesse la demanda" (Las Siete Partidas II cit. (nota 75), p. 6).

O fragmento constante de Part. V, 11, 8 apresenta múltiplos aspectos de interesse para nossa análise. Entretanto, preliminarmente cumpre destacar a junção que é promovida - sob o termo unificante "personero" - entre a "representação negocial" e a "representação legal", tomadas ambas as expressões na sua acepção contemporânea: "Ley. viij. Quales personas puede rescebir promission por otri. Personero del Rey: o del comun, de alguna cibdad, o villa, o de alguña tierra. E otrosi el guardador de alguno huerfano, o el q fuesse dado por guardador de algund loco, o desmemoriado. Cada vno destos pueden rescebir promission, en nome de aql, cuyo personero es: O cuyo guardador. E vale tal promission, e puede la demandar, tanbien aquel en cuyo nome fuesse recebida: como el procurador, o guardador que la rescibio: en nome de aql. Mas si personero de otro ome qualquier, que non fuesse de ninguno destos sobredichos, rescibiesse promission de otro, en nome de aquel, cuyo personero es, como quier que vale la promission: pero non puede demandar, aquel en cuyo nome fue fecha, que le de, o quel fagan lo q es prometido, fasta que el personero, q la rescibio por el: le otorgue poder: que la pueda demandar. E si por auentura el personero, non quisiere, otorgar poder, de demandar la promissiõ a aquel, en cuyo nome fue fecha: el judgador del logar deue entregar, en tantos de los bienes del personero, quanto podria valer, o montar, lo que es en la promission. E si fuere tan pobre, que não aya en que entregarse, assi como es sobredicho, entonce, aquel en cuyo nome fue fecha la promission, puede la demandar, tan bien, como si el mismo, la ouiesse rescebido" (Las Siete Partidas III cit. (nota 75), p. 63verso). De fato, há um tratamento unificante para hipóteses substancialmente distintas: uma derivada de incumbência negocial, e outra decorrente de atribuição legal (ou judicial); aliás, tal tendência pode ser entrevista em nosso próprio Código Civil vigente - o qual em capítulo único ("da representação") pretende reunir tais figuras, ressalvadas as suas respectivas peculiaridades técnicas. Voltaremos a este fragmento das "Siete Partidas" mais adiante (nesta mesma nota de rodapé), a propósito da apreciação dos efeitos representativos decorrentes da "personeria".

No que concerne à possibilidade de substituição do agente no exercício da "personeria", já havíamos feito alusão ao fragmento constante de Part. III, 5, 19 em ocasião anterior (nota 76). Eis os termos empregados pelo legislador castelhano a respeito da questão: "Ley. xix. que es lo q puede fazer el psonero (que es lo que puede fazer el personero). Razonar, nin fazer, non puede el personero mas cosas (enel pleyto, nin meter a juyzio) de quanto le fuesse otorgado, o mandado, por razon dela personeria. (...) E otrosi dezimos, que el personero non puede poner otro en su logar, en aquel pleyto mismo, sobre que el fue dado, si primeramente non lo ouiesse comencado, por demãda, o por respuesta. Pero si le fuesse otorgado tal poderio enla carta dela personeria: estõce lo podria fazer ante, e despues, E esto ha logar elos personeros, que son dados para seguir los pleytos en juyzio. Ma los otros que son fechos para recabdar, o fazer otras cosas fuera de juyzio: estos atales, bien pueden dar otros personeros en su logar, cada que quisieren. E valdra lo que fuere fecho conellos, tambien como si lo fiziessen con aquellos que los pusieron en su logar Pero si estos fiziessen alguna cosa, a daño del señor: estõce los primeros personeros que los cogieron, e los pusieron en sus logares, son tenudos de se parar a ello" (Las Siete Partidas II cit. (nota 75), pp. 35verso-36verso). Deste modo, como já prescrevia o próprio "Dotrinal" (Dot. II, 1, 8), conquanto genericamente vedada a substituição do "procurator ad litem", admite-se - sem maiores reservas - a substituição do "personero" provido de incumbências de natureza extrajudicial.

Com relação ao excerto constante de Part. III, 5, 21, de igual modo já havíamos nos manifestado sobre a necessidade de prestação de garantia, pelo "personero", quando não restassem inequívocos os termos da "carta de personeria" - notadamente no que tange aos poderes outorgados ao agente (cf. nota 76). A propósito, assim se manifestou o legislador no fragmento em questão: "Ley. xxj. porque cosas el personero 
nõ ha poder de demandar, o defender el pleyto en juyzio si primeramente non diere fiadores (porq cosa el personero nõ ha poder de demandar, o de defender el pleyto en juyzio, si primeramente non diere fiadores). Dvbdosas, o mal fechas, a las vezes traen los personeros las cartas de personeria en juyzio. De manera q non puede saber ciertamente, si son valederas, o non. E porque las cosas q passan ante los judgadores, deuen ser ciertas, de guisa que valan, Dezimos, que quando tal dubda como esta acaeciere, que non deue dar poder a tal personero, contra la otra parte, que lo refierta, a menos de dar primeramente fiadores, o recabdo, que por lo que el fiziere enel pleyto, q estara por ello, e lo aura por firme, el que le fizo su personero. Mas quando la personeria fuesse complida, deue ser cabido el personero, para fazer la demanda. E nõ le deuen embargar, nin demandar otro recabdo. Fueras ede, si este personero del demandador, non quisiesse dar fiadores de respõder, e de defender, a aquel cuyo personero era, en aquellos pleytos que la otra parte dixesse, q queria mouer, ante aql judgador mismo, cõtra aquel que lo fiziera personero. Ca estonce derecho es, que assi como non quiere dar recabdo para responder en juyzio, por el dueño del pleyto, q non pueda demandar por el. E esto que diximos enesta ley, ha logar enlos personeros del demandador. Mas el personero del demandado, quier traya carta complida de personeria, quier non, siepre deue dar recabdo de fiadores, o de peños, que lo que fuere judgado sobre el pleyto q defiede, que se cupla en todas guisas. Fueras ende, si enla carta dela personeria, dixesse señaladamente, q el q lo fiziera personero, el mismo era fiador por el de cuplir, e de pagar todo lo q enel pleyto fuesse judgado. Ca estõce nõ lo deue demãdar otra fiadura" (Las Siete Partidas II cit. (nota 75), pp. 36verso-37). Merece destaque a evidente influência do "Dotrinal" (Dot. II, 1, 8) sobre esta específica disposição constante das "Siete Partidas".

Por fim, no que tange aos efeitos representativos decorrentes da "personeria", os contornos do respectivo regime jurídico parecem decorrer de uma conjugação entre diversos fragmentos das "Siete Partidas": por um lado, na Part. III, 5, 27 parece ser consagrada uma eficácia representativa direta (nos moldes das demais fontes do direito castelhano, conforme analisado em nota 76), que pode ser depreendida da categórica exclusão dos bens do "procurator ad litem" do alcance de eventuais investidas da parte com a qual tivesse litigado em prol do principal. Neste sentido, assim dispôs o legislador castelhano de modo inequívoco: "Ley. xxvij. en cuyos bienes deue ser cumplido el juyzio que es dado contra el personero del demandado (en cuyos bienes deue ser cumplido el juyzio que es dado, contra el personero del demandado). Contra el personero de aql a quien demãdassen, seyendo dado juyzio sobre pleyto, e q le fuesse otorgada la personeria: dezimos que se deue cuplir enlos bienes, tan solamete de aql que le dio por su personero. E si por auentura nõ le fallassen tãtos bienes delos suyos, en que el juyzio se pudiesse cuplir: estõce deue ser cuplido, enlos bienes delos fiadores, q el personero del demandado dio, e nõ enlos del personero" (Las Siete Partidas II cit. (nota 75), pp. 38-38verso). Entretanto, na Part. III, 5, 25 (transcrita em nota 76) se atribuem ao "personero" judicial deveres aparentemente incompatíveis com a eficácia representativa direta defluente do fragmento anteriormente mencionado; uma vez que se estabelece que o agente "es tenudo de dar cuenta al señor del pleyto, de todas las cosas que recibiere, o ouiere por razon de aquel pleyto, en que es personero (...) todo lo que el personero ende leuare, tenudo es de lo dar al Señor del pleyto (...) e aun dezimos, q desto es tenudo de dar le, e de otorgar le todo el derecho q ganasse en juyzio, por qual manera quier, por razõ de aql pleyto" (Las Siete Partidas cit. (nota 75), p. 38). Desta forma, ao mesmo tempo em que se tenciona resguardar o patrimônio do procurador (quanto à eficácia passiva da gestão), se estabelece uma série de obrigações que sugerem a pertinência imediata dos efeitos da gestão ao próprio agente; incumbindo-se-lhe de, em um momento subseqüente, promover a transferência dos direitos adquiridos ao seu destinatário mediato. Nesse sentido, outros dois fragmentos das "Siete Partidas" evidenciam que as ações que beneficiassem o principal haveriam de ser exercidas pelo unicamente pelo "personero" (admitindo-se seu exercício pelo próprio interessado em hipóteses excepcionais); assim, na Part. V, 11, 8 - já transcrita nesta mesma nota de rodapé - se dispõe que, excetuados os casos de "representação legal", o exercício das ações cumpriria exclusivamente ao agente; de modo que a atuação do principal dependeria de outorga de poder realizada pelo próprio "personero". Corroborando tal assertiva, a regra estabelecida no fragmento seguinte (Part. V, 11, 9) excetua a sua antecedente, utilizando para tanto os seguintes termos: "Ley. ix. Como los Señores pueden demandar lo que fue prometido a sus personeros. Ciertas cosas son en las promissiones, que resciben los personeros de algunos, que las podrian demãdar, aquellos: en cuyo nome son fechas: maguer non les otorguen poder los personeros que las rescibieron por ellos. E esto seria, quando la promission rescibiesse el personero, e estouiesse delante, aquel: en cuyo nome se fizo, o maguer non estouiesse delante: si la promission es fecha sobre la cosa que fuesse suya, propria: de aquel cuyo personero es. Assi como: sobre loguero, de algunas de sus casas: o sobre renta de algunas sus heredades, o sobre otra cosa semejante destas, o si la rescebiesse el personero en juyzio, sobre el pleyto q razonasse, o demandasse o amparasse por el" (Las Siete Partidas III cit. (nota 75), p. 63verso). Temos aí uma exceção, expressa em lei, à aplicação da regra geral.

Note-se que tal sistema é complementado por outras duas disposições que se coadunam perfeitamente com as diretrizes romanas aplicáveis à "procuratio". Por um lado, se preceitua a aquisição de posse - e mesmo do domínio - por meio da atuação do "procurator" (Part. V, 12, 22): "ca pues su mayordomo, o su personero (...) 

como repositório de uma disciplina jurídica voltada à amizade (e seus efeitos): eventuais reflexos no âmbito do mandato. No último título da "Partida Quarta" se encontra articulada uma exposição - de base aristotélica - a respeito da amizade e de suas respectivas projeções no âmbito jurídico: após definir a "amistad” (Part. IV, 27 pr.), enaltecer seus benefícios (Part. IV, 27, 2) e enumerar as razões de seu declínio (Part. IV, 27, 7), o legislador a distingue de outras manifestações de apreço ou afinidade - tais como o "amor", o "bem-querer" e a "concórdia" (Part. IV, 27, 1). Tomando-se a confiança lastreada na convivência prolongada - como seu fundamento (Part. IV, 27, 3), é realizada uma diferenciação quanto às modalidades de amizade à luz de sua respectiva origem: desta forma, não corresponderiam a manifestações autênticas aquelas estribadas na "natureza" ou no "interesse" - resultando verdadeira "amistad" unicamente na hipótese de "bondade intrínseca" dos sujeitos envolvidos (Part. IV, 27, 4). Por sua vez, no que concerne à eficácia jurídica defluente do vínculo, três ordens de deveres parecem dimanar da "amicitia": lealdade, sigilo e atuação em prol do "alter"; todavia, deve-se observar que enquanto na Part. IV, 27, 5 se estabelece que o sujeito "deue bien obrar por su amigo (...)

los rescibe [a importância mutuada] por mandado del: tenudo es, como si el mismo [o principal] los rescibiesse" (Las Siete Partidas III cit. (nota 75), p. 79verso); e nisto não se inova com relação ao já disposto em G. 2, 95. Além disso, por meio da Part. III. 5, 20 se consagra, no âmbito do direito castelhano, a regra romana defluente da máxima "ratihabitio mandato comparatur": "Ley. xx. comovaldria lo que fiziesse vn ome por otro en juyzio, maguer non ouiesse recebido ende personeria (como valdria lo que fiziesse vn ome por otro en juyzio: maguer non ouiesse ende recebido personeria). Ninguna cosa non puede ser demandada en juyzio por otri, sin otorgamieto del señor della: assi como diximos enla ley ante desta. Pero si alguno demandare en juizyo por otro, assi como personero: e aquel a quien fiziessen la demãda, entrasse en pleyto cõ el, non lo diziedo que se fiziesse personero de aquel por quien demãdaua, si despues desso viniesse aquel, en cuyo nome fazia la demãda, e quisiesse auer por firme lo que era fecho cõel, valdria todo lo que fuesse fecho en juyzio: bie assi como si de comienço, lo ouiesse otorgado por su personero. Fueras ende, si este que demãdaua en boz de personero, fuesse sieruo: o alguno de aqllos a quien es defendido, que nõ pueda ser personero por otri”' (Las Siete Partidas II cit. (nota 75), p. 36verso). Ou seja, sobrevindo ratificação por parte do principal, a atuação do agente desprovido de poderes é inteiramente legitimada, retroagindo os efeitos do ato confirmatório à data da intervenção do "personero".

Desta forma, quanto aos efeitos representativos da atuação do "personero", duas alternativas restam ao estudioso, tomadas em consideração as fontes estampadas nas "Siete Partidas" - propositadamente excluídas duas outras (Part. V, 1, 7 e Part. V, 5, 8) que serão analisadas em parágrafo posterior do presente estudo. De um lado, pode-se admitir passivamente a contradição entre os excertos, sem que se esboce qualquer tentativa de conciliação, considerado o fato de que, à semelhança do que freqüentemente ocorre quanto fontes romanas clássicas coligidas no Digesto, as contradições seriam praticamente inevitáveis em uma obra de tamanhas proporções. Contudo, pode-se intentar uma harmonização entre os textos, partindo-se da premissa de que a orientação romana foi mantida em suas linhas gerais - não se admitindo, salvo na hipótese de aquisição de posse, a eficácia representativa direta da atuação do "procurator" -; a verdadeira reformulação promovida em relação às diretrizes oriundas do "Corpus Iuris Civilis" se limitaria aos efeitos passivos da gestão do "personero": neste caso, as obrigações seriam contraídas diretamente pelo interessado (o principal), resguardando-se o patrimônio do agente. De fato, tomamos partido por esta segunda posição; destacando o fato de que os outros dois fragmentos - a serem analisados mais adiante - com ela se coadunam por completo. 
assi como lo faria por si mismo", no fragmento imediatamente subseqüente se exige ainda mais do agente, na medida em que "muchas veces ha de fazer ome por su amigo cosas (...) que non las faria por si mismo" (Part. IV, 27, 6) ${ }^{81}$.

${ }^{81}$ A definção de amizade - defluente das "Siete Partidas" - deve ser buscada em meio ao proêmio do Título "Del debdo q han los omes entresi por razon de amistad" (Part. IV, 27 pr.) e o fragmento constante de Part. IV, 27, 1: "amistad es cosa que ayuta mucho la volutad a los omes, para amarse mucho. Ca segund dixeron los sabios antiguos, el verdadero amor passa todos los debdos. E pues q enel titulo ante deste fablamos del debdo: q es entre los vassallos, e los señores, por naturaleza, e por bie fecho, por seruicio, o por conoscencia. Queremos aqui dezir delos otros debdos, que han los omes entresi, solamete, por amistad (...) amicitia en latin tanto quier dezir en romance, como amistad e amistad segud dize Aristoteles: es vna virtud que es buena ensi, e prouechosa ala vida delos omes: e ha logar propiamente, quando aquel que ama, es amado del otro aquien ama. ca de otra guisa non seria verdadera amistad e porende dixo, que departimiento: muy grande ha entre amistad, e amor, e bien querencia, e concordia. E puede ome auer amor ala cosa, e non aura amistad a ella: assi como auiene alos enamorados, que aman alas vegadas alas mugeres, que les quiere mal. E porende dixieron los sabios, que amor vence todas las cosas, ca non tan solamente faze amar al ome alas quel amar, mas avn alas que le desaman. E otro si han amor los omes alas piedras preciosas, e alas otras cosas, que non han almas, nin entendimiento para amar a aquellos que las aman. $\mathrm{E}$ assi se prueua, que non es vna cosa amistad e amor: porque amor puede venir de vna parte tan solamente: mas la amistad conuiene en todas guisas que vega de amos ados. E bien querencia, es propiamente buena voluntad, que nasce enel coraçon del ome, luego que oye dezir alguna bondad de ome, o de otra cosa que non vee, o con quien el non ha otro afazimiento queriendol bien señaladamente, por aquella bondad que oyedel, nol o sabiendo aquel aquien quiere ben. E concordia es vna virtud que es semejante ala amistad. E desta se trabajaron los sabios, e los grandes señores, que fizieron los libros delas leyes, porque los omes biuiessen acordadamente. E cõcordia puede ser entre muchos omes.: maguer non ayan entresi amistad ninguna, nin amor: mas los que han de amistad en vno por fuerça, conuiene que ayan entresi concordia. E porende dixo Aristoteles: que si los omes ouiessen entresi verdadera amistad, non aurian menester justicia, nin alcaldes que los judgassen, por que aquella amistad les farie complir e guardar aquello mismo, que quiere e manda la justicia" (Las Siete Partidas II cit. (nota 75), pp. 71verso-72). Ora, além da influência aristotélica do fragmento, deve o intérprete atentar para o método escolástico empregado na distinção entre amor, amizade, bem-querer (ou simpatia) e concórdia. Conquanto unilateral o sentimento de amor, a amizade pressupõe a idéia de reciprocidade; mas não se trata daquela reciprocidade derivada da necessidade de paz (ou mesmo da noção de conveniência): trata-se de uma mútua afeição entre aqueles que convivem - e daí a distinção com relação à simpatia ou bemquerer - e da qual exsurgem deveres de consideração que podem redundar em um tratamento privilegiado ao amigo.

Como se depreende do fragmento constante de Part. IV, 27, 4, nem toda atuação em prol do "alter" está lastreada em um vínculo de amizade verdadeira: "Ley. iiij. Quantas maneras son de amistad. Aristoteles que fizo departimiento naturalmete en todas las cosas deste mundo, dixo q eran tres maneras de amistad. La primera es, de natura. La segunda es, la que ome ha a su amigo, por vso de luengo tiempo, por bondad que aya enel. La tercera es, la que ome ha con otro, por algund pro, o por algud plazer que ha del, o espera auer. E amistad de natura es la q ha el padre o la madre con sus fijos: e el marido a su muger: e esta non tan solamente la han los omes que hã razon ensi, mas avn todas las otras animalias, que han poder de engedrar: porque cada vno dellos ha naturalmete amistad con su compañero, e con los fijos que nasce dellos e amistad han otrosi segud natura, los que son naturales de vna tierra, de manera que quãdo se fallan en otro logar estraño, han amistad vnos con otros, e ayutanse en las cosas que les son menester: bien assi como si fuessen amigos de luengo tiempo. La seguda manera de amistad, es mas noble, que la primera: porque puede ser entre todos los omes, que ayan bondad ensi. e porende es mejor, que la otra: porq esta nasce de bondad tan solamente: e la otra de debdo de natura. e ha ensi todos los bienes de q fablamos en las leyes deste titulo. La tercera manera de amistad, de q de suso fablamos, non es verdadera amistad, porque aquel q ama al otro por su pro, e por plazer que espera del auer, luego q lo aya: o le desfallesca la pro oel plazer que espera auer del amigo, desatasse porende la amistad, que era entre ellos, porque no auia rayz de bondad. E a vn y ha otra manera de amistad segund la costumbre de españa, que pusierõ antiguamente los fijos dalgo entre si, que non se deuen deshonrrar, nin fazer mal vnos a otros, amenos de tornar se la amistad, e se desafiar primeramente. E de esto fablamos enel titulo del desafiamento, en las leyes que fablan en esta razon" (Las Siete Partidas II cit. (nota 75), pp. 72verso-73). Fundado novamente na doutrina aristotélica, o legislador distingue três espécies de amizade: a) a decorrente da natureza (ou da proximidade), evidenciada nas relações familiares e de vizinhança; b) a derivada da bondade intrínseca dos sujeitos envolvidos, estimulada à custa de sentimentos 
de afeição mútua; e c) aquela defluente do interesse, representado pelo proveito potencialmente oferecido pelo "alter". Ora, embora não nos caiba aqui indagar a respeito do enquadramento da "affectio societatis" em meio a um tal sistema, parece-nos - de antemão - difícil inseri-la em meio à segunda categoria. De todo modo, o "mandatum" haveria de ser compreendido, necessariamente, como uma manifestação desta espécie de amizade autêntica.

A respeito dos benefícios proporcionados pela amizade - tanto ao rico como ao pobre - assim dispõe a Part. IV, 27, 2: "Ley. ij. A que tiene pro la amistad. Prouecho grande e bie, viene alos omes dela amistad: de guisa que segund dixo Aristoteles: ningu ome q ayabodad en si, nõ qere biuir eneste mudo sin amigos: maguer fuesse abõdado de todos los bienes que enel son. E quanto los omes son mas honrrados, e mas poderosos, e mas ricos, tanto han menester mas los amigos. E esto por dos razones. La primera por que ellos non podrian auer prouecho delas riquezas, si non vsassen dellas, e tal vso deue ser en fazer bien: e el bien fecho deue ser dado alos amigos, e porende los que amigos non han, non pueden vsar bien delas riquezas que ouieren: maguer sean abõdados dellas. La segunda razon es, porque por los amigos se guardan, a se acrescientan las riquezas e las hõrras que los omes hã ca de otra guisa sin amigos non podrian durar, por que quanto mas honrrado, e mas poderoso es el ome, peor golpe rescibe, sil fallesce ayuda de los amigos. E avn dixo el mismo, que aun los otros omes q nõ sõ ricos, nin poderosos: hã menester en todas guisas ayuda de amigos q los acorrã en su pobreza e los esfuerçe en los peligros que les acaescieren. E sobre todo dixo, que en qualquier edad q sea el ome, ha menester ayuda. ca si fuer niño, ha menester amigos que lo crien, e lo guarden que non faga, nin aprenda cosa que le este mal. e si fuer mãcebo mejor entendera e fara todas las cosas que ouiere de fazer, cõ ayuda de sus amigos que solo. e si fuer viejo ayudar se a de sus amigos, en las cosas de que fuere meguado: o que non puede fazer por si, por los embargos que vienen ala vejez" (Las Siete Partidas II cit. (nota 75), pp. 72-72verso). Aqui merece destaque um dos fundamentos utilizados pelo legislador para justificar a necessidade que o rico tem da amizade dos demais: para além da contribuição que amigo pode oferecer ao incremento de sua própria riqueza, destaca o direito castelhano que o bom uso da coisa deve reverter em prol de outrem - além do próprio proprietário.

No que concerne às razões pelas quais declina a amizade, eis o disposto em Part. IV, 27, 7: "Ley. vij. Por quales razones se desata la amistad. Natural amistad, de q fezimos emiete en las leyes deste titulo, se desata por alguna de aqllas razones q diximos en la sesta partida deste libro: porque puede ome deseredar alos $\mathrm{q}$ desciede del. La otra, q han por naturaleza los q son de vna tierra, desatasse quãdo algunos dellos es manifestamete enemigo della, o del señor q la ha de gouernar, e de mãtener en justicia. Ca pues es enemigo dela tierra, non ha porq ser ninguno su amigo, por razon dela naturaleza q auia conel. La tercera manera de amistad, q ha ome con su amigo, por bõdad del, desfallesce, quãdo el amigo, que era bueno, se faze malo: de manera q nõ se puede castigar, oyerra tã grauemete cõtra su amigo, de guisa q non puede emedar el yerro q le fizo. Mas por efermedad nin por pobreza: nin por mal andança q acaezca al amigo, nõ se deue desatar el amistad q era entre ellos: ante se afirma, e se prueua, en aqlla sazon: mas q en otro tiepo la q es verdadera e buena. La otra manera, q semeja amistad e non lo es: assi como el q ama a otro por su pro: o por plazer q ha del, o espera auer: se desata, quãdo a el desfalesce del amigo, lo q qria assi como desuso diximos" (Las Siete Partidas II cit. (nota 75), p. 73verso). Observe-se que algumas razões de declínio (potencial) da amizade são categoricamente afastadas pelo legislador (tais como a pobreza, a doença, etc.); por óbvio, tais justificativas não ensejariam, portanto, uma resolução do vínculo jurídico decorrente de um tipo contratual nela fundado como é o caso do "mandatum" (contrato estribado na amizade).

Já no que diz respeito ao fundamento da amizade, o legislador castelhano destaca o papel da confiança decorrente da convivência por um considerável intervalo - suscetível de uma frustração reputada de enorme gravidade (Part. IV, 27, 3): "Ley. iij. Como se puede el ome aprouechar del consejo del amigo, e qual ome deue ser castigado para esto (Como se deue el ome aprouechar del consejo del amigo: e qual ome deue ser escogido para esto). Folgança e seguramiento muy grande han los omes quãdo se consejã cõ los amigos. E porende dixo vn sabio, q ouo nõbre Tulio, q ninguna cosa era tã dulce, como auer ome amigo aquie podiesse dezir su volontad assi como assi mismo. Et dixo en otro logar: de libra cõ tu amigo todas las cosas, q ouieres menester. Pero primeramete sabe qen el es: porque muchos son, que prescen amigos de fuera, e son falagueros de palabra: que han la voluntad contraria delo que muestran. E como quier que estos falaguen al ome: pero mas quieren ser amados que amar, e siempre son dañosos alos que los aman. E sobre esta razon dixo otro sabio, que ninguna pestilencia nõ puede empescer al ome eneste mundo tan fuertemente, como el falso amigo, con que ome biue, e departe sus poridades continuamente, non lo conosciendo, e fiando se del. E porende dixo Aristoteles, que ha menester, que ante que ome tome amistad cõ otro, q puñe primeramete de conoscerlo, si es bueno. E esta conoscencia non puede ome auer, si nõ por vso de luengo tiepo: por q los buenos son pocos, e los malos son muchos. E la amistad nõ puede durar, si nõ entre aquellos q han bõdad ensi. Onde los que amigos se fazen, ante que bien se conozcan, ligeramente se departe despues la amistad de entrellos" (Las Siete Partidas II cit. (nota 75), p. 72verso). Tendo-se em vista o fato de que o legislador considera o falso amigo como uma das maiores mazelas com que o homem pode se deparar, percebe-se a 
importância conferida à confiança - e à sua respectiva frustração - no quadro formado pelos contrato nela estribados.

Por fim, quanto aos efeitos jurídicos decorrentes da amizade - em si mesma considerada -, merece destaque a disposição instituída por meio da Part. IV, 27, 5, em virtude qual se declinam as três grandes "guardas" que os amigos devem manter em prol do vínculo estreito que os une: "Ley. v. Como deue ser guardada la amistad entre los amigos. Tres guardas deuen auer, e poner los amigos ensi: porque la amistad dure entre ellos, e non se pueda mudar. La primera es, que siempre deuen ser leales el vno al otro en sus coraçones: e sobre esto dixo Tulio, que el firmamiento e el cimiento dela amistad, es la buena fe, que ome ha a su amigo. e ningund amor nõ puede ser firme en que fe non ha. porque cosa loca seria, e sin razon, demandar lealtad el vn amigo al otro, si el non la ouiesse ensi. E sobre esto dixo Aristoteles, que firme deue ser la voluntad del amigo: e non se deue mouer a creer ninguna cosa mala que digan de su amigo, que ha prouado de luengo tiempo, por leal e por bueno. E porende vn philosofo, aquien dezian que vn su amigo dixera mal del, respondio, e dixo: que si verdad era que su amigo dixera mal, que tiene, que se mouiera a dezirlo por algund bien, e non por su mal. La segunda guarda q deuen los amigos fazer en las palabras, es guardar se de non dezir cosa de su amigo: de que pudiesse ser enfamado, dol puedeve nir mal porende, porque dixo Salomon enel Ecclesiastico, quien deshõrra a su amigo de palabra, desata la amistad que se auia conel. Otrosi, non deue retraer, nin profaçar el vno al otro los seruicios nin las ayudas que se fizieron. E porende dixo Tulio, que omes de mala voluntad son aquellos, que retraen como en manera de afrenta, los bienes, o los plazeres que fizieron a sus amigos. Ca esto non conuiene a ellos, mas a los q los recibieron. Otrosi se deuen guardar, que non descubran las poridades que se dixeren el vno al otro. E sobre esto dixo Salomon: que quien descubre la poridad de su amigo, desata la fe que auia conel. La tercera guarda es, que ome deue bien obrar por su amigo, assi como lo faria por si mismo. Assi como dixo Sant. Agustin: en la amistad non ha vn grado mas alto, que otro. ca siempre deue ser egual entre los amigos. E otrosi dixo Tulio que quando al amigo viene alguna buena andança, o grande honrra: que de los bienes que se siguen della, deue fazer parte a sus amigos" (Las Siete Partidas II cit. (nota 75), p. 73). Aqui temos uma consagração expressa de três grandes espécies de deveres oriundos da amizade (e que hão de promanar em meio a tipos contratuais como o "mandatum"): lealdade, sigilo e atuação em proveito do "alter" segundo os padrões adotados para a gestão dos próprios interesses.

No entanto, o fragmento imediatamente subsequiente (Part. IV, 27, 6), como assinalado no corpo do texto, proclama a exigência de um comportamento ainda mais zeloso por parte daquele que se diz amigo; recorrendo ao exemplo de Pílades e Orestes, o legislador castelhano estabelece por meio das "Siete Partidas" que o verdadeiro amigo atua em prol de seu consorte com um maior escrúpulo do que teria com relação às suas próprias coisas: "Ley. vj. Como deue el ome amar a su amigo. Verdaderamete e sin engaño ninguno deue el ome amar a su amigo: pero en la quantidad de amar fue departimieto entre los sabios: ca los vnos dixeron que ome deue amar a su amigo, tanto, quãto el otro ama a el. E sobre esto dixo Tulio, que esto non era amistad cõ bien querencia: mas era como manera de mercaderia e otros youo, que dixeron, que deue ome amar a su amigo, quanto el se ama. e estos otrosi non dixeron bien: porque puede ser que el amigo non se sabe amar, o non quiere, o non puede. e porende non seria complida amistad la que desta guisa ouiesse ome con su amigo. E otros sabios dixeron, q deue ome amar a su amigo: tanto como assi mismo. e como quier que estos dixeron bien: pero dixo Tulio: que mejor lo pudieran dezir. ca muchas vezes ha de fazer ome por su amigo cosas, que non las faria por si mismo. E porende dizo que ome ha de amar a su amigo, tanto quanto deuria amar assi mismo. E por que eneste tiempo se fallan pocos los que assi quieren amar: porende son pocos los amigos que ayan en si complida amistad. Pero como quier que el ome se deue atrauer en la amistad de su amigo, con todo esso non le deue rogar que yerre: o que faga cosa, que este mal, e maguer le fiziesse tal ruego afincadamente, non gelo deue el otro caber: por que si cayesse en pena, o en mala fama: porende nol cabria la escusacion: maguer diga que lo fizo por su amigo. Pero con todo esso bien deue ome poner su persona, e su auer, a peligro de muerte: o perdimiento por amparança de su amigo, e delo suyo quando menester le fuere. E con esto acuerda, lo que se falla en escrito en las hystorias ãtiguas de dos amigos, que ouo el vno nome Orestes, e el otro Pilades, e los tenia presos vn Rey por maleficios de ue eran acusados. e seyendo este Orestes judgado a muerte: el otro dado por quito, ouieron de embiar por Orestes para fazer justicia del: e llamaron lo que saliesse fuera del logar, dolo tenien preso: e respõdio Pilades, sabiendo que querian matar al otro, que el era Orestes: e respondio Orestes que non era verdad, quel mismo era. E quando el Rey oyo la lealtad destos dos amigos, de como se ofrecia cada vno a muerte, por estorcer al otro: quitolos, a amos a dos, e rogoles, que lo rescibiessen por tercero amigo entre ellos" (Las Siete Partidas II cit. (nota 75), pp. 73-73verso). Com base na lição dos clássicos - perceba-se o recurso ao argumento de autoridade típico do método escolástico de argumentação (e exposição das matérias) - o legislador observa que devemos amar nosso amigo mais do que amamos a nós mesmos; perceba-se, pois, a espécie de "uso moderno" que se faz no referido texto, ao se aludir ao fato de que, à época de edição das "Siete Partidas", já não era usual esta intensidade de afeição - "eneste tiempo se fallan pocos los que assi quieren amar" (73verso). De todo modo, a fim de livrar Orestes de seus algozes, Pílades assume a identidade de seu amigo, oferecendo em holocausto 


\section{$\S$ 102. A atividade legiferante de D. Afonso $X$ (cont.): a disciplina do}

mandato extrajudicial constante da "Partida Quinta". A partir de uma dicotomia fundada na finalidade (graciosa ou lucrativa) dos diversos tipos contratuais (Part. V pr.), a "Partida Quinta" constitui um arcabouço no qual o "mandatum" não goza de sua tradicional autonomia sistemática: assim, podem ser entrevistas alusões esparsas ao "mandado" (e ao "mandadero") em meio a disposições atinentes ao efeitos do pagamento (Part. V, 14, 6) e às formas de celebração da compra e venda (Part. V, 5, 8); no entanto, uma abordagem relativamente unificadora é promovida no Título XII ("Delas fiaduras que los omes fazen entre si, por que las promissiones, e los otros pleytos, e las posturas que fazen sean mejor guardadas"), à custa de uma aproximação entre o referido tipo contratual e a "fiadura" (Part. V, 12 pr.; Part. V, 12, 20). Para além da usual menção à "não-solenidade" do "mandatum" (Part. V, 12, 24) - e de sua descaracterização na hipótese de conselho (Part. $\mathrm{V}, 12,23)$-, aí pode ser vislumbrada uma disciplina verdadeiramente mais desenvolvida, provida de expressa previsão, por exemplo, a respeito da responsabilidade por despesas e prejuízos - experimentados pelas partes ou por terceiros (Part. V, 12, 20; Part. V, 12, 25). Aliás, preceitos especificamente relacionados à eficácia do ajuste perante terceiros podem ser surpreendidos em meio à regulamentação dos "mandados" para pagamento (Part. V, $14,6)$ e prestação de fiança (Part. V, 12, 13) $)^{82}$.

a sua própria vida. E segundo o legislador das "Siete Partidas", um amigo realiza em prol do outro feitos que não seria capaz de promover em seu próprio benefício. Perceba-se que no mandato - em sua variante sem representação - o agente expõe o seu próprio patrimônio em proveito da incumbência que lhe foi cometida pelo mandante; parecendo-nos bastante oportuna a lição legada pelo legislador castelhano neste passo das "Siete Partidas".

${ }^{82}$ As menções esparsas ao "mandatum" podem ser depreendidas tanto das alusões a uma idéia genérica de incumbência, como da própria utilização de uma terminologia comprometida com a respectiva temática; assim, não nos parece casual, por exemplo, a menção à utilização de "mandaderos" para a celebração de uma compra e venda (cf. Part. V, 5, 8).

De todo modo, o sistema contratual construído pelo legislador das "Siete Partidas" se estriba em uma dicotomia estabelecida entre as avenças graciosas e os ajustes com fito de lucro; isso muitos séculos antes de H. GROTIUS forjar o seu paradigma à luz da contraposição referida em nota anterior do presente estudo (nota 57). Nos termos em que fora articulado o proêmio das "Siete Partidas" (Part, V pr.): "Nascen entre los omes muchos enxecos, e grandes cõtiendas, en razon delos pleytos, e delas posturas, que ponen los vnos con otros. E como quier que enel comienço se fagan a plazer de amas las partes, todas las mas vegadas acaesce, que se mudan despues las voluntades, por que han auenir a contienda sobre ello. Onde, pues que enla quarta partida ante desta, fablamos delos casamientos, e del linaje que dellos sale, e de todos los otros debdos, que los omes han entre si, por debdo de parentesco, o de señorio, o de cuñadadgo, o de amistad: en esta quinta diremos, de todos los otros debdos que crescen entre ellos: por razon de postura. Assi como por emprestido: o por donadio: o por condesijo: o por donacion: o por compra: o por vendida: o por camio: o por loguero: o por compañia: o por fiadura: o por peño: o por postura: o por otro pleyto qualquiera com plazer de a mas las partes: e de todas las otras cosas, que a alguna destas razones pertenesce. E por que estos pleytos e posturas, aque llaman en latin contractos, son los vnos de gracia, e de amor, que se fazen los vnos alos otros, e los otros son por razon de su pro, de a mas las partes: porede nos queremos aqui fablar delos pleytos de gracia, por que son los fechos dellos, mas nobles, e mas honrrados, a los que los fazen. Assi como de emprestar, e dar sin 
recebir ende luego camio, o gualardon por ello, e despues fablaremos de cada vno delos otros ordenadamente, assi como conuiene" (Las Siete Partidas III cit. (nota 75), p. 2).

A respeito da aproximação promovida pelo legislador entre o "mandado" e a "fiadura", merecem referência os dois fragmentos nos quais aquela resta mais evidente. Assim, ao cabo do passo constante de Part. V, 12 pr. articula-se a seguinte proposta de análise: "e despues desto diremos de todas las otras cosas, que los omes fazen vnos por otros, por su mandado, o sin el, de que nasce obligacion entre ellos, quees otra manera de fiadura" (Las Siete Partidas III cit. (nota 75), p. 72verso); por sua vez, na Part. V, 12, 20 o legislador volta à carga: "Ley. xx. De la cosa que vno manda fazer a otri a pro de si mesmo. Faze algunos, omes por mãdo de otros alguas cosas, a las vegadas; por que finca cada vno dellos obligado, tambien aquel que lo faze, como aquel otro que lo manda, que es otra manera de obligacion, que es semejante dela fiadura" (Las Siete Partidas III cit. (nota 75), p. 79). Percebe-se, pois, porque o "mandado" não goza de autonomia sistemática no seio das "Siete Partidas"; tudo decorre da estreita aproximação estabelecida entre o "mandatum" e a fiança.

Quanto aos preceitos voltados à disciplina do referido tipo contratual, mostram-se presentes aquelas disposições tradicionalmente reconduzidas aos primeiros passos do livro décimo-sétimo do Digesto. Assim, na Part. V, 12, 24 se observa que o contrato de mandato corresponde a um tipo não-solene, aperfeiçoado à vista do mero consenso estabelecido entre os envolvidos: "Ley. xxiiij. En que manera deue ser fecho em mandado (En que manera deue ser fecho el mandado). Los mandamientos q los omes fazen vnos a otros, de que fablamos en las leyes ante desta, puede ser fechos en muchas maneras. Ca puedese fazer estando delante los que mandan fazer la cosa, e los que reciben el mãdado. E aun se puede fazer por cartas, o por mensajeros ciertos, maguer non esten delante los que mandan fazer la cosa, nin los que reciben el mandamiento. E puede se fazer a dia certo, o so condicion. E a dia certo se podria fazer como si mandasse vn ome aotro por palabra, o por carta, o por mensajero, que diesse a comer e vestir algun ome fasta algun dia señalado. E so condicion se faria como sil mandasse, si tal cosa acaesciere da s fulan tantos marauedis, o tal cosa. E estos mãdamietos sobre dichos de q fablamos fasta aqui, se pueden fazer por tales palabras, diziendo vn ome a otro ruego, o mando, o quiero, q des tãtos mareuedis, o q fagades tal cosa, o q me fiedes. Por qualquier de tales palabras como estas, o por otras semejantes dellas, porque se puede entender que el q faze el mandamiento lo faze con entencion de se obligar, vale el mandamiento, e finca por ello obligado el mãdador, a aquel, que recibe el mandado. E si por auentura, alguno despues que ouiesse fecho el mandamiento por tales palabras como estas, que de suso diximos quisiere dezir que lo non fiziera, con entencion de obligar se, nõ deue ser oydo. Fueras ende si pudiere prouar, por aquellos, ante quien fue fecho, q assies, como el dize, que non lo fizo, con entencion de obligarse, mas de otra manera, lo que seria graue de prouar" (Las Siete Partidas cit. (nota 75), p. 80); da mesma forma, descaracteriza-se expressamente o "conselho" como modalidade de mandato (Part. V, 12, 23): "Ley. xxiij. De la cosa q manda fazer vn ome a otro a pro de aquel que recibe el mãdado (De la cosa que manda fazer vn ome a otro a pro de aquel que recibe el mãdado). A pro tan solamente, de aql que rescibe el mandado, acaesce a las vegadas que manda a otro fazer alguna cosa. E esto seria, como si le dixesse, cõsejo vos, o mandovos, que de los marauedis, que tenes, que compres viñas, o heredades, o otra cosa alguna semjante destas que le mandasse comprar, o mejorar. Ca si esto fiziesse por consejo, o por mandado de otri, maguer le viniesse daño, de tal consejo, o mandamiento, non seria tenudo, de gelo pechar, el que mando fazer. E esto es, por que tal mandamiento como este, mas es consejo que mandamiento. E aquel a quien es fecho, deue catar si es a su pro, o non, ante q lo faga. Ca ninguno non es tenudo por premia de tomar consejo que otro le da, si non quisiere. Porende, non le empece aquel, que lo mando fazer. Fueras ende, si fuesse fallado en verdad, que tal mandamiento, o consejo, auia dado, maliciosamete, o con engaño. Ca entonce, quanto daño le viniesse, por razon del engaño, seria renudo de lo pechar" (Las Siete Partidas cit. (nota 75), p. 79verso).

Em se tratando de contrato celebrado no interesse do mandante, as despesas suportadas pelo mandatário hão de ser reembolsadas pelo primeiro; assim como este último deverá ser responsabilizado sempre que, por sua culpa, sobrevier prejuízo ao mandante ou a terceiros - hipótese esta em que exsurgirá uma solidariedade entre as partes contratantes perante o inocente prejudicado. Tais regras são estabelecidas pela Part. V, 12, 20 (a regular os efeitos internos do ajuste) e pela Part. V, 12, 25 (dispondo sobre a responsabilidade perante os terceiros). Eis o teos dos respectivos textos, para confronto direto pelo leitor: "Ley. xx. De la cosa que vno manda fazer a otri a pro de si mesmo. Faze algunos, omes por mãdo de otros alguas cosas, a las vegadas; por que finca cada vno dellos obligado, tambien aquel que lo faze, como aquel otro que lo manda, que es otra manera de obligacion, que es semejante dela fiadura. E esto puede ser en cinco maneras. La primera es, quando el mandamieto, es a pro tan solamente de aquel que manda fazer la cosa. E esto seria, como si vn ome mãdasse a otro, que le recabdasse todos las cosas, que ouiesse en algu lugar, o le mandasse comprar, o fazer alguna cosa señaladamente, o que entrasse fiador por el, o le mandasse fazer alguna otra cosa semejante destas. Ca si aql a quie mãda fazer la cosa, recibe el mãdamieto tenudo es de cumplir lo. E si alguna cosa pechare, o pagare, o despendiere, en cumplir el mãdamiento, tenudo es otrosi de gelo pechar, aquel por cuyo 


\section{$\S 103$. A atividade legiferante de D. Afonso X (cont.): dois fragmentos das}

\section{"Siete Partidas" relacionados à eficácia representativa do "mandatum”. Especificamente}

no que concerne aos efeitos representativos da atuação do mandatário, as disposições constantes das "Siete Partidas" são relativamente confusas: por um lado, na Part. V, 1, 7 parece ser reconhecida eficácia representativa direta na hipótese de um agente que atua "por mãdado del otro"; entretanto, a amplitude da atribuição e a irresponsabilidade do incumbido - defluente esta do trecho "no es tenudo de lo pagar [o empréstimo] este q lo toma" - parecem apontar para uma estrutura híbrida, também comprometida com o

mãdado lo fizo. Otrosi dezimos, que si aquel que recibe el mandamiento faze algun engaño en non cumplir lo, o por su culpa viene daño al otro, q es tenudo de pechar le todo el daño, q le viniere por razon del. ca tal mandamiento como este recibe los omes, vnos de otros por fazer les amor, e non por fazer les daño" (Las Siete Partidas III cit. (nota 75), p. 79); “Ley. xxv. Quales despesas puede cobrar aquel que las fizo por mando de otri. (Quales despesas puede cobrar aquel que las fizo por mãdado de otro, e quales nõ). Recebiedo vn ome de otro mãdado para fazer alguna cosa guisada, si acaesciere, q pechare algo porende, es tenudo el que gelo mando fazer, de gelo pagar. Mas si le mandasse fazer furto, o robo, o omicidio, o le mãdasse encender algunas casas, o miesses, o le mandasse fazer otro mal alguno a otro atuerto, maguer pagasse porede, alguna cosa, el que recibe el mandado, nõ seria tenudo de fazer ende emienda, aquel que gelo mãdo fazer, como quier, que tãbie el vno, como el otro, deue pechar al tercero ql daño, o el mal recebiesse, todo tãto quãto menoscabasse, o perdiesse, por razõ de tal mãdado" (Las Siete Partidas III cit. (nota 75), p. 80).

Finalmente, quanto aos efeitos do contrato de mandato sobre a esfera jurídica de terceiros, convém destacar, exemplificativamente, o disposto na Part. V, 12, 13; ainda que celebrado no interesse de terceiro, o contrato de mandato produz efeitos, via de regra, somente entre as partes, como se pode depreender do referido fragmento, alusivo à hipótese de mandato para fiança: "Ley. xiij. Como el q mandasse a vno q entrasse fiador por otro tercero, lo deue pechar el daño que le viniere por aquella fiadura (Como el que mandasse a vno que entrasse fiador por otro tercero, lo deue pechar el daño que le viniere por aquella fiadura). Por otro que nõ estuuiesse delante, entrando algun ome fiador nõ lo faziendo por su mandado, mas por mandamiento de otro tercero, dezimos que si tal fiador como este, pagasse alguna cosa, por aql aquien entrasse fiador, q nõ puede demãdar lo que pago, a aquel aquien fio: mas aquel por cuyo mãdado entro fiador. Pero si quando desta manera fiziesse la fiadura, estuuiesse delante aquel, aquien fiaua, e nõ lo contradixesse o entrasse fiador en nome del (...) entõce, en su escogencia es, de aquel que entro fiador, de demandar lo que pago, a aquel aquie fio, o al otro tercero, por cuyo mandado fizo la fiadura. E ellos son tenudos de lo pagar" (Las Siete Partidas III cit. (nota 75), p. 77). Desta forma, prestando garantia por mandato conferido por um sujeito, não pode o fiador demandar o afiançado, salvo se este estava presente no momento em que fora celebrado o negócio de garantia; trata-se de uma situação em que se projetam, excepcionalmente, efeitos contratuais passivos sobre terceiros - no caso o afiançado estranho ao contrato de mandato. Já na Part. V, 14, 6 a situação se cinge ao mandato de pagamento seguido de contra-ordem ao mandatário; visando-se, assim, evitar o efeito liberatório decorrente da dação de numerário a pessoa diversa do credor originário da obrigação. Ora, não chegando à esfera jurídica do devedor (mandatário) a retratação do mandante, plenamente eficaz é o pagamento realizado ao terceiro, seguido dos efeitos jurídicos usuais (dentre os quais a liberação do devedor); ou nos termos adotados pelas "Siete Partidas": "Ley. vj. Como deue ome fazer la paga a otro tercero, por mandado de aquel a quien deuia ser fecha, si despues el defendiesse q non le diesse nada (Como deue ome fazer la paga a otro tercero por mandado de aquel aquien deuia ser fecha si despues le defendiesse que non le diesse nada). Mandando algu ome a su debdor que aquello quel deuiesse que lo pagasse a otro alguno q le señalasse ciertamente, si despues desso le defendiesse que gelo non pagasse, e el debdor contra tal defendimiento lo pagasse, non seria porende quito del debdo. Mas si acaesciesse que se lo pagasse despues que gelo mandasse pagar, e el señor cuydando que lo non auia aun pagado, le defendiesse ue lo non pagasse, entonce quito seria del debdo el que assi fiziesse la paga. Esso mismo dezimos que seria si despues que le ouiesse mandado pagar el debdo, le embiasse dezir por carta, o por mandado cierto, que lo non pagasse. Ca si acaesciesse que non diessen la carta, nin el mandadero, non gelo dixesse, e pagasse el debdo, non sabiendo que lo auia defendido el que gelo mandara pagar, entonce seria quito del debdo, el debdor tambien como si lo ouiesse pagado a el mismo" (Las Siete Partidas cit. (nota 75), p. 99). 
instituto da "procuratio" - e mesmo com os efeitos característicos das "actiones adiecticiae qualitatis". Neste sentido, o fragmento constante de Part. V, 5, 48 (“de la cosa que ome compra de sus dineros mismos por nome de outro y las posturas que son puestas sobre ella si puede valer") denuncia quão promíscuo foi o tratamento dispensado pelo legislador à questão: ao mesmo tempo em que se atribui ao principal a responsabilidade pelas despesas suportadas pelo agente (disposição usualmente atrelada ao "mandatum"), se faz uma referência indiscriminada ao núncio ("mesajero"), ao procurador ("personero") e mesmo à "carta de personeria"; e no sentido de uma rejeição de ordinários efeitos representativos diretos, não apenas se reconhece o dever do incumbido de transferir a propriedade sobre as coisas adquiridas em prol do principal ("aquel q tal cõpra faze tenudo es de dar la cosa a aquel en cuyo nome la compro"), como também se destaca a vinculação do próprio gestor às obrigações decorrentes de sua atuação - observe-se que o principal "es obligado tabien como si por si mismo (...) ouiesse firmado" 83 .

${ }^{83}$ Do passo constante de Part. V, 1, 7 se extrai uma menção àquela espécie de "procurator" empregado pelos romanos para a administração de determinadas atividades, sobretudo comerciais, que em última análise haveriam de ser reconduzidas à titularidade do "paterfamilias": "Ley. vij. Del prestamo q es fecho a aquel que esta en tieda de cambio, o de paños por otri. Cambiador o mecador, que touiesse tienda de paños, o de algun otro menester, si encomendasse aquella tienda a otro, que nõ estouiesse en su poder, e dexandolo y como en su logar, si este atal tomare algund emprestido, por mãdado del otro, que le dexa, o sin su mandado, o lo mete en pro de aql q lo y dexa, tal prestido como este, no es tenudo de lo pagar este q lo toma, mas aql en cuyo logar estaua. Pero si nõ lo tomasse por su mandado. nin lo metiesse en su pro, estõce es tenudo de lo pagar aquel q lo tomo" (Las Siete Partidas cit. (nota 75), p. 4). Com efeito, é inegável que do texto exsurge uma aproximação entre as figuras romanas do "procurator" e do mandatário; entretanto, à exceção do termo "mãdado" (ou "mandado"), a referência efetuada pelo legislador castelhano muito mais se aproxima (sob a perspectiva do direito romano clássico) da primeira personagem, tendo-se em vista o caráter genérico da incumbência mencionada. Mais ainda: à vista da eficácia representativa direta - inclusive passiva decorrentre dos atos praticados pelo agente, faz-se necessária, também, a alusão à atuação dos filhos e escravos em prol do "pater"; os quais, no exercício de autênticas empresas marítimas e terrestres, motivaram a criação pretoriana das chamadas "actiones adiecticiae qualitatis" (cf. nota 29). Ora, a singularidade de tais contornos eficaciais afasta o intérprete de uma evocação automática do "mandatum"; uma vez que provido segundo o direito romano em que o legislador castelhano se inspirou - de efeitos diferenciados (e dissociados de uma eficácia representativa direta).

Ora, a tese de uma aproximação entre figuras outrora muito bem diferenciadas - o "mesajero", o "personero" e o "mandadero" - é corroborada pelo fragmento constante de Part. V, 5, 48: "Ley xlviij. De la cosa que ome compra por sus dineros mesmos por nombre de otro: e delas posturas q son fechas sobre ella, si puede valer (Ley xlviij. De la cosa que ome compra de sus dineros mismos por nome de otro y las posturas que son puestas sobre ella si puede valer). Comprando algund ome de sus dineros mismos, alguna cosa en nome de otro, si aquel en cuyo nome la cõpra, ha por firme, la cõpra, quãdo lo sabe, entõce aquel q tal cõpra faze tenudo es de dar la cosa a aquel en cuyo nome la compro, con los frutos e cõ todas las otras cosas q le pertenesce. Otrosi dezimos, q aquel en cuyo nome es fecha la cõpra, q es tenudo de dar el precio al cõprador, con todas las despensas, q fizo el otro en coger los frutos, e en las otras cosas que fueron fechas a pro de la cosa cõprada. E aun dezimos, q si algun ome embia su mensajero, diziendole assi, ve atal ome, e dile, q si me qere veder tal cosa suya, q le dare tal precio por ella: si aquel aquien lo ambia, otorga la vedida dela cosa, por aql precio, q embia dezir, vale la vendida, maguer non le ouiesse dado carta de personeria, al mesajero por que fiziesse la cõpra. E demas, este en cuyo nome es fecha la vendida e la cõpra, deue guardar los pleytos e las posturas, que puso sobre ella, aquel que la fizo en su nome, que pues que el otorgo la compra que la aya por firme. Esso mismo seria quando algun ome fiziesse su personero a otro, dandole poder que pudiesse vender o comprar alguna cosa, en su nome, señalandole por quanto precio, la vendiesse o la comprasse: si 
$\S 104$. Observações a respeito do regime jurídico da advocacia segundo o direito castelhano: peculiaridades relativas à atividade dos "vozeros". Além das disposições estritamente afetas à "personeria" e ao "mandatum", merecem destaque alguns preceitos relacionados ao regime castelhano do exercício da advocacia; ademais da definição de "vozero" (Dot. II, 2, 1), do enaltecimento de sua utilidade (FD. I, 2, 4) e de uma regulamentação pormenorizada a respeito do seu modo de proceder em juízo (Dot. II, 2, 2), das fontes castelhanas podem ser extraídas regras bastante peculiares, seja de fundo social, seja mesmo relacionadas aos efeitos decorrentes de uma típica relação de confiança. Assim, podem ser considerados exemplos da primeira categoria: a) a outorga de defensor dativo àquele que o suplicar (FD. I, 2, 1), bem como a transferência do "vozero" ao "ex adverso" em circunstâncias excepcionais (Esp. IV, 9, 6); b) o controle administrativo quanto ao exercício profissional (Part. III, 6, 13); c) a restrição à atuação de certos indivíduos, em virtude de suas peculiares características pessoais (FD. I, 2, 2); d) a instituição de um dever de veracidade, a ser observado pelos "vozeros" durante a condução das demandas (FD. I, 2, 3); e) o estabelecimento de critérios de estimação dos salários profissionais (Part. III, 6, 14), seu regime de pagamento (Esp. IV, 9, 8 e Esp. IV, 9, 9) e a vedação peremptória ao pacto de "quota litis" (FD. I, 2, 3); f) a enumeração de causas de impedimento (Esp. IV, 9, 5) - e de mecanismos de sua superação, na hipótese de manobras espúrias por parte de consulentes maliciosos (Esp. IV, 9, 7). Já no que toca à repercussão

este personero atal firmasse la vedida o la compra en nome del otro, deue la auer por firme el q lo embio e es obligado tabien como si el por si mismo, la ouiesse firmado" (Las Siete Partidas III cit. (nota 75), p. 27). Observe-se que a pura alusão ao fato de que a compra é realizada "por nombre de otro" não é suficiente a sustentar, por si só, a caracterização de efeitos representativos diretos; e isso pode ser facilmente demonstrado na medida em que se lance mão da idéia de "representação indireta". Ora, assim como no caso da representação indireta não se produzem efeitos imediatamente sobre a esfera jurídica do principal; da mesma forma, a expressão "em nome de outro" deve ser tomada com a devida cautela, uma vez que pode assinalar hipótese de atuação do agente "em prol" de outrem (e não necessariamente "em nome" do beneficiado).

Deste último excerto se depreende uma junção (ao que parece indevida) entre diversas personagens do direito privado - o "núncio", o "procurador" e o "mandatário". Ora, retomnando as considerações desenvolvidas ao cabo das notas de rodapé 76 e 80, parece-nos que o paradigma castelhano adotou uma eficácia representativa direta, sob a perspectiva ativa, restrita à aquisição de posse (e eventualmente de domínio), segundo as diretrizes decorrentes do próprio sistema jurídico romano. Entretanto, sob a perspectiva passiva, prevaleceu a intenção de preservar o patrimônio do agente, viabilizando-se a percussão direta da esfera jurídica do principal.

De todo modo, a progressiva promiscuidade entre os conceitos de "mesajero", "personero" e "mandadero" ensejou uma aproximação bastante arrojada - e talvez temerária - entre personagens diversas do cenário jurídico privado. Contudo - como já tivemos a oportunidade de destacar (nota 76) -, tomada como premissa a inadmissibilidade de efeitos representativos diretos (no cenário em que se desenvolvera a "procuratio" romana), a disciplina defluente das fontes castelhanas cristaliza um notável avanço, revelador daquela mesma tendência diagnosticável nas fontes canônicas dos séculos XIII e XIV; e compreendida, portanto, como uma simples "tendência", nada mais natural do que o surgimento de certos antagonismos latentes - os quais futuramente serão objeto de uma ação "simplificadora", por parte dos juristas modernos. 
da confiança - recíproca - sobre a esfera jurídica dos advogados e de seus clientes, podem ser ressaltadas: a) a atribuição ao "vozero" de deveres de prudência, transparência e lealdade na administração dos assuntos que lhe forem cometidos (FD. I, 2, 3 e Esp. IV, 9, $5)$; b) a instituição de um dever de sigilo do advogado quanto às peculiaridades da causa que the tenha sido simplesmente apresentada (Part. III, 6, 9 e Part. III, 6, 10); c) a vinculação do cliente em virtude do articulado pelo "vozero", desde que não haja ressalva imediata (Dot. II, 2, 3); d) a cessação do impedimento de assistência à contraparte, caso o consulente tenha demandado o auxílio de outro advogado (FR. I, 9, 3); e) a excepcional atribuição ao "vozero" de uma obrigação de resultado - quando se tenha comprometido por um específico desfecho de demanda judicial (Esp. IV, 9, 4) ${ }^{84}$.

${ }^{84}$ Uma definição de "vozero" pode ser encontrada no "Dotrinal" de "Maestro Jacobo de las Leyes" (Dot. II, $2,1)$ : "abogado es omne que rrazona plejto de otrie e suyo en juyzjo, y puede esto fazer todo omne que sea sabidor de derecho, o del fuero, o de la costunbre de la tierra" (Obras cit. (nota 74), p. 231). No mesmo sentido, cf. Esp. IV, 9, 1 e Part. III, 6, 1. Ora, tal definição evidencia que, ainda durante o direito castelhano, o exercício da advocacia não se confundia com a "procuratio" ("personeria"). Enquanto o procurador é o homem de confiança do principal, encarregado da gestão de seus negócios - ainda que desprovido de certos conhecimentos técnicos específicos - o advogado é o simples perito em direito, apto a (bem) articular em juízo. A fusão promovida entre as figuras do "procurador judicial" e do "advogado" - e que prevalece atualmente - faz com que não se conceba, ao menos tão naturalmente como seria desejável, a outorga dos poderes inerentes à cláusula "ad judicia" a alguém desprovido dos conhecimentos jurídicos mais elementares; observe-se que ao prescrever que "a queixa poderá ser dada por procurador com poderes especiais", o art. 44 do Código de Processo Penal, por exemplo, não se refere (necessariamente) a um advogado. Ao contrário, os arts. 36 e seguintes do Código de Processo Civil aludem a um procurador judicial advogado - aliás, "legalmente habilitado". Isso tudo nos revela a importância do estudo histórico do Direito, na medida em que essa fusão indiscriminada tumultua a compreensão dos conceitos jurídicos mais elementares - ao mesmo tempo em que forja uma relação de confiança completamente artificial entre um sujeito e seu advogado, constituído na calada da noite, por exemplo, para a apresentação de uma defesa processual sujeita a prazo peremptório.

Já no que concerne à utilidade do advogado, as "Flores de Derecho" (FD. I, 2, 4) destacam que a lei autorizara "que los auogados razonassen y demandassen por los duennos delos pleytos por que el iuyz podiesse mas ayna entender y saber ela uerdat" (Obras cit. (nota 74), p. 26). Em idêntico sentido, cf. Dot. II, 2, 1 ( $1^{\mathrm{a}}$ parte). No "Especulo" esta função de auxiliar da justiça é mais explícita, conforme se pode depreender do proêmio do Título "de los vozeros" (Esp. IV, 9 pr.): "el meester de los vozeros es muy provechoso para seer mejor librados los pleitos, e mas ciertamiente. Ca los buenos vozeros enderezan las razones, e dan carrera al judgador por que los libre mas ayna. E otrosi es pro para los dueños de las voces. Ca muchos y a que por mengua de saber razonar, o por miedo, o por verguenza, o por non seer usados de los pleitos, podrien perder su derecho, que los vozeros gelos enderezan porque vienen a acabamiento o a buen estado. E aun y a otra pro, que si los vozeros yerran, mas sin verguenza e sin daño de si pueden emendar el yerro a aquellos que los mandan razonar, que non farien si ellos mismos errasen" (Especulo cit. (nota 75), p. 106). Nas "Siete Partidas", aliás, os termos do "Especulo" são reproduzidos quase que literalmente (cf. Part. III, 6 pr.).

Sobre seu modo de proceder em juízo, o "Dotrinal" assim se refere ao "abogado" (Dot. II, 2, 2): “Cap. 2. Enque manera deuen los abogados rrazonar los pleytos en juyzjo, en demandando o rrespondendo. Separados son los ofiçios delos judgadores y delos abogados, ca los abogados deven esto rrazonar enpie, ante aquellos quelos han de judgar, y los jueces deuen oyr y ljbrar los plejtos seyendo, asi commo deize enel titulo que fabla dellos. E por ende dezjmos, que quando los judgadores mandan alas partes que digan y rrazonen todas aquellas cosas que quisiere dezjr en aquel plejto, que primera mente se deue levantar a dezjr y a rrazonar el damandador o su bozero, y en comjenço desu razon deue rrogar al judgador y alos ende, quel oyan fasta que acabe lo que ha de dezjr. Ca asi commo dizeron los sabios antiguos, que aquel que dize sus palabras ante otros pierden aquel tienpo en quelas dizen si non le oyen bien y no las entienden, y demas tornasele en 
verguença, ya despues desto deue començar [a recontar] el plejto commo paso y poner sus rrazones lo mas apuesta mente que pueda, y si por ventura fuesen [muchos] bozeros de vna parte, vno dellos deue rrazonar, y deue ser aperçebido que non diga njngunas palabras sobejanas, sinon aquellas que perteneçen al plejto. Y otrosy, deue fablar antel juez mansa mente, y en buena manera, y no a grandes bozes, nj tan baxo que nol puedan oyr. Y despues que oviere rrazonado todo su plejto, ase de leua[n]tar el abogado del demandado, y poner sus defensiones, rrazonando aquellas cosas que perteneçen asu plejto, en aquella manera que dixemos del bozero del demandador. Y sobre todo dezjmos, que non deue njnguno dellos atravesar nj destorvar al otro, mjentra que rrazonare. $\mathrm{Y}$ deuese guardar de no vsar ensus rrazones palabras malas nj villanas, fueras ende si algunas perteneçen al pleyto y que no puede escusar. Y el abogado que desta manera rrazonare, deue el judgador onrrar y caber sus rrazones, y alos que contra esto fizjesen, puedeles defender que no rrazonen antel" (Obras cit. (nota 74), pp. 232-233). Além de observações rituais, depreende-se do excerto a atribuição ao advogado dos deveres de urbanidade e respeito à ordem processual. No mesmo sentido, cf. FR. I, 9, 5, Esp. IV, 9, 4 (2 $2^{\text {a }}$ parte) e Part. III, 6, 7.

Com relação às disposições de ordem social mencionadas no corpo do texto, temos como primeira referência a prescrição constante das "Flores de Derecho" quanto à outorga de advogado "dativo" em caso de súplica (ao soberano) por parte do interessado (FD. I, 2, 1): “j. Quales deuen ser. Ley I. Se alguna delas partes que a pleyto ante uos demandar auogado que razone su pleyto, deuedes gelo dar. E mayor mientre apobres y aorfanos y alos omnes que non sopieren por si razonar" (Obras cit. (nota 75), pp. 22-23). No "Fuero Real" a disposição correspondente se mostra bem mais desenvolvida, destacando-se a função social do advogado, que não poderia simplesmente negar o seu ofício a quem o demandasse (sobretudo quando houvesse requisição administrativa), caso contrário poderia ser punido pela autoridade perante a qual exercesse habitualmente as suas atividades (FR. I, 9, 1): "todo ome que a otro demandare, el demandado haya tercer dia para haber conseio sobre la demanda e para buscar vocero; et si vocero non pudiere haber e lo pidiere al alcalle que ha de judgar el pleito, degelo daquellos que suelen tener las voces. Et otrosi dé vocero al demandador si haber nol pudiere, e él avengase con el vocero de cuanto galardon le fará por su ayuda (...) e si non quisiere tener la voz, el alacelle dél otro vocero, e este non tenga voz en todo aquel año en toda la villa si non suya propia: et si otra voz toviere, peche por cada una voz que toviere cincuenta maravedis, los medios al rey, e los medios al alcalle, porque despreció su mandado" (Fuero Real cit. (nota 75), pp. 22-23). É interessantíssimo, aliás, o fundamento evocado pelo legislador das "Siete Partidas" para justificar a atuação gratuita dos "bozeros" em prol daqueles que não pudessem arcar com seus salários ordinários (Part. III, 6, 6): "Ley. vj. como el judgador deue dar bozero a la parte que gelo demandare. Biuda, e huerfano, e otras personas cuytadas, hã de seguir alas vezes en juyzio sus pleytos. E porque aquellos cõ quien hã de contender son poderosos: acaesce q non pueden fallar abogado, que se atreua a razonar por ellos. Onde dezimos, que los judgadores deue dar abogado, a qualquier de las personas sobredichas, que gelo pidiere. E el abogado, a quien el juez lo mãdare, deue razonar por ella, por mesurado salario, E por si auentura fuesse tan cuytada persona, que nõ ouiesse de que lo pagar, deue le mãdar el juez que lo faga por amor de Dios: e el abogado es tenudo de lo fazer. E si la parte ouiere de que pagar al abogado, entõce dezimos que se deue auenir conella" (Las Siete Partidas II cit. (nota 75), p. 39verso). Note-se que no "Especulo" se mostra prevista - em caso de flagrante desequilíbrio entre as partes - a possibilidade de intervenção judicial, no sentido de transferir, compulsoriamente, o advogado de uma das partes ao adversário (Esp. IV, 9, 6): "Otrosi dezimos, que puede toller el vozero el que a pleito de judgar, quando de la una parte vienen muchos vozeros e sabidores del fuero, e de la otra pocos e non tan sabidores. Estonce el judgador puede tomar uno de aquellos que mas sopieren, e darlo al otra parte que oviese mengua de buen vozero" (Especulo cit. (nota 75), p. 107).

Para o exercício profissional regular, as "Siete Partidas" preconizavam a necessidade da autorização administrativa correspondente, nos moldes de uma autêntica "corporação de ofício" (Part. III, 6, 13): "Ley. xiij. Como ninguno non deue ser resceido por abogado, si primeramente nol otorgaren que lo puede ser (Como ninguno non deue ser recebido por abogado si primeramente no le otorgare que lo pueda ser). Estoruadores, e embargadores, delos pleytos, son los q se fazen abogados, non seyedo sabidores, de derecho, nin de fuero, o de costubres, q deuen ser guardadas en juyzio. E porede mandamos, q de aqui adelãte, ninguo, nõ sea osado, de trabajarse, de ser abogado, por otri, en ningu pleyto, amenos de ser primeramete escogido, de los judgadores, e delos sabidores, de derecho de nuestra corte. O delas tierras, de las ciudades, e de las villas en q ouiere de ser abogado. E aql q fallare q es sabidor, o ome para ello, deue le fazer jurar, q el ayudara bie, e lealmete, a todo ome, aquie prometiere su ayuda. E que non se trabajara, a sabiendas, de abogar, en ningun pleyto, que sea metiroso, o falso, o deque entieda que non podra auer buena cima. E aun los pleytos verdaderos, q tomare, que puñara, que se acaben ayna, sin ningu alõgamieto, que el fiziesse maliciosamente. E el q assi fuere escogido: mandamos q sea escrito, el su nome enel libro, do fuere escritos, los nomes, delos otros, abogados aquien fue otorgado, tal poder como este. E qualquier que por si quisiere, tomar poderio, de tener pleyto por otri contra este nuestro mandamiento: mandamos, q non sea oydo, nin le consientan los judgadores, que abogue ante ellos" (Las Siete Partidas II cit. (nota 75), pp. 41-41verso). 
Já no que concerne às limitações ao exercício profissional em decorrência de suas peculiares características pessoais, assim dispunham as "Flores de Derecho" (FD. I, 2, 2): “j. Quales deuen ser. Ley II. Maguer uos conuiene, sen[n]or, que seades sofrido y mesurado contra los auogados, enguisa los deuedes fazer que gardedes toda uia uestra ondra y uestra honestidat. E por esto, non deuedes consintir que rrazonen enuestra corte auogados que sean sordos, o mudos de todo en todo, nen locos, nen sieruo, nin ciegos, nen ereges, nen omne que non aya $x[v]$ ij. annos conplidos, nen ome que sea de mala fama, nen muler, nen monge, ne hermano se non e pleyto de sos monesterios, que ayan licencia de so abade o de so mayor, nem clerigo que aya ordenes de pistola odessende ariba, o que sea beneficiado, se non fuere en su pleyto o de sua eglesia ode pobres que non puedan auer quien razone por elos" (Obras cit. (nota 75), pp. 23-24). Já no "Dotrinal", após acrescentar ao rol dos impedidos a figura do pródigo, "Maestro Jacobo de las Leyes" justifica a proibição do exercício da advocacia pelas mulheres (admitindo-o em caráter excepcional na atuação em "causa própria") (Dot. II, 2, 1): "Cap. 1. Delos abogados y quien lo puede ser (...) otrosi dezjmos, que njnguna muger quando quier que sea sabidora, no puede ser abogada en juyzjo por otrie, y esto por doss rrazones. La primera es porque no es guisada nj onesta cosa quela muger tome ofiçio de varon, estando publjca mente enbuelta conlos omnes para rrazonar por otrie. La segunda porque antigua mente lo defendieron los sabios, por vna muger a que dizen calfurnja, que era sabidora, pero era tan desvergonçada y tan enojosa, de guisa quelos juezes con sus bozes non podian conella; onde ellos, catando la primera rrazon que dixiemos en esta ley, y otrosi, veyendo que quando las mugeres pierden la verguença, es fuerte cosa de oyrlas y de contender conellas, y tomando escarmjento del mal que sufrieron delas bozes de calfurnja, defendieron que njinguna muger no pudiese rrazonar por otrie" (Obras cit. (nota 75), p. 231). Em meio às disposições correspondentes do "Fuero Real" (FR. I, 9, 2 e FR. I, 9, 4) pode-se surpreender, inclusive, a restrição ao exercício da advocacia em virtude da confissão religiosa do "vocero". Por sua vez, no "Especulo" são estendidas as hipóteses de atuação excepcional por parte dos impedidos, a fim de que possam litigar não apenas em seu próprio interesse, como também naquele de seus parentes mais próximos (cf. Esp. IV, 9, 2 e Esp. IV, 9, 3). Pelo regime de restrições segundo as "Siete Partidas", cf. Part. III, 6, 2 (absolutamente impedidos), Part. III, 6, 3 (legitimados unicamente à atuação em "causa própria"), Part. III, 6, 4 (impedido por falta de honorabilidade profissional) e Part. III, 6, 5 (admitidos excepcionalmente para a atuação em prol do interesse próprio e de parentes próximos).

Quanto ao dever de veracidade do "vozero" (proibido de deduzir acusações falsas), assim estabelecem as "Flores de Derecho": "iij. Los que toman salario de amas las partes. Ley III. Otrossi, los auogados que pleytearen conlos duennos delos pleytos por cierta parte dela demanda, non deue[n] auogar en uestra corte, ca el derecho lo defende. E llaman aestos tales en latin rede[m]ptores causarum. Pero se auenir non se podieren elos due[n]nos delas uozes sobre so salario, pueden auere ela uicesima parte dela demanda, seguendo que manda la uestra ley. Otrossi, non deuedes cosentir que los uozeros tomen selario de ambas las partes [y] falsan los pleytos que razonan anteuos, que el derecho lo deffende. E son dichos estos atales en latin preuaricatores causarum. E esto mismo es assi como diz el derecho delos auogados que razonan pleytos falsos asabiendas y son dichos en latin concinatores causarum. E sennor, quando los auogados razonaren ante uos, fazeldos estar en pie y non les consentades que digan palabras torpes nen uilanas, se non aquellas tan sola mientre que pertenescen al pleyto" (Obras cit. (nota 75), pp. 24-26). Observe-se que aí temos não apenas uma restrição aos "concinatores causarum", como também aos "redemptores" (que ajustam com a parte o pacto de "quota litis") e "prevaricatores" (que assistem simultaneamente a ambos os adversários). Quanto à proibição do pacto de "quota litis" - excetuada a vigésima parte, prevista como "alternativa" à remuneração convencional, nos termos das "Flores de Derecho" -, tal preceito foi reiterado no "Fuero Real" (FR. I, 9, 1 e FR. I, 9, 5) e no "Especulo" (Esp. IV, 9, 8, 1ªrte); já nas "Siete Partidas", se comina ao infrator a pena de proibição (definitiva) do exercício profissional (Part. III, 6, 14): "Pero si algu abogado, fuesse tã atreuido, que fiziesse tal postura, como esta con la parte, aquien ayudasse, mãdamos, q despues q le fuere prouado, nõ pueda razonar, por otri en juyzio assi como persona enfamada, e demas que el pleyto q ouiere puesto, con la parte, que non le vala" (Las Siete Partidas II cit. (nota 75), p. 41verso). Reitere-se, aliás, que tal matéria já havia sido disciplinada pelo direito romano pós-clássico, em disposição adotada pelo direito visigótico (CTh. II, 10, 4 = Brev. II, 10, 1). Já quanto aos "prevaricatores causarum", as "Siete Partidas" cominavam-lhes pesada pena (Part. III, 6, 15, $1^{\mathrm{a}}$ parte): "Ley. xv. Que pena deue auer el abogado, q falsamente anduuiere en pleyto (Que pena deue auer el abogado que falsamente anduuiere enel pleyto). Preuaricator en latin, tanto quiere dezir en romance, como abogado que ayuda falsamente, a la parte por quien aboga: e señaladamente quãdo en poridad ayuda, e conseja a la parte cõtraria, e paladinamente faze muestra que ayuda a la suya de quie recebio salario, o se auino de razonar por el. Onde dezimos, q tal abogado como este, deue morir como aleuoso. E delos bienes del deue ser entregado el dueño, de aquel pleyto aquien fizo la falsedad, de todos los daños, e los menoscabos, que recebio andãdo en juyzio" (Las Siete Partidas cit. (nota 75), pp. 41verso-42). Em razão disso, tão logo incumbido da assistência a uma das partes, o "vozero" estava impedido de prestar qualquer espécie de orientação a seu adversário (cf. Esp. IV, 9, 
$5,2^{\mathrm{a}}$ parte), excetuada a hipótese de manobra praticada pelo "falso" consulente, desejoso tão somente de gerar impedimentos que dificultassem a defesa de seu opositor (Esp. IV, 9, 7): "Ley VII. Desechados deven seer con grant derecho aquellos que fueren vozeros o conseieros en algun pleito de la una parte, si despues quisieren seer vozeros o conseieros en aquel pleito mismo por el otra (...) mas dezimos, que si alguno fue llamado o rogado que fuese vozero, o que diese conseio en algun pleito, e non lo quisiese seer, o non lo quisiese dar, que bien puede seer vozero o conseiero de la otra parte, fueras ende si aquel que demandava, porque toviese su voz o quel diese consejo, le oviese descobierto o mostrado todo el fecho en su pleito. Pero si alguno feziere esto maliciosamiente por toller vozero a su contendor, mandamos que el judgador non sufra tal engano como este. Ca sinon podrie seer que el mas poderoso, o el mas rico, o el mas conoscido enbargarie a su contendor por este logar, diziendo su pleito a muchos vozeros porque el otro non pudiese aver ninguno dellos. E por ende dezimos, que el judgador deve dar tales vozeros como estos al quel non pudiere aver, maguer que les aya dicho su pleito el otra parte" (Especulo cit. (nota 75), pp. 107-108). No âmbito das "Siete Partidas" tal impedimento é igualmente previsto (Part. III, 6, 9, $2^{\mathrm{a}}$ parte), repreendendo-se de igual modo aquele que procurasse vários "vozeros" apenas para dificultar a defesa de seu adversário (Part. III, 6, 10, 2 parte). Aliás, consultado o advogado a respeito de certa demanda, permanecia vinculado em razão do impedimento referido; no entanto, se o cliente buscasse orientação de outro "vozero", tal restrição caducava, nos termos previsto no "Fuero Real" (FR. I, 9, 3): "si alguno fuere vocero o conseiero de otro en algun pleito, non pueda dalli adelante seer vocero de la otra parte, nin conseiero en aquel pleito, e si aquel de qui es el pleito demandar a otro conseio o ayuda para su pleito, e aquel a qui lo demandare nol diere conseio, o nol prometiere ayuda, pueda conseyar o razonar por la otra parte si quisiere" (Fuero Real cit. (nota 75), p. 23). Observe-se que tal disposição não foi reiterada nas fontes castelhanas posteriores.

Os critérios para a estimativa da remuneração do advogado constam de fragmento já referido das "Siete Partidas" (Part. III, 6, 14), no qual se alude não só às dimensões do pleito, como também à sabedoria e ao esforço do "vozero": "porende mandamos, que el abogado, tome salario de la parte segund el pleyto fuere grãde, o pequeño, e le conuiniere segun sabiduria, o el trabajo que y lleuare de manera que el mayor salario, que pueda ser, non suba de cient marauedis arriba, quanto quier que sea grãde la demãda, e dende ayuso, segun fuere el pleyto" (Las Siete Partidas II cit. (nota 75), p. 41verso). Já quanto ao seu regime de pagamento, a única disposição castelhana com que nos deparamos consta do "Especulo" (Esp. IV, 9, 8, 2 parte): "pero este galardon deve tomar desta manera, el tercio desque el pleito fuere comenzado, e el otro tercio despues que fueren entradas las vozes, en guisa que non ayan mas que razonar las partes, e esto ante que den el juyzio afinado. E el tercio postremero, despues que el juyzio fuere conplido. Mas por este galardon non tenemos por derecho que sea tenudo el vozero de seguir el alzada, dueras ende sil diere sus despensas el señor del pleito. E como quier que el vozero se deve tener por pagado deste galardon que desuso dixiemos en esta ley, si el pleito fuere en casa del rey, el galardon deve seer a bien vista del rey, segunt que el pleito fuere, o aquel que el rey diere por vozero" (Especulo cit. (nota 75), p. 108).

Por sua vez, no que concerne aos efeitos decorrentes da relação de confiança mantida entre as partes, há que se destacar primeiramente os deveres de prudência, transparência e lealdade do "vozero", estabelecidos em Esp. IV, 9, 5: "Ley V. Guardando el vozero tres cosas que diremos en esta ley, faze conplidamiente lo que deve. E sone stas, que sea mesurado e verdadero e leal. E mesurado deve seer en razonar apuestamiente, non escarneciendo, nin denostando, nin diziendo mal al judgador, nin a aquel contra quien razonare. E por si aventura alguna razon acaesciere en el pleito que sea denuesto e faga la voz, non lo diga el vozero, mas dé la escriptura al judgador, ó la dexe dezir al dueno de la voz. E el vozero que contra esto fiziere, non razone mas pleito por otri, e aya la pena que manda en la ochava, e en la novena ley del primer titulo deste libro quarto. Verdadero deve otrosi el bozero seer non razonando falsamiente las leys, nin diziendo otras razones mintirosas, nin aduziendo falsas proevas, nin siendo puntero, nin escatimoso, nin demandando plazos por razon de alongar aquel pleito a sabiendas. Otrosi dezimos, que deve seer leal el vozero en razonando, non dexando de razonar ninguna cosa de las que entendiere que son meester en el pleito. Ca si por su culpa alguna cosa perdiese el dueño de la voz, él gelo deve todo pechar" (Especulo cit. (nota 75), p. 107). Como teremos a ocasião de destacar mais adiante, tais elementos hão de constituir as bases sobre as quais deverá ser edificada toda a eficácia jurídica decorrente do contrato de mandato: "confiança" (caracterizada pelo dever de "transparência") e "gestão colaborativa" (evidenciada pela "prudência' do agente); ambas reunidas pelo espectro semântico da "lealdade" - e atreladas, funcionalmente, ao caráter "instrumental" de tal espécie de avença.

Além disso, deve o advogado guardar sigilo a respeito da demanda que the tenha sido apresentada pelo consulente, não se restringindo seus deveres, portanto, ao simples impedimento de atuar diretamente em prol do adversário. A este respeito, dois fragmentos das "Siete Partidas" são claros: em Part. III, 6, 9 (1 $1^{\mathrm{a}}$ parte) se estabelece que "guisada cosa es, e derecha, que los abogados, aquie dize los omes las poridades de sus pleytos, q las guarden, e q non las descubran, ala otra parte nin fagan engaño, en ningua manera, q ser pueda. Porque la otra parte, que enellos se fia, e cuyos abogados son pierdã su pleyto, o se les empeore. Ca pues que 


\section{$\S$ 105. Encerramento do capítulo e apresentação do tema sucessivo.}

Tivemos a oportunidade de analisar, neste capítulo, os contornos eficaciais da "personeria" e do "mandado" segundo o direito castelhano; ao mesmo tempo em que a representação negocial se desenvolve no contexto europeu (graças à preciosa contribuição do direito comum), especificamente no âmbito ibérico pudemos surpreender uma abordagem indiscriminada dos conceitos de "mesajero", "personero" e "mandadero": descortinandose, assim, um panorama bastante propício à aproximação - e quem sabe à fusão - entre institutos jurídicos substancialmente diversos. Deste modo, ainda que as fontes castelhanas nos tenham legado, por exemplo, uma frondosa disciplina a respeito da "amistad", alguma dúvida ainda parece despontar quando confrontados os fragmentos relacionados à eficácia (representativa) do "mandatum": mais do que a uma estrita obscuridade dos textos, parecenos que tal resultado deva ser atribuído a uma falta de rigor científico que permeava a

el recibio el pleyto, de la vna parte, en su fe, e en su verdad, nõ se deue meter, por cõsejero, nin por desengañador, dela otra" (Las Siete Partidas II cit. (nota 75), p. 40verso); por sua volta, em Part. III, 6, 10 (2 parte) o legislador castelhano preceitua que "vienen los omes a las vegadas, e muestrã alos abogados sus pleytos, e descubre les sus poridades: por que puedan mejor tomar consejo, e ayuda dellos. E acaece alas vezes, q despues que ellos, son sabidores del fecho que se tienen maliciosamente diziendo que los non ayudaran, si non por precio desguisado. En tal caso como este dezimos: q si la parte q descubriesse su pleyto al abogado, le quisiesse pagar su salario conuenible, o le fiziesse seguro dello a bien vista de omes buenos, q tenudoes el bozero, de le ayudar e consejar bien, e lealmete" (Las Siete Partidas II cit. (nota 75), p. 40verso). Além disso, a manifestação do advogado perante o juízo vincula seu cliente, salvo se imediatamente rechaçada pelo interessado. Neste sentido, já dispunha o "Maestro Jacobo de las Leyes" em seu "Dotrinal" (Dot. II, 2, 3): "Cap. 3. Quando el abogado dixere alguna palabra por yerro en juyzio, que tenga danno asu parte commo la puede rreuocar. Las palabras y las rrazones quelos abogados dizeren, sobre los plejtos que ovieren de rrazonar en juyzjo, estando delante de aquello cuyos bozeros son, mucho las deuen catar, y asmar afinada mente ante quelas digan, que sean apro dela parte por quien abogan. Y si tales fueren, deuenlas dezjr, y si non son tales quelas tuellan, ca toda cosa quel abogado dixere en juyzjo, estando delante aquel a quien perteneçe el plejto, sila no contradixese entendiendola, tanto valdria, y asi deue ser cabida, commo sila dixese por su boca mjsma el sennor del plejto; pero siel abogado o el sennor del plejto, dixeren en juyzjo alguna cosa por yerro, que sea adanno de aquel por quien rrazona, bien la puede emendar en qualquier logar que este, ante que sea dada la sentençia definjtiva, prouando primera mente el yerro. Mas despues que tal sentençia fuese dada, no podria emendar el yerro njn deue ser oydo, fueras ende si el plejto fuese de huerfano menor de veynte y çinco annos, ca ental plejto commo este tanbien deue seer oydo despues del juyzjo acabado, commo antes, si quisiese provar el yerro" (Obras cit. (nota 75), p. 234); e em termos quase idênticos, cf. Part. III, 6, 8.

Finalmente, o advogado não assumia, via de regra, qualquer espécie de obrigação pelo resultado quanto ao desfecho do litígio; no entanto, se fosse por ele prometida a vitória ao seu cliente, haveria de ser responsabilizado pelo prejuízo, mesmo que não tivesse incorrido em culpa, em uma espécie de responsabilização objetiva. Eis os termos adotados no "Especulo" (Esp. IV, 9, 4, $1^{\text {a }}$ parte): "Ley IV. Mientes metudos deven seer los vozeros, de que dixiemos en estas otras leyes, de fazer e de guardar muchas cosas que mostraremos en esta ley. Onde dezimos que la primera cosa que deve fazer el vozero es de escoger e parar mientes que el pleito que toma que sea derecho. Ca si tal non fuere, e lo recebiese faziendo fiuza que el dueño de la voz que lo él vencerá, devel pechar quanto dañol viniere, e las depensas que feziere por razon de aquel pleito" (Especulo cit. (nota 75), p. 107); no mesmo sentido, as "Siete Partidas" sugerem cautela ao "vozero" (Part. III, 6, 15, parte final), prescrevendo que "e au dezimos, q el abogado, se deue mucho guardar, de nõ prometer ala parte, q vencera el pleyto q recibe en su encomienda. Ca si despues nol venciesse assi como auia prometido seria tenudo de pechar al dueño, del pleyto todo quanto daño, o menoscabo le veniesse porende, e demas las despensas que ouiesse fecho andando en juyzio sobre aquel pleyto" (Las Siete Partidas II cit. (nota 75), p. 42). 
legislação de então; de todo modo, pudemos destacar as linhas gerais que conformaram a regulamentação deste tipo contratual em meados do século XIII. Resta-nos investigar, agora, a disciplina propriamente portuguesa a respeito do tema; prossigamos, portanto, em nossa pretensiosa incursão historiográfica ${ }^{85}$.

\footnotetext{
${ }^{85}$ Ou seja, à moda justinianéia, o "mandatum" é compreendido como fonte por excelência da "procuratio"; todavia, admitindo-se a eficácia representativa direta em caráter generalizado, não mais existe um maior obstáculo à aproximação entre os dois conceitos ("mandato" e "representação direta"), esvaziando-se progressivamente o conceito de procuração - em detrimento do robustecimento da acepção instrumental do termo (procuração compreendida como "carta de personeria"). Todavia, tal estado de coisas não implicara, necessariamente, uma "essencialização" da "representação direta" no contexto do tipo contratual referido; tendo sido mantida íntegra, portanto, a "causa-função" do instituto.
} 


\section{CAPÍTULO VII.}

\section{LINEAMENTOS SOBRE A EFICÁCIA DA "PROCURAÇÃO" SEGUNDO AS FONTES DO DIREITO LUSITANO.}

\section{$\S$ 106. Apresentação das fontes do direito lusitano e observações de caráter}

preliminar. No âmbito estritamente português, voltaremos nossa atenção a cinco diplomas fundamentais para a historiografia jurídica luso-brasileira: de um lado, dedicaremo-nos ao "Livro das Leis e Posturas" e às "Ordenações de D. Duarte", duas compilações de legislação editada entre os séculos XIII e XIV, em grande parte coincidentes quanto ao seu respectivo conteúdo (ao mesmo tempo em que caracterizadas pela iterada repetição de preceitos normativos de teor semelhante); de outra banda, desenvolveremos uma análise conjunta das subseqüentes "Ordenações do Reino", as quais foram responsáveis pelas primeiras tentativas de sistematização - ainda que de certo modo rudimentar - do direito vigente em Portugal. Além disso, será necessário examinar o teor da legislação extravagante promulgada no período compreendido entre a publicação das sucessivas “Ordenações” (Afonsinas, 1446; Manuelinas, 1521; Filipinas, 1603); para tanto, lançaremos mão de alguns dos repertórios mais autorizados - dentre os quais se destacam, por exemplo, a "Synopsis Chronologica" de José Anastácio de Figueiredo e a coletânea de “Leis Extravagantes" organizada pelo licenciado Duarte Nunes do Lião ${ }^{86}$.

\footnotetext{
${ }^{86}$ Por um enfoque panorâmico das fontes do direito lusitano, cf. M. J. de ALMEIDA CosTA, História cit. (nota 09), pp. 273-293; Ordenações cit. (nota 16), pp. 259-270; Leis, Cânones, Direito, in Dicionário de História de Portugal II, Lisboa, Iniciativas Editoriais, 1963, pp. 677-695; T. de NORONHA, Ordenações do Reino Edições do Século XVI (additamento ao cancioneiro geral de Garcia de Rezende), Porto, Livraria Internacional, 1871; G. BRAGA DA CRUZ, O direito subsidiário cit. (nota 16), pp. 296-349; M. CAETANO, História cit. (nota 16), pp. 529-551 e 595-636; CÂNDIDO MENDES DE ALMEIDA, Código cit. (nota 16), pp. XIX-XXVIII; L. C. de AZEVEDO, O Reinado de D. Manuel cit. (nota 16), pp. 19-32; J. C. MoreIRA ALVES, Panorama cit. (nota 16), pp. 187-188; I. M. PovedA VelasCO, Ordenações cit. (nota 16), pp. 11-67; N. E. GOMES DA SiLVA, História cit. (nota 16), pp. 270-366; O sistema de fontes cit. (nota 16), pp. 429-455; Algumas Notas sobre a Edição das Ordenações Manuelinas de 1512-1513, in Scientia Jurídica 148-149 (1977), pp. 575-591; Algumas notas sobre a edição das Ordenações Manuelinas de 1521, in Scientia Juridica 30 (1981), pp. 456-467; M. PAULO MERÊA, Resumo cit. (nota 16), pp. 132-141; M. A. COELHO DA ROCHA, Ensaio cit. (nota 16), pp. 117-126, 127-133 e 188-197; J. G. B. CÂMARA, Código Filipino cit. (nota 64), pp. 235-242; V. LoBo DA CostA, Contribuição cit. (nota 64), pp. 360-361; L. de M. LeME, $O$ direito cit. (nota 64), pp. 79-82; M. R. MARQUES, História cit. (nota 64), p. 71 (mais uma vez em trecho de proveito relativamente duvidoso); W. V. do NASCimento, Lições de História do Direito, $12^{\mathrm{a}}$ ed., Rio de Janeiro, Forense, 2000, pp. 193-195; H. VALLADÃo, História do Direito, especialmente do direito brasileiro - Parte I, Rio de Janeiro, Livraria Freitas Bastos, 1972, pp. 65-71; A. SANTOS Justo, O Direito Brasileiro cit. (nota 16), p. 4.

Deve-se observar, desde logo, que as duas coletâneas de legislação lusitana medieval ("Livro das Leis e Posturas" e "Ordenações de D. Duarte") apresentam uma série de disposições comuns, a par de outras coligidas tão somente em um dos diplomas. Desta forma, um considerável número de preceitos analisados a seguir mostram-se reproduzidos nas duas coleções; em tais casos, tomaremos como ponto de partida a versão constante do "Livro das Leis e Posturas" - providenciando-se, em caso de discrepância, um cotejo com a transcrição contida nas "Ordenações de D. Duarte".
} 


\section{$\S$ 107. Pressuposto metodológico de análise: a "junção" entre a}

"procuração" e a "advocacia" em meio às fontes do direito lusitano. Diferentemente do que se verificou quanto aos direitos visigótico e castelhano, as fontes lusitanas denunciam mais do que uma simples aproximação funcional entre a "procuratio" e o "mandatum": assim, equiparações expressas entre "vogados" e "precuradores" podem ser surpreendidas em meio a diversas passagens do "Livro das Leis e Posturas" (tal como se dá, por exemplo, na Lei de 23 de agosto de 1303, na Carta Régia de 08 de julho de 1314 e na Postura de 04 de agosto de 1322); por sua vez, nas "Ordenações de D. Duarte", ao mesmo tempo em que se reprova a "maliçia dalguum uogado ou procurador", se determina ao escrivão judicial que "nom uogue nem seia procurador". Já no âmbito das "Ordenações do Reino de Portugal", por reiteradas vezes se vislumbra um tratamento promíscuo entre a "procuração" e a "advocacia": assim na versão Afonsina (Ord. Af. I, 13, 1; Ord. Af. I, 13,

Ao contrário das "Ordenações do Reino de Portugal" (Afonsinas, Manuelinas e Filipinas), as "Ordenações de D. Duarte" não se mostram estruturadas à vista das matérias ali tratadas; em lugar disso, predomina uma reunião de preceitos segundo o monarca responsável por cada disposição - sobretudo D. Afonso III, D. Dinis e D. Afonso IV. Com efeito, sendo bastante mais reduzida a produção legislativa de D. Duarte ali coligida, seu nome se deve sobretudo à "Tavoa ou indice das materias (...) redigido por aquelle monarcha" (A. Herculano, Portugaliae Monumenta Historica - Leges e Consuetudines I, s. 1., Olisiponi, 1868, pp. 151). De sua parte, o "Livro das Leis e Posturas" sequer conta com tal espécie de conformação; corresponde, pois, a uma reunião inteiramente desordenada de textos legais produzidos durante a segunda metade da dinastia afonsina. Coube à pesquisadora Maria Teresa Campos Rodrigues - já no ano de 1971 - o mérito da elaboração de um índice desta compilação. De todo modo, à vista da falta de melhores subsídios, advertimos que a citação de tais fontes será feita da seguinte forma: quanto ao "Livro das Leis e Posturas", utilizaremonos do índice de Maria Teresa Campos Rodrigues (e daí os títulos das leis oferecidos em linguagem moderna); por sua volta, acerca das "Ordenações de D. Duarte", não obstante o mérito do monarca quanto à confecção da aludida tábua, à vista de discrepâncias entre o seu conteúdo e as referências internas constantes da própria compilação, lançaremos mão dos títulos apresentados no corpo do texto.

Quanto às coletâneas de legislação extravagante, utilizaremo-nos: a) para o período compreendido entre as "Ordenações Afonsinas" e as "Ordenações Manuelinas" (1446-1521), da obra de J. ANASTÁCIO DE FigUEIREDO, Synopsis Chronologica de Subsidios ainda os mais raros para a história e o estudo critico da legislação portugueza, Lisboa, Academia das Sciencias, 1790; b) para o período compreendido entre as "Ordenações Manuelinas" e as "Ordenações Filipinas" (1521-1603), da obra de DuARTE NuNES DO Lião, Leis Extravagantes collegidas e relatadas pelo licenciado Dvarte Nvnez do Liam per mandado do muito alto \& muito poderoso Rei Dom Sebastiam nosso Senhor, Lisboa, Antonio Gonçaluez, 1569; c) e para o período posterior às "Ordenações Filipinas" (a partir de 1603), sobretudo dos trabalhos de JOÃO PEDRO RIBEIRO (Indice Chronologico Remissivo da Legislação Portugueza Posterior à Publicação do Codigo Filippino com hum Appendice, Lisboa, Typografia da Academia Real das Sciencias, 1805-1820) e M. BORGES CARNEIRO (Resumo Chronologico das Leis mais Uteis no Foro e Uso da Vida Civil, publicadas até o tempo presente, Lisboa, Impressão Régia, 1820). Além disso, utilizaremo-nos do Repertorio das Ordenações, e Leis do Reino de Portugal (Coimbra, Imprensa da Universidade, 1795) e das remissões de C. MENDES DE AlMEIDA em seu Código Philippino cit. (nota 16).

Finalmente, quanto ao método de análise das fontes referidas neste capítulo, faz-se necessário observar que à semelhança do que foi feito com relação aos textos castelhanos - será mencionada com maior vagar a primeira disposição lusitana concernente a algum dos aspectos da eficácia do "mandato" ou da "procuração". Em seguida, far-se-á uma simples remissão aos textos legislativos posteriores (nos quais a mesma matéria tenha sido objeto de nova regulamentação, sem alteração de fundo). Caso tenha havido modificação quanto à orientação adotada, buscaremos promover o necessário confronto entre o direito anterior e a legislação superveniente. 

meio à legislação extravagante - pré-filipina - pode ser entrevista uma indiscriminada alusão ao "procurar ou auogar" (S. IV, 17, 13). Desta forma, embora até o momento tenhamos pretendido apartar analiticamente o "mandato" da "procuração", não podemos deixar de mencionar a "junção" entre tais institutos operada pelo legislador português, fato que se evidencia com progressivo vigor, à medida em que nos distanciamos das fontes mais longínquas do direito lusíada ${ }^{87}$.

${ }^{87}$ Quanto ao "Livro das Leis e Posturas", eis o teor da Lei de 23 de agosto de 1303 ("Lei pela qual se determina que nenhum procurador ou advogado receba honorários antes que o pleito esteja terminado por sentença ou transaç̧ão"): "Ley em como o precurador nem vogado nom leue o solayro que lhi ham de dar dalguu preyto que tenha nada ata que o preyto sseia acabado por sentença ou per aueença das partes. Dom Denis pela graça de deus Rey de Portugal e do algarue. A uos Pero stevez meu meyrinho ssaude Sabede que eu Julguey com mha corte que nenhuu vogado nem precurador non tome nenhua Rem en pano nem en pam nem en carne nem en vinho nem em outra nianda nenhua de qualquer ualia que sseia nem outra cousa nenhua aaqueles a que teuerem os preytos ou esperarem logo a teer ata que o preyto sseia determjnhado per sentença defenetjua ou per aueença das partes. Porque entendo que fazem muytas delongas e muytas bullas nos preytos porque sse fazem hi muytas delongas. E quem esto filhar mando que dali adeante nom tenha preyto en mha terra e fique polo ssolayro E esto que sse guarde en todos os meus Reynos saluo se o vogado ou precurador teuer herdade e prestamo en ssa vida daquel que lha der. Outrossy mando que nenhuu vogado nem precurador nom filhe nem faça põer os dinheiros en ujgariça aaquel que aiuda. mays filhe del fiador ou obrigaçom pera auer seu ssolayro E qualquer sobreJujz de qualquer logar que o souber que esta mha ley passa deue o dizer a mjm sso pena da mha merçee. Porque uos mando que façades esta carta leer en todo o uosso meyrinhado que se compra e aguarde vnde al nom façades. Dada en lixbõa. xxiij. dias dagosto ElRey o mandou com ssa corte Lourenço perez a fez Era. M.iij/ e xi ano" (Livro das Leis e Posturas, Lisboa, Faculdade de Direito da Universidade de Lisboa, 1971, pp. 83-84). Como se vê, nesta disposição se deflagra uma equiparação entre advogados e procuradores, a propósito da regulamentação sobre o modo de pagamento das respectivas remunerações. Com ligeiras divergências redacionais (além das trocas de "Pero stevez" por "pero fernandez" e "Lourenço perez" por "afonsso perez"), esta lei encontra-se reproduzida nas "Ordenações de D. Duarte", sob o título "como Ell rrej manda que uogados E procuradores nom leuem solairos" (Ordenações Del-Rei Dom Duarte, Lisboa, Fundação Calouste Gulbenkian, 1988, p. 191).

Por sua vez, na Carta Régia de 08 de julho de 1314 há uma nova aproximação entre "vogados" e "precuradores", a pretexto do regime de pagamento de suas remunerações ("Lei pela qual se estabelecem as penas a aplicar a procuradores e advogados que recebam das partes quaisquer ofertas ou os seus honorários antes da sentença definitiva, bem como às partes que se tenham servido deste meio para os corromper e impedir o andamento legal do pleito"): "Carta contra os vogados e contra os precuradores da corte e dos Reynos. Dom Denis pela graça de deus Rey de Portugal e do algarue A quantos esta carta uirem faço ssaber que eu ueendo e conssijrando como na mha corte e nos meus Reynos sse faziam mujtas perlongas e muytas maliçias nos preytos per Razom que os vogados e os precuradores leuauam das partes mujtas dõas e grandes seruiços en pam e en vjnho e en carne e en outras cousas muytas que nom leyxauam porem a leuar seus ssolayros conpridamente $\mathrm{E}$ eu ueendo e conssijrando que per razom dos seruiços que assy Reçebiam que era mujto mais que nos ssolayros montaua. faziam as dictas perlongas per Razom de sseerem assy seruidos E querendo eu esquiuar estas perlongas todas e estas maliçias que eles todos faziam por as dictas razões $\mathrm{E}$ catando como poderia fazer que taaes cousas como estas nom husassem e que os preytos fossem metudos en caReyra de sseerem chegados e desenbargados aginha com deus e com dereyto e que as gentes nom sse andassem dessecando do que auiam $\mathrm{E}$ eu auendo consselho com mha corte tenho por bem e por ley ponho para ssenpre que daqui adeante vogado nem precurador nom filhe sseruiço nemhuu daqueles que teuerem preytos doutrem por essa Razom de pam nem vinho nsm de carne nem doutra cousa nenhua / nem solayro 
nem parte del ata que o preyto seia acabado per sentença defenetjua ou per aueença das partes E os vogados ou os precuradores que contra esto ueerem e aqueles que lho derem fiquem por falssos e aiam pena de falssos en esta maneyra que lhis cortem os pees e as maaos e que lhis tirem senhos olhos tambem os que lhos derem como aqueles que lhos tomarem. E mando aos Jujzes da mha casa so pena da mha merçee que sse taaes cousas souberem que mho digam e outrosy mando aas iustiças dos logares que sse ssouberem en uerdade que taaes cousas fazem que prendam aqueles que as fezerem e façam en eles iustiça assy como dicto he. e ssenom ouuer hi acusadores e o eles souberem digam no logo e ssabham ende a uerdade e sse acharem que ssom hi culpados em hindo contra a mha ley façam en eles a dicta mha iustiça tambem no que o da tambem como naquel que o Reçebe. Esto mando que sse faça so pena dos corpos Esto sse entende tambem na mha corte come nos meus Reynos. Dante en lixbõa viij dias de iulho ElRey o mandou com Consselho de ssa corte Lourenço anes a fez Era de mil. e iij. e Lij. anos" (Livro das Leis cit. (nota 87), pp. 184-185). Assim como a disposição anterior, também a Carta Régia de 08 de julho de 1314 está reproduzida, com algumas alterações redacionais, nas "Ordenações de D. Duarte" (sob o título "ley que uogados nem procuradores nom tomem serujcos daquelles a que os feitos teuerem"); sendo-lhe atribuída, contudo, a data de $1^{\circ}$ de julho de 1514 (Ordenações Del-Rei cit. (nota 87), pp. 296-297).

Novamente a propósito do sistema de pagamento das importâncias devidas aos "precuradores" e aos "vogados", a Postura de 04 de agosto de 1322 equipara as duas personagens, a fim de autorizar a antecipação de metade do valor devido ao agente, inclusive sob a forma de víveres ("Lei pela qual se estabelece que os advogados e procuradores possam receber metade dos seus honorários antes de findas as causas"): "Postura dos vogados e dos precuradores. como deuiam leuar os selayros. Era de mil e trezentos . e Lx. anos iiij. dias dagosto en lixbõa pos ElRey postura que os vogados e os precuradores leuem logo a meadade dos ssolayros. e a outra meadade depois que os fectos forem acabados E que tomem seruiços de capom e de galinha e de pichel de vjnho e ata meyo de carneyro e nom mais. E esto sse entende nos fectos que duram e nos que ham de uijr. Jtem pos que todo homem que apelar da sentença que contra el derem de. v. libras a fondo que lhi nom dem a apelaçom E sse ueer aa casa dEIRey que lha nom Reçebam" (Livro das Leis cit. (nota 87), p. 215; e em Ordenações Del-Rei cit. (nota 87), pp. 205 e 307, com algumas modificações redacionais, sob os títulos "quanto deuem de leuar os uogados dos solairos dos feitos que teuerem" e "como El Rey mandou que os uogados leuem serujço dos feitos").

Como se vê, a aproximação entre tais figuras foi promovida nas várias oportunidades em que se dispôs a respeito de seu sistema remuneratório. Por sua vez, ao disciplinar a restrição (subjetiva) ao exercício de tais funções, o "Livro das Leis e Posturas" - ainda que de modo oblíquo - as justapõe ("Lei pela qual se estabelece que os mouros e judeus não advoguem em pleito de cristãos, nem tão pouco os tabeliães sejam procuradores com procuração que eles próprios tenham exarado"): "Como os Judeus e os mouros nom podem sseer vogados. Outrossy mouro ou Judeu. en preyto christãao e homem que sseia dado por fiel antre as partes que deue a dar testemunhas sse mester for tambem pola hua parte come pola outra. E outrossy tabelliom sse a precuraçom foy fecta per ssa mãao nom deue a sseer precurador en casa dElRey nem en outro logar nem en nenhuu preyto E homem a que sseia achada falssidade sse a sentença he dada contra el" (Livro das Leis cit. (nota 87), p. 211). Conquanto tal disposição não encontre correspondente nas "Ordenações de D. Duarte", também nesta última coletânea podemos entrever uma outra equiparação, lançada a pretexto da proibição da advocacia por parte dos escrivães das audiências ("Ley. xbj. que nom uoguem"): "Deffendo que nenhuu scripuam da audiençia nom uogue nem seia procurador ssaaluo sse for por sseu preito ou per mandado del rrey" (Ordenações Del-Rei cit. (nota 87), p. 168). Já no que toca ao agente (advogado ou procurador) malicioso, nas "Ordenações de D. Duarte" consta disposição em que se determina (alternativamente) sua suspensão, proibição de exercício ou expulsão (“Como deue dar pena ao Juiz se nom liurar os feitos E outrosy ao procurador maliçioso"): "E se depoys hi tornar E achar que alguuns daquelles feitos nom som desenbargados per culpa dos Juizes ou per outra maneira como dito he deue-lho estranhar asy como suso dito he. E se for per maliçia dalguum uogado ou procurador ou per outro quallquer deue-lho estranhar asy como uyr que conpre deytando-o da terra ou defendendo-lhe que nom uogue ataa tenpo çerto ou ataa que seJa merçee del Rej ou outra pena quall uyr que he rrazom segundo no feito couber" (Ordenações Del-Rei cit. (nota 87), p. 504).

Nas "Ordenações Afonsinas" podemos entrever uma série de aproximações, concentradas - sobretudo - sob o título "Dos Procuradores, e dos que nom podem fazer Procuradores" (Ord. Af. I, 13). Assim, em Ord. Af. I, 13, 1 deparamo-nos com o seguinte período: "Ordenamos, e Mandamos, que aquelles, que ouverem de seer Procuradores em a Nossa Corte (...) bem, e dereitamente, e sem malicia trautem os feitos, e d'outra guisa nenhuu nom vogue, nem procure" (Ordenações Afonsinas I, Lisboa, Fundação Calouste Gulbenkian, 1998, pp. 84-85); no mesmo sentido, em Ord. Af. I, 13, 2: "Mandamos a esses Procuradores, que se trabalhem de veerem as posturas, e Leys, e Ordenaçooes, e as guardem, e usem bem da vogaria" (Ordenações Afonsinas I cit. (nota 87), p. 85); em Ord. Af. I, 13, 3: "Mandamos aos ditos Procuradores, que nom tomem carrego para procurar, nem vogar, ataaque lhe dem enformaçom de todo feito per scripto" (Ordenações Afonsinas I cit. 
(nota 87), pp. 85-86); em Ord. Af. I, 13, 7: "Serão avisados estes Procuradores, que nom desamparem os preitos, nem se vaaõ da Corte (...) e se as partes tomarem outro Procurador, ou Voguado por dinheiro per culpa delles, paguem-lhes quanto derem aos Voguados, e Procuradores, que assy fillharem" (Ordenações Afonsinas I cit. (nota 87), p. 87); e em Ord. Af. I, 13, 20: "Nenhuu Procurador, que tenha já solairo, ou parte delle d'alguu pera teer seu preito, nom pode seer Voguado por a outra parte" (Ordenações Afonsinas I cit. (nota 87), p. 90).

Mas em outros títulos da versão Afonsina podem ser divisadas equiparações equivalentes às referidas logo acima: assim em Ord. Af. I, 16, 11, ao se proibir a atuação dos escrivães das audiências (no mesmo sentido da "Ley. xbj. que nom uoguem" contida nas "Ordenações de D. Duarte"): "Outro sy Mandamos, que nom voguem, nem procurem nenhuus feitos, salvo se for per Nosso mandado" (Ordenações Afonsinas I cit. (nota 87), p. 104); em Ord. Af. III, 20, 4: "E assi pertence ao Autor deliberar as cousas, ante que comece o feito, as quaes the comprem pera aver vencimento delle; porque todo o Autor, que quiser acusar, e demandar, deve-se aconselhar com seus amigos, e deliberar com Sabedores, e entendidos se he bem, e seu proveito fazer a demanda, ou acusação, que quer fazer; e veja se tem taes provas de testemunhas, ou Escripturas nos casos, que testemunhas nom ham de receber, perque possa provar, o que entende de demandar; e ter Procurador, ou Vogado, que seja sabedor, em tal guisa, que ante que comece o feito, seja avisado que lhe naõ faleça cousa alguua" (Ordenações Afonsinas III, Lisboa, Fundação Calouste Gulbenkian, 1999, p. 76); em Ord. Af. III, 20, 7: "E dizemos, que o Reo deve aver o tralado do Libello, que contra elle dão, e aver inducias pera deliberar, e aver seu Conselho, se contenderá em se defender, ou se leixará o feito, e não contenderá mais; e pera vir com suas defensoens, e excepçoens, e recusaçoens, e Voguado, ou Procurador, segundo adiante dizemos" (Ordenações Afonsinas III cit. (nota 87), p. 77); em Ord. Af. III, 51: "Que o Cavaleiro, ou Fidalguo naõ precure, nem vogue por outrem em Juizo"(Ordenações Afonsinas III cit. (nota 87), p. 174); em Ord. Af. III, 117 pr.: "Defezo he per Direito, que homem poderozo per rezam de Officio nem vogue, nem procure em pubrico nem em escondido por alguuma pessoa" (Ordenações Afonsinas III cit. (nota 87), p. 423); em Ord. Af. V, 64: "Dos Vogados, e Procuradores, que som prevaricadores, vogando por anballas partes" (Ordenações Afonsinas V, Lisboa, Fundação Calouste Gulbenkian, 1999, p. 260); e em Ord. Af. V, 64, 1: "E por tanto dizemos, que se alguum Vogado, ou Procurador ouvesse recebido d'alguma parte preço ou outro dom, pera vogar ou procurar seu preito, e de feito o vogasse ou procurasse por ella, e em durando esse feito elle vogasse ou procurasse polla outra parte escondidamente, tal como este com justa razom deve seer contado por falso e alleivoso" (Ordenações Afonsinas $V$ cit. (nota 87), p. 261).

Em meio às "Ordenações Manuelinas", por sua volta, também podemos vislumbrar uma aproximação entre tais personagens. Assim, embora afastado, em regra, da atuação em prol de interesses particulares, em casos excepcionais o "Procurador da Coroa" poderia assistir aos fidalgos, "procurando" ou "vogando" (Ord. Man. I, 11, 2): "Porem nom lhe Embargamos que possa procurar, ou voguar nos feitos dos Fidalguos, que trazem Nossas Terras, Rendas, ou Dereitos, e d'outras pessoas, que traguam alguas cousas Nossas, e da Coroa de Nossos Reynos" (Ordenações Manuelinas I, Lisboa, Fundação Calouste Gulbenkian, 1984, p. 100); da mesma forma, proibindo-se tais atividades aos membros da administração, assim dispunha o preceito contido em Ord. Man. I, 56, 28: "Item ninhuu Alcaide, nem Meirinho qualquer que seja, nom auogará, nem procurará no Luguar onde for Alcaide, ou Meirinho por algua pessoa" (Ordenações Manuelinas I cit. (nota 87), p. 394); no mesmo sentido - agora acerca dos tabeliães - o preceito instituído em Ord. Man. I, 60, 23: "Item nom seram Juizes em ninhuu tempo que forem Tabaliaes, nem voguaram, nem procuraram em Juizo por algua pessoa" (Ordenações Manuelinas I cit. (nota 87), p. 430); bem como os títulos constantes de Ord. Man. III, 34: "Das pessoas a que he defeso, que nom procurem, ou voguem" (Ordenações Manuelinas III, Lisboa, Fundação Calouste Gulbenkian, 1984, p. 118); e de Ord. Man. V, 55: "Dos Aduogados, e Procuradores, que usam de aduoguar por ambas as partes" (Ordenações Manuelinas V, Lisboa, Fundação Calouste Gulbenkian, 1984, p. 184).

Durante o período pré-filipino, por meio de uma Carta Régia de 13 de janeiro de 1539, D. João III instituiu os requisitos necessários ao exercício da magistratura e da advocacia, tomando promiscuamente as atividades de "procurar" e "vogar" (S. IV, 17, 13): "e os que houuessem de procurar ou auogar, tiuessem oito annos na dita Vniuersidade [Coimbra]" (Leis Extravagantes cit. (nota 86), p. 166). Por fim, nas "Ordenações Filipinas" podem ser encontradas várias equiparações, tanto genéricas - como no caso de Ord. Fil. III, 28: "Das Pessoas, a que he defeso procurar ou advogar" (Codigo Philippino cit. (nota 16), p. 612) - quanto específicas, tal qual se pode depreender de Ord. Fil. I, 24, 18 (a propósito da restrição à atuação dos escrivães das audiências): "Item, os Scrivães das audiencias não advogarão, nem procurarão em alguns feitos" (Código Philippino cit. (nota 16), p. 63)

Assim, embora nas fontes do direito lusitano medieval (coligidas no "Livro das Leis e Posturas" e nas "Ordenações de D. Duarte") ainda persista, esporadicamente, uma dissociação entre a "procuração" e a "vogaria" (meramente "formal", à vista dos regimes jurídicos paralelos para as duas hipóteses), a autonomia "estrutural" entre as figuras vai definhando paulatinamente, a ponto de não se vislumbrar diferença entre as 
$\S$ 108. O "Livro das Leis e Posturas" e as "Ordenações de D. Duarte": impedimentos à atuação do agente e notas sobre a forma da procuração. No "Livro das Leis e Posturas" e nas "Ordenações de D. Duarte" podem ser entrevistas diversas limitações de natureza subjetiva, relacionadas tanto ao agente quanto ao próprio principal: restrições de ordem etária, religiosa, funcional, processual, criminal ou mesmo ética informam as atuações do "procurador" e do "vogado" - estendendo-se algumas das quais ao constituinte. Já no que concerne à forma do negócio jurídico de outorga de poderes, tais fontes medievais apontam para a adoção de um sistema rígido, estribado no ato notarial, na "carta selada" e na procuração "apud acta"; aliás, divisando claramente a distinção entre a forma do negócio jurídico e o meio de sua respectiva prova, o legislador lusitano admitiu, em caráter excepcional, a comprovação daquele ato por meios outros (de natureza nãodocumental). Especificamente no que concerne ao conteúdo da procuração (instrumento), já se estabelecia a necessidade de indicação do principal, do procurador, do objeto da outorga, do juízo perante o qual tramitava o processo e da data em que o ato havia sido celebrado. No entanto, um formulário encartado no "Livro das Leis e Posturas" ("formulário de procuração") indica ainda a utilização da "cláusula de rato": o que induz o entendimento de que não era admitida - em caráter ordinário - uma eficácia representativa (direta) decorrente dos atos praticados pelo agente; sendo necessária, portanto, uma manifestação expressa (e formal) por parte do principal, no sentido da "apreensão" de tais efeitos (ainda que de modo antecipado) ${ }^{88}$.

mesmas ao tempo em que vigoravam as "Ordenações Filipinas"; nas palavras de R. RAIMUNDO NOGUEIRA: "advogado e procurador são aqui termos synonimos, e designam as pessoas habilitadas por auctoridade pública, para patrocinarem em juizo o direito das partes" (Prelecções de Direito Pátrio no anno lectivo de 1795 a 1796: Parte $3^{a}$ - na qual se explicam alguns títulos das Ordenações do Reino, in O Instituto 7 (1859), p. 273). Conquanto até o momento tenhamos pretendido destacar as diferenças entre tais personagens, não nos resta agora outra alternativa senão analisar com menor rigor o emprego de tais expressões por parte do legislador; todavia, tal "afrouxamento" metodológico não nos impedirá de, na medida do possível, reconduzir aos respectivos "escaninhos" científicos a matéria pertinente a cada uma das figuras.

88 Adentrando a análise das fontes do direito lusitano medieval, é necessário que efetuemos um esclarecimento preliminar, voltado ao afastamento expresso de alguns assuntos que - conquanto ostentem uma relação oblíqua com tema enfrentado neste estudo - não apresentam um interesse que justifique uma sua abordagem mais detida. Assim, por meio de um Assento (ou Determinação Régia em Relação) de 06 de fevereiro de 1512 se determinou que os procuradores não poderiam alegar a prevalência do direito comum sobre a legislação pátria - orientação que prevaleceu nas "Ordenações Manuelinas" (Ord. Man. I, 38, 5) e nas "Ordenações Filipinas” (Ord. Fil. I, 48, 6). Contudo, tal disposição só foi necessária porque uma regra contida no "Livro das Leis e Posturas" preceituava exatamente o contrário, asseverando a proeminência do direito canônico, a ponto de suplantar as próprias deliberações reais; a respeito, cf. "Lei pela qual se estabelece que o direito canónico tenha vigor em Portugal e que no caso de conflito entre o direito régio e o direito canónico tenha este supremacia" (Livro das Leis cit. (nota 87), p. 9), também coligida nas "Ordenações de D. Duarte" sob o título "Constituçom primeira que as leis E ordinaçoões que per o dito Rej E per seus socesores forem feytas que seguem os degredos dos padres santos E os ditos da santa Jgreja" (Ordenações Del-Rei cit. (nota 87), p. 43). 
Da mesma forma, ainda que também designado pela expressão "procurador", não analisaremos as disposições concernentes ao "procurador do concelho", considerado como uma espécie de gestor encarregado da administração de bens comuns - e sobre quem pendiam pesadas responsabilidades: a respeito, cf. "Lei com várias disposições sobre o exercício das funções de juízes, advogados, procuradores, tabeliães e outros oficiais da justiça" (Livro das Leis cit. (nota 87), pp. 264-265); "Como os procuradores do conçelho que pellos tenpos forem deuem sseer rregidentes aa proll do conçelho E dos sseus beens" e "Como em cada uilla deue d'auer escpriuam Jurado pera escpreuer os beens do conçelho $E$ todo o que rreçeber o procurador deue sseer escprito per esse escpriuam" (Ordenações Del-Rei cit. (nota 87), pp. 355-356); Ord. Af. I, 29 (especialmente o $\S 8^{\circ}$ ); Ord. Man. I, 50 (especialmente o $\S 1^{\circ}$ ); Ord. Man. II, 26, 43; Ord. Man. V, 83 pr.; Ord. Man. V, 83, 3; Ord. Fil. I, 69 (especialmente os $\S \S 1^{\circ}$ e $3^{\circ}$ ); Ord. Fil. II, 45, 36; Ord. Fil. V, 86 pr.; e Ord. Fil. V, 86, 9.

A respeito das limitações subjetivas ao exercício da "procuração" e da "vogaria", eis o teor da "Lei sobre procuradores, advogados, testemunhas e recursos para "casa del-rei", promulgada por D. Afonso III e definidora das linhas gerais da questão (tal como constante do extrato contido no "Livro das Leis e Posturas"): "Pois que ia uistes as pessõas que podem sseer çitadas aa casa dEIRey. tambem per Razom de ssy come per Razom da cousa sobre que as çitam. E que podem çitar outras com que aiam preytos. bem he que ueiades das pessõas que podem sseer precuradores e daqueles que os podem fazer. E ssobre quaaess cousas podem sseer Reçebudos por precuradores. Todo homem pode seer precurador por outro em casa dElRey saluo aqueles que som defesos de dereyto e de costume. De custume som defesos todo homem que aia Raçom dEIRey que nom pode seer precurador em nenhuu preyto. saluo se for precurador contra outro que aia Raçom come el ca entom bem pode seer precurador o que ha Raçom dEIRey (...) Do que ha Raçom delRey. Otrossy sse alguu que aia Raçom dElRey for estabeleçudo por precurador e ante que lhi seia posta a eyçepçom que nom deue sseer precurador pode sostetuir outro en seu logo e que sseia tal pesõa que possa seer precurador ualRa bem aaquele que o sostetujr e Reçebe lo ham por precurador ssegundo costume e segundo dereyto. Ca o dereyto quer assy que tal poder aia e tal dereyto en este caso os precuradores come os Jujzes delegados e assy sse Julguem. Ca sse alguu gaanha en seu preyto que ha com outro Jujz delegado dalguu prinçepe. e aquel Jujz que gaanhou he tal pessõa que a outra parte o poderia deytar per dereyto que nom fosse sseu Jujz sse ante que lhi sseia posta a eyçepçom ou eyçepções da parte que nom pode seer Jujz. e el que da seu poder a outro homem que pode bem seer Jujz ou aquel preyto ualRa bem e ficaria por Jujz. E sse aquel der sseu poder ante que lha eyçepçom fosse posta. como quer que o ele nom podesse sseer se lhi a eyçepçom ante posessem E assy en este caso o dos precuradores e assy sse Julgam (...) Dos que deuem a sseer precuradores. De dereyto som defesos homem que nom aia hidade conprida nom possa sseer precurador e a hidade ha de . xiiij. anos. e Mouro ou Judeu em preyto de christãao. E o homem que sseia dado por fiel antre as partes que deuem dar testemunho se mester for. tambem pola hua parte come pola outra. E outrossy tabelliom se a precuraçom for fecta per sa mãao nom deue seer precurador en casa dEIRey. nem en otro logar nem en aquel logar hu he tabelliom nom deue seer precurador em nenhuu preyto. E o homem que for achado en algua falssidade sse sentença he dada contra ele (...) Dos que podem estabeleçer precuradores. Todo homem pode estabeleçer precurador em sseu preyto saluo aqueles que he defeso de dereyto e de costume $\mathrm{E}$ aos que he defeso som estes homem que nom sseia de hidade conprida saluo se o faz per seu tetor. homem que sseia acusado ou demandado dalguu crime. E outrossy aquel que o demanda ou acusa de fecto de crime nom pode demandar nem acusar per precurador mais ele pessoaujlmente se deue defender. E otrosy homem que sseia çitado que pessõaujlmente parezca nom pode estabeleçer precurador E todas as demandas outras que alguu faz ou el faz a outrem podem e deuem seer reçebudos por precuradores ssaluo en preytos crimjnaaes (...) Daqueles que podem seer vogados e nom ssegundo costume. Todo homem pode seer uogado en qual preyto quer. e por qual pessõa quer saluo aaquel que he defeso que nunca tenha preyto ou que o nom tenha por huu ano. quanto he en aquel tempo nom no deue a teer. nem Judeu nem mouro. nom deue seer uogado en preytos de christãaos nem homem que sseia achado en algua falssidade se ssentença for dada contra ele nem homem que tenha ia o ssolayro ou parte dele. dalguu pera teer seu preyto nom pode seer uogado pola outra parte. saluo se este de que el tem o ssolayro tem outro vogado $\mathrm{E}$ a outra parte nom poder auer uogado que tenha seu preyto. Ca enton como quer que ssa confissom sabha e o solayro dele Reçebesse conueRa que o de por uogado aa outra parte que nom pode auer uogado. saluo se este de que Reçebeo o ssolayro ou parte dele quer ante ficar com este vogado. e leyxar aa outra parte o outro que tenha com ele pera aiuda de seu preyto. Ca en sa escolhença he daquel que dous uogados tem ou mais de filhar quem quiser e o outro leyxar a sseu contemptor. E sse aquele vogado que ele leyxar a sseu contemptor aia ia o ssolayro del Reçebudo. ou parte dele deue lho atornar. poys que vogado da outra parte fica. Poys que ia sabedes das pesõas nom podem seer vogados en nenhuu preyto. segundo dereyto e costume" (Livro das Leis cit. (nota 87), pp. 34-36). Assim, depreende-se de tal disposição a existência de uma série de limitações à figura do "procurador", seja de ordem etária (menores de quatorze anos), religiosa (mouros e judeus), funcional (tabeliães e agentes da administração), processual (garantes) ou mesmo criminal (condenados pela prática de 
falsidade). Algumas delas se estendiam ao próprio constituinte (como no caso da incapacidade absoluta); sobre quem pendiam, aliás, restrições específicas, de natureza processual (comparecimento pessoal determinado pelo órgão jurisdicional) e criminal (acusados da prática de crimes greves e seus acusadores). Quanto aos "vogados", vislumbra-se um regime jurídico bastante similar, caracterizado ainda pela inadmissão dos "proibidos" de atuar e daquele que tivesse percebido remuneração (total ou parcial) de uma das partes. Note-se que tal disposição encontra-se reproduzida em uma série de textos coligidos nas "Ordenações de D. Duarte": a respeito, cf. "capitollo. xbij. quaaes podem seer procuradores por outros em Juizo", “capitollo. xbiij. quaaes podem seer procuradors por outros ou nom", "capitollo xix quaaes pessoas nom podem sseer procuradores por outros", "capitollo. xx. quaaes pessoas deuem estabeleçer por procuradores ou nom" e "capitollo. xxj. quaaes pessoas podem sseer uogados ou nom" (Ordenações Del-Rei cit. (nota 87), pp. 146-148).

Conquanto tal lei conforme o "núcleo" da disciplina estabelecida pelas fontes lusitanas medievais, outras ainda complementam tal sistema: algumas delas simplesmente confirmando o seu teor, como no caso da Provisão de 24 de agosto de 1282 - em virtude da qual D. Dinis confirma a proibição da "procuração" aos agentes da administração pública (Livro das Leis cit. (nota 87), p. 126; e em Ordenações Del-Rei cit. (nota 87 ), p. 165 , sob o título "ley quinta como nom pode procurar por outrem quem ha rraçom del rrey") - e do estilo da Corte mencionado no "Livro das Leis e Posturas" ("Lei pela qual se estabelece a idade mínima de 14 anos para se ser procurador") e nas "Ordenações de D. Duarte" ("Costituçom Clbj quem pode sseer procurador"), em decorrência do qual se reitera a idade mínima para o exercício de tal função (Livro das Leis cit. (nota 87), p. 217; e em Ordenações Del-Rei cit. (nota 87), p. 120). Confira-se, ainda, o estilo da Corte compilado nas "Ordenações de D. Duarte" sob o título "Costituçam CRiiij quaaes Nom podem procurar", em virtude do qual a primeira regra é reiterada (Ordenações Del-Rei cit. (nota 87), 119). Merece específico confronto a consagração da orientação romana a respeito da utilização de filhos (e demais pessoas próximas do círculo doméstico) para a administração dos negócios familiares: no entanto, em uma disposição de cunho judicial, assinala-se a necessidade de outorga de poderes mediante "procuração" - tal como se depreende da regra intitulada "dos procuradores" contida nas "Ordenações de D. Duarte" (Ordenações Del-Rei cit. (nota 87), p. 314).

Outras disposições ampliam a liberdade dos agentes, como no caso da "Lei pela qual se determina que qualquer pessoa, sem distinção de sexo, pode constituir procuradores" (Livro das Leis cit. (nota 87), p. 212; e em Ordenações Del-Rei cit. (nota 87), p. 113, sob o título "Costituçam Cxxbij. Como podem ffazer procurador").

Finalmente, algumas regras ampliam o regime de limitações, a fim de proibir o exercício de tais atividades ("vogaria" ou "procura") por algumas categoriais especiais. Assim quanto aos clérigos ("Lei pela qual se estabelece que os clérigos não advoguem nem sejam procuradores", in Livro das Leis cit. (nota 87), p. 259; e em Ordenações Del-Rei cit. (nota 87), p. 350, sob o título "ley per que nhuum creligo non deue uogar nem procurar em conçelho"); sobrejuízes ("Lei pela qual se determina que, em princípio, nenhum sobrejuiz ou ouvidor possa advogar na corte", in Livro das Leis cit. (nota 87), p. 91); e escrivães das audiências ("Ley. xbj. que nom uoguem", in Ordenações Del-Rei cit. (nota 87), p. 168).

Duas disposições afloram especificamente quanto aos tabeliães: a primeira, constante da "Lei pela qual se estabelece que os mouros e judeus não advoguem em pleito de cristãos, nem tão pouco os tabeliães sejam procuradores com procuração que eles próprios tenham exarado", instituindo uma vedação indiscriminada à sua atuação como "procuradores" (Livro das Leis cit. (nota 87), p. 211, já transcrita na nota 87); e a segunda, estabelecida no Regimento dos Tabeliães (de 15 de janeiro de 1305), de teor excepcionante, em virtude da qual se admitia, em caráter excepcional, o concurso deste agente como "vogado", sempre que seus próprios interesses (ou das pessoas que com ele habitavam) tivessem sido lesados: "segundo artigoo. Dizem que uogam perdante os Jujzes por quem sse pagam e nom no leyxam por defesa dos Jujzes. ElRey lhis defende que nom voguem saluo se lhis alguem fezer mal ou desaguisado ou a alguus de ssa casa que comerem sseu pam ou uestirem seu pano que os defendam com seu dereyto e nom sseiam porende theudos aa dicta pena" (Livro das Leis cit. (nota 87), p. 63; e em Ordenações Del-Rei cit. (nota 87), p. 196, sob o título "que nom voguem perante os Juizes").

Quanto aos cavaleiros, por sua vez, duas provisões de conteúdo similar despontam: de um lado, a "Lei pela qual se determina que os moradores da casa do rei, sendo cavaleiros, só possam advogar em causa própria, e bem assim só entrem nas audiências quando o rei o mande ao sobrejuiz ou ouvidor do pleito. Outrossim para que os sobrejuízes e ouvidores da corte não advoguem sem especial resolução do rei”, de 15 de janeiro de 1303 (in Livro das Leis cit. (nota 87), p. 197; e em Ordenações Del-Rei cit. (nota 87), p. 188, sob o título "como nehuum ouençall nem ofiçiall dell rrey nom voge por outrem"), em virtude da qual se proíbe a sua atuação como advogados; e de outro, a "Lei pela qual se determina que os moradores da casa do rei, sendo cavaleiros, só possam advogar em causa própria e bem assim só entrem nas audiências quando o rei o mande ao sobrejuiz ou ouvidor do pleito" (in Livro das Leis cit. (nota 87), p. 211), a reiterar a disposição precedente. 
Note-se que ao mesmo tempo em que se proibia a atuação de clérigos e cavaleiros como "procuradores" e "vogados" (cf. "Como os caualeiros E crerigos E homes d'ordem uaam seer no conçelho a uogar", in Ordenações Del-Rei cit. (nota 87), pp. 426-427), era determinada a utilização compulsória de tais agentes sempre que qualquer integrante de uma destas categorias fosse interessado no litígio; trata-se de uma disposição que, visando coibir o abuso dos "poderosos" (e em um claro influxo visigótico-castelhano), foi instituída por meio da "Lei pela qual se proíbe que as pessoas poderosas compareçam nas audiências nos casos em que por direito possam ser representadas por seus procuradores" - cuja data de promulgação, por sinal, é incerta (1325-1357): "Ley que os poderosos nom deuem de hir per pesõas a audiencia. TRabalhar se deue o prinçipe de fazer e mandar ordinhar os Juyzes de seu ssenhorio per tal gisa que aqueles que perante eles. demandas am com alguus poderossos por temor deles nem podem segir ho seu dereito como fariam se os com seus Jguaes ouuessem ou com os procuradores dos dictos poderosos outrosij os Juyzes por Reuerença dos dictos poderosos se poderiam mouer a alguas cousas de que se sofreriam se os dictos poderosos presentes nom fossem Porem nos Dom afonsso o quarto querendo leuar adeante o que nosa uoontade senpre foij que cada huu aia Jgualdade de derecto no noso Senhorio asij que os Meores per poder dos mayores nom desperesca ho seu derecto Poren ordinhamos e estabelleçemos por lej que nenhuu arçebispo nem bispo nem abade nem abadesa nem Meestre nem Priol do Ospital nem Rico homem nem Rica dona venham perante os nosos Juyzes asij da nosa Corte como da nossa terra per pessõas em aqueles casos que per derecto podem trautar per procuradores asij que estem hij a seus fectos E se hij star quiser asj em fecto que seiam demandados comme em fectos que seiam demandadores. Mandamos aos Juyzes que deles conhosçessem que os nom ouçades alhj adeante. E em aqueles fectos que demandadores som asj que percam os demandadores as demandas que fezerem. E se demandados forem que fiquem uençudos daquelo que lhis demandarem. pero se os Juyzes virem que he cumpridoyro de virem per pessõas em alguus autos Teemos por bem que possam hij vijr e estar em aquel auto que o Juyz vir que he cumpridoyro E nom mais. Outrosj teemos por bem que possam vijr ante os Juyzes a dizer a eses Juyzes que tenhom por bem de liurar seus fectos tanto que os começar douuir partindo se Logo senom cayam na dicta pea Outrosj porque he per nos he mandado que nenhuas pessõas nom venham uogar perante os nosos sobreJuyzes E ouuydores senom aqueles que estabelleçudos som pera esto porem Mandamos aos sobredictos Juyzes E ouuydores que ueiam aquelo que esta rrazom per nos he mandado E que o guardem pello que per nos he mandado $\mathrm{E}$ se o nom guardarem teemos por bem que nom aia todo aquela medes rrazom de nos" (Livro das Leis cit. (nota 87), pp. 430-431). Observe-se que o sistema de restrições foi mantido, em suas linhas gerais, pelas sucessivas "Ordenações do Reino de Portugal”. Assim quanto à aptidão genérica à "procuração” (Ord. Af. I, 13, 12; Ord. Man. I, 38, 14; Ord. Fil. I, 48, 19) e com relação às ressalvas à atuação: a) de tabeliães, impedidos de "procurar" ou "vogar" (Ord. Af. I, 13, 17; Ord. Af. I, 13, 18; Ord. Af. I, 47, 14; Ord. Man. I, 38, 18; Ord. Man. I, 60, 23; Ord. Fil. I, 48, 23); b) de escrivães, também proibidos de "procurar" ou "vogar" (Ord. Af. I, 13, 28; Ord. Af. I, 16, 11; Ord. Man. I, 20, 21; Ord. Man. I, 38, 19; Ord. Fil. I, 24, 18; Ord. Fil. I, 48, 24); c) de condenados por crime de falsidade (Ord. Af. I, 13, 19) ou ainda por outro crime infamante (Ord. Man. I, 38, 20; Ord. Fil. I, 48, 25); d) de absolutamente incapazes (menores de 14 anos, conforme Ord. Af. I, 13, 14; ou menores de 25 anos, consoante Ord. Man. I, 38, 15 e Ord. Fil. I, 48, 20); e) de testemunhas ou garantes processuais (Ord. Af. I, 13, 16; Ord. Man. I, 38, 16; Ord. Fil. I, 48, 21); f) daqueles que tiverem recebido qualquer remuneração de uma das partes (Ord. Af. I, 13, 20; Ord. Man. I, 38, 22; Ord. Fil. I, 48, 27); g) de cavaleiros, fidalgos (Ord. Af. III, 51) e clérigos (Ord. Man. I, 38, 17; Ord. Man. III, 34 pr.; Ord. Man. III, 34, 1; Ord. Fil. I, 48, 22; Ord. Fil. III, 28 pr.; Ord. Fil. III, 28, 1); h) de poderosos (Ord. Af. III, 117; Ord. Man. III, 34, 2; Ord. Fil. III, 28, 2); i) de agentes da administração (Ord. Af. I, 13, 13) - em especial alcaides e meirinhos (Ord. Man. I, 56, 28 ; Ord. Fil. I, 48, 24).

Nas "Ordenações Afonsinas" se proibia a atuação de mouros e judeus, que não poderiam ser "procuradores" ou "vogados" de cristãos (Ord. Af. I, 13, 15); restrição essa que não foi confirmada nas "Ordenações" subseqüentes. Em lugar de tal discriminação, foi instituída nas “Ordenações Manuelinas” uma limitação quanto àquele que tivesse sido privado de suas funções em decorrência de erro profissional (Ord. Man. I, 38, 21): "e qualquer pessoa, que perdesse qualquer Officio por erro que nelle fezesse, nom poderá seer procurador" (Ordenações Manuelinas I cit. (nota 87), p. 240); tal disposição foi corroborada - observe-se pela versão filipina (Ord. Fil. I, 48, 26). Também nas “Ordenações Manuelinas” foi estabelecida uma restrição (parcial) em razão do parentesco entre o "procurador" e o juiz responsável pela solução da controvérsia (Ord. Man. I, 38, 24 e Ord. Man. I, 60, 24): “24. Item todos os sobreditos, que assi podem seer Procuradores, nom poderam procurar perante alguu Julgador, que seja seu pay, ou seu irmão, ou cunhado no mesmo gráo" (Ordenações Manuelinas I cit. (nota 87), p. 241); preceito que também prevaleceu no texto filipino (Ord. Fil. I, 48, 29 e Ord. Fil. I, 79, 45). Aliás, por meio do Decreto de 19 de novembro de 1722 cujo teor foi posteriormente reiterado pelo Decreto de 09 de janeiro de 1723 - todos os Ministros foram impedidos de exercer a procuração em prol das partes, ou mesmo de "por ellas se empenhar" (cf. JOÃO PEDRO RIBEIRO, Indice Chronologico I cit. (nota 86), p. 311). 
Note-se que à míngua de disposições processuais (relacionadas aos impedidos de "procurar") nas fontes do direito lusitano medieval, as "Ordenações do Reino" dispuseram de maneira uniforme no sentido do cabimento da argüição da questão por meio de exceção (Ord. Af. III, 20, 15; Ord. Af. III, 20, 17; Ord. Af. III, 20, 18; Ord. Man. III, 15, 11), facultando-se ao "procurador" substabelecer seus poderes até o manejo de tal expediente pelo adversário (Ord. Af. III, 22; Ord. Man. I, 38, 23; Ord. Fil. I, 48, 28).

No que toca ao constituinte, as disposições das "Ordenações do Reino" referendaram o preceituado pelo direito português medieval, tendo prevalecido, por exemplo, a proibição do emprego de procurador quando determinado o comparecimento pessoal do demandado (Ord. Af. I, 13, 24; Ord. Man. I, 38, 28), ou mesmo nas demandas que envolvessem crimes graves (com penas cominadas superiores ao degredo temporário) - a surtir efeito tanto sobre o acusado como sobre o seu acusador (Ord. Af. I, 13, 22; Ord. Af. I, 13, 23; Ord. Man. I, 38, 27). Merece destaque o fato de que o limite etário instituído pelas fontes mais antigas (14 anos) foi mantido pelas "Ordenações Afonsinas" (Ord. Af. I, 13, 21); facultando-se ao menor postular licença real, concedida em caráter excepcional (Ord. Af. I, 13, 25). Com o advento das "Ordenações Manuelinas", tal limite foi estendido até os 25 anos (Ord. Man. I, 38, 25), conquanto tivesse sido preservada a possibilidade de postular a autorização real a partir dos 14 anos (Ord. Man. I, 38, 26). Observe-se que nas "Ordenações Filipinas" tal idade mínima (para postular licença especial) foi reduzida aos 12 anos para as mulheres (tendo sido mantidos os 14 anos para os homens); entretanto, a autorização deveria ser concedida, a partir de então, pelo curador (ou pela própria autoridade judiciária).

Com relação à forma da "procuração" (instrumento), duas disposições contidas no "Livro das Leis e Posturas" guardam pertinência com a questão; pela "Lei sobre a procuração em que se mencione o juiz, as partes e a coisa objeto do litígio" se estabelecem não só as duas formas básicas do ato ("per tabelliom" ou por "carta de seelo"), como também os elementos indispensáveis ao seu conteúdo (partes, juízo e objeto) e a respectiva sanção na hipótese de inobservância do preceito (invalidade): "En outra parte he estabeleçudo que a procuraçom en que seia contehudo o Jujz e as partes. e a cousa ssobre que he a contenda ualha a tanto que sseia fecta per tabelliom ou de carta de seelo seelada que sseia certa" (Livro das Leis cit. (nota 87), p. 218; e em Ordenações Del-Rei cit. (nota 87), p. 98, sob o título "Constituçom Lbiij como E per que guisa a procuraçom he auondosa"). Por sua vez, pela "Lei sobre a validade da procuração de um concelho quando aí não há tabelião" se preceitua uma forma especial de procuração (aplicável unicamente aos procuradores dos "concelhos"): "En outra parte he estabeleçudo como alguu conçelho que nom aia tabelliom çita ou o çitam enuia o Jujz com dous homeens boons e com o sseelo do conçelho sse o ham. e sse o nom ham com a carta do foro ualha a esse conçelho por precuraçom" (Livro das Leis cit. (nota 87), p. 218; e em Ordenações DelRei cit. (nota 87), p. 98).

Com relação à primeira regra, cumpre destacar que em dispositivo constante unicamente nas "Ordenações de D. Duarte" ("Costituçam Cxxbij como podem ffazer procurador") são instituídos outros elementos, além daqueles previstos na legislação já referida: "Jtem he estabeleçido que a procuraçom em que for scripto o nome do procurador $\mathrm{E}$ o daquell que o ffez $\mathrm{E}$ a coussa sobre que o ffez procurador $\mathrm{E}$ o nome do Juiz perante que he o ffeito $\mathrm{E}$ a era $\mathrm{E}$ o mes $\mathrm{E}$ o dia em que for feitaa ualha tall procuraçom se for Scripta per tabaliam ou per escripuam que tenha o ffeito" (Ordenações Del-Rei cit. (nota 87), p. 113). Assim, além dos demais elementos, deve ser indicado - naturalmente - o "procurador", bem como a data de celebração do ato; no entanto, de um "formulário de procuração" encartado no "Livro das Leis e Posturas" se extrai a (aparente) utilização da "cláusula de rato"; um mecanismo propício à apreensão (pelo principal) dos efeitos da gestão praticada pelo "procurador": "E (sic) promisit se ratum habiturum et firmam quicquid perdictos procuratores uel eorum alterum aut per substitutum uel substitutos ab eis uel eorum altero actum fuerit in premyssis et quo libet eorumdem" (Livro das Leis cit. (nota 87), p. 127). Tal fato parece evidenciar que não se admitia, à época, uma eficácia representativa direta da gestão praticada pelo "procurador"; sendo necessário o emprego de tal instrumento a fim de que fosse efetuada uma apropriação semelhante à "ratificação" (ulterior); sobre a eficácia da "cláusula de rato", eis as palavras de F. de S. L. PESSOA JORGE: "tal fórmula corresponde à ideia central da procuração (...) ou seja, à declaração dirigida (...) aos terceiros de que se apropria dos efeitos do acto praticado em seu nome pelo mandatário" ( $O$ mandato cit. (nota 09 ), p. 63, nota 71 ).

Observe-se que as duas espécies básicas de "procuração" ("per tabelliom" ou por "carta de seelo") correspondem a modalidades de forma do negócio jurídico; no entanto, sua prova, em casos excepcionais, poderia ser feita por meio de expedientes outros, conforme se depreende da "Lei sobre os procuradores": "En outra parte he estabeleçudo sse alguu homem he que aia preyto com outro e ha de meter alguem por seu precurador ante aqueles Jujzes que aquel preyto ounerem outorgar ante eles por seu precurador alguem $\mathrm{e}$ perdante ElRey se mester for ou perdante a ssa corte se lhi for mester mandamos que lhi ualha assi ssobre a alçada come sobre toda a demanda se lhi for mester. e a Razõar sobre a alçada. E se ssobre esto non troxer precuraçom proueo em na corte e ualha lhi. E nas outras cousas husaram as precurações assi como he deuisado na corte" (Livro das Leis cit. (nota 87), p. 218; e em Ordenações Del-Rei cit. (nota 87), p. 98, sob o título "Constituçom Lx como o procurador do feito pode procurar perante o Juiz da apellaçom"). Ou seja, 
$\S$ 109. "Livro das Leis e Posturas" e "Ordenações de D. Duarte”: eficácia da atuação do "procurador". No que concerne à eficácia da "procuração", as fontes do direito lusitano medieval se detiveram, sobretudo, em três aspectos: em primeiro lugar, voltaram-se ao resguardo de determinadas questões de ordem pública, ao proibir o emprego generalizado da "procuração geral" e ao determinar que os "procuradores" observassem estritamente as disposições do direito pátrio (ainda que o direito comum preceituasse em sentido diverso). Além disso, foram disciplinados diversos aspectos (econômicos ou não) do vínculo estabelecido entre o agente e seu constituinte; assim, visando garantir um quadro de "gestão colaborativa" (e incentivar o comportamento escorreito do "procurador"), foram adotadas diversas disposições de matiz indutivo (e por vezes repressivo): daí as obrigações do agente de tomar - antecipadamente - informações completas (e escritas) a respeito do litígio; de informar (oportunamente) o principal sobre fato superveniente que possa prejudicar seus interesses; de efetuar, periodicamente, a

ainda que ambas as modalidades sejam caracterizadas por seu caráter formal, admitia-se a produção da prova do negócio jurídico de outorga de poderes (procuração-ato) por meio de mecanismos outros - diferentes da exibição da procuração-instrumento.

Finalmente, cabe a retomada do trecho final da "Costituçam Cxxbij como podem ffazer procurador" acima transcrita (como parte integrante das "Ordenações de D. Duarte"); com efeito, se estabelece ao cabo da regra a possibilidade de lavratura do negócio jurídico "apud acta" ("per escripuam que tenha o feito"). Note-se que tal regra institui - ao lado das procurações por "tabelião" e por "carta selada" - uma terceira forma de outorga de poderes, realizada diante do próprio juízo; neste sentido, outro preceito coligido nas "Ordenações de D. Duarte" ("Costituçam CRiij dos procuradores"): "Costume he em Cassa del rrey que cada huum pode estabeleçer seu procurador dante o Juiz. nom Sendo pressente seu auerssairo Emperoo cautela seera que o ffaça dante o notairo da Corte que nom digam os Juizes que sse nom acordam ou dante testemunhas" (Ordenações Del-Rei cit. (nota 87), p. 119).

Note-se que tais disposições do direito português medieval foram mantidas, em larga medida, pelas "Ordenações do Reino" subseqüentes. Assim, no que concerne às espécies de "procuração" (compreendidas como integrantes de um rol taxativo, abrangente inclusive da procuração "apud acta"), cf. a Ord. Af. I, 13, 6 (na qual se outorga privilégio aos cavaleiros e doutores de lavrar procuração por seu próprio punho): "Item. Mandamos, que a procuraçom, perque alguu faz Procurador, seja feita per Taballião, ou per Carta seellada de tal seello, que faça fé, e d'outra guisa naõ valha; pero se for scripta, e assinada per maõ de Cavalleiro, ou Doutor, Mandamos, que faça fé, como se fosse feita per Taballiom; e esto se nom entenda nas procuraçoes, que som feitas apud acta, porque taaes, como estas, se podem fazer pelo scripvaõ que no feito screpver" (Ordenações Afonsinas I cit. (nota 87), p. 87); tal preceito - complementado (quanto à procuração "apud acta") pela Ord. Af. I, 13, 27 - foi reiterado pelas "Ordenações Manuelinas" (Ord. Man. I, 38, 7; Ord. Man. I, 38, 8; Ord. Man. III, 15, 5), estendendo-se a faculdade de lavrar procuração por punho próprio às outras pessoas "a cujos escriptos por bem de Nossas Ordenaçoes se deue dar fee como a escripturas pubricas" (Ordenações Manuelinas I cit. (nota 87), p. 237). Em sentido idêntico ao regime defluentes das "Ordenações Manuelinas" é aquele que decorre das "Ordenações Filipinas" (Ord. Fil. III, 29 pr.). Já no âmbito da legislação brasileira, merecem destaque os artigos $6^{\circ}, 7^{\circ}$ e $8^{\circ}$ do Aviso $n^{\circ} 82$ (de 30 de março de 1849), por meio dos quais foram estabelecidas: a) a possibilidade (aos viscondes, barões sem grandeza, fidalgos da Casa Imperial, magistrados, doutores, advogados, cavaleiros da Ordem do Império, Oficiais Militares, negociantes matriculados, abades beneditinos, beneficiados, clérigos de ordens sacras, bem como as respectivas esposas ou viúvas) de lavratura de procuração escrita e assinada por mão própria; b) e a faculdade (aos condes, marqueses, duques, viscondes, barões com grandeza, arcebispos, bispos, detentores de título do conselho e respectivas esposas ou viúvas) de lavratura de procuração por mão alheia (conquanto assinada por mão própria). 
respectiva prestação de contas; e de justificar adequadamente o substabelecimento dos poderes que outrora the tenham sido outorgados. Mesmo no que toca às projeções econômicas do liame, contundente foi a intervenção do legislador medieval, controlando não só o montante da remuneração atribuída aos "procuradores", como também o próprio regime de seu pagamento - e estabelecendo, ademais, uma responsabilidade patrimonial (e não raro corporal) na hipótese de malogro quanto à gestão dos interesses confiados. Aos preceitos contidos no "Livro das Leis e Posturas" e nas "Ordenações de D. Duarte" não escapou sequer a regulamentação dos efeitos do negócio de outorga perante terceiros: entrevendo-se disposições relacionadas à aferição da "suficiência" do "procurador" - a partir de um exame da extensão dos poderes que lhe tivessem sido atribuídos por seu constituinte $^{89}$.

${ }^{89}$ Quanto à estrita observância das posturas, eis o teor de uma "Lei sobre procuradores" coligida no "Livro das Leis e Posturas": "Item se appelar ou soplicar contra as pusturas de ssa Corte pague as custas de ssa cassa aas partes (...) Jtem manda que guardem as sas pusturas e que as aiam todas" (Livro das Leis cit. (nota 87), pp. 98-99; e em Ordenações Del-Rei cit. (nota 87), p. 169, "Ley. xx" e "Ley. xxij"). No mesmo sentido conquanto denunciando a já referida promiscuidade entre "procuração" e "vogaria" - a "Lei pela qual se determinam emolumentos e honorários de escrivães da corte, advogados, procuradores e porteiros das audiências com várias outras determinações relativas ao serviços dos mesmos", de 12 de junho de 1302: "Item mando que guarden as posturas. e que as aiam todas e que husen ben de uogueria" (Livro das Leis cit. (nota 87), p. 166); bem como a "Lei pela qual se determinam emolumentos e honorários dos escrivães da corte, advogados, procuradores e porteiros das audiências, com várias outras determinações relativas ao serviço dos mesmos", de 10 de junho de 1303 (Livro das Leis cit. (nota 87), p. 199). Tal orientação prevaleceu nas "Ordenações Afonsinas" (Ord. Af. I, 13, 2), tendo sido determinada não só a observância das "posturas" como - naturalmente - também das "Leys, e Ordenaçooes" (Ordenações Afonsinas I cit. (nota 87), p. 85).

Todavia, gradualmente a influência do direito comum vai exigir uma manifestação mais categórica do legislador, sobretudo à vista de disposições anteriores que asseguravam a prevalência do direito canônico sobre a legislação reinícola. Como tivemos a oportunidade de observar em nota imediatamente anterior, foi o Assento de 06 de fevereiro de 1512 o responsável pela reafirmação da autoridade do direito pátrio, posta em xeque pelos procuradores que postulavam na corte (cf. J. ANASTÁCIO DE FIGUEIREDO, Synopsis Chronologica $I$ cit. (nota 86), p. 170). Neste sentido, as "Ordenações Manuelinas" foram bastante mais contundentes, tal qual se pode depreender de Ord. Man. I, 38, 4 ("E mandamos a esses Procuradores, que tenham os Liuros todos das Nossas Ordenaçoes, e nom procurem contra ellas") e Ord. Man. I, 38, 5: "E porque Nossa tençam he, que Nossas Ordenaçoes sejam mui inteiramente guardadas. Defendemos a todos os Procuradores, assi na Nossa Corte, e Casa de Sopricaçam, como da Casa do Ciuel, e a todas outras pessoas, que em cada hua das ditas Casas feito trouuerem, ou procurarem, ou requererem, que por palaura, nem por escripto nom aleguem, nem requeiram contra algua Ordenaçam por Nós aprouada, que se nom deuem comprir, nem guardar, nem por ella julguar, dizendo que he contra Dereito Commum, ou contra Dereito Canonico, em quanto tal Ordenaçam nom for por Nós reuogada" (Ordenações Manuelinas I cit. (nota 87), pp. 235-236). Em sentido idêntico, cf. Ord. Fil. I, 48, 6.

Por sua vez, no que concerne à proibição das procurações gerais, a "Lei com várias disposições sobre o exercício das funções de juízes, advogados, procuradores, tabeliães e outros oficiais de justiça" assim dispunha: "Como os procuradores nom deuem filhar em sy Procurações geraes. Outrosy hé dito, que alguus entendiam aver preitos, e demandas contra alguas pessoas no concelho, e querem fazer Procurador alguu dos do Concelho, pera lhe teerem esses feitos, que asy entendem a aver contra certas pessoas, e sobre certas cousas, esses Procuradores não querem consentir em sserem seus Procuradores, moormente nos feitos, que som de pequena contia, e de que levam pequeno selario, salvo se os fezerem seus Procuradores jeeraes em todos seus feitos e lhes assinaarem cada anno prestamos por razom dessas Procurações; e algumas pessoas simprezes, que esto bem nom entendem, nem sabem quantas diferenças em esto há, preventura ham creudo, 
que nom leva mais do o fazer seu Procurador jeeral, que especial no feito, que há, ou entende a aver mandam fazer essas Procurações jeerães, segundo lhes elles dizem; e depois que esses feitos, que essas pessoas ham som fiindos guardam tempo, a que os beem demandar por esses solairos, e prestamos, que dizem, que devem d'aver por seerem asy seus Procuradores em cada huu anno, e traze nos por esta razom em demanda, e levam delles algo; o que hé contra conciencia, e em perigoo de suas almas, e polo gram dapno que desto recrecia foi posta defeza em alguas Villas, e logares polo Juizes, e homeens boons, que a Villa aviam de reger, que se nom fezesse; Ordenaram, e pozeram certo hordenamento que como se sobre esto fezesse, o qual se nom aguardava como devia. Porem manda ElRey, e defende, que nenhuu Procurador nom filhe em sy Procuração jeeral de nenhua pessoa da Villa, nem do Termo e se a filhar, e em esto consentir nom possa per ella, nem por razom della demandar nem veencer solario nenhuu, nem prestamos daquel cujo Procurador hé, nem doutro nenhuu, e se o demandar, ou Receber seja thudo de o tornar aa parte outro tanto, quanto delle levar, ou mandar, ou d'outrem por el, e se o a parte nom quizer demandar, o Procurador do Concelho hu esto acontecer o demande, e ajão pera o Concelho; e o procurador, que contra esto for des hua vez adeante, seja privado do Officio da Procuraçom pera sempre (...) Como os Juizes devem outorgar aos Procuradores que filhem as Procurações jeerães d'alguas pessoas, a que forem necessarias. Porque alguas pessoas aviam costumado de fazerem procuradores jeeraes por muitos feitos, que haviam, ou entendiam a aver, para não serem estorvados de seus lavores, ou por alguas cousas, que lhes era muito mester. Quando tal razam acontecer, manda ElRey, que quando alguas pessoas, asy como aldeãaos, ou lavradores, ou outras pessoas quaesquer quizerem fazer Procurações jeeraes vãao perante os Juizes, ou Alvaziis, e elles vejam essas pessoas, que querem fazer essas Procurações se som taaes, que lhes cumprem de as fazerem, e que por esses Alvaziis sejam dezemganados desto: e quando os Alvaziis, ou Juizes virem, que essas pessoas som taaes, ou se lhes mostrarem razom, que lhes faz mester de fazerem taaes Procurações entom lho devem d'outorgar, e quando asy for visto, e outorgado por os ditos Juizes, ou Alvaziis, entam esses Procuradores possam tirar e aver o seu direito dessas Procurações jeeraes, e possam levar, e aver daquelles cujos Procuradores forem seus solairos, ou aprestemos; e se d'outra guisa for feita a Procuraçam, manda ElRey, que esses Procuradores, ajam a pena sobredita, e esto que susodito hé, nom se entenda nas pessoas, que som auzentes, ou que som fora da Villa, e do Termo. Nem outrosy dos Bispos, e dos Priores, nem das Jgrejas Sagraaes, e Regrantes, ou Conventuaaes, nem dos cabidos, e Collegios, nem Conventos, ou Comendas dos quaes esses Procuradores possam filhar Procurações jeeraes, ou especiaes sem a pena sobredita" (Livro das Leis cit. (nota 87), pp. 268-270; e em Ordenações Del-Rei cit. (nota 87), pp. 359-361, sob os títulos "como os procuradores nom deuem filhar em ssy procuraçoes Jeeraaes" e "Como os Juizes deuem outorgar aos procuradores que filhem as procurações Jeeraaes dalguas pessoas a que forem neçessarias"). Note-se que as "procurações gerais" eram consideradas, portanto, mecanismos abusivos de que se serviam os procuradores, prejudicando os próprios constituintes por meio da exigência constante de contrapartidas nem sempre correspondentes ao interesse patrocinado pelo agente. Desta forma, havendo expressa atenção do legislador em relação à vulnerabilidade de algumas espécies de trabalhadores hipossuficientes (aldeãos e camponeses), tal expediente foi considerado prejudicial, merecendo uma reprovação categórica, que somente cedia espaço a determinadas hipóteses excepcionais - nas quais o instrumento verdadeiramente pudesse atender às necessidades do principal.

Tal preocupação não inspirou o legislador afonsino, que admitiu a possibilidade de lavratura de procuração geral ou especial, segundo o livre entendimento do constituinte (Ord. Af. I, 13, 26). Contudo, ainda que as "Ordenações do Reino" não tivessem vedado a procuração geral, proibiram - visando coibir extorsões simuladas - a venda de desembargos (ainda que camuflada pela outorga de uma procuração específica para recebimento, desprovida do correspondente dever de prestação de contas); neste sentido - lastreando-se no Alvará de 17 de agosto de 1499 e no Regimento da Fazenda de 17 de outubro de 1516 (cap. 219) - cf. Ord. Man. IV, 40 pr. e Ord. Fil. IV, 14, 1.

É evidente que tais situações diagnosticadas pelo legislador denunciam um desvirtuamento daquele mecanismo de "gestão colaborativa" que deveria permear o vínculo mantido entre o "procurador" e seu constituinte. Exatamente por isso D. Dinis promulgou a Lei de 23 de agosto de 1303 - transcrita em nota 87 e contante de Livro de Leis cit. (nota 87), pp. 83-84 e Ordenações Del-Rei cit. (nota 87), p. 191 -, em decorrência da qual se proibia qualquer remuneração do agente antes que o pleito estivesse encerrado por sentença definitiva; ora, se o procurador não buscasse uma solução célere ao litígio por apreço ao interesse do principal, de uma forma ou de outra haveria de zelar pelo mesmo, uma vez que só receberia sua contrapartida com feito completamente terminado. Em idêntico sentido a Carta Régia de 08 de julho de 1314 - transcrita em nota 87 (Livro das Leis cit. (nota 87), p. 184-185; e em Ordenações Del-Rei cit. (nota 87), pp. 296-297) -, em virtude da qual não apenas se proibiam as antecipações em espécie, como também em víveres, sujeitando quem os tomasse (e quem os desse) à pena de ter seus pés e mãos decepados, alhém dos olhos arrancados. Foi somente por meio da Postura de 04 de agosto de 1322 (transcrita em nota 87) que se passou a admitir a antecipação de metade da remuneração logo por ocasião da aceitação do encargo (Livro das Leis cit. (nota 87), p. 215; e em Ordenações Del-Rei cit. (nota 87), pp. 205 e 307, com algumas modificações redacionais); 
note-se que tal postura foi reiterada pela Carta Régia de 17 de agosto de 1322, dirigida especificamente aos "aluazijs de tauira" (Livro das Leis cit. (nota 87), pp. 86-87; em Ordenações Del-Rei cit. (nota 87), pp. 308309, sob o título "Como el Rey mandou que os uogados E procuradores leuem o meo do sollairo nos comecos dos feitos"). E a questão somente ficou resolvida de modo definitivo - no âmbito das fontes lusitanas medievais - por força da "Lei pela qual se proibe aos advogados e procuradores receberem qualquer dádiva dos seus constituintes e determinando a forma por que lhe seriam pagos os seus honorários", de 14 de março de 1351: "Lei que vogado nem procurador nem Juyz nem ovuidor nem escriuam nem tabaliom nem almoxariffe nom tomem seruicos de nenhuus que peranteles aiam de fazer. por razom de sseus officios nem os outros ouencaes. Dom afonso pella graça de deus Rej de Portugal E do algarue a quantos esta carta virem faço saber que a mjm he dicto que na mha Corte e nos meus Rejnos se faziam mujtas perlongas E mujtas maliçias nos fectos por rrazom que os voguados e os procuradores leuam das partes mujtas dõas e grandes seruiços de pam e de vjnho e de Carne e doutras cousas e que nom lejxham porem de leuar todos os seus solajros $\mathrm{E}$ veendo e consijrando per rrazom das Cousas que assj rreçebiam que Era aas uezes mujto mais que nos seus solajros montaua faziam as dictas perlongas per rrazom de sserem asj seruidos E querendo Eu esquiuar todas estas maliçias e perlongas $\mathrm{E}$ catando commo poderia fazer que taaes cousas nom fezessem $\mathrm{e}$ que os fectos fosem çedo desenbargados com derecto como deuiam e que as gentes nom se andasem. estragando E veendo ia commo esto fora defeso per ElRej meu padre per hua lej sua que sobresto fez Teenho por bem e ponho por lej pera senpre que voguado nem procurador nom. filhe pam nem vinho nem Carne nem outras cousas daqueles cuius fectos teuerem nem doutrem per sa rrazom Enquanto eses fectos teuerem nem doutrem per esa rrazom enquanto eses fectos durarem $\mathrm{E}$ tenho por bem que os solajros deses fectos que teuerem aiam per esta gisa terço do solajro no começo do fecto e terço abertas e pubricadas as Enquirições E $\mathrm{o}$ outro terço acabado o fecto $\mathrm{E}$ os vogados e procuradores que contra esto fezerem se filharem das partes cuios fectos teuerem cousas que valham de Cinque libras a fundo açoutados pubricamente $\mathrm{E}$ se filharem cousas que valham major quantia moiram porem Esta pea Mando que aiam os vogados e procuradores que filharem dõas ou outras cousas daqueles contra que os fectos teuerem $\mathrm{E}$ os que lhis esas cousas derem paguem em tres dobro o que assj derem $\mathrm{E}$ o terço desto seia pera o acusador $\mathrm{E}$ as duas partes pera as Obras do Comuum daquel logar hu for fecto E cada huu do Poboo possa esto acusar E mando aos Juizes da mha Casa so pea da mha merçee E outrossij aas Justiças dos meus Rejnos que se souberem em uerdade que alguus taaes cousas fazem que prendam aqueles que as fezerem $\mathrm{E}$ façam em eles Justiça como dicto he $\mathrm{E}$ esto se entende tambem na mha Corte como em todolos meus Rejnos E outrosj tenho por bem E mando que os meus sobreJuyzes Ouujdores Corregedores Juizes Contadores Tesourejro Veedores almoxharifes Enqueredores que filharem pam vinho Carne ou outras cousas daquelas que perante eles ouuerem fectos com que ouuerem de ffazer em seus ofizios alguas Cousas que aiam a pea posta em esta lej contra os vogados e procuradores E per esta lej nom entendo a Reuogar as lex que ia per mjm som postas em esta rrazom Esta pea mando que aiam os Tabelliões e scriuãaes que filharem as dictas cousas daqueles cuios fectos teuerem ou daqueles com que eles ouuerem de fazer alguas cousas em seus ofizios Esto se entende tambem nos scriuães das audiençias comme. nos scriuãaes dos meus ofizios quaesquer que seiam E outrosj nos scriuães dos Concelhos Dada em Santarem quatorze dias de março elRej o mandou Gonçalo paez a fez Era de mil trezentos e ojtenta e noue anos ElRej a viu" (Livro das Leis cit. (nota 87), pp. 437-439; e reproduzida na Carta Régia de 30 de abril de 1351, consoante Ordenações Del-Rei cit. (nota 87), pp. 531-532, sob o título "ley em que el Rej defende que procurador nem uogado Nem Juiz nem almoxarife nem sobreJuiz Nem estpriuam nem sacador nom tomem seruiços dos que teuerem os feytos nem dos que com elles ouuerem de fazer"). Assim, deveriam os "procuradores" receber sua remuneração em três parcelas: a primeira no início do feito; a segunda quando da publicação das inquirições; e a derradeira quando do encerramento da lide (por sentença definitiva). Tal orientação foi mantida pelas "Ordenações do Reino", acrescida da proibição de que os procuradores recebessem quaisquer dádivas dos adversários de seus constituintes (Ord. Af. I, 13, 32; Ord. Af. I, 13, 33; Ord. Man. I, 38, 34; Ord. Man. I, 71, 18; Ord. Fil. I, 92, 17).

De fato, a suspeita com que eram entrevistas as atividades do "procurador" - e que motivaram tão incisiva intervenção real - não era sem motivo; ao contrário, nas próprias "Ordenações de D. Duarte" consta uma denúncia feita a D. Afonso IV ("Como os Juizes nom deuem dar carta aos uogados E percuradores pera çitarem pellos solairos sem enformaçom", Lei de 17 de novembro de 1350), alusiva a uma prática extorsiva adotada pelos procuradores das instâncias ordinárias, que constrangiam as partes ao pagamento de contrapartidas, sob a constante ameaça de cobrança judicial de tais valores: "Dom affonso pella graça de deus Rey de portugall E cetera A uos meus sobreJuizes E a toda-llas outras minhas Justiças dos meus rregnos que esta carta virdes saude sabede que os poboos do meu Senhorio se agrauarom a mym outro dia quando fiz cortes em santarem dizendo que rreçebyam grande agrauamento dos procuradores que procurauom os feitos ante uos porque diziam que as uezes acontecia de fazerem hi alguuns seus precuradores Jeeraes por alguns feitos que perante uos auyam $\mathrm{E}$ que pasauom quatro $\mathrm{E}$ çinquo annos que nom auyam feito nenhuum per dante uos $\mathrm{E}$ que elles queryam delles leuar E leuauom os solairos de todos aquelles annos posto que em elles feyto 
nehuum nom ouuesse per dante uos. Outrosy diziam que uos daueys a eses percuradores cartas pera çitarem per dante uos alguuns per rrazom dos solairos que deziam que lhes deuyam sem uos Seendo mostrada per elles enformaçom aguisada per que lhes elles fosem thudos. E que pero thes elles nom fosem obrigados que lhes dauom algo do seu ante que uyrem a esas çitaçoees Por que alguuns rreçeberyam muy gram dapno porque eram de longas comarcas desy por nom danarem o que auyam per dante Uos E porque a mym cabe de guardar os meus soJeytos de dano E tolher as maliçias E os maaes dellas Porem tenho por bem E mando-uos que cando alguus preytos dos procuradores sobre os sollairos vierem per dante uos que nom Julguedes a eses procuradores sallairos Saluo daquelles anos que achardes que alguuns feytos ouuerom ou ouuerem per dante uos em que os elles aJudarom ou aJudarem (...) Outrosy tenho por bem E mando-uos que daquy adiante nom dees cartas a eses procuradores pera çitar alguuns per rrazom de seus sollairos Saluo se uos ante mostrarem obrigaçom feita per tabaliam ou per minha carta de obrigaçom ou for contheudo $\mathrm{Na}$ auença do feyto que $\mathrm{o}$ fez seu percurador E entom fazee-lhes pagar eses sollairos como per mym he mandado E se alguas cartas foram dadas per nos contra esto mando que se nom faça per ellas obra nehua Outrosy Mando a cada huum de uos Justiças em Uosos Julgados que façaees pobricar esta minha carta em Juizo honde al nom ffaçades dada em torres uedras xvij dias de nouenbro el Rej o mandou pero fernandez a fez Era de mill E trezentos E oytenta E oyto annos" (Ordenações Del-Rei cit. (nota 87), p. 530). Ora, era natural a reação do monarca diante de tais abusos relatados - embora relacionados à conduta de tão somente "alguns" agentes.

De toda forma, a gestão de que se desincumbia o agente deveria privilegiar os interesses do principal; daí que se o procurador se deparasse com fato novo, a respeito do qual não dispunha de informações precisas, deveria imediatamente diligenciar instruções de seu constituinte, conforme estabelecia a "Ordenação de D. Afonso IV, contendo 18 leis e várias outras resoluções sobre a forma pela qual as justiças procederiam nos processos, como receberiam as apelações, quando aceitariam advogados, e maneira pela qual estes e os procuradores exerceriam o seu ofício", de 18 de fevereiro de 1332, por sua Lei IV (Livro das Leis cit. (nota 87), pp. 229230; e em Ordenações Del-Rei cit. (nota 87), pp. 319-320, sob o título "Como o procurador que ujeer da terra se nom souber os nomes das testemunhas como as deue de nomear na terra perante os emqueridores"). Excetuada tal circunstância excepcional, a respeito de todos ou outros dados concernentes à demanda, deveria o próprio "procurador" deles tomar conhecimento sob a forma de instruções específicas e detalhadas, a fim de que fosse garantida a realização do intuito do constituinte; neste sentido dispunha a Lei $\mathrm{V}$ da mesma Ordenação de 18 de fevereiro de 1332: "Ley quinta. Per esta maneyra outrossy os preytos sseerem milhor e mais aginha desembargados. as partes prinçipaaes cada que mandarem precuradores aa corte tambem sobre çitaçom come sobre apelaçom. quer interlacutoria que defenetjua ou ssobre outra Razom qualquer deuem a contar todo o fecto ao precurador nom tam solamente ssobre a çitaçom ou sobre o artigoo da apelaçom. mais sobre o preyto todo prinçipal contando lho e dando tho todo per scripto pera nom escaeçer ao precurador nem poder eRar nem pera fazer outra maliçia $\mathrm{E}$ o demandador de lhi logo per escripto as testemunhas pera poder prouar sa demanda $\mathrm{E}$ outrossy sobre todos os outros artigoos en que entende que lhi conpre proua. $\mathrm{E}$ o demandado outrossy lhi de as testemunhas que entende aa dar ssobre todas as eyçepções tambem dilatorias come perantorias dando lhi os nomes en scripto E cada hua das eyçepções ou Razões sobre que entendem dar as testemunhas. E quantas testemunhas de sobre cada hua delas" (Livro das Leis cit. (nota 87), p. 230; e em Ordenações Del-Rei cit. (nota 87), p. 320, sob o título "Como as partes deuem dar aos procuradores per Scripto enformacom de seu feito E os nomes das testemunhas que uuerem pera prouar seu feito"). Em idêntico sentido - determinando que o "procurador" tomasse informações detalhadas (e escritas) de seu constituinte, antes de dar início às suas atividades - as "Ordenações Afonsinas" (Ord. Af. I, 13, 3 e Ord. Af. I, 13, 4) assim dispunham: "Item. Mandamos aos ditos Procuradores, que nom tomem carrego pera procurar, nem vogar ataa que lhe dem enformaçom de todo o feito per scripto, assinada per sua maaõ, e guarde-a bem (...) Item. Quando tomarem essas informaçooes, sejam avisados de as averem compridamente, assy sobre o principal, como sobre todalas outras excepçooes, e razoões, que se no feito requerem, e nomes de testemunhas, porque se pode provar, porque pera esto nom se lhe dará tempo pera se aconselhar com a parte" (Ordenações Afonsinas I cit. (nota 87), pp. 85-86); cf., ainda, Ord. Af. III, 20, 4 e Cortes de Lisboa de 1498 (cap. 10).

Note-se que ao determinar (ao procurador) a tomada de "informações" (junto ao seu constituinte) há uma significativa retomada de disciplina que, em verdade, nos parece diretamente ligada ao contrato de mandato e ao específico tema das "instruções" (dirigidas pelo mandante ao mandatário). De todo modo, as "Ordenações Manuelinas", neste particular, são bastante mais enfáticas: conquanto não preceituassem - em caso de inobservância das instruções durante a execução da incumbência - a invalidade da gestão, mas tão somente a punição do agente (sem prejuízo da reparação do dano experimentado pelo principal), realçaram o caráter vinculado da atuação do procurador (suscetível de controle jurisdicional à vista das instruções entregues pelo principal); eis o teor de Ord. Man. I, 38, 36: "E mandamos (...) que o dito Procurador nom faça artiguo alguu, que nom seja contheudo nas ditas enformaçoes (...) as quaes enformaçoes os ditos Procuradores teram em seu poder bem guardadas, pera as amostrarem aos Julguadores, quando lhes for 
mandado (...) pera se veer se os ditos Procuradores procuraram os feitos verdadeiramente, e segundo as enformaçoes que lhes foram dadas (...) E se os Julguadores, que dos taees feitos forem Juizes, acharem, que alguu nam seguindo a enformaçam da parte procurou seu feito erradamente, e por sua culpa a parte recebeo dãno, faça todo emendar, e paguar aa parte pelos bens do Procurador, que em tal culpa for achado, se a parte o requerer. E aalem desto o Procurador, que por malicia nom seguir a enformaçom da parte, será punido segundo sua culpa, e o erro que nisso cometer" (Ordenações Manuelinas I cit. (nota 87), pp. 245-246). No mesmo sentido, cf. Ord. Man. III, 15, 2; Ord. Fil. I, 48, 15; Ord. Fil. I, 48, 16; Ord. Fil. I, 48, 17; Ord. Fil. I, 48, 18 e Ord. Fil. III, 20, 2. Perceba-se que de tais disposições resta claro ser natural a exibição em juízo do instrumento comprobatório da outorga de poderes (a procuração-instrumento); embora, em caráter excepcional, se admitisse a apresentação das instruções conferidas pelo principal ao seu agente ("enformaçoes").

A respeito da - compulsória - prestação de contas (anual) por parte do procurador, cf. a lei "Como filhem conto dos procuradores que forom ante per. x. annos" contida nas "Ordenações de D. Duarte" (Ordenações Del-Rei cit. (nota 87), p. 515); e quanto à necessidade de justificativa - plausível e devidamente declinada para a prática do substabelecimento pelo procurador, eis o teor de um dos preceitos contidos na já referida "Lei com várias disposições sobre o exercício das funções de juízes, advogados, procuradores, tabeliães e outros oficiais de justiça": "Como os Juizes nom devem de receber sobestaballecimentos de huus Procuradores a outros, sem informação direita. Outrosy defende ElRey aos Juizes, ou Alvaziis, que não recebam os sobestaballecimentos, nem os Procuradores, que asy forem sobestaballecidos jeeralmente nem especialmente polos ditos Procuradores, salvo se o que for sobestaballecido mostrar enformaçam direita, e poder tal, porque possa verdadeiramente trautar esses feitos, e dar a elles recado, e resposta, asy como for mester, e como a parte prencipal, ou aquel por que he sobestabellecido devia fazer se prezente fosse, e em outra guisa o sobestabellecimento nom valha, e os Procuradores, que o fezerem ajam a pena suso escripta" (Livro das Leis cit. (nota 87), p. 267; e em Ordenações Del-Rei cit. (nota 87), p. 358, sob o título "Como os Jujzes nom deuem de rreçeber ssoestabelleçimentos dhuuns procuradores a outros ssem emformaçom direjta").

Quanto aos aspectos econômicos do vínculo mantido entre o procurador e o principal cabe uma observação especial: embora entre os romanos não se admitisse uma incumbência remunerada - mediante contrapartida representada pelos "salários" (mas tão somente sob a forma de "honorários") -, a necessidade de uma compensação ao agente foi progressivamente denunciada pelos direitos visigótico e castelhano; desta forma, não é de se estranhar a admissão pelo direito lusitano medieval de uma remuneração ao "procurador" (e mesmo ao "vogado"), compreendida como um próprio "salário". Diferentemente dos juristas romanos, o legislador português estava preocupado com uma eventual "sociedade" - de todo leonina - implemantada entre a parte e seu procurador, à vista da situação de fragilidade da primeira (freqüientemente explorada por um agente oportunista). Neste sentido, por meio de uma Carta Régia de 26 de fevereiro de 1283, D. Dinis estabeleceu um limite máximo para a remuneração dos "vogados", consistente na vigésima parte daquele proveito experimentado pelo principal com o desfacho da demanda (ou a importância de cem libras): "E porque os vogados leuam tanto dos preytos que as nossas gentes eram estragadas. porem stabeleçemos que nenhuu vogado de nossa corte contado a ualia do preyto que teuerem E esta uijntena entendesse ata Çem libras . e nom mais como quer que o preyto que tem sseia de gram ualia. e o vogado que esto passar sseia de maa nomeada como de ssusodicto he" (Livro das Leis cit. (nota 87), p. 190; e em Ordenações Del-Rei cit. (nota 87), pp. 175 e 293, sob os títulos "ley que os vogados quando os feitos ueerem Jurem que manteem dereito" e "Quanto deuem leuar os uogados dos sollairos dos feitos"). Observe-se que esta remuneração equivalia ao dobro do limite atribuído aos "procuradores" ("quarentena", ou o máximo de vinte libras), obviamente proibidos de fazer qualquer espécie de ajuste com o agente do adversário em detrimento do interesse de seu constituinte; tudo conforme assinalam a Lei de 12 de junho de 1302 (Livro das Leis cit. (nota 87), pp. 165-167), a Lei de 10 de junho de 1303 (Livro das Leis cit. (nota 87), pp. 199-200), a "Lei sobre procuradores" há pouco referida (Livro das Leis cit. (nota 87), pp. 98-99; e em Ordenações Del-Rei cit. (nota 87), p. 169, "Ley. xix" e "Ley xxj”) e uma disposição contida unicamente nas "Ordenações de D. Duarte" ("Da Jura que ham de fazer os percuradores E uogados") por meio da qual se exigia, inclusive, o juramento dos agentes de que atuariam em estrita observância de tais preceitos (Ordenações Del-Rei cit. (nota 87), pp. 517-518). Tal disciplina foi posteriormente desenvolvida de modo mais minudente e detalhado nas "Ordenações Afonsinas" (Ord. Af. I, 45), nas quais se determinou, inclusive, a privação dos ofícios aos procuradores que fizessem "companhia antre sy sobre o sallairo", conforme estabelecido em Ord. Af. I, 13, 31 (Ordenações Afonsinas I cit. (nota 87), p. 93). Não obstante o posterior agravamento de tal pena (uma vez que segundo o fragmento de Ord. Man. I, 38, 31 haveria de se aplicar o degredo perpétuo), o regime relacionado a taxas, limites, forma de pagamento e base de cálculo permaneceu, em linhas gerais, o mesmo; neste sentido, cf. Ord. Man. I, 71; Ord. Fil. I, 48, 11; Ord. Fil. I, 92. E a competência para conhecer das 
matérias afetas aos salários dos procuradores, que de início pertencia ao "Chanceler Mor" (Ord. Man. I, 2, 33), passou ao "Juiz da Chancelaria da Casa da Suplicação" (S. I, 3, 1, 3; S. I, 3, 1, 10; Ord. Fil. I, 14, 2).

Ainda quanto às projeções financeiras do liame estabelecido entre o procurador e seu constituinte, merece destaque a previsão de uma responsabilidade subjetiva do agente na hipótese de prejuízo causado ao principal em decorrência de gestão imperfeita. Cumpre observar, contudo, que as fontes lusitanas medievais assinalam que, de início, foi imposta não apenas uma responsabilidade patrimonial pelo dano, mas inclusive corporal, havendo confirmação expressa desta afirmação na "Lei sobre procuradores" há pouco referida (Livro das Leis cit. (nota 87), pp. 98-99; e em Ordenações Del-Rei cit. (nota 87), p. 168, "Ley. xbiij”), na Lei de 12 de junho de 1302 (Livro das Leis cit. (nota 87), p. 166) e nas próprias "Ordenações Afonsinas" (Ord. Af. I, 13, 3 e Ord. Af. I, 13, 29). Isto nos causa certa estranheza, uma vez que já na "Ordenação de D. Afonso IV, contendo 18 leis e várias outras resoluções sobre a forma pela qual as justiças procederiam nos processos, como receberiam as apelações, quando aceitariam advogados, e maneira pela qual estes e os procuradores exerceriam o seu ofício" (de 18 de fevereiro de 1332) se estabelece como pena genérica unicamente a perda dos respectivos salários, ainda que eventualmente agravada na hipótese de grave malícia do procurador: "se alguus Vogados, algumas Vegadas acharem que nom vem aos feitos, nem catarem por elles o direito das partes, que ha de ajudar, por aquella maneira que cumpre, como quer que dito seja, que em nos preitos de que for, vençudo a parte, que ha d'ajudar, que nom leve sollairo della. E pero crescendo a malicia deve crecer a pena, e pera aver esta pena desta maldade, e seer exemplo aos outros de a nom fazerem, deve a este seer defesso, que nom vogue nhuu feito" (Livro das Leis cit. (nota 87), pp. 240-241). Conquanto excessivamente suave - na medida em que ordinariamente não previa mais do que a perda da remuneração - tal disposição evidencia um afastamento da responsabilidade corporal do agente. No sentido de uma responsabilidade tão somente patrimonial - embora pela íntegra do dano experimentado pelo principal - cf. Ord. Man. I, 38, 29; Ord. Man. III, 15, 27 e Ord. Fil. I, 48, 10.

No que toca aos efeitos do negócio jurídico (de outorga) sobre terceiros, assim dispõe a "Lei pela qual se determina a forma que se devia seguir nos diversos pleitos, tendo por fim providenciar contra o abuso que os advogados e procuradores praticavam, prolongando fraudulentamente as causas de que tratavam", de 15 de setembro de 1313: "Jtem se quiser dizer o que he demandado que aquel que o demanda que nom he pessoa que lhi possa fazer a demanda ou se ueen prouadores e alguu que quer dizer contra outro que nom podee seer procurador en que a procuraçom que trage nom he auoondosa pera demandar ou pera defender deue logo dizer todalas Razões que ouuer en cada huu destes prazos" (Livro das Leis cit. (nota 87), p. 170). Note-se que há previsão de exceção movida pelo adversário não só para a hipótese de impedimento do procurador - mas inclusive no caso de insuficiência dos poderes outorgados ("da eixeiçom dos procuradores", in Ordenações Del-Rei cit. (nota 87), p. 286). De todo modo, a responsabilidade pelo controle da suficiência dos poderes outorgados era atribuída ao próprio órgão jurisdicional ("Ordenação de D. Afonso IV, contendo 18 leis e várias outras resoluções sobre a forma pela qual as justiças procederiam nos processos, como receberiam as apelações, quando aceitariam advogados, e maneira pela qual estes e os procuradores exerceriam o seu ofício", de 18 de fevereiro de 1332, por sua Lei I): "E sse anbas as partes ou cada hua delas ueerem per procuradores os sobreJujzes deuem logo a ueer as precurações que tragem E sse forem auondosas deuem logo a hir pelo preyto adeante assy como dicto he $\mathrm{E}$ sse o nom forem os ssobreJujzes o deuem a coReger e assinaar logo tenpo conuenhauil a precuraçom auondosa pagando aa outra parte que for detheuda as custas daqueles dias ou lhas fazendo pagar ao tabelliom sse uirem que per ssa mjngua a precuraçom nom he auondosa. e outra Reuelia nom na Julguem. E depoys que a parte ueer ou precurador auondoso uaa pelo preyto adeante como dicto he" (Livro das Leis cit. (nota 87), p. 228; e em Ordenações Del-Rei cit. (nota 87), pp. 317-318, sob o título "Se as partes enujarem os seus procuradores os sobreJuizes deuem de ueer as procuraçoees E se acharem que os procuradores som auondosos deuem a hir pollo feito adiante").

Nas "Ordenações Afonsinas" nos deparamos com uma disciplina bastante mais minudente a respeito da questão, uma vez que esta não é abordada apenas sob a perspectiva material, mas inclusive processual. Assim, quando a parte comparece em juízo por meio de procurador, estabelece o texto afonsino um dever de controle quanto à suficiência do negócio jurídico de outorga, atribuído ao próprio órgão jurisdicional (Ord. Af. III, 20,11): "Item. Se alguu faz citar outro, e ambos vem a Juizo, deve o Juiz de ver se cada huua das partes ou ambas vem per Procuradores, ou per pessoa; e se veerem per Procurador, veja loguo a Procuraçaõ se he abastante pera tal feito, e assi o pernuncie o Julgador; e ate que assi nom seja julguado, nam vaa pelo feito em diante; porque muitas vezes acontece fazerem-se grandes processos com Procuraçoens naõ soficientes, e quando sam achadas por taes, anichelam todos os processos com grande gasto, e despeza das partes: e por tanto Mandamos aos Juizes, que dos feitos conhecerem, que ante que por os ditos feitos procedam, dem detriminaçaõ sobre as ditas Procuraçoens, como dito he, ca em outra guisa paguarám per seus bees aas partes toda perda, e gasto, que por a dita rezam ouverem recebido" (Ordenações Afonsinas III cit. (nota 87), p. 79). Observe-se que embora seja atribuída ao magistrado a responsabilidade direta pelo controle quanto à suficiência dos poderes dos procuradores, o texto afonsino faculta aos próprios adversários tal 
investigação; assim, em Ord. Af. III, 20, 15 se estabelece que "assy deve o Reo ver se o Autor vem per pessoa, se per Procurador (...) e se per Procurador, deve dizer contra a Procuraçaõ daquelle, que o citou, ou contra a pessoa do Procurador, que o naõ pode ser por a Procuraçaõ naõ ser sofficiente" (Ordenações Afonsinas III cit. (nota 87), pp. 81-82). Com efeito, na hipótese de insuficiência dos poderes, caso se tratasse do procurador do autor, o réu seria então absolvido; e em se tratando do agente do réu, seria este considerado revel (Ord. Af. I, 13, 9; Ord. Af. III, 20, 17; Ord. Af. III, 20, 18). Entretanto, tais sanções não eram aplicadas imediatamente (Ord. Af. III, 68, 4); em uma consagração do princípio da economia processual (em meados do século XV), determinava-se ao magistrado que concedesse prazo para a regularização da procuração (procuração-ato), seja mediante nova outorga de poderes, seja sob a forma de ratificação dos atos praticados pelo agente: "E se os Juizes d'alçada acharem, que cada huua das cousas falecidas, ou erradas no dito processo sam necessarias pera a sustancia do Juizo, façam-nas correger, e poer em elle, em tal guisa que o Juizo seja ordenado como deve, e nam anulem porem o processo, como dito he: assy como se o feito fosse tratado per Procurador com procuraçom nom sufficiente (...) ca em taes casos, e outros semelhantes devem os Juizes d'alçada mandar ao que fez a procuraçam nom suficiente pera o dito Juizo, que a faça soficiente, e abastante pera ello, ou confirme o Juizo, que per a primeira procuraçam foy tratado, se não ouver rezam lidima, porque o nam aja de fazer" (Ordenações Afonsinas III cit. (nota 87), p. 253). Curiosamente, tal confirmação seria feita à vista de uma intimação da parte por meio do próprio procurador "insuficiente" (Ord. Af. I, 13,11), cujos atos tinham sua validade suspensa até que sobreviesse a nova outorga - ou a referida ratificação (Ord. Af. I, 13, 8).

Nas "Ordenações Manuelinas" as disposições relativas ao tema são em quase tudo idênticas; neste sentido, cf. Ord. Man. I, 38, 12; Ord. Man. I, 38, 13; Ord. Man. III, 15, 10; e Ord. Man. III, 15, 11. Todavia, merece destaque o fato de que, sendo constatada pelo órgão jusrisdicional a insuficiência da procuração, não mais se determina uma intimação da parte por meio do procurador "insuficiente"; caberia, na hipótese, uma comunicação direta do magistrado à parte, a fim de que providenciasse, em prazo razoável, a provisão de poderes (ou a ratificação). Eis o teor de Ord. Man. III, 49, 1: "E se o erro do processo for por se aleguar (...) que se trautou o feito por Procurador nom suficiente (...) e se aleguar o tal erro no primeiro Juizo antes de o Juiz teer dada sentença, elle mesmo o soprirá, mandando ao que fez a procuraçam nom suficiente, que a faça suficiente (...) assinando-lhe pera ello termo conueniente, segundo a distancia do Luguar onde esteuer o que assi ha de fazer a procuraçam (...) e esto todo fará, sem por ello os autos atee alli processados serem auidos por ninhuus" (Ordenações Manuelinas III cit. (nota 87), pp. 183-184).

As "Ordenações Filipinas" dispuseram em sentido idêntico a respeito da questão (cf. Ord. Fil. III, 20, 10; Ord. Fil. III, 20, 11; Ord. Fil. III, 20, 12; e Ord. Fil. III, 63, 1); o que não deixa de nos parecer uma espécie de retrocesso, uma vez que - posto de parte qualquer juízo de mérito a respeito da responsabilidade dos juízes (por meio de seu próprio patrimônio pessoal) pelo controle imperfeito da suficiência dos negócios jurídicos de outorga de poderes - no período pré-filipino foi promulgada (por D. João III) a Carta Régia de 05 de julho de 1526, em virtude da qual se atribuiu o ônus (econômico) de tal prejuízo à parte a quem a culpa poderia ser imputada (S. III, 1, 7, 33): "e sendo algus autos julgados por nenhus, por causa do desfallecimento dalgua solenidade, será condenada nas custas a parte, por cuja culpa desfallesceo a tal solenidade, por onde os autos forão ãnullados" (Leis Extravagantes cit. (nota 86), p. 97 verso).

Por fim, quanto à extensão dos poderes outorgados pelo constituinte ao seu procurador, há que se destacar a existência de várias disposições do direito lusitano medieval relativas ao assunto: em primeiro lugar, a "Lei pela qual se estabelece que os procuradores chamados à composição possam alegar árbitros" ("Costituçam CRbj do poder dos procuradores"), em virtude da qual os agentes providos de poderes para transigir se compreendiam também aptos à celebração de compromisso (Livros das Leis cit. (nota 87), p. 224; e em Ordenações Del-Rei cit. (nota 87), p. 119). Além disso, na já referida "Lei sobre os procuradores" se preceituava a ampla abrangência da procuração judicial, a abranger não somente a instância na qual era concedida, mas tornando o agente apto a procurar durante toda a demanda, se necessário fosse (nas "Ordenações de D. Duarte" a matéria é disciplinada na "Constituçom Lx como o procurador do feito pode procurar perante o Juiz da apellaçom"): "En outra parte he estabeleçudo sse alguu homem he que aia preyto com outro e ha de meter alguem por seu precurador ante aqueles Jujzes que aquel preyto ouuerem outorgar ante eles por seu precurador alguem e perdante ElRey se mester for ou perdante a ssa corte se lhi for mester mandamos que lhi ualha assi ssobre a alçada come sobre toda a demanda se lhi for mester. e a Razõar sobre a alçada" (Livro das Leis cit. (nota 87), p. 218; e em Ordenações Del-Rei cit. (nota 87), p. 98). Por sua vez, a utilidade da regra contida na "Constituçam CRij como o procurador pode procurar" (preceito constante unicamente nas "Ordenações de D. Duarte") é inversamente proporcional à sua extensão: "Costume he em cassa del Rej que sse alguum ssoestabeleçe seu procurador E o estabeleçeo ssobre aquelle artigoo que spiçiallmente he chamado assi como sobre purgar rreualia ou sobre carta del Rej faça ende mençaam na procuraçom" (Ordenações Del-Rei cit. (nota 87), pp. 118-119); de fato, aí temos a consagração da necessidade de poderes especiais para a prática de algumas espécies de atos (judiciais), como a purgação da 
$\S$ 110. "Livro das Leis e Posturas" e "Ordenações de Dom Duarte": eficácia da atuação do "vogado". Favorecendo sua aproximação em relação ao "procurador", o "Livro das Leis e Posturas" e as "Ordenações de D. Duarte" atribuem dois deveres fundamentais ao "vogado": em primeiro lugar, deve observar criteriosamente as "posturas", sob pena de responsabilidade pelas custas de interposição de recurso inadmissível; além disso, cumpre-lhe promover uma "gestão colaborativa" do processo, evidenciada por um acompanhamento diligente do procedimento - ao qual deveria imprimir uma brevidade correspondente aos interesses de seu cliente. Aliás, tamanha era a preocupação do legislador com a celeridade processual, que se buscou limitar o número de "vogados" a acompanhar o litígio - restringindo-se, ainda, as oportunidades de dilação do feito para o aconselhamento das partes junto aos seus patronos. Especificamente no âmbito da relação mantida entre o advogado e seu cliente, as fontes lusitanas medievais preceituavam a responsabilização daquele (por meio da perda de seus salários) nos casos de desídia ou de abandono da causa - sendo que nesta última hipótese também se determinavam a reparação dos prejuízos experimentados, o reembolso das despesas assumidas (com a contratação de substituto) e a restituição, em dobro, das parcelas remuneratórias antecipadas ao agente ${ }^{90}$.

revelia; observe-se que na "Lei pela qual se determina que, nem na corte, nem nas audiências dos concelhos, haja advogados nem procuradores de número, e estabelecendo várias outras providências para evitar demoras no seguimento dos pleitos" - de 03 de novembro de 1352 - se prevê o juramento como ato pessoal da parte, suscetível de prática por meio de procurador (Livro das Leis cit. (nota 87), p. 456).

Durante o século XIX a questão foi disciplinada no âmbito da legislação brasileira, por meio dos artigos $2^{\circ} \mathrm{e}$ $3^{\circ}$ do Aviso ${ }^{\circ} 82$, de 30 de março de 1849 , nos quais se estabeleceu a necessidade de poderes especiais para que o procurador recebesse (e desse quitação) pelo constituinte, além do prazo ânuo de vigência do negócio jurídico de outorga - excetuada a hipótese de procuração com prazo indeterminado de vigência, cuja eficácia ficava subordinada, de todo modo, à apresentação "ad hoc" de sua "publica-forma" (bem como da certidão de vida do principal).

90 A respeito da responsabilidade e dos deveres genéricos dos "vogados", eis o que dispõe a "Lei sobre advogados": "Dos vogados. Jtem do feyto dos uogados manda que hussen e aguardem as sas pusturas e aiam todos e hussem bem da uogayrya e nom façam perlonga nos preytos nem nos tragan maliciosamente so a pea scrita na ssa ley. E sse esses uogados desempararen hos preytos e se forem da corte sen leçença sua delRey manda que paguem as custas aaqueles cuius preytos teuerem e se as partes tomarem outros uogados por dynheyros. per culpa deles manda que lhis paguem quanto derem aos uogados que tomarem. E sse hos uogados que sse forom reçeberom ia alguus dynheyros daqueles cuius preytos leixarom manda elRey que lho tornem dubrados. E sse pela uentuyra per mygua do uogado deren sentença de Reuelya outra qualquer contra a parte per que si lhy sigua perda ou dano manda elRey que lho corregua todo de ssa cassa o uogado que auya o preyto a defender. E sse non ouuer per que o corregua hos danos e as perdas e as custas. manda elRey que correguam pelos corpos. Jtem sse appellar contra as pusturas de ssa corte pague as custas de ssa cassa aa parte e esto meesmo manda se mouerem contra as sas pusturas saluo se lho elRey ffezer de graça e esto manda que sse guarde tambem nos procuradores come nos uogados" (Livro das Leis cit. (nota 87), p. 99; e em Ordenações Del-Rei cit. (nota 87), pp. 169-170, sob os títulos "Ley xxiij dos uogados como deuem leuar os ssolairos" e "'Ley. xxiiij. que sse apellar contra a postura que pague as Custas"). Note-se que em tal diploma a "uogayrya" é disciplinada com relativa autonomia em relação à "procuração" (a despeito da aproximação levada a efeito na parte final do texto legal) - o que não se verifica nas Leis de 12 de junho de 
1302 (Livro das Leis cit. (nota 87), pp. 165-167) e 10 de junho de 1303 (Livro das Leis cit. (nota 87), pp. 199-200). Aliás, na "Ley .xx. que pena deue d'aueer o procurador que apelar contra a postura da corte" coligida tão somente nas "Ordenações de D. Duarte" - se reconduz ao "procurador" disposição normalmente atribuída ao regime da "vogaria" (Ordenações Del-Rei cit. (nota 87), p. 169). No mesmo sentido da referida "Lei sobre advogados", cf. Ord. Af. I, 13, 2; Ord. Af. I, 13, 3; e Ord. Af. I, 13, 29. Quanto ao abandono da causa, contudo, encontramos nas "Ordenações Afonsinas" (Ord. Af. I, 13, 7) previsão de isenção da pena em "caso de necessidade taõ grande, e taõ manifesta, per que elle deva seer relevado desta pena, posto que em ella encorra" (Ordenações Afonsinas I cit. (nota 87), p. 88). De tal forma, ainda que à custa do recurso a conceitos jurídicos indeterminados, evidencia-se uma espécie de temperamento ao excessivo rigor defluente da aplicação automática do regime jurídico afeto ao abandono da causa pelo advogado.

Já no que toca às "Ordenações Manuelinas", há que se destacar a ampliação da responsabilidade do "vogado" que inobserva as posturas, na medida em que lhe são imputadas as custas processuais em qualquer hipótese de violação, e não apenas por ocasião da interposição de recurso (cf. Ord. Man. I, 4, 15; Ord. Man. I, 38, 29; e Ord. Man. I, 38, 4). Por sua vez, desponta uma primeira disciplina a respeito do procedimento de "liberação" do advogado durante o pleno exercício de suas funções (Ord. Man. I, 38, 9): "e seram auisados esses Procuradores, que nom desemparem os feitos, nem se vam da Corte, ou d'outros Luguares onde os trautarem, saluo se teuerem tal necessidade ou impedimento, que nom possam al fazer, a qual notificaram ao Juiz do feito; e auendo tal Juiz enformaçam do impedimento, ou necessidade que lhe he aleguada, sendo o impedimento tal, por que nom pode, ou nom deue seer Procurador, a parte, ou partes contrairas, que os feitos quiserem seguir, hiram citar as outras partes, pera proseguirem os ditos feitos" (Ordenações Manuelinas I cit. (nota 87), p. 238). Ressalte-se, ainda, que em caso de abandono (injustificado) da causa, a reparação - à custa dos bens do infrator - é reforçada pela possibilidade de prisão coercitiva do advogado (Ord. Man. I, 38, 11): "e nom tendo por onde paguar será preso atee a parte, ou partes serem satisfeitas" (Ordenações Manuelinas I cit. (nota 87), p. 238). Sem qualquer alteração de fundo, cf. Lei de 18 de novembro de 1577 (§ 25); Lei de 24 de março de 1590 (§ 17); Ord. Fil. I, 6, 11; Ord. Fil. I, 48, 7; Ord. Fil. I, 48, 8; e Ord. Fil. I, 48, 9.

Acerca da responsabilidade dos advogados em caso de desídia (com a conseqüente perda de seus salários), cf. a já referida "Ordenação de D. Afonso IV, contendo 18 leis e várias outras resoluções sobre a forma pela qual as justiças procederiam nos processos, como receberiam as apelações, quando aceitariam advogados, e maneira pela qual estes e os procuradores exerceriam o seu ofício", de 18 de fevereiro de 1332 (Livro das Leis cit. (nota 87), pp. 240-241; e em Ordenações Del-Rei cit. (nota 87), pp. 333-334, sob os títulos "Como se deue de fazer quando as partes negarem o feito $\mathrm{E}$ se os uogados forem negrigentes como nom deuem d'auer sollairo" e "Que pena deuem d'auer os uogados E procuradores que maliciosamente trautarem os feitos ou em elles forem negligentes").

Tivemos a oportunidade de observar que em meio às fontes castelhanas havia uma limitação à multiplicidade de agentes encarregados do exercício da "personeria" judicial (FR. I, 10, 15); conquanto ali tal providência fosse justificada à vista da salutar tramitação do processo no qual tal pluralidade se verificasse, em meio às fontes lusitanas medievais outra foi a explicação oferecida para tal restrição ("Lei pela qual se determina a forma que se devia seguir nos diversos pleitos, tendo por fim providenciar contra o abuso que os advogados e procuradores praticavam, prolongando fraudulentamente as causas de que tratavam", de 15 de setembro de 1313): "Jtem nos feytos se faz muytas perlongas per Razon que as partes tomam dous dous uogados ou mais E por estan as outras audiençias quedas porque todolos uogados estan en huu preito. E pera esta delonga e este dano seer tolheito cada huua das partes tomem senhos uogados quaes quisserem dos que touerem por uogados e os outros se os mester ouuerem nas outras audiençias logo uaan a eles e nom seiam enbargados pero esten naquel preito e aian daJudar algua das partes pois ia cada huua das partes escolher senhos uogados principaes e nom seiam atendudos hos outros uogados nas outras audiençias saluo aquels que as partes escolherem pera aJuda do seu feito" (Livro das Leis cit. (nota 87), p. 175; e em Ordenações Del-Rei cit. (nota 87), p. 292, sob o título "Como as partes nom deuem filhar mais que huum uogado"). Como se pode observar, tal preceito deita raízes em considerações coletivas, voltadas à adequada administração dos litígios (considerados "em bloco"). Daí a razão do "substabelecimento compulsório" determinado pela Provisão "Como o procurador que trouuer mujtos feitos da terra se forem partidos per desuairadas audeancias deue soestabelleçer procuradores em cada hua audiançia E pode fazer seu feito" (Ordenações Del-Rei cit. (nota 87), p. 315).

A respeito do aconselhamento das partes por seus "vogados" - bem como das restrições legais a tal faculdade - cf., em meio às fontes medievais, a "Ordenaçom. iiij. quaaes pesoas nom podem auer uogados em seus preitos" (Ordenações Del-Rei cit. (nota 87), pp. 78-79); bem como a já mencionada "Ordenação de D. Afonso IV, contendo 18 leis e várias outras resoluções sobre a forma pela qual as justiças procederiam nos processos, como receberiam as apelações, quando aceitariam advogados, e maneira pela qual estes e os procuradores exerceriam o seu ofício", de 18 de fevereiro de 1332 (Livro das Leis cit. (nota 87), pp. 239-240; 
$\S$ 111. "Livro das Leis e Posturas" e "Ordenações de Dom Duarte": disposições de cunho ético-moralizador e a proibição da atuação "maliciosa" do agente. Conquanto em algumas raras passagens do "Livro das Leis e Posturas" e das "Ordenações de D. Duarte" os "procuradores" e "vogados" tenham sido considerados autênticos auxiliares do juízo na busca pela verdade, preponderou o pessimismo a respeito de sua atuação - a ponto de terem sido proscritos por D. Afonso IV (por meio da Lei de 20 de maio de 1351). Visando coibir a malícia de tais agentes, foram promulgadas regras destinadas a obviar as principais manobras processuais relacionadas ao seu concurso; prescrevendo-se-lhes um comportamento leal - a implicar, inclusive, o juramento sobre os "sanctos auangelhos" - ao mesmo tempo em que se determinou a oitiva das partes antes da manifestação de seus "vogados", foi vedada qualquer espécie de contato íntimo entre o interessado e alguma das personagens envolvidas no desenrolar da lide. E à semelhança do que se pôde vislumbrar quanto aos direitos visigótico e castelhano, houve uma preocupação constante com o efetivo equilíbrio entre as partes envolvidas no litígio, a fim de que ambas estivessem adequadamente assistidas - mesmo que a controvérsia implicasse a necessária participação de pessoas poderosas ${ }^{91}$.

e em Ordenações Del-Rei cit. (nota 87), p. 332, sob o título "Como os uogados deuem fazer"). Com relação às "Ordenações do Reino", cf. Ord. Man. III, 15, 4.

${ }^{91}$ Em uma abordagem favorável à atuação dos "procuradores" e dos "vogados", na "Lei pela qual se determina a forma que se devia seguir nos diversos pleitos, tendo por fim providenciar contra o abuso que os advogados e procuradores praticavam, prolongando fraudulentamente as causas de que tratavam" (de 15 de setembro de 1313) se assevera que tais agentes deveriam se comportar com a lisura devida, a fim de colaborar com a descoberta da verdade: "Jtem hos uogados hos procuradores deuen ben e dereitamente punhar de chegar se e sabere se a uerdade asy como he conteudo nas coussas sussodictas ou per outros quaesquer per que se aJnda mais aginha possa fazer" (Livro das Leis cit. (nota 87), p. 175; e em Ordenações Del-Rei cit. (nota 87), p. 292, sob o título "como os procuradores E os uogados deuem husar").

No entanto, prevaleceu uma impressão negativa a respeito da atividade desenvolvida por tais personagens; neste sentido, no proêmio da "Ordenação de D. Afonso IV, contendo 18 leis e várias outras resoluções sobre a forma pela qual as justiças procederiam nos processos, como receberiam as apelações, quando aceitariam advogados, e maneira pela qual estes e os procuradores exerceriam o seu ofício", de 18 de fevereiro de 1332, se observa que "Dom affonsso ueendo que nos seus Reynos muytos Reçebiam gram dano pela delonga en que andauam nas demandas que faziam ou que lhi eram fectas E que esto era per tal guisa que ahijnda que cada huu uençesse que tiraua ende mayor dano que em prol daquelo que uençia $\mathrm{E}$ que aas uezes per proçessos que se faziam como non deujam alguus perdiam o seu derejto $\mathrm{E}$ uençiam aqueles que deujam a seer uençudos (...) E que a mayor parte deste dano e desta delonga era pelos precuradores que eram na nossa corte que uogauam e precurauam os preytos e que catauam tantas delongas e aas uezes tantas maliçias per que os preytos que sse podiam desenbargar en breue tenpo durauam longamente e alguus nunca eram desenbargados. E porem nos querendo catar camjnho per que este mal sseia Refreado E os que demandas ouuerem nom andem en delongados preytos e possam auer Jgualdade de dereyto. o qual dano pode seer escusado con gram prol ssegundo o Razom que sse segue" (Livro das Leis cit. (nota 87), p. 226; e em Ordenações Del-Rei cit. (nota 87), pp. 315-316, sob o título "Esta he a ordenaçom que fez o muy nobre Rey dom afonsso o quarto em Razom dos feitos como se am de trautar E liurar na sa corte E nos seus Regnos na quall estabelleçeo que nom ouuese uogados nem procuradores Regidentes na sa corte"). Em sentido idêntico, no âmbito do direito lusitano medieval, cf. a "Lei sobre procuradores" (Livro das Leis cit. (nota 87), pp. 9899; e em Ordenações Del-Rei cit. (nota 87), p. 168, sob o título "ley. xbiij. que pena deuem auer os 
procuradores que deteuerem os feitos"), a "Lei sobre advogados" (Livro das Leis cit. (nota 87), p. 99), a Lei de 12 de junho de 1302 (Livro das Leis cit. (nota 87), pp. 166-167) e a "Lei com várias disposições sobre o exercício das funções de juízes, advogados, procuradores, tabeliães e outros oficiais de justiça" - na qual se comina, inclusive, a pena de privação definitiva de tais ofícios (Livro das Leis cit. (nota 87), pp. 265-266; e em Ordenações Del-Rei cit. (nota 87), pp. 356-357, sob o título "Como os Juizes nom deuem conssintir aos Vogados E procuradores que trautem os feitos malleçiosamente E que pea deue d'auer o que esto fezer”). Com relação ao período das "Ordenações do Reino", sem qualquer alteração de fundo, cf. Ord. Af. I, 13, 29; Ord. Af. I, 13, 32; e o Alvará de 04 de julho de 1515 (referido em J. ANASTÁcio DE FigueIREDO, Synopsis Chronologica I cit. (nota 86), p. 200).

Com efeito, tal situação de animadversão culminou com a proscrição dos advogados e procuradores de Portugal, promovida por D. Afonso IV, à custa da Lei de 20 de maio de 1351: "Tenho por bem e ponho por lej pera senpre $\mathrm{E}$ mando que daqui adeante nom aiam vogados nem procuradores $\mathrm{E}$ se os vogados e procuradores uoguarem ou procurarem os Juizes de cada huu loguar dos meus senhorios lhis deffendam so pea dos corpos que nom voguem daqui adeante so pea de lhes fazer eu em eles o que for mha merçee $\mathrm{E}$ outrosj lhes defendo. so pea da mha merçee que nom façam nenhuas rrazões ascondudamente aas partes" (Livro das Leis cit. (nota 87), p. 439; e em Ordenações Del-Rei cit. (nota 87), p. 549, sob o título "ley per que el rej mandou que no seu Regno nom aJa uogados nem procuradores"); cf. ainda, a Lei de 03 de novembro de 1352, confirmando tais disposições especificamente quanto aos "procuradores de número" (Livro das Leis cit. (nota 87), pp. 452-458; especialmente pp. 452-453).

Ademais, a análise das fontes do direito lusitano medieval nos revela uma atenção especial do legislador com relação à repressão ao emprego malicioso de expedientes processuais pelos "procuradores" e "vogados"; neste sentido, pela "Lei pela qual se determina que em certas condições se não atenda advogado" se reprovou a constituição de advogado após o encerramento da instrução processual, às vésperas da leitura da sentença respectiva - exceto se a parte sustenta que há matéria que a favorece e que não foi alegada ou considerada pelo juiz (hipótese em que a parte deverá proferir “juramento", produzindo alegações no prazo judicial respectivo): "como nom atendam aa parte vogado. En outra parte seer faz perlonga grande per que as partes ou os procuradores pedem que lhis atendam uogados depois que he ensarrado no Juyz e lhis assijna dia a que uenham ouuyr sentença sobrello ensarramento que en esse Juyz fezerom para se tolher depoys que as partes. per si ou per seus uogados ensarrarem no Juyz e lhis assinaar dia a que uenham ouuyr sentença. se as partes ambas ou cada hua dellas dizem que lhis atendam uogados. o Juyz nom lhos atenda e de sentença segundo en el for ensarrado. E se apellar per rrazom do uogado. o Juyz nom lha receba nem lhe ualha a apellaçom. pero se quiser dizer alguas rrazões de nouo ueesem ou outras que aynda nom disesse que fossem taaes que fezessem aJuda a seu ffeyto per que despereceria o seu dereyto se as nom disesse. Entom o Juyz receba del Juramento que as rrazões que quer dizer que as nom quer dizer maliciosamente. e se Jurar e o Juyz uir que som recebedoyras. entom lhi ponha prazo a que uenha en outro dia com uogado ou per si a poer. e se non ueer outro prazo pera esto nom ia. E o Juyz Julgue pello que lhi adeante foy dicto. E se apellar per rrazom do prazo que lhi o juyz nom da nom lha receba nem ualha a apellaçom e uaa adeante pello preito commo vir que he dereito" (Livro das Leis cit. (nota 87), pp. 89-90). No mesmo sentido, cf. a Lei de 15 de setembro de 1313 (Livro das Leis cit. (nota 87), pp. 174-175; e em Ordenações Del-Rei cit. (nota 87), p. 291, sob os títulos "como aas partes non deuem atender uogados" e "em quaaes casos aa parte ou a seu procurador nom deuem Receber apellaçom”); Ord. Af. III, 49; e Ord. Man. III, 33. Por meio da Carta Régia de 05 de julho de 1526 (S. III, 1, 7, 25), D. João III extirpou a exceção já prevista no texto medieval, inadmitindo - em qualquer hipótese - a constituição de advogado após a conclusão do feito; orientação que prevaleceu, afinal, nas "Ordenações Filipinas” (Ord. Fil. III, 20, 30).

Por sua vez, visando coibir abusos relacionados a pedidos de dilação - sob o fundamento da necessidade de aconselhamento junto aos respectivos advogados - a "Lei pela qual se declara prejuro aquele que, jurando de malícia, quando pede advogado, o não apresente no dia que lhe for marcado e se regulamentam apelações em terras sujeitas a jurisdição de ordens", do mês de janeiro de 1271, assim dispõe: "Como o procurador que pede uogado e Jura se nom uem fica periuro. Estabelecemos que se alguem iura de malicia quando pede uogado e lhi pooem dia assynado a que o de. e nom uay ou manda. por el ao dya assynado mandamus que fique por ffe peiuro (...) e esto foy estabeleçudo no mes de Janeiro. Era. M. CCC e ix" (Livro das Leis cit. (nota 87), pp. 95-96; e em Ordenações Del-Rei cit. (nota 87), p. 108, sob o título "constituçom. Cbiij. que pena deue d'auer o que pede uogado se nom ueem con ell ao tenpo"). No mesmo sentido, cf. "Lei com várias disposições sobre o exercício das funções de juízes, advogados, procuradores, tabeliães e outros oficiais da justiça" (Livro das Leis cit. (nota 87), p. 266; e em Ordenações Del-Rei cit. (nota 87), p. 357, sob o título "como E a que tenpo o procurador que o feito teuer deue a pidir vogado E que pea deue d'auer o procurador que o pidir como nom deue").

Pela prescrição de um bom uso da "vogaria" - no âmbito das fontes do direito lusitano medieval - cf. a "Lei sobre advogados" (Livro das Leis cit. (nota 87), p. 99; e em Ordenações Del-Rei cit. (nota 87), p. 169, sob o 
título "Ley xxiij dos uogados como deuem leuar os ssolairos"), a Lei de 12 de junho de 1302 (Livro das Leis cit. (nota 87), pp. 166-167), a Lei de 26 de fevereiro de 1283 (Livro das Leis cit. (nota 87), p. 190; e em Ordenações Del-Rei cit. (nota 87), pp. 175 e 293, sob os títulos "ley que os vogados quando os feitos ueerem Jurem que manteem dereito" e "como os uogados E procuradores deuem Jurar que manteem bos preitos"), a Lei de 10 de junho de 1303 (Livro das Leis cit. (nota 87), p. 199), a Lei de 18 de fevereiro de 1332 (Livro das Leis cit. (nota 87), pp. 238-241; e em Ordenações Del-Rei cit. (nota 87), p. 332, sob o título "como deuem dar uogado") e a "Ordenaçom ij. como no artijgo da apellaçom Recebam aas partes Razooes de nouo E hu dous sobreJuizes acordarem que esta sentença ualha E quantos uogados deue auer em cada audiancia" (Ordenações Del-Rei cit. (nota 87), p. 313). Em meio às "Ordenações do Reino de Portugal”, cf. Ord. Af. I, 13, 2 e Ord. Man. I, 38, 4.

No que toca à oportunidade da manifestação dos advogados, a Lei de 18 de fevereiro de 1332 determina que esta se dê após a oitiva das partes, a fím de que a convicção do órgão jurisdicional não seja prejudicada por induções maliciosas de tais agentes: "quando as partes veerem perante os Juizes ou sobreJuizes per sy, ou per seus Procuradores, que lhe contem o preito todo. Comvem a saber o demandado toda a sá demanda, e o demandador toda a sá defessa; e seja logo too escripto, e atá que o asy saibham, nom lhe recebam Vogado nenhuu porque o Vogado com malicia tornaria o feito de guiza, que os Juizes nom saberiam compridamente a verdade delle" (Livro das Leis cit. (nota 87), p. 238; e em Ordenações Del-Rei cit. (nota 87), pp. 331-332, sob o título "nos feitos que forem trautados nos conçelhos como os Juizes deuem saber a uerdade per as partes ante que lhes Reçebam os uogados nem procuradores").

Uma disposição interessante - exclusivamente constante das fontes lusitanas medievais - consta da Lei de 29 de julho de 1311, por meio da qual se proibiu qualquer espécie de contato íntimo entre as personagens envolvidas na solução do litígio e algum dos interessados: "estabelezco e ponho por ley com consselho de mha corte que daqui en deante nenhuu sobreJuiz, nem ouujdor nem clerigo nem leygo. nem precurador nem vogado nem scriuam nem porteyro. nem meyrinho nem algoz. nem outro nenhuu que hi tenha oficio que tanga aa Justiça nom Jazca. nem aia maao afamamento en fecto de fornizio com nenhua molher que ande en preyto nem casada nem ujuua nem virgem nem outra nenhua de qual guisa quer que sseia. tambem filha dalgo come vilãa" (Livro das Leis cit. (nota 87), p. 79; e em Ordenações Del-Rei cit. (nota 87), pp. 283-284, sob o título "ley que pena deue auer aquelle que tem ofiçio de Justiça se Jouuer com molher que aJa feito perante ell").

Merece destaque, ainda, a existência de uma série de preceitos voltados a promover o equilíbrio entre as partes litigantes - ambas devendo estar adequadamente assistidas por advogados capacitados. Neste sentido, a "Lei sobre procuradores, advogados, testemunhas e recursos para "casa del-rei"" assim estabelece: "Todo homem pode seer uogado en qual preyto quer (...) saluo (...) homem que tenha ia o ssolayro ou parte dele. dalguu pera teer seu preyto nom pode seer uogado pola outra parte. saluo se este de que el tem o ssolayro tem outro vogado E a outra parte nom poder auer uogado que tenha seu preyto. Ca enton como quer que ssa confissom sabha eo solayro dele Reçebesse conueRa que o de por uogado aa outra parte que nom pode auer uogado. saluo se este de que Reçebeo o ssolayro ou parte dele quer ante ficar com este vogado. e leyxar aa outra parte o outro que tenha com ele pera aiuda de seu preyto. Ca en sa escolhença he daquel que dous uogados tem ou mais de filhar quem quiser e o outro leyxar a sseu contemptor. E sse aquele vogado que ele leyxar a sseu contemptor aia ia o ssolayro del Reçebudo. ou parte dele deue lho atornar. poys que vogado da outra parte fica. Poys que ia sabedes das pesõas nom podem seer vogados en nenhuu preyto. segundo dereyto e costume" (Livro das Leis cit. (nota 87), pp. 35-36). Em sentido idêntico, ainda em meio às fontes do direito lusitano medieval, cf. as três "Leis sobre advogados na corte" (Livro das Leis cit. (nota 87), pp. 93, 122 e 218; e em Ordenações Del-Rei cit. (nota 87), pp. 98 e 107, sob os títulos "constituçom Lxi como na corte del rrey deue d'auer dous vogados" e "constituçom Ciij Como o que ha feito nom pode ffilhar mais de huum vogado"). No âmbito das "Ordenações do Reino de Portugal”, cf. Ord. Af. I, 13, 5; Ord. Af. I, 13, 20 ; Ord. Man. I, 38, 6; Ord. Man. I, 38, 22; Ord. Fil. III, 20, 14.

Finalmente, também podem ser consideradas disposições sociais aquelas envolvidas com a proteção às partes processuais que litigassem com poderosos; com efeito, em meio à "Concórdia de 40 artigos entre D. Dinis e os bispos do reino" (de 07 de março de 1289), o artigo XXIII preceitua (em resposta à reclamação promovida): "respondem os dauandictos procuradores que esse Rey ha en ssa casa vogados a que dam raçom e uestir que uoguem polo poboo e pola clerizia contra el meessmo aynda se mester for onde creem os procuradores que esto que se contem no artigo que o nom soube. elRey nem no ouuyo, que ffecto fosse ca se o soubesse, fezera o enmendar. E prometem que elRey mandara daqui adeante que taaes cousas nom se façam. É que praz a esse Rey que cada huu em ssa terra. liuremente aia uogado e cada huu vogado liuremente possa uogar assy como perteeçe e que os Jujzes lhj proueam de Vogados, aqueles que os nom ouuerem. e que se contra esto ffor fecto enmenda lo ha aaqueles que se ende queixarem" (Livro das Leis cit. (nota 87), p. 350; e em Ordenações Del-Rei cit. (nota 87), pp. 236-237, sob o título "como defende que nom aJa hi vogados"). 
§ 112. "Livro das Leis e Posturas" e "Ordenações de Dom Duarte”: duas disposições de ordem técnica, voltadas ao contingenciamento (administrativo) da procuradoria e à "vênia conjugal” (ou "procuração"). Quanto às fontes coligidas no "Livro das Leis e Posturas" e nas "Ordenações de D. Duarte", restam duas observações a fazer: em primeiro lugar, cumpre destacar a existência de uma espécie de contingenciamento profissional da procuradoria, criado pela "Lei com várias disposições sobre o exercício das funções de juízes, advogados, procuradores, tabeliães e outros oficiais de justiça", na qual se reconheceu a classe dos "procuradores de número"; contudo, ainda que durante um certo período tenha parecido necessário um controle administrativo sobre o exercício de tal atividade, tal categoria foi abolida posteriormente - conforme se depreende da Lei de 03 de novembro de 1352. Por sua volta, merece menção especial o regime jurídico da "vênia conjugal", instituído pela mesma Lei: buscando-se resguardar, ainda que parcialmente, o patrimônio da esposa (dos prejuízos decorrentes de uma malograda administração do acervo comum por parte do cônjuge), tornou-se indispensável sua outorga de "poder" (ou "procuração") para que o marido pudesse litigar sobre bem de raiz; além disso, nas “Ordenações de D. Duarte" é referido um costume por meio do qual se estende o emprego de tal instrumento à prática de atos de disposição (e mesmo à celebração de alguns contratos). De todo modo, parece-nos que neste ponto se evidencia uma junção indevida entre institutos jurídicos consideravelmente distintos; pois enquanto na "procuração" o agente atua em prol do principal, por meio da gestão de bens que integram o patrimônio deste último, na "vênia conjugal" pretende-se proteger os interesses daquele que, conquanto não seja titular (direto) de direito sobre o bem, pode ser afetado mediatamente - por um negócio jurídico concernente ao mesmo ${ }^{92}$.

\footnotetext{
92 A respeito do contingenciamento profissional instituído por meio do reconhecimento da categoria dos "procuradores de número", eis o teor do extrato correspondente da "Lei com várias disposições sobre o exercício das funções de juízes, advogados, procuradores, tabeliães e outros oficiais de justiça", compilada no "Livro das Leis e Posturas": "Como ElRey manda que em cada Villa aja certo numero de Procuradores ataá quatro, e que o Concelho nom ponha hy mais, nem brite o numero. Porque os Procuradores som muitos nas Villas, e nom podem aver porque se mantenham dos preitos, que tem, e por essa razom catam caminho, porque aja hy mais feitos, e durem mais, que deviam, e porque os homens não fazem sá prol de andarem em muitas demandas, e porlongadas, e pero ja sobre esto foi estabellecido certo numero de Procuradores, os Juizes e os outros que atá aqui foram, aqui esto pertencia britaram esse estabellecimento, porque alugaram seus parentes, ou criados, ou aquelles a que heram thudos, ou porque erão rogados, e meteram aalem desse numero outros muitos. Porem defende ElRey que em nhua Villa não aja mais de quatro Procuradores do numero, e se acontecer, que algum destes que ora hy ha de falecer por morte, ou por outra maneira qualquer, que nom ponham outros em seu logo ataá que sejão tornados ao dito numero de quatro, e des y adeante nom ponham mais, salvo se alguu morrer, ou leixar o Officio for alguma maneira, entam os Juizes com os Vereadores e homeens boons da Villa escolham outro para meterem em seu logo, que seja entendido, e de boas condicões, e hidonio pera este Officio, e doutra guisa os Juizes nem outros nhuus, nam possam fazer Procuradores, e se o fizerem nom o possam seer, nem os recebam por Procuradores esses que assy fizerem, e
} 
demais que seja estranhado a esses que o fezerem, como aaquelles que despreçam mandado d'EIREY" (Livro das Leis cit. (nota 87), pp. 270-271; e em Ordenações Del-Rei cit. (nota 87), p. 361, sob o título "como el Rey manda que em cada villa aJa çerto numero de procuradores ataa quatro $\mathrm{E}$ que o conçelho nom ponha hi mais nem brite o numero"). Ainda no âmbito das fontes do direito lusitano medieval, cf. "Dos procuradores E uogados se achar que nom som taaes quaaes deuem que ponham outros ou tolham delles se muytos forem" (Ordenações Del-Rei cit. (nota 87), p. 505).

No que toca ao regime jurídico da "vênia conjugal", do "Livro das Leis e Posturas" pode ser extraída a seguinte disposição, constante da "Lei pela qual se determina que o marido não possa litigar sobre coisa imóvel sem consentimento da mulher": "Que molher nom pode meter a preyto cousa de rrayz sem seu marido. Estabeleçemos que aquel que a molher nom possa aduzer nem meter a Juizo, quer seia auctor quer Reo casa nem herdade nem ujnha nem outra cousa que nom seia mouel sen procuraçon ou sem consentimento de ssa molher. e se o fezer en outra guyssa senom commo susodyto he non ualha quanto hy for feyto" (Livro das Leis cit. (nota 87), pp. 123-124). Note-se que há uma aparente contradição entre o início do texto e seu desenvolvimento (anuncia-se prescrição relacionada à esposa e se regula o comportamento do marido); contudo, no extrato correspondente, constante das "Ordenações de D. Duarte", tal equívoco material é contornado pelo título "Constituçom CXij como o que he casado nom pode meter a preito nem a Juizo posissam sem outorga ou procuraçom de ssa molher" (Ordenações Del-Rei cit. (nota 87), p. 109). Entretanto, como se pode depreender da análise de tal dispositivo, alude-se à "vênia conjugal" por meio das expressões "procuração" e "consentimento"; ora, evidenciando-se em um ato unilateral, o negócio jurídico de outorga de poderes não pode ser confundido com manifestação de consentimento. Da mesma forma, despontando tutela aos interesses daquela que não é titular (direta) de direitos sobre um determinado bem de raiz, parece-nos inteiramente fora de propósito o emprego do termo "procuração". Justificando a orientação de tal preceito, na Lei de 03 de novembro de 1352 se ressalta que "et porque achamos que alguus fectos de Rayz ou doutras cousas semelhauijs a eles eram amilhadas que as Molheres dos Reos nom eram chamadas ou os autores eram cassados e demandauam sem poder das ssaa molheres o que nom podiam per nossa ley. pola qual razom Recebiam gram dampno. MANDAMOS e ordinhamos que tanto que o Juyz vir e entender o que o autor pede que demanda e o que el pede tange a cousa de rayz ou de Rendas ou trebutos pera senpre que o Juyz faca pergunta aas partes se tragem poder de sas molheres e se disserem que nom tragem poder ou trouxerem procuracom nom sofficiente asijnem lhis dia a que a tragam sofficiente e avondosa e nom leyxem entanto douuir o fecto E quando veerem as procuracões facan as poer na auta e valha o que for fecto ata esse ponto" (Livro das Leis cit. (nota 87), p. 456). Expandindo-se a aplicação de tal instituto a alguns contratos (bem como aos negócios de disposição subseqüentes), eis o teor do costume compilado nas "Ordenações de D. Duarte": "costume he desy he dereito que o marido possa vender E meter a preito E a Juizo asy em demandar como em defender os beens movijs que ouuer com sua molher sem procuraçam E outorgamento della. E pode rrendar as herdades E posysoees taa dez anos salluo se lhe for defeso pollas Justiças que o nom faça ou se for Jullgado por treedor ou aleyuoso" (Ordenações Del-Rei cit. (nota 87), p. 207).

Em meio às "Ordenações do Reino", há que se destacar a existência de inúmeros aspectos da "vênia conjugal" de indiscutível interesse - tais como as consequiências de sua inobservância nos âmbitos processual (Ord. Af. III, 45 pr.; Ord. Man. III, 32 pr.; Ord. Fil. III, 47 pr.) e material (Ord. Af. III, 46; Ord. Af. IV, 11; Ord. Af. IV, 16; Ord. Man. IV, 6; Ord. Man. IV, 13; Ord. Fil. IV, 48; Ord. Fil. IV, 60; Ord. Fil. IV, 64), as implicações do casamento superveniente à demanda (Ord. Af. III, 45, 4; Ord. Man. III, 32, 3; Ord. Fil. III, 47, 3), a responsabilidade pelo controle de sua necessidade (Ord. Af. III, 45, 2; Ord. Man. III, 32, 2; S. III, 1, 7 , 33; Ord. Fil. III, 47, 2), o acolhimento da aparência relacionada à manutenção do estado civil do litigante (Ord. Af. III, 45, 5; Ord. Man. III, 32, 4; Ord. Fil. III, 47, 3) e os mecanismos destinados à coibição de fraudes (Ord. Af. III, 45, 13; Ord. Af. III, 45, 14; Ord. Af. III, 45, 15).

Contudo, dados os limites específicos do presente estudo, limitamo-nos a observar o posicionamento adotado por tais fontes do direito lusitano - posteriores ao "Livro das Leis e Posturas" e às "Ordenações de D. Duarte" - no que concerne à aproximação entre "vênia conjugal" e "procuração". Assim, por uma abordagem indistinta de tais espécies, cf. Ord. Af. III, 45, 1 e o cap. 7 das Cortes de Lisboa de 1498.

Observe-se, contudo, que no Regimento da Fazenda de 17 de outubro de 1516 - por seu capítulo 170 - havia menção indiscrimada a "outorgamento" ou "consentimento": "Item se algu homem casado ficar por fiador de qualquer pessoa sem outorgamento da sua mulher, não poderá por tal fiança obrigar os bens de raiz quato pertence á ametade, que a dita sua mulher nos ditos bens tiver, nem se fará por tal fiança ou obrigação execução algua na dita ametade dos bens de raiz; e isto que dito he, nos praz que assi meesmo haja lugar em quaesquer pessoas, que fiarem alguns nossos Rendeiros, ou alguns outros nossos devedores sem outorgamento de suas mulheres: por quanto queremos que por taes fianças se não possa fazer execução na ametade dos bens de raiz, que ás mulheres, que nas ditas fianças não consentirão, pertencer; e isto sem embargo de por ElRey D. Affonso meu tio (a que Deus perdoe) ser determinado que em suas rendas e diuidas podessem os maridos fiar e obrigar todos os seus bens sem consentimento de suas mulheres: e esta maneyra 


\section{$\S$ 113. "Ordenações Afonsinas": impedimentos objetivos à utilização de}

procurador (crimes com pena cominada superior ao degredo e comparecimento determinado pelo órgão jurisdicional). Tivemos a oportunidade de observar que a legislação lusitana medieval proibia, genericamente, a atuação de procuradores em processos criminais. Todavia, tal vedação foi mitigada no cenário das "Ordenações Afonsinas", conforme se pode depreender da conjugação entre Ord. Af. III, 8 ("Dos que podem, e devem ser citados que pareçam pessoalmente em Juizo") e Ord. Af. I, 13, 22: com efeito, somente o acusado pela prática de crime ao qual se cominava pena maior do que o degredo estava impedido de lançar mão de tal personagem para atuar em juízo assim como aquele que teve seu comparecimento pessoal determinado pelo órgão jurisdicional. Note-se, entretanto, que a um tal panorama devem ser acrescidas duas regras adicionais: em primeiro lugar, caso houvesse demanda promovida contra algum fidalgo tendo sido este convocado à corte pelo próprio soberano - não poderia ser empregado agente para postular em seu favor; além disso, em caso de impedimento excepcional, poderia ser utilizada uma espécie de "escusador", cuja atuação estaria exclusivamente jungida à justificação da "auzencia" do acusado perante o magistrado - evitando-se, assim, a aplicação dos efeitos da revelia. Por fim, em virtude de considerações eqüitativas, cumpre observar que nas circunstâncias em que ao réu é vedado o emprego de procurador, também dele não se pode valer o próprio autor ${ }^{93}$.

se terá na obrigação, que os Rendeiros fizerem de suas fazenda nas rendas, que tomarem” (cf. J. ANASTÁCIO DE FigueIREDO, Synopsis Chronologica I cit. (nota 87), p. 211). Embora tais termos ("outorgamento" ou "consentimento") para nós estejam longe de caracterizar qualquer sinonímia, demonstram de modo eloqüente a inoportunidade da menção à "procuração". Entretanto, em aparente retrocesso, as "Ordenações" posteriores aludiram novamente à "procuração" (neste sentido, cf. Ord. Man. III, 32, 1 e Ord. Fil. III, 47 pr.).

93 Ao contrário das fontes medievais, que impediam a utilização de procurador em quaisquer processos criminais, as "Ordenações Afonsinas" restringiram bastante o alcance do preceito proibitivo (Ord. Af. III, 8 pr. e Ord. Af. III, 8, 1): "Todo aquelle, que he citado a Juizo por feito Civel, pode mandar seu Procurador abastante, que por elle aja de responder, e naõ he theudo de hir responder a Juizo per pessoa contra sua vontade, salvo quando o Julgador lho mandar expressamente pera lhe fazer alguas perguntas, que necessariamente pertencem a bem do feito, sem as quaes justamente naõ pode ser dosembarguado; em tal caso deve o Reo per pessoa hir a Juizo responder aas perguntas, que lhe forem feitas; e naõ obedecendo elle ao mandado do Julguador, pode ser penado segundo a calidade do feito, e ao Julguador bem parecer (...) E dizemos que em feito crime pode o Reo citado parecer per seu Procurador abastante, que por elle responda em Juizo, se o crime he tam leve, em que naõ caiba mor pena que de degredo, ou dahi pera fundo; e se mor pena hi coubesse, que de degredo, tal caso lhe naõ deve hi ser recebido per Procurador, mas deve pessoalmente vir a Juizo defender-se do Crime, em que he culpado: e em outra guisa procederam contra elle á sua revelia, como for achado per Direito" (Ordenações Afonsinas III cit. (nota 87), p. 27). No mesmo sentido, cf. Ord. Af. I, 13, 22. Por sua vez, em meio às "Ordenações Manuelinas" a restrição foi novamente ampliada, a fim de que somente se admitisse o emprego do agente quando a pena de degredo cominada não fosse de caráter perpétuo (Ord. Man. I, 38, 27; Ord. Man. III, 7 pr.; Ord. Man. III, 7, 1; e Ord. Man. V, 1, 6); e quando não se tivessem outorgado ao demandado benefícios como "Carta de Seguro, ou de Fiança, ou sendo preso sobre sua menage pera andar pola Cidade, ou Villa, porque em cada huu destes casos (...) sempre 


\section{§ 114. “Ordenações Afonsinas": eficácia da atuação do "procurador”. Em}

um cenário caracterizado pela incerteza quanto aos limites entre a "procuração" e o "mandato", as "Ordenações Afonsinas" denunciam um comprometimento não só com a estrutura legada pela jurisprudência clássica, mas também com as necessidades ostentadas pela prática da época; desta forma, persistem - por um lado - elementos evidenciadores das linhas gerais do paradigma romano, tais como a confiança subjacente à relação entre o constituinte e seu procurador (Ord. Af. I, 13, 20), a proibição ao pacto de "quota litis" (Ord. Af. I, 13, 30) e as principais regras concernentes aos pressupostos e efeitos da extinção da procuração (Ord. Af. III, 21 e Ord. Af. III, 23). Aliás, quanto à citação por intermédio de procurador, toda uma disciplina é erigida à luz da investigação sobre a suficiência dos poderes que lhe foram conferidos (Ord. Af. III, 2). Entretanto, o

os sobreditos seram obriguados parecer em pessoa em juizo" (Ordenações Manuelinas III cit. (nota 87), p. 25). A respeito da prisão domiciliar, aliás, cf. Ord. Man. V, 67, 4; Ord. Man. V, 67, 5 e S. IV, 21, 12. No âmbito das "Ordenações Filipinas", cf. Ord. Fil. III, 7 pr.; Ord. Fil. III, 7, 2; Ord. Fil. V, 120, 3; Ord. Fil. V, 120, 4; e Ord. Fil. V, 124, 14.

Especificamente sobre a convocação de fidalgo à corte, cf. Ord. Af. III, 8, 3; Ord. Man. III, 7, 3; Ord. Fil. III, 7, 1. Já quanto ao emprego (excepcional) de escusador, eis o teor de Ord. Af. III, 8, 2: "E se alguu for citado pessoalmente pera responder em feito crime, honde caiba mor pena, que de degredo, posto que em tal caso elle se naõ possa defender per Procurador, que per elle responda ao feito principal, se elle for embargado de tal, e tam evidente necessidade, que pessoalmente nom possa parecer em Juizo, poderá mandar seu Procurador, que por elle, e em seu nome alegue, e mostre o embarguo, e rezaõ de sua auzencia, e necessidade porque naõ pode pessoalmente parecer no dito Juizo; o qual Procurador deve ser ouvido ácerqua do dito embarguo, e se alegar rezaõ lidema acerca do dito embarguo, deve-lhe ser recebida; e ainda alguus Doutores disseraõ, que pera allegar tal embarguo, e absencia, naõ tam somente deve ser recebido o Procurador, mas ainda qualquer do Povo sem Procuraçaõ, ainda que seja meor de vinte cinco annos, mulher, ou servo" (Ordenações Afonsinas III cit. (nota 87), p. 28). Note-se que além do reconhecimento (implícito) da eficácia representativa direta da atuação do procurador ("que por elle, e em seu nome alegue"), tal disposição destaca a influência do direito comum sobre o pensamento jurídico contemporâneo às primeiras "Ordenações do Reino de Portugal". No mesmo sentido da disposição transcrita, cf. Ord. Af. III, 20, 6; Ord. Man. III, 7, 2; Ord. Man. III, 15, 3; e Ord. Fil. III, 20, 3. Contudo, por meio de uma Determinação Régia de 08 de agosto de 1558, D. Sebastião proibiu o manejo - pelos procuradores dos "absentes" - da exceção judicial de suspeição do órgão jurisdicional; cabendo unicamente a provocação do próprio soberano, para pronunciamento específico acerca do caso (S. III, 2, 13). Observe-se que tal restrição à atividade do procurador prevaleceu, ainda, nas Ordenações Filipinas (Ord. Fil. III, 7, 3).

Quanto à presença dos acusadores (proibidos de empregar procurador quando necessário o comparecimento pessoal do demandado), cf. Ord. Af. I, 13, 23; Ord. Man. I, 38, 27; e Ord. Man. V, 1, 11. Especificamente a respeito da acusação promovida pelo menor (por intermédio de seu tutor), cf. o Assento (Determinação Régia em Relação) de 23 de novembro de 1578 (ad. a S. III, 1), por meio do qual se determina que o tutor demande pessoalmente o acusado, sem utilizar procurador (cf. DUARTE NUNES DO LIÃO, Leis Extravagantes cit. (nota 86), pp. 217-217verso). Daí o teor das disposições encontradas nas “Ordenações Filipinas” (Ord. Fil. V, 124, 15 e Ord. Fil. V, 124, 16).

Assim como tivemos a oportunidade de esclarecer no início de nota anterior (nota 88), também a respeito das “Ordenações Afonsinas" é necessário afastar algumas matérias que, conquanto tangentes à procuração e ao mandato, mostram-se regidas por princípios diversos. Assim, sobre o "Procurador dos Nossos Feitos" (bem como seus privilégios, inclusive de jurisdição), cf. Ord. Af. I, 5, 4; Ord. Af. I, 9; Alvará de $1^{\circ}$ de julho de 1513; Alvará de 28 de março de 1514; Ord. Man. I, 6, 8; Ord. Man. I, 11; Ord. Man. II, 43; S. I, 9, 1; S. I, 9, 2; S. I, 9, 3; S. I, 9, 4; S. V, 1, 1, 9; Ord. Fil. I, 12; e Ord. Fil. I, 13. Por sua vez, acerca das prerrogativas jurisdicionais ativas e passivas dos "Procuradores da Corte", cf. Ord. Af. III, 4, 7; Ord. Af. III, 43, 2; Ord. Af. III, 5, 2; Ord. Man. III, 4, 9; Ord. Man. III, 5 pr.; S. I, 3, 1, 10; Ord. Fil. III, 5, 11; e Ord. Fil. III, 6 pr.. 
compromisso com este modelo não é absoluto: ao mesmo tempo em que parece despontar um elemento sinalagmático em meio a esta relação (Ord. Af. V, 64 pr.), da coordenação entre Ord. Af. III, 2, 3 e uma singular disposição constante do título "Do que gançou graça d'ElRey, per que nom possa ser demandado a tempo certo, como deve usar dessa graça contra sy" (Ord. Af. III, 112, 5) pode ser depreendida a excepcional necessidade de ratificação para a efetiva transladação dos efeitos (dos atos praticados pelo agente) ao patrimônio do principal; com isso, não apenas se incorpora - extraordinariamente - à "procuração" uma regra concernente ao mandato, como ainda se mitigam os efeitos representativos diretos defluentes da atuação do procurador - tudo à margem do elíptico trecho "sem sua expressa authoridade, ou especial mandado"94.

94 Evidenciando a relação de confiança subjacente ao vínculo mantido entre o constituinte e seu "procurador", eis o que dispõe o preceito constante de Ord. Af. I, 13, 20: "Item. Nenhuu procurador, que tenha já sollairo, ou parte delle d'alguu pera teer seu preito, nom pode seer Voguado por a outra parte" (Ordenações Afonsinas I cit. (nota 87), p. 90). De modo ainda mais incisivo, tal relação é reconhecida em Ord. Af. V, 64, onde se dispõe a respeito "Dos Vogados, e Procuradores, que som prevaricadores, vogando por anballas partes": "Segundo disserom os sabedores antigos, por grande pecado he contado toda ingratidooe praceiramente cometida contra aquelle, de que ha recebido alguum beneficio (...) E por muyto maior deve ja seer contado, se a ingratidooe he cometida encubertamente, em dampno daquelle que o beneficio fez, nom seendo dello sabedor, mostrando-se esse ingrato boa vontade, e senbrante per aparença de pallavra, e fazendo-lhe dampno enganosamente per via encuberta e escondida; ca tal como este deve razoadamente seer contado por falso e alleivoso (...) E por tanto dizemos, que se alguum Vogado, ou Procurador (...) vogasse ou procurasse polla outra parte escondidamente, tal como este com justa razom deve seer contado por falso e alleivoso, porque sô specia d'amizade falsamente engana aquel (...) mostrando-lhe per palavra reconhecimento fingidiço e enganoso, fazendo per obra o contrairo, pois ajuda o seu aversairo, contra o qual deveria vogar; e por tanto o que tal fezesse, deveria ser asperamente escarmentado. Porem mandamos, que o que tal maldade fezer seja degradado por sempre pera as Ilhas, e nunca mais uze do officio" (Ordenações Afonsinas V cit. (nota 87), pp. 260-261). Note-se que tal orientação é mantida, em linhas gerais, pelas “Ordenações Manuelinas" (Ord. Man. I, 38, 34 e Ord. Man. V, 55); aliás, no texto manuelino se reconhece a regular atuação do "procurador" mesmo se acometido de moléstia - que não implique seu afastamento prolongado, caso contrário deveria o adversário providenciar a citação do principal para constituição de novo agente, a fim de que se desse regular prosseguimento ao feito (Ord. Man. I, 38, 10). E as "Ordenações Filipinas", enfim, adotaram as mesmas diretrizes de suas antecessoras (Ord. Fil. I, 48, 13 e Ord. Fil. III, 20, 13).

Contudo, do mesmo título "Dos Vogados, e Procuradores, que som prevaricadores, vogando por anballas partes" deve ser extraída uma outra passagem na qual se evidencia o fundamento do comportamento escorreito do procurador (em aparente contradição com as disposições relativas à amizade que pudemos extrair de Part. IV, 27, 4): "segundo a Ley natural e verdadeira amizade, he divido conhecimento de remuneraçom e bem fazer, segundo a qualidade do beneficio recebido (...) se alguum Vogado, ou Procurador, ouvesse recebido d'alguma parte preço ou outro dom (...) e em durando esse feito elle vogasse ou procurasse polla outra parte (...) deve seer contado por falso e alleivoso, porque sô specia d'amizade falsamente engana aquel, de que ha beneficio recebido" (Ordenações Afonsinas V cit. (nota 87), pp. 260-261). Ora, fica evidente a perspectiva sinalgmática que assume a relação mantida entre tais sujeitos; segundo tal dispositivo das "Ordenações Afonsinas", a razão da lealdade do procurador deve ser buscada em meio à remuneração ("preço ou outro dom") atribuída pelo constituinte. Ora, não sendo a onerosidade essencial à atuação do procurador, tal perspectiva nos parece inteiramente equivocada.

Sobre a vedação ao pacto de "quota litis", cf. Ord. Af. I, 13, 30; Ord. Man. I, 38, 30 (admitindo-se antecipação dos "salários" em víveres); e Ord. Fil. I, 48, 11 (em sentido idêntico ao da versão Manuelina).

Quanto à extinção da procuração, as "Ordenações Afonsinas" aludem a diversas causas, de ordem natural (Ord. Af. III, 23) ou decorrentes da vontade de um dos sujeitos (Ord. Af. III, 21). Tomando-se em consideração a contestação da lide, as soluções apresentadas para as hipóteses são distintas, conforme aquela 
tenha ocorrido ou não. Assim, morrendo o principal antes da contestação da lide (Ord. Af. III, 23 pr.), "loguo espira o poderio de sua procuração, e cessa todo seu Officio [do procurador] em tal guisa" (Ordenações Afonsinas III cit. (nota 87), p. 87); no entanto, se o falecimento lhe é posterior, "nom espira porem o Officio do Procurador, nem perderá de seu poderio cousa alguma, ante dizemos, que deve seguir o preito ate que seja acabado, assi, e tam compridamente, como se o Senhor do preito fosse vivo, ainda que não haja nova Procuração, ou mandado de seus herdeiros" (Ordenações Afonsinas III cit. (nota 87), p. 87). Em se tratando da morte do procurador, o mesmo critério haveria de ser empregado (Ord. Af. III, 23, 1): "Outro sy dizemos, que se o Procurador morresse ante da lide contestada, espira com todo seu Officio; e se morresse depois da lide contestada, seus herdeiros poderam acabar o preito, que o Senhor houvesse começado, se esses herdeiros forem homens entendidos, e Letrados, em tal maneira que o Senhor do preito seja delles contente" (Ordenações Afonsinas III cit. (nota 87), p. 87). Aliás, ressaltando a gestão colaborativa inerente a tal vínculo, o legislador afonsino destacou o dever de recorrer do procurador (sob pena de responsabilidade), mesmo que seu ofício expirasse em virtude da prolatação de sentença pelo órgão jurisdicional inferior (Ord. Af. III, 23, 2): "e dizemos que se acaba, e espira em todo o Officio do Procurador, que he estabelecido pera procurar em Juizo, tanto que julgarem esse feito per Sentença defenitiva; peroo quando o Juiz assi julgar contra aquelle, cujo Procurador elle for, deve elle apellar de sua Sentença: e esto pode elle bem fazer, ainda que lhe naõ seja dado poder pera ello na Carta da Procuraçaõ; mas naõ poderá seguir essa apellaçaõ, sem novo mandado, ou nova Procuraçaõ do Senhor do preito pera ello; porque na apellaçaõ se começa nova instancia, e por tanto he necessario nova Procuraçaõ do Senhor do preito pera o Procurador, que queira em ella procurar" (Ordenações Afonsinas III cit. (nota 87), pp. 87-88). No mesmo sentido de tais disposições, as "Ordenações Manuelinas" tão somente acrescentam a previsão de suspensão do processo tão logo se dê a morte da parte (Ord. Man. III, 18 pr.) e a possibilidade de oferecimento de embargos de declaração pelo procurador provido de poderes para litigar na instância inferior (Ord. Man. III, 18, 2). No âmbito das "Ordenações Filipinas", sem qualquer inovação quanto à matéria, cf. Ord. Fil. III, 27.

Note-se que a contestação da lide também é tomada como marco decisivo no panorama da extinção da procuração por deliberação unilateral do sujeito: antes de tal ocorrência, tanto a revogação quanto a renúncia não necessitam de justificativa declinada; todavia, depois de contestada a lide, é necessário o oferecimento de fundamento plausível para a extinção da procuração. Neste sentido, eis o teor de Ord. Af. III, 21, 1: "E dizemos, que depois que o Procurador ouver a lide contestada, naõ o podera o Senhor do preito revoguar, e fazer outro, se o seu contendor o contrario disser, dizendo que naõ pode litiguar com tantos Procuradores, ou esse Procurador o contradigua, avendo-se por deshonrado por ello: saluo se esse Senhor do preito aleguar alguua justa rezaõ, por que o assy quer fazer, a saber, se esse Procurador fosse embargado de alguu tal embarguo, que razoadamente naõ podesse seu preito bem precurar, ou novamente fosse feito seu imiguo, ou amiguo de seu contentor; ca em taes casos, e outros similhantes pode o Senhor do preito em todo o tempo revoguar seu Procurador, ainda que a lide com elle seja contestada, nom embarguante que o seu Contentor, e o dito seu Procurador assy revoguado o contrairo digaõ, ou cada um delles: e bem assi nos ditos casos, e cada huum delles poderá o Procurador depois da lide contestada livremente leixar o preito, e a Procuraçaõ, notificando-o assi ao Senhor do preito, pera fazer outro Procurador, que seu feito precure" (Ordenações Afonsinas III cit. (nota 87), pp. 84-85). Merece destaque o fato de que o legislador manifestou pleno conhecimento da natureza receptícia de ambos os negócios jurídicos (revogação e renúncia), conforme denuncia Ord. Af. III, 21 pr.: "fazendo huu homem outro seu Procurador sobre alguu preito, se depois fezer outro Procurador naquelle mesmo preito, loguo revogua o primeiro, e tiralhe o poderio todo, que the primeiramente avia dado, e da-o em todo ao segundo: pero quando assy quer revoguar o primeiro, deve-o fazer saber ao Juiz, e a seu contentor: e naõ o fazendo assy, deve valer quanto o primeiro Procurador rezoar, e fizer em esse preito, assi como se nunqua fosse revoguado" (Ordenações Afonsinas III cit. (nota 87), p. 84). Além disso, destacou a existência de deveres - de fundo ético - subsistentes à extinção da procuração pela renúncia do agente (Ord. Af. III, 21, 2): "bem assi dizemos do Procurador, que amte da lide contestada poderá livremente leixar a Procuraçaô, notificando-o assi ao senhor do preito, com tanto que naõ procure pola outra parte contraira depois que do Senhor do preito ouver recebido alguu preço, ou sabido por elle os segredos da demanda; ca em taes casos, ainda que livremente possa leixar a Procuraçaõ tornando o preço, que ouve (...) segundo o que ouver merecido, nom poderá procurar por a outra parte contraira; e fazendo o contrairo dello deve ser penado como falsario" (Ordenações Afonsinas III cit. (nota 87), pp. 85). As "Ordenações do Reino" posteriores mantiveram, em linhas gerais, a orientação proveniente do texto afonsino; entretanto, a versão subseqüente acrescentou expressa previsão sobre o pagamento (ao procurador) de sua remuneração - bem como acerca da reparação dos prejuízos experimentados durante a execução da incumbência. A respeito, cf. Ord. Man. III, 17 pr.; Ord. Man. III, 17, 1; Ord. Fil. III, 26 pr.; e Ord. Fil. III, 26, 1 .

Quanto à citação promovida por intermédio de agente, cumpre observar que as "Ordenações Afonsinas" a admitiam sem maiores reservas, desde que o procurador (geral ou especial) tivesse poderes suficientes para a 
§ 115. "Ordenações Afonsinas": coibição à conduta "maliciosa" do agente e disposições administrativas sobre a procuradoria. Ao contrário das fontes lusitanas medievais, as "Ordenações Afonsinas" consideraram proveitosa a atuação dos procuradores (Ord. Af. I, 13, 1); no entanto, nem por isso deixaram de reprimir eventual conduta maliciosa do agente - levada a efeito em juízo ou mesmo extrajudicialmente. Assim, tendo-se em vista que regras de um incipiente direito econômico haviam submetido a atuação de mercadores estrangeiros a um rígido controle, foram expressamente vedadas as atividades comerciais e cambiais empreendidas por meio de agente, operando-se um reconhecimento oblíquo, aliás, do mandato sem representação (Ord. Af. IV, 4, 2); no âmbito judicial, por sua vez, sobrevieram não apenas uma repreensão severa aos "prevaricadores" (Ord. Af. V, 64), como também a veemente proibição do trespasse de direitos a pessoa poderosa - obviando-se, assim, a intimidação de adversários e magistrados (Ord. Af. III, 118). Por fim, as “Ordenações Afonsinas” assinalam a adoção de medidas voltadas ao controle administrativo da procuradoria: à exceção dos lugares nos quais, por privilégio, inexistissem "procuradores do numero", todos os postulantes - então

prática do ato (Ord. Af. III, 2 pr.): "Achamos per Direito que se o Autor no começo da demanda quiser citar o Procurador do Reo, leixando de citar a parte principal, que o pode bem fazer, se esse Procurador he geral, ou especial, e suficiente pera aquelle auto, pera que o querem citar" (Ordenações Afonsinas III cit. (nota 87), pp. 10-11). Por sua vez, denunciando efeitos representativos diretos defluentes da (in)ação do procurador, eis o teor de Ord. Af. III, 2, 3: "E no caso, onde dissemos, que o Procurador possa ser citado no começo da demanda, Mandamos, que sendo elle suficiente Procurador, aa sua revelia possa proceder assy, e tam compridamente, como fariaõ, se a parte principal em sua pessoa fosse citada" (Ordenações Afonsinas III cit. (nota 87), pp. 11-12). No mesmo sentido, cf. Ord. Man. III, 2, 1; e Ord. Fil. III, $2,1$.

Com efeito, se de tal regra pode ser depreendida uma consagração - ainda que oblíqua - de efeitos representativos diretos defluentes da atuação do "procurador", tal preceito não ostenta uma aplicação absoluta. Ao contrário, pode ser surpreendida uma eloqüente exceção em Ord. Af. III, 112, 5: "E bem assy se alguum, como Procurador d'outro, impetrasse similhante graça pera aquelle, cujo Procurador fosse, sem sua expressa authoridade, ou especial mandado, nom empeceria a esse, em cujo nome fosse tal graça impetrada, pera ser theudo uzar della contra sy: salvo se a elle por alguma guisa louvasse, e confirmasse; ca em tal caso assy lhe empeceria, como se a elle mesmo ouvesse impetrada: e esse Procurador, que assy a dita graça impetrou, será theúdo usar della contra sy mesmo, pois que a impetrou sem especial mandado daquelle, pera que a impetrou, assy como se a impetrada ouvesse pera sy" (Ordenações Afonsinas III cit. (nota 87), pp. 405406). No mesmo sentido, cf. Ord. Man. III, 80, 4 e Ord. Fil. III, 38, 4. Note-se que nesta hipótese conquanto genericamente apto à prática de atos responsáveis pela percussão direta do patrimônio do principal - o procurador (mandatário) tem sobre si a sombra dos efeitos da impetração da graça: apenas se verifica uma transladação da eficácia quando a outorga de poderes seja efetivamente respaldada por uma "incumbência" "expressa authoridade, ou especial mandado" - do constituinte (mandante), ou por sua aprovação subseqüiente. Todavia, no sentido de uma inadmissão de efeitos representativos diretos - à vista da necessidade de um ato subseqüente de trespasse por parte do agente - eis a seguinte posição de Francisco de Caldas Pereyra e Castro: "in eo tamen dissidet à procuratore, qui contractus verba in propriam personã dirigit, nomine tamen domini, qua ratione sibi actiones quaerere dicitur, quas domino cedere tenetur (...) ratio est , quia per liberam personam nobis directo actionesquaeri non possunt" (Analyticvs commentarius, sive Ad Typum Instrumenti Emptionis \& Venditionis Tractatus, tum pragmaticis cum gymnastis ad modum utilis ac neceßarius, Francofvrti, Typis Hartmanni Palthenij, 1619, p. 42). Em sentido semelhante, F. de S. L. PESSOA JORGE considera que este específico excerto desperta incertezas quanto à admissibilidade geral de uma eficácia representativa direta - defluente da atuação do procurador ( $O$ Mandato cit. (nota 09), pp. 75-76). 
eleitos pelos "concelhos" - deveriam ser submetidos a exame perante o "Chanceller Moor"

(Ord. Af. I, 2, 19); e uma vez aprovados, poderiam exercer suas funções tão logo expedidas

suas "cartas seelladas" - desde que antes jurassem conduzir os feitos "bem, e direitamente, e sem malicia" (Ord. Af. I, 13, 1 e Ord. Af. I, 13, 12) ${ }^{95}$.

${ }^{95}$ Reconhecendo a utilidade decorrente da atividade desenvolvida pelos procuradores, assim se expressam as "Ordenações Afonsinas" (Ord. Af. I, 13, 1): "Muito proveitosa cousa nos parece haver hi Procuradores Letrados, e entendidos, que procurem os feitos, que alguus ouverem assi em a Nossa Corte, como na Nossa Casa do Civil, e nas Cidades, Villas, e Lugares dos Nossos Regnos" (Ordenações Afonsinas I cit. (nota 87), p. 84). No mesmo sentido, cf. Ord. Man. I, 38 pr. - sem qualquer correspondente na versão Filipina.

Por sua vez, atendendo a reclamações que lhe foram dirigidas nas cortes, D. Fernando editou provisão sobre os mercadores estrangeiros, que serviu de subsídio a Ord. Af. IV, 4, 1 e Ord. Af. IV, 4, 2: "I. Como a nós fosse denunciado pelos Concelhos, e Mercadores, e per outros muitos da nossa terra, que muitos Mercadores d'outras Naçooes estranhas vivem, e estam nos Nossos Regnos, e som exentos dos carregos do cõmum, e do nosso serviço; e que pooem as mercadorias, e cousas, que trazem a este Regno em aquella monta, e valia que querem; e compram, e mandam comprar per todas as partes do Regno as que acham na terra mui refeces; e tiram, e levam as nossas moedas pera fora de nossos Regnos contra nossa defesa, e accrecentam em seus algos, e riquezas, e as enviam pera outras partes d'outros senhorios: e os Mercadores nossos naturaaes, que ham de sopportar os carregos de nosso serviço, e do cõmuu, nom podem antre elles gaançar, e fazer sua prol. (...) 2. E esguardando nós que tanto que compre ao nosso Estado, e ao bem publico dos nossos subjeitos serem ricos, e abastados, tanto mais devemos, e somos theudo de olher por prol dos nossos Regnos, e naturaaes, que dos Estrangeiros, e tolher, e arredar aquello, per que lhes pode seer embargado de fazer sua prol, e accrescentar em seus algos: porem de Concelho de nossa Corte, e do Ifante Dom Johã nosso Ir maaõ, e do Conde Dom Affonso, e Priol do Esprital, e dos Prelados, e Meestres da Cavallaria, e dos outros Fidalgos, e Cavalleiros, e Cidadaaõs da nossa terra, que sobre esto mandamos chamar, hordenamos, e mandamos, e defendemos, que nenhuu Mercador de fora de nossos Regnos nom compre per sy nem per outrem nenhuu aver de peso comisinho, salvo pera seu mantimento; nem moeda, nem metal, nem outra nenhua mercadoria em nenhuu lugar de nossos Regnos, fora da Cidade de Lixboa, nem dê seus dinheiros a outros de nossa terra pera comprarem nenhuas mercadarias fora da dita Cidade" (Ordenações Afonsinas IV, Lisboa, Fundação Calouste Gulbenkian, 1999, pp. 46-47). Com efeito, visando evitar o emprego da interposição de pessoa a fim de burlar a proibição legal, o legislador previu "que nenhuu Mercador de fora de nossos Regnos nom compre per sy nem per outrem (...) nem dê seus dinheiros a outros de nossa terra pera comprarem nenhuas mercadarias fora da dita Cidade" - o que evidencia a efetiva utilização do mandato sem representação para o atingimento de tal escopo. A respeito da questão, cf. ainda Ord. Man. IV, 2, 2.

Já tivemos a oportunidade de nos pronunciar sobre a repressão aos prevaricadores no início da nota de rodapé imediatamente anterior (nota 94); de qualquer forma, quanto à questão, cf. Ord. Af. V, 64; Ord. Man. I, 38, 34; Ord. Man. V, 55; e Ord. Fil. I, 48, 13. Merece destaque, ainda, a proibição do trespasse de direitos a pessoa poderosa (como mecanismo de intimidação do virtual adversário), punida com a proibição do emprego de procurador; tudo de conformidade com o estabelecido em Ord. Af. III, 118 pr. e Ord. Af. III, 118, 2: "Mandamos, e Estabelecemos por Ley, que se alguum tever aução contra outro, assy real, como pessoal, e ante da demanda começada a ceder, ou trasmudar em alguum poderozo per rezam do Officio, como dito he no Titulo suso dito, aquelle, que tal cessaõ, ou transmudaçam de acçam assy fezer, perca toda aução, e direito, que hy ouver, e aquelle que fez a dita cessaõ, nem aquelle, a que foi feita, nunqua ja mais possam usar d'alguum direito que hy tivessem, porque todo avemos por perdido; e alem desto Nós daremos ao dito nosso Official, que tal couza fezer, escarmento e pena, como acharmos que per Direito merece. (...) 2. E se a tal cessam, ou tresmudamento da auçam fosse feita a alguuma pessoa nom poderoza per rezam do Officio, mas per qualquer outra rezam, assy como Cavallaria, ou outra Denidade, em tal caso Mandamos, que aquelle, a que tal cessaõ ou tresmudamento da auçam for feita, nom possa della uzar, nem seja recebido per ella a demanda; e aquelle que a fezer faça sua demanda, se quizer, assy como a faria ante da sua cessaõ: pero que a nom poderá fazer, se nam per sy mesmo, e nam será recebido a ella per nenhuum Procurador; porque esto lhe damos por pena, por a cessão, e transmudamento, que assy fez enguanosamente ao poderozo, por defraudar a outra parte, pensando de the dar duro adversario, per que seu direito fosse danificado" (Ordenações Afonsinas III cit. (nota 87), pp. 425-426). Na mesma linha do estabelecido pelo texto afonsino, cf. Ord. Man. III, 84 pr.; Ord. Man. III, 84, 2; Ord. Fil. III, 39 pr.; e Ord. Fil. III, 39, 2.

Finalmente, a respeito do controle administrativo da atividade desenvolvida pelos procuradores, três dispositivos principais merecem destaque: em primeiro lugar, em Ord. Af. I, 2, 19 se atribui ao "Chanceller 


\section{§ 116. Legislação superveniente às "Ordenações Afonsinas": aspectos}

relacionados à procuração. No que tange à atividade dos procuradores, a legislação superveniente às "Ordenações Afonsinas" circunscreve-se a alguns poucos preceitos, voltados, sobretudo, à garantia de imparcialidade dos magistrados e ao próprio procedimento judicial. Assim, quanto ao primeiro aspecto, por meio das Determinações

Moor" a competência para o exame e credenciamento dos diversos procuradores atuantes no Reino: "Item. Dará Cartas d'Officios de Procuradores das Audiencias Nossas, e d'ante os Corregedores das Comarcas, e d'ante os Juizes da Terra (...) os quaees primeiramente per elle serom examinados, se som autos pera taaes Officios" (Ordenações Afonsinas I cit. (nota 87), p. 22). Excetuadas as localidades nas quais, por privilégio real, inexistissem "procuradores do numero", o procurador somente poderia exercer suas funções se previamente autorizado pela Administração, por meio da expedição de sua "carta seellada", conforme se depreende da coordenação entre Ord. Af. I, 13, 1 e Ord. Af. I, 13, 12: “ I. (...) Ordenamos, e Mandamos, que aquelles, que ouverem de seer Procuradores em a Nossa Corte, e Casa, sejam examinados pelo Nosso Chanceller Moor, e os das Cidades, Villas, e Luguares sejam enlegidos pelos Officiaes desses Lugares, e com essa enliçom venhaõ ao Nosso Chanceller Moor pera os examinar, e os que achar perteencentes pera ello, dêlhes suas Cartas seelladas com o seello da Nossa Chancellaria, fazendo-os hi jurar, que bem, e direitamente, e sem malicia trautem os feitos, e d'outra guisa nenhuu nom vogue, nem procure; e nom embargando taaes enliçooes, que os Concelhos ham de fazer, fique lugar a Nós, e aos outros Reys, que depois Nós forem, de darmos taaes Officios a quem Nossa mercee for, sem outra nenhuua enliçom; e nom se entenda esto em alguus lugares, a que aprouve nom haver hi Procuradores do numero, mais quantos quizessem procurar, salvante aquelles, que fossem achados, que nom eram perteencentes, e lhes fosse defezo, que nom podessem procurar, ou tevessem taees Officios, que per as Ordenaçooes lhes seja defeso que nom possaõ procurar (...) 12. Item. Todo homem pode seer Procurador, e procurar por outro em a Nossa Corte, e Casa do Civil, e perante outros quaesquer Juizes, com tanto que tenhaõ poder das partes, e Nossas Cartas pera procurar, salvo aos que he defeso" (Ordenações Afonsinas I cit. (nota 87), pp. 84-85 e 89).

Nas “Ordenações Manuelinas" é mantida a exigência de aprovação em prévio exame para a procuradoria perante as instâncias ordinárias (Ord. Man. I, 2, 28) - dispensada unicamente para os detentores do grau mínimo de bacharel (em Direito Civil ou Canônico). Aliás, visando a obtenção de um equilíbrio entre a demanda por procuradores e o número de credenciados, em Ord. Man. I, 38, 2 se prevê que o "Chanceller Moor (...) dará suas Cartas auendo enformaçom de quantos ha na Correiçam, ou Cidade, ou Villa pera onde pedem as ditas Cartas de Procurador, e assi dos que sam necessarios, em modo que nom sejam mais, que os que parecer que abastaram, e que razoadamente se poderam manter" (Ordenações Manuelinas I cit. (nota 87), p. 234). Sobre os requisitos específicos para a procuradoria da Corte e da Casa do Cível, bem como a respeito das sanções relacionadas ao exercício irregular de tais funções, cf. Ord. Man. I, 38 pr.; Ord. Man. I, 38, 1; e Ord. Man. I, 38, 3.

Por meio da Lei de 10 de outubro de 1534, D. João III modificou a competência para o exame das diversas classes de procuradores: em lugar do "Chanceller Moor", a aferição dos postulantes ao ofício de "Procurador da Casa da Suplicação" foi atribuída ao chanceler do respectivo tribunal (S. I, 2, 1, 9); por sua vez, quanto aos aspirantes às demais procuradorias (da Corte, da Casa do Cível, das correições do reino e ordinária), sua argüição foi cometida aos Desembargadores do Paço (S. I, 4, 2, 6 e S. I, 4, 2, 17). Quanto à delimitação do número de "Procuradores da Casa da Suplicação", cf. a Provisão de 25 de julho de 1567 (S. I, 21, 3), por meio da qual se determinou a existência de 24 (vinte e quatro) oficiais - contingente aumentado para 40 (quarenta) por força da Lei de 18 de novembro de 1577 (§ 27). Em meio às "Ordenações Filipinas", no mesmo sentido das disposições referidas, cf. Ord. Fil. I, 4, 8; Ord. Fil. I, 48, 1; Ord. Fil. I, 48, 2; Ord. Fil. I, 48, 4; Ord. Fil. I, 48, 5; e Assentos (da Casa da Suplicação) de 09 de janeiro de 1620 e de 27 de abril de 1723 (apud CÂNDIDo MENDES DE AlMEIDA, Auxiliar Juridico, Rio de Janeiro, Typographia do Instituto Philomatico, 1869, pp. 139 e 215).

Por fim, resta observar que por meio da Carta Régia de 13 de janeiro de 1539, D. João III instituiu a obrigatoriedade do curso jurídico (na Faculdade de Direito de Coimbra) para o exercício da procuradoria, inclusive perante a Casa da Suplicação (S. IV, 17, 13): “Ordenou elRei dom Ioão III. que os letrados, que houvessem de tomar para desembargadores, studassem em Coimbra em dereito canonico ou ciuil doze annos ao menos, ou tiuessem oito annos, \& quatro de seruiço de juizes de fora, ouuidores, ou corregedores, ou procuradores da casa da supplicação. E que os que houuessem de procurar ou auogar, tiuessem oito annos na dita Vniversidade" (DUARTE NUNES DE LIÃO, Leis Extravagantes cit. (nota 86), p. 166). Observadas tais adaptações, cf. Ord. Fil. I, 48 pr. e Ord. Fil. I, 48, 3. 
Régias de 02 de julho de 1434 e de 17 de junho de 1502 - bem como do Alvará de 30 de outubro de 1516 - foi vedada qualquer espécie de diligência das partes (ou de seus procuradores) à residência dos desembargadores envolvidos na solução do processo que lhes interessava. Por sua volta, quanto ao procedimento adotado em juízo, destaque-se que por força do Alvará de 07 de abril de 1494 - e do subseqüente de 13 de fevereiro de 1510 se prescreveu aos "Procuradores da Casa da Suplicação" escrupulosa obediência à ordem de antigüidade para a tomada de seus respectivos assentos; além disso, em virtude da Ordenação de 03 de abril de 1500 se determinou que - ainda que houvesse mais de um procurador encarregado da administração de um mesmo processo - somente um único arrazoado poderia ser oferecido quanto a um específico litígio ${ }^{96}$.

\footnotetext{
${ }^{96}$ A respeito da vedação de incursões à residência dos desembargadores, várias são as disposições do período anterior às "Ordenações Manuelinas": sobre a Determinação Régia de 02 de julho de 1434 ("para que as partes não vão fallar aos Desembargadores a suas casas, sob pena de dois mil reaes brancos por cada vez"), cf. J. ANASTÁCIO DE FIGUEIREDO, Synopsis Chronologica I cit. (nota 86), p. 27; quanto à Determinação Régia de 17 de junho de 1502 ("por que se ordenou, que a Determinação Régia de 2 de julho de 1434 se cumprisse e guardasse inteiramente; com a addição porem, que a pena fosse de seis mil reaes"), cf. J. ANASTÁCIO DE FIGUEIREDO, Synopsis Chronologica I cit. (nota 86), p. 159; por fim, a respeito do Alvará de 30 de outubro de 1516 ("em que se determina, que os Desembargadores não requeirão feitos pelas partes, nem vão a casa d'outros Desembargadores falla-lhe nelles (...) nem tomem presentes nem dinheiro emprestado do Procurador"), cf. J. ANASTÁCIO DE FigueIREDO, Synopsis Chronologica I cit. (nota 86), p. 216. No mesmo sentido, cf. Ord. Man. I, 38, 32; Ord. Man. III, 35 pr.; e Ord. Fil. I, 48, 12.

Quanto à ordem de tomada dos assentos pelos "Procuradores da Casa da Suplicação", dois são os diplomas mais significativos do período subseqüente às "Ordenações Afonsinas": sobre o Alvará de 07 de abril de 1494 ("em que se determina, que os Procuradores da Casa da Supplicação não pervertão a ordem dos seus assentos"), cf. J. ANASTÁCIO DE FIGUEIREDO, Synopsis Chronologica I cit. (nota 86), p. 133; e acerca do Alvará de 13 de fevereiro de 1510 ("em que se determina que os Procuradores da Casa da Supplicação, se assentem segundo as suas antiguidades"), cf. J. ANASTÁCIO DE FIGUEIREDO, Synopsis Chronologica I cit. (nota 86), p. 166. As "Ordenações Manuelinas", contudo, derrogaram o princípio da antigüidade, na medida em que consagraram a proeminência do procurador graduado sobre os procuradores "de linguagem" mais antigos na audiência (Ord. Man. I, 77, 5): "E os Procuradores teram seus assentos ordenados, e daqui pordiante se assentará cada huu segundo for mais antiguo na dita Audiencia no procurar, posto que menor gráo tenha, que o que mais moderno for no procurar. Porem onde ouuer Procuradores graduados, e outros de lingoagem, que que graduados nom sejam, sempre se assentará e falará primeiro o que for graduado, posto que o nom graduado seja mais antiguo no procurar na dita Audiencia" (Ordenações Manuelinas I cit. (nota 87), p. 561). Tal regra foi posteriormente confirmada pelo Alvará de 03 de novembro de 1545 (S. I, 21, 1), tendo prevalecido ainda nas "Ordenações Filipinas" (Ord. Fil. III, 19, 7).

Finalmente, visando resguardar a celeridade do procedimento, a Ordenação (ou Determinação Régia) de 03 de abril de 1500 estabeleceu "que no feito, aonde houvesse dois Procuradores, se não dessem dois termos para razoar, e se faça hum só arrezoado" (cf. J. ANASTÁCIO DE FigueIREDO, Synopsis Chronologica I cit. (nota 86), p. 156). Note-se que tal orientação prevaleceu nas "Ordenações Manuelinas", que acrescentaram à disposição a prescrição de que somente um dos procuradores haveria de articular as razões em prol da parte (Ord. Man. I, 38, 33): "E posto que cada hua das partes tenha mais de huu Procurador, nom razoará no feito senom huu delles" (Ordenações Manuelinas I cit. (nota 87), p. 244). Em meio aos mesmos preceitos, aliás, pode ser entrevista a garantia de bilateralidade de audiência das partes (Ord. Man. I, 38, 32): "E por milhor despacho dos feitos Mandamos, que os Procuradores razoem, e diguam por escripto todo o Dereito da sua parte em huas soos razoes (...) e entonce nom ouuiram huu Procurador sem outro" (Ordenações Manuelinas I cit. (nota 87), pp. 243-244). No mesmo sentido, cf. ainda Ord. Man. III, 15, 12; Ord. Man. III, 15, 14; Ord. Fil. III, 20, 40 (inclusive quanto à garantia de bilateralidade de audiência) e Ord. Fil. III, 20, 41.
} 


\section{$\S$ 117. "Ordenações Manuelinas": eficácia da atuação do "procurador".}

Quanto à eficácia da atuação do procurador, as "Ordenações Manuelinas" ostentam uma posição de destaque, não só em virtude da implantação de algumas regras até hoje conservadas - como a respeito da proibição de riscos, acréscimos, supressões e cotas (Ord. Man. I, 38, 35) -, mas também em decorrência do incidental reconhecimento da procuração extrajudicial - especificamente voltada à constituição de um novo agente, incumbido este de procurar em juízo (Ord. Man. I, 38, 36). No entanto, para além disso, exsurge uma meticulosa - conquanto esparsa - disciplina relacionada aos efeitos da conduta do procurador sobre a esfera jurídica de seu constituinte: assim, da falsidade do instrumento de procuração deflui a nulidade de todo o procedimento, sem que qualquer prejuízo decorrente da atuação do "falso" procurador possa ser imputado à parte (Ord. Man. III, 49, 5). Entretanto, no que concerne à procuradoria "autêntica", as "Ordenações Manuelinas" distinguem, ainda que de maneira implícita, as modalidades de ilícito praticadas pelo agente: uma vez violada disposição "legal" (tal como se verifica em Ord. Man. III, 15, 16), a sanção é cominada ao próprio procurador, sem que desponte prejuízo imediato à parte, à vista de expressa ressalva (em casos excepcionais) por parte do legislador; contudo, caso as instruções conferidas pelo constituinte não tenham sido escrupulosamente observadas pelo agente, tal descumprimento implica efeitos exclusivamente obrigacionais ("inter partes”), não projetando quaisquer reflexos sobre a validade dos atos processuais praticados (Ord. Man. I, 38, 36) ${ }^{97}$.

\footnotetext{
${ }^{97}$ Assim como tivemos a oportunidade de ressalvar em oportunidades anteriores (vide notas 88 e 93), faz-se necessário, também no âmbito das "Ordenações Manuelinas", promover um afastamento preliminar de matérias que, conquanto mediatamente relacionadas com a idéia de procuração, não se mostram diretamente comprometidas com o objeto de nossas considerações. Assim, sobre o privilégio dos procuradores das vilas e dos concelhos - em virtude do qual não lhes seriam aplicadas "penas vis" - cf. Ord. Man. V, 40; S. IV, 22, 9; e Ord. Fil. V, 138 pr..

Quanto à proibição relacionada a riscos, acréscimos, supressões e cotas nos autos processuais, eis o teor da severa disposição constante de Ord. Man. I, 38, 35: "Item. Mandamos a todos os procuradores, que despois que nos feitos, em que assi procurarem, oferecerem em Juizo libelo, ou quaesquer artiguos, ou razoes, nom possam nos ditos libelo, artiguos, ou razoes riscar cousa algua, nem adder, nem demenuir, sem licença do Julguador, que for Juiz do feito, ouuida a parte se for cousa de seu perjuizo; e o Procurador, que o contrairo fezer, seja priuado do Officio, e degredado por dous annos per cada huu dos Luguares d'Alem em Africa. E bem assi nom poderam escreuer na margem em ninhua folha dos feitos ninhua razam, soomente poderam cotar, e poer aquellas cotas, que o Juiz póde poer (...) e fazendo o contrairo seram suspensos dous mezes de seus Officios, ou aueram outra maior pena, segundo a qualidade das palauras" (Ordenações Manuelinas III cit. (nota 87), p. 244). No mesmo sentido, cf. Ord. Fil. I, 48, 14 - bem como os Assentos da Casa da Suplicação de 02 de maio de 1654 e de 11 de fevereiro de 1658 (apud CÂNDIDO MENDES DE ALMEIDA, Auxiliar cit. (nota 95), pp. 167; 170-171).

Note-se que o dispositivo ressalva os interesses da parte, que não poderia ser prejudicada pela conduta ilícita adotada por seu procurador ("ouuida a parte se for cousa de seu perjuizo"). Em conformidade com tal orientação, a atuação do "falso" procurador não poderia redundar, obviamente, em prejuízo daquele que não o havia constituído como seu agente (Ord. Man. III, 49, 5): "E se o erro do processo for por (...) que se
} 
$\S$ 118. Algumas regras sobre a "procuração" segundo a legislação extravagante e as "Ordenações Filipinas": impedimentos subjetivos e os efeitos do malogro da pretensão recursal. É possível afirmar que nas "Ordenações Manuelinas" podem ser entrevistos os contornos fundamentais da procuração judicial anterior à codificação de 1867. Com efeito, a respeito deste específico tema, são poucas as disposições estabelecidas pela legislação extravagante, merecendo destaque o Alvará de 03 de novembro de 1512 (por meio do qual se proibiu aos nacionais a "aceitação" de procuração para pleitear benefícios em prol de estrangeiros) e o Regimento dos Desembargadores do Paço de 02 de novembro de 1564 (que cominou pena aos procuradores que interpusessem recursos não providos pela instância superior). Por sua vez, as "Ordenações Filipinas" se limitaram a reiterar as linhas gerais da "procuração" judicial estabelecidas pelas fontes que lhes antecederam; entretanto, a respeito da variante extrajudicial praticamente nada havia sido estatuído (à exceção da menção incidental constante de Ord. Man. I, 38, 36 e de Ord. Fil. I, 48, 15): razão pela qual se mostrava

trautou com Procurador falso, que offereceu falsa procuraçam (...) o tal erro se nom poderá soprir em ninhua parte de qualquer Juizo que seja aleguado; antes todo o processo será ninhuu” (Ordenações Manuelinas III cit. (nota 87), p. 186). Sem qualquer alteração de fundo, cf. Ord. Fil. III, 63, 5.

Daí a oportunidade para uma distinção entre a atuação ilegal do procurador (quando contraria disposição contida em regra geral e abstrata) e a simples inobservância das instruções confiadas por seu constituinte. No primeiro caso, há que se preservar o interesse da parte, imputando-se a responsabilidade correspondente unicamente ao agente; entretanto, na segunda hipótese, não pode sobrevir o prejuízo de terceiro diante da escolha (talvez precipitada) do principal (quando elegeu livremente quem seria o seu procurador). Neste sentido - além da regra constante de Ord. Man. I, 38, 35 - o preceito estabelecido em Ord. Man. III, 15, 16 bem exemplifica a primeira hipótese: "E o Procurador que nom der o feito ao termo que lhe for assinado, posto que nom seja acusado pêra o dar, paguará vinte cruzados (...) porem nom tolhemos, que despois que deer o feito ao termo que lhe era assinado, senom satisfezer com os artiguos com que auia de viir, se lhe pera artiguos era dado, que possa pedir o segundo, ou terceiro termo pera os ditos artiguos, se ainda lhe couber" (Ordenações Manuelinas III cit. (nota 87), p. 57). Todavia, evidenciando a segunda hipótese acima destacada, assim se pronuncia o legislador em Ord. Man. I, 38, 36: "E se os Julguadores, que dos taees feitos forem Juizes, acharem, que alguu nam seguindo a enformaçam da parte procurou seu feito erradamente, e por sua culpa a parte recebeo dãno, faça todo emendar, e paguar aa parte pelos bens do Procurador, que em tal culpa for achado, se a parte o requerer. E aalem desto o Procurador, que por malicia nom seguir a enformaçam da parte, será punido segundo sua culpa, e o erro que nisso cometer. E posto que alguus feitos se trautem, e determinem sem os Procuradores auerem as enformaçoes das partes, na maneira que dito he, Auemos por bem, que as sentenças que em taees feitos forem dadas nom sejam por isso anuladas, nem impedidas as execuçoes dellas" (Ordenações Manuelinas I cit. (nota 87), pp. 246-247). Parece-nos desnecessário destacar que o dever de reparação somente exsurgiria se sobreviesse "dãno" (e o prejudicado efetivamente demandasse seu agente): o que evidencia o fato de que não bastava a inobservância das instruções, sendo necessário, ainda, o malogro da gestão confiada - traços evidenciadores de uma gestão colaborativa subjacente ao vínculo entre o procurador e seu constituinte. No mesmo sentido das disposições acima referidas, cf. Lei de 18 de novembro de 1577 (§ 26); Ord. Fil. III, 20, 45; e Ord. Fil. I, 48, 17.

Finalmente, a respeito da menção incidental ao procurador extrajudicial - constituído unicamente para a ulterior outorga de poderes ao agente incumbido da atuação em juízo - cf. Ord. Man. I, 38, 36 e Ord. Fil. I, $48,15$. 
necessário o apelo ao direito subsidiário - tal qual preconizado pelas sucessivas "Ordenações do Reino de Portugal"98.

\section{$\S 119$. Encerramento do capítulo e apresentação do tema sucessivo. Desta}

forma, a propósito da procuração extrajudicial, faz-se necessária uma análise da disciplina concernente ao direito subsidiário nas sucessivas "Ordenações do Reino"; mas para além disso, parece-nos oportuna uma abordagem sobre o processo de fortalecimento e declínio do direito romano em Portugal. Assim, em meio ao próximo capítulo de nossa investigação, buscaremos evidenciar não apenas o compromisso entre tal instituto e o fortalecimento do direito justinianeu no cenário lusitano, mas também a íntima relação entre a sua reforma e o desprestígio desta fonte tradicional. Como teremos a oportunidade de observar, a ascensão do iluminismo jurídico vai produzir reflexos bastante significativos

${ }^{98}$ Por meio do Alvará de 03 de novembro de 1512 - que a despeito de sua data não constou da edição definitiva das "Ordenações Manuelinas" - D. Manuel proibiu aos seus nacionais a aceitação de procuração para pleitear benefícios concedidos a estrangeiros (S. IV, 12, 1): "Ordenov \& defedeo el Rei Dom Manuel, que sancta gloria aja, que natural algum seu de qualquer corte \& condição que fosse, não fosse tam ousado, que acceptasse em seus regnos \& senhorios benefícios algus de homem estrangeiro per qualquer via, modo, \& maneira que fosse, nem acceptasse procuração de algum estrangeiro, que beneficio tiuesse acceptado em seus regnos, nem em maneira algua por elle requeresse" (Leis Extravagantes cit. (nota 86), p. 153verso). Observe-se que tal orientação foi inteiramente mantida pelas "Ordenações Filipinas", como se pode depreender de Ord. Fil. II, 13, 1 ( $1^{\text {a }}$ parte). Não obstante o interesse de uma investigação histórica sobre as razões que motivaram a exclusão de tal provisão das "Ordenações Manuelinas", uma questão relativa ao seu conteúdo deve ser destacada: como já mencionado - por reiteradas vezes - a respeito do direito lusitano, depreende-se de tal excerto uma fusão indiscriminada entre a "procuração" e o "mandato": ou de que outra forma poderíamos explicar a proibição à "aceitação" de um negócio jurídico unilateral (tal qual a outorga de poder)?

Por sua vez, o Regimento dos Desembargadores do Paço de 02 de novembro de 1564 oferece interesse por ter permitido a punição dos procuradores que interpusessem recursos não providos pela instância superior ( $\mathrm{S}$. I, 4, 1, 121): "E sendo a sentença, de que assi pedir reuista, confirmada no caso da dita reuista, o procurador que fizer ou assinar a petição, pagaraa a terça parte dos ditos sesenta cruzados, aa parte q os depositar: o que assi se mandaraa \& declararaa na própria sentença que se der. E não lha querendo a dita parte leuar, pagaraa o dito procurador a dita quantia, ametade para o sollicitador da justiça, que o requerer, ou para qualquer pessoa que o accusar, \& a outra ametade para os captiuos" (Leis Extravagantes cit. (nota 86), p. 17). Note-se que - como teremos a oportunidade de destacar no capítulo subseqüente de nossa análise - um dos principais objetivos da Lei de 18 de agosto de 1769 ("Lei da Boa Razão") foi o de impedir a utilização maliciosa de expedientes processuais - sobretudo recursais - como forma de obstar o andamento regular dos procedimentos judiciais. De tal forma, tal disposição pode ser incluída em um complexo mais amplo de medidas tendentes ao esvaziamento da atuação nociva de advogados e procuradores - os quais, atualmente, não contam com uma ameaça de reprimenda tão severa quanto a defluente de tais diplomas. Confrontar, ainda, o Assento de 16 de novembro de 1700 da Casa da Suplicação (apud CÂNDIDo MENDES DE ALMEIDA, Auxiliar cit. (nota 95), pp. 200-201).

Finalmente, a respeito do reconhecimento da procuração extrajudicial - conquanto com efeitos limitados à subseqüente outorga de poderes ao agente responsável pela atuação em juízo - assim dispunham as "Ordenações Filipinas" (Ord. Fil. I, 48, 15): "E mandamos que todos os Procuradores, que em Juizo houverem de procurar por algumas partes, hajam dellas informação de todo o negocio (...) as quaes lhe serão dadas pelas partes, ou per Procuradores, a que as partes para a dita causa fizerem procuração per Tabellião das Notas, ou per mão propria" (Código Philippino cit. (nota 16), p. 89). Além da reiteração de disposição constante das Ordenações Manuelinas (Ord. Man. I, 38, 36), merece destaque o outro reconhecimento que, implicitamente, se faz em tal preceito, a respeito da procuração extrajudicial (defluente do período "que em Juizo houverem de procurar"); portanto, também poderiam procurar "fora do Juízo". 
quanto ao desenvolvimento posterior do direito civil português; de maneira que as sementes lançadas pelas reformas pombalinas da aplicação e do ensino do direito gerarão frutos - a serem colhidos, sobretudo, com o advento da codificação civil de 1867. 


\title{
CAPÍTULO VIII.
}

\section{A ASCENSÃO E O DECLÍNIO DO DIREITO JUSTINIANEU NO PANORAMA DAS FONTES JURÍDICAS LUSITANAS: NOTAS SOBRE A TRANSIÇÃO RUMO A UM MANDATO DE CONTORNOS LIBERAIS.}

\author{
$\S$ 120. Justificativa de inversão (provisória): da história interna às
} historiografias externa e do pensamento jurídico. Até o momento nossa análise esteve comprometida com o desenvolvimento de uma historiografia interna, preponderamente voltada ao "mandatum"; no entanto, inexistindo nas "Ordenações do Reino de Portugal" disposições específicas a respeito dos contornos eficaciais da variante extrajudicial do tipo contratual referido, P. J. de MELlo FREIRE dos Reis já observava que foram recebidas "em nossas leis e costumes quase todas as disposições que se acham estabelecidas no direito romano, pois foram tiradas do direito das gentes". Tal assertiva - principalmente por sua parte final - provoca uma mudança provisória quanto ao método histórico de abordagem do tema: antes de prosseguirmos em nossa incursão a respeito da trajetória do mandato luso-brasileiro, faz-se necessário compreender de que forma o direito romano se tornou poderoso subsídio à lacunosidade das fontes do direito lusitano; e particularmente, de que modo foi alvejado pelo espírito iluminista a partir da segunda metade do século XVIII, em um movimento que determinou - ainda que de maneira oblíqua - a conformação assumida pelo aludido tipo contratual nos cenários português e brasileiro dos séculos seguintes ${ }^{99}$.

\footnotetext{
${ }^{99}$ Assim se pronuncia P. J. de Mello FreIRE dos Reis no texto (latino) original: "Enimvero de mandato, et mandatariis, seu procuratoribus extrajudicium specialem titulum nom habemus; ea tamen fere omnia legibus nostris et moribus recipimus, quae jure Romano sancita inveniuntur; sunt etenim e jure gentium deducta" (Institutiones cit. (nota 16), p. 22); por sua vez, eis o teor do trecho segundo a tradução portuguesa : "Ora, nós não possuímos título nenhum especial acerca do mandato e dos mandatários, isto é, dos procuradores extrajudiciais; todavia, recebemos em nossas leis e costumes quase todas as disposições que se acham estabelecidas no direito romano, pois foram tiradas do direito das gentes" (Institutiones Juris Civilis Lusitani cum Publici tum Privati, trad. port. de Miguel Pinto de Meneses, Instituições de Direito Civil Português Tanto Público como Particular, in Boletim do Ministério da Justiça 168 (1967), p. 59).

Assim, percebe-se que o direito romano era aplicado ao contrato de mandato - à vista da falta de disposição expressa constante das "Ordenações Filipinas”. Desta forma, faz-se necessário deixar a historiografia interna por um instante, a fim de que possamos dedicar nossa atenção ao papel desempenhado pelo direito justinianeu no cenário das fontes do direito lusitano. Note-se que em meio ao trecho destacado é justificada a utilização do direito romano em decorrência de sua conformidade ao "direito das gentes". Tal observação não nos parece acidental; ao contrário, cremos que aí se tem uma evidência de um processo de "depuração" das fontes justinianéias, instalado em Portugal pelas reformas pombalinas da aplicação e do ensino do direito, durante a segunda metade do século XVIII. É exatamente a esse assunto que se volta o presente capítulo desta exposição.

A respeito da utilização do direito justinianeu como fonte subsidiária aos textos lusitanos, cf. M. J. de AlmeIda Costa, História cit. (nota 09), pp. 308-317; Fundamentos cit. (nota 16), p. 114; Ordenações cit. (nota 16), pp. 263, 266 e 268; La présence cit. (nota 16), p. 57; Romanismo cit. (nota 74), pp. 32-35; Enquadramento histórico do Código Civil Português, in Boletim da Faculdade de Direito da Universidade de Coimbra 37 (1961), pp. 147-148; M. CAETANo, História cit. (nota 16), pp. 547-551; B. AnTUNES, Apontamentos cit. (nota 16), pp. 137-138; CÂNDIDO MENDES DE AlmEIDA, Código cit. (nota 16), p. XXVI; L. C. de Azevedo, O Reinado cit. (nota 16), pp. 24 e 26; J. C. Moreira Alves, Panorama cit. (nota 16), p.
} 


\section{$\S$ 121. Robustecimento do direito romano no panorama das fontes do}

direito lusitano. Efetuada a confrontação de algumas fontes do direito lusitano medieval, percebe-se que o direito romano vai granjeando, paulatinamente, uma importância cada vez maior no cenário jurídico português; conquanto seu primeiro influxo ainda se desse à custa das fontes castelhanas do século XIII (tal qual evidencia a estrutura interna dos "Foros da Guarda"), já em 1361 D. Pedro I acolhia reclamação dos estudantes da Universidade de Coimbra, que postulavam o reconhecimento da autoridade dos próprios textos justinianeus - bem como de suas fontes secundárias mais autorizadas - sem a necessidade da tradicional intermediação das "Siete Partidas" (Provisão de 13 de abril). Com efeito, vários documentos evidenciam uma progressiva recepção do direito romano imperial (e de seu respectivo desenvolvimento medieval) durante os séculos XIV e XV: nesse sentido, o Alvará de 19 de maio de 1425 e a "Carta de Bruges" denunciam a indiscutível reputação angariada pela obra de Bártolo em terras portuguesas; por sua vez, na Carta Régia de 18 de abril de 1426 se reconhece que - visando contornar o difícil contato da magistratura municipal com os textos latinos - D. João I havia determinado,

188; I. M. PovedA Velasco, Ordenações cit. (nota 16), pp. 19-20, 22 e 24; F. C. PONTES DE MiRANDA, Fontes cit. (nota 16), p. 62; O. GOMES, Raízes cit. (nota 16), pp. 5-6; A. SANTOS Justo, O Direito Brasileiro cit (nota 16), p. 4; A. A. VIEIRA CURA, Direito Romano cit. (nota 16), pp. 232-238; N. E. GoMES DA SILVA, História cit. (nota 16), pp. 275-290, 296-301 e 355-358; O sistema de fontes cit. (nota 16), pp. 442-455; G. BRAGA DA CRUZ, Formação Histórica cit. (nota 16), pp. 29-30; O Direito Subsidiário cit. (nota 16), pp. 245436; La Formation du Droit Civil Portugais Moderne et le Code Napoléon, in Obras Esparsas II - Estudos de História do Direito - Direito Moderno (2 $2^{a}$ parte), Coimbra, Imprensa da Universidade, 1981, p. 5; M. Paulo MerÊA, Resumo cit. (nota 16), pp. 147-148; R. R. NogueIRA, Prelecções cit. (nota 16), pp. 125-126; M. A. COElHO DA Rocha, Ensaio cit. (nota 16), pp. 125-126, 129, 191; H. da GAMA BARROS, História cit. (nota 16), pp. 134-135; A. M. HesPanHA, História cit. (nota 16), pp. 500-503; J. G. B. CÂMARA, Subsídios cit. (nota 16), pp. 77-88; M. de AlBuQuerQue, Bártolo e Bartolomismo na História do Direito Português, in Boletim do Ministério da Justiça 304 (1981), pp. 36-42; J. VALLET DE GOYTISOLO, El derecho romano cit. (nota 74), pp. 473-476; M. R. MARQues, O Liberalismo e a Codificação do Direito Civil em Portugal Subsídios para o Estudo da Implantação em Portugal do Direito Moderno, Coimbra, Imprensa da Universidade, 1987, pp. 18-22; Elementos para uma aproximação do estudo do usus modernus pandectarum em Portugal, in Boletim da Faculdade de Direito da Universidade de Coimbra 58 (1982), pp. 801-807; História cit. (nota 64), pp. 71-88; A. TEIXEIRA DE FreITAS, Consolidação cit. (nota 16), pp. XXXII-XXXIII. Por fim, acerca da distinção entre historiografia jurídica interna (dos institutos) e externa (das fontes) aludindo, ainda, a uma historiografia do próprio pensamento jurídico - cf. M. J. de ALMEIDA CosTA, História cit. (nota 09), pp. 32-33; A. SANTOS Justo, Nótulas de História do Pensamento Juridico (História do Direito),Coimbra, Coimbra Editora, 2005, p. 5; bem como L. CABRAl DE MonCADA, O problema metodológico na ciência da história do direito português, in Estudos de História do Direito II, Coimbra, Imprensa da Universidade, 1949, pp. 180-181 (mencionando, em tom de reprovação, unicamente as duas primeiras vertentes).

Já tivemos a oportunidade de nos pronunciar, com maior minúcia, sobre a matéria concernente ao presente capítulo; a respeito, cf. E. L. R. POUSADA, Preservação da tradição jurídica luso-brasileira: Teixeira de Freitas e a Introdução à Consolidação das Leis Civis, Dissertação (Mestrado) - Faculdade de Direito da U.S.P., São Paulo, 2006, pp. 23-92. 
algum tempo antes, a tradução de "caddhua ley [do "Codex"] e grossa e no bartallo que de sobrello he escripto"100.

${ }^{100}$ A estrutura interna dos "Foros da Guarda" denuncia a importância das fontes castelhanas como elemento de intermediação no processo de recepção do direito justinianeu em Portugal; no exemplar situado no Arquivo Nacional da Torre do Tombo, podem ser entrevistas: a versão portuguesa das "Flores de Derecho", a versão portuguesa do "Foral da Guarda" (fuero breve), os "foros e costumes" (estatutos municipais do concelho da Guarda), a transcrição de Leis Gerais portuguesas anteriores a 1273, a versão portuguesa dos "Nueve tiempos de los pleitos" e a versão portuguesa do "Fuero Real". Temos aí não apenas um trecho da obra doutrinária de "Maestro Jacobo de las Leyes", mas também parte da produção legislativa do próprio D. Afonso X (o Sábio).

A existência de versão portuguesa das "Flores de Derecho", dos "Nueve tiempos de los pleitos" e do "Fuero Real" evidencia a importância de tais instrumentos como direito subsidiário empregado pelos juízes da cidade da Guarda. Como observa G. BRAGA DA CRUZ, os erros quanto à tradução portuguesa das "Flores de Derecho" denunciam a popularidade atingida por tais obras ( $O$ Direito subsidiário cit. (nota 16), pp. 273275). A respeito da presença de tais fontes nos "Foros da Guarda", cf. M. PAULO MERÊA, Versão cit. (nota 74), pp. 444-457; Flores de Direito, in Boletim da Faculdade de Direito da Universidade de Coimbra 6 (1917), pp. 341-371; M. CAETANO, História cit. (nota 16), p. 341; e N. E. GoMes Da Silva, História cit. (nota 16), p. 229. Especificamente sobre a tradução das "Siete Partidas" - determinada por D. Dinis - cf. M. A. COElHO dA Rocha, Ensaio cit. (nota 16), p. 79.

Na Provisão de 13 de abril de 1361, D. Pedro I acolhe a pretensão dos estudantes de Coimbra, que buscavam o reconhecimento de seus direitos a partir dos próprios textos justinianeus, complementados pela produção dos "doutores" do direito comum; com efeito, os discentes pareciam encontrar resistência no espírito tradicional do Reitor, que somente admitia postulação fundamentada no texto das "Siete Partidas". Assim, foi necessária a manifestação expressa do monarca, dirimindo a controvérsia: "Outrossy me enujarom dizer que quando acontece que elles allegam em alguuns fectos perante uos seus djreitos per seus liuros que lhes nom queredes delles conhecer saluo se uos mostrarem esses djreitos em liuros de partida (...) sobre esto tenho por bem e mandouos que quando uos elles alguuns djreitos mostrarem per seus liuros nos dictos fectos que lhos aguardedes auendo ante conselho com letrados que delo saybham de guisa que as partes nom recebam agrauamento sem razam vm [de] al nom façades" (apud G. BRAGA DA CRUZ, O Direito Subsidiário cit. (nota 16), pp. 288-289, 280 e 284). Há outra transcrição (ligeiramente diferente) na obra de N. E. GOMES DA SILVA (História cit. (nota 16), pp. 231-232). Sobre o papel desta provisão como elemento demonstrativo da ampla utilização das "Siete Partidas" em Portugal - em um movimento de transição rumo à utilização direta das fontes justinianéias - cf. J. ANASTÁCIO DE FIGUEIREDO, Sobre qual foi a Epoca certa da introducção do Direito de Justiniano em Portugal, o modo da sua introducção, e os gráos de autoridade, que entre nós adquirio. Por cuja occasião se tracta toda a importante matéria das Ord. Liv. III, tít. 64 in Memórias de Litteratura Portugueza I, Lisboa, Officina da Academia Real de Sciencias, 1792, pp. 285-286; A. CAETANO Do Amaral, Sobre a Fórma de Governo, e Costumes dos Póvos que habitaraõ o terreno Lusitano, desde os primeiros tempos conhecidos, até ao estabelecimento da Monarquia Portugueza in Memorias da Litteratura Portugueza I, Lisboa, Academia Real das Sciencias de Lisboa, 1792, pp. 213-214; H. da GaMA BARros, História cit. (nota 16), p. 126; M. J. de AlmeIDA Costa, Romanismo cit. (nota 74), p. 26; M. PAUlo MerêA, Resumo cit. (nota 16), pp. 125-126; M. CAETANO, História cit. (nota 16), p. 342; A. M. HESPANHA, História cit. (nota 16), pp. 494-495.

Por sua vez, pelo Alvará de 19 de maio de 1425 D. Duarte se dirige ao corregedor, aos juízes e às justiças da cidade de Lisboa, aludindo à "pena que he scripta no proemio do bartallo per que percam os beens os juizes e procuradores se julgarem e precurarem fora daquello que ell hordena. $\mathrm{E}$ a el praz que aquella pena dos beens sse tire aos juizes e procuradores. E no all todo que este o proemyo em sua força afora naquello que ell ffez decraraçom, per hua carta que sobrello enuyou a p. annes lobato" (apud N. E. GOMES DA SILVA, História cit. (nota 16), pp. 267-268, nota 2). A respeito da importância deste alvará, N. E. GoMES DA SILVA destaca que nele se pode entrever uma consagração expressa da autoridade de Bártolo em solo português: "assim, em Maio de 1425, D. João I - aceitando, embora, uma excepção e fazendo uma decraraçom - confirmava, genericamente, o proemio de bartallo (que este o proemyo em sua força)" (História cit. (nota 16), p. 268, nota 2). G. BRAGA DA CRUZ acrescenta que "D. João I tinha, de facto, imposto anteriormente um certo acatamento (não sabemos qual) da obra de Bártolo" (O Direito Subsidiário cit. (nota 16), p. 290); cf., ainda, M. de Albuquerque, Bártolo cit. (nota 99), pp. 20-22 e 87; e A. M. HeSPANHA, História cit. (nota 16), p. 495 (nota 1063). 
De sua parte, a "Carta de Bruges" corresponde a uma missiva enviada por D. Pedro a seu irmão D. Duarte; trata-se de um extenso documento em que são versados os mais variados temas, dentre os quais o modelo de administração da justiça então em vigor. A. MOREIRA DE SÁ destaca que "os assuntos constantes do 'rolação', ou sobre os quais o Infante se pronunciou são: uns de natureza espiritual, como instrução e reforma do clero, e emenda da Universidade; outros de natureza temporal, como governo dos povos, tendo em vista um melhor povoamento e eqüitativa distribuição de privilégios, obras públicas, correições, administração da justiça, maneira de evitar despesas excessivas, questão de Ceuta, moeda, conselho da coroa, etc." ( $A$ < Carta de Bruges >> do Infante D. Pedro, in Biblos XXVIII (1952), pp. 35 e 38). De seu teor integral pode ser extraído o seguinte período: “A justiça, senhor, que he outra ujrtude, me pareçe que não reyna nos corações daqueles que tem carrego de julgarem a uosa terra, afora no do senhor rey e no uoso; e se mais são eu não são certo. E ajnda me pereçe senhor que esta justiça que asy he em uosos corações, não sae de la fora como deuja sayr, porque não somente uos deujeis querer que em toda uosa terra se gardasse a todos dereitura, mas ajnda ordenardes como se fezesse. E esto seria ordenando que os que ouuesem de ter carrego de uosa justiça, fosem bos e temesem mais a deus que a vose mais de perderem a uosa merçe que de todalas outras afeições nem proueitos mal gançados. E quando estes serujsem como deujam, reçebesem conheçidos galardões; e os que fizesem o contrayro, e uos delo foseis çerto, como agora sois e fostes dalguns outros, naom escaparem dalgua pena. Ca bem sabereis senhor que uos sois posto no mundo, per autorjdade do apostolo, pera louuor dons bons e ujngança dos maos. E se desto bem vsardes, não sey mais outra suficiente regra pera melhoramento de todos os que ouuerdes de reger. Pareçe me, senhor, que a justiça tem duas partes: hua he dar a cada hum o que he seu; e a outra dar lho sem delonga. E ajnda que eu cuydo que ambas em uosa terra jgoalmente faleçem, da derradeira são bem çerto e esta faz tão grande dano em uosa terra que a muytos feitos aqueles que tarde uençem, ficão vençidos. E eu vejo em uosa corte muytos offiçiaes de justiça e de todos eles sayr poucos desembargos; e pareçe me que se pode destes e da multidom dos cortesãos, de que uos diante escreuerey, bem fyrmar o dicto de ysaias: Multiplicasti gentem, sed nom magnificasti leticiam. Bem creo senhor que seis tyuesem uontade de desembargar e fosem diligentes em seu offiçio que farião mais que çinquoenta que tal uontade nom tem. E pareçe me, senhor, que pera abreuyamento dos feytos aproueitara muyto seguyr se a maneira que o senhor rey ordenou sobre o bartolo contanto que o liuro seja bem ordenado e corrydo por dous bons doctores, afora aquele que o treladou. E yso mesmo de as leys e ordenações do reyno serem proujdas e atituladas cada hua daquelo a que pertençe. E se antre elas fosem achadas alguas que ja fosem reuogadas, que as tyrem pois que delas não haõ dusar; e as boas ordenações se gardasem nas cousas sobre que são feytas" (cf. A. MOREIRA DE SÁ, A <〈Carta de Bruges〉> cit. (nota 68), pp. 49-50). Percebe-se a importância granjeada pela obra de Bártolo no meio português de então, uma vez que sua obra foi considerada elemento importante para a superação das mazelas que assolavam a administração judiciária da época. A respeito de tais considerações, além do estudo de A. MorEIRA DE SÁ, cf. N. E. GoMES DA SiLVA, $O$ sistema de fontes cit. (nota 16), pp. 441-442; A. M. HesPANHA, História cit. (nota 16), p. 495 (nota 1063); M. J. de Almeida Costa, Romanismo cit. (nota 74), p. 31 (nota 30); M. de AlbuQuerQue, Bártolo cit. (nota 99), pp. 27-30.

Finalmente, a Carta Régia de 18 de abril de 1426 demonstra ter sido ordenada a tradução não só dos "Comentários" de Bártolo, como ainda da "Glosa” de Acúrsio e do "Codex" justinianeu: "Corregedor e comçelho e homes bõos do nossa muy nobre leall cidade de Lixboa. Bem sabees o tralado que nos tomamos per que os feitos de nossos Reignos fossem desembargados per huu termo soo O qual foy outorizado pella força das leix do codigo, e decraradas e outorizadas pellas entençõees finaaes das grossas de sua final enteçom dacursio que sobrello escrepveo, ora fosse per hua grossa ou per duas ou per tres ou mais segundo he escripto, nos liuros. E esto quissemos que as conclussoies de bartallo, que de sobellas leix do codigo ffez, que estas sejam auteticadas, Ca esta he nossa Vontade, de os feitos nom seerem desembargados se nõ per hua enteçom e openyõ, segundo ja he escripto. E porque estas leyx e estas grossas e Leitura de bartallo a no nom parecia que per elas ouuessem de Senteçiar, porque os tralados de tirar de latim em linguajem nom som tam craros, que os homes que muyto nõ sabem os podessem bem entender, por esto nos trabalhamos de fazer hua decraração em cadhua ley e na grossa e no bartallo que de sobrello he escripto pella qual mandamos aos nossos desembargadores que per aquella decraraçom façam liurar os feitos e dar as Sentenças agora per os feitos que perdante elles correre que caibham nas leix e titulos, que em esses dous liuros que nos lla mandamos som contheudos. E ainda mais por que nos possemos em alguas leix que nos pareçiam que eram muyto craras que estauam bem. Assim o Julgaae pella guissa que he escripto posto que em ellas nom seja outra decraração segundo mais compridamente verees per o proemyo destes dous liuros que uos agora mandamos. E vos poce estes liuros na Camara desse Conçelho presos per hua cadea bem grande e longa. E nom os leixees veer a ninguém salvo aaquelles que feitos ouuerem ou a seus procuradores ou sse temerem dauer alguus feitos. E esto seja presemte o escripuam da dita camara. Ende al nõ façades. Dante em aaluerca XVIII ${ }^{\circ}$ dias dabril Lopafonso a fez ano de 1426" (apud M. J. de AlmEIDA CostA, Romanismo cit. (nota 74), pp. 30-31). Esta carta régia demonstra de modo contundente a autoridade atingida por essas três fontes 
$\S$ 122. A lacunosidade das "Ordenações do Reino de Portugal” e a articulação de um sistema de direito subsidiário: a solução defluente das "Ordenações Afonsinas" (Ord. Af. II, 9). Dotadas de uma estrutura relativamente rudimentar, as "Ordenações Afonsinas" estavam longe de caracterizar um "código" (tomada em consideração a acepção moderna do termo): articuladas em estilo histórico-narrativo, suas longas disposições não conformavam um texto "claro" e "simples" (perfeição formal); além disso, o conjunto de suas normas não evidenciava aquela "plenitude" pretendida pelo movimento codificador. De todo modo, a maturidade do legislador de então já recomendava mecanismos voltados à colmatação das lacunas de seu texto; conquanto preponderasse a preocupação com a supremacia do direito pátrio (e com um virtual conflito entre as jurisdições canônica e secular), em Ord. Af. II, 9 - sob o título “Quando a Ley contradiz aa Degratal, qual dellas se deve guardar" - se estabeleceu um refinado sistema de integração de todo o arcabouço jurídico lusitano. Tomando-se por ponto de partida o "critério de pecado" (Ord. Af. II, 9, 1), estabeleceu-se a aplicação subsidiária do direito canônico sempre que uma tal espécie de falta pudesse ser divisada em meio ao objeto da lide; no entanto, em matéria temporal, deveria o intérprete lançar mão das "Leyx Imperiaaes acerca do dito caso" (Ord. Af. II, 9 pr.), com a possibilidade de recurso

relacionadas ao direito justinianeu: tamanha foi sua importância que se determinou a tradução portuguesa dos textos originais ("decrarações"). Nesse sentido, cf. N. E. GOMES DA SILVA, O sistema de fontes cit. (nota 16), pp. 437-441; História cit. (nota 16), pp. 267-268 (nota 2); H. da GAMA BARROS, História cit. (nota 16), pp. 123-124 (nota 4); A. Herculano, Portugaliae cit. (nota 86), p. 148 (nota 3); M. J. de AlmeIDA CostA, La présence cit. (nota 16), pp. 54-55; Romanismo cit. (nota 74), pp. 30-32; A. M. HESPANHA, História cit. (nota 16), pp. 497-500; M. de AlbuQUerQue, Bártolo cit. (nota 99), pp. 22-27.

Para que se estime o grau de aceitação da obra de Bártolo em Portugal (durante os séculos XIV e XV), vale a pena destacar as conclusões de M. de ALBUQUERQUE a respeito da questão: "1. A influência de Bártolo deve ter-se feito sentir em Portugal desde os fins do século XIV. 2. De qualquer forma, no princípio do século XV tal influência é incontestável, para o que, decerto, contribuíram os estudantes portugueses que freqüentavam então as universidades italianas, em especial a de Bolonha. 3. Entre as provas da influência de Bártolo pode apontar-se a existência de obras suas na livraria dos primeiros monarcas de Avis, o alvará de 19 de Maio de 1425 e a chamada carta de Bruges. 4. A carta régia de 18 de Abril de 1426 confere valor normativo à tradução autêntica do comentário bartoliano ao Código. 5. O Regimento da Casa de Suplicação demonstra que, fosse qual fosse o alcance das disposições da carta régia citada, no mais alto tribunal do país a opinio Bartoli, já ampliada a outras obras que não o comentário ao Código, prevalecia sobre o jus regni, o jus proprium. 6. Fora, porém, do círculo restrito desse tribunal e de alguns juristas mais letrados, a influência de Bártolo nesse primeiro período foi restrita, para não dizer mínima” (Bártolo cit. (nota 99), pp. 87-88). As conclusões de $n^{\circ} \mathrm{s} 1$ a 5 confirmam as idéias lançadas neste tópico; a sexta conclusão, porém, é o elemento que nos permite indagar sobre o papel desempenhado pela opinio Bartoli com a promulgação das Ordenações Afonsinas. A respeito da influência de Acúrsio neste panorama, cf. M. J. de ALMEIDA CostA, La présence cit. (nota 16), p. 57. 
sucessivo às obras de Acúrsio e Bártolo - asseverando-se, quanto a este último, que "sua opiniom comunalmente he mais conforme aa razom" (Ord. Af. II, 9, 2) ${ }^{101}$.

${ }^{101}$ Considerando as "Ordenações Afonsinas" o primeiro código de toda a Europa, CÂNDIDO MENDES DE ALMEIDA reprova, neste sentido, as lições de J. BENTHAM, nas quais tal prioridade era expressamente conferida ao Código Dinamarquês de 1683 (Código cit. (nota 16), pp. XX-XXI). De todo modo, ainda que ao diploma português seja reconhecida a posição de destaque pretendida pelo autor brasileiro, não se pode considerá-lo um código "moderno", provido daquela sistematicidade que o torna diferente da simples coletânea de legislação contida em um "livro único"; nesse sentido, G. TARELLO observa que "'Codice' e 'C.' sono vocaboli di remota ascendenza, derivando (assieme a Côde, Codigo e altri vocaboli di lingue romanze) da codex, il libro compatto e cucito sul dorso. I libri compatti e cuciti sui dorsi contenenti materiali giuridici, nuovi o vecchi, raccolti da privati o da autorità, ebbero il nome di codex (codice, codex, codigo); l'area di impiego del vocabolo germanico Gesetzbuch, libro di leggi; l'intertraducibilità incompleta venne a complicare gli usi dotti e tecnici; e molte volte, in ispecie dagli storici del diritto, si parla ancora di codice in um senso che si collega semplicemente a raccolte di materiali giuridici caratterizzati dall'essere stati uma volta, da parti di qualcuno, imessi in um libro compatto e cucito sul dorso. Più sovente, oggi, quando si parla di 'codice' (e di 'C.'), ci si riferisce ad una classe di oggetti (e ad un processo storico) i cui collegamenti con il libro cucito sul dorso sono molto remoti" (G. TARELLo, Codificazione, in Digesto delle Discipline privatistiche (Sezione Civile) II (1988), p. 465).

Promulgadas pelo Infante D. Pedro - durante a menoridade de D. Afonso V - as "Ordenações Afonsinas" se caracterizam por seu teor compilativo, fato que se evidencia pela iterada referência à fonte originária das regras coligidas; a propósito, I. M. POVEDA VELASCO destaca seu estilo histórico-narrativo: "quanto ao conteúdo, as Ordenações recolhem abundantes leis régias, geralmente reproduzidas na íntegra, mencionando o monarca que as promulgou, a data e o local de sua publicação. São, também, numerosas as respostas régias a artigos ou capítulos das Cortes. Nesses casos inclui-se breve notícia a respeito das circunstâncias em que se deram. A compilação mantém, ainda, normas consuetudinárias que passam a valer como lei. Aparecem, finalmente, regras do direito justinianeu, interpretadas pelos antigos glosadores e adaptadas pelos compiladores, e textos do direito castelhano, notadamente das Partidas" (Ordenações cit. (nota 16), p. 19). No mesmo sentido, cf. M. PAulo MerêA, Resumo cit. (nota 16), pp. 132-133; M. A. Coelho Da Rocha, Ensaio cit. (nota 16), pp. 117-126; M. CAETANO, História cit. (nota 16), pp. 529-551; M. J. de ALMEIDA CostA, Ordenações cit. (nota 16), pp. 260-264; História cit. (nota 09), pp. 273-281; Nota de apresentação, in Ordenações Afonsinas - Livro I, Coimbra, Fundação Calouste Gulbenkian, 1984, pp. 5-11; L. J. CORREIA DA SILVA, Prefação, in Ordenações Afonsinas I, 2a ed., Coimbra, Fundação Calosute Gulbenkian, 1984, pp. IXXX; CÂNDIDo Mendes de AlmeIdA, Código cit. (nota 16), pp. XX-XXII; F. C. PONTES DE Miranda, Fontes cit. (nota 16), pp. 38-40; J. G. B. CÂMARA, Subsídios cit. (nota 16), pp. 57-64; G. BRAGA DA CRUZ, $O$ Direito Subsidiário cit. (nota 16), pp. 296-307; A. M. HeSPANHA, História cit. (nota 16), p. 526; H. da GAMA BARRos, História cit. (nota 16), pp.132-136; N. E. GOMES DA SILVA, O sistema de fontes cit. (nota 16), pp. 429-455.

A codificação moderna, contudo, deveria se pautar pela simplicidade (dos textos) e pela plenitude (do sistema articulado): "i due requisiti fondamentali che deve avere una buona legislazione, cioè la perfezione formale e la perfezione sostanziale: la legislazione deve essere perfetta formalmente, cioè deve enunciare le norme giuridiche in modo chiaro e preciso; e deve essere perfetta sostanzialmente, cioè devono contenere norme che regolino tutti i rapporti sociali" (N. BoBBIO, Il positivismo cit. (nota 55), p. 60). Conquanto as "Ordenações Afonsinas" - dado seu estilo histórico-narrativo - estivessem muito longe daquela "perfeição formal" pretendida pelo movimento codificador, no que concerne à plenitude do sistema, uma espécie de "norma de fechamento" pode ser entrevista em Portugal (já em meados do século XV): trata-se da disciplina do direito subsidiário, articulada em Ord. Af. II, 9. Eis o teor da referida disposição: "Estabelecemos, e poemos por Ley, que quando alguu caso for trazido em pratica, que seja determinado per algua Ley do Regno, ou estillo da nossa Corte, ou custume dos nossos Regnos antigamente usado, seja per elles julgado, e desembargado finalmente, nom embargante que as Leyx Imperiaaes acerca do dito caso ajam desposto em outra guisa, porque onde a Ley do Regno dispoem, cessam todalas outras Leys, e Direitos; e quando o caso, de que se trauta, nom for determinado per Ley do Regno, mandamos que seja julgado, e findo pelas Leys Imperiaaes, e pelos Santos Canones. 1. E acontecendo, que acerca de tal caso as Leyx Imperiaaes sejam contrairas aos Canones, mandamos que assy nas cousas temporaaes, como espirituaaes, se guardem os Canones, se o caso tal for, que guardando as Leyx Imperiaaes traga pecado; pode-se poer enxemplo no possuidor de maa fe, que segundo as Leyx Imperiaaes per trinta annos possoindo sem titulo, prescrepve a cousa alhea, e segundo Direito Canonico, o possuidor de maa fé nom pode prescrepver per nenhuu tempo: se 
em tal caso se guardassem as Leyx Imperiaaes, guardando-as, necessariamente trazeria pecado ao possuidor, o que nom devemos a consentir, maiormente que em tal caso devemos necessariamente obediencia ao Padre Santo, e aa Santa Igreja, de que os Canones procedem, a qual nõ devemos em nenhuu caso aos Emperadores, de que as Leyx Imperiaaes procedem; e por tanto convem que em tal caso, e em outro semelhante se guarde o Direito Canonico, e nom o Direito Imperial: e no caso temporal, que a guarda das Leyx Imperiaaes nom traga pecado, ellas devem seer guardadas, nom embargante que os Canones sejam em contraira desposiçom. 2. E se o caso, de que se trauta em pratica, non fosse determinado per Ley do Regno, ou estillo, ou custume suso dito, ou Leyx Imperiaaes, ou Santos Canones, entom mandamos que se guardem as grosas d'Acursio encorporadas nas ditas Leyx. E quando pelas ditas grosas o caso nom for determinado, mandamos, que se guarde a opiniom de Bartholo, nõ embargante, que os A. outros Doutores diguam o contrairo; porque somos bem certo, que assy foi sempre usado, e praticado em tempo dos Reyx meu Avoo, e padre da gloriosa memoria; e ainda nos parece, polo que já alguas vezes vimos, e ouvimos a muitos Leterados, que sua opiniom comunalmente he mais conforme aa razom, que a de nenhuu outro Doutor; e em outra guisa seguirsia grande confusom aos Desembargadores, segundo se mostra per clara esperiencia. E acontecendo caso, ao qual per nenhuu dos ditos modos nom fosse previsto, mandamos que o notifiquem a Nos pera o determinarmos; porque nom tamsomente taaes determinaçoões som desembargo daquelle feito, que se trauta, mais som Ley pera desembargarem outro semelhante. 3. Item. Despois desto achamos outra duvida. Se acontecesse caso, em o qual nõ fosse matéria de pecado, o qual nom fosse determinado per Ley do Regno, nem per estillo da nossa Corte, nem per custume dos nossos Regnos, nem per Ley Imperial, e fosse determinado per Canones per huu modo, e pelas grosas, e Doutores das Leyx per outro modo, se se guardará em tal caso o texto dos Cânones, ou as grosas dos Doutores das Leys Imperiaaes; e a causa desta duvida he, porque as grosas, e Doutores do Direito Civil se fundam per Leyx Imperiaaes, as quaaes allegam provar sua teençom: em tal caso seja remetido aa nossa Corte, e guarde-se sobre ello a nossa determinaçom" (Ordenações Afonsinas II, Lisboa, Fundação Calouste Gulbenkian, 1998, pp. 161-164).

Observe-se que do proêmio é possível extrair uma consagração da primazia do direito pátrio sobre quaisquer outras fontes do direito; ainda que aqui se reconheça um papel relevante ao direito comum, estamos bastante longe daquela situação de proeminência do direito canônico que outrora caracterizara uma das mais importantes manifestações legislativas da monarquia lusitana recém-implementada (neste específico sentido, cf. "Lei pela qual se estabelece que o direito canónico tenha vigor em Portugal e que no caso de conflito entre o direito régio e o direito canónico tenha este supremacia", in Livro das Leis cit. (nota 87), p. 9; e em Ordenações Del-Rei cit. (nota 87), p. 43, sob o título "Constituçom primeira que as leis E ordinaçoões que per o dito Rej E per seus socesores forem feytas que seguem os degredos dos padres santos E os ditos da santa Jgreja").

Merece destaque, ainda, a posição sistemática conferida ao tema: considerando-se em primeiro plano um potencial conflito entre as jurisdições canônica e secular, a matéria foi objeto de regulamentação em meio ao Livro II das "Ordenações Afonsinas" (destinado a uma miscelânea de assuntos que não pareciam facilmente remontáveis aos livros restantes da compilação). Voltando-se o Livro I a uma espécie de direito administrativo, os Livros III, IV e V se destinavam, respectivamente, ao processo civil, ao direito civil (material) e à temática penal como um todo (substantiva e adjetiva); desta forma, restava ao Livro II aquela matéria que "parecia" reconduzir a uma espécie de conflito entre as jurisdições "espiritual" e "temporal" (sob a epígrafe "Quando a Ley contradiz aa Degratal, qual dellas se deve guardar"). Como destaca M. PAULO MERÊA, a divisão das "Ordenações" em cinco livros decorreu provavelmente da estrutura adotada pelas "Decretais" (Resumo cit. (nota 16), p. 133). No mesmo sentido, cf. M. J. de AlmEIDA CostA, Ordenações cit. (nota 16), p. 262.

Embora a disciplina tenha "aparentemente" surgido para a composição de um potencial conflito de jurisdições, G. BRAGA DA CRUZ destaca que "não quer isto dizer (...) que a regulamentação aí dada ao problema do direito subsidiário não extravase amplamente os limites duma pura questão de conflito entre o direito do século e o direito da Igreja ou entre dois poderes de que esses ordenamentos jurídicos são a expressão; mas não há dúvida que é assim que o problema é posto, a demonstrar que era nisso que residia, segundo o espírito da época, o verdadeiro cerne da questão" (G. BRAGA DA CRUZ, O Direito Subsidiário cit. (nota 16), pp. 298-299). Neste mesmo sentido, cf. M. CAETANO, História cit. (nota 16), p. 548; J. ANASTÁCIO DE FIGUEIREDO, Sobre qual foi a Epoca cit. (nota 100), pp. 307-309; M. PAUlO MERÊA, Resumo cit. (nota 16), p. 147; M. A. COELHO DA RochA, Ensaio cit. (nota 16), pp. 125-126.

De fato, tal "conflito" deve ser tomado em sentido estritamente técnico; sem que com isso se possa divisar qualquer espécie de hostilidade entre as autoridades secular e eclesiástica (ao menos no plano legislativo); isso se torna evidente em decorrência da razão - positiva - declinada pelo legislador, quando alude à aplicação do direito canônico: "devemos necessariamente obediencia ao Padre Santo". Desta forma, em lugar de um "conflito de jurisdições", parece que se depreende uma pluralidade de sistemas jurídicos "interessados" no caso: algo que a doutrina dos últimos dois séculos pretende designar pela expressão 
"conflito de leis no espaço" - e que corresponde ao objeto do direito internacional privado (a respeito, cf. G. BRAGa Da CRUZ, O Direito Subsidiário cit. (nota 16), p. 304). De toda forma, devemos destacar que - ao contrário do direito canônico - quanto ao direito romano não se declina qualquer fundamento positivo para sua utilização em subsídio à legislação reinícola; ao contrário, a preocupação do legislador se cinge, principalmente, à negação de uma "iurisdictio Imperii". Tal circunstância não passou despercebida a G. BRAGA DA CRUZ: "trata-se, como se vê, duma justificação extremamente curiosa, não só por ser uma afirmação solene da doutrina da isenção da iurisdictio Imperii, sempre defendida pelos pensadores hispânicos em relação aos reinos cristãos da Península, como pelo contraste que oferece, ao invocar uma razão positiva da observância do direito canônico (a obediência devida ao Papa e à Igreja) contra uma razão meramente negativa do acatamento do direito romano (o não dever Portugal obediência ao Imperador), mas deixando sem explicar por que motivo, afinal, deve o direito romano ser observado como direito subsidiário (...) explicação que só será tentada mais tarde, como veremos, no preceito correspondente das Ordenações Manuelinas de 1521" (O Direito Subsidiário cit. (nota 16), pp. 304-305); por sua vez, destacando a necessidade - à época - de se repelir a tese da iurisdictio Imperii, cf. N. E. GOMES DA SILVA, História cit. (nota 16), p. 276.

De todo modo, a fim de evitar um conflito entre as próprias disciplinas subsidiárias, estabeleceu-se um parâmetro delimitador da preponderância do direito da Igreja: o "critério de pecado"; ou seja, vislumbrandose "pecado" na conduta objeto de regulamentação subsidiária, haveria de prevalecer - sempre - a orientação instituída pelos "Santos Canones".

Já no que concerne aos doutores do direito comum, um panorama interessante se descortina: enquanto a aplicação subsidiária da "Glosa" é determinada sem qualquer espécie de justificativa (ou mesmo de ressalva), o emprego dos "Comentários" de Bártolo é lastreado em fundamentos de ordem "racional" ("que sua opiniom he mais conforme aa razom"), "tradicional" ("que assy foi sempre usado, e praticado em tempo dos Reyx meu Avoo, e Padre da gloriosa memoria") e "prática" ("em outra guisa seguir-sia grande confusom aos Desembargadores, segundo se mostra per clara esperiencia"). A respeito, cf. G. BRAGA DA CRUZ, O Direito Subsidiário cit. (nota 16), p. 305; M. de AlBuQuerQue, Bártolo cit. (nota 99), pp. 87-89; A. M. HeSPANHA, História cit. (nota 16), pp. 500-502; R. R. NogUEIRA, Prelecções cit. (nota 16), p. 121; M. J. de ALMEIDA Costa, Romanismo cit. (nota 74), p. 30; N. E. Gomes DA SILVA, $O$ sistema de fontes cit. (nota 16), p. 437. Note-se que o primeiro fundamento já nos permite entrever um afloramento da "boa razão" como lastro para a "heterointegração" do sistema; neste sentido, M. CAETANO observa: "encontra-se assim já a ideia de que a boa razão é critério de opção entre os pareceres jurídicos para decidir um caso sub judice" (História cit. (nota 16), p. 551). Por sua vez, o último nos evidencia uma preocupação do legislador com a "segurança jurídica" o que é corroborado não só pela prevalência de Bártolo sobre os demais doutores ("nõ embargante, que os outros Doutores diguam o contrairo"), como ainda pelos efeitos "erga omnes" de uma decisão proferida pelo monarca na hipótese de insuficiência das fontes indicadas em Ord. Af. II, 9 pr., Ord. Af. II, 9, 1 e Ord. Af. II, 9, 2 ( $1^{\mathrm{a}}$ parte).

De fato, na hipótese de omissão de todas as fontes indicadas, a integração do sistema seria promovida à custa da deliberação do monarca, com efeitos que não se restringiam ao caso concreto, uma vez que "nom tamsomente taaes determinaçoões som desembargo daquelle feito, que se trauta, mais som Ley pera desembargarem outro semelhante". Neste sentido, vale notar que o funcionamento do sistema é muito similar àquele que se pratica, ainda hoje, no âmbito do "Common Law", em que a decisão de um caso "novo" se torna um precedente - vinculante - para as situações (similares) supervenientes. Tal expediente deveria ser observado, ainda, quando houvesse conflito entre o estatuído pelos doutores do direito comum e a disciplina decorrente do direito canônico - caso a questão não envolvesse, por óbvio, a prática de um "pecado".

A respeito do direito subsidiário nas "Ordenações Afonsinas", cf. M. J. de Almeida Costa, História cit. (nota 09), pp. 311-313; Fundamentos cit. (nota 16), p. 114; Ordenações cit. (nota 16), p. 263; La présence cit. (nota 16), p. 56; Enquadramento cit. (nota 99), pp. 147-148; M. CAETANO, História cit. (nota 16), pp. 547-551; J. C. Moreira Alves, Panorama cit. (nota 16), p. 188; I. M. Poveda Velasco, Ordenações cit. (nota 16), pp. 19-20; A. A. VIEIRA CURA, Direito Romano cit. (nota 16), pp. 232-234; N. E. GOMES DA SILVA, História cit. (nota 16), pp. 275-290; $O$ sistema de fontes cit. (nota 16), pp. 442-455; G. BRAGA DA CruZ, O Direito Subsidiário cit. (nota 16), pp. 296-307; M. PAUlo MerêA, Resumo cit. (nota 16), p. 147; R. R. Nogueira, Prelecções cit. (nota 16), p. 125; M. A. CoElHo Da Rocha, Ensaio cit. (nota 16), pp. 125126; A. M. HeSPANHA, História cit. (nota 16), pp. 500-502; M. de AlBuQUERQUe, Bártolo cit. (nota 99), pp. 36-43; J. VALLET DE GOYTISOLO, El derecho romano cit. (nota 74), p. 475; História cit. (nota 64), pp. 75-79. A respeito dos sentidos emprestados aos termos "autointegração" e "heterointegração", cf. N. BOBBiO, Il positivismo cit. (nota 55), p. 81 - ao tratar do art. $4^{\circ}$ do "Code Civil" e de seu papel como "regra de fechamento" do sistema jurídico francês. 


\section{$\S$ 123. A disciplina do direito subsidiário segundo as "Ordenações}

Manuelinas". A disciplina do direito subsidiário foi sensivelmente alterada quando da edição das "Ordenações Manuelinas” (Ord. Man. II, 5): a despeito da manutenção de seu enquadramento formal (em meio ao Livro II) - e da reiteração de regras importantes como a concernente ao "critério de pecado" - não se entrevia mais aquela preocupação anterior com um conflito entre as jurisdições canônica e secular; em lugar disso, buscou-se ampliar o alcance do direito reinícola, merecendo destaque a consagração expressa dos "costumes locais" como fonte do direito lusitano (Ord. Man. II, 5 pr.). Ao contrário da aplicação do direito canônico - que permanecia regulada por disposições de todo semelhantes às constantes das "Ordenações Afonsinas" - quanto às "Leys Imperiaes" houve uma profunda reformulação: ao mesmo tempo em que se reconheceu uma razão positiva para a sua utilização ("pola boa razam em que sam fundadas"), houve uma expressa preocupação por parte do legislador em recomendar a observância dos textos de Acúrsio e Bártolo apenas quando não tivessem sido reprovados pela "communis opinio doctorum" (Ord. Man. II, 5, 1) - e especificamente quanto ao comentador, somente por aquela que lhe tivesse sido posterior $^{102}$.

\footnotetext{
${ }^{102}$ A despeito da manutenção da estrutura subjacente às suas antecessoras (com a repartição em livros, títulos e parágrafos), as "Ordenações Manuelinas" se caracterizam, sobretudo, pelo estilo "decretório" empregado pelo legislador: "ao contrário das Afonsinas, as Ordenações Manuelinas não são mera compilação de leis anteriores, transcritas na sua maior parte no teor original e indicando o nome do monarca que as promulgara. Em geral, todas as leis são reescritas, em estilo decretório, como se de leis novas se tratasse, embora não passando muitas vezes de nova forma dada a leis já vigentes. Fazendo esse esforço de abstração das coordenadas espaço-temporais, e dando à redação cunho mais hipotético e abstrato, as Ordenações Manuelinas são consideradas por alguns como precursoras das modernas codificações" (I. M. POVEDA VELASCO, Ordenações cit. (nota 16), p. 22); com efeito, L. C. de AZEVEDO destaca a intenção de se conferir "ao conteúdo a feição de corpo legislativo" (O Reinado cit. (nota 16), p. 24). Ocorre que tal circunstância implica em prejuízos ao historiador, na medida em que o texto passa a oferecer "um menor interesse para a reconstituição do direito anterior" (M. J. de ALMEIDA CosTA, Nota de apresentação, in Ordenações Manuelinas - Livro I, Coimbra, Fundação Calouste Gulbenkian, 1984, p. 7). A respeito das "Ordenações Manuelinas", em geral, cf. F. X. de O. MATtos, Prefação, in Ordenações Manuelinas Livro I, Coimbra, Fundação Calouste Gulbenkian, 1984, pp. I-XXX; M. PAUlo MERÊA, Resumo cit. (nota 16), pp. 136-137; M. A. Coelho Da Rocha, Ensaio cit. (nota 16), pp. 127-129; M. CAETANO, Subsídios para a História das Fontes do Direito em Portugal no séc. XVI in História cit. (nota 16), pp. 621-633; N. E. GoMES DA SILVA, História cit. (nota 16), pp. 290-296; Algumas notas cit. (nota 86), pp. 456-467; M. J. de ALMEIDA CosTA, Ordenações cit. (nota 16), pp. 264-267; História cit. (nota 09), pp. 281-285; A. M. HESPANHA, História cit. (nota 16), pp. 526-527; CÂNDIDO Mendes DE AlMEIDA, Código cit. (nota 16), p. XXII; F. C. PONTES DE Miranda, Fontes cit. (nota 16), pp. 40-41; J. G. B. CÂMARA, Subsídios cit. (nota 16), pp. 77-88; J. M. Scholz, Legislação e Jurisprudência em Portugal nos Sécs. XVI a XVIII, in Scientia Iuridica 142-143 (1976), pp. 520-525.

Note-se que o título relativo ao direito subsidiário é um dos que denuncia de modo mais claro a diferença entre as "Ordenações Manuelinas" e suas antecessoras; além disso, ilustra de maneira singular a distinção entre as duas versões do próprio texto manuelino (1514 e 1521). A despeito da manutenção de seu enquadramento formal (em meio ao Livro II), sua epígrafe esclarece a nova perspectiva conferida ao tema: em lugar de um conflito entre jurisdições, buscava-se saber "Como se julguaram os casos, que nom forem determinados por Nossas Ordenaçoens". A propósito, eis o texto de Ord. Man. II, 5: "Quando alguu caso for
} 
trazido em practica, que seja determinado por algua Ley de Nossos Reynos, ou Estillo de Nossa Corte, ou Custume em os ditos Reynos, ou em cada hua parte delles longuamente vsado, e tal que por Dereito se deua guardar, seja per elles julguado, nom embarguante que as Leys Imperiaes acerca do dito caso desponham em outra maneira, porque onde a Ley, Estilo, ou Custume do Reino despoem, cessem todas outras Leys e Dereitos. E quando o caso de que se trauta nom for determinado por Ley, Estilo, ou Custume do Reyno, Mandamos que seja julguado, sendo materia que tragua pecado, por os Santos Canones; e sendo materia que nom traga pecado, Mandamos que seja julguado polas Leys Imperiaes, posto que os Sacros Canones determinem o contrairo, as quaes Leys Imperiaes Mandamos soomente guardar pola boa razam em que sam fundadas. 1. E se o caso de que se trauta em pratica nom for determinado por Ley do Reyno, ou Estilo, ou Custume suso dito, ou Leys Imperiaes, ou Santos Canones, entam Mandamos que se guardem as Grosas de Acursio encorporadas nas ditas Leys, quando por comum opiniam dos Doutores nom forem reprouadas, e quando por as ditas Grosas o caso nom for determinado, Mandamos que se guarde a opiniam de Bartolo, nom embarguante que alguus Doutores teuessem o contrairo; saluo se a comum opiniam dos Doutores, que depois delle escreueram, for contraira, porque a sua opiniam comunmente he mais conforme aa razam. 2. E acontecendo caso, ao qual por ninhuu dos ditos modos fosse prouido, Mandamos que o notifiquem a Nós, pera o Determinarmos; porque nom soomente taees determinaçoens sam desembarguo daquelle feito que se trauta, mas sam Ley pera desembarguarem outros semelhantes. 3. Item se acontecesse caso o qual nom fosse materia de pecado, e nom fosse determinado por Ley do Reyno, nem Estilo de Nossa Corte, nem Custume de Nossos Reynos, nem Ley Imperial, e fosse determinado por os Textos dos Canones por huu modo, e por as Grosas, e Doutores das Leys por outro modo, Mandamos que tal caso seja remetido a Nós, e guarde-se sobre ello Nossa Determinaçam" (Ordenações Manuelinas II, Lisboa, Fundação Calouste Gulbenkian, 1984, pp. 21-22).

Além da fusão entre o proêmio e o parágrafo primeiro do texto afonsino correspondente, foi acrescentada a previsão expressa do "costume local" como fonte do direito lusitano. Assim, o direito nacional passou a abarcar - paralelamente às leis do Reino e aos estilos da Corte - não apenas os costumes nacionais, mas também as fontes consuetudinárias locais. Ainda que o texto afonsino possibilitasse um tal entendimento (à custa de uma interpretação extensiva), a tarefa do exegeta foi simplificada por meio do emprego da expressão "em cada hua parte delles longuamente vsado" - G. BRAGA DA CRUZ observa que "o legislador entendeu conveniente - talvez para esclarecer qualquer dúvida surgida na interpretação do texto das anteriores Ordenações - acentuar a validade do costume local no mesmo plano do costume geral" (O Direito Subsidiário cit. (nota 16), p. 335, nota $1, a$ ).

Merece destaque o fato de que - ao mesmo tempo em que o legislador deixa de aludir à natureza temporal ou espiritual das questões - o "critério de pecado" é robustecido, tomando-se-lhe como fator decisivo na aplicação das Leis Imperiais ou dos Santos Cânones: "deixa de fazer-se a distinção (...) entre problemas jurídicos de ordem espiritual (...) e problemas jurídicos de ordem temporal (...) e reconduz-se tudo a um problema único, onde só conta o critério do pecado, qualquer que seja a natureza do caso a resolver" (G. BRAGA DA CRUZ, O Direito Subsidiário cit. (nota 16), p. 336).

A referida alteração da epígrafe do título aponta para uma mudança de perspectiva quanto ao tema, entrando em declínio a ultrapassada compreensão da questão como um "conflito entre jurisdições" (G. BRAGA DA CRUZ, O Direito Subsidiário cit. (nota 16), pp. 333-334); no mesmo sentido, N. E. GOMES DA SILVA qualifica a epígrafe como "mais correcta" (História cit. (nota 16), p. 296). Aliás, nas "Ordenações Manuelinas" ocorre a supressão do "aparato formal" desta idéia - na medida em que não se reproduziu a menção afonsina ao dever de obediência ao "Padre Santo".

Já no que concerne ao direito romano, ao mesmo tempo em que se deixa de lado a questão concernente à "iurisdictio Imperii" (razão negativa), empresta-se um fundamento positivo para a observância das Leis Imperiais: a "boa razam em que sam fundadas". Destacando a mudança promovida pela versão definitiva das "Ordenações Manuelinas", G. BRAGA DA CRUZ sustenta que "substitui-se essa razão de ordem negativa do acatamento devido ao direito romano, por uma razão de ordem positiva desse acatamento (...) no fundo a explicação não deixa de ser a mesma, na medida em que se quer significar que a aplicação do direito romano assenta na sua autoridade intrínseca - a boa razão em que seus preceitos são fundados - e não na autoridade extrínseca que lhe advém de as suas normas procederem do Imperador - e serem expressão, portanto, duma iurisdictio Imperii de que Portugal está isento -; mas, pelo menos, acaba-se com a incongruência em que tinha caído o legislador afonsino - e de que o legislador manuelino de 1512-1514 se não libertara -, ao invocar, no próprio texto que ordenava a aplicação subsidiária do direito romano, justamente a razão por que não lhe é devida obediência"(O Direito Subsidiário cit. (nota 16), pp. 338-341). No mesmo sentido, cf. M. J. de Almeida Costa, História cit. (nota 09), p. 314; bem como N. E. GoMES DA Silva, História cit. (nota 16), p. 297.

O reconhecimento da "boa razão" que permeava os textos justinianeus não é fato estranho a fontes anteriores do direito lusíada: em Ord. Af. II, 63, 3, por exemplo, se recorre à "natural razom, firmada per Ley, e per 
Direito dos Sabedores". Segundo asseveram respeitáveis doutrinadores, nas "Ordenações Manuelinas" a expressão "boa razão" teria um sentido diverso daquele que lhe foi atribuído, posteriormente, pela Lei de 18 de agosto de 1769: apresenta ali um sentido próximo ao de uma "ratio naturalis"; nesse sentido, as lições de G. Braga da CRuZ, O Direito Subsidiário cit. (nota 16), p. 338 (nota 2); e de M. PAUlo MerÊA, Direito romano, direito comum e boa razão, in Boletim da Faculdade de Direito da Universidade de Coimbra 16 (1939-1940), pp. 539-543. Assim, a "boa razão" seria simplesmente pressuposta, não se podendo negar aplicação à regra justinianéia que nela não se fundamentasse. Como observa G. BRAGA DA CRUZ, à expressão é conferido um sentido de que "o bom senso tem primazia sobre a própria lei", tomando-se o direito romano, em bloco, como elemento demonstrativo de uma "ratio scripta"; com efeito, o autor destaca que "a generalidade dos autores, porém, não toca neste problema, mesmo quando cita rotineiramente aqueles tópicos escolásticos sobre o primado da razão natural (...) admitindo, assim, implicitamente, a aplicação dos preceitos do direito romano, a título subsidiário, sem quaisquer reservas 'talvez (...) por encararem o direito romano em bloco como ratio scripta ou como tendo por si a presunção de boa razão' ( $O$ Direito subsidiário cit. (nota 16), pp. 355-365). Na mesma linha de raciocínio, cf. M. P. MÊREA, Direito romano cit. (nota 102), p. 541. Contudo, a questão não nos parece tão simples; conquanto a ela - por ora - não possamos nos dedicar com o vagar necessário, devemos ao menos assinalar a existência de um precedente medieval daquela postura adotada durante o consulado pombalino: na "Lei pela qual se determina que, nem na corte, nem nas audiências dos concelhos, haja advogados nem procuradores de número, e estabelecendo várias outras providências para evitar demoras no seguimento dos pleitos" - de 03 de novembro de 1352 - se observa, mais de quatrocentos anos antes da "Lei da Boa Razão", que "nom deuemos guardar os dictos dereytos escriptos se nom enquanto ssom fundados em boa Razom e em prol dos nossos ssubiectos" (Livro das Leis cit. (nota 87), p. 454).

Caso não fosse encontrada disposição aplicável em meio às "Leis Imperiais", o intérprete deveria lançar mão, sucessivamente, da "Glosa" e dos "Comentários". Há que se observar que a primeira versão das "Ordenações Manuelinas" (1514) manteve quase que integralmente o sistema afonsino, à exceção de uma alteração bastante significativa: a "communis opinio doctorum" foi consagrada como elemento de aferição da autoridade dos textos de Acúrsio e de Bártolo; ainda que tenham permanecido no quadro das fontes do direito subsidiário, a "Glosa" e os "Comentários" não poderiam ter sido contrariados pela opinião comum dos doutores - hipótese em que perderiam seu valor como elemento integrativo do sistema. Com efeito, G. BRAGA DA CRUZ destaca que "o título referente ao direito subsidiário é justamente um dos exemplos mais flagrantes destes dois escalões da reforma manuelina, pois tem uma redacção muito diversa na versão primitiva e na versão definitiva das Ordenações de D. Manuel I" (O Direito Subsidiário cit. (nota 16), pp. 327-328).

Ora, uma interpretação meramente gramatical de Ord. Man. II, 5 poderia conduzir o estudioso ao entendimento de que a "communis opinio doctorum" teria um poder meramente negativo, no sentido de tão somente destituir Acúrsio e Bártolo de sua respectiva autoridade. Entretanto, G. BRAGA DA CRUZ sustenta a afirmação da própria "opinião comum dos doutores" como fonte do direito subsidiário ("em lugar", portanto, da "Glosa" e dos "Comentários"). Não se nega, aqui, que uma tal exegese tenha sido confirmada pela prática; aliás, a primazia da "communis opinio" será uma das causas imediatas do apego excessivo à jurisprudência e, conseqüentemente, do advento da própria "Lei da Boa Razão". No entanto, é necessário ressaltar que a literalidade do texto não implica, por si só, na elevação da comunidade doutoral à categoria de fonte do direito subsidiário: a "opinião comum dos doutores" teria, portanto, uma força simplesmente refreadora da aplicação indevida da "Glosa" e dos "Comentários". Neste sentido, N. E. GOMES DA SILVA reconhece talvez a contragosto - que o alcance do texto é mais estrito: "a lei declara que Acúrsio e Bártolo só valem se não forem contrariados pela communis opinio, mas não afirma que, em tal caso, será de seguir a comum opinião: o texto diz que a communis opinio tem força para impedir a aplicação de Acúrsio ou Bártolo, mas não diz - ao menos expressamente - que os pode substituir" (História cit. (nota 16), p. 299).

De qualquer modo, cumpre destacar que a posição de G. BRAGA DA CRUZ é adotada pela maioria absoluta da doutrina: o mesmo N. E. GOMES DA SILVA, por exemplo, destaca que "na escala das fontes de direito subsidiário passa a ter primazia a comum opiniam dos Doutores: o facto de esta firmar ou reprovar Acúrsio ou Bártolo é mero acidente de referência (...) [sendo já outro o] centro de gravidade" (História cit. (nota 16), p. 299); M. CAETANO, por sua vez, fala em sobreposição da comum opinião dos Doutores (História cit. (nota 16), p. 629); e M. PAULO MERÊA acrescenta que os jurisconsultos "constantemente também alegavam como lei a opinio communis" (Resumo cit. (nota 16), p. 147). Em contrapartida, M. J. de AlMEIDA CostA destaca que a linha interpretativa de tais autores, ao alçar a "communis opinio" à categoria de fonte do direito subsidiário, não é pacífica (M. J. de AlMEIDA CosTA, História cit. (nota 09), p. 315); e que mesmo a força negativa da opinião comum "parece ter constituído, na prática, verdadeira letra morta" (Romanismo cit. (nota 74), p. 33; La présence cit. (nota 16), p. 56). De toda forma, vale ressaltar que a obra de Bártolo acabou por 


\section{$\S$ 124. A disciplina do direito subsidiário consoante as "Ordenações}

Filipinas". As razões que levaram à promulgação das "Ordenações Filipinas" correspondem a objeto de acesa controvérsia em meio à doutrina especializada: conquanto sua maioria propenda à compreensão do epísódio como um esforço de D. Filipe II para granjear a simpatia dos portugueses (poucas décadas depois da União Ibérica), há quem sustente que tal coletânea serviu à mitigação das excessivas concessões à Igreja Católica (levadas a efeito pelos últimos reis da Dinastia de Avis); de todo modo, prevalece o consenso quanto à oportunidade de uma revisão do sistema então vigente, capaz de reunir, em um único diploma, as disposições constantes das "Ordenações Manuelinas", da coletânea do licenciado Duarte Nunes do Lião e da legislação posterior ao ano de 1569. Já no que concerne especificamente ao direito subsidiário, poucas alterações nos parecem dignas de nota: em primeiro lugar, sobreveio um novo enquadramento formal do tema em meio ao Livro III das "Ordenações" (Ord. Fil. III, 64) - completando-se, assim, o processo de extirpação daquele virtual "conflito de jurisdições" que outrora se podia divisar (Ord. Af. II, 9 e Ord. Man. II, 5); mas para além disso, conferiu-se uma nova feição ao instituto, que passou a ser concebido como um complexo de regras de julgamento.

resistir, chegando por vezes a prevalecer sobre opinião comum dos doutores (M. de ALBUQUERQUE, Bártolo cit. (nota 99), pp. 88-89).

A própria justificativa da preferência de Bártolo - que outrora se estribara em fundamentos tradicionais, racionais e pragmáticos - é bastante alterada, na medida em que sua opinião só é acolhida em virtude da sua natural (mas não absoluta) maior conformidade à razão; preterindo-se a uniformização dos julgados, abre-se oportunidade a uma inevitável instabilidade, decorrente da freqüente invocação das mais variadas posições (adotadas pelos comentadores e acatadas pelos diversos tribunais do Reino). Exatamente para pôr cobro a tal estado de coisas é que exsurgirá, mais tarde, a Lei de 18 de agosto de 1769 - particularmente no que concerne ao estabelecimento de assentos vinculantes, proferidos exclusivamente pela Casa de Suplicação (parágrafos $1^{\circ}$ a $8^{\circ}$ ).

Finalmente, deve-se observar que persistindo dúvida quanto à adequada interpretação de determinado preceito legal, deveria esta ser encaminhada ao Regedor da Casa da Suplicação, a fim de que fosse fixada sua interpretação autêntica, por meio da edição de assentos uniformizadores. Em razão da feição vinculativa de tais provimentos, deveriam ser aplicadas penalidades àqueles que não observassem o direito em vigor, nos moldes de Ord. Man. V, 58 (e como já preceituava o Alvará de 10 de dezembro de 1518, por seu parágrafo primeiro). Tal questão não passou despercebida a L. C. de AZEVEDO, que compreende tal sanção como uma espécie de antecipação dos resultados da reforma empreendida pela Lei de 18 de agosto de 1769 (O Reinado cit. (nota 16), p. 29).

Por aspectos gerais da disciplina do direito subsidiário segundo as "Ordenações Manuelinas", cf. M. J. de AlMEIDA Costa, História cit. (nota 09), pp. 314-316; Fundamentos cit. (nota 16), p. 114; Ordenações cit. (nota 16), p. 266; La présence cit. (nota 16), p. 56; Enquadramento cit. (nota 99), p. 148; M. CAETANO, História cit. (nota 16), pp. 628-630; L. C. de AZEVEDO, O Reinado cit. (nota 16), pp. 24 e 26; J. C. MoREIRA Alves, Panorama cit. (nota 16), p. 188; I. M. Poveda Velasco, Ordenações cit. (nota 16), p. 22; A. A. VIEIRA CURA, Direito Romano cit. (nota 16), pp. 234-236; N. E. GoMES DA SILVA, História cit. (nota 16), pp. 296-301; G. BRAgA DA CRUZ, O Direito Subsidiário cit. (nota 16), pp. 308-346; M. PAUlo MERÊA, Resumo cit. (nota 16), pp. 147-148; R. R. NoGUEIRA, Prelecções cit. (nota 16), p. 125; M. A. COELHO DA RoCHA, Ensaio cit. (nota 16), p. 129; A. M. HESPANHA, História cit. (nota 16), pp. 502-503; M. de ALBUQUERQUE, Bártolo cit. (nota 99), pp. 50-64; J. VALLET DE GOYTISOLO, El derecho romano cit. (nota 74), pp. 475-476; M. R. MARQues, O Liberalismo cit. (nota 99), p. 19 (nota 21); Elementos cit. (nota 99), pp. 802-803; História cit. (nota 64), pp. 79-83. 
Deste modo, pretendeu-se transformar em matéria "processual civil" aquilo que modernamente corresponde ao "direito internacional privado" - "sobredireito" também conhecido pela expressão "conflito de leis no espaço"103.

103 Como observado no corpo do texto, as justificativas para o fato da promulgação das "Ordenações Filipinas" são variadas: tanto existe quem propenda em favor de uma tentativa de granjear a simpatia do povo português, como também há quem se incline em favor de uma reação aos excessos praticados em favor da Igreja Católica (sobretudo sob a influência do Concílio de Trento). No entanto, tem prevalecido uma posição intermediária, na qual se destaca, inclusive, a necessidade de atualização da legislação portuguesa, à vista dos acréscimos verificados no período posterior ao ano de 1521. Neste sentido, eis a posição de I. M. POVEDA VELASCO: "não se trata de obra inovadora. No fundo, a preocupação principal foi reunir, num mesmo texto, as Ordenações Manuelinas, a Coleção de Duarte Nunes do Leão e as leis a esta posteriores. Para tanto concorreu, além da crise em que se encontrava à época a cultura jurídica, no rescaldo da investida humanista contra o Direito Romano, a preocupação política de Felipe II de não ferir a suscetibilidade dos novos súditos, manifestando assim o seu respeito pelas instituições portuguesas. Por isso, a legislação filipina nada mais é que uma atualização das Ordenações Manuelinas e não propriamente uma legislação castelhanizante" (Ordenações cit. (nota 16), p. 24). Em contrapartida, dando destaque à reação contra as investidas da Igreja Católica, merece destaque a opinião de CÂNDIDO MENDES DE ALMEIDA: "Mas parece que não foi o interesse de harmonisar a Legislação extravagante depois do reinado de D. Manoel, com a nova situação política da Monarchia, nem a pueril vaidade ou calculo politico de fazer esquecer a Legislação dos precedentes Monarchas, e obter a estima dos Portuguezes, o que mais actuou no seu animo para levar a effeito a codificação, hoje conhecida, por Codigo Philippino. Havia um motivo mais poderoso que a isso obrigava o impulso da Realesa no seu exclusivo predominio no Estado, e os devotos do Direito Romano ou Imperial. Esse motivo era o Concilio de Trento, aceito e proclamado em Portugal sem restricções, pelas Leis do reinado de D. Sebastião. Essa aceitação dava novo realce ao Direito Canonico, collocando-o quasi no ponto em que se achava na epocha de D. Affonso II, em que se julgava de nenhum vigor a Legislação Civil que lhe era adversa, sem declaração authentica" (Código cit. (nota 16), p. XXIII). Observe-se que a nota final do autor é alusiva à Cúria de Coimbra de 1211, quando se estabeleceu que as Leis do Reino não valessem se fossem "feitas ou estabeleçudas" contra "os dereytos da Santa egreja de Roma" - a respeito, cf. A. Herculano, Portugaliae cit. (nota 86), pp. 163-164; Livro das Leis cit. (nota 87), p. 9; e Ordenações DelRei cit. (nota 87), p. 43.

Por uma síntese do histórico relacionado às "Ordenações Filipinas”, cf. M. PAUlo MERÊA, Resumo cit. (nota 16), pp. 139-140; M. A. COElHo DA RochA, Ensaio cit. (nota 16), pp. 188-196; M. J. de AlmeIDA CostA, Ordenações cit. (nota 16), pp. 267-269; História cit. (nota 09), pp. 281-285; Nota de apresentação, in Ordenações Filipinas - Livro I, Coimbra, Fundação Calouste Gulbenkian, 1984, pp. 5-12; J. J. F. GORDO, Fontes próximas da compilação filippina ou indice das Ordenações e Extravagantes, Lisboa, Academia Real das Sciencias, 1792, passim; A. M. Hespanha, História cit. (nota 16), p. 527; J. G. B. CÂMARA, Subsídios cit. (nota 16), pp. 157-177; Código cit. (nota 64), pp. 222-252; J. M. SCHOLZ, Legislação cit. (nota 102), pp. 525-530; F. C. PONTES DE MirAndA, Fontes cit. (nota 16), p. 42; N. E. GoMES DA SiLva, História cit. (nota 16), p. 313. Entretanto, o estudo mais exauriente a respeito das fontes das "Ordenações Filipinas" ainda é o de J. P. Ribeiro (Sobre as Fontes do Código Filippino, in Memórias da Litteratura Portugueza II, Lisboa, Officina da Academia Real de Sciencias, 1792, pp. 46-170).

Especificamente no que concerne ao direito subsidiário, merece destaque o novo enquadramento formal do instituto: a matéria foi transferida para o Livro III, situada agora entre o julgamento por verdade sabida e alguns preceitos relacionados às sentenças (interlocutórias e definitivas). Eis o teor de Ord. Fil. III, 64, título que guardou a mesma epígrafe da versão manuelina ("Como se julgarão os casos, que não forem determinados por as Ordenações"): "Quando algum caso fôr trazido em pratica, que seja determinado per alguma Lei de nossos Reinos, ou stylo de nossa Corte, ou costume em os ditos Reinos, ou em cada huma parte delles longamente usado, e tal, que por Direito se deva guardar, seja per elles julgado, sem embargo do que as Leis Imperiaes ácerca do dito caso em outra maneira dispoem; porque onde a Lei, stylo, ou costume de nossos Reinos dispoem, cessem todas as outras Leis, e Direito. E quando o caso, de que se trata, não fôr determinado por Lei, stylo, ou costume de nossos Reinos, mandamos que seja julgado sendo materia, que traga peccado, per os sagrados Cânones. E sendo materia, que não traga peccado, seja julgado pelas Leis Imperiaes, posto que os sagrados Cânones determinem o contrario. As quaes Leis Imperiaes mandamos, sómente guardar pela boa razão em que são fundadas. 1. E se o caso, de que se trata em pratica, não fôr determinado por Lei de nossos Reinos, stylo, ou costume acima dito, ou Leis Imperiaes, ou pelos sagrados Canones, então mandamos que se guardem as Glosas de Accursio, incorporadas nas ditas Leis, quando por 


\section{$\S 125$. A aplicação prática do direito subsidiário (a questão do critério de}

número e as incertezas geradas). Durante o período de vigência das "Ordenações do Reino de Portugal”, embora não tenha havido qualquer dúvida quanto à prevalência do direito pátrio, não se pode negar que, em caso de conflito entre as regras do direito reinícola e os preceitos justinianeus, aquelas eram interpretadas restritivamente - ao contrário do que se verificava quando ambas dispunham de maneira similar ("odiosa limitanda, favorabilia amplianda"). Entretanto, na hipótese de omissão das fontes lusitanas, inúmeras dúvidas exsurgiam a respeito do recurso ao direito justinianeu: tal arcabouço deveria ser tomado, "em bloco", como consagração autêntica de uma "ratio scripta"? Ou tal conformidade

commum opinião dos Doutores não forem reprovadas; e quando pelas ditas Glosas o caso não fôr determinado, se guarde a opinião de Bartolo, por que sua opinião commumente he mais conforme á razão, sem embargo que alguns Doutores tivessem o contrario; salvo, se a commum opinião dos Doutores, que depois delle screveram, for contraria. 2. E acontecendo caso, ao qual por nenhum dos ditos modos fosse provido, mandamos que o notifiquem a Nós, para o determinarmos; porque não sómente taes determinações são desembargo daquelle feito que se trata, mas são Leis para dezembargarem outros semelhantes. 3. E sendo o caso, de que se trata tal, que não seja materia de peccado, e não fosse determinado per Lei do Reino, nem stylo de nossa Corte, nem costume de nossos Reinos, nem Lei Imperial, e fosse determinado pelos textos dos Canones per hum modo, e per as Glosas e Doutores das Leis por outro modo, mandamos que tal caso seja remetido a Nós, para darmos sobre isso nossa determinação, a qual se guardará" (CÂNDIDO MENDES DE AlmeIDA, Código cit. (nota 16), pp. 663-665).

Note-se que a nova posição da matéria esfacela completamente aquele "conflito de jurisdições" que se pôde divisar em meio às "Ordenações Afonsinas"; portanto, aqui temos um remate à tarefa iniciada pelas Ordenações de 1521. No entanto, a simplificação promovida pelo legislador nos parece um tanto excessiva: ao se reduzir o instituto à categoria de simples "regra de julgamento", deixa-se inteiramente de lado a temática afeta ao "conflito de leis no espaço" (direito internacional privado). O próprio G. BRAGA DA CRUZ destaca sua incerteza quanto ao desfecho do problema: "é discutível se o enquadramento dado pelo legislador filipino ao problema do direito subsidiário - ao fazer dele um puro problema de direito processual, ligado ao julgamento das causas judiciais - teria sido o mais indicado e o mais feliz; mas o que importa registar é a preocupação que houve de romper com o seu enquadramento tradicional, que nada já justificava na mentalidade jurídica da época, e dar-lhe uma colocação, no texto das Ordenações, que exteriorizasse suficientemente a sua natureza de problema independente de qualquer conflito de jurisdições" (G. BRAGA DA CRUZ, O Direito Subsidiário cit. (nota 16), p. 349). De fato, embora seja possível polemizar a respeito da posição sistemática eleita pelo legislador (Livro III), não se pode deixar de reconhecer seu mérito, ao suplantar definitivamente o elemento controvertido deste instituto. Neste sentido, cf. N. E. GoMES DA SILVA, História cit. (nota 16), p. 314; A. M. HesPanHA, História cit. (nota 16), p. 503; M. de ALBUQUERQUE, Bártolo cit. (nota 99), pp. 65-66.

Por considerações gerais a respeito do direito subsidiário nas “Ordenações Filipinas”, cf. M. J. de ALMEIDA Costa, História cit. (nota 09), pp. 314-316; Fundamentos cit. (nota 16), p. 114; Ordenações cit. (nota 16), p. 268; La présence cit. (nota 16), p. 56; Romanismo cit. (nota 74), p. 33; Enquadramento cit. (nota 99), p. 148; Debate jurídico e solução pombalina, in Boletim da Faculdade de Direito da Universidade de Coimbra 58 (1982), p. 19; CÂNDIDO MENDES DE AlmeIDA, Código cit. (nota 16), p. XXVI; J. C. MoreIRA Alves, Panorama cit. (nota 16), p. 188; I. M. PovedA VElASCO, Ordenações cit. (nota 16), p. 24; O. GoMES, Raízes cit. (nota 16), p. 6; A. A. VIEIRA CURA, Direito Romano cit. (nota 16), pp. 236-238; N. E. GoMES DA SILVA, História cit. (nota 16), pp. 311-315; G. BRAGA DA CRUZ, Formação Histórica cit. (nota 16), pp. 29-30; O Direito Subsidiário cit. (nota 16), pp. 347-349; La Formation cit. (nota 99), p. 5; M. PAUlo MERÊA, Resumo cit. (nota 16), pp. 147-148; Direito romano cit. (nota 102), p. 541; R. R. NoGUEIRA, Prelecções cit. (nota 16), p. 125; M. A. COElHo DA RochA, Ensaio cit. (nota 16), p. 191; A. M. HesPANHA, História cit. (nota 16), p. 503; J. G. B. CÂMARA, Subsídios cit. (nota 16), pp. 168-169; M. de AlbUQUERQUE, Bártolo cit. (nota 99), pp. 65-66; J. VAllet DE Goytisolo, El derecho romano cit. (nota 74), pp. 475-476; M. R. MARQUES, $O$ Liberalismo cit. (nota 99), p. 19 (nota 21); Elementos cit. (nota 99), pp. 803-804; L. de M. LEME, O direito cit. (nota 64), p. 82. 
deveria ser objeto de uma análise "ad hoc"? Por sua vez, sendo a "boa razão" o fundamento da autoridade das "Leys Imperiaes", não seria legítimo buscar em meio à própria "ratio naturalis" o subsídio de que carecia o direito português (principalmente quando também omisso o direito justinianeu)? Finalmente, a fim de se aferir a autoridade das obras de Acúrsio e Bártolo - segundo o juízo da "communis opinio doctorum" deveria ser empregado um critério puramente numérico, um parâmetro eminentemente qualitativo ou uma variante híbrida? Note-se que todas essas dúvidas redundaram em desfavor da própria disposição; pois ainda que fosse difícil determinar a posição da doutrina em relação às obras de Acúrsio e Bártolo, o mesmo não se poderia afirmar quanto à orientação de tais jurisconsultos a respeito das mais variadas questões. Além disso, tamanha incerteza certamente favoreceu à compreensão da jurisprudência como mecanismo, por excelência, de revelação do direito vigente; justificando-se, assim, o seu progressivo fortalecimento. De todo modo, o estado de insatisfação era tão acentuado que os procuradores do Porto postularam - nas Cortes de Lisboa de 1619 - que mesmo as questões mais prosaicas fossem disciplinadas por meio de "lei"; pois os eventuais prejuízos da atividade legiferante lhes pareciam preferíveis ao arbítrio dos julgadores - em seu constante apelo à "opinião comum dos doutores"104.

\footnotetext{
${ }^{104}$ Deve-se observar, primeiramente, que a despeito de sua formulação expressa em Ord. Af. II, 9, o princípio da primazia do direito pátrio jamais foi posto em xeque pelos autores portugueses do período das "Ordenações do Reino de Portugal"; conquanto plausível a tese de que tenha havido certo abuso quanto ao emprego das opiniões dos doutores - do direito comum - há que se destacar, todavia, a constante afirmação da prevalência do "nostrum jus commune peculiare". Neste sentido, M. PAULO MÊREA assevera que era corrente entre os jurisconsultos lusitanos a afirmação de que "em Portugal $<<$ direito comum $>>$ era, não o direito romano, mas o direito nacional" (Direito Romano cit. (nota 102), p. 541). Na mesma linha de raciocínio, G. BRAGA DA CRUZ destaca que "apesar dos abusos que os tribunais freqüentemente cometiam, aplicando por vezes o direito romano com menosprezo do direito nacional, pode dizer-se que, pelo menos em princípio, a prioridade dada pelas Ordenações às leis pátrias, costumes do reino e estilos da Corte nunca foi posta em causa" (O Direito Subsidiário cit. (nota 16), p. 350). Aliás, reportando-se ao trabalho de juristas portugueses dos séculos XVI, XVII e XVIII, este autor assevera que - mesmo às vésperas das reformas pombalinas da aplicação e do ensino do direito - a prioridade das leis nacionais sobre o direito subsidiário correspondia a ponto sobre o qual não havia maior controvérsia: e comprova suas afirmações por meio de preciosas citações de quinhentistas como António da Gama ("nam ius nostrum Regium ius comune est"), Álvaro Valasco ("Ius Regium ordinationum censetur ius commune apud nos"), Jorge de Cabedo e Luís Correia (O Direito Subsidiário cit. (nota 16), pp. 350-351); seiscentistas como Francisco de Caldas Pereyra e Castro, Gabriel Pereira de Castro, Ignacio Pereira de Sousa, Domingos Antunez Portugal e António Mendes Arouca (por todos, "nostra Lex Regia nostrum ius commune constituit") (O Direito Subsidiário cit. (nota 16), pp. 351-352); e setecentistas como Silvestre Gomes de Moraes, João Rodrigues Cordeyro e Manuel Gonçalves da Sylva ("Sunt enim leges Regni nostrum jus commune peculiare") (O Direito Subsidiário cit. (nota 16), p. 352). Mesmo fora de Portugal se reconhecia tal postura dos juristas lusitanos, tal como se depreende do seguinte trecho constante da obra de A. DUCK: "Et Ius Regium Lusitaniae ita accommodandum est ad Ius Caesareum, ut Casus eodem Jure expressi, patiantur omnes Interpretationes \& extensiones, quas Ius Romanum admittit, XII, Quamvis autem Iurisconsulti Lusitaniae frequentius tradant, pro Majestate Principis sui tuenda, Ius Regium esse Ius Comune in Lusitania; \& e Ius Caesareum non habere vim Imperii sed Rationis solum; \& poenas Iure Regio impositas tollere poenas Iuris Caesarei; \& in Lusitânia Causas esse Iure
} 
Regio, non Iure Romano decidendas" (apud G. BRAGA DA CRUZ, O Direito Subsidiário cit. (nota 16), p. 352).

No entanto, as regras de direito pátrio contrárias aos preceitos romanos deveriam ser interpretadas restritivamente; preconizando-se sua interpretação extensiva, ao contrário, caso estivessem em conformidade com o direito justinianeu ("odiosa limitanda, favorabilia amplianda"). Neste sentido, cf. G. BRAGA DA CRUZ, O Direito Subsidiário cit. (nota 16), pp. 381-382; M. J. de AlmeIDA CostA, História cit. (nota 09), p. 316; bem como J. C. MOREIRA Alves, A formação romanística de Teixeira de Freitas e seu espírito inovador, in SCHIPANI, Sandro, Augusto Teixeira de Freitas e il diritto latinoamericano, Padova, CEDAM, 1988, p. 17.

Já na hipótese de omissão das fontes portuguesas, o recurso natural - tal qual preconizado pelo texto das sucessivas "Ordenações do Reino" - deveria ser ao direito subsidiário. No entanto, em uma espécie de antecipação ao parágrafo décimo-primeiro da Lei de 18 de agosto de 1769, certos autores (tais como Álvaro Valasco, Ignácio Pereira de Souza e Manuel Gonçalves da Sylva) defendiam o prévio emprego de uma analogia com a legislação pátria; a respeito, cf. M. PAUlo MERÊA, Direito romano cit. (nota 102), p. 543 (nota 1); e G. BRAGA DA CRUZ, O Direito Subsidiário cit. (nota 16), pp. 354-355.

Quando se considera, por sua vez, aquela menção à "boa razão" realizada em Ord. Man. II, 5 pr., exsurge a seguinte dúvida ao pesquisador: o direito justinianeu foi tomado - na prática - como repositório autêntico de uma "ratio scripta", insuscetível de ser aferida caso a caso? Ou foi submetido a uma análise "ad hoc"?

Ora, a alusão a uma razão positiva para o acatamento das "Leis Imperiais" trouxe conseqüências bem mais profundas do que a simplicidade de seu enunciado poderia sugerir. Alguns jurisconsultos da época a tomaram como uma mera "justificativa" para a eleição do direito romano como mecanismo de heterointegração do sistema português; desta forma, o "Corpus Iuris Civilis" foi tomado, em bloco, como acervo de uma "razão natural" latente. Parece-nos que é este o sentido que se deve atribuir ao trecho inicial de Ord. Af. II, 63, 3, mencionado em nota anterior (nota 102); e de fato, tal orientação parece ser natural àquele pesquisador que pretende compreender a recepção do direito justinianeu como um processo contínuo - que tem por apogeu a Carta Régia de 18 de abril de 1426 - em meio ao qual se buscou um simples título de legitimação, por ocasião da promulgação das “Ordenações Manuelinas". Por uma indicação dos jurisconsultos adeptos de tal postura, cf. G. Braga DA CRUZ, O Direito Subsidiário cit. (nota 16), pp. 362-363; e M. PAUlO MERÊA, Direito romano cit. (nota 102), p. 541.

Entretanto, se a "boa razão" dos textos romanos deixa de ser compreendida como simples "justificativa" - e é alçada ao nível de autêntico "fundamento" do recurso a um direito "estrangeiro" (estranho) - só se poderia lançar mão daqueles preceitos em que efetivamente tal virtude se evidenciasse. Note-se que esta orientação também se explica historicamente, não só em virtude da preocupação - progressivamente mitigada - de se reafirmar a isenção portuguesa da "iurisdictio Imperii", mas também em decorrência de expressa previsão neste sentido constante da própria legislação lusitana medieval - neste sentido, cf. o trecho da Lei de 03 de novembro de 1352 já transcrito em nota 102 (Livro das Leis cit. (nota 87), p. 454). Com isso, houve não só quem prescrevesse uma análise individual da compatibilidade dos textos romanos com a "boa razão" - M. PAulo MerêA menciona Manuel da Costa, Domingos Antunez Portugal e Manuel Gonçalves da Sylva (Direito romano cit. (nota 102), p. 542) - como quem reputasse legítimo o recurso direto a tal cláusula geral para o preenchimento das lacunas derivadas de omissão das fontes lusitanas. Desta forma, a "boa razão" deixaria de ter um simples poder negativo (de evitar a aplicação de preceitos romanos com ela incompatíveis), para alcançar a categoria de autêntica fonte subsidiária; com base nas obras de Luís Correia e de Diogo de Sá, N. E. Gomes DA Silva chega a uma tal conclusão (História cit. (nota 16), p. 309) veementemente rechaçada por G. BRAGA DA CRUZ (O Direito Subsidiário cit. (nota 16), pp. 356-357 e pp. 363-364). Ainda a respeito do tema, cf. A. M. HesPanHA, História cit. (nota 16), pp. 503-511.

Como tivemos a oportunidade de observar, a aplicação subsidiária das obras de Acúrsio e Bártolo sofre uma sensível limitação a partir da primeira versão das "Ordenações Manuelinas" (1514), ocasião em que passam a ser submetidas ao crivo da "communis opinio doctorum". Vale registar que do texto legal parece decorrer a consagração de um critério puramente majoritário para sua estimação; no entanto, alguns jurisconsultos portugueses do século XVI - influenciados pela corrente humanista - chegaram a defender que a "verior opinio" haveria de prevalecer sempre, ainda que contrariasse o posicionamento majoritário da doutrina. São os casos de Manuel da Costa, Aires Pinhel e Heitor Rodrigues, conforme informam G. BRAGA DA CRUZ ( $O$ Direito Subsidiário cit. (nota 16), pp. 365-367) e M. J. de AlmEIDA CostA (História cit. (nota 09), pp. 327). E o resultado de tal embate foi a adoção de um critério misto de aferição da "opinião comum": ainda que o modelo numérico (de origem escolástico-bartolista) tenha suplantado o paradigma qualitativo, a maioria representativa da "communis opinio" deveria ser estimada à vista de uma produção qualificada, derivada unicamente dos resultados obtidos por autores que houvessem se dedicado "ex professo" a um determinado tema. Sintetizando o legado da escola humanista em Portugal, G. BRAGA DA CRUZ observa que "a generalizada simpatia dos melhores expoentes da nossa literatura jurídica por este critério misto (simultaneamente quantitativo e qualitativo) na determinação da communis opinio é talvez o fruto mais 
palpável que a corrente humanista do direito entre nós legou à corrente escolástica que, além de nunca se ter deixado dominar por aquela, acabou totalmente por superá-la, sem deixar de lhe pagar o seu tributo num ou noutro ponto em que para sempre ficou marcado por ela (...) a opinio communis seria, sem dúvida - nem de outro modo mereceria esse nome -, a opinião da maioria dos autores; mas duma maioria qualificada: da maioria dos autores que tivessem versado ex professo o assunto em causa, analisando-o e discutindo-o, e não da maioria dos que simplesmente se lhes tivessem referido, louvando-se na opinião alheia" ( $O$ Direito Subsidiário cit. (nota 16), pp. 367-369). Na prática, contudo, o critério misto não era respeitado sequer por seus próprios adeptos: "os mesmos juristas que isto sustentavam teoricamente eram os primeiros a coalhar as suas obras de citações intermináveis, sempre na preocupação de deslumbrar e convencer pelo exclusivo peso do número, sem distinguirem entre as autoridades que tinham tratado o assunto ex professo e as que se tinham limitado a reproduzir as opiniões de outrem" (G. BRAGA DA CRUZ, O Direito Subsidiário cit. (nota 16), pp. 370-375). A respeito do assunto, cf. ainda M. PAUlo MerÊA, Resumo cit. (nota 16), p. 155; M. J. de AlMEIDA COSTA, História cit. (nota 09), pp. 323-324; N. E GOMES DA Silva, História cit. (nota 16), pp. 335352; e A. M. HesPanHA, História cit. (nota 16), pp. 509-511 (obra esta em que se promove uma apreciação sintética sobre o percurso do humanismo jurídico em Portugal).

A prática forense, entretanto, enfrentava os sérios prejuízos decorrentes da dificuldade de se depurar a "opinião comum dos doutores"; a existência de inúmeras sutilezas no processo de definição da "communis opinio" - tais como as regras: da liberdade judicial na hipótese de duas opiniões comuns contrárias; a que estatuía a preferência de uma opinião "recepta in Curia"; a que determinava a prevalência da opinião mais conforme ao costume (ou que reduzisse o número de demandas); a que determinava a superioridade da opinião dos canonistas sobre a dos teólogos; a que privilegiava a opinião que harmonizasse as demais; e em sentido contrário, a que exaltava a opinião que promovesse distinção, uma vez que seria a mais próxima da verdade - acabou desacreditando o próprio critério, proporcionando-se, assim, um ambiente propício à ascensão da jurisprudência (como um mecanismo de declaração que oferecia um grau mais elevado de certeza): "compreende-se que, no meio desta confusão, o valor da communis opinio como tal (...) tendesse, na prática, a diluir-se e a desacreditar-se, fazendo sentir a toda gente - aos doutrinadores, aos tribunais e, mais do que a ninguém, aos litigantes que se aventuravam a pleitear no meio deste mar revolto - a necessidade de encontrar outros pontos de apoio mais seguros (...) [houve então uma progressiva adesão à praxe dos tribunais superiores] como expressão autorizada dessa opinio communis menos sujeita aos riscos da incerteza e do arbítrio" (G. BRAGA DA CRUZ, O Direito Subsidiário cit. (nota 16), pp. 377-379). No mesmo sentido, cf. M. A. Coelho DA RochA, Ensaio cit. (nota 16), p. 191; P. J. de MEllo FreIRE dos Reis, Historiae cit. (nota 16), pp. 105-108; CÂNDIDo Mendes De Almeida, Código cit. (nota 16), p. 665; N. E. GoMes DA Silva, História cit. (nota 16), pp. 357-358; J. VALLET DE GOYTISOLO, El derecho romano cit. (nota 74), p. 476; M. R. MARQUES, Elementos cit. (nota 99), p. 804; e História cit. (nota 64), p. 87. Merece destaque o fato de que tal orientação foi consagrada em Assento de 23 de março de 1786, no qual a Casa da Suplicação reconhece que "a verdadeira intelligencia da sobredita Ord. (...) confirmada pela praxe e Estylo de julgar, e decisão dos Arestos, que he o melhor interprete das Leis, e seguida universalmente dos Drs. do Reino, deve ella servir de regular os casos ocorrentes no Foro" (apud CÂNDIDO MENDES DE AlMEIDA, Auxiliar cit. (nota 95), p. 283).

No entanto, parece que nem mesmo a jurisprudência pôde oferecer um grau de certeza satisfatório aos jurisdicionados. Em reclamação do ano de 1619 os procuradores do Porto já manifestavam tal descontentamento, postulando que as questões mais relevantes fossem resolvidas pelo próprio monarca, por meio da edição da legislação necessária: "Tendo Vossa Magestade mandado por suas ordenações que os casos que não estiverem determinados por ley do reyno, ou costume estilo delle, ou leys imperiaes: ou sagrados canones, ou glosas de Accursio, ou opinião de Bartolo se julguem e determinem pella opinião commum dos Doctores, vierão elles á ser tam varios no que em alguas cousas sentirão, que andão impressas alguas opinioens cómuas contra outras cómuas, de que nasce vir a estar na vontade e arbitrio dos julgadores a decisão de muitas cousas de importancia. Pedimos a Vossa Magestade haja por bem mandar que as questoens que costumão ordinariamente ser de mais importancia se decidão, e determinem por ley, para que seus vassallos se não metão em demandas, que pendem de mero arbitrio dos julgadores" (apud G. Braga da CRUZ, O Direito Subsidiário, cit. (nota 16), pp. 379-380). A respeito de tal estado de incerteza e insatisfação, cf. A. M. HesPANHA, História cit. (nota 16), pp. 511-514; bem como M. de ALBUQUERQUE, Bártolo cit. (nota 99), pp. 69-74 (onde são destacados os principais efeitos da referida reclamação).

Pode-se afirmar que em tais circunstâncias o efeito da "communis opinio doctorum" foi, afinal, exatamente o contrário daquele pretendido pelo legislador manuelino: tamanha era a dificuldade de sua determinação, que as posições de Acúrsio e Bártolo ressurgem robustecidas. Bem o demonstra o Regimento da Relação do Rio de Janeiro - de 13 de outubro de 1751 - que por seu Título primeiro, parágrafo 7, assim dispunha: "Para o expediente do despacho haverá na Relação as Ordenações do Reino, com seus Repertórios; e haverá também um jogo de Textos de Leis, com as Glossas de Accursio e outro de Canones; como tambem um jogo de Bartholos da ultima edição" (apud CÂNDIDo MENDES DE AlmeIDA, Código cit. (nota 16), p. 665). Neste 


\section{$\S$ 126. Luís Antonio Verney e a preconizada reforma da aplicação e do}

ensino do direito. Considerado um dos maiores responsáveis pela introdução do Iluminismo em Portugal, Luís António Verney articulou suas principais idéias relacionadas ao sistema jurídico português na "Carta XIII" de seu "Verdadeiro Método de Estudar"; nela o autor faz uma série de críticas ao currículo universitário e à praxe judiciária da época: ao mesmo tempo em que destaca a ausência de uma série de disciplinas consideradas indispensáveis à formação do jurista de então (tais como o direito municipal, a economia, a política, o direito natural e o direito das gentes), desfecha uma crítica severa ao direito romano - à vista da pouca clareza de seus expositores e das dificuldades inerentes ao estabelecimento da "communis opinio doctorum" (segundo o critério puramente quantitativo de origem escolástico-bartolista). Diante de um tal estado de coisas, L. A. VERNEY sugere ao monarca uma reforma relacionada ao ensino jurídico - à semelhança do que alguns anos antes ocorrera na França e na Inglaterra - por meio da qual se determine o estudo a partir dos próprios textos legais (se necessário complementados por um brevíssimo comentário, à moda do desenvolvido por J. G. HEINECCII), iluminados tanto pela historiografia (romana e lusitana), quanto pela própria experiência jurídica estrangeira; já no que concerne à aplicação do direito, preconiza a edição de leis claras e breves - "menos sujeitas a interpretações (...) em modo tal, que com estas leis devessem conformar-se em tudo os Juízes"105.

mesmo sentido são as conclusões de M. de ALBUQUERQUE: “13. Durante o período filipino, a despeito da subordinação oficial à communis opinio, a opinio Bartoli atinge o apogeu na prática e no ensino (...) 15 . Neste período a autoridade de Bártolo subverterá, com prejuízo da communis opinio, o esquema de fontes de direito subsidiário (...) 17. Apesar disso, o Regimento da Relação do Rio de Janeiro (1751) consagra ainda o valor de Acúrsio e Bártolo" (Bártolo cit. (nota 99), pp. 88-89).

Merece menção, finalmente, a prática atribuída a Jorge de Cabedo de utilizar o direito espanhol quando as fontes justinianéias não fossem suficientes para oferecer solução à questão apresentada. Ora, se a Lei de 18 de agosto de 1769 vai favorecer a adoção dos preceitos das nações civilizadas como direito subsidiário, os termos por meio dos quais o fará serão outros. A respeito, cf. G. BRAGA DA CRUZ, O Direito Subsidiário cit. (nota 16), p. 383.

${ }^{105}$ Eis uma síntese dos principais traços biográficos de Luís António Verney (particularmente relacionados ao presente estudo): filho do imigrante francês Dionísio Verney (que chegara e Portugal ao final do século XVII) e da Sra. Maria da Conceição Arnaut, o autor nasceu em 23 de julho de 1713, na cidade de Lisboa. Teve suas primeiras lições com o Padre Manuel de Aguiar Paixão, seu primeiro preceptor; algum tempo depois foi encaminhado ao Colégio de Santo Antão, onde teve seus primeiros contatos com os jesuítas; em seguida foi enviado à Congregação do Oratório, tendo permanecido pouco tempo aí, uma vez que logo foi transferido ao Colégio da Madre de Deus, dirigido pelos mesmos encarregados da administração e do ensino da Universidade de Évora. Laureando-se em Teologia em apenas dois anos, partiu para Roma aos vinte e três, com o intuito de repetir seus estudos teológicos e graduar-se em Jurisprudência Civil.

Prestigiado em meio ao círculo intelectual romano, Luís António Verney é designado para ocupar a posição de Arcediago da Sexta Cadeira da Sé de Évora, tomando posse do cargo em 24 de fevereiro de 1742. Admitido na academia literária "Arcádia de Roma" (da qual participava o próprio D. João V), escreve suas primeiras orações sob o pseudônimo de Verenio Orgiano. 
Interessa-nos destacar que a partir do ano de 1746 despontam as suas primeiras manifestações pedagógicas: "Ora é por esta altura, entre a sua formatura em Itália e 1746, que Verney se decide a ser um renovador em matéria pedagógica (...) Verney entendeu que o tipo de cultura que esses meios lhe proporcionavam era mais racionável que o tipo de cultura que lhe tinha sido fornecido. Conferiu um e outro, e decidiu-se pelo novo. Então passou a redigir, com quanta velocidade podia, as muitíssimas folhas de papel que seriam necessárias para apresentar os volumes em que as mesmíssimas disciplinas aprendidas fossem orientadas e metodizadas mais racionàvelmente" (A. SALGADO JúNIOR, Biografia breve de Luís António Verney (Prefácio), in L. A. VERNEY, Verdadeiro Método de Estudar II - Estudos Literários, Lisboa, Livraria Sá da Costa Editora, 1950, p. XIX).

O modelo de trabalho de Luís António Verney consiste em uma autêntica "reforma" pedagógica - projetada à custa da crítica ao paradigma então prevalecente. Desta forma, sua obra pode ser decomposta em dois aspectos principais: de um lado, o estabelecimento das linhas gerais de um novo modelo de ensino (particularmente universitário); de outro, uma crítica ferrenha ao sistema pedagógico praticado pelos jesuítas, que então dirigiam, inclusive, a Universidade de Coimbra. Note-se que tais reparos foram desenvolvidos por meio de uma série de "cartas" - provavelmente destinadas a Sebastião José de Carvalho e Melo (Marquês de Pombal) - posteriormente reunidas em uma obra intitulada "Verdadeiro Método de Estudar" (publicada no ano de 1746). De todas as missivas, interessa-nos sobretudo a carta décima-terceira, na qual Luís António Verney tece observações relacionadas à aplicação e ao ensino do direito da época.

A despeito de sua angústia em não conseguir publicar grande parte de seus estudos, é exatamente a publicação do "Verdadeiro Método de Estudar" que vai lhe atribuir indiscutível notoriedade histórica confirmada por seu posterior acolhimento por meio das reformas pombalinas da aplicação e do ensino do direito. A respeito de sua influência sobre o Marquês de Pombal, cf. J. B. de MACEDO, Estrangeirados, um Conceito a rever, in Bracara Augusta 28 (1974), pp. 179-202; bem como R. de CARVALHO, O Recurso a Pessoal Estrangeiro no Tempo de Pombal, in Revista de História das Idéias 1982-1983 (número especial intitulado O Marquês de Pombal e o seu Tempo I), pp. 91-115. Quanto à sua personalidade, obra panfletária - e sobretudo a respeito do impacto de seus textos sobre a cultura da época - merece menção a bibliografia que tivemos a oportunidade de coligir noutra oportunidade - cf. E. L. R. PouSADA, Preservação cit. (nota 99), pp. 59-60 (nota 123).

As críticas do autor ao modelo jurídico então prevalecente podem ser sintetizadas da seguinte forma: a) o ensino do direito romano preponderava, indevidamente, sobre o aprendizado do direito nacional (aplicado com uma freqüência muito maior pelos estudantes recém-formados); b) o estudo do direito justinianeu desviava a atenção dos discentes daquelas ciências jurídicas (modernas) que deveriam, preponderantemente, consumir seu tempo, tais como o direito natural e o direito das gentes; c) o estudo dos textos antigos era realizado de maneira "contemplativa", preponderando a veneração sobre a efetiva preocupação com os defeitos intrínsecos do direito justinianeu; d) predominava - indevidamente - o método escolástico-bartolista, tanto no foro, como na academia (de maneira que o critério numérico de aferição da "communis opinio" conduzia a uma incerteza equivalente à ignorância sistemática dos estudantes forjados à custa do método analítico); e) faltava aos estudantes uma formação propedêutica mais robusta (assim como noções elementares de economia e política); f) inexistiam estudos mais criteriosos acerca da história do direito (romano e lusitano) e sobre o direito comparado.

L. A. VERNEY observa que os estudantes da Universidade de Coimbra colavam grau sem que tivessem as mais elementares noções a respeito do direito nacional (e particularmente da legislação municipal); ocorre que a prática subseqüente deles exigia exatamente aquilo que o curso universitário não oferecera, sendo de se divisar uma preocupação com a formação profissional em meio à reforma universitária projetada: "deve o estudante ler o Direito Português ou as leis municipais, notando as coisas em que diversifica do Comum. Sem dúvida, é digno de admiração que saiam os homens das Universidades falando muito nas leis de Justiniano, que só servem faltando a lei municipal, e nada saibam daquela lei por que se hão de governar! (...) As leis municipais são sujeitas a várias interpretações, como as romanas; e por que não ensinará um Leitor na Universidade aos que querem seguir o Foro a melhor inteligência destas leis, e mais seguida e mais conforme às decisões dos tribunais supremos? (...) muito bem a conhecem em outros Reinos estrangeiros, em que se estabeleceram cadeiras de Direito Municipal, o que especialmente fez Luís XIV em França (...) este estudo também se deve fazer na Universidade; e talvez que assim se poupassem muitas demandas, que nascem da ignorância da Lei" (Verdadeiro Método de Estudar IV - Estudos Médicos, Jurídicos e Teológicos, Lisboa, Livraria Sá da Costa Editora, 1952, p. 195).

Em uma manifestação de repulsa ao emprego do direito romano para a solução dos problemas de então ("mos italicus"), L. A. VERNEY se opõe à tomada da codificação justinianéia como repositório, por excelência, de uma autêntica "ratio scripta"; em seu lugar, preconiza o estudo do "direito natural" e do "direito das gentes", muito mais propícios - respectivamente - à descoberta de uma verdade (jurídica) imutável e à manutenção de um intercâmbio eficiente com povos representativos de outras culturas: "[a Ética] expõe os diversos ofícios e 
obrigações do Homem, que deve fazer, para se conformar com a recta razão, a que chamam Jurisprudência Natural ou Universal (...) Da Jurisprudência Natural nasceram todas as leis civis, e principalmente as Leis Romanas, de que nós hoje usamos. De que fica claro que quem não sabe os princípios da Jurisprudência natural, não pode entender bem a Romana, que é a mesma Lei Civil. Este é aquele ponto mui dificultoso, que não entendem os que estudam nessa Universidade, e nem menos os que ensinam; porque, se o entendessem, deveriam regular diferentemente os estudos (...) por pouco que se considere a matéria, se achará que estes documentos [os textos romanos] não são bons para resolver tudo. Suponhamos que nasce uma controvérsia entre uma Nação européia com os Turcos, ou Chinas, ou Malabares, sobre a violação da paz, ou coisa semelhante. Julga V. P. que hão de ter autoridade entre eles as Pandectas de Justiniano, ou as Decretais, ou Moralistas? Tanta como se aqueles nos alegassem com o Alcorão; os outros com Confúcio, ou outro semelhante doutor dos seus. Nestes casos, ou se trate com os Asiáticos, ou Europeus, ou qualquer gente racionável, é necessário ter prontas, não as Leis Romanas, mas as das Gentes, ou do Direito natural, abraçado por todos os que usam da razão, para poder mostrar a justiça da nossa causa e injustiça da sua. Estas são as verdadeiras fontes da justiça, de que se tiram as soluções dos tais casos, e de que se devem tirar, não só naqueles, mas ainda nos que sucedem entre Nações cultas" (Verdadeiro cit. (nota 105), pp. 112-113 e 130132).

Desta forma, o direito romano é admitido com ressalvas, na medida em que consubstancie uma derivação de noções universais, adaptável às necessidades da sociedade de então - aquilo que virá a ser o "usus modernus pandectarum" português. Neste sentido, L. CABRAL DE MONCADA destaca que "a própria lei romana, que é geralmente recebida, deve acomodar-se a eles e assim dar origem às máximas que são afinal sempre uma dedução da ética, do direito natural e das gentes" ( $O$ século XVIII cit. (nota 55), pp. 96-98). Com efeito, L. A. VERNEY aponta para inúmeros defeitos das "Leis Imperiais": "não exprimem claramente a mente do legislador" (Verdadeiro cit. (nota 105), pp. 180-181); não "acautelam todos os casos possíveis" (Verdadeiro cit. (nota 105), p. 181); "não bastam (...) para descobrir e interpretar a vontade dos homens, a qual se tira dos fatos, ou das palavras dos tais homens" (Verdadeiro cit. (nota 105), p. 182); são "diferentes [as] idéias dos doutores e juízes que as explicam" (Verdadeiro cit. (nota 09), p. 183). Assim, o autor enuncia que "é necessário que o estudante advirta algumas coisas que comummente advertem poucos Jurisconsultos. Deve, pois, persuadir-se que esta Jurisprudência e estes livros do Direito não merecem todos aqueles elogios que verá nas glosas e alguns intérpretes que se oferecerem. São bons, é verdade; têm muito boas regras para conhecer o justo e injusto. Mas têm também muitos defeitos intrínsecos e extrínsecos. Quem não forma este conceito das Leis Romanas, engana-se muito, e não é bom para julgar. Por mais de seiscentos anos que os Jurisconsultos explicam estas leis, raríssimo antigo se tem achado que confesse plenamente isto; algum mais moderno, especialmente os Tudescos, é que o têm confessado sinceramente (...) Antes, pelo contrário, como acima disse, todos os velhos defendem a bondade destas leis para julgar tudo" (Verdadeiro cit. (nota 105), pp. 179-180).

Por tal razão, manifesta-se contra uma "veneração" ao direito justinianeu; a própria impressão negativa que deflui de seu juízo sobre a figura de Justiniano parece que influenciou o proêmio da Lei de 18 de agosto de 1769; L. A. VERNEY reputa ignorantes não apenas os jurisconsultos romanos, como também aqueles que, sem uma maior acuidade histórica, apegaram-se ao seu legado sem qualquer espécie de questionamento. De tal modo, resultará de seu discurso uma apologia aos estudos históricos, entremeada pelo elogio ao "mos gallicus" praticado pela Escola Culta: "Estes tais idólatras de Justiniano supõem que o seu legislador teve revelações divinas; e, com esta idéia, não se resolvem a dizer que disse mal em muitas coisas e se contradisse em outras, mas tudo querem justificar. Porém, nisto enganam-se manifestamente. Justiniano era um Príncipe imprudente, inconstante, e pouco próprio para legislador. Era tão inclinado a decidir tudo, ou bem, ou mal, que também quis fazer leis em matéria de religião. Publicou muitas leis más, e mudou muitas imprudentemente. Os que compuseram a colecção do Direito também sabiam pouco o seu ofício e não puderam evitar muitos erros e enganos; especialmente Triboniano era imprudente e pouco verídico. Os Imperadores do Oriente conheceram mui bem estes defeitos em Justiniano. O Imperador Basílio Macedônico, como diz Cedreno nos seus Anais, condenava a grande extensão de Justiniano, e falta de clareza e ordem; e, com efeito, para uso seu, publicou um compêndio do Código de Justiniano. Seu filho Leão publicou outro compêndio das Pandectas; e outros Imperadores Gregos, conhecendo a insuficiência daquela obra, fizeram também epítomes do Direito. Os mesmos Visigotos preferiram o Código de Teodósio ao de Justiniano. Onde, quem não conhece isto, não é bom para comentador. Por este motivo é necessária a História, para vermos como se devem entender e tomar as coisas; e, por este mesmo princípio, não devemos fazer caso do que dizem muitos intérpretes (...) estes homens [os doutores do direito comum (glosadores e comentadores)] naquele tempo eram venerados; mas, para dizer a verdade, eram, ainda que doutos, ignorantes das antiguidades; de sorte que abriram a porta a mil sutilezas, o que deu matéria de engrossar tanto os volumes legais, que hoje não se podem suportar. No século XVI, apareceram homens que, servindo-se da notícia da Antigüidade, interpretaram melhor as leis. Deste número foram Cujácio, Mureto, Hotomano, Gotofredo, 
António Fabro, etc., os quais, com sua profunda erudição, mostraram os erros dos antecedentes no explicar o Código e Digestos, e nos deram mais acertadas interpretações” (Verdadeiro cit. (nota 105), pp. 170; 158159).

No entanto, a crítica do autor não se limita à substância representada pelo direito justinianeu; o próprio método escolástico-bartolista - em suas projeções profissional e acadêmica - foi objeto de inúmeras manifestações de reprovação. Assim, no âmbito da praxe judiciária, L. A. VERNEY fustiga a "communis opinio doctorum" (destacando a contribuição do critério numérico para o seu desprestígio): "daí para diante é que se aumentaram as sutilezas. Um levantou uma doutrina nova, ou por capricho, ou por necessitar dela para alguma escritura. Os discípulos abraçaram-na. Algum Advogado serviu-se dela para outro caso. E desta sorte, citando uns a outros, se fez comum. Apareceu outro Advogado, a quem não agradava. Impugnou-a. Teve sequazes. E temos outra opinião comum contrária. E desta sorte apareceram tantas opiniões comuns, contrárias entre si, que é uma piedade. Este é o caso que tem sucedido a Bártolo, Baldo, Rafael Fulgósio, e outros muitos, que pecavam deste vício; muitos dos quais, não só por necessidade, mas por sua alta recriação, contrariavam os antecedentes, como fez Baldo, que muito de propósito censura em várias partes Bártolo, seu mestre (...) Enfim, isto chegou a termos, que hoje não se sabe qual é a opinião comum (...) nenhum [autor] se contenta de dizer pouco, contanto que diga bem; todo o ponto está em acarretar erudição e amontoar textos sem pés nem cabeça. Como se, para um homem ser bom Jurista, tivesse necessidade de saber quantos textos se acham no Direito Civil sobre a mesma matéria!" (Verdadeiro cit. (nota 105), pp. 186-192 e 175). E as dificuldades inerentes à determinação da "opinião comum" contribuíram para o constante estado de incerteza no âmbito dos tribunais: "são sujeitos os homens a mil incoerências, contradições, enganos etc.. Têm idéias gerais do justo e injusto (...) Diversificam muito os doutores sobre o mesmo ponto. Os mesmos Juízes de um só tribunal, uns afirmam, e outros negam, ainda que cada um tenha bem examinado a causa. O pior é que o mesmo tribunal revoga às vezes o que primeiro tinha determinado (...) de sorte que, ainda no Foro, o ter tido muitas sentenças não produz certeza de justiça, mas somente presunção de recto juízo. E assim, nos casos particulares disputáveis, por confissão dos mesmos Juristas, só a opinião é a que regula tudo; nem há certeza alguma que aquele tal fato se compreenda debaixo daquela tal lei. E às vezes é tão obscura a verdade, que se acharam juízes de consciência, os quais não quiseram julgar, mas persuadiram a concórdia e ajuste racionável entre as partes (...) daqui se conhece concludentemente que a Jurisprudência não é aquela regra certa do justo ou injusto que comummente se diz, mas que tem defeitos tais, que não há indústria que os possa emendar, senão no caso que os Príncipes reformassem muita coisa (...) Aquele grande Rei da Sardenha Vitório Amadeu, que ordenou belíssimos regulamentos para a felicidade dos seus vassalos, reformando a Jurisprudência, ordena assim: Querendo nós que, para a decisão das causas, se observe unicamente: em primeiro lugar, as nossas constituições; $2^{\circ}$ os estatutos locais; $3^{\circ}$ as decisões dos nossos magistrados; e, em último lugar, o texto da Lei comum; - e assim proibimos aos Advogados citar nas suas alegações algum doutor nas matérias legais, e aos Juízes, tanto supremos, como inferiores, proibimos julgar pelas opiniões deles, sub pena etc.. Isto mesmo ordenou nos seus Estatutos um Duque de Urbino, e há muito tempo que se pratica em França, Inglaterra, Veneza e outros países (...) e isto mesmo era mais conforme ao que ordena Justiniano quando proíbe os Intérpretes. Contudo isso, não deixa de estar sujeito a suas dificuldades, havendo casos em que as leis não falam, ou são obscuras, e podendo os Advogados servir-se das doutrinas sem as nomear. O remédio que neste particular se podia sugerir aos Príncipes é este: que, com o parecer dos melhores letrados, determinassem muitos pontos controversos entre os Jurisconsultos, explicando em que casos particulares entrem; e isto com as leis mais claras e breves que pudesse ser, e menos sujeitas a interpretações. Em modo tal, que com estas leis devessem conformar-se em tudo os Juízes; houvesse uma regra certa de julgar (...) Mas, enquanto não se cuida nesta reforma, não desaprovo que citem e se sirvam dos autores, contanto que sejam poucos em número, e dos que tenham, com profundo juízo e erudição, examinado a matéria" (Verdadeiro cit. (nota 105), pp. 183-185 e 214-217). De tal modo, nesta parte final encontramos não apenas um reconhecimento do critério misto na aferição da "opinião comum" (como uma espécie de remédio provisório), mas também uma manifestação semelhante àquela com que nos deparamos quando analisada a reclamação dos procuradores do Porto nas Cortes de Lisboa de 1619.

Por sua vez, no âmbito acadêmico, L. A. VERNEY ataca a pedagogia escolástico-bartolista, cristalizada no método analítico que, com sua excessiva minudência, impedia que o estudante tivesse uma compreensão panorâmica do fenômeno jurídico. Destacando tal preocupação de índole sistemática, o autor recomenda a adoção do método sintético-compendiário, em virtude do qual o discente adquiriria uma aptidão genérica à solução dos mais variados problemas: "é coisa digna de riso que, reduzindo Justiniano o Corpo do Direito a poucas palavras nas suas Instituições, para que os estudantes pudessem formar em breve a idéia de todo o Direito, a qual com o tempo fossem ampliando, queiram os Mestres que os estudantes comecem pelo Mânzio, Oinitom, Vínio, e outros autores difusíssimos, os quais não dizem palavra que não confirmem com dez textos; e, com tanta erudição, confundem o juízo e impedem a percepção. De que nasce que os estudantes tanto entendem as Instituições como a língua da China; e passam aquele primeiro ano lendo muito, e 
entendendo pouco; e comummente não acabam o primeiro livro. Daqui passam a estudar uma postila de algum tratado particular. Mas diga-me V. P. como há de entender bem uma postila de Dote, de Substitutionibus, de Jure accrescendi, etc., um que não sabe que parentesco ela tem com o Direito, ou por que se trata no corpo dele! (...) concluo que o principiante deve fugir de todos os comentários, e ler a primeira vez as Instituições; na segunda, notar no seu caderno, em que tenha dispostos os títulos delas, as coisas que apontamos, perguntando ao Mestre quais são as leis revogadas, etc.. E quando não tivesse ocasião de lho perguntar, só em tal caso e, com algumas cautelas, lhe permitiria ler o mais curto expositor, e somente no dito ponto (...) tendo, pois, o estudante entendido que as Instituições são um compêndio do que se contém nas Pandectas e nos Códigos (que é o mesmo que dizer, de quase todo o corpo do Direito), deve notar juntamente quais são os títulos do Direito que já não estão em uso, para os deixar; porque é tempo perdido estudar as coisas que não hão-de servir (...) o principal ponto está em reduzir às Leis à sua ordem natural [como fez Jean Domat (citado por L. A. VERNEY à p. 177)] (...) como deviam ser dirigidas, se acaso Triboniano e seus companheiros conhecessem (que certamente não conheceram) aquilo a que nós chamamos Método (...) onde, para formar verdadeira idéia do Direito, e estudar o que deve, deixando o que não deve, é necessário ao estudante não só fazer o resumo dos livros, mas, em outro caderno separado, fazer o seu índex dos tratados e títulos, pelo estilo que dizemos, o qual, sem dúvida alguma, ajudará muito com o tempo para reconhecer a coerência ou antinomia das Leis" (Verdadeiro cit. (nota 105), pp. 116-117; 174-175; 176 e 178-179). Notese, ainda, que L. A. VERNEY manifestava sua indignação a respeito da atribuição de posições em tribunais especializados - como os da Fazenda e de Ultramar - a juristas completamente desprovidos das noções mais elementares de Economia e Política (cf. Verdadeiro cit. (nota 105), pp. 135-136, especialmente p. 132).

Superado o aspecto crítico de sua obra, desponta a feição reformadora do autor; que recomenda o robustecimento dos estudos propedêuticos (inclusive históricos) e a valorização da experiência jurídica estrangeira: "se ele soubesse que a Gramática e o Latim se podem saber em dois anos, e a Retórica no terceiro; que um simples ano de Lógica, se for boa e bem explicada, lhe pode dar grande luz para entender a Lei; que, lendo bem uma Ética antes de entrar na Lei, e entendendo bem a História, tem feito a metade do caminho, etc. - então compreenderia que lhe aconselhamos, não coisas impossíveis, mas mui fáceis, e que, seguindo a Lei pelo método que dizemos, não empregaria tanto tempo, e sairia com mais utilidade. E, tendo bebido estes princípios, ficava apto para, no discurso da vida e dos estudos, adiantar-se incrivelmente (...) posso mostrar a V. P., entre os Estrangeiros, muitas obras medíocres; mas muitas selectíssimas, ou falemos dos Repetentes, ou Tratadistas, ou Consulentes. E, sem sair da minha Itália (onde primeiro que em outra parte renasceu o Direito Romano no $\mathrm{XII}^{\circ}$ século, e aonde pelo espaço de alguns séculos foram aprender os mais da Europa), posso apontar a V. P. dúzias e dúzias de autores insignes na Cadeira e no Foro, de alguns dos quais vejo que se servem mui bem estes Senhores Portugueses, não obstante que murmurem tanto dos Estrangeiros" (Verdadeiro cit. (nota 105), pp. 143 e 126). De fato, tal aspecto da doutrina de L. A. VERNEY que certamente influenciará, mais adiante, as reformas pombalinas da aplicação e do ensino do direito - não passou despercebido a um de seus mais expressivos estudiosos: "é preciso, por último, conhecer a história do direito nacional, sem a qual não pode haver verdadeira compreensão das leis; é mister seguir o exemplo dos alemães e dos holandeses; e é preciso olhar para as outras nações cultas e ter notícia das leis dos outros povos, para saber quais são as justas e as injustas" (L. CABRAL DE MONCADA, O século XVIII cit. (nota 55), pp. 96-98).

Especificamente sobre a posição de Luís António Verney a respeito da Jurisprudência, cf. L. CABRAL DE MONCADA, Conceito e Função Jurisprudência segundo Verney, in Boletim do Ministério da Justiça 14 (1949), pp. 5-24. Acerca da projeção de sua obra no exterior, verificar a bibliografia que pudemos coligir noutra ocasião (E. L. R. PouSADA, Preservação cit. (nota 99), p. 60).

Note-se que a obra de Luís António Verney vai produzir um ambiente intelectual favorável ao ímpeto reformador (típico do iluminismo italiano do século XVIII). Como em seu "Verdadeiro Método de Estudar" o autor ataca o método escolástico-bartolista - então praticado na Universidade de Coimbra - sua obra influenciará o "Compêndio Histórico sobre o Estado da Universidade de Coimbra no tempo da invasão dos Jesuítas", elaborado pela Junta da Providência Literária no ano de 1771 (documento que preparou terreno para a reforma dos Estatutos da Universidade, implementada no ano seguinte).

A fim de que se compreenda a importância da obra de Luís António Verney no cenário intelectual - e particularmente jurídico - do Portugal setecentista, tenha-se em vista que, em caráter exemplificativo, fazem menção expressa à influência do autor sobre as reformas pombalinas da aplicação e do ensino do direito: J. C. Moreira Alves, A Contribuição do Antigo Direito Português no Código Civil Brasileiro, in M. CAETANO J. C. Moreira Alves - C. do Couto e Silva - M. J. de Almeida Costa, Estudos de Direito Civil Brasileiro e Português (I Jornada Luso-Brasileira de Direito Civil), São Paulo, Revista dos Tribunais, 1980, p. 33; M. PAUlo MerÊA, Resumo cit. (nota 16), p. 160; M. J. de AlMEIDA CostA, Fundamentos cit. (nota 16), p. 116; M. J. de Almeida Costa, Debate cit. (nota 103), pp. 16-17; M. A. CoElHo DA RoCHA, Ensaio cit. (nota 16), pp. 213-222; J. J. LOPES PRAÇA, História da Philosophia em Portugal nas suas Relações com o Movimento 
$\S$ 127. Iluminismo jurídico português: principais características. Embora alguns autores pretendam sintetizar o "iluminismo jurídico português" por meio da alusão ao binômio estabelecido entre os conceitos de "racionalismo" e "voluntarismo", parece-nos que inúmeras outras características podem ser entrevistas em tal movimento. Postas de parte aquelas que extrapolam os limites de nossa atual investigação - tais como o "regalismo" (nas relações entre Igreja e Estado) e o "humanistarismo" (especificamente quanto ao direito penal) -, pode-se afirmar que seus aspectos mais relevantes são os seguintes: influência da escola do direito natural ("jusracionalista"); uso moderno do direito justinianeu ("usus modernus pandectarum"); hostilidade ao critério puramente numérico de aferição da "communis opinio doctorum" (de origem escolástico-bartolista); repúdio ao direito romano reprovado pelo direito natural (ou pelo direito das gentes); apreço pelo direito nacional (inclusive municipal); valorização da experiência jurídica estrangeira (embrião de uma ciência lusíada do direito comparado); incremento dos estudos histórico-críticos (romanos e lusitanos); aversão ao sistema analítico da escolástica bartolista - com a conseqüente predileção pelo método sintético-compendiário (cujo principal modelo foi a obra de J. G. HEINECCII). Note-se que tais elementos poderão ser entrevistos nos dois principais veículos de implementação das reformas pombalinas da aplicação e do ensino do direito - vale dizer, a "Lei da Boa Razão" e os "Estatutos da Universidade de Coimbra de 1772",106.

Geral da Philosophia, Coimbra, Imprensa Litteraria, 1868, pp. 228-232; N. E. GOMES DA SILVA, História cit. (nota 16), pp. 474-478; J. R. de LIMA LOPES, $O$ Direito cit. (nota 14), p. 228; J. LÚCIO DE AZEVEDO, $O$ Marquês de Pombal e a sua Época, Lisboa, Clássica Editora, 1990, p. 245; e C. Castelo Branco, Perfil do Marquês de Pombal, $2^{\mathrm{a}}$ ed., Porto, Lopes \& C., 1900, passim.

${ }^{106}$ M. J. de ALMEIDA COSTA atribui à fase do "iluminismo jurídico" português as seguintes características básicas: preponderância do racionalismo; uso moderno do direito romano; influxo da jurisprudência elegante dos Países Baixos; projeção do iluminismo filosófico e do humanitarismo jurídico (História cit. (nota 09), pp. 353-364; Debate cit. (nota 103), pp. 2-16). Na verdade, tal autor sintetiza a lição de M. PAULO MERÊA, o qual decompõe tais elementos em um rol ligeiramente maior; caracterizando o período como a resultante do influxo: do direito natural e das gentes; do uso moderno do direito romano; da jurisprudência elegante; do direito nacional; do iluminismo francês; do humanitarismo; e do regalismo (Resumo cit. (nota 16), pp. 159161). A propósito, por uma definição do iluminismo jurídico português estribada no binômio estabelecido entre os conceitos de "voluntarismo" e "racionalismo", cf. N. E. GOMES DA SILVA, História cit. (nota 16), p. 372.

Limitando-se aos aspectos estritamente técnicos - que mais nos interessam, diga-se de passagem - G. BRAGA DA CRUZ, por sua vez, destaca o papel preponderante desempenhado pelo jusnaturalismo racionalista e pelo próprio "usus modernus pandectarum" - considerando-os as facetas mais significativas desta época $(O$ Direito Subsidiário cit. (nota 16), pp. 387-388; La Formation cit. (nota 99), pp. 11-12). Ora, a despeito da indiscutível profundidade com que este autor se dedicou à questão, acreditamos que outros aspectos merecem específica menção. Por tal razão, consideramos mais adequada a síntese promovida por L. CABRAL DE MONCADA, pois atrela a orientação adotada durante o consulado pombalino às diretrizes lançadas por Luís António Verney em seu "Verdadeiro Método de Estudar"; com efeito, segundo este autor, são estas as principais notas que singularizam o período: "hostilidade ao direito romano puro, tal como ele historicamente 

gerais da Lei de 18 de agosto de 1769 ("Lei da Boa Razão”). As diretrizes lançadas no "Verdadeiro Método de Estudar" foram objeto de paulatina implementação ao longo de todo o terceiro quartel do século XVIII, principalmente em decorrência da enérgica atuação do Marquês de Pombal. Ainda que as reformas tenham envolvido alguns aspectos de fundo - como no que toca à disciplina do direito sucessório, alterada pelas Leis de 25 de junho de 1766 e de 09 de setembro de 1769 - pode-se afirmar, no entanto, que uma considerável parcela do direito privado foi sensivelmente reformulada à custa da mera substituição de critérios hermenêutico-integrativos; voltada à prática jurídica (e sobretudo à

existia, e aos critérios da sua aplicação prática até então seguidos; tendência para regular e limitar na sua aplicação a parte dele, ainda em vigor, pelas exigências da razão natural e pelo uso que dele faziam as nações modernas; grande favor e condescendência também para com as tradições jurídicas e direitos nacionais; e, finalmente, uma marcada simpatia pelo próprio direito estrangeiro das nações civilizadas, entre as quais vigorava, prendendo-as num forte sentimento de solidariedade espiritual, o chamado direito das gentes como uma emanação, ele próprio, do direito natural e da razão humana" (O Século XVIII cit. (nota 55), pp. 91-92). Pela abordagem do assunto no âmbito da historiografia geral, cf. D. PERES, História de Portugal VI, Barcelos, Portucalense Editora, 1934, pp. 421-467; F. de ALMEIDA, História de Portugal V - Instituições Políticas e Sociais de 1580 a 1816, Coimbra, Editor Fortunato de Almeida, 1927, pp. 7-12 e 430-441; J. AMEAL, História de Portugal, Porto, Livraria Tavares Martins, 1940, pp. 514-549; A. H. de OliveIRA MARQUes, História de Portugal, Lisboa, Imprensa Nacional - Casa da Moeda, 1991, pp. 86-95; F. J. C. FAlCon, A Época Pombalina (Política Econômica e Monarquia Ilustrada), São Paulo, Ática, 1982, pp. 393396; K. MaXwell, Marquês de Pombal - Paradoxo do Iluminismo, Rio de Janeiro, Paz e Terra, 1996, pp. 95-117; J. H. SARAIVA, História Concisa de Portugal, $18^{\mathrm{a}}$ ed., Mira-Sintra Publicações Europa-América, 1996, pp. 247-259; T. SoARES, O Marquês de Pombal, Brasília, Editora da Universidade de Brasília, 1983, pp. 209-228; J. BAPTISTA MACHAdO, Pombal, Marquês de, in Dicionário de História de Portugal V, Porto, Livraria Figueirinhas, 2002, pp. 113-121; J. ANTUNES, Notas sobre o Sentido ideológico da reforma Pombalina - a propósito de alguns Documentos da Imprensa da Universidade de Coimbra, in Revista de História das Idéias 1982-1983 (número especial intitulado O Marquês de Pombal e o seu Tempo I), pp. 143197; P. CALMON, A Reforma da Universidade e os dois Brasileiros que a Planejaram, in Revista de História das Idéias 1982-1983 (número especial intitulado O Marquês de Pombal e o seu Tempo II), pp. 93-100; J. SERRÃo, Repensar Pombal, in Pombal Revisitado - Comunicações ao Colóquio Internacional Organizado pela Comissão de Comemoração do $2^{\circ}$ centenário da Morte do Marquês de Pombal II, Lisboa, Estampa, 1984, pp. 353-359; M. B. M. N. da SILVA, A Legislação Pombalina e a Estrutura da família no Antigo Regime Português, in Pombal Revisitado - Comunicações ao Colóquio Internacional Organizado pela Comissão de Comemoração do $2^{\circ}$ centenário da Morte do Marquês de Pombal I, Lisboa, Estampa, 1984, pp. 405-414; L. R. TORgAL, Acerca do Significado do Pombalismo, in Revista de História das Idéias 1982-1983 (número especial intitulado O Marquês de Pombal e o seu Tempo I), pp. 7-17. Quanto à repercussão das reformas sob a perspectiva da Universidade de Coimbra, cf. M. BRANDÃo - M. LOPES D’ALMEIDA, A Universidade de Coimbra: Esboço da sua História, Coimbra, Imprensa da Universidade, 1937, passim; T. BRAGA, História da Universidade de Coimbra nas suas Relações com a Instrução Pública Portugueza, Lisboa, Academia Real de Sciencias, 1892-1902, passim.

Sob a perspectiva estritamente jurídica, cf. L. CABRAL DE MONCADA, Italia e Portogallo nel'Settecento, in Estudos de História do Direito III, Coimbra, Imprensa da Universidade, 1950, pp. 153-192; O Iluminismo Ítalo-Austríaco, in Estudos Filosóficos e Históricos (Artigos, Discursos, Conferências e Rescensões Críticas) II, Coimbra, Imprensa da Universidade, 1959, pp. 465-470; A. R. de OLIVEIRA, Poder e Sociedade. A Legislação Pombalina e a Antiga Sociedade Portuguesa, in Revista de História das Idéias 1982-1983 (número especial intitulado O Marquês de Pombal e o seu Tempo I), pp. 51-80.

A respeito da posição do Marquês de Pombal sobre a questão religiosa, do "regalismo" português e das restrições à liberdade de opinião - decorrentes da instituição da "Mesa Censória" pela Lei de 05 de abril de 1768 - cf. as observações e a bibliografia que tivemos a oportunidade de coligir noutra ocasião (E. L. R. POUSADA, Preservação cit. (nota 99), p. 71, nota 143). 
aplicação do direito subsidiário), a Lei de 18 de agosto de 1769 redirecionou o emprego do direito justinianeu, tomando por base parâmetros destoantes daqueles que até então vinham sendo praticados pela "communis opinio doctorum". Também conhecida por "Lei da Boa Razão", sua regulamentação pode ser decomposta, analiticamente, em oito partes principais: a) seu proêmio; b) a disciplina afeta ao estabelecimento e aos efeitos dos assentos da Casa da Suplicação $(\S 1$ a $\S 8)$; c) a reestruturação do sistema de direito subsidiário (§ 9); d) a reafirmação da primazia absoluta do direito pátrio (§ 10); e) a expressa recomendação da analogia como mecanismo primeiro para a colmatação de lacunas ( $(11) ; \mathrm{f})$ a dissociação absoluta entre as jurisdições canônica e secular (§ 12); g) a proscrição de Acúrsio, de Bártolo e da própria “opinião comum dos doutores” (§ 13); h) e, finalmente, a tomada do costume como autêntica fonte do direito positivo, estabelecendose seus respectivos requisitos legais ( $§ 14)$. De todo esse arcabouço, interessam-nos, sobretudo, as regras estabelecidas no proêmio e nos parágrafos 9, 10, 11 e 13 desta Lei objeto da análise desenvolvida a seguir ${ }^{107}$.

${ }^{107}$ A implementação do "iluminismo jurídico" em Portugal se deu de maneira gradual, por meio de uma série de reformas que se voltaram, primeiramente, à praxe judiciária (1769) e à pedagogia universitária (1772). Contudo, também podem ser apontadas medidas pontuais em alguns setores específicos da legislação particularmente aquele que modernamente designamos por "civil". Neste sentido, o movimento se insere no contexto jurídico lusitano - da segunda metade do século XVIII - de maneira enérgica (uma vez que trará repercussões bastante amplas), ainda que fragmentado em uma série de medidas relativamente autônomas. Sobre o caráter paulatino do movimento de reforma, assim se pronuncia L. CABRAL DE MONCADA: "Pode-se dizer que (...) se deu em sucessivas etapes, entre os séculos XVII e XVIII, não sendo antes da segunda metade do último que entre nós se consumou definitivamente, invadindo a sua influência primeiro o campo da legislação, e daí passando, pouco depois, para o da pedagogia, o da jurisprudência e o do próprio direito privado" (O Século XVIII cit. (nota 55), p. 92). Por sua vez, M. J. de AlmEIDA CostA confirma a divisão adotada: "produziram-se estas [as reformas pombalinas] em três sectores: o da actividade científico-prática dos juristas, o do ensino do direito e o das modificações legislativas pontuais" (Debate cit. (nota 103), p. 17). Ora, no que concerne à praxe judiciária não havia necessidade de uma investida direta para a implementação das novas idéias; as "Ordenações do Reino de Portugal" eram tão lacunosas que a alteração do sistema de direito subsidiário surtiria uma ampla repercussão, alcançando-se os mais variados âmbitos do direito privado. É essa, aliás, a linha de raciocínio desenvolvida por G. BRAGA DA CRUZ: "para fazer vingar as idéias do jusnaturalismo racionalista e do usus modernus pandectarum (...) mais do que empreender directamente grandes reformas das instituições, o que importava era afeiçoar ao novo credo ideológico o esquema das fontes subsidiárias de direito. Especialmente no campo do direito privado, era tão deficiente a legislação nacional e de tal forma vasto o domínio da integração das respectivas lacunas, que bastava alterar as Ordenações nesse ponto concreto para provocar uma verdadeira revolução nos quadros do direito vigente" (O Direito Subsidiário cit. (nota 16), pp. 387-389).

A despeito disso, em alguns casos o legislador reputou indispensável uma intervenção direta para a reformulação do sistema até então prevalecente. Foi o que ocorreu com relação ao direito sucessário: o ideário iluminista era tão infenso ao modelo testamentário (justinianeu) que houve a necessidade de medidas contundentes para a implementação da sucessão legítima. A respeito desta questão, L. CABRAL DE MONCADA destaca o papel desempenhado pelas Leis de 25 de junho de 1766 e de 09 de setembro de 1769, responsáveis pela articulação em texto legal de uma autêntica filosofia sobre a destinação do acervo hereditário: "a lei de 25 de junho de 1766 restringiu consideravelmente o direito de testar. Tomando como pretexto os abusos que todos os dias se praticavam na extorsão dos testamentos, de que eram vítimas pessoas de espírito débil, doentes ou idosas, praticados por parentes afastados ou pessoas eclesiásticas, em detrimento dos naturais herdeiros legítimos dos testadores, a lei proíbe, em princípio, para o futuro, todos os testamentos (...) [mas] a 


\section{$\S$ 129. Reformas pombalinas da aplicação e do ensino do direito: a Lei de}

18 de agosto de 1769 como um mecanismo de reafirmação da primazia do direito pátrio.

O proêmio da "Lei da Boa Razão" atribui o estado de incerteza da jurisprudência de então

aos abusos hermenêuticos praticados pelos advogados, como que a semear dúvidas em

detrimento de disposições de clareza indiscutível; diante de uma tal espécie de afronta ao direito lusitano, robustece-se preceito anteriormente estabelecido - tanto pelas “Ordenações Manuelinas" (Ord. Man. V, 58, 1) quanto pelas subseqüentes "Filipinas" (Ord. Fil. I, 4, 4 e Ord. Fil. I, 5, 5) - a respeito da interpretação autêntica da lei e das penas atribuídas aos julgadores que não guardassem seu teor. Além disso, a primazia do direito português é reafirmada pelo parágrafo décimo da Lei de 18 de agosto de 1769: isso se dá

lei de 1766 não era uma simples lei de defesa da vontade livre dos testadores, como à primeira vista poderia parecer; era uma lei que (...) visava, acima de tudo, defender os direitos de certos parentes, da família, e bem assim a sucessão legítima e legitimária (...) [por sua vez] a referida lei de 9 de setembro de 1769 (...) sobrevindo pouco depois da lei da Boa Razão, constitui a mais interessante lei pombalina sobre matéria de direito privado, em que as tendências jusnaturalísticas daquele diploma mais profunda e diretamente se revelam. Promulgada como esclarecimento à anterior, de fato, amplia-a e desenvolve-lhe o pensamento à luz de várias considerações filosóficas, por forma a constituir com ela um verdadeiro <<novo código >> de todo o direito sucessório da época (...) limitava mais severamente do que a anterior a faculdade de testar e contrastava assim, mais uma vez, todo o nosso direito histórico, o qual só conhecia, como quota legitimária, os dois terços dos bens, sem distinção da sua proveniência, e, como herdeiros legitimários, apenas os descendentes e os ascendentes. Além disso, a mesma lei aumentava os direitos dos herdeiros forçados; restaurava o direito visigótico da chamada melhora (melioratio); estendia o princípio da legítima a todos os parentes colaterais, tornados também herdeiros legitimários, ainda além do quarto grau; e fazia enfim reviver a distinção germânica e medieval dos bens em hereditários e adquiridos (avoenga e ganhadia), que já outrora tinha existido no direito português dos séculos XIII e XIV" (O Século XVIII cit. (nota 55), pp. 108, 111 e 113-114).

Observe-se que no preâmbulo da Lei de 09 de setembro de 1769 a sucessão legítima era reputada uma decorrência do direito natural; de sua parte, o modelo testamentário era considerado uma invenção supersticiosa dos romanos "ímpios e gentios". L. CABRAL DE MONCADA destaca que a nova disciplina foi buscada tanto na Alemanha (provavelmente pelo recurso à obra de J. G. HEINECII), quanto no antigo direito castelhano (especificamente no que concerne à melhora); posto de parte o elemento castelhano, fica evidente a exaltação do direito das nações modernas (e civilizadas) da Europa, em detrimento da tradição jurídica lusitana. Com efeito, assim o autor arremata seu argumento: "Essas leis foram exclusivamente um produto e uma consequiência lógica das idéias da Escola do direito natural, da luta contra o direito romano, e do fervor com que então foram acolhidas as doutrinas e os exemplos vindos lá de fora, das nações modernas e sobretudo das germânicas" (O Século XVIII cit. (nota 55), pp. 114-120)

Por um panorama das principais reformas de fundo implementadas durante o consulado pombalino, cf. P. J. de Mello Freire dos Reis, Historiae cit. (nota 16), pp. 62-67; M. A. CoelHo DA Rocha, Ensaio cit. (nota 16), pp. 193-194.

Por uma análise genérica da Lei de 18 de agosto de 1769, cf. M. Paulo MerÊA, Resumo cit. (nota 16), pp. 161-162; N. E. GOMES DA SiLVA, História cit. (nota 16), pp. 392-397; M. J. de ALMEIDA CosTA, História cit. (nota 09), pp. 366-372; Debate cit. (nota 103), pp. 17-24; L. CABRAL DE MONCADA, O Século XVIII cit. (nota 55), pp. 99-100; G. BRAGa DA CRUZ, O Direito Subsidiário cit. (nota 16), pp. 385-409; La Formation cit. (nota 99), pp. 9-12; J. VALLET DE GoYTISOlo, El derecho romano cit. (nota 74), p. 477; P. J. de Mello FreIRE dos Reis, Historiae cit. (nota 16), pp. 67-69; M. A. COELHO DA ROCHA, Ensaio cit. (nota 16), pp. 192193.

Como daqui por diante dedicaremos nossa atenção tão somente ao proêmio e aos parágrafos $9,10,11$ e 13 da Lei de 18 de agosto de 1769 , remetemos o leitor, quanto aos demais aspectos da Lei da Boa Razão ( $\S 1$ 1, 2 , $3,4,5,6,7,8,12$ e 14), às considerações que tivemos a oportunidade de expender noutra ocasião (cf. E. L. R. PousAdA, Preservação cit. (nota 99), pp. 75-78). 
não apenas por meio da expressa rejeição da máxima "odiosa limitanda, favorabilia amplianda", mas também em virtude da cominação de severas penalidades aos advogados que a invocassem - assim como aos magistrados que a acolhessem em seus julgados. Por sua vez, o parágrafo décimo-primeiro prescreve ao intérprete o emprego da analogia como principal critério para a colmatação das lacunas do sistema; assim, antes de lançar mão do direito subsidiário, deveria buscar o "genuino (...) e natural sentido" da legislação pátria ${ }^{108}$.

108 À vista da expressa consagração - em texto legal - de várias características do "iluminismo jurídico" português, efetua-se a transcrição do proêmio da Lei de 18 de agosto de 1769: "D. José, por graça de Deos, Rey de Portugal, e dos Algarves, d'aquem, e d'além Mar em África, Senhor de Guiné, e da Conquista, Navegação, Commercio da Ethiopia, Arabia, Persia, e da India, etc. Faço saber aos que esta minha Carta de lei virem, que por quanto depois de muitos annos tem sido hum dos mais importantes objectos de attenção, $\mathrm{e}$ do cuidado de todas as Nações polidas da Europa, o de precaverem com sabias providencias as interpretações abusivas, que offendem a magestade das Leis; desauthorisão a reputação dos Magistrados; e tem perplexa a justiça dos litigantes; de sorte que no direito, e dominio dos bens dos Vassallos não possa haver aquella provavel certeza, que sò póde conservar entre elles o publico socego: Considerando Eu a obrigação que tenho de procurar aos Póvos, que a Divina Omnipotencia pôz debaixo da minha protecção, toda a possivel segurança nas suas propriedades, estabelecendo com ella a união, e paz entre as famílias, de modo que humas não inquietem as outras com as injustas demandas, a que muitas vezes são animadas por frivolos pretextos tirados das extravagantes subtilezas, com que aquelles, que as aconselhão, e promovem, querem temerariamente entender as Leis mais claras, e menos susceptiveis de intelligencias, que ordinariamente são oppostas ao espirito dellas, e que nellas se acha litteralmente significado por palavras exclusivas de tão sediciosas, e prejudiciaes cavilações: Tenho ouvido sobre este grave, e delicado negocio hum grande número de Ministros do meu Conselho, e Desembargo, de muito timorata consciencia, muito zelosos do serviço de Deos, e meu; e muitos doutos, e versados, nas sciencias do Direito Público, e Diplomatico, de que depende a bôa, e sã legislatura; das Leis Patrias; dos louvaveis costumes destes Reinos; das Leis dos Antigos Romanos vulgarmente chamadas Direito Civil; e das de todas as Nações mais illuminadas, que hoje se conhecem; foi por todos nas repetidas Sessões (que se tiverão sobre esta materia) uniformemente assentado, que o meio mais proprio, e efficaz para se occorrer ás sobreditas interpretações abusivas, he o que o Senhor Rey D. Manoel de gloriosa memoria (reputando justamente as mesmas interpretações por crimes graves) deixou estabelecido pelo liv. 5 tit. $58 \S 1$ da sua Ord.; e que della se transportou para o liv. 1 tit. $4 \S 1$, tit. $5 \S 5$ da Compilação das Ordenações publicada no anno de 1602; e para o $\S 8$ da Reformação do anno de 1605 ; se eu fosse servido excitar eficazmente a disposição dos ditos paragraphos, de sorte que constituão impreteriveis regras para os Julgadores; e fosse servido declarallos, e modificallos de modo que mais não possam cahir em esquecimento, nem suspender-se, alterar-se, ou rduzir-se a termos de questão a observancia delles nos casos occorrentes. E conformando-me com os ditos pareceres, e com o que nelles foi assentado: Quero, mando, e he minha vontade, que daqui em diante se observe aos ditos respeitos o seguinte" (apud CÂNDIDO MENDES DE AlMEIDA, Código cit. (nota 16), pp. 725-726).

Desta "exposição de motivos" podem ser depreendidas diversas características do movimento ora analisado: em primeiro lugar, merece destaque o expresso reconhecimento ao auxílio prestado pelos especialistas em direito público e diplomático (ressaltando-se, ainda que indiretamente, a importância do direito das gentes em um tal cenário). Da mesma forma, do texto se extrai uma alusão ao papel precursor das nações "iluminadas" (polidas) da Europa, especificamente a respeito das soluções jurídicas afinal adotadas - ainda que simplesmente confirmassem a orientação assumida pelo próprio legislador lusíada alguns séculos antes, em meio às "Ordenações Manuelinas" (Ord. Man. V, 58, 1). Por fim, deve-se ressaltar que por meio de uma tal provisão D. José I visava pôr cobro a um estado de incerteza que fora o motivo da reclamação dos procuradores do Porto já durante as Cortes de Lisboa de 1619. A respeito de tais questões, cf. J. H. CoRreIA Telles, Commentario Critico á Lei da Boa Razão em data de 18 de agosto de 1769, in Revista de Direito Civil, Imobiliário, Agrário e Empresarial 3 (1978), pp. 348-350.

Quanto à relação estabelecida entre o direito pátrio e o elemento justinianeu, eis o que dispôs a "Lei da Boa Razão", por seu parágrafo décimo: "por quanto ao mesmo tempo me foi tambem presente, que da sobredita generalidade supersticiosa das referidas Leis chamadas Imperiaes se costumão extrahir outras regras para se interpretarem as minhas Leis nos casos occorrentes: entendendo-se que estas Leis Patrias se devem restringir, quando são correctorias do Direito Romano: e que onde são com elle conformes se devem alargar, para 


\title{
$\S$ 130. Reformas pombalinas da aplicação e do ensino do direito: a Lei de
}

\author{
18 de agosto de 1769 e a reformulação do sistema de direito subsidiário. Sob a alegação
}

de sua ignorância em matéria de filologia, latinidade, história do direito romano, direito

divino e direito natural, as obras de Acúrsio e Bártolo são veementemente proscritas pelo

parágrafo décimo-terceiro da Lei de 18 de agosto de 1769: ao mesmo tempo em que o legislador exalta a "verior opinio", rechaça de modo categórico a "communis opinio doctorum" que - lastreada no método analítico de origem escolástico-bartolista - era considerada, até então, como o instrumento mais autorizado para a revelação da "boa

receberem todas as ampliações, e todas as limitações, com que se achão ampliadas, e limitadas as regras conteúdas nos Textos, das quaes as mesmas Leis Patrias, se suppõe, que fôrão deduzidas, seguindo-se desta inadmissivel Jurisprudencia (...) mando outro sim, que as referidas restricções, e ampliações extrahidas dos textos do Direito Civil, que atégora perturbarão as disposições das minhas Leis, e o socego publico dos meus Vassallos, fiquem inteiramente abolidas, para não mais serem allegadas pelos Advogados, debaixo das mesmas penas acima ordenadas, ou seguidas pelos Julgadores, debaixo da pena de suspensão de seus Officios até Minha mercê, e das mais, que reservo ao Meu Real arbitrio" (apud CÂNDIDO MENDES DE Almeida, Código cit. (nota 16), pp. 728-729).

Segundo J. H. CORREIA Telles, as leis romanas não deveriam ser postas - inteiramente - de parte, mas deveriam ser conformadas ao direito nacional, tomado este como autêntico direito comum: "aquele período da nossa Lei, não deve entender-se por si só; deve juntar-se aos seguintes, e a soma de todos eles vem a ser; que as Leis Pátrias recebem interpretação de si mesmas, e não das Leis Imperiais, que pareçam análogas (...) se não deve atender se as Leis do Reino são ou não corretórias do Direito comum, para as limitarmos ou ampliarmos, por isso que elas mesmas são o nosso Direito comum" (Commentário cit. (nota 108), pp. 371372). A respeito, cf. P. J. de Mello Freire dos Reis, Historiae cit. (nota 16), p. 68; M. A. COelHo DA ROCHA, Ensaio cit. (nota 16), pp. 192-193.

Ora, a despeito da razoabilidade das concluões de tais autores, parecem não conferir o valor devido à verdadeira "descompostura" contida em outro trecho do mesmo parágrafo, no qual se alude aos principais prejuízos decorrentes de uma influência excessiva dos textos romanos sobre a hermenêutica devotada ao direito pátrio: "primeiramente não poderem os meus Vassallos ser governados, e os seus direitos, e dominios seguros, como o devem estar, pelas disposições das minhas Leis, vivas, claras, e conforme ao espirito nacional, e ao estado presente das cousas destes Reinos: em segundo lugar ficarem os direitos, e dominios dos mesmos Vassallos vacillando entregues ás contingentes disposições, e ás intrincadas confusões das leis Mortas, e quasi incomprehensiveis daquella Republica acabada, e daqulle Imperio extincto depois de tantos seculos: e isto sem que se tenhão feito sobre esta importante materia as reflexões que erão necessarias, para se comprehender por huma parte, que muitas das Leis destes Reinos, que são correctorias do Direito Civil forão assim estabelecidas, porque os sabios Legisladores dellas se quizerão muito advertida, e providentemente apartar do Direito Romanocom rasões fundamentaes muitas vezes não só diversas, mas contrarias ás que havião constituido o espirito dos textos do Direito Civil, de que se apartarão (...) e sem se advertir pela outra parte, que muitas outras das referidas Leis Patrias, que parecem conformes ao Direito Romano; ou forão fundadas em razões nacionaes, e especificas, a que nenhuma sorte se podem applicar as ampliações, e limitações das segundas das sobreditas Leis; ou adoptárão dellas somente o que em si continhão de Ethica, de Direito Natural, e de boa razão: mas de nenhuma sorte as especulações, com que os Consultos Romanos ampliarão no Direito Civil aquelles simplices, e primitivos principios, que são inalteraveis por sua natureza" (apud CÂNDIDO MENDES DE ALMEIDA, Código cit. (nota 16), pp. 728-729). Desta forma, visando coibir os abusos decorrentes da praxe, a Lei de 18 de agosto de 1769 determinou que as restrições e as ampliações se deduzissem - unicamente - do espírito da própria legislação pátria, evitando-se, assim, interferências que pudessem deturpar o sentido pretendido pelos legisladores reinícolas; eis o intuito do parágrafo décimo-primeiro da "Lei da Boa Razão": "Exceptuo comtudo as restricções, e ampliações, que necessariamente se deduzem do espirito das minhas Leis significado pelas palavras dellas tomadas no seu genuino, e natural sentido: as que se reduzirem aos principios acima declarados: e as que por identidade de razão, e por força de comprehensão, se acharem dentro no espirito das disposições das Minhas ditas Leis" (apud CÂNDIDO MENDES DE AlMEIDA, Código cit. (nota 16), p. 729). A respeito do alcance das disposições ora referidas, cf. G. BRAGA DA CRUZ, O Direito Subsidiário cit. (nota 16), p. 354. 
razão" em que se fundavam os textos romanos. Contudo, o legislador pombalino já não aludia àquela racionalidade pressuposta ("ratio scripta") que outrora justificara o recurso às Leis Imperiais no texto das "Ordenações Manuelinas" (ou mesmo das "Ordenações Filipinas"); em lugar disso, o parágrafo nono da "Lei da Boa Razão" consagra o uso moderno como mecanismo de legitimação do direito romano. Note-se que tal assertiva é corroborada pelo influxo simultâneo da "Escola do Direito Natural" (e do "Direito das Gentes"), do método histórico-crítico (cujaciano) e do direito estrangeiro das nações iluminadas - tudo nos mesmos moldes preconizados por L. A. VERNEY na "Carta XIII" de seu "Verdadeiro Método de Estudar". Aliás, segundo J. H. CORREIA TELLES, três são as prescrições fundamentais contidas no referido parágrafo: a proeminência das disposições nacionais em relação ao direito justinianeu; o acolhimento deste último pela "boa razão" em que são fundados os seus preceitos; e a predileção (em caso de lacuna do sistema reinícola) pela legislação das nações iluminadas da Europa - em matéria política, econômica, mercantil ou marítima ${ }^{109}$.

109 O parágrafo décimo-terceiro da "Lei da Boa Razão" consubstancia um repúdio veemente das obras de Acúrsio e de Bártolo, considerados dois dos expoentes mais autorizados daquela tradição de fundo escolástico que se desenvolveu desde o surgimento da Escola de Bolonha (e de seus estudos sobre o direito justinianeu renascido), à custa do emprego do "mos italicus". Com efeito, por meio de uma reprovação expressa, o legislador pombalino buscava obter o efeito inverso da elevação - legal - de tais textos à categoria de fontes subsidiárias do direito lusíada (tal como se podia depreender, gradativamente, do Alvará de 19 de maio de 1425, da "Carta de Bruges", da Carta Régia de 18 de abril de 1426 e mesmo de Ord. Af. II, 9). Mas além do repúdio a tais autores, observa-se uma destituição da "communis opinio doctorum" - e do próprio método analítico, contrário ao caráter verdadeiro e simples da Jurisprudência (cf. M. R. MARQUES, Elementos cit. (nota 99), p. 809). No entanto, o estado de incerteza - gerado pela dificuldade de se determinar a "opinião comum" - não seria solucionado imediatamente; o que levou J. H. CORREIA TELLES a afirmar que a destituição de tais autoridades "deixou a Jurisprudencia nacional em hum arbitrario mais amplo, do que antes era" (Commentario cit. (nota 108), pp. 379).

Eis o teor do parágrafo décimo-terceiro da Lei de 18 de agosto de 1769: "Item: sendo certo, e hoje de nenhum douto ignorado, que Accursio e Bartholo, cujas auctoridades mandou seguir a mesma Ord. no $\S 1$ do sobredito tit., forão destituidos não só da instrucção da História Romana, sem a qual não podião bem entender os textos que fizerão os assumptos dos seus vastos escriptos; e não só do conhecimento da Philologia, e da bôa Latinidade, em que fôrão concebidos os referidos textos; mas tambem das fundamentaes regras de Direito Natural, e Divino, que devião reger o espirito das Leis, sobre que escreverão: E sendo igualmente certo, que ou para supprirem aquellas luzes, que lhes faltavão; ou porque na falta dellas ficárão os seus juizos vagos, errantes, e sem boas razões a que se contrahissem; vierão a introduzir na Jurisprudencia (cujo caráter formão a verdade, e a simplicidade) as quasi innumeraveis questões metaphysicas, com que depois daquella Escola Bartholina se tem illaqueado, e confundido os direitos, e dominios dos litigantes intoleravelmente: mando que as glosas, e opiniões dos sobreditos Accursio, e Bartholo não possão mais ser allegadas em Juízo, nem seguidas na pratica dos Julgadores; e que antes muito pelo contrario em hum, e outro caso sejam sempre as bôas razões acima declaradas, e não as auctoridades daquelles, ou de outros semelhantes Doutores da mesma Escola, as que hajão de decidir no fôro os casos occorrentes; revogando tambem nesta parte a mesma Ordenação, que o contrario determina" (apud CÂNDIDO MENDES DE ALMEIDA, Código cit. (nota 16), pp. 729-730).

Sobre a contraposição entre a "verior" e a "communis opinio" - em decorrência do influxo humanista que se verificou em Portugal durante o século XVI - cf. as observações lançadas na nota 104 (ao tratarmos do surgimento do critério misto para a determinação da "opinião comum"). Note-se que a repulsa à Escola bartolista - manifestada no parágrafo décimo-terceiro da Lei de 18 de Agosto de 1769 - revela não só o 
declínio do critério majoritário, como também a ascensão do método histórico-crítico ("mos gallicus"), que volta à carga. Nas palavras de N. E. GOMES DA SILVA "retomava-se, deste modo, o caminho encetado pela corrente racionalista do Humanismo" (História cit. (nota 16), p. 393).

Por sua vez, eis o teor do parágrafo nono da "Lei da Boa Razão": "Item: Sendo-me presente, que a Ordenação do livro $3^{\circ}$ titulo 64 no preambulo, que mandou julgar os casos omissos nas Leis Patrias, estylos da Côrte, e costumes do Reino, pelas leis que chamou Imperiaes, não obstante a restricção, e limitação finaes do mesmo Preambulo conteúdas nas palavras - as quaes Leis Imperiaes mandamos somente guardar pela boa razão em que são fundadas -, se tem tomado por pretexto, tanto para que nas allegações, e dicisões se vão pondo em esquecimento as Leis Patrias, fazendo-se uzo sómente das dos Romanos; como para se argumentar, e julgar pelas ditas Leis de Direito Civil geral, e indistinctamente, sem se fazer differença entre as que são fundadas naquella boa razão, que a sobredita Ord. do Reino determina por unico fundamento para as mandar seguir; e entre as que; ou tem visivel incompatibilidade com a boa razão; ou não tem razão alguma, que possa sustentallas, ou tem por unicas razões, não só os interesses dos differentes partidos, que nas revoluções da Republica, e do Imperio Romano, governarão o espírito dos seus Prudentes e Consultos, segundo as diversas facções, seitas, que seguirão; mas também tiverão por fundamento outras razões assim de particulares costumes dos mesmos Romanos, que nada podem ter de communs com os das Nações, que presentemente habitão a Europa, como superstições proprias da Gentilidade dos mesmos Romanos, e inteiramente alheias da Christandade dos seculos, que depois delles se seguirão: Mando por huma parte, que debaixo das penas ao diante declaradas se não possa fazer uso nas ditas allegações, e Decisões de Textos, ou de authoridades de alguns Escriptores, em quanto houver Ordenações do Reino, Leis Patrias, e uzos dos meus Reinos legitimamente approvados tambem na fórma abaixo declarada: E mando pela outra parte, que aquella boa razão, que o sobredito Preambulo determinou, que fosse na praxe de julgar subsidiaria, não possa nunca ser a da authoridade extrinseca destes, ou daquelles Textos do Direito Civil, ou abstractos, ou ainda com concordancia de outros; mas sim, e tão sómente: ou aquella boa razão, que consiste nos primitivos principios, que contém verdades essenciaes, intrinsecas, e inalteraveis, que a Ethica dos mesmos Romanos havia estabelecido, e que os Direitos Divino, e Natural formalisarão para servirem de Regras Moraes, e Civis entre o Christiauismo: ou aquella boa razão, que se funda nas outras regras, que de universál consentimento estabeleceo o Direito das Gentes para a direcção, e governo de todas as Nações civilisadas: ou aquella boa razão que se estabelece nas Leis Politicas, Economicas, Mercantis e Maritimas, que as mesmas Nações Christãs tem promulgado com manifestas utilidades, do socego publico, do estabelecimento da reputação, e do augmento dos cabedaes dos Povos, que com as disciplinas destas sabias, e proveitosas Leis vivem felices á sombra dos thronos, e debaixo dos auspicios dos seus respectivos Monarchas, e Principes Soberanos: Sendo muito mais racionavel, e muito mais coherente, que nestas interessantes materias se recorra antes em casos de necessidade ao subsidio proximo das sobreditas Leis das Nações Christãs, illuminadas, e polidas, que com ellas estão resplandecendo na boa, depurada, e sã Jurisprudencia; em muitas outras erudições uteis, e necessarias; e na felicidade; do que ir buscar sem boas razões, ou sem razão digna de attender-se, depois de mais de 17 seculos o soccorro ás Leis de huns Gentios; que nos seus principios Moraes, e Civis forão muitas vezes perturbados, e corrompidos na sobredita fórma; que do Direito Natural tiverão apenas as poucas, e geraes noções, que manifestão os termos com que o definirão; que do Direito Divino, he certo, que não souberão cousa alguma; e que do Commercio, da Navegação, da Arithmetica Politica, e da Economia do Estado, que fazem hoje tão importantes objectos dos Governos Supremos, não chegarão a ter o menor conhecimento" (apud CÂNDIDO MENDES DE AlMEIDA, Código cit. (nota 16), p. 728).

Como já observado em outra oportunidade (nota 102), a Lei de 18 de agosto de 1769 empresta um significado peculiar à expressão "boa razão", tomada não mais como "ratio scripta" inerente a todo o arcabouço conformado pelo direito justinianeu, mas sim como um mecanismo de legitimação de textos "potencialmente" defasados - à vista de sua utilização primígena em circunstâncias consideravelmente diversas daquelas que preponderavam no terceiro quartel do século XVIII. Observe-se, ainda, que do parágrafo nono podem ser depreendidas três acepções emprestadas à referida expressão: a que reflete verdades essenciais, intrínsecas e inalteráveis (direito natural); a que consubstancia regras estabelecidas por universal consentimento para a direção e governo das nações civilizadas (direito das gentes); e a confirmada pelas Leis Políticas, Econômicas, Mercantis e Marítimas das nações iluminadas (direito positivo moderno). A respeito, cf. J. H. CORREIA TELLES, Commentario cit. (nota 108), pp. 357 e seguintes; G. BRAGA DA CRUZ, $O$ Direito Subsidiário cit. (nota 16), pp. 405-406. Destacando a indeterminação decorrente da vagueza de uma expressão já empregada nas próprias "Ordenações Manuelinas", G. BRAGA DA CRUZ observa que "é então que aproveita o ensejo para, como soe dizer-se, 'encher de vinho novo os odres velhos', injetando nas encanecidas estruturas do direito português todo o pensamento racionalista e iluminista da escola do direito natural e do "usus modernus pandectarum"' (O Direito Subsidiário cit. (nota 16), p. 404). Note-se que no parágrafo nono da "Lei da Boa Razão" não se eleva - ao menos expressamente - o direito estrangeiro à categoria de fonte do direito subsidiário lusitano; assim como se verificou quanto à "communis opinio 
$\S$ 131. Reformas pombalinas da aplicação e do ensino do direito: os Estatutos da Universidade de Coimbra de 1772 e a instalação do "usus modernus pandectarum" em Portugal. Se a Lei de 18 de agosto de 1769 estabelece um novo fundamento para a utilização subsidiária do direito justinianeu, o critério prático para a verificação de sua compatibilidade com os ditames da "boa razão" somente sobrevirá com os "Estatutos da Universidade de Coimbra" de 1772; em seu Livro II (Tít. V, cap. 2, §§ 13 a 16) é preconizado o "usus modernus pandectarum", para cuja aferição são estabelecidas algumas regras, segundo as quais não poderiam ser invocados os preceitos romanos: a) de inspiração pagã; b) em desconformidade com a moral cristã; c) contrários às regras de direito natural e de direito das gentes; d) relativos a matérias políticas, econômicas, mercantis e marítimas. Para a realização de um tal esforço investigativo, os "Estatutos" autorizavam - e até mesmo recomendavam - a utilização das obras dos jurisconsultos de toda a Europa iluminada. Note-se que enquanto no parágrafo nono da "Lei da Boa Razão" se consagra o "uso moderno" como "mecanismo de legitimação" do direito romano - ao abrir as portas do sistema português para o direito natural, para o direito das gentes e para a experiência jurídica estrangeira - os "Estatutos da Universidade de Coimbra", por sua vez, vão ainda mais longe, ao elevá-lo à categoria de autêntico "método de investigação" do

doctorum" no contexto das "Ordenações Manuelinas", a força que o texto legal the emprestou foi simplesmente negativa, no sentido de impedir a aplicação do direito justinianeu que não lhe fosse conforme. Com efeito, o texto (equívoco) somente alude à maior razoabilidade de um recurso ao direito moderno estrangeiro; e isso parece decorrer da conjugação entre a "Lei da Boa Razão" e os Estatutos da Universidade de Coimbra de 1772. Em sentido diverso, cf. G. BRAGA DA CRUZ, O Direito Subsidiário cit. (nota 16), p. 418 (que entende já autorizado o recurso ao direito estrangeiro segundo a própria Lei de 18 de agosto de 1769); em sentido idêntico, M. Borges Carneiro, Direito Civil de Portugal - contendo tres livros: I. Das pessoas, II. Das cousas, III. Das obrigações e acções I, Lisboa, Typ. de Maria da Madre de Deus, 1858, pp. 58-60. De todo modo, tal situação há de mudar pouco depois, como teremos a oportunidade de observar mais à frente. Pela alusão a tais questões por parte de Luís António Verney, cf. nota 105. Observe-se, ainda, que não há como se confundir, no contexto português, a "Escola do Direito Natural" com o "usus modernus pandectarum": "Esta [Escola do direito natural] é uma escola toda de filosofia e jurisprudência teorética (GRÓCIO e PUFENDORF); aquela [usus modernus pandectarum] uma escola teórico-prática, se escola se the pode chamar; isto é, uma corrente ou direção da jurisprudência alemã, determinada pela primeira, como ponto de vista influenciador, e pelo direito germânico como elemento substancialmente deformador do romanismo puro (LAUTERBACH, STRUV, StRYK, etc.)" (L. CABRAL DE MONCADA, O Século XVIII cit. (nota 55), p. 91); no mesmo sentido, cf. M. J. de AlmeIDA Costa, História cit. (nota 09), p. 358. Finalmente, destaque-se que o "uso moderno" (do direito romano) é objeto de menção tanto na "Lei da Boa Razão" como nos "Estatutos da Universidade de Coimbra" de 1772; contudo, enquanto ali terá a função de "mecanismo de legitimação" do emprego do direito justinianeu (fundado na "boa razão"), nestes terá a missão de servir como critério de aferição ("método de investigação") daquela compatibilidade a que aludira o legislador pombalino. De todo modo, pelas assertivas de J. H. CoRReIA TELLES referidas na parte final do corpo do texto, cf. Commentario cit. (nota 108), p. 357. 
direito justinianeu ainda aplicável; tudo ao mesmo tempo em que declinam a autoridade extrínseca da "Glosa", dos "Comentários" e da "communis opinio doctorum",

${ }^{110}$ Eis os parágrafos "Estatutos da Universidade de Coimbra" em que se acha consagrado o "usus modernus pandectarum", concebido como método de investigação do direito justinianeu ainda aplicável no século XVIII (Liv. II, Tít. 5, Cap. 2, §§ 13 a 16): "Explorarão $1^{\circ}$ : se as Leis Romanas, que dispõem sobre casos omissos pelas Leis Patrias, contém algum vestigio de superstição Ethnica, e Paganismo dos Romanos, ou involvem algumas reliquias de praticas, e maximas, que por qualquer modo sejão contrarias aos Costumes, e á Moral dos Christãos" (§ 13); "Explorarão $2^{\circ}$ : se são oppostas aos dictames da bôa razão, depois desta bem discutida, qualificada, e informada pelas declarações, e ratificações do Direito Divino: depois de aperfeiçoada e illustrada pela Moral Christã; e depois de bem depurada das falsas, e enganosas apparencias, e illusões, que na indagação das Leis Naturaes padecerão os Estoicos, e outros Filosophos, em cujos systemas beberão os Jurisconsultos Romanos as primeiras maximas da equidade natural, que seguirão nas suas respostas; vindo consequentemente a participarem das mesmas illusões, e enganos, pelas terem derivado, e deduzido da Moral daquelles Gentios, que muitas vezes não atinarão com os verdadeiros dictames da razão por lhes faltar a luz da verdadeira crença" (§ 14); "Explorarão $3^{\circ}$ : se as mesmas Leis dos Romanos se oppõem o Direito das Gentes, ou este se considere em quanto Natural, e na accepção de Positivo, e differentes especies de Consuetudinario ou Pacticio. Porque onde por qualquer das referidas especies de Direito das Gentes se achar recebido e praticado pela maior parte das Nações civilisadas o contrario do que dispõem as Leis Romanas, cessará inteiramente da determinação destas, e prevalecerá sem hesitação o que se achar determinado ou recebido pela pratica, e uso da maior parte das ditas Nações" (§15); "Explorarão $4^{\circ}$ : se as disposições das mesmas Leis Romanas se encontrão com as das Leis Politicas, Economicas, Mercantis e Maritimas das referidas Nações. Porque tendo sido os artigos, que constituem os objectos das referidas especies de Leis, muito mais cultivados, e mais bem regulados nos ultimos seculos pelas sobreditas Nações: por terem estas sobre cada hum delles muito maiores luzes, e conhecimentos muito mais amplos do que tiverão os Romanos; os quaes em tudo o que diz respeito a Navegação, e ao Commercio, tiverão vistas muito curtas, e tendentes a fim muito diverso; fica sem controversia ser muito maior a proporção, e analogia, que as ditas Leis das referidas Nações tem com a Legislação das nossas Leis, que respeita aos ditos objectos da Economia, do Commercio, da Navegação, do que he a proporção, e analogia, que com a mesma Legislação das nossas Leis tem as ditas Leis dos Jurisconsultos Romanos: sendo certo que estes até ignorarão, e desconhecêrão inteiramente quasi todos os Pontos, e Artigos dos referidos objectos; e resultando daqui deverem os mesmos Consultos ceder inteiramente sobre elles ás sobreditas Nações, e serem preferidas para a decisão das causas, e negocios pertencentes aos ditos objectos as Leis, que as mesmas Nações tem estabelecido sobre elles a todas, e quaesquer Leis respectivas aos mesmos objectos, que se possão achar no Corpo do Direito Romano" (§ 16). Portanto, somente o texto justinianeu que não tivesse sido reprovado - após seu exame segundo cada uma destas quatro regras - poderia ser considerado acolhido pelo "usus modernus pandecatarum"; entretanto, sobrevém a indagação: o confronto deveria ser efetuado diretamente contra os textos das leis estrangeiras? A resposta negativa - segundo o estabelecido nos "Novos Estatutos" (Liv. II, Tít. 5, Cap. 3, § 8) - parece inevitável, diante da expressa determinação de uma depuração mediatizada pela produção doutrinária dos jurisconsultos das nações iluminadas de então: "Para se instruirem no dito uso moderno se aproveitarão os Professores do util, e apreciavel trabalho, que para o mesmo fim se acha já feito por grande numero de Jurisconsultos em differentes livros; dos quaes huns são escriptos pela ordem, e serie dos livros, e Titulos, das Leis do Direito Civil Romano; e outros são formados por methodos arbitrarios: sendo huns ordenados com o fim principal de mostrar tão sómente o dito uso: e tendo outros tomado por objecto principal o ensino do Direito Romano; de sorte, que só depois de expostas as Regras, principios delle, he que fazem menção do uso dellas". Pelos trechos dos Estatutos da Universidade de Coimbra de 1772 ora transcritos, cf. J. H. Correia Telles, Commentario cit. (nota 108), pp. 358-359 e 363 (bem como A. A. V. CuRA, Direito Romano cit. (nota 16), pp. 302-303). Estas regras foram sintetizadas por M. de ALMEIDA E SousA nas Notas de uso pratico e criticas addições, ilustrações e remissões á imitação das de Muller a Struvio sobre todos os titulos e paragraphos do livro primeiro das Instituições do direito civil lusitano, do doutor Paschoal José de Mello Freire, Lisboa, Imprensa Nacional, 1868, p. 24); no mesmo sentido, cf. M. R. MARQUES, Elementos cit. (nota 99), p. 811.

O papel dos "Novos Estatutos da Universidade de Coimbra" na implementação do "usus modernus pandectarum" é assim definido por L. C. de MONCADA: "aí se manda, com efeito, fazer o confronto das leis romanas, a aplicar ainda em Portugal, com o direito natural, o divino e o das gentes, o político, o econômico, o mercantil e o marítimo; e aí se estabelece, como critério e meio de facilitar esse confronto, o estudo e conhecimento do chamado uso moderno (usus modernus pandectarum), ou seja, o uso que as nações 


\section{$\S$ 132. A vulnerabilidade do sistema implementado pelas reformas}

pombalinas: "boa razão" e "usus modernus pandectarum" como elementos vinculados à ascensão e ao declínio do iluminismo (jurídico) português. A análise dos efeitos das referidas reformas pombalinas - da aplicação e do ensino do direito - não pode prescindir de uma específica observação relacionada à maleabilidade do conceito de "boa razão": assim como os iluministas dela se serviram para implementar o jusracionalismo português, é exatamente na flexibilidade de tal expressão que também poderemos encontrar a origem do "individualismo crítico" - período que lhe sucedeu na historiografia lusitana, instaurado ainda nas primeiras décadas do século XIX. Ora, como a proscrição do ultrapassado bartolismo não fora acompanhada da eleição "nominal" de novos corifeus, aquela incerteza de outrora - então derivada da dificuldade de se aferir a "communis opinio doctorum" persistiu, conquanto sob uma nova roupagem: despontou, então, uma nova crise - desta vez voltada à definição do "uso moderno" do direito romano (tal qual praticado pelas nações civilizadas da Europa). Note-se que um redirecionamento do "usus modernus pandectarum" poderia implicar a desnaturalização do conceito iluminista de "boa razão":

modernas fazem do direito romano e que afinal nada mais é do que o uso que dele se faz na Alemanha de Struv, de Schilter, de STRIK, etc." (O Século XVIII cit. (nota 55), p. 103). No mesmo sentido, cf. M. P. MerêA, Direito romano cit. (nota 102), p. 543; M. J. de AlMEIDA CosTA, Lei cit. (nota 86), p. 681. A respeito da subsidiariedade do direito estrangeiro a partir da própria "Lei da Boa Razão", cf. G. BRAGA DA CRUZ, O Direito Subsidiário cit. (nota 16), pp. 407-408.

A doutrina majoritária alude aos "Estatutos da Universidade de Coimbra" como um complemento da Lei de 18 de agosto de 1769; a instauração de uma nova "mentalidade" - derivada de uma completa reestruturação pedagógica - deveria se seguir à reforma quanto à praxe judiciária. Neste sentido, cf. P. J. de MELLO FREIRE dos Reis, Historiae cit. (nota 16), pp. 70-71; M. A. COELHO DA ROCHA, Ensaio cit. (nota 16), pp. 217-218; M. P. MERÊA, Resumo cit. (nota 16), pp. 162-163; N. E. GOMES DA SILVA, História cit. (nota 16), pp. 398402; M. J. de AlmeIDA Costa, História cit. (nota 09), pp. 372-377; Debate jurídico cit. (nota 103), pp. 2427; L. Cabral de Moncada, O Século XVIII cit. (nota 55), pp. 102-103; G. Braga Da CruZ, O Direito Subsidiário cit. (nota 16), pp. 408-419; La Formation cit. (nota 99), pp.11-12. M. R. MARQUES assim sintetiza a relação entre os dois instrumentos: "as reformas propostas podiam ser irremediavelmente prejudicadas e ineficazes se não fossem acompanhadas por uma mudança de mentalidade. Como era possível inculcar novas regras de interpretação e de preenchimento de lacunas em juristas viciados pela escola Bartolista nas áridas e académicas digressões pelas inumeráveis doutrinas existentes acerca de questões nem sempre essenciais? Como era possível estimular o gosto pela exactidão e pela precisão na aplicação das leis nacionais em juristas que passavam vários anos em Coimbra a discutir e a pesar as várias opiniones dos DD. sobre a aplicação de alguns parágrafos do corpus iuris civilis? Estas e outras questões, mormente a adesão aos novos horizontes do direito natural racionalista, impunham uma inovação igualmente profunda nos estudos jurídicos" (Elementos cit. (nota 99), p. 812).

Por uma apreciação genérica sobre o emprego do "usus modernus pandectarum" em Portugal, cf. M. R. MARQUES, Elementos cit. (nota 99), pp. 801-826. A propósito, eis a conclusão de M. A. CoELHO DA RoCHA sobre a primeira etapa do "uso moderno" português: "ao mesmo tempo que Montesquieu e outros á luz da razão depuravam as leis antigas, e abriam um novo caminho para a reforma da legislação, eminentes intérpretes segregavam, na infinita collecção do corpo do direito civil, os fragmentos, e textos antiquados, d'aquelles, que ainda eram applicaveis nas suas respectivas nações, reunindo estes em tractados especiaes ou observações, com o titulo de uso moderno. Por este methodo escreveram Strickio, Thomasio, Boehmero, Struvio, Hubero, Voet, Heineccio, e ultimamente Pothier, a cada passo citados pelos nossos escriptores" (Instituições cit. (nota 01), p. 282). 
destituído este de um conteúdo essencialmente jusracionalista, a posição anteriormente ocupada pela "recta ratio" é então assumida por novos parâmetros, de feição acentuadamente liberal. Vejamos, assim, de que maneira o "usus modernus pandectarum" acabou assumindo novos contornos ${ }^{111}$.

\section{§ 133. A reformulação do "usus modernus pandectarum": a utilização da} própria legislação estrangeira como fonte do direito. Ora, como a Lei de 18 de agosto de 1769 não se encarregou de indicar os representantes oficiais do "usus modernus pandectarum”, coube à doutrina - bem como à jurisprudência - a definição prática do conceito iluminista de "boa razão"; contudo, se para P. J. de MELlo FrEIRE dos Reis o "uso moderno" correspondia ao emprego das obras de B. CARPzOV, G. A. STRUVE, S. Pufendorf, S. Stryk, C. ThOmasius, J. H. BÖHMER e J. G. HeineciI, novos parâmetros exsurgem a partir dos estudos de M. de AlmEIDA E SousA (de LobÃo), que nas duas primeiras décadas do século XIX desenvolve os primeiros estudos lusitanos de direito comparado (sob a influência marcante do modelo francês). Abre-se espaço, então, para a utilização do próprio direito estrangeiro (sobretudo francês, sardo, prussiano e austríaco)

\footnotetext{
111 Desta forma, permanece o estado de incerteza que prevalecia até o advento da "Lei da Boa Razão": em lugar das dificuldades inerentes à estimação da "communis opinio doctorum", exsurge o desafio de se estabelecer quais os autores "autorizados" a reconhecer o recebimento - ou não - do direito justinianeu pelas nações civilizadas da Europa: "Quanto a mim este he ainda mais espinhoso, que se seguirmos o trilho das outras regras já dadas; por duas razões: primeiro, porque os Doutores que escreverão nos ultimos tempos, sobre o uso moderno das Pandectas, discordão muito entre si. Nada mais frequente que Strik censurar a Groenewegio, e Leeuwen, a Bugnyon, a Christineo, a Gudelin, a Zypeo, a Regner, a outros Doutores da Belgica, e França, por darem por abrogadas as Leis Romanas, que elle diz não o estarem, ao menos em alguns dos Estados da Allemanha (...) a segunda razão he, porque se faz preciso também averiguar, se o uso moderno derogatorio das Leis Romanas teve ou não principio vicioso" (J. H. CORREIA TELLES, Commentario cit. (nota 108), pp. 362-363). No mesmo sentido, F. C. PONTES DE MIRANDA, Fontes cit. (nota 16), pp. 73-74. O problema teria de ser resolvido, então, a partir da eleição dos representantes - autênticos - do "uso moderno", a ser realizada pelos advogados e magistrados em meio ao cotidiano da atividade forense. A propósito, G. BRAGA DA CRUZ destaca trecho do prefácio primitivo do "Digesto Portuguez" de J. H. CORREIA TELLES, em que este jurista deixa clara a sua insatisfação: "deixadas ellas [a boa e a má razão] nas mãos dos Juizes e Advogados, com liberdade de julgarem e conselharem por ellas; os povos são victimas da priguiça do Legislador, arruinando-se com processos, que se terião evitado com Leis Nacionaes terminantes" (apud O Direito Subsidiário cit. (nota 16), p. 424, nota); note-se que - a despeito da mudança de contexto pode ser retomado o sentido da reclamação dos procuradores do Porto durante as Cortes de Lisboa de 1619. Assim, prenunciando o método de trabalho adotado durante a segunda etapa do "uso moderno" lusitano, J. H. CORREIA TELLES assim se pronuncia: "melhor fôra talvez, que a nossa Lei nos casos omissos mandasse recorrer ás Leis Mercantis, e Maritimas de tal ou tal Nação: conseguir-se-hia assim mais certeza, e menos arbitrio" (Commentario cit. (nota 108), p. 370).

Aludindo à maleabilidade dos conceitos de "recta ratio" e "usus modernus pandectarum", M. J. de ALMEIDA CosTA assinala a forma de viragem experimentada na transição ao "individualismo crítico" português: "simplesmente, atribuiu-se-lhes [aos conceitos de recta ratio e usus modernus pandectarum] um sentido de todo diverso: a boa razão passa a aferir-se pela bitola do individualismo liberal" (Enquadramento cit. (nota 99), p. 150). No mesmo sentido, cf. G. BRAGA DA CRUZ, O Direito Subsidiário cit. (nota 16), p. 428; Formação cit. (nota 16), p. 50; La Formation cit. (nota 99), pp. 15. Sobre o alcance desta nova feição do "uso moderno" trataremos logo adiante.
} 
em subsídio das fontes lusitanas: "se pelos Estatutos era permittido averiguar o uso moderno das nações nos escriptos dos seus JCtos, por maioria de razão deve ser procurado nas suas leis"; com esta justificativa, M. A. COELHO DA ROCHA denuncia um redirecionamento do "usus modernus pandectarum", responsável pelo recurso imediato ao direito das nações civilizadas da Europa. Com isso, aquela controvérsia que outrora estivera concentrada na aferição da "communis opinio doctorum" - e que no período iluminista se voltou à depuração da orientação dos jurisconsultos das nações civilizadas agora se estabelecia a pretexto de uma investigação sobre o direito estrangeiro; o que influenciou, de modo decisivo, no processo que culminará na edição do Código Civil de 1867 - expressão lusíada daquele individualismo (franco-revolucionário) que tomará o lugar da precedente orientação jusracionalista (germânico-conservadora) ${ }^{112}$.

112 Assim, a proscrição de Acúrsio, de Bártolo e da "communis opinio doctorum" não foi seguida da eleição de novos corifeus; de tal modo que, banida a escolástica-bartolista do seio judiciário português, não se providenciou a sua substituição por uma autoridade equivalente. Com isso - ainda que sob uma nova feição o estado de incerteza somente se agravou: "a meu vêr a revogação da Ord., que neste $\S$ se fez, deixou a Jurisprudencia nacional em hum arbitrario mais amplo, do que antes era. Havendo como ha em Direito tantas controversias, e hum Codigo de Leis tão insuficiente para as decidir, que fosse necessario buscar refugio nas dos Romanos, e outras reconhecidas outrossim por defeituosas, e obscuras; quanto melhor não era mandar seguir as opiniões de taes ou taes Doutores, reconhecidos por melhores: do que deixar as decisões no arbítrio da boa rasão! Quantos casos, em que esta boa razão he quasi imperceptivel, ainda aos olhos do mais attento observador! He verdade que Accursio, e Bartholo não forão bons interpretes das Leis Romanas, nem era possivel que o fossem, attento o seculo em que viverão; mas se das suas opiniões não resultava perigo da salvação eterna, quanto melhor segui-las, que vagar na incerteza! Conviria pois que nossa Lei desauthorisando Accursio e Bartholo, lhes substituisse outros Doutores da melhor nota, a fim de ficar menos campo ao perigoso arbitrio dos Julgadores" (Commentario cit. (nota 108), p. 379). Aliás, tal extrato da obra de J. H. CORREIA TElles encontra-se integralmente transcrito nos estudos de M. J. de AlmeIDA CostA ( $L a$ présence cit. (nota 16), p. 62) e M. de AlBUQUERQUe (Bártolo cit. (nota 99), pp. 84-85). Foi a doutrina, enfim, quem assumiu a incumbência de definir, em termos mais concretos, o "usus modernus pandectarum" lusitano - uma vez que entre os anos de 1769 e 1800 tão somente 58 (cinqüenta e oito) assentos acabaram por ser editados pela Casa da Suplicação (Commentario cit. (nota 108), p. 353-354).

Quanto ao papel precursor de M. ALMEIDA E SoUSA (de LOBÃO) na paulatina conformação de uma ciência do direito comparado em Portugal, cf. G. BRAGA DA CRUZ, O Direito Subsidiário cit. (nota 16), p. 430; Formação cit. (nota 16), p. 50; La Formation cit. (nota 99), pp. 15-16; M. J. de AlmEIDA COSTA, Enquadramento cit. (nota 99), p. 151; J. C. MoreIRA Alves, Panorama cit. (nota 16), p. 190; M. R. MARQUES, Elementos cit. (nota 99), pp. 823-824; O Liberalismo cit. (nota 99), p. 149; M. A. COELHO DA RocHA, Instituições cit. (nota 01), p. 284; J. PINTO LOUREIRO, Manuel de Almeida e Sousa, in Jurisconsultos Portugueses do Século XIX - I, Coimbra, Coimbra Editora, 1947, pp. 240-287. Com efeito, tal autor introduz os primeiros estudos de direito comparado em Portugal entre os anos de 1807 e 1817; utilizando-se, para tanto, principalmente do "Code Civil". Pouco tempo depois, A. J. de GouvEIA PINTo lança mão dos Códigos da Sardenha e da Prússia para a elaboração de seu "Tratado regular e prático de testamentos e sucessões" (1820). Por sua vez, J. H. CoRreiA Telles amplia o uso dos códigos francês e prussiano em seu "Digesto Portuguez" (1835). E a tais elementos M. A. COELHO DA RoCHA acrescenta o código austríaco, quando da publicação de suas "Instituições de Direito Civil Portuguez" (1848). Note-se, pois, que todas as obras acima referidas tem sua primeira edição antes da promulgação do Código Civil de 1867: portanto, a doutrina estrangeira era nelas interpretada com base nos cânones hermenêuticos instituídos pela "Lei da Boa Razão". A respeito da utilização da legislação estrangeira pelos jurisconsultos portugueses do século XIX, cf. M. A. COElHO DA RochA, Instituições cit. (nota 01), p. 284; G. BRAGA DA CRUZ, O Direito Subsidiário cit. (nota 16), pp. 431-433; Formação cit. (nota 16), pp. 50-51; La Formation cit. (nota 99), p. 16; M. R. MARQUES, Elementos cit. (nota 99), pp. 823-825; O Liberalismo cit. (nota 99), pp. 149-150. 


\section{$\S 134$. A eficácia representativa (direta) do mandato extrajudicial em meio}

ao processo de implementação do "usus modernus pandectarum” em Portugal. Assim, somente o panorama delineado neste capítulo pode nos oferecer uma explicação razoável para a existência de definições consideravelmente destoantes a respeito de um mesmo tipo contratual - concebidas todas dentro de um intervalo de tempo relativamente reduzido e à vista de um único suporte legislativo. Já tivemos a oportunidade de destacar que P. J. de MELLO FREIRE dos Reis reconhecia a incidência dos dispositivos concernentes ao "mandatum" romano (não representativo), por força da aplicação do sistema de direito subsidiário. Poucos anos mais tarde, J. H. CORREIA TELLES atribuirá ao tipo uma definição na qual o elemento gestório - de origem romana - ainda é preponderante ("os direitos de propriedade serião muitas vezes gravosos a seu dono, se fosse obrigado a exercital-os pessoalmente (...) por isso as Leis concedem, que se possa confiar o exercicio delles a um

Pela assertiva de M. A. COELHO DA RoCHA transcrita no corpo do texto, cf. Instituições cit. (nota 01), p. 284. Observe-se que tal idéia já havia sido aventada por J. H. CORREIA TELLES (Commentario cit. (nota 108), p. 370) - como referido em oportunidade anterior (nota 111). No prefácio ao "Digesto Portuguez" assim se pronuncia o autor: "em apoiar muitos artigos sobre disposições de Codigos estranhos, tambem não introduzi novidade. Outro tanto se encontra em Jurisconsultos nossos, e antigos: e a razão, que davão para sua desculpa, era, que ainda que as Leis d'outro Reino não tivessem autoridade alguma em o nosso, com tudo as suas disposições podião muitas vezes ser abraçadas como opinião mais provavel que merecêra ser adoptada por lei” (Digesto cit. (nota 16), p. 5). Entretanto, G. BRAGA DA CRUZ é categórico ao retorquir tal inovação: "como se o uso moderno referido nos Estatutos não tivesse um significado doutrinal e filosófico muito concreto e específico, simbolizando todo o pensamento duma escola jurisprudencial que fez a ligação entre o jusnaturalismo e o direito romano! E como se os códigos agora invocados, nascidos já à sombra das novas correntes filosófico-jurídicas do individualismo, não estivessem já muito longe - e, por vezes, quase nos antípodas - do pensamento do usus modernus pandectarum!" (O Direito Subsidiário cit. (nota 16), pp. 433435). No mesmo sentido, já em outra oportunidade, cf. La Formation cit. (nota 99), p. 15.

Com efeito, a guinada diagnosticada em M. A. CoElHO DA RoCHA parece inteiramente falaciosa: como tivemos a oportunidade de observar anteriormente (nota 109), a "Lei da Boa Razão" não erigiu o direito das nações civilizadas à categoria de fonte imediata do direito subsidiário; assim, concebido o "uso moderno" como um critério prático destinado a legitimar a aplicação subsidiária do direito justinianeu, ao direito estrangeiro foi conferido, inicialmente, um poder tão somente negativo (de impedir, potencialmente, a aplicação dos textos romanos reprovados). Contudo, na nova acepção empregada ao "usus modernus pandectarum", uma força positiva lhe é atribuída, alçando-o ao "status" de fonte do direito subsidiário.

De todo modo, o reduzido emprego dos assentos uniformizadores pela Casa da Suplicação explica porque a participação da doutrina, nesta mudança de rumos, foi bastante mais significativa; a este respeito, cf. G. Braga DA CRUZ, O Direito Subsidiário cit. (nota 16), p. 436. M. J. de AlmeIDa Costa, por sua vez, destaca: "por tais caminhos se foi preparando espontâneamente, passo a passo, o terreno adequado a uma síntese oficial: representa-a o Código Civil de 1 de Julho de 1867. Convém recordar, todavia, que o desejo de reforma do nosso direito privado já vinha dos começos do último quartel do século XVIII, isto é, do período jusnaturalista. Avivara a preocupação, naturalmente, a típica febre codificadora do Estado liberal" (Enquadramento cit. (nota 109), pp. 152-153). Como único reparo ao autor, lembre-se que as primeiras leis que alteraram substancialmente o direito privado português podem ser entrevistas já na metade da década de 1760 (cf. nota 107).

Note-se que N. BoBBio destaca que o surgimento da "Escola da exegese" só ocorreu graças à prévia polêmica instalada entre o "jusracionalismo" e a "Escola Histórica do Direito" - em virtude da qual, enfrequecido, o direito natural é "dessacralizado" (Il positivismo cit. (nota 55), p. 43). Analogamente, pode-se afirmar que o "individualismo crítico" da primeira metade do século XIX se aproveita das ferramentas previamente dispostas pelo "iluminismo jurídico" - em meio ao seu embate com a escola bartolista portuguesa. 
procurador, ou feitor"); contudo, no que concerne à sua eficácia, admite a irresponsabilidade do mandatário perante os terceiros diante dos quais atuasse ("o mandatário não é fiador do contrato (...) por tanto não póde ser demandado pelo terceiro, com quem contratou") - o que implica, por óbvio, a atribuição de efeitos representativos (diretos) ao instituto. Por sua vez, M. A. COELHO DA RochA vai ainda mais longe, ao introjetar o elemento representativo em sua definição de tal espécie contratual: "mandato é o contracto, pela qual uma pessoa se encarrega de pacticar em nome de outra certo acto, ou de administrar um ou mais negocios alheios"; conquanto o elemento romano ainda esteja presente na parte final do conceito oferecido por este autor, é em seu trecho preambular que poderemos divisar a introdução, em Portugal, do paradigma liberal de origem francesa - em um processo gradual, que encontrará seu natural desfecho no art. $1318^{\circ}$ do Código Civil de $1867^{113}$.

${ }^{113}$ A respeito da posição adotada por P. J. de Mello Freire dos Reis, cf. o trecho inicial de nota de rodapé anterior (nota 99). Note-se que como M. de ALMEIDA E SousA (de LOBÃo) não chegou a comentar o Livro IV das "Institutiones Juris Civilis Lusitani" daquele autor, infelizmente não pudemos encontrar um seu posicionamento explícito acerca do tema. A respeito, cf. Indice do que se contém nos tres volumes de Notas de uso pratico e criticas por Manuel de Almeida e Sousa de Lobão aos Livros I, II e III das Instituições do Dr.Paschoal José de Mello Freire e na Collecção de Dissertações em supplemento ás notas ao Livro III e que faz o IV volume d'esta obra, Lisboa, Imprensa Nacional, 1868.

Contudo, se P. J. de MeLlo FreIRE dos Reis considerava aplicáveis - sem maiores restrições - as disposições estabelecidas pelo direito romano justinianeu, tal posição não se coadunava inteiramente com aquela adotada por um dos mais autorizados representantes do "usus modernus pandectarum" do século XVIII: J. G. HEINECCII. Com efeito, após o advento das reformas pombalinas da aplicação e do ensino do direito, suas "Institutiones" foram adotadas pela cátedra de direito romano da Universidade de Coimbra; e com isso, sua autoridade em Portugal parece inquestionável segundo grande parte da doutrina - exemplificativamente, cf. M. PAULO MERÊA, Lance de olhos sobre o ensino do direito (cânones e leis) desde 1772 até 1804, in Boletim da Faculdade de Direito da Universidade de Coimbra 33 (1957), pp. 200-206 (especialmente p. 204); bem como J. C. Moreira Alves, Aspectos do Ensino do Direito Romano na Faculdade de Direito de São Paulo, durante o Império, in Revista da Faculdade de Direito da Universidade de São Paulo 86 (1991), pp. 20-27. Em uma edição de sua obra publicada pela Universidade de Coimbra (1805) - na versão refundida por J. P. WALDECK - podem ser constatadas diversas passagens nas quais se admitem os efeitos de uma representação direta (contrariamente ao preceituado pelas fontes romanas analisadas pelo autor). Dentre os diversos trechos que podem ser coligidos, desperta maior atenção aquele no qual existe a contraposição entre o "antigo" e o "novo", sintetizada nas seguintes palavras: "per extraneas personas jure quidem antiquo nobis non adquirebatur. At novo iure receptum est, ut per procuratorem nobis adquiri possit non solum possessio, verum etiam dominium, itemque jus pignoris, et jus servitutis" (Institutiones Juris Civilis Heineccianae emendatae atque reformatae, Conimbricae, Typis Academicis, 1805, p. 150; cf. ainda pp. 144 e 308). Desta forma, ao mesmo tempo em que o direito romano deveria ser recebido, mostrava-se indispensável uma sua adaptação às necessidades de uma nova realidade (para a qual a representação direta parecia indispensável). Por sua vez, pelo trecho - transcrito no corpo do texto - da obra de J. H. CORREIA TELLES, cf. Digesto III cit. (nota 16), pp. 98 e 102. Observe-se que, em acatamento ao modelo romano que ainda prevalecia, o autor alude, na primeira parte do excerto, ao fato de que "as Leis" concediam a faculdade de incumbir outro sujeito da administração dos próprios bens; ora, tais "leis" correspondem precisamente ao direito romano, fato que se pode depreender tranquiilamente das notas de rodapé que instruem o texto transcrito. Neste sentido, cf. M. de Almeida e Sousa (de LoBÃo), Indice cit. (nota 113), pp. 39-40.

Ainda quanto à obra de J. H. CORREIA TElLES, deve-se destacar que a atribuição de uma eficácia representativa direta ao mandato extrajudicial vem somente corroborar a orientação estabelecida nas 


\section{$\S 135$. Encerramento do capítulo e apresentação do tema sucessivo. Neste}

capítulo, tivemos a oportunidade de compreender de que forma o elemento justinianeu contribuiu para a gradativa conformação do sistema jurídico lusitano; conquanto seu renascimento tenha sido promissor (inclusive em seu primeiro momento, intermediado pelas fontes castelhanas), as críticas lançadas contra o método "escolástico-bartolista" foram bastante contundentes, atingindo-o duramente. Por sua vez, seu declínio assinala a abertura do direito português a uma nova série de influências: em um primeiro momento, do "usus modernus" praticado pelos jurisconsultos das nações civilizadas da Europa; em seguida, de um pujante direito comparado, no qual preponderava o paradigma francês. Vejamos, a seguir, de que forma este influxo se deu, por meio de uma ligeira incursão a respeito da disciplina do contrato de mandato segundo os códigos portugueses voltados ao direito privado.

"Ordenações do Reino de Portugal" a respeito da variante judicial do instituto; a respeito, cf. Ord. Af. III, 2, 3; Ord. Man. III, 2, 1; e Ord. Fil. III, 2, 1 - bem como $\$ 114$ (e a correspondente nota 94) do presente estudo. Pelo trecho de M. A. COELHO DA ROCHA transcrito no corpo do texto (inclusive quanto aos erros ortográficos ali presentes), cf. Instituições II cit. (nota 01), p. 619. E a respeito da admissão de efeitos representativos diretos (decorrentes dos atos praticados pelo mandatário), cf. p. 623, item $5^{\circ}$ - com expressa invocação de C. E. DELVINCOURT em seu abono.

É interessante destacar que V. F. NETo PAiva ostenta uma posição diferente daquela adotada por M. A. COELHO DA ROCHA, conquanto em obra editada já no início da segunda metade do século XIX. Note-se que a influência romana latente em sua definição de mandato - mitigada, por sinal, pela superveniência de um elemento representativo genérico (derivado da procuração) - pode ser entrevista no seguinte excerto: "mandato é o contracto, pelo qual alguem se obriga a tractar gratuitamente do negocio, que lhe foi commetido. O Sr. Fortuna define mandato o contracto, pelo qual algume pessoa se encarrega gratuitamente da administração e gerencia d'um negocio honesto, que outra pessoa lhe encarregou pela confiança, que n'ella tinha (...) o mandatario, como tal, obra em nome do mandante, representa-o, e para elle adquire os direitos e as obrigações (...) quanto aos direitos, como uteis, de ordinario não ha dúvidas. Quanto ás obrigações porém é mister, que o mandatario as tenha contrahido pelos poderes conferidos pelo mandante" (Curso de Direito Natural II, Coimbra, Imprensa da Universidade, 1856, p. 137). Desta forma, V. F. NETO PAIVA assume um entendimento intermediário - similar ao de J. H. CORREIA TELLES - conquanto decorridos mais de vinte anos da primeira edição do "Digesto Portuguez". Ora, por que não prevaleceu em seu estudo uma concepção similar à de M. A. COELHO DA ROCHA?

A explicação para tal fato não a encontramos em nenhuma das obras até o momento referidas. Fomos achá-la tão somente em meio aos escritos de M. M. da S. BRUSCHY: "póde, porém, dizer-se, que as doctrinas juridicas dos Jctos. francezes teem tido muita influencia entre nós, e por em quanto vencem a que tem a eschola allemã, embora esta, pelos bellos trabalhos de Savigny, Hugo, Niebhur, Maresoll, Muhlenbruch, Mackeldey entre os modernos, Bochmero, Heinecio, Waldeck, Voet, Vinnios e outros antigos, conservem no ensino a merecida preferencia" (Manual do Direito Civil Portuguez segundo a novissima legislação I, Lisboa, Rolland \& Semiond, 1868, p. 25). E assim se torna compreensível a posição de V. F. NETO PAIVA, quando se tem em mira o título completo de seu trabalho: "Curso de Direito Natural segundo o estado actual da Sciencia principalmente em Allemanha professado no primeiro anno da Faculdade de Direito na Universidade de Coimbra".

Observe-se, finalmente, que mesmo na obra de M. A. CoElHo DA RochA o elemento romano não foi extirpado por completo; remanesceu a menção ao "administrar um ou mais negocios alheios" (cf. Instituições II cit. (nota 01), p. 619). Entretanto, a definição de mandato constante do art. $1318^{\circ}$ do Código Civil de 1867 já não o abrange: "Dá-se o contracto de mandato ou procuradoria, quando alguma pessoa se encarrega de prestar, ou fazer alguma cousa, por mandado e em nome de outrem". Voltaremos a tal questão no capítulo subseqüente de nossa exposição. 


\title{
CAPÍTULO IX.
}

\section{UMA HISTORIOGRAFIA INTERNA EXCLUSIVAMENTE PORTUGUESA: INSTAURAÇÃO E REFORMULAÇÃO DE UM CONTRATO DE "MANDATO" DE CONTORNOS LIBERAIS.}

\author{
$\S 136$. O desenvolvimento medieval da "commenda" e a comissão segundo
}

a definição de Cairu: um mandato eminentemente comercial. A configuração do "mandato" português oitocentista está diretamente vinculada à relação mantida entre o referido tipo contratual e a "comissão": à custa de um paulatino desenvolvimento da "commenda" medieval, este instituto angariou uma progressiva autonomia conceitual, acomodando-se, enfim, no cenário do direito comercial; contudo, a acentuada proximidade entre tais modelos dificultou o estabelecimento de uma clara distinção entre os mesmos. Desta forma, enquanto J. da SiLVA LisBoA os apartava segundo o caráter eminentemente mercantil da atuação do comissário, outros critérios foram utilizados com idêntico desiderato; assim, ao se manifestar sobre o projeto do Código Comercial napoleônico, o Tribunal de Comércio de Marselha preconizou - em acolhida a uma prática local ainda então prevalecente - uma definição de comissário fundada em sua atuação não representativa: "celui qui agit en son propre nom ou sous un nom social pour le compte de son commettant". Com efeito, foi exatamente esta orientação - estribada na denegação de uma eficácia representativa (direta) à atuação de tal espécie de agente - que acabou por prevalecer em meio à legislação comercial portuguesa do século XIX ${ }^{114}$.

\footnotetext{
${ }^{114}$ Em uma abordagem sobre a evolução histórica do contrato de comissão, G. SAUTEL destaca a ausência em momentos mais remotos - de limites claros entre esta espécie contratual e o mandato; mais do que a eficácia representativa decorrente da atuação do agente, despontava como elemento característico o caráter mercantil da gestão desenvolvida pelo comissário: "on peut remarquer que, au cours de la rapide esquisse qui précède, nous nous en sommes tenus au fond des institutions en en négligeant totalement l'aspect terminologique: nous avons parlé indifféremment de mandat ou de commission, de commissionaire ou de mandataire, et cela que l'intermédiaire agisse en son nom ou au nom de son donneur d'ordres. Ce faisant, nous suivions simplement l'exemple des auteurs de toutes nationalités antérieurs à notre Code de commerce. Les mots commissio, commission, et dérivés, sont employés couramment dans nos matières à partir du XVII ${ }^{\mathrm{e}}$ siècle, mais ils n'ont pas un sens plus précis que celui de 'mandat', avec tout au plus la spécification 'mandat commercial'. Ils ne sont jamais réservés à l'hypothèse où le mandataire s'engage en son nom propre. Cette hypothèse n'est considérée que comme un cas particulier de la théorie d'ensemble du mandat ou de la commission commerciale. Elle ne comporte pas encore sa terminologie propre (...) Il ne semble même pas qu'il ait jamais existé avant la fin du $\mathrm{XVIII}^{\mathrm{e}}$ siècle un courant tendant à préciser l'emploi du terme commission (...) Il n'y a entre le mandat et la comission autre différence (...) si ce n'est que le mandat est gratuit (...) et la commission a un salaire limité par la coustume; car quant à l'effet du mandat, et de la commission, il est égal en toutes choses (...) D'où la définition ci-dessus indiquée qui, quoiqu'il ait pu paraitre à première vue, ne consacre pas l'existence d'une terminologie propre caractérisant certaines hypothèses de mandat commercial, celles où l'agent contracte en son nom propre" (L'histoire du contrat de commission jusqu'au Code de Commerce, in J. HAMEL (org.), Le contrat de commission - Études de Droit Commercial, Paris, Librairie Dalloz, 1949, pp. 34-36).

Entretanto, o mesmo autor observa que tal situação mudou por ocasião da promulgação do Código Comercial de 1804. Em meio aos seus trabalhos preparatórios, G. SAUTEL se deparou com a manifestação do Tribunal
} 


\section{$\S 137$. A distinção entre a comissão e o mandato mercantil promovida pelo}

Código Comercial de 1833: a incrustação da representação na eficácia do contrato de mandato (em sentido amplo) - e sua elevação a fator discriminante entre suas variantes. Admitindo sua aplicação no âmbito mercantil (art. 767), o Código Comercial de 1833 conferiu ao "mandato" (em sentido amplo) uma conformação consideravelmente genérica, comprometida, sobretudo, com o elemento gestório que - até então - tradicionalmente caracterizara o instituto (art. 762). Tomada a eficácia representativa direta (arts. 45, $768 \mathrm{e}$ 776) como elemento discriminante entre a "comissão" (arts. 39 e 769) e o "mandato mercantil" (arts. 772 e 788), possibilitou-se ao mandatário ("stricto sensu”) percutir a esfera jurídica do mandante - ativa (art. 776 e 780) e passivamente (art. 778). Ao contrário, da atuação do comissário não poderia redundar uma vinculação direta entre o comitente e

de Marselha transcrita no corpo do texto, o que o levou a concluir pela existência de uma prática local consolidada, voltada à atribuição de uma acepção mais "moderna" ao contrato de comissão: "il est possible que des usages locaux se soient établis en ce sens, au moins apparemment. C'est que révèlent certaines observations de tribunaux sur le projet du Code de commerce napoléonien: le tribunal de commerce de Marseille demandait que l'on définit le commissionaire 'celui qui agit en son propre nom ou sous un nom social pour le compte de son commettant'. Cette proposition n'était évidemment pas gratuite; elle demandait l'adoption d'une pratique locale survie depuis un certain temps" (G. SAUTEL, L'histoire cit. (nota 114), p. $35)$.

Ora , a posição de J. da SILVA LISBOA se lastreia na orientação da doutrina então considerada tradicional para a qual a peculiaridade da comissão consistia precisamente em seu objeto mercantil. De modo que o comissário podia atuar, inclusive, como procurador do principal: "a comissão rege-se necessariamente pelas identicas, e substanciaes regras do Contracto que em Direito Civil se chama Mandato; pois na verdade commetter, ou encarregar algum negocio a outro he equivalente, em muitos effeitos, ao acto de dar ordens, ou mandar alguma coisa, acreditando a outro para fazer operações por conta de quem o authoriza; e he o mesmo que constituir Procurador a respeito dos objectos commetidos, e ordenados (...) Convém pois saber em geral as Leis essenciaes do Mandato, ou Constituição de Procuradoria" (Principios de Direito Mercantil, $e$ Leis de Marinha, para uso da mocidade portugueza, destinada ao commercio V - Dos contractos mercantis, Lisboa, Impressão Régia, 1819, p. 548).

Com efeito, o autor alude à simples - ainda que freqüente - "possibilidade" de atuação do comissário em seu próprio nome: "os Commissarios contractão muitas vezes em seu nome proprio, ainda que a operação seja toda por conta do seu Commettente, de quem recebêrão ordem de não divulgar os seus negocios. Neste caso o Commissario fica o principal obrigado a respeito da pessoa com quem contractou; mas a respeito do Commettente a omissão do nome não altera a natureza da Commissão, seus encargos, e acções directas contra o mesmo Commissario, e em tal caso o proprio Commettente não póde usar de acção alguma contra aquelle terceiro (...) aquelle que contracta em nome alheio, e na mera qualidade de Commissario, não he obrigado em seu proprio nome, se procedeo em boa-fé; pois vem a ser como simples feitor, agente, ou ministro; e por tanto os lucros, e os prejuizos dos Contractos acima feitos pertencem ao Commettente. Pela mesma razão, o Commissario em tal caso, huma vez que nomêe a pessoa do Commettente, não póde adquirir algum direito para si" (Princípios cit. (nota 114), p. 553).

Com isso, a orientação de J. da SILVA LISBOA prescinde de qualquer juízo relacionado à eficácia representativa direta defluente dos atos praticados pelo comissário. Por sua vez, a respeito da posição adotada pela legislação comercial portuguesa do século XIX, teremos a oportunidade de nos manifestar logo adiante.

Por derradeiro, também quanto ao presente capítulo se faz necessário reiterar o método de abordagem das fontes primárias já utilizado em ocasiões anteriores: será mencionada com maior vagar a primeira disposição concernente a algum dos assuntos abordados - acompanhada da simples remissão aos textos legislativos posteriores (em meio aos quais a mesma matéria tenha sido objeto de regulamentação semelhante, sem alteração de relevo). Contudo, caso tenha despontado modificação substancial, buscaremos efetuar o regular confronto entre o direito anterior e a normatização modificadora. 
terceiros (art. 43), senão em caráter meramente acessório (art. 792); desta forma, assim como a responsabilidade perante estes caberia tão somente ao agente (art. 42), do mesmo modo se faria necessário um ato subseqüente de transmissão, a fim de que as posições jurídicas ativas fossem transferidas ao principal (art. 803). Entretanto, a proeminência dos interesses do "dominus negotii" ensejou a especial interferência do legislador em duas oportunidades específicas: ao possibilitar o emprego pelo comitente das exceções pessoais ordinariamente atribuídas ao comissário (art. 793); e ao instituir uma ação adjudicatória em favor do mandante, na hipótese de atuação - ilícita - do mandatário em seu próprio nome (art. 777). Finalmente, no artigo 773 se estabelece que no "mandato mercantil" - provido, portanto, de eficácia representativa direta - "o mandante é obrigado a cumprir as obrigações do mandatario, contrahidas em conformidade da ordem dada" ${ }^{\text {"115. }}$.

${ }^{115}$ Em posição destoante daquela defendida por J. da SILVA LISBOA, o Código Comercial de 1833 admitiu, expressamente, o "mandato mercantil" - à vista de elementos específicos que o apartavam da variante "civil" do instituto. De fato, por meio de seu artigo 767, assim foi prevista tal modalidade: "quando o mandato tem logar entre negociantes e por facto de commercio, a convenção é mercantil, e regulada pelas leis deste codigo".

Desta forma, a relação entre o "mandato" e a "comissão" não poderia mais se sustentar na diversidade de seus respectivos universos de aplicação; em lugar da contraposição entre os âmbitos "civil" e "comercial", ao mandato mercantil foram atribuídas especificidades de ordem subjetiva ("entre negociantes") e objetiva ("por facto de commercio"). Note-se que - a despeito da eliminação do aspecto subjetivo - tal orientação prevaleceu quando do advento do Código Comercial de 1888 (art. 231", "caput").

De todo modo, cumpre destacar que J. FERREIRA BORGES adota uma posição vacilante, simultaneamente comprometida com a orientação tradicional e com os novos paradigmas doutrinários: "Chama-se mandato em Direito civil o acto pelo qual uma pessoa se encarrega de fazer um ou mais negocios para outrem. Este mesmo acto em commercio chama-se comissão (...) comissario - é em Direito commercial, o que é mandatario em Direito Civil (...) ha porem uma differença a notar, e é que o commissario obra em seu proprio nome por conta do committente: quando o mandatario obra em nome do mandante" (Diccionario Juridico-Commercial, $2^{a}$ ed., Porto, Typographia de Sebastião José Pereira, 1856, pp. 86-87).

Feito tal esclarecimento preliminar, cumpre então analisar a definição legal conferida ao instituto, constante do artigo 762 do Código Comercial de 1833. Em primeiro lugar, deve-se destacar que tal preceito reforça a natureza contratual do liame estabelecido entre as partes: de fato, tal relação é compreendida como decorrência de uma declaração de vontade conjunta dos sujeitos envolvidos ("mandante" e "mandatário") - e não como resultado de uma deliberação unilateral (tal como se dá com relação ao negócio de outorga de poderes). Daí o alcance da parte final do dispositivo: "o mandato completa-se pela aceitação". A propósito da natureza contratual do ajuste segundo as fontes do direito português dos últimos dois séculos, cf. ainda o art. 791 do CCom/1833 (situado em meio às disposições relacionadas à "comissão") - bem como o art. 1330 do CC/1867 (concernente ao mandato celebrado entre ausentes).

Além disso, quanto à conformação básica do instituto, deve-se destacar que a primeira parte do artigo 762 não denuncia a verdadeira importância conferida pelo legislador à eficácia representativa direta; ao contrário, parece prevalecer o elemento gestório que caracterizara o "mandato" desde as suas origens romanas: "o Mandato em geral é um contracto, pelo qual um dos contrahentes, que se chama mandante, confia a gestão d'um ou mais negocios a outro, que se denomina mandatario, o qual se encarrega, e se obriga a exequil-a". Contudo, a análise de outros dispositivos do Código Comercial de 1833 nos revela que a definição contida no artigo 762 alude tão somente a um tipo "genérico", do qual promanam suas modalidades específicas: o "mandato mercantil" (representativo) e a "comissão" (não representativa). Assim, referindo-se ao "mandato mercantil" (em sentido estrito), o legislador pôs em evidência a eficácia representativa direta que identifica a figura (art. 772): "dá-se o mandato mercantil, quando entre commerciantes e em objecto mercantil o commissario contrahe, não em seu nome, senão em nome do commitente". De sua parte, a "comissão" é apartada da modalidade precedente à vista da atuação do comissário em seu próprio nome: "negociante de 
commissão é propriamente aquelle, que em seu proprio nome, ou debaixo d'uma firma social, sem menção de committente, practica actos de commercio por ordem e conta de committente, carregando por isso commissão" (art. 39); no mesmo sentido, cf. os arts. 771 e 788 do CCom/1833. Por uma definição genérica emprestada ao instituto - e pela recondução da "comissão" à categoria de modalidade do "mandato" (em sentido amplo) - cf. J. FERREIRA BORGES, Diccionario cit. (nota 115), pp. 241 e 86-87 (respectivamente). E no âmbito da legislação comercial posterior, cf. o art. $266^{\circ}$ do CCom/1888.

Assim, percebe-se que houve uma efetiva preocupação em diferenciar as duas modalidades de mandato (genérico), tomando-se por base a eficácia representativa direta caracterizadora da gestão: neste sentido, são eloqüentes os preceitos constantes dos artigos 45 ("Quando um negociante comissario obra em nome expresso d'um comitente, deixa de ser o rigoroso commisario mercantil, ou negociante de commisão: nesse caso os seus direitos e obrigações, como simples mandatario, e como mandatario mercantil, são regulados pelas disposições do titulo - Do mandato") e 768 ("Quando o mandatario contracta com terceiro em seu proprio nome, ou d'uma firma social, a que pertença, é comissario. - Quando o mandatario contracta com terceiro em nome do comittente, é mandatario mercantil, mas não commissario propriamente dito") do Código Comercial de 1833. A respeito da relação entre o "mandato mercantil" e a "comissão", cf. o art. 769 do CCom $/ 1833$ - bem como o art. $267^{\circ}$ do CCom $/ 1888$.

Por oportuno, deve-se observar que - a despeito da clara dissociação entre as variantes "representativa" e "não representativa" do tipo contratual genérico - há uma promiscuidade terminológica latente no Código Comercial de 1833: fato esse que dificulta o emprego das dicotomias "mandante/mandatário" e "comitente/comissário" em suas respectivas acepções técnicas.

Já no que toca à eficácia representativa direta - defluente da atuação do mandatário mercantil (em sentido estrito) - há que se destacar o disposto no artigo 776 do Código Comercial: "o contracto, celebrado por aquelle, que tinha mandato precedente, entende-se contrahido por conta e em nome do committente, como se o mandato tivesse sido expresso para esse caso: e o dominio adquire-se para o mandante". Especificamente quanto à percussão passiva da esfera jurídica do mandante ("representado"), incide o artigo 778 do Código: "quando o mandatario contractar expressamente em nome do committente, não contrahe obrigação propria. $\mathrm{O}$ committente é nesse caso responsavel pelas operações do mandatario, e damnos resultantes da execução da commissão". Por sua vez, no que concerne aos efeitos ativos, aplica-se o disposto no artigo 780 ("assim como o mandatario não contrahe obrigação propria pelas operações da commissão nos termos do artigo penultimo, assim não póde por ellas adquirir direito algum, desde que obrou nessa qualidade, e nomeou a pessoa do committente. A indicação do nome considera-se retroactiva á épocha do contracto, o qual se entende estipulado com a pessoa nomeada"). Quanto às disposições correspondentes no âmbito da legislação oitocentista posterior, cf. o art. $1350^{\circ}$ do CC/1867. E pelas manifestações doutrinárias correspondentes, cf. J. Dias FerreIRA, Codigo Civil Portuguez Annotado III, 2a ed., Coimbra, Imprensa da Universidade, 1898, p. 22; bem como L. da Cunha Gonçalves, Tratado de Direito Civil em Comentário ao Código Civil Português VII-2, 2a ed., São Paulo, Max Limonad, 1955, pp. 610-613.

No âmbito da "comissão", por sua vez, ocorre uma autêntica "blindagem" do patrimônio do comitente contra o qual se impede uma investida direta de terceiros - por meio da atribuição ao comissário de toda a responsabilidade pela operação; neste sentido as disposições dos artigos 43 ("o commerciante só póde ter acção contra as pessoas, que tractarem com o commissario por cessão deste. Da mesma fórma, estas pessoas não tem acção directa contra o committente") e 42 ("o commissario é directamente obrigado para com as pessoas, com quem contracta: e não tem obrigação de declarar a pessoa do committente, salvo no caso de seguros") do Código Comercial de 1833. Corroborando tal sistema, o artigo 803 estabelece que a transferência da propriedade - sobre os efeitos adquiridos por conta do comitente - somente se opera por ocasião da entrega subseqüente à gestão ("O comissario encarregado da compra e remessa de mercadorias, effetuando o contracto, e entregando as fazendas a quem deve transportal-as, passa-as por esse acto para o dominio do committente, como é legislado no titulo - Da compra e venda"). Observe-se que orientação semelhante foi adotada pelo Código Comercial de 1888 (art. $268^{\circ}$ ).

Entretanto, a dissociação sistemática entre os dois modelos - com base na eficácia representativa direta - não é absoluta: excepcionalmente, o próprio legislador se encarregou de afastar as linhas gerais da "comissão" (e do "mandato mercantil") quando a preservação dos princípios pudesse comprometer a tutela de interesses legítimos - de terceiros ou do próprio principal. Assim, como que a mitigar o sistema de representação indireta inerente à "comissão", foram adotadas algumas medidas especiais (que acabaram por impedir uma separação estanque entre as esferas jurídicas do principal e de seu agente): desta forma, por força do artigo 792 é instituída uma responsabilidade acessória do comitente ("quando o commissario, contracta em seu nome por conta do commitente, o committente é devedor accessorio da obrigação principal contrahida pelo commissario"), a qual obviamente não pode ser equiparada à atribuição de uma simples responsabilidade regressiva. Por sua vez, o artigo 793 confere ao principal a faculdade de empregar exceções pessoais que, em princípio, seriam manejáveis tão somente pelo próprio comissário ("ao committente competem todas as 
exceições, que o commissario possa deduzir como devedor principal: mas o committente não póde oppor vício da obrigação do commissario, resultante da incapacidade pessoal deste"); com isso, buscou-se evitar uma discussão posterior a respeito da inadequada utilização dos expedientes jurídicos postos à disposição do agente.

Ora, se nos dois casos acima referidos se constata uma mitigação ao princípio da representação indireta (subjacente à "comissão"), por meio do artigo 777 o legislador buscou assegurar a predominância dos interesses do mandante - mercantil - na hipótese de atuação ilícita do mandatário em nome próprio: "quando porém nos termos do artigo precedente o mandatario, não obstante o mandato, contractou expressamente em seu proprio nome, neste caso o dominio e posse da cousa comprada não se adquire para o mandante: mas compete-lhe a acção directa do mandato para obrigar o mandatario, que faltou á fé, a restituir-lhe as fazendas compradas, offerecido o preço, nos termos legislados no titulo - Da compra e venda". Eis aí, portanto, uma das origens do "dever de atuar em nome alheio" - expressamente consagrado pelo art. 1178, 2 do CC/1966.

Cumpre destacar, finalmente, a imprecisão do enunciado constante do art. 773 do Código Comercial de 1833: "o mandante é obrigado a cumprir as obrigações do mandatario, contrahidas em conformidade da ordem dada". Ora, tendo-se em vista que o "mandato mercantil" é essencilamente representativo, não fosse a parte final do preceito e este seria inteiramente ocioso; desta forma, uma exegese "salvacionista" pretenderá destacar o sentido implícito da estatuição: “o mandante não é obrigado a cumprir as obrigações contraídas em desconformidade da ordem dada". No entanto, posta de parte esta interpretação, o dispositivo não acrescenta absolutamente nada à configuração de um instituto forjado sobre a linha mestra da eficácia representativa direta.

Aliás, a redação empregada é de todo infeliz: o mandante estaria jungido ao cumprimento por força da representação direta subjacente ao tipo? Ou em decorrência da disposição sob análise? Note-se que a resposta que propenda em favor da primeira alternativa destaca a - ao menos parcial - ociosidade do artigo 773; por sua vez, aquela que se incline pela segunda hipótese acaba pondo em dúvida a própria diretriz sistemática eleita pelo legislador (eficácia representativa direta).

Com efeito, a este respeito o Código Civil de 1867 foi muito mais preciso: em lugar do emprego da equívoca expressão "é obrigado a cumprir", deu a eficácia representativa direta por fato inteiramente consumado; assim, os preceitos correspondentes ao artigo 773 (arts. $1345^{\circ}$ e $1346^{\circ}$ ) não se voltam à atribuição de um dever jurídico, mas sim à subtração de qualquer espécie de exceção ao mandante: “O constituinte não póde escusar-se de cumprir todas as obrigações, que o mandatario houver contrahido em seu nome, dentro dos limites do mandato (...) não é lícito ao constituinte eximir-se de cumprir o que lhe é ordenado nos artigos antecedentes, com o fundamento de não ter percebido os proveitos, que do mandato esperava". A respeito do tema, cf. J. DiAS FERREIRA, Codigo cit. (nota 115), pp. 20-21. L. da CunHA GonÇALVES, por sua vez, destaca - em tom cáustico - a controvérsia que envolve tais disposições: "no direito romano impunha-se ao mandante a obrigação de desencarregar o mandatário das obrigações por êle contraídas em nome daquele, assumindo-as êle próprio. Foi esta doutrina, decerto, que determinou o art. 1.345, inteiramente descabido nesta secção; porque, no direito moderno, as obrigações contraídas pelo mandatário, dentro dos limites do mandato, consideram-se pessoalmente estipuladas pelo mandante (...) sem dependência de qualquer acto de sua parte. O mandatário é um comparsa. Celebrado o acto, criada fica a relação jurídica entre o mandante e o terceiro; só êstes ficam na cena jurídica, passando para os bastidores o mandatário. É evidentíssimo, pois, que o mandante não pode escusar-se de cumprir tais obrigações" (Tratado cit. (nota 115), pp. 603-604).

Considerando-se o Código Civil de 1867 como um mecanismo de consagração de um mandato "essencialmente" representativo, suas disposições não militam contra o próprio sistema por meio dele forjado. Em contrapartida, o artigo 773 do CCom/1833 parece ter atuado - ainda que atabalhoadamente contra o próprio modelo legal. Note-se, enfim, que há uma alusão ao cumprimento (pelo principal) de "obrigações do mandatário": ora, reconhecida a eficácia representativa direta inerente ao "mandato mercantil”, não seriam obrigações do próprio mandante?

Embora as definições conferidas ao mandato pela legislação portuguesa dos séculos XIX e XX venham a ser objeto de outras referências ao longo do presente capítulo, remete-se o leitor, desde logo, aos dispositivos correspondentes, a fim de que possa promover sua própria abordagem: assim, a respeito, cf. o art. $1318^{\circ}$ do CC/1867 e o art. $1157^{\circ}$ do CC/1966.

Por uma abordagem doutrinária dos dispositivos - do Código Comercial de 1833 - mencionados na presente nota de rodapé, cf. I. de SOUSA DuARTE, Diccionario de Direito Commercial compilado e annotado, Lisboa, Officina Typographica da Empreza Litteraria de Lisboa, 1880, pp. 64, $72-77$ e 252-255; D. P. F. de SAMPAIO Pimentel, Annotações ao Codigo de Commercio Portuguez (Livro Primeiro da Parte Primeira) I, $2^{\mathrm{a}}$ ed., Coimbra, Imprensa da Universidade, 1866, pp. 25-93. Por sua vez, pela confirmação da distinção entre "mandato" e "comissão" - à custa do elemento representativo - no âmbito da doutrina posterior ao Código Comercial de 1888, cf. F. A. da VeIGA BEIRÃo, Direito Commercial Portuguez, Coimbra, Imprensa da Universidade, 1912, p. 86; A. ANTHERO, Comentario ao Codigo Commercial Portuguez I, Porto, 


\section{$\S$ 138. Disposições sobre as diversas espécies de mandato segundo o}

Código Comercial de 1833. Tomando como premissas a natureza contratual do "mandato" (art. 763) e a onerosidade natural à sua modalidade mercantil (art. 770), o Código Comercial de 1833 institui uma plena liberdade quanto à sua forma (verbal ou escrita) diretamente correspondente àquela que caracteriza a aceitação (expressa ou tácita) que lhe serve de fundamento (art. 764). Com base em uma bem articulada distinção entre o "objeto" e a "amplitude" da gestão, o mandato "em termos gerais" não é confundido com a variante "geral" do tipo; por via de conseqüência, são inteiramente apartadas a atribuição pontual ("mandato especial") e a incumbência que carece de cometimento "específico" conquanto o legislador tenha preferido empregar, neste caso, o termo "expresso" (art. 765). Além disso, articulam-se diversos preceitos hermenêuticos peculiares, tais como: o de que a incumbência para transigir não envolve a faculdade de celebrar compromisso (art. 766); o de que a experiência ordinária deve ser tomada em consideração ao se investigar a abrangência do "mandato geral" (art. 781); e o de que os atos conseqüentes estão implicitamente compreendidos na atribuição de seus antecedentes (art. 783). De toda forma, deve-se destacar que para além de uma proibição quanto ao excesso por parte do mandatário (art. 766) - sujeito às regras da "gestão de negócios" até que sobrevenha eventual ratificação (art. 782) -, este diploma consagra, expressamente, uma "gestão colaborativa" por parte do agente: ainda que tenha sido encarregado de negociar com pessoa determinada, sua atribuição "extende-se a poder negociar-se e contractar com outras pessoas não expressas, uma vez que se dê a mesma razão para fazel-o (...) e que o committente venha a obter o mesmo fim e effeito" (art. 784) $)^{116}$.

Typographia “Artes \& Letras", 1913, p. 442; L. da CunHA GonçALVES, Comentário ao Código Comercial Português II, Lisboa, Empresa Editora José Bastos, 1916, p. 2; Costa PINHEIRO, Estudos de Direito Comercial I - Marcas, Escrituração comercial, Registo comercial, Pessoas e instituiçães auxiliares do comercio, Obrigações mercantis em geral, Coimbra, F. França Amado, 1916-1918, p. 275; A. MeNEZES CordeIro, Manual de Direito Comercial (Introdução, Doutrina Comercial Geral, Contratos comerciais) I, Coimbra, Almedina, 2003, pp. 479-483 (por uma comparação entre os dois paradigmas legais mercantis). Por fim, deve-se fazer uma observação, ainda que ligeira, a respeito de um dado historiográfico relacionado ao "Diccionario Juridico-Commercial" de J. FERREIRA BORGES: em seu frontispício consta a transcrição do Assento de 23 de novembro de 1769, por meio do qual se recomenda a utilização da legislação européia em subsídio à omissão das fontes reinícolas - "as obrigações dos negociantes e suas formas não havendo sido reguladas pelas Leis do Reino, devem regular-se pelas Leis marítimas e commerciaes da Europa, e pelo Direito das Gentes, e practica das nações commerciaes". Contudo, não obstante a entrada em vigor do Código Comercial de 1833 - com disposições especificamente devotadas ao contrato de mandato - as observações do autor permanecem alicerçadas na menção iterada a dispositivos do "Code Civil" de 1804. Tenha-se em mente, portanto, a importância do influxo francês sobre a mentalidade jurídica portuguesa dedicada ao direito privado.

${ }^{116}$ Ao mesmo tempo em que se destaca a natureza contratual do "mandato", por meio do artigo 763 se atribui ao mandatário o dever de executar adequadamente a incumbência confiada, sob pena de responsabilidade na 
hipótese de descumprimento culposo: "acceito o mandato, o mandatario é obrigado a cumpril-o, e responde pelas perdas e damnos resultantes da sua inexecução". Neste sentifo, cf. J. FERREIRA BorGES, Diccionario cit. (nota 115), p. 241; bem como I. de SOUSA DuARTE, Diccionario cit. (nota 115), p. 252. Pelas disposições correspondentes no âmbito da legislação portuguesa posterior, cf. art. $1335^{\circ}$ do $\mathrm{CC} / 1867$; art. $238^{\circ}$ do CCom/1888; e art. $1161^{\circ}$, "a” do CC/1966.

Já no que concerne à remuneração da atividade desenvolvida pelo agente, diferenciam-se sobremaneira as duas modalidades de mandato (em sentido amplo), consoante estabelece o artigo 770 do Código Comercial de 1833: "o mandato póde ser gratuito: a commissão é sempre onerosa". Ao lado da eficácia representativa direta, este é um dos principais elementos distintivos entre o "mandato mercantil" e a "comissão": enquanto a onerosidade é essencial a esta última, mostra-se tão somente natural ao primeiro. Ora, em virtude da noção confusa que empresta ao termo "mandato" - tomando-o, por vezes, como simples correspondente da "comissão" nos quadrantes do direito civil - J. FERREIRA BORGES chega a uma conclusão distinta, considerando o mandato naturalmente gratuito: "uma das principaes differenças que os distingue é, que o mandato é gratuito, a não haver estipulação em contrario; em quanto que a commissão suppoem sempre uma convenção tacita de retribuição" (Diccionario cit. (nota 115), p. 86); equívoco em que não incorre I. de SOUSA DUARTE (Diccionario cit. (nota 115), p. 67). Pela presunção de onerosidade do mandato comercial, cf. art. 232 ", "caput" do CCom/1888. Já no âmbito civil, a presunção manteve-se no sentido da gratuidade, excetuadas as circunstâncias que envolvessem incumbência relacionada a ofício ou profissão lucrativa; neste sentido, o art. $1331^{\circ}$ do Código Civil de 1867: “o mandato presume-se gratuito, não tendo sido estipulada remuneração, excepto se o objecto do mandato for daquelles, que o mandatario tracta por officio ou profissão lucrativa" - orientação similar à que prevaleceu no Código Civil atualmente em vigor (arts. $1158^{\circ}, 1$ e $1167^{\circ}$, "b"). Aliás, é no Código Comercial de 1888 que podemos encontrar a previsão de uma estimação da remuneração do agente segundo os "usos da praça onde for executado o mandato" (artigo $232^{\circ}, \S 1^{\circ}$ ) - no que foi seguido pelo Código Civil de 1966 (art. 1158 , 2). A respeito, cf. J. DiAS FERREIRA, Codigo cit. (nota 115), pp. 12; L. da CUNHA GONÇALVES, Tratado cit. (nota 115), pp. 544-548.

Quanto à forma do contrato de mandato, o Código Comercial de 1833 dispõe a respeito da questão por meio de seu artigo 764: "todo o mandato póde ser verbal ou escripto. A acceitação do mandato póde ser expressa ou tacita. A execução do mandatario prova acceitação". Não obstante sua singeleza, tal preceito guarda uma indiscutível precisão técnica: como teremos a oportunidade de observar mais adiante, o Código Civil de 1867 gerou um desnecessário tumulto ao tomar o contrato de mandato - negócio jurídico bilateral, que somente se reputa perfeito quando da superveniência de aceitação - pelo ato unilateral de atribuição de poderes de representação ("procuração-ato"), documentado na "procuração-instrumento". A respeito do assunto, cf. I. de Sousa DuARTE, Diccionario cit. (nota 115), p. 252. Pelas disposições do Código Civil de 1867 a respeito da forma do mandato, cf. o art. $1318^{\circ}$ (parte final); bem como os arts. $1326^{\circ}$ e $1329^{\circ}$ (por meio dos quais se disciplina a solenidade "ad probationem"). Pela posição da doutrina, cf. J. DiAS FERREIRA, Codigo cit. (nota 115), pp. 5-6; L. da CunHA GonÇALVES, Tratado cit. (nota 115), pp. 512-522. Especificamente a respeito da incumbência judicial - art. $1355^{\circ}$ - teceremos maiores considerações em momento posterior (nota 123).

No que toca à extensão da incumbência, o Código Comercial de 1833 - por seu artigo 765 - evidencia uma perfeita dissociação entre a "amplitude" ("o mandato ou é especial, e para um ou certos negocios sómente: ou geral, e para todos os negocios do mandante") e o "objeto" da gestão confiada ("quando o mandato é concebido em termos geraes, abrange só os actos de pura administração. O mandato para hypothecar, transigir, ou alhear, carece de ser expresso"). Assim sendo, tomando-se em consideração a gravidade da gestão, o mandato poderia ser "em termos gerais" ou "específico" ("expresso"); em contrapartida, voltada a atenção do intérprete à projeção material (e mesmo cronológica) da incumbência, exsurgiriam as hipóteses de mandato "geral" e "especial". Sobre o tema - laconicamente - cf. I. de SouSA DUARTE, Diccionario cit. (nota 115), pp. 252-253. No mesmo sentido de tais disposições, cf. os arts. $1323^{\circ}$ e $1324^{\circ}$ do CC/1867 e o art. $231^{\circ}, \S$ único do CCom/1888.

Entretanto, o Código Civil de 1867 instalou uma perniciosa confusão entre tais aspectos - distintos - do negócio jurídico de incumbência; com efeito, seu art. $1325^{\circ}$ assim dispôs: "a procuração geral só póde auctorisar actos de mera administração". Posta de parte a utilização do termo "procuração", há que se destacar a promoção de uma indevida junção entre a incumbência que se protrai (mandato "geral") e aquela que prescinde de atribuição específica (mandato "em termos gerais"); o resultado final de tal providência foi o artigo $1159^{\circ}, 1$ do Código Civil atualmente em vigor - no qual se estabelece que "o mandato geral só compreende os actos de administração ordinária”. A respeito do art. $1325^{\circ}$ do CC/1867, cf. J. DIAS FERREIRA, Codigo cit. (nota 115), pp. 10-11; L. da CunHA GonÇAlves, Tratado cit. (nota 115), pp. 533-544. Este último autor, aliás, destaca a diferença entre tais perspectivas: "a presente lei parece identificar as palavras 'mandato geral' e 'mandato especial' com as expresões 'mandato redigido em têrmos geraes' e 'mandato para negócios determinados', sendo certo que as duas frases têm sentido diferente, conquanto subtil” (p. 534). Por sua volta, a respeito do art. $1159^{\circ}, 1$ do CC/1966, cf. M. J. de ALMEIDA CostA, Noções de Direito 


\section{$\S$ 139. A eficácia do contrato de mandato segundo o Código Comercial de}

1833. O Código Comercial de 1833 prescreve soluções distintas para a pluralidade de sujeitos num dos pólos da relação decorrente do "mandato mercantil": em se tratando de múltiplos mandantes, serão solidariamente responsáveis perante o agente (art. 786); todavia, no caso de plúrimos mandatários, a solidariedade somente defluirá de avença expressa (art. 785). Já no que concerne à execução da incumbência, exige-se do mandatário um comportamento ativo, escrupulosamente comprometido com a preservação dos interesses do mandante: desta forma, exsurgindo qualquer disputa com terceiro (subseqüente ao cumprimento da atribuição), caso não seja suficiente a exibição do instrumento de outorga, o agente deverá tomar as providências oportunas, buscando posteriormente a ratificação quanto ao excesso praticado (art. 779); na mesma medida,

Civil, Coimbra, Almedina, 1980, p. 272; A. Neto - H. A. MARTins, Código Civil Anotado, $5^{\text {a }}$ ed., Lisboa, Livraria Petrony, 1984, p. 657.

Em contrapartida, merece destaque a iniciativa de se estender a atribuição a hipóteses não expressamente declinadas pelo mandante - mas que de todo modo redundem em um atendimento aos seus respectivos interesses. Assim, o artigo 784 do Código Comercial de 1833 disciplinou a extensão da incumbência a situações semelhantes, desde que atendidos os objetivos subjacentes ao negócio jurídico: "o mandato de negociar e contractar com certas pessoas extende-se a pode negociar-se e contractar com outras pessoas não expressas, uma vez que se dê a mesma razão para fazel-o com as pessoas não expressas, e que o committente venha a obter o mesmo fim e effeito"; a propósito, cf. I. de SOUSA DUARTE, Diccionario cit. (nota 115), p. 254. Em idêntico sentido, o artigo 811 reproduziu tal regra a pretexto do contrato de comissão.

Por sua vez, em seu artigo 781, o Código Comercial de 1833 previa uma interpretação do mandato geral segundo os usos e costumes então prevalecentes ("o mandato geral, dado ao mandatario, entende-se segundo o que é costume, e segundo o que de ordinario se practica, e não se interpreta por cousas extraordinarias").

Além disso, como que a exaltar a teleologia inerente ao negócio de incumbência, o artigo 783 reputou implicitamente abrangidos os atos conseqüentes, relacionados a momento posterior ao cumprimento da tarefa cometida - "no mandato antecedente entende-se comprehendido o que delle é consequencia necessaria. Assim a ordem de vender mercadorias involve a faculdade de poder receber o seu preço". Ora, ainda que voltado a um contexto diverso - vale dizer, ao momento que precede ao adimplemento da obrigação contratualmente definida - o artigo $233^{\circ}$ do CCom/1888 institui disposição que se coaduna inteiramente com o referido arcabouço técnico; no entanto, em lugar dos "atos conseqüentes", teve em mira os "atos instrumentais": "o mandato comercial (...) que só tiver poderes para um negócio determinado, compreende todos os actos necessários à sua execução, posto que não expressamente indicados". Note-se que tal orientação - consagradora de uma feição "instrumental" do mandato (e de uma perspectiva "funcional" da incumbência) - foi mantida, em linhas gerais, pelo Código Civil atualmente em vigor (art. $1159^{\circ}, 2$ ). A respeito, cf. M. J. de Almeida Costa, Noções cit. (nota 116), p. 272; A. NETO - H. A. MARTINS, Código cit. (nota 116), p. 657.

Por fim, o excesso da gestão foi disciplinado minudentemente pelo Código Comercial de 1833. Seu aspecto interno foi objeto do preceito contido na parte inicial do artigo 766 - ao qual correspondem, no âmbito da "comissão", os artigos 804 e 806 - na qual se dispõe que "o mandatario nada póde fazer além do conteudo no mandato", sob pena da natural responsabilidade por perdas e danos. Por sua vez, o aspecto externo do fenômeno foi regulado pelo artigo 782, no qual se preceitua que o excesso do agente há de ser reputado como "gestão de negócios" até a superveniência de eventual ratificação por parte do principal: "quando um commerciante, ou sem mandato, ou excedendo os limites delle, conclue algum negocio para o seu correspondente, é gestor do negocio segundo a lei; mas sendo este contracto ratificado, toma o character de mandato, e se entende feito no logar do gestor, e não do commerciante, que o ratifica". Sobre o assunto, cf. I. de Sousa DuARTE, Diccionario cit. (nota 115), pp. 253-254. A propósito, deve-se destacar que a matéria foi objeto de regulamentação conjunta no âmbito do Código Civil de 1867 (art. 1338); a respeito, cf. J. DiAS FERREIRA, Codigo cit. (nota 115), pp. 15-16; bem como L. da CUNHA GONÇALVES, Tratado cit. (nota 115), pp. 579-581. 
constatada a impossibilidade de dar efetivo cumprimento à tarefa confiada, o incumbido deverá expedir - imediata - informação ao "dominus negotii”, acompanhada de "prova concludente" que o exonere da responsabilidade pelo inadimplemento (art. 775). Além disso, a própria confiança que permeia o vínculo mantido entre as partes é objeto de especial consideração por parte do legislador: assim, em caso de "desvio" por parte do mandatário, fica este obrigado ao pagamento de juros desde a data da malversação (arts. 787 e 294); em contrapartida, na hipótese de inadimplemento por parte do mandante, pode o agente exercitar o seu direito de retenção sobre o próprio objeto da operação (art. 774) ${ }^{117}$.

117 A questão da pluralidade de mandantes sempre foi resolvida de uma maneira mais ou menos uniforme,
tendo-se em vista a proteção dos interesses do mandatário. Desta forma, assim como o interesse da gestão
deve prevalecer sobre aquilo que é conveniente ao mandatário, na mesma medida, a necessidade de lhe
assegurar a retribuição devida passa à frente do interesse - dos plúrimos mandantes - na repartição dos
encargos financeiros da gestão. Assim, o artigo 786 do Código Comercial de 1833 dispunha do seguinte
modo: "quando o mandatario é constituido por muitas pessoas para um negocio commum, cada uma dellas é
solidariamente obrigada para com elle por todos os effeitos do mandato". Note-se que tal dispositivo se
restringe à previsão da solidariedade entre os mandantes (em caso de negócio de interesse comum), deixando
implícita a repartição (posterior) do ônus financeiro da incumbência - o que em nada prejudica, diga-se de
passagem, a compreensão do exato alcance da regra. Por tal ordem de idéias, o Código Civil de 1966 adotou
disposição similar, constante de seu artigo $1169^{\circ}$. No entanto, o Código Civil de 1867 preferiu uma
orientação explícita - consubstanciada em seu artigo $1348^{\circ}$ - ao preceituar "o regresso do constituinte, que
haja pago, contra os outros pela parte respectiva a cada um delles". No que concerne à pluralidade de mandatários, duas questões diferentes - conquanto intimamente relacionadas - não podem ser tomadas indistintamente: de um lado, há que se observar o regime de execução da atribuição; de outro, merece consideração especial o sistema de responsabilização dos agentes em caso de inadimplemento da obrigação. Desta forma, a singela previsão de uma solidariedade entre os devedores atende aos dois problemas simultaneamente. Levando tal fato em consideração, o artigo 785 do Código Comercial de 1833 estabeleceu que "quando n'um mesmo mandato se estabelecem muitos mandatarios, não ha entre elles solidariedade, salvo sendo expressa". Orientação semelhante foi adotada pelo Código Civil de 1867 (art. $1341^{\circ}$ ), conquanto se tenha preferido o desmembramento da regra em duas disposições, relacionadas a cada um dos assuntos mencionados: "Sendo varias pessoas encarregadas conjunctamente do mesmo mandato, responderá cada uma dellas pelos seus actos, se outra cousa não for estipulada. § único. No caso de inexecução do mandato, será a responsabilidade repartida, por egual, entre os mandatarios". Tal posicionamento foi mantido pelo Código Civil atualmente em vigor, que se preocupou não apenas com a articulação de regras distintas (arts. $1160^{\circ}$ e $1166^{\circ}$ ), mas chegou ao ponto de as situar em seções diversas do capítulo relacionado ao mandato. Contudo, vale notar que - talvez como um resquício do tratamento promíscuo conferido ao contrato de mandato e ao negócio unilateral de outorga de poderes (de representação) - o referido artigo $1160^{\circ}$ parece contrariar a natureza contratual do mandato, ao atribuir ao mandante o poder de determinar, unilateralmente, o regime de execução da incumbência: "se alguém incumbir duas ou mais pessoas da prática dos mesmos actos jurídicos, haverá tantos mandatos quantas as pessoas designadas, salvo se o mandante declarar que devem agir conjuntamente"; tal equívoco, obviamente, há de ser contornado por meio da interpretação sistemática realizada pela doutrina (e mesmo pela jurisprudência). Por fim, vale destacar a previsão contida no "caput" do artigo $244^{\circ}$ do Código Comercial de 1888 , no sentido de que a execução do mandato, salvo avença em contrário, presumir-se-á atribuída aos plúrimos mandatários segundo a ordem de nomeação constante do instrumento de incumbência.

A fim de consagrar um modelo de "gestão colaborativa", o Código Comercial de 1833 estabeleceu duas regras importantes: em primeiro lugar, por seu artigo 779 preceituou - quanto ao "mandato mercantil" (representativo) - que a superveniência de controvérsia com terceiro - a respeito de qualquer fato da gestão deveria ensejar a exibição do instrumento de mandato, seguida de um eventual excesso "legítimo" do agente (a ser objeto de posterior ratificação do mandante). Além disso, quanto à impossibilidade superveniente de adimplemento da obrigação, estabeleceu o Código Comercial que ao mandatário competiria a participação imediata do fato ao principal, acompanhada de "prova concludente" em caso de fato impeditivo positivo uma vez que a respeito do "facto negativo" seria suficiente a simples alegação, sujeita à prova em contrário 


\section{$\S 140$. A extinção do contrato de mandato segundo o Código Comercial de}

1833. O Código Comercial de 1833 enumera seis causas extintivas da relação decorrente do "mandato": além do casamento da mulher (mandante ou mandatária), encerra-se o vínculo por força da morte do agente, bem como da interdição (ou da insolvência) de qualquer das partes; ademais, em virtude dos negócios jurídicos da "revogação" e da "renúncia", é possível que o liame tenha termo por iniciativa de apenas um dos sujeitos envolvidos (art. 818). Em alguns casos, aliás, estas modalidades negociais podem ensejar indenização: assim se o mandante for surpreendido pela inoportunidade da renúncia injustificada do agente (art. 822), ou se a revogação não tiver sido acompanhada do reembolso das despesas e da reparação dos prejuízos experimentados no decurso da gestão (art. 819). De toda forma, dada a feição receptícia de tais negócios jurídicos, seus efeitos somente se projetam sobre a esfera jurídica alheia quando da efetiva ciência dos interessados (arts. 821 e 820); por tal razão, a despeito da insubsistência do fundamento da gestão, reputam-se válidos (e eficazes) todos os atos praticados pelo agente antes de ser informado sobre a causa extintiva do liame (art. 824). Por oportuno, deve-se destacar que

produzida pelo mandante (artigo 775). Note-se que tal regra - ainda hoje prevalecente, por força do art. $1161^{\circ}$, "c" do CC/1966 - foi estendida, pelo próprio Código Comercial, ao contrato de consignação (artigo 837); além disso, quando da promulgação do Código Civil de 1867, mereceu um especial desenvolvimento a respeito da variante judicial do tipo (artigo $1362^{\circ}$ ).

Note-se que um dos principais objetivos deste estudo - sob o ponto de vista dogmático - é o de demonstrar que a eficácia do mandato apresenta contornos peculiares, inconfundíveis com aqueles ostentados por qualquer outra espécie contratual - iluminada por princípios próprios, derivados de sua respectiva "causafunção". Desta forma, à vista da relação de "confiança" inerente ao vínculo estabelecido entre o mandante e o mandatário, o legislador previu o pagamento de juros pelo agente, em caso de "desvio" quanto às importâncias - relacionadas ao mandato - que estivessem em seu poder. Assim, o artigo 787 do Código Comercial de 1833 assim previu: "o mandatario deve juros da somma, que empregou em seu uso, nos termos legislados no titulo - Dos juros" - orientação que também prevaleceu no art. $1340^{\circ}$ do CC/1867, no art. $241^{\circ}$, "caput" do CCom/1888 e no art. $1164^{\circ}$ do CC/1966. Observe-se que no art. 59 do CCom/1833 (voltado à “comissão") e no parágrafo único do art. $241^{\circ}$ do CCom/1888 foi preceituada, inclusive, a responsabilidade do agente pelas perdas e danos experimentados pelo principal. De todo modo, voltaremos ao tema mais adiante ao considerarmos, especificamente, o termo inicial da fluência dos juros eleito pelo legislador em cada uma dessas oportunidades.

Ora, como uma espécie de contrapartida à proibição de "desvio", foi autorizada ao mandatário a retenção do objeto da operação cometida, na hipótese de inadimplemento do mandante (quanto ao montante da retribuição devida ao seu agente). Desta forma, o artigo 774 do Código Comercial de 1833 dispôs que "o mandatario tem o direito de reter e a não entregar o objecto da operação a elle commettida, até que seja pago de tudo, o que lhe é devido em consequencia do mandato" - regra que também foi acolhida pelo Código Civil de 1867 (artigo $1349^{\circ}$ ). Por ora, destaque-se apenas que o legislador, nestas duas ocasiões, permitiu a retenção tão somente do "objeto" do mandato - parecendo oportuna uma investigação mais detida sobre o alcance desta expressão (da qual nos desincumbiremos mais à frente). Tal consideração será retomada, mais adiante, ao analisarmos o alcance da regra segundo o Código Civil brasileiro atualmente em vigor.

A respeito das disposições do Código Comercial de 1833 referidas na presente nota de rodapé, cf. I. de Sousa DuARTE, Diccionario cit. (nota 115), pp. 72 e 253-254. Por sua vez, pela doutrina produzida sob a égide do Código Civil de 1867, cf. J. DiAS FERREIRA, Codigo cit. (nota 115), pp. 16-18, 21 e 34-35; e L. da CUNHA GONÇALVES, Tratado cit. (nota 115), pp. 567-570, 576-579, 604-608 e 648-663. Já no que toca aos preceitos do Código Civil de 1966, cf. M. J. de AlmeIDA Costa, Noções cit. (nota 116), p. 272; e A. NETO H. A. MARTins, Código cit. (nota 116), pp. 657-660. 
não obstante a morte do mandante - em virtude da natureza mercantil de uma tal regulamentação - dispôs o legislador no sentido da preservação do vínculo contratual até a superveniência de negócio denunciativo oriundo de seus sucessores (art. 823). No entanto, a mesma diretriz não foi adotada ao se considerar o falecimento do mandatário: em lugar da manutenção "artificial" do vínculo (como uma natural decorrência da "gestão colaborativa" subjacente à relação), optou-se, tão somente, por prescrever aos herdeiros do agente a imediata participação do evento ao principal (art. 825) ${ }^{118}$.

${ }^{118} \mathrm{O}$ artigo 818 do Código Comercial de 1833 contém uma previsão genérica a respeito das modalidades de extinção do liame contratual referido: "o mandato termina: - pela revogação do mandatario: - pela renuncia deste ao mandato: - pela morte natural ou civil, interdicção, ou declaração d'insolvencia, quer do committente, quer do commissario: - pelo casamento da mulher, que deu ou recebeu o mandato". Como teremos a oportunidade de destacar mais adiante (nota 124), o Código Civil de 1867 acompanhou as diretrizes lançadas pela legislação mercantil precedente, acrescentando as hipóteses de decurso do prazo e de exaurimento do objeto da atribuição (artigo $1363^{\circ}, 5^{\circ}$ ). Contudo, merece destaque a posição adotada pelo Código Civil de 1966: responsável por uma dissociação entre os casos de extinção da procuração (artigo $265^{\circ}$ ) e término do mandato (artigos $1170^{\circ}$ e $1174^{\circ}$ ), previu expressamente a hipótese de preservação - salvo justa causa - do liame, a pretexto da proteção ao interesse do procurador ou de terceiro (cf. arts. $265^{\circ}, 3 \mathrm{e}$ $\left.1170^{\circ}, 2\right)$.

Quanto à extinção do vínculo por iniciativa de uma das partes, o Código Comercial de 1833 dispôs em seu artigo 822 acerca do negócio de renúncia: "o mandatario póde renunciar ao mandato, notificando ao mandante a sua renuncia. Todavia se desta renuncia provier prejuizo ao committente, o commissario é por elle responsavel, salvo achando-se o mandatario na impossibilidade de continuar no mandato sem soffrer elle mesmo damno consideravel". Note-se que a previsão de indenização na hipótese de renúncia injustificada foi mantida pelo Código Comercial de 1888 (art. 245\%) e pelo Código Civil de 1966 (art. 1172 ). Neste particular, contudo, parece-nos mais adequada a solução adotada pelo legislador civil de 1867 ao prescrever a adoção das medidas provisionais indispensáveis à preservação dos interesses do mandante, mesmo após a efetiva ciência deste último a respeito do negócio unilateral de extinção do liame (art. 1368 $)$ : "em caso de renuncia do mandatario, será este obrigado a continuar com a gerencia, se do contrário podér seguir-se algum prejuizo ao constituinte, em quanto este não for avisado e não tiver o tempo necessario para prover aos seus interesses". Cumpre observar que no início do século XIX se exigia do mandatário a preservação dos negócios do mandante, desde que os seus próprios interesses não estivessem ameaçados; orientação diferente daquela adotada noutras ocasiões - como, por exemplo, durante a vigência das "Siete Partidas", em meio às quais se sugeria o sacrifício próprio, a fim de que fossem resguardados os interesses de um amigo (cf. Part. IV, 27, 6, referida no § 101 deste estudo).

Especificamente a respeito da revogação, três dispositivos do Código Comercial de 1833 merecem destaque: a) em primeiro lugar, o artigo 819, por meio do qual se assegura a livre atuação do mandante, sem prejuízo da reparação dos danos suportados pelo mandatário (no mesmo sentido, cf. art. 67 do CCom/1833; art. $1364^{\circ}$ do CC/1867; art. $245^{\circ}$ do CCom $/ 1888$; arts. $267^{\circ}, 1170^{\circ}$ e $1172^{\circ}$ do CC/1966); b) além disso, o artigo 821 estabelece a hipótese de revogação tácita, à custa da nomeação de novo agente para a mesma incumbência, desde que efetivamente informada ao antigo mandatário (por uma orientação similar, cf. art. $1365^{\circ}$ do CC/1867 e art. $1171^{\circ}$ do CC/1966); c) por fim, no artigo 820 se assegura a proteção aos interesses de terceiros de boa-fé, que ignoravam a extinção do vínculo que haveria de fundamentar os atos praticados pelo "mandatário" aparente - aliás, pela legislação posterior correspondente, cf. o art. $1369^{\circ}$ ( $3^{\circ}$ e $\S$ único) do $\mathrm{CC} / 1867$ e o art. $266^{\circ}$ do CC/1966.

Com efeito, a legislação posterior mencionada mantém as diretrizes adotadas pelo Código Comercial de 1833, à exceção de algumas adaptações provenientes da influência do direito alienígena. Assim se explica, por exemplo, a faculdade concedida ao constituinte de exigir a restituição do instrumento de outorga de poderes no bojo do próprio negócio jurídico de revogação (art. 1364º § único do CC/1867: "se a procuração for por escripto, poderá o constituinte exigir, que o mandatario lh'a restitua, se a tiver em seu poder"): tratase de clara influência do artigo 2004 do Código Civil francês ("le mandant peut révoquer sa procuration quand bon lui semble, et contraindre, s'il y a lieu, le mandateire à lui remettre, soit l'écrit sous seign privé qui 
$\S$ 141. O Código Civil de 1867 e a consagração de um mandato "essencialmente" representativo: considerações sobre a "desnaturação" da causa-função

do tipo. Por seu artigo 1318 , o Código Civil Português de 1867 conferiu uma nova conformação ao mandato lusitano; mediante uma "questionável" equiparação entre "mandatário" e "procurador", reputou-se caracterizado o tipo "quando alguma pessoa se encarrega de prestar, ou fazer alguma cousa, por mandado e em nome de outrem". Deste modo, foi então adotado um paradigma "essencialmente" representativo, em decorrência do qual o agente - exibidos os seus respectivos poderes e não se tendo obrigado pessoalmente - se mostra ordinariamente isento de qualquer responsabilidade perante terceiros, por força dos atos praticados durante a sua gestão (art. 1352º); por via de

la contient, soit l'original de la procuration, si elle a été délivrée en brevet, soit expédition, s'il en a été gardé minute").

Considerando-se o caráter colaborativo da gestão confiada, dois dispositivos do Código Comercial de 1833 despertam a atenção do intérprete: os artigos 824 e 825 . O primeiro deles preserva a validade e a eficácia dos atos praticados pelo mandatário durante o período imediatamente anterior à sua ciência a respeito de causa extintiva do liame (que o jungia ao mandante): "ignorando o commissario a morte do committente, ou qualquer dos outros factos, que fazem terminar o mandato, o que practicar na ignorancia é valido e effectivo. Neste caso todas as obrigações contrahidas pelo mandatario são exequiveis com terceiros, que estejam em boa fé" (cf. ainda o art. $1369^{\circ}, 2^{\circ}$ do CC $/ 1867$ e o art. $1175^{\circ}$ do CC/1966); ora, tendo declinado o fundamento da gestão conduzida pelo agente, nada mais oportuno do que a referida disposição legal, por meio da qual se extirpa - previamente - toda e qualquer possibilidade de controvérsia a respeito do momento em que seus atos não mais se revestiam das propriedades originais. O segundo preceito atribui a terceiros - herdeiros ou sucessores do mandatário - deveres que somente poderiam ser instituídos "por força de lei", sobretudo à vista de sua imposição mesmo na hipótese de simples inabilitação do agente: "morrendo o commissario, ou tornando-se por qualquer outro modo inhabilitado para exequir a commissão, esta se entenderá terminada e finda; os seus herdeiros ou successores, tendo o conhecimento do mandato, devem immediatamente participar o evento ao committente para prover, como achar a bem: pena de responderem por perdas e damnos, provada a culpa". Note-se que o Código Civil de 1867, a propósito, foi ainda mais longe, ao prescrever a tais sujeitos não apenas a informação do mandante, como também a tomada das providências indispensáveis à preservação de seus respectivos interesses (art. 1367 do CC/1867). Ora, como o Código Civil de 1966 estendeu tal "obrigação" às pessoas que simplesmente convivam com o mandatário - art. $1176^{\circ}$ do CC/1966 - fica evidente o intuito "exclusivo" de se resguardar os interesses do mandante, uma vez que tal espécie de "convivente" pode não apresentar qualquer vínculo sucessório em relação ao agente.

Por fim, merece destaque a regra instituída pelo artigo 823 do Código Comercial de 1833: "a commissão não se entende revogada pelo fallecimento do committente, em quanto por seus legitimos successores não for contramandada. Todos os direitos e obrigações, produzidos pela commissão conferida, passam para os successores". Por ora, cabe-nos observar apenas que o legislador preferiu preservar "indefinidamente" a relação jurídica derivada do mandato, mesmo após a morte do mandante - solução diversa da que será adotada pelo Código Civil de 1867, como teremos a oportunidade de destacar mais adiante (§ 146). De todo modo, pela legislação posterior correspondente, cf. o art. $1366^{\circ}$ do CC/1867 e o art. $1175^{\circ}$ do CC/1966 além do art. 839 do próprio Código Comercial de 1833 (relacionado à "consignação").

A respeito das disposições do Código Comercial de 1833 referidas na presente nota de rodapé, cf. I. de Sousa DuARTE, Diccionario cit. (nota 115), pp. 67, 76 e 254-255. Quanto ao Código Civil de 1867, cf. J. Dias Ferreira, Codigo cit. (nota 115), pp. 35-40; L. da Cunha GonÇAlves, Tratado cit. (nota 115), pp. 663-686; J. TAvares, Os Princípios Fundamentais do Direito Civil II - Pessoas, cousas, factos jurídicos, Coimbra, Coimbra Editora Limitada, 1928, p. 442. Por fim, quanto ao Código Civil de 1966, cf. M. J. de Almeida Costa, Noções cit. (nota 116), pp. 272-273; A. Neto - H. A. MARTins, Código cit. (nota 116), pp. 121-122 e 660-662; I. Galvão Telles, Manual dos Contratos em Geral, $4^{a}$ ed., Coimbra, Coimbra Editora, 2002, pp. 440-441 (quanto à extinção da representação); e J. de O. AsCENSÃo, Teoria Geral do Direito Civil III - Acções e Factos Jurídicos, Lisboa, s.e., 1992, pp. 305-307 (sobre a irrevogabilidade da procuração conferida no interesse de terceiro). 
conseqüência, sua eficácia (ativa e passiva) percute diretamente a esfera jurídica do mandante (art. $1350^{\circ}$ ), desde que respeitados os limites da outorga de poderes representativos - aos quais o legislador português oitocentista impropriamente se refere por meio da expressão "limites do mandato" (art. 1345 ). De toda forma, na hipótese de qualquer excesso praticado durante a gestão, tanto os terceiros quanto o mandante são resguardados pela responsabilidade pessoal do agente - expressamente assegurada pelo artigo $1338^{\circ}$ do Código. Assim, ao mesmo tempo em que se mitigou a feição gestória do tipo, foi sobrelevado um aspecto significativo de sua eficácia (a representação direta); com isso, aquela progressiva aproximação entre o "vogado" e o "personero" - que já se podia divisar no próprio direito castelhano - vai encontrar, enfim, um ambiente favorável à extirpação dos resquícios da "procuratio" romana ainda presentes no sistema lusitano. Em outras palavras, foi promovida uma substancial alteração quanto à "causa-função" do contrato de mandato: conquanto tradicionalmente concebido como um instrumento de gestão confiada, parece ter sido transformado, afinal, em simples fundamento negocial da representação direta ${ }^{119}$.

\footnotetext{
${ }^{119}$ Eis a transcrição integral da definição do contrato de mandato segundo o Código Civil de 1867 (artigo $1318^{\circ}$ ): "dá-se o contracto de mandato ou procuradoria, quando alguma pessoa se encarrega de prestar, ou fazer alguma cousa, por mandado e em nome de outrem". Com efeito, deste enunciado se depreende a importância alcançada pelo elemento representativo na conformação geral do tipo (na medida em que se passa a pressupor a ação do mandatário sempre em nome do mandante). No entanto, uma comparação entre o texto transcrito e o artigo 762 do Código Comercial de 1833 nos informa ainda mais: de fato, o dispositivo mais antigo evidencia não apenas a ação do mandatário de "se encarregar"; deixa clara, também, a intenção do mandante de atribuir a gestão de um assunto a um agente de sua confiança - "o Mandato (...) é um contracto, pelo qual um dos contrahentes, que se chama mandante, confia a gestão d'um ou mais negocios a outro". Assim, percebe-se que ao mesmo tempo em que a eficácia representativa direta ascende rumo à "causa-função" típica, a feição gestória desta espécie contratual declina - preparando-se o terreno, portanto, para a tomada do mandato como simples fundamento negocial da representação direta.

Ora, se é verdade que o Código Civil de 1966 dissociou o "mandato" da "representação" (admitindo expressamente a modalidade não representativa do instituto); se é correto, ainda, dizer que extirpou o resquício romanístico cristalizado na atuação material (dando preferência, por sua vez, à "atuação jurídica" do mandatário); e se é inquestionável, por fim, o expurgo da confusão técnica - instaurada por ocasião da promulgação do Código Civil de 1867 - entre os conceitos de "mandatário" e de "procurador"; não se pode negar, entretanto, que a definição oferecida pelo legislador novecentista também passou ao largo do elemento gestório que caracterizara o tipo contratual - desde o direito romano - até meados do século XIX. Com efeito, como reiteraremos mais adiante ( $(148)$, em seu artigo $1157^{\circ}$ não há a mais leve alusão a um elemento gestório; se este tem sido depreendido pelos estudiosos, assim se faz mais em contemplação da tradição histórica relacionada ao instituto - e de uma interpretação sistemática do arcabouço inserto entre os artigos $1157^{\circ}$ e $1184^{\circ}$ - do que em decorrência do modelo legal efetivamente vigente. De toda forma, retornaremos à questão dentro em breve.

A decorrência principal da configuração típica forjada pelo legislador oitocentista é a percussão imediata da esfera jurídica do mandante por força da atuação de seu mandatário (ressalvada a hipótese de excesso); em outras palavras, consiste na admissão generalizada de uma eficácia representativa direta defluente de uma "realidade única" - que (con)funde "mandato", "procuração" e "representação" (direta). A fim de preencher o panorama assim esquadrinhado, o legislador se utiliza de diversas tintas, inteiramente compatíveis com o eixo motor eleito "ab initio". Desta forma devem ser lidas as regras constantes dos artigos $1352^{\circ}, 1350^{\circ} \mathrm{e}$ $1345^{\circ}$ do Código Civil de 1867.
} 
De fato, o primeiro dispositivo se volta aos efeitos da exibição a terceiro - pelo "mandatário" - do instrumento de outorga de poderes representativos: "o terceiro, que assim houver contractado com o mandatario não terá acção contra elle, se o dicto mandatario lhe houver feito conhecer, quaes eram os seus poderes, e se não se tiver responsabilizado pessoalmente pelo constituinte". Com efeito, do texto transcrito se depreendem duas questões principais: em primeiro lugar, o legislador alude impropriamente ao mandatário, quando em verdade, deveria se referir ao "representante", em que foram investidos poderes de percutir a esfera jurídica alheia por declaração de vontade própria. No entanto, mais relevante do que essa imprecisão é o "status" jurídico conferido a tal providência; feita uma leitura cuidadosa, resulta clara a atribuição de um "ônus" ao agente: se exibe o instrumento e pratica excesso, não pode ser responsabilizado pelo terceiro. Em contrapartida, não tendo havido a prévia demonstração dos poderes de representação, em caso de excesso o "representante" vincula-se pessoalmente perante o terceiro-contratante - o mesmo não se podendo afirmar com relação ao "representando". Tal observação ganha relevo na medida em que se pode constatar um novo quadro com o advento do Código Comercial de 1888, o qual, por meio de seu artigo $242^{\circ}$, transformou o antigo "ônus" em autêntico "dever jurídico", contra o qual poderia ser exercitada a pretensão do terceiro (despontando, assim, uma "obrigação" em sentido técnico): "o mandatário deve, sendo-lhe exigido, exibir o mandato escrito aos terceiros com quem contratar"; note-se que a orientação original foi restabelecida pelo artigo $260^{\circ}$ do Código Civil de 1966.

Aliás, como já tivemos a oportunidade de observar (nota 115), os demais preceitos (arts. $1350^{\circ}$ e $1345^{\circ}$ ) estabelecem de maneira nítida a eficácia representativa direta defluente da atuação do "mandatário" (seja sob a perspectiva ativa, seja sob o enfoque passivo): "o constituinte é responsavel para com qualquer pessoa, nos termos do artigo $1345^{\circ}$, pelo que o mandatario tiver feito, como tal, em relação a essa pessoa; mas o mandatario não tem acção para exigir della, em nome do constituinte, o cumprimento das obrigações contrahidas pela mesma pessoa. Este direito compete ao constituinte (...) o constituinte não póde escusar-se de cumprir todas as obrigações, que o mandatario houver contrahido em seu nome, dentro dos limites do mandato". Assim, em lugar da equívoca atribuição - legal - de um dever ao "representado" (consubstanciado na "obrigação de cumprir" prevista pelo art. 773 do CCom/1833), o legislador civil oitocentista tomou a eficácia representativa direta como pressuposto (metodológico) do mandato, voltando sua atenção à expressa vedação do manejo - por parte do constituinte - de exceções materiais estribadas na alegação de não superveniência dos proveitos esperados da gestão (art. $1346^{\circ}$ do CC/1867).

Por fim, quanto ao excesso praticado durante a gestão, já tivemos a oportunidade de nos pronunciar ao cabo de nota de rodapé anterior (nota 116). Entretanto, há que se ressaltar que a disciplina instituída pelo Código Civil de 1867 contempla os dois aspectos principais do fenômeno em um único enunciado (constante do artigo $1338^{\circ}$ ): "o mandatario, que exceder os seus poderes, será responsavel pelas perdas e damnos que causar, tanto para com o constituinte, como para com qualquer terceiro com quem haja contractado". Assim, a um só tempo o legislador se voltou tanto à perspectiva interna do evento - concernente à relação mantida entre "mandante" e "mandatário" - quanto à sua projeção exterior (relativa à temática da representação). Contudo, o preço pago pelo trato unitário destas questões foi a ausência de uma maior precisão terminológica com relação aos efeitos do "excesso" perante terceiros: ora, ainda que o mesmo sujeito seja responsabilizado - "duplamente" - pelos atos excessivos praticados durante sua gestão, há que se observar que a sua responsabilidade na qualidade de mandatário somente exsurgirá perante o seu mandante. Com relação a terceiros, é responsável na qualidade de "representante"; ou, para utilizarmos uma terminologia ainda mais precisa, de "procurador desprovido de poderes representativos suficientes" - observando-se que a acepção do termo "procurador" aí empregado é a moderna (neste sentido, cf. J. A. C. de GOUVEIA, Da Responsabilidade Contratual, Lisboa, Edição do Autor, 1933, p. 344). Pelas disposições do Código Comercial de 1833 aplicáveis ao "excesso" do agente - além daquelas já mencionadas oportunamente - cf. os artigos 807, 808, 809 e 810. Observe-se, ainda, que as consequiências do excesso sob a específica perspectiva da relação entre o terceiro-contratante e o principal - objeto dos arts. $1351^{\circ}$ do CC/1867 e $268^{\circ}$ do CC/1966 - serão objeto de uma análise comparativa a ser promovida mais à frente ( $\$ 144$ e sua nota 122).

Pela análise doutrinária dos dispositivos do Código Civil de 1867 mencionados na presente nota de rodapé, cf. J. Dias Ferreira, Codigo cit. (nota 115), pp. 5-6, 15-16 e 20-22; G. L. d'A. Cardoso Paúl, Codigo Civil Portuguez approvado por Carta de Lei de 1 de julho de 1867 annotado, Porto-Braga, Livraria Internacional, 1879, pp. 208-219; L. da CUNHA GONÇALVES, Tratado cit. (nota 115), pp. 497-499 (sobre a restrição do mandato à prática de atos jurídicos), 579-581, 600-604 e 610-618; L. CABRAL DE MONCADA, Lições de Direito Civil (Parte Geral) II, Coimbra, Atlântida, 1932, p. 334, nota 01 (pela aproximação entre os conceitos de mandato e representação); F. A. Pires DE Lima - J. de M. ANTUNES VARELA, Noções Fundamentais de Direito Civil (Lições do Prof. Dr. Pires de Lima ao Curso do $1^{\circ}$ Ano Jurídico de 1944-45) I, Coimbra, Coimbra Editora, 1945, pp. 436-437 (admitindo uma modalidade não representativa do mandato no âmbito comercial, designada pela expressão comissão); J. BELEZA DOS SANTOS, A Simulação em Direito Civil I, Coimbra, Coimbra Editora, 1955, p. 274 (asseverando categoricamente a inadmissibilidade do 
mandato sem representação pelo sistema jurídico português então vigente); e M. A. D. de ANDRADE, Teoria Geral cit. (nota 04), pp. 302-303 (sobre o excesso do agente). E quanto às manifestações doutrinárias produzidas sob a égide do Código Civil de 1966, cf. M. J. de AlmEIDA CostA, Noções cit. (nota 116), p. 271; A. Neto - H. A. MARTins, Código cit. (nota 116), pp. 120 e 656; F. A. Pires De LiMA - J. de M. ANTUNES VARElA, Código Civil Anotado I (arts. $1^{o}$ a 761 ), 4 ${ }^{\mathrm{a}}$ ed., Coimbra, Coimbra Editora, 1987, p. 242 (com considerações específicas a respeito do ônus de exibição do instrumento de outorga de poderes representativos); e C. A. da Mota PInTo, Teoria Geral do Direito Civil, $4^{\mathrm{a}}$ ed., Coimbra, Coimbra Editora, 2005, p. 550.

Finalmente, cumpre destacar que a junção metodológica promovida pelo legislador português oitocentista não passou despercebida à doutrina, que se apressou em distinguir os conceitos de mandato e de representação, abrindo caminho para o sistema forjado pelo Código Civil de 1966. Neste sentido, J. A. C. de GOUVEIA observava que "ainda que, conforme o sistema do nosso Código Civil, o mandato é sempre representativo, nada obsta a que o constituinte e o mandatário estipulem que êste actue em nome próprio e sem revelar a sua qualidade (...) não há representação, mas nem porisso deixará de haver mandato" ( $D a$ Responsabilidade cit. (nota 119), p. 339). Por sua vez, G. AlvES MOREIRA já observava que "a representação voluntaria tem a sua principal origem no mandato ou procuração (...) cumpre-nos notar, porém, que o mandato só constitue uma fonte de representação quando alguem se encarrega de, em nome doutrem, realizar qualquer negocio juridico, declarando a sua vontade em nome do mandante, e que pelo mandato póde alguem ser encarregado de realizar um negocio juridico não em nome do mandante, mas em nome proprio, sendo todavia o negocio jurídico realizado no interesse ou por conta do mandante. Neste caso, o mandatario contracta por si, em seu proprio nome, e não no do mandante, ficando assim o mandatario obrigado para com as pessoas com quem contracta, como se o negocio fosse seu, não tendo estas acção alguma contra o mandante, nem este contra ellas. É o que se chama commissão, que o codigo commercial considera, e com razão, como sendo uma fórma de mandato, e definindo este o contracto por que uma pessoa se encarrega de praticar um ou mais actos de commercio por mandado doutrem (...) não deve, pois, confundir-se o mandato com a representação voluntaria, até no caso em que elle tenha por fim a pratica dum acto juridico. Neste caso, para que haja representação, é necessario que o mandatario seja incumbido de realizar o negocio jurídico em nome do mandante" (Instituições do Direito Civil Português I - Parte Geral, Coimbra, Imprensa da Universidade, 1907, pp. 451-452).

De fato, o autor tem inteira razão ao reprovar a confusão entre "mandato" e "representação"; no entanto, no início do trecho transcrito, toma a palavra "procuração" como sinônima do primeiro termo. Tal junção, ressalte-se, não nos parece merecedora de aplausos; como pretendemos demonstrar ao longo deste estudo histórico, a aproximação entre o "mandatário" e o "procurador" se deu, no âmbito do direito português, pela via da justaposição entre o "advogado" e o "procurador judicial". Com isso, percebe-se aqui a conclusão de um processo de progressiva asfixia do "gestor de negócios" incumbido - acepção (romana) clássica do termo "procurador". A conseqüência principal da tendência é a seguinte: ao termo "procuração" restarão duas acepções básicas: a de ato de atribuição de poderes representativos ("procuração-ato") e a de documento representativo da outorga ("procuração-instrumento"); no entanto, a relação jurídica de caráter gestório - que ensejava o emprego da "actio negotiorum gestorum" (e não da "actio mandati") - parece ter entrado em um contínuo processo de declínio ("procuração-gestão").

Ora, a fim de que se tenha uma idéia a respeito do tumulto técnico promovido ao ensejo da fusão entre os conceitos de "mandato", "procuração" e "representação", eis a posição de um dos mais respeitados juristas luso-brasileiros de todo o século XX, ao reprovar a definição do tipo contratual constante do artigo $1318^{\circ}$ : "é uma definição defeituosa, porque leva a confundir o mandato com a prestação de serviços; parece dar um papel secundário ao representado; e converte o contrato em ordem, mandado, sendo certo que se trata só de incumbência. Mais exacto será, pois, dizer que: o mandato é um contrato pelo qual uma pessoa confere a outra o poder, que esta aceita, de a representar num ou em vários actos jurídicos, praticando êstes em exclusivo nome e proveito daquela. A pessoa que transmite os poderes chama-se mandante e é o representado; e a pessoa que aceita e exerce os mesmos poderes diz-se mandatário e é o representante. É a representação, pois, o que distingue o mandato da preposição ou mera comissão" (L. da CUNHA GONÇALVES, Tratado cit. (nota 115), p. 497).

De fato, há que se concordar com todas as críticas deste último autor com relação à definição emprestada ao tipo pelo legislador lusitano oitocentista. Todavia, causa espécie o conceito atribuído em substituição, no qual efetivamente se reduz o mandato à categoria de mero fundamento negocial da representação direta. Só que a perplexidade do investigador é ainda maior quando se percebe que o mesmo autor, uma página antes (p. 496), distinguia "mandato" e "representação" à custa das lições - alemãs - mais autorizadas de então.

Mais ainda: após baralhar os conceitos de "representante" e de "órgão", o autor revela a completa confusão entre os conceitos de "mandato" - contrato que tem origem em um negócio jurídico bilateral - e "procuração" (negócio unilateral de outorga de poderes representativos); em uma passagem obscura, L. da 


\section{$\S 142$. A eficácia do contrato de mandato segundo o Código Civil de 1867:}

“disposições gerais”. A antiga tendência de se expandir a esfera de atuação potencial do procurador é mantida pelo Código Civil Português de 1867: admitido o seu concurso para qualquer finalidade lícita que não envolva a prática de ato personalíssimo (arts. $1333^{\circ} \mathrm{e}$ $1332^{\circ}$ ), persistem, no êmbito extrajudicial, tão somente algumas restrições subjetivas de ordem etária e sexual - que de todo não impedem a atuação de certas espécies de mandatários, sujeitos a um regime de responsabilidades peculiar (art. 1334 ${ }^{\circ}$ ). Por sua vez, reafirmada a natureza gratuita do mandato civil (art. $1331^{\circ}$ ), sua origem contratual é igualmente reforçada (art. $1330^{\circ}$ ) - embora se tenha utilizado, de maneira imprópria, a expressão "só se valida" para aludir ao momento de formação do vínculo obrigacional (questão de "existência"). De todo modo, voltando sua atenção à implementação do princípio da simetria formal - particular, pública e "havida por pública" (arts. $1320^{\circ}, 1321^{\circ}$ e $1322^{\circ}$ ) - entre o objeto da incumbência e o negócio de conferência de poderes (arts. $1327^{\circ}$ e $1328^{\circ}$ ), o legislador oitocentista deu ensejo a um autêntico tumulto técnicoterminológico: ao mesmo tempo em que se fortaleceu a acepção instrumental do termo "procuração" (art. 1319), foram tomados promiscuamente o negócio "bilateral" de incumbência ("mandato") e o ato "unilateral" de outorga de poderes representativos; por tal razão, ao regulamentar a forma "ad probationem" do contrato (arts. $1326^{\circ}$ e $1329^{\circ}$ ), prescreveu-se, indevidamente, a adoção de formalidades que somente se coadunavam com a "procuração" propriamente dita - destinada esta, diversamente do mandato, a projetar seus efeitos sobre a esfera jurídica de terceiros ${ }^{120}$.

CUNHA GONÇALVES assevera com uma serenidade surpreendente: "é um dos raros contratos em que a aceitação da outra parte, neste caso a do mandatário, não figura, em regra, no título em que pelo mandante foram conferidos os poderes" (Tratado cit. (nota 115), p. 498). Ora, a aceitação da parte jamais poderia constar do instrumento, pois o negócio jurídico nele representado é unilateral - conquanto receptício.

Pelas razões expostas, percebemos que o Código Civil de 1867 pretendeu substituir a "nota típica" do contrato de mandato, a fim de reconduzi-la à eficácia representativa direta. Como teremos a oportunidade de reiterar adiante, de uma forma ou de outra, com o advento do Código Civil de 1966 o instituto passou a admitir uma variante não representativa; e na medida em que a "representação direta" perde espaço na contextura elementar do tipo contratual, exsurge uma oportunidade ímpar para uma investigação a respeito de sua essência. O próprio L. da CUNHA GONÇALVES ressalta a importância do tema, embora tenha preferido resgatar a identidade do "mandato" por meio de uma sua comparação com diversos outros institutos - dentre os quais a compra e venda, a emissão, a locação, a prestação de serviços, o transporte, a sociedade, o depósito e a gestão de negócios (Tratado cit. (nota 115), pp. 499-512). De todo modo, retornaremos à questão mais adiante, ao nos debruçarmos - especificamente - sobre a "nota típica" do contrato de mandato.

${ }^{120}$ Por meio de seus artigos $1333^{\circ}$ e $1332^{\circ}$, o Código Civil de 1867 admitiu o concurso de procurador para a prática de quaisquer atos lícitos de caráter não personalíssimo: “o mandatario póde acceitar procuração para todo e qualquer acto, que lhe não seja vedado por disposição da lei (...) póde qualquer mandar fazer por outrem todos os actos juridicos, que por si póde practicar, e que não forem meramente pessoaes". Contudo, uma análise mais detida nos revela uma irrefletida fusão entre as disciplinas concernentes ao "mandato" e à "representação negocial" (direta): assim, o primeiro dispositivo (artigo $1333^{\circ}$ ) - pertinente ao arcabouço 
técnico relacionado ao contrato de mandato - se limita a prescrever a licitude do objeto da atribuição (negócio jurídico bilateral de incumbência), surtindo efeitos restritos ao âmbito da relação mantida entre as partes contratantes ("mandante" e "mandatário"). De sua parte, a segunda disposição (artigo $1332^{\circ}$ ) concerne à admissibilidade da representação negocial direta, em uma consagração moderna das máximas canônicas "potest quis per alium quod potest facere per se ipsum" e "qui facit per alium est perinde ac si faciat per se ipsum" - conquanto especificamente mitigadas a propósito dos atos personalíssimos. Desta forma, a despeito da junção promovida pelo legislador lusitano oitocentista, não se pode deixar de observar que: a) quanto ao artigo $1333^{\circ}$, embora se tenham empregado como correlatos os termos "mandatário" e "procuração", cada um destes apresenta um âmbito próprio de aplicação (o primeiro correspondente à relação mantida entre o incumbido e o principal; e o segundo relacionado à atuação do gestor perante terceiros); b) a respeito do artigo $1332^{\circ}$, embora a disposição se enquadre em meio às regras atinentes ao contrato de mandato, pertinem a um aspecto peculiar de sua eficácia (representação direta) - posteriormente erigido à categoria de autêntico instituto jurídico, conforme se depreende da disciplina articulada entre os artigos $258^{\circ}$ a $269^{\circ}$ do Código Civil em vigor.

Já no que toca à capacidade específica do agente, devem ser diferenciadas as disposições concernentes ao contrato de mandato daquelas outras que se relacionam à aptidão do procurador à prática dos atos que constituem o objeto da incumbência. Assim, por meio de seu artigo $1334^{\circ}$, o Código Civil de 1867 institui preceito relacionado à capacidade (específica) para a assunção das obrigações típicas de mandatário (com âmbito de eficácia restrito ao vínculo pessoal estebelecido com o mandante): "as mulheres casadas, e os menores não emancipados podem ser mandatarios, salvo o disposto no artigo $1354^{\circ}$; mas o mandante só terá acção contra o menor ou contra a mulher casada, em conformidade das regras geraes que regulam a responsabilidade dos actos destas pessoas, excepto se o mandato, sendo escripto, tiver sido auctorisado pelo marido, pae ou tutor do mandatario". Por sua vez, o artigo $263^{\circ}$ do Código Civil de 1966 dispõe a respeito da capacidade para o exercício da procuração (na acepção moderna do termo): "o procurador não necessita de ter mais do que a capacidade de entender e querer exigida pela natureza do negócio que haja de efectuar". Ora, ainda que os dois enunciados pareçam dispor sobre temas semelhantes, a proximidade existente entre suas disposições é meramente aparente: enquanto o primeiro institui regra - de efeitos internos - voltada à relação decorrente do negócio jurídico bilateral de incumbência, o segundo concerne ao exercício dos poderes representativos outorgados por meio de negócio jurídico de origem unilateral.

De fato, a ausência de um maior apuro técnico provocou a extensão ao "mandato" de preceitos que deveriam se restringir ao âmbito da "procuração"; com efeito, por meio dos artigos $1327^{\circ}$ e $1328^{\circ}$ foi instaurado o princípio da simetria formal entre o negócio jurídico unilateral de outorga de poderes representativos ("procuração-ato") e os atos que correspondem ao exercício de tais poderes (objeto da incumbência): "é necessaria procuração pública, ou havida por pública, para os actos que têem de realisar-se por modo authentico, ou para cuja prova é exigido documento authentico (...) é sufficiente a procuração particular para os actos, cuja prova só depende de documento particular". Assim, para a celebração de um contrato dotado de uma específica forma "ad substantiam", a "procuração-ato" deverá se revestir de semelhante solenidade (refletida, por sua vez, na "procuração-instrumento"). Ora, como visam resguardar terceiros de uma eventual investida do principal, tais disposições se justificam inteiramente; por tal razão, foram ratificadas pelo artigo $262^{\circ}, 2$ do Código Civil atualmente em vigor - "salvo disposição legal em contrário, a procuração revestirá a forma exigida para o negócio que o procurador deva realizar".

Entretanto, como já tivemos a oportunidade de advertir (nota 116), o legislador civil oitocentista estendeu indevidamente - o alcance de tais preceitos, atribuindo ao negócio jurídico bilateral de incumbência ("mandato") um requisito formal que a nós parece lhe ser estranho, uma vez que deste contrato não promanam, ordinariamente, quaisquer efeitos sobre a esfera jurídica de terceiros. De todo modo, a respeito do tema, cf. os artigos $1326^{\circ}$ e $1329^{\circ}$ do Código Civil de 1867.

Quanto à "procuração-ato", o Código Civil de 1867 instituiu três modalidades formais: a) a procuração pública (artigo $1320^{\circ}$ ), para fins judiciais ("pelo escrivão (...) exarada em alguns autos") ou extrajudiciais ("por tabellião"); b) a procuração particular (art. $1321^{\circ}$ ), de sua parte "escripta e assignada pelo mandante, ou que foi escripta por outrem, e assignada pelo mandante e mais duas testemunhas"; c) e a procuração havida por pública (artigo $1322^{\circ}$ ), que a despeito de sua origem particular, se reveste da publicidade característica dos primeiros documentos à custa do ato - subseqüente - de reconhecimento praticado pelo tabelião: "São havidas por públicas a procuração escripta e assignada pelo mandante, sendo a letra e a assignatura reconhecidas por tabellião; e a escripta por pessoa diversa do mandante, mas assignada por este e por duas testemunhas, se taes assignaturas forem feitas perante tabellião, que assim o certifique, e as reconheça no proprio documento".

Especificamente a propósito da "procuração", cumpre destacar a preponderância - no sistema delineado pelo Código Civil de 1867 - da acepção instrumental do termo ("procuração-instrumento"); neste sentido, o artigo $1319^{\circ}$ o define da seguinte maneira: "diz-se procuração o documento, em que o mandante ou constituinte 


\section{$\S 143$. A eficácia do contrato de mandato segundo o Código Civil de 1867:}

"das obrigações do mandatário em relação ao constituinte”. Conquanto se entreveja no Código Civil de 1867 uma equiparação entre as figuras do "mandatário" e do "procurador", a idéia de uma gestão subjacente à relação contratual permaneceu, seja em virtude da alusão a um prazo de duração do mandato (art. $1335^{\circ}$ ), seja em decorrência de uma reiterada menção ao termo "gerência" - como a que se faz ao se estipular uma responsabilidade "in concreto" do agente (art. 1336 ${ }^{\circ}$ ), ou mesmo ao se lhe prescrever um dever de prestação de contas ao "dominus negotii" (art. 1339). Além disso, caracterizando-se o vínculo por uma estreita relação de "confiança", ao legislador pareceu oportuna a proibição de uma substituição do agente durante o cumprimento da incumbência - salvo em caso de prévia autorização do mandante, com responsabilidade do

exprime o seu mandato". De modo diferente, o Código Civil de 1966 deu preferência à "procuração-ato", conceituando-a como "o acto pelo qual alguém atribui a outrem, voluntariamente, poderes representativos" (artigo $262^{\circ}, 1$ ). Destacando tal mudança de concepção, assim se pronuncia I. GALVÃo TELLES: "o negócio gerador dos poderes representativos recebe muitas vezes, na linguagem corrente, o nome de mandato. $\mathrm{E}$ assim era denominado no Código de 1867, que o apresentava com estrutura bilateral - o contrato de mandato (aliás também chamado de procuradoria) (...) procuração dizia-se, não o negócio representativo, mas o documento on de o mandante ou constituinte exprimia o seu mandato (art. $\left.1319^{\circ}\right)(\ldots)$ logo na primeira edição do presente Manual, de 1947 (correspondente a lições de 1945-1946), reagíamos contra esta terminologia e a confusão de conceitos a ela subjacente ( $\mathrm{n}^{\circ} 141$, pág. 270). Cremos ter sido a primeira reacção nesse sentido entre nós ocorrida. Sustentávamos que o termo procuração deveria ser o usado para o acto atributivo de poderes de representação (noção substancial), embora pudesse empregar-se também para o documento onde se incluíam tais poderes (noção formal), quando a procuração no primeiro sentido não fosse puramente verbal (...) estas nossas posições encontraram acolhimento no actual Código Civil, cujo artigo $262^{\circ}$ define, no $\mathrm{n}^{\circ} 1$, procuração como o acto pelo qual alguém atribui a outrem poderes representativos, e declara, no $\mathrm{n}^{\mathrm{o}} 2$, que a procuração revestirá a forma exigida para o negócio que o procurador deva realizar" (Manual cit. (nota 118), pp. 421-422). No mesmo sentido, A. de A. FERRER CORREIA assim define a situação então prevalecente: "assim, pois, uma confusão total de mandato e representação voluntária. Paralelamente, à palavra procuração não corresponde qualquer conceito jurídico autónomo. Procuração é o próprio contrato de mandato - algumas vezes também o documento que encorpora ou formaliza este negócio jurídico. Procuração e mandato, representado e mandante, procurador, representante e mandatário, são vocábulos sinónimos. O poder representativo funda-se sempre no mandato, com ele nascendo e se extinguindo" (A procuração na teoria da representação voluntária, in Estudos de Direito Civil, Comercial e Criminal, $2^{a}$ ed., Coimbra, Almedina, 1985, pp. 2-6, especialmente p. 4). Ora, ainda que a proeminência de um enfoque não implique, necessariamente, a supressão do outro, deve-se observar que nenhum deles - seja a "procuração-ato", seja mesmo a "procuração-instrumento" - contempla a chamada "procuração-gestão" - relação jurídica gestória, dominada por princípios próprios que justificaram, no direito romano, a sua inclusão em meio aos "iudicia bona fidei" gerais.

Quanto à repercussão doutrinária dos preceitos do Código Civil de 1867 referidos nesta nota de rodapé, cf. J. Dias Ferreira, Codigo cit. (nota 115), pp. 6-14; F. A. Pires De LiMA - J. de M. ANTUNES VAREla, Noções cit. (nota 119), pp. 437-438 (modalidades de procurações) e 440-441 (natureza contratual, gratuidade presumida e definição do respectivo objeto); e L. da CuNHA GONÇALVES, Tratado cit. (nota 115), pp. 512519, 531-532 e 555-563. Já no que concerne aos dispositivos do Código Civil de 1966, cf. A. NETO - H. A. Martins, Código cit. (nota 116), pp. 120-121; F. A. Pires de LiMA - J. de M. Antunes Varela, Código cit. (nota 119), pp. 244-245; e J. de O. AsCENSÃO, Teoria cit. (nota 118), pp. 297-299.

A respeito do reforço à natureza contratual do "mandato" (artigo 1330 do CC/1867), cf. as observações já desenvolvidas em nota de rodapé anterior (nota 115). No mesmo sentido, aliás, quanto à gratuidade presumida - art. $1331^{\circ}$ do CC/1867 - da variante civil do instituto (nota 116). Note-se que mais adiante teceremos comentários específicos sobre o "mandato judicial" (nota 123). 
substituto nos termos do mandato original (art. $1343^{\circ}$ ), bem como do próprio substituído na hipótese de eleição de um sujeito "notoriamente inhabil ou insolvente" (art. 1342º. No mesmo sentido, por meio do artigo $1337^{\circ}$ foi destacada uma outra singularidade de tal liame: à vista do caráter "colaborativo" da gestão confiada, foi vedada qualquer compensação entre os prejuízos e proveitos dela decorrentes; priorizando-se, assim, os interesses do "principal" - à semelhança dos "iudicia bonae fidei" gerais do direito romano (§ 52). Assim, causa-nos certa estranheza o termo inicial para a fluência de juros em caso de desvio perpetrado pelo mandatário: em lugar do momento do abuso, preferiu-se recorrer à constituição em mora (art. $1340^{\circ}$ ) - deixando-se de lado, pois, a orientação defluente do artigo 294 ( $1^{\mathrm{a}}$ parte) do Código Comercial de $1833^{121}$.

${ }^{121}$ A despeito do declínio daquela feição "gestória" que outrora caracterizara a "procuratio" romana, no Código Civil de 1867 ainda podem ser entrevistas reminiscências comprobatórias de algumas de suas projeções eficaciais. De todo modo, cumpre assinalar que idéia de uma gestão subjacente ao vínculo mantido entre o "mandante" e o "mandatário" pode ser depreendida, por exemplo, de seus artigos $1335^{\circ}, 1339^{\circ} \mathrm{e}$ $1336^{\circ}$. Com efeito, o primeiro dispositivo (artigo $1335^{\circ}$ ) atribui ao mandatário o dever de cumprir a incumbência - que lhe fora confiada pelo mandante - durante o "intervalo" avençado: "o mandatario é obrigado a cumprir o seu mandato, nos termos e pelo tempo por que lhe foi conferido"; ora, em virtude das circunstâncias cronológicas que envolvem a hipótese, tal disposição sugere mais do que uma simples substituição para a "prática" de algum mister. A respeito das disposições alusivas ao dever de cumprimento no âmbito da legislação posterior - ou mesmo do Código Comercial de 1833 - cf. art. 806 do CCom/1833; art. $238^{\circ}$ do CCom/1888; e art. $1161^{\circ}$, "a" do CC/1966.

Contudo, tal noção fica mais evidenciada pelo emprego do termo "gerência", efetuado pelo legislador civil oitocentista em duas ocasiões principais: a) em primeiro lugar, a propósito da previsão de um dever de prestação de contas pelo mandatário (artigo $1339^{\circ}$ ): "o mandatario é obrigado a dar contas exactas da sua gerencia" (no mesmo sentido, conquanto sem o emprego da terminologia posta em destaque, cf. o art. 47 do CCom/1833; e o art. 1161", "d" do CC/1966); b) além disso, ao preceituar a responsabilidade "in concreto" do agente, por meio do artigo $1336^{\circ}$ : "o mandatario deve dedicar á gerencia de que é encarregado a diligencia e cuidado, de que é capaz, para o bom desempenho do mandato; se assim o não fizer, responderá pelas perdas e damnos a que der causa".

Observe-se que este último dispositivo destaca - para além de uma noção de gestão (ínsita ao termo "gerência") - a responsabilidade "sui generis" do mandatário: por meio do emprego da expressão "diligencia e cuidado (...) de que é capaz", refere-se o legislador aos atributos peculiares do agente - que provavelmente ensejaram a sua eleição por parte do principal. Desta forma, depreende-se de tal dispositivo a existência de uma relação de "confiança" entre as partes, irradiadora de uma eficácia jurídica própria - que, de todo modo, não se restringe à simples responsabilidade "in concreto" do agente na hipótese de prejuízos experimentados em decorrência de sua gestão.

Assim, a natureza "intuitu personae" do vínculo enseja a observância de regras jurídicas especiais nos casos de substituição do gestor. Especificamente no âmbito do "mandato" forjado pelo Código Civil de 1867, tais preceitos podem ser surpreendidos junto aos artigos $1342^{\circ}$ e $1343^{\circ}$ : "o mandatario não póde encarregar a outrem o cumprimento do mandato, se para isso não lhe tiverem sido dados poderes; e se the forem dados sem designação de pessoa, responderá pelo substituido, sendo este notoriamente inhabil ou insolvente (...) o mandatario substituido tem para com o mandante os mesmos direitos e obrigações, que tinha o mandatario originario". Ora, da interpretação de tais dispositivos se pode depreender a diferença existente entre os "poderes representativos" - derivados do negócio jurídico unilateral de outorga de poderes - e os correlatos "poderes gestórios", decorrentes do próprio contrato de mandato.

De todo modo, o legislador civil novecentista preferiu atrelar as hipóteses de substituição no exercício da "procuração" (na acepção moderna da expressão) e do "mandato", conforme denuncia o artigo $1165^{\circ}$ do Código Civil vigente: "o mandatário pode, na execução do mandato, fazer-se substituir por outrem ou servirse de auxiliares, nos termos em que o procurador o pode fazer". Por sua vez, o artigo $264^{\circ}$ do Código Civil de 1966 consagrou a utilização de auxiliares (ou subalternos) - anteriormente prevista pelo próprio Código 


\title{
$\S 144$. A eficácia do contrato de mandato segundo o Código Civil de 1867:
}

\author{
"das obrigações do constituinte em relação ao mandatário" e "dos direitos e das
} obrigações do constituinte e do mandatário em relação a terceiro". Por meio de seu artigo $1344^{\circ}$, o Código Civil de 1867 prescreveu a responsabilidade do mandante pelas despesas e prejuízos experimentados pelo mandatário - estendendo-se, assim, o alcance das regras estabelecidas pelos artigos 46 e 794 do Código Comercial de 1833, por sua vez dispostas em meio à disciplina concernente ao contrato de "comissão" (arts. 36 a 86; e 788 a 817). Corroborando a feição "colaborativa" da gestão praticada pelo agente, foram reputados não autorizados os atos que - conquanto formalmente abrangidos pela incumbência contrariassem os interesses do principal, especialmente resguardados à vista de uma perspectiva teleológica da própria avença (art. 1353º. Em contrapartida, foram

Comercial de 1833 (por seu artigo 66) - desde que se mostre conforme aos usos e não se revele contrária à natureza do objeto da incumbência; aliás, além de estipular expressamente a subsistência do vínculo em relação ao procurador (substituído), tal dispositivo ampliou o rol das hipóteses de responsabilidade deste último, a fim de alcançá-lo mesmo em caso de transmissão errônea das instruções inerentes ao vínculo originário: "1. o procurador só pode fazer-se substituir por outrem se o representado o permitir ou se a faculdade de substituição resultar do conteúdo da procuração ou da relação jurídica que a determina. 2. A substituição não envolve exclusão do procurador primitivo, salvo declaração em contrário. 3. Sendo autorizada a substituição, o procurador só é responsável para com o representado se tiver agido com culpa na escolha do substituto ou nas instruções que lhe deu. 4. O procurador pode servir-se de auxiliares na execução da procuração, se outra coisa não resultar do negócio ou da natureza do acto que haja de praticar". Merece destaque, ainda, a menção final que o dispositivo faz à "execução da procuração": expressão que nos parece alusiva a uma reminiscência da "procuração-gestão", eis que incompatível com as demais acepções emprestadas ao termo ("procuração-ato" e "procuração-instrumento").

Além do caráter "intuitu personae" da relação contratual - estribada em um vínculo de "confiança" -, ganha destaque a feição "colaborativa" da gestão executada pelo agente. Desta forma, como que a denunciar a existência de um circuito financeiro peculiar, o artigo $1337^{\circ}$ do Código Civil de 1867 proíbe a compensação entre os proveitos auferidos pelo agente e os prejuízos por ele causados ao principal: "o mandatario não póde compensar os prejuizos, a que deu causa, com os proveitos que, por outro lado, tenha diligenciado para o seu constituinte". Nesta mesma linha, o "desvio" praticado pelo mandatário sempre foi repreendido por meio da previsão do pagamento dos respectivos juros; observação que já foi feita em ocasião anterior (nota 117). Contudo, parece oportuno destacar que o legislador civil oitocentista alterou parcialmente o regime jurídico aplicável, especificamente no que concerne ao termo inicial da fluência dos referidos juros (art. $1340^{\circ}$ ); em lugar da contagem iniciada a partir da malversação, preferiu-se a utilização da regra geral do direito das obrigações, segundo a qual o fluxo se iniciaria a partir da constituição em mora do devedor: "se o mandatario distrahir, em proveito seu, o dinheiro do seu constituinte, será responsavel pelos juros, desde que se achar constituido em móra, se esse dinheiro os não vencer por outro titulo". Com efeito, o artigo 294 do Código Comercial de 1833 estabelecia um regime diverso: "o mandatário é devedor de juros das sommas, que empregar em uso proprio a datar do emprego". De todo modo, pelas disposições correspondentes no âmbito da legislação posterior (e inclusive do próprio Código Comercial de 1833), cf. as remissões efetuadas na parte final de nota de rodapé anterior (nota 117).

A respeito dos dispositivos do Código Comercial de 1833 referidos na presente nota de rodapé, cf. I. de SOUSA DUARTE, Diccionario cit. (nota 115), pp.71-73, 75 e 256. Sobre a posição da doutrina acerca dos dispositivos do Código Civil de 1867 mencionados, cf. J. DiAs FERREIRA, Codigo cit. (nota 115), pp. 15-19; J. A. C. de Gouveia, Da Responsabilidade cit. (nota 119), p. 343; e L. da CunHa GonÇALVES, Tratado cit. (nota 115), pp. 567-569, 571-573, 576-579 e 581-598. Por fim, pela produção doutrinária sob a égide do Código Civil de 1966, cf. A. Neto - H. A. MARTins, Código cit. (nota 116), pp. 121, 658-659; F. A. PIRES DE Lima - J. de M. Antunes Varela, Código cit. (nota 119), pp. 245-246; M. J. de Almeida Costa, Noções cit. (nota 116), p. 272; J. de O. AsCEnSÃO, Teoria cit. (nota 118), p. 321; e I. GALVÃo Telles, Manual cit. (nota 118), pp. 426-428 e 439. 
expressamente rechaçadas quaisquer exceções estribadas na alegação de prejuízo ou da não superveniência do proveito esperado do mandato: não sendo consideradas, portanto, fundamento suficiente para afastar os efeitos representativos diretos da gestão (arts. $1345^{\circ}$ e $1346^{\circ}$ ) - ou mesmo para prejudicar eventuais créditos do agente perante o mandante (arts. $1344^{\circ}, 1346^{\circ}$ e $1347^{\circ}$ ). Por fim, especificamente quanto aos atos resultantes de excesso por parte do "procurador", foi cominada uma "curiosa" sanção de invalidade, com efeitos restritos ao próprio constituinte (art. $1351^{\circ}$ ) - talvez porque já se entrevisse, conquanto por meio da utilização inapropriada do termo "nulidade", a hipótese de ineficácia relativa consagrada pelo art. $268^{\circ}$ do Código Civil de $1966^{122}$.

122 Por meio de seu artigo $1344^{\circ}$, o Código Civil de 1867 prescreveu - ressalvada a hipótese de excesso - a
responsabilidade do mandante pelas despesas e prejuízos experimentados pelo mandatário durante sua
gestão: "o constituinte tem obrigação de indemnisar o mandatario de todas as despezas, que este fizer, e de
todos os prejuizos que lhe provierem do cumprimento do mandato, com tanto que o dicto mandatario não
excedesse os seus poderes, e procedesse de boa fé". É interessante observar este dispositivo condensa, de
maneira imperfeita, dois preceitos instituídos pelo Código Comercial de 1833 a propósito da comissão; com
efeito, em seus artigos 46 e 794 tal diploma assim estatuíra: "o committente é obrigado a satisfazer á vista,
salvo convenção em contrario, a importancia de todos os gastos e desembolços, feitos no desempenho da
commissão, á face d'uma conta legal; mais os juros pelo tempo, que mediar entre o desembolço e o effectivo
pagamento (...) o committente é obrigado a indemnizar o commissario das perdas soffridas por occasião da
sua gestão, sem imprudencia, que lhe seja imputavel". Ainda no âmbito da comissão - além dos preceitos
mencionados - cf. também os arts. 812 e 813 do CCom/1833. Todavia, a síntese promovida pelo legislador civil oitocentista foi bastante prejudicada pelo fato de terem sido descurados, por completo, dois elementos denunciadores do caráter "colaborativo" da gestão implementada pelo agente: quanto a eventuais adiantamentos por este praticados, o artigo 46 do Código Comercial de 1833 é categórico ao determinar o início da fluência dos juros a partir do desembolso (e não da constituição em mora do mandante); ora, temos aí o exato reflexo da regra - mencionada em nota de rodapé anterior (nota 121) - que dispõe a respeito do termo inicial da fluência dos juros em caso de "desvio" praticado pelo mandatário. Além disso, o artigo 794 do Código Comercial revogado previa expressamente a responsabilidade do comitente, mesmo que os prejuízos do mandatário não lhe fossem imputáveis; bastava que não restasse configurada a culpa do agente para que o encargo financeiro fosse transferido mediatamente - do seu patrimônio para a esfera jurídica do principal. A respeito destas duas questões o Código Civil de 1867 não se pronunciou expressamente. Contudo, elas não passaram despercebidas ao legislador civil novecentista, tal como se pode depreender das alíneas "c" e "d" do artigo $1167^{\circ}$ do Código Civil em vigor: "o mandante é obrigado: (...) c) a reembolsar o mandatário das despesas feitas que este fundadamente tenha considerado indispensáveis, com juros legais desde que foram efectuadas; d) a indemnizá-lo do prejuízo sofrido em consequência do mandato, ainda que o mandante tenha procedido sem culpa". Note-se, por fim, que à vista do "espírito colaborativo" subjacente à gestão, prescreve-se a responsabilidade do principal pelas despesas que o mandatário razoavelmente reputou indispensáveis - quer efetivamente o fossem, quer não.

Assim como a simples alegação de ausência de culpa própria não poderia beneficiar o principal (que buscasse se eximir da responsabilidade pelos prejuízos experimentados pelo agente no decurso de sua gestão), da mesma forma, não se admitiu a invocação de fundamentos que implicassem - à margem de qualquer disposição contratual específica - uma transferência dos riscos da operação ao mandatário; e a este respeito o Código Civil de 1867 foi expresso (artigo 1346 ), proibindo o mandante de se isentar "de cumprir o que the é ordenado nos artigos antecedentes, com o fundamento de não ter percebido os proveitos, que do mandato esperava". A propósito da questão, cf. o artigo 773 do Código Comercial de 1833 - bem como outras referências declinadas em nota da rodapé anterior (nota 115).

Mas o fundamento da "gestão colaborativa" influenciou as disposições relacionadas não apenas ao "reembolso" de despesas (ou à "reparação" de prejuízos); também a obrigação relativa à "remuneração" do mandatário sofreu um seu influxo decisivo. Ressalvada a hipótese de culpa do agente, mesmo que sua atuação tenha redundado em desvantagem ao principal, tal fato não haveria de prejudicar, por si só, esta 


\title{
$\S 145$. A eficácia do contrato de mandato segundo o Código Civil de 1867:
}

\author{
"do mandato judicial”. No que toca ao mandato judicial, há que se destacar a preservação
}

de um legado cujo desenvolvimento remonta às próprias fontes do direito lusitano

medieval: tal assertiva é comprovada pela subsistência tanto de restrições à procuradoria

judicial (art. $1354^{\circ}$ ), como também de uma preocupação constante com a garantia de um efetivo direito à defesa (art. $1357^{\circ}$ ); além disso, em diversos preceitos é possível

específica pretensão do mandatário, tal como evidencia o artigo $1347^{\circ}$ do Código Civil de 1867: “o constituinte é obrigado a pagar ao mandatario os salarios estipulados, ou que lhe sejam devidos, conforme o que fica disposto no artigo $1331^{\circ}$, ainda que o mandato não tenha sido vantajoso ao dicto constituinte, excepto quando isso acontecer por culpa ou negligencia do mandatario". Assim como observado quanto ao artigo $1346^{\circ}$, disposição em sentido diverso redundaria, em termos práticos, na atribuição ao agente dos riscos inerentes à própria operação - desnaturando-se, assim, a atuação típica do mandatário ("por conta" do mandante).

Por sua vez, o artigo $1353^{\circ}$ denuncia uma projeção eficacial não só da "gestão colaborativa", como também da feição "instrumental" do mandato; por não constituir um fim em si mesmo - revelando-se, ao contrário, um simples mecanismo para a prática de atos ou negócios ulteriores -, a execução do mandato há de ser continuamente informada pela teleologia subjacente ao negócio bilateral de atribuição. Assim, como já pudemos observar em oportunidade anterior (nota 121), este tipo contratual não visa tão somente a "substituição" do principal; vai mais adiante, ao revestir um autêntico ato de "incumbência" do mandatário, em virtude do qual, em lugar do comportamento relativamente inerte do núncio, exige uma postura verdadeiramente "gestória" por parte do agente. Cuidando do que é alheio como se fosse próprio, o mandatário não deve praticar aquilo que, conquanto autorizado, contraria os interesses daquele por conta de quem atua; eis o sentido do referido dispositivo legal do Código Civil de 1867: "são havidos por não auctorisados, embora sejam da mesma natureza dos auctorisados, os actos que forem evidentemente contrarios ao fim do mandato".

Com relação ao excesso praticado pelo agente, já tivemos a oportunidade de nos manifestar em ocasiões anteriores - cf. as notas de rodapé 116 e 119 (esta última exclusivamente dedicada à confusão terminológica defluente da técnica empregada pelo legislador civil oitocentista). Entretanto, cumpre-nos aqui destacar a peculiar sanção cominada ao cabo do artigo $1351^{\circ}$ do Código Civil de 1867: "os actos, que o mandatario practica em nome do seu constituinte, mas fóra dos limites expressos do mandato, são nullos em relação ao mesmo constituinte, se este não os ratificou tacita ou expressamente". Note-se que esta sanção - com efeitos restritos ao representado - não se coaduna com a extensão subjetiva ("erga omnes") defluente da "nulidade" em sua acepção técnica. De todo modo, mesmo que se tratasse de uma autêntica "anulabilidade", ainda assim tal sanção haveria de produzir resultados no plano da validade do negócio jurídico (ultimado pelo representante desprovido de poderes representativos suficientes).

Ora, a respeito desta mesma hipótese, o Código Civil de 1966 dispôs de maneira diversa, cominando uma sanção de ineficácia relativa, estatuída por seu artigo 268”: "1. O negócio que uma pessoa, sem poderes de representação, celebre em nome de outrem é ineficaz em relação a este, se não for por ele ratificado. 2. A ratificação está sujeita à forma exigida para a procuração e tem eficácia retroactiva, sem prejuízo dos direitos de terceiro. 3. Considera-se negada a ratificação, se não for feita dentro do prazo que a outra parte fixar para o efeito. 4. Enquanto o negócio não for ratificado, tem a outra parte a faculdade de o revogar ou rejeitar, salvo se, no momento da conclusão, conhecia a falta de poderes do representante". Teremos a oportunidade de observar, mais adiante, de que modo tais preceitos influenciaram a posição afinal adotada pelo legislador brasileiro.

Quanto às disposições do Código Comercial de 1833 referidas na presente nota de rodapé, cf. I. de SoUSA DuARTE, Diccionario cit. (nota 115), pp.75-76 e 253. Pela doutrina relacionada ao Código Civil de 1867 (e aos preceitos ora especificamente invocados), cf. J. DIAS FERREIRA, Codigo cit. (nota 115), pp. 20-22; J. A. C. de GouveIA, Da Responsabilidade cit. (nota 119), p. 345; L. da CunHA GonÇAlves, Tratado cit. (nota 115), pp. 600-604 e 613-616; G. ALVES MOREIRA, Instituições cit. (nota 119), pp. 456-457; e J. TAVARES, Os Princípios cit. (nota 118), p. 438. Finalmente, quanto à produção doutrinária desenvolvida após a promulgação do Código Civil de 1966, cf. A. NETO - H. A. MARTins, Código cit. (nota 116), pp. 122-123 e 659-660; F. A. Pires de Lima - J. de M. Antunes VArela, Código cit. (nota 119), pp. 248-249; M. J. de AlmeIDA Costa, Noções cit. (nota 116), p. 272; J. de O. AsCENSÃO, Teoria cit. (nota 118), p. 324; e I. GALVÃo TELLES, Manual cit. (nota 118), p. 435. 
surpreender os resquícios de uma já evanescente distinção entre as atividades do "advogado" e do "procurador" - decorrentes da utilização das conjunções aditiva "e" e alternativa "ou" - tal como se verifica entre os artigos $1358^{\circ}$ e $1362^{\circ}$. Por sua vez, buscando-se resguardar a "confiança" subjacente à relação entre as partes, vedam-se ao mandatário o súbito abandono da causa (art. $1362^{\circ}$ ) e a postulação em favor do adversário (art. $1360^{\circ}$ ) - a quem, aliás, não poderiam ser revelados segredos ou ministrados quaisquer esclarecimentos (art. 1361 $)$. Despontam, ainda, disposições de ordem eminentemente técnica, tais como a que prescreve a forma pública - ou a "havida por pública" - para as procurações judiciais (art. $1355^{\circ}$ ), ou aquela que proíbe a procuração de caráter conjuntivo (art. $1356^{\circ}$ ). Finalmente, merecem menção especial dois preceitos denunciadores de uma intervenção estatal destinada a coibir eventuais abusos por parte dos agentes judiciais: com efeito, ao mesmo tempo em que é ratificada a interdição do pacto de "quota litis" (art. $1358^{\circ}$ ), asseguram-se-lhes tão somente os "salarios do estylo no respectivo auditorio" acrescidos do reembolso das despesas comprovadamente efetuadas com a administração do litígio (art. $\left.1359^{\circ}\right)^{123}$.

\footnotetext{
${ }^{123} \mathrm{Na}$ esteira de uma tradição que remonta às fontes lusitanas medievais (cf. § 108), o Código Civil de 1867 consagra uma série de restrições subjetivas relacionadas à atuação dos procuradores judiciais; por força de seu artigo $1354^{\circ}$, são expressamente impedidos de exercer tal função: " $1^{\circ}$ os menores não emancipados; $2^{\circ}$ as mulheres, excepto em causa propria, ou dos seus ascendentes e descendentes ou de seu marido, achando-se estes impedidos; $3^{\circ}$ os juizes em exercicio, dentro dos limites da sua jurisdicção; $4^{\circ}$ os escrivães e officiaes de justiça nos respectivos julgados, excepto em causa propria; $5^{\circ}$ os magistrados do ministerio publico, em toda e qualquer causa em que possam intervir de officio, dentro dos limites dos seus respectivos districtos; $6^{\circ}$ os que tiverem sido inhibidos, por sentença, de procurar em juizo ou de exercer officio publico; $7^{\circ}$ os ascendentes, descendentes ou irmãos do julgador; $8^{\circ}$ os descendentes contra os ascendentes, e vice-versa, excepto em causa propria". Como se pode observar, as limitações à atuação judicial do agente são bem mais numerosas do que as estabelecidas a propósito da procuração extrajudicial (art. 1334 $4^{\circ}$ do CC/1867); ora, tal fato se explica à vista do tratamento minudente que a legislação portuguesa dispensou à variante judicial do instituto durante o período compreendido entre os séculos XIII e XVII.

Como já tivemos a oportunidade de observar anteriormente (nota 117), também a impossibilidade superviente apresenta contornos próprios, quando vislumbrada no contexto da execução de um mandato para fins judiciais. Em lugar do simples dever de informar - por vezes qualificado pelo ônus de demonstrar o fato impeditivo de natureza positiva (cf. arts. 775 e 837 do CCom/1833 e art. 1161", "c" do CC/1966) - o artigo $1362^{\circ}$ do Código Civil de 1867 atribui ao agente a obrigação de substabelecer seus poderes quando assim autorizado; caso contrário, deve informar o principal para que este possa assumir a administração do processo (por si próprio ou por meio de novo mandatário): "o procurador ou o advogado, que tiver justo impedimento para continuar na procuradoria, não poderá abandonál-a sem substabelecer a procuração, tendo poderes para isso, ou avisar em tempo o seu constituinte, para que nomeie outro; aliás responderá por perdas e damnos". Como se vê, da inobservância de tais deveres deflui a responsabilidade do gestor pelos prejuízos causados ao "dominus negotii".

Por sua vez, a acentuada relevância social do "mandato judicial" ensejou a preservação de uma tendência que já se podia divisar mesmo em meio aos direitos visigótico e castelhano: assim, a procuração para fins judiciais permaneceu imersa em uma atmosfera peculiar, informada por uma intensa intervenção estatal (arts. $1357^{\circ}, 1358^{\circ}$ e $1359^{\circ}$ do $\mathrm{CC} / 1867$ ) e por exigências formais próprias (arts. $1355^{\circ}$ e $1356^{\circ}$ do CC/1867). Além disso, por meio dos artigos $1360^{\circ}$ e $1361^{\circ}$ o legislador civil oitocentista atribuiu a esta específica variante do instituto uma autêntica "pós-eficácia".
} 


\title{
$\S 146$. A eficácia do contrato de mandato segundo o Código Civil de 1867:
}

\author{
"do termo do mandato". A respeito da extinção da relação jurídica defluente do contrato, \\ poucas são as inovações empreendidas pelo Código Civil de 1867; por um lado, desponta
} expressa previsão sobre a possibilidade de revogação do mandato, a despeito da existência

No que concerne à intervenção estatal quanto à constituição do vínculo, merece destaque o artigo $1357^{\circ}$, que disciplina a procuração judicial dativa: "se os procuradores do juizo, por attenção á parte contrária, recusarem a procuração conferida, deverá o juiz, a requerimento do constituinte, nomear algum delles, que a acceite, sob pena de suspensão por seis mezes, não provando escusa legitima". Já no que toca à estrutura do liame, os artigos $1358^{\circ}$ e $1359^{\circ}$ visam evitar o aproveitamento indevido por parte do mandatário, que - em decorrência das circunstâncias peculiares que revestem a formação do contrato - de outra forma poderia se prevalecer da fragilidade momentânea do mandante; comprometendo-se, assim, a idéia de uma prevalência absoluta dos interesses do principal. Neste sentido, sob a ameaça de severa sanção, o primeiro dispositivo mantém a proibição do pacto de "quota litis" ("será nullo todo o contracto, que as partes fizerem com os seus advogados ou procuradores, concedendo-lhes alguma parte do pedido na acção. § único. Os procuradores ou os advogados, que infringirem o que se dispõe neste artigo, serão inhibidos, por espaço de um ano, de procurar ou de advogar em juizo"); e o segundo vai ainda mais longe, ao prescrever um parâmetro oficial de remuneração do agente (estribado nos usos locais): "os procuradores e os advogados haverão os salarios do estylo no respectivo auditorio, além das despezas que fizerem com a causa". Aliás, a respeito deste último preceito, houve uma sua extensão ao mandato extrajudicial pelo Código Comercial de 1888 (artigo $232^{\circ}, \S$ $1^{\circ}$ ); no entanto, foi expressamente ressalvada, entre os comerciantes, a hipótese de avença em sentido contrário - orientação que acabou por prevalecer, em termos ainda mais amplos, em meio ao Código Civil de 1966 (artigo $1158^{\circ}, 2$ ).

Quanto às exigências formais específicas da procuração judicial, merecem destaque os artigos $1355^{\circ}$ (por meio do qual se determina a observância das solenidades típicas das modalidades "pública" e "havida por pública") e $1356^{\circ}$ (em decorrência do qual se veda a procuração conjuntiva), os quais dispõem, respectivamente, da seguinte forma: "o mandato judicial só póde ser conferido por procuração pública, ou havida por tal (...) não será admittida em juizo procuração a dous ou mais procuradores, com a clausula de que um nada possa fazer sem os outros; mas podem conferir-se os mesmo poderes a differentes pessoas simultaneamente". Quanto às prescrições relacionadas à forma da "procuração" em geral - bem como as referentes à solenidade do próprio contrato de mandato - cf. as alusões realizadas em momentos anteriores desta exposição (notas 116 e 120). A respeito do "mandato conjuntivo", deve-se observar que o Código Civil de 1966 o admitiu, genericamente, por meio de seu artigo $1166^{\circ}$ (que disciplina a responsabilidade dos agentes nesta hipótese específica).

Finalmente, como uma espécie de consagração do vínculo de "confiança" subjacente à relação mantida entre as partes contratantes, devem ser destacadas as duas regras do Código Civil de 1867 que instituíram uma póseficácia relacionada ao mandato judicial: por meio do artigo $1360^{\circ}$ o legislador proibiu a atuação do mandatário em prol do adversário de seu mandante, mesmo após a extinção do vínculo contratual respectivo ("o procurador ou o advogado, que houver acceitado o mandato de uma das partes, não póde procurar ou advogar pela outra na mesma causa, ainda que deixe a anterior procuração. § único. O procurador ou advogado, que assim o não cumprir, será suspenso de procurar ou de advogar por espaço de um anno"); por sua vez, no artigo $1361^{\circ}$ é cominada uma severíssima sanção ao mandatário que violar segredo de seu mandante, por meio de informação prestada ao adversário deste (“o procurador ou o advogado, que revelar á parte contrária os segredos do seu constituinte, ou lhe subministrar documentos, ou quaesquer esclarecimentos, será inhibido para sempre de procurar ou de advogar em juizo"). Quanto a estas duas disposições, deve-se observar que o seu teor é diametralmente oposto à orientação perfilhada nas fontes do direito castelhano (cf. § 104); provavelmente porque em lugar da malícia do "mandante", buscava-se coibir, agora, um comportamento desleal por parte do mandatário (ou mesmo de terceiro). Pelas linhas gerais do conceito de pós-eficácia (no âmbito do direito contratual), cf. I. GALVÃo TELLES, Manual cit. (nota 118), pp. 441-442.

Acerca das disposições do Código Comercial de 1833 referidas na presente nota de rodapé, cf. I. de SoUSA DUARTE, Diccionario cit. (nota 115), p. 253. Por sua vez, pela doutrina relacionada ao Código Civil de 1867, cf. J. DiAs FERreIRA, Codigo cit. (nota 115), pp. 23-35; J. A. C. de GouveIA, Da Responsabilidade cit. (nota 119), pp. 346-353; e L. da CUNHA GonÇALVES, Tratado cit. (nota 115), pp. 622-657. Por fim, a respeito da produção doutrinária desenvolvida sob a égide do Código Civil de 1966, cf. A. NETO - H. A. MARTINS, Código cit. (nota 116), pp. 656-658; M. J. de AlMEIDA COSTA, Noções cit. (nota 116), p. 272. 
de condição ou avença em sentido contrário (art. 1364 ${ }^{\circ}$ ); além disso, em acolhimento a uma influência do "Code Civil" (art. 2004), o legislador português facultou ao constituinte a exigência de restituição do instrumento no qual fora documentado o negócio de outorga de poderes representativos (art. $1364^{\circ}$, $\S$ único). Por fim, deve-se destacar o preceito constante do artigo $1366^{\circ}$, por meio do qual se prescreve a prorrogação "artificial" dos efeitos contratuais - a despeito da morte do mandante - durante o prazo necessário às primeiras diligências de seus herdeiros: ao contrário do que se depreende do artigo 823 do Código Comercial de 1833 ( $\$ 140$ ), a relação jurídica não subsiste indefinidamente, até o advento de uma contraordem (oriunda dos sucessores do principal); subtraído o seu fundamento ("posto que o mandato expire"), preceitua-se uma efêmera preservação - "ex vi legis" - daquilo que, ordinariamente, haveria de cair por terra ${ }^{124}$.

${ }^{124}$ A respeito da revogação do mandato, da exigência de restituição do instrumento de outorga de poderes representativos e da influência francesa quanto a este último aspecto, cf. nota de rodapé anterior - nota 118 em que tivemos a oportunidade de discorrer a respeito do tema (e apresentar as referências correspondentes). Por ora, cumpre apenas destacar a previsão constante do "caput" do artigo $1364^{\circ}$ do Código Civil de 1867, na qual se reconhece a possibilidade de revogação da avença mesmo na hipótese de cláusula contratual em sentido diverso ("o constituinte póde revogar, quando e como lhe aprouver, o mandato conferido, sem prejuizo de qualquer condição ou convenção em contrário"). Observe-se que temos aqui uma simplificação excessiva da questão, na medida em que se fundiram, em um único dispositivo, eficácias distintas derivadas de um mesmo negócio jurídico unilateral extintivo - que opera de maneira diversificada nos âmbitos da "procuração" (na acepção moderna da expressão) e do "mandato".

Com efeito, a matéria foi disciplinada pelo Código Civil de 1966 por meio de preceitos relativamente autonômos, situados nos artigos $265^{\circ}$ e $1170^{\circ}$ - note-se que seu artigo $1172^{\circ}$ dispõe tão somente sobre a obrigação de indenizar decorrente do negócio extintivo ilícito.

Assim, sob a perspectiva da "procuração" (negócio jurídico unilateral de outorga de poderes representativos), a alínea 2 do artigo $265^{\circ}$ do Código Civil em vigor pareceria, à primeira vista, inteiramente desnecessária "1. A procuração extingue-se quando o procurador a ela renuncia, ou quando cessa a relação jurídica que lhe serve de base, excepto se outra for, neste caso, a vontade do representado. 2. A procuração é livremente revogável pelo representado, não obstante convenção em contrário ou renúncia ao direito de revogação. 3. Mas, se a procuração tiver sido conferida também no interesse do procurador ou de terceiro, não pode ser revogada sem acordo do interessado, salvo ocorrendo justa causa" - uma vez que, por uma questão de simetria técnica, seria necessária tão somente a manifestação do constituinte para a plena produção dos efeitos extintivos correlatos. Ora, tomando-se a primeira e última partes da alínea 2 em correlação com a alínea 3, depreende-se o intuito do legislador de resguardar, por exemplo, as hipóteses de procuração em causa própria - justificando-se, deste modo, a previsão expressa da "regra", a fim de se consagre, em seguida, sua "exceção". Todavia, a parte intermediária da alínea 2 ("não obstante convenção em contrário") tem efeitos sistemáticos profundamente nocivos, na medida em que permite a contaminação da eficácia do negócio jurídico unilateral por elementos que lhe são inteiramente estranhos - pertencentes, por sua vez, à avença que lhe esteja "funcionalmente" acoplada (vale dizer, o "mandato"). Aliás, parece-nos que F. A. PIRES DE LIMA e J. de M. ANTUNES VARELA incorrem em equívoco ao sustentar uma proibição legal à revogação na hipótese da alínea 2: "expressamente, até, se não admite a renúncia ao direito de revogação ou o seu afastamento por cláusula contratual” (Código cit. (nota 119), p. 246); no mesmo sentido, I. GALVÃO TELLES afirma que "a lei vai ao ponto de proibir a renúncia ao direito de revogar a procuração ou de clausular o afastamento desse direito" (Manual cit. (nota 118), p. 440). Na verdade, a renúncia à revogação bem como seu afastamento contratual - não nos parecem proibidos pela disposição legal: simplesmente não serão hábeis a impedir a livre revogação pelo constituinte - resolvendo-se a questão em perdas e danos (à moda da responsabilidade civil tradicional). Hipótese diversa é a da previsão de ineficácia do negócio extintivo, estatuída pela alínea 3, e considerada gravosa por J. de O. ASCENSÃO: "não se compreende a imposição de um vínculo, mesmo com a ressalva da demonstrabilidade de uma justa causa de revogação" 


\section{$\S$ 147. Disposições sobre o mandato mercantil consoante o Código}

Comercial de 1888. Conquanto ordinariamente lícita a recusa à oferta de mandato, o Código de 1888 prescreve ao comerciante o dever de providenciar as diligências conservativas indispensáveis à preservação dos efeitos que lhe tenham sido enviados pelo proponente (arts. $234^{\circ}$ e $232^{\circ}, \S 2^{\circ}$ ). Todavia, uma vez aceita a proposta, despontam ao mandatário variadas atribuições, com relação às quais a contribuição do legislador foi bastante profícua; assim, especificamente quanto às mercadorias que lhe foram confiadas, deve o agente: examiná-las (por ocasião de seu recebimento), informando ao mandante qualquer discrepância entre o seu estado de fato e as informações constantes das cautelas correspondentes (art. $235^{\circ}$, caput); conservá-las, seja por meio das medidas assecuratórias usuais (art. $236^{\circ}$ ), seja mediante vistorias periódicas, acompanhadas de informação ao

(Teoria cit. (nota 118), pp. 306-307); neste último caso, o preceito impede que o negócio jurídico extintivo surta seus ordinários efeitos - ressalvada a exceção legal ("justa causa").

Ora, se a "livre" revogabilidade do negócio de outorga de poderes deflui de sua própria natureza unilateral, tal conclusão não pode ser estendida, obviamente, ao contrato de mandato. Se este também é "livremente revogável" - conforme prescreve o seu artigo $1170^{\circ}$-, isso se dá por outras razões, provenientes da "causafunção" - e não da estrutura - do vínculo jurídico estabelecido entre os sujeitos envolvidos. Assim, prejudicada a relação de confiança havida entre as partes, não seria razoável compelir o mandante à manutenção do vínculo contratual, mesmo que tenha sido pactuada sua irrevogabilidade. Eis aí a relação existente entre os artigos $1170^{\circ}$ ("1. o mandato é livremente revogável por qualquer das partes, não obstante convenção em contrário ou renúncia ao direito de revogação. 2. se, porém, o mandato tiver sido conferido também no interesse do mandatário ou de terceiro, não pode ser revogado pelo mandante sem acordo do interessado, salvo ocorrendo justa causa") e $1172^{\circ}$ ("a parte que revogar o contrato deve indemnizar a outra do prejuízo que esta sofrer: a) se assim tiver sido convencionado; b) se tiver sido estipulada a irrevogabilidade ou tiver havido renúncia ao direito de revogação; c) se a revogação proceder do mandante e versar sobre mandato oneroso, sempre que o mandato tenha sido conferido por ecrto tempo ou para determinado assunto, ou que o mandante o revogue sem a antecedência conveniente; d) se a revogação proceder do mandatário e não tiver sido realizada com a antecedência conveniente") do Código Civil de 1966: prescreve-se a livre revogabilidade, uma vez que derivada a avença de uma confiança recíproca entre os envolvidos; no entanto, se fora pactuada a irrevogabilidade (ou tendo havido prévia renúncia ao direito de revogação), desponta - como via natural - a responsabilidade contratual (artigo $1172^{\circ}$ ), e não a preservação compulsória do liame.

De todo modo, teremos a oportunidade de voltar ao assunto mais adiante, ao analisarmos o regime jurídico correspondente no âmbito do direito brasileiro.

Quanto à repercussão da morte do mandante sobre a relação jurídica mantida com o mandatário, há que se observar que a orientação assumida pelo artigo $1366^{\circ}$ do Código Civil de 1867 destoa daquela adotada pelo legislador comercial pouco mais de três décadas antes; em lugar de prescrever a subsistência do vínculo por prazo indeterminado - até a superveniência de contraordem dos herdeiros do principal (arts. 823 e 839 do CCom/1833) - o legislador civil preferiu privilegiar os interesses do "de cujus" - uma vez que se trata de contrato destinado a viabilizar uma "gestão colaborativa" - por meio de uma proteção precária conferida aos seus sucessores: "posto que o mandato expire pela morte do constituinte, deve, em tal caso, o mandatario continuar na gerancia, em quanto os herdeiros não proverem sobre o negocio, se do contrário lhes podér resultar algum prejuizo". No mesmo sentido, cf. o art. $1175^{\circ}$ (parte final) do CC/1966.

A respeito das disposições do Código Civil de 1867 referidas na represente nota de rodapé, cf. J. DiAS FERREIRA, Codigo cit. (nota 115), pp. 38-39; L. da CUNHA GonÇALVES, Tratado cit. (nota 115), pp. 666-672 e 675-679; e J. TAVARES, Os Princípios cit. (nota 118), p. 442. No âmbito do Código Civil em vigor, cf. A. Neto - H. A. Martins, Código cit. (nota 116), pp. 121 e 660-662; F. A. Pires De LiMA - J. de M. ANTUNES VARELA, Código cit. (nota 119), pp. 246-247; M. J. de AlMEIDA CosTA, Noções cit. (nota 116), pp. 272-273; J. de O. AsCEnSÃo, Teoria cit. (nota 118), pp. 305-307; e I. GALVÃo Telles, Manual cit. (nota 118), pp. 440-441. 
principal na hipótese de deterioração (art. 237º); e vendê-las, em caso de risco de perecimento iminente, ensejador de providências urgentes (art. $235^{\circ}, \S$ único). Além disso, o mandatário deve praticar todos os atos - inclusive os instrumentais inexpressos (art. 233 , parte final) - inerentes à adequada gestão que lhe fora cometida: efetuando por si próprio, assim, os adiantamentos espontaneamente assumidos por ocasião da celebração do ajuste (art. $243^{\circ}, \S 3^{\circ}$ ); ademais, deve proporcionar ao mandante informação célere e tempestiva sobre o estado da gestão (arts. $239^{\circ}$ e $240^{\circ}$ ), corroborada por uma detalhada prestação final de contas, a respeito da qual o silêncio do principal implicará aprovação tácita (art. $240^{\circ}$, parte final). Já no que concerne ao mandante, cumpre destacar seu dever de remunerar o cumprimento parcial da incumbência (art. $246^{\circ}$ ), bem como sua responsabilidade ordinária pela provisão de fundos - sob pena, inclusive, de suspensão da execução por parte do agente (art. $243^{\circ}, \S \S 1^{\circ}$ e $2^{\circ}$ ), a quem se atribuem privilégios creditórios em caso de adiantamentos espontâneos (art. $247^{\circ}$ ). Por fim, merece menção especial a previsão de aceitação da proposta de mandato pela maioria de seus destinatários (art. 244, § único); bem como a consagração da ineficácia das instruções contratuais perante terceiros, ressalvada a hipótese de seu conhecimento comprovado (art. $\left.242^{\circ}\right)^{125}$.

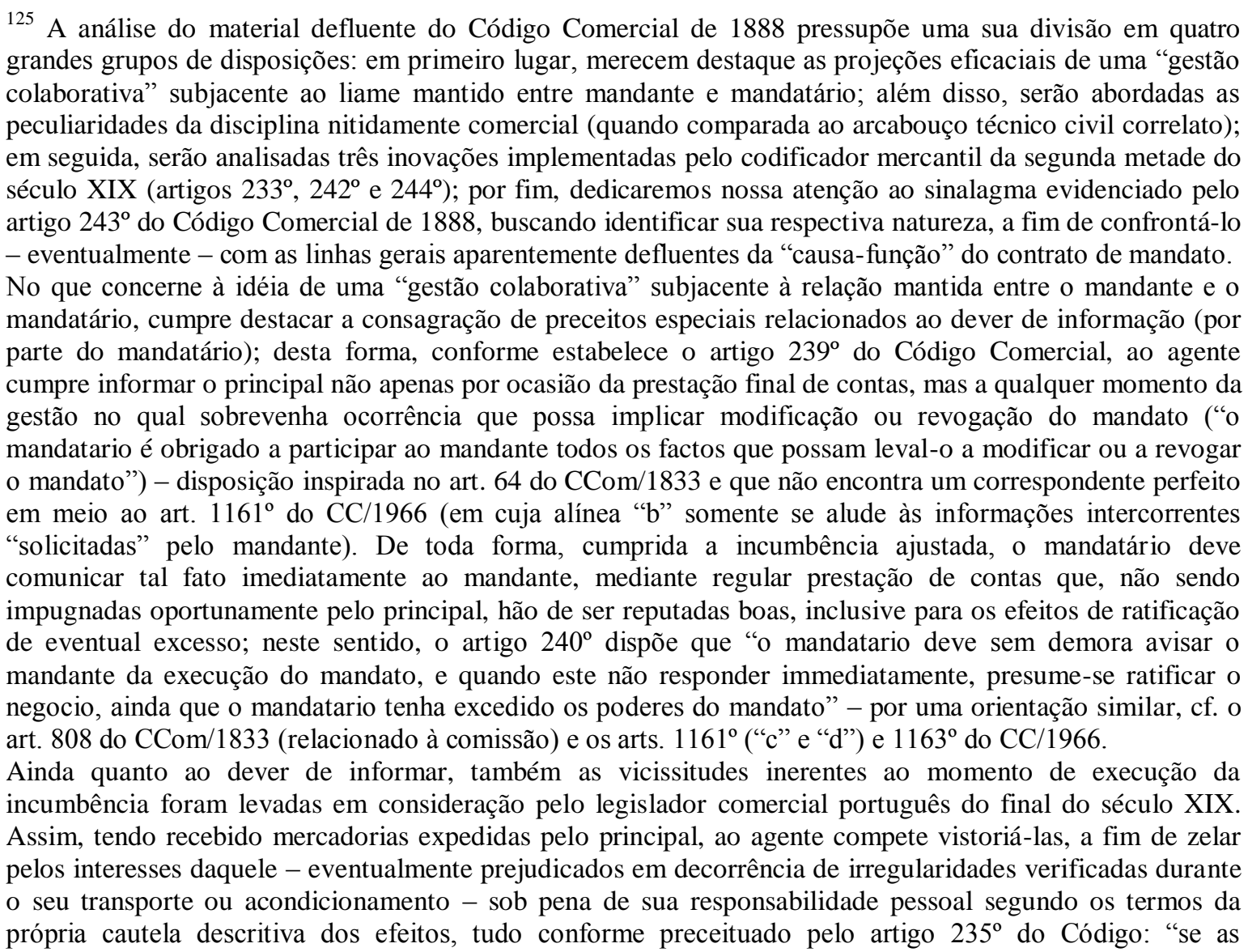


mercadorias que o mandatario receber por conta do mandante apresentarem signaes visiveis de damnificações, soffridas durante o transporte, deve aquelle praticar os actos necessarios à salvaguarda dos direitos d'este, sob pena de ficar responsavel pelas mercadorias recebidas, taes quaes constarem dos respectivos documentos. $\S$ único. se as deteriorações forem tais que exijam providências urgentes, o mandatário poderá fazer vender as mercadorias por corretor ou judicialmente" - note-se que tal disposição se inspirou nos arts. 71 e 72 do CCom/1833 (relacionados à comissão). No mesmo sentido, uma vez recebido o material pelo agente, o Código Comercial de 1888 prescreveu, por seu artigo $237^{\circ}$, o dever de o vistoriar periodicamente ("o mandatario, seja qual fôr a causa dos prejuizos em mercadorias que tenha em si de conta do mandante, é obrigado a fazer verificar em fórma legal a alteração prejudicial ocorrente e avisar o mandante") - aproveitando-se, para tanto, do art. 70 do CCom/1833 (também inserido em meio às disposições relativas à comissão).

A respeito da custódia das mercadorias confiadas ao mandatário - conforme estabelece o artigo $236^{\circ}$ do Código Comercial de 1888 - seus deveres não podem ser tomados como equivalentes aos de um depositário; além da guarda, conservação e vigilância dos bens entregues, ao agente incumbe, inclusive, a celebração do corrente contrato de seguro - dever do qual somente se desoneraria em caso de manifestação inequívoca do principal (expressa ou tácita) em sentido contrário. Neste sentido, assim dispõe o referido dispositivo legal: "o mandatario é responsavel, durante a guarda e conservação das mercadorias do mandante pelos prejuizos não decorrentes do decurso do tempo, caso fortuito, força maior ou vicio inherente á natureza da cousa. $\S$ único. O mandatario deverá segurar contra risco de fogo as mercadorias do mandante, ficando este obrigado a satisfazer o respectivo premio, com as mais despezas, deixando somente de ser responsavel pela falta e continuação do seguro, tendo recebido ordem formal do mandante, para não effectuar, ou tendo elle recusado a remessa de fundos para pagamento do premio". Observe-se que o legislador, novamente, tomou como modelo o arcabouço instituído para a disciplina da comissão pelo Código Comercial de 1833 (arts. 68, 69, 84, 85 e 86$)$

Em contrapartida, os desembolsos promovidos pelo mandatário - em atenção aos interesses do mandante também deveriam estar cercados de uma maior atenção legislativa. Desta forma, o Código Comercial de 1888 estendeu ao mandato um conjunto de regras que, de conformidade com a legislação comercial anterior, somente se encontrava articulado a propósito da comissão (cf. arts. 49, 50 e 51 do CCom/1833). Aliás, eis o teor de seu artigo $247^{\circ}$, por meio do qual se atribuem privilégios aos créditos de titularidade do agente perante o seu principal: "o mandatario commercial gosa dos seguintes privilegios mobiliarios especiaes: $1^{\circ}$. Pelos adiantamentos e despezas que houver feito, pelos juros das quantias desembolsadas, e pela sua remuneração, - nas mercadorias a elle remettidas de praça diversa para serem vendidas por conta do mandante, e que estiverem á sua disposição em seus armazens ou em deposito publico, e n'aquellas que provar com a guia de transporte haverem-lhe sido expedidas, e a que taes creditos respeitarem; $2^{\circ}$. Pelo preço das mercadorias compradas por conta do mandante, - nas mesmas mercadorias, emquanto se acharem á sua disposição nos seus armazens ou em deposito publico; 3. Pelos creditos constantes dos numeros antecedentes, no preço das mercadorias pertencentes ao mandante, quando estas hajam sido vendidas. $\S$ Os creditos referidos no $\mathrm{n}^{\circ} 1$ preferem a todos os creditos sobre o mandante, salvo sendo provenientes de despezas de transporte ou seguro, quer hajam sido constituidos antes quer depois das mercadorias haverem chegado á posse do mandatario".

Além das referidas projeções eficaciais da idéia de uma "gestão colaborativa", o Código Comercial de 1888 denuncia algumas adaptações do instituto ao ambiente mercantil. Novamente à custa de uma influência da disciplina precedente relacionada ao contrato de comissão (cf. o art. 56 do CCom/1833), o legislador atribuiu - por meio do artigo $234^{\circ}$ - ao mero destinatário da oferta de mandato deveres provisionais intimamente relacionados à preservação dos interesses do "pretenso" mandante: "o comerciante que quiser recusar o mandato comercial que lhe é conferido, deve assim communical-o ao mandante pelo modo mais rapido que lhe fôr possivel, sendo, todavia, obrigado a praticar todas as diligencias de indispensavel necessidade para a conservação de quaesquer mercadorias que lhe hajam sido remettidas, ate que o mandante proveja. $\S 1^{\circ}$. Se o mandante nada fizer depois de recebido o aviso, o commerciante a quem hajam sido remettidas as mercadorias recorrerá ao juizo respectivo para que se ordene o deposito e segurança d'ellas por conta de quem pertencer e a venda das que não fôr possivel conservar, ou das necessarias para satisfação das despesas incursas. $\S 2^{\circ}$ A falta de cumprimento de quaisquer das obrigações constantes d'este artigo e seu paragrapho, sujeita o commerciante à indenisação de perdas e damnos". Em contrapartida, o artigo $232^{\circ}, \S 2^{\circ}$ atribuiu uma remuneração proporcional ao destinatário - à vista dos encargos suportados com a tomada de tais providências (" $\$ 2^{\circ}$. se o commerciante não quizer acceitar o mandato, mas tiver apesar disso de praticar as diligencias mencionadas no art. $234^{\circ}$, terá ainda assim direito a uma remuneração proporcional ao trabalho que tiver tido").

Tendo-se em conta, ainda, as peculiaridades da variante mercantil do instituto, nota-se que de sua onerosidade "natural" decorreu a disposição constante do artigo $246^{\circ}$ do Código Comercial de 1888 , por 
meio da qual se determinou a remuneração proporcional - da atividade desenvolvida pelo agente - quando se tenha verificado a extinção precoce da relação jurídica contratual: "terminando o mandato por morte ou interdicção de um dos contrahentes, o mandatario, seus herdeiros ou representantes terão direito a uma compensação proporcional ao que teriam de receber no caso de execução completa".

Já no que concerne às inovações implementadas pelo legislador mercantil do final do século XIX, devem ser destacadas três disposições principais: a) em primeiro lugar, aquela constante do artigo $244^{\circ}$, $\S$ único, em virtude da qual se reconhece a possibilidade de aceitação do mandato por tão somente alguns - desde que constituam maioria - dos destinatários da oferta de contrato ("se houver declaração de deverem obrar conjunctamente e se o mandato não fôr acceito por todas, as que o acceitarem, se constituirem maioria, ficam obrigadas a cumpril-o"); b) além disso, por força da parte final do artigo $233^{\circ}$ (inspirada nos arts. 796 e 799 do CCom/1833), reconheceu-se ao mandatário - a propósito da modalidade "especial" do instituto - a possibilidade de praticar todos os atos instrumentais necessários à plena execução da incumbência confiada (a respeito de sua repercussão posterior, cf. o art. 1159, 2 do CC/1966); c) por fim, ao tornar inoponíveis ao terceiro - salvo em caso de conhecimento comprovado - as instruções relativas ao mandato ("o mandatario deve, sendo-lhe exigido, exhibir o mandato escripto aos terceiros com quem contratar, e não poderá oppôrlhes quaesquer instrucções que houvesse recebido em separado do mandante, salvo provando que tinham conhecimento d'ellas ao tempo do contrato"), o artigo $242^{\circ}$ exprimiu uma regra latente no sistema de dissociação entre "mandato" e "representação" - que serviu de precedente ao artigo $269^{\circ}$ do Código Civil em vigor, o qual por sua vez a estendeu à hipótese da simples possibilidade de ciência ("se a outra parte conhecia, ou devia conhecer o abuso").

Finalmente, cumpre-nos analisar o artigo $243^{\circ}$ do Código, por meio do qual foi atribuída ao mandatário - na hipótese de ausência (original ou superveniente) de provisão - uma exceção (material) voltada à suspensão do cumprimento da incumbência cometida: "o mandante é obrigado a fornecer ao mandatario os meios necessarios á execução do mandato, salva convenção em contrario. $\S 1^{\circ}$. Não será obrigatorio o desempenho de mandato que exija provisão de fundos, embora haja sido acceito, enquanto o mandante não pozér á disposição do mandatario as importancias que lhe forem necessarias. $\S 2^{\circ}$. Ainda depois de recebidos os fundos para a execução do mandato, se fôr necessaria nova remessa e o mandante a recusar, póde o mandatario suspender as suas diligencias. $§ 3^{\circ}$. Estipulada a antecipação de fundos por parte do mandatario, fica este obrigado a suppril-os, excepto no caso de cessação de pagamentos ou fallencia do mandante". Notese que o intuito tutelar do legislador alcançou mesmo alguns dos casos de antecipação convencionalmente atribuída ao próprio agente (cessação de pagamentos ou falência do principal).

Tal disposição - influenciada, quanto a alguns de seus aspectos, pelo art. 58 do CCom/1833 - surtiu evidentes efeitos sobre a disciplina alinhavada pelo legislador civil novecentista (ainda que a abrangência do art. $1168^{\circ}$ do CC/1966 seja restrita aos "meios necessários à execução do mandato"). Contudo, deve-se ter cautela ao analisar o alcance da regra, a fim de não se baralharem os conceitos de "sinalagma genético" e de "sinalagma funcional". Com efeito, um dos principais objetivos deste estudo é o de descaracterizar um sinalagma "genético" no âmbito da variante onerosa do instituto (além de restringir o alcance da modalidade funcional do conceito nos quadros do tipo contratual analisado). No entanto, o artigo $243^{\circ}$ do Código Comercial de 1888 se reporta à outra modalidade de vínculo "interprestacional": em virtude de uma intervenção artificial, o legislador instituiu um liame de natureza funcional entre os deveres de provisão (do mandante) e de execução da incumbência (do mandatário) - atribuindo-se ao agente uma posição favorecida quanto à ordem de cumprimento das prestações. Quanto à dicotomia acima mencionada, eis a lição de I. GALVÃO TELLES: “chama-se contrato sinalagmático aquele de que nascem obrigações para ambas as partes, unidas uma à outra por um vínculo de reciprocidade, denominado, desde o Direito Romano, sinalagma; daí falar-se de contratos sinalagmáticos. Este vínculo surge logo no momento da celebração do contrato, como ligação entre as suas obrigações típicas (sinalagma genético) e perdura ao longo da existência do contrato, acompanhando-o nas suas vicissitudes (sinalagma funcional). O sinalagma genético significa que, na génese do contrato, a obrigação assumida por uma das partes encontra a sua razão de ser nas obrigações assumidas pela outra. O sinalagma funcional significa, por sua vez, que as obrigações de ambos os contraentes permanecem unidas e, nomeadamente, têm de ser cumpridas ao mesmo tempo, visto o cumprimento de cada uma constituir pressuposto do cumprimento da outra" (Manual cit. (nota 118), p. 485).

Quanto às disposições do Código Comercial de 1833 referidas, cf. I. de SoUSA DuARTE, Diccionario cit. (nota 115), pp. 72-74, 76 e 255; J. FERREIRA BORGES, Diccionario cit. (nota 115), pp. 87 (sobre a responsabilidade do mandatário quanto à conservação dos bens confiados pelo mandante); e D. P. F. de SAMPAIO PIMENTEL, Annotações cit. (nota 115), pp. 37-40, 42-44, 60-62, 69-74 e 80-83. Pela doutrina produzida sob a égide do Código Comercial de 1888 (a respeito dos dispositivos referidos nesta nota de rodapé), cf. F. A. da VEIGA BEIRÃO, Direito Commercial cit. (nota 115), pp. 84-86; A. ANTHERO, Comentario cit. (nota 115), pp. 441-462; L. da CunHA GonÇALVES, Comentário cit. (nota 115), pp. 1-45; A. Menezes Cordeiro, Manual cit. (nota 115), pp. 480-485; J. de D. PinheIRo FARINHA, Código Comercial 
$\S$ 148. O Código Civil de 1966 e a dissociação entre o contrato de mandato e a representação negocial. O Código Civil Português de 1966 promoveu uma dissociação sistemática entre o "mandato" e a "representação negocial"; com efeito, em virtude de uma disciplina autônoma articulada em meio à Parte Geral, a eficácia representativa direta foi objeto de um tratamento próprio por parte do legislador - ainda que funcionalmente vinculada ao contrato de mandato, por meio de sua variante "voluntária". Em linhas gerais, buscou-se reconhecer a possibilidade de percussão imediata da esfera jurídica do constituinte por seu procurador, desde que sua atuação se tenha verificado dentro dos limites estipulados no negócio de atribuição (art. 258 ): caso contrário, a declaração promovida pelo agente é ineficaz perante o principal, salvo o caso de ratificação tempestiva e sob a mesma forma do negócio de outorga - anterior à revogação (ou rejeição) por parte do terceiro-destinatário (art. 268 ); note-se que solução idêntica é preconizada na hipótese de "abuso" de representação, desde que qualificado pela ciência (efetiva ou presumível) deste último (art. $269^{\circ}$ ). Por sua vez, a definição conferida ao mandato pelo artigo $1157^{\circ}$ é inteiramente independente da eficácia representativa que - em uma de suas modalidades - pode lhe ser acoplada; hipótese na qual, aliás, o mandatário "tem o dever" de agir em nome do madante (art. 1178 ). Já no caso de "mandato sem representação" (art. $1180^{\circ}$ ), o agente vincula tão somente a si próprio - tanto ativa quanto passivamente (arts. $1181^{\circ}, 1$ e $1182^{\circ}$ ) - por meio dos atos integrantes de sua respectiva gestão; contudo, por força de expressa disposição legal, o exercício de posições subjetivas ativas de natureza obrigacional pode ser realizado diretamente pelo mandante, independentemente de negócio traslativo praticado pelo mandatário (art. 1181², 2) exceção à qual se deve acrescentar a imunidade executiva dos bens que "provisoriamente" integram o patrimônio do agente, uma vez que destinados à ulterior alienação ao principal (art. $\left.1184^{\circ}\right)$. Assim, o elemento representativo é inteiramente desvinculado da "causafunção" do referido tipo contratual - à qual se atrela, a partir de então, a natureza “essencialmente" jurídica de seu objeto potencial (art. 1157º ${ }^{126}$.

Português (Breves notas de legislação, jurisprudência e doutrina), Lisboa, Livraria Morais Editora, 1963, pp. 175-182; e o estudo alentado de M. J. da C. GoMES (Contrato de mandato comercial: questões de tipologia e regime, in As operações comerciais - trabalhos apresentados na disciplina de Direito Comercial do Curso de Mestrado de 1983/84 da Faculdade de Direito de Lisboa, sob a orientação do Prof. Doutor Oliveira Ascensão, Coimbra, Almedina, 1988, pp. 467-564). Finalmente, no âmbito do Código Civil de 1966, cf. A. Neto - H. A. MARTins, Código cit. (nota 116), pp. 657-658 e 660; e M. J. de AlmeidA Costa, Noções cit. (nota 116), p. 272.

126 A representação negocial foi galgada pelo Código Civil de 1966 ao patamar de instituto jurídico "estruturalmente" autônomo - ainda que tenham sido mantidos certos laços expressos que a unam ao 
mandato, tal como evidenciam os seus artigos $265^{\circ}, 1$ e $269^{\circ}$. Com efeito, sob o ponto de vista sistemático, cumpre ainda destacar o seu respectivo enquadramento: tal arcabouço técnico foi articulado no Livro I (Parte Geral), Título II (Das relações jurídicas), Subtítulo III (Dos factos jurídicos), Capítulo I (Negócio jurídico), Secção I (Declaração negocial), Subsecção VI (Representação).

Ao aludirmos - tão somente - a uma autonomia "estrutural" em relação ao mandato, pretendemos evidenciar a origem autônoma das posições jurídicas de "constituinte" e "procurador" - em relação às correlatas de "mandante" e "mandatário". Com efeito, mais adiante teremos a oportunidade de oferecer acepções distintas às dicotomias mandante/mandatário, constituinte/procurador, principal/agente e representado/representante. De todo modo, cabe observar desde logo que a autonomia "estrutural" não implica completa desvinculação "funcional": conquanto as relações jurídicas decorrentes da celebração do contrato de mandato e do negócio jurídico de outorga de poderes (representativos) ostentem peculiaridades que as tornam inconfundíveis (sob o ponto de vista de sua origem, desenvolvimento e extinção), constata-se, no mais das vezes, um surgimento bem como uma existência - concomitante de tais espectros eficaciais. Em outras palavras, tomando-se em conta o fato de que tais institutos nos revelam as vestes jurídicas que envolvem uma única operação econômica, é desta que defluem as principais determinantes do surgimento, do desenvolvimento e da extinção dos vínculos artificialmente construídos pelo Direito. Assim sendo, parece-nos claro que a autonomia estrutural preconizada oferece duas grandes utilidades: por um lado, nos revela a possibilidade de um tratamento diferenciado das eficácias jurídicas defluentes de cada um dos negócios jurídicos mencionados; além disso, viabiliza-nos o (re)conhecimento do "mandato sem representação" - figura relativamente antiga, mas que ainda hoje ostenta um indiscutível interesse prático. Por outro lado, não se tenha dúvida de que "normalmente" tais eficácias exsurgem de modo simultâneo na vida jurídica; no entanto, como o "ordinário" não se confunde com o "necessário", mostra-se de todo conveniente a dissociação entre tais institutos, a fim de que não se baralhem aspectos distintos de uma realidade jurídica única.

No que concerne ao exercício da procuração, o artigo $258^{\circ}$ do Código Civil em vigor estabelece que "o negócio jurídico realizado pelo representante em nome do representado, nos limites dos poderes que lhe competem, produz os seus efeitos na esfera jurídica deste último". Com isso, temos o expresso reconhecimento legislativo da eficácia representativa direta atrelada à atuação do procurador (desde que observados os limites estabelecidos pelo negócio jurídico de outorga de poderes); assim, é na "procuraçãoinstrumento" que poderão ser divisados os limites mencionados pelo legislador português no referido dispositivo legal. Observe-se que diante da alusão a um ato posterior celebrado pelo procurador - "o negócio jurídico realizado" - mostra-se oportuno o emprego dos termos "representante" e "representado", eis que ultrapassado o plano das relações internas, havidas unicamente entre o "procurador" e seu "constituinte"; em lugar disso, envolve-se na operação um terceiro, ao qual respeita unicamente o aspecto representativo da eficácia defluente da atuação do procurador.

Já no que toca ao "excesso" praticado pelo agente, cabe-nos destacar que o assunto foi abordado em diversas notas de rodapé anteriores (notas 116, 119 e 122). Desta forma, interessa-nos somente reiterar a nova solução conferida ao problema pelo legislador português novecentista (artigo $268^{\circ}$ ): em vez da sanção de invalidade preconizada por seu antecessor (cf. arts. $1338^{\circ}$ e $1351^{\circ}$ do CC/1867), deu-se preferência à ineficácia relativa da gestão ("o negócio que uma pessoa, sem poderes de representação, celebre em nome de outrem é ineficaz em relação a este") - suscetível, assim, de ratificação pelo principal (ao contrário da "nulidade" anteriormente cominada à hipótese).

Já no que concerne ao contrato de mandato, parece-nos importante destacar que de sua definição - instituída pelo artigo $1157^{\circ}$ ("mandato é o contrato pelo qual uma das partes se obriga a praticar um ou mais actos jurídicos por conta da outra") - não se extrai uma eficácia representativa (direta) de caráter necessário. Em lugar disso, esta última desponta tão somente atrelada - sob a perspectiva "funcional" - a uma de suas variantes: o "mandato representativo". Com efeito, nesta específica modalidade há uma conjugação entre as disciplinas estatutídas nos Livros I (Parte Geral) e II (Direito das Obrigações) do Código Civil, tal qual se depreende de seu artigo $1178^{\circ}, 1$. Note-se, aliás, que na alínea 2 de tal dispositivo há uma retomada da eficácia jurídica estritamente afeta às relações mantidas entre o "mandatário" e seu "mandante": preceituando-se que nesta variante do instituto a atuação do mandatário em seu próprio nome - quando não autorizada - constitui ilícito contratual - ainda que "ordinariamente" inoponível a terceiros ("o mandatário a quem hajam sido conferidos poderes de representação tem o dever de agir não só por conta, mas em nome do mandante, a não ser que outra coisa tenha sido estipulada"). De todo modo, não houve previsão específica, neste caso, de uma ação adjudicatória, tal como se depreende do Código Comercial de 1833, o qual por seu artigo 777 estabelecia que "quando (...) o mandatario, não obstante o mandato, contractou expressamente em seu proprio nome, neste caso o dominio e posse da cousa comprada não se adquire para o mandante: mas compete-lhe a acção directa do mandato para obrigar o mandatario, que faltou á fé, a restituir-lhe as fazendas compradas, offerecido o preço, nos termos legislados no titulo - Da compra e venda". 
Por sua vez, quanto ao "mandato sem representação" foi articulada uma cuidadosa disciplina, por meio da qual se estabeleceu que - via de regra - da atuação do mandatário não decorreriam (ao mandante) direitos e/ou deveres diretamente oponíveis a terceiros. Eis o sentido que se deve emprestar aos artigos $1180^{\circ}$ ("o mandatário, se agir em nome próprio, adquire os direitos e assume as obrigações decorrentes dos actos que celebra, embora o mandato seja conhecido dos terceiros que participem nos actos ou sejam destinatários destes"), $1181^{\circ}, 1$ ("o mandatário é obrigado a transferir para o mandante os direitos adquiridos em execução do mandato") e $1182^{\circ}$ ("o mandante deve assumir por qualquer das formas indicadas no no 1 do artigo $595^{\circ}$, as obrigações contraídas pelo mandatário em execução do mandato; se não puder fazê-lo deve entregar ao mandatário os meios necessários para as cumprir ou reembolsá-lo do que este houver despendido nesse cumprimento") do Código Civil vigente. Com isso, cria-se um arcabouço técnico propício à "blindagem" da esfera jurídica do mandante, à vista da exposição "imediata" do patrimônio do mandatário - em caso de investidas de terceiros. Destaque-se que se tal "blindagem" é plenamente eficiente sob a perspectiva passiva (tornando inatingível por terceiros o patrimônio do mandante), tal característica é mitigada quando se tem em conta os direitos adquiridos pelo agente; com efeito, por meio dos artigos $1181^{\circ}, 2$ ("relativamente aos créditos, o mandante pode substituir-se ao mandatário no exercício dos respectivos direitos") e $1184^{\circ}$ ("os bens que o mandatário haja adquirido em execução do mandato e devam ser transferidos para o mandante nos termos do $\mathrm{n}^{\mathrm{o}} 1$ do art. $1181^{\circ}$ não respondem pelas obrigações daquele, desde que o mandato conste de documento anterior à data da penhora desses bens e não tenha sido feito o registo da aquisição, quando esta esteja sujeita a registo"), torna-se evidente a preponderância dos interesses do mandante nos casos de frustração de confiança (artigo $1181^{\circ}$ ) ou comportamento desidioso do mandatário (artigo $1184^{\circ}$ ).

Por fim, é oportuno ressaltar que a dissociação entre "mandato" e "representação negocial" (direta) não se deu à custa da edificação de compartimentos absolutamente estanques; se assim o tivesse sido, a eficácia do contrato de mandato jamais poderia produzir efeitos no contexto representativo (vale dizer, diante de terceiros). De fato, via de regra, as instruções inerentes ao negócio de incumbência somente interessam ao mandante e ao seu mandatário, não surtindo quaisquer efeitos perante terceiros; contudo, por expressa disposição legal, o preceito instituído pelo artigo $242^{\circ}$ do Código Comercial de 1888 foi estendido ao âmbito do direito civil (art. $269^{\circ}$ do CC/1966): “o disposto no artigo anterior [ineficácia do negócio perante o "representado"] é aplicável ao caso de o representante ter abusado dos seus poderes, se a outra parte conhecia ou devia conhecer o abuso".

Por uma definição de "abuso", eis a de F. A. PIREs De Lima e J. de M. Antunes VARela: "há abuso dos poderes de representação, quando o representante, actuando embora dentro dos limites formais dos poderes que lhe foram outorgados, utiliza conscientemente esses poderes em sentido contrário ao seu fim ou às indicações do representado" (Código cit. (nota 119), p. 249). Há que se observar, contudo, que o legislador civil novecentista não se contentou em preceituar tal ineficácia (relativa) na hipótese de conhecimento comprovado do terceiro (a respeito da atuação do "representante" de maneira contrária às instruções recebidas); foi ainda mais longe, ao prescrever a aplicação de tal sanção caso simplesmente fosse de se esperar tal ciência por parte do terceiro.

Eis as linhas gerais, portanto, da relação mantida entre o "contrato de mandato" e a "representação negocial" (direta) segundo o Código Civil português atualmente em vigor. Diante do declínio de um mandato essencialmente representativo, exsurge um tipo novo, que a despeito da mesma nomenclatura, guarda uma identidade própria, inconfundível com aquela que se podia depreender do mandato alinhavado pelo Código Civil de 1867. Até sua entrada em vigor, o mandato compreendia a atuação do mandatário em nome do mandante, prevalecendo a sua função de viabilizar a substituição do principal, por meio da atuação de um mandatário-representante. Com o advento da nova ordem, todavia, o tipo contratual homônimo é despojado da eficácia representativa que até então lhe fora essencial; o mandato volta a regular a atuação em prol de outrem ("por conta") - embora não necessariamente em nome alheio. É aí que surge uma pergunta que nos parece imprescindível à depuração de sua "causa-função" típica: o mandato se volta simplesmente à "atuação" em prol de outrem? Ou implica a "gestão" (incumbida) de um negócio alheio?

Caso a resposta propenda à prevalência da segunda hipótese, regras defluentes dos "iudicia bona fidei”" gerais do direito romano ainda hoje seriam aplicáveis, desde que não contrariada qualquer disposição legal. Em outras palavras: pois bem, o legislador português do século XX extraiu do "mandato" a "representação direta" (que indevidamente nele havia sido introjetada por seu antecessor); com isso, as figuras do mandatário e do representante não mais se confundem (ao menos do ponto de vista técnico). Entretanto, o "procurador" teria sido equiparado ao "mandatário"? Ou ao "representante"? Note-se que buscamos, por meio desta análise histórica, investigar não só a relação mantida entre os institutos da "representação negocial" (direta) e do "mandato": cumpre-nos, ainda, indagar sobre a presença contemporânea - ainda que em estado latente - de uma autêntica "procuratio". Procuração tomada em sua acepção de relação jurídica gestória, defluente de prévia incumbência e voltada a uma finalidade distinta - conquanto "funcionalmente" 


\section{$\S 149$. "Princípios gerais" sobre a representação segundo o Código Civil}

de 1966; inovações concernentes à "representação voluntária". A eficácia representativa direta foi elevada à categoria de autêntico instituto jurídico pelo Código Civil de 1966. Revigorada a antiga acepção da "procuração" como "ato" (art. 262, 1 ), estabelece-se que a falta (ou o vício) da manifestação de vontade - bem como estados subjetivos relevantes deve ser apurada, ordinariamente, tomando-se em consideração tão somente a pessoa do próprio agente (art. $259^{\circ}$ ). Além disso, é cominada anulabilidade ao negócio celebrado pelo procurador consigo próprio, ainda que também atuasse como representante de terceiro (art. $\left.261^{\circ}\right)$; sanção afastada unicamente na hipótese de prévia autorização do constituinte - ou quando, por sua própria natureza, a avença excluísse a possibilidade de qualquer conflito de interesses (art. 261, 1 ). Finalmente, cumpre observar que, uma vez extinta a procuração, o agente deve restituir seu respectivo instrumento ao principal, independentemente do manejo de qualquer pretensão por parte deste último (art. $267^{\circ}$ ) preconizando-se, assim, orientação diversa daquela que prevalecera durante a vigência do art. $1364^{\circ}$ do Código Civil revogado ${ }^{127}$.

próxima - da mera "substituição": buscamos investigar a gestão incumbida, recoberta por disposições técnicas especiais, identificáveis na própria contextura do mandato contemporâneo.

De qualquer forma, tecnicamente afastados o "mandatário" do "representante", o legislador português optou por circunscrever o âmbito de aplicação do tipo à prática de "actos jurídicos por conta" alheia. Assim, ao contrário do sistema romano, que admitia sua utilização para revestir a atuação meramente material do mandatário (e teremos a oportunidade de observá-lo noutra ocasião), no sistema português vigente o "mandato" somente se presta à conclusão de atos jurídicos pelo agente. Seria esta a orientação adotada pelo sistema brasileiro? Teremos ensejo de voltar ao assunto mais adiante.

A propósito dos dispositivos legais referidos na presente nota de rodapé, cf. A. NeTO - H. A. MARTins, Código cit. (nota 116), pp. 119-123 e 663-665; F. A. Pires De Lima - J. de M. Antunes VARela, Código cit. (nota 119), pp. 240-250; M. J. de ALMEIDA CosTA, Noções cit. (nota 116), p. 274; J. de O. AsCENSÃo, Teoria cit. (nota 118), pp. 295 e 323-326; C. A. da Mota PINTO, Teoria cit. (nota 119), pp. 539, $542-543$ e 550; e I. GALVÃo TELLES, Manual cit. (nota 118), pp. 435-436 (sobre o "excesso de poderes" e a respeito do "abuso" praticado pelo procurador).

127 A respeito das diferentes acepções emprestadas ao termo "procuração" pelos Códigos Civis de 1867 e 1966, cf. as observações desenvolvidas em notas de rodapé anteriores (notas 116 e 119). Com efeito, cabenos apenas destacar, por ora, que a redação conferida ao artigo $262^{\circ}, 1$ do Código Civil vigente parece privilegiar o ato de atribuição de poderes representativos (em lugar do instrumento no qual tal negócio unilateral é documentado): "diz-se procuração o acto pelo qual alguém atribui a outrem, voluntariamente, poderes representativos".

Por sua vez, no que concerne aos defeitos da declaração de vontade (produzida à custa da intervenção de procurador), o artigo $259^{\circ}$ do Código Civil de 1966 prescreve que sua investigação, ordinariamente, deve se cingir à pessoa do representante, excetuados os casos em que o vício possa ser reconduzido às próprias instruções conferidas pelo constituinte ao seu procurador: "1. À excepção dos elementos em que tenha sido decisiva a vontade do representado, é na pessoa do representante que deve verificar-se, para efeitos de nulidade ou anulabilidade da declaração, a falta ou vício da vontade, bem como o conhecimento ou ignorância dos factos que podem influir nos efeitos do negócio. 2. Ao representado de má fé não aproveita a boa fé do representante". Cumpre-nos ressaltar, aliás, a expressa ressalva do legislador à má-fé do representado: com efeito, sua ciência a respeito de certa circunstância (que envolve o negócio) não se descaracteriza pela interferência de um representante que efetivamente a desconheça. Eis o exemplo fornecido por F. A. PIRES DE LIMA e J. de M. ANTUNES VARELA: “A dá indicações ao seu procurador para 


\section{$\S 150$. A eficácia do contrato de mandato segundo o Código Civil de 1966.}

Com relação à eficácia do mandato, poucas são as inovações de fundo implementadas pelo

Código Civil de 1966: além da previsão de entrega daquilo que foi recebido por conta do mandante, prescreve-se ao mandatário a restituição de eventual saldo da provisão de fundos que o principal promovera (art. $1161^{\circ}$, e); contudo, o agente é isento de qualquer responsabilidade quanto ao adimplemento das obrigações contraídas (por terceiros) durante

comprar certo livro a $B$, ignorando que esse livro não pertence a este. O procurador compra o livro. $A$ está de boa fé, embora o procurador conheça a verdade, porque a compra a $B$ daquele livro entra na esfera da sua determinação (...) nos termos, porém, do $n^{\circ} 2$, nunca a boa fé do representante aproveita ao representado de má fé. Assim, no exemplo referido, se o procurador ignorava que o livro não era do vendedor, mas $A$ o não ignorava, considera-se este de má fé. Há um desvio da regra precedente" (Código cit. (nota 119), pp. 241242).

De sua parte, o artigo $261^{\circ}$ do Código Civil de 1966 pretendeu proibir a prática do "negócio consigo mesmo": “1. É anulável o negócio celebrado pelo representante consigo mesmo, seja em nome próprio, seja em representação de terceiro, a não ser que o representado tenha especificadamente consentido na celebração, ou que o negócio exclua por sua natureza a possibilidade de um conflito de interesses. 2. Considera-se celebrado pelo representante, para o efeito do número precedente, o negócio realizado por aquele em quem tiverem sido substabelecidos os poderes de representação". Especificamente a respeito desta disposição, duas observações principais nos parecem necessárias: em primeiro lugar, deve-se destacar que tal preceito encontra antecedente histórico nos artigos 77 e 79 do Código Comercial de 1833, por meio dos quais se proibia a aquisição de efeitos pelo próprio comissário: "os comissarios não podem adquirir por si, nem por interposta pessoa, effeitos, cuja alheação lhes fôra confiada, sem consentimento expresso do proprietario delles (...) nos casos dos dous artigos precedentes não tem o comissario direito a perceber á commissão ordinaria: ella deverá ser constituida por pacto expresso; e na falta delle, ou não se accordando as partes, a provisão será reduzida á ametade da ordinaria". Em sentido similar, cf. o art. $274^{\circ}$ do CCom/1888.

Ora, posta de parte a questão concernente à sanção cominada (art. 79 do CCom/1833), deve-se ter em conta e esta é a segunda observação - que na situação prevista pelo art. 77 do CCom/1833 há autêntico "negócio consigo mesmo": neste caso, como o comissário negocia em seu próprio nome, quando figura como comprador pratica negócio em que também atua como vendedor (e não como seu representante), vislumbrando-se aí negócio consigo mesmo (na acepção estreita da expressão). Contudo, como o Código Civil de 1966 disciplinou a questão em meio à "representação", parece-nos oportuno destacar que, sob o prisma técnico, inexiste - em tal caso - negócio jurídico consigo mesmo: uma vez que o representante, tomado como terceiro ao contratar em seu nome, tem como contraparte o "representado" (e não a si próprio). De tal maneira, negócio consigo mesmo somente despontará em caso de "mandato sem representação", parecendo-nos equivocada a posição topográfica eleita pelo legislador para a abordagem do assunto.

Finalmente, quanto à revogação do mandato, cf. as observações articuladas em notas de rodapé anteriores (notas 118 e 124). De todo modo, parece-nos importante mencionar a alteração da disciplina concernente à restituição do instrumento de outorga de poderes ao constituinte. Com efeito, o art. $1364^{\circ}$ do CC/1867 preceituava que este último poderia exigi-la do procurador; desta forma, tão somente após a exigência exsurgiria, efetivamente, a obrigação de restituir. O Código Civil de 1966 (artigo 267º), a propósito, adotou disciplina distinta, prescrevendo o surgimento da obrigação tão logo verificada a causa de caducidade (independentemente do exercício de qualquer pretensão por parte do constituinte): "1. O representante deve restituir o documento de onde constem os seus poderes, logo que a procuração tiver caducado. 2. O representante não goza do direito de retenção do documento".

A respeito dos dispositivos do Código Civil de 1966 referidos na presente nota de rodapé, cf. A. NETO - H. A. MARTINS, Código cit. (nota 116), pp. 120-122; I. GALVÃo TELLES, Manual cit. (nota 118), pp. 430-434; J. de O. AsCEnsão, Teoria cit. (nota 118), pp. 297 e 321-323; J. de CASTRO MENDES, Teoria Geral do Direito Civil II, Lisboa, Associação Académica da Faculdade de Direito de Lisboa, 1978, pp. 286-288; F. A. PIRES DE Lima - J. de M. Antunes VARela, Código cit. (nota 119), pp. 241-244 e 248; e C. A. da MotA Pinto, Teoria cit. (nota 119), pp. 551-552. Note-se que a acepção emprestada por estes últimos autores à expressão "negócio consigo mesmo em sentido estrito" é diferente daquela lançada na presente nota de rodapé. De toda forma, voltaremos ao assunto ao abordarmos a disposição correspondente no âmbito do direito civil brasileiro em vigor. 
a sua gestão - ressalvadas as hipóteses de negligência, má-fé ou disposição expressa entre as partes $\left(\operatorname{art} 1183^{\circ}\right.$ ). Por sua vez, no que concerne à extinção do contrato, além da eficácia reflexa defluente da revogação (ou renúncia) da procuração (art. $1179^{\circ}$ ), estabelecem-se dois preceitos relacionados à pluralidade de sujeitos integrantes de um dos pólos da relação jurídica respectiva: em caso de plúrimos mandantes, exige-se o concurso de todos para a eficácia do negócio extintivo correspondente (art. 1173º); já no que toca ao mandato conjuntivo, preceitua-se que a causa de caducidade concernente a um dos mandatários se projeta sobre todo o liame (art. $1177^{\circ}$ ). Interessa ressaltar, finalmente, a corroboração da idéia de "gestão colaborativa" inerente ao vínculo: com efeito, o art. $1162^{\circ}$ estabelece que “o mandatário pode deixar de executar o mandato ou afastar-se das instruções recebidas, quando seja razoável supor que o mandante aprovaria a sua conduta, se conhecesse certas circunstâncias que não foi possível comunicar-lhe em tempo útil”"128.

${ }^{128}$ Por meio de seu artigo $1161^{\circ}$, o Código Civil de 1966 atribuiu ao mandatário uma série de deveres, relacionados não apenas à execução fiel da incumbência (alínea "a"), como também à adequada prestação de informações ao mandante (alíneas "b", "c" e "d"). De fato, já tivemos a oportunidade de nos pronunciar a respeito de tais temas em notas de rodapé anteriores (notas 125, 116, 117 e 121, respectivamente). Por ora, cabe-nos tão somente uma ligeira observação a respeito do dever de restituição do saldo das importâncias confiadas (bem como de entrega do objeto recebido durante a execução do mandato), tal como estabelece a alínea "e" do referido dispositivo legal: "o mandatário é obrigado: (...) e) A entregar ao mandante o que recebeu em execução do mandato ou no exercício deste, se o não despendeu normalmente no cumprimento do contrato". Assim, ao mandatário incumbe não apenas entregar aquilo que recebeu de terceiros em virtude da execução da incumbência, mas também o remanescente de eventuais adiantamentos efetuados pelo mandante, a pretexto da antecipação de despesas (futuras) - as quais, afinal, não se verificaram efetivamente. Note-se que no art. 47 do CCom/1833 pode ser entrevisto um antecedente de tal disciplina, estabelecido a propósito da comissão. Ora, caso o mandatário venha a obter abatimento relacionado a uma despesa de execução da incumbência (previamente adiantada pelo mandante), surge a indagação: em prol de quem reverterá tal economia? Teremos a ocasião de nos pronunciar a respeito da questão na nota de rodapé imediatamente posterior, ao analisarmos o art. 74 do CCom/1833.

Por sua vez, no artigo $1183^{\circ}$ se isenta o mandatário (diligente) de toda e qualquer responsabilidade pelo adimplemento das obrigações contraídas (por terceiros) durante a execução de sua gestão: "salvo estipulação em contrário, o mandatário não é responsável pela falta de cumprimento das obrigações assumidas pelas pessoas com quem haja contratado, a não ser que no momento da celebração do contrato conhecesse ou devesse conhecer a insolvência delas". Mediante o emprego da expressão "salvo disposição em contrário", faz-se referência à chamada comissão "del credere", em virtude da qual se estabelece um agravamento da responsabilidade do agente diretamente proporcional a um incremento de sua remuneração (cf. arts. 75 e 814 do $C$ Com $/ 1833$ e art. $269^{\circ}$ do CCom/1888, todos concernentes à comissão). Não se pode negar, aí, a existência de uma correspectividade entre os deveres de garantia (do mandatário) e de remuneração (do mandante), a apontar para um autêntico sinalagma "genético", em decorrência do qual a prestação de uma das partes tem na contrapartida a sua "razão de ser". A respeito da questão, cf. I. GALVÃo TELLES, Manual cit. (nota 118), p. 485 (trecho transcrito na nota 125).

No que concerne à revogação do mandato, o artigo $1179^{\circ}$ institui um novo elemento de ligação - além daqueles já referidos em nota de rodapé anterior (nota 126), contantes dos arts. $265^{\circ}, 1$ e $269^{\circ}$ do CC/1966 entre as disciplinas da "representação negocial" e deste específico tipo contratual: "a revogação e a renúncia da procuração implicam revogação do mandato". Ora, enquanto nas hipóteses dos artigos $265^{\circ}$ e $269^{\circ}$ se pode divisar um influxo (indireto) do mandato na eficácia jurídica da procuração, neste caso a situação é inversa: o artigo $1179^{\circ}$ consagra a repercussão sobre o mandato das vicissitudes do negócio jurídico de outorga de poderes. Perceba-se que sendo o mandato um contrato estribado na confiança havida entre as partes, sua extinção pode se verificar em virtude de um negócio jurídico unilateral; e isso corresponderia a uma 


\section{$\S 151$. Algumas disposições sobre o contrato de comissão segundo o Código}

Comercial de 1833: evidências de um esvaziamento da "procuração" - compreendida como relação gestória. Em meio à disciplina articulada a respeito da "comissão", o Código Comercial de 1833 nos fornece variados exemplos de projeções eficaciais de uma "gestão colaborativa" - subjacente ao vínculo contratual. Dentre elas, podem ser destacadas as regras que determinam: o cumprimento célere da incumbência (art. 801); a atribuição ao comitente dos benefícios, vantagens ou economias da gestão (art. 74); a validade da comissão com objeto relativamente indeterminado, desde que o comissário possa depreender a vontade do principal das circunstâncias do pedido (art. 798); a formação do preço de venda à custa do acréscimo - exclusivo - das importâncias relativas às despesas e à comissão do agente (art. 790); a proibição da celebração de venda a prazo - conquanto genericamente autorizada - quando o comprador for notoriamente insolvente (art. 53). De sua parte, também a "inobservância" de tal princípio foi objeto da atuação do legislador, ao se prescrever a responsabilidade do comissário que: contrata em termos mais onerosos do que os prevalecentes no mercado (art. 62); não diligencia a cobrança dos créditos

decorrência da conformação peculiar do referido tipo. No entanto, por força do artigo $1179^{\circ}$ viabiliza-se a extinção do contrato sob outro fundamento, de natureza eminentemente estrutural: sendo o negócio de outorga de poderes unilateral, também o é aquele que, simetricamente, lhe põe termo; ora, em razão da disposição acima referida, há uma sua repercussão ("ex vi legis") sobre o próprio contrato de mandato. Assim, curiosamente, a declaração do sujeito teria ao mesmo tempo a natureza de negócio jurídico (quanto à "procuração") e de ato jurídico em sentido estrito (acerca do "mandato").

Quanto às relações nas quais figurem múltiplos sujeitos em um de seus pólos, aplicam-se as disposições especiais estabelecidas nos artigos $1173^{\circ}$ e $1177^{\circ}$ : "sendo o mandato conferido por várias pessoas e para assunto de interesse comum, a revogação só produz efeito se for realizada por todos os mandantes (...) se houver vários mandatários com obrigação de agir conjuntamente, o mandato caduca em relação a todos, embora a causa de caducidade respeite a um deles, salvo convenção em contrário". Na primeira hipótese se preceitua a subsistência da relação jurídica contratual, desde que a avença tenha sido celebrada por meio de declaração única dos mandantes, voltada a incumbência de interesse comum; vale dizer, ausente um de tais pressupostos - como no caso de declarações autônomas (ou mesmo de interesses dissociáveis) - a revogação por um dos mandantes implica sua liberação inidividual em relação ao mandatário. Na segunda hipótese, em razão do caráter conjuntivo da incumbência, a causa extintiva atinente a um dos mandatários projeta seus efeitos sobre todo o liame. Pergunta-se: deve-se admitir, por via de conseqüência, que a impossibilidade de execução por um dos agentes estenda os seus efeitos sobre os demais? Eis uma questão que não foi respondida pelo legislador civil novecentista.

Por fim, merece destaque a regra estabelecida pelo artigo $1162^{\circ}$ do Código Civil vigente, segundo a qual "o mandatário pode deixar de executar o mandato ou afastar-se das instruções recebidas, quando seja razoável supor que o mandante aprovaria a sua conduta, se conhecesse certas circunstâncias que não foi possível comunicar-lhe em tempo útil". Ora, tal preceito - possivelmente inspirado no art. 816 do CCom/1833 (relativo à comissão) - evidencia uma projeção eficacial da idéia de "gestão colaborativa" subjacente ao vínculo contratual. É curioso observar que a técnica legislativa adotada tendeu não à imposição de um dever ao agente (não se disse "o mandatário deve"), mas sim à concessão de uma "esfera de desobediência lícita", reputada mais interessante - ao menos sob a perspectiva do contexto social como um todo - do que a servil obediência às instruções confiadas em circunstâncias diversas, por vezes profundamente defasadas em relação a uma realidade consideravelmente cambiante.

A respeito dos dispositivos do Código Civil de 1966 referidos nesta nota de rodapé, cf. A. NETO - H. A. MARTins, Código cit. (nota 116), pp. 121-123, 658, 661-663 e 665; M. J. de AlmEIDA Costa, Noções cit. (nota 116), pp. 272-273; bem como J. de CASTRO MENDES, Teoria cit. (nota 127), p. 286. 
decorrentes de operações concluídas por conta do comitente (art. 55); toma empréstimos, adiantamentos ou concede prazos sem autorização do principal (art. 52); satisfaz as obrigações contraídas no exercício da comissão com mercadorias pertencentes a terceiro (arts. 78 e 79); não observa, enfim, as instruções relacionadas ao contrato (art. 65). Em contrapartida, ao legislador não pareceu suficiente a simples isenção do comissário diligente quanto aos efeitos prejudiciais da gestão malsucedida (arts. 812 e 813): ao mesmo tempo em que lhe concedeu uma exceção - de direito material - caso possa provar que o comitente não dispõe de meios para suportar os encargos do pedido (art. 805), facultou-lhe a postulação de provimento cautelar quando o valor das mercadorias remetidas não alcançar o montante das despesas experimentadas com seu transporte e recebimento (art. 57). Aliás, ao se forjar o arcabouço concernente à "consignação" (tipo contratual próximo ao "mandato" e à "comissão"), houve a preocupação não apenas de se proibir ao consignatário a venda de suas "fazendas" em prejuízo das do consignante (art. 836), como também de se estabelecer que uma eventual mudança de rota somente poderia beneficiar os interesses deste último $\left(\right.$ art. 833) ${ }^{129}$.

${ }^{129}$ O Código Comercial de 1833 consagra ao menos seis dispositivos à atribuição - ao comissário - de deveres que podem ser reconduzidos à idéia de uma "gestão colaborativa" subjacente ao vínculo contratual (artigos 53, 74, 790, 798, 801 e 802).

Assim, visando resguardar os interesses do comitente, o artigo 801 preceitua o cumprimento célere da incumbência pelo comissário, que não pode postergá-la indevidamente, sob pena de prejudicar aquele que em sua pessoa confiou: "o commissario tem a obrigação de exequir a commissão, que lhe é commettida, apenas tenha opportunidade. Se a differir para tempo remoto e illimitado, responde por perdas e damnos". Aliás, na hipótese de controvérsia acerca da oportunidade da execução do contrato, o artigo 802 estabelece que "havendo duvida sobre o haver-se ou não exequido a commissão em tempo opportuno, a questão será decidida por arbitros commerciaes, que se regularão pelos usos e costumes do logar na especie da transaç̧ão controvertida".

Da mesma forma, a atenção do legislador também se voltou ao aspecto econômico da atribuição, determinando-se que o preço das mercadorias vendidas pelo comissário não poderia ser livremente arbitrado por este último, sob o risco de comprometer a própria viabilidade das negociações. Ora, como o risco da operação haveria de ser suportado pelo principal, estabeleceu-se no artigo 790 que "o commissario não póde carregar sobre o preço das mercadorias a elle commettidas, além das despesas legitimas, mais do que a sua commissão". No mesmo sentido, os atos instrumentais e finais praticados pelo comissário deveriam redundar em efetivo proveito do comitente: assim, quanto aos primeiros se preceituou - nos termos do artigo 74 - que "todo o beneficio, vantagem ou economias, que o commissario obtiver nos contractos, que celebrar por conta alheia, farão a bem do committente"; e quanto aos derradeiros, determinou-se que - na ausência de instruções específicas do principal - "ainda que o commissario tenha auctorização para vender a prazo, não poderá fazer a pessoas conhecidamente insolventes, nem expor os interesses do committente a risco manifesto e notorio, pena de responsabilidade pessoal" (artigo 53). Note-se que esta última disposição foi posteriormente reiterada pelo art. $272^{\circ}$ do CCom/1888 - que ainda proibiu a prática de operações que de algum modo pudessem "expôr os interesses do committente a risco manifesto e notorio".

Por sua vez, em um esforço voltado à conservação do negócio jurídico de oferta, o legislador admitiu a possibilidade de suprimento das deficiências da policitação pelas próprias circunstâncias negociais, livremente apreciáveis pelo oblato de boa-fé: "em regra o mandato, como os demais contractos, deve ter por objecto uma cousa determinada: pena de nullidade. Todavia se o commissario podér por algumas circumstancias conhecer a vontade do committente, valerá e subsistirá a commissão, posto que a principio não recaísse sobre cousa absolutamente certa". 
Ora, ao mesmo tempo em que atribuíu deveres ao agente, o legislador também voltou sua atenção à própria frustração da "gestão colaborativa" acima referida. Na maioria das vezes, sancionou o comportamento do comissário por meio da previsão de uma responsabilidade pelos danos experimentados pelo principal (artigos $62,55,52$ e 65); em uma das hipóteses, contudo, optou por simplesmente reduzir a remuneração devida pelo comitente (artigos 78 e 79).

Com efeito, se comissário celebra contratos cujos termos são prejudiciais ao comitente (tomando-se como parâmetro aqueles prevalecentes em mercado), há que se resguardar a confiança do principal; neste sentido, $o$ art. 62 dispõe que "o commissario, que sem auctoridade expressa do committente fizer uma negociação a preços e condições mais onerosas, do que as currentes na praça ao tempo da transacção, responde ao commitente pelo prejuizo, sem que o releve o haver feito por conta propria negociações da mesma especie por iguaes condições". Destaque-se que a idéia de uma gestão colaborativa é tão arraigada que não basta a demonstração de que o comissário celebrou os seus próprios negócios sob as mesmas condições; ainda assim ele será responsabilizado, à vista da "administração" que lhe foi confiada.

De mesma forma, o agente responderá pelos prejuízos causados ao principal: a) se não diligenciar a cobrança de créditos de titularidade mediata do comitente, tal como preceitua o seu artigo 55 ("se o commissario não verificar a cobrança dos cabedaes de seu committente nas épochas, em que são exigiveis segundo o character e condições de cada negociação, responderá pelas consequencias da omissão, não provando, que com a pontualidade devida usou de meios legaes para obter o pagamento"); b) quando conceder empréstimos, adiantamentos ou prazos sem a autorização do comitente, consoante estabelece o seu artigo 52 ("o comissário, que sem auctorização do committente fizer emprestimos, adiantamentos, ou vendas a prazo, corre o risco da cobrança e pagamento das quantias emprestadas, adiantadas ou fiadas: - e o committente as poderá exigir á vista, cedendo no commissario todos os interesses, vantagem, ou beneficio, que resultar do crédito por este concedido, e pelo committente desapprovado. Exceptua-se o uso das praças em contrario, no caso de não haver ordem expressa para não fazer adiantamentos, nem conceder prazos"), posteriormente reiterado pelo art. $271^{\circ}$ do CCom/1888; c) na hipótese - genérica - de inobservância das instruções relacionadas à incumbência, segundo disposição constante de seu artigo 65 ("todas as consequencias prejudiciaes derivadas de um contracto, feito contra as instrucções do committente, ou com abuso de seus poderes, fazem por conta do commissario, a pezar de que o contracto surta os seus effeitos juridicos. Por tanto o commissario, que fizer uma alheação por conta d'outrem a preço menor, do que lhe fồra marcado, abonará ao committente, a differença do preço, subsistindo não obstante isso a venda. Se o commissario, encarregado de fazer uma compra, exceder o preço, que lhe fôra fixado, será do arbitrio do committente acceitar o contracto, ou deixalo de conta do commissario, salvo se este se conformar com receber sómente o preço marcado. Consistindo o excesso em não ser a cousa comprada da qualidade encommendada, o committente não é obrigado a recebela"), posteriormente preservada pelo art. $270^{\circ}$ do CCom $/ 1888$.

Como acima referido, na hipótese de satisfação dos contratos celebrados - em execução da comissão - por meio da utilização de mercadorias de terceiros, em lugar da responsabilidade civil, preferiu o legislador simplesmente reduzir o montante da remuneração atribuída ao agente, por meio de disposição também aplicável à celebração de "negócio consigo mesmo" - matéria que foi objeto de observações desenvolvidas em nota de rodapé anterior (nota 127). Com efeito, assim dispõem os artigos 78 e 79 do Código Comercial de 1833: “(...) não póde o commissario, sem consentimento expresso do committente, satisfazer uma ordem deste com effeitos, que tenha em seu poder, quer seus, quer de conta alheia (...) nos casos dos dous artigos precedentes ["negócio consigo mesmo" e satisfação com efeitos alheios] não tem o commissario direito a perceber á commissão ordinaria: ella deverá ser constituida por pacto expresso; e na falta delle, ou não se accordando as partes, a provisão será reduzida á ametade da ordinaria".

No âmbito da consignação - tipo contratual expressamente aproximado da sociedade e do mandato pelo art. 826 do CCom/1833 - tal diretriz foi mantida, proibindo-se ao consignatário a comercialização de seus efeitos em prejuízo do consignante (artigo 836): "tendo o consignatario fazendas de conta propria da mesma qualidade das que recebe á consignação, não póde, nos logares determinados para lhes dar saída, vender as proprias, não vendendo igualmente as do consignante: pena de ser obrigado a dividir com este proporcionalmente os lucros havidos das fazendas de sua conta, vendidas com preferencia ás do consignante". Note-se que se do artigo 836 parece defluir uma aproximação em relação ao "mandato", da regra instituída pelo artigo 833 se depreende uma similitude em relação ao contrato de sociedade; com efeito, mudando de modo ab-rupto o local da venda dos produtos que lhe foram confiados, ao consignatário são atribuídos todos os riscos da operação: "se o consignatario, em conta de participação, mudar de viagem ou logar do destino da especulação, e auferir lucro, este fará a beneficio do consignante: perdido o producto, a perda fará por sua conta, e ficará responsavel para com o consignante pelo capital e lucros, com todas as perdas e damnos, e sujeito á acção de barateria, intervindo dolo".

Em contrapartida, tendo o comissário agido diligentemente, sua responsabilidade quanto ao insucesso da operação é totalmente afastada, sob pena de - na hipótese contrária - se lhe atribuírem riscos que competem 
$\S 152$. Encerramento do capítulo e apresentação do tema sucessivo. Neste capítulo tivemos a oportunidade da analisar a conformação do "mandato" segundo os Códigos Civis portugueses: foi possível divisar de que forma o elemento representativo (direto) gradualmente se incrustou na eficácia do tipo contratual - chegando ao ponto de contagiar a sua "causa-função" (durante a vigência do Código de 1867). Com efeito, ao mesmo tempo em que se verifica a ascensão da "procuração-instrumento", declina a feição gestória desta espécie contratual; de maneira que se podia entrever a sua virtual redução à categoria de - simples - fundamento negocial da representação direta. Contudo, o Código de 1966 resgatou a figura do "mandato sem representação": e por meio de uma estrutura sistemática bem articulada, acabou por dissociar - inteiramente - a representação direta da função típica atrelada ao modelo; contudo, ao removê-la gerou uma "crise de identidade" que acabou por justificar todo o trabalho desenvolvido até o momento. Assim, posta de parte a representação direta, qual vem a ser a "causa" do mandato? Quais as suas repercussões sobre a eficácia jurídica do tipo? Antes de oferecermos resposta a tais indagações - algo que só poderemos fazer em uma oportunidade ulterior de nossa linha de pesquisa - pretendemos encerrar nossa análise histórica por meio de uma ligeira abordagem sobre a evolução do mandato no sistema jurídico - estritamente - brasileiro.

ao próprio principal. Neste sentido, os artigos 812 e 813 dispõem de maneira inequívoca: "o commissario, que provar haver empregado toda a diligencia e attenção no preenchimento do mandato, não é responsavel pela inexecução da commissão (...) o commisario não responde pelo mau exito da expedição, que lhe fôra commetida, salvo no caso de negligencia ou culpa".

Aliás, por meio dos artigos 57 e 806 são acautelados os legítimos interesses do agente, potencialmente expostos - de modo indevido - em virtude da virtual inadimplência do comitente. Assim, o primeiro dos preceitos estabelece que "igual diligencia [requerimento de depósito judicial e eventual venda dos efeitos] deve practicar o commissario, quando o valor presumido dos effeitos consignados não póde cobrir os gastos a desembolçar pelo transporte e recebimento delles. O juiz accordará o deposito, e proverá na venda, ouvindo os credores das despesas, e o procurador do dono dos effeitos, se algum se appresentar"; neste caso, o legislador facultou ao comissário a postulação de um provimento de natureza cautelar, uma vez que - não ostentando uma feição satisfativa - resguarda adequadamente a posição do agente. Já o segundo dispositivo atribui ao comissário uma exceção material, caso se mostre verossímil sua alegação de que o comitente não dispõe de meios para adimplir as obrigações derivadas do pedido formulado: "posto que em regra o commissario mercantil é obrigado a exequir a commissão, cuja ordem acceitára, esta regra cessa, tendo o commissario prova de que o committente não tem os meios sufficientes para o pagamento do montante das fazendas pedidas". Nestas circunstâncias, verifica-se que tal exceção se funda em um sinalagma "funcional" artificialmente instituído por meio da disposição legal ora referida. Acerca do tema, cf. I. GALVÃo TELLES, Manual cit. (nota 118), pp. 485-486.

A respeito das disposições do Código Comercial de 1833 referidas na presente nota de rodapé, cf. I. de Sousa DuARTe, Diccionario cit. (nota 115), pp. 65, 67, 72-76 e 256; D. P. F. de SAMPAIO PIMENTEL, Annotações cit. (nota 115), pp. 28-32, 38-41, 45-52, 67-68, 73-74, 79-80 e 83-85; e J. FERREIRA BORGES, Diccionario cit. (nota 115), p. 87 (especificamente quanto à vinculação do agente às instruções confiadas). 


\section{CAPÍTULO X. \\ HISTORIOGRAFIA EXCLUSIVAMENTE BRASILEIRA: OS CONTORNOS EFICACIAIS DO CONTRATO DE MANDATO ANTERIOR AO CÓDIGO CIVIL DE 2002.}

$\S 153$. A Lei de 20 de outubro de 1823 e a preservação do direito lusitano moderno (em meio ao cenário brasileiro posterior à Independência); a previsão da elaboração de um código civil constante da Constituição de 1824. A proclamação da Independência do Brasil assinala o surgimento de uma necessidade imediata ao Estado recém-soberano: a conformação de um sistema apto à organização de sua vida jurídica interna (seja no âmbito público, seja mesmo na órbita privada). A fim de obviar tal demanda, a Lei de 20 de outubro de 1823 prescreveu, provisoriamente, a vigência da legislação portuguesa promulgada até 25 de abril de 1821; com isso, as "Ordenações Filipinas" - bem como a legislação que lhe era extravagante - permaneceram em vigor no "Imperio do Brazil" em caráter precário, sendo gradativamente expurgadas de nosso sistema jurídico (na medida em que se editava uma legislação genuinamente nacional). Especificamente no que concerne ao direito privado, cumpre observar que a Constituição de 1824 prenunciou a edição de um código civil "fundado nas sólidas bases da justiça e eqüidade" (artigo 179, XVIII); no entanto, a promessa do constituinte não vingou de imediato, exsurgindo a obra completa tão somente no primeiro quartel do século seguinte. Contudo, antes mesmo de seu advento, importantes textos legais se voltaram à disciplina do contrato de mandato: dentre eles, merecem destaque o "Código Comercial" (1850) e a “Consolidação das Leis Civis" (1858); além disso, os próprios anteprojetos - bem como os trabalhos preparatórios - da codificação civil novecentista evidenciam interessantes aspectos relacionados ao objeto de nossas pesquisas. Iniciemos nossa investigação, portanto, a partir da análise de tais fontes: a fim de que possamos - então - compreender a contextura deste específico tipo contratual, tal qual forjado pelo legislador de $1916^{130}$.

\footnotetext{
${ }^{130}$ Eis o teor da Lei de 20 de outubro de 1823: "D. Pedro I, por graça de Deos e unanime acclamação dos Povos, Imperador Constitucional e Perpetuo Defensor do Brazil, a todos os nossos fieis subditos, saúde. A Assembléa Geral Constituinte e Legislativa do Imperio do Brazil tem decretado o seguinte: A Assembléa Geral Constituinte e Legislativa do Imperio do Brazil decreta: Art. 1. As Ordenações, Leis, Regimentos, Alvarás, Decretos e Resoluções promulgadas pelos Reys de Portugal, e pelas quaes o Brazil se governava até o dia 25 de Abril de 1821, em que S. M. Fidelissima, actual Rey de Portugal e Algarves se ausentou desta Côrte, e todas as que forão promulgadas daquella data em diante pelo Sr. D. Pedro de Alcantara como Regente do Brazil emquanto Reino, e como Imperador Constitucional delle, desde que se erigio em Imperio, ficão em inteiro vigor na parte em que não tiverem sido revogadas, para por ellas se regularem os negocios do interior deste Imperio, em quanto se não organisar hum novo Codigo, ou não fôrem especialmente alteradas. Art. $2^{\circ}$. Todos os Decretos publicados pelas Côrtes de Portugal, que vão especificados na tabella junta, ficão igualmente valiosos emquanto não fôrem expressamente revogados. Paço da Assembléa, em 27 de Setembro de 1823. Mandamos, portanto, á todas as autoridades civis, militares e ecclesiasticas que
} 


\section{$\S$ 154. O Código Comercial e as linhas gerais do mandato mercantil. A}

disciplina articulada entre os artigos 140 e 164 do Código Comercial se assenta em uma premissa fundamental: a natureza contratual do mandato (artigo 141); deste modo, a superveniência da aceitação (inclusive sob a forma tácita) acarreta a inadmissibilidade de retratação do agente (artigo 143) - excetuada unicamente a hipótese de fundado desconhecimento, por parte deste último, de circunstâncias relevantes relacionadas ao principal (artigo 144). Por sua vez, no que toca ao objeto do contrato, ao preceituar a abrangência dos atos "conexos e conseqüentes" pelo "mandato geral", o artigo 145 do Código aproxima indevidamente esta modalidade da variante "em termos gerais" do instituto; baralhando-se, assim, a "amplitude" e o "objeto" da gestão incumbida. Por fim, ao mesmo tempo em que preconiza a contratação sob a forma escrita (pública ou particular), o artigo 140 assim define o tipo contratual referido: "dá-se mandato mercantil, quando um comerciante confia a outrem a gestão de um ou mais negócios mercantis, obrando o mandatário e obrigando-se em nome do comitente" ${ }^{\prime 131}$.

cumprão e fação cumprir o referido Decreto em todas as suas partes, e ao Chanceller-mór do Imperio que o faça publicar na Chancellaria, passar por ella e registrar nos livros da mesma Chancellaria a que tocar, remettendo os exemplares delle a todos os lugares á que se costumão remetter, e ficando o original ahi até que se estabeleça o Archivo Publico, para onde devem ser remettidos taes diplomas. Dada no Palacio do Rio de Janeiro, aos 20 dias do mez de Outubro de 1823, $2^{\circ}$ da Independencia e do Imperio. Imperador com guarda. José Joaquim Carneiro de Campos. Carta de Lei, pela qual V. M. I. manda executar o Decreto da Assembléa geral Constituinte e Legislativa do Imperio do Brazil, que declara o Código, Leis, Decretos, e Resoluções que provisoriamente ficão em vigor para terem observancia neste mesmo Imperio, tudo na fórma acima exposta. Para V. M. I. vêr. José Joaquim dos Santos Marrocos a fez. Nesta secretaria de Estado esta Carta de Lei nesta Chancellaria-mór da Corte e Imperio do Brazil. Rio, 30 de Outubro de 1823. Francisco Xavier Raposo de Albuquerque. Registrada nesta Chancellaria-mór da Côrte e Imperio do Brazil a fl. 31 v. do liv. $1^{\circ}$ das Leis e Alvarás. Rio de Janeiro, 30 de Outubro de 1823. Floriano de Medeiros Gomes" (cf. CÂNDIDO MENDES DE AlMEIDA, Código cit. (nota 16), p. LXXV).

Por sua vez, a Constituição Imperial previa a elaboração de um código civil nos seguintes termos: “art. 179. A inviolabilidade dos direitos civis, e politicos dos Cidadãos Brasileiros, que tem por base a liberdade, a segurança individual, e a propriedade, he garantida pela Constituição do Imperio pela maneira seguinte: (...) XVIII. Organisar-se-ha quanto antes hum Codigo Civil, e Criminal, fundado nas solidas bases da justiça, e equidade" (cf. CÂNDIDo MENDES DE AlMEIDA, Código cit. (nota 16), pp. 258-259).

A respeito da importância destas duas disposições para a conformação do moderno direito privado brasileiro, cf. J. G. B. CÂmara, Subsídios cit. (nota 16), p. 104; Direito Público e Privado no Segundo Reinado in Estudos Jurídicos e de História, Rio de Janeiro, Barrister's, 1987, pp. 44-45; H. VAlLADÃO, História cit. (nota 86), p. 35; F. C. PONTES DE MIRANDA, Fontes cit. (nota 16), p. 66-67; O. GoMes, Raízes cit. (nota 16), p. 7; J. C. Moreira Alves, Panorama cit. (nota 16), p. 186; C. BeviláQuA, Código Civil dos Estados Unidos do Brasil commentado, $3^{\mathrm{a}}$ ed., Rio de Janeiro, Livraria Francisco Alves, 1927, pp. 9-11; A. SANTOS Justo, O Direito cit. (nota 16), p. 9; I. de CARVAlHo NeTO, Histórico da codificação civil brasileira in Novo Código Civil - Questões Controvertidas - Parte Geral do Código Civil (Série Grandes Temas do Direito Privado VI), São Paulo, Método, 2007, pp. 19-20.

${ }^{131}$ A definição de mandato contida no artigo 140 do Código Comercial parece não prescindir da eficácia representativa direta ordinariamente atrelada ao instituto; todavia, como teremos a oportunidade de observar mais adiante, nos artigos 149 e 150 se admite - em meio à disciplina deste mesmo tipo contratual - a atuação do agente em seu próprio nome. Assim como se deu com relação ao Código Comercial português de 1833, a eficácia representativa direta foi tomada como fator discriminante entre o "mandato" e a "comissão"; neste 
sentido, confronte-se a definição deste último tipo contratual, constante do artigo 165 do Código Comercial brasileiro: "a comissão mercantil é o contrato do mandato relativo a negócios mercantis, quando, pelo menos, o comissário é comerciante, sem que nesta gestão seja necessário declarar ou mencionar o nome do comitente". Note-se que - de acordo com o referido artigo 165 - o comissário poderia atuar em seu próprio nome mesmo que o terceiro com quem viesse a contratar tivesse inteira ciência da "interposição" viabilizada pelo negócio de gestão; daí a conclusão de que enquanto o contingenciamento eficacial se destacava em meio às preocupações de nosso legislador mercantil oitocentista, a "ocultação" do principal - eventualmente associada ao instituto - passava a desempenhar um papel secundário.

A análise das fontes primárias posteriores ao Código Comercial - legisladas ou meramente projetadas - nos revela uma proeminência da eficácia representativa direta na conformação do tipo contratual referido. Com efeito, tal peculiaridade deflui: do artigo 2853 do "Esboço" de Código Civil ("haverá mandato, como contrato (art. 1830), quando uma das partes se tiver obrigado a representar a outra em um ou mais atos da vida civil"); do artigo 2266 do Anteprojeto Felício dos Santos ("no contrato de mandato, ou procuradoria, o mandatario se obriga gratuitamente, ou mediante certa retribuição, a prestar, ou fazer alguma cousa em nome e por conta do mandante"); do artigo 1442 do Anteprojeto Clóvis Beviláqua ("tem logar o mandato, quando alguem institue outrem seu representante, conferindo-lhe poderes para que execute um acto ou uma serie de actos juridicos"); do artigo 1506 de sua variante revista ("tem logar o mandato, quando alguem confere a outrem poderes para que, em seu nome, pratique um ou mais actos ou administre um ou mais negocios. A procuração é o instrumento do mandato"); dos artigos 1288 do Projeto da Câmara dos Deputados n ${ }^{\circ}$ 1/1902 ("effectua-se o mandato, quando alguem confere a outrem poderes para que, em seu nome, pratique um ou mais actos ou administre um ou mais negocios. A procuração é o instrumento do mandato"), do Parecer $n^{\circ}$ 269/1912 do Senado Federal ("opera-se o mandato, quando alguem recebe de outrem poderes, para, em seu nome, praticar actos, ou administrar interesses. A procuração é o instrumento do mandato") e do Código Civil de 1916 ("opera-se o mandato, quando alguem recebe de outrem poderes, para, em seu nome, praticar actos ou administrar interesses. A procuração é o instrumento do mandato"); do artigo 628 do Anteprojeto de Código das Obrigações de Caio Mário da Silva Pereira ("o mandante confere ao mandatário poderes para, em seu nome, praticar atos ou administrar interesses"); do artigo 668 do Anteprojeto de Código Civil elaborado pela comissão presidida por Miguel Reale ("opera-se o mandato, quando alguém recebe de outrem poderes, para, em seu nome, praticar atos, ou administrar interesses. A procuração é o instrumento do mandato"); do artigo 652 da versão revista deste Anteprojeto ("opera-se o mandato, quando alguém recebe de outrem poderes, para, em seu nome, praticar atos, ou administrar interesses. A procuração é o instrumento do mandato"); do artigo 662 do Projeto da Câmara dos Deputados de 1975 ("opera-se o mandato, quando alguém recebe de outrem poderes, para, em seu nome, praticar atos, ou administrar interesses. A procuração é o instrumento do mandato"); e do artigo 653 do Código Civil vigente ("opera-se o mandato quando alguém recebe de outrem poderes para, em seu nome, praticar atos ou administrar interesses. A procuração é o instrumento do mandato"). Ora, quanto a este aspecto, é curioso observar que o Anteprojeto Coelho Rodrigues não se enveredou pela trilha representativa, mantendo uma definição de mandato estribada na feição gestória da atuação do mandatário: "considera-se Mandato o contrato pelo qual uma pessoa se obriga, mediante salário ou gratuitamente a fazer alguma coisa a outrem que dela a incumbiu" (artigo 1063).

Note-se que além da pretendida "essencialização" da eficácia representativa direta (ordinariamente defluente do contrato de mandato), outra tendência pode ser divisada da comparação entre as definições emprestadas ao instituto pelas sucessivas fontes do direito privado brasileiro: por meio da introdução de dois adendos, a comissão encarregada da revisão do Anteprojeto Clóvis Beviláqua restabeleceu os limites tradicionais do objeto do contrato de mandato; assim, em lugar de uma aplicação circunscrita aos negócios jurídicos, preconizou-se a utilização do tipo contratual para a administração de interesses - admitindo-se, assim, que simples atos materiais pudessem ser objeto de uma tal espécie de contratação. Além disso, incluiu-se a previsão da "procuração" como instrumento - por excelência - do mandato; com isso, foram baralhados os instrumentos do negócio jurídico (unilateral) de outorga de poderes ("procuração") e do contrato em que se ajustava a incumbência do agente ("mandato"). Como teremos a oportunidade de observar mais adiante, tal mistura não passou despercebida ao próprio legislador quando se deu prosseguimento ao trâmite legislativo que redundou no artigo 1330 do Código Civil de 1916 - no qual se evidencia uma tendência à diferenciação entre os referidos negócios jurídicos.

Por definições "essencialmente" representativas do mandato mercantil, cf. A. de SousA PINTO, Diccionario da Legislação Commercial Brazileira contendo a reprodução textual ou analytica, e em muitos pontos annotada, de todos os artigos não revogados do respectivo Codigo e das leis, decretos e outras disposições legaes em vigor, concernentes ao commercio terrestre e marítimo, ás sociedades anonymas e ao processo no juizo federal - seguido de um appendice no qual se acham alphabeticamente ordenadas differentes disposições regulamentares, excedentes da esphera do direito commercial, mas com esta materia relacionadas, e de um quadro de legislação concordada I, Lisboa, Editores Tavares Cardoso \& Irmão, 1892, 
p. 259 (e pp. 219-220 do vol. II); C. FALCÃO, Codigo Commercial Brasileiro - annotado theorica $e$ praticamente, de acordo com as leis em vigor e a jurisprudencia, Rio de Janeiro, Livraria Quaresma Editora, 1926, p. 56; C. TRIPOLI, Elementos de Direito Comercial para uso nas Escolas de Comercio, São Paulo, Empreza Graphica Revista dos Tribunaes, 1932, pp. 54-55; D. A. da VeIGA, Codigo Commercial commentado e posto ao par da doutrina, legislação e jurisprudencia modernas, Rio de Janeiro - São Paulo Recife, Laemmert, 1898, pp. 292-293; Dous JURISCONSUlTOS, Repertorio systematico do Codigo Commercial Brasileiro, Rio de Janeiro, Typographia Guanabarense de L. A. F. de Menezes, 1850, p. 87; J. LiBerato BARroso, Contractos e Obrigações Mercantis - Parte $1^{a}$ (Títulos V a XIV do Codigo Commercial), Rio de Janeiro, B. L. Garnier, 1871, pp. 13-14; J. X. CARVALHo DE MEndonÇA, Tratado de Direito Commercial Brasileiro - Das obrigações, dos contratos e da prescripção em materia commercial VIII, Rio de Janeiro, Livraria Editora Freitas Bastos, 1939, pp. 210-212; J. J. P. da SiLvA RAmos, Abecedario Juridico-Commercial ou compilação por ordem alphabetica das disposições actualmente em vigor do Codigo Commercial do Imperio do Brasil, Rio de Janeiro, Eduardo \& Henrique Laemmert, 1861, p. $369 ;$ S. O. D’Araujo Costa, Codigo Commercial do Imperio do Brasil, Rio de Janeiro, Eduardo \& Henrique Laemmert, 1864, p. 42; L. M. VIDAL, Manual do direito comercial para uso do povo, Rio de Janeiro, Eduardo \& Henrique Laemmert, 1877, pp. 46-47; e W. FERREIRA, Tratado de Direito Comercial XI - O estatuto obrigacional do comércio e os títulos de crédito, São Paulo, Saraiva, 1963, pp. 5-12. Este último autor destaca de modo contundente a importância do elemento representativo para a conformação do tipo contratual objeto de nossa análise: "opera o mandatário, por via dêle, sempre e necessàriamente, em nome e por conta do mandante, a quem representa: por êste é que êle fala, trata, contrata, transaciona fazendo-lhe as vêzes. Projeta-se o mandante na pessoa do mandatário. Nele penetra. Exprime-se êste por palavras próprias, com a sua própria e inconfundível entonação; mas através dêle e delas a vontade do outro contraente se manifesta e se ajusta com a do terceiro contratante, firmando-se recìprocamente o vínculo obrigacional. Transmigra-se a vontade do mandante e como que na do mandatário se incorpora, dominando-o no contratar. A representação é o elemento específico do mandato (...) conferindo o comerciante a uma ou mais pessoas a gestão de seus negócios mercantis; dentro de seu estabelecimento comercial, obrigando-se em nome dêle, existe o mandato, tácito ou expresso, como pressuposto de outro contrato - o de preposição mercantil; e aqueles são seus prepostos" (Tratado de Direito Comercial cit. (nota 131), pp. 7-8).

De fato, embora a terminologia empregada pelo legislador mercantil oitocentista não tenha sido a mais precisa - sendo freqüente a utilização promíscua dos termos "mandante" e "comitente", por exemplo -, não resta maior dúvida quanto ao fato de que a doutrina comercial majoritária tomou a eficácia representativa direta como elemento discriminatório entre o "mandato" e a "comissão"; a este respeito, exemplificativamente, cf. A. BAPTISTA LEONE, Mandato e comissão mercantil, Bahia, s. e., 1900, pp. 7-98; e P. F. de OliveIRA, Do mandato e da commissão mercantil, in São Paulo Judiciário 23/24/25 (1910), pp. 141-146 (23), 279-299 (23), 427-443 (23), 3-12 (24), 125-128 (24), 233-245 (24), 345-350 (24), 1-9 (25), 123-124 (25). No entanto, J. J. GONÇALVES DE ANDRADE já advertia quanto à impropriedade da generalização daquilo que de ordinário se verificava em matéria de mandato: "a redação do art. 1984 do cod. civ. fr. não parece a comentadores insignes, isempta de defeitos, patenteando, em seu conceito, os inconvenientes das difinições legaes (...) as inadvertencias do legislador, accrescenta o sr. Troplong, não são indifferentes como as do autor. Os espiritos distrahidos, as intelligencias acanhadas, cujo alcance não vae além do texto, os demandistas de má fé, que precisam de cavillações, encontram nas definições inexactas, uns ciladas, outros, subterfugios. O dezar que enxergam na redacção do mencionado artigo, consiste em declarar o legislador - 'que o mandatario tracta em nome do committente o negocio cuja gestão acceitára'. No entanto, ponderão, são frequentes os actos da vida civil, em que o mandatario faz em seu nome negocios de outrem, sem que por isso cessem as relações do mandato (...) esse pretenso defeito da lei franceza, vemo-lo reproduzido em todos os codigos civis, que a tiveram por norma, até em o novissimo portuguez, art. 1318 (...) equivale a dizer que o legislador enunciou com exactidão o mandato genero, ou ordinario, characterisado pela representação; mas não prohibiu que o mandato, em alguma de suas relações, fosse submettido, segundo o interesse das partes, a regras differentes, que dando-lhe feições distinctas o tornassem uma especie destacada do genero" (A doutrina do mandato commercial abrange egualmente o mandato qualificado?, São Paulo, Typ. do Ypiranga, 1868, pp. 12-13).

Mesmo no âmbito civil - imediatamente anterior à codificação novecentista - a questão relativa à admissibilidade generalizada da eficácia representativa direta não resta de todo clara, ao menos à luz das mais célebres obras da literatura jurídica brasileira do século XIX. L. TRIGO DE LOUREIRO, por exemplo, admite-a de modo inequívoco na seguinte definição emprestada ao instituto: "chama-se mandato o contrato benefico, pelo qual alguem commette a outro, e este se encarrega de fazer alguma cousa, ou a gerir algum negocio em nome daquelle, e gratuitamente" (Instituições de Direito Civil Brasileiro II, $4^{\mathrm{a}}$ ed., Rio de Janeiro, B. L. Garnier, 1872, p. 244); no entanto, na página imediata destaca que diante da ausência de disposições concernentes ao tipo em meio ao direito pátrio, fazia-se necessário o recurso ao paradigma 
romano (não representativo): “observa-se porém entre nós o que a esse respeito se acha determinado pelo Direito Romano, isto é, na Instit. liv. 3, tit. 26, no Dig. liv. 17, tit. 1, e no Cod. liv. 4, tit. 35, por ser deduzido do Direito das Gentes, e conforme com a boa razão" (Instituições cit. (nota 131), p. 245).

Ora, não se pode esquecer que o direito justinianeu de que então se lançava mão era aquele depreendido por meio do emprego da "recta ratio" racionalista, franca adepta do modelo representativo. Assim, embora L. TRIGO DE LOUREIRO preconize a obrigação do mandante de "ratificar tudo quanto foi feito em seu nome pelo mandatario dentro dos limites do mandato" (Instituições cit. (nota 131), p. 244), tal assertiva não deve ser entrevista como um obstáculo à conclusão de que, em meados do século XIX, já se admitia amplamente a representação direta derivada do mandato. Lamentavalmente, na "Consolidação das Leis Civis" A. TEIXEIRA DE FREITAS não o evidencia de modo claro; bem ao contrário, aliás, este autor instaura uma certa "confusão" ao observar que "as palavras desse Art. 140 do Cod. - em nome do committente - servem só para distinguir o mandato e a commissão; posto que por excepção, nem o mandato (...) perde seu caracter por figurar o mandatario em seu proprio nome, nem a commissão deixa de ser tal por figurar o committente em nome do commissario" (Consolidação cit. (nota 16), p. 319, com o trecho final transcrito atentamente, segundo os termos utilizados pelo próprio autor). No entanto, em parecer de $1^{\circ}$ de abril de 1862 , A. TEIXEIRA DE FREITAS assevera de maneira induvidosa que o "procurador não obra em seu proprio nome", devendo a ação do credor ser promovida contra a viúva e os herdeiros do constituinte falecido (cf. J. J. RoDRIGUES (org.), Consultas Juridicas sobre questões de direito civil, commercial, criminal, administrativo e ecclesiastico II, Lisboa, Livraria Clássica Editora, 1915, p. 55). Eis a razão por que J. M. da TRINDADE define o mandato como o "contracto pelo qual uma pessoa se encarrega de praticar em nome de outra certo acto, ou de administrar um ou mais negocios alheios" (Collecção de apontamentos juridicos sobre as procurações extrajudiciaes com a recopilação das disposições doutrinaes ácerca das mesmas procurações, Rio de Janeiro, Eduardo \& Henrique Laemmert, 1862, p. 21). Trata-se de uma manifestação do "usus modernus pandectarum" brasileiro, decorrente da ausência de disposição expressa do direito reinícola sobre o contrato de mandato: "o nosso direito patrio é deficiente nas instituições do mandato; além de um ou outro ponto ácerca do assumpto, apenas estatue sobre o procuratorio judicial: por isso recorremos, nos casos omissos, ao direito romano e aos codigos das nações cultas, por autorização da Ord. Liv. $3^{\circ}$ Tit. 64, e da lei de 18 de Agosto de 1769" (Collecção cit. (nota 131), pp. X-XI; e também mais adiante, à p. 55). No sentido da simples manutenção das fontes lusitanas (acrescidas da legislação luso-brasileira extravagante), cf. T. de ALENCAR ARARIPE, Codigo Civil Brazileiro ou Leis Civis do Brazil (dispostas por ordem de materias em seu estado actual), Rio de Janeiro, Laemmert \& C., 1885, pp. 147-153 - com a transcrição das disposições das "Ordenações Filipinas" afetas ao "mandato", ao "mandato nas repartições fiscaes, e procuração por instrumento particular para ellas", à "revogação do mandato judicial", à "terminação do mandato judicial” e às "pessoas às quais é defeso procurar".

De todo modo, com a promulgação do Código Civil de 1916, a questão relacionada à admissibilidade da eficácia representativa direta no âmbito do "mandato" restou parcialmente superada; de fato, o mandato passou a comportar - "ex vi legis" - uma eficácia representativa direta dele imediatamente decorrente (artigo 1288). No entanto, sobrevieram então duas indagações principais: em primeiro lugar, poderia haver mandato desprovido de representação? Além disso, teria a representação (direta) sido erigida ao patamar de "nota típica" do contrato de mandato?

A maioria absoluta da doutrina imediatamente posterior à promulgação do Código Civil de 1916 tomou partido pela "essência" representativa do "mandato". Neste sentido, cf. A. BEvILÁQuA, Codigo Civil Brasileiro anotado, 12 $2^{\mathrm{a}}$ ed., Rio de Janeiro, Francisco Alves, 1957, p. 355; A. do VAlle SiQuEIRA, Codigo Civil Brasileiro, São Paulo, Saraiva \& C., 1922, p. 428; A. Dionysio GAMA, Tratado Theorico e Pratico de Direito Civil Brasileiro I - Introdução ao Estudo do Direito e Teoria Geral do Direito Civil, Rio de Janeiro, Livraria Editora Leite Ribeiro, 1927, p. 212; Das procurações - Teoria e prática, 6 a ed., São Paulo, Saraiva \& Cia., 1946, pp. 13-19; A. CAMARGO, Elementos de Direito Civil e de Direito Constitucional, Ribeirão Preto, Livraria Valada, s.d., p. 92; A. CHACON COUTO, Ligeiras observações sobre o mandato, Santo Anastácio, s.e., 1951, p. 7; A. ChAVES, Lições de Direito Civil IV-Obrigações (Contratos em Espécie), São Paulo, Revista dos Tribunais, 1977, pp. 285-286; A. FAIRBANKS, Mandato e comissão, São Paulo, Saraiva, 1923, pp. 9 e 103; A. L. da CÂMARA LeAL, Manual Elementar de Direito Civil III - Direito das Obrigações (theoria particular) - direito das sucessões, Saraiva \& C., 1930, p. 98; A. MARMitT, Mandato, Rio de Janeiro, Aide, 1992, pp. 11-36 e 175-179; A. WALD, Curso de Direito Civil Brasileiro - Obrigações e Contratos, $8^{a}$ ed., São Paulo, Revista dos Tribunais, 1989, pp. 299-301; C. FALCÃo, Codigo Civil Brazileiro reduzido á ordem alphabetica, Rio de Janeiro - São Paulo - Belo Horizonte, Livraria Francisco Alves, 1917, p. 143; C. Beviláqua, Codigo cit. (nota 05), pp. 28-31; D. ARruda Miranda, Anotações ao Código Civil Brasileiro III (Direito das Obrigações a Direito das Sucessões), São Paulo, Saraiva, 1986, pp. 367-368 e 372-373; E. EsPínola, Systema do Direito Civil Brasileiro I - Introducção e Parte Geral, Rio de Janeiro São Paulo - Belo Horizonte, Livraria Francisco Alves, 1938, p. 571; Dos contratos nominados cit. (nota 12), 
pp. 350-352 e 356-357; E. PESSÔA, Da procuração cit. (nota 47), pp. 3-5 e 19; F. R. LEITE FILHO, Curso cit. (nota 05), pp. 345-346; F. A P. LANDin FilHo, O mandato cit. (nota 09), pp. 12, 17, 30-33, 37 e 39 ; F. C. P. Rodrigues - L. da S. LouReIRo Filho, Código Civil Brasileiro interpretado pelos tribunais, São Paulo, Livraria Oliveira Mendes, 1998, pp. 873-874; F. C. de SAN TIAGO DANTAS, Programa cit. (nota 05), pp. 369 e 373; F. K. COMPARATO, Aparência de representação - a insustentabilidade de uma teoria, in Revista de Direito Mercantil, Industrial, Econômico e Financeiro 111 (1998), p. 40; G. SCIASCIA, Direito Romano e Direito Civil Brasileiro (textos e apontamentos extravagantes), São Paulo, Saraiva, 1947, pp. 154-158; G. LACERDA, Obrigações Civis VII - Ilícitos contratuais. Ilícitos extracontratuais. Seguro. Prestação de contas. Mandato. Doação. Empreitada. Corretagem. Fiança. Construção (casos selecionados), Rio de Janeiro, Forense, 2001, pp. 199-216 (especialmente pp. 206, 209, 211-214); J. do AMARAL GuRGEL, Contractos no Codigo Civil Brasileiro I (theoria dos contractos), São Paulo, Saraiva \& Cia., 1939, p. 75; J. GonÇALVES MAIA, Theoria e pratica das procurações, Recife, Imprensa Industrial, 1917, p. 11; J. L. ALVES, Código cit. (nota 05), pp. 348-349; J. F. de LIMA, Curso cit. (nota 05), pp. 564-565; J. M. de CARVAlHo SAnTos, Codigo cit. (nota 05), pp. 108-119; J. de SAMPAIO DORIA, Codigo Civil Brazileiro - Indice remissivo e analytico, São Paulo, Livraria e Officinas Magalhães, 1916, pp. 92 e 124; L. LEITE, Codigo Civil Brasileiro annotado, São Paulo, Escolas Prof. do Lyceu C. de Jesus, 1923, pp. 424-425; L. R. de Freitas Gomes, Contrato, Rio de Janeiro, Renovar, 1999, p. 285; M. I. CARVALHO DE MENDONÇA, Contratos no direito civil brasileiro, $4^{\mathrm{a}}$ ed., Rio de Janeiro, Forense, 1957, p. 193; M. PAUlo MERÊA, Codigo Civil Brasileiro annotado, Lisboa, Livraria Clássica Editora, 1917, pp. 404-405; M. M. de SERPA LOPES, Curso cit. (nota 05), pp. 238-240 e 253; M. TERRA, O mandato e sua forma, in Revista dos Tribunais 640 (1989), p. 44; O. J. De PlácIDO E SILVA, Tratado cit. (nota 47), pp. 18-19, 25-29; P. SOARES NETTO, Noções Elementares de Direito Civil Brasileiro, Porto Alegre, Globo, 1936, p. 244; R. L. FRANÇA, Manual cit. (nota 05), pp. 183-184; S. VAMPRÉ, Manual de Direito Civil Brasileiro III (Contractos e Direito das Sucessões), Rio de Janeiro, F. Briguiet \& Cia., 1920, pp. 123-125; T. Fulgencio Alves Pereira, Programmas de direito civil (Primeiro anno do curso e primeira parte do segundo) na Faculdade Livre de Direito de Bello Horizonte, Bello Horizonte, Imprensa Official do Estado de Minas, 1921, p. 134; T. PRATES DA FonSECA, Noções de Direito Civil Brasileiro, Rio de Janeiro, Livraria Editora Freitas Bastos, 1941, pp. 194-195; Y. S. CAHALI, Contratos Nominados - Doutrina e Jurisprudência, São Paulo, Saraiva, 1995, pp. 497-500. A exemplificar tal posicionamento, merece transcrição a manifestação de M. I. CARVALHO DE MENDONÇA: “o que, nos tempos actuaes, caracterisa essencialmente o mandato é a idéa de representação e de revogabilidade (...) no direito patrio, o que caracterisa o mandato é que o mandatario deve preencher um ou mais actos juridicos, em nome e como representante do mandante (...) é a representação no mandato que distingue essa figura jurídica da do arrendamento, em que também existe um certo gráu de gestão: - da de locação, em que ha tambem prestação de serviço; da comissão, onde tambem serviços existem, sem que o arrendatario, o locatario e o comissario representem o dono do immovel ou o beneficiario do serviço (...) quaisquer, porém, que sejam as criticas secundarias que taes expressões possam suscitar, não ha como poder negar que a representação é a idéa suprema do mandato, a caracteristica que só a elle pertence entre todas as especies de contractos" (Contratos cit. (nota 131), pp. 193-195). No mesmo sentido, considerando a "representação" a "nota típica" do contrato de mandato, eis a lição de M. M. de SERPA LOPES: "o traço característico do mandato em nosso direito é a representação. As divergências doutrinárias criadas pelos teóricos germânicos partem da apreciação do seu próprio direito objetivo, que desligou do mandato a procuração e a representação, considerando o primeiro um contrato de caráter distinto" (Curso cit. (nota 05), p. 240).

Todavia, em sentido contrário à doutrina de M. M. de SERPA LOPES, O. GOMES sustenta a ausência de uma maior homogeneidade quanto à definição da "causa-função" do contrato de mandato: "a determinação de seu traço característico não é feita, segura e uniformemente. Para alguns escritores, seria a gratuidade, como no Direito Romano, para outros, a representação. Como, porém, se admitem mandato salariado e o mandato sem representação, a gratuidade e a representação não podem constituir elemento distintivo do contrato. Recorre-se à qualidade dos atos a cuja prática se obriga o mandatário, havendo mandato, se for incumbido de realizar atos jurídicos, embora também possa encarregar-se da prática de atos materiais. É difícil, não obstante, isolar traço suficiente ao pronto reconhecimento do mandato. Certos contratos, como o de prestação de serviços, se lhe assemelham, notadamente quando envolvem poder de representação" (Contratos cit. (nota 23), pp. 346-348). Em outro escrito, por sua vez, este autor volta à carga a pretexto da distinção entre o negócio jurídico (bilateral) de incumbência ("mandato") e o negócio unilateral de outorga de poderes de representação ("procuração"): "impõe-se a distinção, não somente porque o mandato e a procuração não se superpõem necessàriamente, mas, também, porque são relações jurídicas de natureza diversa que, justapostas, revelam aspectos diferentes de um fenômeno aparentemente unitário. Quando o mandatário é procurador, o vínculo entre êle e o mandante é o lado interno da relação mais extensa em que participam, enquanto o lado externo se ostenta na qualidade de procurador, em razão da qual trata com terceiros. Nesta hipótese, o mandato é a relação subjacente à procuração. Como, porém, o poder de agir em nome de outrem encontra 
em outras relações jurídicas a razão de sua outorga, nascendo de negócio unilateral não vinculado necessàriamente ao mandato, sua noção é mais vasta e demanda desdobramento à parte, não se justificando a disciplina do poder de representação no capítulo dedicado a um contrato nominado, de causa típica, que o dispensa em muitos casos, mas, sobretudo, que o exige sempre que o mandante pretenda do mandatário que aja em seu nome" ( $O$ poder de representação, in Jurídica - Revista da Divisão Jurídica do Instituto do Açúcar e do Álcool s.n. (1970), pp. 4-5). Em síntese, O. GOMES conclui: "a procuração é figura autônoma e independente do mandato, que lhe é subjacente, as mais das vêzes, e se destina a regular a relação interna de gestão entre mandante e mandatário (...) en conclusión: la representación no es esencial al mandato, debiendo eliminarse la contradicción entre los arts. 1288 y 1307 del Código Civil brasileño" (O poder cit. (nota 131), pp. 12-14).

Ora, não se pode esquecer, por outro lado, o fato de que em meio à própria tramitação do projeto - que redundou no Código Civil de 1916 - houve quem alertasse para a existência de uma contradição entre os artigos 1288 e 1307 da futura codificação. O Deputado Solidônio Leite destacou que "as palavras - 'em nome do mandante' - indicam a necessidade da representação; mas não é esta senão a execução do mandato que constitue o caracteristico essencial deste contracto, cuja noção juridica subsiste na esphera das relações entre o mandante e o mandatario, ainda que este tenha agido em seu proprio nome" (Codigo Civil brasileiro: trabalhos relativos à sua elaboração II, Rio de Janeiro, Imprensa Nacional, 1918, pp. 501-502). O próprio F. C. PONTES DE MIRANDA - que não conferiu maior atenção à interposição gestória viabilizada pelo artigo 1307 do Código Civil (cf. Tratado de Direito Privado XLIII cit. (nota 04), pp. 4-5 e 11, das quais se extrai a definição emprestada ao tipo pelo autor) - já chamava a atenção da comunidade jurídica brasileira, em 1928, para a necessidade de se apartarem os negócios jurídicos de incumbência e de outorga de poderes representativos: "é querer resistir á elaboração scientífica que se operou nos ultimos cincoenta annos (...) limitou-se [o sistema do Código Civil] a tratar, esparsamente, da representação legal (gesetzliche Vertretungsmacht) e do mandato (Auftrag) como contrato, mas incluindo dispositivos que poderiam, com vantagens, ficar na Parte Geral, como os arts. 1289 e 1294, e deixando de formular alguns que seriam úteis (cp. B.G.B. $\S \S 164-180$ ), bem como a regra sobre contracto consigo mesmo (...) no systema do Codigo, tambem não se trata da representação voluntaria que derive de outro contracto, - o de locação de serviços, por exemplo - o que produz, na pratica, difficualdades graves, e evidencia a premencia de se recorrer a expedientes extra-technicos" (Fontes cit. (nota 16), p. 330).

A alusão de F. C. PONTES DE MIRANDA aos primorosos resultados da pandectística alemã - no que concerne à dissociação entre os conceitos de "mandato", "procuração" e "representação" (direta) - não podem obscurecer que o próprio A. TEIXEIRA DE FREITAS em seu "Esboço" de Código Civil havia divisado uma dupla acepção a ser emprestada ao termo "mandato": em primeiro lugar, o "mandato-contrato" a que se referia o artigo 2853 há pouco referido; além disso, um "mandato-ato unilateral" (artigo 2856), suscetível de uma profícua aproximação em relação ao negócio jurídico de procuração ("haverá mandato, como ato unilateral, quando uma ou mais pessoas tiverem conferido autorização a outra ou mais pessoas para representá-las em um ou mais atos da vida civil. Antes de aceita pelo mandatário a autorização, não haverá contrato de mandato"). Pela origem de tal dissociação no pensamento deste autor, cf. Consolidação cit. (nota 16), p. 318, nota 1 ("antes de aceito pelo mandatario, o mandato é acto unilateral. Depois de aceito, é contracto bilateral imperfeito").

Eis aí o germe de que partiram - cronologicamente ordenadas - as manifestações de J. P. CAVALCANTI (Direito Civil - Escritos Diversos, Rio de Janeiro, Forense, 1983, pp. 276-288 e 399-406); F. M. DE MATTIA, Aparência cit. (nota 06), pp. 19 e 29; J. P. CAVALCANTI, Sobre o ato ou negócio jurídico de procuração, Recife, Fundação Antônio dos Santos Abranches (FASA), 1992, passim; R. LOTUFO, Questões cit.(nota 26), pp. 74-89; M. C. do. A. KroetZ, A representação cit. (nota 41), pp. 46, 62-65; e M. G. MAIA JÚNIOR, A representação cit. (nota 04), pp. 31, 41-42 e 77. Este último autor, de modo perspicaz, observa que "nas normas pertinentes ao contrato de mandato, encontram-se disciplinadas, de modo assistemático, a representação; a procuração, como instrumento da outorga de poderes indispensável à representação; e o contrato de mandato" (A representação cit. (nota 04), p. 42). E F. A. P. LANDIN FILHO define o instituto de uma maneira diferenciada: "contrato pelo qual se criam a alguém o dever e a obrigação, perante outrem, da gestão de negócios que lhe entregam, com ou sem poder de representar" ( $O$ mandato cit. (nota 09), pp. 1920).

Assim, não é de se estranhar que - no contexto do contrato de mandato contemporâneo - da "essencialidade" representativa de outrora se tenha iniciado um movimento em direção à "naturalidade" representativa (tomada tão somente como aquilo que ordinariamente ocorre); todavia, ainda existem relevantes manifestações em sentido contrário, como que a considerar o mandato um contrato de "representação" - cf. CAIO MÁrio da Silva Pereira, Instituições cit. (nota 02), pp. 397-398; C. E . N. CAMILlO - G. M. TAVALERA - J. S. Fujita - L. A. Scavone Júnior (coords.), Comentários cit. (nota 02), pp. 584-585; F. UlHOA Coelho, Curso cit. (nota 02), p. 299; G. R. Nicolau, Direito cit. (nota 06), p. 124; MARIA HelENA DinIZ, 
Curso cit. (nota 02), p. 351; N. G. B. Dower, Curso cit. (nota 02), pp. 281-282; O. R. B. SANDOval, Do mandato, in D. Franciulli NetTo - G. F. Mendes - I. G. da S. MARTins Filho, O novo Código Civil Estudos em Homenagem ao Prof. Miguel Reale, São Paulo, LTr, 2003, pp. 580-591; R. FIUZA (coord.), Novo Código cit. (nota 02), pp. 600-601; S. de S. Venosa, Direito cit. (nota 02), p. 251; Silvio Rodrigues, Direito cit. (nota 02), pp. 285, 288-289; V. RÁo, Ato Jurídico - Noção, pressupostos, elementos essenciais e acidentais. O problema do conflito entre os elementos volitivos e a declaração, $4^{\mathrm{a}}$ ed., São Paulo, Revista dos Tribunais, 1999, p. 245; WAShINGTON De BARROS MonTEIRO, Curso cit. (nota 02), p. 260.

Embora se tenha robustecido a doutrina (outrora minoritária) que compreende o contrato de mandato como autêntico instrumento de gestão, nesta seara ainda resta uma viva polêmica doutrinária voltada à depuração da "nota típica" do instituto - se voltada a uma autêntica "gestão" ou à simples "substituição" do mandante. $\mathrm{Na}$ obra de WASHINGTON DE BARRos Monteiro, por exemplo, persistem as assertivas de que "o que caracteriza, portanto, o mandato é a idéia de representação, suprema, básica, fundamental, não figurando em outros contratos (...) [e] no mandato, pois, é imanente e imprescindível a idéia de representação, que estabelece relação contratual direta entre o representado e terceira pessoa, através do representante" (Curso cit. (nota 02), pp. 261-262); como se o poder de representação não pudesse ser utilizado, por exemplo, para a prática de negócios jurídicos unilaterais. Ora, posta de parte a equivocada alusão a uma representação "convencional" - uma vez que a eficácia representativa direta (erigida a autêntico instituto jurídico pelo legislador civil de 2002) decorre de negócio jurídico unilateral - algumas manifestações doutrinárias revelam, ainda hoje, a ausência de uma completa depuração de tais conceitos em nosso país. Exemplificativamente, tomemos em consideração o exercício simplificador deste último autor: "a palavra mandato designa, presentemente, ora o próprio contrato, ora o poder conferido ao mandatário, ora o título pelo qual se outorga esse poder, ora o instrumento do contrato" (Curso cit. (nota 02), p. 260). Ou então a miscelânea de S. de S. VENOSA que toma o poder de representação como aspecto interno da relação gestória ao observar que "há duas relações bem nítidas nesse negócio jurídico (...) uma relação interna, que vincula o mandante e o mandatário, disciplinando os seus limites (...) a esses limites se reporta o poder de representação" (Direito cit. (nota 02), p. 255). C. R. GONÇALVES, por sua vez, após equiparar os conceitos de "mandato" e "procuração", naturalmente conclui que o primeiro "é contrato porque resulta de um acordo de vontades: a do mandante, que outorga a procuração, e a do mandatário, que a aceita (...) procuração é ato unilateral de oferta; o mandato é bilateral e somente se perfaz com a aceitação dessa oferta" (Direito Civil Brasileiro III - Contratos e Atos Unilaterais, 6 a ed., São Paulo, Saraiva, 2009, pp. 388 e 395).

Pela progressiva ampliação dos horizontes doutrinários da dissociação entre "mandato", "procuração" e "representação", cf. A. de Assis, Contratos nominados - mandato, comissão, agência e distribuição, corretagem, transporte, São Paulo, Revista dos Tribunais, 2005, pp. 23-29; C. L. BUENO DE GODOY, Do mandato, in C. Peluso, Código Civil Comentado - Doutrina e Jurisprudência, $2^{\mathrm{a}}$ ed., São Paulo, Manole, 2008, pp. 605-607; C. P. M. CRUZ E TUCCI, Interposição cit. (nota 09), pp. 117; F. AMARAL, Direito Civil Introdução, Rio de Janeiro - São Paulo - Recife, Renovar, 2008, pp. 449, 452-453; F. M. DE MAtTIA, Aparência cit. (nota 06), p. 18 (nota 40); J. B. VILlela, Parte geral do Código Civil, in Seminário Novo Código Civil Brasileiro: o que muda na vida do cidadão, Brasília, Centro de Documentação e Informação (Coordenação de Publicações), 2003, p. 212; J. C. MOREIRA ALVES, O negócio jurídico no novo Código Civil Brasileiro, in Jurisprudência Catarinense 102 (2004), pp. 40-41; O novo Código Civil Brasileiro: principais inovações na disciplina do negócio jurídico e suas bases romanísticas, in Roma e America - Diritto Romano Comune 16 (2003), pp. 17-18; A Parte cit. (nota 03), p. 105; J. P. CAVALCANTI, O Congresso e o projeto de Código Civil, in Reforma do Código Civil - Ciclo de Estudos, Recife, Instituto dos Advogados de Pernambuco, 1975, pp. 59-61; M. G. MAIA JÚNIOR, A representação cit. (nota 04), p. 30; M. C. do. A. KroetZ, A representação cit. (nota 41), p. 35; N. C. B. CAMPELlo, Da representação, in M. L. Delgado J. F. Alves, Questões Controvertidas - Parte Geral do Código Civil (Série Grandes Temas do Direito Privado VI), São Paulo, Método, 2007, pp. 394, 420-423, 429-433; O.Gomes, Contratos cit (nota 23), pp. 426; e R. Lotufo, Código cit. (nota 02), pp. 323-328. No mesmo sentido - conquanto levantem suspeita quanto à prestabilidade prática do mandato sem representação - cf. L. MATTIETTO, A representação voluntária e o negócio jurídico de procuração, in Revista Trimestral de Direito Civil 4 (2000), p. 55; G. TEPEDINO, A técnica cit. (nota 05), pp. 67-68 e 78-80; e A. SCHREIBER, A representação no novo Código Civil, in G. TePedino, A Parte Geral do Novo Código Civil: Estudos na Perspectiva Civil-Constitucional, Rio de Janeiro - São Paulo, Renovar, 2002, pp. 228-232 e 240-241.

Mesmo quanto ao objeto do contrato de mandato ainda existe certa polêmica, que de certa maneira inspira a investigação sobre a "causa-função" do instituto. Parte considerável da doutrina reputa - à moda italiana de 1942 (posteriormente feita lusitana em 1966) - suscetíveis de "mandato" tão somente os atos jurídicos em sentido estrito e os negócios jurídicos. Tal perspectiva, embora compatível com a expressão "praticar atos", não se coaduna por completo com a que lhe completa ("administrar interesses"). Apenas a título ilustrativo, destaque-se que no início da segunda metade do século passado E. ESPínOLA já alertava para a diferente 
abrangência do contrato de mandato consoante os diferentes sistemas jurídicos objeto da análise do estudioso: "no direito romano, no direito comum e em vários códigos modernos, o mandato não se limita à incumbência de preaticar atos jurídicos, podendo ter por objeto a realização de qualquer ato material (...) dizendo a nossa lei 'praticar atos ou administrar interêsses', deixa ver que não exclui da esfera do mandato a prática de atos puramente materiais" (Dos contratos nominados cit. (nota 12), pp. 350-351). M. M. de SERPA LOPES efetua a oportuna contraposição entre a feição germânica do instituto (mais ampla, a abranger a prática de atos jurídicos e materiais) e a compleição da categoria segundo a correspondente concepção francesa (Curso cit. (nota 05), p. 242). De maneira contundente, F. C. PONTES DE MIRANDA observa que a amplitude do objeto da incumbência não pode ser sacrificada em virtude da eventual deficiência da terminologia empregada pelo legislador: “nas expressões 'gestão de negócios', 'cuidado de negócios', 'gerência de negócios', já se revela impropriedade, se não se restringe o conceito àquelas espécies em que se tratam 'negócios'. Êsse sentido estrito não é o usual, nem o que resulta dos dados históricos. Também se gestionam interêsses que não consistem em negócios jurídicos, nem, sequer, em atos jurídicos. Cuida-se de atos-fatos jurídicos e até de fatos, que interessam ao dono do bem ou dos bens. A expressão 'negócio' foi empregada em sentido latíssimo, de modo que abrange qualquer fato que entre na esfera dos interêsses de alguém" (Tratado de Direito Privado XLIII cit. (nota 04), p. 10).

Superada a questão concernente à definição do "mandato", necessário se faz observar que ao nosso legislador comercial oitocentista não passou despercebida a sua natureza contratual: com efeito, ao mesmo tempo em que se estabeleceu que o contrato de mandato somente se reputaria aperfeiçoado com a aceitação do oblato (descurando-se, indevidamente, da hipótese de oferta derivada do próprio agente), foi instituída uma inteira liberdade de forma quanto à aceitação; neste sentido, o artigo 141 dispõe que "completa-se o mandato pela aceitação do mandatário; e a aceitação pode ser expressa ou tácita; o princípio da execução prova a aceitação para todo o mandato". Pela disciplina subseqüente - legislada (ou simplesmente projetada) - da formação do contrato a partir da aceitação (e quanto às modalidades desta), cf. os arts. 2907, 2908, 2909, 2910, 2898, 2899, 2904 e 2905 do "Esboço" de Código Civil (daqui por diante simplesmente "Esboço"); o art. 2268 do Anteprojeto de Felício dos Santos (AntFS); o art. 1065 do Anteprojeto de Coelho Rodrigues (AntCR); o art. 1444 do Anteprojeto de Clóvis Beviláqua (AntCB); o art. 1509 do Anteprojeto de Clóvis Beviláqua em sua versão revista (AntCBRev); o art. 1292 do Projeto da Câmara dos Deputados no 1/1902 (PCD n $\left.{ }^{\circ} 1 / 1902\right)$; o art. 1292 do Parecer no 269/1912 do Senado Federal ao Projeto da Câmara dos Deputados (PSF n 269/1912); o art. 1292 do Código Civil de 1916 (CC/1916); o art. 638 do Anteprojeto de Código das Obrigações de Caio Mário da Silva Pereira (AntCM); o art. 607 do Anteprojeto de Código das Obrigações de Caio Mário da Silva Pereira Revisto - PL no 3264/65 (AntCMRev); o art. 673 do Anteprojeto da Comissão presidida por Miguel Reale (AntMR); o art. 658 do Anteprojeto da Comissão presidida por Miguel Reale em sua versão revista (AntMRRev); o art. 668 do Projeto da Câmara dos Deputados no 634/1975 (PCD n 634/1975); e o art. 659 do Código Civil vigente (CC/2002). Acerca das modalidades de aceitação do mandato, cf. Consolidação cit. (nota 16), p. 318 (nota 1). Observe-se que o Código Comercial consagra a modalidade "tácita" de aceitação, sem se pronunciar sobre a chamada aceitação "presumida"; tal matéria será objeto de análise posterior, oportunidade na qual pretenderemos apartar tais conceitos.

Uma vez aceita a incumbência, não se admite a livre exoneração do mandatário - diante da irretratabilidade genérica de sua declaração negocial, nos termos do artigo 143 do Código Comercial (daqui em diante CCom). Tão somente em duas hipóteses tal vinculação é excepcionada: "se sobrevier causa justificada que o impossibilite de continuar na sua execução" (artigo 143 do CCom) e em caso de "conhecimento [superveniente] de que o comitente se acha em circunstâncias que ele ignorava ao tempo em que aceitou" (artigo $144,1^{\mathrm{a}}$ parte do CCom). Note-se que neste último caso se prescreve ao mandatário o emprego de aviso exonerativo - a fim de que o mandante possa tomar as providências necessárias ao prosseguimento da gestão, por si próprio ou por meio de outrem (art. 144, $2^{\mathrm{a}}$ parte do CCom). Como bem observa F. C. PONTES DE MIRANDA, a denúncia no âmbito do mandato - seja civil ou comercial - é sempre "vazia" (desprovida de fundamentação), no que concerne à perfeição do efeito extintivo do liame; o oferecimento de uma justa causa - como que a "encher" o negócio jurídico denunciativo - simplesmente tem por finalidade evitar o surgimento de eventual pretensão indenizatória por parte do mandante (Tratado de Direito Privado XLIII cit. (nota 04), pp. 89-90). Por sua volta - como teremos a oportunidade de observar em breve - no artigo 144 se viabiliza a suspensão da execução do contrato à vista da artificial criação (legislativa) de um "sinalagma funcional". A respeito do tema, no âmbito da legislação civil projetada, cf. os arts. 2910, 2915, 3032 e 3034 do "Esboço".

Ora, o leitor sagaz percebe de imediato que, admitida a aceitação tácita - derivada da apreciação do comportamento concludente do destinatário da oferta - não seria de se exigir maior formalidade quanto à conclusão do contrato. Aparentemente, no entanto, o legislador preconizou a forma escrita (pública ou particular) para o "mandato"; assim o dispõe a parte final do artigo 140 do Código Comercial: "o mandato requer instrumento público ou particular, em cuja classe entram as cartas missivas; contudo, poderá provar-se 
por testemunha nos casos em que é admissível este gênero de prova (art. 123)". Por óbvio - frise-se - que aqui o legislador se refere à outorga dos poderes de representação ("procuração-ato"), ainda que equivocadamente tenha empregado o termo "mandato".

Ocorre que à terminologia imperfeita do codificador mercantil não escapou a legislação civil brasileira que se lhe seguiu: a esse respeito, cf. os arts. 2888, 2889, 2890, 2895, 2896, 2897 e 2906 do "Esboço"; o art. 1064 do AntCR; o art. 1443 do AntCB; o art. 1507 do AntCBRev; o art. 1290 do PCD no 1/1902; o art. 1290 do PSF no 269/1912; o art. 1290 do CC/1916; os arts. 633, 634 e 635 do AntCM; os arts. 602 e 603 do AntCMRev; os arts. 671 e 672 do AntMR; os arts. 655 e 656 do AntMRRev; os arts. 665 e 666 do PCD n 634/1975; e os arts. 656 e 657 do CC/2002.

Exatamente em virtude da falta de um maior rigor quanto às expressões utilizadas no texto legal, instaurou-se acesa polêmica quando da promulgação do Código Civil de 1916, a propósito da consagração - ou não - do "princípio da simetria" em matéria de forma aplicada ao negócio jurídico de outorga de poderes representativos ("procuração"). Voltaremos ao tema mais adiante, ao analisarmos as disposições concernentes à forma da procuração. No entanto, há que se observar de imediato que - ao contrário do que supõe certa doutrina enaltecedora do direito alienígena (sobretudo de origem alemã) - a previsão do chamado "procurador tolerado" já pode ser divisada no "Esboço" de Código Civil, o qual por seu artigo 2896 assim estabelecia: "o mandato tácito pode resultar, não só de fatos positivos do mandante, como de sua inação ou silêncio: ou deixando continuar seu mandatário ou preposto nos atos ulteriores da mesma gestão; ou não impedindo, podendo impedir, o que sabe estar alguém fazendo em seu nome, ou ter começado a fazer". Assim, a filiação de tal figura (Duldungsvollmacht) aos $\S 170$ e 172 do BGB - bem como à produção doutrinária e jurisprudencial que lhe foi subseqüente - nos parece, ao menos, precipitada. Conquanto ainda não se observasse - claramente - no Brasil a dissociação entre os negócios de incumbência e de outorga de poderes, algo de relativamente inovador pode ser depreendido de nossas fontes do direito privado (mesmo que simplesmente projetado). A respeito do posicionamento ora repudiado cf., exemplificativamente, A. Menezes CordeIRo (Manual cit. (nota 115), pp. 477-479); bem como M. I. CARVAlHo DE MENDONÇA (Contratos cit. (nota 131), pp. 200-208), que alude ao artigo 1874 do Código Civil argentino sem conferir a mesma atenção à sua fonte remota. Observe-se ainda que tal dispositivo do "Esboço" foi posteriormente aproveitado no Anteprojeto de Felício dos Santos (art. 2314). E da mesma forma, por falta de uma precisão maior quanto aos conceitos abordados, M. C. do. A. KROETZ parece incorrer em sérias confusões a respeito da forma da procuração - e inclusive quanto à procuração "tácita" (A representação cit. (nota 41), pp. 82-84). Quanto a este aspecto, cumpre-nos destacar a distinção entre os conceitos de "ato autorizado" e "ato tolerado" efetuada por A. CANDIAN (Atto autorizzato, atto materiale lecito, atto tollerato. Contributo alla teoria dell'atto giuridico, in Scritti giuridici in onore di Francesco Carnelutti III, Padova, CEDAM, 1950, pp. 453-ss).

Finalmente, no que concerne à amplitude do negócio jurídico de incumbência, o Código Comercial de 1850 (con)fundiu os conceitos de mandato "geral" e "em termos gerais" (artigo 145): "o mandato geral abrange todos os atos de gerência conexos e conseqüentes, segundo se entende e pratica pelos comerciantes em casos semelhantes no lugar da execução; mas, na generalidade dos poderes não se compreendem os de alhear, hipotecar, assinar fianças, transações, ou compromissos de credores, entrar em companhias ou sociedades, nem os outros quaisquer atos para os quais se exigem neste Código poderes especiais". Como se pode depreender da análise deste dispositivo, sua primeira parte se refere à amplitude da incumbência, ao passo que o trecho derradeiro concerne à extensão dos poderes de representação outorgados ao procurador.

Assim, tomada em consideração a "amplitude" da gestão, tem-se qua a incumbência pode ser mais ("mandato geral") ou menos abrangente ("mandato especial"); no entanto, tendo-se em conta o objeto da atribuição, percebe-se que ora se busca a simples administração do negócio confiado ("mandato em termos gerais"), ora se pretende a concatenação de operações mais expressivas, por meio das quais o patrimônio do principal se expõe da maneira mais contundente ("mandato com poderes especiais"). Desta forma, a despeito do paralelismo existente entre as dicotomias "mandato geral/mandato especial" e "mandato em termos gerais/mandato com poderes especiais", não pode o intérprete permutar indiscriminadamente os seus respectivos termos - embora algumas das legislações modernas tenham associado, indevidamente, o "mandato geral" à variante "em termos gerais". Neste sentido, J. L. ALVES observa que "o mandato especial, como o geral, póde ser concebido em termos geraes ou conferir determinados poderes. O mandato especial para determinado negocio, concebido em termos geraes, só confere poderes de administração nesse negocio. Assim, tambem, o mandato geral, concebido em termos geraes, só confere poderes de administração em todos os negocios do mandante" (Código cit. (nota 05), p. 357). Tal entendimento já encontrava alicerce em acórdão da Relação do Maranhão de 21 de outubro de 1856 (apud J. M. da TRINDADE, Collecção cit. (nota 131), pp. 302-304).

Pela abordagem da dicotomia "mandato geral/mandato especial" no âmbito da legislação (positiva ou projetada) posterior, cf. os arts. 2874, 2878, 2880, 2882, 2883 e 2884 do "Esboço"; os arts. 2270, 2271 e 
2272 do AntFS; o art. 1066 do AntCR; o art. 1446 do AntCB; o art. 1511 do AntCBRev; o art. 1294 do PCD no 1/1912; o art. 1294 do PSF no 269/1912; o art. 1294 do CC/1916; o art. 636 do AntCM; o art. 605 do AntCMRev; o art. 674 do AntMR; o art. 659 do AntMRRev; o art. 669 do PCD n ${ }^{\circ}$ 634/1975; e o art. 660 do $\mathrm{CC} / 2002$.

Note-se que o legislador foi suficientemente hábil para entrever a necessidade de inclusão dos atos "conexos e conseqüentes" vinculados à gestão. Tal perspicácia inspirou a legislação projetada que redundou no Código Civil de 1916 (cf. os arts. 2929, 2930 e 2931 do "Esboço" e o art. 2274 do AntFS) e no diploma que o revogou (cf. o art. 636 do AntCM e o art. 605 do AntCMRev). Destaca, oportunamente, M. M. de SERPA LOPES que "o mandatário, no desempenho de seus deveres, pode não só realizar o ato principal de que foi incumbido, como ainda todos os atos accessórios indispensáveis ao cumprimento do principal" (Curso cit. (nota 05), p. 267). No entanto, o legislador nada "criava" quanto a este ponto, pois como observa G. DONATUTI, a amplitude da incumbência já admitia uma interpretação mais arrojada - quanto à vontade do mandante - em meio ao próprio direito justinianeu (Mandato incerto, in Studi di diritto romano I, Milano, Dott. A. Giuffrè, 1976, p. 193).

Por fim, no que concerne à dicotomia "mandato em termos gerais/mandato com poderes especiais", algumas observações devem ser lançadas. Em primeiro lugar, cabe destacar que a primeira categoria engloba um conceito jurídico indeterminado, que carece de maior concretude a fim de que se explicite o seu respectivo alcence. Por tal razão, o mesmo M. M. de SERPA LOPES observava que "por atos de administração se entendem tôdas as operações destinadas à conservação de uma coisa ou de um determinado patrimônio e ao recebimento das rendas comuns, sem que importe em alterar a medida e a substância do próprio patrimônio. Duas concepções existem, a propósito da linha demarcatória entre atos de administração e atos de disposição: a primeira, rigorosa, pretende que, sejam quais forem as circunstâncias de fato, por atos de administração se devem exclusivamente entender as operações absolutamente isentas de qualquer efeito de disposição, mesmo que o ato dispositivo possa se refletir vantajoso no interêsse de uma boa administração; a segunda, mais dúctil, aceita a possibilidade de atenuações ao princípio da proibição de atos de disposição, de modo que, em determinadas circunstâncias, certos podêres podem ser incluídos entre os de administração (...) o conceito de atos de administração deve ser formulado por meio de uma noção funcional e não técnica, pois que esta não pode ser decisiva por si só. Atos que, em si e isoladamente, podem ser de disposição, postos, ao contrário, no quadro de um conjunto de operações convertem-se em simples atos de administração. Exemplifico com a hipótese de uma venda de títulos ameaçados de baixa e sua sub-rogação em outros títulos de perspectivas mais seguras. É de parecer que a questão comporta uma interpretação em função da prática dos negócios (...) a extensão dos poderes de um mandato me têrmos geraes deve sobretudo constituir trabalho de interpretação judicial, sòmente dando elastério aos poderes notòriamente resultantes da própria vontade do mandante (...) os atos de administração não excluem, de um modo absoluto, certos atos de disposição, como, por exemplo, a venda de mercadorias e objetos suscetíveis de perecerem e mesmo o próprio empréstimo, quando as necessidades reais e imperativas da administração o imponham" (Curso cit. (nota 05), pp. 248-250). Com efeito, antecipando um compartilhamento de funções entre o Legislativo e o Judiciário no processo de "jurislação", M. I. CARVALHO DE MENDONÇA também destacava ser "muito diffícil, sinão de todo impraticavel, dar a formula geral que caracterise a verdadeira administração no mandato geral (...) esta constitue sempre uma indagação de facto e por isso do dominio da jurisprudencia" (Contractos cit. (nota 131), p. 212). Assim, o mandato "institório" - por exemplo - não pode ser adequadamente cumprido sem que o mandatário pratique atos de alienação indispensáveis à conservação da fazenda que the fora cometida (cf. W. FERREIRA, Tratado cit. (nota 131), p. 15).

Além disso, é necessário evidenciar a utilização de uma cláusula geral para o fechamento da regra estabelecida pelo artigo 145 do Código Comercial; com efeito, o período derradeiro da disposição - "outros quaisquer atos para os quais se exigem (...) poderes especiais" - oferece uma amplitude que proporciona a ampliação casuística do teor da disciplina. A catalogação das hipóteses nas quais se exigem poderes especiais foi efetuada por diversos doutrinadores, destacando-se - dentre as por nós consultadas - as referências de M. I. CARVAlHo De MendonçA (Contractos cit. (nota 131), pp. 205-207) e J. GonÇAlves Maia. Este último autor alude à necessidade de poderes especiais para: a) o substabelecimento; b) o oferecimento de queixacrime; c) a prestação de juramento; d) a adição de herança (ou sua renúncia); e) a assinatura de termo de fiança (artigo 20 do Decreto $n^{\circ} 465$ de 17 de agosto de 1846; Aviso no 414 de 06 de novembro de 1874) f) a venda, a doação ou qualquer negócio que redunde em alienação (cf. o Aviso ${ }^{\circ} 49$ de 10 de fevereiro de 1857, o artigo 12 da Lei $n^{\circ} 1114$ de 27 de setembro de 1860, os artigos $5^{\circ}$ e $8^{\circ}$ do Decreto $n^{\circ} 2699$ de 28 de novembro de 1860, o artigo 54 do Decreto $\mathrm{n}^{\circ}$ 451-B de 31 de maio de 1890 e o artigo 103 do Decreto $\mathrm{n}^{\circ}$ 955A de 05 de novembro de 1890); g) a transação (artigo $3^{\circ}$ das Disposições Provisórias da Lei de 29 de novembro de 1832 e artigo 26 do Regulamento ${ }^{\circ} 737$ de 25 de novembro de 1850) e o compromisso; h) a remissão, o perdão e a outorga de quitação (Portaria da Diretoria Geral das Rendas de 07 de agosto de 1858); i) o exercício da escolha (opção); j) a prestação de contas testamentária; l) a constituição de hipoteca, penhor 
ou outro gravame real (artigo $5^{\circ}$ do Decreto $n^{\circ} 482$ de 14 de novembro de 1846; artigo 54 do Decreto ${ }^{\circ} 451$ B de 31 de maio de 1890); m) a posse; n) a invocação da suspeição do magistrado; o) a transferência de apólices da dívida pública ou seus equivalentes (artigos 58 a 64 da Lei de 15 de novembro de 1827; Aviso de 29 de abril de 1839; Aviso de 03 de fevereiro de 1841; Lei n 241 de 29 de novembro de 1841; Lei n 116 de 15 de janeiro de 1842; Ordem n ${ }^{\circ} 10$ de 05 de fevereiro de 1850; Ordem n 79 de 17 de março de 1852; artigo $3^{\circ}$ do Decreto $n^{\circ} 8260$ de 24 de setembro de 1881; artigo 115 do Decreto $n^{\circ} 9370$ de 14 de fevereiro de 1885; Decreto $\mathrm{n}^{\circ} 6711$ de 07 de novembro de 1907) ou a percepção de seus juros (artigo $1^{\circ}$ do Decreto de 08 de outubro de 1828 e Decisão $n^{\circ} 100$ de 23 de abril de 1849); p) a aceitação de letra, bem como o saque, endosso ou emissão de nota promissória (Ordem de 27 de março de 1866; e artigos $1^{\circ}, 8^{\circ}, 11,14$ e 54 da Lei n 2044 de 31 de dezembro de 1908); q) o comparecimento e a posse perante Assembléia-Geral de sociedade anônima (artigo 15, $\S 8^{\circ}$ da Lei $n^{\circ} 3150$ de 04 de novembro de 1882, mantido a despeito da reforma empreendida pelo Decreto $\mathrm{n}^{\circ} 164$ de 17 de janeiro de 1890 e correspondente ao artigo 133 do Decreto $\mathrm{n}^{\circ} 434$ de 04 de julho de 1891), excetuadas as instituições financeiras (artigo $2^{\circ}, \S 12$ da Lei $n^{\circ} 1083$ de 22 de agosto de 1860, Aviso de 09 de fevereiro de 1861, Aviso de 12 de junho de 1861 e Aviso de 03 outubro de 1861); r) a abertura de crédito junto a instituição financeira; s) o recebimento de citação (os artigos 48, 55 e 56 do Regulamento $\mathrm{n}^{\circ} 737$ de 25 de novembro de 1850 facultam, em hipóteses específicas, o recebimento por prepostos do comerciante, no que foram confirmados pelo artigo 106 do Decreto $\mathrm{n}^{\mathrm{o}} 848$ de 11 de outubro de 1890); t) a prestação de confissão (artigo 155 do Regulamento $\mathrm{n}^{\circ} 737$ de 25 de novembro de 1850); u) o concurso em matrimônio ou desquite; v) a renúncia ao foro do domicílio; x) a assinatura de termo de reconhecimento de filho natural; z) o requerimento de homologação de sentença estrangeira; a.1) a colação ou renúncia a benefício; b.1) o benefício de restituição; c.1) o pedido de liquidação forçada de companhia (artigos $2^{\circ}$ e $3^{\circ}$ do Decreto $n^{\circ} 3065$ de 06 de maio de 1882 e artigo 38 do Decreto $n^{\circ} 917$ de 24 de outubro de 1890); d.1) o depósito e o pedido de registro de marcas (artigo $5^{\circ}$ do Decreto Legislativo $\mathrm{n}^{\mathrm{o}} 1236$ de 24 de setembro de 1904); e.1) a desistência de recurso extraordinário; f.1) a interposição de recurso eleitoral (artigo 12, a da Lei $\mathrm{n}^{\mathrm{o}} 3139$ de 02 de agosto de 1916); g.1) o requerimento de naturalização (artigo $7^{\circ}$ da Lei $\mathrm{n}^{\circ} 6948$ de 04 de maio de 1908); h.1) a prática de atos prejudiciais à liberdade do sujeito; i.1) a representação em sumário de crimes inafiançáveis (Theoria cit. (nota 131), pp. 69-122). Laconicamente, o Decreto $n^{\circ} 2519$ de 22 de maio de 1897 estabeleceu - por seu artigo $8^{\circ}\left(\S 3^{\circ}\right)$ - que os portadores de obrigações poderiam se fazer representar diante da companhia devedora por procuradores "munidos de poderes sufficientes". Note-se que J. M. da TRINDADE já enumerava em 1862 - exemplificativamente - 25 (vinte e cinco) hipóteses nas quais se fazia necessária a outorga de poderes especiais ao procurador (Collecção cit. (nota 131), pp. 54-69). $\mathrm{Na}$ "Consolidação", A. TEIXEIRA DE FREITAS aponta alguns casos de poderes especiais que admitem interpretação extensiva (Consolidação cit. (nota 16), pp. 329-330, notas 28, 29 e 30); sendo de se observar que o autor, neste particular, não destoava do Aviso no 236 de 23 de junho de 1866 (por meio do qual se reconhecia que "a clausula de - receber -, nas procurações, contém virtualmente a de - dar quitação"). Em sentido diverso, o mesmo J. M. da TRINDADE assevera que "o mandato é por sua natureza estrito e inampliavel caso a caso (...) tudo o que se exceda é nullo, e não prejudica ao mandante (...) em regra a procuração, embora seja geral e com amplos poderes, só abrange as faculdades de administração, e não de disposição" (Collecção cit. (nota 131), p. 23). No entanto, páginas depois o autor preconiza a autorização implícita para doar sempre que a procuração conferir ao agente poderes para remitir "porque em suma remittir é doar" (Collecção cit. (nota 131), pp. 59-60, nota 39); e mais à frente (pp. 61-62, nota 43) noticia controvérsia doutrinária relacionada à implicitude dos poderes para recebimento do preço (na hipótese de singela outorga de poderes para "vender"). Aliás, observe-se que este último autor oferece uma classificação "sui generis" do tipo quanto ao seu objeto, à custa de uma "quadripartição" nas categorias "geral", "especial e geral”, “em termos gerais” e "especial” (cf. J. M. da TRINDADE, Collecção cit. (nota 131), pp. 28-29).

Pela abordagem da temática referida no âmbito das fontes legisladas (ou simplesmente projetadas), cf. o art. 470 da Consolidação das Leis Civis (daqui por diante CLC); os arts. 2879, 2881 e 2883 do "Esboço"; o art. 2272 do AntFS; os arts. 1067 e 1068 do AntCR; o art. 1447 do AntCB; o art. 1512 do AntCBRev; o art. 1295 do PCD n 1/1902; o art. 1295 do PSF no 269/1912; o art. 1295 do CC/1916; o art. 42 do Anteprojeto de Código das Obrigações (Parte Geral) de Orosimbo Nonato, Philadelpho Azevedo e Hahnemann Guimarães (AntOPH); os arts. 636 e 637 do AntCM; os arts. 605 e 606 do AntCMRev; o art. 114 do Anteprojeto de Parte Geral de José Carlos Moreira Alves (AntPGMA); o art. 675 do AntMR; o art. 660 do AntMRRev; o art. 670 do PCD n ${ }^{\circ}$ 634/1975; e o art. 661 do CC/2002.

É oportuno mencionar o fato de que não é pacífico o alcance da expressão "poderes especiais", sobretudo quando cotejada com sua correlata "poderes expressos". Neste sentido, o artigo 1295 do Código Civil de 1916 (integralmente reproduzido pelo artigo 661 do Código Civil vigente) suscitou acesa polêmica, sobretudo à vista de seu parágrafo primeiro: "o mandato em termos gerais só confere poderes de administração. $\S 1^{\circ}$ Para alienar, hipotecar, transigir, ou praticar outros quaisquer atos, que exorbitem da administração ordinária, depende a procuração de poderes especiais e expressos; $\S 2^{\circ} \mathrm{O}$ poder de transigir 
(arts. 1025 a 1036) não importa o de firmar compromisso (arts. 1037 a 1048)”. Em uma apressada interpretação do preceito - em meio à qual são tratados promiscuamente os conceitos de "mandato geral", "mandato em termos gerais", "mandato especial" e "outorga de poderes especiais" - J. GILDENOR DE ALBUQUERQUE traça conclusões inteiramente lastreadas em direito alienígena que - à vista de simplificações conceituais excessivas - se mostra insuficiente para a compreensão do fenômeno no sistema jurídico brasileiro (Mandato - poderes especiais e expressos, in Revista Forense 213 (1966), pp. 485-487).

A posição majoritária da doutrina pode ser sintetizada da conclusão de M. G. MAIA JÚNIOR: “os poderes são específicos ou expressos quando particularizam a natureza dos atos a serem praticados pelo representante, sendo desta natureza os poderes conferidos, em regra, para a consecução de atos que importem disposição ou instituição de gravaes ou ônus" (A representação cit. (nota 04), p. 94). Como se vê, inexiste uma maior preocupação técnica em diferenciar o significado dos termos "expressos", "especiais" e "específicos" quando atrelados à noção de poderes. M. M. de SERPA LOPES chega ao ponto de afirmar haver "uma certa redundância no emprêgo simultâneo daqueles (...) têrmos" (Curso cit. (nota 05), p. 250).

Temos para conosco que a solução para tal entrave perpassa a seguinte ordem de idéias: quando o legislador supõe a outorga de poderes expressos, há que se compreender que não se contentou com a conferência decorrente de uma interpretação que exceda ao emprego do método gramatical. Quem confere poderes expressos, há que tê-lo feito de maneira clara, eloqüente e inequívoca; se há necessidade de apuração das circunstâncias, é sinal de que a outorga não foi expressa. Superado tal obstáculo, faz-se necessária atenção especial do conferente: não basta a outorga em ato único (caso tenham sido conferidos, também, poderes de simples administração); é imprescindível que se ultime declaração autônoma, na qual seja deduzido o intuito de se conferir poder especial, exorbitante da mera gestão. Finalmente, poderia se exigir que fossem confiados poderes para a prática de um ato (ato-objeto) determinado; nestas circunstâncias, não estaríamos diante nem de poderes "expressos", nem de poderes "especiais". Assim, teria ido mais longe o legislador ao exigir poderes "específicos". A respeito - diferentemente daquilo que é por nós propugnado - cf. o Enunciado $\mathrm{n}^{\circ}$ 183 da III Jornada de Direito Civil realizada pelo Conselho da Justiça Federal ("para os casos em que o parágrafo primeiro do art. 661 exige poderes especiais, a procuração deve conter a identificação do objeto").

Em duas oportunidades distintas W. FERREIRA lançou mão dessa distinção. Em seu Tratado de Direito Comercial destacou que "quem tenha poderes para obrigar-se cambiàriamente, não necessita de poderes especiais para cada letra de câmbio ou nota promissória, particularmente. Se assim se entendesse e se houvesse de praticar, o mandato seria desnecessário: em vez de passar tantas procurações quantas fôssem as cambiais, uma para cada qual, muito mais fácil e menos dispendioso seria ao comerciante lançar sua assinatura, não nas procurações, mas desde logo nos títulos, diretamente em cada um" (Tratado cit. (nota 131), p. 19). Noutra ocasião, à luz de uma terminologia peculiar, assim se pronunciou: "o mandato especial se distingue em generico e especifico ou especialissimo. É especial generico quando se extende a uma série ou categoria de negocios, determinados no genero, mas não na especie, e autoriza o mandatario a pratical-os no tempo e pelo modo que achar melhor: tal o mandato que o autoriza a constituir hypothecas ou a assignar cambiaes. É específico, ou especialissmo, quando se refere exclusivamente a um ou mais negocios especifica e determinadamente indicados, mesmo na sua especie: por exemplo, ou para vender o predio numero tanto de tal rua, ou para acceitar dez letras de cambio da importnacia de tanto cada uma, e assim por diante" (Mandato, in Revista dos Tribunais 67 (1928), pp. 233).

Observe-se, enfim, que a distinção ora proposta encontra respaldo em nosso direito civil oitocentista projetado: no artigo 2883 do "Esboço", A. TEIXEIRA DE FREITAS enunciava a necessidade de uma distinção entre poderes especiais conferidos "em abstrato" ou "em concreto": "os poderes especiais exigidos no art. 2881, ou o mandato especial (art. 2882) podem ser conferidos: em abstrato, isto é, indicando-se em geral o ato ou contrato. Ou nominativamente, isto é, indicando-se a pessoa com quem o mandante deva contratar, ou o objeto do ato ou contrato. Exige-se que os poderes sejam conferidos nominativamente nos casos do art. 2881, n's $^{\circ}, 7,13$ e 17 '”.

A propósito dos dispositivos do Código Comercial analisados nesta nota de rodapé, cf. A. de SoUSA PINTO, Diccionario cit. (nota 131), pp. 259 (vol. I), 217-220 (vol. II); C. FALCÃO, Codigo cit. (nota 131), pp. 56-57; C. TRIPOLI, Elementos cit. (nota 131), pp. 54-55; D. A. da VEIGA, Codigo cit. (nota 131), pp. 292-294 e 299302; Dous JurisConsultos, Repertorio cit. (nota 131), pp. 87; J. LiBERATO BARRoso, Contractos cit. (nota 131), pp. 13-17; J. X. CARvalho de MendonçA, Tratado cit. (nota 131), pp. 210-212; J. J. P. da Silva RAmos, Abecedario cit. (nota 131), pp. 367-370; S. O. D’ARAujo Costa, Codigo cit. (nota 131), pp. 42-43; L. M. VIDAL, Manual cit. (nota 131), pp. 46-47; W. FERREIRA, Tratado cit. (nota 131), pp. 5-16 e 23-26.

Quanto aos dispositivos do Código Civil de 1916 objeto de nossa análise na presente nota de rodapé, cf. Codigo Civil brasileiro: trabalhos cit. (nota 131), pp. 501-502; A. BEVILÁQUA, Codigo cit. (nota 131), pp. 355-358; A. do VAlle SiQueIra, Codigo cit. (nota 131), pp. 428-431; A. Dionysio Gama, Tratado cit. (nota 131), pp. 212 e 313; A. CAMARgo, Elementos cit. (nota 131), pp. 92-93; A. ChACON Couto, Ligeiras observações cit. (nota 131), pp. 8-12; A. CHAVES, Lições cit. (nota 131), pp. 285-288, 290-294 e 300; A. L. 


\section{$\S$ 155. O Código Comercial e o papel da eficácia representativa direta na}

contextura do mandato: admissibilidade da variante desprovida de efeitos representativos. Da definição constante do artigo 140 se extrai que o mandato, tal qual forjado pelo Código Comercial, parece ensejar uma atuação representativa do mandatário; em contrapartida, nos artigos 149 e 150 se faz menção a uma atuação do agente em "seu próprio nome". Aliás, por meio destas disposições se estabelece, em termos genéricos, a responsabilidade última do mandante (“comitente”) pela gestão empreendida pelo mandatário: seja de modo imediato junto a terceiros, sob os moldes de uma eficácia representativa direta ("sempre que o mandatário contratar expressamente em nome do comitente"); seja de maneira mediata, sob a forma de um ato ulterior de apreensão dos efeitos gestórios (à vista de uma vinculação direta do próprio agente perante outrem). Além disso, por meio de um

da CÂMARA LeAL, Manual cit. (nota 131), pp. 98-102; A. MARMitT, Mandato cit. (nota 131), pp. 11-36, 108113 e 175-182; A. WALD, Curso cit. (nota 131), pp. 299-303; C. FALCÃo, Codigo cit. (nota 131), pp. 143144; C. Beviláqua, Codigo cit. (nota 05), pp. 28-31 e 35-42; D. ArrudA MirandA, Anotações cit. (nota 131), pp. 367-374; E. EsPínOlA, Systema cit. (nota 131), pp. 569-571; Dos contratos nominados cit. (nota 12), pp. 350-359; E. PESSÔA, Da procuração cit. (nota 131), pp. 3-9, 19, 25-26; F. C. PONTES DE MIRANDA, Fontes cit. (nota 16), p. 332; F. M. DE MATTIA, Aparência cit. (nota 06), pp. 19 e 29; F. R. LEITE FILHO, Curso cit. (nota 05), pp. 345-349; F. A P. LANDIN FILHO, O mandato cit. (nota 09), pp. 12, 17, 30-39; F. C. P. Rodrigues - L. da S. Loureiro FilHo, Código cit. (nota 131), pp. 873-880; F. C. de SAN Tiago DANTAS, Programa cit. (nota 05), pp. 369-374; F. K. COMPARATO, Aparência cit. (nota 131), pp. 42; G. SCIASCIA, Direito Romano cit. (nota 131), pp. 154-161; G. LACERDA, Obrigações cit. (nota 131), pp. 199-222; J. do Amaral Gurgel, Contractos cit. (nota 131), pp. 75-76 e 126-127; J. L. Alves, Código cit. (nota 05), pp. 348-358; J. F. de LIMA, Curso cit. (nota 05), pp. 564-578; J. GONÇALVES MAIA, Theoria cit. (nota 131), pp. 13, 43-47, 57, 66-69, 121 e 148-154; J. M. de CARVAlHo SAnTos, Codigo cit. (nota 05), pp. 108-119, 131145, 148-150 e 154-181; J. de SAMPaIo Doria, Codigo cit. (nota 131), pp. 92 e 124; L. Leite, Codigo cit. (nota 131), pp. 424-429; L. R. de FreitAs Gomes, Contrato cit. (nota 131), pp. 285 e 292-294; M. C. do. A. KroetZ, A representação cit. (nota 41), pp. 46, 62-65 e 87-88; M. I. CARVALHO DE MENDONÇA, Contratos cit. (nota 131), pp. 193-207; M. PAUlo MERÊA, Codigo cit. (nota 131), pp. 404-406; M. M. de SERPA LOPES, Curso cit. (nota 05), pp. 238-240, 244-254 e 261-262; M. TERRA, O mandato cit. (nota 131), p. 44; O. GoMes, Contratos cit. (nota 23), pp. 346-349; O poder cit. (nota 131), pp. 3 e 10-11; P. SoARES NETTO, Noções cit. (nota 131), pp. 244-248; R. L. FRANÇA, Manual cit. (nota 05), pp. 183-193; R. LotUFO, Questões cit.(nota 26), pp. 91-101; S. VAMPRÉ, Manual cit. (nota 131), p. 116 ; T. Fulgencio Alves Pereira, Programmas cit. (nota 131), pp. 134-137; T. PRATES DA FONSECA, Noções cit. (nota 131), pp. 194-197; Y. S. CAHALI, Contratos cit. (nota 131), pp. 497-504.

Por fim, acerca das disposições constantes do Código Civil vigente (e referidas na presente nota de rodapé), cf. A. Villaça AzeVEdo - S. de S. Venosa, Código cit. (nota 02), pp. 353-356; A. de Assis, Contratos cit. (nota 131), pp. 23-29, 44-45 e 51-64; CAIO MÁRIO da Silva Pereira, Instituições cit. (nota 02), pp. 397-404; C. A. BitTAR, Os contratos no projeto de Código Civil, in Revista de Direito Mercantil, Industrial, Econômico e Financeiro 104 (1996), p. 54; C. E . N. CAMillo - G. M. TAVAlERA - J. S. FuJiTA - L. A. SCAVONE JÚNIOR (coords.), Comentários cit. (nota 02), pp. 584-588; C. L. BUENo DE GOdoY, Do mandato cit. (nota 131), pp. 605-608, 610-611 e 613-616; C. R. GonÇALVES, Direito cit. (nota 131), pp. 386-403; F. Ulhoa Coelho, Curso cit. (nota 02), pp. 311-315; F. Amaral, Direito cit. (nota 131), pp. 449, $452-457$ e 461-462; MARIA Helena Diniz, Curso (nota 02), pp. 351-362; N. C. B. CAMPEllo, Da representação cit. (nota 131), pp. 394 e 420-433; N. G. B. Dower, Curso cit. (nota 02), pp. 281-288; N. NERY JUNIOR - R. M. de Andrade Nery, Código cit. (nota 02), pp. 469-474; N. DuARTe, Da representação, in C. PELuso, Código Civil Comentado - Doutrina e Jurisprudência, $2^{\mathrm{a}}$ ed., São Paulo, Manole, 2008, p. 101; O.GoMES, Contratos cit. (nota 23), pp. 426-428; O. R. B. SANDOVAL, Do mandato cit. (nota 131), pp. 580-591, 595-601 e 603-608; R. FIUZA (coord.), Novo Código cit. (nota 02), pp. 600-611; S. de S. VenOSA, Direito cit. (nota 02), pp. 251-262; S. L. F. da RochA, Curso cit. (nota 02), pp. 295-299; Silvio RodrigueS, Direito cit. (nota 02), pp. 285-293; WASHINGTON DE BARRos Monteiro, Curso cit. (nota 02), pp. 260-273. 
enunciado pouco preciso, o artigo 163 estabelece a possibilidade de ratificação do excesso pelo mandante; pergunta-se: tratar-se-ia de um negócio jurídico com eficácia meramente externa? Simplesmente interna? Ou simultaneamente externa e interna? Ora, todas essas observações confluem para um fenômeno semelhante àquele divisado em meio ao Código Comercial Português de 1833: embora o "mandato" e a "comissão" constituam objeto de disciplinas "formalmente" autônomas, é freqüente a utilização promíscua da terminologia peculiar a cada uma das espécies contratuais. Mais do que isso, parece que o legislador efetivamente incentivou um intercâmbio entre tais institutos: à vista das proposições remissivas dispostas nos artigos 164 e 190, é possível depreender que embora o "mandato" se afigure irredutível à "comissão", o inverso é admitido sem maiores ressalvas - ainda que postas de parte as regras constantes dos artigos 165, 166, 171, 172, 173, 174, 176, 177, $178,179,186$ e 189 , aplicáveis unicamente ao último tipo contratual ${ }^{132}$.

132 A eficácia representativa direta atrelada ao contrato de mandato mercantil pode ser depreendida do período que integra a primeira parte do artigo 150 do Código Comercial: "sempre que o mandatário contratar expressamente em nome do comitente, será este o único responsável”. A despeito da impropriedade do emprego do termo "comitente" em um tal contexto, pode-se extrair de tal disposição uma consagração da irresponsabilidade do agente sempre que este atue perante terceiros no exercício dos poderes de representação que lhe tenham sido outorgados pelo principal. No sentido da atribuição de uma eficácia representativa direta à atuação do procurador, cf. a Resolução de 12 de junho de 1823 - coligida por J. M. da TRINDADE (Colecção cit. (nota 131), pp. 171-173). No entanto, a parte final daquele dispositivo se volta à atuação do mandatário em seu próprio nome, desprovido dos poderes de representação - ou ao menos sem exercitá-los - que ordinariamente acompanham tal modelo de gestão: "ficará, porém, o mandatário pessoalmente obrigado se obrar no seu próprio nome, ainda que o negócio seja de conta do comitente".

Note-se que é corrente na doutrina a observação de que, quando o mandatário atua em seu próprio nome, não despontam quaisquer efeitos jurídicos ao mandante. Nesse sentido, A. SCHREIBER observa "alguns autores referem-se à interposição como representação indireta, mediata ou imprópria. Embora haja traços comuns entre a representação e a chamada representação imprópria, não há neste último caso a 'contemplatio domini', que caracteriza aquela primeira. Por conta disto, os negócios realizados por representação imprópria (rectius: interposição) não vinculam o 'representado', sequer potencialmente (...) a atuação no interesse de outrem, mas em nome próprio, só tem sido considerada eficaz com relação ao interessado naquelas hipóteses que configuram simulação" (A representação cit. (nota 131), pp. 230-231). No mesmo sentido, L. MAтTIETTO destaca que "a dupla transferência, que se faz necessária pela falta da eficácia direta, exclui toda a idéia de representação (...) no negócio em nome próprio mas por conta de outrem, o fato de que o interessado seja, sob o prisma econômico, o dominus negotii, não é levado em consideração na relação com o terceiro" (A representação cit. (nota 131), p. 60). Ora, tal assertiva não nos parece adequada, uma vez que contraria frontalmente o teor do artigo 149 do Código Comercial, no qual se estabelece a responsabilidade do mandante - pelos atos praticados pelo mandatário - ainda que o agente atue em seu próprio nome ("o comitente é responsável por todos os atos praticados pelo mandatário dentro dos limites do mandato, ou este obre em seu próprio nome, ou em nome do comitente").

De fato, a análise do referido artigo 149 nos evidencia que o contrato de mandato apresenta uma eficácia jurídica peculiar, relacionada ao conjunto de posições jurídicas subjetivas (ativas e passivas) a serem exercitadas pelos sujeitos da relação contratual; neste específico contexto, ainda que eficácia representativa direta não deflua da atuação do agente em nome próprio, não nos parece correto considerar sua gestão como desprovida de efeitos perante o mandante. Em outras palavras, ainda que os atos praticados pelo mandatário sem que tenham sido exercidos os poderes de representação - não percutam a esfera jurídica do mandante para viabilizar, diretamente, a aquisição de direitos e deveres, não se pode deixar de considerá-los suporte fático suficiente ao surgimento de pretensões (ou ações) e obrigações afetas ao patrimônio do principal. Eis a 
explicação não só para o teor do artigo 149 do Código Comercial, como também para a ação cominatória estabelecida no artigo 152 do mesmo diploma - origem remota do artigo 671 do Código Civil vigente.

Aliás, M. M. de SERPA LOPES conferiu especial atenção à questão, na medida em que repudiou a existência de um mandato sem representação no direito brasileiro, à vista do significado amplo que emprestara ao termo "representação", suficientemente abrangente de suas modalidades "direta" e "indireta". Desta forma, a representação assumiria um contorno mais econômico, associado à idéia de "gestão"; de molde que todo e qualquer mandato haveria de ser representativo: "no fundo das coisas, um mandato supõe sempre a representação entre as partes; o mandatário age necessàriamente por conta do mandante, e somente em face de terceiros é que êle pode apresentar-se sem representação, porque esta representação (que existe, no fundo) não aparece no que the diz respeito (...) abstenhamo-nos de falar de mandato sem representação, mas sim de mandato sem representação em face de terceiros. Tal é, por conseguinte, o verdadeiro sentido e conciliatório caráter essencial da representação no mandato, com a possibilidade de poder apresentar-se um mandato aparentemente sem representação" (Curso cit. (nota 05), p. 240). Com efeito, ao analisar o alcance do artigo 1309 do Código Civil de 1916, este autor destaca como dever do mandante "desonerar o mandatário das obrigações assumidas em face de terceiros" (Curso cit. (nota 05), p. 278). Como justificar, assim, a assertiva de que da execução do mandato sem representação não decorreriam efeitos ao mandante?

Em meio aos trabalhos preparatórios que redundaram no Código Civil de 1916, o Deputado Solidônio Leite observava atentamente a "ordinariedade" da eficácia representativa direta atrelada ao contrato de mandato; contudo, sem que esta se convertesse em autêntica "essencialidade": "no mandato distinguem-se duas ordens de relações jurídicas: uma entre o mandante e o mandatário, outra entre estes e os terceiros. O desapparecimento de qualquer dellas não importa a insubsistencia do mandato. Assim, póde não haver relações obrigacionaes entre o mandante e o mandatario menor (...) permanecendo as obrigações do dito mandante para com os terceiros; do mesmo modo póde deixar de existir o mandato quanto a estes, subsistindo na esphera das relações entre o mandante e o mandatario - o que acontece quando este age em seu proprio nome" (Codigo Civil brasileiro: trabalhos cit. (nota 131), p. 504).

O próprio O. GOMES já entrevia no artigo 1307 do Código Civil de 1916 uma fonte de celeuma doutrinária, somente passível de superação à custa de uma dissociação entre os conceitos de "mandato", "procuração" e "representação": "uma vez que o mandato pode envolver a representação, ou não, nem sempre agindo o mandatário em nome do mandante, possível não é confundir as duas figuras jurídicas, cumprindo, à doutrina distingui-las, sem embargo de haver o legislador dispôsto, por equívoco, que sòmente se opera mandato quando alguém recebe de outrem poderes, para, em seu nome, praticar atos, ou administrar interesses (...) numa reforma legislativa, deve-se eliminar a controdição entre os artigos 1288 e 1307 do Código vigente, admitindo-se que a representação não é essencial ao mandato. Cumpre discipliná-la autônomamente, em capítulo especial, mas em têrmos que permitam oferecer solução às inúmeras questões que suscita" ( $O$ poder cit. (nota 131), pp. 4 e 12).

Com efeito, a admissão do mandato sem representação entre nós foi resultado de um paulatino esforço desenvolvido pela doutrina, sobretudo à custa da exegese do artigo 150 do Código Comercial (e do artigo 1307 do Código Civil de 1916). Observe-se que se em E. Espínola podemos surpreender o período "se não há representação, não há mandato" (Dos contratos cit. (nota 12), p. 352), já em M. I. CARVALHO DE MENDONÇA desponta a necessidade de se incorporar a "exceção" ao sistema: "é ainda fora de dúvida (...) que as relações de direito entre mandante e mandatário subsistem, ainda quando êste obre em seu nome, tendo por objeto negócio do mandato" (Contratos cit. (nota 131), p. 194).

Uma vez aberta a trilha, a doutrina por vezes vacilou; por exemplo, ao considerar a ocultação do principal como um elemento indissociável da variante do instituto desprovida de efeitos representativos: "caracteriza a representação indireta a ausência da contemplatio domini, ou seja, o representante, ao agir, não manifesta à contraparte sua qualidade de representante, deixando de esclarecer que os efeitos do negócio jurídico realizado não recairão na sua própria esfera jurídica, mas sim na de outrem, não participante do negócio jurídico" (M. G. MAIA JÚNIOR, A representação cit. (nota 04), p. 127). Ora, como atentamente destacou L. MATTIETTO, o mandato sem representação pode ter aplicação ainda que o terceiro tenha inteira ciência da relação jurídica mantida entre as partes do negócio de incumbência (A representação cit. (nota 131), p. 63).

Em sentido contrário à posição defendida neste estudo, C. P. M. CRUZ E TUCCI sustenta que - a despeito da dissociação sistemática entre "mandato" e "representação" promovida no Código Civil vigente - o contrato de mandato ainda apresenta essência representativa, correspondendo a variante prevista no artigo 663 do Código Civil de 2002 à simples confirmação excepcional de uma figura atípica, inconfundível com o modelo crivado pelo legislador da segunda metade do século XX: "é importante notar que o art. 663, que se refere à hipótese do mandatário agir em seu próprio nome, acaba por confirmar a conclusão de que, entre nós, o mandato típico é sempre representativo. Com efeito, o dispositivo de lei examinado estabelece que quando, por exceção, o mandatário agir em seu próprio nome, ter-se-á por desvirtuada a representação, de sorte que os efeitos do negócio jurídico recairão sobre o mandatário e não sobre o mandante. A rigor, isso não importa 
admitir que o legislador pretendeu introduzir o tipo legal do mandato sem representação. Pelo contrário, verifica-se que o mandato brasileiro é representativo, pressupõe a concessão de poderes ao mandatário, para que este possa atuar em nome e por conta do mandante, de tal modo que, se agir em seu próprio nome, desvirtua a função típica do contrato (representação) e o mandante não estará de qualquer forma vinculado ao negócio realizado com terceiro (...) agindo o mandatário em seu próprio nome, descaracteriza-se o mandato típico, e não há qualquer previsão, na lei, sobre direitos ou obrigações que caiam ou devam recair sobre a pessoa do mandante que não foi representado" (Interposição cit. (nota 09), p. 119). No sentido da atipicidade do mandato sem representação, cf. ainda F. A. P. LANDIN FILHO, O mandato cit. (nota 09), pp. 14 e 112.

Ora, tal perspectiva nos parece franco retrocesso no caminho trilhado pela ciência jurídica brasileira rumo à dissociação entre "mandato", "procuração" e "representação". De fato, parece-nos que os autores que consideram o mandato sem representação modalidade contratual atípica não dissociam adequadamente o instituto jurídico (compreendido como complexo normativo) do texto que lhe serve de fundamento. Nesse sentido, F. C. PONTES DE MIRANDA observa que "o mandato e o poder de representação não se confundem (...) no Código Civil (...) procuração está por documento, forma de eficácia usual, sem que se devesse tirar daí que o Código Civil se ateve à atitude dos velhos códigos segundo a qual o poder de representação e o mandato são o mesmo" (Tratado de Direito Privado XLIII cit. (nota 04), p. 8).

Contudo, diante das considerações dos autores que reputam atípica a variante não representativa do instituto, é chegada hora de tecermos duas ou três observações indispensáveis ao prosseguimento da presente análise.

Em primeiro lugar, há que se observar que do "contrato" de mandato somente defluem - via de regra efeitos que percutem a esfera jurídica das partes contratantes; desta forma, a utilização dos termos "mandante" e "mandatário" deve ser criteriosa, a ponto de não se deixar contaminar pelo envolvimento dos mesmos sujeitos de direito em eventos que venham a surtir efeitos perante terceiros. Se "Caio" e "Tício" celebram contrato de mandato, o primeiro somente é mandatário em relação ao segundo; e a ninguém mais interessa aquilo que diz respeito tão somente à relação mandatário-mandante.

Em segundo lugar, da outorga de poderes de representação via negócio jurídico unilateral - a "procuraçãoato" - defluem efeitos perante terceiros; daí o ensejo apropriado à utilização dos termos "representante" e "representando". Por meio do negócio de outorga de poderes simplesmente se abre, em potência, a esfera jurídica daquele que ainda não foi representado, a fim de que eventualmente o seja, por meio da prática de negócios jurídicos representantivos pelo "representante". Desta forma, não nos parece correto o emprego da expressão "representado" quando, em verdade, pode acontecer de não se seguir à outorga de poderes seu exercício por parte do "representante"; nestas circunstâncias, aquele que outorgara poderes representado não foi. Conservou-se na posição de simples "representando".

Ora, em terceiro lugar, cumpre observar que - como bem ressaltara M. M. de SERPA LOPES - todo e qualquer mandato enseja uma intermediação: diante disso, à vista do influxo da função sócio-econômica do instituto sobre a sua eficácia, parece-nos adequado considerar que, em geral, no mandato existe uma relação entre um "agente" (intermediário) e aquele em prol de quem atua ("principal").

Desta forma, as dicotomias "mandante/mandatário", "representando/representante" e "principal/agente" não se confundem em nossa concepção a respeito do instituto ora analisado. A primeira tem em consideração o negócio de incumbência (e sua regular execução); a segunda concerne ao influxo do exercício da gestão sobre terceiros - e daí a tendência (talvez questionável) de se erigir a eficácia representativa direta em instituto autônomo ("representação") -; e a terceira se refere à função de intermediação desempenhada pelo encarregado.

Ocorre, no entanto, que a realidade subjacente ao fenômeno não é completamente abrangida pela terminologia ora preconizada. Em verdade, um quarto par de personagens é costumeiramente atrelado a esse fenômeno único; trata-se da dupla "procurador" e "constituinte". Aqui, cumpre ressalvar que a doutrina contemporânea toma a figura do "procurador" como aquele a quem foram outorgados os poderes de representação; de forma que, em verdade, haveria uma proximidade conceitual em relação ao par "representando/representante".

Todavia, embora este não seja o lugar apropriado à abordagem dogmática que pretendemos desenvolver noutro contexto, cabe-nos reiterar que o "procurator" romano era, antes de mais nada, um "gestor" incumbido, desprovido de poderes de representação e atrelado à chamada "actio negotiorum gestorum". Ora, a análise histórica até aqui desenvolvida nos demonstra que o elemento gestório foi sendo gradativamente mitigado ao mesmo tempo em que, por outro lado, ganhava espaço, progressivamente, a chamada substituição (do principal). Com a aproximação justinianéia entre as figuras do "procurador" e do "mandatário", à "substituição" se acresceu a função de "gestão" (administração); e no momento em que a representação direta é trazida à ordinariedade do mandato, há que se somar tal ingrediente à mistura promovida pela legislação imperial romana. Enfim, acabamos por chegar - em pleno século XX - ao ponto de compreender o mandato como contrato cuja idéia suprema é a de representação. Postas de parte indagações já formuladas noutras oportunidades, desponta indispensável uma discriminação conceitual 
rigorosa entre os âmbitos de atuação de cada uma das personagens: "mandante", "mandatário", "representando" (eventual "representado"), "representante", "principal", "agente", "constituinte" e "procurador". Observe-se, tão somente, que a reunião de elementos heterogêneos sob uma única rubrica ("representação") não se justifica - em todos os matizes da disciplina comum às variantes "legal" e "negocial" - apenas à vista da eficácia representativa direta subjacente ao fenômeno. Segundo nos parece, o que se busca com a reunião de figuras tão distintas - como o "representante legal" e o "representante negocial" - sob a mesma disciplina é introjetar o elemento fiduciário (derivado da "procuratio") em uma gestão atribuída, "ex vi legis", a alguém.

Ora, feitas tais considerações, resulta claro que as "instruções" inerentes ao mandato não podem - via de regra - surtir efeitos perante aqueles que não se enquadram nas posições de "mandante" e "mandatário". Com isso, a eficácia representativa direta há de despontar inarredavelmente, ainda que frustrados os objetivos pretendidos pelo "mandante", desde que não vazados (pelo "representando") no instrumento de procuração ("procuração-instrumento") levado ao conhecimento do terceiro (pelo "representante"). É esse o sentido da regra constante do artigo 1313 do Código Civil de 1916 - a qual encontra no artigo 679 do Código Civil vigente o seu regular correspondente. Pela falta de uma maior precisão quanto a tais conceitos, M. I. CARVALHO DE MENDONÇA baralha as idéias de "excesso" (de poderes) e "abuso" (no exercício da gestão), chegando a conclusões inadmissíveis: "os terceiros não se podem prejudicar com as malversações do mandatário, se trataram com êle nos restritos têrmos do mandato, pouco lhes importando os excessos que não podiam reconhecer. Assim, se A dá a B mandato para contrair empréstimo de 5:000\$000 e se B, abusando de tais poderes, contrai o empréstimo com $\mathrm{C}$ depois com $\mathrm{D}$ e ainda depois com $\mathrm{E}$, claro está que excedeu os poderes que lhe foram conferidos. Mas nem $\mathrm{D}$ nem $\mathrm{E}$ podiam verificar que o mandato já estava esgotado com a realização do primeiro e único empréstimo que A teve em vista; êles verificaram, ao contrário, que B tinha poderes para realizar o mútuo; seus direitos se firmaram para o efeito de exigirem o pagamento de A, tendo êste somente ação contra seu mandatário (...) em todos os casos, porém, se o mandante não ratifica os atos do mandatário, executados com excesso de mandato, tais atos são nulos e o mandatário responde por perdas e danos" (Contratos cit. (nota 131), p. 224). Com efeito, a notícia que o autor nos dá, por meio de seu exemplo, não é de qualquer excesso, mas sim de abuso, sendo válidos e eficazes - e não "nulos" - os atos praticados durante a gestão do mandatário; daí a importância de elementos limitadores dos poderes outorgados por meio da "procuração-ato": seja a limitação temporal de vigência, seja a adoção de outorga "específica" (na acepção por nós emprestada ao termo conforme nota de rodapé imediatamente anterior), tudo acaba por contribuir para que se evitem hipóteses como a trazida à lume pelo doutrinador - a respeito da importância de uma descrição minudente dos limites da outorga, cf. os Despachos de 10 de dezembro de 1857 e de 20 de dezembro de 1858 , bem como a Portaria de 27 de novembro de 1861 . E não pense o leitor que a crítica que ora fazemos deflui de doutrina contemporânea: J. M. da TRINDADE já destacava que "o mandante é responsável ao terceiro que contractou com o seu procurador em virtude de uma procuração de poder indefinito, mas restringido por instrucções secretas, de que o terceiro não teve conhecimento" (Collecção cit. (nota 131), p. 54). A respeito dos reflexos práticos destas nossas considerações, cf. a análise de G. SEGRÈ (Sulla inoponibilità al terzo di buona fede dei limiti ai poteri di rappresentanza non risultanti dal documento esibitogli, in Scritti giuridici, Roma, Società Editrice del Foro Italiano, 1938, passim); bem como o pontual estudo de P. VIRGA (Eccesso di potere per mancata prefissione di parametri di riferimento, in Scritti in onore di Massimo Severo Giannini, Milano, Dott. A. Giuffrè, 1988, pp. 583-ss). No entanto, a imprecisão técnica era tamanha que se aludia a "excesso de mandato" - em sede legislativa - a respeito dos atos praticados pelos órgãos das pessoas jurídicas (artigo $9^{\circ}$ da Lei $n^{\circ} 173$ de 10 de setembro de 1893); orientação que não se coaduna com a distinção entre autêntica "representação" e simples "presentação" (orgânica).

No entanto, como teremos a oportunidade de observar mais adiante, a regra contida no artigo 119 do Código Civil de 2002 tornou ainda mais interessante a questão, ao permitir um excepcional influxo das "instruções" - inerentes ao "mandato" (e alheias à "procuração") - sobre o negócio jurídico representativo, praticado pelo "representante-mandatário" em conflito de interesses com o "representado-mandante". De todo modo, tornaremos ao tema mais à frente.

Tomando-se por base as mesmas considerações, há que se discutir o alcance da regra estabelecida no artigo 163 do Código Comercial: "quando um comerciante sem mandato, ou excedendo os limites deste, conclui algum negócio para o seu correspondente, é gestor de negócio segundo as disposições da lei geral; mas se este for ratificado, toma o caráter de mandato mercantil, e entende-se feito no lugar do gestor". Pergunta-se: a norma se dirige à relação mantida entre o "representado" e terceiros, ou concerne ao vínculo que une "mandante" e "mandatário"?

Adotadas as considerações acima deduzidas, cumpre observar que se está diante de um dispositivo bifronte: o "excesso" que atinge terceiros é aquele que se evidencia quando praticados pelo "representante" atos que não estão respaldados pela outorga de poderes de representação consubstanciada na "procuração-instrumento"; nessas circunstâncias, o ato praticado pelo "representante" é ineficaz perante o "representado", salvo 
ratificação superveniente. Ou seja, neste caso, "excesso" e "ratificação" se aferem segundo o instrumento de procuração e geram efeitos no âmbito da "representação" - afeta às relações que envolvem interesses de terceiros.

Todavia, este mesmo excesso vai surtir efeitos no âmbito da relação interna mantida entre "mandante" e "mandatário", uma vez que este último, agindo em excesso, não adimpliu satisfatoriamente a obrigação que contratualmente assumira. Desta forma, o "excesso" e a "ratificação" também produzem efeitos em meio à relação mantida entre as partes do negócio jurídico bilateral de incumbência. No sentido da dupla eficácia da "ratificação", cf. M. I. CARVALHO DE MENDONÇA, Contratos cit. (nota 131), pp. 223-224.

Assim, por disciplinar aspectos que interessam não apenas a terceiros - mas também às próprias partes da relação jurídica decorrente do negócio de atribuição - tal regra deveria compor não apenas o arcabouço técnico normativo da "representação", como também o afeto ao instituto do contrato de mandato. Ou seja, em nossa opinião, tal dispositivo deveria ser repetido nas duas seções respectivas de uma codificação que preconizasse a autonomia entre tais "institutos" - ou ao menos deveria constar uma regra remissiva nalguma delas.

Assim, quanto à eficácia representativa direta defluente do mandato com representação, na esteira do preceituado pelo artigo 150 do Código Comercial, cf. no âmbito da fontes legisladas (ou simplesmente projetadas) os arts. 2911, 2952, 2988 e 2989 do "Esboço"; os arts. 2282 e 2295 do AntFS; o art. 1082 do AntCR; o art. 1457 do AntCB; o art. 35 do AntOPH; os arts. 37 e 656 do AntCM; os arts. 38 e 623 do AntCMRev; o art. 111 do AntPGMA; o art. 115 do AntMR; o art. 114 do AntMRRev; o art. 114 do PCD no 634/1975; e o art. 116 do CC/2002. Observe-se que embora o Anteprojeto de Código das Obrigações de Caio Mário da Silva Pereira pretendesse abordar o mandato e a representação de maneira autônoma, disciplinou aparentemente de modo indevido - a eficácia representativa direta em meio ao contrato de mandato (art. 656 do AntCM e art. 623 do AntCMRev).

Por sua vez, no que toca à atuação do mandatário em seu próprio nome ("mandato sem representação"), nos moldes do estabelecido pelos artigos 149 e 150 do Código Comercial, cf. os arts. 2939 (5), 2959, 2963, 3001, 3002 e 3003 do "Esboço"; os arts. 2279 e 2280 do AntFS; o art. 1071 do AntCR; o art. 1516 do AntCBRev; o art. 1307 do PCD no 1/1912; o art. 1307 do PSF no 269/1912; o art. 1307 do CC/1916; o art. 36 do AntOPH; o art. 39 do AntCM; o art. 39 do AntCMRev; o art. 662 do AntMRRev; o art. 672 do PCD n ${ }^{\circ}$ 634/1975; e o art. 663 do CC/2002. Destaque-se que nos anteprojetos de Código das Obrigações a atuação do agente em nome próprio veio disciplinada em meio à representação (art. 36 do AntOPH, art. 39 do AntCM e art. 39 do AntCMRev); opção metodológica com a qual não concordamos, uma vez que não ensejadora de qualquer vínculo jurídico direto entre o principal e o terceiro - evidenciando-se apenas uma "representação" na acepção lata do termo, tal como anunciado por M. M. de SERPA LOPES em trecho transcrito ao início da presente nota de rodapé.

No que toca à responsabilidade do "representado" pelos atos ultimados - perante terceiros - durante a gestão do "representante", cf. os arts. 2911, 2990 e 2992 do "Esboço"; o art. 2278 do AntFS; o art. 1085 do AntCR; o art. 1461 do AntCB; os arts. 1527 e 1531 do AntCBRev; os arts. 1309 e 1313 do PCD n 1/1912; os arts. 1309 e 1313 do PSF n ${ }^{\circ}$ 269/1912; os arts. 1309 e 1313 do CC/1916; o art. 651 do AntCM; o art. 618 do AntCMRev; os arts. 686 e 690 do AntMR; os arts. 674 e 678 do AntMRRev; os arts. 684 e 688 do PCD n 634/1975; e os arts. 675 e 679 do CC/2002. Quanto às fontes posteriores ao Anteprojeto da Comissão presidida por Miguel Reale (arts. 686 e 690 do AntMR, arts. 674 e 678 do AntMRRev, arts. 684 e 688 do PCD n 634/1975 e arts. 675 e 679 do CC/2002), parece-nos que não se observou a diretriz fundamental já estabelecida na "Exposição de Motivos" do Anteprojeto de Parte Geral do Código das Obrigações de Orosimbo Nonato, Philadelpho Azevedo e Hahnemann Guimarães: "a representação (...) obedecerá a princípios uniformes, que devem resguardar a boa fé de terceiros, obrigados a tratar com interposta pessoa"; ora, se assim o fosse, tais dispositivos deveriam estar contidos em meio à disciplina afeta à representação - e não junto ao arcabouço destinado à regulação da relação "mandante/mandatário".

No que toca à disciplina do "excesso" e da "ratificação" (inclusive pela regra "ratihabitio mandatu comparatur") constante do artigo 163 do Código Comercial, cf. no âmbito da legislação promulgada e projetada os arts. $2922\left(1^{\circ}\right), 2923\left(1^{\circ}\right), 2924\left(1^{\circ}\right), 2933,2934,2936,2996,2953,2954,2955,2986,2989$, 2992, 2993 e 2994 do "Esboço"; o art. 2277 do AntFS; os arts. 1072 e 1082 do AntCR; o art. 1452 do AntCB; os arts. 1517, 1521, 1527 e 1530 do AntCBRev; os arts. 1296 e 1297 do PCD n $1 / 1912$; os arts. 1296 e 1297 do PSF no 269/1912; os arts. 1296 e 1297 do CC/1916; o art. 44 do AntOPH; os arts. 39, 42, 647, 648, 649 e 656 do AntCM; os arts. 39, 42, 614, 615, 616 e 623 do AntCMRev; o art. 120 do AntPGMA; os arts. 676 e 677 do AntMR; os arts. 661 e 664 do AntMRRev; os arts. 671 e 674 do PCD n 634/1975; e os arts. 662 e 665 do CC/2002.

Ora, diante da orientação preconizada por Orosimbo Nonato, Philadelpho Azevedo e Hahnemann Guimarães, é de se estranhar que algumas disposições - cf. os arts. 647, 648, 649 e 656 do AntCM; arts. 614, 615, 616 e 623 do AntCMRev; arts. 676 e 677 do AntMR; arts. 661 e 664 do AntMRRev; arts. 671 e 674 do PCD n 
634/1975; e arts. 662 e 665 do CC/2002 - claramente concernentes à representação tenham sido articuladas em meio a preceitos afetos ao contrato de mandato. Como dissemos logo acima, o "excesso" e a "ratificação" surtem efeitos no âmbito da relação interna; porém, nada justifica que o interesse de terceiros venha a ser disciplinado junto à regulação de um vínculo gestório que lhes é inteiramente estranho.

Por tal ordem de idéias, parece-nos oportuna a sugestão de José Carlos Moreira Alves, no sentido de se disciplinar tal questão em meio ao arcabouço concernente à "representação", contido na Parte Geral da futura codificação ("art. 120. Pode o representado ratificar ou impugnar os atos praticados em seu nome sem poderes suficientes. Parágrafo único. A ratificação há de ser expressa, ou resultar de ato inequívoco, e retroagirá à data do ato").

Pela bibliografia comercial afeta ao tema abordado, cf. A. de SoUSA PINTO, Diccionario cit. (nota 131), pp. 262-266 (vol. I) e 218-221 (vol. II); C. FAlCÃo, Codigo cit. (nota 131), pp. 58-62; D. A. da VEIGA, Codigo cit. (nota 131), pp. 308-309 e 333-335; Dous JURISCONSUltos, Repertorio cit. (nota 131), pp. 30 e 87; J. LiBerato BARroso, Contractos cit. (nota 131), pp. 18-19 e 27; J. J. P. da Silva RAmos, Abecedario cit. (nota 131), pp. 139-143 e 368-370; S. O. D’ARAujo Costa, Codigo cit. (nota 131), pp. 43-46; L. M. VIDAL, Manual cit. (nota 131), pp. 48; W. FERREIRA, Tratado cit. (nota 131), pp. 24-25 e 38-54.

Em meio ao panorama civil pré-codificatório, cf. J. M. da TRINDADE, Collecção cit. (nota 131), pp. 31-33 e 48-49.

Já no âmbito da doutrina produzida sob a égide do Código Civil de 1916, cf. Codigo Civil brasileiro: trabalhos cit. (nota 131), pp. 504-509; A. BEVILÁQUA, Codigo cit. (nota 131), pp. 358-362; A. do VALLE SiQueIRA, Codigo cit. (nota 131), pp. 431-436; A. FERNANDES, Curso de Direito Civil Brasileiro Introdução I, Rio de Janeiro, A. Coelho Branco Fo , 1942, pp. 309-314; A. CHAVES, Lições cit. (nota 131), pp. 284-285 e 304-311; A. L. da CÂMARA LEAL, Manual cit. (nota 131), pp. 102-108; A. MARMiTT, Mandato cit. (nota 131), pp. 193-194 e 208-210; A. WALD, Curso cit. (nota 131), pp. 301-305; C. FAlCÃo, Codigo cit. (nota 131), pp. 144-145; C. BEVILÁQuA, Codigo cit. (nota 05), pp. $42-43$ e 53-59; D. ArRudA MirANDA, Anotações cit. (nota 131), pp. 371-374 e 380-385; E. EsPíNOLA, Systema cit. (nota 131), pp. 570-572; Dos contratos nominados cit. (nota 12), pp. 358-365; E. PESSÔA, Da procuração cit. (nota 131), pp. 5-6 e 12-14; F. C. Pontes DE Miranda, Fontes cit. (nota 16), pp. 332-334; F. M. DE MATTIA, Aparência cit. (nota 06), pp. 13-14; F. R. LeITE FILHO, Curso cit. (nota 05), pp. 350-351; F. A P. LANDIN FilhO, O mandato cit. (nota 09), pp. 14 e 36; F. C. P. Rodrigues - L. da S. Loureiro FilHO, Código cit. (nota 131), pp. 880-882 e 890891; F. C. de SAn Tiago Dantas, Programa cit. (nota 05), pp. 373-376; F. K. CoMPARATO, Aparência cit. (nota 131), pp. 41; G. SCIASCIA, Direito Romano cit. (nota 131), pp. 158-159; G. LACERDA, Obrigações cit. (nota 131), pp. 217-222; J. do AMARAL GuRGel, Contractos cit. (nota 131), pp. 58-59 e 497; J. L. ALVES, Código cit. (nota 05), pp. 358-359 e 369-374; J. F. de LIMA, Curso cit. (nota 05), pp. 581-595; J. GILDENOR DE AlbuQuerque, Mandato cit. (nota 131), p. 490; J. GonÇAlVES MAIA, Theoria cit. (nota 131), pp. 12, 123 e 143; J. M. de CARvalho SAntos, Codigo cit. (nota 05), pp. 182-220, 272-273, 276-280 e 291-292; J. de SAMPAIO Doria, Codigo cit. (nota 131), pp. 91-92; L. LeITE, Codigo cit. (nota 131), pp. 429-434; L. R. de Freitas GoMes, Contrato cit. (nota 131), pp. 294-298; M. C. do. A. KroETZ, A representação cit. (nota 41), pp. 46, 55, 68, 74, 88-89 e 93-97; M. I. CARVAlHo DE MEndonÇA, Contratos cit. (nota 131), pp. 222-228 e 236-239; M. PAulo MerêA, Codigo cit. (nota 131), pp. 405-409; M. M. de SERPA LoPeS, Curso cit. (nota 05), pp. 240-241, 273, 278-285; O. GoMES, Contratos cit. (nota 23), pp. 346-351; O poder cit. (nota 131), p. 4; P. Soares NetTo, Noções cit. (nota 131), pp. 248; R. L. FrançA, Manual cit. (nota 05), pp. 185 e $192-$ 195; S. VAMPRÉ, Manual cit. (nota 131), pp. 138-139; T. Fulgencio Alves Pereira, Programmas cit. (nota 131), pp. 139-142; T. PRATES DA FonseCA, Noções cit. (nota 131), p. 196.

Por fim, quanto à bibliografia voltada ao Código Civil vigente, cf. A. SCHREIBER, A representação cit. (nota 131), pp. 229-232 e 240-241; A. VillaÇA AzEvedo, Código Civil cit. (nota 04), pp. 96-100 e 112; A. Villaça AZEVEDo - S. de S. Venosa, Código cit. (nota 02), pp. 110 e 357-364; A. de Assis, Contratos cit. (nota 131), pp. 64-71, 74-75, 95-97 e 105-106; CAIO MÁrIO da Silva Pereira, Instituições cit. (nota 06), pp. 399-410; Instituições cit. (nota 02), pp. 614, 619 e 621; C. A. BITTAR, Os contratos cit. (nota 131), pp. 56; C. A. BitTAR Filho - M. S. BitTar, Código cit. (nota 02), pp. 24 e 56; C. E . N. CAMillo - G. M. TAVAlerA J. S. Fujita - L. A. SCAvone Júnior (coords.), Comentários cit. (nota 02), pp. 227 e 588-596; C. L. BUENO DE Godoy, Do mandato cit. (nota 131), pp. 616-621 e 629-633; C. R. GonÇALVES, Direito cit. (nota 131), pp. 387-392, 403-404 e 410-411; F. UlHoA COELHO, Curso cit. (nota 02), pp. 300-302 e 316-324; F. AMARAl, Direito cit. (nota 131), pp. 452-458 e 463-466; G. TEPEDINO, A técnica cit. (nota 05), pp. 69-70 e 78-80; L. MAtTietTo, A representação cit. (nota 131), pp. 56-59; L. R. de Freitas Gomes, Contrato cit. (nota 131), p. 286; M. G. MAIA JúNIOR, A representação cit. (nota 04), pp. 28-30; M. C. do. A. KROETZ, A representação cit. (nota 41), p. 35; MARIA HELENA DINIZ, Curso cit. (nota 06), p. 445; Curso cit. (nota 02), pp. 352-353 e 371-374; N. C. B. CAMPELlO, Da representação cit. (nota 131), pp. 401-402, 411-417 e 430 434; N. G. B. Dower, Curso cit. (nota 06), p. 298; Curso cit. (nota 02), pp. 287-294; N. NERY JUNIOR - R. M. de ANDrade Nery, Código cit. (nota 02), pp. 234 e 474-478; N. DuARTE, Da representação cit. (nota 131), 


\section{$\S$ 156. O Código Comercial e os deveres atribuídos ao mandatário. Quanto}

aos deveres do mandatário, desponta em primeiro plano aquele relacionado à execução pessoal da incumbência, de acordo com as instruções conferidas pelo mandante, e mediante a adoção de um comportamento compatível com o padrão representado pelo "comerciante ativo e probo" (artigo 142) - sob pena de responsabilidade pelos prejuízos eventualmente causados ao principal (artigo 162). Contudo, este perfil de atuação do agente não se mostra imune a adaptações (de origem negocial ou legal): podem as partes, por exemplo, admitir o concurso de terceiros para o desempenho das atribuições cometidas (artigo 146); ademais, em circunstâncias excepcionais (artigo 168) - como no caso da falta irremediável de instruções ou de fato superveniente que justifique sua inobservância - o mandatário pode atuar livremente, pautando-se no "uso do comércio" e em seu comportamento regular na gestão de assuntos próprios ("diligentia quam suis") - inclusive para os efeitos da apuração de eventual responsabilidade civil. Além disso, de maneira clara, é atribuído ao agente o ônus da exibição do instrumento do negócio de outorga de poderes representativos: ou seja, no âmbito do mandato representativo, "apresentando o mandato" o agente se isenta de toda e qualquer responsabilidade perante terceiros; caso contrário, só lhe resta a via de uma eventual ratificação do principal (artigo 151). Por fim, evidenciando a proeminência dos interesses do mandante, o legislador não apenas prescreveu uma destinação "imperativa" de seus fundos sob poder do mandatário (artigo 153), como também lhe outorgou uma ação adjudicatória na hipótese de frustração deliberada do mandato para a aquisição (artigo 152): "se o mandatário, tendo fundos ou crédito aberto do comitente, comprar, em nome dele mandatário, algum objeto que devera comprar para o comitente por ter sido individualmente designado no mandato, terá este ação para obrigar à entrega da coisa comprada"133.

pp. 100-101; O.GoMes, Contratos cit. (nota 23), pp. 425 e 430-431; O. R. B. SANDOVAL, Do mandato cit. (nota 131), pp. 583, 608-611 e 621-624; R. LoTUFO, Código cit. (nota 02), pp. 328-329; R. FIUZA (coord.), Novo Código cit. (nota 02), pp. 123, 611-615 e 625-629; S. de S. VENOSA, Direito cit. (nota 06), pp. 339-342; Direito cit. (nota 02), pp. 252, 260-261 e 271-272; S. L. F. da RocHA, Curso cit. (nota 02), pp. 299-300; Silvio Rodrigues, Direito cit. (nota 06), pp. 286-298; Direito cit. (nota 02), pp. 165-166; V. RÁo, Ato Jurídico cit. (nota 131), p. 245; WASHINGTON DE BARROS MONTEIRO, Curso cit. (nota 06), p. 220; e Curso cit. (nota 02), pp. 273-284.

133 A disciplina da execução do mandato mercantil somente pode ser adequadamente depreendida pelo intérprete a partir de uma prévia conjugação de oito dispositivos contidos no Título VI ("Do mandato mercantil”') da Primeira Parte do Código Comercial.

A regra fundamental deste sistema está disposta no artigo 142, que preconiza a observância escrupulosa das instruções por parte de um mandatário sobre quem paira o dever de adotar comportamento condizente com o padrão (abstrato) representado pelo "bom pai de família" mercantil: "aceito o mandato, o mandatário é obrigado a cumpri-lo segundo as ordens e instruções do comitente; empregando na sua execução a mesma 
diligência que qualquer comerciante ativo e probo costuma empregar na gerência dos seus próprios negócios".

A regra contida no artigo 142 faz alusão à observância criteriosa das instruções por parte do mandatário. No entanto, tal preceito é excepcionado pelos artigos 168 e 169. Consoante o primeiro deles, à vista da falta de instruções - ou da superveniência de acontecimento imprevisto - ao mandatário é aberto o flanco da livre administração do negócio confiado ("o comissário que aceitar o mandato, expressa ou tacitamente, é obrigado a cumpri-lo na forma das ordens e instruções do comitente; na falta destas, e na impossibilidade de as receber em tempo oportuno, ou ocorrendo sucesso imprevisto, poderá exeqüir o mandato, obrando como faria em negócio próprio e conformando-se com o uso do comércio em casos semelhantes"). Por sua vez, no artigo 169 se prescreve a isenção de responsabilidade do agente quando - segundo os resultados da gestão, os padrões administrativos prevalecentes na praça comercial, a análise da intenção do mandatário ou a superveniência de ratificação - não houver razão suficiente para que se considere reprovável sua conduta na administração da incumbência que lhe foi confiada ("o comissário que se afastar das instruções recebidas, ou na execução do mandato não satisfizer ao que é de estilo e uso do comércio, responderá por perdas e danos ao comitente. Será, porém, justificável o excesso da comissão: 1. quando resultar vantagem ao comitente; 2. não admitindo demora a operação cometida, ou podendo resultar dano de sua expedição, uma vez que o comissário tenha obrado segundo o costume geralmente praticado no comércio; 3 . podendo presumir-se, em boa-fé, que o comissário não teve intenção de exceder os limites da comissão; 4. nos casos do art. 163"). Ora, a doutrina resguardou a idéia de que ao mandatário compete uma "observância estrita" da intenção do mandante - e não uma "obediência estreita" aos termos da incumbência. Com efeito, J. M. da TRINDADE destacava que "a procuração, ainda que contenha clausulas geraes e amplos poderes, não autoriza ao procurador para fazer o que sabe repugna á vontade do constituinte (...) ainda que se concedesse poder especial para transigir, não póde o procurador transigir acerca de direitos claros e incontroversos de seu constituinte (...) porque semelhante transacção importa uma doação, que o procurador não póde fazer sem especial poder" (Collecção cit. (nota 131), p. 23); por sua vez, C. BEVILÁQUA sustentara que "a primeira obrigação do mandatário é cumprir, fielmente, o mandato, seguindo as instruções do mandante e, sendo possível, mais vantajosamente, ainda" (Codigo cit. (nota 05), p. 46); M. I. CARVALHO DE MENDONÇA, por sua vez, ressaltou que "o mandatário pode deixar de executar o mandato sem responsabilidade quando sobrevêm fatos tais que, se fossem conhecidos do mandante, êste mesmo deixaria de executar a operação (...) um outro caso em que pode obrar do mesmo modo é quando executa o mandato, não em seus têrmos, mas em condições mais vantajosas, ou quando deixa de o executar por ver das circunstâncias que a execução seria danosa ao mandante (...) o princípio que impõe ao mandatário a obrigação de se não afastar dos poderes recebidos não implica o respeito farisaico à letra do instrumento e sim à intenção e fim que o mandante revelou (...) o interêsse do mandante é o critério para decidir se um ato eqüipolente pode ser praticado no desempenho do encargo" (Contratos cit. (nota 131), pp. 219-220 e 227).

Aliás, é curioso que um de nossos principais privatistas do século XX não se sentisse confortável para distinguir as atuações do mandatário e do empregado, quando submetidos a "diretrizes" definidas pela contraparte contratual: "o mandatário é obrigado a exercer sua atividade conforme as instruções do mandante, dadas contemporaneamente à conclusão do contrato ou no curso da execução. Tais instruções não se confundem com as ordens que o empregador dá ao empregado na execução do contrato de trabalho, mas importam direção do comportamento de um contratante pelo outro. Existe, com efeito, subordinação do mandatário ao mandante que, embora mais suave do que a dependência pessoal do empregado, dificulta, em certas circunstâncias, a distinção entre o mandato e determinadas modalidades do contrato de trabalho" (O. Gomes, Contratos cit. (nota 23), p. 350). No mesmo sentido, S. de S. Venosa (Direito cit. (nota 02), 259). Todavia, parece-nos que - neste caso - a argúcia do observador não foi seguida da técnica do cientista; inexiste subordinação no mandato. Ao contrário do contrato de trabalho, em que existem partes contrapostas (frente a frente) e em relação de subordinação, no mandato o que se verifica é algo de completamente diverso. Em uma posição intermediária, a prestação de serviços ensejaria uma relação entre partes contrapostas (frente a frente) mas em relação de coordenação; neste caso, a conduta do locador de serviços (prestador) há de ser dirigida pelas diretrizes lançadas pelo locatário (tomador), em um contexto no qual concorrem todos os remédios (materiais) típicos de uma relação jurídica bilateral (sinalagmática). No contrato de mandato, diferentemente, estamos diante de um ambiente completamente distinto daquele em que se desenvolve a relação de trabalho: as partes estão lado a lado (e não frente a frente) em uma relação de coordenação; com isso, não apenas as instruções podem ser objeto de alteração pelo mandatário à vista das circunstâncias, como ainda se mostram inteiramente inaplicáveis os remédios bilaterais previstos pela legislação para os contratos sinalagmáticos (tais como a cláusula resolutória e a "exceptio non adimpleti contractus").

A observância das instruções estabelecidas pelo mandante foi objeto de cuidadosa disciplina por parte do legislador mercantil oitocentista. Ao mesmo tempo em que prescreveu uma "destinação imperativa de 
fundos" no artigo 153 ("o comerciante, que tiver na sua mão fundos disponíveis do comitente, não pode se recusar ao cumprimento das suas ordens relativamente ao emprego ou disposição dos mesmos fundos; pena de responder por perdas e danos que dessa falta resultarem"), proporcionou ao principal um instrumento eficaz na hipótese de deliberada frustração - por parte do agente - da "causa concreta" contratual (artigo 152): "se o mandatário, tendo fundos ou crédito aberto do comitente, comprar, em nome dele mandatário, algum objeto que devera comprar para o comitente por ter sido individualmente designado no mandato, terá este ação para obrigar à entrega da coisa comprada". Neste sentido, W. FERREIRA destacava assistir "ao comitente, contra o comissário, ação de imissão de posse, na forma do art. 381, III, do Código de Processo Civil [de 1939]" (Tratado cit. (nota 131), p. 97). Perceba-se que a antiga distinção entre "mandato imperativo" e "mandato com livre administração" ainda rendia frutos em meio à legislação mercantil brasileira do século XIX; contudo, em J. M. da TRINDADE já podemos entrever certa restrição ao exercício dos poderes por parte do agente, ainda que tenham sido conferidos de maneira ampla pelo principal: "o mandato com a cláusula 'tratareis do negocio como vos agradar ou parecer, etc.' (...) não induz livre arbitrio" (Collecção cit. (nota 131), p. 23).

Caso o mandatário não tenha observado o padrão de zelo esperado, exsurge ao mandante pretensão indenizatória a ser promovida com fundamento no artigo 162 do Código Comercial: "o mandatário responde ao comitente por todas as perdas e danos que no cumprimento do mandato the causar, quer procedam de fraude, dolo ou malícia, quer ainda mesmo os que possam atribuir-se somente a omissão ou negligência culpável (art. 139)".

Merece destaque, ainda, a regra estabelecida no artigo 151 do Código Comercial, segundo a qual se isenta o "mandatário" ("representante") de toda e qualquer responsabilidade perante terceiro caso the tenha exibido o instrumento do negócio de outorga de poderes representação (ou ratificação suficiente da gestão): "havendo contestação entre um terceiro e o mandatário, que com ele contratou em nome do comitente, o mandatário ficará livre de toda responsabilidade, apresentando o mandato ou ratificação daquele por conta de quem contratou".

Por fim, cumpre-nos enfrentar uma questão bastante delicada, relacionada à substituição do "agente" no exercício da administração confiada. Note-se que o emprego do termo "agente", neste caso, parece-nos o único suficientemente genérico para abranger os aspectos internos e externos do fenômeno. Expliquemo-nos. Em se tratando de mandato sem representação, o problema se resolve com maior facilidade, à vista do fato de que a substituição do incumbido somente surtirá efeitos entre as partes, no âmbito da relação defluente do negócio jurídico (bilateral) de incumbência. Contudo, em matéria de mandato representativo, faz-se necessário resgatar os conceitos burilados em nota imediatamente anterior.

Ora, sob a perspectiva da relação "mandante/mandatário", a possibilidade de substituição do agente haverá de ser apurada de acordo com o negócio bilateral de incumbência celebrado entre os interessados. Assim, por exemplo, pode ter sido ajustada a execução pessoal da atribuição, vedada qualquer espécie de auxílio estranho. Todavia, há que se indagar: tal regra negocial se estende à esfera de terceiros? Celebrado contrato entre o - indevidamente - substabelecido e terceiro de boa-fé, há possibilidade de resistência (por parte do "representado") à pretensão deste último?

Segundo nos parece, a resposta é extremamente simples, e foi dada de maneira acertada - ainda que de modo sistematicamente reprovável - pelo Código Civil brasileiro de 2002. Com efeito, seu artigo 667 dispõe a respeito da substituição durante o curso da execução do contrato de mandato; todavia, perdido em meio a disposições relacionadas ao negócio jurídico bilateral de incumbência, resta o preceito constante do $\S 3^{\circ}$, no qual se preconiza a ineficácia do negócio jurídico representativo sempre que a proibição de substabelecimento constar do instrumento do negócio unilateral de outorga de poderes. Nesta linha, M. M. de SERPA LOPES (Curso cit. (nota 05), pp. 270-271). Em sentido diverso, preconizando a ineficácia do negócio representativo em quaisquer casos, cf. J. GonÇALVES MAIA, Theoria cit. (nota 131), p. 73. No entanto, cumpre observar que o mesmo M. M. de SERPA LOPES adota solução que nos parece inteiramente equivocada quanto ao substabelecimento de poderes a sujeito previamente designado pelo principal: "cumpre, porém, distinguir, quanto a essa responsabilidade, a hipótese não prevista em lei de ter o mandante indicado o eventual substituto do mandatário, isto é, a pessoa a ser eleita para figurar no substabelecimento (...) entendemos que, em tal ocorrendo, o substabelecimento feito na pessoa indicada pelo mandante importa em exonerar o mandatário de qualquer responsabilidade" (Curso cit. (nota 05), p. 272). Ao contrário, consideramos que - sobrevindo razão fundada para que se entreveja no substabelecimento iminente risco de prejuízo ao principal - cabe ao mandatário informar imediatamente o mandante, e não substabelecer desinteressadamente, como se não houvesse um elemento de gestão colaborativa subjacente à sua atividade.

Desta forma, percebe-se que a disciplina da substituição do "agente" - assim como tivemos a oportunidade de afirmar quanto ao "excesso" (e à "ratificação") na execução do mandato - é bifronte, uma vez que pode percutir tanto a esfera jurídica das partes envolvidas no negócio de incumbência ("contrato de mandato"), como também a de terceiros interessados na incolumidade do negócio celebrado com representante munido 
de poderes suficientes - ainda que ilegitimamente investido em suas funções, à vista do disposto entre as partes em contrato de mandato. Note-se, contudo, que se o terceiro tiver ciência da vedação contratual à substituição - ainda que tal restrição não conste do instrumento do negócio jurídico unilateral de outorga -, sua pretensão poderá ser legitimamente repelida pelo "representado", uma vez que o artigo 119 do Código Civil em vigor possibilita, excepcionalmente, que as vicissitudes relacionadas ao "título" da representação alcancem a eficácia do "modo" de representar.

De todo modo, a questão foi abordada de maneira singela pelo legislador mercantil oitocentista (artigo 146): “o mandatário não pode sub-rogar, se o mandato não contém cláusula expressa que autorize a delegação". Interessante observar que a doutrina desde logo percebeu que a outorga de poderes para o substabelecimento poderia se dar de maneira implícita - por exemplo, quando o banco mandatário não tivesse filial no local em que deveria ser diligenciada a cobrança do título cambiário (V. RÁo, Mandato - entrega de letra de câmbio a estabelecimento bancário para cobrança - inexistência de filial no lugar do pagamento - poderes para substabelecer presumidos - prejuízos por falta de protesto oportuno - irresponsabilidade do mandatário, in Revista dos Tribunais 167 (1947), pp. 457-460).

Quanto ao dever de execução da incumbência no âmbito das fontes subseqüentes (legisladas ou meramente projetadas), cf. os arts. 2911, 2912, 2914 (1 e $\left.3^{\circ}\right), 2915,2921,2922,2923,2924,2925,2926,2927,2928$, 2932, 2933, 2935, 2936, 2996, 2937, 2939, 3003, 2999, 3000, 3032 (3º e 3033 do "Esboço"; o art. 2283 do AntFS; os arts. 1068 e 1073 do AntCR; os arts. 1513 e 1517 do AntCBRev; o art. 642 do AntCM; o art. 611 do AntCMRev; o art. 679 do AntMR; o art. 666 do AntMRRev; o art. 676 do PCD n 634/1975; e o art. 667 do $\mathrm{CC} / 2002$.

Por sua vez, no que toca ao padrão de comportamento exigido do mandatário, ao contrário da legislação comercial (preconizante de parâmetros abstratos), o legislador civil preferiu o critério da "diligentia quam suis". Daí a razão por que nos parece inteiramente equivocada M. C. do A. KROETZ ao invocar - talvez em um esforço retórico - o "princípio geral de boa-fé" e o padrão abstrato do "bonus paterfamilias" ( $A$ representação cit. (nota 41), pp. 65-67). No mesmo sentido - com o que não estamos de acordo - S. RODRIGUES (Direito cit. (nota 06), pp. 291-295) e S. de S. VENOSA (Direito cit. (nota 02), p. 258). A este respeito, cf. os arts. 2937 ( $\left.3^{\circ}\right)$ e 2938 do "Esboço"; o art. 2284 do AntFS; o art. 1300 do PCD no 1/1912; o art. 1300 do PSF no 269/1912; o art. 1300 do CC/1916; o art. 679 do AntMR; o art. 666 do AntMRRev; o art. 676 do PCD no 634/1975; e o art. 667 do CC/2002.

No que concerne às vicissitudes relacionadas às instruções do mandante - ausência, superveniência de fato imprevisto ou fundamentos exonerativos de responsabilidade em caso de inobservância - cf. o art. 2932 do "Esboço"; o art. 1085 do AntCR; o art. 1461 do AntCB; e os arts. 1513 e 1531 do AntCBRev.

A respeito da "destinação imperativa de fundos", não encontramos disposição similar ao artigo 153 do Código Comercial em meio às fontes positivas (ou projetadas) posteriores. No entanto, a ação cominatória prevista no artigo 152 do Código Comercial - tendente à adjudicação do bem adquirido pelo mandatário (em seu próprio nome) com fundos pertencentes ao mandante - foi resgatada pelo legislador civil ao ensejo da tramitação do texto que redundou no Código Civil de 2002; a este respeito, cf. o art. 670 do AntMRRev; o art. 680 do PCD nº 634/1975; e o art. 671 do CC/2002.

Observe-se que, irredutível defensora da "atipicidade" do mandato desprovido de representação, C. P. M. CRUZ E TUCCI reconhece o progresso viabilizado pelo art. 671 do Código Civil vigente: "o art. 671 do novo Código Civil constitui, um passo adiante, na admissão do mandato sem representação (...) existe aí, efetivamente, uma porta franqueada para a admissão plena do mandato sem representação, conquanto mantenha a sua condição de contrato atípico (...) o referido dispositivo cuida de uma única hipótese: o mandato para adquirir. Ademais, trata-se de dispositivo isolado, que não é coerente com o restante do capítulo do mandato. A sua existência não me pareceu suficiente para embasar a afirmação de que o mandato sem representação, agora, é típico. pode-se dizer apenas que, desenganadamente, é lícito" (Interposição cit. (nota 09), p. 120).

Quanto à responsabilidade do mandatário perante o mandante, cf. o art. 471 da CLC (aludindo ao “procurador"); os arts. 2937 (3), 2938, 2940 e 2941 do "Esboço"; o art. 2284 do AntFS; os arts. 1073 e 1074 do AntCR; os arts. 1517 e 1518 do AntCBRev; o art. 1300 do PCD n 1/1912; o art. 1300 do PSF n $^{\circ}$ 269/1912; o art. 1300 do CC/1916; os arts. 644 e 657 do AntCM; os arts. 611 e 624 do AntCMRev; o art. 679 do AntMR; o art. 666 do AntMRRev; o art. 676 do PCD no 634/1975; e o art. 667 do CC/2002. Merece destaque o fato de que o "Esboço" (art. 2938), o Anteprojeto de Coelho Rodrigues (art. 1074) e a versão revista do Anteprojeto de Clóvis Beviláqua (art. 1518) preconizavam uma responsabilidade do mandatário graduada segundo a gratuidade (ou onerosidade) da avença. O próprio M. I. CARVALHO DE MENDONÇA o sustentou - à margem de disposição legal que amparasse um tal entendimento (Contratos cit. (nota 131), p. 230). No entanto, posta de parte tal orientação "bilateralizante" do tipo, prevaleceu a responsabilidade idêntica do mandatário em qualquer hipótese. Observe-se que tal constatação não nos parece sem conseqüências no que concerne à análise de um eventual "sinalagma genético" à base do mandato oneroso; 
com efeito, noutra oportunidade tencionaremos discorrer sobre a inaplicabilidade dos conceitos de sinalagma ("genético" e "funcional") ao contrato de mandato, provido que é de mecanismo sancionatório próprio aos contratos bilaterais imperfeitos (o direito de retenção).

Por fim, sobre a substituição do "agente" no curso da administração confiada, cf. os arts. 2914 (2), 2916, 2917, 2918, 2919, 2920, 3005 e 3020 do "Esboço"; os arts. 2273, 2286, 2287, 2288, 2289, 2290 e 2291 do AntFS; os arts. 1076 e 1077 do AntCR; os arts. 1448 e 1449 do AntCB; o art. 1519 do AntCBRev; o art. 1300 do PCD no 1/1912; o art. 1300 do PSF no 269/1912; o art. 1300 do CC/1916; os arts. 640 e 641 do AntCM; os arts. 609 e 610 do AntCMRev; os arts. 116, 117 e 118 do AntPGMA; os arts. 670 e 679 (§ $\left.3^{\circ}\right)$ do AntMR; os arts. 654 e $666\left(\S 3^{\circ}\right)$ do AntMRRev; os arts. 664 e $676\left(\S 3^{\circ}\right)$ do PCD n ${ }^{\circ} 634 / 1975$; e os arts. 655 e $667\left(\$ 3^{\circ}\right)$ do $C C / 2002$.

Especificamente a respeito da substituição do "agente" e seu caráter bifronte, parece-nos adequada a proposta do autor do Anteprojeto de Parte Geral do Código Civil atualmente em vigor, José Carlos Moreira Alves, no sentido de que fosse disciplinada no âmbito da Parte Geral - junto ao instituto da representação - a matéria relacionada ao substabelecimento de poderes de representação. Obviamente que sem prejuízo da necessária regulamentação da questão na Parte Especial, quanto às repercussões da substituição sobre a relação contratual (mandante/mandatário). Todavia, a sugestão do relator não obteve acolhimento da Comissão presidida por Miguel Reale, restando a matéria disciplinada - de maneira relativamente "confusa" - em seção única do arcabouço voltado ao tipo contratual objeto de nossas investigações.

Observe-se, finalmente, que a regra constante do artigo 655 do Código Civil em vigor guarda inteira correspondência com a resposta ao $4^{\circ}$ quesito constante do Aviso n 20 de 13 de janeiro de 1876 ("que póde substabelecer, por seu próprio punho, ou sómente com sua assignatura, as procurações, quem tem direito de passal-as de um ou outro modo, ainda quando sejam ellas feitas por Tabellião"). Tal diploma teria um simples sabor histórico, não fosse a resposta ao $2^{\circ}$ quesito ali apresentado: "devem [os substabelecimentos] conter a data da procuração, o nome do tabellião, o lugar onde foi passada, e alguma restricção, que o constituído queira fazer"; ora, diante do disposto no art. 1807 do Código Civil de 1916 (bem como do art. 2045 do Código Civil de 2002), parece-nos que tal preceito se encontra em pleno vigor. Aliás, no sentido do Aviso citado, a Ordem $n^{\circ} 74$ de 11 de abril de 1859 já prescrevia que não poderia substabelecer por instrumento particular aquele que não pudesse outorgar procuração senão por instrumento público.

Pela doutrina mercantil relacionada ao tema (produzida durante a vigência do Código Comercial), cf. A. de Sousa PINTO, Diccionario cit. (nota 131), pp. 262-267 (vol.I) e 217-219 (vol.II); C. FALCÃo, Codigo cit. (nota 131), pp. 56-65; D. A. da VEIGA, Codigo cit. (nota 131), pp. 298-305, 310-314, 332 e 343-346; Dous JuRISCONSUlTOS, Repertorio cit. (nota 131), pp. 28-30 e 87; J. LIBERATO BARROSO, Contractos cit. (nota 131), pp. 14-21 e 26-32; J. J. P. da SILVA RAMOS, Abecedario cit. (nota 131), pp. 140-143 e 367-370; S. O. D’Araujo Costa, Codigo cit. (nota 131), pp. 42-47; L. M. VidAl, Manual cit. (nota 131), pp. 47-50; W. FERREIRA, Tratado cit. (nota 131), pp. 12-13, 20-2561-62, 72-81 e 97.

No panorama civil pré-codificatório, cf. J. M. da TRINDADE, Collecção cit. (nota 131), pp. 33-34.

Quanto à doutrina civil produzida sob a égide do Código Civil de 1916, cf. Codigo Civil brasileiro: trabalhos cit. (nota 131), pp. 504-506; A. BEviláquA, Codigo cit. (nota 131), pp. 358-359; A. do VALLE SIQUEIRA, Codigo cit. (nota 131), pp. 432; A. CHAVES, Lições cit. (nota 131), pp. 301-303; A. L. da CÂMARA LEAL, Manual cit. (nota 131), pp. 104-105; A. MARMITT, Mandato cit. (nota 131), pp. 195-196 e 206-208; A. WALD, Curso cit. (nota 131), pp. 304-305; C. FALCÃO, Codigo cit. (nota 131), pp. 145; C. BEVILÁQUA, Codigo cit. (nota 05), pp. 45-47; D. ARRUdA MiRANDA, Anotações cit. (nota 131), pp. 376-381; E. EsPínOLA, Systema cit. (nota 131), pp. 359-361; E. PESSÔA, Da procuração cit. (nota 131), pp. 9-10 e 26-27; F. C. Pontes de Miranda, Fontes cit. (nota 16), pp. 332; F. R. LeITE Filho, Curso cit. (nota 05), pp. 349; F. C. P. Rodrigues - L. da S. Loureiro Filho, Código cit. (nota 131), pp. 883-887; F. C. de SAn Tiago DanTaS, Programa cit. (nota 05), pp. 375; H. THEODORO JÚNIOR, Locação - Comodato - Mandato, $2^{\text {a }}$ ed., São Paulo, LEUD (Livraria e Editora Universitária de Direito Ltda.), 1987, pp. 329-333; J. L. ALves, Código cit. (nota 05), pp. 362-364; J. F. de LIMA, Curso cit. (nota 05), pp. 574-575 e 579-584 (equivocadamente alude à responsabilidade do mandatário substabelecente por caso fortuito na hipótese de substituição simplesmente não autorizada); J. GONÇALVES MAIA, Theoria cit. (nota 131), pp. 25 e 69-74 (considerando "ineficazes" os atos praticados pelo substabelecido, em caso de substituição proibida); J. M. de CARVALHO SANTOS, Codigo cit. (nota 05), pp. 227-249; J. de SAMPAIO DoriA, Codigo cit. (nota 131), pp. 91-92; L. LeITE, Codigo cit. (nota 131), p. 430; L. R. de Freitas Gomes, Contrato cit. (nota 131), pp. 287-296; M. C. do. A. KroETZ, A representação cit. (nota 41), pp. 65-67 e 89-91; M. G. MAIA JÚNIOR, A representação cit. (nota 04), pp. 108112 (inclusive nota 136); M. I. CARVAlHo de MENDOnÇA, Contratos cit. (nota 131), pp. 219-220, $229-231$ e 239-242; M. PAulo MerêA, Codigo cit. (nota 131), pp. 405-407; M. M. de SERPA Lopes, Curso cit. (nota 05), pp. 267-274; O. GoMES, Contratos cit. (nota 23), pp. 350-355; P. SoARES NeTTO, Noções cit. (nota 131), pp. 245-250; R. L. FRANÇA, Manual cit. (nota 05), pp. 191-194; R. LotUFO, Questões cit.(nota 26), p. 107; S. VAMPRÉ, Manual cit. (nota 131), pp. 134-135; T. FUlGENCIO Alves Pereira, Programmas cit. (nota 131), pp. 


\section{$\S$ 157. O Código Comercial e os deveres conferidos ao mandante. Quanto}

aos deveres do mandante, a posição central é ocupada pelo artigo 154, que lhe atribui a responsabilidade pela remuneração do mandatário e pelas antecipações por este efetuadas de maneira espontânea. Note-se que a feição mercantil da disciplina se evidencia não apenas pela onerosidade da incumbência, como também em virtude da possibilidade de estimação da "retribuição" segundo os usos do local de cumprimento do ajuste ("uso e prática mercantil do lugar onde se cumprir o mandato"); ademais, no artigo 185 se estabelece que tais importâncias devem ser pagas à vista, com juros devidos a partir do desembolso - no que concerne, por óbvio, às despesas suportadas pelo agente. Cumpre destacar que o número reduzido de tais deveres é contrabalançado por precisas intervenções do legislador no aspecto dinâmico da eficácia contratual esquadrinhada. Assim, especificamente com relação ao dever de provisão, é construído um sinalagma funcional que excepciona o princípio da "gestão colaborativa" (caracterizador, de modo geral, da atuação do mandatário): embora ordinariamente deva atuar de maneira "provisional”, o artigo 144 confere ao agente uma exceção material - impeditiva do início da gestão (ou suspensiva da execução já principiada) - caso o "suprimento de fundos" não tenha sido efetuado oportunamente pelo principal. Por sua vez, o artigo 156 é ainda mais abrangente, ao lhe facultar a retenção do "objeto da operação" confiada até que seja satisfeito "de tudo quanto lhe for devido em conseqüência do mandato"134.

138-139; T. PRATES DA FONSECA, Noções cit. (nota 131), p. 198; Y. S. CAHALI, Contratos cit. (nota 131), pp. 512-515 (reputando "nulos" os atos excessivos praticados pelo agente).

Por fim, quanto à bibliografia produzida a propósito do Código Civil de 2002, cf. A. VILLAÇA AZEVEDO - S. de S. Venosa, Código cit. (nota 02), pp. 354-355 e 358-361; A. de Assis, Contratos cit. (nota 131), pp. 3543, 77-82 e 88-90; CAIO MÁRIO da Silva Pereira, Instituições cit. (nota 02), pp. 399, 405-406; C. A. BITTAR FilHo - M. S. BitTar, Código cit. (nota 02), pp. 56-57; C. E . N. CAMillo - G. M. TAVAlera - J. S. FujitA - L. A. SCAVone JúNIOR (coords.), Comentários cit. (nota 02), pp. 585-586 e 590-592; C. L. BUENO DE GodoY, Do mandato cit. (nota 131), pp. 622-626; C. P. M. CRUZ E TUCCI, Interposição cit. (nota 09), pp. 119-120; C. R. GonÇAlves, Direito cit. (nota 131), pp. 396-397 e 404-407; F. UlhoA Coelho, Curso cit. (nota 02), pp. 316-322; F. AMARAL, Direito cit. (nota 131), pp. 458-459 e 466-468; M. G. MAIA JÚNIOR, $A$ representação cit. (nota 04), p. 44; MARIA HelENA DinIZ, Curso cit. (nota 02), pp. 352, 359 e 366-374; N. C. B. CAMPELlo, Da representação cit. (nota 131), pp. 415-419; N. G. B. DowER, Curso cit. (nota 02), pp. 290292 e 301-303; N. Nery Junior - R. M. de ANDRAde Nery, Código cit. (nota 02), pp. 471 e 475-477; O.Gomes, Contratos cit. (nota 23), pp. 429-436; O. R. B. SANDOval, Do mandato cit. (nota 131), pp. 593594 e 612-618; R. FiuZA (coord.), Novo Código cit. (nota 02), pp. 603-605 e 617-622; S. de S. VENOSA, Direito cit. (nota 02), pp. 258 e 269-271; S. L. F. da RoCHA, Curso cit. (nota 02), pp. 299-300 e 314; SILVIO Rodrigues, Direito cit. (nota 02), pp. 290-295; WASHINGTON DE BARROS MONTEIRO, Curso cit. (nota 02), pp. 266-267, 277-279 e 298.

${ }^{134}$ A principal obrigação do mandante concerne ao pagamento da retribuição devida ao mandatário. Note-se que - no contexto analisado - é neste aspecto que o mandato mercantil se diferencia de seu correlato civil: enquanto o primeiro é presumidamente oneroso, o segundo é naturalmente gratuito; todavia, este princípio não se encontra expresso em nenhum dispositivo do Código Comercial. Neste sentido, o artigo 154 do Código Comercial tão somente estabelece: “O comitente é obrigado a pagar ao mandatário todas as despesas 
e desembolsos que este fizer na execução do mandato, e os salários ou comissões que forem devidas por ajuste expresso, ou por uso e prática mercantil do lugar onde se cumprir o mandato, na falta de ajuste".

No entanto, deve-se observar que a remuneração do mandatário mercantil é tão somente natural, à vista da possibilidade de ajuste expresso das partes no sentido do afastamento da disposição legal acima referida, uma vez que dispositiva parece.

Todavia, o sentido emprestado à remuneração é diverso, quando se está diante, por exemplo, do contrato de comissão; quanto a este, o artigo 186 - inaplicável mesmo ao mandato mercantil, à luz do artigo 164 do Código Comercial - estabelece de maneira contundente a "essencialidade" da remuneração do comissário: "Todo comissário tem direito de exigir do comitente uma comissão pelo seu trabalho, a qual, quando não tiver sido expressamente convencionada, será regulada pelo uso comercial do lugar onde se tiver executado o mandato (art. 154)".

Observe-se que todas as importâncias devidas pelo mandante ao mandatário devem ser pagas à vista (na falta de ajuste em sentido diverso); além disso, conferindo-se destaque ao circuito financeiro diferenciado do tipo contratual ora analisado, é determinado o fluxo de juros a partir do respectivo desembolso - e não de eventual interpelação por parte do credor. Todos esses aspectos são abordados no artigo 185 do Código Comercial, o qual, ademais, estabelece que a base para o controle de tais importâncias será o material constante dos livros mercantis do mandatário (cominando-se sanções penais na hipótese de irregularidade): "O comitente é obrigado a satisfazer à vista, salvo convenção em contrário, a importância de todas as despesas e desembolsos feitos no pagamento da comissão, com os juros pelo tempo que mediar entre o desembolso e o efeitovo pagamento, e comissões que forem devidas. As contas dadas pelo comissário ao comitente devem concordar com os seus livros e assentos mercantis; e no caso de não concordarem poderá ter lugar a ação criminal de furto".

Por sua vez, o artigo 156 do Código Comercial atribui ao mandatário o direito de retenção - abrangente de todo o objeto da operação - pelas importâncias que lhe sejam devidas (pelo mandante) em decorrência do contrato de mandato: "O mandatário tem direito para reter, do objeto da operação que lhe foi cometida, quanto baste para pagamento de tudo quanto the for devido em conseqüência do mandato". Perceba-se que o alcance do dispositivo é bastante amplo, uma vez que se assegura ao mandatário o exercício de tal mecanismo de defesa sob a alegação de qualquer espécie de crédito que tenha contra o mandante, desde que devido no contexto da execução do mandato em questão - obviamente não abrangidos créditos de "outra natureza" que o mandatário tenha contra o mesmo mandante.

No entanto, aqui exsurge uma das questões mais importantes do estudo até o momento realizado: qual o papel deste direito de retenção, sobretudo quando comparado à regra estabelecida na parte final do artigo 144 do mesmo Código Comercial ("pode igualmente o mandatário deixar de exeqüir o mandato, quando a execução depender de suprimento de fundos, enquanto não receber do comitente os necessários; e até suspender a execução já principiada se as somas recebidas não forem suficientes")? De que maneira podem ser coordenados tais mecanismos de defesa, em um cenário tão peculiar como o decorrente da celebração de um contrato estribado na confiança, eivado de uma instrumentalidade própria (já que o mandato não é um fim em si mesmo) e voltado ao desempenho de uma gestão colaborativa por parte do agente?

Para oferecermos uma resposta, faz-se necessária uma pequena diferenciação entre quatro conceitos que, embora relacionados, não guardam similitude autorizante de uma sua utilização indiscriminada. Para os efeitos deste estudo, "retribuição" corresponde a toda e qualquer importância devida pelo mandante ao mandatário; trata-se de um conceito abrangente, que a um só tempo envolve o pagamento tanto de uma "remuneração" ao agente, como também de outras importâncias voltadas à recomposição do patrimônio do mandatário - que, com seus préstimos, empregou seu tempo e seu esforço em prol do mandante. Neste cenário, além da "remuneração" (presente tão somente no mandato oneroso), são devidas ao mandatário a "reparação" dos prejuízos experimentados e o "reembolso" das despesas antecipadas.

Ora, neste contexto, estabelece o Código Comercial (art. 156) que por tudo aquilo que integrar a "retribuição" poderá o agente exercitar o "direito de retenção"; o alcance do dispositivo é bastante mais amplo do que o da regra correspondente do Código Civil de 1916 (art. 1315), por meio da qual se o assegurava ao agente apenas para o efeito de "se reembolsar do que no desempenho do encargo despendeu". Embora considerada injusta por parte da doutrina, a regra civil tinha um menor alcance do que a sua correspondente no âmbito do mandato mercantil. E o Código Civil de 2002, por meio de dois dispositivos (arts. 664 e 681), assegurou ao mandatário o direito de retenção. Pelo primeiro deles, conferiu ao agente o poder de reter o "objeto da operação" até que se lhe seja pago tudo o que lhe for devido em virtude do contrato de mandato ("o mandatário tem o direito de reter, do objeto da operação que lhe foi cometida, quanto baste para pagamento de tudo que lhe for devido em conseqüência do mandato"). Já no segundo foi menos acautelador, ao garantir ao mandatário tão somente o "ressarcimento" das despesas espontaneamente antecipadas. Todavia, permitiu que o instrumento alcançasse um objeto mais amplo; pois ao admitir a retenção da "coisa de que tenha a posse em virtude do mandato", o legislador possibilitou ao mandatário 
alcançar, por exemplo, os instrumentos que lhe foram conferidos pelo mandante, a fim de bem executar a incumbência cometida. Nesse sentido, a diferenciar "objeto do mandato" de "objetos pertencentes ao mesmo mandante e relativos à execução do mandato", cf. E. EsPínOlA, Dos contratos nominados cit. (nota 12), p. 366.

Ora, se o direito de retenção é o mecanismo de defesa - por excelência - para a tutela do mandatário, poderia o agente se servir da "exceptio non adimpleti contractus"? A pergunta deve ser respondida em etapas.

Primeiramente devemos ter em conta o fato de que os mecanismos de defesa do credor podem ser estabelecidos em termos genéricos ou específicos. O Código Civil vigente, por exemplo, estabelece - em termos amplos - como mecanismos de defesa do credor a "exceptio non adimpleti contractus" (artigos $476 \mathrm{e}$ 477) e a "cláusula resolutória" (artigos 474 e 475). No entanto, ali não se acha um dispositivo com a mesma compleição afeto ao direito de retenção; de maneira diversa, previu o legislador tal meio de defesa de maneira incidental, em meio à disciplina da específica eficácia das diversas relações jurídicas. Assim como se estatuiu quanto ao contrato de depósito (artigos 633 e 644), também com relação ao contrato de mandato (artigos 664 e 681) tal instrumento foi posto à disposição do credor. Assim, há que se indagar se tais mecanismos são cumuláveis entre si.

A análise do Código Comercial nos permite dizer que sim, diante da expressa construção pelo legislador de um "sinalagma funcional" a atingir parcela da responsabilidade do mandante pela retribuição ao mandatário; pois se não se admite o exercício da "exceptio non adimpleti contractus" com relação à remuneração e à indenização pelos prejuízos experimentados pelo agente, é facultado a este último, todavia, o emprego de tal expediente caso a "provisão de fundos" - relacionada às despesas de execução do mandato - não tenha sido efetuada regularmente pelo principal. Portanto, segundo o Código Comercial (artigos 144, $2^{\mathrm{a}}$ parte e 156) tais mecanismos são cumuláveis, desde que observadas as limitações estabelecidas pelo próprio legislador.

Ocorre que no âmbito civil - seja face ao Código Civil de 1916, seja em relação ao Código Civil de 2002 inexiste previsão similar àquela constante da legislação mercantil (ora revogada, por sinal). Uma interpretação sistemática nos conduziria, atualmente, à aplicação das regras dos artigos 476 e 477 também ao contrato de mandato (desde que, para tanto, se o considerasse "bilateral"). Reputando legítima a abstenção do mandatário em tais circunstâncias, cf. C. BEVILÁQUA, Codigo cit. (nota 05), p. 56; D. ARRUdA MiRANDA, Anotações cit. (nota 131), p. 383; J. L. Alves, Código cit. (nota 05), p. 371; O. GoMES, Contratos cit. (nota 23), pp. 350-351; S. VAMPRÉ, Manual cit. (nota 131), p. 139. No âmbito do Código Civil vigente, seguem a mesma linha de idéias CAIO MÁRIO da Silva Pereira, Instituições cit. (nota 02), pp. 399 e 409-410; C. L. BuENO DE Godoy, Do mandato cit. (nota 131), p. 630 (lançando mão inclusive da disposição revogada do Código Comercial que, malgrado sua ab-rogação, permaneceria latente no sistema como um princípio); C. R. GonÇAlves, Direito cit. (nota 131), pp. 410-411; F. UlhoA Coelho, Curso cit. (nota 02), p. 320; S. de S. Venosa, Direito cit. (nota 02), p. 260; e WASHington de BARros MonTEIRo, Curso cit. (nota 02), p. 283. Em posição isolada, M. C. do. A. KROETZ alude à possibilidade de renúncia, conquanto não mencione o cabimento da "exceptio non adimpleti contractus" (A representação cit. (nota 41), p. 68).

Ocorre que a responsabilidade pelas despesas ("reembolso") e prejuízos ("reparação") experimentados pelo mandatário não é suficiente para tornar o contrato bilateral (ou sinalagmático); nesse sentido, M. M. de SERPA LOPES observa que "o único ponto que transforma o mandato num contrato sinalagmático consiste na obrigação de remunerar os serviços do mandatário (...) os contratos, sujeitos, assim, a obrigações supervenientes, não perdem a sua qualidade de unilateral, desde que se considere a falta de interdependência entre a obrigação nascida no momento da formação do contrato e a acessória, que só aparece no curso de sua execução" (Curso cit. (nota 05), pp. 276-277). Apenas a previsão de uma remuneração teria - talvez - a feição de uma autêntica contrapartida, viabilizadora de uma espécie de troca material, apta a evidenciar um "sinalagma genético"; ainda lançando mão do mesmo autor, cabe destacar esta sua outra observação: "o contrato de mandato perde a sua qualidade de unilateral para se transformar em bilateral, cabendo ao mandatário o direito de exigir do mandante a remuneração ajustada (...) um contrato unilateral se convencionado gratuitamente e bilateral ou sinalgamático se estabelecida a remuneração do mandatário" (Curso cit. (nota 05), p. 276). Mas para que se possa considerar o mandato oneroso um contrato bilateral, é necessário que sejam respondidas - previamente - as seguintes indagações: a remuneração do mandatário constitui uma autêntica contrapartida ("salários")? Ou corresponde a uma simples gratificação ("honorários")? Por que alguns contratos romanos apresentavam nomes duplos ("emptio venditio", "locatio conductio"), enquanto outros ostentavam nomes simples ("mutuum", "depositum", "commodatum", "societas", "mandatum")? Por que em seu "Esboço" A. TEIXEIRA DE FrEITAS previa que algumas despesas "deveriam" ser suportadas pelo próprio mandatário, sem o comprometimento da gestão? Ora, este é um assunto sobre o qual nos deteremos noutra oportunidade, estando já apresentadas as fontes de nosso direito a respeito do tema.

No entanto, apenas para suscitar uma reflexão do próprio leitor, devemos destacar a hesitação de M. I. CARVAlHO DE MENDONÇA a respeito da questão: “o salário prometido no mandato é uma verdadeira 
contraprestação. Como, porém, não é um equivalente, o contrato não se desvirtua tornando-se comutativo e continua unilateral (...) o fato de prometer o mandante um salário não implica obrigar-se pelo contrato de mandato, e desnatura dêsse modo a índole unilateral da convenção, pois que, no fundo, tal promessa é potestativa de sua parte; depende, como o próprio mandato, de sua exclusiva vontade, que pode eliminar uma ou outra. Obrigar-se a pagar é, pois, contrair uma obrigação, não 'ex mandato', mas posterior a êle e dêle independente" (Contractos cit. (nota 131), p. 193). Postas de parte a menção indevida ao termo "comutativo" e a fundamentação do autor - com a qual não concordamos em absoluto - tal excerto nos chama a atenção em virtude do esforço voltado à descaracterização de uma correspectividade entre as prestações dos sujeitos vinculados por meio do contrato de mandato. Em tal sentido, J. M. da TRINDADE já observava, em meados do século XIX, que "os honorários não desnaturão o mandato, porquanto o que, por sua natureza, é pecuniariamente inapreciavel, conserva sempre o seu caracter de benefficio (que nunca se paga)" (Collecção cit. (nota 131), p. 22).

A respeito dos deveres do mandante relacionados à "retribuição" ao mandatário, cf. os arts. $2960\left(2^{\circ}\right.$ e $\left.4^{\circ}\right)$, 2961, 2963, 2964, 2965, 2966, 2967, 2968, 2969, 2971, 2972, 2973, 2974, 2975, 2976 (arbitramento segundo os usos), 2977 e 2978 do "Esboço"; o art. 2296 do AntFS; o art. 1083 do AntCR; o art. 1458 do AntCB; o art. 1528 do AntCBRev; o art. 1310 do PCD no 1/1912; o art. 1310 do PSF n ${ }^{\circ}$ 269/1912; o art. 1310 do CC/1916; os arts. 652, 653 e 661 do AntCM; os arts. 619, 620 e 627 do AntCMRev; o art. 687 do AntMR; o art. 675 do AntMRRev; o art. 685 do PCD no 634/1975; e o art. 676 do CC/2002.

Quanto ao direito de retenção do agente, cf. o art. 2987 do "Esboço" (com abrangência máxima); o art. 2298 do AntFS; o art. 1533 do AntCBRev; o art. 1315 do PCD n ${ }^{\circ} 1 / 1912$; o art. 1315 do PSF n 269/1912; o art. 1315 do CC/1916; o art. 655 do AntCM (despesas ou indenização); o art. 622 do AntCMRev (despesas ou indenização); o art. 692 do AntMR (aludindo à coisa possuída pelo mandatário); os arts. 663 e 680 do AntMRRev; os arts. 673 e 690 do PCD no 634/1975; e os arts. 664 e 681 do CC/2002. Além disso, quanto à sua extensão segundo a legislação vigente, cf. o Enunciado no 184 da III Jornada de Direito Civil realizada pelo Conselho da Justiça Federal.

Por sua vez, sobre o "sinalagma funcional" estabelecido pelo legislador mercantil a respeito da provisão de fundos, cf. os artigos $2960\left(1^{\circ}\right)$ e 2962 do "Esboço"; o art. 1309 do PCD n 1/1912; o art. 1309 do PSF no 269/1912; o art. 1309 do CC/1916; o art. 651 do AntCM; o art. 618 do AntCMRev; o art. 686 do AntMR; o art. 674 do AntMRRev; o art. 684 do PCD nº 634/1975; e o art. 675 do CC/2002.

Por fim, quanto ao termo inicial para a fluência dos juros relacionados às antecipações efetuadas espontaneamente pelo mandatário (data do desembolso), cf. os arts. 2960 (3), 2964 e 2970 do "Esboço"; o art. 1080 do AntCR; o art. 1459 do AntCB (sem que tenha havido definição quanto ao termo inicial); o art. 1529 do AntCBRev; o art. 1311 do PCD no 1/1912; o art. 1311 do PSF no 269/1912; o art. 1311 do CC/1916; o art. 653 do AntCM; o art. 620 do AntCMRev; o art. 688 do AntMR; o art. 676 do AntMRRev; o art. 686 do PCD nº 634/1975; e o art. 677 do CC/2002.

Pela doutrina produzida durante a vigência das disposições do Código Comercial a respeito do mandato mercantil, cf. A. de SousA PINTO, Diccionario cit. (nota 131), pp. 265-268 (vol. I) e 217-218 (vol. II); C. FALCÃO, Codigo cit. (nota 131), pp. 57-60 e 68-69; C. TRIPOLI, Elementos cit. (nota 131), p. 56; D. A. da VeIGA, Codigo cit. (nota 131), pp. 300-301, 315-320 e 368-370; Dous JURISCONSUlTOS, Repertorio cit. (nota 131), pp. 29-30 e 87; J. LiBerato BARroso, Contractos cit. (nota 131), pp. 15-16, 21-22 e 40; J. J. P. da Silva Ramos, Abecedario cit. (nota 131), pp. 140-146 e 367-368; S. O. D’Araujo Costa, Codigo cit. (nota 131), pp. 42-44 e 49-50; L. M. VIDAL, Manual cit. (nota 131), pp. 47-48 e 52-53; W. FERREIRA, Tratado cit. (nota 131), pp. 12, 23-26 e 91-98.

A respeito da doutrina civil afeta ao Código Civil de 1916, cf. Codigo Civil brasileiro: trabalhos cit. (nota 131), pp. 508-509; A. Beviláqua, Codigo cit. (nota 131), pp. 361-362; A. do VAlle Siqueira, Codigo cit. (nota 131), pp. 435-437; A. CHACON COUTO, Ligeiras observações cit. (nota 131), p. 8 (entrevendo reciprocidade no âmbito do mandato); A. CHAVES, Lições cit. (nota 131), pp. 304-307; A. L. da CÂMARA LEAL, Manual cit. (nota 131), pp. 107-108; A. MARMITT, Mandato cit. (nota 131), pp. 193-195; A. WALD, Curso cit. (nota 131), pp. 304-307; C. FALCÃo, Codigo cit. (nota 131), p. 145; C. BEVILÁQuA, Codigo cit. (nota 05), pp. 54-57 e 60-61; D. ARRUdA MirAndA, Anotações cit. (nota 131), pp. 383-385; E. EsPÍNOLA, Dos contratos nominados cit. (nota 12), pp. 364-366; E. PESSÔA, Da procuração cit. (nota 131), pp. 6, 13-14; Estevam De Almeida, Parecer, in Revista dos Tribunais 25 (1918), p. 356; F. C. PONTES DE MIRANDA, Fontes cit. (nota 16), pp. 333-334; F. R. LeITE FILHO, Curso cit. (nota 05), pp. 351; F. C. de SAN TIAGO Dantas, Programa cit. (nota 05), p. 376; G. SCIASCIA, Direito Romano cit. (nota 131), pp. 158-159; H. THEODORO JÚNIOR, Locação cit. (nota 133), pp. 407-409; J. do AMARAL GuRGEL, Contractos cit. (nota 131), pp. 58-59 e 80 (repudiando, por anacrônica, a categoria dos contratos bilaterais imperfeitos, que o autor prefere reputar simplesmente unilaterais); J. L. ALVES, Código cit. (nota 05), pp. 371-376; J. F. de LIMA, Curso cit. (nota 05), pp. 590-594 (aludindo, por equívoco, ao art. 1300 do Código Civil de 1916); J. GonçAlves Maia, Theoria cit. (nota 131), p. 12; J. M. de CARvalho SAntos, Codigo cit. (nota 05), pp. 


\section{$\S$ 158. O Código Comercial e algumas peculiaridades relacionadas à}

formação e à execução do contrato de mandato. Algumas peculiaridades da disciplina relacionada à formação e à execução do contrato de mandato merecem, ainda, o devido destaque: a pluralidade de mandatários, por exemplo, sugeriu ao legislador a oportunidade de uma previsão expressa a respeito não apenas de seu regime de atuação - tendo-se preferido, na ausência de discriminação pelo mandante, a sucessividade presumida (em lugar das incumbências de caráter "conjuntivo" ou solidário) - como também da possibilidade de aceitação por tão somente parte dos destinatários da proposta (artigo 147). Por sua vez, no que toca aos mandantes plúrimos - desde que o mandato concirna a "negócio comum" - preceituou-se a solidariedade entre estes; todavia, a inexistência de uma estruturação sistemática mais arrojada dá margem a dúvidas quando confrontada com a redação conferida à parte final do artigo 148 ("cada uma delas será solidariamente obrigada por todos os efeitos do mandato"): ora, especificamente quanto ao mandato representativo, exsurgiria uma solidariedade diante de terceiros? Embora francamente pareça-nos que não, a feição categórica do texto legal enseja tal espécie de filigrana. Finalmente, corroborando as idéias de "confiança" e de "gestão colaborativa" (respectivamente responsáveis pelas sustentação e orientação do arquétipo do mandato), o artigo 155 estipula a aplicação de juros recíprocos às partes envolvidas: “o comitente e o mandatário são obrigados a pagar juros um ao outro reciprocamente; o primeiro pelos

276-285 e 296-298; J. de SAMPAIO DoriA, Codigo cit. (nota 131), pp. 91-92; L. LeITE, Codigo cit. (nota 131), pp. 433-434; L. R. de Freitas Gomes, Contrato cit. (nota 131), pp. 297-299; M. C. do. A. KroetZ, A representação cit. (nota 41), pp. 66-68; M. I. CARVALHO DE MENDONÇA, Contratos cit. (nota 131), pp. 232239; M. PAulo MerêA, Codigo cit. (nota 131), pp. 409-410; M. M. de SERPA LoPeS, Curso cit. (nota 05), pp. 241 e 276-284; O. GoMES, Contratos cit. (nota 23), pp. 350-351; R. L. FRANÇA, Manual cit. (nota 05), pp. 185 e 195; R. LOTUFO, Questões cit. (nota 26), pp. 105-106; S. VAMPRÉ, Manual cit. (nota 131), pp. 138-140; T. Fulgencio Alves Pereira, Programmas cit. (nota 131), pp. 141-142; T. PRATES DA FonseCA, Noções cit. (nota 131), pp. 196-197.

Por fim, pela produção doutrinária voltada ao Código Civil de 2002, cf. A. VILLAÇA AzEVEDO - S. de S. Venosa, Código cit. (nota 02), pp. 363-365; A. de Assis, Contratos cit. (nota 131), pp. 95-101 e 108-109; Caio Mário da Silva Pereira, Instituições cit. (nota 02), pp. 399 e 408-410; C. E . N. CAMILlO - G. M. TAVAlera - J. S. Fujita - L. A. SCAVOne Júnior (coords.), Comentários cit. (nota 02), pp. 594-597; C. L. BuEno DE GODOY, Do mandato cit. (nota 131), pp. 629-635; C. P. M. CRUZ E TuCCI, Interposição cit. (nota 09), pp. 119-123; C. R. GonÇAlves, Direito cit. (nota 131), pp. 389 e 411-412; F. UlhoA CoElHo, Curso cit. (nota 02), pp. 319-320; F. AMARAL, Direito cit. (nota 131), pp. 466-467; MARIA HelENA DinIZ, Curso cit. (nota 02), pp. 352-353 e 368-374; N. G. B. DOWER, Curso cit. (nota 02), pp. 293-294; N. NERY JUNIOR R. M. de ANDRADE NerY, Código cit. (nota 02), pp. 477-478; O.GoMES, Contratos cit. (nota 23), pp. 430431; O. R. B. SANDoval, Do mandato cit. (nota 131), pp. 621-622 e 625; R. FiUZA (coord.), Novo Código cit. (nota 02), pp. 625-627 e 630-631; S. de S. VENOSA, Direito cit. (nota 02), pp. 260-261 e 267; S. L. F. da Rocha, Curso cit. (nota 02), pp. 300-301; Silvio RoDRIGUES, Direito cit. (nota 02), pp. 289 e 297-298; WASHINGTON DE BARros MonTEIRO, Curso cit. (nota 02), pp. 281-285. 


\title{
dinheiros que o mandatário haja adiantado para cumprimento das suas ordens, e o segundo
}

\author{
pela mora que possa ter na entrega dos fundos que pertencerem ao comitente" ${ }^{\text {135. }}$.
}

135 Dois são os objetos principais da atenção do estudioso com relação à matéria objeto da presente nota de
rodapé: o regime do mandato com pluralidade subjetiva num de seus pólos (ou em ambos); e o modelo
diferenciado a respeito do termo inicial para a fluência dos juros no âmbito da relação
"mandante/mandatário".
Quanto ao primeiro dos conteúdos, há que se desdobrar a atenção do intérprete nas duas modalidades de
pluralidades subjetivas afetas ao mandato: um tanto mais complexa, de fato, é a disciplina atinente à
pluralidade de mandatários - ao passo que menor atenção do legislador mereceu a hipótese de plúrimos
mandantes.

No que concerne à pluralidade de mandatários, quatro são os regimes principais de atuação dos agentes: a) sucessividade; b) conjunção; c) solidariedade; e d) discriminação. No mandato sucessivo existem vários mandatários simultaneamente atrelados ao mandante por meio do liame contratual, embora o concurso de cada um deles - na execução da avença - somente se dê mediante a inércia (ou impedimento) daquele indicado previamente na ordem de precedências (negocialmente fixada). Tal definição, se não constar do instrumento de procuração, não produz qualquer efeito sobre a esfera jurídica de terceiro - salvo conhecimento comprovado por parte deste último (ou fator que indique a plausibilidade de uma tal ciência), na forma do artigo 119 do Código Civil vigente.

Observe-se, portanto, que a "sucessividade na execução" do mandato não se confunde com a oferta de mandato voltada a mandatário único, conquanto dotada de plúrimos destinatários, sob a condição de que a eventual aceitação de cada um dos potenciais oblatos somente seria aferida diante da inequívoca recusa por parte do destinatário precedente: "os mandatários sucessivos têm de obrar um em falta do outro anterior, ou dos outros anteriores. Isso não quer dizer que o mandatário nomeado em segundo, terceiro ou posterior lugar sòmente possa aceitar se o anterior ou os anteriores não aceitaram. Êsses que sòmente podem aceitar se o anterior ou os anteriores não aceitaram são os ordinalmente nomeados, e não os nomeados no mesmo instrumento, que são sucessivos quanto ao exercício, ao adimplemento" (F. C. PONTES DE MIRANDA, Tratado de Direito Privado XLIII cit. (nota 04), p. 33).

Já a cláusula conjuntiva denota a necessária participação de todos os mandatários, sob pena de inadimplemento do contrato celebrado com o mandante. Note-se que nossa definição relacionada à consequiência da inobservância da conjuntividade é extremamente ampla, à vista da necessidade de uma aferição das peculiaridades do caso concreto. Expliquemo-nos. Se a atuação conjunta estiver determinada no contrato de mandato, eventual negócio jurídico representativo praticado pelo procurador suficiente será existente, válido e inteiramente eficaz perante terceiros, somente podendo ser impugnado na hipótese do artigo 119 do Código Civil em vigor. Todavia, se a atuação conjunta estiver atrelada aos "representantes" - e não apenas aos "mandatários" - sob a forma de cláusula constante do negócio jurídico unilateral de outorga de poderes de representação, o negócio praticado sem o concurso de qualquer dos procuradores será inteiramente ineficaz perante o mandante, à vista do "excesso" praticado pelos agentes que concorreram para o ato - em sentido diverso, considerando a situação hipótese de "nulidade", uma vez que "uma só andorinha não fará verão”, cf. W. FERREIRA, Tratado cit. (nota 131), p. 20.

Há quem sustente a possibilidade de ratificação, neste caso, por parte dos procuradores que não estiveram presentes ao ato, tornando-o assim eficaz perante o representado (C. R. GONÇALVES, Direito cit. (nota 131), p. 402). No entanto, adotamos aqui posição diversa, uma vez que a ratificação nos parece ato privativo do principal. Ou seja, das duas uma: ou o principal ratifica o ato e este será eficaz na forma do artigo 662, § único do Código Civil vigente; ou todos os procuradores deverão concorrer, novamente, em negócio jurídico comum. Parece-nos que o que não se pode admitir é a manifestação em etapas, uma vez que a outorga de poderes prescreveu uma declaração negocial única.

A cláusula de solidariedade, por sua vez, foi tomada como regra dispositiva pelo legislador civil ao ensejo da promulgação do Código Civil de 2002. Anteriormente prevalecera - seja no Código Comercial, por seu artigo 147 ("quando no mesmo mandato se estabelece mais de um mandatário, entende-se que são todos constituídos para obrarem na falta, e depois dos outros, pela ordem da nomeação; salvo declarando-se expressamente no mandato que devem obrar solidária e conjuntamente; neste último caso, ainda que todos não aceitem, a maioria dos que aceitarem poderá exeqüir o mandato"), seja no Código Civil de 1916 (artigo 1304) - a cláusula de sucessividade; porém agora vigora a regra de que, na ausência de disposição contrária, o objeto do mandato poderá ser executado por todo e qualquer mandatário, ainda que sem o concurso dos demais agentes. Como o regime do contrato de mandato é mais flexível quanto à sua forma, tal matéria poderá ser apurada pelos mais diversos meios em Direito admitidos, mas exclusivamente no que concerne à 
relação entre as partes - para efeitos de verificação do adimplemento contratual programado. Quanto a terceiros, insistamos, prevalece o disposto no instrumento de outorga de poderes de representação; viabilizada a atuação de qualquer dos representantes, o negócio representativo praticado será inatacável. Assim, diante de previsão diversa constante do instrumento procuratório, da qual decorra contradição face aos termos do contrato de mandato, prevalecerá, sempre, com relação aos terceiros de boa-fé, o instrumento do negócio jurídico de outorga de poderes representativos - desde que não infirmado o seu conteúdo por circunstâncias autorizadoras da aplicação do artigo 119 do Código Civil vigente.

Por fim, pode estar vinculada a execução do mandato à perfeita discriminação da incumbência conferida a cada um dos mandatários. Em tais circunstâncias, observa a doutrina que há, em verdade, pluralidade de mandatos, e não apenas pluralidade subjetiva (de agentes). Nesta hipótese, contudo, há que ter em devida conta a possibilidade de conjugação entre as diversas cláusulas, desde que inexista contradição recíproca. Assim, por exemplo, a execução pode ser discriminada - embora para efeitos de adimplemento se tenha estatuído o regime de solidariedade, mediante eventual regresso dos devedores adimplentes contra o mandatário culpado. Nesse sentido, F. C. PONTES DE MIRANDA destaca que "nada obsta a que se combinem, expressamente, as quatro espécies (solidariedade, conjunção, discriminação, sucessividade), desde que não haja contradição" (Tratado de Direito Privado XLIII cit. (nota 04), p. 32).

Todavia, o que não se há de admitir é a subversão do regime aplicável a cada uma das modalidades de cláusula acima referidas. De fato, no Aviso no 317 de 21 de setembro de 1874 foi admitida a solidariedade entre os procuradores, a despeito da inexistência de cláusula "in solidum": "si a procuração que confere poderes a mais de um procurador para receber vencimentos, sem a clausula in-solidum, só deve ser aceita quando apresentada pelos mandatários conjunctamente, ou si póde ser exhibida por um delles para os devidos effeitos (...) O Governo Imperial approva a decisão, pela qual V. Ex., de accôrdo com o parecer do Procurador da Corôa, declarou ao Inspector da Thesouraria Provincial, que na espécie sujeita aos poderes da procuração, não contendo a clausula alludida, cabem a qualquer dos mandatários indistinctamente". Parecenos que se equivocou o procurador da Coroa, uma vez que, na ausência de orientação diversa dos interessados, haveria de se aplicar o regime legal (dispositivo), orientando-se a solução pela aplicação da sucessividade na execução da incumbência.

Observe-se que a todo momento destacamos a necessidade de uma verificação cuidadosa a respeito do âmbito em que tais cláusulas - sucessividade, conjunção, solidariedade e discriminação - produzirão os seus respectivos efeitos. Um exemplo justificará nosso pretenso zelo quanto a tal ponto: suponha-se que Caio tenha incumbido Tício e Mévio da alienação de um bem situado em praça distante, mediante contrato de mandato no qual tenha sido ajustado que, diante da habilidade negocial da contraparte determinada (Rufo), os dois agentes deveriam atuar em conjunto, para evitar que este último prevalecesse quanto a todas as disposições contratuais. No entanto, no instrumento de outorga de poderes representativos inexiste qualquer menção à conjuntividade do concurso dos procuradores, viabilizando-se, assim, o negócio celebrado à custa da participação de tão somente um dos representantes nomeados. Falecendo Tício, Mévio celebra o negócio representativo com Rufo. Pergunta-se: este contrato poderá ser impugnado por Caio?

Ora, se estivéssemos diante do Código Civil de 1916, seria muito difícil sustentar a invalidade do negócio representativo, a menos que se buscasse anulá-lo mediante a demonstração do dolo de Rufo (artigo 92 do Código Civil revogado). No entanto, segundo o Código Civil vigente, duas considerações hão de ser feitas: em primeiro lugar, via de regra, haverá uma segregação entre o teor do contrato de mandato e o conteúdo do negócio jurídico unilateral de outorga de poderes de representação ("procuração-ato"), a fim de que somente este último influencie a aferição da regularidade do negócio representativo praticado; no entanto, além disso, deverá ser efetuada uma investigação sobre o eventual influxo do contrato de mandato sobre o negócio jurídico representativo. Pois excepcionalmente - com o lastro conferido pelo artigo 119 do Código Civil vigente - será possível impugnar o ato celebrado pelo representante de boa-fé, desde que caracterizado o conflito entre a atuação do representante (que também é mandatário) e as instruções derivadas do contrato de mandato. Com isso, há que se observar que o artigo 119 do Código Civil em vigor contempla não apenas a idéia de um conflito "subjetivo" de interesses (no caso do representante de má-fé), mas também de uma simples disparidade entre a ação do "representante" e o intuito do "representando", desde que efetivamente conhecido - ou simplesmente conhecível - do terceiro que concorre para a celebração do negócio representativo (conflito "objetivo" de interesses). Abre-se, portanto, uma porta para o influxo do "título" sobre o "modo" da representação negocial regular.

É necessário destacar, ainda, que a despeito da infeliz redação utilizada pelo legislador, o artigo 147 do Código Comercial consagra a possibilidade de aceitação por tão somente alguns dos destinatários da oferta de mandato. De fato, se “todos" os destinatários da oferta não aceitarem, não há mandato viável - malgrado a redação do referido dispositivo do Código Comercial (reprovando a infeliz redação, cf. F. C. PONTES DE MirANDA, Tratado de Direito Privado XLIII cit. (nota 04), pp. 32). Todavia, compreendida a "ratio legis", 
merece destaque esta possibilidade de aceitação parcial, não contemplada por qualquer das fontes do direito privado brasileiro que lhe foram posteriores.

No que toca à pluralidade de mandantes, a questão é bastante mais simples, desde que feita expressa censura ao teor do artigo 148 do Código Comercial, inclusive em decorrência da falta de uma sistematização mais desenvolvida em nossa codificação mercantil. De fato, tal dispositivo estabelece que "se o mandatário for constituído por diversas pessoas para um negócio comum, cada uma delas será solidariamente obrigada por todos os efeitos do mandato". Ora, o negócio representativo praticado - à vista da lamentável sistematização adotada por nosso legislador mercantil oitocentista - não pode deixar de ser inclú́do dentre "todos" os efeitos do mandato. Bastava que o legislador tivesse lançado mão de uma repartição sistemática - à moda daquela que posteriormente foi empregada no Código Civil de 1916 - para que a hipótese fosse submetida ao âmbito das relações entre o mandante e o mandatário - ou que conscientemente tal regra fosse arrastada ao cenário das relações mantidas entre os plúrimos "mandantes" e terceiros. Diante da inexistência de uma tal restrição sistemática, o termo "todos", utilizado pelo legislador, ressoa-nos ainda mais estridente. De maneira que, segundo nos parece, somente à custa de uma interpretação restritiva é que tal preceito pode ser reconduzido ao seu autêntico âmbito de aplicação. Eis a razão, talvez, para a ressalva de J. L. Alves ao dispositivo correspondente no âmbito da codificação civil brasileira de 1916 (artigo 1314): "tal solidariedade só existe para com o mandatario e não para com os terceiros com quem elle tratar em nome dos mandantes, salvo poderes expressos para que o mandatario os obrigue solidariamente" (Código cit. (nota 05), p. 375).

Finalmente, merece alusão o regime diferenciado para a fluência de juros no âmbito da relação mandante/mandatário. Com efeito, estabelece o artigo 155 do Código Comercial: "o comitente e o mandatário são obrigados a pagar juros um ao outro reciprocamente; e o primeiro pelos dinheiros que o mandatário haja adiantado para cumprimento das suas ordens, e o segundo pela mora que possa ter na entrega dos fundos que pertencerem ao comitente". Ainda que tal disposição encontre algum reflexo na legislação posterior - sob a forma da previsão individual de termos iniciais de fluência dos juros devidos por uma das partes à outra - não encontramos em nossas pesquisas, à exceção do artigo 2294 do Anteprojeto de Coelho Rodrigues, disposição na qual se evidenciasse, de um modo tão eloqüente, a existência de um circuito financeiro diferenciado neste tipo contratual - dado este que nos parece intimamente vinculado à "causafunção" do instituto ora abordado. A propósito da análise de um caso concreto, sustentaram a aplicação da referida regra ao direito civil pré-codificado CÂNDIDO DE OLIVEIRA, J. M. de SÁ BENEvideS e Justino GONÇALVES DE ANDRADE (Mandato, in Revista Forense 6 (1906), pp. 415-416)

De qualquer forma, este dispositivo (artigo 155) está vinculado a um outro, também estabelecido no Código Comercial - a propósito do contrato de comissão (expressamente contemplado, aliás, pela regra remissiva do artigo 164 do Estatuto Comercial substantivo). Trata-se do artigo 180, que assim dispõe: "o comissário que distrair do destino ordenado os fundos do seu comitente responderá pelos juros a datar do dia em que recebeu os mesmos fundos, e pelos prejuízos resultantes do não-cumprimento das ordens; sem prejuízo das ações criminais a que possa dar lugar o dolo ou fraude". Observe-se que a despeito da inexistência de menção à persecução penal referida pela legislação mercantil, a diretriz deste dispositivo foi reiterada na legislação civil que lhe foi posterior - seja no âmbito do Código Civil de 1916 (artigo 1303), seja em meio ao Código Civil de 2002 (artigo 670).

Pelas fontes supervenientes (legisladas ou projetadas) dedicadas à pluralidade de mandatários, cf. os arts. 2859, 2860, 2861, 2862, 2863, 2949, 2950, 2951 e 3022 do "Esboço"; o art. do 2292 AntFS; o art. 1079 do AntCR; o art. 1454 do AntCB; o art. 1524 do AntCBRev; o art. 1304 do PCD no 1/1912; o art. 1304 do PSF no 269/1912; o art. 1304 do CC/1916; o art. 41 do AntOPH (abordando a pluralidade subjetiva sob a perspectiva da "representação"); o art. 630 do AntCM; o art. 599 do AntCMRev; o art. 115 do AntPGMA; o art. 683 do AntMR; o art. 671 do AntMRRev; o art. 681 do PCD nº 634/1975; e o art. 672 do CC/2002.

Note-se que a despeito da iniciativa de Orosimbo Nonato, Philadelpho Azevedo e Hahnemann Guimarães evidenciada no Anteprojeto de Parte Geral de Código das Obrigações (artigo 41) - posteriormente retiterada no Anteprojeto da Parte Geral do Código Civil de José Carlos Moreira Alves (artigo 115) - não houve previsão de um regime jurídico autônomo quanto à pluralidade de representantes. De todo modo, à doutrina cabe estender, na medida do possível, a regra constante do artigo 672 do Código Civil vigente, desde que ressalvados os termos do instrumento de procuração ("procuração-instrumento"), na forma mencionada linhas atrás.

A respeito da hipótese de plúrimos mandantes, cf. os arts. 2983, 2984, 2985, 2986, 3004 e 3021 do "Esboço"; o art. 2293 do AntFS; o art. 1086 do AntCR; o art. 1462 do AntCB; o art. 1532 do AntCBRev; o art. 1314 do PCD no 1/1912; o art. 1314 do PSF no 269/1912; o art. 1314 do CC/1916; o art. 658 do AntCM; o art. 625 do AntCMRev; o art. 691 do AntMR; o art. 679 do AntMRRev; o art. 689 do PCD n ${ }^{\circ}$ 634/1975; e o art. 680 do $\mathrm{CC} / 2002$.

E acerca do termo inicial para a fluência de juros (na hipótese de malversação pelo mandatário), cf. o art. 2294 do AntFS; o art. 1080 do AntCR; o art. 1453 do AntCB; o art. 1523 do AntCBRev; o art. 1303 do PCD 


\section{$\S$ 159. O Código Comercial e a disciplina relacionada à extinção do}

contrato de mandato. No que concerne à extinção da relação jurídica decorrente do mandato, o artigo 157 do Código Comercial alude às suas principais causas, fazendo expressa menção: à morte, inabilitação ou quebra de qualquer das partes; aos negócios jurídicos unilaterais de revogação e de renúncia; e ao casamento da mulher contratante (desde que não concorra "autorização" superveniente de seu marido). Ainda no que toca às causas extintivas do liame, o artigo 158 dispõe especificamente sobre a modalidade tácita de revogação, evidenciada pela nomeação de um novo agente (para o desempenho de

$\mathrm{n}^{\mathrm{o}}$ 1/1912; o art. 1303 do PSF no 269/1912; o art. 1303 do CC/1916; o art. 645 do AntCM; o art. 612 do AntCMRev; o art. 682 do AntMR; o art. 669 do AntMRRev; o art. 679 do PCD no 634/1975; e o art. 670 do $\mathrm{CC} / 2002$.

Pela doutrina mercantil produzida durante a vigência do Código Comercial, cf. A. de SoUSA PINTO, Diccionario cit. (nota 131), pp. 264-267 (vol. I) e 217-218 (vol. II); C. FALCÃO, Codigo cit. (nota 131), pp. 58-60 e 67; D. A. da VeIGA, Codigo cit. (nota 131), pp. 306-308, 319 e 360-362; Dous JuRISCONSULTOS, Repertorio cit. (nota 131), pp. 29-30 e 87; J. LIBERATO BARROSO, Contractos cit. (nota 131), pp. 17-18, 21 e 38; J. J. P. da Silva RAmos, Abecedario cit. (nota 131), pp. 140, 145 e 367-370; S. O. D'Araujo Costa, Codigo cit. (nota 131), pp. 43-44 e 49; L. M. VIDAL, Manual cit. (nota 131), pp. 48 e 51; e W. FERREIRA, Tratado cit. (nota 131), pp. 19-20, 25-26 e 90-91.

Já quanto à doutrina produzida sob a égide do Código Civil de 1916, cf. Codigo Civil brasileiro: trabalhos cit. (nota 131), p. 508; A. BeviláQuA, Codigo cit. (nota 131), pp. 360-362; A. do VAlle SiQueIRA, Codigo cit. (nota 131), pp. 433-436; A. CHAVES, Lições cit. (nota 131), pp. 294, 300, 304 e 311; A. L. da CÂMARA LEAL, Manual cit. (nota 131), pp. 105-108; A. MARMITT, Mandato cit. (nota 131), pp. 113-114, 121-123 e 194-195; A. WALD, Curso cit. (nota 131), p. 305; C. BEVILÁQUA, Codigo cit. (nota 05), pp. 49-51 e 59-60; D. ARruda Miranda, Anotações cit. (nota 131), pp. 378-384; E. EsPínola, Dos contratos nominados cit. (nota 12), pp. 362-365; E. PESSÔA, Da procuração cit. (nota 131), pp. 10-14; F. C. PONTES DE MIRANDA, Fontes cit. (nota 16), pp. 332-334; F. R. LeITE FilHo, Curso cit. (nota 05), pp. 350-351; F. C. de SAN TIAGO DANTAS, Programa cit. (nota 05), p. 376; G. LACERDA, Obrigações cit. (nota 131), pp. 193-216 (especialmente p. 214); J. L. Alves, Código cit. (nota 05), pp. 366-368 e 375-376; J. F. de LiMA, Curso cit. (nota 05), pp. 580-581, 586 e 595; J. GONÇALVES MAIA, Theoria cit. (nota 131), pp. 64-66; J. M. de CARvalho SAntos, Codigo cit. (nota 05), pp. 258-264 e 293-295; J. de SAMPAIO Doria, Codigo cit. (nota 131), pp. 91-92; L. LEITE, Codigo cit. (nota 131), pp. 431-434; L. R. de FREITAS GoMES, Contrato cit. (nota 131), pp. 296-297; M. C. do. A. KRoETZ, A representação cit. (nota 41), pp. 62 e 67; M. I. CARVALHO DE MENDONÇA, Contratos cit. (nota 131), pp. 221-222, 231-232 e 236-237; M. PAUlo MerÊA, Codigo cit. (nota 131), pp. 408-410; M. M. de SERPA LOPES, Curso cit. (nota 05), pp. 274-275 e 281-282; O. GOMES, Contratos cit. (nota 23), p. 354; O poder cit. (nota 131), p. 11; P. SOARES NETTO, Noções cit. (nota 131), pp. 244-254; R. L. FrAnÇA, Manual cit. (nota 05), pp. 193-195; S. VAMPRÉ, Manual cit. (nota 131), pp. 136-141; T. Fulgencio Alves Pereira, Programmas cit. (nota 131), pp. 138, 140 e 142; Y. S. CAHAli, Contratos cit. (nota 131), p. 512.

Por fim, quanto à bibliografia produzida a propósito do Código Civil de 2002, cf. A. VILLAÇA AZEVEDO - S. de S. Venosa, Código cit. (nota 02), pp. 361-364; A. de Assis, Contratos cit. (nota 131), pp. 86-88, 90-92 e 106-108; CAIO MÁrio da Silva Pereira, Instituições cit. (nota 02), pp. 406-409; C. A. BiTTAR FilHO - M. S. BitTar, Código cit. (nota 02), p. 57; C. E . N. CAMillo - G. M. TAVAlera - J. S. FujitA - L. A. SCAVOne JÚNIOR (coords.), Comentários cit. (nota 02), pp. 592-596; C. L. BuENO DE GODOY, Do mandato cit. (nota 131), pp. 625-627 e 634; C. R. GonÇAlves, Direito cit. (nota 131), pp. 398, 402, 408 e 412; F. UlHOA COElHO, Curso cit. (nota 06), pp. 314 e 318; F. AMARAl, Direito cit. (nota 131), pp. 460-461 e 466; MARIA Helena Diniz, Curso cit. (nota 02), pp. 360-361, 370 e 374; N. G. B. Dower, Curso cit. (nota 02), pp. 292295 e 303; N. NERY JUNIOR - R. M. de ANDRADE NERY, Código cit. (nota 02), pp. 477-478; O.GOMES, Contratos cit. (nota 23), p. 435; O. R. B. SANDOVAL, Do mandato cit. (nota 131), pp. 618-619 e 624; R. FIUZA (coord.), Novo Código cit. (nota 02), pp. 621-623 e 629-630; S. de S. VENOSA, Direito cit. (nota 02), pp. 259-263; Silvio Rodrigues, Direito cit. (nota 02), p. 298; WASHINGTON DE BARRos MonTEIRO, Curso cit. (nota 02), pp. 278-280, 285 e 298 - valendo observar que este último autor defende, ainda hoje, que a sucessividade é a regra dispositiva no que concerne à pluralidade de agentes. 
idêntica incumbência). Sob outra perspectiva, tomando-se a extinção do liame como elemento do próprio suporte fático normativo, as regras constantes dos artigos subseqüentes se voltam aos desdobramentos da cessação do vínculo: assim, o artigo 161 preserva a "gestão colaborativa" subjacente à relação jurídica, atribuindo aos herdeiros sucessores ou representantes legais - do agente falecido não só o dever de informação ao principal, como também o de adotar as medidas necessárias à preservação dos seus interesses; por outro lado, no artigo 160 se entrevê a reiteração do caráter receptício dos atos informativos da extinção do liame, bem como da "validade" dos negócios praticados até o momento da efetiva ciência do mandatário. No entanto, duas proposições prescritivas despertam a atenção do intérprete, não apenas em virtude de seu caráter inovador, mas principalmente em decorrência de sua feição eminentemente mercantil: na parte final do já referido artigo 160 desponta uma expressa disposição voltada ao resguardo dos atos conseqüentes, evidenciadores de um simples desdobramento de seus antecedentes (ultimados estes sob a plena eficácia da relação jurídica gestória); além disso, por meio do artigo 159 se confere ao "mandante" o ônus da utilização do sistema de registros públicos, tanto para a investidura como para a destituição do "mandatário" geral - sob pena de, assim não o fazendo, responder pelos atos praticados pelo destituído, presumidos "válidos" por força de lei ${ }^{136}$.

${ }^{136}$ O Código Comercial brasileiro é um diploma de sua época; desta forma, alguns enunciados prescritivos que pareceriam aberrantes ao intérprete de hoje devem ser analisados à luz das concepções prevalecentes no momento de sua promulgação. Desta forma, o artigo 157 da codificação mercantil assim assinala as causas extintivas do liame contratual decorrente do mandato: "O mandato acaba: 1. pela revogação do comitente; 2. quando o mandatário demite de si o mandato; 3 . pela morte natural ou civil, inabilitação para contratar, ou falimento, quer do comitente, quer do mandatário; 4. pelo casamento da mulher comerciante que deu ou recebeu o mandato, quando o marido negar a sua autorização pela forma determinada no art. 29". A este rol se devem acrescer: a cessação derivada do encerramento do exercício, a respeito das procurações para percepção de valores perante a Fazenda Nacional (artigo $3^{\circ}$ do Aviso no 82 de 30 de março de 1849 e Ordem $\mathrm{n}^{\circ} 79$ de 14 de março de 1853); e a extinção decorrente do esgotamento do objeto da incumbência - tal como se pode depreender da Portaria de 11 de junho de 1852 e do Despacho de 29 de setembro de 1859 (apud J. M. da TRINDADE, Collecção cit. (nota 131), pp. 272-273 e 373-374). Não obstante tais acréscimos, há que se destacar a eventual mitigação da anuidade de vigência da procuração para percepção de valores (cf. Decisão $\mathrm{n}^{\circ} 100$ de 23 de abril de 1849, Portaria de 07 de julho de 1855 e Ordem n 53 de 15 de fevereiro de 1858).

Por um lado, se a juristas da própria época pareceu reprovável a menção do inciso 3 à "morte civil" - neste sentido A. TEIXEIRA DE FREITAS destaca ter sido "uma inadvertencia fallar-se em morte civil no Art. $157 \S 3^{\circ}$ do Cod. do Com., imitando-se o Cod. Com. de Portugal (...) é para lastimar, que nas Obras de Coelho da Rocha, e de Liz Teixeira, própaguem semelhantes doutrinas!" (Consolidação cit. (nota 16), pp. 596-597, nota 6) -, não se pode dizer o mesmo quanto à extinção do mandato em decorrência do casamento da mandante (ou mandatária) não seguido da regular autorização do marido quanto ao exercício da atividade comercial (artigo 29 do Código Comercial). Trata-se, pois, de exigência legal que há de ser compreendida à luz do direito de então, com a ressalva de que quando da promulgação do Código Civil de 1916 já se havia limitado tal restrição ao concurso de mulher exclusivamente como mandatária. Ademais, quanto à cessação do liame em virtude da decretação de falência de uma das partes, o Decreto $n^{\circ} 917$ de 24 de outubro de 1890, por seus artigos 17 e 20, restringiu a extinção, "ipso facto", à hipótese em que o falido figurava como mandatário restando a critério do síndico a denúncia do contrato em caso de falência do mandante. Idêntica foi a 
orientação do Decreto-lei no 7.661/45 (por seu artigo 49). Com a promulgação da Lei Federal no 11.101/05, seu artigo 120 prescreveu a extinção do mandato tanto na hipótese de falência do agente $\left(\S 2^{\circ}\right)$, como no caso de quebra do principal ("caput") - excetuada a hipótese de mandato judicial conferido pelo falido ( $\left(1^{\circ}\right)$.

De todo modo, há que destacar não apenas a previsão expressa da extinção do liame por meio de negócio jurídico unilateral (artigos 157, 1 e 2 e 158), como também a menção inequívoca ao caráter receptício do ato de informação relacionado à cessação do vínculo (artigo 160). Assim, a respeito da extinção do vínculo por iniciativa do principal (artigo 157, 1), é prevista no artigo 158 a revogação tácita (ou implícita) do vínculo: "a nomeação do novo mandatário é sempre derrogatória do mandato anterior, ainda que esta cláusula se não expresse no novo mandato".

A propósito deste dispositivo, devemos aqui ter em conta três observações principais: em primeiro lugar, deve-se destacar que os dispositivos relacionados à extinção do contrato de mandato são, em regra, suscetíveis de aplicação ao negócio jurídico unilateral de outorga de poderes ("procuração"). Ressalvados, por exemplo, casos como os de procuração em causa própria, a superveniência de causa extintiva do contrato de mandato implica, por via reflexa, a cessação dos poderes outorgados ao "procurador" - a fim de que atuasse como "representante" do denunciante junto a terceiro. De todo modo, não houve tal preocupação por parte de nosso legislador mercantil, assim como também ocorreu - posteriormente - com relação à maioria das fontes legisladas e projetadas que lhe sucederam - cf. o art. 473 da CLC; os arts. 3006, 3007, 3009, 3037 e 3042 do "Esboço"; o art. 2299 do AntFS; o art. 1087 do AntCR; os arts. 1534 e 1550 do AntCBRev (o último relacionado ao mandato judicial); o art. 1316 do PCD n ${ }^{\circ}$ 1/1912; o art. 1316 do PSF n 269/1912; o art. 1316 do CC/1916; o art. 48 do AntOPH (abordando o fenômeno sob a perspectiva da "representação"); o art. 659 do AntCM; o art. 626 do AntCMRev; o art. 122 do AntPGMA (abordando o fenômeno sob a perspectiva da "representação"); o art. 693 do AntMR; o art. 681 do AntMRRev; o art. 691 do PCD no 634/1975; e o art. 682 do CC/2002. Merecem destaque, todavia, o Anteprojeto de Parte Geral de Código das Obrigações de Orosimbo Nonato, Philadelpho Azevedo e Hahnemann Guimarães (artigo 48) e o Anteprojeto de Parte Geral do Código Civil de José Carlos Moreira Alves (artigo 122), os quais - a despeito da natural limitação quanto ao conteúdo disciplinado (passível de eventual extensão, via hermenêutica, à terminação do mandato) - anteviram a necessidade de uma disciplina autônoma vinculada à extinção da representação (inclusive a negocial).

Em segundo lugar, há que se observar que a "revogação" corresponde a negócio jurídico unilateral receptício: produz seus efeitos, portanto, tão somente quando de sua chegada ao efetivo conhecimento do destinatário. Desta forma, bem ressalta F. K. COMPARATO que "entre nós, já se apontaram as disposições dos arts. $1318 \mathrm{e}$ 1321 do Código Civil como exceções ao princípio da vontade auto-regradora do mandante, para com base nelas fundar a teoria da representação aparente, mas o raciocínio é incorreto. Partiu-se de uma deficiente análise do negócio jurídico que põe fim à relação de mandato. Deixou-se de levar em consideração o fato óbvio de que o direito potestativo resolutório do mandante é um negócio jurídico receptível, isto é, que só cobra efeito no momento em que é levado ao conhecimento, quer do mandatário, quer dos terceiros com os quais ele contratou. Logo, trata-se de uma limitação de efeitos do ato resolutório 'ex vi legis', e nunca de uma extensão de efeitos do mandato por via interpretativa" (Aparência cit. (nota 131), pp. 40-41). Além do destinatário direto da crítica - o estudioso F. M. DE MATTIA - incorreram no equívoco alguns autores que seguiram suas pegadas, tais como M. G. MAIA JÚNIOR (A representação cit. (nota 04), p. 105) e H. BORGHI (Teoria da Aparência no Direito Brasileiro - Aparência de Direito e Aparência no Direito, no Direito Privado e no Direito Processual Civil - Confrontações e aplicações, inclusive na jurisprudência, São Paulo, Lejus, 1999, pp. 98-104 - parecendo-nos unicamente admissível, como demonstrativa de sua tese, a decisão coligida pelo autor sob o $\mathrm{n}^{\mathrm{o}} 4$ ).

No entanto, não se pode descurar o fato de que se trata de "negócio jurídico", e não de "ato jurídico em sentido estrito"; de maneira que a revogação tácita somente pode defluir da constituição de um novo agente se o ânimo de destituição do predecessor puder ser efetivamente depreendido da manifestação do principal. Caso contrário, não se trataria de "revogação tácita", mas sim de "revogação presumida" - por uma definição (que nos parece inteiramente equivocada) sobre o negócio jurídico receptício de revogação, cf. L. MAtTietTo, A representação cit. (nota 131), p. 67.

Ora, como não se trata de eficácia jurídica "ex lege", mas sim de norma dispositiva de incidência condicionada (à inexistência de manifestação contrária por parte do interessado), não se pode interpretar o artigo 158 do Código Comercial senão de acordo com a ressalva feita por J. L. ALVES ao dispositivo correspondente no âmbito do Código Civil de 1916 (artigo 1319): "o texto estabelece uma regra, que pressupõe a intenção de revogar o mandato anterior, pois que, para o mesmo negócio, podem ser constituídos varios procuradores. Assim, para que a nomeação de outro mandatario importe em revogação do mandato anterior, é necessario, não só que se trate do mesmo negocio, mas que a nova procuração tenha por fim revogar a primeira e não sómente dar a outrem os mesmos poderes já conferidos ao mandatario, de modo que um ou outro possa tratar do negócio ou que o segundo apenas tenha que funcionar na falta do primeiro" 
(Código cit. (nota 05), pp. 382-383). Conferindo-se elevada importância à interpretação das circunstâncias, pela Resolução de 16 de agosto de 1823 se decidiu em favor do segundo procurador, à vista do intuito derrogatório relativo à outorga primeira (cf. J. M. TRINDADE, Collecção cit. (nota 131), pp. 173-180); posição que foi mantida, aliás, no Despacho de 16 de setembro de 1852. Em termos genéricos, cf. a Portaria de 29 de março de 1826, em decorrência da qual se estabelecia a primazia da outorga posterior, além de um minucioso procedimento a ser adotado em caso de dúvida (apud J. M. TRINDADE, Colleção cit. (nota 131), pp. 182-185). Daí nos parecer inexplicável o teor do Aviso $\mathrm{n}^{\circ} 560$ de 15 de dezembro de 1866, por meio do qual se enunciava que o recebimento de quaisquer prestações pelo constituinte implicava - "ipso facto" - a "revogação tácita do mandato" - cf. ainda o Aviso de 06 de junho de 1863 (também relacionado ao principal que percebe algumas parcelas de seu crédito durante a ausência temporária de seu procurador).

Finalmente, há que se observar a utilização de uma terminologia pouco apropriada à diferenciação entre os negócios jurídicos voltados à extinção de liames duradouros. Como observa F. C. PONTES DE MIRANDA, melhor teria sido o emprego de expressões mais apropriadas à representação do fenômeno, ainda que distantes da tradição terminológica nacional: "as leis, por influência de tradição classificatória e terminológica, chamam revogação ao que se poderia conceber como denúncia vazia, por parte do mandante. Consequiência: tem-se de considerar a eficácia do ato como desconstitutivo do suporte fáctico, e não como desconstitutivo do negócio jurídico ou da sua eficácia (...) revogação é a retirada da voz (revocatio) (...) o têrmo 'denúncia' seria melhor, mas de algumas conseqüências um tanto diferentes" (Tratado de Direito Privado XLIII cit. (nota 04), pp. 79-81).

Por sua vez, o artigo 160 do Código Comercial, em sua primeira parte, estatui que a eficácia extintiva do liame somente se desencadeia com a sua efetiva ciência por parte dos interessados: "a morte do comitente, ou a sua incapacidade civil, não prejudica a validade dos atos praticados pelo mandatário até que receba a notícia". Feita a ressalva de que os atos serão praticados pelo agente na qualidade de "representante" - e não de "mandatário" -, cumpre destacar que a regra não se vincula à "validade" dos atos de gestão, mas sim à sua "eficácia": "o art. 1321 concerne à ignorância, pelo mandatário, de qualquer causa de extinção do mandato. Os atos praticados pelo mandatário que sabia da morte do mandante são ineficazes em relação ao mandante: o mandatário não o é mais e obrou falsamente (...) o art. 1321 fala de serem 'válidos' (...) mas o caso é de eficácia, e não de validade" (F. C. PONTES DE MIRANDA, Tratado de Direito Privado cit. (nota 04), p. 93). No mesmo sentido - ainda no panorama civil pré-codificatório - cf. J. M. da TRINDADE, Collecção cit. (nota 131), pp. 42-43 (nota 24) e 45-46. A respeito do tema, repelindo expressamente a solução legal quando os terceiros tiverem comprovada ciência da respectiva causa extintiva, cf. D. ARRUDA MiRANDA, Anotações cit. (nota 131), p. 390; e T. FUlGencio Alves Pereira, Programmas cit. (nota 131), p. 146 ("se os terceiros conheciam a extinção do mandato, e o mandatario a ignora, não tem applicação o preceito em vista da má-fé daquelles").

Deve-se destacar, aliás, que em previsão de indiscutível préstimo ao interesse de terceiros, o artigo 159 do Código Comercial prescrevia a utilização do sistema de registros públicos para a produção de efeitos "erga omnes" dos atos de investidura e de demissão do agente: "o instrumento do mandato geral e o de sua revogação deverão ser registrados no Tribunal do Comércio do domicílio do mandante e do mandatário, ou no cartório do escrivão do juízo do comércio, nos lugares distantes da residência do tribunal. A falta de registro estabelece a presunção da validade dos atos praticados pelo mandatário destituído". Há que se ressalvar, contudo, que o termo "validade" (empregado pelo legislador na parte final do dispositivo) é de todo inadequado; a ausência de tal providência por parte do "representado" implica inoponibilidade da denúncia perante terceiros - restando existente, válido e eficaz todo e qualquer eventual negócio representativo concluído com o "representante" destituído. Nas palavras do próprio F. C. PONTES DE MIRANDA, "perante os terceiros (...) o que decide é a boa fé" (Tratado de Direito Privado XLIII cit. (nota 04), p. 80). Por tal ordem de idéias, J. M. da TRINDADE recomendava a publicação em todos os casos de revogação: "a revogação da procuração geral ad negotia deve ser declarada por editaes; sendo porém especial para um certo acto e determinado negocio, se deve intimar ao outro contrahente (...) é bom estylo o mandante fazer annunciar nas gazetas a revogação da procuração, para que ninguem contracte com o procurador revogado sobre negocios delle mandante" (Collecção cit. (nota 131), p. 44). Note-se que tal disposição foi posteriormente retomada sob a via projetada - em três oportunidades: no "Esboço" (art. 3015), no Anteprojeto de Parte Geral de Código das Obrigações de Orosimbo Nonato, Philadelpho Azevedo e Hahnemann Guimarães (artigo 49) e no Anteprojeto de Parte Geral do Código Civil de José Carlos Moreira Alves (artigo 123). Todavia, não houve acolhida no âmbito das fontes legisladas, tornando mais dispendiosa a produção de prova relacionada à ciência da cessação dos poderes de representação.

Por sua vez, assegurando proteção efetiva aos interesses do mandante, o artigo 161 atribuiu ("ex lege") aos herdeiros do mandatário falecido - durante o curso da gestão - o dever de participação imediata de tal fato ao mandante, eventualmente atrelado - segundo as circunstâncias - a medidas de caráter provisional, voltadas à garantia de eficiência da administração confiada: "morrendo o mandatário, seus herdeiros, sucessores, ou 
representantes legais são obrigados a participá-lo ao comitente, e, até receberem novas ordens, devem zelar pelos interesses deste, e concluir os atos de gestão começados pelo finado mandatário, se da mora puder vir dano ao comitente". Perceba-se, pois, que a eficácia do contrato de mandato é protraída durante um período em que não mais corresponde à relação jurídica que outrora lhe dera respaldo. Em período precioso, F. C. PONTES DE MIRANDA assim sintetiza o fenômeno: “os casos dos arts 1319 (ex argumento), 1320, 1321-1323 do Código Civil são de ultra-eficácia, isto é, eficácia que persiste após a causa da extinção. O mandato não existe mais. Os seus efeitos continuam, como fumaça de fôgo extinto. O que se estabelece, no art. 1321, não só se refere à morte, mas, também, à interdição, à mudança de estado, à incapacidade postulacional do mandatário advogado, à situação do substabelecente já sem podêres de substabelecimento. Ex lege, o mandato é ultra-eficaz: continuam-lhe os efeitos, pôsto que êle se houvesse extinto" (Tratado de Direito Privado XLIII cit. (nota 04), p. 105).

Por fim, não se pode deixar de destacar que na parte final do artigo 160 do Código Comercial se prescreveu a autonomia do mandatário quanto à ultimação dos atos conseqüentes a outros já praticados pelo agente quando de sua ciência a respeito da extinção do negócio jurídico (bilateral) de incumbência: "a morte do comitente, ou a sua incapacidade civil, não prejudica a validade dos atos praticados pelo mandatário até que receba a notícia, nem tampouco aos atos sucessivos que forem conseqüência dos primeiros, necessários para o adimplemento do mandato". Eis aí uma das origens, pois, do parágrafo único do artigo 686 do Código Civil vigente.

Pelas fontes - legisladas ou simplesmente projetadas - afetas à revogação tácita do mandato (inclusive por meio da contratação de novo mandatário), cf. os arts. 3025, 3026, 3027, 3028, 3029 e 3030 do "Esboço"; os arts. 2301, 2302, 2303 e 2304 do AntFS; o art. 1090 do AntCR; o art. 1465 do AntCB; o art. 1537 do AntCBRev; o art. 1319 do PCD no 1/1912; o art. 1319 do PSF no 269/1912; o art. 1319 do CC/1916; o art. 51 do AntOPH (sob a perspectiva da "representação"); o art. 663 do AntCM; o art. 629 do AntCMRev; o art. 125 do AntPGMA (também sob a perspectiva da "representação"); o art. 698 do AntMR; o art. 686 do AntMRRev; o art. 696 do PCD n 634/1975; e o art. 687 do CC/2002. Como já observado, diante do caráter bifronte do tema - uma vez que a revogação do "mandato" pode estar atrelada à revogação da "procuração" seria bastante conveniente a reiteração da regra em meio aos dois ambientes; ou ao menos, seria recomendável a utilização de regra remissiva quanto a um deles, articulando-se as hipóteses junto ao instituto correlato. No entanto, as sugestões levadas a efeito pelo Anteprojeto de Parte Geral de Código das Obrigações de Orosimbo Nonato, Philadelpho Azevedo e Hahnemann Guimarães (artigo 51) - bem como pelo Anteprojeto de Parte Geral do Código Civil de José Carlos Moreira Alves (artigo 125) - não foram acolhidas, cabendo à doutrina desenvolver um esforço hermenêutico voltado à questão.

Já no que concerne à imprescindibilidade da ciência do destinatário - para a perfeição dos efeitos da causa extintiva do liame - cf. o art. 3010 do "Esboço" e o art. 2305 do AntFS. E quanto à inatacabilidade dos atos praticados pelo agente ao tempo em que ignorava a causa de cessação do vínculo, cf. os arts. 3010 e 3011 do "Esboço"; o art. 1092 do AntCR; os artigos 55 e 56 do Decreto n ${ }^{\circ} 451-\mathrm{B}$ de 31 de maio de 1890; o art. 1540 do AntCBRev; o art. 1321 do PCD n 1/1912; o art. 1321 do PSF no 269/1912; o art. 1321 do CC/1916; o art. 52 do AntOPH (já sob a perspectiva da "representação"); o art. 664 do AntCM; o art. 630 do AntCMRev; o art. 127 do AntPGMA; o art. 700 do AntMR; o art. 688 do AntMRRev; o art. 698 do PCD n 634/1975; e o art. 689 do CC/2002. Assim como tivemos a oportunidade de observar logo acima, a presente regra pode apresentar dois âmbitos de aplicação: quanto à relação derivada do negócio de incumbência, sua disciplina há de ser desenvolvida em meio ao arcabouço relacionado ao contrato de mandato; todavia, no que toca à extinção dos poderes de representação, haveria de exsurgir um complexo de normas especificamente voltado à representação negocial. Este, pois, o intuito aparente das iniciativas constantes do Anteprojeto de Parte Geral de Código das Obrigações de Orosimbo Nonato, Philadelpho Azevedo e Hahnemann Guimarães (artigo 52) e do Anteprojeto de Parte Geral do Código Civil de José Carlos Moreira Alves (artigo 127). Todavia, a matéria permaneceu disciplinada unicamente em meio ao capítulo relacionado ao contrato de mandato.

A respeito do dever de informação sobre a morte do mandatário (e das medidas provisionais relacionadas à preservação dos interesses do mandante), cf. os arts. 3016, 3018 e 3019 do "Esboço"; o art. 2308 do AntFS; o art. 1093 do AntCR; o art. 1468 do AntCB; o art. 1541 do AntCBRev; o art. 1322 do PCD n 1/1912; o art. 1322 do PSF no 269/1912; o art. 1322 do CC/1916; o art. 129 do AntPGMA; o art. 701 do AntMR; o art. 689 do AntMRRev; o art. 699 do PCD n 634/1975; e o art. 690 do CC/2002. Ao contrário do que afirmamos com relação às disposições precedentes, consideramos que esta regra está intimamente relacionada à feição gestória do instituto do "mandato" - parecendo-nos exercício artificial a atribuição de um tal efeito à existência de uma "relação representativa". Com efeito, o cometimento de tais providências provisionais decorre da existência de uma gestão colaborativa tutelada juridicamente por meio da estrutura do contrato de mandato. No entanto, em lugar de sugerir a aplicação de tal regra, pela via analógica, às hipóteses de representação legal, o autor do Anteprojeto de Parte Geral do Código Civil (José Carlos Moreira Alves) 


\title{
$\S$ 160. O Código Comercial e a absorção pelo "mandato" de regras
} relacionadas à "comissão" (artigo 164). Como já tivemos a oportunidade de anunciar em momento anterior ( $\S 155$ ), o legislador mercantil brasileiro pretendeu fomentar um

\begin{abstract}
houve por bem considerá-la parte integrante do instituto da representação (artigo 127). Todavia, diante da ausência de interesses de terceiros envolvidos na questão, parece-nos inadequado, neste caso, o enquadramento proposto pelo autor.

Pela doutrina mercantil afeta ao tema ora analisado, cf. A. de SousA PINTO, Diccionario cit. (nota 131), pp. 267 (vol. I) e 217-221 (vol. II); C. FALCão, Codigo cit. (nota 131), pp. 61-62; C. TRIPOLI, Elementos cit. (nota 131), pp. 55-56; D. A. da VeIGA, Codigo cit. (nota 131), pp. 321 e 328-331; Dous JuRISCONSUltos, Repertorio cit. (nota 131), pp. 30 e 87; J. LIBERATO BARROSO, Contractos cit. (nota 131), pp. 22-26; J. J. P. da Silva Ramos, Abecedario cit. (nota 131), pp. 140 e 369-370; S. O. D'Araujo Costa, Codigo cit. (nota 131), p. 45; L. M. VIDAL, Manual cit. (nota 131), pp. 48-49; e W. FERREIRA, Tratado cit. (nota 131), pp. 3237.
\end{abstract}

Pela abordagem do tema no panorama civil anterior à codificação, cf. J. M. da TRINDADE, Collecção cit. (nota 131), pp. 39-45 (com expressa menção à extinção em decorrência da investidura do sujeito em profissão religiosa).

Já no que concerne à doutrina civil produzida sob a égide do Código Civil de 1916, cf. Codigo Civil brasileiro: trabalhos cit. (nota 131), pp. 509-510; A. BEVILÁQUA, Codigo cit. (nota 131), pp. 362-365; A. do VAlle SiQueIRA, Codigo cit. (nota 131), pp. 437-439; A. CAMARGO, Elementos cit. (nota 131), pp. 93; A. ChAVes, Lições cit. (nota 131), pp. 315-317 e 320-323; A. L. da CÂMARA LeAL, Manual cit. (nota 131), pp. 109-111; A. MARMITT, Mandato cit. (nota 131), p. 123; A. WALD, Curso cit. (nota 131), pp. 306-308; C. FALCÃo, Codigo cit. (nota 131), p. 145; C. BeVILÁQUA, Codigo cit. (nota 05), pp. 61-64 e 68-72; D. ARRUDA MIRANDA, Anotações cit. (nota 131), pp. 368 e 387-390; E. EsPínola, Dos contratos nominados cit. (nota 12), pp. 363 e 367-370; E. PESSÔA, Da procuração cit. (nota 131), pp. 15-17; EsteVAM DE ALMEIDA, Parecer cit. (nota 134), p. 356; F. C. PonTES DE MIRANDA, Fontes cit. (nota 16), pp. 334-335; F. R. LeITE Filho, Curso cit. (nota 05), pp. 351-353; F. C. P. Rodrigues - L. da S. Loureiro Filho, Código cit. (nota 131), pp. 891-895; F. C. de SAN TIAGo DanTas, Programa cit. (nota 05), pp. 372 e 376-377; G. SCIASCIA, Direito Romano cit. (nota 131), pp. 159-160; G. LACERDA, Obrigações cit. (nota 131), pp. 189-192; H. THEODORO JÚNIOR, Locação cit. (nota 133), pp. 306-329, 385-386 e 390-393; J. do AMARAL GURGEL, Contractos cit. (nota 131), pp. 80-82 e 331; J. L. ALVES, Código cit. (nota 05), pp. 376-378 e 382-386; J. F. de LiMA, Curso cit. (nota 05), pp. 597-606; J. GONÇALVES MAIA, Theoria cit. (nota 131), pp. 164-182; J. M. de Carvalho Santos, Codigo cit. (nota 05), pp. 299-311, 326-328 e 333-336; J. de Sampaio Doria, Codigo cit. (nota 131), pp. 91-92; L. LeITE, Codigo cit. (nota 131), pp. 434-437; L. R. de FreITAS GoMeS, Contrato cit. (nota 131), pp. 297-299; M. C. do. A. KROETZ, A representação cit. (nota 41), pp. 103-112 (à p. 107 a autora alude, indevidamente, à ciência do procurador como "pressuposto de existência" da revogação); M. I. Carvalho De Mendonça, Contratos cit. (nota 131), pp. 243-245, 249-250 e 253-254; M. PAulo MerÊA, Codigo cit. (nota 131), pp. 410-411; M. M. de SeRPA LoPES, Curso cit. (nota 05), pp. 288-297; O. GoMES, Contratos cit. (nota 23), pp. 351-355; O poder cit. (nota 131), pp. 11-12; P. SOARES NeTTO, Noções cit. (nota 131), pp. 250-251; R. L. FranÇA, Manual cit. (nota 05), pp. 195-197; R. LotUFO, Questões cit.(nota 26), pp. 101-103 e 107-116; S. VAMPRÉ, Manual cit. (nota 131), pp. 138-144; T. FULGENCIO Alves Pereira, Programmas cit. (nota 131), pp. 143-146; T. PRATES DA FonSECA, Noções cit. (nota 131), pp. 198199; Y. S. CAHALI, Contratos cit. (nota 131), pp. 515-516.

Por fim, quanto à doutrina produzida a propósito do Código Civil de 2002, cf. A. VILlaÇA AZEVEDO - S. de S. Venosa, Código cit. (nota 02), pp. 365-368; A. de Assis, Contratos cit. (nota 131), pp. 109-119 e 131138; CAio Mário da Silva Pereira, Instituições cit. (nota 02), pp. 411-414; C. E. N. CAMILlo - G. M. TAVAlera - J. S. Fujita - L. A. SCAvone JúNIOR (coords.), Comentários cit. (nota 02), pp. 597-600; C. L. Bueno De Godoy, Do mandato cit. (nota 131), pp. 635-646; C. R. GonÇALVES, Direito cit. (nota 131), pp. 400 e 412-416; F. UlhoA Coelho, Curso cit. (nota 02), pp. 325-328; F. AMARAL, Direito cit. (nota 131), pp. 456-457, 460, 465 e 470-473; Maria Helena Diniz, Curso cit. (nota 02), pp. 354 e 371-378; N. C. B. CAMPEllo, Da representação cit. (nota 131), pp. 399 e 419-420; N. G. B. Dower, Curso cit. (nota 02), pp. 295-301; N. NERY Junior - R. M. de ANDRADE Nery, Código cit. (nota 02), pp. 478-481; O. GoMeS, Contratos cit. (nota 23), pp. 413 e 431-433; O. R. B. SANDOVAL, Do mandato cit. (nota 131), pp. 596, 625629 e 632-635; R. FiuzA (coord.), Novo Código cit. (nota 02), pp. 631-634 e 637-640; S. de S. VeNosa, Direito cit. (nota 02), pp. 260-263 e 274-281; S. L. F. da RocHA, Curso cit. (nota 02), pp. 302-304; SILvIO Rodrigues, Direito cit. (nota 02), pp. 287-289 e 302-305; WASHINGTON DE BARRos MONTEIRO, Curso cit. (nota 02), pp. 281 e 285-292. 
intercâmbio entre as eficácias dos contratos de "mandato" e de "comissão"; neste sentido, o artigo 164 dispõe que se aplicam também ao tipo contratual objeto de nossas investigações uma série de proposições constantes do Título VII da Parte Primeira do Código Comercial (artigos 167, 168, 169, 170, 175, 180, 181, 182, 183, 184, 185, 187 e 188). Algumas delas já foram analisadas em ocasiões anteriores (artigos 168, 169, 180 e 185, abordados nos $\S \S 156,157$ e 158); outras, no entanto, merecem um tratamento específico nesta oportunidade. Assim, no que toca à relação entre o "mandante" e terceiros, faculta-se ao primeiro o manejo de todas as exceções oponíveis pelo próprio "mandatário", excetuada aquela fundada na incapacidade deste (artigo 167). Por sua vez, no âmbito da relação gestória, são atribuídos ao mandatário os deveres de custódia (artigo 170) inclusive de fundos metálicos (artigo 181) - e de contratação de seguro (artigo 184), sob pena de responsabilidade por danos eventualmente experimentados pelo mandante; ainda no sentido da preservação dos interesses deste último, ao "comissário" é cominada a obrigação de indenizar em caso de contratação sob moldes mais dispendiosos do que os prevalecentes em mercado - de nada aproveitando a alegação de negociação de efeitos próprios em termos semelhantes (artigo 183). Em contrapartida, isenta-se o agente da responsabilidade pelo adimplemento de obrigações contraídas por terceiros durante sua gestão (artigo 175), bem como pelos riscos relacionados ao trânsito de fundos metálicos já expedidos - ressalvando-se unicamente a hipótese de inobservância das instruções relacionadas à remessa dos valores (artigo 182). Por fim, visando-se recompensar a "gestão colaborativa" empreendida pelo mandatário fiel, prescreve-se o dever de remuneração (integral ou proporcional) nos casos de extinção precoce (artigo 187) e de revogação injustificada do mandato - observando-se, quanto a esta, o parâmetro mínimo da "meia comissão" (artigo 188) ${ }^{137}$.

${ }^{137}$ Como já tivemos a oportunidade de observar anteriormente, o legislador mercantil brasileiro procurou incentivar um intercâmbio entre as regras disciplinadoras dos tipos contratuais do "mandato" e da “comissão". Com efeito, em seu artigo 190, o Código Comercial prescreve a aplicação de todas as regras do primeiro instituto àquela que seria a sua variante ordinariamente desprovida de efeitos representativos diretos ("as disposições do Título VI - Do mandato mercantil - são aplicáveis à comissão mercantil"). Em contrapartida, algumas das disposições forjadas para disciplinar o contrato de comissão foram aproveitadas pelo próprio legislador, a fim de que também pudessem informar a eficácia regular do contrato de mandato mercantil; desta forma, o artigo 164 do Código Comercial prescreveu que "as disposições do Título VII - Da comissão mercantil - arts. 167, 168, 169, 170, 175, 180, 181, 182, 183, 184, 185, 187 e 188, são aplicáveis ao mandato mercantil".

Alguns desses dispositivos expressamente invocados pelo legislador já foram objeto de nossa análise em oportunidade anterior deste estudo (artigos 168, 169, 180 e 185). De toda forma, resta-nos ainda quase que uma dezena de disposições que merecem uma abordagem mais criteriosa.

Assim, o artigo 167 do Código Comercial estabelece - dentro dos limites da boa-fé - uma exceção ao princípio da eficácia representativa direta - que parece permear (segundo a maior parte da doutrina) o 
instituto do mandato mercantil. Assim estatui o referido dispositivo: "competem ao comitente todas as exceções que pode opor o comissário; mas não poderá alegar a incapacidade deste, ainda quando se prove, para anular os efeitos da obrigação, contraída pelo mesmo comissário”. Ora, como a comissão é caracterizada pela ausência de uma eficácia representativa direta, atuando o comissário em seu próprio nome - à vista da finalidade de se implementar uma interposição de pessoa que favoreça o comitente -, efetivamente tal regra parece de cabimento indiscutível ao referido tipo contratual, uma vez que abrevia o exercício de expedientes materiais e processuais que, em última análise, redundarão em resultados que serão suportados pelo comitente - a quem a eficácia da gestão, mais cedo ou mais tarde, há de ser finalmente atribuída.

No entanto, tomando-se em consideração o mandato mercantil, a questão se altera significativamente, uma vez que aqui prevalece o princípio da representação direta; desta forma, embora o "mandatário" seja um autêntico "representante" - e não um mero "núncio" - a apreciação dos atos inerentes à gestão segundo a sua pessoa se cinge à imprescindibilidade de seu concurso. Ora, se o "mandatário" ("representante") participa da gestão com o intuito de simplesmente viabilizar a substituição do principal - sem assumir para si, via de regra, qualquer espécie de efeito daquela decorrente -, parece-nos óbvia a inextensibilidade ao "mandante" ("representado") das exceções materiais de que disponha o agente contra o terceiro que concorreu para a celebração do negócio jurídico representativo. Desta forma, o termo "exceções" empregado no artigo 167 do Código Comercial somente pode ser tomado em sua acepção mais estrita quando relacionado ao contrato de comissão; no que concerne à sua aplicação ao mandato, viabilizada pela regra constante do artigo 164, consideramos que o referido termo deva ser tomado como uma espécie de alusão aos requisitos de validade do negócio jurídico. De tal forma que, por exemplo, um defeito do negócio jurídico - celebrado por meio de "mandatário" - poderia ser aventado, obviamente, pelo "mandante".

Por sua vez, no artigo 170 do Código Comercial se comete ao agente o dever de custódia dos bens do principal que tiver consigo: “o comissário é responsável pela boa guarda e conservação dos efeitos de seus comitentes, quer lhes tenham sido consignados, quer os tenha ele comprado, ou os recebesse como em depósito, ou para remetê-los para outro lugar; salvo caso fortuito ou de força maior, ou se a deterioração provier de vício inerente à natureza da coisa". Perceba-se que o dispositivo alude à boa "guarda e conservação"; entretanto, o dever genérico do agente - inclusive do mandatário - é mais amplo, por se atrelar à "custódia" dos bens confiados. A "custódia", como dever mais amplo, congloba a um só tempo a "guarda" (proteção contra a deterioração decorrente de fatores extrínsecos), a "conservação" (proteção contra o perecimento derivado de fatores intrínsecos) e, por vezes, a própria "vigilância". Mesmo o exercício de eventuais direitos, por vezes, pode estar atrelado ao dever genérico de custódia; conquanto seja este um estudo dedicado à história do direito brasileiro, não podemos nos furtar - a esse respeito - à alusão ao “caput" do artigo 42 da Lei Federal n $n^{\circ} 6.404 / 76$, no qual se atribui à instituição financeira responsável pela custódia de ações fungíveis poderes - e deveres (artigo $41, \S 5^{\circ}$ ) - relacionados, por exemplo, ao exercício do direito de preferência para subscrição de ações. É esse dever de custódia que o artigo 170 do Código Comercial atribui, também, ao mandatário (via artigo 164). Note-se que tal disposição inspirou, posteriormente, o artigo 2947 do "Esboço" de Código Civil.

Como desdobramento do dever de custódia deflui a obrigação do mandatário de contratar seguro (sempre que receber ordem neste sentido por parte do mandante), estabelecida pelo artigo 184 do Código Comercial: "o comissário que receber ordem para fazer algum seguro será responsável pelos prejuízos que resultarem se o não efetuar, tendo na sua mão fundos suficientes do comitente para satisfazer o prêmio". Ora, não dispondo o mandatário de fundos suficientes fornecidos pelo mandante - e não tendo havido estipulação no sentido do reembolso de tais importâncias - estaria isento de responsabilidade se não efetuasse a contratação? Embora o dispositivo não nos ofereça resposta clara, duas alternativas contrárias exsurgem: ou se considera aplicável a segunda parte do artigo 144 do Código Comercial (ensejador da suspensão de execução por parte do mandatário), ou se atribui ao agente, por força das circunstâncias, o dever de assumir tais despesas momentaneamente. Esta última solução, que nos parece excepcional, se coaduna com o intuito de "gestão colaborativa" existente à base do contrato de mandato; todavia, diante de seu caráter esporádico, sua aplicação estaria sujeita à superveniência de fundadas razões que ensejassem a sua observância - a serem apuradas de acordo com a matéria concreta objeto da análise do intérprete.

Também hão de ser consideradas desdobramento do dever de custódia as regras estabelecidas nos artigos 181 e 182 do Código Comercial, afetas à específica responsabilidade do mandatário quanto a fundos metálicos (de titularidade do mandante) que estejam sob seu poder. O primeiro preceito dispõe sobre a regra geral aplicável à questão: "o comissário é responsável pela perda ou extravio de fundos de terceiro em dinheiro, metais preciosos, ou brilhantes existentes em seu poder, ainda mesmo que o dano provenha de caso fortuito ou força maior, se não provar que na sua guarda empregou a diligência que em casos semelhantes empregam os comerciantes acautelados"; note-se que aqui volta à carga o padrão médio do homem mercantil, por meio da menção ao "comerciante acautelado". O segundo preceito, por sua vez, excepciona a aplicação do precedente, desde que efetivamente ultimada a expedição dos bens ao mandante (e observadas 


\section{$\S$ 161. O Código Comercial e as regras da "comissão” não estendidas}

(expressamente) ao "mandato". Ultrapassadas as remissões (ao regime da "comissão") efetuadas pelo artigo 164 do Código Comercial, em meio às disposições remanescentes podem ser encontradas duas espécies de proposições: de um lado, um conjunto de regras inconciliáveis com o modelo de mandato forjado pelo legislador mercantil oitocentista; de outro, regras que - conquanto não tenham sido expressamente albergadas pelo artigo 164 não revelam uma incompatibilidade que impeça, ao menos sob a perspectiva acadêmica, uma sua abordagem a propósito da análise do contrato de mandato. Assim, como integrantes da primeira categoria, podem ser indicados os preceitos constantes dos artigos 165, 166 e 179 - respectivamente voltados à conceituação do tipo, ao afastamento da

escrupulosamente as suas instruções): “os riscos ocorrentes na devolução de fundos do poder do comissário para a mão do comitente correm por conta deste; salvo se aquele se desviar das ordens e instruções recebidas, ou dos meios usados no lugar da remessa, se nenhuma houver recebido".

Embora o contrato de mandato seja celebrado no interesse do mandante, não se pode negar que, quando oneroso, gera proveito também ao mandatário, sob a forma de uma "remuneração". Ora, a prevalência do interesse do mandante enseja a extinção do liame por sua iniciativa unilateral ("revogação" ou "denúncia"), sem a necessidade de que qualquer fundamento seja apresentado à contraparte. Trata-se, pois, de denúncia "vazia", uma vez que a apresentação de fundamento tem a finalidade exclusiva de evitar eventual pretensão indenizatória da contraparte (cf. F. C. PONTES DE MIRANDA, Tratado de Direito Privado XLIII cit. (nota 04), p. 90).

Assim, se a extinção do liame deflui de fator irredutível à vontade do principal, aplica-se o disposto no artigo 187 do Código Comercial, que prescreve o pagamento de remuneração parcial ao comissário (mandatário), proporcional ao estágio em que se desdobrou a gestão: "a comissão deve-se por inteiro, tendo-se concluído a operação ou mandato; no caso de morte ou despedida do comissário, é devida unicamente a quota correspondente aos atos por este praticados". No entanto, se a cessação decorre de deliberação unilateral do principal, sem que fundamento tenha sido apresentado, a denúncia vazia implica o pagamento mínimo da metade da remuneração ajustada, tal como estabelece o artigo 188 do Código Comercial: "quando, porém, o comitente retirar o mandato antes de concluído, sem causa justificada procedida de culpa do comissário, nunca poderá pagar-se menos de meia comissão, ainda que esta não seja a que exatamente corresponda aos trabalhos praticados". Note-se que estes preceitos do Código Comercial inspiraram algumas fontes civis posteriores (de caráter simplesmente projetado), tal como se pode depreender: dos arts. 2972, 2973, 2974, 2975, 2976, 2977 e 2978 do "Esboço"; do art. 661 do AntCM; e do art. 627 do AntCMRev.

Finalmente, há que se observar que o Código Comercial comete ao agente a adoção de uma "gestão colaborativa" (em prol do principal), não se admitindo que adote um padrão de conduta incompatível com o intuito de obtenção de uma máxima eficiência administrativa. Desta forma, o artigo 183 preceitua que "o comissário que fizer uma negociação a preço e condições mais onerosas do que as correntes, ao tempo da transação, na praça onde ela se operou, responderá pelo prejuízo, sem que o releve o haver feito iguais negociações por conta própria". No entanto, tal dever do "mandatário" não o transforma em "sócio" do "mandante", uma vez que não lhe cabe, salvo expressa cláusula "del credere", a responsabilidade quanto ao adimplemento das obrigações contraídas por terceiros (artigo 175): "o comissário não responde pela insolvência das pessoas com quem contratar em execução da comissão, se ao tempo do contrato eram reputadas idôneas; salvo nos casos do art. 179, ou obrando com culpa ou dolo". A respeito, cf. o artigo 2941 do "Esboço" de Código Civil.

Pela doutrina mercantil concernente aos assuntos abordados na presente nota de rodapé, cf. A. de SoUSA PINTO, Diccionario cit. (nota 131), pp. 259 e 263-268 (vol. I) e 217-221 (vol. II); C. FALCÃO, Codigo cit. (nota 131), pp. 63-69; C. TRIPOLI, Elementos cit. (nota 131), pp. 56-57; D. A. da VEIGA, Codigo cit. (nota 131), pp. 336, 342, 347-348, 353-354 e 362-371; DOUS JURISCONSULTOS, Repertorio cit. (nota 131), pp. 2830 e 87; J. Liberato Barroso, Contractos cit. (nota 131), pp. 27-40; J. J. P. da Silva Ramos, Abecedario cit. (nota 131), pp. 141-146 e 370; S. O. D’ARAujo CoSTA, Codigo cit. (nota 131), pp. 46-50 e 86; L. M. VIDAL, Manual cit. (nota 131), pp. 49-52; W. FERREIRA, Tratado cit. (nota 131), pp. 64, 81 e 89-93. 
eficácia representativa direta (ordinária) e ao incremento da responsabilidade do agente (por meio da estipulação da cláusula "del credere"). No entanto, nenhuma antinomia real parece defluir da conjugação entre o mandato e os demais enunciados articulados a propósito da comissão. Assim, quanto aos deveres do comissário, prevalece a mesma idéia de "gestão colaborativa" que caracteriza o mandato - tal como se pode depreender dos artigos 171 (dever de informação e averiguação de danos), 172 (dever de inspeção, por ocasião da entrega, dos efeitos recebidos de terceiros), 173 (venda urgente das mercadorias sobre as quais penda risco de perecimento iminente) e 178 (dever de diligenciar a cobrança dos créditos de titularidade "mediata" do comitente). Aliás, visando mitigar o rigor de tais disposições, o artigo 176 reconhece ao comissário a faculdade de conceder prazos de pagamento usuais na praça respectiva, desde que instruções contrárias não lhe tenham sido conferidas pelo comitente - e sejam escrupulosamente efetuadas as discriminações correspondentes por ocasião das prestações de contas periódicas (artigo 177). Da mesma forma, a desoneração estatuída pelo artigo 174 do Código Comercial não parece ser inconciliável com o regime de responsabilidades inerente ao mandato - caso tenha sido admitida, pelo mandante, a delegação da execução da incumbêcia a terceiros. Por fim, dada a peculiar estreiteza do vínculo mantido entre as partes da relação gestória, causa estranheza a não-extensão ao mandatário dos privilégios creditórios atribuídos ao comissário pelo artigo $189^{138}$.

\footnotetext{
138 Algumas regras forjadas pelo legislador mercantil a propósito da comissão são absolutamente inconciliáveis com o arcabouço afeto ao contrato de mandato. Assim, a menção a uma eficácia representativa tão somente indireta impede que os preceitos constantes dos artigos 165 ("a comissão mercantil é o contrato de mandato relativo a negócios mercantis, quando, pelo menos, o comissário é comerciante, sem que nesta gestão seja necessário declarar ou mencionar o nome do comitente") e 166 ("o comissário, contratando em seu próprio nome, ou no nome da sua firma ou razão social, fica diretamente obrigado às pessoas com quem contratar, sem que estas tenham ação contra o comitente, nem este contra elas; salvo se o comissário fizer cessão dos seus direitos a favor de uma das partes") do Código Comercial sejam estendidos ao mandato mercantil - o qual, em suas linhas gerais, pressupõe a atuação do mandatário também em nome do mandante (artigo 140). Da mesma forma, no artigo 179 se faz menção à chamada comissão "del credere", por meio da qual ocorre um agravamento da responsabilidade do agente, contrabalançado por um incremento correlato em sua remuneração ("a comissão del credere constitui o comissário garante solidário ao comitente da solvabilidade e pontualidade daqueles com quem tratar por conta deste, sem que possa ser ouvido com reclamação alguma. Se o del credere não houver sido ajustado por escrito, e todavia o comitente o tiver aceitado ou consentido, mas impugnar o quantitativo, será este regulado pelo estilo da praça onde residir o comissário, e na falta de estilo por arbitradores"). Conquanto não seja esta a ocasião oportuna para tecermos maiores considerações a respeito do assunto, é necessário observar que a estipulação da cláusula "del credere" implica uma espécie de compartilhamento do interesse gerido pelo comissário, uma vez que o sucesso da gestão favorece não apenas ao principal, como também ao próprio agente. Perceba-se que a admissão de modalidades de mandato nas quais "também" exista um interesse do mandatário a ser favorecido (v.g. no mandato de crédito) não se confunde com o compartilhamento divisado na hipótese da comissão "del credere": pois que, em termos jurídicos (ainda que do ponto de vista fático inexista tal correspondência), o mandatário cumpre a sua obrigação a fim de garantir ao mandante a gestão adequada de seu negócio ocupando a "remuneração" um papel relevante, porém secundário.
} 
Já na comissão "del credere" a atuação do agente está diretamente vinculada ao correspectivo que lhe é atribuído pelo sistema jurídico. Embora a atuação do mandatário também possa - sob a perspectiva fática estar voltada à percepção da remuneração, juridicamente sua gestão há de ser recebida pelo ordenamento como uma manifestação do interesse do agente em servir ao principal (em virtude de um negócio bilateral de incumbência). E tal ordem de raciocínio também poderia, em tese, ser estendida à comissão ordinária, desde que a eficácia representativa indireta fosse tomada como seu único fator discriminante em relação ao mandato.

No entanto, a estipulação da cláusula "del credere" afasta por completo este modelo; não há como se sustentar, artificialmente, uma realidade jurídica em completo descompasso com aquela que deflui dos fatos apresentados ao intérprete: a celebração do "del credere" assinala o surgimento de um novo móvel à atuação do incumbido. Em suma, no mandato - ainda que remunerado (ou mesmo "qualificado") - o interesse que está à frente é o do mandante; já na avença consubstanciada no "del credere", o interesse do agente ocupa uma posição - ao menos - equivalente à do principal.

Perguntar-se-á, então, o leitor: este autor pretende reduzir a incumbência "del credere" a um modelo no qual predomine a bilateralidade típica de uma prestação de serviços? Nossa resposta é terminantemente negativa. A incumbência "del credere" - como todas e quaisquer avenças de colaboração nas quais a remuneração do agente esteja atrelada ao êxito da atividade gerida - evidencia que as partes estão lado a lado, diante de terceiros; os problemas que têm entre si não surtem efeitos sobre a esfera jurídica destes últimos, perante os quais aparecem em bloco unitário, conquanto desprovido de personalidade jurídica autônoma. Os expedientes "bilaterais" de defesa do credor - tais como a "cláusula resolutória" e a "exceptio non adimpleti contractus" não podem ser empregados pelas partes, pois se mostram incompatíveis com a "estrutura" do contrato de colaboração.

Já no mandato, a inadmissibilidade dos "expedientes bilaterais" deriva não apenas de sua eficácia peculiar provida de um mecanismo de defesa próprio (o direito de retenção) - mas também de uma incompatibilidade entre tais instrumentos e a "causa-função" do referido tipo contratual: não é possível que o mandatário, simultaneamente, suspenda a execução e atue provisionalmente. A primeira solução é indicada pela generalidade dos "contratos bilaterais"; a segunda resposta decorre da eficácia peculiar aos contratos de gestão colaborativa.

Durante algum tempo se discutiu a respeito do regime jurídico a que está submetido o diretor de uma sociedade anônima: é empregado? Locador de serviço? Ora, se por um lado o "empregado" deve "obedecer" às "ordens" do "empregador", goza de direitos não previstos ao locador de serviços (dentre os quais, v.g., o direito de greve). Por sua vez, o "locador de serviço" há que "observar" as "instruções" que lhe foram conferidas pelo "locatário". Mas se estas instruções se mostram em descompasso com a realidade com que se depara o locador no momento da execução de suas atribuições - possivelmente em virtude de uma informação equivocada a que teve acesso o locatário (e retransmitida ao locador) - este deverá suspender a execução do contrato? Ou mesmo executar a tarefa de modo "diverso" daquele assinalado pelo locatário? Rios de tinta são necessários para lastrear o recurso à boa-fé objetiva, amparando-se, assim, uma atuação do locador nesse sentido.

Ora, o que se quer destacar aqui é que para oferecer resposta a esta última indagação - se a situação for qualificada como a de um contrato de mandato - é completamente desnecessário o recurso à boa-fé objetiva. O mandatário "deve" agir em proveito do mandante - mesmo que para isso tenha de contrariar as suas instruções - se houver elementos suficientes para demonstrar que esta via atenderá efetivamente ao interesse do principal - ao passo que a estrita observância das instruções redundaria no malogro da administração confiada.

Assim e em suma: no contrato de prestação de serviços as partes estão frente a frente, cada uma preocupada com a concatenação de seus próprios interesses. Na avença "del credere", as partes estão lado a lado, voltadas ao desenvolvimento de uma gestão que redundará no benefício comum. Finalmente, no mandato - ainda que remunerado - o mandatário atua em prol do interesse do mandante. A qualificação de um fato concreto como mandato enseja, portanto, a invocação de um arcabouço próprio, dotado de uma eficácia peculiar e irredutível aos mais diversos institutos jurídicos.

A propósito, quanto à incompatibilidade entre o contrato de mandato e a cláusula "del credere", eis o que dispõe o artigo 2941 do "Esboço" de Código Civil: "é caso fortuito a insolvabilidade de terceiros com quem tenha contratado em virtude de mandato, contanto que, ao tempo de contratar, dela não soubesse ou tivesse razão de saber. Quando o mandatário houver tomado a seu cargo tal insolvabilidade (art. 884, $\mathrm{n}^{\circ} 1$ ), aplicarse-á o disposto no Código do Comércio sobre a comissão del credere".

Feita essa observação preliminar, não podemos negar que algumas regras forjadas para o contrato de comissão podem ser proveitosamente estendidas ao mandato, ainda que exclusivamente sob a perspectiva acadêmica, uma vez que tendo havido a possibilidade de uma expressa - e ampla - remissão (artigo 190), o 
legislador mercantil assim não o fez, preferindo selecionar, um a um, os dispositivos passíveis de informar o tipo contratual vizinho (artigo 164).

O primeiro conjunto de disposições passíveis de extensão ao "mandato" corresponde ao formado pelos deveres do comissário relacionados ao recebimento, à vistoria regular, à venda urgente e à expedição dos efeitos do comitente.

A vistoria ordinária das mercadorias do comitente - que o comissário tem consigo - é disciplinada pelo artigo 171 do Código Comercial nos seguintes termos: "o comissário é obrigado a fazer aviso ao comitente, na primeira ocasião oportuna que se the oferecer, de qualquer dano que sofrerem os efeitos existentes em seu poder, e a verificar em forma legal a verdadeira origem donde proveio o dano". Vale dizer, não basta ao comissário apenas informar: deve informar e zelar pela apuração da responsabilidade pelos danos, tal como o faria se o negócio cometido fosse próprio (embora não se preconize a "diligentia quam suis").

Ora, tal vistoria somente pode ser realizada quanto a bens do comitente já recebidos pelo comissário. E o procedimento relacionado ao recebimento de mercadorias - submetidas a prévio contrato de transporte celebrado com terceiro - é detalhadamente regulado pelo artigo 172 do Código Comercial, por meio do qual se atribui ao comissário o dever de inspeção imediata do material recebido, a fim de que sejam efetuadas as regulares ressalvas e perseguida a eventual responsabilidade do transportador: "iguais diligências deve praticar o comissário todas as vezes que, ao receber os efeitos consignados, notar avaria, diminuição, ou estado diverso daquele que constar dos conhecimentos, faturas ou avisos de remessa; se for omisso, o comitente terá ação para exigir dele que responda pelos efeitos nos termos precisos em que os conhecimentos, cautelas, faturas, ou cartas de remessa os designarem; sem que ao comissário possa admitirse outra defesa que não seja a prova de ter praticado as diligências sobreditas".

O cenário de colaboração entre as partes é tão evidente que a superveniência de circunstâncias adversas - que possam comprometer de maneira grave o interesse do comitente - implica a atribuição ao comissário de um dever de venda imediata em prol dos interesses do principal: "acontecendo nos efeitos consignados alteração que torne urgente a sua venda para salvar a parte possível do seu valor, o comissário procederá à venda urgente dos efeitos danificados, em hasta pública, em benefício e por conta de quem pertencer". Note-se que este artigo 173 do Código Comercial não faculta ao comissário a venda ("poderá proceder"); imputa-lhe um dever ("procederá").

Não vemos razão por que as disposições dos artigos 171, 172 e 173 do Código Comercial - ao menos sob a perspectiva teórica - não possam informar o arquétipo do contrato de mandato.

Do mesmo modo, a regra estatuída pelo artigo 174 - relacionada à substituição no curso da expedição de mercadorias - parece-nos inteiramente adaptável, via analógica, ao contrato de mandato: "o comissário encarregado de fazer expedir uma carregação de mercadorias em porto ou lugar diferente, por via de comissário que ele haja de nomear, não responde pelos atos deste, provando que lhe transmitiu fielmente as ordens do comitente, e que gozava de crédito entre comerciantes". Tal disposição parece-nos em harmonia com aquelas que regulam a substituição no curso da execução do negócio jurídico de incumbência, pois ao mesmo tempo em que se atribui ao agente um conjunto mais amplo de deveres, preocupa-se o legislador em eximi-lo dos riscos inerentes à operação - que devem ser suportados, inarredavelmente, pelo principal.

Uma segunda categoria de regras suscetíveis de extensão ao mandato corresponde àquele conjunto de disposições afetas aos termos de negociação e ao controle sobre a execução dos contratos celebrados com terceiros. Com relação aos parâmetros de negociação, o artigo 176 do Código Comercial faculta ao comissário conceder os prazos de pagamento usuais na praça de atuação, desde que inexistente instrução do comitente em sentido contrário ("o comissário presume-se autorizado para conceder os prazos que forem de uso da praça, sempre que não tiver ordem em contrário do comitente"). Neste caso, o sacrifício econômico será experimentado pelo comitente, à vista da falta de orientação inequívoca em senso diverso; a menos que em sua prestação de contas - imediata - o comissário não tenha efetuado a discriminação de tal circunstância, tal como preconiza o artigo 177 do Código Comercial ("o comissário que tiver vendido a pagamento deve declarar no aviso e conta que remeter ao comitente o nome e domicílio dos compradores, e os prazos estipulados; deixando de fazer esta declaração explícita, presume-se que a venda foi efetuada a dinheiro de contado, e não será admitida ao comissário prova em contrário").

Assim como observado com relação aos deveres imediatamente anteriores, não se pode atribuir ao comissário o risco da operação, se atuou de maneira criteriosa e geriu colaborativamente o negócio confiado (artigo 176); no entanto, se age com desídia, a retorsão do legislador é implacável (artigo 177). E é exatamente essa a idéia subjacente ao artigo 178 do Código Comercial, que imputa ao comissário absoluto escrúpulo quanto à cobrança de valores devidos ao comitente: "vencidos os pagamentos das mercadorias ou efeitos vendidos a prazo, o comissário é obrigado a procurar e fazer efetiva a sua cobrança; e se nesta se portar com omissão ou negligência culpável, responderá ao comitente por perdas e danos supervenientes". 


\section{$\S 162$. A Consolidação das Leis Civis o regime do contrato de mandato. A}

Consolidação das Leis Civis sintetizou, em pouco mais de vinte artigos, as proposições concernentes ao contrato de mandato estabelecidas nas Ordenações Filipinas; diante de seu teor simplesmente compilatório (que em nada ofusca o incremento sistemático empreendido por seu autor), pode-se afirmar que suas disposições são escassas, sobretudo quando comparadas ao conjunto de preceitos articulados nos sucessivos anteprojetos de nossa primeira codificação civil. Sob a perspectiva formal, além da confirmação da procuração "apud acta" (artigo 460), prescreve-se ordinariamente a observância da escritura pública para a constituição de agente (artigos 456 e 463), excetuadas as hipóteses em que se autoriza - por privilégio próprio ou resultante de extensão legal (artigo 459) - a utilização de instrumento particular escrito e assinado - ou tão somente assinado (artigo 457 ) - por mão própria (artigo 458). No que concerne à capacidade para a outorga de poderes, preceituam-se a inaptidão absoluta do impúbere (artigo 461) e a admissibilidade da atuação do relativamente incapaz - desde que assistido por seu curador ou

De fato, também com relação aos artigos 176, 177 e 178 do Código Comercial não compreendemos a razão por que tais regras não foram estendidas ao mandato mercantil. De maneira que tais preceitos parecem-nos passíveis de recondução ao modelo ideal do contrato de mandato.

Finalmente, deve-se observar que o artigo 189 do Código Comercial atribui ao comissário privilégio especial sobre os efeitos do comitente que tenha consigo (na hipótese de quebra do principal): "no caso de falência do comitente, tem o comissário hipoteca e precedência privilegiada nos efeitos do mesmo comitente, para indenização e embolso de todas as despesas, adiantamentos que tiver feito, comissões vendidas e juros respectivos, enquanto os mesmo efeitos se acharem à sua disposição em seus armazéns, nas estações públicas, ou em qualquer outro lugar, ou mesmo achando-se em caminho para o poder do falido, se provar a remessa por conhecimentos ou cautelas competentes de data anterior à declaração da quebra (art. 806)". Note-se que - a nosso ver inexplicavelmente - tal garantia não foi estendida ao mandatário por parte do legislador - por meio da cláusula remissiva constante do artigo 164 do Código. Apenas para que se atribua mérito a quem é devido - ou ao menos nos parece sê-lo - destaque-se que, em sentido diverso, no artigo 2987 do "Esboço" de Código Civil se atribui tal privilégio ao mandatário, em caso de eventual concurso de credores sobre os bens do mandante ("até que seja pago dos adiantamentos e despesas que houver feito com os juros respectivos, e de sua retribuição ou comissão, o mandatário poderá reter em seu poder, quanto baste para o pagamento, quaisquer bens ou valores pertencentes ao mandante que ainda se achem à sua disposição. Em concurso de credores do mandante exercerá sobre esses bens ou valores o privilégio que se lhe dá no Livro $4^{\circ}$ deste Código"). A respeito, cf. ainda o art. 102, $\S 2^{\circ}$ do Decreto-lei $n^{\circ} 7661 / 45$ e o art. 83, IV da Lei Federal $\mathrm{n}^{\circ} 11.101 / 05$.

A propósito de remissões, aliás, cumpre destacar, por fim, que o artigo 190 do Código Comercial elegeu o contrato de mandato como subsídio para os casos omissos no arcabouço específico da "comissão" ("as disposições do Título VI - Do mandato mercantil - são aplicáveis à comissão mercantil"). Providência bastante usual, aliás, eis que em ocasiões outras do mandato se lançou mão para subsidiar o defectivo da disciplina sobre "representações voluntárias" (art. 2854 do "Esboço" e art. 43 do AntCM) e "gestão de negócios" (art. 2311 do AntFS).

Pela doutrina mercantil produzida a respeito da matéria abordada nesta nota de rodapé, cf. A. de SousA PINTO, Diccionario cit. (nota 131), pp. 259, 263-264 e 266; C. FALCÃo, Codigo cit. (nota 131), pp. 65-70; C. TRIPOLI, Elementos cit. (nota 131), pp. 56-57; D. A. da VeIGA, Codigo cit. (nota 131), pp. 349-358 e 371372; Dous JurisConsultos, Repertorio cit. (nota 131), pp. 28-31; J. LiberATO BARROSO, Contractos cit. (nota 131), pp. 32-36 e 41-44; J. J. P. da Silva Ramos, Abecedario cit. (nota 131), pp. 141-145 e 370; S. O. D'Araujo Costa, Codigo cit. (nota 131), pp. 47-50 e 86; L. M. Vidal, Manual cit. (nota 131), pp. 50-52; e W. FERREIRA, Tratado cit. (nota 131), pp. 48, 81-89, 94-96 e 109. 
especificamente autorizado pelo órgão jurisdicional competente (artigo 462). Por sua vez, no que toca à aptidão à procuradoria extrajudicial, exsurgem algumas poucas restrições à atuação fiscal de funcionários do Tesouro (artigo 464), obviadas em determinadas hipóteses excepcionais nas quais se descaracterize um conflito de interesses (artigo 465); quanto à procuração judicial, persistem as restrições absolutas de ordem etária, funcional, penal, administrativa e religiosa (artigo 466) - e as relativas derivadas de relações de parentesco mantidas com o magistrado (artigo 467). Por fim, despontam disposições pontuais voltadas à vedação do pacto de "quota litis" (artigo 468), ao arbitramento excepcional de honorários advocatícios (artigo 469) e a vicissitudes relacionadas aos negócios jurídicos de revogação (artigos 474 e 475) e de renúncia (artigo 476) - além de ressalvas referentes à atuação do procurador em prol do adversário de seu constituinte originário (artigo 472) ${ }^{139}$.

\footnotetext{
139 À vista de sua natureza eminentemente sintetizadora, a "Consolidação das Leis Civis" aborda a matéria concernente ao contrato de mandato em pouco mais de vinte disposições, em meio às quais são reunidas regras preponderantemente voltadas à variante judicial do instituto. De toda forma, suas copiosas notas reúnem diversos apontamentos a respeito da legislação extravagante relacionada aos variados assuntos versados no corpo do texto. É nas notas de rodapé da "Consolidação", aliás, que podemos encontrar alguns dos repentes do cientista que mais adiante será o responsável pela edição do mais impressionante anteprojeto de Código Civil a que tivemos acesso em meio às nossas pesquisas.

As disposições relativas ao mandato podem ser divididas em quatro grandes grupos: um primeiro, voltado à disciplina de questões eminentemente formais (artigos 456, 457, 458, 459, 460 e 463); um segundo conjunto, relacionado a algumas poucas restrições subjetivas, ora de caráter absoluto, ora de feições meramente relativas (artigos 461, 462, 464, 465, 466 e 467); um terceiro elenco, devotado a preceitos de fundo moralizador (artigos 468 e 472); e, finalmente, um derradeiro grupo concernente a aspectos residuais, tais como o arbitramento de honorários advocatícios (artigo 469) e as vicissitudes afetas à denúncia extemporânea do mandato judicial (artigos 474, 475 e 476).
}

No que toca aos aspectos formais, a regra central do sistema corresponde ao artigo 456 da Consolidação das Leis Civis, por meio do qual se estabelecem as duas modalidades básicas de procuração: “o procurador não é legitimamente constituido, senão por procuração feita em instrumentos publicos dos Tabelliães; ou em instrumentos particulares de pessoas, á quem se-concede este privilegio". Note-se que embora inserida em capítulo denominado "Do mandato", a disciplina compreendida entre os artigos 456 e 476 se reporta à procuração, sem que se dissociem na "Consolidação" o negócio jurídico bilateral de incumbência ("contrato de mandato") e o negócio unilateral de outorga de poderes representativos ("procuração-ato"). De qualquer forma, esta regra enuncia de modo claro a proeminência da procuração por instrumento público (dos tabeliães) - ocupando a modalidade por instrumento particular uma posição excepcional no sistema. De fato, mesmo o substabelecimento, via de regra, haveria de ser feito diante do tabelião (Aviso $\mathrm{n}^{\circ} 434$ de 16 de novembro de 1874). Para todos os efeitos legais, de conformidade com o estatuído pela Lei de 30 de outubro de 1830 (por meio da qual se equiparou o "juiz de paz" ao "tabelião de notas"), os juízes de paz poderiam lavrar procurações que haveriam de ser reputadas conferidas por instrumento público - orientação que restou confirmada pelo Aviso no 264 de 23 de setembro de 1835, pelo Aviso $\mathrm{n}^{\circ} 187$ de 25 de junho de 1851 e pelo Aviso $\mathrm{n}^{\circ} 184$ de 30 de junho de 1870 (resposta ao $2^{\circ}$ quesito). No entanto, a mesma equiparação não foi promovida a propósito do "escrivão do almoxarifado da colonia" (cf. Ordem no 182 de 11 de junho de 1851 e Ordem no 92 de 13 de março de 1857 apud J. M. da TRINDADE, Collecção cit. (nota 131), pp. 258-261 e 313). No entanto, o referido preceito da "Consolidação" recebe o necessário complemento - no que toca à atuação judicial do procurador - da disposição constante do artigo 460 da Consolidação, que regula a chamada procuração "apud acta": "para negocios judiciaes as procurações podem ser feitas apud acta pelo Escrivão da Causa, em presença do Juiz, e com assignatura do constituinte". A despeito da regra estabelecida no corpo do texto - derivada do direito positivo então vigente - A. TEIXEIRA DE FREITAS imediatamente observa, em nota 
de rodapé, que a procuração "apud acta” não se costumava fazer, à época, mediante ato solene presidido pelo juiz da causa: "Em presença do juiz -: não está em uso, como acontece com muitos outros actos judiciaes, que correm nos cartorios fóra da presença do Juiz. As procurações, e os substabelecimentos, apud acta tomão-se á requerimento das partes, e por despacho do Juiz" (Consolidação cit. (nota 16), p. 323). A respeito da procuração "apud acta" (considerando-a inteiramente vigente ao final da primeira metade do século XIX), cf. J. M. da Rocha CABRAL, Consulta, in J. J. RodRigues (org.), Consultas cit. (nota 131), pp. 338-339. E no âmbito das fontes supervenientes do direito privado brasileiro, cf. o artigo 2893 do "Esboço" de Código Civil.

Ademais, dissemos acima que a procuração por instrumento particular ocupava uma posição "excepcional" no sistema; porém, não "residual". Tamanho era o número de exceções à regra que o preceito defluente do artigo 456 não pode ser obtido sem que imediatamente saltem aos olhos do intérprete as exceções relacionadas àqueles que poderiam produzir instrumento particular escrito e assinado por mão própria - cf. o artigo 458 da Consolidação das Leis Civis ("Podem fazêr procuração por instrumentos particulares, assignados e escriptos de seu punho: $\S 1^{\circ}$ Os Bispos titulares; $\S 2^{\circ}$ Os Viscondes, e Barões sem Grandeza; $\S$ $3^{\circ}$ Os Fidalgos da Casa Imperial; $\S 4^{\circ}$ Os Magistrados; $\S 5^{\circ}$ Os Doutôres, e Advogados; $\S 6^{\circ}$ Os Cavalleiros das Ordens do Imperio; $\S 7^{\circ}$ Os Officiaes Militares até o pôsto de Capitão; $\S 8^{\circ}$ Os Abbades, que gozão das prerogativas episcopaes; os Beneficiados, e os Clerigos de Ordens Sacras") - ou tão somente assinado de próprio punho - e escrito por mão alheia, tal como estabelece o artigo 457 da Consolidação das Leis Civis ("Podem fazêr procuração por instrumentos particulares, tão somente assignados, e escriptos por mão alheia: $\S 1^{\circ}$ Os Principes; $\S 2^{\circ}$ Os Arcebispos, e Bispos Diocesanos; $\S 3^{\circ}$ Os Duques, Marquezes, e Condes; $\S 4^{\circ}$ Os Viscondes, e Barões com Grandeza; $\S 5^{\circ}$ Os que têm Titulo de Conselho; $\S 6^{\circ}$ Os commerciantes matriculados"). Estas duas últimas regras foram estabelecidas, aliás, por meio dos artigos $6^{\circ}$ e $7^{\circ}$ do Aviso ${ }^{\circ}$ 82 de 30 de março de 1849 (complementado pela Ordem de 07 de julho de 1849, pela Portaria de 27 de setembro de 1849, pela Ordem n ${ }^{\circ} 9$ de 08 de janeiro de 1857 e pelos artigos 27 e 28 das Instruções de 26 de abril de 1859). Posteriormente sobreveio o Decreto Legislativo $\mathrm{n}^{\circ} 79$ de 23 de agosto de 1892, por meio do qual a faculdade de passar procuração por instrumento particular foi estendida a todos os sujeitos capazes artigo $1^{\circ}$ (com redação reformulada por meio de interpretação autêntica realizada pelo Decreto $n^{\circ} 2243$ de 19 de março de 1896).

Quanto à procuração outorgada pelos comerciantes, deve-se observar que o Assento $6^{\circ}$, de 23 de novembro de 1769 já havia propugnado a observância - a respeito - da legislação das nações iluminadas (e não do direito romano). Por sua vez, o artigo 21 do Código Comercial já lhes havia conferido a prerrogativa de outorgarem poderes por meio de instrumento escrito por mão alheia (confirmado pela Ordem $n^{\circ} 125$ de 10 de maio de 1852). Por sua vez, o Aviso $\mathrm{n}^{\circ} 148$ de $1^{\circ}$ de agosto de 1854 estabeleceu que tal prerrogativa era conferida à sociedade (titular da firma), e não aos seus respectivos sócios. Pela confirmação de tais disposições, cf. o artigo $2^{\circ}$ do Decreto $\mathrm{n}^{\circ} 1597$ de $1^{\circ}$ de maio de 1855 (Regulamento para os Tribunais do Comércio). Note-se, ainda, que por meio do Aviso $\mathrm{n}^{\circ} 472$ de 14 de novembro de 1877 foi assegurada a matrícula ao comerciante ainda que fora do exercício do comércio - com todos os direitos e prerrogativas dela decorrentes. Tendo-se em vista a controvérsia a respeito da natureza de tais faculdades do comerciante se autênticos "privilégios" ou simples "prerrogativas" -, não se pode negar que houve quem sustentasse a derrocada de tal modelo com a promulgação da Constituição Federal de 24 de fevereiro de 1891 (artigos 72 e 83). Pelo repúdio a tal orientação - com o que concordamos inteiramente - cf. F. C. PONTES DE MIRANDA, Tratado de Direito Privado XLIII cit. (nota 04), pp. 23-27).

Por sua vez, no que toca à acepção emprestada ao termo "magistrados" (utilizado no artigo 478, $\S 4^{\circ}$ da "Consolidação"), cf. a Circular n 9 de 29 de janeiro de 1844, o Aviso no 11 de 12 de janeiro de 1854, a Ordem no 356 de 14 de novembro de 1855 e o Aviso $\mathrm{n}^{\mathrm{o}} 12$ de 14 de janeiro de 1858 - todos no sentido de uma interpretação restritiva da prerrogativa, insuscetível de extensão, por exemplo, aos juízes municipais (em sentido absolutamente contrário, aliás, à Ordem de 14 de fevereiro de 1855). A respeito dos cavaleiros e oficiais militares cf., ainda, as Ordens no 291 de 28 de agosto de 1857 e de 23 de agosto de 1867 (por uma interpretação extensiva da expressão "cavalleiros"), o Aviso de 26 de abril de 1849, a Provisão de 23 de setembro de 1850, o Aviso n 160 de 09 de julho de 1853 e o Aviso n ${ }^{\circ} 104$ de 20 de maio de 1854 - estes últimos pela extensão da prerrogativa aos oficiais da Guarda Nacional, desde que detentores do posto mínimo de capitão (Despacho de 13 de outubro de 1856, Aviso no 338 de 17 de outubro de 1856 e Despacho de 12 de setembro de 1859). No mesmo sentido da regra geral cf., ainda, o Aviso $\mathrm{n}^{\circ} 66$ de 16 de fevereiro de 1855 e o Aviso 402 de 29 de dezembro de 1855. No entanto, à vista de circunstâncias excepcionais, se admitiu a procuração passada de próprio punho pelo $2^{\circ}$ tenente Felisberto Antonio Correia de Araujo (cf. Ordem de 04 de março de 1853 apud J. M. da TRINDADE, Collecção cit. (nota 131), p. 277). E pelo Aviso de 22 de novembro de 1856 se estendeu a prerrogativa aos primeiros-tenentes da armada "officiaes de Fazenda de embarque". 
A respeito destas duas espécies de procuração - objeto da disciplina estatuída nos artigos 457 e 458 da "Consolidação" - cf. J. M. da TRINDADE, Collecção cit. (nota 131), pp. 97-105 (e principalmente a interpretação autêntica constante da Circular de 30 de junho de 1851). Tenha-se em conta - ao menos - a previsão da "possibilidade" de se exigir o reconhecimento de firma nas procurações passadas por instrumento particular, tal qual recomendado no Aviso $\mathrm{n}^{\circ} 330$ de 17 de novembro de 1870 (no âmbito das repartições públicas); bem como a possibilidade do emprego de instrumentos impressos pelos tabeliães, sem qualquer espécie de prejuízo ao ato (Aviso no 5 de 02 de março de 1887).

Além disso, tendo-se em conta o fato de que o artigo 459 da Consolidação previa regra de extensão de tais "privilégios" - às esposas e viúvas de seus destinatários ("as molhéres casadas, ou viuvas, das pessoas acima especificadas, tem os mesmos privilegios de seus maridos") -, percebe-se desde logo quão reduzido era o espectro de aplicação da regra geral estabelecida no artigo 456 (cf. o precedente artigo $8^{\circ}$ do Aviso de 30 de março de 1849 e os supervenientes Aviso $\mathrm{n}^{\circ} 206$ de 30 de abril de 1881 e artigo 56, § $4^{\circ}$ do Decreto $\mathrm{n}^{\circ} 181$, de 24 de janeiro de 1890, ambos corroboradores do referido artigo 459 da Consolidação); principalmente quando se tem em vista - à luz do artigo 463 da Consolidação das Leis Civis - o fato de que algumas Irmandades e Casas de Misericórdia podiam outorgar poderes de representação por ato de seus próprios funcionários ("As Irmandades, e Casas de Misericordia, que não tiverem compromissos devidamente approvados, onde se comprehenda a faculdade de passarem procurações por seus Escrivães, ou Secretarios, só podem instituir procuradôres por intermedio dos Tabelliães") - segundo a forma prevista no Aviso $\mathrm{n}^{\circ} 253$ de 11 de dezembro de 1849. Ainda sobre as irmandades, cf. o Aviso $\mathrm{n}^{\circ} 244$ de 08 de outubro de 1851, por meio do qual se afasta expressamente o privilégio da Irmandade Santa Philomena, uma vez que seus compromissos não haviam sido previamente aprovados pela autoridade competente (bem como J. M. TRINDADE, Collecção cit. (nota 131), pp. 203-204 e 365-366). Também merece análise a Ordem no 28 de 28 de janeiro de 1852, por meio da qual se admitiram as procurações outorgadas pelos órgãos - estatutariamente previstos - do Banco do Brasil.

Ora, em nota de rodapé anterior (nota 131) tivemos a oportunidade de nos pronunciar a respeito dos distintos significados emprestados ao termo "forma" quando aproximado do negócio jurídico bilateral de incumbência ("mandato") e do negócio unilateral de outorga de poderes representativos ("procuração"); O. GoMES, a respeito, observa que "o contrato de mandato pode ser verbal, e a procuração, escrita" (Contratos cit. (nota 23), p. 349). E como vimos, o Código Comercial disciplinou por seu artigo 140 a forma da procuração, embora se tivesse aí utilizado - indevidamente - o termo "mandato": "o mandato requer instrumento público ou particular, em cuja classe entram as cartas missivas; contudo, poderá provar-se por testemunhas nos casos em que é admissível este gênero de prova". Aliás, também tivemos a oportunidade de destacar que entendimento diverso redundaria em contradição entre o referido dispositivo e o artigo subsequiente (artigo 141), no qual é admitida a modalidade tácita de aceitação ("completa-se o mandato pela aceitação do mandatário; e a aceitação pode ser expressa ou tácita; o princípio da execução prova a aceitação para todo o mandato"). Ora, se não há aceitação solene, como se atrelar maior exigência formal a um negócio jurídico dela dependente?

Com efeito, a doutrina nacional da primeira metade do século XX não conferiu maior atenção à distinção entre o negócio jurídico bilateral de incumbência ("contrato de mandato") e o negócio unilateral de outorga de poderes representativos ("procuração"). Daí a sinonímia preconizada por J. GONÇALVES MAIA, Theoria cit. (nota 131), p. 13. Demonstrando, de maneira sucinta, a confusão entre tais conceitos, P. SOARES NETTO assim define a procuração: "a procuração é um contrato unilateral, isto é, assinado por uma só pessoa ou várias mas representando uma só atitude que é a de quem transmite poderes" (Noções cit. (nota 131), p. 248). Em trecho mais desenvolvido, R. LIMONGI FRANÇA refere-se equivocadamente ao fenômeno, sugerindo uma providência prática peculiar (que nos parece denunciadora da completa indiscriminação entre os institutos): "ordinàriamente apresenta-se [o mandato] como um contrato anômalo quanto à manifestação de vontade do outorgado. Com efeito, o uso tem reiterado a ausência dessa manifestação no próprio instrumento dêsse ato jurídico. A nosso ver, constitui êste um inconveniente que pode ser sanado com a aposição, no final da procuração, da anuência da outra parte (...) de grande utilidade seria o expediente, entre nós não usado, de comparecer o procurador no instrumento do mandato, declarando a sua aceitação ou simplesmente apondo o seu 'de acôrdo' ao pé do têrmo. Nenhuma lei o impede e a data dessa declaração de vontade seria a do próprio contrato, que, a partir daí comerçaria a gerar os respectivos efeitos" (Manual cit. (nota 05), pp. 185 e 191). Note-se que tal promiscuidade parece-nos ainda mais censurável quando se tem em consideração o fato de que A. TEIXEIRA DE FREITAS já antevia com relativa clareza a distinção entre os institutos, resultando-lhe evidente que "a - procuração em Notas - não é escriptura de contracto (...) é instrumento publico de acto unilateral (...) no contracto de mandato, ordinariamente, o acto unilateral do mandante precede ao acto unilateral da aceitação pelo mandatario" (Consolidação cit. (nota 16), p. 320, nota 1).

Pois bem. Diferentemente do Código Comercial, a Consolidação das Leis Civis se voltou expressamente à procuração, ainda que nela não se tenha utilizado o termo em sua acepção mais precisa; com efeito, é mister 
reiterar que - segundo nos parece - não há distinção nesta obra entre o contrato de mandato e o negócio jurídico unilateral de outorga de poderes. E esta é uma observação que nos parece de extrema importância quando tomado em consideração o processo de paulatina gestação do "princípio da simetria" formal no âmbito do direito brasileiro.

De fato, uma análise histórica nos evidencia a tendência à instauração de uma simetria (formal) entre o objeto da incumbência e o negócio jurídico de outorga de poderes ("procuração-ato") - sem que com daí decorra a necessidade de uma correspondência formal que alcance o negócio jurídico bilateral de atribuição (o "contrato de mandato").

Assim, já no "Esboço" de Código Civil se pode entrever a tendência à adoção do "princípio da simetria" entre o objeto da incumbência e o negócio unilateral de outorga de poderes representativos. Com efeito, no artigo 2892 é preconizado o emprego da procuração pública sempre que o objeto da gestão envolva ato submetido a esta espécie peculiar de forma: "este Código exige procuração por instrumento público, sempre que o objeto do mandato for qualquer dos atos para os quais a lei decreta exclusivamente, ou com pena de nulidade, a forma de escritura pública (arts. 1244, 1318, 1580, 1630, 1657, 1929, 2150 e 2243)".

Desta feita, posta de parte qualquer inclinação pessoal a respeito do "princípio da simetria", deve-se observar que grande parte da polêmica instaurada em meio à doutrina brasileira da primeira metade do século XX se deveu, principalmente, à inadequada compreensão do âmbito de eficácia de cada um dos negócios jurídicos envolvidos na execução do contrato de mandato - sobretudo no que concerne à sua variante representativa. Assim, ao contrário do negócio unilateral de outorga de poderes representativos ("procuração-ato"), o negócio jurídico bilateral de incumbência não produz, via de regra, qualquer eficácia sobre a esfera jurídica de terceiros; ou seja, excetuada a hipótese do artigo 119 do Código Civil vigente, à contraparte do negócio jurídico representativo - por sinal, objeto do contrato de mandato com representação - interessa apenas o conteúdo do negócio de outorga de poderes representativos ("procuração"): uma vez que é à custa de seu controle eficiente que se verificará a eficácia representativa direta - percuntindo-se, assim, a esfera jurídica do representando. Ou então - em caso de ineficiência quanto a esta aferição - se verificará o "excesso" por parte do agente (que atua sem poderes suficientes).

De tal forma, em primeiro lugar, cumpre-nos repelir, energicamente, a aplicação do "princípio da simetria" ao contrato de mandato, uma vez que este, em princípio, não interessa a quaisquer terceiros. Desta forma, parece-nos completamente descabida uma interpretação que pretenda estabelecer uma simetria formal que alcance o próprio contrato de mandato. Ora, como negócio de incumbência ordinariamente não haverá de produzir qualquer efeito sobre a esfera jurídica de terceiros, parecem-nos inteiramente equivocados alguns dispositivos encontrados em meio às fontes do direito privado subseqüentes - arts. 634 e 635 do AntCM; art. 603 do AntCMRev; art. 672 do AntMR; art. 656 do AntMRRev; art. 666 do PCD nº 634/1975; e art. 657 do $\mathrm{CC} / 2002$ - nos quais se subordina a forma do contrato de mandato à solenidade preceituada quanto ao seu objeto.

Note-se que tal conclusão não decorre de qualquer opinião pessoal deste pesquisador, mas de simples questão de natureza eminentemente técnica. Ora, tendo sido a forma da procuração habilmente disciplinada no Anteprojeto da Parte Geral do Código das Obrigações de Orosimbo Nonato, Philadelpho Azevedo e Hahnamann Guimarães (artigos 39 e 40), poderia o legislador subseqüente ter evitado a confusão semântica entre a forma aplicada ao "mandato" e aquela relacionada à "procuração". Neste sentido, embora o artigo 635 do Anteprojeto de Código das Obrigações de Caio Mário da Silva Pereira aludisse a "mandato", andaram bem os revisores ao se utilizarem do termo "procuração", a fim de que se evitasse a persistência do tumulto técnico; assim, no artigo 604 da versão revista do Anteprojeto de Código das Obrigações de Caio Mário da Silva Pereira foi mantido o sentido pretendido por seu autor - o repúdio ao "princípio da simetria" - sem que se comprometesse a terminologia afeta ao tema ("não está adstrita a procuração aos requisitos de forma exigidos para o ato a que se destina"). Desta maneira, sob o ponto de vista teórico, o princípio da simetria jamais redundará em preceito relacionado à forma do contrato de mandato.

Com efeito, este aspecto foi adequadamente analisado por M. M. de SERPA LOPES, conquanto não se evidencie em seu texto uma utilização apurada da linguagem jurídica devotada ao assunto: "o mandato prova as relações entre as próprias partes: representante e representado; a procuração, os poderes do representante em face de terceiros (...) no direito francês, e igualmente no nosso, a relação contratual do mandato e a da procuração estão ambas numa conexão de causa e efeito, ao passo que no direito germânico, ao contrário, a procuração é originàriamente independente e não acessória face à relação causal. O mandato dá o direito de agir por outrem ou no interêsse de outrem, ao passo que a procuração confere o poder de representar outrem. E porque representam dois atos distintos pode acontecer que o mandato seja limitado por certas instruções não consignadas na procuração (...) o mandato é a causa e a procuração o seu efeito" (Curso cit. (nota 05), pp. 254-255). Ora, embora não concordemos inteiramente com este autor - uma vez que nos parece compatível com o sistema brasileiro a autonomia do negócio unilateral de outorga de poderes de representação, inclusive atrelado a outras espécies de contrato (v. g. a locação, a empreitada, o comodato, 
etc.) -, seu texto demonstra uma inteira percepção quanto às distintas finalidades dos negócios jurídicos referidos. Todavia, em lugar de uma relação de "causa e efeito", preferimos divisar no fenômeno algo semelhante à distinção entre "título e modo" - usual em meio à aquisição derivada de direitos reais - aplicada à representação de origem negocial.

No entanto - diversamente do que se assevera a respeito do contrato de mandato - apreciação outra deve ser feita com relação à publicidade aplicada ao negócio jurídico de outorga de poderes representativos ("procuração"): de fato, a respeito deste consideramos conveniente não apenas o "princípio da simetria das formas", mas também a utilização do sistema de registros públicos. O primeiro para a proteção do constituinte ("representando"); e o segundo para a tutela de terceiros que negociem com o "representante". Tal dissociação, segundo nos parece, não tem sido adequadamente promovida pela doutrina devotada à questão. Expliquemo-nos, pois.

Em um dos mais sérios estudos a respeito da questão, B. LIMA SOBRINHO explica, sob a perspectiva histórica, o processo de expansão da procuração por instrumento particular: "a procuração era, no regimen das Ordenações Filippinas, um instrumento independente da natureza do acto que autorizava e apenas relacionado com a qualidade das pessoas que o faziam sendo, nas duas formas particulares, um privilegio. Este privilegio é que a legislação posterior, denominada leis extravagantes, ampliou constantemente por impulso das tendencias liberaes que predominaram na direcção do século XIX (...) o desenvolvimento do nosso Direito Civil fôra lógico. O caracter personalissimo das varias formas de procuração, a dependencia em que ellas estavam das pessoas que as faziam, foi o que a Constituição Federal extinguiu. Appareceu, então, o caracter autonomo da procuração, feita instrumento independente e especial no decreto 79, de 1892. O ultimo passo seria estabelecer um laço íntimo entre o mandato e o acto que procurava realizar. Esse passo o Codigo Civil devia dar, e realmente deu" (Das procurações: o mandato conferido para concluir um dos contractos do art. 134 do Codigo Civil requer instrumento publico?, in Revista de Direito Civil, Commercial e Criminal 47 (1918), pp. 58-60).

No entanto, ao justificar a adoção do "princípio da simetria" (segundo o regime do Código Civil de 1916), o autor incorreu em flagrante impropriedade, aludindo ao emprego da escritura pública como salvaguarda dos interesses de terceiros: "o mandato destinado a autorizar um contracto teria em seu favor todos os argumentos que justificavam a solemnidade desse mesmo contracto, isto é, a necessidade de authenticar a autorização, melhor reflexão da parte, ou a perfeita e livre manifestação do consentimento, ou ainda o interesse de terceiros" (Das procurações cit. (nota 139), p. 60). Ora, a formalidade do ato somente redunda na proteção de terceiros por via reflexa - uma vez que, circundado de maiores solenidades, mostra-se mais dificultosa, por exemplo, a prova de defeito do negócio celebrado por meio de escritura pública. Neste sentido, M. TERRA destaca que "a forma pública, vale dizer, a declaração de vontade emitida perante um tabelião, quando imposta por lei, objetiva a proteção da parte contra eventual decisão precipitada e de asseguramento da prova e a garantir o assessoramento jurídico das partes ao emitirem a sua vontade, devendo o tabelião instruí-los, entre outras coisas, a respeito da transcendência do negócio, contribuindo a exigência formalista a que as partes meditem bem suas resoluções e não se precipitem a tomá-las antes do tempo" ( $O$ mandato cit. (nota 131), p. 44).

De maneira diversa, a extensão "erga omnes" dos efeitos do negócio de outorga se deve não à solenidade do ato, mas sim ao emprego do sistema de registros públicos; fato que não passou despercebido, por exemplo, a D. ARRUDA MIRANDA: "embora a procuração feita por instrumento particular e por pessoa capaz prove as obrigações convencionais de qualquer valor, seus efeitos não se operam, a respeito de terceiros, antes de transcrito no registro público (art. 135) na forma do art. 127, I, da Lei n. 6015, de 31 de dezembro de 1973" (Anotações cit. (nota 131), p. 369). E de fato o caso é de ineficácia, embora algumas linhas depois este mesmo autor se refira à providência como "condição essencial à sua validade" (Anotações cit. (nota 131), p. 369).

Além disso, outro sério inconveniente que se vislumbra na exposição de B. LIMA SOBRINHO diz respeito à aproximação entre o negócio jurídico de outorga de poderes representativos e a vênia conjugal atrelada ao negócio de disposição (Das procurações cit. (nota 139), pp. 58-60). E quanto a este aspecto, o autor é acompanhado - a nosso ver indevidamente - por M. I. CARVALHO DE MENDONÇA que, conquanto defendesse a inaplicação do "princípio da simetria", atrelava a questão à vênia conjugal: "a forma pública ou particular do instrumento do mandato é questão de mera escolha do mandante. O caso único em que a lei exige forma solene é o da outorga uxória ao marido para o efeito da alienação de imóveis" (Contratos cit. (nota 131), p. 216). Neste ponto, correto C. BEVILÁQUA ao distinguir o âmbito de aplicação destes institutos (que já eram aproximados pelas fontes medievais de nosso direito reinícola): "para dar cunho de irrecusável a essa intelligencia da lei, invoca-se o disposto no art. 132 (...) este dispositivo, porém, não se enquadra na theoria do mandato. Refere-se aos casos de outorga uxoria ou marital, de auctorização paterna ou tutelar, e outros semelhantes (...) e a razão da lei é que acto e a annuencia, em taes casos, formam um todo logico e juridico. $\mathrm{O}$ acto depende da annuencia para existir com os effeitos que a lei lhe reconhece. Ambos constituem um só 
momento gerador de consequencias legaes. No mandato, porém, assim não é" (Quando a procuração exige instrumento público, in Revista Forense 30 (1918), p. 86). Não obstante tais considerações, não raro podemos encontrar tal aproximação inclusive no âmbito legislativo; a respeito, cf. o Decreto $\mathrm{n}^{\circ} 498$ de 19 de junho de 1890, o Decreto n 585 de 19 de julho de 1890 e o Decreto 955-A de 05 de novembro de 1890 (artigo 88).

Fato é, todavia, que o Código Civil de 1916 disciplinou a questão por meio dos artigos 1289 (§ 3) e 1291 . Este último dispositivo, conquanto aludisse ao mandato, disciplinava a forma da procuração à vista do objeto da incumbência conferida ("para os actos que exigem instrumento publico ou particular, não se admitte mandato verbal"). Neste particular, a despeito da posição de B. LIMA SOBRINHO - que entreviu no preceito uma consagração do princípio da simetria (Das procurações cit. (nota 139), p. 61) -, parece-nos acertada a conclusão de F. C. PONTES DE MIRANDA, para quem o Código Civil de 1916 adotou uma modalidade híbrida, passível de ser designada como um sistema de "simetria da forma escrita" (Tratado de Direito Privado XLIII cit. (nota 04), pp. 27-29). Vale dizer, prescrita forma solene para o objeto da incumbência, forçosamente seria de se adotar procuração escrita para a outorga de poderes de representação.

Ora, para que o leitor tenha idéia do estado de insegurança a respeito do tema, merece reprodução a conclusão de M. TERRA: “o mandato conferido por instrumento particular com o objetivo de prática de atos de alienação ou oneração de imóveis de valor acima da taxa legal é válido e eficaz, não se lhe aplicando a regra da simetria de forma (...) em face da controvérsia doutrinária e jurisprudencial ainda hoje prevalecente, recomenda-se, por cautela, a forma pública do mandato para a prática de atos em que a lei determina tal modo, eis que mais vale uma segurança negocial do que uma bela tese jurídica a se defender" ( $O$ mandato cit. (nota 139), pp. 49-50). Neste mesmo sentido o trabalho precedente de S. MAC-DowELL (Effeitos do mandato por instrumento particular em face do Codigo Civil, in Revista de Direito Civil, Commercial e Criminal 60 (1921), p. 244).

Todavia, o Código Civil de 2002 adotou o "princípio da simetria" em sua inteireza, por meio de seu artigo 657 ("a outorga do mandato está sujeita à forma exigida por lei para o ato a ser praticado. Não se admite mandato verbal quando o ato deva ser praticado por escrito").

A respeito da forma da procuração, no âmbito das fontes civis (legisladas ou mesmo projetadas), cf. os arts. 2890, 2891, 2892, 2893, 2894, 2902, 2903 e 2906 do "Esboço"; os art. 1508 e 1543 do AntCBRev (o último relacionado à outorga judicial); os arts. 1289, 1291 e 1324 do PCD no 1/1902; os arts. 1289, 1291 e 1324 do PSF n n $^{\circ}$ 269/1912; os arts. 1289, 1291 e 1324 do CC/1916; os arts. 39 e 40 do AntOPH; os arts. 631,632 e 634 do AntCM; os arts. 600, 601, 603 e 604 do AntCMRev; os arts. 113 e 114 do AntPGMA; o art. 669 do AntMR; o art. 653 do AntMRRev; o art. 663 do PCD n 634/1975; e o art. 654 do CC/2002. Ora, tomando-se em consideração o fato de que tais preceitos se voltam à outorga de poderes representativos, tal disciplina haveria de ter sido desenvolvida em meio ao arcabouço concernente à representação, e não junto às disposições relacionadas ao tipo contratual ora analisado. Desta forma, parece-nos acertada a orientação adotada no Anteprojeto da Parte Geral do Código das Obrigações de Orosimbo Nonato, Philadelpho Azevedo e Hahnamann Guimarães (artigos 39 e 40) - posteriormente reiterada no Anteprojeto de Parte Geral do Código Civil de José Carlos Moreira Alves (artigos 113 e 114).

A respeito das restrições subjetivas concernentes ao constituinte, a Consolidação das Leis Civis continha duas disposições, relacionadas aos impúberes ("art. 461. O menor até a idade de quatorze annos, e a menor até a de doze, não podem fazêr procuração") e aos relativamente incapazes ("art. 462. Depois dessa idade podem fazêl-a com autorisação do Juiz do processo, ou de seus curadôres”). Neste particular, aliás, a Consolidação das Leis Civis evidencia o seu compromisso com o direito vigente por ocasião de sua confecção; em nota de rodapé A. TEIXEIRA DE FREITAS observa que ao condenado se restringia tão somente o exercício de direitos políticos: desta forma, aquele que se achasse sujeito ao regime penitenciário poderia constituir agente incumbido da gestão de seus negócios (Consolidação cit. (nota 16), p. 324, nota 13). Assim, a obra de A. TEIXEIRA DE FREITAS avança em relação à doutrina que lhe era contemporânea: J. M. da TRINDADE, por exemplo, asseverava que o civilmente morto - assim como o menor, o louco, o escravo, o excomungado, a mulher casada, o falido e o religioso professo - não poderia constituir procurador (Collecção cit. (nota 131), pp. 83-89). A respeito da procuração relacionada aos condenados, interditos e presos, cf. o Despacho no 143 de 28 de abril de 1851 e o Aviso no 402 de 29 de agosto de 1863 (ambos pela negativa) - expressamente afastados pelo Aviso no 27 de 27 de janeiro de 1864 (por meio do qual se considerou que a sentença de pronúncia, por exemplo, não prejudica a livre administração dos próprios bens pelo pronunciado). No mesmo sentido desta última fonte, cf. o Aviso no 32 de 19 de janeiro de 1880.

Já no que toca ao procurador, os artigos 464 e 465 definiam os limites da proibição ao exercício da procuração extrajudicial pelos funcionários do Fisco: a primeira regra, com um cunho proibitivo ("não podem sêr procuradôres de partes em negocios, que, directa ou indirectamente, activa ou passivamente, pertenção, ou digão respeito, á Fazenda Nacional; os Empregados do Thesouro, e das Thesourarias"); e a derradeira, de feição excepcionante ("da prohibição desta procuradoria exceptuão-se os negocios de interesse dos ascendentes, ou descendentes; irmãos, ou cunhados; dos Empregados fóra dos casos de devêrem sêr 
despachados, ou expedidos, por estes"). A idéia subjacente a tais disposições, como se pode depreender com naturalidade, corresponde à preservação do interesse fazendário na hipótese de um conflito de interesses que pudesse afetar o exercício funcional regular (por parte do servidor). Aliás, tais disposições reiteram o conteúdo da Provisão de 29 de janeiro de 1812, do Aviso no 260 de 10 de novembro de 1840, da Ordem de 21 de janeiro de 1842, do Decreto $\mathrm{n}^{\circ} 736$ de 20 de novembro de 1850 (artigo 66), da Ordem de 22 de abril de 1854, do Decreto no 1739 de 26 de março de 1856 (artigo 47), do Decreto no 1769 de 16 de junho de 1856 (artigo 98), do Despacho de 20 de agosto de 1857 e do Despacho de $1^{\circ}$ de abril de 1859 . Note-se que tal regra não pode ser considerada um antecedente do artigo 117 do Código Civil vigente, pois resguarda os interesses afetos ao exercício de uma função pública; ao passo que a regra ora vigente preserva interesses eminentemente particulares.

Também no que concerne a restrições ao exercício da procuradoria, duas outras regras - atinentes à variante judicial do instituto - defluem do texto da Consolidação das Leis Civis: no artigo 466 se sintetiza o rol dos absolutamente impedidos de procurar em juízo ("não podem ser procuradôres em Juizo: § $1^{\circ}$. os menores de 21 annos; $\S 2^{\circ}$. os Magistrados, Tabelliães, Escrivães, e Officiaes de Justiça;§ $3^{\circ}$. os condemnados por falsidade; $\S 4^{\circ}$. os que perdêrão o officio por erro nelle commettido; $\S 5^{\circ}$. os Clérigos, e os Religiosos, excepto por suas Igrejas, pelas pessôas miseraveis, e por seus ascendentes e irmãos"); a este rol o Decreto ${ }^{\circ}$ 3259 de 11 de abril de 1899 acrescentou a figura do cônsul (artigo 381). Em segundo lugar, no artigo 467 se estabelecem limitações de caráter relativo, fundadas em vínculo de parentesco mantido com o magistrado incumbido de decidir a controvérsia ("aos que podem sêr procuradores em Juizo é prohibido exercêr mandato perante Juiz, que seja seu pai, irmão, ou cunhado") - na mesma linha do estabelecido, aliás, por meio do Aviso ${ }^{\circ} 106$ de 29 de setembro de 1845. A respeito destas limitações teve ocasião de se pronunciar A. E. de CASTILHO BARRETO, sustentando que a simples outorga de procuração não se constituía em elemento suficiente para que o procurador pudesse atuar em juízo; seria necessária a regular habilitação, conferida segundo as disposições estabelecidas no Livro I das Ordenações Filipinas (Consulta, in J. J. RodRIGUES (org.), Consultas cit. (nota 131), pp. 363-365). Todavia, não se pode negar a admissibilidade da procuração outorgada a pessoa da confiança do constituinte, desde que antes da propositura da ação fosse regularmente substabelecida àquele que tivesse aptidão ao exercício da pretensão em juízo (capacidade postulatória). Notese, contudo, que este regime diverge parcialmente daquele estabelecido nas Ordenações do Reino de Portugal, eis que solução distinta era conferida caso a falta de tal aptidão do procurador não fosse oportunamente alegada pelo adversário.

Além disso, cumpre ressaltar que a restrição ao exercício da procuração pelos menores atingia tão somente a variante judicial do instituto; no âmbito extrajudicial, os púberes e as mulheres poderiam atuar perante terceiros como procuradores, derivando de tal gestão efeitos representativos diretos inatacáveis pelo principal: "quanto ao mandato extrajudicial, é de doutrina, que os menores adultos (assim coimo as molhéres casadas) podem sêr mandatarios; mas para o effeito somente da validade de seus actos, em relação ao mandante; e a terceiros, que estiverem nos limites do mandato (...) a razão é, que esses incapazes não tratão de actos proprios, mas de actos de terceiros, á quem representão como mandatarios, e portanto apreciados pela capacidade civil dos representados" (Consolidação cit. (nota 16), p. 325, nota 17). Em sentido bastante liberal - com o qual não concordamos - J. M. da TRINDADE assevera ser desnecessária a própria puberdade do agente, desde que se revele indiscutível o seu discernimento (Collecção cit. (nota 131), p. 64, nota 45; aliás, em aparente contradição com o elenco de pp. 90 a 97). Aliás, cumpre observar que no âmbito judicial a vedação ao exercício da procuração pelo menor (de 21 anos) contava com uma importante exceção, relacionada àquele que obtivesse o grau de bacharel em Direito (Despacho de 16 de outubro de 1854). Todavia, por força da Resolução de 31 de outubro de 1831 - combinada com os artigos $3^{\circ}$ e 92 dos Estatutos dos Cursos Jurídicos do Império (Decreto $\mathrm{n}^{\circ} 1134$ de 30 de março de 1853) - necessariamente os bacharelandos haveriam de obter o grau após completados os 21 (vinte e um) anos de idade; com isso, a restrição - prevista na Consolidação - se aplicou sem nenhuma espécie de mitigação.

Pela projeção de tais disposições no âmbito do direito civil brasileiro posterior (legislado ou simplesmente projetado), cf. o art. 1544 do AntCBRev; o art. 1325 do PCD no 1/1912; o art. 1325 do PSF no 269/1912; e o art. 1325 do CC/1916.

A "Consolidação" evidencia ainda - por seus artigos 468 e 472 - duas disposições de fundo ético: a primeira consistente na vedação ao pacto de "quota litis" ("art. 468. aos Advogados é tambem prohibido fazêr contractos com as partes para havêrem alguma cousa, se-lhes vencêrem as demandas. Somente podem levar os honorarios taxados na Lei"); e a segunda relacionada à proibição do patrocínio dos interesses da parte adversa ("art. 472. não póde o procuradôr, que aceitou o mandato, aceital-o depois pela parte contraria; advogando, ou solicitando, em favôr desta"). A. TEIXEIRA DE FREITAS já observava, em nota da "Consolidação", que a proibição da "quota litis" não alcançava a atuação dos procuradores judiciais de seu tempo; assim, embora permanecesse a proibição de contratos com remuneração dependente do êxito da demanda, poderiam as partes exceder o limite previsto na regulamentação judiciária: "a prohibição da quota 
litis é extensiva aos procuradôres judiciaes. Não obstante a nullidade de taes contractos, os Advogados, e Procuradores judiciaes, que os-fizerem, podem havêr o justo valor dos seus trabalhos (...) só podem os Advogados, não satisfazendo-se com as taxas do Regimento, estipular sem condição uma quantia redonda para retribuição de seus honorarios, pagavel de uma vêz, ou em prestações, seja qual fôr o exito das pretenções incumbidas" (Consolidação cit. (nota 16), pp. 326-328, nota 23). Tal posicionamento de A. TEIXEIRA DE FREITAS se acha alicerçado no artigo 202 do Decreto $n^{\circ} 5737$ de 02 de setembro de 1874, que alterou o "Regimento das custas judiciarias" (cf. ainda o Aviso n 118 de 13 de março de 1875, resposta ao $2^{\circ}$ quesito). E aliás, a vedação à "quota litis" (estabelecida pelo Alvará de $1^{\circ}$ de agosto de 1774) havia sido suspensa pelo Decreto de 17 de julho de 1778. Pela admissão da participação do mandatário nos proveitos da execução da incumbência - excetuada a variante judicial do instituto (objeto de disciplina própria, derivada da legislação processual) - cf. o artigo 2977 do "Esboço" de Código Civil. Por sua vez, no que toca à proibição do patroocínio dos interesses da parte adversa, uma projeção desta disposição pode ser entrevista no artigo 1552 da versão revista do Anteprojeto Clóvis Beviláqua.

Finalmente, em caráter residual, duas matérias foram objeto de disposições específicas na Consolidação das Leis Civis: em primeiro lugar, o arbitramento de honorários profissionais, sempre que se mostrassem insuficientes aqueles previstos em lei ("art. 469. não se-conformando os Advogados com as taxas marcadas na lei para seus trabalhos, podem requerêr arbitramento") - observando-se que o "ius singulare" previsto na Consolidação era passível, segundo alguns, de extensão a outras categorias profisisonais (médicos), de acordo com o disposto no Alvará de 22 de janeiro de 1810 (§ 34). Pelo procedimento relacionado ao arbitramento de honorários, cf. o Regimento $\mathrm{n}^{\circ} 1569$ de 03 de março de 1855 - revogado pelo Decreto $\mathrm{n}^{\circ}$ 5737 de 02 de setembro de 1874 (artigo 202). A respeito da questão, cf. ainda o art. 2976 do "Esboço" de Código Civil - bem como EsteVAm De AlmeIDA, Parecer cit. (nota 134), p. 356; JoÃo ArRudA, Parecer, in Revista dos Tribunais 25 (1918), p. 359; e C. BEVILÁQuA, Parecer, in Revista dos Tribunais 25 (1918), pp. 439-440. Note-se que o arbitramento de honorários seria posteriormente restaurado - na via projetada - pela versão revista do Anteprojeto Clóvis Beviláqua (artigo 1549).

Em segundo lugar, a extinção unilateral da procuradoria judicial - após a contestação da lide - somente haveria de ser admitida excepcionalmente ("art. 474. O procuradôr póde oppôr-se, á que o mandante revogue a procuração, se a lide já estivér contestada"), à vista da demonstração de justa causa (superveniente) por parte do interessado ("art. 475. mas, não obstante a contestação da lide, o mandante tem direito de revogar a procuração, allegando justa causa; como seja, impedimento do procuradôr para bem desempenhar o mandato, inimizade superveniente, ou amizade com seu contendôr"; "art. 476. igual direito compete ao procuradôr nos referidos casos para reunciar a procuração depois da lide contestada, fazendo intimar a renuncia ao mandante, para que nomêe outro procuradôr"). A respeito deste segundo tema, A. TEIXEIRA DE FREITAS destaca a inobservância dos dipositivos da "Consolidação" ora referidos: "esta disposição [art. 474], com a dos dois Arts. que se-seguem, não se-observa. O mandato é revogavel, e renunciavel, em todo o estado da causa" (Consolidação cit. (nota 16), p. 332, nota 38).

No âmbito da legislação pré-codificatória merecem destaque, ainda, as disposições esparsas estabelecidas a respeito: a) dos aspectos tributários afetos aos selos exigíveis nas procurações (Ordem $\mathrm{n}^{\circ} 40$ de $1^{\circ}$ de julho de 1844; Ordem no 98 de 29 de outubro de 1844; artigos 34 e 35 do Decreto no 681 de 10 de julho de 1850; Ordem n ${ }^{\circ} 119$ de 13 de setembro de 1850; Ordem n 215 de 28 de novembro de 1850; Ordem no 202 de 25 de agosto de 1852; Ordem n 264 de 30 de novembro de 1853; artigos 58, 59 e 86 do Decreto no 2713 de 26 de dezembro de 1860; Regulamento $\mathrm{n}^{\circ} 4505$ de 09 de abril de 1870; Aviso $\mathrm{n}^{\mathrm{o}} 39$ de 12 de fevereiro de 1872; Aviso $n^{\circ} 374$ de 16 de outubro de 1874; e Decreto $n^{\circ} 2573$ de 03 de agosto de 1897); b) das certidões de vida (do principal) exigíveis dos procuradores, sobretudo no âmbito das repartições públicas (Decreto de 10 de abril de 1832; Aviso de 14 de setembro de 1841; Aviso no 319 de 04 de outubro de 1841; Ordem no 334 de 15 de novembro de 1841; Portaria de 05 de janeiro de 1847; artigo $4^{\circ}$ do Decreto $\mathrm{n}^{\circ} 4113$ de 04 de março de 1868; artigo 20 do Decreto $n^{\circ} 4355$ de 17 de abril de 1869; e Decreto no 8596 de 08 de março de 1911) inclusive privando de efeitos a procuração para recebimento de dívida relativa a exercícios findos, hipótese em que o pagamento somente haveria de ser feito "em mão dos próprios credores" (Circular de 15 de novembro de 1844, revogada pelo Aviso Circular $\mathrm{n}^{\mathrm{o}} 356$ de 25 de outubro de 1856); c) das atividades a serem exercidas pelos procuradores municipais no âmbito de sua competência (Ordem n ${ }^{\circ} 153$ de 08 de junho de 1849); d) da eficácia das procurações conferidas no estrangeiro (artigo 79 do Regimento Consular de 14 de abril de 1834; artigo 208 do Decreto no 520 de 11 de junho de 1847; artigo 140, § $2^{\circ}$ do Regulamento $\mathrm{n}^{\mathrm{o}} 737$ de 25 de novembro de 1850; Ordem no 136 de 28 de maio de 1852; Despacho de 08 de outubro de 1857; Despacho de 23 de março de 1858; Despacho de 09 de fevereiro de 1859 e Despacho de $1^{\circ}$ de abril de 1861); e) dos reflexos processuais do exercício do procuradoria judicial (artigos 217 a 229 do Decreto $n^{\circ} 3084$ de 05 de novembro de 1898); f) dos procedimentos de matrícula e inscrição (em concursos para o cargo de lente) perante as Faculdades de Direito (artigo 63 do Decreto no 1386 de 28 de abril de 1854; artigos 35 e 116 do Decreto $\mathrm{n}^{\mathrm{o}} 1568$ de 24 de fevereiro de 1855); g) do procedimento relacionado às procurações no âmbito das 


\section{$\S$ 163. O "Esboço" de Código Civil e as linhas gerais do contrato de}

mandato. Partindo-se da curiosa distinção entre os conceitos de "mandato-contrato" e “mandato-ato unilateral" (artigo 2857), no "Esboço" de Código Civil é desenvolvida uma minuciosa disciplina sobre o tipo contratual objeto de nossas investigações, articulada ao

alfândegas, excluindo-se seu emprego para os atos que demandassem atuação pessoal do interessado (Ordem $n^{\circ} 51$ de 21 de março de 1838; Ordem n 142 de 25 de novembro de 1846; artigo $4^{\circ}$ do Decreto $n^{\circ} 2473$ de 24 de setembro de 1859; e artigos 585 e 768 do Decreto no 2647 de 19 de setembro de 1860) - sendo de se observar que a atuação pessoal do interessado também foi exigida para o ato que consubstanciasse a assunção de moratória (Despacho de 28 de dezembro de 1854).

Pela bibliografia - concernente ao tema abordado na presente nota de rodapé - produzida durante o período pré-codificatório, cf. A. TEIXEIRA DE FREITAS, Consolidação cit. (nota 16), pp. ; CÂNDIDO DE OLIVEIRA, Mandato cit. (nota 139), pp. 317-333; C. A. de CARvalHo, Direito Civil Brazileiro Recopilado ou Nova Consolidação das Leis Civis (vigentes em 11 de agosto de 1899), Porto, E. Nogueira, 1915, pp. 411-418 (com preciosas indicações de disposições modificativas do direito então vigente); e J. M. da TRINDADE, Collecção cit. (nota 131), passim.

No âmbito da doutrina produzida sob a égide do Código Civil de 1916, cf. A. BEvILÁQUA, Codigo cit. (nota 131), pp. 355-357; A. do VAlle SiQueIRA, Codigo cit. (nota 131), pp. 428-430; A. DionYsio GaMA, Tratado cit. (nota 131), p. 313; A. CAMARGo, Elementos cit. (nota 131), pp. 92; A. ChACON Couto, Ligeiras observações cit. (nota 131), pp. 9-15; A. CHAVES, Lições cit. (nota 131), pp. 289-294, 300 e 306; A. L. da CÂMARA LEAL, Manual cit. (nota 131), pp. 100-101; A. MARMITT, Mandato cit. (nota 131), pp. $20-23$ e $115-$ 121; A. WALD, Curso cit. (nota 131), pp. 301-304; C. FALCÃo, Codigo cit. (nota 131), pp. 143-144; C. BeVIlÁqua, Codigo cit. (nota 05), pp. 31-38; D. ARRUdA MiRANDA, Anotações cit. (nota 131), pp. 368-373; E. EsPínOla, Dos contratos nominados cit. (nota 12), pp. 354-356; E. PESSÔA, Da procuração cit. (nota 131), pp. 9 e 19-27; F. C. Pontes De Miranda, Fontes cit. (nota 16), pp. 331-332; F. R. Leite Filho, Curso cit. (nota 05), pp. 346-348; F. C. P. RodrigueS - L. da S. LOUREIRO FILHO, Código cit. (nota 131), pp. 874876; F. C. de San Tiago Dantas, Programa cit. (nota 05), p. 373; H. TheOdORO Júnior, Locação cit. (nota 133), pp. 333-336 e 379-382; JoÃo ARRUdA, Compra e Venda, in Revista dos Tribunais 24 (1917), pp. 274275; J. do Amaral Gurgel, Contractos cit. (nota 131), p. 403; J. L. Alves, Código cit. (nota 05), pp. 349354 e 387; J. F. de LiMA, Curso cit. (nota 05), pp. 567-575 e 611; J. GonÇALVES MAIA, Theoria cit. (nota 131), pp. 13, 26-56, 69-70, 140 e 159-161; J. M. de CARVAlHo SANTOS, Codigo cit. (nota 05), pp. 112, 119130, 133 e 146-147; J. de SAMPAIO Doria, Codigo cit. (nota 131), pp. 92 e 124; L. LeITE, Codigo cit. (nota 131), pp. 425-428; L. R. de Freitas Gomes, Contrato cit. (nota 131), p. 289; M. C. do. A. Kroetz, A representação cit. (nota 41), pp. 61 e 72-91; M. I. CARVALHO DE MENDONÇA, Contratos cit. (nota 131), pp. 211-219; M. Paulo MerêA, Codigo cit. (nota 131), pp. 405-406; M. M. de SERPA Lopes, Curso cit. (nota 05), pp. 254-255 e 263-267; M. TERRA, O mandato cit. (nota 131), pp. 43-50; O. GOMES, Contratos cit. (nota 23), pp. 349-355; O poder cit. (nota 131), p. 10; P. SOARES NETTO, Noções cit. (nota 131), pp. 244-248; R. L. FRANÇA, Manual cit. (nota 05), pp. 185-191; R. LoTUFO, Questões cit.(nota 26), pp. 117-125; S. VAMPRÉ, Manual cit. (nota 131), pp. 124-128; T. FulgENCIO Alves Pereira, Programmas cit. (nota 131), pp. 135-136 e 149; T. PRATES DA FonSECA, Noções cit. (nota 131), pp. 195-196; Y. S. CAHALI, Contratos cit. (nota 131), pp. 503-506 e 514.

E no que concerne à doutrina produzida a respeito do Código Civil de 2002, cf. A. VILLAÇA AZEVEDO - S. de S. Venosa, Código cit. (nota 02), pp. 353-355; A. de ASSIS, Contratos cit. (nota 131), pp. 29-43 e 45-48; CAIO Mário da Silva Pereira, Instituições cit. (nota 02), pp. 400-403; C. A. BitTAR FilHO - M. S. BitTAR, Código cit. (nota 02), p. 56; C. E . N. CAMILlO - G. M. TAVAlERA - J. S. FuJitA - L. A. SCAVONE JÚNIOR (coords.), Comentários cit. (nota 02), pp. 585-586; C. L. BUENO DE GodOY, Do mandato cit. (nota 131), pp. 607-612; C. R. GonÇAlVES, Direito cit. (nota 131), pp. 392-399 e 407; F. UlHOA CoElho, Curso cit. (nota 02), pp. 315-316 e 322; F. AMARAL, Direito cit. (nota 131), pp. 460-463 e 468; M. G. MAIA JÚNIOR, A representação cit. (nota 04), p. 44; MARIA HELENA DINIZ, Curso cit. (nota 02), pp. 352-359; M. TERRA, $O$ mandato cit. (nota 131), p. 44; N. C. B. CAMPELlO, Da representação cit. (nota 131), pp. 395-401 e 419 ; N. G. B. Dower, Curso cit. (nota 02), pp. 284-286 e 291; N. NERY JUNIOR - R. M. de ANDRADE NERY, Código cit. (nota 02), pp. 470-472; O.GoMES, Contratos cit. (nota 23), pp. 428 e 434; O. R. B. SANDOVAL, Do mandato cit. (nota 131), pp. 591-594 e 601-602; R. FIUZA (coord.), Novo Código cit. (nota 02), pp. 601-607; S. de S. VenOSA, Direito cit. (nota 02), pp. 257-258, 261-266 e 270; S. L. F. da RocHA, Curso cit. (nota 02), pp. 297-298 e 314; Silvio Rodrigues, Direito cit. (nota 02), pp. 290-291; e WASHINGTON DE BARROS MONTEIRO, Curso cit. (nota 02), pp. 265-268 e 277. 
longo de quase duas centenas de disposições. Com relação à formação do liame obrigacional, merecem destaque os preceitos voltados à modalidade presumida de aceitação (artigos 2900, 2901 e 2912); por sua vez, a respeito da capacidade dos contraentes - aferível em momentos distintos de acordo com a posição ocupada na relação jurídica contratual (artigo 2869) - se prescreve o amplo emprego do negócio de atribuição, ressalvadas unicamente as hipóteses nas quais se pressupõem a habilitação legal do agente ou o exercício pessoal do objeto da incumbência (artigos 2865, 2866 e 2867) preconizando-se, inclusive, o irrestrito concurso de púberes, mulheres e falidos, embora submetidos a um regime de responsabilidades específico (artigo 2868). No que concerne ao objeto contratual, admite-se genericamente a incumbência para fins lícitos (artigos 2873 e 2948), desde que não envolva ato em relação ao qual a representação negocial seja vedada (artigos 2870, 2871 e 2872); aliás, seguindo-se a tradição justinianéia relacionada à aferição dos interesses envolvidos na atribuição (artigos 2874 e 2875), afasta-se do tipo a recomendação ou conselho (artigos 2858 e 2877) - ao mesmo tempo em que se submete a regime específico o ato celebrado por meio de um "testa de ferro" (artigo 2864). No que toca à eficácia do contrato, conquanto adotada a gratuidade natural da avença (artigo 2855), admite-se a presunção de remuneração em hipóteses específicas (artigo 2856); por sua vez, o conflito de interesses é objeto de uma minudente regulamentação, devotada aos momentos de formação (artigo 2876), execução (artigo 2939) e extinção do vínculo contratual (artigos 3032 e 3033). Por fim, exsurge também um arcabouço comprometido com os elementos acidentais do ajuste (artigo 2885) - disciplinando-se, assim, a execução da incumbência por períodos determinado (artigos 2885 e 2886) e indeterminado de duração (artigos 2887 e 3008$)^{140}$.

\footnotetext{
${ }^{140}$ Já tivemos a oportunidade de observar que o "Esboço" de Código Civil propunha - ainda que à custa de uma terminologia relativamente condenável - a distinção entre o contrato de mandato (artigo 2853) e o negócio jurídico unilateral de outorga (artigo 2857). Com efeito, na parte inicial do artigo 2857 A. TEIXEIRA DE FREITAS aludiu a este último por meio da expressão "ato unilateral" ("haverá mandato, como ato unilateral, quando uma ou mais pessoas tiverem conferido autorização a outra ou mais pessoas para representá-lasem um ou mais atos da vida civil"). No entanto, como se pode perceber, não chegou a diferençar, no bojo da mesma realidade fática, uma dupla significação jurídica: de fato, na parte final do referido dispositivo enuncia que "antes de aceita pelo mandatário a autorização, não haverá contrato de mandato (arts. 1883 a 1836)". Ora, a mesma conduta do "principal" pode ser tomada pelo intérprete como negócio jurídico unilateral de outorga de poderes representativos (e daí se falar em "representando" e "representante"), ou como negócio jurídico unilateral de oferta de mandato (e daí se aludir a eventuais "mandante" e "mandatário"). Todavia, considerando-se o panorama que prevalecia à época (em nosso ambiente jurídico), parece-nos um considerável avanço a distinção entre o "mandato-contrato" e o "mandatoato unilateral" - principalmente quando também se tem em conta a previsão de uma atuação do agente em seu próprio nome, desprovido, pois, de poderes de representação (arts. 2939, 5 , 2959, 2963, 3001, 3002 e $3003)$.
} 
Ora, a parte final do aludido artigo 2857 evidencia que sem a aceitação (do destinatário da oferta) não exsurge, via de regra, o negócio jurídico bilateral de incumbência ("contrato de mandato"). Pois bem, para a formação deste negócio jurídico podem concorrer não apenas a aceitação expressa (mediante declaração), como também a manifestação tácita de consentimento do oblato; nem por isso será necessário recorrer a qualquer espécie de "presunção". No caso da aceitação tácita - depreendida do comportamento concludente do destinatário, inequívoco e incompatível com uma interpretação diversa - há efetiva concordância por parte do oblato. Neste sentido, o artigo 2904 do "Esboço" indica o cabimento ordinário de todo e qualquer meio de prova: "a aceitação do mandato conferido por procuração, ou quando o mandante confessa havê-lo conferido, pode ser provada por qualquer meio, ainda que o valor do negócio ou ato exceda a taxa da lei”. É esta, pois, a regra de formação de todo e qualquer contrato.

No entanto, o "Esboço" de Código Civil prescreveu - em três dispositivos diferentes - uma outra modalidade de formação do contrato (decorrente da indiscutível incidência da regra, mesmo que a despeito da ausência de uma manifestação favorável por parte do destinatário da policitação): assim, no artigo 2900 estabeleceu que "entre presentes (art. 1838), presume-se aceito o mandato se o mandante entregou sua procuração ao mandatário e este a recebeu sem reserva ou protesto"; e no que se refere à oferta entre ausentes, assim dispôs - na via projetada - o artigo 2901: “entre ausentes (art. 1838), a aceitação do mandatário não resultará do silêncio do mandatário, senão nos seguintes casos: $1^{\circ}$. Se o mandante remeteu por agente sua procuração ao mandatário (art. 1840) e este a recebeu sem reserva ou protesto; $2^{\circ}$. Se o mandante lhe remeteu sua procuração em carta (art. 1841) e ele a recebeu e reteve em seu poder, sem dar resposta, a não provar que a falta de resposta foi motivada por impossibilidade ou justa causa (art. 1855); $3^{\circ}$. Se o mandante lhe conferiu por carta (art. 1841) mandato relativo a negócios, de que por ofício, profissão, meio de vida, ou como comissário de comércio, costuma encarregar-se, e ele recebeu a carta e não lhe deu resposta (art. 1855)".

Ora, em ambos os preceitos se estabelece que o contrato de mandato exsurge, juridicamente, conquanto não sobrevinda a aceitação por parte do mandatário; em todos os casos as circunstâncias negociais pareceram ao legislador tamanho modo relevantes que se pretendeu edificar, "ex lege", uma eficácia contratual a despeito da inexistência do suporte fático que ordinariamente dá ensejo a um vínculo desta natureza. Ou seja, atribuiuse - indiretamente - ao destinatário da oferta um dever de recusar, derivado da conjugação entre as circunstâncias negociais referidas e a oferta levada a seu conhecimento pelo proponente. Note-se, pois, que não exsurge qualquer espécie de relação jurídica contratual se o destinatário da policitação responder tempestivamente ao ofertante, levando ao seu conhecimento a sua recusa. O que não se há de admitir é o comportamento indiferente do destinatário da proposta de incumbência; com efeito, o artigo 2912 o "Esboço" encerra a disciplina relacionada ao tema da seguinte forma: "se, no caso do art. 2901, no 3, o mandatário não executar o mandato, e nada responder, ou responder tardiamente que o não aceita, será responsável pelo prejuízo que o mandante resultar da falta, ou da demora, da resposta".

Não podem ser confundidos, no entanto, os conceitos: C. BEVILÁQUA, por exemplo, aproxima indevidamente as hipóteses de "mandato tácito" - na qual há incumbência - e de "gestão de negócios" - em que a atribuição inexiste (Codigo cit. (nota 05), pp. 35-36); no mesmo sentido, J. GonÇALVES MAIA (Theoria cit. (nota 131), pp. 12-13). F. C. de SAN TIAGO DANTAS, por sua volta, baralha indevidamente oferta e aceitação, a ponto de concluir no sentido de que "o mandato tácito resulta do começo da execução" (Programa cit. (nota 05), p. 373); em idêntico sentido, O. GoMes (Contratos cit. (nota 23), p. 349). Equívoco, nos parece, pois no "mandato" tácito também a incumbência se depreende das circunstâncias - pense-se no colega que encontra sobre sua mesa petição, subscrita e assinada pelo viajante, a fim de que seja protocolada tempestivamente. Na "aceitação" tácita, conquanto expressa a proposta de atribuição, é das circunstâncias que se depreende a concordância do destinatário: no mesmo exemplo dado logo acima, se a petição está acompanhada de bilhete, e o colega a protocola sem responder ao ofertante, aí sim, teremos aceitação tácita (mas não mandato tácito); no entanto, caso adote um semelhante comportamento sem que existisse qualquer espécie de bilhete, tanto a oferta quanto a aceitação haverão de ser depreendidas das circunstâncias relacionadas ao caso concreto.

Por tal razão também se equivoca M. G. MAIA JÚNIOR ao considerar "sutil" a distinção entre "procuração tácita" e "procuração presumida" (A representação cit. (nota 04), p. 108). Ora, se atendendo a meu pedido um amigo leva meu livro gasto à encadernadora, lá comparecendo eu no dia seguinte para pagar o devido, o caso é de "procuração tácita", uma vez que de meu comportamento posterior se extrai a outorga de poderes representativos; contudo, no caso de "procuração presumida" pode inexistir incumbência, muito embora haja percussão da esfera jurídica do falso representado, à vista das circunstâncias - eis aí o sentido do artigo 2896 do "Esboço". Neste exato sentido - embora misturando os negócios jurídicos de "incumbência" (mandato) e de "outorga" (procuração) - F. K. COMPARATO assinala que "o mandato tácito supõe uma outorga efetiva de poderes (e, portanto, uma inequívoca manifestação de vontade), enquanto na chamada representação aparente não ocorre nenhum consentimento do suposto representado aos atos praticados pelo falso representante" (Aparência cit. (nota 131), p. 43). No entanto, linhas após o autor incorre em flagrante contradição ao 
asseverar que se "alguém tolera que outrem aja em seu nome, tratando juridicamente com terceiros (...) não se pode deixar de reconhecer um mandato tácito"(Aparência cit. (nota 131), p. 43).

Por sua vez, C. L. BUENO DE GODOY evoca - a nosso ver também equivocadamente - a aceitação "tácita" quando se refere à manifestação "gestual" do destinatário da oferta (Do mandato cit. (nota 131), p. 613). Ora, ainda que pela via gestual, a manifestação do sujeito tem por finalidade incutir no policitante o entendimento de que a oferta foi aceita: mais do que uma simples manifestação, há autêntica declaração; não nos parece o caso de aceitação "tácita", uma vez que o consentimento existente foi apurado a partir de uma declaração deliberadamente dirigida ao ofertante - sendo caso, pois, de aceitação "expressa". M. M. de SERPA LOPES assevera que "o característico do mandato tácito assenta no grau de certeza dêle resultante, o qual é menos intenso do que no mandato expresso" (Curso cit. (nota 05), pp. 251-252). Não nos parece correto também este autor. A questão não é de certeza, mas sim de "direcionalidade" da conduta do agente: se este atua dirigindo um breve aceno por meio de seu dedo polegar, houve aceitação expressa (conquanto pudesse tal ação decorrer de um cacoete do oblato); se move todo o corpanzil rumo à execução, a certeza da aceitação é muito maior - conquanto nem por isso deixe de se qualificar como "tácita".

E da mesma forma, não se podem tomar por sinônimas as expressões "aceitação tácita" e "aceitação presumida": na primeira hipótese consentimento houve por parte do destinatário - muito embora não vertido em "declaração" dirigida ao oferente. No segundo caso, a aceitação - no plano fático - simplesmente "pode" ter acontecido: ocorrida ou não no plano psíquico, é da conjugação entre a oferta e as circunstâncias negociais (eleitas pelo legislador) que deflui a eficácia jurídica típica do contrato de mandato. Por tal ordem de idéias, enganado também nos parece M. M. de SERPA LOPES ao tomar a segunda categoria como uma simples variante da primeira: "o nosso Código Civil [de 1916] admitiu duas modalidades de aceitação tácita: aceitação tácita por atos inequívocos e aceitação tácita por presunção" (Curso cit. (nota 05), p. 261). J. L. ALVES também alude, indevidamente, a uma presunção de autorização a respeito do mandato tácito (Código cit. (nota 05), p. 353); R. LOTUFO, por sua vez, percorre mais de uma dezena de páginas nas quais se evidencia uma completa confusão entre tais conceitos (Questões cit.(nota 26), pp. 91-101). Merece destaque, em contrapartida, a análise pontual de J. GONÇALVES MAIA em estudo monográfico a respeito do mandato presumido (Do mandato offerecido mediante publicidade, Rio de Janeiro, Typ. Santa Helena, 1922, pp. 4154). E por uma abordagem pouco usual do tema, cf. G. DonATUTI, Mandatum praesumptum, in Studi in memoria di Aldo Albertoni I, Padova, CEDAM, 1935, pp. 367-378.

Note-se que tal arcabouço - projetado - influenciou diretamente o nosso direito civil subseqüente, podendo ser consideradas seu desdobramento as regras estabelecidas: no art. 1445 do AntCB; no art. 1510 do AntCBRev; no art. 1293 do PCD n 1/1912; no art. 1293 do PSF no 269/1912; no art. 1293 do CC/1916; no art. 639 do AntCM; e no art. 608do AntCMRev.

Quanto à capacidade das partes contratantes, seis disposições do "Esboço" disciplinam a matéria. No que toca ao mandante, o artigo 2865 proíbe - pela via projetada - a contratação sempre que dela puder decorrer uma tentativa de fraude à lei, na medida em que se mostre necessário o concurso pessoal do próprio incumbente: "tem capacidade para ser mandante quem a tiver para o ato ou atos que encarregar ao mandatário (arts. 1358 e 1872). Excetuam-se: $1^{\circ}$. Os atos que o mandante não pode exercer por si, mas que pode exercer por mandatários; $2^{\circ}$. Os atos para os quais o mandante tem capacidade, mas que não pode exercer por mandatários".

Os atos a que se refere a primeira exceção são aqueles reservados por lei a determinadas categorias "profissionais", tal como se pode depreender da conjugação entre os artigos 2866 ("os atos que o mandante não pode exercer por si mesmo, mas que pode encarregar a mandatários, são unicamente os do art. $2856, \mathrm{n}^{\circ}$ 2") e 2856, $2^{\circ}$ do "Esboço" (“quando consistir no exercício de atribuições ou funções conferidas por lei ao mandatário, como as de advogados, procuradores judiciais, corretores e agentes de leilões"). Nesta hipótese, aliás, a execução da incumbência é vedada não apenas ao mandante, como também a qualquer espécie de sujeito não habilitado ao exercício do mister - tal como preconizado pelo artigo 2867 ("proíbe-se que sejam mandatários dos atos do artigo antecedente pessoas a quem a lei não tenha conferido atribuição para exercêlos. Fora destes casos especiais, podem ser mandatários todas as pessoas capazes de fazer contratos em geral").

No que toca às mulheres casadas, restrições despontam não apenas quando figuram como mandantes ("art. 3042. (...) subsistirá (...) o mandato conferido pela mulher antes de seu casamento, se for relativo a atos que ela possa exercer sem dependência da autorização do marido"), mas também quando são designadas por outrem para o desempenho da atribuição confiada. De fato, em seu artigo 2868 o "Esboço" admite o concurso da mulher casada como mandatária, assim como também o faz com relação ao menor relativamente incapaz e ao falido ("também podem ser mandatários (...) os menores adultos emancipados e não emancipados, e as mulheres casadas sem assistência ou autorização de seus maridos ( $\operatorname{art} .1870, \mathrm{n}^{\circ} \mathrm{s} 2,3$ e 4), mas para o efeito somente da validade de seus atos em relação ao mandante, e a terceiros, que estiverem nos limites do mandato. Quanto às obrigações desses mandatários para com o mandante, e para com terceiros, 
observar-se-á o disposto nos arts. 1878, 1879 e 2621. Podem igualmente ser mandatários os comerciantes falidos (art. 1870, $\mathrm{n}^{\circ}$ 5), não tendo, porém, o mandante e terceiros com quem esses mandatários contratarem algum direito sobre os bens da massa falida").

Observe-se que a apuração da capacidade dos contratantes haveria de ser feita segundo as circunstâncias prevalecentes à época das manifestações dos envolvidos, tal qual estabelecido no artigo 2869 do "Esboço" ("a capacidade do mandante será julgada em relação ao dia em que conferiu o mandato e a do mandatário em relação ao dia em que o aceitou").

Deve-se assinalar que inexistiam no Código Comercial e na Consolidação das Leis Civis disposições relacionadas à capacidade das partes contratantes; a propósito, observe-se que em nota de rodapé imediatamente anterior abordamos restrições subjetivas que a "Consolidação" coligiu a respeito da atuação dos "procuradores". Como já tivemos a oportunidade de observar, na Consolidação das Leis Civis não houve um tratamento sistemático relacionado ao mandato como tipo contratual; a relação jurídica havida entre o principal e seu agente sempre foi considerada sob a perspectiva de uma iminente atuação deste último perante terceiros. Por tal razão, a disciplina ali articulada se reconduz muito adequadamente ao negócio jurídico unilateral de outorga de poderes; no entanto, a capacidade dos contratantes (envolvidos na celebração do mandato) somente será objeto de uma regulamentação mais consistente a partir do impulso representado pelos mencionados dispositivos do "Esboço" de Código Civil. Pelos frutos de tal arcabouço no âmbito das fontes legisladas (ou meramente projetadas), cf. o art. 2276 do AntFS; os arts. 1069 e 1070 do AntCR; os arts. 1514 e 1515 do AntCBRev; os arts. 1298 e 1299 do PCD n ${ }^{\circ} 1 / 1912$; os arts. 1298 e 1299 do PSF n 269/1912; os arts. 1298 e 1299 do CC/1916; o art. 629 do AntCM; o art. 678 do AntMR; o art. 665 do AntMRRev; o art. 675 do PCD n 634/1975; e o art. 666 do CC/2002.

Com o tirocínio que lhe é peculiar, M. M. de SERPA LOPES observa - sob o regime do Código Civil de 1916 que a responsabilidade da mulher (artigo 1299) era mais acentuada do que a do menor (artigo 1298), contra quem o mandante não tinha ação senão de confomidade com as regras gerais: "uma vez esta concedida [a autorização], a mulher assume a posição de uma verdadeira mandatária, sem qualquer benefício atenuador de sua responsabilidade, que passa a ser a comum, como a de qualquer outro mandatário" (Curso cit. (nota 05), p. 259). Em contrapartida, dois doutrinadores mineiros acabam por confundir - a propósito da análise do art. 1288 do CC/16 - as figuras do representante e do núncio: assim, T. FulGENCIO Alves Pereira observa que "a capacidade do mandatário é indifferente para a execução do mandato, negocio de confiança mesmo para terceiros, uma vez que é com o mandante que elles se põem em relações (...) o mandatário é apenas intermediário ou porta-voz" (Programmas cit. (nota 131), p. 135); em termos praticamente idênticos, cf. J. F. de LimA, Curso cit. (nota 05), p. 568.

No que concerne ao objeto do contrato de mandato, há que se observar a pressuposição - como regra geral da variante representativa do instituto. Com efeito, no artigo 2870 a representação é tomada como fator decisivo para a qualificação do tipo ("podem ser objeto do mandato todos os atos lícitos suscetíveis de produzir alguma aquisição, modificação ou extinção de direitos (arts. 435, 436 e 437), a que for extensiva a representação"). Assim, prevista a licitude como atributo indispensável ao objeto da avença, explica-se o teor do artigo 2872 do "Esboço", por meio do qual se proscreve do âmbito típico a convenção que tenha por objeto ato que o mandante não possa exercer por si próprio: "atos que o mandante não pode exercer sem nulidade são atos ilícitos (art. 444 e 842, n. $1^{\circ}$ ), que não podem ser objeto do mandato. Estão neste caso os atos para os quais o mandante não tiver capacidade, ou não a tiver a pessoa com quem o mandatário tenha de contratar, ou cujo objeto for impossível, ilícito ou imoral ou que forem encarregados para serem exercidos por um modo ou por uma forma que a lei proíba". Ora, com relação à variante representativa do instituto tal disposição nos parece inócua, uma vez que não seriam obviados, por força da atuação do "representante", os obstáculos erigidos à ação do próprio principal. Assim, parece-nos que tal disposição se volta, sobretudo, ao mandato sem representação, conquanto esta observação não conte com o respaldo doutrinário - dentre as fontes por nós pesquisadas.

No entanto, nossa afirmação tem fundamento na íntima correlação entre este dispositivo e o preceito estampado no artigo 2864 do mesmo "Esboço" de Código Civil: "negócios em que tenha figurado testas de ferro, ou interpostas pessoas, reputar-se-ão feitos por mandatários em relação às partes que os autorizaram, mas não em relação a terceiros, ou quando houver simulação fraudulenta (arts. 526 e 527)". Expliquemo-nos. A "interposição" corresponde a um mecanismo desde há muito conhecido da doutrina, remontável - em uma expressão mais familiar - à chamada "representação indireta"; neste fenômeno, o agente atua no interesse do principal ("por conta"), conquanto de sua gerência não deflua eficácia representativa direta imediatamente atribuível à esfera jurídica deste último. Tomado em consideração o negócio de incumbência, a questão se resolve dentro dos quadrantes do contrato de mandato, mais precisamente à custa de sua variante desprovida de efeitos representativos imediatos ("mandato sem representação").

Ocorre que à interposição genérica - considerada ordinariamente como "causa-função" específica do mandato sem representação - correspondem as mais variadas finalidades práticas divisadas pelas partes que 
celebram uma avença específica. Se o fim é lícito - como por exemplo evitar a especulação excessiva por parte de um terceiro -, o expediente não é reprovado pelo Direito; tem-se aí aquilo que ordinariamente se costuma designar pela expressão "interposição real". Todavia, a finalidade concreta divisada pelas partes ("causa concreta"), por vezes, pode ser ilícita, na medida em que o destinatário final dos efeitos da gestão, por exemplo, esteja impedido de adquirir determinado bem por força de disposição legal. Nestas circunstâncias, a atuação do agente poderá ser designada como uma "interposição fraudulenta".

Note-se, pois, que em ambos os casos - interposições "real" e "fraudulenta" - tão somente as partes envolvidas no negócio jurídico de atribuição têm ciência da realidade decorrente do processo. Terceiros dela não podem ter conhecimento, sob pena de se frustrar o intuito dos envolvidos na gestão confiada (seja ele lícito ou não).

Pois bem. Tais situações não se confundem com a chamada "interposição simulada", relacionada à atuação do "testa de ferro". Neste caso o resultado da gestão permanece dentro da esfera jurídica do "interposto", conquanto os efeitos práticos e econômicos sejam experientados pelo próprio "interponente"; no entanto, um dado adicional extremamente relevante diz respeito à indispensável ciência por parte do terceiro que celebra um eventual contrato com o "interposto". Neste caso, existe mandato; existe mandato sem representação; existe mandato sem representação para a obtenção de fins vedados pelo ordenamento jurídico; e existe mandato sem representação para a obtenção de fins vedados pelo ordenamento jurídico com a ciência do terceiro que concorre para a execução da incumbência.

Desta forma, as figuras da "interposição real", da "interposição fraudulenta" e da "interposição fictícia" (ou simulada) são inconfundíveis. No entanto, C. P. M. CRUZ E TUCCI empregou aproximadamente meia dúzia de páginas para concluir ser "impossível a existência de interposição real em fraude à lei (...) toda interposição que viola a norma cogente é fictícia e configura simulação" (Interposição cit. (nota 09), p. 68).

Tome-se, pois, o seguinte exemplo: Caio pede a Tício que compre do pai do primeiro (insciente) bem imóvel que não lhe seria alienado sem o assentimento de Públio, seu irmão (e rival). Pois bem, atuando Tício em proveito de Caio, temos como assente que a hipótese configura mandato - e como o intuito é a ocultação do principal, mandato "sem representação". Ora, se o pai desconhece tal interposição, como reputá-la simulada (ou fictícia)? Parece-nos inteiramente impossível. No entanto, à vista do intuito de frustrar os direitos de Públio, a situação ultrapassa os limites da mera "interposição real" e atinge a esfera da modalidade "fraudulenta" do fenômeno. Não se podem confundir as hipóteses de negócio jurídico "simulado" (em que as partes querem algo e atuam falsamente, inspirando em outrem a crença de que pretendem algo de diverso), "fraudulento" (na qual aquilo que os sujeitos pretendem é ilícito) e "indireto" (em que o resultado da operação é, simplesmente, um "meio" para se alcançar um efeito ulterior). Não é este um estudo que se proponha a solver problemas dogmáticos. Pretendemos apenas realizar uma recolha de materiais dispersos pela História Luso-Brasileira, a fim de que problemas dogmáticos venham a ser solvidos por mentes mais preparadas. No entanto, esta nos parece a explicação mais razoável para o disposto nos artigos 2872 e 2864 do "Esboço", sequer referidos pela autora mencionada em seu estudo - monográfico - a respeito do tema. De todo modo, a respeito do conceito de negócio jurídico simulado, cf. G. SEGRÈ, In materia di simulazione nei negozi giuridici, in Scritti giuridici, Roma, Società Editrice del Foro Italiano, 1938; bem como A. G. SPOTA, Negocio juridico simulado, in Curso sobre temas de derecho civil, Buenos Aires, Instituto Argentino de Cultura Notarial, 1971, pp. 383-416. Por sua vez, quanto ao negócio jurídico indireto, cf. T. AsCARELLI, Il negozio indiretto e le società commerciali, in Studi di diritto commerciale in onore di Cesare Vivante I, Roma, Società Editrice del Foro Italiano, 1931, passim. Por uma distinção entre os referidos conceitos, cf. J. C. Moreira Alves, II - Aspectos Jurídicos - Figuras correlatas: abuso de forma, abuso de direito, dolo, negócios jurídicos simulados, fraude à lei, negócio indireto e dissimulação, in Anais do Seminário Internacional sobre Elisão Fiscal, Brasília, s.e., 2002, pp. 63-77.

Assim, por meio do artigo 2872 do "Esboço" A. TEIXEIRA DE FREITAS pretendeu coibir a interposição meramente - fraudulenta. E por sua vez, mediante o artigo 2864, buscou fulminar a interposição simulada (ou fictícia). Tudo isso cerca de meio século antes da publicação da obra de F. FERRARA (Della simulazione dei negozi giuridici). O artigo 2872 do "Esboço", aliás, encontra reflexo no art. 118 do AntMR. Daí a importância do estudo da História do Direito - e particularmente do direito brasileiro.

Ocorre que os estudos historiográficos não orientam apenas a abordagem destes específicos dispositivos do "Esboço"; outras disposições revelam uma influência histórica indisfarçável. À moda do estabelecido nas fontes romanas (D. 17, 1, 2 pr. (Gai. 2 rer. quot.)), o artigo 2874 preceitua quais os interesses que podem constituir objeto do contrato de mandato: "o mandato pode ter por objeto um ou mais atos ou negócios a exercer do interesse exclusivo do mandante, ou do interesse comum do mandante e do mandatário, ou do interesse comum do mandante e do terceiro, ou do interesse exclusivo do terceiro". Note-se, todavia, que ao autor do "Esboço" escapou uma das modalidades previstas no passo romano acima referido: o mandato conferido no interesse comum do mandatário e de terceiro. Curiosamente, aliás, também F. C. PONTES DE MIRANDA se equivocou ao traduzir este fragmento, sem a necessária alusão ao negócio de incumbência que 
tenha por objeto a gestão no interesse comum do mandante e de terceiro (Tratado de Direito Privado XLIII cit. (nota 04), p. 16). De qualquer forma, pelo alcance de tais conceitos, cf. A. BURDESE, Mandatum mea aliena tua gratia, in Studi in onore di Vincenzo Arangio-Ruiz nel XLV anno del suo insegnamento I, Napoli, Editore Jovene, s.d., pp. 219-ss.

De todo modo, ao autor do "Esboço" não passou despercebida a hipótese de "incumbência" no exclusivo interesse do encarregado; e à semelhança das fontes romanas - representadas por D. 17, 1, 2 pr. (Gai. 2 rer . quot.) e D. 17, 1, 2, 6 (Gai. 2 rer. quot.)) - proscreveu o "conselho" do âmbito do contrato de mandato, tal como se pode depreender dos artigos 2858 ("a simples recomendação não é mandato. Se a pessoa a quem a recomendação for feita alegar que houve mandato, a decisão deve ser negativa em caso de dúvida") e 2877 do "Esboço" ("quando alguém declarar a outrem o que lhe cumpre fazer em negócios de seu exclusivo interesse, haverá um simples conselho, e não um mandato. Todavia, será responsável pelos prejuízos que do conselho resultarem: $1^{\circ}$. Quem o deu de má fé, ainda que nenhum estipêndio recebesse; $2^{\circ}$. Quem recebeu estipêndio e aconselhou com tal negligência, que não fora de esperar das pessoas de sua profissão no assunto sobre que versou o conselho").

Note-se que enquanto na primeira disposição (artigo 2858) a atenção de A. TEIXEIRA DE FREITAS esteve voltada à descaracterização do tipo contratual referido, na segunda (artigo 2877) o jurista se inclinou à atribuição de uma responsabilidade civil de caráter excepcional - seja de origem contratual $\left(2^{\circ}\right)$ ou não $\left(1^{\circ}\right)$. Em relativa contradição com o referido artigo 2858, o autor do "Esboço" preconizou a nulidade do negó cio de incumbência do exclusivo interesse do mandatário; em disposição que se refere ao mandato desprovido de objeto, assim se prescreveu no artigo 2875: "Será nulo o mandato por falta de objeto: $1^{\circ}$. Quando antes de sua aceitação o ato ou negócio encarregado já estiver concluído; $2^{\circ}$ Quando o ato ou negócio encarregado for do interesse exclusivo do mandatário". Obviamente que não podemos conciliar as normas conflitantes, a menos que se empreste ao termo "recomendação" acepção outra que não se confunda com a de negócio jurídico de incumbência no exclusivo interesse do incumbido. Talvez tenha sido este o intuito do autor do "Esboço" ao lançar mão da expressão "simples recomendação". No entanto, se assim não o for, obviamente que o "mandato" não poderá ser - simultaneamente - "nulo" (artigo 2875) e "inexistente" (artigo 2858).

Ainda com relação ao objeto do contrato, orienta-se o "Esboço" pela rejeição deliberada do mandato ilícito. Assim, no artigo 2873 se estabelece que dele não decorrerá qualquer ação em benefício das partes, a menos que o agente tenha aceito a atribuição em decorrência de erro quanto à licitude da incumbência ("Se o mandatário aceitar mandato ilícito, não se atenderá a qualquer ação entre ele e o mandante, que em tal mandato se fundar, salvo se o mandatário autor provar tê-lo aceitado de boa-fé, isto é, não sabendo, nem tendo razão de saber que o mandato era ilícito"). Em íntima relação com este preceito está a regra contida no artigo 2948 do "Esboço", na qual se diferenciam, à moda escolástica, os resultados ilícitos à luz de sua respectiva fonte: "Se, por ser ilícito o mandato, resultarem lucros ilícitos do negócio encarregado, não poderá o mandante exigir que o mandatário lhos entregue (art. 2873). Se, porém, tendo sido lícito o mandato, resultarem lucros ilícitos por abuso do mandatário, poderá o mandante exigir que lhe sejam entregues".

Ora, da conjugação entre estes dois dispositivos desponta a regra geral de que do mandato ilícito não decorrem ações às partes - ação em sentido material, naturalmente. No entanto, à vista da boa-fé dos envolvidos, excepciona-se a aplicação da regra geral: no primeiro caso (artigo 2873), em razão falsa apreciação da realidade que caracterizou a conduta do incumbido (trata-se de uma exceção também de amplitude geral, inerente ao sistema como um todo). No entanto, no segundo caso (artigo 2948), a atribição de ação ao principal deflui de uma manifestação específica do princípio da boa-fé no âmbito do contrato de mandato: à vista da "gestão colaborativa" caracterizadora do vínculo mantido entre o incumbido e o incumbente, conferem-se a este último os resultados - conquanto ilícitos - da atribuição inatacável.

Em disposição atinente à representação, o "Esboço" de Código Civil propôs norma inovadora no cenário jurídico nacional de então (e acabou por influenciar uma série de fontes projetadas e legisladas que se lhe seguiram); com efeito, A. TEIXEIRA DE FREITAS afastou do objeto do mandato não apenas os atos personalíssimos - de efeitos jurídicos "inter vivos" ou "causa mortis" - como também as duas hipóteses da famigerada "contratação consigo mesmo" (pelo mandatário). Eis o teor do artigo 2871 do "Esboço": "A representação não é extensiva (art. 52), sob pena de nulidade: $1^{\circ}$. Às disposições de última vontade (art. 439); $2^{\circ}$. Aos atos entre vivos (art. 438), cujo exercício por mandatário se proíbe neste Código (art. 1281), ou em outras leis (art. 2865, $\mathrm{n}^{\circ} 2$ ); $3^{\circ}$. Aos contratos do mandante, em que a outra parte for o próprio mandatário (arts. 1983, $\mathrm{n}^{\circ} 7$, e 1984, $\mathrm{n}^{\circ} 8$ ); $4^{\circ}$. Aos contratos do mandante, em que a outra parte for pessoa de quem o mandatário seja representante necessário ou voluntário, a menos que o mandatário seja corretor e como tal aceite o mandato de ambas as partes por ser negócio de sua profíssão". Por ora, não podemos deixar de registrar nossa admiração quanto à perspicácia de A. TEIXEIRA DE FREITAS, que não se deixou seduzir por expressões equivocadas como aquela que remonta à "contratação consigo mesmo". Ora, se o mandatário é além disso - representante, obviamente que não pode celebrar contrato consigo mesmo em hipótese alguma, a menos que também fosse o próprio representado; e se assim não o é, há que se diferenciar o concurso do 
representante para a emissão da declaração volitiva e a assunção de posição jurídica na relação contratual decorrente (do negócio representativo). No momento em que o "contrato consigo mesmo" é celebrado, a confusão que perturba alguns intérpretes se dá única e exclusivamente no plano fático; no mundo jurídico, ao contrário, inexiste contratação consigo mesmo (nesta hipótese). O negócio jurídico representativo é concluído entre o principal (por meio de seu representante) e o terceiro (no caso, o agente). "Contrato consigo mesmo", em acepção técnica, parece-nos defluir unicamente na hipótese de mandato sem representação: por exemplo quando o comissário, que negocia em nome próprio, comparece como contraparte e concorre para a contratação; neste caso, parece-nos inafastável o direito do incumbido à "comissão" (verba) correspondente. Nós voltaremos ao assunto mais adiante, a propósito da análise dos referidos reflexos no âmbito da representação disciplinada pelo legislador brasileiro do século XX (seja no âmbito do conflito de interesses em geral, seja especificamente a respeito do "contrato consigo mesmo"). No entanto, há que se observar que esta disposição evidencia uma atenção especial (do autor do "Esboço") ao problema do conflito de interesses - no âmbito específico do contrato de mandato.

Ocorre que este preceito não é o único em que A. TEIXEIRA DE FREITAS se volta à temática referida. Ao contrário, este autor já tratava - autonomamente - a questão relativa ao "conflito de interesses" nos momentos de formação, execução e extinção da relação jurídica contratual. Tomando em consideração o ambiente de harmonia que deveria circundar a relação entre os sujeitos do negócio jurídico de incumbência estribado, antes de mais nada, nas idéias de "confiança" e de "gestão colaborativa" - o autor precreveu, a respeito da aceitação da oferta de mandato (artigo 2876), que "o mandatário não deve aceitá-lo, quando seus próprios interesses, ou os de pessoa de quem já seja representante necessário ou voluntário, estiverem em oposição com os do mandante. Se os interesses do mandante forem opostos aos do mandatário, tudo o que este fizer de útil só ao mandante aproveitará. Se forem opostos aos de pessoa também representada pelo mandatário, aproveitará a um dos representados o que for feito em seu nome, uma vez que não se tenha conluiado com o mandatário para prejudicar ao outro representado. Terceiros de boa-fé, não obstante a má fé do mandatário, não serão prejudicados nos direitos que adquirirem contra o mandante". Note-se, pois, que o autor se preocupou também com a posição dos terceiros de boa-fé - conquanto tal matéria, a rigor, se refira à representação (e não ao mandato propriamente).

Já no que toca à execução do mandato, o autor do "Esboço" teve em mira o conflito de interesses superveniente à aceitação da incumbência; assim, dispondo a respeito da "lealdade" inerente à gestão colaborativa confiada ao agente, no artigo 2939, $2^{\circ}$ A. TEIXEIRA DE FREITAS projetou: “não executará lealmente o mandato (art. 2914, $n^{\circ} 3$ ): (...) $2^{\circ}$. Se, havendo oposição entre seus interesses e os do mandante, der preferências aos seus (art. 2876)". Finalmente, no que concerne ao conflito de interesses que enseja a virtual cessação do vínculo mantido entre as partes, o autor do "Esboço", vacilante, acaba por considerar a renúncia do mandatário como um seu autêntico dever; no entanto, não sem antes conjecturar a respeito de um mandatário "benemérito" - coisa que deve ter havido um dia (mais entre os romanos, menos à época do autor do "Esboço" e raramente hoje em dia). Eis então o teor dos dois dispositivos nos quais a matéria é enfrentada pelo jurista brasileiro (artigos $3032,3^{\circ}$ e 3033 ): “terá o mandatário justa causa para renunciar ao mandato ou este seja civil ou comercial (art. 3009, $\mathrm{n}^{\circ}$ 7): (...) $3^{\circ}$. Se a execução do mandato se opuser a seus próprios interesses ou aos de pessoa de quem seja representante necessário ou voluntário (...) no caso do artigo antecedente, $\mathrm{n}^{\circ} 3$, é mesmo obrigação do mandatário não continuar no mandato, e, se continuar, é aplicável o disposto no art. 2876. Poderá, todavia, continuar, se os interesses do mandante forem opostos aos seus, dando preferência aos do mandante (art. 2939, n 2)".

O "Esboço" de Código Civil se volta, ainda, à articulação - sob a forma de preceitos expressos - do princípio de que o mandato civil se presume gratuito (ao passo que o seu correlato mercantil é presumidamente oneroso); é isso que se pode depreender da conjugação entre os seus artigos 2855 ("o mandato pode ser gratuito ou oneroso (artigos 442 e 443). Reputar-se-á gratuito, quando não se tiver ajustado que o mandatário perceba uma retribuição pelo seu trabalho ou não se presumir tal ajuste") e 2856 ("presume-se tal ajuste: $1^{\circ}$. Quando o mandato for comercial, ainda que não seja preposição ou comissão; $2^{\circ}$. Quando consistir no exercício de atribuições ou funções conferidas por lei ao mandatário, como as de advogados, procuradores judiciais, corretores e agentes de leilões; $3^{\circ}$. Quando consistir em trabalhos próprios da profissão lucrativa do mandatário ou de seu meio de vida"). Ou seja: se prescreve a gratuidade como regra para o mandato civil, desde que não afastada por convenção das partes - a regra é dispositiva e evidencia, pois, um elemento "natural" do tipo - ou por circunstâncias reputadas suficientemente relevantes - a ponto de suscitar a atenção especial do legislador (consubstanciada nas alíneas do artigo 2856 do "Esboço").

Ora, não nos cabe retroceder a questões já abordadas durante o curso da presente exposição - a respeito do papel da remuneração no contexto da eficácia jurídica do contrato de mandato (nota 134). A opinião então prevalecente pode ser sintetizada na manifestação de M. I. CARVALHO DE MENDONÇA: “a questão da gratuidade do mandato é um desses fenomenos que revelam a lei da persistencia, mas que perderam de todo sua significação actual" (Contratos cit. (nota 131), p. 200). E note-se que esta não é uma posição decorrente 
do movimento de codificação do direito civil; aludindo ao "uso moderno", F. MENDES PIMENTEL observa a alteração gradativa que se promoveu com o passar dos tempos: "segundo (...) o uso moderno, a gratuidade não é da essência, mas só da natureza do mandato" (Mandato, in Revista Forense 25 (1906), p. 288).

De fato, já nos dedicamos ao tema no âmbito da evolução do próprio direito brasileiro. Todavia, dois aspectos nos parecem dignos de menção especial, à vista de sua importância para a compreensão: da realidade "sui generis" subjacente aos negócios de confiança (nos quais prevalece a idéia de uma gestão colaborativa); e do papel significativo da História do Direito como mecanismo voltado à solução de alguns problemas que despontam ao intérprete contemporâneo.

A realidade inerente ao contrato de mandato suscita uma especial reflexão do leitor a respeito da existência de um mecanismo garantidor de um equilíbrio no âmbito dos mais diversos tipos contratuais. Advirta-se, desde logo, que este equilíbrio nem sempre corresponderá a um sistema de contrapartidas entre os sujeitos envolvidos na relação jurídica contratual. De fato, dissemos acima que não nos parece adequado o emprego da "exceptio non adimpleti contractus" no âmbito do contrato de mandato - salvo previsão expressa do legislador, a construir artificialmente um sinalagma funcional entre os deveres das partes. Dissemos ainda que consideramos o direito de retenção o expediente apropriado para a defesa dos interesses do mandatário "prejudicado", a fim de que possa receber toda a retribuição que lhe seja devida.

Ora, o fato de não poder lançar mão dos remédios sinalagmáticos implica uma espécie de prejuízo - sob a perspectiva prática - ao mandatário, na medida em que não pode suspender a execução que lhe foi confiada pelo mandante. No entanto, existe uma espécie de alento a uma tal situação desfavorável, uma vez que por meio do artigo 2971 do "Esboço" se preconiza a autonomia da remuneração do agente em relação ao desfecho da gestão empreendida: "quando o mandato for gratuito, o mandatário, sob qualquer pretexto, nada poderá exigir a título de retribuição. Quando for oneroso, tem direito à sua retribuição, e por inteiro, ainda que o negócio encarregado não tivesse bom êxito, salvo se convencionou, que, no caso de mau êxito, nada receberia, ou só receberia uma parte da retribuição". Tal disposição ultrapassa os estreitos limites dos artigos 187 e 188 do Código Comercial há pouco analisados. O que temos aqui é a atribuição de todo o risco de insucesso da gestão ao mandante - exceto se por previsão expressa as partes decidirem afastar tal regra. Teremos a oportunidade de observar, mais adiante, que tal preceito frutificou em meio ao Anteprojeto de Joaquim Felício dos Santos, sob a forma de exceção material expressamente afastada da esfera jurídica do mandante (artigo 2297).

Ainda com relação à remuneração do mandatário, é importante destacar que no "Esboço" de Código Civil encontraremos uma das únicas previsões relacionadas ao momento do pagamento de tal importância. Ainda que o termo "retribuição" tenha sido utilizado pelo autor com o sentido que nós emprestamos à palavra "remuneração", o teor do artigo 2978 é absolutamente claro: "não se tendo ajustado o tempo em que a retribuição deve ser paga, e sem prejuízo do disposto nos artigos antecedentes sobre os casos de resolução do mandato, o mandatário não poderá exigi-la senão depois de concluído o negócio encarregado, ou depois da prestação de suas contas se assim o reclamar o mandante". Embora inexistente disposição similar em meio às fontes do direito brasileiro por nós estudadas, não se pode esquecer que tal matéria havia sido objeto de regulamentação em meio do direito português medieval e inclusive durante o período de vigência das Ordenações Afonsinas (Ord. Af. I, 13, 32 e Ord. Af. I, 13, 33) e Manuelinas (Ord. Man. I, 38, 34) conquanto somente se tenha aí disposto a respeito da variante judicial do instituto. Eis aí mais uma manifestação do proveito - ao pragmático jurista contemporâneo - que o estudo da História do Direito pode lhe oferecer.

A respeito do reflexo de tais disposições do "Esboço" (acerca da remuneração do mandatário) no âmbito das fontes do direito civil brasileiro posteriores (legisladas ou meramente projetadas), cf. o art. 2269 do AntFS; os arts. 1063, 1064 e 1074 do AntCR; o art. 1443 do AntCB; os arts. 1507 e 1518 do AntCBRev; o art. 1290 do PCD n ${ }^{\circ}$ 1/1912; o art. 1290 do PSF no 269/1912; o art. 1290 do CC/1916; o art. 652 do AntCM; o art. 619 do AntCMRev; o art. 672 do AntMR; o art. 657 do AntMRRev; o art. 667 do PCD nº 634/1975; e o art. 658 do CC/2002. Mesmo o arbitramento da remuneração - não estimada em contrato - segundo os usos, tal qual prescreve o Código Civil vigente (artigo 658, § único), guarda inteira correspondência com a primeira parte do artigo 2976 do "Esboço".

Por fim, resta-nos dizer algumas palavras a respeito da vigência do contrato de mandato. A este respeito, o "Esboço" de Código Civil traz meia dúzia de disposições bastante relevantes. Os artigos 2885 e 2886 disciplinam a subordinação dos efeitos do negócio jurídico aos elementos "acidentais" que lhe tenham sido atrelados. Com efeito, pelo primeiro deles (artigo 2885) se estabelece que "o mandato pode ser conferido para ser aceito depois de um prazo ou no caso de cumprir-se uma condição. Pode ser conferido ou aceito por tempo determinado ou indeterminado"; em verdade, diante da redação emprestada ao período, A. TEIXEIRA DE FREITAS acabou por postergar o momento de aceitação da oferta - em lugar de simplesmente se prescrever, por exemplo, a suspensão dos efeitos do ajuste. Assim, atribuiu-se eficácia ao negócio unilateral de oferta, possibilitando-se ao - pretenso - "mandatário" efetuar sua recusa algum tempo depois (ou quando 
do implemento da condição). De tal maneira que as conseqüências acabam sendo bastante diversas, uma vez que, segundo o dispositivo do "Esboço", o mandatário não estará vinculado desde logo.

Por sua vez, pelo segundo (artigo 2886) se prescreve - no âmbito do contrato de mandato - a simples adoção das regras gerais aplicáveis à condição e ao termo (resolutivos ou suspensivos): "será de tempo determinado: $1^{\circ}$. Quando ficar constituído para o mandatário executá-lo, ou começar a executá-lo, depois de um prazo, ou no caso de cumprir-se uma condição, ou assim se estipulasse expressamente, ou a determinação do prazo resulte das circunstâncias do negócio encarregado; $2^{\circ}$. Quando ficar constituído para a gestão do mandatário durar até que se vença um prazo, ou até que se cumpra uma condição".

Inexiste crítica, de nossa parte, à segunda alínea do dispositivo, na qual se alude às variantes resolutivas dos elementos acidentais do negócio jurídico. Todavia, o mesmo não se pode afirmar a respeito da alínea primeira: ao contrário do que sustenta A. TEIXEIRA DE FREITAS, não acreditamos que a simples estipulação de um termo suspensivo - ou de uma condição de igual natureza - seja suficiente para tornar o mandato um contrato vigente durante um prazo determinado. Em verdade, nessas hipóteses, o advento do termo (ou o implemento da condição) desencadeará uma eficácia jurídica cuja duração estará intimamente vinculada à vontade das partes (e ao objeto da atribuição); e isso parece ter sido intuído pelo próprio autor do "Esboço", conforme se pode depreender dos seus artigos 2887, 3006 e 3008, nos quais se alude à cessação do vínculo à custa de negócio jurídico unilateral denunciativo.

De fato, no artigo 2887 se estabelece o alcance do mandato por prazo indeterminado: "em todos os outros casos o mandato será de tempo indeterminado ou perpétuo, isto é, para durar enquanto o mandante viver e não revogá-lo, ou o mandatário não renunciá-lo. Por tal se reputará o mandato expressamente constituído para durar enquanto viver o mandante ou o mandatário". É aqui que A. TEIXEIRA DE FREITAS incorre em equívoco, pois não há necessidade de previsão expressa das partes a respeito do prazo de duração do mandato; caso quedem silentes, há de se presumir que a avença perdurará até que seja concluído o seu respectivo objeto. E é esse o entendimento a que é conduzido o intérprete quando confronta tal disposição e a parte final da alínea primeira do artigo 3006 do "Esboço" ("cessa o mandato: $1^{\circ}$. Se foi contratado por tempo determinado (art. 2886), findo esse tempo, se antes dele o mandatário não concluir o negócio encarregado; $2^{\circ}$. Se foi contratado por tempo indeterminado (art. 2887), quando o mandante o revogar, ou quando o mandatário o renunciar, ou concluir o negócio encarregado; (...").

Neste passo, parece que o autor do "Esboço" acabou por incorrer em equívoco, na medida em que o mandato submetido a termo inicial pode ter duração por prazo indeterminado. E quanto ao mandato por prazo indeterminado, o "Esboço" estabelece que a relação perdura indefinidamente, sem a necessidade de qualquer espécie de (re)novação; "enquanto o mandante não revogar o mandato de tempo indeterminado (art. 3006, $\mathrm{n}^{\circ}$ 2), presume-se que persevera ne mesma vontade, e o mandato durará sem necessidade de renovação, qualquer que seja o tempo decorrido". Em solução que reputamos insatisfatória, J. M. da TRINDADE defendia que o mandato "se presume revogado, quando decorrem muitos annos sem ter execução" (Collecção cit. (nota 131), pp. 42-43, nota 24).

Finalmente, por meio do artigo 3007 do "Esboço" se disciplina a eficácia decorrente da superveniência do termo (ou do implemento da condição) sobre a relação jurídica respectiva, caso não se tenha por assente que a previsão das partes (o elemento acidental) ostentou um tom simplesmente enunciativo (sem que se buscasse tolher os efeitos da relação ainda não exauridos pela execução da incumbência): "quando se tiver fixado prazo ou estabelecido condição para a duração do mandato e o negócio encarregado for de duração limitada, o mandato cessará vencido o prazo ou cumprida a condição, ainda que o mandatário nada tenha feito ou o negócio não esteja concluído, a não constar que o prazo se estipulou na persuasão de ser suficiente para a conclusão do negócio".

A respeito de uma longínqua influência de tais disposições do "Esboço" (sobre os elementos acidentais do negócio jurídico aplicados ao mandato) sobre as fontes do direito civil brasileiro posteriores, cf. o art. 2283 do AntFS; o art. 1073 do AntCR; e o art. 1517 do AntCBRev.

Sobre a doutrina produzida durante a vigência do Código Civil de 1916 - a respeito da matéria abordada nesta nota de rodapé - cf. A. Beviláqua, Codigo cit. (nota 131), pp. 356-358; A. do VAlle SiQueIRA, Codigo cit. (nota 131), pp. 429-431; A. CAMARGO, Elementos cit. (nota 131), pp. 92-93; A. ChACON CouTO, Ligeiras observações cit. (nota 131), pp. 8-12; A. CHAVES, Lições cit. (nota 131), pp. 287-294; A. L. da CÂMARA Leal, Manual cit. (nota 131), pp. 98-103; A. MARMITT, Mandato cit. (nota 131), pp. 108-110; A. WALD, Curso cit. (nota 131), pp. 300-303; C. FALCÃo, Codigo cit. (nota 131), pp. 144-145; C. BEvILÁQuA, Codigo cit. (nota 05), pp. 35-39 e 43-45; D. ARRUdA MIRANDA, Anotações cit. (nota 131), pp. 367-373; E. ESPínOla, Dos contratos nominados cit. (nota 12), pp. 351-357; E. PESSÔA, Da procuração cit. (nota 131), pp. 6-9 e 23; F. C. PONTES DE MiRANDA, Fontes cit. (nota 16), pp. 332-333; F. M. DE MATTIA, Aparência cit. (nota 06), pp. 16 e 50-51; F. R. LeITE FilHo, Curso cit. (nota 05), pp. 346-348; F. C. de SAN TIAGo DanTaS, Programa cit. (nota 05), pp. 372-373; F. K. ComPARATO, Aparência cit. (nota 131), p. 42; G. SCIASCIA, Direito Romano cit. (nota 131), p. 161; J. do AMARAL GurGel, Contractos cit. (nota 131), pp. 76 e 126-127; 


\section{$\S$ 164. O "Esboço" de Código Civil e os deveres atribuídos ao mandatário.}

Em lugar da previsão de um genérico dever de execução da incumbência "segundo as ordens e instruções" do mandante (tal como estabeleceram os artigos 142 e 168 do Código Comercial), no "Esboço" de Código Civil se preconiza uma eficácia bastante mais articulada, suscetível de eventualmente percutir mesmo a esfera jurídica daquele que, tão logo possível, se encarrega de recusar expressamente a atribuição cometida (artigo 2913). De fato, imputam-se diversos deveres laterais ao agente, tais como os relacionados à informação (artigo 2937, $1^{\circ}$ ), execução oportuna (artigo 2937, $2^{\circ}$ ), preservação de segredo (artigo 2939, 4\%), antecipação excepcional (artigo 2961) e paralisação da gestão cujo insucesso é iminente (artigo 2939, 3º); já no que toca à prestação de contas (artigo 2914, $4^{\circ}$ ), prescreve-se a sua exigibilidade inclusive durante o curso da própria gestão (artigo 2942): reputando-se ineficaz - total ou parcialmente - a cláusula relacionada à sua dispensa, salvo nas hipóteses de provisão limitada ou doação (artigos 2943 e 2944). Além disso, é prevista também a entrega de todas as vantagens - lícitas ou não (artigo 2948) obtidas durante o cumprimento da incumbência (artigos 2914, 4 e 2945), além da restituição de tudo aquilo que o mandante houvera confiado para o adequado desempenho da tarefa (artigo 2946). Finalmente, a respeito do exercício da representação negocial,

J. L. Alves, Código cit. (nota 05), pp. 352-356 e 360-362; J. F. de LiMA, Curso cit. (nota 05), pp. 565-570 e 575-576; J. GonÇAlves MaIA, Theoria cit. (nota 131), pp. 12, 148-154 e 159-161; J. M. de CARVAlHO SANTOS, Codigo cit. (nota 05), pp. 117-118, 131-145, 151-153 e 221-226; J. de SAMPaIO Doria, Codigo cit. (nota 131), p. 92; L. LeITE, Codigo cit. (nota 131), pp. 427-430; L. R. de FreITAS GoMES, Contrato cit. (nota 131), pp. 289 e 294; M. C. do. A. KROETZ, A representação cit. (nota 41), pp. 62-79; M. G. MAIA JÚNIOR, A representação cit. (nota 04), pp. 42, 49, 96-108, 120-121 e 140; M. I. CARVALHO DE MENDONÇA, Contratos cit. (nota 131), pp. 200-208 e 212-215; M. PAUlo MerêA, Codigo cit. (nota 131), pp. 406-407; M. M. de SeRPA LOPES, Curso cit. (nota 05), pp. 244, 250-253, 256-260, 262-267 e 276; O. GOMES, Contratos cit. (nota 23), pp. 348-349; P. SOARES NeTTO, Noções cit. (nota 131), pp. 244-248; R. L. FRANÇA, Manual cit. (nota 05), pp. 185-192; R. LOTUFO, Questões cit.(nota 26), pp. 91-101, 106 e 117; S. VAMPRÉ, Manual cit. (nota 131), pp. 125 e 129-139; O que é o Código Civil: conferencias realisadas na Universidade de São Paulo, São Paulo, Livraria e Officinas Magalhães, 1916, p. 116; T. FulgenCIO Alves Pereira, Programmas cit. (nota 131), pp. 134-137; T. PrateS DA FonseCa, Noções cit. (nota 131), pp. 194-198; Y. S. CAHALI, Contratos cit. (nota 131), pp. 504.

E no que concerne à produção voltada ao Código Civil de 2002, cf. A. SCHREIBER, A representação cit. (nota 131), p. 229; A. Villaça Azevedo - S. de S. Venosa, Código cit. (nota 02), pp. 355-358; A. de Assis, Contratos cit. (nota 131), pp. 48-51 e 75-77; CAIO MÁRIO da Silva Pereira, Instituições cit. (nota 02), pp. 398-400; C. A. BitTAR FilHO - M. S. BitTar, Código cit. (nota 02), pp. 56-57; C. E . N. CAMillo - G. M. TAVAlERA - J. S. FUJitA - L. A. SCAVONE JÚNIOR (coords.), Comentários cit. (nota 02), pp. 587-590; C. L. Bueno de Godoy, Do mandato cit. (nota 131), pp. 606, 612 e 621-622; C. R. GONÇALVES, Direito cit. (nota 131), pp. 389, 393-394 e 398-399; F. UlhoA Coelho, Curso cit. (nota 02), pp. 312-317; F. AMARAL, Direito cit. (nota 131), p. 461; Maria Helena Diniz, Curso cit. (nota 02), pp. 352, 356 e 360; N. C. B. CAMPELlo, Da representação cit. (nota 131), pp. 424-425; N. G. B. DOWER, Curso cit. (nota 02), pp. 283-286; N. NERY Junior - R. M. de ANDRADE NERY, Código cit. (nota 02), pp. 472-475; O.GoMES, Contratos cit. (nota 23), pp. 427-431; O. R. B. SANDOVAL, Do mandato cit. (nota 131), pp. 602-603 e 611-612; R. FiuZA (coord.), Novo Código cit. (nota 02), pp. 607-608 e 615-616; S. de S. VenOSA, Direito cit. (nota 02), pp. 254, 258 e 267; S. L. F. da Rocha, Curso cit. (nota 02), p. 297; SILvio RodRIGUES, Direito cit. (nota 02), pp. 288-289; WASHington De BARros Monteiro, Curso cit. (nota 02), pp. 263-269 e 274-275. 
comete-se ao procurador a exibição da documentação comprobatória da regular outorga de poderes representativos (artigos 2956, 2957 e 2958), sob pena de sua responsabilidade pessoal caso assim não o faça (artigo 2955); em contrapartida, uma vez tomada tal providência, o excesso eventualmente praticado (perante terceiro ciente) acarretaria a própria "nulidade" da contratação - tal como disposto no artigo 2953 do anteprojeto ora analisado $^{141}$.

${ }^{141}$ A eficácia do contrato de mandato não prescinde de contornos próprios que evidenciem as idéias de "confiança", "gestão colaborativa" e "instrumentalidade" que lhe são subjacentes. No entanto, as circunstâncias que envolvem tal tipo contratual são tão peculiares que sugeriram a A. TEIXEIRA DE FREITAS a adoção de alguns expedientes completamente alheios à generalidade dos contratos. Assim, por exemplo, o artigo 2913 do "Esboço" contém uma das mais evidentes consagrações da boa-fé objetiva como mecanismo de atribuição de deveres aos sujeitos de direito (ainda que não estejam vinculados por meio de qualquer liame contratual); eis o seu teor: "posto que o mandatário não aceite o mandato, e o comunique em tempo ao mandante, incumbe-lhe, se o negócio ou ato encarregado for urgente, dar as providências necessárias a bem dos interesses ou direitos do mandante, sob pena de responder pelo prejuízo que de sua omissão resultar". Ora, a análise de tal disposição nos chama a atenção por alguns aspectos: em primeiro lugar pelo lapso técnico do autor do "Esboço", ao aludir à figura do "mandatário" que não aceita o mandato; ora, se não aceita, "mandatário" não é. Esta observação - que à primeira vista pareceria envolver uma questão de lana caprina - parece-nos extremamente relevante para a definição do regime jurídico de responsabilidade do "pretenso" mandatário; não se trata de responsabilidade contratual, pois de mandato não se trata - mas sim de responsabilidade aquiliana estabelecida, "ex vi legis", pelo legislador (projetado). Desta forma, se depreende de tal dispositivo uma dupla eficácia elementar, atrelada, por sua volta, a um suporte fático que faz menção: a uma oferta; a uma recusa; e a circunstâncias tais que ensejam uma pronta atuação provisional do destinatário da policitação.

A dupla eficácia exsurgente do preceito se relaciona à atribuição de dois deveres àquele que pretende recusar a oferta: em primeiro lugar, deve repelir a proposta com presteza (uma vez que interesses do ofertante, dignos de tutela, aguardam uma sua decisão); em segundo lugar, incumbe-lhe diligenciar pela proteção à eficácia do objeto da gestão - mesmo que não vá aceitar a referida proposta. E é este o segundo aspecto deste preceito que nos desperta a atenção.

Em verdade, analisando-se a posição de tal preceito no "Esboço", percebe-se que este sucede ao artigo 2912 - já analisado - no qual se atribui ao "mandatário profissional" o dever de recusar. Ou seja, A. TEIXEIRA DE FREITAS tinha a possibilidade de restringir o alcance deste artigo 2913, por meio de uma similar redução do espectro subjetivo ao qual seria direcionado; no entanto, não o fez. Preferiu atrelar tais deveres (resposta tempestiva e gestão provisional) a qualquer destinatário de uma oferta de mandato. Ora, como tal regra não se volta ao destinatário de qualquer proposta - mas tão somente a de mandato - e nem se aplica com relação a sujeitos determinados ("mandatários profissionais"), percebe-se que tal preceito está a meio caminho, entre a generalidade e a especialidade. Entenda o leitor que - em suma - o dever de provisão não deriva: do ambiente social geral (não se trata de uma cláusula geral suficientemente ampla como a atual boa-fé objetiva); da pertinência do mandatário a uma categoria específica; da celebração do contrato (uma derivação do "pacta sunt servanda"). Em síntese, o dever de provisão estabelecido no artigo 2913 do "Esboço" decorre das circunstâncias que podem envolver - eventualmente - uma oferta de mandato na qual já se pode divisar, certamente, uma dose de "confiança" a ser protegida.

Já sob a perspectiva do contrato de mandato celebrado, duas disposições envolvem um conjunto de significativos deveres laterais atribuídos ao agente (artigos 2937 e 2939). Por um lado, o artigo 2937 do "Esboço" comete ao mandatário não apenas a obrigação de executar diligentemente o objeto da incumbência; mais do que isso, ao agente compete cumpri-la "oportunamente", fornecendo ao principal - prontamente toda e qualquer informação sobre a gestão que possa lhe interessar: "o mandatário não executará diligentemente o mandato (art. 2914, $\mathrm{n}^{\circ} 3$ ): $1^{\circ}$. Deixando de fazer pronto aviso ao mandante do estado, incidentes e conclusão do negócio encarregado; $2^{\circ}$. Demorando a execução do mandato, antecipando-a ou deixando de fazer em ocasião oportuna o que era necessário; $3^{\circ}$. Sempre que em sua gerência não se houver com a mesma diligência que costuma empregar em seus próprios negócios do mesmo gênero (art. 847)". No artigo 2939, por sua vez, além de se repreender a atuação dolosa, "interessada" ou mesmo simplesmente contrária às instruções do mandante, condenam-se as gestões ineficiente e indiscreta: "Não executará 
lealmente o mandato (art. 2914, $\mathrm{n}^{\circ} 3$ ): $1^{\circ}$. Sempre que em sua gerência se houver com dolo; $2^{\circ}$. Se, havendo oposição entre os seus interesses e os do mandante, der preferências aos seus (art. 2876); $3^{\circ}$. Se levar a efeito o que lhe foi ordenado, tendo ciência do mau êxito, quando o mandante o ignorava; $4^{\circ}$. Se for indiscreto, quando pela natureza do mandato devia guardar segredo; $5^{\circ}$. Se, com prejuízo do mandante, figurar em seu próprio nome, quando isso não the foi ordenado ou facultado expressamente, ou tacitamente pela natureza do negócio e circunstâncias".

A respeito deste artigo 2939 cumpre observar que, postos de parte os preceitos relacionados a temas já abordados - ou que serão objeto de análise futura $\left(1^{\circ}, 2^{\circ}\right.$ e $\left.5^{\circ}\right)$-, as demais regras atendem ao mesmo princípio inspirador do artigo 2913; só que projetando os seus efeitos dentro do âmbito estritamente contratual. São deveres como esses de informação (artigo 2937, $1^{\circ}$ ), execução oportuna (artigo 2937, $2^{\circ}$ ), sigilo (artigo 2939, $4^{\circ}$ ) e suspensão do cumprimento prejudicial (artigo 2939, $3^{\circ}$ ) - tão caros ao "Esboço" de A. TEIXEIRA DE FREITAS - que afastam o contrato de mandato - mesmo que remunerado - de qualquer tentativa de aproximação em relação à prestação de serviços. Ora, não nos cabe - aqui - tecer maiores considerações de ordem dogmática a respeito do contrato de mandato; e menos ainda promover incursões em meio a um direito comparado que este pesquisador talvez não domine tal qual pretendesse. Mas não podemos nos furtar à seguinte observação (a ser objeto de desenvolvimento nalguma ocasião futura): a ciência jurídica alemã simplificou de tal modo a dissociação entre o contrato de mandato e seus congêneres que, no final das contas, parece não saber responder o que o mandato é, mas apenas aquilo que o mandato deixa de ser. As simplificações excessivas, por vezes, nos permitem diferenciar elefantes de canários (tome-se por base o respectivo tamanho do menor elefante comparado ao maior dos canários); no entanto, o critério do tamanho não nos informa sobre aquilo que vem a ser um elefante - simplesmente se mostra eficiente para diferenciálo de um canário. Eis o papel da gratuidade essencial ao mandato no panorama de uma ciência tolhida em seu poder criativo pela pena implacável de um legislador pragmático. Deixam-se de lado as vicissitudes eficicaciais que tornam absolutamente distintos os contratos de mandato e de prestação de serviços para que se considere a questão - quase que exclusivamente - sob a perspectiva de uma presença (ou ausência) do elemento remuneratório. F. C. PONTES DE MIRANDA, a este respeito, desfecha sua crítica ao modelo alemão: "a dificuldade de caracterização foi, em grande parte, causa dessa escapada para a solução simplista. Destoou da grande altura técnica, a que se alçou o Código Civil alemão, o seu conceito de mandato, qual o interpretou a doutrina dominante" (Tratado de Direito Privado cit. (nota 04), p. 7).

Em vista disso, pois, despontam soluções que nos parecem inconciliáveis com o modelo representado pelo mandato em meio à nossa doutrina de maior envergadura: "o mandatário não é (...) obrigado a restituir o que houver recebido a título de gratificação por ocasião da execução do mandato" (Contratos cit. (nota 131), p. 221). Ora, adotado como fundamento do tipo o princípio da "gestão colaborativa", toda e qualquer importância percebida junto a terceiros deveria ser revertida, pelo agente, em benefício do principal.

Ocorre que todas essas prescrições atinentes à eficácia do contrato de mandato encontram-se enfeixadas em uma disposição que ocupa uma posição nevrálgica no sistema desenvolvido por A. TEIXEIRA DE FREITAS para a descrição deste específico tipo contratual (e particularmente das obrigações atribuídas ao mandatário): trata-se, pois, do artigo 2914 do "Esboço". Neste preceito - além de uma incursão em campo pouco explorado por nossa própria doutrina contemporânea - o autor do "Esboço" abre espaço a uma das obrigações mais importantes do agente em sua qualidade de "gestor": aquela relacionada à prestação regular de contas ao constituinte ("fica obrigado o mandatário em relação ao mandante: $1^{\circ}$. A executar o mandato em sua plenitude; $2^{\circ}$. A executá-lo por si mesmo, ainda que o mandante não lhe tenha imposto esta obrigação; $3^{\circ}$. A executá-la com exatidão, boa diligência e lealdade; $4^{\circ}$. A prestar contas de sua gerência, se assim for necessário, entregando o que em virtude dela recebeu e o que deixou de receber por sua culpa"). Nós já tivemos a oportunidade de estipular uma espécie de quadripartição de perspectivas segundo as quais a fenomenologia do mandato pode ser encarada: trata-se das dicotomias "mandante/mandatário", "principal/agente", "constituinte/procurador" e "representando/representante". Mencionamos que ao termo "procurador" se associou, progressivamente, a idéia de um sujeito dotado de poderes para percutir a esfera jurídica alheia mediante ato próprio; ocorre que - como tivemos a oportunidade de observar em meio a nossas incursões pelo direito romano - com a reforma justinianéia houve uma unificação das figuras do mandatário e do "procurator" ("verus"). Com isso, aos poucos se foi esvaziando a concepção da "procuratio" como negócio jurídico responsável pela atribuição de uma "obrigação de gestão" ao procurador; no entanto, a "obrigação de substituição" inerente ao mandato perseverou, de maneira que a índole gestória do resultado desta fusão acabou assumindo, paulatinamente, um caráter cada vez mais secundário.

Em contrapartida, o florescimento medieval de uma representação direta - admitida generalizadamente acabou por contribuir ainda mais para o incremento desta fissura na "causa-função" do tipo: o contrato de mandato perde aos poucos a sua feição gestória e assume preponderantemente o caráter de fundamento contratual da representação negocial (direta). Algumas "excrescências" acabam por militar contra esse sentido simplificador da "evolução" histórica do instituto: um exemplo acaba por ser o mandato sem 
representação, por meio do qual fica evidenciada a feição gestória do tipo, uma vez que retirada - pela natureza (jurídica) das coisas - do ambiente contemplado pelo intérprete a representação negocial direta que tanto impediu que se divisasse a verdadeira essência do tipo contratual objeto de nossos estudos. Ora, tomado em consideração este específico panorama evolutivo, parece-nos imprescindível uma abordagem bastante cuidadosa deste artigo 2914 do "Esboço", uma vez que nele radicam reminiscências de um mandato que, embora um tanto defasado - à vista da intensa influência romanística sobre a obra de A. TEIXEIRA DE FREITAS - acaba por assumir a função de mecanismo conciliador entre as novas exigências sociais (eficácia representativa direta e gratuidade tão somente "natural", por exemplo) e o conteúdo ético inexpugnável do tipo. Em suma: por mais que a "ciência" jurídica pretenda conceber o mandato como um contrato vizinho à locação de serviços, não há como se deixar de destacar a proximidade muito maior entre aquele tipo (D. 17 , 1) e outros dois modelos nos quais preponderavam as idéias de "confiança" e de "gestão colaborativa": o “depósito" (D. 16, 3) e a "sociedade" (D. 17, 2). Por uma apreciação sobre a "ordem" das matérias na elaboração do "Corpus Iuris Civilis", cf. V. SINAISKI, Vasili, Ordre des matières dans la législation de Justinien in Studi in memoria di Aldo Albertoni I, Padova, CEDAM, passim.

Ora, como desdobramentos da obrigação de prestação de contas (prevista, inicialmente, no artigo $2914,4^{\circ}$ do "Esboço") devem ser tomadas as regras estabelecidas nos artigos 2942, 2943 e 2944 da mesma codificação projetada. Pelo primeiro de tais dispositivos (artigo 2942) se prescreve o seu cabimento ordinário ao final da gestão, ainda que as contas também possam ser tomadas durante o curso da gestão; no entanto, ao jurista pareceu tamanho modo relevante tal obrigação que considerou ineficaz toda e qualquer cláusula exonerativa em contrário: "a obrigação que tem o mandatário de prestar contas de sua gerência (art. 2914, nº 4) será cumprida por ocasião de cessar o mandato, e antes de cessar sempre que o mandante o exija, ainda mesmo que por cláusula do contrato fosse relevado de prestá-las". No entanto, a fim de não prejudicar a relação de confiança já existente entre as partes convenentes, admitiu o pacto que isentasse o mandatário do dever implícito - de documentar os atos praticados durante o exercício de sua administração; é o sentido que nos parece defluir do artigo 2943 da mesmo anteprojeto ("essa cláusula reputar-se-á não escrita se pelas circunstâncias não se conhecer evidentemente que a intenção do mandante foi fazer ao mandatário uma doação. Não se proíbe, porém, estipular que, prestando suas contas, o mandatário não tenha obrigação de documentá-las"). E a fim de mitigar os rigores das abstrações excessivas, o autor do "Esboço" anteviu a existência de mandatos carregados de um vínculo de proximidade menos estreito entre as partes; neste caso, de acordo com o artigo 2944 "quando o mandatário houver recebido uma quantia designada para as despesas do mandato, ou convencionou recebê-la, com a cláusula de nada poder exigir além dela, ainda que as despesas a excedam, não terá obrigação de prestar contas do que realmente despendeu, nem o mandante poderá exigir a restituição de qualquer sobra". Trata-se de uma situação em que o mandato concreto se distancia do arquétipo do instituto, aproximando-se, pois, dos modelos bilaterais típicos (tais como a "compra e venda" e a "locação").

Observe-se que o dever de prestação de contas sempre foi tão caro à doutrina que a posição de A. TEIXEIRA DE FREITAS vertida no artigo 2942 acabou germinando em meio aos nossos intérpretes: T. FULGENCIO Alves Pereira, por exemplo, considerou ineficaz tal dispensa, uma vez que "a essência dos contractos não depende da vontade das partes" (Programmas cit. (nota 131), p. 139). Em idêntico sentido, cf. J. F. de LiMA, Curso cit. (nota 05), p. 585. M. I. CARVALHO DE MENDONÇA, por sua vez, evidencia - sem chegar a tal ponto - a importância de tal dever na medida em que considera seu adimplemento um pressuposto indispensável a qualquer espécie de demanda por parte do mandatário: "a obrigação de prestar contas é tão da essência do mandato que o mandatário nenhuma ação pode propor contra o mandante antes de lhas haver prestado" (Contratos cit. (nota 131), p. 220).

Como exemplo da projeção do dever de prestação de contas (tal qual disciplinado no "Esboço") no âmbito das fontes do direito civil brasileiro posteriores (legisladas ou simplesmente projetadas), cf. o art. 2285 do AntFS; o art. 1075 do AntCR; o art. 1451 do AntCB; o art. 1520 do AntCBRev; o art. 1301 do PCD n 1/1912; o art. 1301 do PSF no 269/1912; o art. 1301 do CC/1916; o arts. 643 e 666 do AntCM; o art. 611 do AntCMRev; o art. 680 do AntMR; o art. 667 do AntMRRev; o art. 677 do PCD nº 634/1975; e o art. 668 do CC/2002.

Note-se que pelo artigo 2914, $4^{\circ}$ do "Esboço" se comete ainda ao mandatário outro dever inafastável da eficácia regular do tipo: aquele relacionado à (re)transmissão das vantagens derivadas da gestão. Como visto, diante da admissão da eficácia representativa direta como regra inerente ao modelo, não aludiu o autor a um dever de "transmissão" daquilo que fora recebido em decorrência da execução da incumbência; prescreveu-se ao agente, simplesmente, a "entrega" dos resultados da gerência - que não lhe pertenceriam, por óbvio, em meio a um cenário no qual prevalecesse a eficácia representativa direta. E o dever de transmissão dos resultados também possui os seus naturais desdobramentos: além daquele relacionado ao resultado ilícito da gestão - previsto no artigo 2948 por nós já analisado - desponta, por exemplo, a obrigação de restituir instrumentos e materiais entregues para o regular desempenho da gerência, tal como estabelece o artigo 2946 
do "Esboço" ("o disposto no artigo antecedente, $\mathrm{n}^{\mathrm{o}} 1$, é extensivo aos títulos, documentos e papéis, que o mandante tenha confiado ao mandatário em virtude do mandato, mas não às cartas missivas que por ocasião do mandato lhe tenha escrito"); da mesma forma, as importâncias percebidas pelo mandatário não podem ter outro destino, via de regra, senão o patrimônio do mandante. É o que preceitua, por sua volta, o artigo 2945 da mesma codificação projetada: "a obrigação que tem o mandatário de entregar o recebido em virtude do mandato (art. 2914, $\mathrm{n}^{\circ}$ 4) compreende: $1^{\circ}$. Tudo o que o mandante the confiou, e de que não dispôs por sua ordem, salvo o legislado no artigo antecedente; $2^{\circ}$. Tudo o que recebeu de terceiros, embora o recebesse sem direito; $3^{\circ}$. Todos os lucros resultantes do negócio encarregado, a não ter havido estipulação em contrário".

Observe-se que, neste particular, a posição de M. I. CARVALHO DE MENDONÇA é consideravelmente diferente daquela que se depreende do artigo 2948 do "Esboço": "se, porém, receber mais do que o devido por simples erro de cálculo ou de conta, então o pagamento não era intencionalmente dirigido ao mandante, o excesso é involuntário e, portanto, não deve aproveitar ao mesmo mandante e sim ser reposto pelo mandatário ao terceiro prejudicado" (Contratos cit. (nota 131), p. 221).

Do mesmo modo, como reflexos da disciplina - constante do "Esboço" - relacionada à transmissão dos resultados gestórios, cf. o art. 1075 do AntCR; o art. 1451 do AntCB; o art. 1520 do AntCBRev; o art. 1301 do PCD no 1/1912; o art. 1301 do PSF no 269/1912; o art. 1301 do CC/1916; o art. 643 do AntCM; o art. 611 do AntCMRev; o art. 680 do AntMR; o art. 667 do AntMRRev; o art. 677 do PCD no 634/1975; e o art. 668 do $\mathrm{CC} / 2002$.

Por fim, devem ser analisadas algumas disposições do "Esboço" de Código Civil relacionadas à disciplina do excesso praticado pelo "mandatário". Note-se que o Código Comercial disciplinou a questão do excesso, por meio de seu artigo 163; no entanto, teve em conta simplesmente as relações mantidas entre o terceiro e o falso - "representado". Não conferiu maior atenção às vicissitudes relacionadas à posição do "representante". Neste passo, a contribuição do "Esboço" é bastante significativa, uma vez que por meio de cinco artigos (2956, 2957, 2958, 2955 e 2953) disciplinou - sob a perspectiva meramente projetada - a questão, com decisivos reflexos quanto à orientação das fontes do direito civil brasileiro que lhe sucederam.

Assim, no artigo 2956 do "Esboço" se atribui ao terceiro - que trata com o "representante" - o direito de exigir a exibição do instrumento de outorga de poderes representativos ("procuração"): "terceiros com quem o mandatário queria contratar em nome do mandante têm direito de exigir que se lhes apresente o original da procuração e carta de ordens ou instruções a que ela se refira. Ordens reservadas ou instruções secretas do mandante não terão influência alguma sobre direitos de terceiros que contrataram em vista da procuração, ordens ou instruções que lhe foram apresentadas". Observe-se, pois, que a matéria não se circunscreve ao âmbito da relação mantida entre "mandante" e "mandatário"; assim, extravasa os limites do contrato de mandato e acaba por invadir a esfera da chamada representação negocial. Ora, o problema está no fato de que A. TEIXEIRA DE FREITAS não distinguia - com a clareza que entendemos necessária - a dissociação entre o negócio bilateral de incumbência e o ato de outorga de poderes representativos; por isso, acabou por prescrever - a nosso ver, indevidamente - que tal prerrogativa do terceiro se estendia até o limite das instruções conferidas por meio do contrato de mandato. Com isso, parece-nos que devassou - mesmo que inconscientemente - a esfera da relação de incumbência; ainda que, hesitante, tenha se referido a "instruções secretas" na parte final do preceito. Neste particular, C. BEVILÁQUA também alude a "instruções internas" ineficazes perante terceiros (Codigo cit. (nota 05), p. 51).

À vista dos reflexos probatórios das diferentes formas atreladas à celebração do mandato, o autor prescreveu não apenas diversos meios de comprovação do negócio de outorga (artigo 2957), como também um procedimento específico para a averiguação da identidade do mandatário "suspeito"; de fato, tal disciplina foi estabelecida no artigo 2958 do "Esboço": "se o mandatário for pessoa suspeita, a parte com quem ele tenha de contratar também pode exigir a prova da identidade de sua pessoa. Pode igualmente exigir certidão de vida do mandante, tendo justo receio de que seja falecido". Ora, na parte final deste preceito se encontra a fonte de uma singular contradição no âmbito da obra de A. TEIXEIRA DE FREITAS; pois este autor, em acréscimo (constante da terceira edição, de 1876) à nota 34 ao artigo 473 da Consolidação das Leis Civis considerava "absurda" a exigência das chamadas "certidões de vida" do mandante (A. TEIXEIRA DE FREITAS, Consolidação cit. (nota 16), p. 331).

Perceba-se que, como mencionado logo acima, o artigo 2956 do "Esboço" atribuía um direito ao terceiro que viesse a tratar com o representante; não conferia um dever de exibição - independente - a este último, tal como o faz o artigo 118 do Código Civil vigente. Esta questão, ao contrário do que pode parecer, não resulta em elucubração cerebrina desprovida de reflexos práticos bastante contundentes; pois o artigo 2955 do "Esboço" atribui ao agente a responsabilidade pelo desconhecimento da extensão dos poderes conferidos ao representante ("ficará, porém, pessoalmente obrigado, e poderá ser demandado pelo cumprimento do contrato, ou pela indenização das perdas e interesses, se a parte com quem contratou não sabia dos poderes do mandato"). E se tal preceito guarda perfeita correspondência com a diretriz eleita por nosso legislador de 
2002 (artigo 118), parece descompassada com o direito subjetivo conferido pelo artigo 2956 da mesma codificação projetada.

De todo modo, pelos reflexos deste arcabouço no âmbito das fontes posteriores do direito civil brasileiro, cf. o art. 2281 do AntFS; o art. 1081do AntCR; o art. 1455 do AntCB; o art. 1525 do AntCBRev; o art. 1305 do $\mathrm{PCD} \mathrm{n}^{\circ}$ 1/1912; o art. 1305 do PSF no 269/1912; o art. 1305 do CC/1916; o art. 43 do AntOPH; os arts. 41 e 646 do AntCM; os arts. 41 e 613 do AntCMRev; o art. 119 do AntPGMA; o art. 117 do AntMR; o art. 116 do AntMRRev; o art. 116 do PCD n $634 / 1975$; e o art. 118 do CC/2002. Note-se que a questão foi reconduzida pelo Anteprojeto de Parte Geral do Código das Obrigações (de Orosimbo Nonato, Philadelpho Azevedo e Hahnemann Guimarães) ao âmbito da representação - aspecto em que posteriormente vacilou, por vezes, a legislação projetada brasileira rumo à codificação civil deste século XXI. Voltaremos ao assunto mais adiante.

Por fim, cumpre-nos apenas anunciar um assunto que será abordado em maiores detalhes com a análise do Anteprojeto de Clóvis Beviláqua: o artigo 2953 do "Esboço" de Código Civil imputa ao próprio terceiro a responsabilidade por sua ineficiência quanto ao controle dos poderes do "representante": "quando figurar em nome do mandante fora do mandato e o mandante não ratificar o contrato, ou não se der algum dos casos do art. 2933, será nulo o contrato, se a parte com quem o mandatário contratou sabia dos poderes do mandato". Neste passo, tal orientação efetivamente se revela coerente com o "supra" referido artigo 2956 do "Esboço". No entanto, pede-se ao leitor que redobre sua atenção quanto ao conseqüente jurídico preconizado por A. TEIXEIRA DE FREITAS nesta hipótese: a "nulidade" do contrato. Com efeito, como teremos a oportunidade de reiterar mais adiante, esta não foi a solução adotada pelo legislador brasileiro no âmbito de nossos dois Códigos Civis. De todo modo, tal matéria será objeto de considerações logo à frente.

Pela doutrina produzida - a respeito da matéria objeto da presente nota de rodapé - sob a égide do Código Civil de 1916, cf. A. Beviláqua, Codigo cit. (nota 131), pp. 359-360; A. do Valle Siqueira, Codigo cit. (nota 131), pp. 433-434; A. CHAVES, Lições cit. (nota 131), pp. 302-303; A. L. da CÂMARA LEAL, Manual cit. (nota 131), pp. 105-106; A. MARMITT, Mandato cit. (nota 131), pp. 196-197, 202-206 e 210-211; A. WALD, Curso cit. (nota 131), p. 305; C. BEviláQua, Codigo cit. (nota 05), pp. 47-48 e 51; D. ARrudA MIRANDA, Anotações cit. (nota 131), pp. 378-381; E. EsPíNola, Dos contratos nominados cit. (nota 12), pp. 359-362; E. PEssôA, Da procuração cit. (nota 131), pp. 9-11; F. C. PONTES DE MIRANDA, Fontes cit. (nota 16), pp. 332-333; F. R. LeITE FILHo, Curso cit. (nota 05), pp. 349-351; F. C. P. RodRIGUeS - L. da S. Loureiro FilHo, Código cit. (nota 131), pp. 887-888; F. C. de SAn TIAGo DanTas, Programa cit. (nota 05), pp. 373-376; F. K. COMPARATO, Aparência cit. (nota 131), pp. 41-42; G. LACERDA, Obrigações cit. (nota 131), pp. 189-216 e 223-235; J. L. ALves, Código cit. (nota 05), pp. 364-365 e 368; J. F. de LiMA, Curso cit. (nota 05), pp. 579, 585 e 587; J. GonÇAlVES MAIA, Theoria cit. (nota 131), p. 25; J. M. de CARVAlHO SANTOS, Codigo cit. (nota 05), pp. 250-256 e 265-268; J. de SAMPaIo Doria, Codigo cit. (nota 131), pp. 9192; L. Leite, Codigo cit. (nota 131), pp. 431-432; L. MATTIETTO, A representação cit. (nota 131), p. 67; L. R. de Freitas Gomes, Contrato cit. (nota 131), p. 296; M. C. do. A. KROETZ, A representação cit. (nota 41), pp. 66-68 e 77; M. I. CARVAlHo De MendonÇa, Contratos cit. (nota 131), pp. 220-222; M. Paulo MerêA, Codigo cit. (nota 131), pp. 407-408; M. M. de SERPA LOPES, Curso cit. (nota 05), pp. 267, 273-275 e 285; O. GOMES, Contratos cit. (nota 23), pp. 350; O poder cit. (nota 131), p. 7; R. L. FRANÇA, Manual cit. (nota 05), pp. 193-194; S. VAMPRÉ, Manual cit. (nota 131), pp. 135-137; T. FUlGENCIO Alves Pereira, Programmas cit. (nota 131), pp. 138-140; T. PRATES DA FONSECA, Noções cit. (nota 131), p. 198.

Por sua vez, pela doutrina produzida à vista do Código Civil de 2002, cf. A. Villaça AzEvedo, Código Civil cit. (nota 04), pp. 105-107; A. VillaÇA AZEVEDO - S. de S. Venosa, Código cit. (nota 02), pp. 111 e 360; A. de Assis, Contratos cit. (nota 131), pp. 83-85; CAIO MÁrIo da Silva Pereira, Instituições cit. (nota 06), pp. 619-620; Instituições cit. (nota 02), pp. 405-410; C. A. BITTAR FILHO - M. S. BITTAR, Código cit. (nota 02), p. 24; C. E . N. CAMillo - G. M. TAVALERA - J. S. FuJita - L. A. SCAVone Júnior (coords.), Comentários cit. (nota 02), pp. 227-228 e 591; C. L. BUENO DE GODOY, Do mandato cit. (nota 131), pp. 624 e 628; C. R. GonÇAlves, Direito cit. (nota 131), pp. 404-409; F. UlHOA Coelho, Curso cit. (nota 06), pp. 317-318; Curso cit. (nota 02), pp. 302; F. AMARAL, Direito cit. (nota 131), pp. 458 e 466; M. G. MAIA JÚNIOR, A representação cit. (nota 04), pp. 43-44; M. C. do. A. KROETZ, A representação cit. (nota 41), p. 35; Maria Helena Diniz, Curso cit. (nota 06), pp. 446; Curso cit. (nota 02), pp. 353 e 370-372; N. C. B. CAMPello, Da representação cit. (nota 131), pp. 399 e 412; N. G. B. Dower, Curso cit. (nota 06), p. 298; Curso cit. (nota 02), pp. 292-293; N. NERY JUNIOR - R. M. de ANDRADE NERY, Código cit. (nota 02), pp. 235 e 476; N. DuARTE, Da representação cit. (nota 131), p. 102; O.GoMES, Contratos cit. (nota 23), pp. 425-430; O. R. B. Sandoval, Do mandato cit. (nota 131), pp. 583 e 616-617; R. Lotufo, Código cit. (nota 02), pp. 332-335; R. FiuZa (coord.), Novo Código cit. (nota 02), pp. 124 e 619-620; S. de S. Venosa, Direito cit. (nota 06), pp. 339-341; Direito cit. (nota 02), p. 259; S. L. F. da Rocha, Curso cit. (nota 02), p. 299; Silvio RodRIGUes, Direito cit. (nota 02), pp. 293-296; V. RÁo, Ato Jurídico cit. (nota 131), p. 245; WASHINGTON De Barros Monteiro, Curso cit. (nota 06), p. 221; Curso cit. (nota 02), pp. 277-280. 
$\S$ 165. O "Esboço" de Código Civil e os deveres do mandante. Além da remuneração do mandatário (artigo 2960, $4^{\circ}$ ), ao mandante incumbem outros três deveres fundamentais: a) garantir a disponibilidade dos meios indispensáveis à execução da incumbência (artigo 2960, 10 ); b) reembolsar - mediante a observância de juros correntes desde a data do desembolso (artigo 2960, $3^{\circ}$ ) - os adiantamentos e despesas efetuados pelo agente (artigos 2960, $2^{\circ}$ e 2964); e c) indenizar prejuízos que lhe sejam imputáveis, experimentados pelo mandatário durante o curso da gestão (artigos $2960,5^{\circ}$ e 2980 ). No entanto, tais obrigações não devem ser tomadas por absolutas, como bem demonstram outras disposições responsáveis por uma série de mitigações ao modelo ora apresentado: assim, salvo se demonstrada a sua imprescindibilidade, a substituição do mandatário não obriga o mandante quanto à remuneração daqueles que lhe fizeram as vezes (artigo 2979); da mesma forma, não exsurge dever de indenizar nos casos de culpa do próprio agente (artigo 2982) e de força maior superveniente à incumbência remunerada (artigo 2981). Por sua vez, no "Esboço" de Código Civil se pretende incrementar o sinalagma funcional já introduzido no sistema jurídico brasileiro algum tempo antes (pelo artigo 144 do CCom): ao mesmo tempo em que se prevêem específicas despesas de antecipação compulsória pelo mandatário (artigo 2961), estabelece-se que, quanto às demais, a ausência de regular provisão lhe facultaria a suspensão do desempenho das atribuições contratuais; não lhe podendo ser imputado, por via de consequiência, qualquer prejuízo defluente do eventual adimplemento tardio - ou mesmo da inexecução - da incumbência confiada (artigo 2962) $)^{142}$.

\footnotetext{
${ }^{142}$ Já tivemos a oportunidade de nos manifestar, em ocasião anterior (nota 134), a respeito do dever de provisão do mandante - bem como das projeções de um "sinalagma funcional" sobre as diversas espécies de valores que integram a retribuição devida pelo principal ao seu agente.

Contudo, cumpre-nos ressaltar a existência de duas espécies de prescrições relacionadas ao assunto, merecedoras de consideração em separado, à vista de sua diferente conjugação com os fundamentos do tipo contratual objeto de nossas investigações.

Em primeiro lugar, deve-se ressaltar que o dever de provisão do mandante - diretamente vinculado à excepcional suspensão de execução da incumbência por parte do mandatário - encontra-se mitigado, em seu rigor, pela regra constante do artigo 2961 do "Esboço", na qual se estabelece que o mandatário deve, nalgumas ocasiões, efetuar despesas às suas próprias expensas, uma vez que as circunstâncias - ou mesmo a vontade expressa das partes - justifiquem o afastamento do regime geral prevalecente quanto ao instituto: "o mandatário não tem obrigação de fornecer quantia alguma para a execução do mandato, salvo: $1^{\circ}$. Se a isso expressamente se obrigou; $2^{\circ}$. Se as despesas forem tais, que, por sua natureza ou segundo o uso do lugar, não devam ser pagas pelo mandante senão depois de feitas ou depois de executado o mandato; $3^{\circ}$. Se forem módicas e urgentes". Ora, parece-nos oportuno apenas um reparo ao dispositivo ora analisado: em sua terceira alínea prevê o dever de antecipação - por parte do mandatário - caso as despesas sejam módicas "e" urgentes; ora, como conciliar esta disposição com a atribuição de um dever mais gravoso àquele que sequer aceitou a incumbência (artigo 2913)? Parece-nos, pois, que em lugar da conjunção aditiva "e" deveria ter figurado no dispositivo a alternativa "ou" - que em nada desnaturaria a estrutura do tipo em questão.
} 
A regra contida no artigo 2961 se completa, ainda, pelo preceito constante do artigo 2964 do "Esboço", o qual - de maneira absolutamente coerente com o preceituado a respeito do termo inicial para a fluência dos juros relativos a quantias desembolsadas voluntariamente pelo mandatário - considera como antecipações do mandatário todas as verbas postas por este à disposição do mandante (ou de terceiros), desde o momento em que estejam a serviço do principal: "são adiantamentos do mandato, não só as quantias efetivamente desembolsadas pelo mandatário para pagar aos credores do mandante, e em geral para a execução do mandato, como as que, por ordem do mandante, houver posto à sua disposição, ou à disposição de alguém, ainda que desde logo não as desembolse". Nada mais natural - e coerente com o circuito financeiro diferenciado que subjaz ao contrato de mandato.

Além disso, merecem consideração especial as regras limitadoras do dever de retribuição do mandante. Como já tivemos a oportunidade de observar anteriormente, para os efeitos deste estudo, o conceito de "retribuição" corresponde a um gênero conglobante das seguintes espécies: "remuneração" (salário ou honorário), "reembolso" (de despesas) e "reparação" (de prejuízos). Ora, o artigo 2960 alcança todas essas verbas com suas cinco alíneas: "fica obrigado o mandante em relação ao mandatário: $1^{\circ}$. A provê-lo oportunamente de todos os meios necessários para a execução do mandato; $2^{\circ}$. A pagar-lhe os adiantamentos e despesas que por motivo do mandato tenha feito; $3^{\circ}$. A pagar-lhe juros desde o dia em que houver feito tais adiantamentos e despesas; $4^{\circ}$. A pagar-lhe a retribuição de seu serviço, se o mandato for oneroso; $5^{\circ}$. A indenizá-lo dos prejuízos que por sua culpa lhe ocasionar ou que lhe resultarem da execução do mandato".

Especificamente a respeito dos desembolsos efetuados pelo mandatário, cumpre que tenhamos em mente a previsão constante do artigo 2914, $2^{\circ}$ do "Esboço", no sentido de que o mandato, salvo avença em contrário, deve ser executado diretamente pelo mandatário. Assim, explica-se o teor do artigo 2979, por meio do qual se estabelece que as despesas relacionadas à substituição do agente não podem ser exigidas do mandante, salvo se lhe tiverem sido atribuídas convencionalmente - ou se resultar imprescindível a delegação, como meio garantidor da própria execução eficiente da incumbência ("não tem obrigação o mandante de pagar retribuições ou comissões, que o mandatário tenha pago a pessoas que o substituíram na execução do mandato, a menos que a substituição fosse indispensável").

Já no que concerne ao dever de indenizar os prejuízos experimentados pelo agente, despontam aplicáveis as regras estabelecidas nos artigos 2980, 2981 e 2982 do "Esboço". A primeira delas (artigo 2980) simplesmente adapta ao contexto específico do mandato o princípio genérico da responsabilidade por culpa: "ou o mandato seja gratuito ou oneroso, incumbe ao mandante indenizar o prejuízo que por sua culpa tenha ocasionado ao mandatário na execução dele". Por meio da derradeira (artigo 2982), por sua vez - mantendo a lógica informativa do sistema - inverte-se a previsão, a fim de isentar mandante sempre que houver culpa do próprio mandatário ("nenhum direito compete ao mandatário para haver do mandante prejuízos ocasionados pela execução do mandato, sempre que tais prejuízos resultarem de sua própria culpa"). No entanto, A. TEIXEIRA DE FREITAS não lançou mão de similar naturalidade ao se debruçar sobre os princípios reguladores da relação jurídica defluente do contrato de mandato: "confiança", "gestão colaborativa" e "instrumentalidade".

De fato, a idéia de uma gestão colaborativa - em que todo o benefício da administração efetuada pelo mandatário compete ao mandante - acarreta a necessária atribuição ao principal de todo o risco relacionado à execução da incumbência (inclusive quanto às hipóteses de caso fortuito e força maior). No entanto, em cláusula exonerativa que nos parece em descompasso com a contextura eficacial peculiar ao tipo, o autor do "Esboço" preceituou, no artigo 2981, que "se o prejuízo resultar de força maior, o mandante só terá obrigação de indenizá-lo quando o mandato for gratuito. Reputar-se-á prejuízo ocasionado pela execução do mandato tão-somente aquele que o mandatário não teria sofrido, se não houvesse aceitado o mandato".

A primeira parte do preceito nos parece inadmissível pois se funda em princípio expressamente repelido no bojo deste estudo: a presença de uma remuneração não nos parece fator indicativo da bilateralização da relação jurídica contratual decorrente; a contextura eficacial básica do instituto independe de quaisquer elementos de caráter eventual. Se assim não o fosse não haveria um "mandato" (genérico), mas apenas "mandato oneroso" ao lado do "mandato gratuito" (tal como se dá na relação entre "mútuo" e "comodato"). No entanto, os contornos eficaciais elementares do tipo não podem variar segundo aspectos meramente contingentes. Ora, como a remuneração, em nosso direito, nunca foi elevada à essência do contrato de mandato, não nos parece que lhe seja possível atingir a "nota típica" - "causa-função" - do instituto, alcançando a disposição de seus efeitos regulares - segundo a conformação idealizada, em termos genéricos, pelo legislador.

A segunda parte da disposição, contudo, nos parece bastante oportuna, uma vez que oferece solução - por meio de uma fórmula sintetizadora - a um problema que assombra a própria doutrina contemporânea dedicada ao tema; com efeito, deverá o mandante ser responsabilizado por todo e qualquer prejuízo experimentado pelo mandatário por "ocasião" da execução do ajuste? Ou tão somente por aquele que tiver por "causa" o cumprimento da atribuição? 
Em solução que nos parece retrógrada e desconforme à "nota típica" do instituto, O. GoMES assevera que "a sanção imposta ao mandante, quando culpa nenhuma lhe cabe nas perdas, é injustificável. A circunstância de ter, no seu interesse, posto em atividade o mandatário, não é suficiente para fundamentar o dever de indenizar" (Contratos cit. (nota 23), p. 351). Em sentido oposto, WASHINGTON DE BARROS MONTEIRO considera a distinção sem significado, preconizando a responsabilidade do principal em toda hipótese de prejuízo do agente (Curso cit. (nota 02), p. 284) - no que parece ser seguido por S. L. F. da RoCHA (Curso cit. (nota 02), p. 302). Note-se que tal orientação já era preconizada em meados do século XVIII por J. M. da TRINDADE por se tratar da solução "mais conforme á boa razão" (Collecção cit. (nota 131), p. 32).

M. I. CARVAlHo DE MENDONÇA, por sua vez, adota solução menos radical, profundamente influenciada pelas circunstâncias do caso concreto: "o direito romano fazia certas distinções que entram na concepção moderna do instituto. Assim, se o mandatário sofreu um incidente fortuito, seja: um assalto, um naufrágio, um incêndio, etc., deve-se examinar se as quantias que consigo levava eram exigidas e necessárias para a execução do mandato. Em tal caso, deve ser indenizado. Em caso contrário, há um verdadeiro fortuito que não vincula o mandante a indenizar (...) vê-se, pois, que as perdas a serem indenizadas são restritas ao sacrifício diretamente suportado na execução do mandato; não, porém, às perdas pessoais possíveis na ocasião de o executar e que com êle não tinham relação direta" (Contratos cit. (nota 131), pp. 234-235).

Esta última nos parece, de fato, a melhor orientação. Aliás, M. M. de SERPA LOPES observa, com argúcia, que "essa responsabilidade do mandante perdura mesmo após a extinção do mandato, desde que se trate de um dano provadamente ligado à execução do mandato" (Curso cit. (nota 05), p. 280). Pense-se, por exemplo, na hipótese do mandatário que se acidenta após diligência devotada à prestação final de contas a seu mandante.

Pela abordagem da matéria concernente à indenização das perdas experimentadas pelo agente durante a execução da incumbência, no âmbito das fontes primárias do direito civil brasileiro (legisladas ou meramente projetadas), cf. o art. 1084 do AntCR; o art. 1460 do AntCB; o art. 1530 do AntCBRev; o art. 1312 do PCD $n^{\circ}$ 1/1912; o art. 1312 do PSF no 269/1912; o art. 1312 do CC/1916; o art. 654 do AntCM; o art. 621 do AntCMRev; o art. 689 do AntMR; o art. 677 do AntMRRev; o art. 687 do PCD no 634/1975; e o art. 678 do CC/2002. Observe-se que durante a tramitação do Anteprojeto de Clóvis Beviláqua a orientação do legislador a respeito do tema foi ligeiramente alterada, com a ampliação da hipótese de ressalva (ao dever de indenizar): além da culpa do agente, também julgou oportuno o legislador isentar o principal quando se tivesse constatado o "excesso" durante a execução da incumbência (art. 1530 do AntCBRev). Orientação que prevalece ainda hoje, de acordo com o Código Civil vigente (art. 678 do CC/2002).

Pela doutrina produzida sob a égide do Código Civil de 1916, cf. A. BEVILÁQUA, Codigo cit. (nota 131), p. 361 (asseverando, a nosso ver absurdamente, que ao mandatário incumbiria o dever de "provar que está isento de culpa"); A. do VAlle SiQueIRA, Codigo cit. (nota 131), pp. 436; A. ChAVES, Lições cit. (nota 131), pp. 307-308; A. L. da CÂMARA LeAL, Manual cit. (nota 131), p. 108; A. MARMITT, Mandato cit. (nota 131), p. 194; A. WALD, Curso cit. (nota 131), p. 305; C. BEVILÁQUA, Codigo cit. (nota 05), p. 58; D. ARRUDA MirAndA, Anotações cit. (nota 131), p. 383; E. EsPínOla, Dos contratos nominados cit. (nota 12), p. 365; E. PessôA, Da procuração cit. (nota 131), p. 13; F. C. PONTES DE MiRANDA, Fontes cit. (nota 16), p. 333; F. R. LeITE Filho, Curso cit. (nota 05), p. 351; J. L. Alves, Código cit. (nota 05), pp. 373-374; J. F. de LiMA, Curso cit. (nota 05), pp. 590-592; J. M. de CARvalho SANTOS, Codigo cit. (nota 05), pp. 288-290; J. de SAMPAIO Doria, Codigo cit. (nota 131), pp. 91-92; L. LeITE, Codigo cit. (nota 131), p. 434; L. R. de FreITAS Gomes, Contrato cit. (nota 131), p. 297; M. C. do. A. KROETZ, A representação cit. (nota 41), p. 68; M. G. MAIA JÚNIOR, A representação cit. (nota 04), p. 140; M. I. CARVALHO DE MENDONÇA, Contratos cit. (nota 131), pp. 234-236; M. PAUlo MerÊA, Codigo cit. (nota 131), p. 409; M. M. de SERPA LoPes, Curso cit. (nota 05), pp. 277-280; O. GOMES, Contratos cit. (nota 23), pp. 351; R. L. FRANÇA, Manual cit. (nota 05), p. 195; S. VAMPRÉ, Manual cit. (nota 131), pp. 140-141; T. FUlGENCIO Alves Pereira, Programmas cit. (nota 131), p. 141.

No que toca, por sua vez, à doutrina produzida a propósito do Código Civil de 2002, cf. A. VILlAÇA AZEVEDo - S. de S. Venosa, Código cit. (nota 02), p. 364; A. de Assis, Contratos cit. (nota 131), pp. 103105; CAIO MÁrio da Silva Pereira, Instituições cit. (nota 02), p. 409; C. E . N. CAMILlO - G. M. TAVALERA J. S. FujitA - L. A. SCAvone JúnioR (coords.), Comentários cit. (nota 02), p. 595; C. L. Bueno DE GodoY, Do mandato cit. (nota 131), pp. 632-633; C. R. GonÇALVES, Direito cit. (nota 131), p. 411; F. UlHOA Coelho, Curso cit. (nota 02), p. 320; F. AMAral, Direito cit. (nota 131), p. 467; MARIA Helena DinIZ, Curso cit. (nota 02), p. 373; N. G. B. Dower, Curso cit. (nota 02), p. 294; N. NeRY JUNIOR - R. M. de Andrade Nery, Código cit. (nota 02), p. 478; O. R. B. SANDOVAl, Do mandato cit. (nota 131), p. 623; R. FiUZA (coord.), Novo Código cit. (nota 02), p. 628; S. de S. VENOSA, Direito cit. (nota 02), p. 261; S. L. F. da Rocha, Curso cit. (nota 02), p. 301; SILVIO RodRIGUeS, Direito cit. (nota 02), p. 298; WASHINGTON DE BARros MONTEIRO, Curso cit. (nota 02), pp. 283-284. 


\section{$\S$ 166. O "Esboço" de Código Civil e algumas peculiaridades da eficácia}

do contrato de mandato. No "Esboço" de Código Civil estão articuladas disposições que revelam ao estudioso certas peculiaridades do tipo contratual objeto de nossas investigações. Assim, tomada em consideração a "instrumentalidade" - e o âmbito de eficácia - do negócio jurídico de outorga de poderes representativos, preceitua-se no artigo 2892 sua simetria formal em relação ao ato objeto da própria incumbência; de sua parte, por meio dos artigos 2997 e 2998 se reconhecem efeitos similares aos do negócio de outorga na hipótese de declaração do representado dirigida diretamente ao terceiro naturalmente com efeitos restritos à atuação do representante junto a este. Além disso, corroborando-se a idéia de uma "gestão colaborativa" subjacente ao tipo, é regulada a concorrência entre o mandante e o mandatário pelo mesmo objeto: assim, celebrados dois negócios à custa da boa-fé de todos os envolvidos, preserva-se o ajuste ultimado em primeiro lugar, respondendo o principal perante o terceiro com quem fora celebrada a segunda contratação (artigos 2999 e 3000); em contrapartida, em caso de má-fé do mandatário, é este quem há de suportar todos os efeitos prejudiciais do negócio concluído - em virtude da própria frustração da "confiança” inerente à relação atributiva (artigo $3000)^{143}$.

143 Já tivemos a oportunidade de nos manifestar anteriormente a respeito da evolução do "princípio da simetria" no direito brasileiro (nota 139). De toda forma, cumpre-nos destacar aqui que o artigo 2892 corresponde à primeira consagração da diretriz no âmbito de nossas fontes exclusivamente nacionais. Além disso, merece destaque a terminologia adequada utilizada pelo A. TEIXEIRA DE FrEITAS, alusiva à "procuração" e não ao "mandato" ("este Código exige procuração por instrumento público, sempre que o objeto do mandato for qualquer dos atos para os quais a lei decreta exclusivamente, ou com pena de nulidade, a forma de escritura pública (arts. 1244, 1318, 1580, 1630, 1657, 1929, 2150 e 2243)"). Pela projeção de tal disposição no âmbito das fontes do direito civil brasileiro subseqüente (notadamente o art. 2267 do AntFS) assim como pela bibliografia produzida a respeito do tema - cf. as referências lançadas na mencionada nota de rodapé anterior (nota 139).

Por sua vez, no "Esboço" pode ser encontrada uma espécie de reminiscência do ato de investidura do "procurador" praticado diretamente pelo principal em face de terceiros. A situação é relativamente diversa da tradicional, uma vez que ordinariamente o instrumento do negócio de outorga de poderes fica sob custódia do agente, que o apresenta (ele próprio) a terceiros. Daí a razão pela qual O. GOMES considera insustentável a rejeição do terceiro como destinatário do negócio de outorga de poderes: "tanto é destinatário o terceiro que a procuração só se torna eficaz quando procurador lhe transmite a sua condição, agindo, ao transmiti-la, na qualidade de núncio" ( $O$ poder cit. (nota 131), p. 7). No entanto, referimo-nos à investidura do agente por ato do principal transmitido diretamente por este último ao conhecimento de terceiros. A respeito do assunto, o "Esboço" contém duas disposições específicas: uma voltada à declaração escrita ("artigo. 2997. se alguém declarar por escrito a terceiro ter encarregado a certa pessoa um negócio designado, ficará obrigado pelo que em seu nome for feito entre essa pessoa e o terceiro a quem fez a declaração, ainda que a essa pessoa não desse procuração") e outra devotada à participação verbal ao terceiro ("artigo 2998. mas, se da declaração for verbal, o declarante só ficará obrigado, quando o terceiro a quem a fez entregou em virtude dela alguma coisa à pessoa indicada como mandatário"). Conquanto nenhum destes preceitos tenha sido aproveitado em meio às nossas fontes do direito civil subseqüente, merece destaque a alusão de J. GONÇALVES MAIA ao assunto: "a carta que se refere a um terceiro e a quem naturalmente foi communicado o seu conteúdo, já não conserva esse caracter secreto, maxime se a vontade nella expressa já teve começo de execução na incumbência por 


\section{§ 167. O "Esboço" de Código Civil e a cessação da eficácia do mandato. A}

cessação dos efeitos do mandato foi objeto de uma municiosa disciplina articulada no "Esboço" de Código Civil. Por um lado, foi conferida especial atenção à tutela dos interesses de terceiros, pois ao mesmo tempo em que se tornaram insuscetíveis de prejuízo por força de causa extintiva que não lhes tenha sido adequadamente noticiada (artigos 3014 e 3015), facultou-se àqueles últimos, em caráter exclusivo, a desistência quanto aos contratos celebrados - na presença do mandatário - após a extinção do liame gestório (artigos 3012 e 3013). Além disso, efetuou-se uma abordagem cuidadosa dos negócios de "renúncia" e de "revogação": sobre o primeiro, tanto se previu o seu livre exercício nas hipóteses de "justa causa" (artigo 3032) - afora as quais poderia exsurgir um correspondente dever de indenizar (artigo 3034) - quanto se qualificou como "negotiorum gestio" os atos de prosseguimento do mandato praticados após a denúncia do mandatário (artigo 3035). Já no que concerne à revogação, além de sua expressa aplicabilidade à variante onerosa do tipo (artigo 3023), foram previstas as suas modalidades expressa e tácita (artigo 3024) - tendo merecido destaque, inclusive, o efeito caducificante da nomeação de um novo agente (artigo 3025). Note-se que não passou despercebida a Augusto Teixeira de Freitas a eventual irrevogabilidade do "mandato" (artigos 3023 e 3031); a qual, em alguns casos, foi expressamente relacionada à irrenunciabilidade correspondente (artigo 3036). Além disso, foram abordados alguns aspectos pontuais relacionados ao tipo contratual referido - tais como o dever de restituição do instrumento

parte do terceiro a quem a carta se refere. Assim, a carta a um amigo, ou comittente, em que se diz que seja incumbido um terceiro de certo negocio, não pode deixar de fazer prova do mandato e produzir effeito juridico" (Theoria cit. (nota 131), pp. 32-33). Impossível a este pesquisador não recorrer à "actio quod iussu" romana.

Por fim, o "Esboço" disciplinou em dois dispositivos a hipótese de concorrência entre o mandante e o mandatário para a concatenação do objeto da gestão (artigos 2999 e 3000). Em determinados contextos pode resultar das circunstâncias que o mandante pretende reservar a si próprio a faculdade de intentar o objeto do mandato - conquanto tal iniciativa não deva ser tomada como fator determinante da extinção do contrato de mandato. O artigo 2999 se volta ao âmbito externo do fenômeno, concernindo propriamente à representação, e não è relação derivada do negócio bilateral de incumbência ("contratando duas pessoas sobre o mesmo objeto, uma com o mandatário e outra com o mandante, e não podendo subsistir os dois contratos, subsistirá o que for de data anterior"). Por sua vez, o artigo 3000 tem em mira a relação mantida entre as partes do negócio de atribuição, à vista da boa-fé caracterizadora do comportamento do agente: "no caso do artigo antecedente, se o mandatário contratou de boa-fé o mandante será responsável pelo prejuízo causado a terceiro cujo contrato não subsistir. Se contratou de má fé, isto é, tendo já sido prevenido pelo mandante, só ele será responsável por tal prejuízo".

Tratar-se-ia se mero exercício estéril por parte de A. TEIXEIRA DE FREITAS, sem qualquer repercussão prática e reflexos futuros? Pela repercussão prática da questão, sugere-se ao leitor que confronte a Resolução de 07 de agosto de 1824 e o Aviso $\mathrm{n}^{\circ} 229$ de 23 de julho de 1858, ambos contidos na coletânea de J. M. da TRINDADE (Collecção cit. (nota 131), pp. 180-182 e 352-353). Já no que concerne aos reflexos futuros, cf. o art. 663 do AntCM; e o art. 629 do AntCMRev. Tais dispositivos projetados revelam a apreciação excessivamente simplificadora do concurso do principal, tomado indiscriminadamente como causa extintiva do contrato de mandato. 
do negócio de outorga de poderes representativos (artigo 3017) e a perduração excepcional do vínculo em caso de morte - ou incapacidade superveniente - de uma das partes (artigos 3038, 3039, 3040 e 3042). Merece destaque, finalmente, a especial cominação de uma sanção de nulidade ao mandato "post mortem": a qual somente seria de se declarar caso o ato não pudesse ser tomado como disposição de última vontade - prevendo-se, conquanto para efeitos específicos, a conversão substancial do negócio jurídico (artigo 3041) ${ }^{144}$.

${ }^{144}$ Os aspectos gerais da extinção do contrato de mandato já foram objeto de nossa análise noutra oportunidade (nota 136). Assim, resta-nos abordar aqui algumas peculiaridades do arcabouço concernente ao tema tal qual constante do "Esboço" de Código Civil.

Assim, por exemplo, no que concerne à causa extintiva do contrato de mandato, já tivemos a oportunidade de observar que seus efeitos somente se operam - em relação ao mandatário - com a efetiva ciência por parte do agente a seu respeito; é o que decorre do artigo 160 do Código Comercial, alusivo tão somente à morte e à incapacidade superveniente do mandante. Todavia, de um mesmo fato pode decorrer a cessação dos efeitos não apenas do vínculo contratual mantido entre o agente e seu principal, como também do negócio jurídico de outorga de poderes representativos. Já mencionamos - à exaustão - que no "Esboço" de Código Civil não existe um tratamento sistemático autônomo dos negócios jurídicos de "incumbência" ("contrato de mandato") e de outorga de poderes ("procuração"). Contudo, deve-se ter em conta que toda alusão à figura do terceiro implica menção implícita ao aspecto externo da relação. Daí o ganho de perspectiva proporcionado pelo "Esboço" de Código Civil, por meio da disciplina desenvolvida entre os seus artigos 3012 e 3015.

Os dois primeiros artigos (3012 e 3013) se voltam à proteção dos interesses de terceiro que - de boa-fé celebrou contrato após o advento da causa de cessação dos poderes de representação conferidos ao agente. Por meio do artigo 3012 se prevê a vinculação ordinária do mandante (ou de seus herdeiros), ressalvada a ulterior ação regressiva contra o representante que, ciente da causa extintiva, levou a efeito o exercício da representação maliciosamente: "em relação a terceiros que, ignorando sem culpa a cessão do mandato, tenham contratado com o mandatário, o contrato será obrigatório para o mandante, seus herdeiros ou representantes, salvo seu direito contra o mandatário, se este sabia da cessação". Ressalve-se apenas a menção a efeitos obrigatórios para o representante (expressão que deve ser tomada com toda a cautela pelo intérprete). De sua parte, o artigo 3013 se volta ao outro pólo do negócio jurídico representativo, facultando ao terceiro - e tão somente a ele - a desistência quanto ao negócio concluído por meio da atuação do representante ("é livre a terceiros obrigar ou não o mandante, seus herdeiros ou representantes pelos contratos que houverem feito com o mandatário na ignorância da cessação do mandato, mas o mandante, seus herdeiros ou representantes não poderão prevalecer-se dessa ignorância para obrigá-los pelo que foi feito depois da cessação do mandato"); disposição bastante importante, uma vez que em caso de obrigação de fazer de caráter personalíssimo, sua execução por parte de outrem pode se mostrar inteiramente desinteressante àquele que concorreu para a celebração da avença com o representante.

Pela projeção de tais dispositivos do "Esboço" de Código Civil no âmbito de nossas fontes posteriores (legisladas ou simplesmente projetadas), cf. o art. 1089 do AntCR (com a previsão, inclusive, de ações criminais contra o procurador infiel); o art. 1464 do AntCB; o art. 1536 do AntCBRev; o art. 1318 do PCD n ${ }^{\circ}$ 1/1912; o art. 1318 do PSF n 269/1912; o art. 1318 do CC/1916; o art. 50 do AntOPH; o art. 662 do AntCM; o art. 628 do AntCMRev; o art. 124 do AntPGMA; o art. 697 do AntMR; o art. 685 do AntMRRev; o art. 695 do PCD no 634/1975; e o art. 686 do CC/2002. Note-se que o Anteprojeto de Parte Geral do Código das Obrigações de Orosimbo Nonato, Philadelpho Azevedo e Hahnemann Guimarães efetivamente pretendeu trazer a questão ao âmbito da representação (o que nos parece inteiramente acertado). Posição retomada, aliás, no Anteprojeto de Parte Geral do Código Civil desenvolvido por José Carlos Moreira Alves. Todavia, lamentavelmente, o assunto permaneceu disciplinado em meio às regras concernentes ao tipo contratual objeto de nossa análise.

Por sua vez, o artigo 3014 do "Esboço" de Código Civil disciplina o procedimento a ser adotado pelo "representando" (ou seus herdeiros) a fim de levarem ao conhecimento de eventuais terceiros a ocorrência da causa extintiva dos efeitos do negócio de outorga de poderes representativos: "para darem ciência ao mandatário da cessação do mandato, ou a terceiros com quem o mandatário foi encarregado de contratar ou estava para contratar, o mandante, seus herdeiros ou representantes podem à sua custa requerer que sejam notificados, sem mais outro procedimento ulterior". Não se pode negar a coordenação natural entre este 
dispositivo - projetado - e o artigo 159 do Código Comercial, no qual se prescreve a utilização do sistema de registros públicos para que os negócios de constituição e extinção operem seus efeitos "erga omnes". Aliás, de modo implícito, tal disciplina é adotada pelo "Esboço" em seu artigo 3015 ("em falta dessa notificação judicial, a ciência da cessação do mandato pode ser provada por todos os meios, e segundo as circunstâncias, atender-se-á aos anúncios publicados para advertência de terceiros"). J. L. ALVES reputa irrelevante tal providência, mostrando-se necessária a obtenção de tais efeitos - necessariamente - pela via judicial: "no mandato para tratar com pessoas indeterminadas, o costume é o aviso, pela imprensa, de que o mandato foi revogado. Este aviso, porém, não tem valor jurídico algum. Será mais segura cautela a intimação, por edital, publicado pela imprensa, em virtude de ordem judicial" (Código cit. (nota 05), p. 382). Em posição eclética após definir os terceiros de boa-fé objeto de proteção legal - F. MORATO conclui no sentido de que devem ser empregados "todos os meios adequados (...) o que pode variar de caso a caso" (Miscellanea Jurídica, São Paulo, s. e., 1945, pp. 440-441).

Em contrapartida, ao representante (ou seus herdeiros) se comete dever correspondente no artigo 3016 ("para darem ciência ao mandante da cessação do mandato, o mandatário, seus herdeiros ou representantes igualmente podem à sua custa requerer que o mandante seja notificado e também sem mais outro procedimento ulterior. Incumbe-lhes cientificar prontamente o mandante, pena de responderem pelo prejuízo que a demora resultar, a não provarem legítimo impedimento"); no entanto, como se pode depreender da leitura de tal preceito, a responsabilidade do agente é acentuada pelo legislador, uma vez que da delonga - na transmissão de tal informação - podem defluir prejuízos sensíveis a legítimos interesses do "representando", dignos da tutela conferida pelo legislador (pela via projetada). Observe-se que tais disposições do "Esboço" influenciaram o art. 660 do AntCM - e o art. 627 do AntCMRev.

Também com relação à renúncia do mandatário não houve inovação do "Esboço" de Código Civil no sentido de instituí-la; fato é que já havia sido prevista no Código Comercial (artigo 157, 2) e na Consolidação das Leis Civis (artigo 473, $\S 3^{\circ}$ ). No entanto, é no "Esboço" que podemos encontrar a primeira regulamentação do assunto, constante dos artigos 3032, 3034 e 3035. Compreendida como negócio extintivo da relação jurídica decorrente do contrato de mandato, a hipótese de "renúncia" do mandatário é compreendida por alguns autores como ensejo de "denúncia" - em sentido técnico - suscetível de motivação ou não, de acordo com as circunstâncias relacionadas ao caso concreto. De todo modo, a respeito da denúncia "cheia" (motivada por uma "justa causa"), o autor do "Esboço" de Código Civil preconizou a disciplina constante de seu artigo 3032: "terá o mandatário justa causa para renunciar ao mandato ou este seja civil ou comercial (art. 3009, $\mathrm{n}^{\circ} 7$ ): $1^{\circ}$. Se vier a conhecer a impossibilidade de executá-lo ou que é ilícito (arts. 2872 e 2873); $2^{\mathrm{o}}$. Se the for impossível continuar por superveniência de enfermidade, pela necessidade de ausentar-se ou por outro motivo atendível; $3^{\circ}$. Se a execução do mandato se opuser a seus próprios interesses ou aos de pessoa de quem seja representante necessário ou voluntário; $4^{\circ}$. Se a execução do mandato depender de suprimento de fundos ou de outros meios e o mandante não os fornecer oportunamente ou fornecer insuficientes; $5^{\circ}$. Se vier a saber do estado de insolvência ou das más circunstâncias do mandante; $6^{\circ}$. Se lhe sobrevier inimizade com o mandante; $7^{\circ}$. No caso do art. 2919, substabelecendo sem reserva de poderes, se tal reserva não lhe foi ordenada". Nestas hipóteses, pois, o mandatário está desobrigado de qualquer indenização ao mandante em virtude da extinção precipitada do liame, à vista da inexistência de culpa que lhe seja atribuível. No entanto, a denúncia "vazia" (imotivada ou "sem justa causa") enseja indenização por parte do agente sempre que sobrevierem prejuízos ao principal, na forma estabelecida pelo artigo 3034 do "Esboço" ("se o mandatário renunciar o mandato sem justa causa, será responsável pelos prejuízos que de sua renúncia resultarem ao mandante"). Daí o equívoco de O. GoMES ao repelir - em tom de desdém - a denúncia vazia no âmbito do mandato: "se a renúncia dispensasse justa causa não teria sentido a obrigação assumida pelo mandatário" (Contratos cit. (nota 23), p. 352). Não atentou este jurista ao fato de que a imprescindibilidade de uma "justa causa" somente está ligada à extinção negocial das avenças estipuladas por prazo determinado - e não àquelas de duração indefinida (a este respeito, cf. A. JUNQUEIRA DE AZEVEDO, Qualificação jurídica de "acordo operacional" (contrato atípico, complexo, com fortes elementos de contrato de know how e de mandato com administração). Contratos de duração e não-denunciabilidade dos contratos de duração determinada. Denúncia ilícita, in Revista Forense 380 (2005), pp. 239-255). Por sinal, a respeito de uma apreciação criteriosa sobre os contratos "de duração", cf. M. STOLFI, Appunti critici sui contratti di durata, in Studi in memoria di Bernardino Scorza, Roma, Soc. Ed. del Foro Italiano, 1940, passim.

Observe-se que, em disposição de conteúdo técnico irrepreensível, A. TEIXEIRA DE FREITAS preceitua que todo e qualquer ato de gestão praticado pelo "renunciante" após a extinção do vínculo há de ser submetido à disciplina da gestão de negócios, e não do mandato já exaurido; é este o teor do artigo 3035 do "Esboço" de Código Civil ("se, depois da renúncia, continuar no mandato por si ou por outrem fora do caso do art. 3018, não obrigará o mandante pelo que fizer, ainda que este a ignorasse, salvo seu direito como gestor oficioso"). Pelos reflexos de tal disciplina articulada no "Esboço" sobre as fontes do direito civil brasileiro que the 
sucederam, cf. o art. 2306 do AntFS; o art. 1091 do AntCR; o art. 1466 do AntCB; o art. 1538 do AntCBRev; o art. 1320 do PCD no 1/1912; o art. 1320 do PSF no 269/1912; o art. 1320 do CC/1916; o art. 665 do AntCM; o art. 631 do AntCMRev; o art. 126 do AntPGMA; o art. 699 do AntMR; o art. 687 do AntMRRev; o art. 697 do PCD no 634/1975; e o art. 688 do CC/2002. Observe-se que o Anteprojeto de Joaquim Felício dos Santos prescrevia, laconicamente, a indenizabilidade em caso de renúncia do agente, sem qualquer alusão à (in)existência de uma "justa causa" para tanto. Aliás, o fundamento para a renúncia motivada ("justa causa") sofrerá sensível alteração já no Anteprojeto de Coelho Rodrigues. De todo modo, voltaremos ao tema mais à frente. No entanto, cumpre destacar que não nos parece acertada a sugestão de José Carlos Moreira Alves no sentido de que tal matéria fosse disciplinada em meio à Parte Geral do Código Civil; trata-se de matéria concernente à relação gestória, insuscetível de produzir quaisquer efeitos relacionados a terceiros. Se a questão ensejava um tratamento unitário - à vista de seus reflexos também no âmbito da representação necessária - cremos que a via adequada corresponderia a uma remissão expressa (em meio a tal disciplina) ao preceituado a respeito da questão junto ao arcabouço referente ao contrato de mandato.

Também com relação à revogação não existe inovação por parte do autor do "Esboço" no sentido de instituíla; todavia, não podemos retirar seu mérito em haver previsto de maneira clara a distinção entre as modalidades tácita e expressa de revogação. Neste sentido, o artigo 3024 do "Esboço" dispõe que "a revogação do mandato pode ser expressa ou tácita. A revogação expressa pode ser por escrito ou verbal". Só que ao contrário do que se depreende de algumas fontes projetadas de nosso direito civil posterior (cf. trecho final da nota de rodapé imediatamente anterior, A. TEIXEIRA DE FreITAS compreendeu claramente a necessidade de se considerar a revogação um negócio jurídico (e não um ato jurídico em sentido estrito); desta forma, o efeito extintivo da relação jurídica decorrente do contrato de mandato somente haveria de despontar caso isso fosse de se depreender da intenção do mandante consubstanciada em seus atos subseqüentes. É este o sentido que nos parece defluir do artigo 3025 do "Esboço" ("haverá revogação tácita do mandato quando a continuação do negócio encarregado não se puder conciliar com as disposições ulteriores do mandante, como, por exemplo, nomeando novo mandatário para o mesmo negócio, ainda que a segunda procuração não derrogue a primeira").

Por fim, no artigo 3023 se preconiza a livre revogabilidade do mandato, ainda que onerosa a incumbência ("se o mandato não for irrevogável, e ainda que seja oneroso (arts. 2855 e 2856), é livre ao mandante revogálo quando lhe aprouver ou o mandatário tenha já começado a executá-lo ou nada ainda tenha feito"). A respeito dos reflexos da disciplina articulada no "Esboço" sobre as fontes subseqüentes de nosso direito civil, cf. o art. 2300 do AntFS; o art. 1088 do AntCR; o art. 1463 do AntCB; o art. 660 do AntCM; e o art. 627 do AntCMRev.

No entanto, essa "livre revogabilidade" haveria de ceder lugar à perduração do ajuste quando prevista em contrato sua irrevogabilidade - ou ainda quando se estivesse diante de mandato correspondente a condição de contrato bilateral. Nestes casos - bem como na hipótese de "mandato" conferido a sócio-administrador por força do contrato social - haveria de se observar o estabelecido no artigo 3031 do "Esboço" ("é irrevogável o mandato: $1^{\circ}$. Quando se tiver convencionado que o mandante não possa revogá-lo; $2^{\circ}$. Nos casos em geral em que for condição de um contrato bilateral (art. 441) ou meio de cumprir uma obrigação contratada, como nas letras e ordens o mandato de pagá-las (art. 2180, $\mathrm{n}^{\circ} 3$ ); $3^{\circ}$. Quando o sócio for administrador da sociedade por estipulação do contrato social, a não dar-se alguma das causas designadas no Capítulo 13 desta Seção (art. $2854, \mathrm{n}^{\circ} 3$ )"). Aliás, atrelando - indevidamente - as idéias de "irrevogabilidade" e "irrenunciabilidade" o autor do "Esboço" preceituou, por meio do artigo 3036, que "é irrenunciável o mandato, quando for irrevogável nos casos do art. 3031, n 2".

A respeito das origens e do alcance da irrevogabilidade atrelada a contrato bilateral, cf. o Despacho de 19 de abril de 1858 (apud J. M. da TRINDADE, Collecção cit. (nota 131), p.) e os artigos $4^{\circ}, 5^{\circ}$ e $6^{\circ}$ do Decreto ${ }^{\circ}$ 771 de 20 de setembro de 1890 .

Aqui se faz necessário observar que uma grande controvérsia doutrinária exsurgiu a propósito da cláusula de irrevogabilidade atrelada ao contrato de mandato (sobretudo quando relacionada à "procuratio in rem suam"). Dentre os mais evidentes equívocos - em nossa falível, porém meditada opinião - estão as posições de: F. R. LEITE FILHO, que reputa conflitantes as disposições afetas à cessão de direitos e à procuração em causa própria (Curso cit. (nota 05), p. 353); E. EsPíNOLA, que entrevê eficácia translativa de domínio na procuração em causa própria (Procuração em causa própria - effeitos: contracto consigo mesmo, in Revista Forense 45 (1925), pp. 16-22, especialmente p. 18); J. F. DE LIMA, que igualmente assevera ser a procuração em causa própria "transcrita ou não transcrita (...) um título de transferência de direitos" (Curso cit. (nota 05), p. 601); e O. GOMES, que assevera equivocadamente que o procurador em causa própria age "em nome próprio": "transmitido o direito ao procurador em causa própria, passa este a agir em seu próprio nome, no seu próprio interesse e por sua própria conta" (Contratos cit. (nota 23), p. 356).

Fato é que a situação gerou uma dificuldade muito grande aos operadores do Direito, que se viam cercados das mais diversas perspectivas a respeito de um único problema; nesse sentido, C. PAULO DA ROCHA assim 
observava, com olhos de advogado: "ora considera-se a cláusula de irrevogabilidade uma obrigação de nãofazer, que se resolve em perdas e danos; ora se afirma a irrevogabilidade de modo absoluto, considerando-se nula a revogação e nulos os atos praticados pelo mandante; outros, temperando os rigores da irrevogabilidade, distinguem a irrevogabilidade em absoluta e relativa para, nesta, permitir a revogação; outros, ainda, apreciam a categoria da irrevogabilidade por natureza da que não é, não permitindo a revogação na primeira hipótese e consentindo na segunda; havendo, ainda, os que distinguem o mandato irrevogável, em que subsiste interêsse do mandante, das hipóteses em que não há interêsse do mandante, para, numa, permitir a revogação, e na outra, não admitir; e, ainda, há os que sustentam a nulidade pleno jure da cláusula de irrevogabilidade, quando estabelecida de modo geral e sem causa justa; e outros preferindo a rescisão comum a todos os contratos. O jurista prático, o advogado, o homem de negócios, em face de soluções tão díspares não sabem como proceder, porque não podem atinar com a interpretação que, no futuro, lhe irão dar ao negócio ou à ação judicial" (Do cancelamento do mandato irrevogável, in Revista Forense 126 (1949), p. 377).

Embora se justifique a insatisfação deste autor, temos de reconhecer que preponderou, ao menos durante a primeira metade do século XX, a posição que compreendia tal cláusula como simplesmente ensejadora de uma obrigação de não fazer por parte do mandante; caso descumprida, sujeitaria o inadimplente ao pagamento das perdas e danos correspondentes. Era a posição, por exemplo, de: L. PRATES (Pode-se revogar o mandato irrevogável?, in Revista Forense 62 (1934), pp. 116-117); V. RÁo (Mandato, in Revista Forense 105 (1946), p. 487); e M. da Costa MANSO (Mandato em causa própria, in Revista Forense 110 (1947), pp. 347-348). Em sentido contrário, F. C. PONTES DE MIRANDA asseverava que "quando o mandante ou o outorgante da procuração insere a cláusula de irrevogabilidade, cessa o seu poder de revogar (...) ser irrevogável não significa haver, para o outorgante, obrigação de não revogar (...) quem insere cláusula de irrevogabilidade não assume dever e obrigação de não revogar: não pode revogar" (Tratado de Direito Privado XLIII cit. (nota 04), p. 80). No mesmo sentido, hoje, M. G. MAIA JÚNIOR (A representação cit. (nota 04), p. 44) e SiLvio RodRIGUES (Direito cit. (nota 02), pp. 298-300).

Cremos que nenhuma destas soluções radicais seja a mais adequada: se F. C. PONTES DE MIRANDA nos parece correto quanto aos efeitos da cláusula de irrevogabilidade "em geral", não nos inspira a mesma aderência à luz das peculiaridades do contrato de mandato; seria de se exigir do mandante - que ainda tem interesse na execução da incumbência - a manutenção de um liame artificial, ao qual falta o suporte indispensável do elemento fiduciário? Parece-nos efetivamente que não. Neste sentido, consideramos adequada a posição de A. WALD, que confere destaque ao referido elemento citado: "podemos afirmar que a irrevogabilidade é absoluta, não permitindo a revogação, quando desapareceu o elemento fiduciário e o direito na realidade foi transferido ao mandatário, sendo relativamente irrevogável, resolvendo-se a revogação em perdas e danos, quando perdura o elemento fiduciário na relação de mandato" (Curso cit. (nota 131), p. 308). É o sentido em que já argumentava M. M. de SERPA LOPES (Curso cit. (nota 05), p. 302).

Note-se que tal disciplina desenvolvida no "Esboço" projetou efeitos sobre as seguintes fontes do direito civil brasileiro subseqüentes: art. 2300 do AntFS; art. 1535 do AntCBRev; art. 1317 do PCD n 1/1912; art. 1317 do PSF no 269/1912; art. 1317 do CC/1916; arts. 667, 668 e 669 do AntCM; arts. 632, 633 e 634 do AntCMRev; arts. 694, 695 e 696 do AntMR; arts. 682, 683 e 684 do AntMRRev; arts. 692,693 e 694 do PCD no 634/1975; e arts. 683, 684 e 685 do CC/2002. No Anteprojeto de Joaquim Felício dos Santos se previa a possibilidade de revogação a despeito da cláusula de irrevogabilidade, ensejando-se, simplesmente, a reparação dos danos eventualmente causados ao agente. Entretanto, outra foi a orientação adotada no Anteprojeto de Código das Obrigações de Caio Mário da Silva Pereira, no qual se estabelecia a ineficácia genérica da revogação (diante da cláusula), excetuada a hipótese de "justa causa (...) que deve ser cumpridamente provada".

Durante a tramitação deste último anteprojeto houve alteração significativa de posicionamento, podendo-se assinalar: a) uma aproximação entre o mandato com cláusula de irrevogabilidade e a procuração em causa própria; b) a retomada da solução anterior (no sentido de que a revogação ilícita haveria de preponderar, a despeito das perdas e danos a que desse causa); c) e a manutenção da ineficácia da revogação do mandato atrelado a contrato bilateral (ou que consubstanciasse meio de se adimplir obrigação previamente ajustada). Esta orientação prevaleceu, em linhas gerais, no Anteprojeto de Código Civil elaborado pela Comissão presidida por Miguel Reale; no entanto, em seu artigo 696 foi instituída regra que disciplinou a "procuração em causa própria", atribuindo-se-lhe os efeitos que até então a doutrina e a jurisprudência à mesma conferiam. Todavia, expressa ressalva foi feita à aquisição de seu objeto pelo próprio procurador ("não poderá transferir para si mesmo os bens móveis ou imóveis objeto do mandato"). Tal proibição foi expurgada quando da publicação da versão revista do Anteprojeto de Código Civil, em cujo artigo 684 se admitia expressamente tal espécie de aquisição. Daí por diante a matéria não sofreu qualquer alteração - de destaque - até sua definição em meio ao Código Civil vigente. 
Merece destaque, ainda, a previsão de um dever ao procurador intimamente relacionado à extinção da relação jurídica representativa: trata-se da restituição do instrumento do negócio de outorga de poderes, estatuída pelo artigo 3017 do "Esboço" nos seguintes termos: "cessando o mandato, o mandatário deve restituir a procuração original, salvo: $1^{\circ}$. Se ela se tiver perdido; $2^{\circ}$. Se a não tiver em seu poder por havê-la entregue a terceiro com quem contratou em nome do mandante (art. 2957); $3^{\circ}$. Se ela constar de carta missiva, que lhe seja necessária por tratar de negócio estranho ao mandato". Posteriormente tal disciplina foi reiterada no art. 2300 do AntFS e no art. 1088 do AntCR.

Merecem consideração especial quatro dispositivos do "Esboço" nos quais se preceitua a perduração da relação jurídica decorrente do contrato de mandato, mesmo a despeito da morte de um dos sujeitos. Inicialmente, cumpre destacar que a regra geral consiste na dissolução do vínculo à vista de tal intercorrência. No entanto, o artigo 3038 do "Esboço" previu a "sobrevivência" da relação em caso de disposição expressa das partes ou de irrevogabilidade defluente de sua estreita relação com contrato bilateral coligado ("não se resolve pelo falecimento do mandante ou do mandatário: $1^{\circ}$. Quando se tiver convencionado sua continuação, não obstante o falecimento de um ou de outro; $2^{\circ}$. Quando for irrevogável nos casos do art. 3031, $\mathrm{n}^{\circ} 2^{\prime \prime)}$. Tal disposição sofreu o acréscimo expansivo do artigo 3040, em virtude do qual se estendeu tal conseqüência ao mandato comercial, exclusivamente na hipótese de morte do principal ("não se resolve pelo falecimento do mandante se for comercial, ainda que não seja preposição"). Por outro lado, foi restringida em seu alcance pelo artigo 3039 que previu a inaplicabilidade desta exceção quando pudesse comprometer o interesse de incapazes ("não obstante a convenção de continuar o mandato depois do falecimento do mandante ou do mandatário, resolve-se todavia, se os herdeiros forem menores ou tiverem outra incapacidade"). Ora, ainda que tal disposição nos pareça compreensível quando se trate de herdeiros do mandatário falecido, não nos parece razoável quando se der a morte do mandante - uma vez que tais incapazes, via de regra, somente experimentariam proveitos da gestão regularmente conduzida pelo agente pré-constituído. Visando conformar o alcance de tal princípio à sua teleologia, o artigo 3042 do "Esboço" previu, em sua parte primeira, a extensão da solução excepcional ao caso de incapacidade superveniente de qualquer das partes ("o que fica disposto sobre a resolução do mandato por falecimento do mandante ou do mandatário procede nos caso de incapacidade que a um ou outro sobrevenha (art. 3010, no 9)").

Por fim, cumpre-nos destacar a vedação ao mandato "post mortem" por parte de A. TEIXEIRA DE FREITAS, mediante a previsão contida no artigo 3041 do "Esboço": "qualquer mandato destinado a executar-se depois do falecimento do mandante, que não possa valer como disposição de última vontade, será nulo". Note-se, pois, que tal disposição não prescreve, pura e simplesmente, a nulidade desta espécie de mandato; ao contrário, toma partido em prol de uma interpretação favorável à vontade do "de cujus", em um exemplo remoto daquilo que se concebe atualmente sob o nome de "conversão substancial do negócio jurídico" objeto de regulamentação pelo artigo 170 do Código Civil vigente. A respeito do vetusto procurador instituído por testamento, cf. o estudo de E. WEISS ('Procurator ex testamento', in Studi in onore di Vincenzo Arangio-Ruiz nel XLV anno del suo insegnamento IV, Napoli, Editore Jovene, 1953, pp. 61-ss).

Pela bibliografia pré-codificatória relacionada ao tema, cf. J. M. da TRINDADE, Collecção cit. (nota 131), pp. 39-40; e M. M. da C. CRUZ, A procuração cit. (nota 04), pp. 1-56.

No que concerne à bibliografia produzida sob a égide do Código Civil de 1916, cf. A. BEVILÁQUA, Codigo cit. (nota 131), pp. 363-365; A. do VAlle SiQueIRA, Codigo cit. (nota 131), pp. 437-439; A. CAMARGO, Elementos cit. (nota 131), p. 93; A. CHAVES, Lições cit. (nota 131), pp. 317-320; A. L. da CÂMARA LEAL, Manual cit. (nota 131), pp. 109-110; A. MARMITT, Mandato cit. (nota 131), pp. 37-55 e 201-202; A. WALD, Curso cit. (nota 131), pp. 303-308; C. BEVILÁQuA, Codigo cit. (nota 05), pp. 64-70; D. ARRUdA MirANDA, Anotações cit. (nota 131), pp. 368, 373 e 388-391; E. EsPínOlA, Dos contratos nominados cit. (nota 12), pp. 367-370; E. PESSÔA, Da procuração cit. (nota 131), pp. 15-16 e 29-30; F. C. PONTES DE MiRANDA, Fontes cit. (nota 16), pp. 334-335; F. R. LeITE FILHO, Curso cit. (nota 05), pp. 349-352; F. C. de SAN TiagO DANTAS, Programa cit. (nota 05), pp. 372-378; G. SCIASCIA, Direito Romano cit. (nota 131), pp. 160-161; J. do Amaral Gurgel, Contractos cit. (nota 131), pp. 49-54; J. L. Alves, Código cit. (nota 05), pp. 378-384; J. F. de LiMA, Curso cit. (nota 05), pp. 599-604; J. GONÇALVES MAIA, Theoria cit. (nota 131), pp. 70, 132141, 166 e 171; J. M. de CARvalho SAntos, Codigo cit. (nota 05), pp. 312-325 e 329-332; J. de SAMPAIO DoriA, Codigo cit. (nota 131), pp. 91-92 e 124; L. LEITE, Codigo cit. (nota 131), pp. 435-437; L. R. de Freitas Gomes, Contrato cit. (nota 131), pp. 298-300; M. C. do. A. KroETZ, A representação cit. (nota 41), pp. 106-112; M. G. MAIA JÚNIOR, A representação cit. (nota 04), pp. 105-107, 139 e 181-183; M. I. CARvalho de Mendonça, Contratos cit. (nota 131), pp. 214-216 e 243-253; M. Paulo MerÊa, Codigo cit. (nota 131), pp. 405 e 410-411; M. M. de SERPA LOPES, Curso cit. (nota 05), pp. 243, 288-294 e 297-304; O. GoMes, Contratos cit. (nota 23), pp. 352-356; O poder cit. (nota 131), pp. 9-12; P. SoARES NeTTO, Noções cit. (nota 131), pp. 248-254; R. L. FRANÇA, Manual cit. (nota 05), pp. 188-197; R. LotUfO, Questões cit.(nota 26), pp. 101-103, 107 e 114-116; S. VAMPRÉ, Manual cit. (nota 131), pp. 142-146; T. FULGENCIO 
$\S$ 168. O Anteprojeto de Joaquim Felicio dos Santos: três propostas inovadoras relacionadas ao contrato de mandato. O anteprojeto elaborado por Joaquim Felício dos Santos se caracterizou por algumas inovações que - conquanto pouco numerosas - redundaram em frutos consistentes, uma vez que foram efetivamente implementadas quando do advento de nossa primeira codificação civil. Assim, quanto à obrigação de indenizar ao agente o montante dos prejuízos experimentados no decurso da gestão, o artigo 2297 preconizou a inadmissibilidade da exceção material fundada na alegação da não superveniência dos resultados esperados - pelo mandante - com a execução da incumbência; por sua vez, visando prestigiar a "gestão colaborativa" subjacente ao vínculo, o artigo 2307 pretendeu conferir ao mandatário o dever de prosseguir, provisionalmente, na atribuição que lhe fora cometida, ainda que tenha tido notícia da morte ou incapacidade superveniente do mandante - ao menos enquanto "os herdeiros, ou representante do mandante, não proverem sobre o negocio, si do contrario lhes puder resultar algum prejuizo". Por fim, à vista da confiança lastreadora do liame, por meio do artigo 2309 se previa o provisório prosseguimento da gestão em caso de renúncia súbita do agente: "em caso de renuncia do mandatario, será elle obrigado a continuar com a gerencia, si do contrario puder seguir-se algum prejuizo ao mandante, emquanto este não fôr avisado, e não tiver tempo para prover aos seus interesses"; no entanto, ao contrário das demais, esta última proposta não foi acolhida por ocasião da promulgação do Código Civil de $1916^{145}$.

\footnotetext{
Alves Pereira, Programmas cit. (nota 131), pp. 143-146; T. PRATES DA FONSECA, Noções cit. (nota 131), pp. 199-200.

Já no que toca à bibliografia produzida a respeito do Código Civil de 2002, cf. A. VILLAÇA Azevedo, Código Civil cit. (nota 04), p. 98; A. VIllaça AZEvedo - S. de S. Venosa, Código cit. (nota 02), pp. 366368; A. de Assis, Contratos cit. (nota 131), pp. 120-124 e 128-135; CAIO MárIO da Silva Pereira, Instituições cit. (nota 02), pp. 399 e 412-415; C. A. BITTAR FilHO - M. S. BITTAR, Código cit. (nota 02), p. 57; C. E . N. CAMILlO - G. M. TAVAlera - J. S. Fujita - L. A. SCAvone Júnior (coords.), Comentários cit. (nota 02), pp. 598-600; C. L. BUENO DE GodoY, Do mandato cit. (nota 131), pp. 638-644; C. R. GONÇALVES, Direito cit. (nota 131), pp. 400 e 413-420; F. UlHOA CoelHo, Curso cit. (nota 02), pp. 325-327; F. AMARAL, Direito cit. (nota 131), pp. 471-473; M. G. MAIA JÚNIOR, A representação cit. (nota 04), p. 44; MARIA Helena Diniz, Curso cit. (nota 02), pp. 354 e 371-376; N. C. B. CAMPELlo, Da representação cit. (nota 131), p. 419; N. G. B. Dower, Curso cit. (nota 02), pp. 296-301; N. NERY JUNIOR - R. M. de ANDRADE NeRY, Código cit. (nota 02), pp. 479-481; O.GoMes, Contratos cit. (nota 23), pp. 432-437; O. R. B. SANDOVal, Do mandato cit. (nota 131), pp. 629-634; R. FiUZA (coord.), Novo Código cit. (nota 02), pp. 634639; S. de S. Venosa, Direito cit. (nota 02), pp. 274-279; S. L. F. da Rocha, Curso cit. (nota 02), pp. 303307; Silvio Rodrigues, Direito cit. (nota 02), pp. 298-304; WASHington De BARros Monteiro, Curso cit. (nota 02), pp. 287-293.

${ }^{145}$ Como já tivemos a oportunidade de observar à exaustão, a eventual existência de uma remuneração atribuída ao mandatário não implica correspectividade entre os deveres das partes: isto porque da a arquitetura eficacial do tipo é uma só, haja ou não remuneração. No entanto, a respeito disso já nos pronunciamos há pouco (nota 142).
} 
No entanto, é no Anteprojeto de Joaquim Felício dos Santos que encontramos uma regra - tradicional em nosso direito pós-codificado - corroboradora de um tal entendimento. Ora, tivemos a oportunidade de observar que A. TEIXEIRA DE FREITAS concebia - a nosso ver equivocamente - um sistema de responsabilidades distintas do mandatário, conforme houvesse (ou não) remuneração prevista em contrato (art. 2981 do "Esboço"). Na oportunidade em que analisamos tal preceito (nota 142) acabamos por rejeitar a posição do autor, uma vez que a previsão de uma remuneração não afastaria o fato de que a contratação é realizada no interesse do mandante - que haveria de suportar, naturalmente, todos os riscos da gestão.

Pois bem, a regra constante do artigo 2297 do Anteprojeto ora analisado corrobora tal linha de raciocínio, uma vez que desvincula completamente o montante da remuneração do agente - e por via de consequiência, o próprio dever de remunerar - e o resultado da gestão empreendida pelo mandatário: "o mandante não póde eximir-se da obrigação de que trata o artigo antecedente, com o fundamento de não haver percebido da execução do mandato os proveitos, que esperava". Nas palavras de J. L. ALVES esta regra apresenta uma importância sistemática indisfarçável, uma vez que "no direito do mandatário á remuneração estipulada (...) ainda que o negócio não surta effeito, está uma das mais importantes differenças do mandato e da gestão de negocios, na qual o dono só é obrigado ás despesas, quando o negócio foi utilmente administrado" (Código cit. (nota 05), p. 372). Temos aí, pois, a expressa repulsa a toda e qualquer exceção do mandante fundada na ausência do proveito esperado da gestão.

Pelos reflexos desta disposição no âmbito das fontes do direito civil brasileiro posterior, cf. o art. 1083 do AntCR; o art. 1458 do AntCB; o art. 1528 do AntCBRev; o art. 1310 do PCD no 1/1912; o art. 1310 do PSF n 269/1912; o art. 1310 do CC/1916; o art. 687 do AntMR; o art. 675 do AntMRRev; o art. 685 do PCD no 634/1975; e o art. 676 do CC/2002.

Outra regra do Anteprojeto de Joaquim Felício dos Santos que desperta a atenção do intérprete é aquela por meio da qual se atribui ao mandatário o dever de zelar pelos interesses do mandante, ainda que tenha recebido notícia de sua morte ou incapacidade superveniente; é o que dispõe o seu artigo 2307 ("ainda que o mandatário tenha noticias da extincção do mandato, por morte ou incapacidade superveniente do mandante, deve continuar na sua gerencia, emquanto os herdeiros, ou representante do mandante, não proverem sobre o negocio, si do contrario lhes puder resultar algum prejuízo"). O estudioso atento já entrevê a relação existente entre este preceito e os artigos 160 e 161 do Código Comercial. No entanto, tais disposições não se adéquam perfeitamente ao suporte fático da primeira regra, pois se voltam à validade da gestão do mandatário que ignora a causa de extinção (art. 160 do CCom) e às medidas provisionais a serem adotadas pelos herdeiros do mandatário falecido (art. 161 do CCom). No entanto, a "ratio legis" é semelhante, uma vez que inspirada na idéia de uma "gestão colaborativa" subjacente ao liame mantido entre as partes.

Os reflexos desta disposição em meio às fontes (legisladas ou simplesmente projetadas) do direito civil brasileiro subseqüente podem ser apontados nos seguintes preceitos: art. 1073 do AntCR; art. 1467 do AntCB; art. 1539 do AntCBRev; art. 1308 do PCD no 1/1912; art. 1308 do PSF no 269/1912; art. 1308 do CC/1916; art. 650do AntCM; art. 617 do AntCMRev; art. 128 do AntPGMA; art. 685 do AntMR; art. 673 do AntMRRev; art. 683 do PCD no 634/1975; e art. 674 do CC/2002. Observe-se que o Anteprojeto de Clóvis Beviláqua (e sua versão revista) não aludiam à extensão de tal dever provisional à hipótese de incapacidade do principal - mas tão somente ao caso de sua morte. E o Anteprojeto de Parte Geral do Código Civil de José Carlos Moreira Alves pretendia estender tal preceito a toda e qualquer espécie de gestão. A respeito disso já nos manifestamos: a menos que se empreste ao termo "representação" uma acepção lata - a ponto de abarcar sua variante indireta - tal medida nos parece inaceitável; a alternativa adequada à sua extensão às hipóteses de representação necessária haveria de ser uma conseqüente regra remissiva - ou mesmo a simples repetição do enunciado em local apropriado. Mas não a unificação tal qual pretendida, uma vez que pautada pela consideração exclusiva da representação direta.

Por fim, no artigo 2309 do Anteprojeto de Joaquim Felício dos Santos existe a reprovação indireta à denúncia súbita por parte do agente: "em caso de renuncia do mandatario, será elle obrigado a continuar com a gerencia, si do contrario puder seguir-se algum prejuízo ao mandante, e quanto este não fôr avisado, e não tiver o tempo necessário para prover aos seus interesses". Trata-se de um corolário do elemento fiduciário subjacente à relação, que seria frustrado caso se admitisse uma denúncia - "vazia" - abrupta por parte do mandatário, em prejuízo da gestão de interesse que lhe foram confiados. Das propostas de Joaquim Felício dos Santos aqui referidas, esta foi a que contou com uma menor adesão - conquanto se revele igualmente pautada em imperativos éticos que remontam às fontes mais antigas de nosso direito luso-brasileiro. Por projeções desta iniciativa em nosso direito civil posterior (projetado), cf. os arts. 650 e 655 do AntCM - bem como os arts. 617 e 631 do AntCMRev.

Pela bibliografia devotada ao assunto - no âmbito da doutrina produzida sob a égide do Código Civil de 1916 - cf. A. Beviláqua, Codigo cit. (nota 131), pp. 360-361; A. do Valle Siqueira, Codigo cit. (nota 131), pp. 434-435; A. Chacon Couto, Ligeiras observações cit. (nota 131), p. 8; A. ChAVEs, Lições cit. (nota 131), pp. 304-307; A. L. da CÂMARA LeAL, Manual cit. (nota 131), pp. 106-107; A. MARMitT, Mandato cit. (nota 


\section{$\S$ 169. O Anteprojeto Coelho Rodrigues e as propostas de inovação}

relacionadas ao regime do contrato de mandato. A respeito do contrato de mandato, o anteprojeto de Antônio Coelho Rodrigues conteve um maior número de inovações do que o seu antecessor imediato. Com relação ao substabelecimento, por exemplo, foram oferecidas duas novas proposições: por força do artigo 1077 se previa que a indenização paga por qualquer dos co-responsáveis - em caso de substituição ilícita - produziria a amortização da dívida total, reduzindo-se, assim, o débito a ser cobrado junto ao outro codevedor; por sua vez, o artigo 1078 prescrevia a nulidade do repasse de poderes relacionados à execução da incumbência especial, desde que não tivesse sido expressamente facultado no próprio instrumento de outorga. Já no que concerne à ineficácia do negócio de revogação perante terceiros de boa-fé, a inovação se restringiu à atribuição de ações criminais ao principal, desde que prejudicado pela atuação de seu agente infiel (artigo 1089). Note-se que tais sugestões não foram adotadas quando da promulgação do Código Civil de 1916. Ao contrário, duas outras acabaram vingando quando do advento de nossa primeira codificação civil: em primeiro lugar, por meio do artigo 1091 se introduzia o "prejuízo próprio" - desde que considerável - como um fundamento novo para a renúncia do mandatário, elisivo de qualquer medida indenizatória

131), pp. 194 e 197; A. WALD, Curso cit. (nota 131), p. 305; C. BEVILÁQUA, Codigo cit. (nota 05), pp. 54-57; D. ARRUdA MiRANDA, Anotações cit. (nota 131), pp. 380, 383 e 388; E. EspínOla, Dos contratos nominados cit. (nota 12), pp. 363-364; E. PESSÔA, Da procuração cit. (nota 131), pp. 11-13; F. C. PONTES DE MIRANDA, Fontes cit. (nota 16), pp. 332-333; F. R. LEITE FILHO, Curso cit. (nota 05), pp. 350-351; F. C. P. RODRIGUES - L. da S. Loureiro Filho, Código cit. (nota 131), pp. 888-890; F. C. de San Tiago Dantas, Programa cit. (nota 05), p. 376; J. L. Alves, Código cit. (nota 05), pp. 370-373; J. F. de LIMA, Curso cit. (nota 05), pp. 581 e 591-593; J. GonÇAlves Maia, Theoria cit. (nota 131), p. 173; J. M. de CARvalho SAntos, Codigo cit. (nota 05), pp. 274-275 e 281-285; J. de SAMPAIO Doria, Codigo cit. (nota 131), pp. 91-92; L. LEITE, Codigo cit. (nota 131), p. 443; L. R. de Freitas Gomes, Contrato cit. (nota 131), pp. 296-299; M. C. do. A. KROETZ, A representação cit. (nota 41), pp. 66-68; M. I. CARVAlHO DE MENDONÇA, Contratos cit. (nota 131), pp. 232-233; M. PAulo MerêA, Codigo cit. (nota 131), p. 409; M. M. de SERPA LoPes, Curso cit. (nota 05), pp. 276-281; O. GoMes, Contratos cit. (nota 23), pp. 350-351; O poder cit. (nota 131), p. 12; R. L. FRANÇA, Manual cit. (nota 05), pp. 194-196; S. VAMPRÉ, Manual cit. (nota 131), pp. 138-139; T. FULGENCIO Alves Pereira, Programmas cit. (nota 131), pp. 138-142; T. PRATES DA FONSECA, Noções cit. (nota 131), pp. 196199.

Já no que concerne à doutrina relacionada ao Código Civil de 2002, cf. A. VILLAÇA AzEVEDO - S. de S. Venosa, Código cit. (nota 02), pp. 362-363; A. de ASSIS, Contratos cit. (nota 131), pp. 94-95 e 97-101; CAIO MÁRIO da Silva Pereira, Instituições cit. (nota 02), pp. 407-408; C. E . N. CAMILlO - G. M. TAVALERA - J. S. Fujita - L. A. SCAVONE JÚNior (coords.), Comentários cit. (nota 02), pp. 593-594; C. L. BuENO DE GODOY, Do mandato cit. (nota 131), pp. 628-631; C. P. M. CRUZ E TUCCI, Interposição cit. (nota 09), pp. 122-123; C. R. GONÇAlves, Direito cit. (nota 131), pp. 409-411; F. UlhoA CoElho, Curso cit. (nota 02), pp. 316-319; F. AMAral, Direito cit. (nota 131), pp. 467 e 472; MARIA Helena Diniz, Curso cit. (nota 02), pp. 368-373; N. G. B. Dower, Curso cit. (nota 02), pp. 293-294; N. NERY JunIOR - R. M. de ANDRADE NeRY, Código cit. (nota 02), pp. 477-478; O.GoMeS, Contratos cit. (nota 23), pp. 430-431; O. R. B. SANDOVAL, Do mandato cit. (nota 131), pp. 620-622; R. FIUZA (coord.), Novo Código cit. (nota 02), pp. 624-627; S. de S. VENOSA, Direito cit. (nota 02), pp. 260-261 e 267; S. L. F. da RochA, Curso cit. (nota 02), p. 301; SILVIO RodRIGUES, Direito cit. (nota 02), pp. 289, 297-298 e 304; WASHINGTON DE BARROS MONTEIRO, Curso cit. (nota 02), pp. 281-283. 
por parte do mandante; além disso, no artigo 1094 as "medidas conservatórias" eram apresentadas como um parâmetro objetivo para a atuação provisional dos herdeiros do agente falecido $^{146}$.

${ }^{146}$ O Anteprojeto de Antônio Coelho Rodrigues ofereceu cinco contribuições principais a respeito da disciplina do contrato de mandato.

A primeira regra inovadora corresponde à disposição prevista em seu artigo 1077, alusivo às hipóteses de substabelecimento ilícito previstas no dispositivo imediatamente antecedente; com efeito, a propósito da responsabilidade do mandatário (e do irregularmente substabelecido) o preceito estabelece que "em cada um dos casos do artigo antecedente, o mandante pode também acionar o substituto, e a ação proposta contra um não perime a competente contra o outro; mas a indenização paga pelo primeiro acionado, exonerará, até a concorrente quantia, a responsabilidade do segundo para com o mandante". Este preceito atribui ao mandante, em síntese, a faculdade de escolher livremente quem será o demandado para a reparação dos prejuízos decorrentes da substituição indevida durante o exercício da gestão; como estabelece ainda o legislador (projetado), o prejudicado poderá demandar ambos os responsáveis simultaneamente. Obviamente que a responsabilidade de tais sujeitos não decorreria "ipso facto" da substituição irregular - sendo necessária, obviamente, a demonstração de que os prejuízos experimentados pelo principal decorreram do fato da substituição. Observe-se que aqui não se cogita de representação mútua entre co-obrigados, mas apenas de reflexos do adimplemento por um dos devedores sobre a esfera jurídica do outro (a respeito do assunto, cf. o estudo de P. VEAUX-FoURNERIE e D. VEAUX (La représentantion mutuélle des coobligés, in Études dédiés à Alex Weill, Paris, Dalloz, s.d.).

O artigo 1078 do Anteprojeto de Coelho Rodrigues também concerne ao tema do substabelecimento; e nele se prescreve a "nulidade" do negócio de substituição quanto ao mandato "especial", salvo se permissão neste sentido contar do próprio instrumento de outorga: "é nulo o substabelecimento do mandato especial, que não contiver poder expresso para substabelecer, e constante do próprio título". Perceba-se que o dispositivo apresenta diversos aspectos aos quais deve estar atento o intérprete. O primeiro deles corresponde à ausência de uma diferenciação entre os negócios jurídicos de "incumbência" ("contrato de mandato") e de "outorga" de poderes representativos ("procuração"). A indicação do fato do substabelecimento, por si só, não é suficiente para que se possa divisar o espectro de aplicação do preceito - principalmente porque o fenômeno da substituição pertine não apenas ao exercício dos poderes de representação (aspecto externo), como também à relação contratual respectiva (eis que pode consistir em ilícito relativo).

Ora, a "nulidade" prescrita na disposição há que ser tomada com diferentes acepções, conforme se tenha em consideração o aspecto externo (ou interno) do fenômeno. É preciso destacar que tal sanção não pode prejudicar terceiros de boa-fé que venham a celebrar contratos com o substabelecido irregularmente - quando a proibição de substabelecer não constar do instrumento do negócio jurídico de outorga de poderes representativos. Eis o segundo aspecto importante da disciplina desenvolvida nesta disposição. Finalmente, não se pode descurar do fato de que tal preceito somente se aplica à incumbência especial, vale dizer, àquela que se volta a tão somente uma providência (mandato "ad hoc"). A todas essas questões, aliás, deve ser somada a dificuldade inerente à possibilidade de que um único negócio de outorga de poderes se associe a mandatos distintos; e o inverso também é de se admitir. Nesses casos, a especialidade haveria de ser tomada em relação ao mandato (negócio de "incumbência")? Ou à procuração (negócio de outorga)? Embora o enquadramento sistemático sugira a primeira hipótese, tudo leva a crer que a intenção do legislador tenha sido a de alcançar a segunda. Observe-se que tal disposição influenciou o art. 1450 do AntCB.

A terceira disposição inovadora do Anteprojeto de Coelho Rodrigues consiste em seu artigo 1089, por meio do qual se atribui ao mandante ação criminal contra o mandatário caso este tenha celebrado - maliciosamente - negócio com terceiro insciente da revogação: "a revogação do mandato, notificada somente ao mandatário, não pode ser oposta aos terceiros, que de boa fé trataram com ele ignorando-a, mas ficam salvas ao constituinte todas as ações civis ou criminais que no caso possam caber contra o próprio mandatário". Tal disposição, que revela acréscimo exclusivamente por sua parte derradeira, foi reiterada no art. 1464 do AntCBRev.

Ora, estas três primeiras inovaç̃es do Anteprojeto de Coelho Rodrigues não foram acolhidas pelo legislador brasileiro que se the seguiu. No entanto, outras duas o foram - e ainda hoje perduram sob a forma de disposições constantes do Código Civil vigente.

A primeira contribuição efetivamente adotada pelo legislador consta do artigo 1091 do Anteprojeto, no qual se disciplina o exercício da renúncia pelo mandatário do seguinte modo: "o mandatário pode renunciar ao mandato, comunicando sua renúncia ao mandante; se, porém, este for prejudicado pela inoportunidade da renúncia ou pela falta de tempo para prover convenientemente a substituição, deve ser indenizado pelo 
mandatário, salvo provando este que não podia continuar sem sofrer também um prejuízo considerável”. Ora, do cotejo entre esta disposição e o artigo 3032 do "Esboço" se depreende a substituição de uma fórmula casuística - fundada na idéia matriz de "justa causa" - pelo conceito jurídico indeterminado contido na expressão "prejuízo considerável". A fim de tornar a idéia um tanto mais palpável, tenha em vista a definição oferecida por J. L. ALVES: "como risco de prejuízo considerável se deve entender todo aquele que exigir diminuição do patrimônio para executar o mandato, ou apresentar perigo pessoal" (Código cit. (nota 05), p. 384). No entanto, como observa ainda o autor "é também uma questão de facto" (p. 384). De modo que o papel do juiz na definição de tal questão parece ser decisivo. Pela projeção de tal disposição no panorama das fontes do direito civil brasileiro subseqüentes, cf. o art. 1466 do AntCB; o art. 1538 do AntCBRev; o art. 1320 do PCD no 1/1912; o art. 1320 do PSF no 269/1912; o art. 1320 do CC/1916; o art. 126 do AntPGMA; o art. 699 do AntMR; o art. 687 do AntMRRev; o art. 697 do PCD n ${ }^{\circ}$ 634/1975; e o art. 688 do CC/2002. Da mesma forma como observado há pouco, perece-nos inadequada a sugestão de José Carlos Moreira Alves no sentido de que tal matéria fosse remetida ao âmbito da Parte Geral; conquanto também demonstre pertinência a respeito da representação necessária, tal matéria não se vincula aos interesses de terceiros que suscitam um tratamento orgânico da eficácia representativa direta.

Por fim, no artigo 1094 do Anteprojeto de Antonio Coelho Rodrigues se ofereceu um parâmetro aos limites dos atos de gestão que os herdeiros - do mandatário - haveriam de praticar: tratam-se, exclusivamente, de "medidas conservatórias" ("os herdeiros, no caso do artigo anterior, devem limitar-se a requerer as medidas conservatórias, ou continuar os negócios pendentes, que não possam ser demorados sem perigo e, dentro desse limite, seus atos serão respectivamente regulados pelas mesmas disposições que os do mandatário"). J. L. ALVES assim define o alcance de tal expressão: "medidas conservatórias de direitos, como interromper a prescrição, requerer o sequestro de bens do devedor que intente fugir, defender a posse do mandante, etc., ou á conclusão de negócio já iniciado, desde que aquelas ou estas não possam ser adiadas sem perigo, isto é, desde que, não tomadas antes que o mandante possa providenciar directamente, não mais surtiriam effeito. Tudo é pois questão de facto" (Código cit. (nota 05), pp. 385-386). Observe-se, porém, que a extensão das medidas conservatórias dependerá do caso concreto, uma vez que, à semelhança do que expusemos a respeito do conceito de atos de administração, por vezes a conservação pode implicar eventuais atos de alienação; por tal razão, D. ARRUDA MIRANDA destaca que "não havendo urgência, nem necessidade (...) basta aos herdeiros a simples comunicação da morte do mandatário" (Anotações cit. (nota 131), p. 390). O que não se deve admitir é a confusão propugnada por M. M. de SERPA LOPES - Curso cit. (nota 05), p. 295 - que levanta dúvida a respeito da qualificação dos atos praticados por tais herdeiros (se corresponderiam a um prolongamento do mandato ou a uma gestão de negócios). Obviamente que, à luz da parte final deste artigo 1094, trata-se de uma prorrogação, "ex vi legis", do mandato de que inicialmente foi parte o próprio "de cujus"; com isso, o ressarcimento de despesas, a reparação de prejuízos e a remuneração dos herdeiros pelos atos praticados neste período excepcional - não estarão vinculados à apreciação da "utilidade" dos atos de gestão ultimados. Observe-se que este preceito influenciou nossas principais fontes do direito civil que the foram subseqüentes; a respeito, cf. o art. 1469 do AntCB; o art. 1542 do AntCBRev; o art. 1323 do PCD n ${ }^{\circ}$ 1/1912; o art. 1323 do PSF n ${ }^{\circ}$ 269/1912; o art. 1323 do CC/1916; o art. 130 do AntPGMA; o art. 702 do AntMR; o art. 690 do AntMRRev; o art. 700 do PCD no 634/1975; e o art. 691 do CC/2002. A respeito da iniciativa de José Carlos Moreira Alves de se remeter tal questão ao âmbito da Parte Geral do Código Civil, confrontar as observações levadas a efeito no parágrafo anterior - eis que inteiramente pertinentes à hipótese ora abordada.

Pela bibliografia produzida durante a vigência do Código Civil de 1916, cf. Codigo Civil brasileiro: trabalhos cit. (nota 131), p. 510; A. BeVILÁQua, Codigo cit. (nota 131), p. 365; A. do Valle SiQueIRA, Codigo cit. (nota 131), pp. 438-439; A. CHAVES, Lições cit. (nota 131), pp. 319-321; A. L. da CÂMARA LEAL, Manual cit. (nota 131), pp. 110-111; A. WALD, Curso cit. (nota 131), pp. 306-308; C. BEVILÁQUA, Codigo cit. (nota 05), pp. 69-73; D. ARruda MirandA, Anotações cit. (nota 131), pp. 387-390; E. Espínola, Dos contratos nominados cit. (nota 12), pp. 370-371; E. PESSÔA, Da procuração cit. (nota 131), p. 16; F. C. Pontes De MiRANDA, Fontes cit. (nota 16), pp. 334-335; F. R. LeITE Filho, Curso cit. (nota 05), p. 352; F. C. de San Tiago Dantas, Programa cit. (nota 05), pp. 372-376; G. Sciascia, Direito Romano cit. (nota 131), pp. 160-161; J. L. ALves, Código cit. (nota 05), pp. 383-386; J. F. de LiMA, Curso cit. (nota 05), pp. 603-605; J. Gonçalves Maia, Theoria cit. (nota 131), p. 171; J. M. de Carvalho Santos, Codigo cit. (nota 05), pp. 329-332 e 337-338; J. de SAMPaIo Doria, Codigo cit. (nota 131), pp. 91-92 e 124; L. LeITE, Codigo cit. (nota 131), pp. 437-438; L. R. de Freitas Gomes, Contrato cit. (nota 131), p. 299; M. C. do. A. KroetZ, A representação cit. (nota 41), pp. 105 e 112; M. G. MAIA JÚNIOR, A representação cit. (nota 04), pp. 182-183; M. I. CARVALHO DE MENDONÇA, Contratos cit. (nota 131), pp. 222-223, 245 e 252-253; M. PAulo MerÊA, Codigo cit. (nota 131), p. 411; M. M. de SERPa LOPES, Curso cit. (nota 05), pp. 293-295; O. GOMES, Contratos cit. (nota 23), p. 352; O poder cit. (nota 131), p. 12; P. SOARES NeTTO, Noções cit. (nota 131), p. 248; R. L. FRANÇA, Manual cit. (nota 05), p. 196; R. LOTUFO, Questões cit.(nota 26), pp. 114-116; S. 


\section{$\S$ 170. O Anteprojeto Clóvis Beviláqua, sua tramitação legislativa e as}

inovações relacionadas à disciplina do mandato extrajudicial. A respeito do mandato extrajudicial, poucas foram as inovações que podem ser relacionadas ao anteprojeto de Clóvis Beviláqua (bem como à sua respectiva tramitação legislativa). Aliás, ao próprio autor pode ser atribuída - unicamente - a substituição da sanção cominada ao terceiro ciente do excesso praticado pelo mandatário: assim, em lugar da uma autêntica "nulidade" - tal como divisara, por exemplo, Augusto Teixeira de Freitas em seu "Esboço" (artigo 2953) - Clóvis Beviláqua concebeu uma simples "ineficácia” (“a parte (...) não terá acção contra o mesmo mandatario nem contra o mandante"), tal como se pode depreender do artigo 1456 da versão originalmente submetida ao Governo Republicano. Já à "Comissão Especial" encarregada da revisão dos trabalhos oferecidos, podem ser filiadas duas modificações substanciais do regime jurídico da variante extrajudicial do tipo: em primeiro lugar, foi introduzido o artigo 1522 do anteprojeto revisto, em que se prescreve a incompensabilidade entre os proveitos obtidos e os prejuízos causados pelo mandatário (sob expressa inspiração do artigo 1337 do Código Civil português); além disso, quanto ao dever do mandante de indenizar o mandatário pelos prejuízos experimentados no decurso da gestão, foram ampliadas as hipóteses excepcionantes de uma tal obrigação, a fim de se albergar, além da culpa própria, os casos de excesso de poderes por parte do agente - tal é o sentido do artigo 1530 do anteprojeto revisto (por meio do qual se modificou o artigo 1460 dos trabalhos apresentados em 1899) ${ }^{147}$.

VAMPRÉ, Manual cit. (nota 131), p. 143; T. Fulgencio Alves Pereira, Programmas cit. (nota 131), pp. 144145.

Já no que toca à doutrina produzida a respeito do Código Civil de 2002, cf. A. VILLAÇA AZEVEDO - S. de S. Venosa, Código cit. (nota 02), pp. 367-368; A. de Assis, Contratos cit. (nota 131), pp. 133-135 e 138-139; CaIo Mário da Silva Pereira, Instituições cit. (nota 02), pp. 413-414; C. A. BitTAR FILHO - M. S. BitTaR, Código cit. (nota 02), p. 57; C. E . N. CAMILlo - G. M. TAVAlera - J. S. FuJITA - L. A. SCAVONE Júnior (coords.), Comentários cit. (nota 02), pp. 600-601; C. L. BUENO DE GODOY, Do mandato cit. (nota 131), pp. 643-647; C. R. GonÇalves, Direito cit. (nota 131), pp. 414-415; F. UlHOA CoelHo, Curso cit. (nota 02), pp. 326-328; F. Amaral, Direito cit. (nota 131), pp. 471-472; MARIA Helena DinIZ, Curso cit. (nota 02), pp. 376-377; N. C. B. CAMPELlo, Da representação cit. (nota 131), p. 419; N. G. B. Dower, Curso cit. (nota 02), pp. 298-300; N. NERY JUNIOR - R. M. de ANDRADE NERY, Código cit. (nota 02), p. 481; O.GOMES, Contratos cit. (nota 23), pp. 432-433; O. R. B. SANDOVAL, Do mandato cit. (nota 131), pp. 633-636; R. FiuZA (coord.), Novo Código cit. (nota 02), pp. 638-641; S. de S. VENOSA, Direito cit. (nota 02), pp. 279-280; S. L. F. da Rocha, Curso cit. (nota 02), pp. 303-304; SiLvio RodRIGUES, Direito cit. (nota 02), pp. 303-305; WASHINGTON DE BARROS MONTEIRO, Curso cit. (nota 02), pp. 288-290.

${ }^{147}$ A única contribuição original do Anteprojeto de Clóvis Beviláqua - a respeito do contrato de mandato corresponde ao preceito constante de seu artigo 1456, no qual se sanciona o terceiro que, ciente da falta de poderes suficientes por parte do representante, ainda assim celebra (com o falso procurador) o negócio jurídico representativo. Em lugar da nulidade preconizada por A. TEIXEIRA DE FreITAS em seu "Esboço" (artigo 2953), o Anteprojeto de Clóvis Beviláqua prescreve a ineficácia relativa do ajuste - uma vez que passível de ratificação por parte do "representado". Eis o seu respectivo teor: "a parte que, depois de conhecer os poderes do mandatário fizer com elle accôrdo exorbitante do mandato, sem exigir caução de 
ratificação, não terá acção contra o mesmo mandatario nem contra o mandante". Note-se que neste dispositivo se prescreve o emprego subsidiário da "caução de rato" - fora, pois, do âmbito judicial (no qual sempre teve largo uso). No entanto, é importante destacar que esse aspecto não corresponde a uma inovação do Anteprojeto de Clóvis Beviláqua: no Aviso n 43 de 18 de março de 1882 se assevera que "consistindo a caução de rato na promessa feita pelo procurador forense de apresentar em época determinada o instrumento de procuração que por qualquer circumstancia não lhe chegou ás mãos a tempo de defender, no prazo da lei, o direito de seu constituinte, póde ella ad instar da pratica forense, ser admittida também no fôro administrativo sem prejuizo do interesse publico e com vantagem do direito dos cidadãos"; ou seja, há algum tempo já se admitia o emprego de tal expediente fora dos estritos limites do processo judicial.

A respeito desta preceito algumas impropriedades foram cometidas por nossa doutrina. Assim, por exemplo, C. BEVILÁQUA analisa a questão de maneira retrógrada, concebendo a regra segundo os moldes apregoados no "Esboço" de Código Civil: "priva-o, por isso, o Codigo de qualquer acção: contra o mandatario, porque este não tratou em seu proprio nome; contra o mandante, porque a responsabilidade deste se mede pelos termos do mandato (...) o contrato não tem validade" (Codigo cit. (nota 05), p. 52); no mesmo sentido, D. ARRUDA MIRANDA (Anotações cit. (nota 131), p. 380). Ora, não se trata de questão concernente à validade do contrato: caso o principal considere oportuna a sua execução, basta que o ratifique, sem a necessidade de uma nova contratação; a inovação empreendida pelo Anteprojeto Clóvis Beviláqua consistiu exatamente na alteração de perspectiva relacionada ao assunto: em lugar da validade, passou-se a questionar a eficácia do negócio jurídico representativo.

M. M. de SERPA LOPES, por sua vez, entreviu neste preceito a construção de uma presunção contra o terceiro: "considera-se, em face dêsse dispositivo, existir contra o terceiro uma presunção de haver êle tomado conhecimento dos poderes conferidos ao mandatario, dada a consciência que deve ter da necessidade dêsse primeiro cuidado em seu próprio benefício" (Curso cit. (nota 05), p. 273). Não é esse - segundo nos parece o alcance exato da regra. O dever de exibição do instrumento de outorga de poderes ainda incumbe ao agente; se o terceiro nega que houve tal exibição, cumpre ao "representante" evidenciá-lo. No entanto, uma vez comprovada a apresentação, todo o rigor da norma milita contra aquele.

Ademais, à vista de seu enunciado, pode-se afirmar que o assunto não se circunscreve à relação mantida entre o incumbente e o incumbido. Extravasa-a, a fim de percutir a esfera jurídica de terceiros. Por tal ordem de idéias, tal preceito não diz respeito ao contrato de mandato, mas sim ao exercício da representação negocial; razão por que seria de todo conveniente a sua remessa ao âmbito sistemático respectivo, fora do arcabouço destinado ao tipo contratual objeto de nossa análise.

Pela projeção deste preceito em meio às fontes do direito civil brasileiro subseqüente, cf. o art. 1526 do AntCBRev; o art. 1306 do PCD n 1/1912; o art. 1306 do PSF no 269/1912; o art. 1306 do CC/1916; o art. 47 do AntOPH; o art. 646 do AntCM; o art. 613 do AntCMRev; o art. 121 do AntPGMA; o art. 684 do AntMR; o art. 672 do AntMRRev; o art. 682 do PCD no 634/1975; e o art. 673 do CC/2002. De fato - à luz das considerações articuladas no parágrafo anterior - parece-nos inteiramente pertinente a sugestão de remessa da regra à Parte Geral, tal como se fez no Anteprojeto de Parte Geral do Código das Obrigações de Orosimbo Nonato, Philadelpho Azevedo e Hahnemann Guimarães (artigo 47) - reiterado, por sua vez, no Anteprojeto de Parte Geral do Código Civil de José Carlos Moreira Alves (artigo 121). No entanto, não tendo sido acolhida a iniciativa, a matéria resta, ainda, em meio ao arcabouço destinado ao contrato de mandato.

Como fruto, por sua vez, dos reparos efetuados ao Anteprojeto Beviláqua, despontaram outros dois preceitos - que acabaram por ser, afinal, incorporados ao Código Civil de 1916. A primeira regra corresponde ao artigo 1522 da versão revista do Anteprojeto Beviláqua, o qual dispõe da seguinte forma: "o mandatário não pode compensar os prejuízos a que deu causa com os proveitos que, por outro lado, tenha diligenciado para seu constituinte". Conforme informação constante da Ata da $37^{\mathrm{a}}$ Reunião da Comissão Revisora - realizada em 12 de julho de 1900 - a nova disposição foi deliberadamente inspirada no artigo 1337 do Código Civil português de 1867. Ora, considerada em si mesma, a regra efetivamente dá margem ao entendimento que a reputa espúria, uma vez que nela se cogitaria de uma compensação entre débitos todos pertinentes ao mandatário - tendo como correlatos créditos de titularidade do mandante. Neste sentido, J. L. ALVES anota que "os lucros são devidos por um titulo; a indemnização por outro; mas tudo é devido ao mandante pelo mandatário" (Código cit. (nota 05), p. 366). No entanto, esta apreciação nos parece equivocada, uma vez que não resulta de uma interpretação sistemático-teleológica da regra; ora, segundo nos parece, o termo "compensar" foi utilizado em uma acepção extremamente lata no artigo 1522 da versão revista do Anteprojeto Clóvis Beviláqua: o que se busca aí é evitar uma apreciação global da eficiência gestória. Ou seja, se o mandatário se comportou de modo diligente durante quase todo o tempo da gestão, mas cometeu um lapso ao seu final, não poderá lançar mão dos prodigiosos resultados anteriormente alcançados de molde a mitigar a sua responsabilidade pelos prejuízos causados; assim, este preceito se adequaria aos parâmetros de uma "gestão colaborativa eficiente". 


\section{$\S$ 171. O Anteprojeto de Clóvis Beviláqua Revisto, sua tramitação}

legislativa e a disciplina do mandato judicial. A introdução de uma disciplina especialmente voltada ao mandato judicial se deve à iniciativa da comissão encarregada da

Quanto aos reflexos deste preceito no âmbito das fontes posteriores do direito civil brasileiro, cf. o art. 1302 do PCD n 1/1912; o art. 1302 do PSF no 269/1912; o art. 1302 do CC/1916; o art. 644 do AntCM; o art. 611 do AntCMRev; o art. 681 do AntMR; o art. 668 do AntMRRev; o art. 678 do PCD n 634/1975; e o art. 669 do $\mathrm{CC} / 2002$.

Já tivemos a oportunidade de nos pronunciar (nota 142) sobre a limitação da responsabilidade do mandante quanto aos prejuízos experimentados pelo mandatário durante o curso da gestão. Resta-nos, finalmente, destacar que a versão revista do Anteprojeto Clóvis Beviláqua contou com uma ligeira - porém significativa - alteração da regra disciplinadora da questão. Com efeito, seu artigo 1530 prescreve que "o mandante deve igualmente indemnizar o mandatário das perdas que soffrer em razão da execução do mandato, não tendo havido da parte delle culpa ou excesso de poderes". Assim, acrescentou-se à hipótese exonerativa da parte final outro fundamento liberatório (além da culpa do agente): o "excesso" por parte do "mandatáriorepresentante". De fato, já foi mencionado à exaustão que - conquanto as obrigações referentes à relação incumbente/incumbido pertinam ao âmbito interno do fenômeno gestório - o "excesso" é matéria de caráter bifronte: ao mesmo tempo em que surte efeitos em relação a terceiros, configura uma hipótese de inadimplemento contratual. Daí a projeção de seus reflexos, também, no âmbito interno do fenômeno gestório. Aliás, as hipóteses exonerativas estão tão vinculadas que C. BEVILÁQUA afirma que "o excesso de poder é um caso de culpa" (Codigo cit. (nota 05), p. 58).

Pela projeção desta alteração em meio às fontes subseqüentes do direito civil brasileiro, cf. o art. 1312 do PCD n $1 / 1912$; o art. 1312 do PSF n ${ }^{\circ}$ 269/1912; o art. 1312 do CC/1916; o art. 654 do AntCM; o art. 621 do AntCMRev; o art. 689 do AntMR; o art. 677 do AntMRRev; o art. 687 do PCD nº 634/1975; e o art. 678 do CC/2002.

Quanto à bibliografia produzida - a respeito das matérias abordadas na presente nota de rodapé - sob a égide do Código Civil de 1916, cf. Codigo Civil brasileiro: trabalhos cit. (nota 131), p. 508; A. BEVILÁQUA, Codigo cit. (nota 131), pp. 360-361; A. do VAlle SiQueIrA, Codigo cit. (nota 131), pp. 433-436; A. CHAVES, Lições cit. (nota 131), pp. 303-308; A. L. da CÂMARA LEAL, Manual cit. (nota 131), pp. 105-108; A. MARMITT, Mandato cit. (nota 131), pp. 194-196; A. WALD, Curso cit. (nota 131), p. 305; C. BEVILÁQUA, Codigo cit. (nota 05), pp. 49-53 e 58; D. ARrudA MirAndA, Anotações cit. (nota 131), pp. 378-383; E. ESPÍNOLA, Dos contratos nominados cit. (nota 12), pp. 362-365; E. PESSÔA, Da procuração cit. (nota 131), pp. 12-13; F. C. PONTES DE MiRANDA, Fontes cit. (nota 16), p. 333; F. M. DE MATTIA, Aparência cit. (nota 06), pp. 16-17; F. R. LEITE FILHO, Curso cit. (nota 05), pp. 350-351; F. K. CoMPARATO, Aparência cit. (nota 131), p. 42; J. L. Alves, Código cit. (nota 05), pp. 365-369 e 373-374; J. F. de LiMA, Curso cit. (nota 05), pp. 586-588 e 590-592; J. M. de CARvalho SAntos, Codigo cit. (nota 05), pp. 257, 269-271 e 288-290; J. de SAMPAIO Doria, Codigo cit. (nota 131), pp. 91-92 e 124; L. LeITE, Codigo cit. (nota 131), pp. 431-434; L. R. de Freitas Gomes, Contrato cit. (nota 131), pp. 296-297; M. C. do. A. KroetZ, A representação cit. (nota 41), p. 68; M. G. MAIA JÚNIOR, A representação cit. (nota 04), pp. 140, 144 e 148; M. I. CARVALHO DE MENDOnÇA, Contratos cit. (nota 131), pp. 229 e 234-236; M. PAUlo MERÊA, Codigo cit. (nota 131), pp. 408-409; M. M. de SERPA LOPES, Curso cit. (nota 05), pp. 273-275, 277-280 e 285; O. GoMES, Contratos cit. (nota 23), p. 351; R. L. FrAnÇA, Manual cit. (nota 05), pp. 194-195; S. VAMPRÉ, Manual cit. (nota 131), pp. 135-137 e 140-141; T. FulgENCIO Alves Pereira, Programmas cit. (nota 131), pp. 140-141.

Já no que concerne à doutrina devotada ao Código Civil de 2002, cf. A. VILlaÇA AzEVEDo - S. de S. Venosa, Código cit. (nota 02), pp. 360-364; A. de Assis, Contratos cit. (nota 131), pp. 85-86, 93-94 e 103105; CAIO Mário da Silva Pereira, Instituições cit. (nota 02), pp. 406-409; C. E . N. CAMILlO - G. M. TAVAlera - J. S. Fujita - L. A. SCAVOne Júnior (coords.), Comentários cit. (nota 02), pp. 592-595; C. L. Bueno De Godoy, Do mandato cit. (nota 131), pp. 625-628 e 632-633; C. R. GonÇALVES, Direito cit. (nota 131), pp. 408-411; F. UlhoA Coelho, Curso cit. (nota 06), p. 302; Curso cit. (nota 02), pp. 318-324; F. Amaral, Direito cit. (nota 131), p. 467; MARIA Helena Diniz, Curso cit. (nota 02), pp. 370-373; N. G. B. DOWER, Curso cit. (nota 02), pp. 288 e 294; N. NERY JUNIOR - R. M. de ANDRADE NERY, Código cit. (nota 02), pp. 477-478; O.GoMeS, Contratos cit. (nota 23), p. 430; O. R. B. SANDOVAL, Do mandato cit. (nota 131), pp. 617, 620 e 623; R. FiUZA (coord.), Novo Código cit. (nota 02), pp. 620-624 e 628; S. de S. VENOSA, Direito cit. (nota 02), pp. 259-261; S. L. F. da RochA, Curso cit. (nota 02), pp. 300-301; SILVIO RoDRIGUES, Direito cit. (nota 02), pp. 294 e 297-298; WASHINGTON DE BARROS MONTEIRO, Curso cit. (nota 02), pp. 278280 e 283-284. 
análise do anteprojeto elaborado por Clóvis Beviláqua. Com efeito, o articulado correspondente pode ser sintetizado nas seguintes proposições principais: a) utilização compulsória da forma pública (ou particular autenticada) para a "conferência" do mandato judicial (artigo 1543); b) exigência de habilitação especial para a procuradoria em juízo, da qual se afastavam terminantemente os incapazes, os juízes e aqueles que tivessem sido atingidos por um especial efeito da condenação criminal (artigo 1544); c) restrição à atuação do agente investido em funções judiciais ou vinculado ao magistrado por relação de parentesco (artigo 1544); d) estatuição dos limites relacionados à "procuração para o fôro em geral", da qual se afastavam - ressalvada a ausência do constituinte - as demandas específicas e os atos para os quais se exigissem poderes especiais (artigo 1545); e) estabelecimento da presunção de sucessividade - passível de conversão à conjuntividade na hipótese de mandatários plúrimos (artigo 1546); f) ineficácia exonerativa do substabelecimento sem reserva de poderes não noticiado ao constituinte (artigo 1547); g) vedação à renúncia injustificada, sob pena de responsabilidade pelos danos experimentados pelo principal (artigo 1548); h) fixação de parâmetros remuneratórios da gestão, relacionados à "importância dos serviços", ao "valor da demanda" e à "posse do constituinte" (artigo 1549); i) enumeração das causas de cessação do liame gestório, com expressa menção à morte, ao substabelecimento de poderes, à revogação e à renúncia, inclusive com a atribuição ao agente de deveres de gestão provisional nesta última hipótese (artigos 1550 e 1551); j) cominação de deveres éticos, adstritos à proibição de assistência ao adversário do constituinte, à preservação "relativa" do sigilo e à vedação da retenção de autos recebidos das serventias judiciais (artigo 1552). No entanto, a disposição que nos despertou maior interesse foi inserida em meio à tramitação dos trabalhos preparatórios na Câmara dos Deputados; com efeito, o artigo 1330 do "Projecto da Camara n. 1/1902" dissocia claramente o contrato de mandato do negócio jurídico de outorga de poderes representativos: "as obrigações do advogado e do procurador serão reguladas, não sómente pelos poderes da procuração, mas principalmente pelo contracto, escripto ou verbal, em que os seus serviços tiverem sido ajustados"148.

\footnotetext{
${ }^{148}$ Quanto ao mandato judicial, a principal inovação empreendida pela Comissão encarregada da revisão do Anteprojeto Clóvis Beviláqua consistiu na previsão de um capítulo próprio para a abordagem do tema: pois, de fato, algumas das disposições sugeridas guardavam inteira correspondência com preceitos estabelecidos na Consolidação das Leis Civis; assim, os artigos 1543, 1544, 1549, 1550 e 1552 - sobre os quais já nos pronunciamos, aliás, em oportunidades anteriores (notas 136 e 139).

Resta-nos, todavia, tecer algumas considerações a respeito dos cinco dispositivos remanescentes da versão revista do Anteprojeto Clóvis Beviláqua.
} 
O primeiro deles corresponde ao artigo 1545 , por meio do qual se preconizava que "a procuração para o foro em geral não se entende para certa e determinada causa, salvo ausência do constituinte, nem confere poderes para actos que os exigirem especiais". De fato, tal dispositivo parece não oferecer maiores obstáculos hermenêuticos ao intérprete. Contudo, sua tramitação legislativa resultou em alteração substancial do enunciado, que acabou por assumir - após a intervenção do Senado Federal - os seguintes contornos: "a procuração para o foro em geral não confere poderes para actos que os exijam especiaes". Com isso, o pressuposto elementar para a atuação do procurador assim investido - a ausência do principal - foi extirpado pela pena gramatical do Senador Ruy Barbosa. E o resultado de tal intervenção acabou sendo trágico, tal como observa J. L. ALVES: "mas, o que quereria dizer o Pr. Com. Dispondo que 'a procuração para o fồro em geral não se entende para certa e determinada causa'? Na verdade, se a procuração é para o fôro em geral, mas não se entende para certa e determinada causa, para que serviria ella, para que fins se entenderia? Seria um mandato sem objectivo" (Código cit. (nota 05), pp. 388-389). E a razão desse estado - ao que nos parece - foi a supressão do pressuposto de atuação "excepcional" do procurador (assim investido) em uma certa e determinada causa: a ausência do constituinte.

Observe-se que o referido artigo 1545 da versão revista do Anteprojeto Beviláqua se projetou: no art. 1326 do PCD no 1/1912; no art. 1326 do PSF no 269/1912; e no art. 1326 do CC/1916.

Por sua vez, o artigo 1546 da versão revista do Anteprojeto Clóvis Beviláqua contém regra concernente à pluralidade subjetiva de agentes incumbidos do patrocínio dos interesses do principal: "constituidos para mesma causa e pela mesma pessoa, dois ou mais procuradores, consideram-se nomeados para funccionar um na falta do outro e pela ordem de sua nomeação, podendo, todavia, a nomeação conjuncta conter clausulas de que um nada possa fazer sem os outros". De fato, tal disposição - que não guarda qualquer inovação a respeito da disciplina geral da pluralidade subjetiva de agentes (cf. nota 135) - foi posteriormente acolhida, quanto à variante judicial, nas seguintes fontes do direito civil brasileiro: art. 1327 do PCD n 1/1912; art. 1327 do PSF no 269/1912; e art. 1327 do CC/1916.

Já o artigo 1547 da versão revista prescreve que "o substabelecimento sem reserva de poderes, não sendo notificado ao constituinte, não isenta o procurador de responder pelas obrigações do mandato". Ora, tal preceito - que encontrou acolhida no art. 1328 do PCD n $1 / 1912$, no art. 1328 do PSF no 269/1912 e no art. 1328 do CC/1916 - se fundamenta não apenas na índole receptícia do ato (que deveria ser informado ao principal, a fim de que produzisse perante este seus efeitos), como também na relação de confiança subjacente ao vínculo; note-se, nesse sentido, que a disposição apenas se volta ao substabelecimento "sem reserva de poderes" - a fim de que sejam resguardados os legítimos interesses do principal, de cuja gestão o agente voluntariamente se encarregou. M. M. de SERPA LOPES ressalva - acertadamente - que "é dispensável (...) essa notificação se o substabelecimento se processou com a concordância expressa ou tácita do constituinte" (Curso cit. (nota 05), p. 309).

No artigo 1548 da versão revista do Anteprojeto Clóvis Beviláqua encontramos uma das disposições de fundo ético especialmente voltadas à variante judicial do instituto por nós analisado: "depois que o advogado tiver acceitado o patrocínio da causa, não poderá delle escusar-se, salvo por motivo justo, declarado por affirmação solenne e intimada a parte ou seu procurador para nomear outro advogado, até a primeira audiencia, pena de responsabilidade pelos prejuizos resultantes". A fim de proporcionar adequada proteção à confiança do mandante - e seguindo a mesma diretriz inspiradora da disposição precedente (relacionada ao substabelecimento sem reservas) - o legislador proibiu, em termos genéricos, a denúncia "vazia" no curso da execução do contrato de mandato para fins judiciais. Tal disposição, aliás, encontrou acolhida em meio a algumas fontes do nosso direito civil posterior - tal como evidenciam o art. 1329 do PCD n ${ }^{\circ} 1 / 1912$, o art. 1329 do PSF no 269/1912 e o art. 1329 do CC/1916. Contudo, na parte inicial do artigo 1551 da versão revista do Anteprojeto Clóvis Beviláqua se prescrevia que, a despeito da denúncia (renúncia), o agente ficava "obrigado a seguir a causa ate que o constituinte nomeie novo procurador, no prazo que the fồ para isso assignado". Este preceito não foi reiterado em meio às fontes do direito civil posteriores, encontrando previsão correspondente - tão somente - em meio à legislação processual reguladora da atividade dos procuradores judiciais.

Deve-se observar que caso o mandatário se convencesse - após ter assumido a gerência dos interesses processuais de seu constituinte - da injustiça manifesta da pretensão de seu mandante, não lhe caberia, diante de uma eventual sentença desfavorável, quedar inerte, a pretexto de uma isenção de consciência: ao contrário, haveria de renunciar imediatamente. Neste sentido, pois, a posição de J. L. ALVES (Código cit. (nota 05), p. 391) e de C. Beviláqua (Código cit. (nota 05), p. 80). Aliás, este último autor observava - pouco após a promulgação do Código Civil de 1916 - que "enquanto houver recurso, deve o procurador utilizal-o em favor do constituinte (...) era regra das Ordenações, que subsiste pela boa razão em que se funda" (Código cit. (nota 05), p. 63); no mesmo sentido, S. VAMPRÉ (Manual cit. (nota 131), pp. 141-144). Ora, à vista da argumentação dos autores - bem como dos arts. 1807 do CC/16 e 2045 do CC/2002 - acreditamos que a conclusão não seja diferente em uma abordagem contemporânea do tema. 


\section{$\S$ 172. O Código Civil de 1916 e o acolhimento da variante não}

representativa do mandato. No âmbito de nossa codificação civil novecentista, o mandato

Finalmente, cumpre observar que o artigo 1330 do "Projecto da Camara n. 1/1902" estabeleceu disposição que a um só tempo contribuiu e dificultou a construção de uma autonomia do contrato de mandato (em geral): "as obrigações do advogado e do procurador serão reguladas, não somente pelos poderes da procuração, mas principalmente pelo contracto, escripto ou verbal, em que os seus serviços tiverem sido ajustados". Por um lado, de seu enunciado se extrai a dissociação entre o negócio jurídico de incumbência (contrato) e o ato de outorga de poderes representativos (negócio unilateral); sob este prisma, o dispositivo é bastante importante, pois se contrapõe decisivamente à regra de que a "procuração é o instrumento do mandato".

No entanto, por outro lado, tal preceito aludiu a um contrato em que tenham sido ajustados "serviços" prestados pelo advogado (ou procurador). E esta parte final suscitou as mais diversas interpretações por parte da doutrina: assim, por exemplo, T. FUlGENCIO Alves Pereira concebia o contrato de advocacia como sendo "simultaneamente mandato e locação de serviços" (Programmas cit. (nota 131), p. 147); no que foi seguido, aliás, por Y. S. CAHALI (Contratos cit. (nota 131), p. 498) e J. F. de LIMA, (Curso cit. (nota 05), p. 613).

Em posição própria, F. C. PONTES DE MIRANDA distingue o "contrato de advogado" do mandato, asseverando que "o contrato de advogado é negócio jurídico bilateral distinto do contrato de mandato e da procuração, que é negócio jurídico unilateral (...) tem havido grave confusão entre o contrato de locação de serviços, ou o contrato de trabalho do advogado e o mandato (...) o contrato de serviços ou de obra ou de trabalho em que é figurante o advogado, regula-se, no seu conteúdo e no modo de se fazer a prestação de serviços, pelo contrato, em suas cláusulas, inclusive tácitas, conforme os usos do tráfico e as circunstâncias (...) por vêzes, pela natureza do serviço, há de prevalecer a liberdade limitada em relação às ordens de quem tem direito aos serviços (...) é lamentável a invocação das regras jurídicas sôbre o mandato, por faltar conhecimento da distinção mandato e procuração, que levou a falar-se de mandato judicial, sem se advertir que o mandato judicial é raro e frequentíssima, necessária mesmo, a procuração judicial" (Tratado de Direito Privado XLIII cit. (nota 04), pp. 126-128).

Conquanto a posição de F. C. PONTES DE MiRANDA nos pareça excessivamente radical, de seu excerto já se pode extrair a importância conferida pelo autor às circunstâncias negociais que envolvem a celebração do ajuste. Se de fato nem sempre existirá contrato de mandato, isso decorre - mais do que de uma fenomenologia inerente à atividade do advogado - da eficácia jurídica que as partes pretenderam constituir, em concreto ("causa concreta"), por meio da declaração negocial de que resultou o contrato. Vale dizer: existirão advogados que se submetem ao regime da locação de serviços e outros que desempenham suas incumbências sob a veste jurídica de um mandato. Aliás, outros ainda realizarão suas atribuições como autênticos profissionais empregados. Tudo deflui das circunstâncias. É por isso que J. GoNÇALVES MAIA conclama o intérprete - assim como o faz F. C. PONTES DE MIRANDA - à análise das peculiaridades do caso concreto (Theoria cit. (nota 131), pp. 21-22).

Pela doutrina produzida - a respeito da matéria abordada nesta nota de rodapé - no âmbito do Código Civil de 1916, cf. Codigo Civil brasileiro: trabalhos cit. (nota 131), pp. 510-512; A. BEVILÁQUA, Codigo cit. (nota 131), pp. 365-367; A. do VAlle Siqueira, Codigo cit. (nota 131), pp. 439-441; A. ChaCON Couto, Ligeiras observações cit. (nota 131), p. 11; A. CHAVES, Lições cit. (nota 131), pp. 295-300 e 304-305; A. L. da CÂMARA LEAL, Manual cit. (nota 131), pp. 112-114; A. MARMITT, Mandato cit. (nota 131), pp. 113-115; A. WALD, Curso cit. (nota 131), pp. 308-309; C. FALCÃo, Codigo cit. (nota 131), pp. 145-146; C. BEVILÁQUA, Codigo cit. (nota 05), pp. 73-81; D. ARRUDA MIRANDA, Anotações cit. (nota 131), pp. 392-397; E. ESPÍNOLA, Dos contratos nominados cit. (nota 12), pp. 371-373 e 378; E. PESSÔA, Da procuração cit. (nota 131), pp. 89 e 31-32; F. C. PONTES DE MiRAnda, Fontes cit. (nota 16), p. 335; F. R. Leite Filho, Curso cit. (nota 05), p. 349; F. CAMPos, Direito Civil, Rio de Janeiro - São Paulo, Livraria Freitas Bastos S.A., 1956, pp. 404405; F. C. P. Rodrigues - L. da S. Loureiro Filho, Código cit. (nota 131), pp. 895-897; F. C. de SAN Tiago Dantas, Programa cit. (nota 05), p. 378; J. L. Alves, Código cit. (nota 05), pp. 386-391; J. F. de LIMA, Curso cit. (nota 05), pp. 607-614; J. GonÇALVES MAIA, Theoria cit. (nota 131), pp. 122-131, 161-163 e 182; J. M. de CARVAlho SAntos, Codigo cit. (nota 05), pp. 339-381; J. de SAMPaio Doria, Codigo cit. (nota 131), pp. 91-92 e 124; L. LEITE, Codigo cit. (nota 131), pp. 438-440; M. I. CARVALHO DE MENDONÇA, Contratos cit. (nota 131), pp. 201, 205-209 e 214-215; M. PAULO MERÊA, Codigo cit. (nota 131), pp. 412413; M. M. de SERPA LOPES, Curso cit. (nota 05), pp. 304-310; O. GoMeS, Contratos cit. (nota 23), p. 349; R. L. FRANÇA, Manual cit. (nota 05), pp. 189 e 197-199; S. VAMPRÉ, Manual cit. (nota 131), pp. 146-151; T. Fulgencio Alves Pereira, Programmas cit. (nota 131), pp. 147-149; T. PRATES DA FOnSECA, Noções cit. (nota 131), pp. 200-201; Y. S. CAHALI, Contratos cit. (nota 131), pp. 497-515. 
se mostra disciplinado em capítulo próprio (Capítulo VII - "Do mandato") constante do Título V ("Das várias espécies de contratos”) do Livro III ("Do direito das obrigações”) da Parte Especial. Subdividido em cinco seções, reúne em compartimentos relativamente autônomos as regras - respectivamente - concernentes: a) às "disposições gerais" (artigos 1288 a 1299); b) às "obrigações do mandatário" (artigos 1300 a 1308); c) às "obrigações do mandante" (artigos 1309 a 1315); d) à "extinção do mandato" (artigos 1316 a 1323); e e) ao "mandato judicial" (artigos 1324 a 1330). Posta de parte a discussão a respeito do conteúdo de cada proposição integrante deste arcabouço, há que se conferir especial atenção a uma disposição específica da versão afinal promulgada; com efeito, lastreando-se em uma manifestação iterada de nossa legislação vigente e projetada - tal como se pode depreender do Código Comercial (artigos 149 e 150), do "Esboço" de Código Civil (artigos 2939, 2959, 2963, 3001, 3002 e 3003), do anteprojeto Felício dos Santos (artigos 2279 e 2280) e do anteprojeto Coelho Rodrigues (artigo 1071) - a comissão encarregada da análise da proposta elaborada por Clóvis Beviláqua promoveu a introdução de um dispositivo novo (artigo 1516 do "Projecto revisto"), que tramitou perante a Câmara dos Deputados ("Projecto da Camara n. 1/1902") e o Senado Federal (“Emendas do Senado ao projecto da Camara n. 1/1902") sob o número 1307 - exatamente como constou, aliás, da versão afinal promulgada. Com efeito, seu teor é bastante peculiar, pois - ao mesmo tempo em que parece contrariar a definição constante do artigo 1288 do Código Civil de 1916 consagra, expressamente, o mandato sem representação no direito civil brasileiro do século XX: "se o mandatário obrar em seu próprio nome, não terá o mandante ação contra os que com ele contrataram, nem estes contra o mandante. Em tal caso, o mandatário ficará diretamente obrigado, como se seu fora o negócio, para com a pessoa, com quem contratou"; note-se que ao lado desta manifestação expressa do legislador, sobrevieram em nosso primeiro Código Civil duas outras disposições das quais se pode depreender um reconhecimento implícito da variante não representativa do instituto (artigos 1301 e 1309) ${ }^{149}$.

\footnotetext{
${ }^{149}$ Embora o Anteprojeto de Clóvis Beviláqua não aludisse ao mandato sem representação - considerando a eficácia representativa direta matéria "essencial" ao tipo contratual referido - durante sua tramitação a conformação geral do instituto variou consideravelmente. Com efeito, uma das principais alterações correspondeu ao acréscimo do artigo 1516 ao Anteprojeto original, já em sua versão revista; eis o seu respectivo teor: "si o mandatario agir em seu proprio nome, não terá o mandante acção contra os que com elle contrataram, nem estes contra o mandante. Em tal caso, o mandatario fica obrigado directamente para com a pessoa com quem contractou, como si o negocio fôra seu".

Embora tal dispositivo contivesse matéria estranha à orientação do Anteprojeto Clóvis Beviláqua, não inovava - em verdade - em relação às fontes precedentes de nosso direito civil pátrio. Posta de parte a análise
} 
das fontes reinícolas, era fora de dúvida - de fato - a assunção progressiva da representação direta no âmbito eficacial do contrato de mandato brasileiro. Todavia, excetuado o "incompleto" Anteprojeto de José Thomaz Nabuco de Araújo, todas as fontes projetadas contemplaram o "mandato sem representação", ainda que como fenômeno marginal, em relação ao já exuberante - e não mais tão somente florescente - mandato representativo: neste sentido, cf. os arts. 2939 (5०), 2959, 2963, 3001, 3002 e 3003 do "Esboço"; os arts. 2279 e 2280 do AntFS; o art. 1071 do AntCR; o referido art. 1516 do AntCBRev; o art. 1307 do PCD n 1/1912; o art. 1307 do PSF n ${ }^{\circ}$ 269/1912; e o art. 1307 do CC/1916.

Contudo, a despeito de sua posição periférica no contexto do mandato esquadrinhado pelo legislador de 1916, tal figura ainda desempenhou uma função sistemática extremamente significativa: sua simples existência impediu a essencialização da representação no âmbito da arquitetura eficacial do tipo. Com efeito, a inclusão do referido dispositivo - na versão revista do Anteprojeto Clóvis Beviláqua - abriu uma considerável fissura na estrutura "representativa" do instituto. Como já tivemos a oportunidade de observar, a antinomia estabelecida entre este dispositivo e a regra central do tipo - o artigo 1288 do Código Civil de 1916 - levaram O. GOMES a propugnar sua solução por meio de uma eventual reforma legislativa $(O$ poder cit. (nota 131), pp. 12-14).

Ora, quando se admite a existência de um mandato sem representação - seja ele marginal ou não - exsurge uma pergunta de elevado grau de dificuldade, a perturbar constantemente o intérprete: o que vem a ser, então, o "mandato"?

Se alguns sistemas jurídicos admitem a representação como "essência" do mandato, não há como se esconder o artigo 1307 do Código Civil de 1916 debaixo do tapete. Se existem sistemas jurídicos que propugnam um mandato essencialmente gratuito - e assim diferenciam-no com tranqüilidade da onerosa locação de serviços - tal solução não se ajusta ao mandato tropical, que se amolda tão bem às necessidades de nosso contexto social, carente de uma remuneração (mesmo que eventual) aos valorosos préstimos do mandatário (cf. o art. 1290, § único do CC/16). Se outros sistemas, ainda, oferecem um mandato que se presta unicamente à prática de atos jurídicos, tal resposta não se conforma, perfeitamente, ao ambiente brasileiro - em que se admite um contrato de mandato por meio do qual se encarregue o mandatário da simples administração de interesses (art. 1288 do CC/16).

Então, ressurge - como que um fantasma - a indagação: o que vem a ser o mandato brasileiro? Qual a sua "nota típica"? Em que tal instituto se diferencia da locação de serviços? Como estremá-lo do contrato de trabalho (em que exista representação por parte do trabalhador)? São muitas as perguntas. E temos para conosco uma resposta íntima a cada uma delas - a qual será divulgada futuramente, fora do contexto deste estudo.

De todo modo, a corrente majoritária no Brasil permaneceu a defender a essência representativa do contrato de mandato. Vale dizer: o mandatário, além de agir - sempre - "por conta" do mandante, também haveria de atuar inarredavelmente "em seu nome". No entanto, não é só à custa do artigo 1307 de nosso primeiro Código Civil que podemos sustentar a admissão - implícita - de um mandato sem representação entre nós. Também outros dois dispositivos apontam nessa direção: de um lado, o artigo 1301 do Código Civil de 1916, no qual se estabelece que "o mandatário é obrigado a dar contas de sua gerencia ao mandante, transferindolhe as vantagens provenientes do mandato, por qualquer título que seja". Ora, se não existem palavras inúteis na lei, qual o alcance da expressão "transferindo-lhe", senão a de praticar os necessários atos de transmissão de direitos? Ora, esta expressão denuncia, de modo oblíquo - é forçoso reconhecer - que a eficácia representativa direta, conquanto generalizada, não se aplica a toda e qualquer espécie de mandato.

Da mesma forma, o artigo 1309 do Código Civil de 1916 preceitua as principais obrigações do mandante: "o mandante é obrigado a satisfazer todas as obrigações contraídas pelo mandatário, na conformidade do mandato conferido, e adiantar a importância das despesas necessárias à execução dele, quando o mandatário lho pedir". Perceba-se que em um cenário no qual a eficácia representativa direta constitui a regra, completamente desnecessário se mostra o preceito inicial constante do dispositivo. A menos que se esteja diante de um tipo contratual que "ordinariamente" carregue consigo a representação, muito embora um e outro possam ser dissociados. E não foi esse, pois, o intuito de nosso legislador civil posterior? Dissociar mandato e representação? Note-se que em Proposta de Emenda $n^{\circ} 457$ ao art. do PCD n ${ }^{\circ}$ 634/1975, o Deputado Fernando Coelho assim se pronunciou: "não é correta a vinculação da procuração ao mandato, consagrada na parte final do artigo. Nesse sentido é a melhor doutrina. Pode haver mandato sem procuração e procuração sem mandato. Mais certo que o Projeto, o Código Civil de Portugal considerou a procuração como o ato pelo qual alguém atribui a outrem, voluntariamente, poderes representativos - e o contrato de mandato, aquele pelo qual uma das partes se obriga a praticar um ou mais atos jurídicos por conta de outro. Através da presente emenda se exclui a parte final do artigo, incorreta e desnecessária". E a resposta oferecida pelo Relator Senador Josaphat Marinho foi a seguinte: "o Projeto repete o atual Código. A crítica feita na justificação não me parece feliz. Não consigo entender como possa haver procuração sem mandato; pois a procuração é o instrumento do mandato". 
$\S$ 173. A "Parte Geral" do "Anteprojeto de Código das Obrigações" (1941) e o material "transplantado" do contrato de mandato: o negócio jurídico de outorga de poderes, o exercício da representação negocial e a específica questão do "excesso". Dentre as diversas tentativas de reforma da legislação civil promulgada em 1916, destaca-se, primeiramente, o "Anteprojeto de Código das Obrigações" - de autoria de Orosimbo Nonato, Philadelpho Azevedo e Hahnemann Guimarães - cuja "Parte Geral" foi publicada no ano de 1941. Tomando-se como elemento discriminante a atuação do agente perante terceiros, em meio ao Capítulo I ("Da declaração de vontade") do Título I ("Da constituição das obrigações") foi articulada uma ampla disciplina, por meio da qual se pretendeu conferir à "representação" uma autonomia sistemática (Seção II) - que aos seus autores parecia verdadeiramente indispensável. Das dezoito disposições que integram a respectiva seção (artigos 35 a 52), a maioria absoluta resultou de uma simples transposição de materiais que se achavam dispostos - de acordo com o Código Civil então vigente - em meio à disciplina do "mandato" (artigos 35, 39, 40, 42, 43, 44, 47, 48, 50, 51 e 52): assim, no que tange ao negócio jurídico de outorga de poderes representativos, despontaram disposições relacionadas não apenas à sua forma (artigo 39), como também ao seu respectivo conteúdo (artigos 40 e 42); já no que toca ao exercício - regular - da representação, preconizou-se a percussão imediata da esfera jurídica do representado pelos atos praticados por seu representante (artigo 35) - tendo exsurgido disciplina específica, aliás, a propósito da pluralidade de agentes (artigo 41). Por fim, o excesso de poderes foi objeto de uma abordagem detalhada: não apenas se atribuiu ao representante o ônus da exibição do instrumento do negócio de outorga (artigo 43), como também se disciplinou, minudentemente, o próprio procedimento de "confirmação" dos atos excessivos praticados pelo agente (artigos 44, 45 e 46) - tendo sido prescrita, além disso, a ineficácia do negócio celebrado por este último junto ao terceiro ciente da ausência dos poderes representativos regulares (artigo 47) ${ }^{150}$.

É fato que a doutrina tem admitido - progressivamente - o mandato sem representação no contexto de nosso direito civil contemporâneo. Aliás, em nota de rodapé anterior (nota 131) pudemos expor o panorama doutrinário atual a respeito da relação entre "procuração", "mandato" e "representação". De maneira que por referências bibliográficas e considerações mais minudentes sob o ponto de vista técnico - à mesma tomamos a liberdade de remeter o leitor.

${ }^{150}$ O Anteprojeto de Parte Geral do Código das Obrigações de Orosimbo Nonato, Philadelpho Azevedo e Hahnemann Guimarães corresponde a uma das iniciativas mais significativas no processo histórico-jurídico nacional de dissociação entre os institutos da "representação" e do "contrato de mandato". Dentre as suas disposições que remontam a uma simples transposição de preceitos - situados em meio ao arcabouço devotado ao contrato de mandato, segundo o Código Civil de 1916 - estão as constantes dos artigos 39 e 40, voltadas à disciplina da forma do negócio jurídico de outorga de poderes de representação. 
À semelhança do estabelecido pelo artigo 1291 do Código Civil de 1916 (impropriamente alusivo ao "mandato"), tais juristas preceituaram - por meio do artigo 39 - que "a outorga da representação não está sujeita à forma exigida para o ato que o representante deve celebrar, mas tem de ser feita por escrito, na forma do art. $7^{\circ}$, se o ato exigir instrumento público ou particular". Este preceito em nada inova - quanto ao fundo - em relação ao referido art. 1291 do CC/16. No entanto, corroborando-se nossa argumentação exposta noutra oportunidade (nota 139), temos aqui uma consagração expressa da idéia de que o "princípio da simetria" pertine à "procuração" - negócio de outorga de poderes de representação (que concorre diretamente para a celebração do negócio jurídico representativo) - e não ao contrato de mandato (negócio jurídico de "incumbência"). E o que fica dito aqui há de ser aceito a despeito da posição adotada por cada pesquisador a respeito do cabimento ou não da diretriz mencionada.

Por sua vez, ao artigo 40 do Anteprojeto prescreve que "o instrumento particular deve conter a data e o lugar em que for passado, a designação do outorgado e bem assim o objeto da outorga, a natureza e a extensão dos poderes conferidos". Do mesmo modo, esta regra guarda inteira correspondência com o artigo $1289, \S 1^{\circ}$ do Código Civil de 1916. No entanto, como tivemos a oportunidade de observar, tal regra pertine à forma do negócio de outorga de poderes representativos, parecendo-nos inteiramente pertinente a proposta de remanejamento da matéria evidenciada no dispositivo ora referido do Anteprojeto. No entanto, a proposta dos autores malogrou, encontrando correspondência - quanto ao seu intuito sistemático - tão somente no Anteprojeto de Parte Geral do Código Civil de José Carlos Moreira Alves (arts. 113 e 114). Quanto às demais fontes do direito civil brasileiro que sucederam àquele Anteprojeto, permaneceu-se no equívoco de regular a forma do negócio de outorga em meio ao arcabouço do contrato de mandato; a respeito, cf. os arts. 631, 632 e 634 do AntCM; os arts. 600, 601, 603 e 604 do AntCMRev; o art. 669 do AntMR; o art. 653 do AntMRRev; o art. 663 do PCD n ${ }^{\circ}$ 634/1975; e o art. 654 do CC/2002.

Por sua vez, o artigo 42 do Anteprojeto de Parte Geral do Código das Obrigações de Orosimbo Nonato, Philadelpho Azevedo e Hahnemann Guimarães divisou - acertadamente - que a dicotomia estabelecida entre "poderes de administração" e "poderes especiais" não concernia ao negócio jurídico de incumbência, mas sim ao ato de outorga de poderes de representação: "para contrair obrigações, que importem alienação ou exorbitem da administração ordinária, precisa o representante de poderes expressos". Ou seja, em muito pouco foi alterado o fundo da regra (correspondente ao art. 1295 do CC/16), embora se tenha proposto o seu novo enquadramento sistemático. Novamente, tal orientação contou com posterior reiteração no Anteprojeto de Parte Geral do Código Civil de José Carlos Moreira Alves (artigo 114). No entanto, de igual modo, prevaleceu a orientação precedente em meio às fontes do direito civil brasileiro posteriores - cf. o art. 637 do AntCM; o art. 606 do AntCMRev; o art. 675 do AntMR; o art. 660 do AntMRRev; o art. 670 do PCD n 634/1975; e o art. 661 do CC/2002.

Já no que concerne à eficácia representativa direta dos atos praticados pelo agente, o Anteprojeto de 1941 estabeleceu, em seu artigo 35, que "a declaração de vontade pelo representante, no limite do poder outorgado e em nome do representado, produz desde logo efeitos em relação a este". Tal iniciativa - que somente encontrava no Código Civil de 1916 um antecedente implícito (art. 1296 "caput", "a contrario sensu") - foi bem acolhida pelas demais fontes do direito civil brasileiro que a sucederam, tal como se pode depreender: do art. 37 do AntCM; do art. 38 do AntCMRev; do art. 111 do AntPGMA; do art. 115 do AntMR; do art. 114 do AntMRRev; do art. 114 do PCD $\mathrm{n}^{\circ}$ 634/1975; e do art. 116 do CC/2002. No entanto, alguma reminiscência do "confuso" modelo anterior pode ser depreendida do art. 656 do AntCM - e do correspondente art. 623 do AntCMRev.

Já no que concerne à pluralidade de agentes, o artigo 41 do referido Anteprojeto acena não apenas para um novo enquadramento sistemático da questão, como também para uma nova orientação quanto à regra de fundo subjacente ao tema: "sendo dois ou mais os representantes nomeados no mesmo instrumento, entendese que podem todos exercer os poderes outorgados, se não forem expressamente declarados conjuntos, expecificadamente designados para atos diferentes, ou subordinados à ordem sucessiva". De fato, a atuação dos agentes corresponde a um dos temas de orientação dúplice, na medida em que projeta seus efeitos não apenas perante terceiros, como também produz reflexos em meio à própria relação contratual de incumbência. De todo modo, a prática de atos junto a terceiros apontará para um necessário exame do instrumento do negócio jurídico unilateral de outorga de poderes representativos; e nesse sentido, pois, o acerto do enquadramento sistemático proposto pelos juristas encarregados deste Anteprojeto. Aliás, sua iniciativa foi posteriormente corroborada no Anteprojeto de Parte Geral do Código Civil de José Carlos Moreira Alves (artigo 115). No entanto, as demais fontes do direito civil brasileiro subseqüentes não aderiram à proposta, permanecendo a questão disciplinada exclusivamente em meio ao arcabouço concernente ao contrato de mandato. Não se diz aqui que a questão não guarda pertinência com o âmbito interno da fenomenologia da representação; todavia, além desta perspectiva interna, também seus desdobramentos exteriores haveriam de ter merecido a ordinária atenção do legislador. A respeito, cf. o art. 
630 do AntCM; o art. 599 do AntCMRev; o art. 683 do AntMR; o art. 671 do AntMRRev; o art. 681 do PCD $n^{\circ}$ 634/1975; e o art. 672 do CC/2002.

A disciplina concernente ao "excesso" de poderes foi uma das que mais se beneficiou com a proposta de novo enquadramento sistemático. De fato, assim como mencionamos com relação ao regime da pluralidade de agentes, também a questão do excesso apresenta natureza bifronte, pois ao mesmo tempo em que surte efeitos em face de terceiros, implica em inadimplemento do contrato de mandato. No entanto, uma disciplina exclusivamente atrelada ao tipo contratual não atende - segundo pensamos - à melhor conformação científica do fenômeno. Assim, com relação ao dever do agente de exibir o instrumento de outorga de poderes representativos a terceiros, a iniciativa constante do artigo 43 do Anteprojeto de 1941 é digna de aplauso: "o representante é obrigado a dar prova da extensão de seus poderes às pessoas com quem tratar em nome do representado, sob pena de responder pelo ato excessivo". Com efeito, como versa sobre o exercício dos poderes de representação perante terceiros, a matéria necessariamente deveria receber tratamento junto ao instituto da representação; e assim foi feito no referido Anteprojeto. Razão pela qual foi acolhida entre as seguintes fontes do direito civil brasileiro posteriores: o art. 41 do AntCM; o art. 41 do AntCMRev; o art. 119 do AntPGMA; o art. 117 do AntMR; o art. 116 do AntMRRev; o art. 116 do PCD no 634/1975; e o art. 118 do CC/2002. Todavia, este tema recebeu duplo tratamento por parte do Anteprojeto de Código das Obrigações de Caio Mário da Silva Pereira, que a respeito dispôs também em meio ao arcabouço relacionado ao contrato de mandato (artigo 646) - inclusive na versão revista deste último Anteprojeto (artigo 613).

Ainda com relação ao excesso, os artigos 44, 45 e 46 do Anteprojeto de Parte Geral do Código das Obrigações de Orosimbo Nonato, Philadelpho Azevedo e Hahnemann Guimarães disciplinaram minucioso processo relacionado à "confirmação" pelo principal. Como a questão também apresenta natureza bifronte, parece-nos fora de dúvida o cabimento de uma disciplina voltada à regulação dos efeitos externos de tal irregularidade cometida pelo agente. Assim, no artigo 44 se estabelece a regra básica do sistema, que em nada inova em relação ao art. 1296 do $\mathrm{CC} / 16$ : "vale o ato praticado sem poderes suficientes, se o representado o confirma. Parágrafo único. A confirmação há de ser expressa, ou resultar de ato inequívoco, e retroage à data do ato". Por sua vez, o artigo 45 inova ao facultar ao terceiro o emprego de uma interpelação judicial, a fim de que o principal decida se vai ratificar o ato excessivo de seu procurador ("a parte interessada na confirmação pode interpelar o representado, para que a declare dentro do prazo que o juiz assinar, considerando-se recusada se o representado guardar silêncio"). Relacionada a esta disposição está a regra imediatamente subseqüente (artigo 46), por meio da qual se faculta ao terceiro, até o momento da ratificação - salvo o caso de emprego da interpelação judicial - a desistência quanto ao negócio representativo celebrado ("até que a confirmação seja declarada, salvo no caso de interpelação, pode o terceiro revogar a declaração feita ao representante sem poderes suficientes"). Com efeito, a proposta do referido Anteprojeto - no sentido de um remanejamento sistemático da disciplina concernente à ratificação não contou com a adesão das fontes posteriores do direito civil brasileiro, à exceção do Anteprojeto de Parte Geral do Código Civil de José Carlos Moreira Alves (artigo 120). O Anteprojeto de Código das Obrigações de Caio Mário da Silva Pereira chegou a dispor sobre a responsabilidade irrestrita do representante em caso de excesso, prevendo - genericamente - a possibilidade de ratificação (arts. 39 e 42 do AntCM; e arts. 39 e 42 do AntCMRev). No entanto, quanto à ratificação propriamente dita, preponderou a tendência - que consideramos inadequada - de disciplinar a matéria em meio às regras relativas ao contrato de mandato; a respeito, cf. os arts. 647, 648, 649 e 656 do AntCM; os arts. 614, 615, 616 e 623 do AntCMRev; os arts. 676 e 667 do AntMR; os arts. 661 e 664 do AntMRRev; os arts. 671 e 674 do PCD nº 634/1975; e os arts. 662 e 665 do CC/2002.

Finalmente, quanto ao terceiro que - ciente do excesso - celebra o negócio representativo a despeito da ausência de poderes de representação suficientes por parte do agente, o Anteprojeto de 1941 dispôs, por meio de seu artigo 47, que "o terceiro que, depois de conhecer os poderes do representante, celebra com ele ato excessivo da representação, não tem ação contra o representante, salvo se este lhe prometeu a confirmação, ou se responsabilizou pessoalmente". Primeiramente, observe-se que, embora o dispositivo se tenha omitido, nenhuma ação teria o terceiro contra o representado - por força do artigo 35 do Anteprojeto referido. Além disso, cumpre-nos destacar que é decorrência natural da presença do interesse de terceiros que a matéria seja objeto de disciplina em meio ao instituto da representação - em nada se relacionando, pois, com a relação jurídica decorrente do contrato de mandato (negócio jurídico bilateral de incumbência). Assim, parece-nos inteiramente acertada a orientação adotada no Anteprojeto, no sentido do remanejamento sistemático da disciplina. Nesse mesmo sentido - novamente - se posicionou o Anteprojeto de Parte Geral do Código Civil de José Carlos Moreira Alves (artigo 121). No entanto, as fontes posteriores do direito civil brasileiro consideraram mais adequada a manutenção da regulamentação em meio à disciplina do contrato de mandato. A respeito, cf. o art. 646 do AntCM; o art. 613 do AntCMRev; o art. 684 do AntMR; o art. 672 do AntMRRev; o art. 682 do PCD no 634/1975; e o art. 673 do CC/2002. 


\section{$\S$ 174. A "Parte Geral" do "Anteprojeto de Código das Obrigações"}

(1941): a cessação da representação e as inovações pretendidas por seus autores. Como já tivemos a oportunidade de observar, um dos principais intentos dos autores da "Parte Geral" do "Anteprojeto de Código das Obrigações" (1941) foi o de libertar "o instituto da representação (...) de sua condição servil ao mandato"; deste modo, por meio de uma espécie de "destilação jurídica", buscou-se extrair das disposições do Código Civil a respeito deste tipo aquilo que concernisse à eficácia representativa direta - que se encontrava, pois, em meio a um processo de autêntica emancipação sistemática. Desta forma, a maioria das proposições relacionadas à sua cessação foi obtida a partir de uma simples transposição de enunciados - adaptados - originalmente concebidos para a disciplina do modelo contratual referido; assim se fez, por exemplo, com relação à enumeração das causas extintivas do liame (artigos 48 e 51) e a respeito da preservação dos negócios celebrados perante terceiros de boa-fé - que desconhecessem a superveniência do fato extintivo (artigos 50 e 52). Por outro lado, preconizou-se a adoção de algumas novas regras, tais como: a) a utilização do sistema de registros públicos para que os negócios jurídicos de outorga e de denúncia pudessem surtir efeitos jurídicos "erga omnes" (artigo 49); b) a apuração da "contemplatio domini" segundo as circunstâncias relacionadas à prática do negócio representativo (artigo 36); e c) a aferição da validade da

Note-se também que - à exceção dos opúsculos de J. P. CAVALCANTI (Direito Civil cit. (nota 131), passim) nenhuma crítica similar à efetuada nesta nota de rodapé foi encontrada em meio à doutrina produzida a respeito do Código Civil de 2002 (e de suas respectivas fontes). A respeito, cf. A. SCHREIBER, A representação cit. (nota 131), pp. 231-232; A. VILlAÇA AZEVEDO, Código Civil cit. (nota 04), pp. 96-100, 105-107 e 112; A. VillaçA AZEVEDo - S. de S. VENOSA, Código cit. (nota 02), pp. 110-111 e 357-362; A. de Assis, Contratos cit. (nota 131), pp. 64-69, 74-75 e 93-94; CAIO MÁRIO da Silva Pereira, Instituições cit. (nota 06), pp. 614 e 619-621; Instituições cit. (nota 02), pp. 404 e 407-410; C. A. BITTAR, Os contratos cit. (nota 131), p. 56; C. A. BitTAR FilHO - M. S. BitTar, Código cit. (nota 02), p. 24; C. E . N. CAMILlO - G. M. TAVAlERA - J. S. FujitA - L. A. SCAVONE Júnior (coords.), Comentários cit. (nota 02), pp. 227-228 e 588-593; C. L. Bueno DE Godoy, Do mandato cit. (nota 131), pp. 616-620 e 627-628; C. P. M. CRUZ E TuCCI, Interposição cit. (nota 09), p. 52; C. R. GonÇALVES, Direito cit. (nota 131), pp. 387, 403-404 e 409; F. UlhoA CoElho, Curso cit. (nota 06), pp. 323-324; Curso cit. (nota 02), pp. 300-302; F. Amaral, Direito cit. (nota 131), pp. 457-458; G. TEPEDINO, A técnica cit. (nota 05), p. 70; M. G. MAIA JÚNIOR, A representação cit. (nota 04), pp. 43-44; M. C. do. A. KROETZ, A representação cit. (nota 41), p. 35; MARIA Helena Diniz, Curso cit. (nota 06), pp. 445-446; Curso cit. (nota 02), pp. 353, 370-372; N. C. B. CAMPEllo, Da representação cit. (nota 131), pp. 399 e 412-417 (aludindo à invalidade dos atos excessivos); N. G. B. Dower, Curso cit. (nota 06), p. 298; Curso cit. (nota 02), pp. 288-293; N. NeRY JUNIOR - R. M. de ANDRADE NERY, Código cit. (nota 02), pp. 234-235 e 474-477; N. DUARTE, Da representação cit. (nota 131), pp. 100-102; O.GoMES, Contratos cit. (nota 23), pp. 425-431; O. R. B. SANDOVAL, Do mandato cit. (nota 131), pp. 583, 608-611 e 620; R. LOTUFO, Código cit. (nota 02), pp. 328-329 e 332-335; R. FIUZA (coord.), Novo Código cit. (nota 02), pp. 123-124, 611-615 e 623-624; S. de S. VENOSA, Direito cit. (nota 06), pp. 339342; Direito cit. (nota 02), pp. 259 e 271-272 (aludindo à invalidade dos atos excessivos); S. L. F. da RocHA, Curso cit. (nota 02), pp. 299-300; SILVIO RoDRIGUES, Direito cit. (nota 06), pp. 286-297; Direito cit. (nota 02), pp. 165-166; V. RÁo, Ato Jurídico cit. (nota 131), p. 245; WASHINGTON DE BARRos MonTEIRO, Curso cit. (nota 06), pp. 220-221; Curso cit. (nota 02), pp. 273-274 e 280-282 (aludindo à invalidade dos atos excessivos). 
declaração negocial - via de regra - de acordo com a pessoa do próprio representante (artigo 38). No entanto, como a referida autonomia haveria de ser edificada sobre o fundamento de uma atuação do agente perante terceiros, parece-nos inapropriado o preceito constante do artigo 37 do anteprojeto (que dispõe a respeito do "contrato consigo mesmo"): em primeiro lugar porque embora a celebração do negócio representativo envolva o concurso do representante, há que se observar que este, como tal, não contrai qualquer obrigação em nome próprio; de maneira que um autêntico "contrato consigo mesmo" não poderia ser divisado em um sistema que pretende consagrar a eficácia representativa direta da atuação do agente. Além disso, não se pode deixar de destacar que o conflito de interesses a ser obviado por tal disposição não chega a se projetar externamente ao liame - restringindo-se à perspectiva interna do vínculo (relação gestória mantida entre o constituinte e seu procurador $)^{151}$.

${ }^{151}$ A cessação da representação foi disciplinada pelo Anteprojeto de Parte Geral do Código das Obrigações de Orosimbo Nonato, Philadelpho Azevedo e Hahnemann Guimarães mediante seu artigo 48, no qual se assinalam as causas extintivas de tal eficácia (erigida a instituto autônomo): “cessa a representação: I - pela revogação ou renúncia ; II - pela morte ou interdição de uma das partes ; III - pelo implemento da condição resolutiva, do termo final, ou pela conclusão do negócio; IV - quando extinguir-se o ato em que se funda a representação, ou cessar a situação que a determinou". Este dispositivo, quanto à matéria de fundo, pouco inova em relação ao art. 1316 do CC/16; de fato, sua principal virtude corresponde à emancipação sistemática do instituto da representação.

No entanto, não se pode esquecer que a matéria disciplinada pelo preceito corresponde a uma daquelas que se projeta tanto no âmbito da relação jurídica interna ("contrato de mandato") quanto diante de terceiros ("representação"). Assim, a causa extintiva dos efeitos do negócio de outorga - de poderes representativos freqüentemente percute a eficácia contratual ordinariamente atrelada ao tipo contratual referido, desencadeando - simultaneamente - efeitos internos e externos. Deste modo, a rigor, tal matéria haveria de ser disciplinada nos dois âmbitos - da "representação" e do "mandato" - sem que houvesse qualquer intersecção necessária entre as regulamentações.

Quanto ao fundo disciplinado, em verdade, dois aspectos merecem destaque: em primeiro lugar a previsão expressa da extinção do vínculo em decorrência do implemento do evento futuro a que se acha subordinada a eficácia do negócio jurídico de outorga de poderes. Tal iniciativa do legislador - projetado - nos parece louvável, sendo merecedora de todo aplauso. Com a observação de que nada obstaria a reiteração de tal orientação - como acima dito - em meio à disciplina do "contrato de mandato".

Além disso, há pouco (nota 139) lançamos mão do raciocínio analógico para explicar a relação mantida entre o contrato de mandato e a representação negocial: contrariando a orientação de M. M. de SERPA Lopes - que alude a um vínculo de "causa e efeito" - consideramos o contrato de mandato um - e tão somente um "título" fundamentador da "representação negocial", por sua vez derivada de "modo" específico (a "procuração"). Pois bem, tal ordem de idéias parece encontrar respaldo no inciso IV do referido artigo 48 do Anteprojeto de 1941: pois ao aludir ao "ato em que se funda a representação" (ou à "situação que a determinou") o legislador estabeleceu um liame eficacial entre o "título", o "modo" e os efeitos da representação direta; de maneira que a causa de extinção da relação jurídica contratual (de "incumbência") acabaria por produzir efeitos jurídicos indiretos sobre a eficácia do negócio jurídico de outorga de poderes ("procuração"). Orientação de todo salutar dos legisladores de 1941 - posteriormente referendada pelo Anteprojeto de Parte Geral do Código Civil de José Carlos Moreira Alves (artigo 122); a qual, no entanto, lamentavelmente não encontrou eco em meio às fontes do direito civil brasileiro que se lhe seguiram (cf. o art. 659 do AntCM; o art. 626 do AntCMRev; o art. 693 do AntMR; o art. 681 do AntMRRev; o art. 691 do PCD n ${ }^{\circ}$ 634/1975; e o art. 682 do CC/2002).

Note-se que a extinção dos efeitos do negócio jurídico de outorga de poderes representativos interessa consideravelmente, aliás - a terceiros que eventualmente negociações com o representante. Assim, tomando- 
se em consideração tais interesses dignos de tutela jurídica, o artigo 52 do Anteprojeto de 1941 transpôs ao âmbito da representação a regra contida no art. 1321 do CC/16 - exclusivamente afeta ao contrato de mandato ("são válidos, a respeito dos interessados de boa fé, os atos com estes ajustados pelo representante, enquanto ignora a morte do representado ou a extinção, por qualquer outra causa, da representação"). Aqui, novamente, estamos diante de um fato jurídico que pode projetar seus efeitos nos âmbitos interno e externo da fenomenologia da representação: não fosse tal espécie de preceito e o intérprete estaria jungido - por força da aplicação dos princípios - a considerar extintas a relação contratual de incumbência e a eficácia representativa potencial (atrelada ao exercício dos poderes conferidos por meio do ato de outorga). Desta forma, à vista do intuito protetivo (em relação a terceiros), parece-nos adequada a transposição pretendida pelos legisladores projetados; com a única ressalva de que tal a legitimidade da gestão também deveria ser respaldada no âmbito interno da gestão - mediante reiteração do preceito em meio às disposições integrantes do arcabouço normativo disciplinador do tipo contratual objeto de nossas investigações. Note-se que - ainda aqui - a orientação adotada no referido artigo 52 foi acompanhada por José Carlos Moreira Alves em seu Anteprojeto de Parte Geral do Código Civil (artigo 127). Todavia, mais uma vez - também - prevaleceu a orientação oposta, conservando-se tal miscigenação conceitual; neste sentido, cf. art. 664 do AntCM; o art. 630 do AntCMRev; o art. 700 do AntMR; o art. 688 do AntMRRev; o art. 698 do PCD n 634/1975; e o art. 689 do $\mathrm{CC} / 2002$.

Quanto ao fundo da regra, deve-se observar - como o faz C. L. BUENO DE GODOY quanto à disposição correspondente do Código Civil de 2002 (artigo 689) - que o dispositivo, a despeito da terminologia empregada, se volta à "eficácia" do negócio jurídico representativo, e não à sua "validade" (Do mandato cit. (nota 131), pp. 644-645). Devem ser rechaçadas, por outro lado, as posições de O. R. B. SANDOVAL (Do mandato cit. (nota 131), p. 596) e de S. de S. VENOSA (Direito cit. (nota 02), pp. 279-281): o primeiro por entrever, na hipótese, uma modalidade de "mandato aparente"; e o segundo por aludir, indevidamente, a um mandato "post mortem".

Ora, a tutela dos interesses de terceiros está intimamente vinculada à eficiência do sistema de registros públicos, como já tivemos a oportunidade de observar (nota 136); em tal sentido, o artigo 49 do Anteprojeto de Parte Geral do Código das Obrigações de Orosimbo Nonato, Philadelpho Azevedo e Hahnemann Guimarães pretendeu contribuir, prescrevendo que "a revogação pode ser declarada por aviso na imprensa e averbada à margem de notas públicas, quando delas constar a outorga, ressalvada a boa-fé de terceiros”. É fato que consideramos inadequada a ressalva final do dispositivo projetado, uma vez que, em verdade, ou prevalece o sistema de registros, ou se dá passagem à boa fé de terceiros. No entanto, considerada a finalidade de tal mecanismo, parece-nos que a proteção "suficiente" aos interesses destes últimos é uma decorrência fundamental de seu funcionamento: devendo-se, assim, prestigiá-lo sempre que possível ressalvando-se tão somente casos excepcionalíssimos. No entanto, considerada a proposta dos legisladores, parece-nos, novamente, digna de aplauso a iniciativa; a qual, embora retomasse regra antiga - prevista no art. 159 do CCom e no art. 3015 do "Esboço" - apenas foi considerada adequada por José Carlos Moreira Alves em seu Anteprojeto de Parte geral do Código Civil (artigo 123).

Ainda na mesma linha de proteção aos legítimos interesses de terceiros, o artigo 50 do Anteprojeto de 1941 preceituava a ineficácia - perante estes - do negócio jurídico de revogação informado tão somente ao agente: "a revogação, notificada somente ao representante, não vale contra os terceiros, que, ignorando-a, com ele trataram". Ora, quanto ao seu fundo, tal regra simplesmente adapta - quanto à terminologia relacionada ao novo enquadramento - o preceito constante do art. 1318 do CC/16. No entanto, o leitor sagaz perceberá, desde logo, que o dispositivo não contempla as ações regressivas do principal contra seu agente; no entanto, como tal aspecto concerne à relação interna - subjacente ao fenômeno -, parece-nos irrepreensível a orientação adotada pelos legisladores projetados. $\mathrm{O}$ assunto haveria de ser disciplinado, também, em meio ao arcabouço jurídico afeto ao contrato de mandato. Não foi esta, todavia, a orientação adotada por José Carlos Moreira Alves, que preferiu ressalvar expressamente - no artigo 124 de seu Anteprojeto de Parte Geral do Código Civil - as ações que "no caso, lhe possam caber contra o procurador". Talvez não seja necessário reiterar - mais uma vez - que também com relação a este tema as fontes do direito civil brasileiro subseqüentes preferiram conservar a "confusão" prevalecente no sistema de 1916; a respeito, cf. art. 662 do AntCM; o art. 628 do AntCMRev; o art. 697 do AntMR; o art. 685 do AntMRRev; o art. 695 do PCD nº 634/1975; e o art. 686 do CC/2002.

Outra matéria que suscita duplo efeito - nos âmbitos interno e externo da fenomenologia da representação - é a relacionada aos efeitos derrogatórios da constituição de novo agente por parte do principal. Tal assunto foi assim disciplinado - pela via projetada - pelo artigo 51 do Anteprojeto de Parte Geral do Código das Obrigações de Orosimbo Nonato, Philadelpho Azevedo e Hahnemann Guimarães: "comunicada ao representante a nomeação de outro para o mesmo negócio, considera-se revogada a representação anterior". Ora, quanto a este dispositivo, algumas ressalvas devem ser feitas. Em primeiro lugar, tendo-se em vista o fato de que a ereção da eficácia representativa direta a autêntico "instituto" teve por finalidade a tutela 
jurídica de terceiros, não nos parece que tal dispositivo efetivamente os contemple de modo satisfatório: pois o conhecimento da revogação por parte do representante não justifica a extensão do efeito derrogatório a terceiros. Ora, se o leitor nos disser que à hipótese se aplicaria - quanto aos terceiros - o citado artigo 50 do referido Anteprojeto, perguntaremos em réplica: então, que razão justificaria a presença da regra do artigo 51 em meio ao arcabouço da "representação"? Não seria suficiente sua articulação sob a disciplina afeta ao contrato de mandato? A resposta a esta última indagação nos parece, sem dúvida, afirmativa. Por tal razão, consideramos supérflua a regra do artigo 51 do Anteprojeto de 1941, merecendo aproveitamento respectivo em meio ao arcabouço do tipo contratual objeto de nossas investigações. De todo modo, tal orientação foi adotada por José Carlos Moreira Alves em meio ao seu Anteprojeto de Parte Geral do Código Civil (artigo 125). Neste particular, contudo, consideramos que a posição mais adequada foi aquela adotada pelas demais fontes do direito civil brasileiro subseqüentes ao Anteprojeto referido; a respeito, cf. art. 663 do AntCM (embora se utilizando do termo "representante"); o art. 629 do AntCMRev (conquanto empregado, aqui, o termo "procurador"); o art. 698 do AntMR; o art. 686 do AntMRRev; o art. 696 do PCD no 634/1975; e o art. 687 do CC/2002.

A principal exceção do Anteprojeto de 1941 ao princípio da eficácia representativa direta - defluente da atuação do procurador - corresponde à previsão constante de seu artigo 36 , no qual se estabelece que "a prova de que a declaração se fez em nome do representado pode resultar das circunstâncias, respondendo pessoalmente o representante se não deu a conhecer que procedia em nome de outrem". Aqui temos uma consagração oblíqua à hipótese - marginalizada - da representação indireta, em meio à qual o agente atua em seu próprio nome, conquanto administre os interesses envolvidos por conta do representado. Além disso, o dispositivo vai mais além, preconizando a responsabilidade pessoal do mandatário que não declina a terceiros seu papel de "representante" do principal; desta forma, parece-nos irrepreensível a orientação do Anteprojeto de Código das Obrigações de Orosimbo Nonato, Philadelpho Azevedo e Hahnemann Guimarães, uma vez que se oferece eficiente tutela a terceiros por meio do preceito estabelecido no referido artigo 36 , no qual, ademais, se faz apelo às circunstâncias negociais como elemento hermenêutico a ser considerado pelo intérprete. Note-se, pois, que tal iniciativa foi adotada pelo Anteprojeto de Código das Obrigações de Caio Mário da Silva Pereira (artigo 39) - inclusive em sua variante revista (art. 39 do AntCMRev).

O artigo 38 do Anteprojeto de Parte Geral do Código das Obrigações de Orosimbo Nonato, Philadelpho Azevedo e Hahnemann Guimarães - concernente à validade da declaração negocial proferida por meio de representante - não contou, lamentavelmente, com qualquer espécie de respaldo legislativo em meio às fontes do direito civil brasileiro que the sucederam. Por oportuno, seu enunciado assim prescrevia: "para estabelecer-se a validade da declaração, considera-se a pessoa do representante, a menos que se trate de circunstâncias que influíram na outorga da representação". Aliás, quanto a este aspecto, J. C. MOREIRA ALVES observa que o Anteprojeto de Código Civil elaborado pela comissão presidida por Miguel Reale "ao invés de tomar posição nessa questão melindrosa (...) preferira, como sucedia com vários outros códigos, deixar a matéria à consideração da jurisprudência e da doutrina, à luz dos princípios gerais" (A Parte Geral cit. (nota 131), p. 139). Em estudo futuro pretendermos demonstrar as razões de nossa discordância. No entanto, como aqui pretendemos tão somente coligir o material disperso em nossa historiografia jurídica, consideramos bem-sucedido nosso esforço ainda que nos detenhamos neste ponto.

Finalmente, cumpre destacar a previsão expressa, no artigo 37 do Anteprojeto de 1941, de uma vedação genérica ao "contrato consigo mesmo": "o representante não pode, salvo se a lei ou o representado o permitirem, contrair consigo mesmo as obrigações que foi autorizado a assumir". Ora, já tivemos a oportunidade de nos pronunciar a respeito da expressão "contrato consigo mesmo" - que consideramos absolutamente inadequada - e da tutela conferida pelo legislador ao "conflito de interesses" (nota 140). Resta-nos aqui, por fim, tecer alguns poucos comentários acerca do enquadramento sistemático adotado pelo Anteprojeto de Parte Geral do Código das Obrigações de Orosimbo Nonato, Philadelpho Azevedo e Hahnemann Guimarães; ora, ao contrário do que sustentam tais juristas - no que foram acompanhados, aliás, pela unanimidade das fontes do direito civil brasileiro posteriores (cf. o art. 40 do AntCM; o art. 40 do AntCMRev; o art. 112 do AntPGMA; o art. 116 do AntMR; o art. 115 do AntMRRev; o art. 115 do PCD n 634/1975; e o art. 117 do CC/2002) - reputamos o "conflito de interesses" uma matéria que concerne, exclusivamente, à relação gestória subjacente à administração confiada ao representante. Note-se que, ainda que tal matéria também possa oferecer interesse quanto à representação necessária (ou legal), tal fato - por si só - não justifica a transposição da matéria para o âmbito do instituto da representação: inexistem interesses de terceiros envolvidos, uma vez que a contraparte no negócio jurídico representativo é o próprio representante. Dá-se algo similar à situação do título de crédito que, conquanto "criado", ainda não foi posto em circulação ("emitido"). A frustração - que se dá na contratação consigo mesmo - é à confiança daquele que o investiu em tal posição, e não aos legítimos interesses de terceiros; em outras palavras, o problema pertine à "relação gestória" - representação indireta disciplinada pelo "mandato" em meio ao direito das obrigações (conquanto suscetível de extensão a outras searas do direito civil) - e não à representação direta, 


\section{§ 175. O “Anteprojeto de Código das Obrigações” de Caio Mário da Silva}

Pereira e suas peculiaridades. Embora o "Anteprojeto de Código das Obrigações" elaborado por Caio Mário da Silva Pereira em 1963 - dispusesse de modo relativamente autônomo a respeito da "representação" e do "mandato", pode-se afirmar que suas inovações se circunscreveram ao primeiro instituto. Assim, por meio de uma metonímia de valor duvidoso - uma vez que se toma o sujeito de direito pelo negócio jurídico dele defluente - o seu artigo 38 estabelecia que a atribuição de poderes representativos haveria de decorrer da "lei" ou do "interessado". Já no artigo 39 se estendia - por força de sua conjugação com o artigo 41 - o alcance da responsabilidade do representante na hipótese de excesso: com efeito, em lugar da ordinária exoneração decorrente da exibição do instrumento de outorga, prescrevia-se - de modo irrestrito - a vinculação do agente que exorbitasse dos poderes que outrora lhe tivessem sido conferidos. Além disso, no artigo 43 se preconizava - por meio de uma cláusula remissiva - a incidência das regras concernentes ao contrato de mandato; note-se que além de comprometer a autonomia sistemática entre os institutos, tal disposição também continha uma indevida alusão à

erigida a instituto autônomo pelo legislador civil. Além disso, como bem ressalta E. EsPíNOLA: "uma relação juridica procedente de auto-contracto só se nos afigura possível em princípio e compativel com o systema da legislação patria e, em geral, das legislações modernas, quando a declaração de vontade do representante se dirige unicamente á celebração do acto, ao estabelecimento do vinculo e absolutamente não á determinação do conteúdo obrigacional" (Procuração cit. (nota 144), p. 22). Desta forma, em posição contrária à orientação - unânime - das fontes do direito civil brasileiro posteriores ao Anteprojeto de 1941, reputamos tal questão um tema alheio à representação direta. Note-se, por fim, que no Anteprojeto de Parte Geral do Código Civil José Carlos Moreira Alves incluiu expressamente - sob a regra proibitiva - a hipótese de substabelecimento de poderes (voltado a, maliciosamente, ludibriar a vedação prevista no "caput").

Pela doutrina devotada ao assunto - em alusão às disposições correspondentes do Código Civil de 2002 - cf. A. Villaça Azevedo, Código Civil cit. (nota 04), pp. 101-104; A. Villaça AzEVEdo - S. de S. VenOSA, Código cit. (nota 02), pp. 110-111 e 367-368; A. de ASSIS, Contratos cit. (nota 131), pp. 128-132 e 135-137; CAIO MÁRIO da Silva Pereira, Instituições cit. (nota 06), pp. 623-624; Instituições cit. (nota 02), pp. 399-414; C. A. Bittar Filho - M. S. Bittar, Código cit. (nota 02), pp. 24 e 57; C. E . N. Camillo - G. M. TAVAlera - J. S. Fujita - L. A. SCAVONE Júnior (coords.), Comentários cit. (nota 02), pp. 227 e 599-600; C. L. Bueno De Godoy, Do mandato cit. (nota 131), pp. 641-645; C. R. GonçALVES, Direito cit. (nota 131), pp. 400, 413-415 e 418-420; F. UlhoA CoElho, Curso cit. (nota 06), pp. 301-302; Curso cit. (nota 02), pp. 325-328; F. AmARAl, Direito cit. (nota 131), pp. 456-460 e 468-472; G. R. NiCOLAU, Direito cit. (nota 06), pp. 124-125; G. TEPEDINO, A técnica cit. (nota 05), pp. 75-78; J. C. MoREIRA AlVES, O negócio cit. (nota 131), p. 40; O novo Código cit. (nota 131), pp. 17-18; A Parte Geral cit. (nota 131), pp. 105-106; M. G. MAIA Júnior, A representação cit. (nota 04), pp. 30, 44, 147 e 173-179; M. C. do. A. Kroetz, A representação cit. (nota 41), p. 35; MARIA HelENA DINIZ, Curso cit. (nota 06), pp. 446; Curso cit. (nota 02), pp. 354 e 371-378; N. C. B. CAMPEllo, Da representação cit. (nota 131), pp. 413 e 419; N. G. B. DowER, Curso cit. (nota 06), p. 300; Curso cit. (nota 02), pp. 296-301; N. NERY JUNIOR - R. M. de ANDRADE NERY, Código cit. (nota 02), pp. 234-235 e 480-481; N. DUARTE, Da representação cit. (nota 131), pp. 101-102; O.Gomes, Contratos cit. (nota 23), pp. 425, 432 e 435; O. R. B. SANDOVAL, Do mandato cit. (nota 131), pp.583, 596 e 632-634; R. Lotufo, Código cit. (nota 02), pp. 330-332; R. FiUZA (coord.), Novo Código cit. (nota 02), pp. 123-124 e 636-640; S. de S. VENOSA, Direito cit. (nota 06), pp. 341-342; Direito cit. (nota 02), pp. 260-263 e 275-280; S. L. F. da RochA, Curso cit. (nota 02), pp. 303-307; Silvio RodRIGUES, Direito cit. (nota 06), pp. 287 e 303-304; Direito cit. (nota 02), pp. 166-167; V. RÁO, Ato Jurídico cit. (nota 131), p. 245; WASHINGTON DE BARros MonteIRo, Curso cit. (nota 06), pp. 220-221; e Curso cit. (nota 02), pp. 583 , 596 e 632-634. 
representação "convencional": adjetivo este tão inadequado que na versão constante do Projeto de Lei $\mathrm{n}^{\mathrm{o}}$ 3264/65 foi substituído pelo termo "voluntária" - o qual, por sua vez, embora não redunde em um maior prejuízo técnico, parece padecer do mesmo ímpeto metonímico que se vislumbra no mencionado artigo $38^{152}$.

${ }^{152} \mathrm{O}$ artigo 38 do Anteprojeto de Código das Obrigações de Caio Mário da Silva Pereira dispôs sobre as fontes da atribuição de poderes de representação: "os poderes de representação são conferidos pela lei ou pelo interessado". Tal dispositivo - segundo nos parece - padece de evidente vício técnico, derivado de uma metonímia inadvertidamente utilizada por seu autor: com efeito, a atribuição de poderes representativos não se faz pelo interessado, em seu íntimo querer: faz-se necessária a outorga por meio do negócio jurídico respectivo. Tanto isso é verdade que, antes de emitida a declaração, nenhum efeito atributivo (dos referidos poderes) pode ser divisado. Daí a razão por que preferimos a expressão "negócio jurídico" - ou mesmo declaração negocial - em lugar da empregada pelo autor do referido Anteprojeto. No entanto, a orientação ora criticada acabou por prevalecer; a respeito, cf. o art. 37 do AntCMRev; o art. 114 do AntMR; o art. 113 do AntMRRev; o art. 113 do PCD no 634/1975; e o art. 115 do CC/2002.

No entanto, mudança de orientação técnica flagrante decorre do artigo 39 do aludido Anteprojeto: "a prova da representação pode resultar das circunstâncias, mas em qualquer caso responde o representante, se não deu a conhecer que procedia em nome de outrem, ou se excedeu os poderes". Ora, aqui a alteração de rumos foi drástica (e a nosso ver desastrosa): em lugar da utilização da conjunção aditiva "e", o autor lançou mão da alternativa "ou"; com isso, subverteu-se o sistema até então prevalecente. Expliquemo-nos.

A exibição do instrumento de outorga de poderes representativos sempre foi tomada por nosso legislador como um mecanismo de exoneração do agente: uma vez apresentado ao terceiro, liberava-se de toda e qualquer responsabilidade, atribuindo-se a este último todo o risco em caso de excesso de poderes praticado pelo agente - a respeito, cf. o art. 2953 do "Esboço"; o art. 1456 do AntCB; o art. 1526 do AntCBRev; o art. 1306 do PCD no 1/1912; o art. 1306 do PSF no 269/1912; o art. 1306 do CC/1916; e o art. 47 do AntOPH. Ocorre que a solução oferecida no artigo 39 do Anteprojeto de Código das Obrigações de Caio Mário da Silva Pereira - reiterada no artigo 39 de sua versão revista - é completamente diversa, uma vez que atribui ao agente, irrestritamente, a responsabilidade perante terceiros em caso de excesso. Note-se que tal orientação, aliás, se encontra em contradição com o próprio artigo 646 do referido Anteprojeto (reiterado como artigo 613 da versão revista), no qual se adota a diretriz tradicional em nosso sistema jurídico: "o mandatário é obrigado a exibir o instrumento de mandato às pessoas com quem, nessa qualidade tratar, sob pena de responder a elas por qualquer ato que exceda os poderes recebidos. Mas o terceiro que, depois de conhecer os poderes do mandatário, com ele fizer contrato exorbitante daqueles poderes, não tem ação nem contra o mandante, nem contra o mandatário, salvo se este lhe prometeu ratificação do mandante, ou pessoalmente assumiu a responsabilidade do negócio". Diga-se, de passagem, que a orientação tradicional acabou por prevalecer em meio às fontes subseqüentes de nosso direito civil: a respeito, cf. o art. 121 do AntPGMA; o art. 684 do AntMR; o art. 672 do AntMRRev; o art. 682 do PCD n ${ }^{\circ}$ 634/1975; e o art. 673 do CC/2002 observando-se que tão somente o Anteprojeto de Parte Geral do Código Civil de José Carlos Moreira Alves pretendeu que a questão fosse submetida à disciplina da representação.

Finalmente, merece destaque a regra remissiva situada no artigo 43 do Anteprojeto de Código das Obrigações de Caio Mário da Silva Pereira: "os requisitos e os efeitos da representação legal são os estabelecidos nas normas respectivas, e os originários da representação convencional regulam-se pela disciplina do mandato, desenvolvida neste código além das disposições legais ou regulamentares especiais". Posta de parte a indevida menção a uma representação "convencional" - tenha-se em conta que a atribuição de poderes representativos decorre de negócio jurídico unilateral -, parece-nos que esta disposição corresponde ao preceito mais deletério no panorama de emancipação sistemática da representação ("direta"). Para que não sejamos sobremaneira indelicados, devemos dizer que a contribuição do referido dispositivo para este processo se assemelha ao papel da cláusula "revogam-se as disposições em contrário" - ainda hoje corriqueiramente encontráveis em nossa legislação. Ora, diante do art. $2^{\circ}, \S 1^{\circ}$ da Lei de Introdução ao Código Civil, pergunta-se: qual o préstimo desta espécie de disposição? Parece-nos que absolutamente nenhum.

Pois bem: também nos parece que o autor do Anteprojeto de Código das Obrigações hesitou quanto à dissociação entre os conceitos de "mandato", "procuração" e "representação"; talvez aí tenhamos uma explicação para a contradição mencionada logo acima. No entanto, preferiu a cômoda solução de remeter a questão à doutrina e à jurisprudência. Definitivamente, não nos parece que esta seja a solução mais adequada ao problema. Em Proposta de Emenda n 162 (ao art. 118 do PCD n ${ }^{\circ}$ 634/1975), o Deputado Fernando 


\title{
$\S$ 176. O "Anteprojeto da Parte Geral do Código Civil” de José Carlos
}

\author{
Moreira Alves: contribuição documental do estudo e aspectos peculiares da disciplina
}

proposta. Sob a perspectiva histórica, uma significativa contribuição que se pretende trazer

com o presente estudo corresponde à apresentação do trecho concernente à disciplina da representação segundo o "Anteprojeto da Parte Geral do Código Civil” de 1970 - de autoria de José Carlos Moreira Alves. Dentre os vinte dispositivos que integram o capítulo respectivo, interessam-nos mais de perto - à vista de seu caráter inovador - os artigos 116, 117, 118, 126, 128, 129 e 130: destes, os três primeiros se voltam à admissibilidade, à

Coelho assinalava que "a remissão que o Projeto faz, na parte final do art. 118, da disciplina da chamada representação voluntária para a Parte Especial do Código, importa numa contradição com a Parte Geral. Ademais, vai implicar em vincular a procuração ao mandato, na consideração daquele como instrumento deste. Impõe-se assim, a supressão da parte final do artigo". Neste sentido, M. G. MAIA JÚNIOR desfecha sua crítica: "supre [o Anteprojeto que redundou no Código Civil de 2002 (continente de disposição semelhante)] (...) em parte, a omissão do Código Civil ao disciplinar em sua parte geral, nos arts. 115 a 120 , as regras básicas da representação. Remete, contudo, a disciplina da representação voluntária para as regras do contrato de mandato, incidindo nas mesmas falhas do atual, não diferenciando a representação, o contrato de mandato e a procuração, como instrumento de outorga do poder de representar" (A representação cit. (nota 04), p. 43); na mesma linha, A. SCHREIBER afirma que "a dedicação de um capítulo inteiro de sua parte geral ao tema da representação (artigos 115 a 120) sugere que a nova codificação reconheceu a plena autonomia do instituto (...) o legislador parece, contudo, arrepender-se de tal avanço e voltar atrás no derradeiro dispositivo" (A representação cit. (nota 131), p. 237).

Fato é que tal posição acabou por produzir reflexos em meio às fontes posteriores de nosso direito civil; a respeito, cf. o art. 43 do AntCMRev (do qual foi retirada a menção expressa ao mandato e à legislação especial); o art. 120 do AntMR; o art. 118 do AntMRRev; o art. 118 do PCD n 634/1975; e o art. 120 do $\mathrm{CC} / 2002$.

Por tal ordem de idéias somos levados a discordar de A. JUNQUEIRA DE AZEVEDo e F. P. de C. MARINO (atualizadores da obra de O. GoMES), quando asseveram que "o Código Civil de 2002 reservou um capítulo no Livro III da Parte geral para disciplinar a representação em geral (...) trata separadamente, portanto, da representação e do mandato, atendendo à distinção examinada pelo autor" (Contratos cit. (nota 23), pp. 425426).

Pela bibliografia produzida a respeito dos assuntos analisados na presente nota de rodapé - à luz do Código Civil de 2002 - cf. A. SCHREIBER, A representação cit. (nota 131), pp. 228, 232-234 e 237-238; A. VILLAÇA AzEVEdo, Código Civil cit. (nota 04), pp. 92-95 e 111-112; A. VillaÇA AzEVEDo - S. de S. VenosA, Código cit. (nota 02), pp. 109-112; CAIO MÁRIO da Silva Pereira, Instituições cit. (nota 06), pp. 621-625; C. A. BitTar Filho - M. S. BitTar, Código cit. (nota 02), p. 24; C. E . N. Camillo - G. M. TAvalera - J. S. Fujita - L. A. SCAvone JúNIOR (coords.), Comentários cit. (nota 02), pp. 226-228; C. L. BuenO DE GodOY, Do mandato cit. (nota 131), p. 606 (aludindo à representação "convencional”); C. P. M. CRUZ E TUCCI, Interposição cit. (nota 09), pp. 49-50; F. UlhoA CoElHo, Curso cit. (nota 06), p. 299; F. AMARAL, Direito cit. (nota 131), pp. 448 e 452-454; G. R. NiCOLAU, Direito cit. (nota 06), p. 124; G. TEPEDINO, A técnica cit. (nota 05), pp. 67-68; J. B. VILlela, Parte geral cit. (nota 131), p. 212; J. C. Moreira AlVES, O negócio cit. (nota 131), p. 40; A Parte Geral cit. (nota 131), pp. 79, 88, 105-106 e 139; J. P. CAVAlCANTI, O Congresso cit. (nota 131), p. 59; L. MATTIETTO, A representação cit. (nota 131), p. 55; L. R. de FreitAs GOMES, Contrato cit. (nota 131), p. 286; M. G. MAIA JÚNIOR, A representação cit. (nota 04), pp. 30 e 43; M. C. do. A. Kroetz, A representação cit. (nota 41), p. 35; MARIA Helena Diniz, Curso cit. (nota 06), p. 445; N. C. B. CAMPEllo, Da representação cit. (nota 131), p. 396; N. G. B. Dower, Curso cit. (nota 06), pp. 298-301; N. Nery JUnior - R. M. de ANDRAde Nery, Código cit. (nota 02), pp. 233-236; N. DuARTE, Da representação cit. (nota 131), pp. 100-103; O.GOMES, Contratos cit. (nota 23), pp. 424-425; O. R. B. SANDOval, Do mandato cit. (nota 131), p. 583; R. Lotufo, Código cit. (nota 02), pp. 323-328 e 339-340; R. FIUZA (coord.), Novo Código cit. (nota 02), pp. 122-125; S. de S. VENOSA, Direito cit. (nota 06), pp. 335-339; Silvio Rodrigues, Direito cit. (nota 06), p. 287; Direito cit. (nota 02), p. 165; V. RÁo, Ato Jurídico cit. (nota 131), p. 245; WASHINGTON DE BARROS MONTEIRO, Curso cit. (nota 06), pp. 219-221; e Curso cit. (nota 02), p. 261. 
responsabilidade e à forma do substabelecimento (artigos 116, 117 e 118); por sua vez, no artigo 126 se prescreve a responsabilidade do representante - ressalvado o prejuízo próprio “considerável" - pela denúncia súbita que cause dano ao representado. Já em caso de "perigo na demora", o artigo 128 imputa ao agente - mesmo após o advento de causa extintiva do vínculo - deveres de natureza provisional; os quais, na hipótese de sua morte (artigo 129), são estendidos aos seus herdeiros - observando-se, de todo modo, o limite relativo às providências de caráter essencialmente conservativo (artigo 130). Ora, não podemos deixar de observar que destes, apenas o artigo 116 - relacionado à forma do substabelecimento - se projeta, ordinariamente, sobre a esfera jurídica de terceiros; mesmo quanto aos artigos 128 e 129 é necessário um esforço hermenêutico considerável para que se possa divisar o interesse de um estranho na conclusão de atos já iniciados quando da cessação da representação. Já os artigos 117, 118, 126 e 130 respeitam exclusivamente a aspectos internos da relação jurídica gestória, parecendo não se justificar - à primeira vista - a sua estipulação em meio à disciplina da representação. Perceba-se que a plurivocidade do termo "procuração" nos sugere que o autor, além de se referir ao instrumento de outorga de poderes representativos, pretendeu contemplar - também - a relação gestória a que os romanos se referiam por meio da expressão "procuratio"; de todo modo, se "mandato" e "representação" não se confundem, mostra-se necessária uma análise mais cuidadosa dos contornos eficaciais da gestão incumbida - tarefa que não pode prescindir não só da historiografia jurídica, como também de uma abordagem específica da variante "indireta" do instituto emancipando ${ }^{153}$.

\footnotetext{
${ }^{153}$ A primeira observação que se deve fazer a respeito do Anteprojeto de Parte Geral do Código Civil de José Carlos Moreira Alves corresponde ao necessário reconhecimento de seu papel restaurador das linhas gerais estabelecidas - a respeito do instituto da representação (direta) - pelo Anteprojeto de Parte Geral do Código das Obrigações de Orosimbo Nonato, Philadelpho Azevedo e Hahnemann Guimarães. Com efeito, o Anteprojeto de 1970 retirou deste último seus artigos 111, 113, 114, 115, 119, 120, 121, 122, 123, 125 e 127 - sendo que do Anteprojeto de Código das Obrigações de Caio Mário da Silva Pereira se originou o seu artigo 112. No entanto, afora tais disposições, todas as demais correspondem à manifestação inovadora de seu autor; analisemos, pois, cada um destes preceitos.

O substabelecimento foi objeto da disciplina desenvolvida entre os artigos 116 e 118 do Anteprojeto. No artigo 116 assim se estabelece a forma livre de seu instrumento: "ainda quando se outorgue representação por instrumento público, pode-se substabelecer mediante instrumento particular". Com efeito, tal regra merece ligeira ressalva, uma vez que - em atenção ao interesse de terceiros a ser resguardado no âmbito do instituto da "representação" - o princípio da simetria das formas impõe, necessariamente, a observância da forma pública - por ocasião do substabelecimento - sempre que a procuração tenha sido outorgada por instrumento público à vista de disposição legal - e não por simples iniciativa das partes. Neste sentido o Enunciado no 182 da III Jornada de Direito Civil realizada pelo Conselho da Justiça Federal: "o mandato outorgado por instrumento público previsto no art. 655 do Código Civil somente admite substabelecimento por instrumento particular quando a forma pública for facultativa e não integrar a substância do ato". De todo modo, pela projeção de tal dispositivo no âmbito das fontes do direito civil brasileiro subseqüentes, cf. o art. 670 do AntMR; o art. 654 do AntMRRev; o art. 664 do PCD n 634/1975; e o art. 655 do CC/2002.
} 
Por sua vez, o artigo 117 prescreve que "quem, autorizado a fazê-lo, substabelecer, sòmente responde pelos atos do substabelecido se tiver agido com culpa na escolha, ou nas instruções que lhe deu. Parágrafo único. Se a procuração fôr omissa sôbre o substabelecimento, o procurador será responsável, também, se o substabelecido proceder culposamente"; tal regra - que se filia ao art. 1300 do CC/16 - se coordena com a disposição imediatamente seguinte (artigo 118), na qual se disciplina o responsabilidade do substabelecente na hipótese de vedação à delegação: "se, apesar de proibição expressa, o procurador substabelecer, responde êle até pelo dano resultante de fôrça maior, salvo se provar que o prejuízo ocorreria ainda que não tivesse havido substabelecimento". Estas duas últimas disposições, todavia, parecem-nos voltadas aos aspectos internos da relação gestória - diferentemente do que se dá com relação ao artigo 116 do aludido Anteprojeto. Por tal razão, parece-nos que andaram bem as fontes subseqüentes do direito brasileiro em manter a matéria disciplinada em meio à regulamentação do contrato de mandato - a respeito, cf. o art. 679 do AntMR; o art. 666 do AntMRRev; o art. 676 do PCD no 634/1975; e o art. 667 do CC/2002. Note-se, todavia, que o $\S 3^{\circ}$ de cada um destes últimos quatro dispositivos referidos alude à proibição do substabelecimento constante da procuração: ora, tratando-se de regra alusiva ao instrumento do negócio jurídico de outorga de poderes representativos - suscetível de produzir efeitos diante de terceiros - deveria constar, pois, do arcabouço normativo atinente à "representação" - em meio à Parte Geral do Código Civil.

Por sua vez, no artigo 126 do Anteprojeto de 1970 se estabelece que "a renúncia da representação será comunicada ao representado, que, se fôr prejudicado pela sua inoportunidade, ou pela falta de tempo, a fim de prover à substituição do procurador, será indenizado pelo representante, salvo se êste provar que não podia continuar a representá-lo sem prejuízo considerável". Com efeito, a análise de tal preceito nos revela que o mesmo corresponde a uma simples adaptação do art. 1320 do CC/16 à terminologia relacionada ao instituto da representação. Tal regra, porém, parece-nos - da mesma forma como observamos a respeito dos artigos 117 e 118 do Anteprojeto - preceito voltado à tutela da "confiança" subjacente à relação jurídica decorrente do contrato de mandato. Desta forma, cremos inadequado o remanejamento do preceito, parecendo-nos mais oportuno que permaneça junto à disciplina afeta ao contrato de mandato. Neste sentido, aliás, as fontes posteriores do direito civil brasileiro - cf. o art. 699 do AntMR; o art. 687 do AntMRRev; o art. 697 do PCD no 634/1975; e o art. 688 do CC/2002.

O artigo 128 do Anteprojeto de Parte Geral do Código Civil de José Carlos Moreira Alves, por sua volta, comete ao agente o dever de prosseguir provisionalmente na gestão, a despeito da ciência da causa de extinção dos efeitos ordinários da outorga: "embora ciente da morte ou interdição do representado, deve o representante concluir o negócio já começado, se houver perigo na demora". Disposição inspirada no art. 1308 do CC/16 - e que do mesmo modo parece-nos concernente à relação gestória, em sentido similar ao prevalecente em meio às fontes subseqüentes do direito civil brasileiro (art. 685 do AntMR; art. 673 do AntMRRev; art. 683 do PCD no 634/1975; e art. 674 do CC/2002).

O artigo 129 do Anteprojeto de 1970 dispunha sobre a morte do representante durante a pendência de negócio a ele atribuído ("se falecer o representante, pendente o negócio a êle cometido, os herdeiros, tendo ciência da representação, avisarão o representado, e providenciarão a bem dêle, como as circunstâncias exigirem"); disposição inspirada no Código Civil de 1916 (artigo 1322), assim como o artigo 130 (cf. art. 1323 do CC/16), por meio da qual se limitam os atos dos herdeiros às medidas meramente conservativas ("os herdeiros, no caso do artigo antecedente, devem limitar-se às medidas conservatórias, ou continuar os negócios pendentes, que se não possam demorar sem perigo, regulando-se os seus serviços, dentro nesse limite pelas mesmas normas, a que os do representante estão sujeitos"). Novamente, parece-nos, pois, que as regras desenvolvidas pelo autor do Anteprojeto pertinem mais à relação gestória do que à eficácia representativa direta propriamente dita. Neste sentido, aliás, seguiram as fontes subseqüentes de nosso direito civil, que permaneceram a disciplinar tais questões junto ao tipo contratual objeto de nossa análise - cf. os arts. 700 e 701 do AntMR; os arts. 689 e 690 do AntMRRev; os arts. 699 e 700 do PCD n 634/1975; e os arts. 690 e 691 do CC/2002.

Ora, diante de tais observações, pergunta-se: por que razão o autor do Anteprojeto de Parte Geral do Código Civil de 1970 pretendeu remeter todas as regras mencionadas neste parágrafo ao âmbito da Parte geral, sob a disciplina da "representação"? Note-se que - à exceção do artigo 116 do referido Anteprojeto - as demais foram por nós consideradas como relativas à relação gestória (inerente ao contrato de mandato), sem qualquer espécie de projeção diante de terceiros. Teria o autor se equivocado?

Temos para conosco que não. Mas para que nossa justificativa se torne mais clara, lançamos mão de texto outro em que o autor analisa a questão à luz do direito romano: "antes de entrarmos na análise do mandato, é mister distingui-lo de uma figura afim - a procuratio. Na procuratio, que tem raízes na antiga família romana, o procurator - em geral, um liberto - é o senhor de fato do patrimônio que se encontra sob sua administração, tanto que, com relação a ele, tem poderes amplos (...) segundo parece, o procurador verdadeiro era munido de mandato (tanto assim que o gestor de negócios era um falsus procurator), mas se distinguia do mandatário por cuidar prolongadamente dos negócios de outrem, e não por um só momento. Já 


\section{$\S$ 177. O "Anteprojeto de Código Civil" de 1972: proposta de inovação}

relacionada ao objeto da representação. O “Anteprojeto de Código Civil” de 1972 foi elaborado por uma comissão composta por Miguel Reale, José Carlos Moreira Alves (Parte Geral), Agostinho de Arruda Alvim (Do Direito das Obrigações), Sylvio Marcondes (Da Atividade Negocial), Ebert Vianna Chamoun (Do Direito das Coisas), Clóvis do Couto e Silva (Do Direito de Família) e Torquato Castro (Do Direito das Sucessões) - presidida, desde o início dos trabalhos, pelo primeiro destes. No que concerne à disciplina do

o mandato, que surgia graças ao ius gentium (...) é, no direito clássico, caracterizado pelo princípio da exata determinação da missão confiada ao mandatário; apenas ao final desse período é que vai surgir a figura do mandato geral (isto é, aquele em que não se precisa qual será a atividade a ser desenvolvida pelo mandatário). Portanto, no direito clássico, coexistem a procuratio e o mandato, mas os textos não explicam bem a relação entre esses dois institutos. No direito pós-clássico, procuratio e mandato se fundem, surgindo, por isso, as figuras do uerus procurator (procurador constituído por mandato) e do falsus procurator (procurador a quem não se outorgou mandato e que, portanto, age espontaneamente, como negotiorum gestor)" (Direito Romano cit. (nota 45), p. 169).

Sendo o único romanista que integrou a Comissão presidida por Miguel Reale, a José Carlos Moreira Alves não deveria causar estranheza o duplo sentido emprestado - pelo Código Civil de 1916 - ao mandato: ao mesmo tempo em que em seu arcabouço podiam ser entrevistas regras atinentes à "substituição", outras tantas ali existiam que se voltavam à "gestão". Ora, embora a "representação direta" esteja jungida exclusivamente à percussão imediata da esfera jurídica do principal (por meio de ato praticado por seu procurador), sua correlata indireta se desprende de tal estreiteza para alcançar uma feição verdadeiramente "gestória". Diante da conveniência de uma extensão de tal aspecto também à representação legal (ou necessária), o autor houve por bem em transportar o regramento gestório à Parte Geral.

Se nós concordamos com tal providência? Em termos. Pois na medida em que se admite tal oportunidade, necessariamente se expande o conceito de representação, a fim de albergar a variante indireta do instituto. $\mathrm{O}$ que reputamos inadmissível é que se fizesse a remessa pretendida à luz de uma premissa com ela incompatível (a regulação exclusiva da representação direta). No entanto, se se cede espaço à representação indireta, obviamente que não haveria qualquer objeção de nossa parte.

Todavia, tal impasse nos assinala uma questão que não nos parece ter recebido resposta adequada por parte da doutrina brasileira até hoje produzida: em que medida é no aspecto gestório do contrato de mandato que poderemos encontrar uma reminiscência da "procuratio" romana? E mais: de que modo - posto de parte o contrato de fidúcia - tais feições evidenciam uma disciplina relativamente próxima da administração confiada, submetida ao "trust" angloamericano?

Tais questões ensejam uma nova investigação, que ultrapassa os limites metodológicos do estudo a que ora nos dedicamos.

Pela bibliografia produzida a respeito da matéria objeto de análise nesta nota de rodapé - à luz do Código Civil de 2002 - cf. A. Villaça AZEVEdo - S. de S. VenosA, Código cit. (nota 02), pp. 354-359, 362 e $367-$ 368; A. de Assis, Contratos cit. (nota 131), pp. 35-43, 77-82, 94-95 e 133-139; CAIO MÁRIO da Silva Pereira, Instituições cit. (nota 06), pp. 399 e 405-414; C. A. BITTAR FILHO - M. S. BitTAR, Código cit. (nota 02), pp. 56-57; C. E . N. CAmillo - G. M. TAVAlera - J. S. Fujita - L. A. SCAvone Júnior (coords.), Comentários cit. (nota 02), pp. 585-586, 590-594 e 600-601; C. L. BUENO DE GODOY, Do mandato cit. (nota 131), pp. 622624, 628-629 e 643-647 (aludindo à hipótese do art. 690 do CC/2002 como de mandato "post mortem"); C. R. GonÇAlVES, Direito cit. (nota 131), pp. 396-397, 404-409 e 414-415; F. UlhoA Coelho, Curso cit. (nota 06), pp. 316-317 e 321-328; F. AMARAL, Direito cit. (nota 131), pp. 458-459 e 468-472; M. G. MAIA JÚNIOR, A representação cit. (nota 04), p. 44; MARIA HelenA DinIZ, Curso cit. (nota 02), pp. 352, 359, 366-369 e 371-377; N. C. B. CAMPEllo, Da representação cit. (nota 131), pp. 415-419; N. G. B. DoweR, Curso cit. (nota 02), pp. 290-300; N. NERY JUNIOR - R. M. de ANDRADE NERY, Código cit. (nota 02), pp. 471 e $475-$ 481; O.Gomes, Contratos cit. (nota 23), pp. 429-436; O. R. B. SANDOVAL, Do mandato cit. (nota 131), pp. 593-594, 620-621 e 633-636; R. FIUZA (coord.), Novo Código cit. (nota 02), pp. 603-605, 617-619, 624 e 638-641; S. de S. VenOSA, Direito cit. (nota 02), pp. 258-260, 269-271 e 279-280; S. L. F. da RochA, Curso cit. (nota 02), pp. 299-304 e 314; SILVIO RoDRIGUES, Direito cit. (nota 02), pp. 290-297 e 303-305; WASHINGTON DE BARRos MonTEIRO, Curso cit. (nota 02), pp. 266-267, 275-277, 281, 288-290 e 298. 
"mandato" e da "representação", a única inovação - em relação ao panorama legislativo precedente - correspondeu ao artigo 118, por meio do qual se dispôs que "para a validade do ato concluído pelo representante, é necessário que o mesmo não seja vedado ao representado". Postas de parte a influência e a precedência do artigo 2872 do "Esboço" de Código Civil, há que se destacar a adequação da pretendida transposição do preceito ao contexto normativo da "representação"; no entanto, tendo sido posteriormente reputada desnecessária, tal regra foi extirpada do "Anteprojeto de Código Civil revisto" (1973) e do Projeto que tramitou perante a Congresso Nacional desde 1975 - não constando, naturalmente, do Código Civil promulgado pela Lei Federal no 10.406/02 $2^{154}$.

$\S$ 178. O Código Civil de 2002 e a pretendida dissociação entre o "mandato" e a "representação". O Código Civil de 2002 pretendeu dissociar os institutos da "representação" e do "mandato"; todavia, a remissão do artigo 120 à Parte Especial nos indica a sobrevivência de uma zona nebulosa entre os referidos institutos jurídicos. Aliás, a definição constante do artigo 653 - "opera-se o mandato quando alguém recebe de outrem poderes para, em seu nome, praticar atos ou administrar interesses" - é ainda mais nociva, pois ao mesmo tempo em que considera a representação essencial ao mandato, acaba por reduzi-la à posição de um simples aspecto eficacial desta espécie contratual. Efetuada a análise de cada um dos dispositivos que integram os arcabouços normativos relacionados à “representação" (artigos 115 a 120) e ao "mandato" (artigos 653 a 692), pode-se afirmar que mais de uma dezena das regras contidas na Parte Especial deveriam ter sido articuladas em meio à disciplina da primeira; do mesmo modo, alguns preceitos contidos na Parte Geral encontrariam uma acomodação natural em meio à regulamentação deste último. Ora, o apartamento metodológico de tais proposições é matéria atinente às conclusões do presente estudo. Passemos, portanto, às nossas considerações finais.

\footnotetext{
${ }^{154}$ A regra constante do artigo 118 do Anteprojeto elaborado pela comissão presidida por Miguel Reale encontra seu antecedente mais remoto - no âmbito da historiografia jurídica brasileira - no artigo 2872 do "Esboço" de Código Civil, a respeito do qual, aliás, já tivemos a oportunidade de nos pronunciar (nota 140). Daí a razão por que - quanto ao seu respectivo conteúdo (e bibliografia pertinente) - remetemos o leitor à passagem citada.

A respeito do expurgo de tal dispositivo do Anteprojeto de Código Civil, cf. J. C. Moreira Alves, A Parte Geral cit. (nota 131), p. 88.
} 


\section{CAPÍTULO FINAL. CONSIDERAÇõES CONCLUSIVAS.}

Este estudo se voltou à análise das principais fontes primárias devotadas ao "mandato luso-brasileiro". Todavia, a fim de que chegássemos até ele, foi necessário percorrer uma longa trajetória, em meio à qual tivemos a oportunidade de travar contato, primeiramente, com uma historiografia geral - especificamente voltada à relação mantida entre os institutos da "procuração", do "mandato" e da "representação".

Do direito romano pudemos haurir diversos elementos. A começar pela "procuratio": instituto de contornos originalmente mais sociais do que jurídicos, aos poucos ela foi adotada pelo tradicional "ius civile". A despeito de sua origem familiar, a sua esfera de aplicação vai se ampliando gradativamente: até o momento em que, em sua fase de apogeu, libertos e homens livres atuam freqüentemente como "procuratores" de outrem. Incumbido de uma gestão "ampla", o "procurator" se mostra vinculado ao seu principal graças à virtual "actio negotiorum gestorum" correspondente.

Algum tempo depois, à vista das progressivas exigências comerciais de uma Roma em franca expansão, do "ius gentium" desponta a necessidade de se forjar um instrumento jurídico apto à tutela de uma incumbência de feições mais específicas: surge então o "mandatum" - o qual, de modo paulatino, se desenvolve paralelamente à "procuratio". Por sua vez, uma ação diversa é atribuída às partes envolvidas no contrato: a "actio mandati" ("directa" e "contraria").

Além de ações próprias, em decorrência de suas peculiaridades funcionais, cada instituto recebe um enquadramento jurídico peculiar: enquanto a "procuratio" se submete aos chamados "iudicia bonae fidei" gerais, o "mandatum" se insere em meio aos correlatos - especiais. De toda forma, à margem das diferenças fundamentais entre tais institutos, desponta sobranceira a regra geral consagrada em G. 2, 95: "per extraneam personam nobis adquiri non posse" ("não podemos adquirir por pessoa estranha") excetuada, tão somente, quanto à aquisição da posse.

Contudo, o ímpeto dinâmico do sistema jurídico também se manifestou em relação às fontes romanas: em rota contrária à orientação primígena, exsurge tendência à unificação entre os referidos institutos - manifestada na absorção da "procuratio" pelo "mandatum". A "actio negotiorum gestorum" é então remanejada, a fim de que por meio dela seja resguardada a atuação do gestor espontâneo ("falsus procurator"); de sua parte, o "verus procurator" passa a se submeter à "actio mandati". 
Tudo isso ocorre em um panorama consideravelmente novo: ao mesmo tempo em que o "mandatum" passa a integrar os "iudicia generalia", as progressivas mitigações ao princípio da inadmissibilidade da representação direta - sob a forma das chamadas "actiones adiecticiae qualitatis" - acabam por preparar terreno a uma reformulação que somente se operará fora do contexto romano.

De fato, fundado no pressuposto de que o Papa é o "representante" de Jesus Cristo entre os homens, o direito canônico adotou uma orientação inteiramente nova: máximas como "potest quis per alium quod potest facere per se ipsum" e "qui facit per alium est perinde ac si faciat per se ipsum" acabam por imantar suas principais fontes, nelas incutindo um elemento novo - insuscetível de ser encontrado entre os textos romanos.

Por sua vez, os doutores do direito comum buscaram encher os odres velhos de um vinho novo: tomando como ponto de partida certos textos clássicos voltados à atuação do escravo, juristas como Bártolo buscaram equiparar o notário ao "servus publicus" romano - para tanto lançando mão de fragmentos de diversos jurisconsultos, dentre os quais Marcelo, Ulpiano e Papiniano.

O robustecimento da representação negocial preparou caminho à sua "essencialização" no âmbito do mandato; todavia, o passo definitivo ainda não havia sido dado. E foi graças à produção jusracionalista que se difundiu uma nova concepção a respeito deste instituto: do posto de simples instrumento de gestão, o mandato então foi galgado à categoria de fundamento negocial da representação direta. Juristas como Hugo Grotius, Samuel Pufendorf, Jean Domat, Georg Adam Struvi, Christian Wolff e Johaniss Voet contribuíram para o remate final, consubstanciado no artigo 1984 do "Code Civil". Daí em diante prevaleceu - em inúmeros sistemas jurídicos submetidos à influência francesa - a compreensão de que este tipo contratual carregava consigo - inarredavelmente - a idéia de "representação".

Superada essa etapa de nosso estudo - voltada a evidenciar o processo de paulatina incrustação da eficácia representativa direta na "nota típica" do instituto pudemos passar, então, a uma análise "pretensamente" exauriente das fontes primárias do mandato luso-brasileiro.

Assim, no âmbito do direito visigótico - a despeito do caráter fragmentário de algumas de suas fontes (tais como o "Código de Eurico" e a "Lex Romana 
Visigothorum") - pudemos surpreender algumas reminiscências do modelo romano pósclássico, preservado do ímpeto simplicador que - a respeito do tema - caracterizou o direito justinianeu. De todo modo, às vésperas do século XIII, pouco se podia fazer ante o ineviável influxo do direito imperial - agora renascido e informado por um novo sistema de valores.

Como tivemos a oportunidade de observar, o renascimento do direito justinaneu em Portugal foi viabilizado, em um primeiro momento, pelas fontes castelhanas atribuídas a Mestre Jácome das Leis ("Flores de Derecho", "Dotrinal" e "Los Noue Tienpos Delos Pleytos") e D. Afonso X ("Fuero Real”, "Espéculo" e "Siete Partidas”). Seu estudo direto nos informou que as expressões "mesajero", "personero" e "mandadero" já eram empregadas promiscuamente em meados do século XIII; de tal modo que esse primeiro influxo ibérico nos pareceu, em linhas gerais, permeado pela falta de uma maior acuidade técnica. Contudo, ainda permaneciam "sistematicamente" apartados o "personero" (procurador) e o "vozero" (advogado).

Em contrapartida, as fontes do direito lusitano medieval - reunidas no "Livro das Leis e Posturas" e nas "Ordenações de D. Duarte" - nos sugerem uma realidade bastante diversa: o rigor das sanções cominadas era inversamente proporcional à "liberalidade" com que se abordavam, sem maior critério, os conceitos de "procurador" e de "advogado". Note-se que pudemos coligir uma série de textos relacionados ao tema; e embora não houvesse uma disciplina articulada a respeito do mandato extrajudicial, não nos parece adequado negar o préstimo - ainda que oblíquo - de tais fontes para a reconstrução das linhas gerais do negócio jurídico de incumbência. Aliás, o mesmo se pode afirmar acerca do direito lusitano posterior - contido nas sucessivas "Ordenações do Reino de Portugal".

À vista da lacunosidade das várias "Ordenações”, as fontes justinianéias foram então aplicadas - subsidiariamente - quanto à variante extrajudicial do instituto. Tivemos a oportunidade de analisar o processo de ascensão - e apogeu - do direito romano imperial em Portugal; encerrado, todavia, no contexto de uma luta de Luís António Verney contra o bartolismo e a insegurança jurídica atribuída ao método escolástico. Despontam como novas palavras de ordem as idéias de "simplicidade", "clareza", "síntese" e sobretudo - "modernidade". 
Fez-se necessário, então, um esforço legislativo para que se removesse o anacrônico entrave justinianeu. Durante o Consulado Pombalino, a Lei de 18 de agosto de 1769 e os Estatutos da Universidade de Combra de 1772 viabilizaram a projetada transição; exsurge, então, um ambiente francamente favorável à implementação dos novos resultados obtidos pelo racionalismo. No âmbito do mandato - como em todo o direito civil, aliás - a influência francesa não se fez tardar: a introdução dos estudos de direito comparado em Portugal (graças ao papel precursor de Manuel de Almeida e Sousa) viabilizou uma utilização freqüente do "Code Civil" como fonte de inspiração - e a esse respeito as obras de José Homem Correia Telles e Manuel António Coelho da Rocha são bastante elucidativas.

Diante de tal cenário as codificações portuguesas do século XIX passam a referendar o influxo deste novo ideário. No que concerne ao contrato de mandato, a eficácia representativa direta se incrusta em sua "essência": a diferença entre o referido tipo contratual e a comissão passa a ser - efetivamente - a feição representativa do primeiro. Todavia, uma variante despojada de tais efeitos permanece - latente - à margem do modelo consolidado; essa foi, aliás, a orientação do Código Civil de 1867 e dos dois Códigos Comerciais portugueses (de 1833 e 1888). No entanto, um panorama bastante diverso exsurge no século XX: diante das exigências científicas de uma dissociação entre "mandato" e "representação", doutrina e legislação se apressam em oferecer novos contornos a cada uma das categorias - remodelando, ainda, o conceito de "procuração" (agora tomado por negócio unilateral de outorga de poderes representativos).

Com a Independência do Brasil houve uma necessidade de se conferir direito próprio à nação recém-soberana; no entanto, não foi essa uma tarefa de que o nosso legislador se desimcumbiu com facilidade. Em meio a disposições das "Ordenações Filipinas" - ainda aplicáveis por força da Lei de 20 de outubro de 1823 -, Alvarás, Avisos, Ordens e Despachos, Augusto Teixeira de Freitas buscou, primeiramente, "consolidar" o que o mandato luso-brasileiro era - para que depois "esboçasse" os contornos de nossa própria orientação sobre o instituto. Obra de gênio, seu "Esboço" ficou a meio passo daquilo que este pesquisador reputa por arquétipo de "mandato"; muito além - diga-se de passagem - de todas as fontes - nacionais ou estrangeiras - a que tivemos acesso em meio às nossas investigações. 
A despeito da falta de uma - completa - dissociação entre o negócio de “incumbência" (mandato) e o ato de outorga de poderes representativos (procuração), o "Esboço" guarda em si algo de extremamente valioso e que chega a transcender os limites dessa importantíssima distinção. De fato, nele podemos divisar, ao lado da essência representativa (e de uma variante marginal desprovida de representação), projeções eficaciais de um vínculo que - estribado na "confiança" - se volta não apenas à "substituição" do principal, mas também à "gestão" de seus interesses. O atuar "por conta" alheia - que progressivamente se esvaziou graças ao protagonismo crescente da representação direta - apresenta peculiaridades eficaciais que não passaram despercebidas a Augusto Teixeira de Freitas.

Os demais Anteprojetos que redundaram no Código Civil de 1916 contribuíram - em alguns aspectos pontuais - à nossa primeira conformação legislada do instituto. No entanto, todos - à exceção do Anteprojeto Clóvis Beviláqua - admitiram expressamente que o mandatário "também” poderia atuar em nome próprio. E assim como que a evidenciar uma tradição jurídica luso-brasileira renegada pela metrópole - o artigo 1307 daquele diploma permaneceu, como que fantasma, em meio a um arcabouço que se pretendia representativo - mas que de uma forma ou de outra não se conseguia libertar de suas próprias contradições internas. E para tanto, os artigos 1301 e 1309 também colaboraram decisivamente - ainda que de modo implícito.

Os Anteprojetos que redundaram em nosso Código Civil de 2002 também tiveram méritos indiscutíveis: no que concerne ao objeto de nossas investigações, todos evidenciaram uma inequívoca preocupação em dissociar a "representação" do "mandato". Obviamente, alguns tiveram uma maior acuidade sistemática. Neste sentido, merecem destaque o Anteprojeto de Parte Geral do Código das Obrigações de Orosimbo Nonato, Philadelpho Azevedo e Hahnemann Guimarães e o Anteprojeto de Parte Geral do Código Civil de José Carlos Moreira Alves.

Os demais Anteprojetos contribuíram - nalguns pouquíssimos aspectos para oferecer a conformação atual dos institutos mencionados. Aliás, é forçoso reconhecer que o artigo 120 do Código Civil vigente menos auxilia do que atrapalha o intérprete. Razão pela qual tomamos a liberdade de - em jeito de conclusão - oferecer nossa perspectiva a respeito da pertinência sistemática dos dispositivos do Código Civil de 2002 devotados ao "mandato" e à "representação" (direta). 
De fato, reputamos pertinentes - exclusivamente - ao contrato de mandato as regras contidas nos artigos 117, 656, 658, 659, 664, 668, 669, 670, 671, 674, 676, 677, 678, 680, 681, 687, 688, 690, 691 e 692 - todos do Código Civil vigente. Por sua vez, parecem-nos relacionados unicamente à representação (direta) os artigos 115, 116, 118, 120, 654, 655, 661, 673 e 685 do mesmo diploma.

Finalmente, algumas regras parecem se projetar sobre os dois institutos. São as contidas nos seguintes artigos: 119, 653, 657, 660, 662, 663, 665, 666, 667, 672, 675, $679,682,683,684,686$ e 689. Note-se que o caráter bifronte de tais dispositivos ensejaria sua reprodução em ambos os arcabouços técnicos. Aliás - diga-se de passagem, uma vez que a análise do direito comparado não integra, senão incidentalmente, o objeto da presente exposição - foi essa a orientação adotada, por exemplo, nos artigos 72 e 415 do atual Código Civil holandês (de 1992).

Cumpre-nos encerrar o presente estudo reiterando a contribuição documental que pretendemos oferecer por meio da publicação do já referido excerto concernente à disciplina da "representação" - do Anteprojeto de Parte Geral do Código Civil de José Carlos Moreira Alves. Graças a essa imensa gentileza - derivada de indiscutível escrúpulo científico - de seu autor, tivemos a oportunidade de discordar quanto a alguns - poucos - de seus enunciados. Não de bom grado. E nem com alegria. Talvez por isso seja necessária uma explicação final.

É que a "ciência" jurídica moderna só se tem importado - ultimamente com a representação "direta", de feição "substitutiva"; o intérprete que alude aos efeitos de uma representação "indireta" - e parece que foi este o caso quanto aos artigos 117, 118, 126, 128, 129 e 130 do Anteprojeto - é observado em tom de desconfiança e de deboche. Temos para conosco, pois, que foi a esta modalidade - marginalizada - que a elevada cultura jurídica de seu autor se voltou (no que toca, obviamente, a tais preceitos). Contudo, à vista do "estado da técnica", não nos pareceu que pudessem prevalecer quaisquer disposições que ameaçassem o predomínio da implacável representação direta - variante que se mostrou mais afável à certeza pretendida pelos "iluminados". De modo sereno, infelizmente, somos forçados a reconhecer este "dado".

No entanto, os "cientistas" de hoje parecem não saber o que evocam ao pronunciar - levianamente - o termo "procuração": pois para além da "procuraçãoinstrumento" (e mesmo da "procuração-ato"), parece existir uma “procuração-relação 
gestória"; a qual só pode ser divisada, contudo, por aquele que volta a sua atenção à História do Direito - e que pretende, tomado novo fôlego, evidenciar que as linhas fundamentais de um contrato de gestão, mais do que no direito alienígena, se acham perdidas em conhecidos odres velhos, postos de lado pela arrogância do estudioso imaturo. 


\section{BIBLIOGRAFIA.}

. ABREU, José, O negócio jurídico e sua teoria geral, São Paulo, Saraiva, 1984;

. ADAM, Henri, Droit romain: rapports du mandat et du mandateire avec les tiers. Droit français: rapports du mandat, Paris, Typographie et Lithographie Ves. Renou, Maulde et Cock, 1874;

. AlbaladeJo, Manuel, El negocio juridico, Barcelona, Librería Bosch, 1958;

. AlBertario, Emilio, Ancora “verus” e "falsus procurator” in SDHI 2 (1936); , Procurator unius rei, in Studi di diritto romano III - Obbligazioni,

Milano, Dott. A. Giuffrè, 1933; , La cosidetta crisi del metodo interpolazionistico, in Studi di diritto romano V-Storia, Metodologia, Esegesi, Milano, Antonino Giuffrè Editore, 1937; , Sulla Epitome Gai in Studi di diritto romano V, Milano, Dott. A. Giuffrè, 1933;

- Albuquerque, José Gildenor, Mandato - poderes especiais e expressos, in Revista Forense 213 (1966);

. Albuquerque, Martim de, Bártolo e Bartolomismo na História do Direito Português, in Boletim do Ministério da Justiça 304 (1981); , O século XVIII na legislação de Pombal in Pensamiento juridico y sociedad internacional - Libro-homenaje al profesor D. Antonio Truyol Serra I, Madrid, Universidad Complutense, 1986, pp. 59-ss;

. AlmeIDA, Estevam de, Parecer, in Revista dos Tribunais 25 (1918);

. Almeida, Fortunato de, História de Portugal V-Instituições Políticas e Sociais de 1580 a 1816, Coimbra, Editor Fortunato de Almeida, 1927;

- Almeida Costa, Mário Júlio de, Debate jurídico e solução pombalina, in Boletim da Faculdade de Direito da Universidade de Coimbra 58 (1982); , Enquadramento histórico do Código Civil Português, in Boletim da

Faculdade de Direito da Universidade de Coimbra 37 (1961); , Fundamentos Históricos do Direito Brasileiro, in CAETANo, Marcello;

Moreira Alves, José Carlos; Couto e Silva, Clóvis do; Almeida Costa, Mário Júlio de, Estudos de Direito Civil Brasileiro e Português (I Jornada Luso-Brasileira de Direito Civil), São Paulo, Revista dos Tribunais, 1980; , História do Direito Português, $3^{\mathrm{a}}$ ed., Coimbra, Almedina, 2003; 
, La présence d'Accurse dans L'Histoire du Droit Portugais, in Boletim da Faculdade de Direito da Universidade de Coimbra 41 (1965);

, Leis, Cânones, Direito, in Dicionário de História de Portugal II, Lisboa, Iniciativas Editoriais, 1963;

, Noções de Direito Civil, Coimbra, Almedina, 1980;

, Nota de apresentação, in Ordenações Afonsinas - Livro I, Coimbra,

Fundação Calouste Gulbenkian, 1984;

, Nota de apresentação, in Ordenações Filipinas - Livro I, Coimbra,

Fundação Calouste Gulbenkian, 1984;

, Nota de apresentação, in Ordenações Manuelinas - Livro I, Coimbra,

Fundação Calouste Gulbenkian, 1984;

, Ordenações, in Boletim da Faculdade de Direito da Universidade de

Coimbra 44 (1968);

, Para a história da cultura jurídica medieva em Portugal, in Boletim da

Faculdade de Direito da Universidade de Coimbra 35 (1959);

, Romanismo e bartolismo no direito português, in Boletim da Faculdade

de Direito da Universidade de Coimbra 36 (1960);

. Almeida e Sousa (de Lobão), Manuel de, Indice do que se contém nos tres volumes de Notas de uso pratico e criticas por Manuel de Almeida e Sousa de Lobão aos Livros I, II e III das Instituições do Dr. Paschoal José de Mello Freire e na Collecção de Dissertações em supplemento ás notas ao Livro III e que faz o IV volume d'esta obra, Lisboa, Imprensa Nacional, 1868;

, Notas de uso pratico e criticas addições, ilustrações e remissões á imitação das de Muller a Struvio sobre todos os titulos e paragraphos do livro primeiro das Instituições do direito civil lusitano, do doutor Paschoal José de Mello Freire, Lisboa, Imprensa Nacional, 1868;

. Alvarez SuARez, Ursicino, Instituciones de derecho romano I (introducción histórica, conceptos fundamentales, hechos y negocios jurídicos), Madrid, UNED, 1973;

. Alves, João Luiz, Código Civil da República dos Estados Unidos do Brasil promulgado pela Lei n. 3.071, de 1 de janeiro de 1916 annotado II, 2 a ed., São Paulo, Saraiva, 1935;

. Alves Moreira, Guilherme, Instituições do Direito Civil Português I - Parte Geral, Coimbra, Imprensa da Universidade, 1907; 
. Amaral, Francisco, Direito Civil - Introdução, Rio de Janeiro - São Paulo - Recife, Renovar, 2008;

- Amaral Gurgel, J. do, Contractos no Codigo Civil Brasileiro I (theoria dos contractos), São Paulo, Saraiva \& Cia., 1939;

. Amazonas De FigueIREDO, Genuino, Tratado de Direito Romano, Rio de Janeiro, Freitas Bastos, 1930;

. Ambrosino, Rodolfo, Le applicazioni innovative della mancipatio, in Studi in memoria di Emilio Albertario II, Milano, Dott. A. Giuffrè, 1953;

. AmeAl, João, História de Portugal, Porto, Livraria Tavares Martins, 1940;

. ANASTÁCIO DE FigueIREDO, José, Sobre qual foi a Epoca certa da introducção do Direito de Justiniano em Portugal, o modo da sua introducção, e os gráos de autoridade, que entre nós adquirio. Por cuja occasião se tracta toda a importante matéria das Ord. Liv. III, tít. 64 in Memórias de Litteratura Portugueza I, Lisboa, Officina da Academia Real de Sciencias, 1792;

, Synopsis Chronologica de Subsidios ainda os mais raros para a história e o estudo critico da legislação portugueza, Lisboa, Academia das Sciencias, 1790;

. Andrade, Manuel A. Domingues de, Teoria Geral da Relação Jurídica - Facto Jurídico, em especial Negócio Jurídico II, Coimbra, Almedina, 1998;

. Angelini, Piero, Il 'procurator', Milano, Dott. A. Giuffrè Editore, 1971;

. Anthero, Adriano, Comentario ao Codigo Commercial Portuguez I, Porto, Typographia “Artes \& Letras", 1913;

. Antunes, Bernardo, Apontamentos para a cadeira de História do Direito Português, Coimbra, Livraria Neves Editora, s.d.;

. Antunes, José, Notas sobre o Sentido ideológico da reforma Pombalina - a propósito de alguns Documentos da Imprensa da Universidade de Coimbra, in Revista de História das Idéias 1982-1983 (número especial intitulado O Marquês de Pombal e o seu Tempo I);

. Arangio-Ruiz, Vincenzo, Corso di istituzioni di diritto romano (diritti reali e di obbligazione), Napoli, Nicola Jovene E. C. Editore, 1921; , Istituzioni di diritto romano, $14^{\mathrm{a}}$ ed., Napoli, Casa Editrice Dott. Eugenio Jovene, 1978; , Il mandato in diritto romano - Corso di lezioni svolto nell'Università di Roma (anno 1948-1949), Napoli, Casa Editrice Dott. Eugenio Jovene, 1965; 
, Società in diritto romano - Corso di lezioni svolto nell'Università di Roma: anno 1949-50, Napoli, Eugenio Jovene, 1950;

. ARARIPE, Tristão de Alencar, Codigo Civil Brazileiro ou Leis Civis do Brazil (dispostas por ordem de materias em seu estado actual), Rio de Janeiro, Laemmert \& C., 1885;

. ARCHI, Gian Gualberto, L'Epitome Gai' - studio sul tardo diritto romano in Occidente, Milano, Dott. Antonino Giuffrè, 1937; , Teodosio II e la sua codificazione, Napoli, Edizioni Scientifiche Italiane, 1976 ;

. ARnDTS, Ludwig, Lehrbuch der Pandekten, trad. it de Filippo Serafini, Trattato delle pandette I, $3^{\mathrm{a}}$ ed., Bologna, Tipi Fava e Garagnani, 1877;

. ARrudA, João, Compra e Venda, in Revista dos Tribunais 24 (1917);

. ARrudA, João, Parecer, in Revista dos Tribunais 25 (1918);

- Arruda Miranda, Darcy, Anotações ao Código Civil Brasileiro III (Direito das Obrigações a Direito das Sucessões), São Paulo, Saraiva, 1986;

. AsCARELli, Tullio, Il negozio indiretto e le società commerciali, in Studi di diritto commerciale in onore di Cesare Vivante I, Roma, Società Editrice del Foro Italiano, 1931; , Negócio jurídico indirecto, Lisboa, Jornal do Fôro, 1965; , Per uno studio della realtà giuridica effetuale, in Problemi giuridici II, Milano, Casa Editrice Dott. A. Giuffrè, 1959; , Problemas das sociedades anônimas e direito comparado, São Paulo, Saraiva, 1945;

- Ascensão, José de Oliveira, Teoria Geral do Direito Civil III - Acções e Factos Jurídicos, Lisboa, s.e., 1992;

. AsCOLI, Alfredo, $L$ ' actio negotiorum gestorum directa contro il pupillo, in Studi in onore di Pietro Bonfante nel suo XL anno d'insegnamento II, Milano, Fratelli Treves, 1930;

. Assis, Araken de, Contratos nominados: mandato, comissão, agência e distribuição, corretagem e transporte, São Paulo, Revista dos Tribunais, 2005;

. Astuti, Guido, Lezioni di storia del diritto italiano - Le fonti età romano-barbarica, Padova, CEDAM, 1968;

. Azevedo, Luiz Carlos de, O direito visigótico, in Revista da Faculdade de Direito da Universidade de São Paulo 96(2001); , O Reinado de D. Manuel e as Ordenações Manuelinas, in Revista da Faculdade de Direito da Universidade de São Paulo 95 (2000); 
; CRuZ e TuCCI, José Rogério, Lições de História do Processo Civil

Romano, São Paulo, Revista dos Tribunais, 2001;

. Baptista Machado, João, Pombal, Marquês de, in Dicionário de História de Portugal $V$, Porto, Livraria Figueirinhas, 2002;

. BARTOLO DE SASSOFERRATO, Bartoli commentaria in priman Digesti novi partem doctiss. viri Do. Petri Pauli Parisij Cardinalis admodum reuerendi non paucis additionibus nuper illustrata, accuratéque castigata, Lvgdvni, Petrus Fradin, 1555;

, Bartoli commentaria in secvndam Digesti novi partem, Do. Petri Pauli

Paris. Andreae Barb. Alexan. Lofaei additionibus, multisque emendationibus illustrata accuratè, \& multa cum diligentia castigata, Lvgdvni, Petrus Fradin, 1555;

, Bartoli commentaria in secvundam Digesti veteris partem, Doctis. viri

Do. Petri pauli Parisii Cardinalis admodum reuerendi non paucis additionibus nuper illustrata, accuratéque castigata, Lvgdvni, Petrus Fradin, 1555;

, Bartoli prima in Digestum vetus, Alexandre Imolaei, Andreae Barbatiae,

Celsi Hugonis ac Petri Pauli Parisii adnotamentis rerumque summis ornata fidelissimisque typis excusa, Lvgdvni, Petrus Fradin, 1555;

- BAudelot, Bernard, Un grand jurisconsulte du XVII siècle: Jean Domat, Paris, Universitè de Paris (Thèse de Droit), 1939;

. Beleza dos Santos, José, A Simulação em Direito Civil I, Coimbra, Coimbra Editora, 1955 ;

. BENECH, M., La Lex romana Visigothorum dite Bréviaire d'Alaric, in Mélanges de droit et d'histoire, Paris, Cottilon, s.d.;

. Bertolini, C., Appunti didattici di diritto romano II - Il processo civile, Torino, Unione Tipografico-Editrice Torinese, 1914;

. BeSta, Enrico, Obbligazioni nella storia del diritto italiano - appunti di lezioni, Padova, Litotipo, 1926;

. Betancourt, Fernando, Derecho romano clásico, Sevilla, Universidad de Sevilla, 2001;

. BETTI, Emilio, L'attuazione di due rapporti causali attraverso un unico atto di tradizione (contributo alla teoria della delegazine a dare) in Bullettino dell' Istituto di Diritto Romano 41 (1933);

, Teoria generale del negozio giuridico, $2^{\mathrm{a}}$ ed., Torino, Unione

Tiprografico-Editrice Torinese, 1960; 
. Beviláqua, Achilles, Codigo Civil Brasileiro anotado, 12a ed., Rio de Janeiro, Francisco Alves, 1957;

. Beviláqua, Clóvis, Código Civil dos Estados Unidos do Brasil Commentado I, $3^{\mathrm{a}}$ ed., Rio de Janeiro, Livraria Francisco Alves, 1927; , Codigo Civil dos Estados Unidos do Brasil Commentado V-2, $5^{\mathrm{a}}$ ed., Rio de Janeiro, Livraria Francisco Alves, 1943; , Parecer, in Revista dos Tribunais 25 (1918); , Quando a procuração exige instrumento público, in Revista Forense 30

(1918);

. BITTAR, Carlos Alberto, Os contratos no projeto de Código Civil, in Revista de Direito Mercantil, Industrial, Econômico e Financeiro 104 (1996);

- Bittar Filho, Carlos Alberto; BitTar, Marcia Sguizzardi, Código Civil 2002 Inovações, São Paulo, IOB Thomson, 2005;

. BobBIo, Norberto, Dalla struttura alla funzione - nuovi studi di teoria del diritto, Milano, Edizioni di Comunità, 1977; , Il positivismo giuridico - lezioni di Filosofia del diritto raccolte dal

Dott. Nello Morra, Torino, G. Giappichelli, 1979; , Teoria della norma giuridica, Torino, G. Giappichelli, 1958;

. Bodin de Moraes, Maria Celina, A causa dos contratos, in Revista Trimestral de Direito Civil 21 (2005);

. Bonet Ramon, Francisco, Naturaleza jurídica del contrato de mandato, Barcelona, Bosch, 1941;

. Bonfante, Pietro, Diritto romano, Milano, Dott. A. Giuffrè Editore, 1976; , Facoltà e decadenza del procuratore romano, in Studii giuridici dedicati

e offerti a Francesco Schupfer nella ricorrenza del XXXV anno del suo insegnamento I, Torino, Fratelli Bocca, 1898; , Istituzioni di diritto romano, $10^{\mathrm{a}}$ ed., Torino, G. Giappichelli, 1946;

. Bonifacio, F., Cognitor, procurator e rapporto processuale, in Studi in onore di Pietro de Francisci, Milano, Giuffrè, 1956;

. Bonjean, Georges, Explication méthodique des Institutes de Justinien II, Paris, A. Durand et Pedone-Lauriel, 1880;

. BONNECASE, Julien, La pensée juridique française de 1804 a l'heure présente - ses variations et ses traits essentiels I, Bordeaux, Delmas, 1933; 
. Borges Carneiro, Manuel, Borges Carneiro, Direito Civil de Portugal - contendo tres livros: I. Das pessoas, II. Das cousas, III. Das obrigações e acções I, Lisboa, Typ. de Maria da Madre de Deus, 1858; , Resumo Chronologico das Leis mais Uteis no Foro e Uso da Vida Civil, publicadas até o tempo presente, Lisboa, Impressão Régia, 1820;

. Borghi, Hélio, Teoria da Aparência no Direito Brasileiro - Aparência de Direito e Aparência no Direito, no Direito Privado e no Direito Processual Civil - Confrontações e aplicações, inclusive na jurisprudência, São Paulo, Lejus, 1999;

. Braga, Theóphilo, História da Universidade de Coimbra nas suas Relações com a Instrução Pública Portugueza, Lisboa, Academia Real de Sciencias, 1892-1902;

. BRAga DA CRUZ, Guilherme, Direito romano vulgar ocidental, in Obras Esparsas IEstudos de História do Direito - Direito Antigo (1 ${ }^{a}$ parte), Coimbra, Imprensa da Universidade, 1979;

, Formação Histórica do Moderno Direito Privado Português e Brasileiro, in Obras Esparsas II - Estudos de História do Direito - Direito Moderno - $1^{a}$ parte, Coimbra, Imprensa da Universidade, 1981;

, La Formation du Droit Civil Portugais Moderne et le Code Napoléon, in Obras Esparsas II - Estudos de História do Direito - Direito Moderno (2a parte), Coimbra, Imprensa da Universidade, 1981;

O Direito Subsidiário na História do Direito Português in Obras

Esparsas II - Estudos de História do Direito - Direito Moderno - $2^{a}$ parte, Coimbra, Imprensa da Universidade, 1981;

. Brandão, Mário; Lopes D’Almeida, Manuel, A Universidade de Coimbra: Esboço da sua História, Coimbra, Imprensa da Universidade, 1937;

. Briguglio, Filippo, Studi sul procurator I - L'aquisto del possesso e della proprietà, Milano, Dott. A. Giuffrè Editore, 2007;

. BRunnemanni, Joannis, Commentarius in Codicem Justinianeum quo singulae leges et authenticae breviter et succincte explicantur; quaestiones in academis, et foro frequentatae resolvuntur; axiomata ab interpretibus subinde proposita examinantur, et alia ex ipsis textibus notabilia eruuntur; quaeque alias ad analysin pertinent per compendium quasi dilucide traduntur; inserto hinc inde quid de jure tam communi novissimo, quam etc. etc. opus theoretico-practicum cui praeter indicem rerum et verborum locupletissimum accessit ex ejusdem auctoris commentario ad Pandectas, 
notabilium, quae circa leges affines inibi commentatus est II, Laureti, Ex Typis Fratrum Rossi Editorum, 1843;

. BRUNNER, Heinrich, Historia del derecho germánico, Barcelona - Madrid - Buenos Aires - Rio de Janeiro, Editorial Labor, 1956;

- Bruschy, Manuel Maria da Silva, Manual do Direito Civil Portuguez segundo a novissima legislação I, Lisboa, Rolland \& Semiond, 1868;

. BuCKLAND, William W.; MCNAIR, Arnold D., Roman law \& common law - a comparison in outline, Cambridge, Cambridge University Press, 1936;

. BuONAMici, F., Storia della procedura civile romana, Pisa, Nistri, 1886;

. BuRdeSE, Alberto, Mandatum mea aliena tua gratia, in Studi in onore di Vincenzo Arangio-Ruiz nel XLV anno del suo insegnamento I, Napoli, Editore Jovene, s.d.; , Manuale di diritto privato romano, Torino, Unione Tipografico-Editrice

Torinese, 1964;

. BUSSI, Emilio, La formazione dei dogmi di diritto privato nel diritto comune (diritti reali e diritti di obbligazione), Padova, Casa Editrice Dott. Antonio Milani, 1937;

, La formazione dei dogmi di diritto privato nel diritto comune (contratti, successione, diritti di famiglia), Padova, Casa Editrice Dott. Antonio Milani, 1971; , La rappresentanza negli atti 'inter vivos' dei nascituri non concepiti e delle persone assenti secondo il diritto comune, in Rivista di diritto privato 3 (1933); , La rappresentanza notarile del diritto intermedio, in Rivista di diritto privato 3 (1933);

. CABral De Moncada, Luís, Conceito e Função Jurisprudência segundo Verney, in Boletim do Ministério da Justiça 14 (1949); , Filosofia do Direito e do Estado I, Coimbra, Arménio Amado, 19471966 ; , Italia e Portogallo nel'Settecento, in Estudos de História do Direito III, Coimbra, Imprensa da Universidade, 1950; , Lições de Direito Civil (Parte Geral) II, Coimbra, Atlântida, 1932; , O Iluminismo Ítalo-Austríaco, in Estudos Filosóficos e Históricos (Artigos, Discursos, Conferências e Rescensões Críticas) II, Coimbra, Imprensa da Universidade, 1959;

, O problema metodológico na ciência da história do direito português, in Estudos de História do Direito II, Coimbra, Imprensa da Universidade, 1949; 
, O 'século XVIII' na legislação de Pombal, in Estudos de História do

Direito I, Coimbra, Imprensa da Universidade, 1948;

, Um 'iluminista' português do século XVIII: Luís António Verney, in

Estudos de História do Direito III: Século XVIII - Iluminismo Católico; Verney: Muratori, Coimbra, Imprensa da Universidade, 1950;

- Caetano, Marcello, As sesmarias no direito luso-brasileiro in CaEtano, Marcello; Moreira Alves, José Carlos; Couto e Silva, Clóvis do; Almeida Costa, Mário Júlio de, Estudos de Direito Civil Brasileiro e Português (I Jornada Luso-Brasileira de Direito Civil), São Paulo, Revista dos Tribunais, 1980; , História do Direito Português (sécs. XII - XVI) seguida de Subsídios para a história das fontes do direito em Portugal no séc. XVI, $4^{\mathrm{a}}$ ed., Lisboa, Verbo, 2000; . Caetano do Amaral, António, Sobre a Fórma de Governo, e Costumes dos Póvos que habitarã̃ o terreno Lusitano, desde os primeiros tempos conhecidos, até ao estabelecimento da Monarquia Portugueza in Memorias da Litteratura Portugueza I, Lisboa, Academia Real das Sciencias de Lisboa, 1792;

. CAhali, Yussef Said, Contratos nominados: doutrina e jurisprudência, São Paulo, Saraiva, 1995;

- Calasso, Francesco, Citramontani, ultramontani e il problema storico del diritto commune, in L'Europa e il diritto romano - studi in memoria di Paolo Koschaker II, Milano, Dott. A. Giuffrè, 1954;

,Il negozio giuridico - lezioni di storia del diritto italiano, $2^{\mathrm{a}}$ ed., Milano,

Giuffrè, 1959;

, Il problema storico del diritto comune, in Studi di storia e diritto in onore di Enrico Besta per il XL anno del suo insegnamento II, Milano, Giuffrè, s.d.;

. CAlmon, Pedro, A Reforma da Universidade e os dois Brasileiros que a Planejaram, in Revista de História das Idéias 1982-1983 (número especial intitulado O Marquês de Pombal e o seu Tempo II);

. CÂMara, José Gomes Bezerra, Código Filipino ou Ordenações do Reino, in Estudos Jurídicos e de História, Rio de Janeiro, Barrister's, 1987;

, Direito Público e Privado no Segundo Reinado in Estudos Jurídicos e de

História, Rio de Janeiro, Barrister's, 1987; , Subsídios para a História do Direito Pátrio, Rio de Janeiro, Livraria Brasiliana Editora, 1966; 
. CÂmara Leal, Antonio Luiz da, Manual Elementar de Direito Civil III - Direito das Obrigações (theoria particular) - direito das sucessões, Saraiva \& C., 1930;

- Camargo, Albino, Elementos de Direito Civil e de Direito Constitucional, Ribeirão Preto, Livraria Valada, s.d.;

- Camillo, Carlos Eduardo Nicoletti; TAlavera, Glauber Moreno; Fujita, Jorge Shiguemitsu; SCAvone JR., Luiz Antonio (coords.), Comentários ao Código Civil - artigo por artigo, São Paulo, Revista dos Tribunais, 2006;

. CAminha, Gregorio Martins, Tractado da Fórma dos Libellos, das Allegações Judiciaes, do Processo do Juizo Secular e Ecclesiastico, e dos Contractos, com suas Glossas, Coimbra, Real Collegio das Artes, 1731;

. CAmpello, Nalva Cristina Barbosa, Da representação, in M. L. Delgado - J. F. Alves, Questões Controvertidas - Parte Geral do Código Civil (Série Grandes Temas do Direito Privado VI), São Paulo, Método, 2007;

. Campos, Francisco, Direito Civil, Rio de Janeiro - São Paulo, Livraria Freitas Bastos S.A., 1956;

. CANDIAn, Aurelio, Atto autorizzato, atto materiale lecito, atto tollerato. Contributo alla teoria dell'atto giuridico, in Scritti giuridici in onore di Francesco Carnelutti III, Padova, CEDAM, 1950;

. CAPPELlini, Paolo, Rapprezentanza (diritto intermedio), in ED 38 (1987);

. CARBoni, M., Sul concetto di 'nuntius', in Scritti giuridici dedicati e offerti a Giampietro Chironi nel XXXIII anno del suo insegnamento I, Milano-Torino-Roma, Fratelli Bocca, 1915 ;

. Cardoso Paúl, Gaspar Loureiro d'Almeida, Codigo Civil Portuguez approvado por Carta de Lei de 1 de julho de 1867 annotado, Porto-Braga, Livraria Internacional, 1879;

. CARIOTA Ferrara, Luigi, Il negozio giuridico nel diritto privato italiano, Napoli, Morano, 1956;

. Carpintero, Francisco; Megías Quirós, José Justo, Christian Wolff, in R. Domingo (ed.), Juristas universales II - Juristas modernos (siglos XVI al XVIII: de Zasio a Savigny), Madrid-Barcelona, Ediciones Jurídicas y Sociales Marcial Pons, 2004;

- Carvalho, Carlos Augusto de, Direito Civil Brazileiro Recopilado ou Nova Consolidação das Leis Civis (vigentes em 11 de agosto de 1899), Porto, E. Nogueira, 1915; 
. Carvalho, Rômulo de, O Recurso a Pessoal Estrangeiro no Tempo de Pombal, in Revista de História das Idéias $1982-1983$ (número especial intitulado O Marquês de Pombal e o seu Tempo I);

. Carvalho de MendonçA, José Xavier, Tratado de Direito Commercial Brasileiro - Das obrigações, dos contratos e da prescripção em materia commercial VIII, Rio de Janeiro, Livraria Editora Freitas Bastos, 1939;

. Carvalho de MendonçA, Manuel Ignácio, Contratos no direito civil brasileiro, $4^{\mathrm{a}}$ ed., Rio de Janeiro, Forense, 1957;

. Carvalho Neto, Inácio de, Histórico da codificação civil brasileira in Novo Código Civil - Questões Controvertidas - Parte Geral do Código Civil (Série Grandes Temas do Direito Privado VI), São Paulo, Método, 2007;

- Carvalho Santos, Joaquim Manoel de, Codigo Civil Brasileiro Interpretado principalmente do ponto de vista pratico - Direito das Obrigações (arts. 1265-1362) XVIII, $2^{\mathrm{a}}$ ed., Rio de Janeiro, Livraria Editora Freitas Bastos, 1938;

. CAssirer, Ernst, Die Philosophie der Aufklärung, trad. it. de Ervino Pocar, Filosofia dell'illuminismo, Firenze, Nuova Italia, 1952;

. Castelo Branco, Camilo, Perfil do Marquês de Pombal, $2^{\mathrm{a}}$ ed., Porto, Lopes \& C., 1900 ;

- Castro Mendes, João de, Teoria Geral do Direito Civil II, Lisboa, Associação Académica da Faculdade de Direito de Lisboa, 1978;

. Caumont, Aldrick, Étude sur le vie et les travaux de Grotius, ou, le droit naturel et le droit international, Paris, Durand, 1862;

. Cavalcanti, José Paulo, Direito Civil - Escritos Diversos, Rio de Janeiro, Forense, 1983 ; , O Congresso e o projeto de Código Civil, in Reforma do Código Civil-

Ciclo de Estudos, Recife, Instituto dos Advogados de Pernambuco, 1975; , Sobre o ato ou negócio jurídico de procuração, Recife, Fundação Antônio dos Santos Abranches (FASA), 1992;

- Cavanna, Adriano, Storia del diritto moderno in Europa I - le fonti e il pensiero giuridico, Milano, A. Giuffrè, 1979;

. Chacon Couto, Alcides, Ligeiras observações sobre o mandato, Santo Anastácio, s.e., 1951;

. Chamoun, Ebert, Instituições de direito romano, $3^{\mathrm{a}}$ ed., Rio de Janeiro, Forense, 1957; 
. Chaves, Antonio, Lições de Direito Civil IV - Obrigações (Contratos em Espécie), São Paulo, Revista dos Tribunais, 1977;

. Clamageran, J.-J., Du louage d'industrie, du mandat et de la comission en droit romain dans l'ancien droit français, Paris, Auguste Durand, 1856;

. COASE, Ronald, The problem of the social cost, in The firm, the market and the law, Chicago-London, The University of Chicago Press, 1988;

. Coelho, Fábio Ulhoa, Curso de Direito Civil I, $2^{\mathrm{a}}$ ed., São Paulo, Saraiva, 2006; , Curso de Direito Civil III, São Paulo, Saraiva, 2005;

- Coelho DA Rocha, Manuel António, Ensaio sôbre a História do Governo e da Legislação de Portugal para servir de introducção ao estudo do direito pátrio, $4^{\mathrm{a}}$ ed., Coimbra, Imprensa da Universidade, 1861; , Instituições de Direito Civil Portuguez - para uso dos seus discípulos, s.

i. ed., Rio de Janeiro, H. Garnier, 1907;

. CoIng, Helmut, Europäisches Privatrecht, trad. esp. de Antonio Pérez Martín, Derecho Privado Europeo I - derecho común mas antiguo (1500-1800), Madrid, Fundação Cultural del Notariado, 1996;

. Comparato, Fábio Konder, Aparência de representação - a insustentabilidade de uma teoria, in Revista de Direito Mercantil, Industrial, Econômico e Financeiro 111 (1998); , Aspectos jurídicos da Macro-emprêsa, São Paulo, Revista dos Tribunais, 1970 ;

. Contreras, Pedro de Pablo, Johann Gottlieb Heinecke (Heineccius, Heinecio), in R. DomINGO (ed.), Juristas universales II - Juristas modernos (siglos XVI al XVIII: de Zasio a Savigny), Madrid-Barcelona, Ediciones Jurídicas y Sociales Marcial Pons, 2004;

- Correia, Alexandre; SciAsciA, Gaetano, Manual de Direito Romano e textos em correspondência com os artigos do Código Civil brasileiro I, $2^{\mathrm{a}}$ ed., São Paulo, Saraiva, 1953 ;

. Correia Da Silva, Luís Joaquim, Prefação, in Ordenações Afonsinas I, $2^{\mathrm{a}}$ ed., Coimbra, Fundação Calosute Gulbenkian, 1984;

. Correia Telles, José Hommem, Commentario Critico á Lei da Boa Razão em data de 18 de agosto de 1769, in Revista de Direito Civil, Imobiliário, Agrário e Empresarial 3 (1978); 
, Digesto Portuguez ou Tratado dos modos de adquirir a propriedade; de a gozar e administrar; e de a transferir por derradeira vontade; para servir de subsidio ao 'Novo Codigo Civil', Lisboa, Livraria Classica Editora, 1909; , Manual do Tabellião, Lisboa, Imprensa Nacional, 1859;

. Corriente, José Antonio, Hugo Grocio (Huig de Groot, Grotius, Hugo el Grande), in R. DomINGO (ed.), Juristas universales II - Juristas modernos (siglos XVI al XVIII: de Zasio a Savigny), Madrid-Barcelona, Ediciones Jurídicas y Sociales Marcial Pons, 2004;

. CORTESE, Ennio, Causa (diritto intermedio), in ED 6 (1974);

- Costa, Emilio, Storia del diritto romano privato - dalle origini alle compilazioni giustinianee, Milano-Torino-Roma, Fratelli Bocca Editori, 1911;

. Costa Pinheiro, Estudos de Direito Comercial I - Marcas, Escrituração comercial, Registo comercial, Pessoas e instituições auxiliares do comercio, Obrigações mercantis em geral, Coimbra, F. França Amado, 1916-1918;

. Crespo Allue, Fernando, La revocation del mandato, Madrid, Montecorvo, 1984;

. CRetella Júnior, José, Curso de direito romano - o direito romano e o direito civil brasileiro, $24^{\mathrm{a}}$ ed., Rio de Janeiro, Forense, 2000;

. CROOK, J. A., Legal Advocacy in the Roman World, London, Gerald Duckworth \& Co. Ltd., 1995;

. Cruz, Manoel Martins da Costa, A procuração em causa própria definida e aplicada pela jurisprudência, São Paulo, Typ. Univeral, s.d.;

. Cruz e TuccI, Cibele Pinheiro Marçal, Interposição de pessoa nos negócios jurídicos, Tese (Doutorado) - Faculdade de Direito da Universidade de São Paulo, São Paulo, 2004;

. CviACII, IACOBI, Opervm Postvmorvm quae de ivre reliqvit tomvs secvndvs sive Ivlivs Pavlvs, id est, ad Ivlii Pavli libros ad edictvm; et libros quaestionvm recitationes exactissimae, Lvtetiae Parisiorvm, Impensis Societatis Typographicae Librorum Oficij Ecclesiastici, 1658;

, Opervm Postvmorvm quae de ivre reliquit tomvs quintvs sive Codex Ivstinianvs, id est, ad Codicem Ivstinianvm recitationes solemnes, Lvtetiae Parisiorvm, Impensis Societatis Typographicae Librorum Oficij Ecclesiastici, 1658;

. Cunha Gonçalves, Luiz da, Comentário ao Código Comercial Português II, Lisboa, Empresa Editora José Bastos, 1916;

, Tratado de Direito Civil em Comentário ao Código Civil Português VII-

2, $2^{a}$ ed., São Paulo, Max Limonad, 1955; 
. CuQ, Édouard, Institutions juridiques des romains, Paris, Librairie Plon, 1917;

. D’Araujo Costa, Salustiano O., Codigo Commercial do Imperio do Brasil, Rio de Janeiro, Eduardo \& Henrique Laemmert, 1864;

. D’Ors, Alvaro, Elementos de derecho privado romano, $2^{\mathrm{a}}$ ed., Pamplona, Ediciones Universidad de Navarra, 1975; , El Codigo de Eurico - Edición, Palingenesia, Indices), in Estudios

Visigoticos II, Roma-Madrid, Consejo Superior de Investigaciones Cientificas Delegacion de Roma (Cuadernos del Instituto Juridico Español n. 12), 1960;

. DAVID, René, Les grands systèmes de droit contemporains, $7^{\mathrm{a}}$ ed., Paris, Dalloz, 1978;

. DE LOS Mozos, José Luís, El negocio juridico (estudios de derecho civil), Madrid, Editorial Montecorvo, 1987;

. De MATTEI, Rodolfo, Sul concetto di barbaro e barbarie nel Medio Evo, in Studi di storia e diritto in onore di Enrico Besta per il XL anno del suo insegnamento IV, Milano, Giuffrè, s.d.;

. De MatTIA, Fábio Maria, Aparência de representação, São Paulo, CID, 1999;

. De Plácido e Silva, Oscar José, Tratado do Mandato e Prática das Procurações, $3^{\mathrm{a}}$ ed., Curitiba-São Paulo-Rio, Guaíra, s.d.;

. Demangeat, Charles, Cours élémentaire de droit romain II, $3^{\mathrm{a}}$ ed., Paris, 1876;

. DeRnBurg, Heinrich, Obligationenrecht, trad. it. de Francesco Bernardino Cicala, Diritto delle obbligazioni, Torino, Fratelli Bocca, 1903;

. Di MARZo, Salvatore, Istituzioni di diritto romano, Milano, Dott. A. Giuffrè, 1938;

. Dias Ferreira, José, Codigo Civil Portuguez Annotado III, $2^{\mathrm{a}}$ ed., Coimbra, Imprensa da Universidade, 1898;

. DíEZ-PiCAZO, Luis, La representacion em el derecho privado, Madrid, Civitas, 1979;

. DinIZ, Maria Helena, Curso de Direito Civil Brasileiro - Teoria Geral do Direito Civil I, $23^{\mathrm{a}}$ ed., São Paulo, Saraiva, 2006; , Curso de Direito Civil Brasileiro - Teoria das Obrigações Contratuais e

Extracontratuais, $20^{\text {a }}$ ed., São Paulo, Saraiva, 2004;

. Dionysio Gama, Affonso, Tratado Theorico e Pratico de Direito Civil Brasileiro I Introdução ao Estudo do Direito e Teoria Geral do Direito Civil, Rio de Janeiro, Livraria Editora Leite Ribeiro, 1927; , Das procurações - Teoria e prática, $6^{\mathrm{a}}$ ed., São Paulo, Saraiva \& Cia., 1946 ; 
. DomAT, Jean, Les Loix civiles dans leur ordre naturel; le droit public, et legum delectus I, Paris, Nyon ainé, 1777;

. Domingo, Rafael, Georg Adam Struve, in R. Domingo (ed.), Juristas universales II Juristas modernos (siglos XVI al XVIII: de Zasio a Savigny), Madrid-Barcelona, Ediciones Jurídicas y Sociales Marcial Pons, 2004; , Juristas universales, Madrid-Barcelona, Ediciones Jurídicas y Sociales

Marcial Pons, 2004;

. DonATUTI, Guido, Mandato, in NDI 8 (1939); , Mandato incerto, in Studi di diritto romano I, Milano, Dott. A. Giuffrè, 1976; , Mandatum praesumptum, in Studi in memoria di Aldo Albertoni I, Padova, CEDAM, 1935; , Studi sul procurator II - Verus et falsus procurator, in Studi di diritto romano I, Milano, Dott. A. Giuffrè, 1976; , Sul fr. 55, Dig. 17, 1 mandati (vel contra), in Studi di diritto romano I, Milano, Dott. A. Giuffrè, 1976;

. Donelli, Hugonis, Opera Omnia, Commentariorum de iure civili III, Lucae, Typis Joannis Riccomini, 1763;

, Opera Omnia, Tomus Undecimus et commentariorum in selectos quosdam titulos digestorum volumen secundum, Lucae, Typis Joannis Riccomini, 1767;

. Doral, José Antonio; DEL ARCO, Miguel Angel, El negocio juridico, s.l., Trivium, 1982; . Dous JuRisconsultos, Repertorio systematico do Codigo Commercial Brasileiro, Rio de Janeiro, Typographia Guanabarense de L. A. F. de Menezes, 1850;

. DOVERI, Alessandro, Istituzioni di diritto romano - acresciuta per note di confronto col codice civile italiano II, $2^{\mathrm{a}}$ ed., Firenze, Le Monier, 1866;

. Dower, Nelson Godoy Bassil, Curso Moderno de Direito Civil - Parte Geral I, $4^{\mathrm{a}}$ ed., São Paulo, Nelpa, 2007;

, Curso Moderno de Direito Civil - Contratos e Responsabilidade Civil, $3^{\text {a }}$ ed., São Paulo, Nelpa, 2007;

. Duarte, Nestor, Da representação, in C. Peluso, Código Civil Comentado - Doutrina e Jurisprudência, $2^{\text {a }}$ ed., São Paulo, Manole, 2008; 
. DuARTE NunES Do LiÃO, Leis Extravagantes collegidas e relatadas pelo licenciado Dvarte Nvnez do Liam per mandado do muito alto \& muito poderoso Rei Dom Sebastiam nosso Senhor, Lisboa, Antonio Gonçaluez, 1569;

. DUMONT, François, La gratuité du mandat en droit romain, in Studi in onore di Vincenzo Arangio-Ruiz nel XLV anno del suo insegnamento II, Napoli, Editore Jovene, 1953;

. DURANDO, Edoardo, Il tabellionato: o, notariato nelle leggi romane, nelle leggi medioevali italiane e nelle posteriori specialmente piemontesi, Torino, Fratelli Bocca, 1897 ;

. EnNerCCERUs, Ludwig; KIPP, Theodor; WolfF, Martin, Lehrbuch des Bürgerlichen Rechts - Einleitung - Allgemeiner Teil, trad. esp. de Blas Pérez González e José Alguer, Tratado de Derecho Civil - Parte General - nacimiento, extinción y modificación de los derechos subjetivos, pretensiones y excepciones, ejercicio y aseguramiento de los derechos, Barcelona, Casa Editorial Bosch, 1935;

. ESPÍNOLA, Eduardo, Dos contratos nominados no direito civil brasileiro, Rio de Janeiro, Gazeta Judiciária Editora, 1953;

. EsPínOLA, Eduardo, Procuração em causa própria - effeitos: contracto consigo mesmo, in Revista Forense 45 (1925); , Systema do Direito Civil Brasileiro I - Introducção e Parte Geral, Rio de Janeiro - São Paulo - Belo Horizonte, Livraria Francisco Alves, 1938;

. EstradA, Liniers de, Manual de Historia del Derecho Argentino (Español - Indiano Argentino), Buenos Aires, Abeledo-Perrot, 1978;

. EwALD, François, Naissance du Code civil: la raisón du législateur, Paris, Flammarion, 1989 ;

. EysingA, Van, Gothofredus e Grotius in La tecnique et les principes du droit public études em l'honneur de Georges Scelle I, Paris, Libreirie Générale de Droit et de Jurisprudence, 1950;

. FAIRBANKS, Armando, Mandato e commissão, São Paulo, Saraiva, 1923;

. FALCÃo, César, Codigo Civil Brazileiro reduzido á ordem alphabetica, Rio de Janeiro São Paulo - Belo Horizonte, Livraria Francisco Alves, 1917; , Codigo Commercial Brasileiro - annotado theorica e praticamente, de acordo com as leis em vigor e a jurisprudencia, Rio de Janeiro, Livraria Quaresma Editora, 1926; 
. FAlcon, Francisco José Calazans, A Época Pombalina (Política Econômica e Monarquia Ilustrada), São Paulo, Ática, 1982;

. FedELE, Pio, Causa (diritto canonico), in ED 6 (1974);

. FENET, Pierre-Antoine, Recueil complet des travaux préparatoires du Code Civil suivi d'une édition de ce Code a laquelle sont ajoutés les lois, decréts et ordonnances formant le complément de la législation civile de la France, et ou se trouvent indiqués, sous chaque article séparément, tous les passages du recueil qui s'y rattachent XIV, Paris, Imprimerie de Marchand du Breuil, 1827;

. Fernandes, Adaucto, Curso de Direito Civil Brasileiro - Introdução I, Rio de Janeiro, A. Coelho Branco Fo , 1942;

. Ferreira, Mário, Do mandato em causa própria no direito civil brasileiro, São Paulo, Saraiva, 1933;

. FERreIRA, Waldemar, Mandato, in Revista dos Tribunais 67 (1928); , Tratado de Direito Comercial XI - O estatuto obrigacional do comércio e os títulos de crédito, São Paulo, Saraiva, 1963;

. Ferreira Borges, José, Diccionario Juridico-Commercial, $2^{\mathrm{a}}$ ed., Porto, Typographia de Sebastião José Pereira, 1856;

- FERrer CORREIA, António de Arruda, A procuração na teoria da representação voluntária, in Estudos de Direito Civil, Comercial e Criminal, $2^{\mathrm{a}}$ ed., Coimbra, Almedina, 1985 ;

. FERrini, Contardo, Manuale di Pandette, $3^{\mathrm{a}}$ ed., Milano, Società Editrice Libraria, 1917;

. FIUZA, Ricardo (coord.), Novo Código Civil Comentado, $5^{\text {a }}$ ed., São Paulo, Saraiva, 2006;

. Flores, Donato R., Notas sobre o Mandato em Causa Própria - o que é tal mandato e como faze-lo, São Paulo, Revista dos Tribunais, 1933;

. Fonseca, Tito Prates da, Noções de Direito Civil Brasileiro, Rio de Janeiro, Livraria Editora Freitas Bastos, 1941;

. FoucAult, Émile, Droit romain: de la representation dans le mandat et gestion d'affaires, Paris, G. Pedone-Lauriel, 1893;

. FranÇA, Rubens Limongi, Manual de Direito Civil IV-2 - Doutrina das obrigações contratuais, Doutrina das obrigações extracontratuais, São Paulo, Revista dos Tribunais, 1969 ; 
. Frese, Benedikt, Defensio, Solutio Expromissio des unberufenen Dritten, in Studi in onore di Pietro Bonfante nel XL anno d'insegnamento IV, Milano, Fratelli Treves Editori, 1930;

. FRESQUeT, Raymond Frederic de, Traité élémentaire de droit romain II, Paris, A. Maresq et Dujardin Librairies, s.d., p. 192;

. Fulgencio Alves Pereira, Tito, Programmas de direito civil (Primeiro anno do curso e primeira parte do segundo) na Faculdade Livre de Direito de Bello Horizonte, Bello Horizonte, Imprensa Official do Estado de Minas, 1921;

- Gagliano, Pablo Stolze; Pamplona Filho, Rodolfo, Novo Curso de Direito Civil Brasileiro - Parte Geral I, $8^{\text {a }}$ ed., São Paulo, Saraiva, 2006;

. Galgano, Francesco, Il negozio giuridico, Milano, Dott. A. Giuffrè, 1988;

. Galvão Telles, Inocêncio, Manual dos Contratos em Geral, $4^{\mathrm{a}}$ ed., Coimbra, Coimbra Editora, 2002;

- Gama Barros, Henrique da, História da Administração Pública em Portugal nos séculos XII a XV I, 2a ed., Lisboa, Livraria Sá da Costa - Editora, 1945;

. García-Gallo, Alfonso, Consideracion critica de los estudios sobre la legislacion y la costumbre visigodas, in Anuario de Historia del Derecho Español 44 (1974); , Curso de Historia del Derecho Español I: Introduccion e historia de las bases de la formacion del derecho, de las fuentes y del derecho publico, $5^{\mathrm{a}}$ ed., Madrid, s. e., 1950;

, La obra legislativa de Alfonso X - hechos e hipotesis, in Anuario de Historia del Derecho Español 54 (1984);

. GAZZAnigA, Jean-Louis, Mandat et représentacion dans l'ancien droit in Droits: Révue Française de Théorie Juridique 6 (1987);

. GIFFARD, André Edmond Victor, Droit romain et ancien droit français, $3^{\mathrm{a}}$ ed., Paris, Dalloz, 1970;

. GILISSEN, John, Introduction Historique au Droit, 1979, trad. port. de António Manuel Botelho Hespanha, Introdução Histórica ao Direito, Lisboa, Fundação Calouste Gulbenkian, 1988;

. Giorgianni, Michele, Causa (diritto privato), in ED 6 (1974);

- Giovene, Achille, Negozio giuridico rispetto ai terzi, Torino, Unione TipograficoEditrice Torinese, 1917; 
. GIRARD, Paul Frédéric, Manuel élémentaire de droit romain, $4^{\mathrm{a}}$ ed., Paris, Arthur Rousseau Éditeur, 1906;

. Godoy, Cláudio Luiz Bueno de, Do mandato, in C. Peluso, Código Civil Comentado Doutrina e Jurisprudência, $2^{\mathrm{a}}$ ed., São Paulo, Manole, 2008;

. GOMES, Luiz Roldão de Freitas, Contrato, Rio de Janeiro, Renovar, 1999;

. Gomes, Manuel Januário da Costa, Contrato de mandato comercial: questões de tipologia e regime, in As operações comerciais - trabalhos apresentados na disciplina de Direito Comercial do Curso de Mestrado de 1983/84 da Faculdade de Direito de Lisboa, sob a orientação do Prof. Doutor Oliveira Ascensão, Coimbra, Almedina, 1988;

. Gomes, Orlando, Contratos, $18^{\mathrm{a}}$ ed., Rio de Janeiro, Forense, 1999; , O poder de representação in Jurídica - Revista da Divisão Jurídica do Instituto do Açúcar e do Álcool s.n. (1970); , Raízes Históricas e Sociológicas do Código Civil Brasileiro, Salvador, Publicações da Universidade da Bahia, 1958;

- Gomes da Silva, Nuno Espinosa, Algumas Notas sobre a Edição das Ordenações Manuelinas de 1512-1513, in Scientia Jurídica 148-149 (1977); , Algumas notas sobre a edição das Ordenações Manuelinas de 1521, in Scientia Juridica 30 (1981); , História do Direito Português - Fontes de Direito, $3^{\mathrm{a}}$ ed., Lisboa, Fundação Calouste Gulbenkian, 2000; , O sistema de fontes nas Ordenações Afonsinas, in Scientia Iuridica 29 (1980);

. Gonçalves, Carlos Roberto, Direito Civil Brasileiro III - Contratos e Atos Unilaterais, $6^{\text {a }}$ ed., São Paulo, Saraiva, 2009;

. GonÇAlves de AndRAde, João Jacintho, A doutrina do mandato commercial abrange egualmente o mandato qualificado?, São Paulo, Typ. do Ypiranga, 1868;

. Gonçalves MaiA, José, Do mandato offerecido mediante publicidade, Rio de Janeiro, Typ. Santa Helena, 1922;

. GONÇAlVES MAIA, José, Theoria e pratica das procurações, Recife, Imprensa Industrial, 1917 ;

. GoRDO, Joaquim José Ferreira, Fontes próximas da compilação filippina ou indice das Ordenações e Extravagantes, Lisboa, Academia Real das Sciencias, 1792; 
. GORLA, Gino, Interessi e problemi della comparazione fra il diritto nostro e la 'common law' in Studi in memoria di Tullio Ascarelli II, Milano, Casa Editrice Dott. A. Giuffrè, 1969 ;

, 'Ratio decidendi', principio di diritto (e 'obiter dictum') in Studi in onore di Antonio Segni II, Milano, Giuffrè, 1967;

. Gouveia, Jaime Augusto Cardoso de, Da Responsabilidade Contratual, Lisboa, Edição do Autor, 1933;

. Greenidge, A. H. J., The legal procedure of Cicero's time, New York, Augustus M. Kelley, 1971;

. Grosso, Giuseppe, Causa (diritto romano), in ED 6 (1974);

, Schemi giuridici e società nella storia del diritto privato romano dall'epoca arcaica alla giurisprudenza classica: diritti reali e obbligazioni, Torino, G. Giappichelli, 1970;

. Grotius, Hugo, De Jure Belli ac Pacis Libri Tres, in quibus Jus Naturae \& Gentium, item Juris Publici praecipua explicantur, Washington, Carnegie Institution, 1913; , De Jure Belli ac Pacis Libri Tres, in quibus Jus Naturae \& Gentium, item Juris Publici praecipua explicantur, trad. esp. de Jaime Torrubiano Ripoll, Del derecho de la guerra y de la paz, Madrid, Editorial Reus, 1925; , Inleydinge tot de Hollandsche Rechts-geleerdheyt, trad. ing. de R. W.

Lee, The jurisprudence of Holland I - text translation and notes, Oxford, Clarendon Press, 1938 ;

. GuARINO, Antonio, Diritto privato romano, $12^{\mathrm{a}}$ ed., Napoli, Editore Jovene, 2001; , L'esaurimento del ius honorarium e la pretesa codificazione dell'editto in Studi in memoria di Emilio Albertario I, Milano, Dott. A. Giuffrè, 1953; , Profilo del diritto romano, $8^{\text {a }}$ ed., Napoli, Jovene, 1994;

. Guido Mor, Carlo, I giudici della Contessa Matilde e la rinascita del diritto romano in Studi in onore di Benvenuto Donati, Modena, Premiata Cooperativa Tipografi, 1954;

. HÄNEL, Gustav Friedrich, Lex Romana Visigothorum, Leipzig, Sumptibus et Typis B. G. Teubneri, 1849;

. HEINECII, Johann Gottlieb, Recitationes in Elementa Juris Civilis secundum ordinem Institutionum, Conimbricae, Typis Academicis, 1817; 
Recitationes in Elementa Juris Civilis secundum ordinem Institutionum, trad. cast. de Luis de Collantes y Bustamente, Recitaciones del derecho Civil Romano II, $8^{\mathrm{a}}$ ed., Valencia, Librería de Pascual Aguilar, 1888;

. Herculano, Alexandre, Portugaliae Monumenta Historica-Leges e Consuetudines I, s. 1., Olisiponi, 1868;

- Hespanha, António Manuel, Cultura jurídica européia - síntese de um milênio, Florianópolis, Fundação Boiteux, 2005; , História das Instituições - Épocas Medieval e Moderna, Coimbra,

Almedina, 1982; , Panorama histórico da cultura jurídica européia, $2^{\mathrm{a}}$ ed., Mira-Sintra, Publicações Europa-América, 1998;

. HEYD, Wilhelm, Geschichte des Levantehandels im Mittelalter, trad. fr. de Pauteur, Histoire du commerce du levant au moyen-âge, Amsterdam, A. M. Hakkert, 1967;

. HobBes, Thomas, The elements of law natural and politic, London, Simpkin-Marshall and Co., 1889;

. HoraK, Franz, Dogmatica e casuística no direito romano e nos direitos modernos, in Revista de Direito Civil, Imobiliário, Agrário e Empresarial 28 (1984);

. HUPKA, Josef, La representación voluntaria en los negocios jurídicos, Madrid, Revista de Derecho Privado, 1930;

. ITURRIAGA ROMERo, José, La representacion em el derecho privado, Lima, Universidad Nacional Mayor de San Marcos, 1974;

. JHERING, Rudolf von, Études complémentaires de l'esprit du droit romain V-IX, Paris, Librairie A. Marescq, 1903; , Der Zweck im Recht I, $2^{\mathrm{a}}$ ed., Leipzig, Breitkopf \& Härtel, 1884;

. JolowicZ, H. F., Roman regulae and english maxims in L'Europa e il diritto romano studi in memoria di Paolo Koschaker I, Milano, Dott. A. Giuffrè, 1954;

. JUNQUEIRA DE AZEVEDO, Antonio, Negócio jurídico e declaração negocial (noções gerais e formação da declaração negocial), Tese (Titularidade) - Faculdade de Direito da Universidade de São Paulo, São Paulo, 1986;

, Qualificação jurídica de "acordo operacional” (contrato atípico, complexo, com fortes elementos de contrato de know how e de mandato com administração). Contratos de duração e não-denunciabilidade dos contratos de duração determinada. Denúncia ilícita, in Revista Forense 380 (2005); 
. KAN, J. van, L'unification du droit et les résistences des jurisconsultes sous l'ancien regime in Mélanges Paul Fournier, Paris, Sirey, 1929;

. KARAM, Munir, O processo de codificação do direito civil brasileiro (da Consolidação de T. de Freitas ao Projeto Beviláqua); o sistema do Esboço, in S. ScHIPANI (coord.), Augusto Teixeira de Freitas e il diritto latinoamericano, Padova, CEDAM, 1988;

. KASER, Max, Römisches Privatrecht, trad. port. de Samuel Rodrigues e Ferdinand Hämmerle, Direito Privado Romano, Lisboa, Fundação Calouste Gulbenkian, 1999;

. Kelsen, Hans, Allgemeine Theorie der Normen, trad. it. de Mirella Torre, Teoria generale delle norme, Torino, Giulio Einaudi, 1985;

. Kroetz, Maria Candida do Amaral, A representação voluntária no direito privado, São Paulo, Revista dos Tribunais, 1997;

. LACERDA, Galeno, Obrigações Civis VII - Ilícitos contratuais. Ilícitos extracontratuais. Seguro. Prestação de contas. Mandato. Doação. Empreitada. Corretagem. Fiança. Construção (casos selecionados), Rio de Janeiro, Forense, 2001;

. LAGRANGE, Eugene, Manuel de droit romain ou explication des institutes de Justinien par demandes et réponses, $8^{\mathrm{a}}$ ed., Paris, J.-B. Mulot, 1861;

. LANDIN FILHO, Francisco Antonio Paes, O mandato civil sem representação, Campinas, Agá Juris, 2000;

. Lauria, Mario, Ius civile - Ius honorarium in Scritti di diritto romano in onore di Contardo Ferrini pubblicati dalla R. Università di Pavia, Milano, Ulrico Hoepli, 1946;

. LeITe, Licurgo, Codigo Civil Brasileiro annotado, São Paulo, Escolas Prof. do Lyceu C. de Jesus, 1923;

. LEITE, Solidônio, Codigo Civil brasileiro: trabalhos relativos à sua elaboração II, Rio de Janeiro, Imprensa Nacional, 1918;

- Leite Filho, Fernando Rudge, Curso de Direito Civil - Parte Geral, Direito das Obrigações, São Paulo, Edições Lael, 1973;

. LEME, Lino de Moraes, Mandato em causa própria: da procuração in rem propria como título hábil para a transmissão de direitos reais sobre imóveis. Controvérsia na doutrina e na jurisprudência. Aquisição de domínio pelo próprio mandatário, mediante intervenção em ação divisória. Inadmissibilidade, mormente tendo-se apoiado em instrumento público não levado a registro, sem perfeita individualização do imóvel e sem assinatura de testemunhas. Prevalência do título de quem adquiriu o mesmo bem diretamente do 
mandante, por meio de escritura pública devidamente formalizada, in Revista dos Tribunais 182/40; , O direito na Península Ibérica, in Revista da Faculdade de Direito da Universidade de São Paulo 53 (1958);

. LeONE, Arlindo Baptista, Mandato e comissão mercantil, Bahia, s. e., 1900;

. LEPOINTE, Gabriel, Les obligations en droit romain, Paris, Editions Domat Montchrestien, 1955

. Liberato BARroso, José, Contractos e Obrigações Mercantis - Parte $1^{a}$ (Títulos V a XIV do Codigo Commercial), Rio de Janeiro, B. L. Garnier, 1871;

. LiMA, Domingos Sávio Brandão de, Origem e evolução da procuração em causa própria, São Paulo, DIP, 1977;

. Lima, João Franzen de, Curso de Direito Civil Brasileiro II-2 - Direito das Obrigações Dos contratos e das Obrigações por Declaração Unilateral de Vontade, $3^{\mathrm{a}}$ ed., Rio de Janeiro, Forense, 1979;

. LimA, Ruy Cirne, Pequena história territorial do Brasil - sesmarias e terras devolutas, $4^{\mathrm{a}}$ ed., Brasília, Escola de Administração Fazendária, 1988;

. LIMA LOPES, José Reinaldo de, O Direito na História - lições introdutórias, São Paulo, Max Limonad, 2000;

. LIMA SOBRINHO, Barboza, Das procurações: o mandato conferido para concluir um dos contractos do art. 134 do Codigo Civil requer instrumento publico?, in Revista de Direito Civil, Commercial e Criminal 47 (1918);

. LoBo Da Costa, Valdomiro, Contribuição ao estudo da história do direito brasileiro, in Revista da Faculdade de Direito da Universidade de São Paulo 50 (1955);

. LOCKE, John, Essai sur l'entendement humain, in Oeuvres de Locke et Leibnitz, Paris, Firmin Didot Frères, 1839; , The second treatise of Government: an Essay concerning the true original, extent, and end of Civil Government, in Two Treatises of Government, Cambridge, Cambridge University Press, 1996;

. LoNGO, Giannetto, Mandato (diritto romano), in NNDI 10 (1964);

- LóPEZ-Jacoiste DíAZ, Eugenia, Johannes Voet, in R. Domingo (ed.), Juristas universales II - Juristas modernos (siglos XVI al XVIII: de Zasio a Savigny), MadridBarcelona, Ediciones Jurídicas y Sociales Marcial Pons, 2004; 
. LOPES PrAÇA, José Joaquim, História da Philosophia em Portugal nas suas Relações com o Movimento Geral da Philosophia, Coimbra, Imprensa Litteraria, 1868;

. Lotufo, Renan, Código Civil Comentado I - Parte Geral: arts. $1^{\circ}$ a 232, São Paulo, Saraiva, 2003;

, Questões relativas a mandato, representação e procuração, São Paulo,

Saraiva, 2001;

. Lúcio DE AZEVEDo, João, O Marquês de Pombal e a sua Época, Lisboa, Clássica Editora, 1990 ;

- MaC-Dowell, Samuel, Effeitos do mandato por instrumento particular em face do Codigo Civil, in Revista de Direito Civil, Commercial e Criminal 60 (1921);

. MACEDO, Jorge Borges de, Estrangeirados, um Conceito a rever, in Bracara Augusta 28 (1974);

- Machado, Antonio Cláudio da Costa, Oliveira, Juarez de, Barreto, Zacarias, Código Civil de 2002 Comparado e Anotado, 2a ed., São Paulo, Juarez de Oliveira, 2003;

. MACKELDEY, Ferdinand, Lehrbuch des heutigen Römischen Rechts, trad. fr. de J. Beving, Manuel de droit romain, contenant la théorie des Institutes, précédée d'une introduction a l'étude du droit romain, $3^{\mathrm{a}}$ ed., Bruxelles, Société Typographique Belge, 1846;

. MAdeIRA, Eliane Maria Agati, Laesio enormis, Tese (Doutorado) - Faculdade de Direito da U.S.P., São Paulo, 1998;

. MAdeIRA, Hélcio Maciel França, História da Advocacia - Origens da profissão de advogado no direito romano, São Paulo, Revista dos Tribunais, 2002;

. MAIA JÚNIOR, Mairan Gonçalves, A representação no negócio jurídico, São Paulo, Revista dos Tribunais, 2001;

. MARKy, Thomas, Curso elementar de direito romano, $8^{\mathrm{a}}$ ed., São Paulo, Saraiva, 1995;

. MARmitT, Arnaldo, Mandato, Rio de Janeiro, Aide, 1992;

. MARQues, Mário Reis, Codificação e paradigmas da modernidade, Coimbra, Coimbra Editora, 2003;

, Elementos para uma aproximação do estudo do usus modernus pandectarum em Portugal, in Boletim da Faculdade de Direito da Universidade de Coimbra 58 (1982); , História do Direito Português Medieval e Moderno, $2^{\mathrm{a}}$ ed., Coimbra, Almedina, 2002; 
, O Liberalismo e a Codificação do Direito Civil em Portugal - Subsídios

para o Estudo da Implantação em Portugal do Direito Moderno, Coimbra, Imprensa da Universidade, 1987;

. Martini, Remo, Mandato nel diritto romano in Digesto IV: Discipline Privatistiche (sezione civile) 11 (1996);

- Matos Peixoto, José Carlos de, Curso de Direito Romano I - Partes introdutória e geral, Rio de Janeiro, Companhia Editora Fortaleza, 1950;

. MATTIETTO, Leonardo, A representação voluntária e o negócio jurídico de procuração, in Revista Trimestral de Direito Civil 4 (2000);

- Mattos, Francisco Xavier de Oliveira, Prefação, in Ordenações Manuelinas Livro I, Coimbra, Fundação Calouste Gulbenkian, 1984;

. MaXwell, Kenneth, Marquês de Pombal - Paradoxo do Iluminismo, Rio de Janeiro, Paz e Terra, 1996;

. MAYnZ, Charles, Cours de droit romain II, Bruxelles, Librairie Polytechnique d'Aug. Decq, 1870;

. MAYR, Robert von, Römische Rechsgeschichte, trad. esp. de Wenceslao Roces, Historia del derecho romano, Barcelona, Editorial Labor, 1926;

. MeIRA, Sílvio Augusto de Bastos, Instituições de Direito Romano, $3^{\mathrm{a}}$ ed., São Paulo, Max Limonad, 1968;

. Mello Freire dos Reis, Pascoal José de, Historiae Juris civilis lusitani liber singularis, trad. port. de Miguel Pinto de Menezes, História do Direito Civil Português in Boletim do Ministério da Justiça 174 (1968); , Institutiones Juris Civilis Lusitani cum Publici tum Privati - Liber IV:

De obligationibus et actionibus, $2^{\mathrm{a}}$ ed., Conimbricae, Ex Typis Academicis, 1845; , Institutiones Juris Civilis Lusitani cum Publici tum Privati, trad. port. de Miguel Pinto de Meneses, Instituições de Direito Civil Português - Tanto Público como Particular, in Boletim do Ministério da Justiça 168 (1967);

. Mendes de AlmeIdA, Cândido, Auxiliar Juridico servindo de appendice a decima quarta edição do Codigo Philippino ou Ordenações do Reino de Portugal recopiladas por mandado de El-Rey D. Philippe I - obra util aos que se dedicão ao estudo do direito e da jurisprudência pátria, Rio de Janeiro, Typographia do Instituto Philomatico, 1869; 
, Código Philippino ou Ordenações e Leis no Reino de Portugal recopiladas por mandado d'El-Rey D. Philippe I, $14^{\mathrm{a}}$ ed., Rio de Janeiro, Typographia do Instituto Philomathico, 1870;

- Menezes Cordeiro, António, Manual de Direito Comercial (Introdução, Doutrina Comercial Geral, Contratos comerciais) I, Coimbra, Almedina, 2003;

. Michel, Jacques, Gratuité en droit romain, Bruxelles, Université Libre de Bruxelles, 1962

. Minguijón AdRián, Salvador, Historia del Derecho Español, $3^{\mathrm{a}}$ ed., Barcelona - Madrid - Buenos Aires - Rio de Janeiro, 1943;

. MiRAnda, Custódio da Piedade Ubaldino, Teoria geral do negócio jurídico, São Paulo, Atlas, 1991;

. Miró Junior, Joaquim, A procuração em causa própria e seus efeitos, Tese (LivreDocência) - Faculdade de Ciências Econômicas da Universidade do Paraná, Curitiba, 1952 ;

. Molitor, Jean-Philippe, Les obligations en droit romain avec l'indication des rapports entre la législation romaine et le droit français II, $2^{\mathrm{a}}$ ed., Paris, Auguste Durand, 1867;

- MonIER, Raymond, Manuel Élémentaire de Droit Romain II - deuxième année de licence: diplômes d'études supérieures de droit romain et de droit privé (les obligations), $4^{\mathrm{a}}$ ed., Paris, Éditions Domat Montchrestien, 1948;

. Monteiro, Washington de Barros, Curso de Direito Civil - Parte Geral I, 40 a ed. (revista e atualizada por Ana Cristina de Barros Monteiro França Pinto), São Paulo, Saraiva, 2005; , Curso de Direito Civil - Direito das Obrigações (2 ${ }^{a}$ parte $)$ - dos contratos em geral, das várias espécies de contrato, dos atos unilaterais, da responsabilidade civil V, 34 a ed. (revista e atualizada por Carlos Alberto Dabus Maluf e Regina Beatriz Tavares da Silva, de acordo com o novo Código Civil, Lei $\mathrm{n}^{\circ} 10.406$, de 10-1-2002), São Paulo, Saraiva, 2003;

. Moreira Alves, José Carlos, A Contribuição do Antigo Direito Português no Código Civil Brasileiro, in Caetano, Marcello; Moreira Alves, José Carlos; Couto e Silva, Clóvis do; Almeida Costa, Mário Júlio de, Estudos de Direito Civil Brasileiro e Português (I Jornada Luso-Brasileira de Direito Civil), São Paulo, Revista dos Tribunais, 1980 ; 
, A formação romanística de Teixeira de Freitas e seu espírito inovador, in SCHIPANI, Sandro, Augusto Teixeira de Freitas e il diritto latinoamericano, Padova, CEDAM, 1988;

, A Parte Geral do Projeto de Código Civil Brasileiro - com análise do texto aprovado pela Câmara dos Deputados, São Paulo, Saraiva, 1986;

, Aspectos do Ensino do Direito Romano na Faculdade de Direito de São

Paulo, durante o Império, in Revista da Faculdade de Direito da Universidade de São Paulo 86 (1991);

, II - Aspectos Jurídicos - Figuras correlatas: abuso de forma, abuso de direito, dolo, negocios jurídicos simulados, fraude à lei, negócio indireto e dissimulação, in Anais do Seminário Internacional sobre Elisão Fiscal, Brasília, s.e., 2002; , Direito romano I: História do direito romano - instituições do direito romano: a) Parte Geral; b) Parte Especial: Direito das Coisas, Rio de Janeiro, Forense, 2001;

, Direito Romano II - Instituições de Direito Romano: B) Parte Especial:

Direito das obrigações; direito de família; direito das sucessões, $6^{\mathrm{a}}$ ed., Rio de Janeiro, Forense, 1997;

, O negócio jurídico no novo Código Civil Brasileiro, in Jurisprudência Catarinense 102 (2004);

, O novo Código Civil Brasileiro: principais inovações na disciplina do negócio jurídico e suas bases romanísticas, in Roma e America - Diritto Romano Comune 16 (2003); , Panorama do Direito Civil Brasileiro: das Origens aos Dias Atuais in

Revista da Faculdade de Direito da Universidade de São Paulo 88 (1993); , Universidade, cultura e direito romano, in Revista da Faculdade de Direito da Universidade de São Paulo 87 (1992);

. MoreIRA De SÁ, Artur, A < Carta de Bruges $>>$ do Infante D. Pedro, in Biblos XXVIII (1952);

. Mosset ItURRASPe, Jorge, Mandatos, Buenos Aires, Ediar S.A., 1979;

. Mota PinTo, Carlos Alberto da, Teoria Geral do Direito Civil, $4^{\mathrm{a}}$ ed., Coimbra, Coimbra Editora, 2005;

. Muñoz-Arraco, José Manuel Pérez-Prendes, Breviario de Derecho Germánico, Madrid, Servicio de Publicaciones Facultad Derecho Universidad Complutense Madrid, 1993; 
. Nascimento, Walter Vieira do, Lições de História do Direito, 12ª ed., Rio de Janeiro, Forense, 2000;

- Nery Junior, Nelson; Andrade Nery, Rosa Maria de, Código Civil Anotado e legislação extravagante, $2^{\mathrm{a}}$ ed., São Paulo, Revista dos Tribunais, 2003;

. Neto, Abílio; Martins, Herlânder A., Código Civil Anotado, 5ª ed., Lisboa, Livraria Petrony, 1984;

- Neto Paiva, Vicente Ferrer, Curso de Direito Natural segundo o estado actual da Sciencia principalmente em Allemanha professado no primeiro anno da Faculdade de Direito na Universidade de Coimbra II, Coimbra, Imprensa da Universidade, 1856;

- Neves, António Castanheira, Digesta - Escritos acerca do direito, do pensamento jurídico, da sua metodologia e outros, Coimbra, Coimbra Editora, 1995;

. NichOlas, Barry, An introduction to roman law, Oxford, Clarendon Press, 1962;

. Nicolau, Gustavo Rene, Direito Civil - Parte Geral, 2ª ed., São Paulo, Atlas, 2006;

. NogueIRA, Ricardo Raimundo, Prelecções de direito pátrio, in O Instituto 12 (1865);

. Nonato, Orosimbo; AzEvedo, Philadelpho; Guimarães, Hahnemann, Exposição de motivos do Anteprojeto de Código das Obrigações - Parte Geral (1941), in Código Civil Anteprojetos I, Brasília, Senado Federal - Subsecretaria de Edições Técnicas, 1989;

. NoODT, Gerard, Opera omnia III, Neapoli, Fratres Terres, 1786;

. Noronha, Tito de, Ordenações do Reino - Edições do Século XVI (additamento ao cancioneiro geral de Garcia de Rezende), Porto, Livraria Internacional, 1871;

. NÖRR, Dieter, Sulla specificità del mandato romano, in SDHI 60 (1994);

. OliveIRA, Antônio Resende de, Poder e Sociedade. A Legislação Pombalina e a Antiga Sociedade Portuguesa, in Revista de História das Idéias 1982-1983 (número especial intitulado O Marquês de Pombal e o seu Tempo I);

- Oliveira, Cândido de - SÁ Benevides, José Maria Corrêa de - Andrade, Justino Gonçalves de, Mandato, in Revista Forense 6 (1906);

. OliveIRA, Ponciano Ferreira de, Do mandato e da commissão mercantil, in São Paulo Judiciário 23/24/25 (1910);

- Oliveira Marques, António Henrique de, História de Portugal, Lisboa, Imprensa Nacional - Casa da Moeda, 1991;

. ORESTANO, Ricardo, “Procuratores”, in NDI 10 (1939); , Rappresentanza, in NDI 10 (1939); , "Procurator (procuratores)", in NNDI 13 (1966); 
, Rappresentanza (diritto romano), in NNDI 14 (1967);

. PACChIONI, Giovanni, Di alcuni probabili interpolazioni nel titolo 'De negotiis gestis', in Scritti giuridici dedicati e offerti a Giampietro Chironi nel XXXIII anno del suo insegnamento I, Milano-Torino-Roma, Fratelli Bocca, 1915;

, Corso di diritto romano II, Innsbruck, Libreria Accademica Wagner,

1905 ;

, Trattato della gestione degli affari altrui secondo il diritto romano e civile, $2^{\mathrm{a}}$ ed., Milano, Casa Editrice Dottor Eugenio Vallardi, 1915;

. PAPERI, Oscar, Considerazioni sull'origine del 'procurator ad litem' in Labeo-Rassegna di Diritto Romano 48 (2002);

. Paulo Da Rocha, Clóvis, Do cancelamento do mandato irrevogável, in Revista Forense 126 (1949);

- Paulo MerêA, Manuel, Codigo Civil Brasileiro annotado, Lisboa, Livraria Clássica Editora, 1917;

, Direito romano, direito comum e boa razão in Boletim da Faculdade de

Direito da Universidade de Coimbra 16 (1939-1940); , Estudos de Direito Visigótico, Coimbra, Imprensa da Universidade, 1948 ; , Flores de Direito, in Boletim da Faculdade de Direito da Universidade de Coimbra 6 (1917);

, Lance de olhos sobre o ensino do direito (cânones e leis) desde 1772 até 1804, in Boletim da Faculdade de Direito da Universidade de Coimbra 33 (1957); , Resumo das Lições de História do Direito Português, Coimbra, Coimbra Editora, 1925;

, Sôbre a origem da palavra 'manda', in Novos Estudos de História do Direito, Barcelos, Minho, 1937;

, Suáres, Grócio, Hobbes:lições de história das doutrinas políticas,

Coimbra, Armênio Amado, 1941;

, Versão portuguesa das flores de las leys - contribuições para a história do direito português, Coimbra, Imprensa da Universidade, 1918;

. Pereira, Caio Mário da Silva, Instituições de Direito Civil - Introdução ao Direito Civil, Teoria Geral do Direito Civil I, $21^{\text {a }}$ ed. (revista e atualizada por Maria Celina Bodin de Moraes, de acordo com o Código Civil de 2002), Rio de Janeiro, Forense, 2006; 
, Instituições de Direito Civil - Contratos, Declaração unilateral de vontade, Responsabilidade civil III, $12^{\text {a }}$ ed. (revista e atualizada por Regis Fichtner, de acordo com o Código Civil de 2002), Rio de Janeiro, Forense, 2006;

. PEREIRA, Virgílio de Sá, Da cláusula 'in rem propriam' nas procurações, in Questões de Direito Civil, Criminal e Processual, 2a ed., Rio de Janeiro - São Paulo, Livraria Freitas Bastos, 1958;

. Peres, Damião, História de Portugal VI, Barcelos, Portucalense Editora, 1934;

- Pereyra e Castro, Francisco Caldas, Analyticvs commentarius, sive Ad Typum Instrumenti Emptionis \& Venditionis Tractatus, tum pragmaticis cum gymnastis ad modum utilis ac neceßarius, Francofvrti, Typis Hartmanni Palthenij, 1619;

. PÉrez Álvarez, Miguel Ángel, Jean Domat, in R. DOMINGO (ed.), Juristas universales II - Juristas modernos (siglos XVI al XVIII: de Zasio a Savigny), Madrid-Barcelona, Ediciones Jurídicas y Sociales Marcial Pons, 2004;

. PÉrez Martín, Antonio, El Fuero Real y Murcia, in Anuario de Historia del Derecho Espanol 54 (1984);

. PEROzZI, Silvio, Istituzioni di diritto romano: obbligazioni ed azioni - diritto ereditario donazioni II, Firenze, G. Barbera Editore, 1908;

. PESSÔA, Eduardo, Da procuração, Rio de Janeiro, Editora Idéia Jurídica, 2001;

. Pessoa Jorge, Fernando de Sandy Lopes, O mandato sem representação, Lisboa, Ática, 1961 ;

. Petit, Carlos, Consuetudo y mos en la Lex Visigothorum, in Anuario de Historia del Derecho Español 54 (1984);

. PeTit, Eugéne, Tratado elemental de derecho romano, Buenos Aires, Editorial Albratros, 1958 ;

. PhARr, Clyde, The Teodosian Code, Princeton, University Press, 1952;

. PIMENTA, Alfredo, Fuero Real de Afonso X, o Sábio - versão portuguesa do século XIII, Lisboa, Instituto para a Alta Cultura, 1946;

. Pinto Loureiro, José, Manuel de Almeida e Sousa, in Jurisconsultos Portugueses do Século XIX - I, Coimbra, Coimbra Editora, 1947;

. Pires de Lima, Fernando Andrade; Antunes VArela, João de Matos, Código Civil Anotado I (arts. $1^{\circ}$ a $761^{\circ}$ ), $4^{\mathrm{a}}$ ed., Coimbra, Coimbra Editora, 1987; , Noções Fundamentais de Direito Civil (Lições do Prof. Dr. Pires de

Lima ao Curso do $1^{\circ}$ Ano Jurídico de 1944-45) I, Coimbra, Coimbra Editora, 1945; 
- Pontes de Miranda, Francisco Cavalcanti, Fontes e Evolução do Direito Civil Brasileiro, Rio de Janeiro, Pimenta de Mello \& C., 1928; , Tratado de Direito Privado I - Parte Geral: Introdução. Pessoas físicas e jurídicas, $4^{\mathrm{a}}$ ed., São Paulo, Revista dos Tribunais, 1983; , Tratado de Direito Privado III - Parte Geral: Negócios jurídicos. Representação. Conteúdo. Forma. Prova, Rio de Janeiro, Borsoi, 1954; , Tratado de Direito Privado XLIII - Direito das Obrigações: Mandato. Gestão de negócios alheios sem outorga. Mediação. Comissão. Corretagem, $3^{\mathrm{a}}$ ed., Rio de Janeiro, Borsoi, 1972;

. Pousada, Estevan Lo Ré, Preservação da tradição jurídica luso-brasileira: Teixeira de Freitas e a Introdução à Consolidação das Leis Civis, Dissertação (Mestrado) - Faculdade de Direito da U.S.P., São Paulo, 2006;

. Poveda Velasco, Ignacio Maria, Ordenações do Reino de Portugal, in Revista da Faculdade de Direito da Universidade de São Paulo 89 (1994);

. Provera, Giuseppe, Mandato (storia), in ED 25 (1975);

. PUFENDORF, Samuel, De iure naturae et gentium libri octo, trad. fr. de Jean Barbeyrac, Le droit de la nature et des gens, ou systeme general des principes les plus importants de la morale, de la jurisprudence, et de la politique, Basle, Emanuel Thourneisen, 1771;

, De officio hominis, et civis secundum legem naturalem libri duo, $5^{\mathrm{a}}$ ed.,

Francofurti-Lipsie, Impensis Henr. Lud. Broenneri, 1758;

. Pugliese, Giovanni, Istituzioni di diritto romano, $2^{\text {a }}$ ed., Torino, G. Giappichelli, 1990;

. QuAdRATO, Renato, Rappresentanza (diritto romano) in Enciclopedia del diritto 38 (1987);

. Raimundo Nogueira, Ricardo, Prelecções de Direito Pátrio no anno lectivo de 1795 a 1796: Parte $3^{a}$ - na qual se explicam alguns títulos das Ordenações do Reino, in $O$ Instituto 7 (1859);

. RÁo, Vicente, Ato Jurídico - Noção, pressupostos, elementos essenciais e acidentais. $O$ problema do conflito entre os elementos volitivos e a declaração, $4^{\mathrm{a}}$ ed., São Paulo, Revista dos Tribunais, 1999; , Mandato - entrega de letra de câmbio a estabelecimento bancário para cobrança - inexistência de filial no lugar do pagamento - poderes para substabelecer presumidos - prejuízos por falta de protesto oportuno - irresponsabilidade do mandatário, in Revista dos Tribunais 167 (1947); 
. RAY, Jean, Essai sur la structure logique du Code Civil Français, Paris, Librairie Félix Alcan, 1926;

. REALE, Miguel, Lições preliminares de direito, 27ª ed., São Paulo, Saraiva, 2002;

. RIBEIRO, João Pedro, Indice Chronologico Remissivo da Legislação Portugueza Posterior à Publicação do Codigo Filippino com hum Appendice, Lisboa, Typografia da Academia Real das Sciencias, 1805-1820; , Sobre as Fontes do Código Filippino, in Memórias da Litteratura

Portugueza II, Lisboa, Officina da Academia Real de Sciencias, 1792;

. Riccobono, Salvatore, La giurisprudenza classica come fattore di evoluzione nel diritto romano in Scritti di diritto romano in onore di Contardo Ferrini pubblicati dalla $R$. Università di Pavia, Milano, Ulrico Hoepli, 1946; , Lineamenti della dottrina della rappresentanza diretta in diritto romano, in Studi di diritto commerciale in onore di Cesare Vivante II, Roma, Società Editrice del Foro Italiano, 1931;

. Rocco, Ugo, Su la esistenza del problema dei destinatari delle norme giuridiche, in Studi in onore di Enrico Redenti nel suo XL anno d'insegnamento II, Milano, Dott. A. Giuffrè, 1951 ;

. Rocha, Silvio Luiz Ferreira da, Curso Avançado de Direito Civil - Contratos III, São Paulo, Revista dos Tribunais, 2002;

. Rocha Cabral, José Marcelino da, Consulta, in J. J. Rodrigues (org.), Consultas cit. (nota 131);

. Rodrigues, Francisco César Pinheiro - Loureiro Filho, Lair da Silva, Código Civil Brasileiro interpretado pelos tribunais, São Paulo, Livraria Oliveira Mendes, 1998;

- Rodrigues (org.), João J., Consultas Juridicas sobre questões de direito civil, commercial, criminal, administrativo e ecclesiastico II, Lisboa, Livraria Clássica Editora, 1915 ;

. Rodrigues, Silvio, Direito Civil - Parte Geral I, 34a ed., São Paulo, Saraiva, 2003; , Direito Civil - Dos Contratos e das Declarações Unilaterais da Vontade III, 29ª ed., São Paulo, Saraiva, 2003;

. RongA, Giovanni, Corso di istituzioni di diritto romano: teoria delle obbligazioni II, $2^{\mathrm{a}}$ ed., Torino, Unione Tipografico-Editrice, 1899; 
. RoTONDI, Giovanni, Appunti sulla stipulatio rem pupilli salvam fore, in Scritti giuridici II - Studii sul diritto romano delle obbligazioni (a cura di Emilio Albertario), Milano, Ulrico Hoepli, 1922;

. Ruiz Gallardón, María Isabel, Samuel Pufendorf, in R. Domingo (ed.), Juristas universales II - Juristas modernos (siglos XVI al XVIII: de Zasio a Savigny), MadridBarcelona, Ediciones Jurídicas y Sociales Marcial Pons, 2004;

. Russo, Giacomo, La costruzione giuridica della rappresentanza volontaria ed il nuovo diritto, in Studi in onore di Mariano d'Amelio III, Roma, Società Editrice del Foro Italiano, 1933;

- Salgado Júnior, António, Biografia breve de Luís António Verney (Prefácio), in VERNEY, Luís António, Verdadeiro Método de Estudar II - Estudos Literários, Lisboa, Livraria Sá da Costa Editora, 1950;

. Salivas, Albert; Bellan, Amédée, Éléments de droit romain II, Paris, A. Giard \& E. Brière, 1884;

. SAmpaio Doria, Julio de, Codigo Civil Brazileiro - Indice remissivo e analytico, São Paulo, Livraria e Officinas Magalhães, 1916;

. Sampaio Pimentel, Diogo Pereira Forjaz de, Annotações ao Codigo de Commercio Portuguez (Livro Primeiro da Parte Primeira) I, $2^{\mathrm{a}}$ ed., Coimbra, Imprensa da Universidade, 1866;

. Sandoval, Ovídio Rocha Barros, Do mandato, in D. Franciulli NetTo - G. F. Mendes - I. G. da S. Martins Filho, O novo Código Civil - Estudos em Homenagem ao Prof. Miguel Reale, São Paulo, LTr, 2003;

. San Tiago Dantas, Franscisco Clementino de, Programa de Direito Civil II - aulas proferidas na Faculdade Nacional de Direito (fim de 1943- 1945) - Os Contratos, Rio de Janeiro, Editora Rio, 1978;

. SANCHEZ Román, Felipe, Estudios de Derecho Civil segun los principios, los precedentes y cuerpos legales del antiguo derecho de Castilla, las leyes civiles generales, las especialidades de las legislaciones forales, la jurisprudencia del Tribunal Supremo y el Código Civil é Historia General de la legislacion española IV: Derechos de Obligaciones (derecho de la contratación), $2^{\mathrm{a}}$ ed, Madrid, Est. Tipográfico "Sucesores de Rivadeneyra", 1899;

. SAnchez Urite, Ernesto A., Mandato y representacion, Buenos Aires, Abeledo Perrot, 1986; 
. Santos Justo, Antonio, Direito privado romano I - Parte Geral (introdução, relação jurídica, defesa dos direitos), Coimbra, Coimbra Editora, 2000;

, Nótulas de História do Pensamento Juridico (História do Direito),Coimbra,

Coimbra Editora, 2005;

, O Direito Brasileiro: Raízes Históricas in Revista Brasileira de Direito

Comparado s/ref.;

. Saraiva, José Hermano, História Concisa de Portugal, $18^{\mathrm{a}}$ ed., Mira-Sintra Publicações Europa-América, 1996;

. SAUTEL, Gérard, L'histoire du contrat de commission jusqu'au Code de Commerce, in HAMEl, Joseph (org.), Le contrat de commission - Études de Droit Commercial, Paris, Librairie Dalloz, 1949;

. SAVIGNY, Friedrich Karl von, Das Obligationenrecht, trad. it. de Giovanni Pacchioni, Le obbligazioni II, Torino, Unione Tipografico-Editrice Torinese, 1915;

, System des heutigen römischen Rechts, trad. it. de Vittorio Scialoja,

Sistema del diritto romano attuale III, Torino, Unione Tipografico-Editrice Torinese, 1900

. Scherillo, Gaetano, Teodosiano, Gregoriano, Ermogeniano in Studi in memoria di Umberto Ratti a cura e con prefazione di Emilio Albertario, Milano, A. Giuffrè, 1934; , Il sistema del Codice Teodosiano in Studi in memoria di Aldo Albertoni

I, Padova, CEDAM, 1935;

. Scholz, Johaness-Michael, Legislação e Jurisprudência em Portugal nos Sécs. XVI a XVIII, in Scientia Iuridica 142-143 (1976);

. SchreIBER, Anderson, A representação no novo código civil, in TEPEDINO, Gustavo, A parte geral do novo código civil: estudos na perspectiva civil-constitucional, Rio de Janeiro - São Paulo, Renovar, 2002;

. Schulz, Fritz, Classical roman law, trad. esp. de José Santa Cruz Teigeiro, Derecho romano clásico, Barcelona, Bosch, 1960; , Principles of Roman Law, Oxford, Clarendon Press, 1936;

. Scialoja, Vittorio, Cognitur und Procuratur, di F. Eisele, in Studi giuridici, Roma, Anônima Romana Editoriale, 1933; , Corso di istituzioni di diritto romano, Roma, Off. Tip. di G. Bolognesi, 1912; 
, L'acquisto del possesso per mezzo dei terzi secondo il diritto romano e

l'attuale di S. Schlossmann, in Studi giuridici I - diritto romano, Roma, Anonima Romana Editoriale, 1933;

, Negozi giuridici - corso di diritto romano nella r. Università di Roma nell'anno accademico 1892-1893 raccolto dai dottori Mapei e Giannini, Roma, Società Editrice del "Foro Italiano", 1933;

. Sciascia, Gaetano, Direito Romano e Direito Civil Brasileiro (textos e apontamentos extravagantes), São Paulo, Saraiva, 1947; , Sinopse de direito romano com tábuas e textos traduzidos, $3^{\mathrm{a}}$ ed., São

Paulo, Saraiva, 1972;

. ScotT, Samuel Parsons, The Civil Law - including The Twelve Tables, The Institutes of Gaius, The Rules of Ulpian, The Opinions of Paulus, The Enactments of Justinian, and The Constitutions of Leo: translated from the original Latin, edited, and compared with all accessible systems of Jurisprudence ancient and modern I, Cincinnati, The Central Trust Company Publishers, 1932; , The Visigotic Code (Forum Judicum), Boston, The Boston Book Company, 1910;

. ScovazZI, Marco, Scritti di storia del diritto germanico, Milano, A. Giuffrè, 1975;

. SEGRÈ, Gino, In materia di simulazione nei negozi giuridici, in Scritti giuridici, Roma, Società Editrice del Foro Italiano, 1938;

, Sulla inoponibilità al terzo di buona fede dei limiti ai poteri di rappresentanza non risultanti dal documento esibitogli, in Scritti giuridici, Roma, Società Editrice del Foro Italiano, 1938; , Sulle formole relative alla negotiorum gestio e sull'editto e il iudicium de operis libertorum, in Studi senesi - Scritti giuridici e di scienze economiche pubblicati in onore di Luigi Moriani nel XXXV anno del suo nascimento II, Torino, Fratelli Bocca, 1906;

. SERAFINI, Filippo, Istituzioni di diritto romano comparato al diritto civile patrio: Delle obbligazioni - diritti di famiglia - diritto di eredità, $7^{\mathrm{a}}$ ed., Modena, Archivio Giuridico, 1899 ;

- Serpa Lopes, Miguel Maria de, Curso de Direito Civil - Fontes das Obrigações: Contratos IV, Rio de Janeiro-São Paulo, Livraria Freitas Bastos, 1958;

. SERRAO, Feliciano, Il procurator, Milano, Antonino Giuffrè Editore, 1947; 
. SERrÃo, Joel, Repensar Pombal, in Pombal Revisitado - Comunicações ao Colóquio Internacional Organizado pela Comissão de Comemoração do $2^{\circ}$ centenário da Morte do Marquês de Pombal II, Lisboa, Estampa, 1984;

- Silva, Maria Beatriz Marques Nizza da, A Legislação Pombalina e a Estrutura da família no Antigo Regime Português, in Pombal Revisitado - Comunicações ao Colóquio Internacional Organizado pela Comissão de Comemoração do $2^{\circ}$ centenário da Morte do Marquês de Pombal I, Lisboa, Estampa,1984;

. Silva LisboA, José da, Principios de Direito Mercantil, e Leis de Marinha, para uso da mocidade portugueza, destinada ao commercio $V$ - Dos contractos mercantis, Lisboa, Impressão Régia, 1819;

. Silva Ramos, Joaquim José Pereira da, Abecedario Juridico-Commercial ou compilação por ordem alphabetica das disposições actualmente em vigor do Codigo Commercial do Imperio do Brasil, Rio de Janeiro, Eduardo \& Henrique Laemmert, 1861;

. SilveIRA MARCHI, Eduardo César, Guia de Metodologia Científica (Teses, Monografias e Artigos), Lecce, Edizioni del Grifo, 2002;

. SINAISKI, Vasili, Ordre des matières dans la législation de Justinien in Studi in memoria di Aldo Albertoni I, Padova, CEDAM, 1935;

. SoAres, Teixeira, O Marquês de Pombal, Brasília, Editora da Universidade de Brasília, 1983 ;

. SoAres NetTo, Porfírio, Noções Elementares de Direito Civil Brasileiro, Porto Alegre, Globo, 1936;

. SolAZZI, Siro, Ancora procuratori senza mandato in Scritti di diritto romano II (19131924), Napoli, Casa Editrice Dott. Eugenio Jovene, 1957;

, Di alcuni punti controversi nella dottrina dell'acquisto del possesso in

Scritti di diritto romano I (1899-1913), Napoli, Casa Editrice Dott. Eugeinio Jovene, 1955; , La definizione del procuratore in Scritti di diritto romano II (1913-

1924), Napoli, Casa Editrice Dott. Eugenio Jovene, 1957;

, Le facoltà del 'procurator bonorum' nel diritto romano-ellenico in

Scritti di diritto romano II (1913-1924), Napoli, Casa Editrice Dott. Eugenio Jovene, 1957; , Procuratori senza mandato in Scritti di diritto romano II (1913-1924),

Napoli, Casa Editrice Dott. Eugenio Jovene, 1957;

, Sulla gestione per conto d'altri in Scritti di diritto romano II (1913-

1924), Napoli, Casa Editrice Dott. Eugenio Jovene, 1957; 
- Sousa DuARTE, Innocencio de, Diccionario de Direito Commercial compilado e annotado, Lisboa, Officina Typographica da Empreza Litteraria de Lisboa, 1880;

. Sousa PinTo, Antonio de, Diccionario da Legislação Commercial Brazileira contendo a reprodução textual ou analytica, e em muitos pontos annotada, de todos os artigos não revogados do respectivo Codigo e das leis, decretos e outras disposições legaes em vigor, concernentes ao commercio terrestre e marítimo, ás sociedades anonymas e ao processo no juizo federal - seguido de um appendice no qual se acham alphabeticamente ordenadas differentes disposições regulamentares, excedentes da esphera do direito commercial, mas com esta materia relacionadas, e de um quadro de legislação concordada I, Lisboa, Editores Tavares Cardoso \& Irmão, 1892;

. Spota, Alberto G., Negocio juridico simulado, in Curso sobre temas de derecho civil, Buenos Aires, Instituto Argentino de Cultura Notarial, 1971;

. Stolfi, Mario, Appunti critici sui contratti di durata, in Studi in memoria di Bernardino Scorza, Roma, Soc. Ed. del Foro Italiano, 1940;

. StRuve, Georg Adam, Evolvtiones Controversiarvm in Syntagmate Ivris Civilis, ab ipso olim in Academia Ienensi adornato, comprehensarum, nec non Resolvtiones Dubiorum \& Textuum obstantium ibi allegatorum, Francofvrti et Lipsiae, Matthaevm Bircknervm, 1684; , Syntagma Jvrisprvdentiae Secundùm ordinem Pandectarum concinnatvm qvo solida juris fundamenta tradvntvr Digestorvm, et affines Codicis, novellarvm ac jvris canonici titvli methodice explicantvr, controversiae nervose resolvuntvr, qvid in foro vsvm habeat - Pars Tertia Pandectarvm (Libro XII. usq ad Lib. XX), Francofvrti et Lipsiae, Ioannis Hoffmanni, 1692;

- TABORDA Ferreira, Vasco, Do conceito de causa dos actos jurídicos, Tese (Doutoramento) - Universidade de Lisboa, Lisboa, 1946;

. TAREllo, Giovanni, Codificazione, in Digesto delle Discipline privatistiche (Sezione Civile) II (1988);

. TARTUCE, Flávio, Direito Civil - Teoria Geral dos Contratos e Contratos em Espécie III, $2^{\text {a }}$ ed., São Paulo, Método, 2007;

. Taubenschlag, R., The law of Greco-Roman Egypt in the light of the Papyri, 332 B.C.640 A.D., New York, Herald Square Press, 1944;

. Tavares, José, Os Princípios Fundamentais do Direito Civil II - Pessoas, cousas, factos jurídicos, Coimbra, Coimbra Editora Limitada, 1928; 
. Teixeira de Carvalho, José Fraga, Epítome das Instituições de Gaio e Introdução, in Revista de Direito Civil, Imobiliário, Agrário e Empresarial 5 (1978);

. TeIXEIRA DE FreITAs, Augusto, Consolidação das Leis Civis, $3^{\mathrm{a}}$ ed., Rio de Janeiro, B. L. Garnier, 1876, pp. XXXII-XXXIII;

- TePedino, Gustavo, A técnica da representação e os novos princípios contratuais, in Direito Civil - Direito Patrimonial e Direito Existencial: Estudo em homenagem à professora Giselda Maria Fernandes Novaes Hironaka, São Paulo, Método, 2006;

. TERRA, Marcelo, O mandato e sua forma, in Revista dos Tribunais 640 (1989);

. TheOdoro JÚnior, Humberto, Locação - Comodato - Mandato, 2a ed., São Paulo, LEUD (Livraria e Editora Universitária de Direito Ltda.), 1987;

. Thomas, Joseph A. C., A note on a 'falsus procurator', in Studi in onore di Giuseppe Grosso II, Torino, G. Giappichelli, 1968;

. TODESCAN, Franco, Il problema della secolarizzazione nel pensiero giuridico di Jean Domat, Milano, Giuffrè, 1987;

. Torgal, Luís Reis, Acerca do Significado do Pombalismo, in Revista de História das Idéias 1982-1983 (número especial intitulado O Marquês de Pombal e o seu Tempo I);

. Treggiari, Ferdinando, Sistematica e metodo del caso come tecniche complementari d'istruzione giuridica: maestri tedeschi ed epigoni italiani dell'Ottocento in Diritto e processo - studi in memoria di Alessandro Giuliani, Napoli, Edizioni Scientifiche Italiane, 2001;

. TRIGo De Loureiro, Lourenço, Instituições de Direito Civil Brasileiro II, $4^{\mathrm{a}}$ ed., Rio de Janeiro, B. L. Garnier, 1872;

. TRINDADE, José Maria da, Collecção de apontamentos juridicos sobre as procurações extrajudiciaes com a recopilação das disposições doutrinaes ácerca das mesmas procurações, Rio de Janeiro, Eduardo \& Henrique Laemmert, 1862;

. TRIPOLI, César, Elementos de Direito Comercial para uso nas Escolas de Comercio, São Paulo, Empreza Graphica Revista dos Tribunaes, 1932;

. UREÑA y SMEnJaud, Rafael; Bonilla y SAn MARTín, Adolfo, Obras del Maestro Jacobo de las leyes - jurisconsulto del siglo XIII, publicadas, en virtud de acuerdo del ilustre colegio de abogados de Murcia, Madrid, Talleres Tipográficos de la Editorial Reus, 1924; . VACCA, Letizia, Contributo allo studio del metodo casistico nel diritto romano, Milano, Dott. A. Giuffrè Editore, 1976; 
. Valladẽo, Haroldo, História do Direito, especialmente do direito brasileiro - Parte I, Rio de Janeiro, Livraria Freitas Bastos, 1972;

. VAlle Siqueira, A. do, Codigo Civil Brasileiro, São Paulo, Saraiva \& C., 1922;

- VAllet de Goytisolo, Juan, El derecho romano como buena razon en Cataluña, in Boletim da Faculdade de Direito da Universidade de Coimbra 58 (1982);

- VAmpré, Spencer, Manual de Direito Civil Brasileiro III (Contractos e Direito das Sucessões), Rio de Janeiro, F. Briguiet \& Cia., 1920; ,O que é o Codigo Civil (conferencias realisadas na Universidade de São Paulo), São Paulo, Livraria e Officinas Magalhães, 1916;

. VeauX-Fournerie, Paulette; VeauX, Daniel, La représentantion mutuélle des coobligés, in Études dédiés à Alex Weill, Paris, Dalloz, s.d.;

. VeIGA, Dídimo Agapito da, Codigo Commercial commentado e posto ao par da doutrina, legislação e jurisprudencia modernas, Rio de Janeiro - São Paulo - Recife, Laemmert, 1898 ;

. VeIga BeIRÃo, Francisco António da, Direito Commercial Portuguez, Coimbra, Imprensa da Universidade, 1912;

. Venosa, Sílvio de Salvo, Direito Civil - Parte Geral I, 7ª ed., São Paulo, Atlas, 2007; , Direito Civil - Contratos em Espécie III, São Paulo, Atlas, 2007;

. VERney, Luís António, Verdadeiro Método de Estudar IV - Estudos Médicos, Jurídicos e Teológicos, Lisboa, Livraria Sá da Costa Editora, 1952;

- VIDAL, Luiz Maria, Manual do direito comercial para uso do povo, Rio de Janeiro, Eduardo \& Henrique Laemmert, 1877;

. VIEIRA CURA, Antonio Alberto, Direito Romano e História do Direito Português: Casos Práticos Resolvidos e Textos, Coimbra, Coimbra Editora, 1995;

- Villaça Azevedo, Álvaro, Código Civil Comentado II - Negócio Jurídico, Atos Jurídicos Lícitos, Atos Ilícitos, São Paulo, Atlas, 2003;

, Venosa, Silvio de Salvo, Código Civil Anotado e Legislação Complementar, São Paulo, Atlas, 2004;

- Villela, João Baptista, Parte geral do Código Civil, in Seminário Novo Código Civil Brasileiro: o que muda na vida do cidadão, Brasília, Centro de Documentação e Informação (Coordenação de Publicações), 2003;

. VIRGA, Pietro, Eccesso di potere per mancata prefissione di parametri di riferimento, in Scritti in onore di Massimo Severo Giannini, Milano, Dott. A. Giuffrè, 1988; 
. VISMARA, Giulio, Le fonti del diritto romano nell'alto medioevo secondo la più recente storiografia (1955-1980), in Studia et Documenta Historiae et Iuris 47 (1981);

. VocI, Pasquale, Manuale di diritto romano - Parte generale II, Milano, Dott. A. Giuffrè, 1998 ; , Piccolo manuale di diritto romano I - Parte generale, Milano, Dott. A.

Giuffrè Editore, 1979;

- Voeltzel, René-Frédéric, Jean Domat (1625-1696): essai de reconstitution de sa philosophie juridique, précédé de la biographie du jurisconsulte, Paris, Sirey, 1936;

. VoET, Johannis, Commentariorum ad Pandectas libri quinquaginta, in quibus, praeter romani juris principia c controversias illustriores, jus etiam hodiernum, et praecipuae fori quaestiones excutiuntur, trad. it. de Leone Fortis, Commento alle Pandette di Giovanni Voet, giureconsulto e professore nella Università di Leida, libri Cinquanta, ne quali, oltre i principii e le più insigni controversie del diritto romano, si disaminano il diritto moderno e le principali quistioni del foro II, Venezia, Pietro Naratovitch, 1847;

- VolterRA, Edoardo, Istituzioni di diritto privato romano, trad. esp. de Jesús Daza Martínez, Instituciones de derecho privado romano, Madrid, Editorial Civitas, 1986;

. WALD, Arnoldo, Curso de Direito Civil Brasileiro - Obrigações e Contratos, $8^{\mathrm{a}}$ ed., São Paulo, Revista dos Tribunais, 1989;

- WALDECK, Iohann Petri, Institutiones Juris Civilis Heineccianae emendatae atque reformatae, Conimbricae, Typis Academicis, 1805;

. Watson, Alan, Contract of mandate in roman law, Oxford, Clarendon Press, 1961;

- WeILler, Augusto, Corte d'Appello di Milano (28 febbraio 1933) - Sui caratteri differenziali tra i consorzi e le società commerciali, in Il Foro Italiano 58 (1933);

. WeIss, Egon, 'Procurator ex testamento', in Studi in onore di Vincenzo Arangio-Ruiz nel XLV anno del suo insegnamento IV, Napoli, Editore Jovene, 1953;

. WIEACKER, Franz, Privatrechtgeschichte der neuzeit, trad. port. de António Manuel Botelho Hespanha, História do Direito Privado Moderno, $2^{\mathrm{a}}$ ed., Lisboa, Fundação Calouste Gulbenkian, 1993;

. Willems, P., Le droit public romain ou les institutions politiques de Rome depouis l'origine de la ville jusqu'a Justinien, $5^{\text {a }}$ ed., Paris, Ernest Thorin, 1884;

. WindsCHEID, Bernard, Pandektenrecht, trad. it. de Carlo Fadda e Paolo Emilio Bensa, Diritto delle pandette - con note e riferimenti al Diritto Civile Italiano I, Torino, Unione Tipografico-Editrice Torinese, 1925; 
- WolfF, Christian, Jus Naturae Methodo Scientifica per Tractatum - Pars Quarta: de actibus ad aliorum utilitatem tendentibus in specie, ubi agitur de donationibus, et de contractibus tam beneficis, quam onerosis praecipuis, et nunc primum cum viri $\mathrm{Cl}$. de Vattel animadversionibus, Francofurti et Lipsiae, Aere Societatis Venetae, 1765. 


\section{RELAÇÃO DAS FONTES UTILIZADAS}

DIREITO ROMANO

\section{Cícero}

Pro Caecina 20, 57;

Pro Roscio Amerino. 38-39;

Pro Roscio Amerino 111-113;

\section{Tábuas}

1,7

Institutas de Gaio
G. 1, 19;
G. 2, 38;
G. 2, 39;
G. 2, 64;
G. 2, 87;
G. 2, 95;
G. 2, 102;
G. 2, 103;
G. 2, 104;
G. 2, 252;
G. 3, 135;
G. 3, 154;
G. 3, 154a;
G. $3,154 \mathrm{~b}$;
G. 3, 155;
G. 3,161 ;
G. 4, 47;
G. 4, 55;
G. 4,62 ;
G. 4,82 ;
G. 4,83 ;
G. 4, 84;
G. 4, 98;
G. 4, 99;
G. 4, 100;
G. 4, 101;
G. 4, 182;

Institutas (Justiniano)

I. 1, 11, 3;

"Codex" 
C. 4, 35, 9 (Dioc. et Max., 285-304);

C. 4, 44, 2 (Diocl. et Max., 285);

C. 4, 44, 8 (Diocl. et Max., 294-305);

C. $8,41,7$;

\section{Digesto}

D. 1, 7, 18 (Marcell. 26 dig.);

D. 2, 14, 12 (Ulp. 4 ad Ed.);

D. 3,1 ;

D. 3,2 ;

D. 3,3 ;

D. 3, 3, 1 (Ulp. 9 ad Ed.);

D. 3, 3, 1 pr. (Ulp. 9 ad ed.);

D. 3, 3, 1, 1 (Ulp. 9 ad Ed.);

D. 3, 3, 2 (Paul. 8 ad Ed.);

D. 3, 3, 3 (Ulp. 9 ad Ed.);

D. 3, 3, 4 (Paul. 8 ad Ed.);

D. 3, 3, 5 (Ulp. 7 ad Ed.);

D. 3, 3, 6 (Paul. 6 ad Ed.);

D. 3, 3, 7 (Ulp. 7 ad Ed.);

D. 3, 3, 8 (Ulp. 8 ad Ed.);

D. 3, 3, 9 (Gai. 3 ad Ed. prov.);

D. 3, 3, 10 (Ulp. 8 ad Ed.);

D. 3, 3, 11 (Paul. 8 ad Ed.);

D. 3, 3, 12 (Gai. 3 ad Ed. prov.);

D. 3, 3, 13 (Ulp. 8 ad Ed.);

D. 3, 3, 14 (Paul. 8 ad Ed.);

D. 3, 3, 15 (Ulp. 8 ad Ed.);

D. 3, 3, 16 (Paul. 8 ad Ed.);

D. 3, 3, 17 (Ulp. 9 ad Ed.);

D. 3, 3, 19 (Ulp. 9 ad Ed.);

D. 3, 3, 20 (Paul. 8 ad Ed.);

D. 3, 3, 21 (Gai. 3 ad Ed. prov.);

D. 3, 3, 22 (Paul. 8 ad Ed.);

D. 3, 3, 23 (Ulp. 9 ad Ed.);

D. 3, 3, 24 (Paul. 8 ad Ed.);

D. 3, 3, 25 (Ulp. 9 ad Ed.);

D. 3, 3, 26 (Paul. 8 ad Ed.);

D. 3, 3, 27 (Ulp. 9 ad Ed.);

D. 3, 3, 29 (Ulp. 9 ad Ed.);

D. 3, 3, 31 (Ulp. 9 ad Ed.);

D. 3, 3, 32 (Paul. 8 ad Ed.);

D. 3, 3, 33 (Ulp. 9 ad Ed.);

D. 3, 3, 33 pr. (Ulp. 9 ad Ed.);

D. 3, 3, 34 (Gai. 3 ad Ed. prov.);

D. 3, 3, 35 (Ulp. 9 ad Ed.);

D. 3, 3, 36 (Paul. 8 ad Ed.);

D. 3, 3, 37 (Ulp. 9 ad Ed.);

D. 3, 3, 38 (Ulp. 40 ad Ed.); 
D. 3, 3, 39 (Ulp. 9 ad Ed.);

D. 3, 3, 40 (Ulp. 9 ad Ed.);

D. 3, 3, 41 (Paul. 9 ad Ed.);

D. 3, 3, 42 (Paul. 8 ad Ed.);

D. 3, 3, 42, 2 (Paul. 8 ad Ed.);

D. 3, 3, 43 (Paul. 9 ad Ed.);

D. 3, 3, 45 (Paul. 9 ad Ed.);

D. 3, 3, 46 (Gai. 3 ad Ed. prov.);

D. 3, 3, 47 (Iul. 4 ad Urs. Fer.);

D. 3, 3, 48 (Gai. 3 ad Ed. prov.);

D. 3, 3, 49 (Paul. 54 ad Ed.);

D. 3, 3, 50 (Gai. 22 ad Ed. prov.);

D. 3, 3, 51 (Ulp. 60 ad Ed.);

D. 3, 3, 52 (Paul. 57 ad Ed.);

D. 3, 3, 53 (Ulp. 60 ad Ed.);

D. 3, 3, 54 (Paul. 50 ad Ed.);

D. 3, 3, 55 (Ulp. 65 ad Ed.);

D. 3, 3, 56 (Ulp. 66 ad Ed.);

D. 3, 3, 57 (Ulp. 74 ad Ed.);

D. 3, 3, 58 (Paul. 71 ad Ed.);

D. 3, 3, 60 (Paul. 4 resp.);

D. 3, 3, 63 (Mod. 6 diff.);

D. 3, 3, 77 (Paul. 57 ad Ed.);

D. 3,4 ;

D. 3, 4, 6, 1 (Paul. 9 ad Ed.);

D. 3,5 ;

D. 3, 5, 1 (Ulp. 10 ad Ed.);

D. 3, 5, 3 pr. (Ulp. $10 \mathrm{ad} E d$.);

D. 3, 5, 3, 8 (Ulp. 10 ad Ed.);

D. 3, 5, 3, 9 (Ulp. 10 ad Ed.);

D. 3, 5, 5, 14 (Ulp. 10 ad Ed.);

D. 3, 5, 7 (Ulp. 10 ad Ed.);

D. 3, 5, 16 (Ulp. 35 ad ed.);

D. 3,6 ;

D. 3, 6, 7 (Paul. 10 ad Ed.);

D. 12, 6, 6 pr. (Paul. 3 ad Sab.);

D. 13, 6, 1 pr. (Ulp. 28 ad Ed.);

D. 14, 3, 6 (Paul. 30 ad Ed.);

D. 15, 3, 3, 2 (Ulp. 29 ad Ed.);

D. $15,3,17$ pr. (Afric. 8 quaest.);

D. 16, 3, 1, 1 (Ulp. 30 ad Ed.);

D. 17,1 ;

D. 17, 1, 3, 2 (Paul. 32 ad Ed.);

D. 17, 1, 6, 1 (Ulp. 31 ad ed.);

D. 17, 1, 6, 6 (Ulp. 31 ad Ed.);

D. 17, 1, 8 (Ulp. 31 ad Ed.);

D. 17, 1, 8 pr. (Ulp. 31 ad Ed.);

D. 17, 1, 10 (Ulp. 31 ad Ed.);

D. 17, 1, 31 (Iul. 14 dig.);

D. 17, 1, 55 (Papin. 1 resp.); 
D. 17, 1, 56, 2 (Papin. 3 respons.);

D. 17, 2, 38 pr. (Paul. 6 ad Sab.);

D. 18, 1, 1, 2 (Paul. 30 ad Ed.);

D. 19, 2, 1 (Paul. 34 ad Ed.);

D. 20, 6, 7, 1 (Gai. lib. sing. ad form. hyp.);

D. 21, 1, 51, 1 (Afric. 8 quaest.);

D. 27, 3, 3 (Pomp. 5 ad Sab.);

D. 27, 8, 1, 15 (Ulp. 36 ad Ed.);

D. 34, 3, 8, 6 (Pomp. 6 ad Sab.);

D. 39, 2, 13, 13 (Ulp. 53 ad Ed.);

D. 39, 5, 10 (Paul. 15 ad Sab.);

D. 41, 3, 41 (Ner. 7 membr.);

D. 44, 1, 50 pr. (Iav. 13 epistul.);

D. 44, 2, 5 (Ulp. 74 ad ed.);

D. 44, 4, 4 (Ulp. 76 ad Ed.);

D. 44, 7, 11 (Paul. 12 ad Sab.);

D. 45, 1, 126, 2 (Paul. 3 quaest.);

D. 45, 3, 35 (Mod. 7 reg.);

D. 46, 2, 8, 5 (Ulp. 46 ad Sab.);

D. 46, 2, 20, 1 (Paul. 72 ad Ed.);

D. 46, 3, 12, pr. (Ulp. 30 ad Sab.);

D. 46, 3, 23 (Pomp. 24 ad Sab.);

D. 46, 3, 34, 3 (Iul. 54 ad Dig.);

D. 46, 3, 87 (Cels. 20 Dig.);

D. 46, 3, 91 (Lab. 6 pith.);

D. 46, 6, 2 (Pap. 79 ad Ed.);

D. 46, 6, 3 (Ulp. 35 ad Ed.);

D. 46, 6, 4 pr. (Ulp. 79 ad Ed.);

D. 46, 7, 3, 2 (Ulp. 77 ad Ed.);

D. 47, 6, 2 (Ulp. 53 ad Ed.);

D. 47, 10, 17, 16 (Ulp. 57 ad Ed.);

D. 50, 17, 22 pr. (Ulp. 28 ad Sab.);

D. 50, 17, 73, 4 (Q. Muc. def.);

\section{Direito CANÔNICO}

\section{Decreto (Graciano)}

c. 3 , C. 5 , qu. 3 ;

\section{Decretais (Gregório IX)}

c. 22 , in $X, 1,3$;

c. 28 , in $X, 1,3$;

c. 1 , in $X, 1,38$;

c. 11 , in $X, 1,38$;

c. 13 , in $X, 1,38$;

c. 19 , in $\mathrm{X}, 2,13$; 
reg. 68 , in $\mathrm{VI}^{\circ}$, De regulis juris; reg. 72 , in $\mathrm{VI}^{\circ}$, De regulis juris; reg. 53 , in $\mathrm{VI}^{\circ}$, De regulis juris; c. 5 , in $\mathrm{VI}^{\mathrm{o}}, 1,19$;

\section{Rota de Gênova}

De. II, n. 15;

De. VIII, n. 5;

De. IX, n. 4;

De. IX, n. 13;

De. LIII, n. 1;

De. LXVII, n. 2;

De. LXXVI, n. 6;

De. LXXVI, n. 9;

De. LXXXXIII, n. 9;

De. CXLVII, n. 10;

De. CLXXIIII, n. 6;

De. CLXXVIII, n. 3;

De. CLXXX, n. 5;

De. CC, n. 4;

\section{DiReITo Visigótico}

\section{Código Teodosiano}

CTh. I, 4, 3 (426 d.C.);

CTh. II, 10, 4 (326 d.C.);

CTh. II, 12;

CTh. II, 12, 1 (368 d.C.);

CTh. II, 12, 3 (382 d.C.);

CTh. II, 12, 4 (393 d.C);

CTh. II, 12, 7 (424 d.C.);

CTh. IX, 39, 3 (398 d.C.);

CTh. X, 4, 1 (313 d.C.);

\section{Código de Eurico}

cap. 283;

cap. 284 ;

cap. 287 ;

\section{Lex Romana Visigothorum}

Brev. II, 10, 1;

Brev. II, 12;

Brev. II, 12, 1;

Brev. II, 12, 3;

Brev. II, 12, 4; 
Brev. II, 12, 7;

Brev. IX, 29, 3;

Brev. X, 3, 1;

\section{Epítome de Gaio}

EG. 2, 9, 18;

EG. 2, 9, 19;

EG. 2, 9, 20;

\section{Sentenças de Paulo}

PS. 1, 2, 1;

PS. 1, 2, 2;

PS. 1, 2, 3;

PS. 1, 2, 4;

PS. 1, 3, 1;

PS. 1, 3, 2;

PS. 2, 6, 1;

PS. 2, 8, 1;

PS. 2, 8, 2;

PS. 2, 8, 3;

PS. 2, 15, 1;

PS. 2, 15, 2;

PS. 2, 15, 3;

PS. 5, 2, 2;

PS. 5, 8, 3;

\section{Liber Iudiciorum}

LI. II, 1, 9;

LI. II, 3, 1;

LI. II, 3, 2;

LI. II, 3, 3;

LI. II, 3, 5;

LI. II, 3, 6;

LI. II, 3, 7;

LI. II, 3, 8;

LI. II, 3, 9;

LI. II, 3, 10;

LI. II, 5, 6;

LI. IV, 2, 16;

LI. V, 4, 14;

LI. V, 5, 6;

LI. V, 5, 7;

LI. X, 1, 10;

\section{Direito Castelhano}


FD. I, 2, 1;

FD. I, 2, 2;

FD. I, 2, 3;

FD. I, 2, 4;

FD. I, 3, 1;

FD. I, 3, 2;

FD. I, 3, 3;

FD. I, 3, 4;

FD. I, 3, 5;

FD. I, 3, 6;

FD. I, 3, 7;

FD. I, 3, 8;

FD. I, 3, 9;

FD. I, 3, 10;

\section{Dotrinal}

Dot. II, 1, 1;

Dot. II, 1, 2;

Dot. II, 1, 3;

Dot. II, 1, 4;

Dot. II, 1, 5;

Dot. II, 1, 6;

Dot. II, 1, 7;

Dot. II, 1, 8;

Dot. II, 1, 9;

Dot. II, 1, 10;

Dot. II, 2, 1;

Dot. II, 2, 2;

Dot. II, 2, 3;

Nueve tiempos de los pleitos

Prólogo;

\section{Fuero Real}

FR. I, 9, 1;

FR. I, 9, 2;

FR. I, 9, 3;

FR. I, 9, 4;

FR. I, 9, 5;

FR. I, 10, 1;

FR. I, 10, 2;

FR. I, 10, 3;

FR. I, 10, 4;

FR. I, 10, 5;

FR. I, 10, 6;

FR. I, 10, 7; 
FR. I, 10, 8;

FR. I, 10, 9;

FR. I, 10, 10;

FR. I, 10, 11;

FR. I, 10, 12;

FR. I, 10, 13;

FR. I, 10, 14;

FR. I, 10, 15;

FR. I, 10, 16;

FR. I, 10, 17;

FR. I, 10, 18;

FR. I, 10, 19;

\section{Espéculo}

Esp. IV, 8 pr.;

Esp. IV, 8, 1 ;

Esp. IV, 8, 2 ;

Esp. IV, 8, 3;

Esp. IV, 8, 4;

Esp. IV, 8, 5;

Esp. IV, 8, 6;

Esp. IV, 8, 7;

Esp. IV, 8, 8;

Esp. IV, 8, 9;

Esp. IV, 8, 10;

Esp. IV, 8, 11;

Esp. IV, 8, 12;

Esp. IV, 8, 13;

Esp. IV, 8, 14;

Esp. IV, 8, 15;

Esp. IV, 8, 16;

Esp. IV, 8, 17;

Esp. IV, 8, 18;

Esp. IV, 8, 19;

Esp. IV, 9 pr.;

Esp. IV, 9, 2;

Esp. IV, 9, 3;

Esp. IV, 9, 4;

Esp. IV, 9, 5;

Esp. IV, 9, 6;

Esp. IV, 9, 7;

Esp. IV, 9, 8;

Esp. IV, 9, 9;

Siete Partidas

Part. III, 2, 9;

Part. III, 2, 10;

Part. III, 2, 13; 
Part. III, 5 pr.;

Part. III, 5, 1;

Part. III, 5, 2;

Part. III, 5, 3;

Part. III, 5, 4;

Part. III, 5, 5;

Part. III, 5, 6;

Part. III, 5, 7;

Part. III, 5, 8;

Part. III, 5, 9;

Part. III, 5, 10;

Part. III, 5, 11;

Part. III, 5, 12;

Part. III, 5, 13;

Part. III, 5, 14;

Part. III, 5, 15;

Part. III, 5, 16;

Part. III, 5, 17;

Part. III, 5, 18;

Part. III, 5, 19;

Part. III, 5, 20;

Part. III, 5, 21;

Part. III, 5, 23;

Part. III, 5, 24;

Part. III, 5, 25;

Part. III, 5, 26;

Part. III, 5, 27;

Part. III, 6 pr.;

Part. III, 6, 2;

Part. III, 6, 3;

Part. III, 6, 4;

Part. III, 6, 5;

Part. III, 6, 6;

Part. III, 6, 7;

Part. III, 6, 8;

Part. III, 6, 9;

Part. III, 6, 10;

Part. III, 6, 13;

Part. III, 6, 14;

Part. III, 6, 15;

Part. IV, 17 pr.;

Part. IV, 17, 5;

Part. IV, 17, 6;

Part. IV, 17, 7;

Part. IV, 17, 12;

Part. IV, 21 pr.;

Part. IV, 21, 7;

Part. IV, 27 pr.;

Part. IV, 27, 1;

Part. IV, 27, 2; 
Part. IV, 27, 3;

Part. IV, 27, 4;

Part. IV, 27, 5;

Part. IV, 27, 6;

Part. IV, 27, 7;

Part. V pr.;

Part. V, 1, 4;

Part. V, 1, 6;

Part. V, 1, 7;

Part. V, 5, 8;

Part. V, 5, 48;

Part. V, 11, 7;

Part. V, 11, 8;

Part. V, 11, 9;

Part. V, 12 pr.;

Part. V, 12, 13;

Part. V, 12, 20;

Part. V, 12, 22;

Part. V, 12, 23;

Part. V, 12, 24;

Part. V, 12, 25;

Part. V, 14, 5;

Part. V, 14, 6;

Part. V, 14, 7;

\section{Direito Português}

\section{Livro das Leis e Posturas}

"lei 01". "Lei pela qual se estabelece que o direito canónico tenha vigor em Portugal e que no caso de conflito entre o direito régio e o direito canónico tenha este supremacia";

"lei 02". "Lei sobre procuradores, advogados, testemunhas e recursos para "casa del-rei"”;

"lei 03". "Lei pela qual se determinam as penas a aplicar a juízes, advogados, alcaides, procuradores e outros homens de justiça que tenham relações carnais com mulheres que sejam parte em processos nos quais eles intervenham", de 29 de julho de 1311;

"lei 04". "Lei pela qual se determina que nenhum procurador ou advogado receba honorários antes que o pleito esteja terminado por sentença ou transacção" - Lei de 23 de agosto de 1303;

"lei 05". "Lei pela qual se determina que os advogados e procuradores recebam metade dos seus honorários no começo da causa e outra metade no seu fim", de 17 de agosto de 1322 ;

"lei 06". "Lei pela qual se determina que em certas condições se não atenda advogado";

"lei 07". "Lei pela qual se determina que, em princípio, nenhum sobrejuiz ou ouvidor possa advogar na corte";

"lei 08". "Lei sobre advogados na corte"; 
"lei 09". "Lei pela qual se declara prejuro aquele que, jurando de malícia, quando pede advogado, o não apresente no dia que lhe for marcado e se regulamentam apelações em terras sujeitas a jurisdição de ordens", do mês de janeiro de 1271;

"lei 10". "Lei sobre procuradores";

"lei 11". Lei sobre advogados;

"lei 12". "Lei sobre advogados na corte";

“lei 13". "Lei pela qual se determina que o marido não possa litigar sobre coisa imóvel sem consentimento da mulher";

"lei 14". "Lei sobre execução de bens para pagamento de dívidas; outrossim sobre o pagamento das custas de um processo; outrossim confirmando uma lei de D. Afonso III sobre os procuradores na corte", de 24 de agosto de 1282;

"lei 15"."formulário de procuração";

"lei 16". "Lei pela qual se determinam emolumentos e honorários de escrivães da corte, advogados, procuradores e porteiros das audiências com várias outras determinações relativas ao serviços dos mesmos", de 12 de junho de 1302;

"lei 17". "Lei pela qual se determina a forma que se devia seguir nos diversos pleitos, tendo por fim providenciar contra o abuso que os advogados e procuradores praticavam, prolongando fraudulentamente as causas de que tratavam", de 15 de setembro de 1313;

"lei 18". "Lei pela qual se estabelecem as penas a aplicar a procuradores e advogados que recebam das partes quaisquer ofertas ou os seus honorários antes da sentença definitiva, bem como às partes que se tenham servido deste meio para os corromper e impedir o andamento legal do pleito" - Carta Régia de 08 de julho de 1314;

“lei 19". "Lei pela qual se determina que nos pleitos jurem os advogados de ambas as partes e também o réu, de litigarem sem malícia nem dolo e só alegarem sua justiça; e outrossim trata dos honorários dos advogados", de 26 de fevereiro de 1283;

"lei 20". "Lei pela qual se determina que os moradores da casa do rei, sendo cavaleiros, só possam advogar em causa própria, e bem assim só entrem nas audiências quando o rei o mande ao sobrejuiz ou ouvidor do pleito. Outrossim para que os sobrejuízes e ouvidores da corte não advoguem sem especial resolução do rei”, de 15 de janeiro de 1303;

"Iei 21". "Lei pela qual se determinam emolumentos e honorários dos escrivães da corte, advogados, procuradores e porteiros das audiências, com várias outras determinações relativas ao serviço dos mesmos", de 10 de junho de 1303;

"lei 22". "Lei pela qual se determina que os moradores da casa do rei, sendo cavaleiros, só possam advogar em causa própria, e bem assim só entrem nas audiências quando o rei o mande ao sobrejuiz ou ouvidor do pleito. Outrossim para que os sobrejuízes e ouvidores da corte não advoguem sem especial resolução do rei”, de 15 de janeiro de 1303;

"lei 23". "Lei pela qual se estabelece que os mouros e judeus não advoguem em pleito de cristãos, nem tão pouco os tabeliães sejam procuradores com procuração que eles próprios tenham exarado";

"lei 24". "Lei pela qual se determina que qualquer pessoa, sem distinção de sexo, pode constituir procuradores";

"lei 25". "Lei pela qual se estabelece que os advogados e procuradores possam receber metade dos seus honorários antes de findas as causas" - Postura de 04 de agosto de 1322; 
“lei 26". "Lei pela qual se estabelece a idade mínima de 14 anos para se ser procurador";

"lei 27"."Lei sobre a procuração em que se mencione o juiz, as partes e a coisa objeto do litígio";

"lei 28"."Lei sobre a validade da procuração de um concelho quando aí não há tabelião";

"lei 29". "Lei sobre os procuradores";

"lei 30". "Lei sobre advogados na corte";

"lei 31". "Lei pela qual se estabelece que os procuradores chamados à composição possam alegar árbitros";

“lei 32". "Ordenação de D. Afonso IV, contendo 18 leis e várias outras resoluções sobre a forma pela qual as justiças procederiam nos processos, como receberiam as apelações, quando aceitariam advogados, e maneira pela qual estes e os procuradores exerceriam o seu ofício", de 18 de fevereiro de 1332 (pp. 190, 192, 195, 196, 198);

"lei 33". "Lei pela qual se estabelece que os clérigos não advoguem nem sejam procuradores";

“lei 34”. "Lei com várias disposições sobre o exercício das funções de juízes, advogados, procuradores, tabeliães e outros oficiais da justiça";

"lei 35". "Concórdia de 40 artigos entre D. Dinis e os bispos do reino", de 07 de março de 1289 ;

"lei 36". "Lei pela qual se proíbe que as pessoas poderosas compareçam nas audiências nos casos em que por direito possam ser representadas por seus procuradores";

"lei 37". "Lei pela qual se proibe aos advogados e procuradores receberem qualquer dádiva dos seus constituintes e determinando a forma por que lhe seriam pagos os seus honorários", de 14 de março de 1351;

"lei 38". "Lei pela qual se proibe o exercício da profissão de advogado e procurador e se tomam outras providências relativas à administração da justiça", de 20 de maio de 1351;

"lei 39". "Lei pela qual se determina que, nem na corte, nem nas audiências dos concelhos, haja advogados nem procuradores de número, e estabelecendo várias outras providências para evitar demoras no seguimento dos pleitos", de 03 de novembro de 1352;

“lei 40". Regimento dos Tabeliães (de 15 de janeiro de 1305);

"lei 41". "Concórdia de 40 artigos entre D. Dinis e os bispos do reino", de 07 de março de 1289 ;

\section{Ordenações de Dom Duarte}

"lei 01". "Constituçom primeira que as leis E ordinaçoões que per o dito Rej E per seus socesores forem feytas que seguem os degredos dos padres santos E os ditos da santa Jgreja";

"lei 04". "Ordenaçom. iiij. quaaes pesoas nom podem auer uogados em seus preitos";

"lei 05". "Constituçom Lbiij como E per que guisa a procuraçom he auondosa";

"lei 07". "Constituçom Lx como o procurador do feito pode procurar perante o Juiz da apellaçom"; 
"lei 08". "Constituçom Lxi como na corte del rrey deue d'auer dous vogados";

"lei 09". "constituçom Ciij Como o que ha feito nom pode ffilhar mais de huum vogado";

"lei 10". "constituçom. Cbiij. que pena deue d'auer o que pede uogado se nom ueem con ell ao tenpo";

"lei 11". "Constituçom CXij como o que he casado nom pode meter a preito nem a Juizo posissam sem outorga ou procuraçom de ssa molher";

"lei 12". "Costituçam Cxxbij como podem ffazer procurador";

"lei 13". "Constituçam CRij como o procurador pode procurar";

"lei 14". "Costituçam CRiij dos procuradores";

"lei 15". "Costituçam CRiiij quaaes Nom podem procurar";

"lei 16". "Costituçam CRbj do poder dos procuradores";

"lei 17". "Costituçom Clbj quem pode sseer procurador";

"lei 18". "capitollo. xbij. quaaes podem seer procuradores por outros em Juizo";

“lei 19". "capitollo. xbiij. quaaes podem seer procuradores por outros ou nom";

"lei 20". "capitollo xix quaaes pessoas nom podem sseer procuradores por outros";

"lei 21". "capitollo. xx. quaaes pessoas deuem estabeleçer por procuradores ou nom";

"lei 22". "capitollo. xxj. quaaes pessoas podem sseer uogados ou nom";

"lei 25". "ley quinta como nom pode procurar por outrem quem ha rraçom del rrey";

"lei 26". "Ley. xbj. que nom uoguem";

"lei 27". "ley. xbiij. que pena deuem auer os procuradores que deteuerem os feitos");

"lei 29". "Ley .xx. que pena deue d'aueer o procurador que apelar contra a postura da corte";

"lei 32". "Ley xxiij dos uogados como deuem leuar os ssolairos";

"lei 33". "Ley . xxiiij. que sse apellar contra a postura que pague as Custas";

"lei 34". "ley que os vogados quando os feitos ueerem Jurem que manteem dereito";

"lei 35". "como nehuum ouençall nem ofiçiall dell rrey nom voge por outrem";

"lei 36". "como Ell rrej manda que uogados E procuradores nom leuem solairos";

"lei 37". "que nom voguem perante os Juizes";

"lei 38". "quanto deuem de leuar os uogados dos solairos dos feitos que teuerem";

"lei 41". "como defende que nom aJa hi vogados";

"lei 42". "ley que pena deue auer aquelle que tem ofiçio de Justiça se Jouuer com molher que aJa feito perante ell";

"lei 43". "da eixeiçom dos procuradores";

"lei 44". "como aas partes non deuem atender uogados";

"lei 45". "em quaees casos aa parte ou a seu procurador nom deuem Receber apellaçom";

"lei 46". "Como as partes nom deuem filhar mais que huum uogado"; 
"lei 47". "como os procuradores E os uogados deuem husar";

"lei 48". "como os uogados E procuradores deuem Jurar que manteem bos preitos";

"lei 49". "Quanto deuem leuar os uogados dos sollairos dos feitos";

"lei 50". "ley que uogados nem procuradores nom tomem serujcos daquelles a que os feitos teuerem";

"lei 51". "como El Rey mandou que os uogados leuem serujço dos feitos";

"lei 52". "Como el Rey mandou que os uogados E procuradores leuem o meo do sollairo nos comecos dos feitos";

"lei 53". "Ordenaçom ij. como no artijgo da apellaçom Recebam aas partes Razooes de nouo $\mathrm{E}$ hu dous sobreJuizes acordarem que esta sentença ualha $\mathrm{E}$ quantos uogados deue auer em cada audiancia";

"lei 54". "Como o procurador que trouuer mujtos feitos da terra se forem partidos per desuairadas audeancias deue soestabelleçer procuradores em cada hua audiançia E pode fazer seu feito";

"lei 55". "dos procuradores";

"lei 56". "Esta he a ordenaçom que fez o muy nobre Rey dom afonsso o quarto em Razom dos feitos como se am de trautar E liurar na sa corte E nos seus Regnos na quall estabelleçeo que nom ouuese uogados nem procuradores Regidentes na sa corte";

"lei 58". "Se as partes enujarem os seus procuradores os sobreJuizes deuem de ueer as procuraçoees E se acharem que os procuradores som auondosos deuem a hir pollo feito adiante";

"lei 59". "Como o procurador que ujeer da terra se nom souber os nomes das testemunhas como as deue de nomear na terra perante os emqueridores";

"lei 60". "Como as partes deuem dar aos procuradores per Scripto enformacom de seu feito $\mathrm{E}$ os nomes das testemunhas que uuerem pera prouar seu feito";

"lei 62". "nos feitos que forem trautados nos conçelhos como os Juizes deuem saber a uerdade per as partes ante que lhes Reçebam os uogados nem procuradores";

"lei 63". "como deuem dar uogado";

"lei 64". "Como os uogados deuem fazer";

"lei 66". "Como se deue de fazer quando as partes negarem o feito E se os uogados forem negrigentes como nom deuem d'auer sollairo";

"lei 67". "Que pena deuem d'auer os uogados E procuradores que maliciosamente trautarem os feitos ou em elles forem negligentes";

"lei 69". "Como os procuradores do conçelho que pellos tenpos forem deuem sseer rregidentes aa proll do conçelho E dos sseus beens";

"lei 70". "Como em cada uilla deue d'auer escpriuam Jurado pera escpreuer os beens do conçelho E todo o que rreçeber o procurador deue sseer escprito per esse escpriuam";

"lei 71". "Como os Juizes nom deuem conssintir aos Vogados E procuradores que trautem os feitos malleçiosamente E que pea deue d'auer o que esto fezer";

"lei 72". "como E a que tenpo o procurador que o feito teuer deue a pidir vogado E que pea deue d'auer o procurador que o pidir como nom deue"; 
"lei 74". "Como os Jujzes nom deuem de rreçeber ssoestabelleçimentos dhuuns procuradores a outros ssem emformaçom direjta";

"lei 76". "como os procuradores nom deuem filhar em ssy procuraçoes Jeeraaes";

"lei 77". "Como os Juizes deuem outorgar aos procuradores que filhem as procurações Jeeraaes dalguas pessoas a que forem neçessarias";

"lei 78". "como el Rey manda que em cada villa aJa çerto numero de procuradores ataa quatro E que o conçelho nom ponha hi mais nem brite o numero";

"lei 80". "Como os caualeiros E crerigos E homes d'ordem uaam seer no conçelho a uogar";

"lei 82". "Como deue dar pena ao Juiz se nom liurar os feitos E outrosy ao procurador maliçioso";

"lei 83". "Dos procuradores E uogados se achar que nom som taaes quaaes deuem que ponham outros ou tolham delles se muytos forem";

"lei 84". "Como filhem conto dos procuradores que forom ante per. x. annos";

"lei 85". "Da Jura que ham de fazer os percuradores E uogados";

"lei 86". "Como os Juizes nom deuem dar carta aos uogados E percuradores pera çitarem pellos solairos sem enformaçom", Lei de 17 de novembro de 1350;

"lei 87". "ley em que el Rej defende que procurador nem uogado Nem Juiz nem almoxarife nem sobreJuiz Nem estpriuam nem sacador nom tomem seruiços dos que teuerem os feytos nem dos que com elles ouuerem de fazer";

"lei 88". "ley per que el rej mandou que no seu Regno nom aJa uogados nem procuradores";

\section{Ordenações Afonsinas}

Ord. Af. I, 2, 19;

Ord. Af. I, 5, 4;

Ord. Af. I, 9;

Ord. Af. I, 13;

Ord. Af. I, 13, 1;

Ord. Af. I, 13, 2;

Ord. Af. I, 13, 3;

Ord. Af. I, 13, 4;

Ord. Af. I, 13, 5;

Ord. Af. I, 13, 6;

Ord. Af. I, 13, 7;

Ord. Af. I, 13, 8;

Ord. Af. I, 13, 9;

Ord. Af. I, 13, 11;

Ord. Af. I, 13, 12;

Ord. Af. I, 13, 13;

Ord. Af. I, 13, 14;

Ord. Af. I, 13, 15;

Ord. Af. I, 13, 16;

Ord. Af. I, 13, 17; 
Ord. Af. I, 13, 18;

Ord. Af. I, 13, 19;

Ord. Af. I, 13, 20;

Ord. Af. I, 13, 21;

Ord. Af. I, 13, 22;

Ord. Af. I, 13, 23;

Ord. Af. I, 13, 24;

Ord. Af. I, 13, 25;

Ord. Af. I, 13, 26;

Ord. Af. I, 13, 27;

Ord. Af. I, 13, 28;

Ord. Af. I, 13, 29;

Ord. Af. I, 13, 30;

Ord. Af. I, 13, 31;

Ord. Af. I, 13, 32;

Ord. Af. I, 13, 33;

Ord. Af. I, 16, 11;

Ord. Af. I, 29;

Ord. Af. I, 45;

Ord. Af. I, 47, 14;

Ord. Af. II, 9;

Ord. Af. II, 9 pr.;

Ord. Af. II, 9, 1;

Ord. Af. II, 9, 2;

Ord. Af. II, 63, 3;

Ord. Af. III, 2;

Ord. Af. III, 2 pr.;

Ord. Af. III, 2, 3;

Ord. Af. III, 4, 7;

Ord. Af. III, 5, 2;

Ord. Af. III, 8;

Ord. Af. III, 8 pr.;

Ord. Af. III, 8, 1;

Ord. Af. III, 8, 2;

Ord. Af. III, 8, 3;

Ord. Af. III, 20, 4;

Ord. Af. III, 20, 6;

Ord. Af. III, 20, 7;

Ord. Af. III, 20, 11;

Ord. Af. III, 20, 15;

Ord. Af. III, 20, 17;

Ord. Af. III, 20, 18;

Ord. Af. III, 21;

Ord. Af. III, 21 pr.;

Ord. Af. III, 21, 1;

Ord. Af. III, 21, 2;

Ord. Af. III, 22;

Ord. Af. III, 23;

Ord. Af. III, 23 pr.;

Ord. Af. III, 23, 1; 
Ord. Af. III, 23, 2;

Ord. Af. III, 43, 2;

Ord. Af. III, 45 pr.;

Ord. Af. III, 45, 1;

Ord. Af. III, 45, 2;

Ord. Af. III, 45, 4;

Ord. Af. III, 45, 5;

Ord. Af. III, 45, 13;

Ord. Af. III, 45, 14;

Ord. Af. III, 45, 15;

Ord. Af. III, 46;

Ord. Af. III, 49;

Ord. Af. III, 51;

Ord. Af. III, 68;

Ord. Af. III, 112, 5;

Ord. Af. III, 117;

Ord. Af. III, 117 pr.;

Ord. Af. III, 118;

Ord. Af. III, 118 pr.;

Ord. Af. III, 118, 2;

Ord. Af. IV, 4, 1;

Ord. Af. IV, 4, 2;

Ord. Af. IV, 11;

Ord. Af. IV, 16;

Ord. Af. IV, 45 pr.;

Ord. Af. V, 64;

Ord. Af. V, 64 pr.;

Ord. Af. V, 64, 1;

\section{Leis Extravagantes (contidas na "Synopsis Chronologica" ou em outras fontes referidas diretamente no corpo do texto)}

Provisão de 13 de abril de 1361;

Alvará de 19 de maio de 1425;

"Carta de Bruges";

Carta Régia de 18 de abril de 1426;

Determinação Régia de 02 de julho de 1434;

Alvará de 07 de abril de 1494;

Cortes de Lisboa de 1498;

Alvará de 17 de agosto de 1499;

Ordenação de 03 de abril de 1500;

Determinação Régia de 17 de junho de 1502;

Alvará de 13 de fevereiro de 1510;

Assento (ou Determinação Régia em Relação) de 06 de fevereiro de 1512;

Alvará de $1^{\circ}$ de julho de 1513 ;

Alvará de 28 de março de 1514;

Alvará de 04 de julho de 1515;

Regimento da Fazenda de 17 de outubro de 1516;

Alvará de 30 de outubro de 1516;

Alvará de 10 de dezembro de 1518; 
Determinação Régia de 08 de agosto de 1558;

Lei de 18 de novembro de 1577;

Assento (Determinação Régia em Relação) de 23 de novembro de 1578;

Lei de 24 de março de 1590 ( $\$ 17$ );

Cortes de Lisboa de 1619;

\section{Ordenações Manuelinas}

Ord. Man. I, 2, 28;

Ord. Man. I, 2, 33;

Ord. Man. I, 4, 15;

Ord. Man. I, 6, 8;

Ord. Man. I, 11;

Ord. Man. I, 11, 2;

Ord. Man. I, 20, 21;

Ord. Man. I, 38 pr.;

Ord. Man. I, 38, 1;

Ord. Man. I, 38, 2;

Ord. Man. I, 38, 3;

Ord. Man. I, 38, 4;

Ord. Man. I, 38, 5;

Ord. Man. I, 38, 6;

Ord. Man. I, 38, 7;

Ord. Man. I, 38, 8;

Ord. Man. I, 38, 9;

Ord. Man. I, 38, 10;

Ord. Man. I, 38, 11;

Ord. Man. I, 38, 12;

Ord. Man. I, 38, 13;

Ord. Man. I, 38, 14;

Ord. Man. I, 38, 15;

Ord. Man. I, 38, 16;

Ord. Man. I, 38, 17;

Ord. Man. I, 38, 18;

Ord. Man. I, 38, 19;

Ord. Man. I, 38, 20;

Ord. Man. I, 38, 21;

Ord. Man. I, 38, 22;

Ord. Man. I, 38, 23;

Ord. Man. I, 38, 24;

Ord. Man. I, 38, 25;

Ord. Man. I, 38, 26;

Ord. Man. I, 38, 27;

Ord. Man. I, 38, 28;

Ord. Man. I, 38, 29;

Ord. Man. I, 38, 30;

Ord. Man. I, 38, 31;

Ord. Man. I, 38, 32;

Ord. Man. I, 38, 33;

Ord. Man. I, 38, 34; 
Ord. Man. I, 38, 35;

Ord. Man. I, 38, 36;

Ord. Man. I, 50;

Ord. Man. I, 56, 28;

Ord. Man. I, 60, 23;

Ord. Man. I, 60, 24;

Ord. Man. I, 71;

Ord. Man. I, 71, 18;

Ord. Man. I, 77, 5;

Ord. Man. II, 5;

Ord. Man. II, 5 pr.;

Ord. Man. II, 5, 1;

Ord. Man. II, 26, 43;

Ord. Man. II, 43;

Ord. Man. III, 2, 1;

Ord. Man. III, 4, 9;

Ord. Man. III, 5 pr.;

Ord. Man. III, 7 pr.;

Ord. Man. III, 7, 1;

Ord. Man. III, 7, 2;

Ord. Man. III, 7, 3;

Ord. Man. III, 15, 2;

Ord. Man. III, 15, 3;

Ord. Man. III, 15, 4;

Ord. Man. III, 15, 5;

Ord. Man. III, 15, 10;

Ord. Man. III, 15, 11;

Ord. Man. III, 15, 12;

Ord. Man. III, 15, 14;

Ord. Man. III, 15, 16;

Ord. Man. III, 15, 27;

Ord. Man. III, 17 pr.;

Ord. Man. III, 17, 1;

Ord. Man. III, 18 pr.;

Ord. Man. III, 18, 2;

Ord. Man. III, 32 pr.;

Ord. Man. III, 32, 1;

Ord. Man. III, 32, 2;

Ord. Man. III, 32, 3;

Ord. Man. III, 32, 4;

Ord. Man. III, 33;

Ord. Man. III, 34;

Ord. Man. III, 34 pr.;

Ord. Man. III, 34, 1;

Ord. Man. III, 34, 2;

Ord. Man. III, 35 pr.;

Ord. Man. III, 49, 1;

Ord. Man. III, 49, 5;

Ord. Man. III, 80, 4;

Ord. Man. III, 84 pr.; 
Ord. Man. III, 84, 2;

Ord. Man. IV, 2, 2;

Ord. Man. IV, 6;

Ord. Man. IV, 13;

Ord. man. IV, 30 pr.;

Ord. Man. IV, 40 pr.;

Ord. Man. V, 1, 6;

Ord. Man. V, 1, 11;

Ord. Man. V, 40;

Ord. Man. V, 55;

Ord. Man. V, 58;

Ord. Man. V, 58, 1;

Ord. Man. V, 67, 4;

Ord. Man. V, 67, 5;

Ord. Man. V, 83 pr.;

Ord. Man. V, 83, 3;

Leis Extravagantes (coligidas pelo licenciado Duarte Nunes do Lião)

S. I, 2, 1, 9;

S. I, 3, 1, 3;

S. I, 3, 1, 10;

S. I, 4, 1, 121;

S. I, 4, 2, 6;

S. I, 4, 2, 17;

S. I, 9, 1;

S. I, 9, 2;

S. I, 9, 3;

S. I, 9, 4;

S. I, 21, 1;

S. I, 21, 3;

S. III, 1, 7, 25;

S. III, 1, 7, 33;

S. III, 2, 13;

S. IV, 12, 1;

S. IV, 17, 13;

S. IV, 21, 12;

S. IV, 22, 9;

S. V, 1, 1, 9;

ad. a S. III, 1;

\section{Ordenações Filipinas}

Ord. Fil. I, 4, 4;

Ord. Fil. I, 4, 8;

Ord. Fil. I, 5, 5;

Ord. Fil. I, 6, 11;

Ord. Fil. I, 12;

Ord. Fil. I, 13;

Ord. Fil. I, 14, 2; 
Ord. Fil. I, 24, 18;

Ord. Fil. I, 48 pr.;

Ord. Fil. I, 48, 1;

Ord. Fil. I, 48, 2;

Ord. Fil. I, 48, 3;

Ord. Fil. I, 48, 4;

Ord. Fil. I, 48, 5;

Ord. Fil. I, 48, 6;

Ord. Fil. I, 48, 7;

Ord. Fil. I, 48, 8;

Ord. Fil. I, 48, 9;

Ord. Fil. I, 48, 10;

Ord. Fil. I, 48, 11;

Ord. Fil. I, 48, 12;

Ord. Fil. I, 48, 13;

Ord. Fil. I, 48, 14;

Ord. Fil. I, 48, 15;

Ord. Fil. I, 48, 16;

Ord. Fil. I, 48, 17;

Ord. Fil. I, 48, 18;

Ord. Fil. I, 48, 19;

Ord. Fil. I, 48, 20;

Ord. Fil. I, 48, 21;

Ord. Fil. I, 48, 22;

Ord. Fil. I, 48, 23;

Ord. Fil. I, 48, 24;

Ord. Fil. I, 48, 25;

Ord. Fil. I, 48, 26;

Ord. Fil. I, 48, 27;

Ord. Fil. I, 48, 28;

Ord. Fil. I, 48, 29;

Ord. Fil. I, 69;

Ord. Fil. I, 79, 45;

Ord. Fil. I, 92;

Ord. Fil. I, 92, 17;

Ord. Fil. II, 13, 1;

Ord. Fil. II, 45, 36;

Ord. Fil. III, 2, 1;

Ord. Fil. III, 5, 11;

Ord. Fil. III, 6 pr.;

Ord. Fil. III, 7 pr.;

Ord. Fil. III, 7, 1;

Ord. Fil. III, 7, 2;

Ord. Fil. III, 7, 3;

Ord. Fil. III, 20, 2;

Ord. Fil. III, 20, 3;

Ord. Fil. III, 20, 10;

Ord. Fil. III, 20, 11;

Ord. Fil. III, 20, 12;

Ord. Fil. III, 20, 13; 
Ord. Fil. III, 20, 14;

Ord. Fil. III, 20, 30;

Ord. Fil. III, 20, 40;

Ord. Fil. III, 20, 41;

Ord. Fil. III, 20, 45;

Ord. Fil. III, 26 pr.;

Ord. Fil. III, 26, 1;

Ord. Fil. III, 27;

Ord. Fil. III, 28;

Ord. Fil. III, 28 pr.;

Ord. Fil. III, 28, 1;

Ord. Fil. III, 28, 2;

Ord. Fil. III, 29 pr.;

Ord. Fil. III, 38, 4;

Ord. Fil. III, 39 pr.;

Ord. Fil. III, 39, 2;

Ord. Fil. III, 47 pr.;

Ord. Fil. III, 47, 2;

Ord. Fil. III, 47, 3;

Ord. Fil. III, 63, 1;

Ord. Fil. III, 63, 5;

Ord. Fil. III, 64;

Ord. Fil. IV, 13 pr.;

Ord. Fil. IV, 14, 1;

Ord. Fil. IV, 48;

Ord. Fil. IV, 60;

Ord. Fil. IV, 64;

Ord. Fil. V, 86 pr.;

Ord. Fil. V, 86, 9;

Ord. Fil. V, 120, 3;

Ord. Fil. V, 120, 4;

Ord. Fil. V, 124, 14;

Ord. Fil. V, 124, 15;

Ord. Fil. V, 124, 16;

Ord. Fil. V, 138 pr.;

Legislação Extravagante (coligidas por João Pedro Ribeiro no "Indice Chronologico" ou em outras fontes referidas diretamente no corpo do texto)

Decreto de 19 de novembro de 1722;

Decreto de 09 de janeiro de 1723;

Regimento da Relação do Rio de Janeiro de 13 de outubro de 1751;

Lei de 25 de junho de 1766;

Lei de 05 de abril de 1768;

Lei de 18 de agosto de 1769 ;

Lei de 09 de setembro de 1769 ;

Assento $6^{\circ}$ de 23 de novembro de 1769 ;

Estatutos da Universidade de Coimbra de 1772;

Alvará de $1^{\circ}$ de agosto de 1774 ;

Decreto de 17 de julho de 1778; 
Alvará de 22 de janeiro de 1810 ;

Provisão de 29 de janeiro de 1812;

\section{Assentos da Casa da Suplicação (constantes do Auxiliar Jurídico de Cândido Mendes} de Almeida)

Assento de 09 de janeiro de 1620;

Assento de 02 de maio de 1654;

Assento de 11 de fevereiro de 1658;

Assento de 16 de novembro de 1700;

Assento de 27 de abril de 1723;

Assento de 23 de novembro de 1769;

Assento de 23 de março de 1786;

Legislação Extravagante brasileira (coligida por Cândido Mendes de Almeida no "Código Philippino")

Aviso $\mathrm{n}^{\mathrm{o}}$ 82, de 30 de março de 1849;

Lei de 20 de outubro de 1823;

Constituição Imperial - artigo 179, XVIII;

\section{Legislação extravagante (obtida na “Coleção das Leis do Império")}

Resolução de 12 de junho de 1823;

Resolução de 16 de agosto de 1823 ;

Resolução de 07 de agosto de 1824;

Portaria de 29 de março de 1826;

Lei de 15 de novembro de 1827 ;

Decreto de 08 de outubro de 1828;

Lei de 30 de outubro de 1830;

Resolução de 31 de outubro de 1831;

Decreto de 10 de abril de 1832;

Disposição Provisória de 29 de novembro de 1832;

Regimento Consular de 14 de abril de 1834;

Aviso $n^{\circ} 264$ de 23 de setembro de 1835;

Ordem n ${ }^{\circ} 51$ de 21 de março de 1838;

Aviso de 29 de abril de 1839;

Circular $\mathrm{n}^{\circ} 260$ de 10 de novembro de 1840;

Aviso de 03 de fevereiro de 1841;

Aviso de 14 de setembro de 1841;

Aviso $\mathrm{n}^{\circ} 319$ de 04 de outubro de 1841;

Ordem n ${ }^{\circ} 334$ de 15 de novembro de 1841;

Lei $n^{\circ} 241$ de 29 de novembro de 1841;

Lei $\mathrm{n}^{\circ} 116$ de 15 de janeiro de 1842 ;

Ordem de 21 de janeiro de 1842 ;

Circular $n^{\circ} 9$ de 29 de janeiro de 1844 ;

Ordem $\mathrm{n}^{\circ} 40$ de $1^{\circ}$ de julho de 1844 ;

Ordem n ${ }^{\circ} 98$ de 29 de outubro de 1844;

Circular $\mathrm{n}^{\circ}$ de 15 de novembro de 1844;

Aviso $\mathrm{n}^{\circ} 106$ de 29 de setembro de 1845; 
Decreto $\mathrm{n}^{\circ} 465$ de 17 de agosto de 1846;

Decreto $n^{\circ} 482$ de 14 de novembro de 1846;

Ordem no 142 de 25 de novembro de 1846;

Portaria de 05 de janeiro de 1847 ;

Decreto $n^{\circ} 520$ de 11 de junho de 1847 ;

Ordem no 30 de março de 1849;

Decisão n ${ }^{\circ} 100$ de 23 de abril de 1849;

Ordem n ${ }^{\circ} 153$ de 08 de junho de 1849;

Ordem n ${ }^{\circ} 253$ de 11 de dezembro de 1849;

Ordem $\mathrm{n}^{\circ} 10$ de 05 de fevereiro de 1850;

Decreto $\mathrm{n}^{\circ} 681$ de 10 de julho de 1850 ;

Ordem no 119 de 13 de setembro de 1850;

Provisão de 23 de setembro de 1850;

Decreto $n^{\circ} 736$ de 20 de novembro de 1850;

Regulamento $\mathrm{n}^{\circ} 737$ de 25 de novembro de 1850;

Ordem n $^{\circ} 215$ de 28 de novembro de 1850;

Despacho $\mathrm{n}^{\circ} 143$ de 28 de abril de 1851;

Ordem $\mathrm{n}^{\circ} 182$ de 11 de junho de 1851;

Circular de 30 de junho de 1851;

Aviso $\mathrm{n}^{\mathrm{o}} 187$ de 25 de junho de 1851 ;

Ordem no 244 de 08 de outubro de 1851;

Ordem $\mathrm{n}^{\circ} 28$ de 28 de janeiro de 1852 ;

Ordem n ${ }^{\circ} 79$ de 17 de março de 1852;

Ordem n ${ }^{\circ} 125$ de 10 de maio de 1852;

Ordem n $n^{\circ} 136$ de 28 de maio de 1852;

Portaria de 11 de junho de 1852;

Ordem n ${ }^{\circ} 202$ de 25 de agosto de 1852;

Despacho de 16 de setembro de 1852;

Ordem de 04 de março de 1853;

Ordem n ${ }^{\circ} 79$ de 14 de março de 1853;

Estatutos de 30 de março de 1853;

Aviso $\mathrm{n}^{\circ} 160$ de 09 de julho de 1853 ;

Ordem no 264 de 30 de novembro de 1853;

Aviso $\mathrm{n}^{\circ} 11$, de 12 de janeiro de 1854;

Ordem de 22 de abril de 1854;

Decreto $\mathrm{n}^{\mathrm{o}} 1386$ de 28 de abril de 1854;

Decisão $\mathrm{n}^{\circ} 104$ de 20 de maio de 1854;

Despacho de 16 de outubro de 1854;

Aviso $\mathrm{n}^{\circ} 148$ de 01 de agosto de 1854;

Despacho de 16 de outubro de 1854;

Despacho de 28 de dezembro de 1854;

Ordem de 14 de fevereiro de 1855;

Regimento $\mathrm{n}^{\circ} 1569$ de 03 de março de 1855 ;

Aviso ${ }^{\circ} 66$ de 16 de fevereiro de 1855 ;

Decreto $n^{\circ} 1568$ de 24 de fevereiro de 1855;

Decreto $\mathrm{n}^{\circ} 1597$ de $1^{\circ}$ de maio de 1855 ;

Portaria de 07 de julho de 1855;

Ordem no 356 de 14 de novembro de 1855 ;

Aviso $\mathrm{n}^{\circ} 402$ de 29 de dezembro de 1855;

Decreto $\mathrm{n}^{\circ} 1739$ de 26 de março de 1856; 
Decreto $\mathrm{n}^{\mathrm{o}} 1769$ de 16 de junho de 1856;

Despacho de 13 de outubro de 1856;

Aviso $n^{\circ} 338$ de 17 de outubro de 1856;

Aviso Circular $\mathrm{n}^{\circ} 356$ de 25 de outubro de 1856;

Aviso de 22 de novembro de 1856;

Ordem $n^{\circ} 9$ de 08 de janeiro de 1857 ;

Aviso $n^{\circ} 49$ de 10 de fevereiro de 1857;

Ordem n ${ }^{\circ} 92$ de 13 de março de 1857;

Despacho de 20 de agosto de 1857;

Ordem n ${ }^{\circ} 291$ de 28 de agosto de 1857;

Despacho de 08 de outubro de 1857;

Despacho de 10 de dezembro de 1857;

Aviso $n^{\circ} 12$ de 14 de janeiro de 1858 ;

Ordem n ${ }^{\circ} 53$ de 15 de fevereiro de 1858;

Despacho de 23 de março de 1858;

Portaria de 07 de agosto de 1858;

Despacho de 20 de dezembro de 1858;

Despacho de 09 de fevereiro de 1859;

Despacho de $1^{\circ}$ de abril de 1859 ;

Ordem $\mathrm{n}^{\circ} 74$ de 11 de abril de 1859;

Instruções de 26 de abril de 1859;

Despacho de 12 de setembro de 1859;

Decreto $^{\circ} 2473$ de 24 de setembro de 1859;

Lei $\mathrm{n}^{\circ} 1083$ de 22 de agosto de 1860;

Decreto ${ }^{\circ} 2647$ de 19 de setembro de 1860;

Lei $\mathrm{n}^{\circ} 1114$ de 27 de setembro de 1860;

Decreto $n^{\circ} 2699$ de 28 de novembro de 1860;

Decreto $n^{\circ} 2713$ de 26 de dezembro de 1860;

Aviso de 09 de fevereiro de 1861;

Despacho de $1^{\circ}$ de abril de 1861 ;

Aviso de 12 de junho de 1861;

Aviso de 03 outubro de 1861;

Portaria de 27 de novembro de 1861;

Aviso de 06 de junho de 1863;

Aviso no 402 de 29 de agosto de 1863;

Aviso $\mathrm{n}^{\mathrm{o}} 27$ de 27 de janeiro de 1864;

Ordem $\mathrm{n}^{\circ}$ de 27 de março de 1866;

Aviso $n^{\circ} 236$ de 23 de junho de 1866;

Aviso $\mathrm{n}^{\circ} 560$ de 15 de dezembro de 1866;

Ord. de 23 de agosto de 1867;

Decreto $\mathrm{n}^{\circ} 4113$ de 04 de março de 1868;

Decreto $\mathrm{n}^{\circ} 4355$ de 17 de abril de 1869;

Regulamento $\mathrm{n}^{\circ} 4505$ de 09 de abril de 1870 ;

Aviso $\mathrm{n}^{\circ} 184$ de 30 de junho de 1870 ;

Aviso $\mathrm{n}^{\mathrm{o}} 330$ de 17 de novembro de 1870 ;

Aviso $n^{\circ} 39$, de 12 de fevereiro de 1872;

Regimento de Custas - Decreto $\mathrm{n}^{\circ} 5737$ de 02 de setembro de 1874);

Aviso $\mathrm{n}^{\circ} 434$ de 16 de novembro de 1874 ;

Aviso $\mathrm{n}^{\circ} 317$ de 21 de setembro de 1874;

Aviso $n^{\circ} 374$ de 16 de outubro de 1874; 
Aviso $\mathrm{n}^{\circ} 414$ de 06 de novembro de 1874;

Aviso $\mathrm{n}^{\mathrm{o}} 118$ de 13 de março de 1875;

Aviso $\mathrm{n}^{\circ} 20$ de 13 de janeiro de 1876 ;

Aviso $\mathrm{n}^{\circ} 472$ de 14 de novembro de 1877 ;

Aviso $\mathrm{n}^{\mathrm{o}} 32$ de 19 de janeiro de 1880 ;

Decreto $\mathrm{n}^{\circ} 8260$ de 24 de setembro de 1881;

Aviso $\mathrm{n}^{\circ} 206$ de 30 de abril de 1881;

Decreto $\mathrm{n}^{\mathrm{o}} 3065$ de 06 de maio de 1882;

Lei $\mathrm{n}^{\circ} 3150$ de 04 de novembro de 1882;

Aviso $n^{\circ} 43$ de 18 de março de 1882;

Decreto ${ }^{\circ} 9370$ de 14 de fevereiro de 1885 ;

Aviso $\mathrm{n}^{\circ} 5$ de 02 de março de 1887;

\section{Legislação extravagante (obtida na "Coleção das Leis da República")}

Decreto $\mathrm{n}^{\circ} 164$ de 17 de janeiro de 1890;

Decreto $\mathrm{n}^{\circ} 181$ de 24 de janeiro de 1890 ;

Decreto $\mathrm{n}^{\circ}$ 451-B de 31 de maio de 1890;

Decreto ${ }^{\circ} 498$ de 19 de junho de 1890;

Decreto $n^{\circ} 585$ de 19 de julho de 1890;

Decreto $\mathrm{n}^{\mathrm{o}} 771$ de 20 de setembro de 1890 ;

Decreto $n^{\circ} 848$ de 11 de outubro de 1890 ;

Decreto $n^{\circ} 917$ de 24 de outubro de 1890 ;

Decreto ${ }^{\circ}$ 955-A de 05 de novembro de 1890;

Decreto n 434 de 04 de julho de 1891;

Constituição de 24 de fevereiro de 1891;

Decreto Legislativo ${ }^{\circ} 79$ de 23 de agosto de 1892;

Lei $\mathrm{n}^{\circ} 173$ de 10 de setembro de 1893;

Decreto $\mathrm{n}^{\mathrm{o}} 2243$ de 19 de março de 1896;

Decreto $\mathrm{n}^{\circ} 2519$ de 22 de maio de 1897 ;

Decreto $\mathrm{n}^{\mathrm{o}} 2573$ de 03 de agosto de 1897;

Decreto $\mathrm{n}^{\mathrm{o}} 3084$ de 05 de novembro de 1898;

Decreto $n^{\circ} 3259$ de 11 de abril de 1899;

Decreto Legislativo n ${ }^{\circ} 1236$, de 24 de setembro de 1904;

Decreto $\mathrm{n}^{\circ} 6711$ de 07 de novembro de 1907;

Lei ${ }^{\circ} 2044$ de 31 de dezembro 1908;

Lei $n^{\circ} 6948$ de 04 de maio de 1908;

Decreto $\mathrm{n}^{\circ} 8593$ de 08 de março de 1911;

Lei n 3139 de 02 de agosto de 1916;

\section{DIREITO MODERNO}

\section{Código Bávaro (1753-1756)}

Liv. IV, Cap. IX;

\section{Código Civil da Louisiana (1804)}

art. 2969; 
Código Civil francês (1804)

art. $4^{\circ}$;

art. 1984;

art. 2004;

Código Civil austríaco (1812)

art. 1029;

Código Comercial português (1833)

art. 39 ;

art. 42 ;

art. 43;

art. 45 ;

art. 46 ;

art. 47;

art. 49;

art. 50 ;

art. 51 ;

art. 52 ;

art. 53;

art. 55;

art. 56;

art. 57 ;

art. 58;

art. 59;

art. 62 ;

art. 64

art. 65;

art. 66;

art. 67;

art. 68;

art. 69;

art. 70;

art. 71;

art. 72;

art. 74;

art. 75;

art. 77;

art. 78;

art. 79;

art. 84;

art. 85;

art. 86;

art. 233;

art. 294;

art. 762;

art. 763; 
art. 764;

art. 765;

art. 766;

art. 767;

art. 768;

art. 769;

art. 770;

art. 771;

art. 772;

art. 773;

art. 774;

art. 775;

art. 776;

art. 777;

art. 778;

art. 779;

art. 780;

art. 781;

art. 782;

art. 783;

art. 784;

art. 785;

art. 786;

art. 787;

art. 788;

art. 790;

art. 791;

art. 792;

art. 793;

art. 794;

art. 796;

art. 798;

art. 799;

art. 801;

art. 802;

art. 803;

art. 804;

art. 805;

art. 806;

art. 807;

art. 808;

art. 809;

art. 810;

art. 811;

art. 812;

art. 813;

art. 814;

art. 816;

art. 818;

art. 819; 
art. 820;

art. 821 ;

art. 822 ;

art. 823;

art. 824;

art. 825;

art. 826;

art. 829;

art. 833;

art. 836;

art. 837 ;

art. 839;

\section{Código Comercial brasileiro (1850)}

art. 21;

art. 140 ;

art. 141 ;

art. 142 ;

art. 143;

art. 144 ;

art. 145 ;

art. 146;

art. 147;

art. 148 ;

art. 149 ;

art. 150;

art. 151;

art. 152;

art. 153;

art. 154;

art. 155;

art. 156;

art. 157;

art. 158;

art. 159;

art. 160;

art. 161;

art. 162;

art. 163;

art. 164;

art. 165;

art. 166;

art. 167;

art. 168;

art. 169;

art. 170;

art. 171;

art. 172;

art. 173; 
art. 174;

art. 175 ;

art. 176;

art. 177;

art. 178;

art. 179 ;

art. 180 ;

art. 181 ;

art. 182 ;

art. 183;

art. 184 ;

art. 185 ;

art. 186;

art. 187 ;

art. 188 ;

art. 189 ;

art. 190;

Código Civil chileno (1855)

art. 2134;

\section{Código Civil equatoriano (1858)}

art. 2065;

\section{Consolidação das Leis Civis (1858)}

art. 456 ;

art. 457 ;

art. 458;

art. 459;

art. 460;

art. 461;

art. 462;

art. 463;

art. 464;

art. 465;

art. 466;

art. 467;

art. 468;

art. 469;

art. 470;

art. 471;

art. 472;

art. 473;

art. 474;

art. 475;

art. 476; 
art. 2853;

art. 2854;

art. 2855;

art. 2856;

art. 2857;

art. 2858;

art. 2859;

art. 2860;

art. 2861;

art. 2862;

art. 2863;

art. 2864;

art. 2865;

art. 2866;

art. 2867;

art. 2868;

art. 2869;

art. 2870;

art. 2871;

art. 2872;

art. 2873;

art. 2874;

art. 2875;

art. 2876;

art. 2877;

art. 2878;

art. 2879;

art. 2880;

art. 2881;

art. 2882;

art. 2883;

art. 2884;

art. 2885;

art. 2886;

art. 2887;

art. 2888;

art. 2889;

art. 2890;

art. 2891;

art. 2892;

art. 2893;

art. 2894;

art. 2895;

art. 2896;

art. 2897;

art. 2898;

art. 2899;

art. 2900; 
art. 2901;

art. 2902;

art. 2903;

art. 2904;

art. 2905;

art. 2906;

art. 2907;

art. 2908;

art. 2909;

art. 2910;

art. 2911;

art. 2912;

art. 2913;

art. 2914;

art. 2915;

art. 2916;

art. 2917;

art. 2918;

art. 2919;

art. 2920;

art. 2921;

art. 2922;

art. 2923;

art. 2924;

art. 2925;

art. 2926;

art. 2927;

art. 2928;

art. 2929;

art. 2930;

art. 2931;

art. 2932;

art. 2933;

art. 2934;

art. 2935;

art. 2936;

art. 2937;

art. 2938;

art. 2939;

art. 2940;

art. 2941;

art. 2942;

art. 2943;

art. 2944;

art. 2945;

art. 2946;

art. 2947;

art. 2948;

art. 2949;

art. 2950; 
art. 2951;

art. 2952;

art. 2953;

art. 2954;

art. 2955;

art. 2956;

art. 2957;

art. 2958;

art. 2959;

art. 2960;

art. 2961;

art. 2962;

art. 2963;

art. 2964;

art. 2965;

art. 2966;

art. 2967;

art. 2968;

art. 2969;

art. 2970;

art. 2971;

art. 2972;

art. 2973;

art. 2974;

art. 2975;

art. 2976;

art. 2977;

art. 2978;

art. 2979;

art. 2980;

art. 2981;

art. 2982 ;

art. 2983;

art. 2984;

art. 2985;

art. 2986;

art. 2987;

art. 2988;

art. 2989;

art. 2990;

art. 2991;

art. 2992;

art. 2993;

art. 2994;

art. 2995;

art. 2996;

art. 2997;

art. 2998;

art. 2999;

art. 3000; 
art. 3001;

art. 3002;

art. 3003;

art. 3004;

art. 3005;

art. 3006;

art. 3007;

art. 3008;

art. 3009;

art. 3010;

art. 3011;

art. 3012;

art. 3013;

art. 3014;

art. 3015;

art. 3016;

art. 3017;

art. 3018;

art. 3019;

art. 3020;

art. 3021;

art. 3022;

art. 3023;

art. 3024;

art. 3025 ;

art. 3026;

art. 3027;

art. 3028;

art. 3029;

art. 3030;

art. 3031;

art. 3032;

art. 3033;

art. 3034;

art. 3035;

art. 3036;

art. 3037;

art. 3038;

art. 3039;

art. 3040;

art. 3041;

art. 3042;

Codice Civile (1865)

art. 1737;

\section{Código Civil português (1867)}

art. $1318^{\circ}$; 
art. $1319^{\circ}$;

art. $1320^{\circ}$;

art. $1321^{\circ}$;

art. $1322^{\circ}$;

art. $1323^{\circ}$;

art. $1324^{\circ}$;

art. $1325^{\circ}$;

art. $1326^{\circ}$;

art. $1327^{\circ}$;

art. $1328^{\circ}$;

art. $1329^{\circ}$;

art. $1330^{\circ}$;

art. $1331^{\circ}$;

art. $1332^{\circ}$;

art. $1333^{\circ}$;

art. $1334^{\circ}$;

art. $1335^{\circ}$;

art. $1336^{\circ}$;

art. $1337^{\circ}$;

art. $1338^{\circ}$;

art. $1339^{\circ}$;

art. $1340^{\circ}$;

art. $1341^{\circ}$;

art. $1342^{\circ}$;

art. $1343^{\circ}$;

art. $1344^{\circ}$;

art. $1345^{\circ}$;

art. $1346^{\circ}$;

art. $1347^{\circ}$;

art. $1348^{\circ}$;

art. $1349^{\circ}$;

art. $1350^{\circ}$;

art. $1351^{\circ}$;

art. $1352^{\circ}$;

art. $1353^{\circ}$;

art. $1354^{\circ}$;

art. $1355^{\circ}$;

art. $1356^{\circ}$;

art. $1357^{\circ}$;

art. $1358^{\circ}$;

art. $1359^{\circ}$;

art. $1360^{\circ}$;

art. $1361^{\circ}$;

art. $1362^{\circ}$;

art. $1363^{\circ}$;

art. $1364^{\circ}$;

art. $1365^{\circ}$;

art. $1366^{\circ}$;

art. $1367^{\circ}$;

art. $1368^{\circ}$; 
art. $1369^{\circ}$;

\section{Código Civil de Quebec (1866)}

art. 1704;

art. 1705;

art. 1709;

\section{Código Civil uruguaio (1868)}

art. 2077;

\section{Código Civil colombiano (1873)}

art. 2160;

Código das Obrigações suíço (1881)

art. 396;

\section{Anteprojeto Felício dos Santos (1881)}

art. 2266;

art. 2267;

art. 2268;

art. 2269;

art. 2270;

art. 2271 ;

art. 2272;

art. 2273;

art. 2274;

art. 2275 ;

art. 2276;

art. 2277;

art. 2278;

art. 2279;

art. 2280;

art. 2281;

art. 2282;

art. 2283;

art. 2284;

art. 2285;

art. 2286;

art. 2287;

art. 2288;

art. 2289;

art. 2290;

art. 2291;

art. 2292;

art. 2293; 
art. 2294;

art. 2295;

art. 2296;

art. 2297;

art. 2298;

art. 2299;

art. 2300;

art. 2301;

art. 2302;

art. 2303;

art. 2304;

art. 2305;

art. 2306;

art. 2307;

art. 2308;

art. 2309;

Código Comercial português (1888)

art. $231^{\circ}$;

art. $232^{\circ}$;

art. $233^{\circ}$;

art. $234^{\circ}$;

art. $235^{\circ}$;

art. $236^{\circ}$;

art. $237^{\circ}$;

art. $238^{\circ}$;

art. $239^{\circ}$;

art. $240^{\circ}$;

art. $241^{\circ}$;

art. $242^{\circ}$;

art. $243^{\circ}$;

art. $244^{\circ}$;

art. $245^{\circ}$;

art. $246^{\circ}$;

art. $247^{\circ}$;

art. $266^{\circ}$;

art. $267^{\circ}$;

art. $268^{\circ}$;

art. $269^{\circ}$;

art. $270^{\circ}$;

art. $271^{\circ}$;

art. $272^{\circ}$;

art. $274^{\circ}$;

\section{Código Civil montenegrino (1888)}

art. 400; 
Anteprojeto Coelho Rodrigues (1893)

art. 1063;

art. 1064;

art. 1065;

art. 1066;

art. 1067;

art. 1068;

art. 1069;

art. 1070;

art. 1071;

art. 1072;

art. 1073;

art. 1074;

art. 1075;

art. 1076;

art. 1077;

art. 1078;

art. 1079;

art. 1080;

art. 1081 ;

art. 1082;

art. 1083;

art. 1084;

art. 1085;

art. 1086;

art. 1087;

art. 1088;

art. 1089;

art. 1090;

art. 1091;

art. 1092;

art. 1093;

art. 1094;

Código Civil japonês (1896)

art. 103;

Anteprojeto Clóvis Beviláqua (1899)

art. 1442;

art. 1443;

art. 1444;

art. 1445 ;

art. 1446;

art. 1447;

art. 1448;

art. 1449;

art. 1450 ; 
art. 1451;

art. 1452;

art. 1453;

art. 1454;

art. 1455;

art. 1456;

art. 1457;

art. 1458;

art. 1459;

art. 1460;

art. 1461;

art. 1462;

art. 1463;

art. 1464;

art. 1465;

art. 1466;

art. 1467;

art. 1468;

art. 1469;

Anteprojeto Clóvis Beviláqua - versão revista

art. 1506;

art. 1507;

art. 1508;

art. 1509;

art. 1510;

art. 1511;

art. 1512;

art. 1513;

art. 1514

art. 1515

art. 1516;

art. 1517;

art. 1518;

art. 1519;

art. 1520;

art. 1521 ;

art. 1522;

art. 1523;

art. 1524;

art. 1525;

art. 1526;

art. 1527;

art. 1528;

art. 1529;

art. 1530;

art. 1531;

art. 1532;

art. 1533 ; 
art. 1534;

art. 1535;

art. 1536;

art. 1537;

art. 1538;

art. 1539;

art. 1540;

art. 1541;

art. 1542;

art. 1543;

art. 1544;

art. 1545;

art. 1546;

art. 1547;

art. 1548;

art. 1549;

art. 1550;

art. 1551;

art. 1552;

Projeto da Câmara dos Deputados no ${ }^{0}$ 1/1902

art. 1288;

art. 1289;

art. 1290;

art. 1291;

art. 1292;

art. 1293;

art. 1294;

art. 1295;

art. 1296;

art. 1297;

art. 1298;

art. 1299;

art. 1300;

art. 1301;

art. 1302;

art. 1303;

art. 1304;

art. 1305;

art. 1306;

art. 1307;

art. 1308;

art. 1309;

art. 1310;

art. 1311;

art. 1312;

art. 1313;

art. 1314;

art. 1315; 
art. 1316;

art. 1317;

art. 1318;

art. 1319;

art. 1320;

art. 1321;

art. 1322;

art. 1323;

art. 1324;

art. 1325;

art. 1326;

art. 1327;

art. 1328;

art. 1329;

art. 1330;

Parecer da Comissão Especial do Senado Federal no n $^{\circ}$ (69/1912

art. 1288;

art. 1289;

art. 1290;

art. 1291;

art. 1292;

art. 1293;

art. 1294;

art. 1295;

art. 1296;

art. 1297;

art. 1298;

art. 1299;

art. 1300;

art. 1301;

art. 1302;

art. 1303;

art. 1304;

art. 1305;

art. 1306;

art. 1307;

art. 1308;

art. 1309;

art. 1310;

art. 1311;

art. 1312;

art. 1313;

art. 1314;

art. 1315;

art. 1316;

art. 1317;

art. 1318;

art. 1319; 
art. 1320;

art. 1321;

art. 1322;

art. 1323;

art. 1324;

art. 1325;

art. 1326;

art. 1327;

art. 1328;

art. 1329;

art. 1330;

\section{Código Civil brasileiro (1916)}

art. 1288;

art. 1289;

art. 1290;

art. 1291;

art. 1292;

art. 1293;

art. 1294;

art. 1295 ;

art. 1296;

art. 1297;

art. 1298;

art. 1299;

art. 1300;

art. 1301;

art. 1302;

art. 1303;

art. 1304;

art. 1305;

art. 1306;

art. 1307;

art. 1308;

art. 1309;

art. 1310;

art. 1311;

art. 1312;

art. 1313;

art. 1314;

art. 1315;

art. 1316;

art. 1317;

art. 1318;

art. 1319;

art. 1320;

art. 1321;

art. 1322;

art. 1323; 
art. 1324;

art. 1325 ;

art. 1326;

art. 1327;

art. 1328;

art. 1329;

art. 1330;

Código Civil chinês (1929)

art. 533;

Anteprojeto de Parte Geral do Código das Obrigações de Orosimbo Nonato, Philadelpho Azevedo e Hahnemann Guimarães (1941)

art. 35;

art. 36 ;

art. 37;

art. 38 ;

art. 39 ;

art. 40 ;

art. 41 ;

art. 42 ;

art. 43;

art. 44;

art. 45;

art. 46;

art. 47;

art. 48;

art. 49;

art. 50;

art. 51 ;

art. 52;

Código Civil italiano (1942)

art. 1708;

Anteprojeto de Código das Obrigações de Caio Mário da Silva Pereira (1963)

art. 37 ;

art. 38 ;

art. 39;

art. 40 ;

art. 41 ;

art. 42 ;

art. 43;

art. 628 ;

art. 629

art. 630 ; 
art. 631;

art. 632;

art. 633;

art. 634;

art. 635;

art. 636;

art. 637;

art. 638 ;

art. 639;

art. 640;

art. 641;

art. 642;

art. 643;

art. 644;

art. 645;

art. 646;

art. 647;

art. 648;

art. 649;

art. 650;

art. 651 ;

art. 652;

art. 653;

art. 654;

art. 655 ;

art. 656;

art. 657;

art. 658;

art. 659;

art. 660;

art. 661;

art. 662 ;

art. 663;

art. 664;

art. 665;

art. 666;

art. 667;

art. 668;

art. 669;

art. 670;

Anteprojeto de Caio Mário da Silva Pereira revisto - Projeto de Código das Obrigações - PL no 3264/65 (1965)

art. 37 ;

art. 38 ;

art. 39;

art. 40

art. 41 ;

art. 42 ; 
art. 43;

art. 599;

art. 600;

art. 601;

art. 602;

art. 603;

art. 604;

art. 605;

art. 606;

art. 607;

art. 608;

art. 609;

art. 610;

art. 611;

art. 612;

art. 613;

art. 614;

art. 615;

art. 616;

art. 617;

art. 618;

art. 619;

art. 620;

art. 621;

art. 622;

art. 623;

art. 624;

art. 625;

art. 626;

art. 627;

art. 628;

art. 629;

art. 630;

art. 631;

art. 632;

art. 633;

art. 634;

art. 635;

Código Civil português (1966)

art. $258^{\circ}$;

art. $259^{\circ}$;

art. $260^{\circ}$;

art. $261^{\circ}$;

art. $262^{\circ}$;

art. $263^{\circ}$;

art, $264^{\circ}$;

art. $265^{\circ}$;

art. $266^{\circ}$; 
art. $267^{\circ}$;

art. $268^{\circ}$;

art. $269^{\circ}$;

art. $1157^{\circ}$;

art. $1158^{\circ}$;

art. $1159^{\circ}$;

art. $1160^{\circ}$;

art. $1161^{\circ}$;

art. $1162^{\circ}$;

art. $1164^{\circ}$;

art. $1165^{\circ}$;

art. $1166^{\circ}$;

art. $1167^{\circ}$;

art. $1168^{\circ}$;

art. $1169^{\circ}$;

art. $1170^{\circ}$;

art. $1171^{\circ}$;

art. $1172^{\circ}$;

art. $1173^{\circ}$;

art. $1174^{\circ}$;

art. $1175^{\circ}$;

art. $1176^{\circ}$;

art. $1177^{\circ}$;

art. $1178^{\circ}$;

art. $1179^{\circ}$;

art. $1180^{\circ}$;

art. $1181^{\circ}$;

art. $1182^{\circ}$;

art. $1183^{\circ}$;

art. $1184^{\circ}$;

Anteprojeto de Parte Geral do Código Civil - José Carlos Moreira Alves (1970)

art. 111;

art. 112;

art. 113;

art. 114;

art. 115;

art. 116 ;

art. 117;

art. 118;

art. 119 ;

art. 120;

art. 121;

art. 122;

art. 123;

art. 124;

art. 125;

art. 126;

art. 127; 
art. 128;

art. 129;

art. 130;

\section{Anteprojeto de Código Civil - Comissão presidida por Miguel Reale (1972)}

art. 114;

art. 115

art. 116;

art. 117

art. 118

art. 119 ;

art. 120

art. 668 ;

art. 669;

art. 670;

art. 671;

art. 672;

art. 673 ;

art. 674;

art. 675;

art. 676;

art. 677;

art. 678;

art. 679;

art. 680;

art. 681;

art. 682 ;

art. 683;

art. 684;

art. 685 ;

art. 686;

art. 687;

art. 688;

art. 689;

art. 690;

art. 691;

art. 692;

art. 693;

art. 694;

art. 695;

art. 696;

art. 697;

art. 698;

art. 699;

art. 700;

art. 701;

art. 702;

art. 703; 
Anteprojeto de Código Civil - Comissão presidida por Miguel Reale - versão revista (1973)

art. 113;

art. 114;

art. 115 ;

art. 116;

art. 117;

art. 118

art. 652 ;

art. 653 ;

art. 654;

art. 655;

art. 656;

art. 657;

art. 658;

art. 659;

art. 660;

art. 661;

art. 662;

art. 663;

art. 664;

art. 665;

art. 666;

art. 667;

art. 668;

art. 669;

art. 670;

art. 671;

art. 672;

art. 673;

art. 674;

art. 675;

art. 676;

art. 677;

art. 678;

art. 679;

art. 680;

art. 681;

art. 682;

art. 683;

art. 684 ;

art. 685;

art. 686;

art. 687;

art. 688;

art. 689;

art. 690;

art. 691; 
Projeto de Código Civil - versão do Congresso Nacional (PCD nº 634/75) (1975)

art. 113;

art. 114;

art. 115;

art. 116;

art. 117

art. 118;

art. 662 ;

art. 663;

art. 664 ;

art. 665 ;

art. 666;

art. 667;

art. 668;

art. 669;

art. 670;

art. 671;

art. 672;

art. 673;

art. 674;

art. 675;

art. 676;

art. 677;

art. 678;

art. 679;

art. 680;

art. 681 ;

art. 682;

art. 683;

art. 684;

art. 685;

art. 686;

art. 687;

art. 688;

art. 689;

art. 690;

art. 691;

art. 692;

art. 693;

art. 694;

art. 695;

art. 696;

art. 697;

art. 698;

art. 699;

art. 700;

art. 701;

Código Civil brasileiro (2002) 
art. 11;

art. 21;

art. 52;

art. 115;

art. 116;

art. 117;

art. 118;

art. 119;

art. 120;

art. 138;

art. 381 ;

art. 382;

art. 383;

art. 384;

art. 425;

art. 467;

art. 468;

art. 469;

art. 470;

art. 471;

art. 653;

art. 654;

art. 655;

art. 656;

art. 657;

art. 658;

art. 659;

art. 660;

art. 661;

art. 662;

art. 663;

art. 664;

art. 665;

art. 666;

art. 667;

art. 668;

art. 669;

art. 670;

art. 671;

art. 672;

art. 673;

art. 674;

art. 675;

art. 676;

art. 677;

art. 678;

art. 679;

art. 680;

art. 681 ; 
art. 682;

art. 683 ;

art. 684 ;

art. 685 ;

art. 686 ;

art. 687

art. 688 ;

art. 689;

art. 690

art. 691 ;

art. 692;

art. 693;

art. 709;

Enunciados aprovados na III Jornada de Direito Civil

182

183

184. 


\section{ANEXO I \\ TÁBUA CRONOLÓGICA DE DIPLOMAS LEGAIS \\ (SISTEMA DIPLOMA/DATA)}

\section{Brasil (Código Civil de 1916 e seus antecedentes).}

\begin{tabular}{|c|c|c|}
\hline Diploma & $\begin{array}{l}\text { ano de } \\
\text { edição }\end{array}$ & sigla \\
\hline Código Comercial & 1850 & CCom \\
\hline Consolidação das Leis Civis & 1858 & CLC \\
\hline Esboço (Augusto Teixeira de Freitas) & 1860 & Esboço \\
\hline Anteprojeto José Thomaz Nabuco de Araújo & 1878 & AntJTNA \\
\hline Anteprojeto Felício dos Santos & 1881 & AntFS \\
\hline Anteprojeto Coelho Rodrigues & 1893 & AntCR \\
\hline Anteprojeto Clóvis Beviláqua & 1899 & AntCB \\
\hline Anteprojeto Clóvis Beviláqua Revisto & 1900 & AntCBRev \\
\hline Projeto da Câmara dos Deputados no 1 & 1902 & $\mathrm{PCD} \mathrm{n}^{\circ} 1 / 1902$ \\
\hline Parecer da Comissão Especial do Senado Federal no 269 & 1912 & $\mathrm{PSF}^{\circ}$ 269/1912 \\
\hline Código Civil brasileiro (1916) & 1916 & $\mathrm{CC} / 16$ \\
\hline
\end{tabular}

\section{Brasil (Código Civil de 2002 e seus antecedentes).}

\begin{tabular}{|l|l|l|}
\hline Diploma & ano de edição & sigla \\
\hline $\begin{array}{l}\text { Anteprojeto de Código das Obrigações (Parte Geral) } \\
\text { (Orosimbo Nonato, Philadelpho Azevedo e Hahnemann Guimarães) }\end{array}$ & 1941 & AntOPH \\
\hline $\begin{array}{l}\text { Anteprojeto de Código Civil } \\
\text { (Orlando Gomes) }\end{array}$ & 1963 & AntOG \\
\hline $\begin{array}{l}\text { Anteprojeto de Código das Obrigações (Negócio Jurídico, Obrigações em } \\
\text { Geral, Contratos e outros títulos de ordem geral) } \\
\text { (Caio Mário da Silva Pereira) }\end{array}$ & 1963 & AntCM \\
\hline $\begin{array}{l}\text { Projeto de Código das Obrigações } \\
\text { (PL no 3.264/65) }\end{array}$ & 1965 & AntCMRev \\
\hline Anteprojeto de Parte Geral do Código Civil (José Carlos Moreira Alves) & 1970 & AntPGMA \\
\hline Anteprojeto de Código Civil & 1972 & AntMR \\
\hline Anteprojeto de Código Civil Revisto & 1973 & AntMRRev \\
\hline $\begin{array}{l}\text { Anteprojeto de Código Civil } \\
\text { (versão do Congresso Nacional) }\end{array}$ & 1975 & $\begin{array}{l}\text { PCD } \\
\text { 634/1975 }\end{array}$ \\
\hline Código Civil brasileiro (2002) & 2002 & CC/2002 \\
\hline
\end{tabular}


ANEXO II

TABELA DE CORRESPONDÊNCIA $N^{\circ}$ I DIREITO CASTELHANO

\begin{tabular}{|c|c|c|c|c|c|c|}
\hline regra & Flores del Derecho & Dotrinal & $\begin{array}{l}\text { Summa Delos } \\
\text { Noue Tienpos } \\
\text { Delos Pleitos } \\
\end{array}$ & Fuero Real & Especulo & Siete Partidas \\
\hline $\begin{array}{l}\text { Advogado (dativo por } \\
\text { súplica) }\end{array}$ & $I, 2,1$ & & & $\mathrm{I}, 9,1$ & & III, 6,6 \\
\hline $\begin{array}{l}\text { Advogado (quem não } \\
\text { pode ser) }\end{array}$ & $\mathrm{I}, 2,2$ & II, 2,1 & & $\begin{array}{l}\mathrm{I}, 9,2 \\
\mathrm{I}, 9,4\end{array}$ & $\begin{array}{l}\text { IV , 9, 2; } \\
\text { IV }, 9,3\end{array}$ & $\begin{array}{l}\text { III, } 6,2 ; \\
\text { III, } 6,3 ; \\
\text { III, } 6,4 ; \\
\text { III, } 6,5\end{array}$ \\
\hline $\begin{array}{l}\text { Advogado (vedação } \\
\text { "pactum quota litis") } \\
\text { "redemptores } \\
\text { causarum" }\end{array}$ & $\mathrm{I}, 2,3$ & & & $\begin{array}{l}\mathrm{I}, 9,1 \\
\mathrm{I}, 9,5\end{array}$ & IV, 9,8 & III, 6,14 \\
\hline $\begin{array}{l}\text { Advogado (vedação } \\
\text { atuar pelas } 2 \text { partes) } \\
\text { "prevaricatores } \\
\text { causarum" }\end{array}$ & $\mathrm{I}, 2,3$ & & & $\mathrm{I}, 9,5$ & IV, 9,7 & III, 6,15 \\
\hline $\begin{array}{l}\text { Advogado (vedação } \\
\text { acusações falsas) } \\
\text { "concinatores } \\
\text { causarum" }\end{array}$ & $\mathrm{I}, 2,3$ & & & & & \\
\hline $\begin{array}{l}\text { Extras - regras do } \\
\text { depoimento pessoal } \\
\text { da parte }\end{array}$ & $\mathrm{I}, 2,4$ & & & & & III, 5,22 \\
\hline Procurador (utilidade) & $\mathrm{I}, 3,1$ & II, 1,1 & & & $\mathrm{IV}, 8, \mathrm{pr}$. & III, 5 pr. \\
\hline $\begin{array}{l}\text { Procurador } \\
\text { (definição) }\end{array}$ & $\mathrm{I}, 3,2$ & II, 1,2 & & & $\mathrm{IV}, 8,1$ & III, 5,1 \\
\hline $\begin{array}{l}\text { Procurador (forma de } \\
\text { constituição) }\end{array}$ & $\mathrm{I}, 3,2$ & II, 1,3 & & $\mathrm{I}, 10,1$ & $\begin{array}{l}\text { IV , } 8,7 \\
\text { IV }, 8,8\end{array}$ & $\begin{array}{l}\text { III, 5, 13; } \\
\text { III, 5, 15 }\end{array}$ \\
\hline $\begin{array}{l}\text { Procurador ("ex } \\
\text { mandato" e } \\
\text { aproximação } \\
\text { funcional) }\end{array}$ & $\mathrm{I}, 3,2$ & II, 1,2 & & & IV $, 8,1$ & \\
\hline Procurador & $\mathrm{I}, 3,3$ & II, 1,5 & & $\mathrm{I}, 10,8$ & IV $, 8,10$ & III, 5,18 \\
\hline
\end{tabular}




\begin{tabular}{|c|c|c|c|c|c|}
\hline $\begin{array}{l}\text { (pluralidade de } \\
\text { agentes e regime } \\
\text { jurídico) }\end{array}$ & & & & & \\
\hline $\begin{array}{l}\text { Procurador (quem não } \\
\text { pode ser e casos } \\
\text { excepcionais de } \\
\text { atuação dos vedados) }\end{array}$ & $I, 3,4$ & II, 1,4 & $\begin{array}{l}\text { I, } 10,3 ; \\
\text { I, } 10,4 ; \\
\text { I, } 10,16\end{array}$ & $\begin{array}{l}\text { IV }, 8,2 \\
\text { IV }, 8,3\end{array}$ & $\begin{array}{l}\text { III, 5, 5; } \\
\text { III, 5, 6; } \\
\text { III, 5, 7; } \\
\text { III, 5, 8; } \\
\text { III, 5, 9; } \\
\text { III, 5, } 19\end{array}$ \\
\hline $\begin{array}{l}\text { Procurador } \\
\text { (legitimado especial, } \\
\text { excepcionalmente } \\
\text { sem mandato e com } \\
\text { caução de rato) }\end{array}$ & $\mathrm{I}, 3,5$ & II, 1,6 & $\begin{array}{l}\text { I, } 10,4 \\
\text { I, } 10,5 \\
\text { I, } 10,14\end{array}$ & $\begin{array}{l}\text { IV }, 8,11 \\
\text { IV }, 8,15\end{array}$ & $\begin{array}{l}\text { III, 5, 10; } \\
\text { IV, } 17,12\end{array}$ \\
\hline $\begin{array}{l}\text { Procurador (sem } \\
\text { poderes expressos e } \\
\text { sem indícios) }\end{array}$ & $\mathrm{I}, 3,6$ & & & & \\
\hline $\begin{array}{l}\text { Procurador (sem } \\
\text { poderes expressos, } \\
\text { mas com indícios e } \\
\text { caução de rato) }\end{array}$ & $\mathrm{I}, 3,7$ & & & & \\
\hline $\begin{array}{l}\text { Gestão de negócios } \\
\text { processual (e } \\
\text { "iudicatum solvi”) }\end{array}$ & $\mathrm{I}, 3,8$ & & $\mathrm{I}, 10,14$ & $\begin{array}{l}\text { IV }, 8,8 \\
\text { IV }, 8,11 \\
\text { IV }, 8,16\end{array}$ & \\
\hline $\begin{array}{l}\text { Procurador } \\
\text { (inadmissibilidade em } \\
\text { certos feitos) }\end{array}$ & $\begin{array}{l}\mathrm{I}, 3,9 \\
\mathrm{I}, 13,3\end{array}$ & II, 1,7 & $\begin{array}{l}\mathrm{I}, 10,2 \\
\mathrm{I}, 10,7\end{array}$ & $\begin{array}{l}\text { IV }, 8,12 \\
\text { IV }, 8,13 \\
\text { IV }, 8,14\end{array}$ & III, 5,12 \\
\hline $\begin{array}{l}\text { Procurador (extinção } \\
\text { da "procura") }\end{array}$ & $\mathrm{I}, 3,10$ & II, 1,9 & $\mathrm{I}, 10,18$ & & III, 5,23 \\
\hline $\begin{array}{l}\text { Procurador (quem } \\
\text { pode constituir) }\end{array}$ & & $I I, 1,2$ & I, 10,9 & $\begin{array}{l}\text { IV }, 8,3 \\
\text { IV }, 8,4 \\
\text { IV }, 8,5 \\
\text { IV }, 8,6\end{array}$ & $\begin{array}{l}\text { III, 5, 2; } \\
\text { III, 5, 3; } \\
\text { III, 5, 4; } \\
\text { III, 5, } 11\end{array}$ \\
\hline $\begin{array}{l}\text { Procuração ("cláusula } \\
\text { de rato") }\end{array}$ & & II, 1,3 & $\begin{array}{l}\text { I, } 10,6 \\
\text { I, } 10,8\end{array}$ & IV $, 8,9$ & \\
\hline $\begin{array}{l}\text { Procurador ("ad } \\
\text { litem" e limites de sua } \\
\text { atuação, segundo } \\
\text { “carta de personeria") }\end{array}$ & & II, 1,8 & $\begin{array}{l}\mathrm{I}, 10,11 \\
\mathrm{I}, 10,13\end{array}$ & $\mathrm{IV}, 8,18$ & $\begin{array}{l}\text { III, } 5,19 \\
\text { III, } 5,21\end{array}$ \\
\hline Procurador & & II, 1,8 & & & \\
\hline
\end{tabular}




\begin{tabular}{|c|c|c|c|c|c|c|}
\hline (substabelecimento) & & & & & & \\
\hline $\begin{array}{l}\text { Procurador } \\
\text { (extrajudicial) }\end{array}$ & & II, 1,8 & & & & III, 5,2 \\
\hline $\begin{array}{l}\text { Procurador } \\
\text { (prorrogação após } \\
\text { morte do principal) }\end{array}$ & & II, 1,9 & & $\mathrm{I}, 10,18$ & IV $, 8,10$ & III, 5,23 \\
\hline $\begin{array}{l}\text { Procurador } \\
\text { (prorrogação após } \\
\text { morte do agente) }\end{array}$ & & II, 1,9 & & $\mathrm{I}, 10,18$ & $\mathrm{IV}, 8,10$ & III, 5, 23 \\
\hline $\begin{array}{l}\text { Procurador } \\
\text { (prorrogação para } \\
\text { efeitos recursais, } \\
\text { mesmo sem previsão } \\
\text { na "carta de } \\
\text { personeria") }\end{array}$ & & II, 1,9 & & $\mathrm{I}, 10,11$ & $\mathrm{IV}, 8,17$ & III, 5,23 \\
\hline $\begin{array}{l}\text { Procurador } \\
\text { (revogação e negócio } \\
\text { receptício) }\end{array}$ & & II, 1,9 & & $\mathrm{I}, 10,12$ & $\begin{array}{l}\text { IV, } 8,10 \\
\text { IV } 8,19\end{array}$ & III, 5,24 \\
\hline $\begin{array}{l}\text { Efeitos da } \\
\text { "procuratio" } \\
\text { (representativos } \\
\text { diretos, com } \\
\text { atingimento dos bens } \\
\text { do principal e dos } \\
\text { garantes, mas não do } \\
\text { procurador) }\end{array}$ & & II, 1,10 & & $\mathrm{I}, 10,17$ & $\begin{array}{l}\text { IV , 8, 12; } \\
\text { IV , 8, 15; } \\
\text { IV , 8, 17; } \\
\text { IV , } 8,19\end{array}$ & $\begin{array}{l}\text { III, 5, 25; } \\
\text { III, 5, 27; } \\
\text { V, 11, 8; } \\
\text { V, } 11,9\end{array}$ \\
\hline $\begin{array}{l}\text { Efeitos da gestão de } \\
\text { negócios processual } \\
\text { (representação } \\
\text { indireta) }\end{array}$ & & II, 1,10 & & & & III, 5, 27 \\
\hline Advogado (utilidade) & $\mathrm{I}, 2,4$ & II, 2,1 & & & IV, 9, pr. & III, 6 pr. \\
\hline Advogado (definição) & & II, 2,1 & & & $\mathrm{IV}, 9,1$ & III, 6,1 \\
\hline $\begin{array}{l}\text { Advogado (modo de } \\
\text { proceder em juízo) }\end{array}$ & & II, 2,2 & & $\mathrm{I}, 9,5$ & $\mathrm{IV}, 9,4$ & III, 6,7 \\
\hline $\begin{array}{l}\text { Advogado (o que diz } \\
\text { diante da parte que } \\
\text { aquiesce, a vincula) }\end{array}$ & & II, 2,3 & & & & III, 6,8 \\
\hline $\begin{array}{l}\text { Momentos do } \\
\text { processo }\end{array}$ & & & Prologo & & & \\
\hline
\end{tabular}




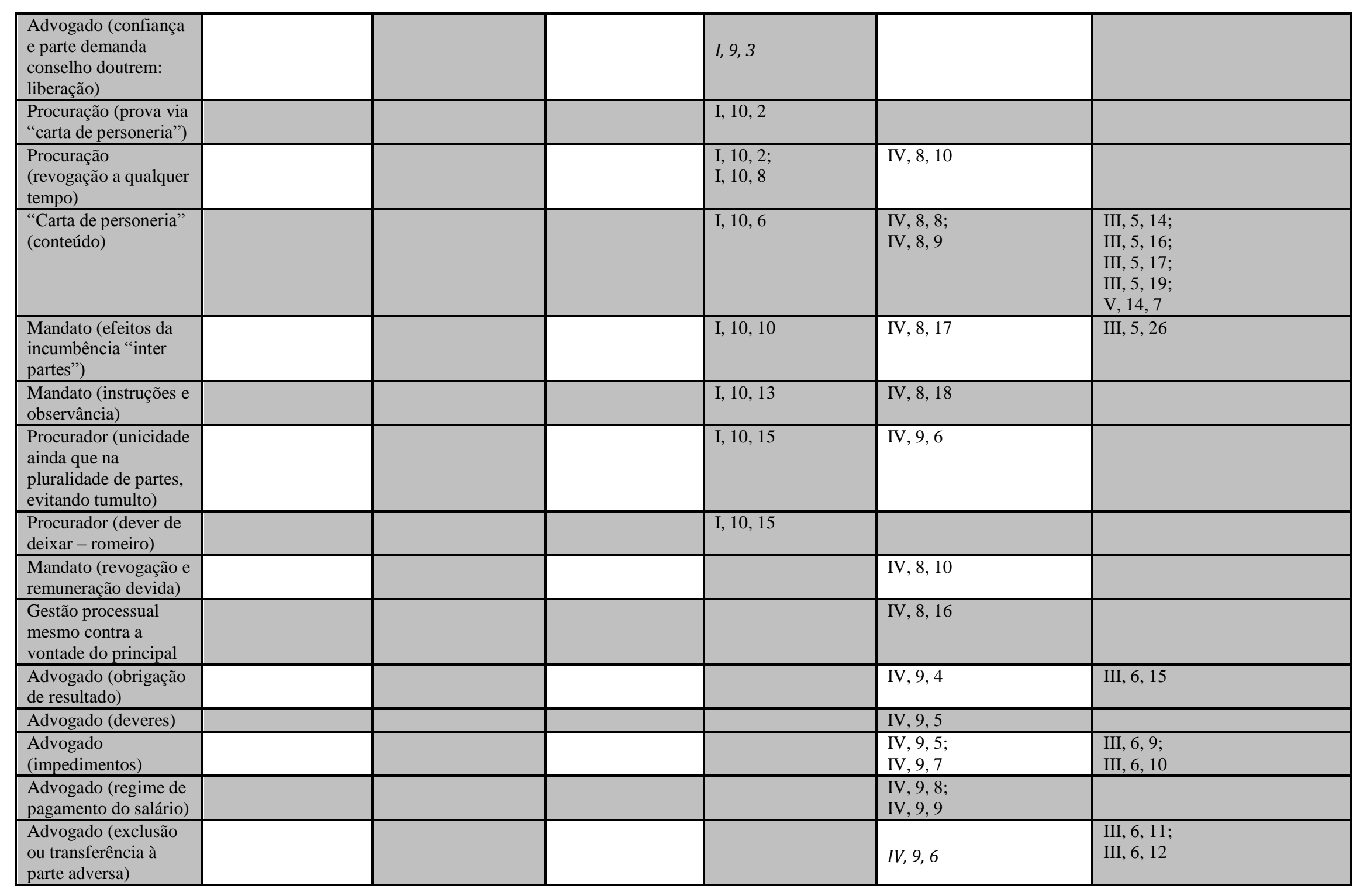




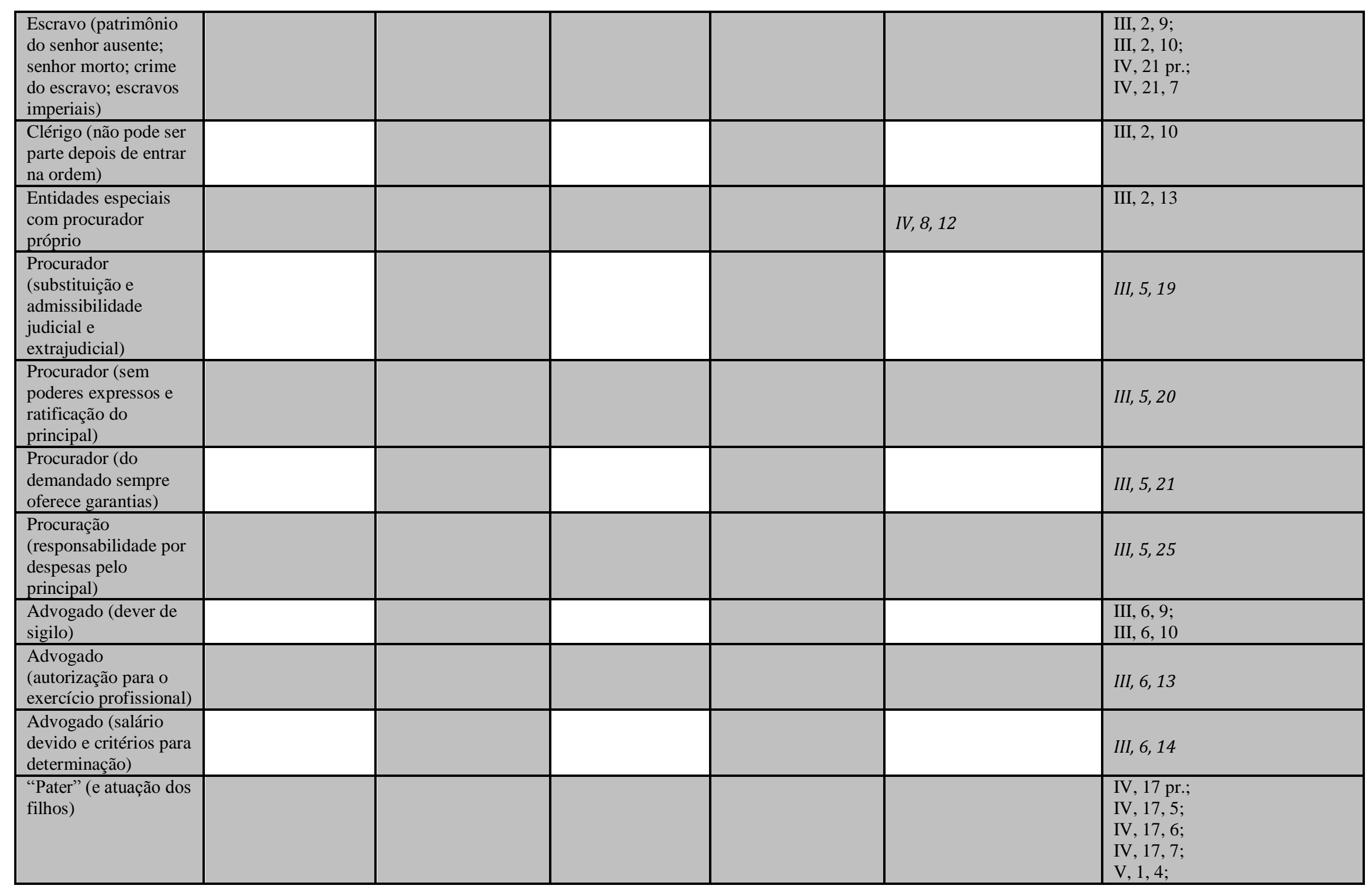




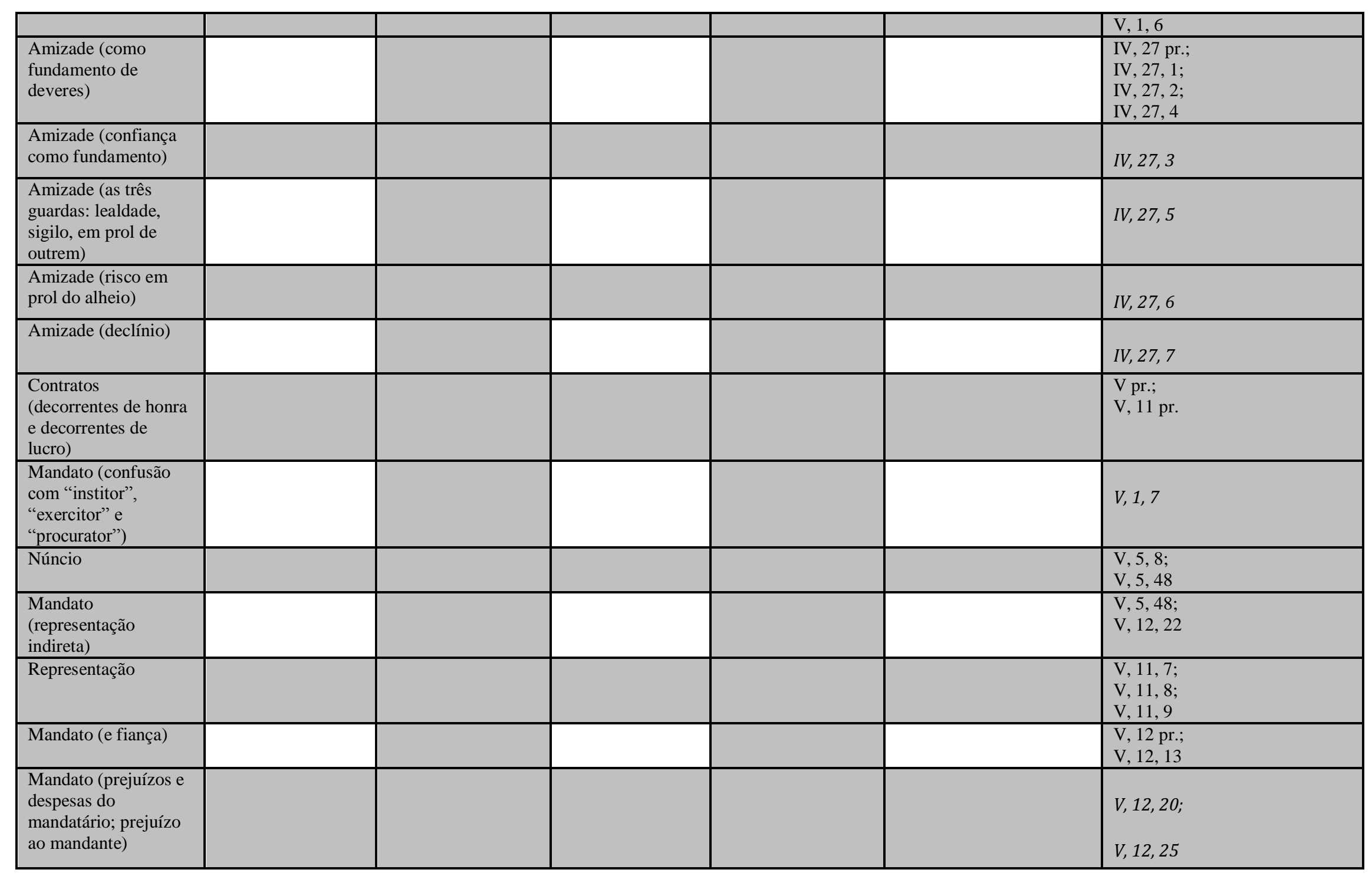




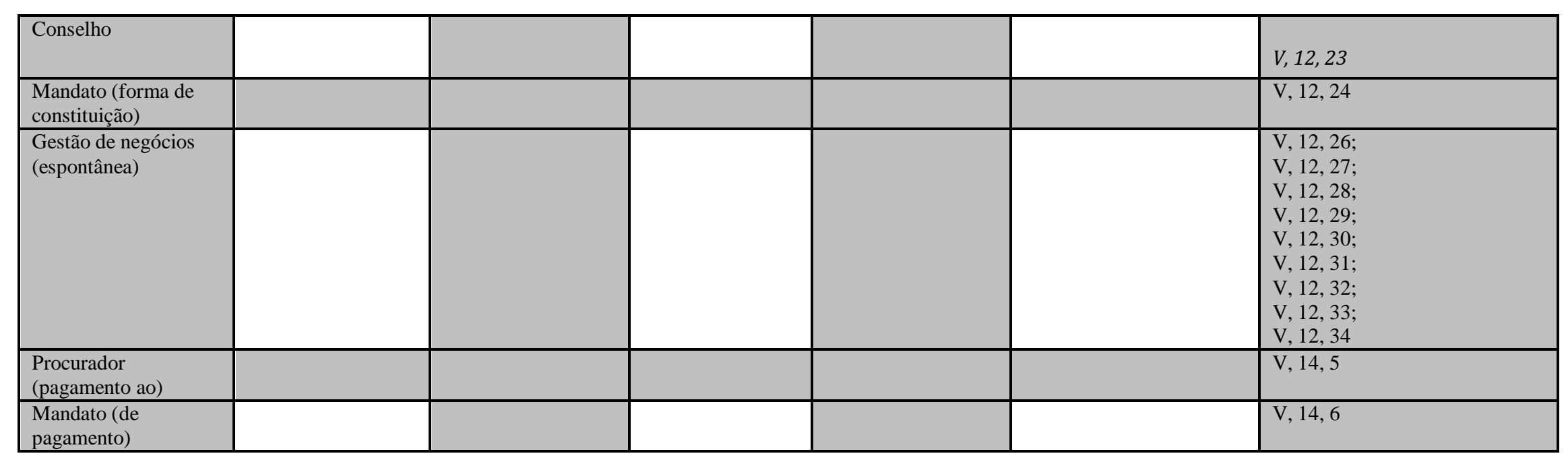




\section{ANEXO III \\ TABELA DE CORRESPONDÊNCIA No II - \\ DIREITO LUSITANO \\ (PERÍODOS MEDIEVAL E MODERNO)}

\begin{tabular}{|c|c|c|c|c|c|c|c|c|}
\hline regra & $\begin{array}{l}\text { Livro das Leis e } \\
\text { Posturas }\end{array}$ & Ord. Dom Duarte & Ord. Afonsinas & $\begin{array}{l}\text { Extravagantes } \\
\text { pós-Afonsinas }\end{array}$ & Ord. Manuelinas & $\begin{array}{l}\text { Extravagantes } \\
\text { pós- } \\
\text { Manuelinas } \\
\text { (coligidas pelo } \\
\text { licenciado } \\
\text { Duarte Nunes } \\
\text { do Lião) }\end{array}$ & Ord. Filipinas & $\begin{array}{l}\text { Extravagantes } \\
\text { pós-Filipinas }\end{array}$ \\
\hline $\begin{array}{l}\text { prevalência direito } \\
\text { canônico sobre o } \\
\text { pátrio (régio) }\end{array}$ & "lei 1" & "lei 1" & & $\begin{array}{l}\text { Assento (ou } \\
\text { Determinação } \\
\text { Régia em } \\
\text { Relação) de } \\
06.02 .1512\end{array}$ & Liv. I, Tít. $38\left(\S 5^{\circ}\right)$ & & Liv. I, Tít. $48\left(\S 6^{\circ}\right)$ & \\
\hline $\begin{array}{l}\text { procurador: quem } \\
\text { (não) pode ser; }\end{array}$ & $\begin{array}{l}\text { "lei 2", "lei 14", "lei } \\
\text { 26", "lei 33" }\end{array}$ & $\begin{array}{l}\text { "lei 15", "lei 17", "lei } \\
18 \text { ", "lei 19", "lei } \\
\text { 20", "lei 25", "lei } \\
\text { 26", "lei 68", "lei 80" }\end{array}$ & $\begin{array}{l}\text { Liv. I, Tít. 13 ( } \S \\
\text { 12, 13, 14, 15, 16, } \\
\text { 17, 18, 19, 20, 28); } \\
\text { Liv. I, Tít. 16 (§ 11); } \\
\text { Liv. I, Tít. } 47 \text { ( } 14) ; \\
\text { Liv. III, Tít. 117; } \\
\text { Liv. III, Tít. 51; } \\
\text { Liv. III, Tít. 22; } \\
\text { Liv. III, Tít. 20 (\$§ } \\
\text { 15, 17, 18) }\end{array}$ & & $\begin{array}{l}\text { Liv. I, Tít. } 20 \text { (§ } 21) ; \\
\text { Liv. I, Tít. } 60(\$ \S 23 \text {, } \\
\text { 24); } \\
\text { Liv. I, Tít. } 38(\$ \S 14 \text {, } \\
\text { 15, 16, 17, 18, 19, 20, } \\
\text { 21, 22, 23, 24); } \\
\text { Liv. I, Tít. } 56 \text { ( } 28) ; \\
\text { Liv. III, Tít. 34; Livro } \\
\text { III, Tít. } 15 \text { ( } 11)\end{array}$ & & $\begin{array}{l}\text { Liv. I, Tít. } 24 \text { (§ } \\
\text { 18); } \\
\text { Liv. I, Tít. } 79 \text { ( } \\
\text { 45); } \\
\text { Liv. I, Tít. } 48 \text { ( } \S \\
\text { 19, 20, 21, 22, 23, } \\
\text { 24, 25, 26, 27, 28, } \\
\text { 29); } \\
\text { Liv. III, Tít. } 28\end{array}$ & $\begin{array}{l}\text { D. de } \\
\text { 19.11.1722; } \\
\text { D. de } \\
09.01 .1723\end{array}$ \\
\hline $\begin{array}{l}\text { procurador: quem } \\
\text { (não) pode } \\
\text { constituir; quem } \\
\text { "deve" constituir } \\
\text { (poderosos) } \\
\end{array}$ & $\begin{array}{l}\text { "lei 2", "lei 24", "lei } \\
36 "\end{array}$ & "lei 12", "lei 21" & $\begin{array}{l}\text { Liv. I, Tít. } 13 \text { (\$§ } \\
21,22,23,24,25)\end{array}$ & & $\begin{array}{l}\text { Liv. I, Tít. } 38 \text { ( } \S 25 \text {, } \\
26,27,28)\end{array}$ & & $\begin{array}{l}\text { Liv. III, Tít. } 29(\S \\
\left.1^{\circ}\right)\end{array}$ & \\
\hline $\begin{array}{l}\text { advogado e } \\
\text { disposição social } \\
\text { (eventual influxo } \\
\text { castelhano); } \\
\text { inclusive para evitar } \\
\text { malícia }\end{array}$ & $\begin{array}{l}\text { "lei 2", "lei 8", "lei } \\
\text { 12", "lei 30" }\end{array}$ & "lei 8", "lei 9" & $\begin{array}{l}\text { Liv. I, Tít. } 13\left(\$ \S 5^{\circ} \text {, }\right. \\
\text { 20) }\end{array}$ & & $\begin{array}{l}\text { Liv. I, Tít. } 38 \text { (\$§6, } \\
\text { 22) }\end{array}$ & & $\begin{array}{l}\text { Liv. III, Tít. } 20 \text { (§ } \\
\text { 14) }\end{array}$ & \\
\hline proibição de & "lei 3" & "lei 42" & & & & & & \\
\hline
\end{tabular}




\begin{tabular}{|c|c|c|c|c|c|c|c|c|}
\hline $\begin{array}{l}\text { compartilhar leito } \\
\text { com interessado no } \\
\text { litígio }\end{array}$ & & & & & & & & \\
\hline $\begin{array}{l}\text { salários e momento } \\
\text { de pagamento (as } \\
\text { questões dos víveres } \\
\text { e da eventual } \\
\text { punição) }\end{array}$ & $\begin{array}{l}\text { "lei 4", "lei 5", "lei } \\
\text { 18", "lei 25"; } \\
\text { "lei 37" }\end{array}$ & $\begin{array}{l}\text { "lei 36", "lei 38", "lei } \\
50 ", " \text { "lei 51", "lei } \\
\text { 52", "lei } 87 \text { " }\end{array}$ & $\begin{array}{l}\text { Liv. I, Tít. } 13(\S \S \\
32,33)\end{array}$ & & Liv. I, Tít. 38 (§ 34) & & & \\
\hline $\begin{array}{l}\text { aproximação entre } \\
\text { "procurador" e } \\
\text { "vogado" }\end{array}$ & $\begin{array}{l}\text { "lei 4", "lei 18", "lei } \\
\text { 23", "lei } 25 "\end{array}$ & $\begin{array}{l}\text { "lei 26", "lei 36", "lei } \\
50 ", " \text { "lei 82" }\end{array}$ & 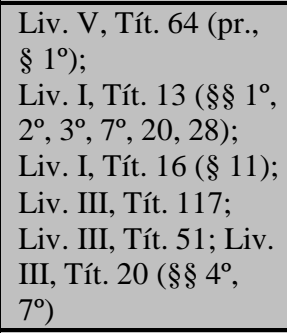 & & $\begin{array}{l}\text { Liv. V, Tít. 55; } \\
\text { Liv. I, Tít. } 60 \text { (§ 23); } \\
\text { Liv. I, Tít. } 56(\S 28) ; \\
\text { Liv. I, Tít. } 11\left(\$ 2^{\circ}\right) ; \\
\text { Liv. III, Tít. } 34\end{array}$ & S. IV $, 17,13$ & $\begin{array}{l}\text { Liv. I, Tít. } 24 \text { (§ } \\
\text { 18); } \\
\text { Liv. III, Tít. } 28\end{array}$ & \\
\hline $\begin{array}{l}\text { idéia de gestão } \\
\text { colaborativa }\end{array}$ & "lei 4" & "lei 36", "lei 86" & & & & & & \\
\hline $\begin{array}{l}\text { efeito imediato e } \\
\text { plano da eficácia }\end{array}$ & $\begin{array}{l}\text { "lei 5", "lei 25", "lei } \\
39 "\end{array}$ & "lei 52" & & & & & & \\
\hline $\begin{array}{l}\text { constituição de } \\
\text { advogado após } \\
\text { encerramento do } \\
\text { feito (próximo à } \\
\text { leitura da sentença) }\end{array}$ & "lei 6", "lei 17" & "lei 44", "lei 45" & Liv. III, Tít. 49 & & Liv. III, Tít. 33 & S. III, $1,7,25$ & $\begin{array}{l}\text { Liv. III, Tít. } 20 \text { (§ } \\
\text { 30) }\end{array}$ & \\
\hline $\begin{array}{l}\text { advogado: quem não } \\
\text { pode ser }\end{array}$ & $\begin{array}{l}\text { "lei 2", "lei 7", "lei } \\
\text { 20", "lei 22", "lei } \\
\text { 23", "lei 33", "lei } \\
40 "\end{array}$ & $\begin{array}{l}\text { "lei 22", "lei 26", "lei } \\
35 ", \text { "lei 37" }\end{array}$ & $\begin{array}{l}\text { Liv. I, Tít. } 16 \text { (§ 11); } \\
\text { Liv. I, Tít. } 47 \text { (\$ 14); } \\
\text { Liv. III, Tít. } 117 ; \\
\text { Liv. III, Tít. } 51 \\
\end{array}$ & & $\begin{array}{l}\text { Liv. I, Tít. } 20 \text { (§ 21); } \\
\text { Liv. I, Tít. } 60(\$ 23) ; \\
\text { Liv. I, Tít. } 56(\S 28) ; \\
\text { Liv. III, Tít. } 34 \\
\end{array}$ & & $\begin{array}{l}\text { Liv. I, Tít. } 24 \text { (§ } \\
\text { 18); } \\
\text { Liv. III, Tít. } 28\end{array}$ & \\
\hline $\begin{array}{l}\text { "perjuro" de quem } \\
\text { pede advogado } \\
\text { (prazo) e não } \\
\text { comparece }\end{array}$ & "lei 9", "lei 34" & "lei 10", "lei 72" & & & & & & \\
\hline $\begin{array}{l}\text { procurador: fontes } \\
\text { de burlas e prejuízos }\end{array}$ & $\begin{array}{l}\text { "lei 10","lei 16", } \\
\text { "lei 32", "lei 34" }\end{array}$ & $\begin{array}{l}\text { "lei 27", "lei 56", “lei } \\
57 ”, " \text { "lei 71", "lei } \\
73 \text { ", "lei 75", "lei 82" }\end{array}$ & $\begin{array}{l}\text { Liv. I, Tít. } 13(\S \S \\
29,32)\end{array}$ & $\begin{array}{l}\text { Alvará de } \\
04.07 .1515\end{array}$ & & & & \\
\hline $\begin{array}{l}\text { procurador: danos e } \\
\text { correção pelos } \\
\text { corpos e pelos bens }\end{array}$ & $\begin{array}{l}\text { "lei 10","lei 16", } \\
\text { "lei 32" }\end{array}$ & "lei 27" & $\begin{array}{l}\text { Liv. I, Tít. } 13\left(\S \S 3^{\circ} \text {, }\right. \\
\text { 29) }\end{array}$ & & $\begin{array}{l}\text { Liv. I, Tít. } 38 \text { (\$ 29); } \\
\text { Liv. III, Tít. } 15(\$ 27)\end{array}$ & & Liv. I, Tít. 48 (§ 10) & \\
\hline
\end{tabular}




\begin{tabular}{|c|c|c|c|c|c|c|c|}
\hline $\begin{array}{l}\text { procurador: } \\
\text { montante de salários } \\
\text { (e não façam } \\
\text { companhia) }\end{array}$ & $\begin{array}{l}\text { "lei 10", "lei 16", } \\
\text { "lei 19", "lei } 21 "\end{array}$ & $\begin{array}{l}\text { "lei 28", "lei 30", "lei } \\
\text { 34", "lei 49", "lei 85" }\end{array}$ & $\begin{array}{l}\text { Liv. I, Tít. } 13 \text { (§ 31); } \\
\text { Liv. I, Tít. } 45\end{array}$ & & $\begin{array}{l}\text { Liv. I, Tít. 71; } \\
\text { Liv. I, Tít. } 2(\$ 33) ; \\
\text { Liv. I, Tít. } 38 \text { (§ 31) }\end{array}$ & $\begin{array}{l}\text { S. I, 3, } 1(\S \S 3 \\
\text { e } 10)\end{array}$ & $\begin{array}{l}\text { Liv. I, Tít. } 14 \text { (§ 2); } \\
\text { Liv. I, Tít. 92; } \\
\text { Liv. I, Tít. } 48 \text { (§ 11) }\end{array}$ \\
\hline $\begin{array}{l}\text { procurador: } \\
\text { observância das } \\
\text { posturas }\end{array}$ & $\begin{array}{l}\text { "lei 10","lei 16", } \\
\text { "lei 21" }\end{array}$ & "lei 31" & Liv. I, Tít. $13\left(\S 2^{\circ}\right)$ & $\begin{array}{l}\text { Assento (ou } \\
\text { Determinação } \\
\text { Régia em } \\
\text { Relação) de } \\
06.02 .1512\end{array}$ & $\begin{array}{l}\text { Liv. I, Tít. } 38\left(\S \S 4^{\circ},\right. \\
\left.5^{\circ}\right)\end{array}$ & & Liv. I, Tít. $48\left(\S 6^{\circ}\right)$ \\
\hline $\begin{array}{l}\text { advogado: bom uso } \\
\text { da advocacia } \\
\text { (atuação leal, dever } \\
\text { de renúncia e } \\
\text { juramento sobre os } \\
\text { evangelhos) }\end{array}$ & $\begin{array}{l}\text { "lei 11"," "lei 16", } \\
\text { "lei 19"," "lei 21", } \\
\text { "lei 32" }\end{array}$ & $\begin{array}{l}\text { "lei 32", "lei 34", "lei } \\
48 \text { ", "lei 53", "lei 63" }\end{array}$ & Liv. I, Tít. $13\left(\S 2^{\circ}\right)$ & & Liv. I, Tít. 38 (§ 4) & & \\
\hline $\begin{array}{l}\text { advogado: } \\
\text { observância das } \\
\text { posturas e } \\
\text { responsabilidade } \\
\text { pelas custas } \\
\text { (eventual) }\end{array}$ & $\begin{array}{l}\text { "lei 11","lei 16", } \\
\text { "lei 21" }\end{array}$ & $\begin{array}{l}\text { "lei 29", "lei 32", "lei } \\
33 "\end{array}$ & $\begin{array}{l}\text { Liv. I, Tít. } 13\left(\S \S 3^{\circ} \text {, }\right. \\
\text { 29) }\end{array}$ & & $\begin{array}{l}\text { Liv. I, Tít. } 4 \text { (§ 15); } \\
\text { Liv. I, Tít. } 38 \text { (§§ } 4 \text { e } \\
\text { 29) }\end{array}$ & & $\begin{array}{l}\text { Liv. I, Tít. } 6 \text { (\$ 11); } \\
\text { Liv. I, Tít. } 48 \text { (§ 7); } \\
\text { Lei de 24.03.1590 } \\
\text { (§ 17); } \\
\text { Lei de 18.11.1577 } \\
(\S 25)\end{array}$ \\
\hline $\begin{array}{l}\text { advogado: dever de } \\
\text { buscar celeridade }\end{array}$ & $\begin{array}{l}\text { "lei 11","lei 16", } \\
\text { "lei 21" }\end{array}$ & "lei 32" & Liv. I, Tít. $13\left(\S 2^{\circ}\right)$ & & Liv. I, Tít. 38 (§ 4) & & \\
\hline $\begin{array}{l}\text { advogado: abandono } \\
\text { e responsabilidade } \\
\text { (despesas, prejuízos } \\
\text { e restituição em } \\
\text { dobro) } \\
\end{array}$ & $\begin{array}{l}\text { "lei 11","lei 16", } \\
\text { "lei 21" }\end{array}$ & "lei 32" & Liv. I, Tít. $13\left(\S 7^{\circ}\right)$ & & $\begin{array}{l}\text { Liv. I, Tít. } 38(\S \S 9, \S \\
11)\end{array}$ & & $\begin{array}{l}\text { Liv. I, Tít. } 48 \text { (§§ } 8 \\
\text { e 9) }\end{array}$ \\
\hline $\begin{array}{l}\text { cônjuge: } \\
\text { "procuração", } \\
\text { "consentimento" ou } \\
\text { "vênia" (pena de } \\
\text { invalidade) - } \\
\text { alienação e processo }\end{array}$ & "lei 13", "lei 39" & "lei 11", "lei 39" & $\begin{array}{l}\text { Liv. IV, Tít. 11; } \\
\text { Liv. IV, Tít. 16; Liv. } \\
\text { III, Tít. 45; Liv. III, } \\
\text { Tít. } 46\end{array}$ & $\begin{array}{l}\text { Regimento da } \\
\text { Fazenda de } \\
\text { 17.10.1516 (cap. } \\
\text { 170); } \\
\text { Cortes de Lisboa } \\
\text { de 1498 (cap. 7) }\end{array}$ & $\begin{array}{l}\text { Liv. IV, Tít. 6; } \\
\text { Liv. IV, Tít. 13; Liv. } \\
\text { III, Tít. } 32\end{array}$ & S. III, $1,7,33$ & $\begin{array}{l}\text { Liv. IV, Tít. 48; } \\
\text { Liv. IV, Tít. 60; } \\
\text { Liv. IV, Tít. 64; } \\
\text { Liv. III, Tít. } 47\end{array}$ \\
\hline $\begin{array}{l}\text { procuração e } \\
\text { "cláusula de rato" }\end{array}$ & "lei 15", "lei 35" & "lei 40" & & & & & \\
\hline $\begin{array}{l}\text { ordem dos litígios: } \\
\text { procurador } \\
\text { insuficiente }\end{array}$ & "lei 17" & "lei 23", "lei 43" & $\begin{array}{l}\text { Liv. I, Tít. } 13\left(\S \S 8^{\circ},\right. \\
\left.9^{\circ}, 11\right) ; \\
\text { Liv. III, Tít. } 68(\S \\
\left.4^{\circ}\right) ;\end{array}$ & & $\begin{array}{l}\text { Liv. I, Tít. } 38(\S \S 12 \text {, } \\
\text { 13); } \\
\text { Liv. III, Tít. } 49\left(\S 1^{\circ}\right) ; \\
\text { Liv. III, Tít. } 15(\$ \S \\
\end{array}$ & S. III, $1,7,33$ & $\begin{array}{l}\text { Liv. III, Tít. } 63 \text { ( } \\
\left.1^{\circ}\right) ; \\
\text { Liv. III, Tít. } 20 \text { ( } \S \\
10,11,12)\end{array}$ \\
\hline
\end{tabular}




\begin{tabular}{|c|c|c|c|c|c|c|c|}
\hline & & & $\begin{array}{l}\text { Liv. III, Tít. } 20 \text { (§\$ } \\
11,15,17,18)\end{array}$ & & $\left.10^{\circ}, 11\right)$ & & \\
\hline $\begin{array}{l}\text { múltiplos advogados } \\
\text { (restrição): para } \\
\text { evitar prejuízo à } \\
\text { tramitação dos } \\
\text { demais processos }\end{array}$ & "lei 17" & "lei 46", "lei 54" & & & & & \\
\hline $\begin{array}{l}\text { procuração: forma e } \\
\text { conteúdo } \\
\text { (elementos) }\end{array}$ & "lei 27", "lei 28" & $\begin{array}{l}\text { "lei 5", "lei 6", "lei } \\
\text { 12" }\end{array}$ & Liv. I, Tít. $13\left(\S 6^{\circ}\right)$ & & Liv. I, Tít. 38 (§ 7) & Liv. III, Tít. 29 (pr.) & \\
\hline $\begin{array}{l}\text { extensão da outorga } \\
\text { de poderes }\end{array}$ & $\begin{array}{l}\text { "lei 29", "lei 31", } \\
\text { "lei 32", "lei 39" }\end{array}$ & $\begin{array}{l}\text { "lei 7", "lei 13", "lei } \\
\text { 16", "lei 58" }\end{array}$ & Liv. I, Tít. 13 (\$ 26) & & & & \\
\hline $\begin{array}{l}\text { prova da procuração } \\
\text { (mesmo sem } \\
\text { documento) }\end{array}$ & "lei 29" & "lei 7" & & & & & \\
\hline $\begin{array}{l}\text { fato superveniente, } \\
\text { informação ao } \\
\text { principal e } \\
\text { instruções } \\
\text { (testemunhas para } \\
\text { contradita) }\end{array}$ & "lei 32" & "lei 59" & Liv. I, Tít. $13\left(\S 4^{\circ}\right)$ & & & & \\
\hline $\begin{array}{l}\text { informação } \\
\text { completa sobre o } \\
\text { litígio (e por escrito) } \\
\end{array}$ & "lei 32" & "lei 60" & $\begin{array}{l}\text { Liv. I, Tít. } 13\left(\S \S 3^{\circ},\right. \\
\left.4^{\circ}\right) ; \\
\text { Liv. III, Tít. } 20, \S 4 \\
\end{array}$ & $\begin{array}{l}\text { Cortes de Lisboa } \\
\text { de } 1498 \text { (art. 10) }\end{array}$ & $\begin{array}{l}\text { Liv. I, Tít. } 38(\S 36) ; \\
\text { Liv. III, Tít. } 15\left(\S 2^{\circ}\right)\end{array}$ & $\begin{array}{l}\text { Liv. I, Tít. } 48 \text { (§§ } \\
\text { 15, 16, 17, 18); Liv. } \\
\text { III, Tít. } 20\left(\S 2^{\circ}\right)\end{array}$ & \\
\hline $\begin{array}{l}\text { advogado: desídia e } \\
\text { perda dos salários } \\
\text { (dentre outras } \\
\text { punições eventuais) }\end{array}$ & "lei 32" & $\begin{array}{l}\text { "lei 65", "lei 66", "lei } \\
67 "\end{array}$ & & & & & \\
\hline $\begin{array}{l}\text { assistência do } \\
\text { advogado após o } \\
\text { contato da parte com } \\
\text { o juiz }\end{array}$ & "lei 32" & "lei 62" & & & & & \\
\hline $\begin{array}{l}\text { procuração geral } \\
\text { (vedação e admissão } \\
\text { em caráter } \\
\text { excepcional) }\end{array}$ & "lei 34" & "lei 76", "lei 77" & Liv. I, Tít. 13 (\$ 26) & & & & \\
\hline $\begin{array}{l}\text { contingenciamento } \\
\text { profissional e } \\
\text { excesso de } \\
\text { procuradores; bem }\end{array}$ & "lei 34" & "lei 78", "lei 83" & & & & & \\
\hline
\end{tabular}




\begin{tabular}{|c|c|c|c|c|c|c|}
\hline $\begin{array}{l}\text { como controle } \\
\text { administrativo }\end{array}$ & & & & & & \\
\hline $\begin{array}{l}\text { substabelecimento } \\
\text { motivado }\end{array}$ & "lei 34" & "lei 74" & & & & \\
\hline $\begin{array}{l}\text { procurador do } \\
\text { concelho }\end{array}$ & "lei 34" & "lei 69", "lei 70" & Liv. I, Tít. $29\left(\S 8^{\circ}\right)$ & Liv. I, Tít. $50\left(\S 1^{\circ}\right)$ & Liv. I, Tít. $69\left(\S 1^{\circ}\right)$ & \\
\hline inquisidores oficiais & $\begin{array}{l}\text { "lei 34" } \\
\text { "lei 32" }\end{array}$ & "lei 78-b", "lei 61" & & & & \\
\hline vedação & "lei 38", "lei 39" & "lei 88 " & & & & \\
\hline $\begin{array}{l}\text { alusão à boa razão } \\
\text { dos textos escritos }\end{array}$ & "lei 39" & & Liv. II, Tít. 63 (§ 3) & & & \\
\hline $\begin{array}{l}\text { proibição de } \\
\text { participação do } \\
\text { alcaide no resultado } \\
\text { do litígio }\end{array}$ & & "lei 3" & & & & \\
\hline $\begin{array}{l}\text { prazo de } \\
\text { aconselhamento } \\
\text { junto ao advogado }\end{array}$ & "lei 32" & "lei 4", "lei 64" & & Liv. III, Tít. $15\left(\S 4^{\circ}\right)$ & & \\
\hline $\begin{array}{l}\text { procuração "apud } \\
\text { acta" }\end{array}$ & & "lei 14" & $\begin{array}{l}\text { Liv. I, Tít. } 13\left(\S \S 6^{\circ} \text {, }\right. \\
\text { 27) }\end{array}$ & $\begin{array}{l}\text { Liv. I, Tít. } 38(\$ 8) ; \\
\text { Liv. III, Tít. } 15\left(\S 5^{\circ}\right) \\
\end{array}$ & Liv. III, Tít. 29 (pr.) & \\
\hline $\begin{array}{l}\text { advogado para o } \\
\text { pobre contra os } \\
\text { abusos dos } \\
\text { poderosos } \\
\text { opressores }\end{array}$ & "lei 41" & "lei 41" & & & & \\
\hline $\begin{array}{l}\text { advogados e } \\
\text { procuradores } \\
\text { auxiliares do juízo } \\
\text { na descoberta da } \\
\text { verdade }\end{array}$ & "lei 17" & "lei 47" & & & & \\
\hline $\begin{array}{l}\text { processo em Relação } \\
\text { e número de } \\
\text { advogados presentes } \\
\text { à sessão }\end{array}$ & & "lei 53" & & & & \\
\hline $\begin{array}{l}\text { possibilidade de } \\
\text { lançar mão dos seus } \\
\text { para "procurarem" } \\
\text { na Corte }\end{array}$ & & "lei $55 "$ & & & & \\
\hline $\begin{array}{l}\text { prestação de contas } \\
\text { dos procuradores }\end{array}$ & & "lei 84" & & & & \\
\hline
\end{tabular}




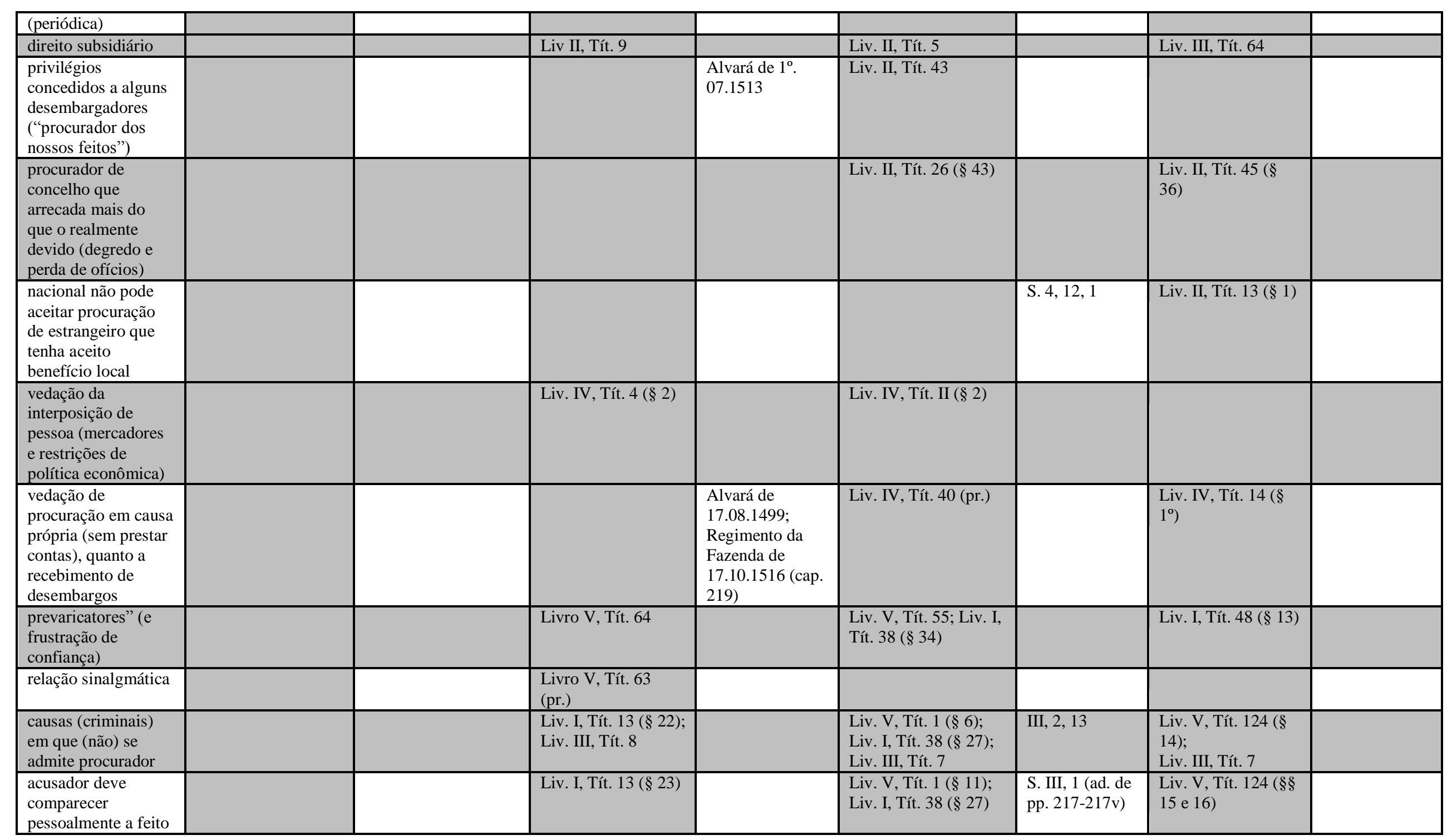




\begin{tabular}{|c|c|c|c|c|c|c|}
\hline $\begin{array}{l}\text { crime (não pode } \\
\text { empregar } \\
\text { procurador) }\end{array}$ & & & & & & \\
\hline $\begin{array}{l}\text { não podem receber } \\
\text { penas vis } \\
\text { (procuradores das } \\
\text { vilas e concelhos) }\end{array}$ & & & Liv. V, Tít. 40 & S. $4,22,9$ & $\begin{array}{l}\text { Liv. V, Tít. } 138 \\
\text { (pr.) }\end{array}$ & \\
\hline $\begin{array}{l}\text { procurador do } \\
\text { concelho e } \\
\text { providências sobre } \\
\text { crime de incêndio }\end{array}$ & & & $\begin{array}{l}\text { Liv. V, Tít. } 83 \text { (pr., } \S \\
3^{\circ} \text { ) }\end{array}$ & & $\begin{array}{l}\text { Liv. V, Tít. } 86 \text { (pr., } \\
\left.\S 9^{\circ}\right) \text {; } \\
\text { Liv. I, Tít. } 69\left(\S 3^{\circ}\right)\end{array}$ & \\
\hline $\begin{array}{l}\text { prisão especial } \\
\text { (domiciliar) e } \\
\text { acompanhamento } \\
\text { processual por meio } \\
\text { de procurador }\end{array}$ & & & $\begin{array}{l}\text { Liv. V, Tít. } 67\left(\S \S 4^{\circ}\right. \\
\left.\text { e } 5^{\circ}\right)\end{array}$ & S. $4,21,12$ & $\begin{array}{l}\text { Liv. V, Tít. } 120(\S \S \\
\left.3^{\circ} \text { e } 4^{\circ}\right)\end{array}$ & \\
\hline $\begin{array}{l}\text { procuradores e } \\
\text { "cartas de ofício" } \\
\text { (autorização para o } \\
\text { exercício } \\
\text { profissional) }\end{array}$ & $\begin{array}{l}\text { Liv. I, Tít. } 2 \text { (§ 19); } \\
\text { Liv. I, Tít. } 13 \text { ( } \$ 1^{\circ} \text {, } \\
\text { 12) }\end{array}$ & & $\begin{array}{l}\text { Liv. I, Tít. } 2 \text { (§ 28); } \\
\text { Liv. I, Tít. } 38 \text { (pr., } \S \S \\
\left.1^{\circ}, 2^{\circ}, 3^{\circ}\right)\end{array}$ & $\begin{array}{l}\text { S. I, 2, 1, 9; } \\
\text { S. IV, 17, 13; } \\
\text { S. I, 4, 2 (\$§ } 6^{\circ} \\
\text { e 17); } \\
\text { S. I, 21, 3; } \\
\text { Lei de } \\
\text { 18.11.1577 (§ } \\
\text { 27) }\end{array}$ & $\begin{array}{l}\text { Liv. I, Tít. } 4\left(\S 8^{\circ}\right) \\
\text { Liv. I, Tít. } 48(\mathrm{pr} \text {, } \\
\left.\S \S 1^{\circ}, 2^{\circ}, 3^{\circ}, 4^{\circ}, 5^{\circ}\right)\end{array}$ & \\
\hline $\begin{array}{l}\text { procurador "dos } \\
\text { nossos feitos" e } \\
\text { jurisdição especial }\end{array}$ & Liv. I, Tít. $5\left(\S 4^{\circ}\right)$ & & Liv. I, Tít. 6 (§ 8) & & & \\
\hline $\begin{array}{l}\text { procurador "dos } \\
\text { nossos feitos" }\end{array}$ & $\begin{array}{l}\text { Liv. I, Tít. } 9 \text { (pr., } \S \S \\
\left.1^{\circ}, 2^{\circ}\right)\end{array}$ & $\begin{array}{l}\text { Alvará de } \\
28.03 .1514\end{array}$ & $\begin{array}{l}\text { Liv. I, Tít. } 11 \text { (pr., } \S \S \\
\left.1^{\circ}, 2^{\circ}, 3^{\circ}, 4^{\circ}\right)\end{array}$ & $\begin{array}{l}\text { S. I, 9, 1; } \\
\text { S. I, 9, 2; } \\
\text { S. I, 9, 3; } \\
\text { S. I, 9, 4; } \\
\text { S. V, 1, 1, 9; } \\
\text { S. V, 1, 1, 11; } \\
\text { Lei de } \\
\text { 26.11.1582; } \\
\text { Lei de } \\
05.12 .1588 ; \\
\text { Provisão de } \\
\text { 18.03.1578 (§ } \\
\text { 11); } \\
\text { Ref. de }\end{array}$ & $\begin{array}{l}\text { Liv. I, Tít. 12; Liv. } \\
\text { I, Tít. } 13\end{array}$ & \\
\hline
\end{tabular}




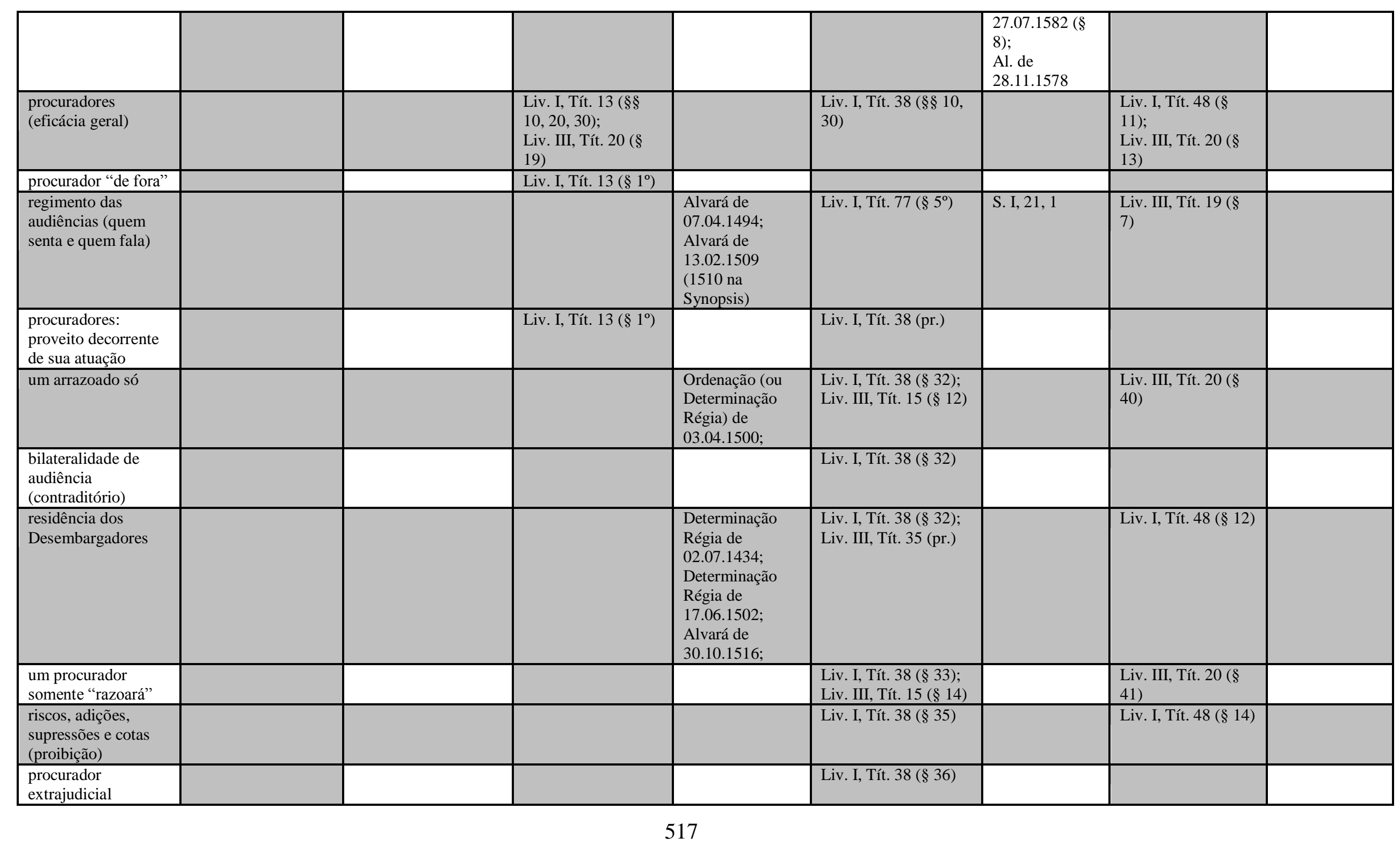




\begin{tabular}{|c|c|c|c|c|}
\hline $\begin{array}{l}\text { inobservância das } \\
\text { instruções e validade } \\
\text { da gestão } \\
\text { (processual) }\end{array}$ & & Liv. I, Tít. 38 (\$ 36) & & Liv. I, Tít. 48 (§ 17) \\
\hline $\begin{array}{l}\text { citação (por meio de } \\
\text { procurador) }\end{array}$ & $\begin{array}{l}\text { Liv. III, Tít. 2; } \\
\text { Liv. III, Tít. } 20 \text { (§ } \\
\text { 12) }\end{array}$ & $\begin{array}{l}\text { Liv. III, Tít. 2; } \\
\text { Liv. III, Tít. } 15\left(\S 7^{\circ}\right)\end{array}$ & & $\begin{array}{l}\text { Liv. III, Tít. 2; Liv. } \\
\text { III, Tít. } 20\left(\$ 8^{\circ}\right)\end{array}$ \\
\hline $\begin{array}{l}\text { privilégio: } \\
\text { procuradores (da } \\
\text { Corte) e citação } \\
\text { pelos seus salários }\end{array}$ & $\begin{array}{l}\text { Liv. III, Tít. } 4\left(\S 7^{\circ}\right) \\
\text { Liv. III, Tít. } 43(\S \\
\left.2^{\circ}\right)\end{array}$ & Liv. III, Tít. 4 (§ 9º & $\begin{array}{l}\text { Lei de } \\
26.11 .1582(\S \\
2)\end{array}$ & $\begin{array}{l}\text { Liv. III, Tít. } 5 \text { (§ } \\
11)\end{array}$ \\
\hline $\begin{array}{l}\text { privilégio: } \\
\text { procuradores (da } \\
\text { Corte) e jurisdição } \\
\text { especial }\end{array}$ & Liv. III, Tít. $5\left(\S 2^{\circ}\right)$ & Liv. III, Tít. 5 (pr.) & S. I, $3,1,10$ & Liv. III, Tít. 6 (pr.) \\
\hline $\begin{array}{l}\text { impetração de } \\
\text { "graça" pelo } \\
\text { procurador sem } \\
\text { "mandado" do } \\
\text { principal: efeitos }\end{array}$ & $\begin{array}{l}\text { Liv. III, Tít. } 112 \text { (§ } \\
\left.5^{\circ}\right) ; \\
\text { Liv. II, Tít. } 37\end{array}$ & Liv. III, Tít. $80\left(\S 4^{\circ}\right)$ & & $\begin{array}{l}\text { Liv. III, Tít. } 38(\S \\
\left.4^{\circ}\right)\end{array}$ \\
\hline $\begin{array}{l}\text { extinção da } \\
\text { "procura" entre } \\
\text { vivos (renúncia e } \\
\text { revogação) }\end{array}$ & Liv. III, Tít. 21 & Liv. III, Tít. 17 & & Liv. III, Tít. 26 \\
\hline $\begin{array}{l}\text { extinção da } \\
\text { "procura" em } \\
\text { decorrência de morte } \\
\text { ou prolatação de } \\
\text { sentença (eficácia } \\
\text { posterior à extinção } \\
\text { e dever de } \\
\text { colaboração: } \\
\text { recurso) }\end{array}$ & Liv. III, Tít. 23 & Liv. III, Tít. 18 & & Liv. III, Tít. 18 \\
\hline $\begin{array}{l}\text { trasladação da coisa } \\
\text { em poderoso e } \\
\text { fraude }\end{array}$ & Liv. III, Tít. 118 & Liv. III, Tít. 84 & & Liv. III, Tít. 39 \\
\hline escusador & $\begin{array}{l}\text { Liv. III, Tít. } 20(\S \\
\left.6^{\circ}\right)\end{array}$ & Liv. III, Tít. $15\left(\S 3^{\circ}\right)$ & & $\begin{array}{l}\text { Liv. III, Tít. } 20(\S \\
\left.3^{\circ}\right)\end{array}$ \\
\hline $\begin{array}{l}\text { falso procurador } \\
\text { (procuração falsa) }\end{array}$ & & Liv. III, Tít. $49\left(\S 5^{\circ}\right)$ & & $\begin{array}{l}\text { Liv. III, Tít. } 63 \text { (§ } \\
\left.5^{\circ}\right)\end{array}$ \\
\hline
\end{tabular}




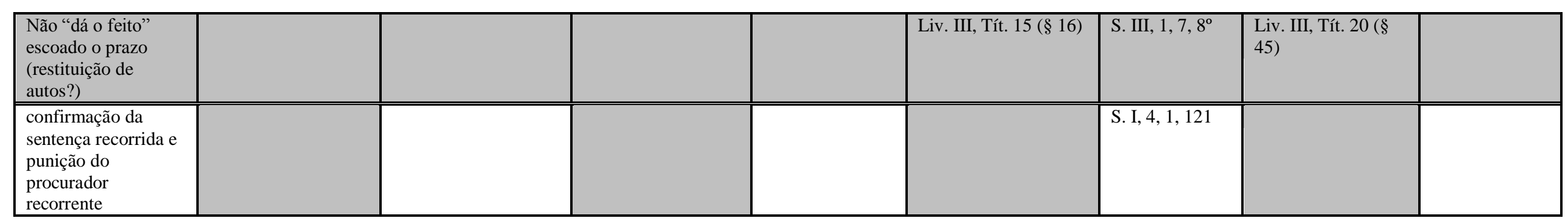

Legenda:

\section{Livro das Leis e Posturas}

"lei 01". "Lei pela qual se estabelece que o direito canónico tenha vigor em Portugal e que no caso de conflito entre o direito régio e o direito canónico tenha este supremacia";

"lei 02". "Lei sobre procuradores, advogados, testemunhas e recursos para "casa del-rei"”;

"lei 03". "Lei pela qual se determinam as penas a aplicar a juízes, advogados, alcaides, procuradores e outros homens de justiça que tenham relações carnais com mulheres que sejam parte em processos nos quais eles intervenham", de 29 de julho de 1311

"lei 04". "Lei pela qual se determina que nenhum procurador ou advogado receba honorários antes que o pleito esteja terminado por sentença ou transaç̧ão" - Lei de 23 de agosto de 1303 ;

"lei 05 ". "Lei pela qual se determina que os advogados e procuradores recebam metade dos seus honorários no começo da causa e outra metade no seu fim", de 17 de agosto de 1322 ;

"lei 06 ". "Lei pela qual se determina que em certas condições se não atenda advogado";

"lei 07 ". "Lei pela qual se determina que, em princípio, nenhum sobrejuiz ou ouvidor possa advogar na corte";

"lei 08 ". "Lei sobre advogados na corte";

"lei 09". "Lei pela qual se declara prejuro aquele que, jurando de malícia, quando pede advogado, o não apresente no dia que lhe for marcado e se regulamentam apelações em terras sujeitas a jurisdição de ordens", do mês de janeiro de 1271;

"lei 10". "Lei sobre procuradores",

"lei 11 ". Lei sobre advogados;

"lei 12". "Lei sobre advogados na corte";

"lei 13". "Lei pela qual se determina que o marido não possa litigar sobre coisa imóvel sem consentimento da mulher";

"lei 14" "Lei sobre execução de bens para pagamento de dívidas; outrossim sobre o pagamento das custas de um processo; outrossim confirmando uma lei de D. Afonso III sobre os procuradores na corte", de 24 de agosto de 1282

"lei 15"."formulário de procuração";

"lei 16". "Lei pela qual se determinam emolumentos e honorários de escrivães da corte, advogados, procuradores e porteiros das audiências com várias outras determinações relativas ao serviços dos mesmos", de 12 de junho de 1302

"lei 17". "Lei pela qual se determina a forma que se devia seguir nos diversos pleitos, tendo por fim providenciar contra o abuso que os advogados e procuradores praticavam, prolongando fraudulentamente as causas de que tratavam", de 15 de setembro de 1313 ;

"lei 18". "Lei pela qual se estabelecem as penas a aplicar a procuradores e advogados que recebam das partes quaisquer ofertas ou os seus honorários antes da sentença definitiva, bem como às partes que se tenham servido deste meio para os corromper e impedir o andamento legal do pleito" - Carta Régia de 08 de julho de 1314;

"lei 19". "Lei pela qual se determina que nos pleitos jurem os advogados de ambas as partes e também o réu, de litigarem sem malícia nem dolo e só alegarem sua justiça; e outrossim trata dos honorários dos advogados", de 26 de fevereiro de 1283; 
"lei 20". "Lei pela qual se determina que os moradores da casa do rei, sendo cavaleiros, só possam advogar em causa própria, e bem assim só entrem nas audiências quando o rei o mande ao sobrejuiz ou ouvidor do pleito. Outrossim para que os sobrejuízes e ouvidores da corte não advoguem sem especial resolução do rei”, de 15 de janeiro de 1303 ;

"lei 21". "Lei pela qual se determinam emolumentos e honorários dos escrivães da corte, advogados, procuradores e porteiros das audiências, com várias outras determinações relativas ao serviço dos mesmos", de 10 de junho de 1303;

"lei 22". "Lei pela qual se determina que os moradores da casa do rei, sendo cavaleiros, só possam advogar em causa própria, e bem assim só entrem nas audiências quando o rei o mande ao sobrejuiz ou ouvidor do pleito. Outrossim para que os sobrejuízes e ouvidores da corte não advoguem sem especial resolução do rei”, de 15 de janeiro de 1303 ;

"lei 23". "Lei pela qual se estabelece que os mouros e judeus não advoguem em pleito de cristãos, nem tão pouco os tabeliães sejam procuradores com procuração que eles próprios tenham exarado";

"lei 24". "Lei pela qual se determina que qualquer pessoa, sem distinção de sexo, pode constituir procuradores";

"lei 25 ". "Lei pela qual se estabelece que os advogados e procuradores possam receber metade dos seus honorários antes de findas as causas" - Postura de 04 de agosto de 1322 ;

"lei $26 "$ ". "Lei pela qual se estabelece a idade mínima de 14 anos para se ser procurador";

"lei 27"."Lei sobre a procuração em que se mencione o juiz, as partes e a coisa objeto do litígio";

"lei 28 " "Lei sobre a validade da procuração de um concelho quando aí não há tabelião";

"lei 29". "Lei sobre os procuradores";

"lei 30". "Lei sobre advogados na corte";

"lei 31 ". "Lei pela qual se estabelece que os procuradores chamados à composição possam alegar árbitros";

"lei 32". "Ordenação de D. Afonso IV, contendo 18 leis e várias outras resoluções sobre a forma pela qual as justiças procederiam nos processos, como receberiam as apelações, quando aceitariam advogados, e maneira pela qual estes e os procuradores exerceriam o seu ofício", de 18 de fevereiro de 1332

"lei 33". "Lei pela qual se estabelece que os clérigos não advoguem nem sejam procuradores";

"lei 34". "Lei com várias disposições sobre o exercício das funções de juízes, advogados, procuradores, tabeliães e outros oficiais da justiça";

"lei 35". "Concórdia de 40 artigos entre D. Dinis e os bispos do reino", de 07 de março de 1289;

"lei 36". "Lei pela qual se proíbe que as pessoas poderosas compareçam nas audiências nos casos em que por direito possam ser representadas por seus procuradores";

"lei 37". "Lei pela qual se proibe aos advogados e procuradores receberem qualquer dádiva dos seus constituintes e determinando a forma por que lhe seriam pagos os seus honorários", de 14 de março de 1351 .

"lei 38". "Lei pela qual se proibe o exercício da profissão de advogado e procurador e se tomam outras providências relativas à administração da justiça", de 20 de maio de 1351 ;

"lei 39". "Lei pela qual se determina que, nem na corte, nem nas audiências dos concelhos, haja advogados nem procuradores de número, e estabelecendo várias outras providências para evitar demoras no seguimento dos pleitos", de 03 de novembro de 1352

"lei 40". Regimento dos Tabeliães (de 15 de janeiro de 1305);

"lei 41". "Concórdia de 40 artigos entre D. Dinis e os bispos do reino", de 07 de março de 1289;

\section{Ordenações de Dom Duarte}

"lei 01". "Constituçom primeira que as leis E ordinaçoões que per o dito Rej E per seus socesores forem feytas que seguem os degredos dos padres santos E os ditos da santa Jgreja";

"lei 02". "Constitucom. xxxiij. como el Rej defende que o alcaide nom uogue nem Rogue por nehuum que o façom Juiz nem almotaçel nem aia parte de sas oueenças";

"lei 03 ". "Constitucom. xxxiiij. per que el Rej. manda que o alcaide nom faca aueença com os uogados nem procuradores per rrazom dos solairos. nem leue parte dos preitos que teuerem";

"lei 04". "Ordenaçom. iiij. quaaes pesoas nom podem auer uogados em seus preitos";

"lei 05". "Constituçom Lbiij como E per que guisa a procuraçom he auondosa";

"lei 06". Constituçom Lix como o procurador do conçelho que nom ouuer ssello pode procurar pella carta do foro;

"lei 07 ". "Constituçom Lx como o procurador do feito pode procurar perante o Juiz da apellaçom";

"lei 08 ". "Constituçom Lxi como na corte del rrey deue d'auer dous vogados";

"lei 09". "constituçom Ciij Como o que ha feito nom pode ffilhar mais de huum vogado"; 
"lei 10". "constituçom. Cbiij. que pena deue d'auer o que pede uogado se nom ueem con ell ao tenpo";

"lei 11". "Constituçom CXij como o que he casado nom pode meter a preito nem a Juizo posissam sem outorga ou procuraçom de ssa molher";

"lei 12" "Costituçam Cxxbij como podem ffazer procurador";

"lei 13". "Constituçam CRij como o procurador pode procurar";

"lei 14". "Costituçam CRiij dos procuradores";

"lei 15". "Costituçam CRiiij quaaes Nom podem procurar";

"lei 16". "Costituçam CRbj do poder dos procuradores";

"lei 17". "Costituçom Clbj quem pode sseer procurador",

"lei 18". "capitollo. xbij. quaaes podem seer procuradores por outros em Juizo";

"lei 19". "capitollo. xbiij. quaaes podem seer procuradores por outros ou nom";

"lei 20 ". "capitollo xix quaaes pessoas nom podem sseer procuradores por outros";

"lei 21 ". "capitollo. xx. quaaes pessoas deuem estabeleçer por procuradores ou nom";

"lei 22". "capitollo. xxj. quaaes pessoas podem sseer uogados ou nom";

"lei 23". "Capitollo .Lb. Como os ssobreJuizes deuem ueer as procuraçõees";

"lei 24". "Capitollo . Lbij. que carta deuem dar os ssobreJuizes. / aa parte ou a Seu procurador";

"lei 25 ". "ley quinta como nom pode procurar por outrem quem ha rraçom del rrey";

"lei 26". "Ley. xbj. que nom uoguem";

"lei 27 " "ley. xbiij. que pena deuem auer os procuradores que deteuerem os feitos";

"lei 28 ". "ley. xix. quanto deuem leuar os procuradores dos solairos dos feitos";

"lei 29". "Ley .xx. que pena deue d'aueer o procurador que apelar contra a postura da corte";

"lei 30". "Ley xxj. que nom façam conpanhia ssobre os ssolairos";

"lei 31". "Ley. xxij. que garde as posturas";

"lei 32". "Ley xxiij dos uogados como deuem leuar os ssolairos",

"lei 33". "Ley . xxiiij. que sse apellar contra a postura que pague as Custas";

"lei 34". "ley que os vogados quando os feitos ueerem Jurem que manteem dereito";

"lei 35". "como nehuum ouençall nem ofiçiall dell rrey nom voge por outrem";

"lei 36". "como Ell rrej manda que uogados E procuradores nom leuem solairos",

"lei 37 ". "que nom voguem perante os Juizes";

"lei 38". "quanto deuem de leuar os uogados dos solairos dos feitos que teuerem";

"lei 39". "Costume he desy he dereito que o marido possa vender E meter a preito (...)";

"lei 40". "Esta outra carta formada da aveença que foy em a corte de rroma antre os procuradores dEll Rey. / E os prellados";

"lei 41 ". "como defende que nom aJa hi vogados";

"lei 42". "ley que pena deue auer aquelle que tem ofiçio de Justiça se Jouuer com molher que aJa feito perante ell";

"lei 43". "da eixeiçom dos procuradores";

"lei 44". "como aas partes non deuem atender uogados";

"lei 45". "em quaees casos aa parte ou a seu procurador nom deuem Receber apellaçom";

"lei 46". "Como as partes nom deuem filhar mais que huum uogado";

"lei 47". "como os procuradores E os uogados deuem husar";

"lei 48". "como os uogados E procuradores deuem Jurar que manteem bos preitos";

"lei 49". "Quanto deuem leuar os uogados dos sollairos dos feitos";

"lei 50". "ley que uogados nem procuradores nom tomem serujcos daquelles a que os feitos teuerem"; 
"lei 51". "como El Rey mandou que os uogados leuem serujço dos feitos";

"lei 52". "Como el Rey mandou que os uogados E procuradores leuem o meo do sollairo nos comecos dos feitos";

"lei 53". "Ordenaçom ij. como no artijgo da apellaçom Recebam aas partes Razooes de nouo E hu dous sobreJuizes acordarem que esta sentença ualha E quantos uogados deue auer em cada audiancia";

"lei 54". "Como o procurador que trouuer mujtos feitos da terra se forem partidos per desuairadas audeancias deue soestabelleçer procuradores em cada hua audiançia E pode fazer seu feito";

"lei 55". "dos procuradores";

"lei 56". "Esta he a ordenaçom que fez o muy nobre Rey dom afonsso o quarto em Razom dos feitos como se am de trautar E liurar na sa corte E nos seus Regnos na quall estabelleçeo que nom ouuese uogados nem procuradores Regidentes na sa corte";

"lei 57". "Como na corte nom aJa uogados nem procuradores Regidentes mas que as partes uenham per sy ou mandem seus procuradores quaees quiserem";

"lei 58". "Se as partes enujarem os seus procuradores os sobreJuizes deuem de ueer as procuraçoees E se acharem que os procuradores som auondosos deuem a hir pollo feito adiante";

"lei 59". "Como o procurador que ujeer da terra se nom souber os nomes das testemunhas como as deue de nomear na terra perante os emqueridores";

"lei 60". "Como as partes deuem dar aos procuradores per Scripto enformacom de seu feito E os nomes das testemunhas que uuerem pera prouar seu feito";

"lei 61" "Como deue seer Scripto na citaçom a causa sobre que he a citaçom pera a parte dar certa enformaçom ao procurador E os nomes dos enqueredores";

"lei 62". "nos feitos que forem trautados nos conçelhos como os Juizes deuem saber a uerdade per as partes ante que lhes Reçebam os uogados nem procuradores";

"lei 63". "como deuem dar uogado";

"lei 64". "Como os uogados deuem fazer";

"lei 65" "Como os procuradores deuem Jurar se as partes cuJos procuradores som teem boos feitos E como os uogados deuem poeer o direito polas partes cuJos feitos sosteuerem E se errarem os feitos ou forem njgrigentes que nom leuem sollairos";

"lei 66" "Como se deue de fazer quando as partes negarem o feito E se os uogados forem negrigentes como nom deuem d'auer sollairo",

"lei 67". "Que pena deuem d'auer os uogados E procuradores que maliciosamente trautarem os feitos ou em elles forem negligentes";

"lei 68". "ley per que nhuum creligo nom deue uogar nem procurar em conçelho";

"lei 69". "Como os procuradores do conçelho que pellos tenpos forem deuem sseer rregidentes aa proll do conçelho E dos sseus beens";

"lei 70". "Como em cada uilla deue d'auer escpriuam Jurado pera escpreuer os beens do conçelho E todo o que rreçeber o procurador deue sseer escprito per esse escpriuam" (p. 182);

"lei 71". "Como os Juizes nom deuem conssintir aos Vogados E procuradores que trautem os feitos malleçiosamente E que pea deue d'auer o que esto fezer";

"lei 72". "como E a que tenpo o procurador que o feito teuer deue a pidir vogado E que pea deue d'auer o procurador que o pidir como nom deue";

"lei 73". "Como os procuradores nom deuem espaçar os feitos ssem mandado das partes. ou dos Jujzes e como os deuem espaçar",

"lei 74". "Como os Jujzes nom deuem de rreçeber ssoestabelleçimentos dhuuns procuradores a outros ssem emformaçom direjta";

"lei 75". "Como os Juizes nom deuem ssofrer aos vogados E procuradores que dellongem os feitos nem fallem os vogados em elles ataa que os Jujzes façom ssas preguntas";

"lei 76". "como os procuradores nom deuem filhar em ssy procuraçoes Jeeraaes";

"lei 77". "Como os Juizes deuem outorgar aos procuradores que filhem as procurações Jeeraaes dalguas pessoas a que forem neçessarias";

"lei 78". "como el Rey manda que em cada villa aJa çerto numero de procuradores ataa quatro E que o conçelho nom ponha hi mais nem brite o numero";

"lei 79". "Rta biij artigoo. agrauan-sse que os poderosos vaão sseer/ na Eliçom dos Juizes".

"lei 80". "Como os caualeiros E crerigos E homes d'ordem uaam seer no conçelho a uogar";

"lei 81". "Como el rrej mandou que os seus conselheiros E sobreJuizees E todo-llos outros ofiçiaes lhe dem em cada mes conto dos seruiços";

"lei 82". "Como deue dar pena ao Juiz se nom liurar os feitos E outrosy ao procurador maliçioso";

"lei 83". "Dos procuradores E uogados se achar que nom som taaes quaaes deuem que ponham outros ou tolham delles se muytos forem";

"lei 84". "Como filhem conto dos procuradores que forom ante per. x. annos";

"lei 85". "Da Jura que ham de fazer os percuradores E uogados";

"lei 86". "Como os Juizes nom deuem dar carta aos uogados E percuradores pera çitarem pellos solairos sem enformaçom", Lei de 17 de novembro de 1350 ;

"lei 87 ". "ley em que el Rej defende que procurador nem uogado Nem Juiz nem almoxarife nem sobreJuiz Nem estpriuam nem sacador nom tomem seruiços dos que teuerem os feytos nem dos que com elles ouuerem de fazer"; 
"lei 88". "ley per que el rej mandou que no seu Regno nom aJa uogados nem procuradores". 


\section{ANEXO IV}

TABELA DE CORRESPONDÊNCIA No ${ }^{\circ}$ III DIREITO PORTUGUÊS CONTEMPORÂNEO

\begin{tabular}{|c|c|c|c|c|}
\hline regra & CCom 1833 & CC 1867 & CCom 1888 & $\mathrm{CC1966}$ \\
\hline mandato (definição) & art. 762 & art. $1318^{\circ}$ & & art. $1157^{\circ}$ \\
\hline $\begin{array}{l}\text { obrigação de executar o mandato } \\
\text { (perdas e danos) }\end{array}$ & art. 763 & art. $1335^{\circ}$ & art. $238^{\circ}$ & art. $1161^{\circ}(\mathrm{a})$ \\
\hline $\begin{array}{l}\text { forma do mandato (vide forma da } \\
\text { procuração) }\end{array}$ & art. 764 & arts. $1318^{\circ}, 1326^{\circ}, 1329^{\circ}, 1355^{\circ}$ & & \\
\hline $\begin{array}{l}\text { forma da aceitação e início da } \\
\text { execução }\end{array}$ & art. 764 & & & \\
\hline $\begin{array}{l}\text { mandato geral, especial, em termos } \\
\text { gerais, específico }\end{array}$ & arts. 765,781 & arts. $1323^{\circ}, 1324^{\circ}, 1325^{\circ}$ & art. $231^{\circ}$ (§ único), $233^{\circ}$ & art. $1159^{\circ}$ \\
\hline $\begin{array}{l}\text { poderes para transação e } \\
\text { compromisso }\end{array}$ & art. 766 & & & \\
\hline vedação de excesso do mandatário & arts. $766,804,806$ & art. $1338^{\circ}$ & & \\
\hline mandato mercantil & art. 767 & & art. $231^{\circ}$ ("caput") & \\
\hline $\begin{array}{l}\text { distinção entre comissário e } \\
\text { mandatário }\end{array}$ & arts. $768,769,45$ & & art. $267^{\circ}$ & \\
\hline onersosidade do mandato & art. 770 & art. $1331^{\circ}$ & art. $232^{\circ}$ ("caput") & arts. $1158^{\circ}(1), 1167^{\circ}(\mathrm{b})$ \\
\hline onerosidade da comissão & arts. $770,789,831$ & & & \\
\hline comércio de comissão & art. 771 & & & \\
\hline mandato e representação & art. 772 & & & art. $1178^{\circ}(1)$ \\
\hline $\begin{array}{l}\text { obrigação de cumprimento } \\
\text { (mandante) }\end{array}$ & art. 773 & arts. $1345^{\circ}, 1346^{\circ}$ & & \\
\hline direito de retenção & art. 774 & art. $1349^{\circ}$ & & \\
\hline $\begin{array}{l}\text { impedimento da execução: } \\
\text { informação e prova }\end{array}$ & arts. 775,837 & art. $1362^{\circ}$ & & art. $1161^{\circ}(\mathrm{c})$ \\
\hline $\begin{array}{l}\text { mandato e eficácia representativa } \\
\text { direta }\end{array}$ & art. 776 & art. $1350^{\circ}$ & & \\
\hline $\begin{array}{l}\text { mandatário (com representação) que } \\
\text { atua em nome próprio - adjudicação }\end{array}$ & art. 777 & & & art. $1178^{\circ}, 2$ \\
\hline $\begin{array}{l}\text { responsabilidade do mandante } \\
\text { (efeitos representativos diretos } \\
\text { passivos) }\end{array}$ & art. 778 & art. $1350^{\circ}$ & & \\
\hline $\begin{array}{l}\text { controvérsia com terceiro (exibição } \\
\text { ou buscar ratificação) }\end{array}$ & art. 779 & & & \\
\hline
\end{tabular}




\begin{tabular}{|c|c|c|c|c|}
\hline efeitos representativos diretos ativos & art. 780 & art. $1350^{\circ}$ & & \\
\hline $\begin{array}{l}\text { ausência de mandato (ou excesso) - } \\
\text { gestão de negócios }\end{array}$ & art. 782 & & & \\
\hline $\begin{array}{l}\text { extensão do mandato: atos } \\
\text { conseqüentes }\end{array}$ & art. 783 & & & \\
\hline $\begin{array}{l}\text { mandato certo e situações } \\
\text { semelhantes }\end{array}$ & arts. 784,811 & & & \\
\hline $\begin{array}{l}\text { pluralidade de mandatários e } \\
\text { responsabilidade }\end{array}$ & art. 785 & art. $1341^{\circ}$ & art. $244^{\circ}$ ("caput") & arts. $1160^{\circ}, 1166^{\circ}$ \\
\hline $\begin{array}{l}\text { pluralidade de mandantes e } \\
\text { responsabilidade }\end{array}$ & art. 786 & art. $1348^{\circ}$ & & art. $1169^{\circ}$ \\
\hline desvio e dever de pagar juros & arts. 787,59 & art. $1340^{\circ}$ & art. $241^{\circ}$ & art. $1164^{\circ}$ \\
\hline término do mandato (modalidades) & art. 818 & art. $1363^{\circ}$ & & arts. $265^{\circ}, 1174^{\circ}$ \\
\hline $\begin{array}{l}\text { revogação (relação mandante- } \\
\text { mandatário) }\end{array}$ & arts. 819,67 & art. $1364^{\circ}$ & art. $245^{\circ}$ & arts. $267^{\circ}, 1170^{\circ}, 1172^{\circ}$ \\
\hline revogação e terceiros de boa fé & arts. 820,67 & art. $1369^{\circ}$ ( $3^{\circ}$ e $\S$ único $)$ & & art. $266^{\circ}$ \\
\hline $\begin{array}{l}\text { novo mandatário e revogação } \\
\text { implícita }\end{array}$ & art. 821 & art. $1365^{\circ}$ & & art. $1171^{\circ}$ \\
\hline $\begin{array}{l}\text { renúncia (relação mandante- } \\
\text { mandatário) }\end{array}$ & art. 822 & art. $1368^{\circ}$ & art. $245^{\circ}$ & art. $1172^{\circ}$ \\
\hline morte do mandante & arts. 823,839 & art. $1366^{\circ}$ & & art. $1175^{\circ}$ \\
\hline $\begin{array}{l}\text { atos do mandatário que ignora } \\
\text { extinção }\end{array}$ & art. 824 & art. $1369^{\circ}\left(2^{\circ}\right)$ & & art. $1175^{\circ}$ \\
\hline $\begin{array}{l}\text { extinção por fato do mandatário: } \\
\text { deveres de seus herdeiros }\end{array}$ & art. 825 & art. $1367^{\circ}$ & & art. $1176^{\circ}$ (1 e 2) \\
\hline responsabilidade do pelos custos & art. 46 & arts. $1344^{\circ}, 1346^{\circ}$ & art. $243^{\circ}$ (“caput”) & art. $1167^{\circ}(\mathrm{a}, \mathrm{b}$ e c $)$ \\
\hline dever de prestar contas & art. 47 & art. $1339^{\circ}$ & & art. $1161^{\circ}, \mathrm{d}$ \\
\hline dever de entregar importâncias & art. 47 & & & art. $1161^{\circ}$ \\
\hline dever de restituir saldos & art. 47 & & & art. $1161^{\circ}(\mathrm{e})$ \\
\hline $\begin{array}{l}\text { inexatidão das contas e } \\
\text { responsabilidade penal }\end{array}$ & art. 48 & & art. 241, (§ único) & \\
\hline $\begin{array}{l}\text { adiantamentos pelo comissário e } \\
\text { privilégios }\end{array}$ & arts. $49,50,51$ & & art. $247^{\circ}$ & \\
\hline $\begin{array}{l}\text { recusa do mandato e diligências } \\
\text { conservativas }\end{array}$ & art. 56 & & arts. $234^{\circ}, 232^{\circ}\left(\S 2^{\circ}\right)$ & \\
\hline $\begin{array}{l}\text { adiantamentos de responsabilidade } \\
\text { do comissário e imunidade do } \\
\text { comitente }\end{array}$ & art. 58 & & art. $243^{\circ}, \S 3^{\circ}$ & \\
\hline dever de informação: presteza e & art. 64 & & arts. $239^{\circ}, 240^{\circ}$ & art. $1161^{\circ}(\mathrm{b}$ e c $)$ \\
\hline
\end{tabular}




\begin{tabular}{|c|c|c|c|c|}
\hline tempestividade & & & & \\
\hline delegação e emprego de subalternos & art. 66 & arts. $1342^{\circ}, 1343^{\circ}$ & & arts. $264^{\circ}, 1165^{\circ}$ \\
\hline $\begin{array}{l}\text { responsabilidade pela conservação } \\
\text { das mercadorias }\end{array}$ & art. 68 & & art. $236^{\circ}$ & \\
\hline $\begin{array}{l}\text { perecimento de mercadorias: decurso } \\
\text { do tempo ou vício intrínseco }\end{array}$ & art. 69 & & art. $236^{\circ}$ (“caput”) & \\
\hline $\begin{array}{l}\text { dever de inspecionar e informar } \\
\text { depreciação }\end{array}$ & art. 70 & & art. $237^{\circ}$ & \\
\hline desconformidade entre fato e cautela & art. 71 & & art. $235^{\circ}$ (“caput") & \\
\hline $\begin{array}{l}\text { risco grave de perecimento e venda } \\
\text { urgente }\end{array}$ & art. 72 & & art. $235^{\circ}$ (§ único) & \\
\hline aquisição pelo próprio agente & arts. 77,79 & & art. $274^{\circ}$ & art. $261^{\circ}$ \\
\hline dever de contratar seguro & arts. $84,85,86$ & & art. $236^{\circ}$ (§ único $)$ & \\
\hline $\begin{array}{l}\text { formação do contrato: oferta e } \\
\text { aceitação }\end{array}$ & art. 791 & art. $1330^{\circ}$ & & \\
\hline $\begin{array}{l}\text { dever de indenizar prejuízos } \\
\text { (mandante) }\end{array}$ & art. 794 & arts. $1344^{\circ}, 1346^{\circ}$ & & art. $1167^{\circ}(\mathrm{d})$ \\
\hline atos instrumentais & arts. 796,799 & & art. $233^{\circ}\left(2^{\mathrm{a}}\right.$ parte $)$ & art. $1159^{\circ}(2)$ \\
\hline observância das instruções & art. 806 & art. $1335^{\circ}$ & art. $238^{\circ}$ & art. $1161^{\circ}(\mathrm{a})$ \\
\hline excesso: disciplina & arts. $807,809,810$ & arts. $1338^{\circ}, 1351^{\circ}$ & & art. 268 \\
\hline $\begin{array}{l}\text { ausência de impugnação e ratificação } \\
\text { implícita }\end{array}$ & art. 808 & & art. $240^{\circ}$ (parte final) & art. $1163^{\circ}$ \\
\hline $\begin{array}{l}\text { hipótese imprevista e livre } \\
\text { interpretação }\end{array}$ & art. 816 & & & art. $1162^{\circ}$ \\
\hline $\begin{array}{l}\text { remuneração estimada segundo os } \\
\text { usos }\end{array}$ & & art. $1359^{\circ}$ & art. $232^{\circ}\left(\S 1^{\circ}\right)$ & art. $1158^{\circ}(2)$ \\
\hline dever de exibir o mandato & & art. $1352^{\circ}$ & art. $242^{\circ}$ & art. $260^{\circ}$ \\
\hline $\begin{array}{l}\text { instruções não atingem terceiros, } \\
\text { salvo conhecimento }\end{array}$ & & & art. $242^{\circ}$ & art. $269^{\circ}$ \\
\hline $\begin{array}{l}\text { suspensão de execução (falta de } \\
\text { provisão) }\end{array}$ & & & art. $243^{\circ}\left(\S \S 1^{\circ}\right.$ e $\left.2^{\circ}\right)$ & art. $1168^{\circ}$ \\
\hline $\begin{array}{l}\text { pluralidade de mandatários e } \\
\text { aceitação de parte dos indicados }\end{array}$ & & & art. $244^{\circ}$ (§ único) & \\
\hline $\begin{array}{l}\text { remuneração parcial (proporcional à } \\
\text { execução) }\end{array}$ & & & art. $246^{\circ}$ & \\
\hline $\begin{array}{l}\text { procuração (acepção instrumental); } \\
\text { vide procuracão como "ato" }\end{array}$ & & art. $1319^{\circ}$ & & \\
\hline $\begin{array}{l}\text { forma da procuração (vide forma do } \\
\text { mandato) }\end{array}$ & & arts. $1319^{\circ}, 1320^{\circ}, 1321^{\circ}, 1322^{\circ}$ & & \\
\hline
\end{tabular}




\begin{tabular}{|c|c|c|}
\hline simetria (princípio da) & arts. $1327^{\circ}, 1328^{\circ} ;$ & art. $262^{\circ}, 2$ \\
\hline $\begin{array}{l}\text { objeto do mandato: atos pessoais } \\
\text { (não personalíssimos) }\end{array}$ & art. $1332^{\circ}$ & \\
\hline objeto lícito & art. $1333^{\circ}$ & \\
\hline mandatário (capacidade) & arts. $1334^{\circ}, 1354^{\circ}$ & art. $263^{\circ}$ \\
\hline "culpa in concreto" & art. $1336^{\circ}$ & \\
\hline $\begin{array}{l}\text { compensação prejuízo-proveito } \\
\text { (proibição) }\end{array}$ & art. $1337^{\circ}$ & \\
\hline $\begin{array}{l}\text { remuneração do mandatário diligente } \\
\text { independe do desfecho do mandato }\end{array}$ & art. $1347^{\circ}$ & \\
\hline $\begin{array}{l}\text { atos autorizados, mas incompatíveis } \\
\text { com o fim do mandato }\end{array}$ & art. $1353^{\circ}$ & \\
\hline procuração conjuntiva & art. $1356^{\circ}$ & art. $1166^{\circ}$ \\
\hline procuração judicial dativa & art. $1357^{\circ}$ & \\
\hline pacto de "quota litis" & art. $1358^{\circ}$ & \\
\hline procuração e atuação pelo adversário & art. $1360^{\circ}$ & \\
\hline $\begin{array}{l}\text { violação de segredo (ministração de } \\
\text { documento) }\end{array}$ & art. $1361^{\circ}$ & \\
\hline $\begin{array}{l}\text { eficácia representativa direta: atuação } \\
\text { dentro dos limites dos poderes }\end{array}$ & & art. $258^{\circ}$ \\
\hline $\begin{array}{l}\text { vício de vontade na pessoa do } \\
\text { representante }\end{array}$ & & $\operatorname{art.} 259^{\circ}$ \\
\hline $\begin{array}{l}\text { procuração (acepção de "ato"); vide } \\
\text { acepção instrumental }\end{array}$ & & art. $262^{\circ}(1)$ \\
\hline $\begin{array}{l}\text { afastamento voluntário das instruções } \\
\text { (ou inexecução) razoável }\end{array}$ & & art. $1162^{\circ}$ \\
\hline $\begin{array}{l}\text { revogação (pluralidade de } \\
\text { mandantes): manifestação de todos }\end{array}$ & & art. $1173^{\circ}$ \\
\hline $\begin{array}{l}\text { caducidade parcial (de efeitos totais) } \\
\text { no mandato conjuntivo }\end{array}$ & & art. $1177^{\circ}$ \\
\hline $\begin{array}{l}\text { revogação e renúncia de procuração: } \\
\text { efeitos projetados sobre o mandato }\end{array}$ & & art. $1179^{\circ}$ \\
\hline $\begin{array}{l}\text { mandato sem representação: } \\
\text { blindagem }\end{array}$ & & art. $1180^{\circ}$ \\
\hline $\begin{array}{l}\text { mandato sem representação: dever de } \\
\text { transferência }\end{array}$ & & art. $1181^{\circ}(1)$ \\
\hline $\begin{array}{l}\text { mandato sem representação: } \\
\text { substituição no exercício de posições } \\
\text { creditórias ("ex lege") }\end{array}$ & & art. $1181^{\circ}, 2$ \\
\hline
\end{tabular}




\begin{tabular}{|c|c|c|c|}
\hline $\begin{array}{l}\text { mandato sem representação: dívidas } \\
\text { contraídas e trespasse ao mandante }\end{array}$ & & & art. $1182^{\circ}$ \\
\hline $\begin{array}{l}\text { responsabilidade do mandatário pelo } \\
\text { adimplemento de terceiros (vide } \\
\text { comissão "del credere") }\end{array}$ & & & art. $1183^{\circ}$ \\
\hline $\begin{array}{l}\text { imunidade à penhora: bens } \\
\text { adquiridos pelo mandatário (mandato } \\
\text { anterior e sem registro) }\end{array}$ & & & art. $1184^{\circ}$ \\
\hline negociante (definição) & art. 36 & & \\
\hline comissários (modalidades) & art. 37 & & \\
\hline $\begin{array}{l}\text { negociante de comissão: relações } \\
\text { com seu comitente e terceiros }\end{array}$ & art. 38 & & \\
\hline comissão (sem representação) & arts. 39,788 & art. $266^{\circ}$ & \\
\hline comissário mercantil (capacidade) & art. 40 & & \\
\hline comissão verbal e ratificação escrita & art. 41 & & \\
\hline $\begin{array}{l}\text { comissário e responsabilidade direta } \\
\text { perante terceiros }\end{array}$ & art. 42 & art. $268^{\circ}$ & \\
\hline $\begin{array}{l}\text { "blindagem": relação entre o } \\
\text { comitente e terceiros (vide mandato } \\
\text { sem representação) }\end{array}$ & art. 43 & art. $268^{\circ}$ & \\
\hline $\begin{array}{l}\text { gerente do comissário e posição face } \\
\text { ao comitente }\end{array}$ & art. 44 & & \\
\hline $\begin{array}{l}\text { empréstimos, adiantamentos e prazos } \\
\text { sem autorização: pelo comissário }\end{array}$ & art. 52 & art. $271^{\circ}$ & \\
\hline $\begin{array}{l}\text { prazo (autorizado) e insolvente } \\
\text { notório }\end{array}$ & art. 53 & art. $272^{\circ}$ & \\
\hline $\begin{array}{l}\text { venda a prazo e descrição } \\
\text { pormenorizada em conta }\end{array}$ & art. 54 & art. $273^{\circ}$ & \\
\hline $\begin{array}{l}\text { comissário que não cobra créditos em } \\
\text { favor do comitente é reponsável }\end{array}$ & art. 55 & & \\
\hline $\begin{array}{l}\text { mercadorias que não cobrem sequer } \\
\text { as despesas }\end{array}$ & art. 57 & & \\
\hline $\begin{array}{l}\text { responsabilidade por fundos } \\
\text { metálicos: a hora da remessa }\end{array}$ & arts. 60,61 & & \\
\hline $\begin{array}{l}\text { comissário que atua de modo mais } \\
\text { oneroso }\end{array}$ & art. 62 & & \\
\hline $\begin{array}{l}\text { observância do direito positivo: } \\
\text { responsabilidade }\end{array}$ & arts. 63,800 & & \\
\hline abuso: vinculação e responsabilidade & art. 65 & art. $270^{\circ}$ & \\
\hline
\end{tabular}




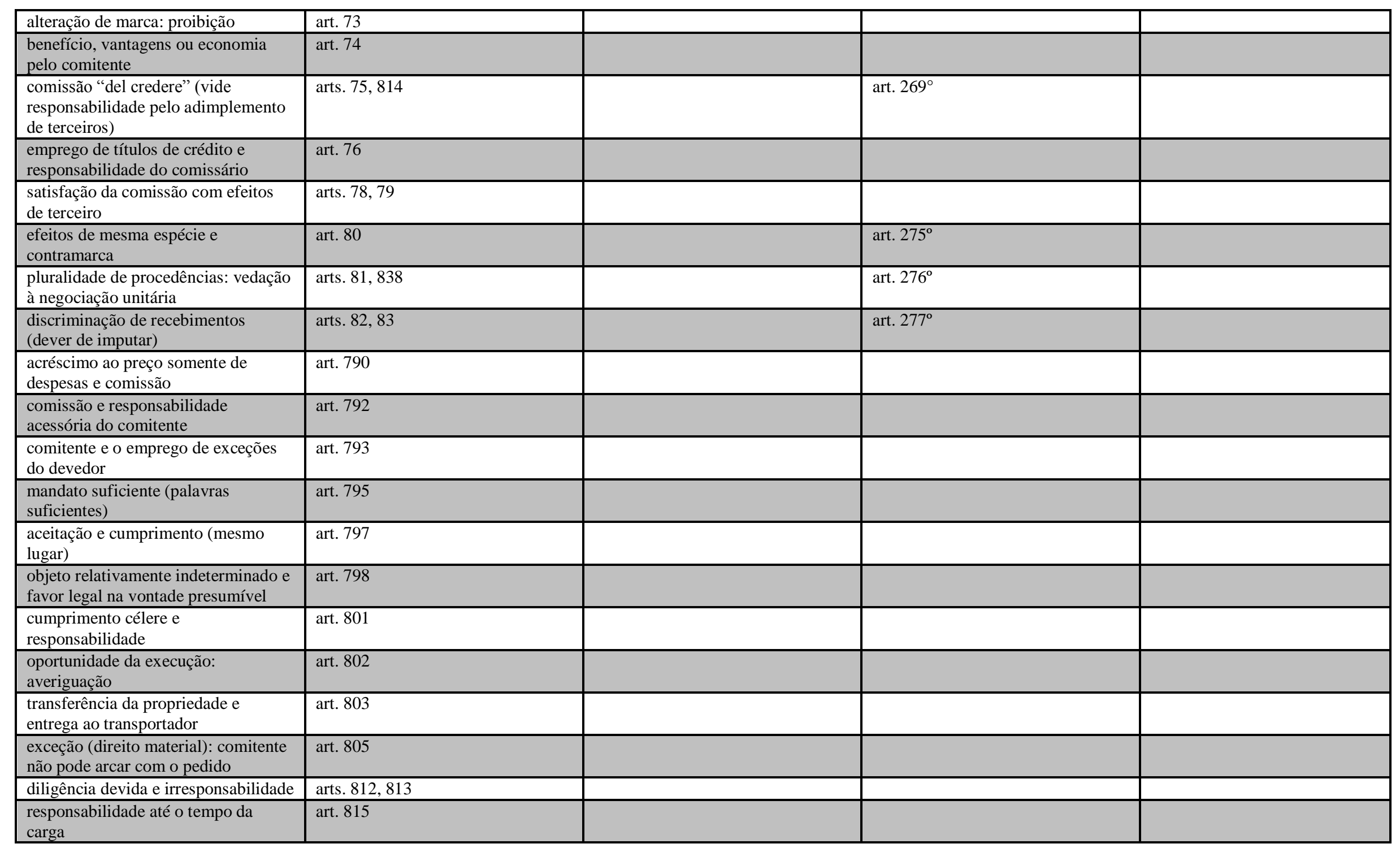




\begin{tabular}{|c|c|c|}
\hline $\begin{array}{l}\text { consignação em conta de } \\
\text { participação e subsídios: mandato e } \\
\text { sociedade }\end{array}$ & art. 826 & \\
\hline $\begin{array}{l}\text { mudança de rota e responsabilidade } \\
\text { do consignatário }\end{array}$ & art. 833 & \\
\hline $\begin{array}{l}\text { consignatário não pode vender do seu } \\
\text { (em prejuízo do consignante) }\end{array}$ & art. 836 & \\
\hline $\begin{array}{l}\text { comissão como mandato } \\
\text { "modificado" (especial) }\end{array}$ & & art. $267^{\circ}$ \\
\hline
\end{tabular}


ANEXO V

TABELA DE CORRESPONDÊNCIA $N^{\circ}$ IV DIREITO BRASILEIRO CONTEMPORÂNEO

\begin{tabular}{|c|c|c|c|c|c|c|c|c|c|c|c|c|c|c|c|c|c|c|c|c|}
\hline regra & $\begin{array}{l}\text { Cod. } \\
\text { Com }\end{array}$ & CLC & Esb. & $\begin{array}{l}\text { Ant. } \\
\text { NA }\end{array}$ & $\begin{array}{l}\text { Ant. } \\
\text { FS }\end{array}$ & $\begin{array}{l}\text { Ant. } \\
\text { CR }\end{array}$ & $\begin{array}{l}\text { Ant. } \\
\text { CB }\end{array}$ & $\begin{array}{l}\text { Ant. } \\
\text { CBR }\end{array}$ & $\begin{array}{l}\text { Proj. } \\
\text { CD } \\
1901\end{array}$ & $\begin{array}{l}\text { Proj. } \\
\text { SF }\end{array}$ & $\begin{array}{l}\mathrm{CC} \\
1916\end{array}$ & $\begin{array}{l}\text { Ant. } \\
\text { OPH }\end{array}$ & $\begin{array}{l}\text { Ant } \\
\text { OG }\end{array}$ & $\begin{array}{l}\text { Ant } \\
\text { CM }\end{array}$ & $\begin{array}{l}\text { Ant. } \\
\text { CM } \\
\text { Rev. }\end{array}$ & $\begin{array}{l}\text { Ant. } \\
\text { P.Ger. } \\
\text { JCMA }\end{array}$ & $\begin{array}{l}\text { Ant. } \\
\text { MR }\end{array}$ & $\begin{array}{l}\text { Ant. } \\
\text { MR } \\
\text { Rev. }\end{array}$ & $\begin{array}{l}\text { Proj. } \\
\text { CD } \\
1975\end{array}$ & $\begin{array}{l}\mathrm{CC} \\
2002\end{array}$ \\
\hline definição & 140 & & 2853 & & 2266 & 1063 & 1442 & 1506 & 1288 & 1288 & 1288 & & & 628 & & & 668 & 652 & 662 & 653 \\
\hline $\begin{array}{l}\text { forma do } \\
\text { mandato (vide } \\
\text { forma da } \\
\text { procuração) }\end{array}$ & 140 & & $\begin{array}{l}2888, \\
2889, \\
2890, \\
2895, \\
2896, \\
2897, \\
2906\end{array}$ & & 2314 & 1064 & 1443 & 1507 & 1290 & 1290 & 1290 & & & $\begin{array}{l}633, \\
634, \\
635\end{array}$ & $\begin{array}{l}602, \\
603\end{array}$ & & $\begin{array}{l}671 \\
672\end{array}$ & $\begin{array}{l}655 \\
656\end{array}$ & $\begin{array}{l}665, \\
666\end{array}$ & $\begin{array}{l}656, \\
657\end{array}$ \\
\hline $\begin{array}{l}\text { natureza } \\
\text { contratual }\end{array}$ & 141 & & $\begin{array}{l}2853, \\
2907, \\
2908, \\
2909, \\
2910\end{array}$ & & & & & & & & & & & & & & & & & \\
\hline $\begin{array}{l}\text { aceitação tácita } \\
\text { (vide aceitação } \\
\text { presumida) }\end{array}$ & 141 & & $\begin{array}{l}2898, \\
2899, \\
2904, \\
2905\end{array}$ & & 2268 & 1065 & 1444 & 1509 & 1292 & 1292 & 1292 & & & 638 & 607 & & 673 & 658 & 668 & 659 \\
\hline $\begin{array}{l}\text { dever de } \\
\text { execução da } \\
\text { incumbência }\end{array}$ & $\begin{array}{l}142, \\
168\end{array}$ & & $\begin{array}{l}2911, \\
2912, \\
2914 \\
\left(1^{\circ} \mathrm{e}\right. \\
\left.3^{\circ}\right), \\
2915, \\
2921, \\
2922, \\
2923, \\
2924, \\
2925, \\
2926, \\
2927, \\
2928, \\
2932,\end{array}$ & & 2283 & $\begin{array}{l}1068, \\
1073\end{array}$ & & $\begin{array}{l}1513, \\
1517\end{array}$ & & & & & & 642 & 611 & & 679 & 666 & 676 & 667 \\
\hline
\end{tabular}




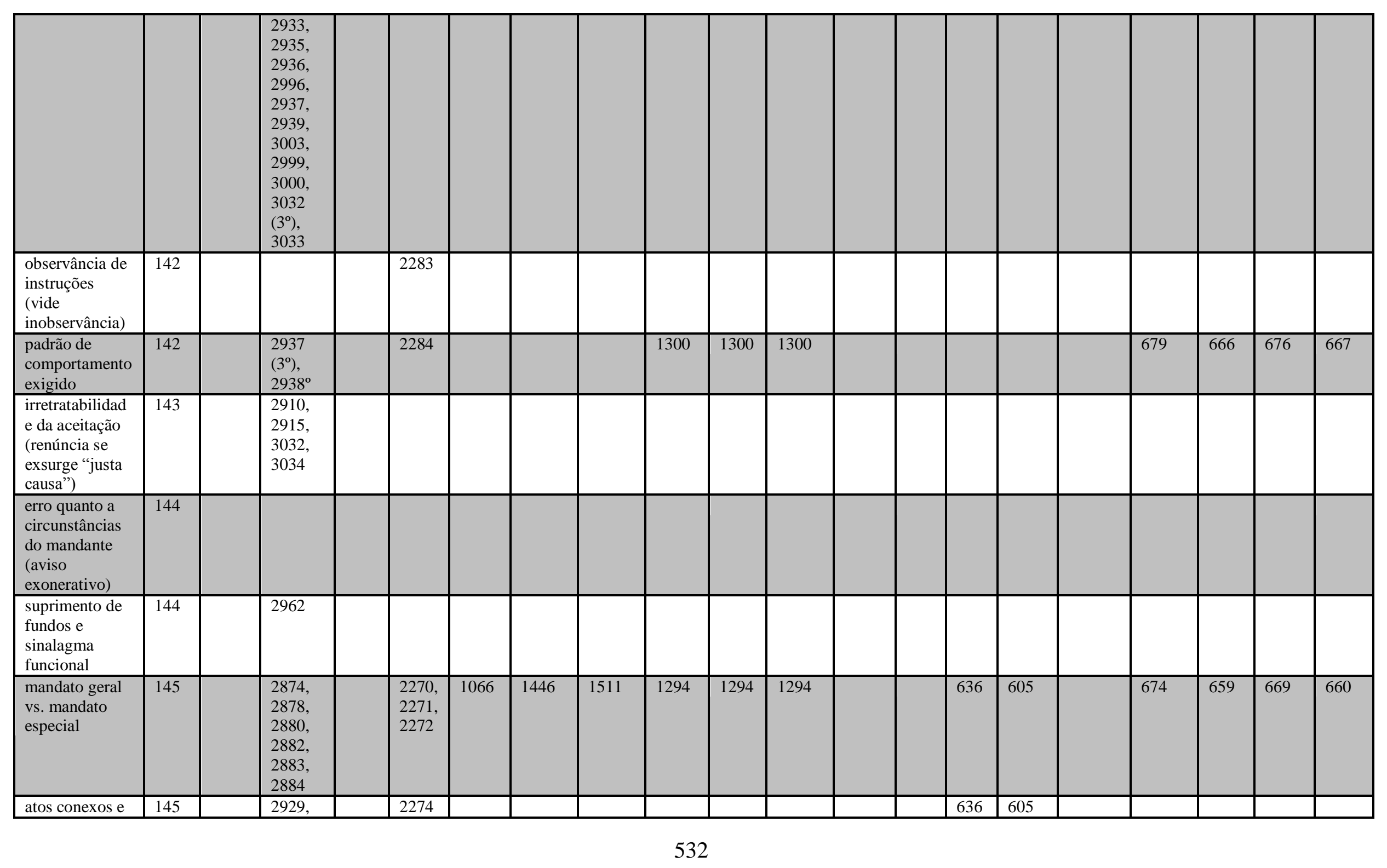




\begin{tabular}{|c|c|c|c|c|c|c|c|c|c|c|c|c|c|c|c|c|c|c|}
\hline $\begin{array}{l}\text { conseqüentes } \\
\text { compreendidos }\end{array}$ & & & $\begin{array}{l}2930, \\
2931\end{array}$ & & & & & & & & & & & & & & & \\
\hline $\begin{array}{l}\text { poderes de } \\
\text { administração }\end{array}$ & 145 & & 2879 & 2272 & 1067 & 1447 & 1512 & 1295 & 1295 & 1295 & & 636 & 605 & 114 & 675 & 660 & 670 & 661 \\
\hline $\begin{array}{l}\text { poderes } \\
\text { especiais }\end{array}$ & 145 & 470 & $\begin{array}{l}2881, \\
2883\end{array}$ & 2272 & $\begin{array}{l}1067, \\
1068\end{array}$ & 1447 & 1512 & & & & 42 & 637 & 606 & 114 & 675 & 660 & 670 & 661 \\
\hline $\begin{array}{l}\text { delegação } \\
\text { (e substabelec.) }\end{array}$ & 146 & & $\begin{array}{l}2914, \\
2^{\circ}, \\
2916, \\
2917, \\
2918, \\
2919, \\
2920, \\
3005, \\
3020\end{array}$ & $\begin{array}{l}2273, \\
2286, \\
2287, \\
2288, \\
2289, \\
2290, \\
2291\end{array}$ & $\begin{array}{l}1076, \\
1077\end{array}$ & $\begin{array}{l}1448, \\
1449\end{array}$ & 1519 & 1300 & 1300 & 1300 & & $\begin{array}{l}640, \\
641\end{array}$ & $\begin{array}{l}609, \\
610\end{array}$ & $\begin{array}{l}116, \\
117, \\
118\end{array}$ & $\begin{array}{l}670, \\
679 \\
\left(\S 3^{\circ}\right)\end{array}$ & $\begin{array}{l}654, \\
666 \\
\left(\S 3^{\circ}\right)\end{array}$ & $\begin{array}{l}664, \\
676 \\
\left(\S 3^{\circ}\right)\end{array}$ & $\begin{array}{l}655, \\
667 \\
\left(\S 3^{\circ}\right)\end{array}$ \\
\hline $\begin{array}{l}\text { pluralidade de } \\
\text { mandatários } \\
\text { (regime) }\end{array}$ & 147 & & $\begin{array}{l}2859, \\
2860, \\
2861, \\
2862, \\
2863, \\
2949, \\
2950, \\
2951, \\
3022\end{array}$ & 2292 & 1079 & 1454 & 1524 & 1304 & 1304 & 1304 & 41 & 630 & 599 & 115 & 683 & 671 & 681 & 672 \\
\hline $\begin{array}{l}\text { pluralidade de } \\
\text { mandatários } \\
\text { (aceitação da } \\
\text { maioria) }\end{array}$ & 147 & & & & & & & & & & & & & & & & & \\
\hline $\begin{array}{l}\text { pluralidade de } \\
\text { mandantes }\end{array}$ & 148 & & $\begin{array}{l}2983, \\
2984, \\
2985, \\
2986, \\
3004, \\
3021\end{array}$ & 2293 & 1086 & 1462 & 1532 & 1314 & 1314 & 1314 & & 658 & 625 & & 691 & 679 & 689 & 680 \\
\hline $\begin{array}{l}\text { responsabilidad } \\
\text { e do mandante } \\
\text { pelos atos do } \\
\text { mandatário }\end{array}$ & 149 & & $\begin{array}{l}2911, \\
2990, \\
2992\end{array}$ & 2278 & 1085 & 1461 & $\begin{array}{l}1527, \\
1531\end{array}$ & $\begin{array}{l}1309, \\
1313\end{array}$ & $\begin{array}{l}1309 \\
1313\end{array}$ & $\begin{array}{l}1309, \\
1313\end{array}$ & & 651 & 618 & & $\begin{array}{l}686, \\
690\end{array}$ & $\begin{array}{l}674, \\
678\end{array}$ & $\begin{array}{l}684 \\
688\end{array}$ & $\begin{array}{l}675 \\
679\end{array}$ \\
\hline $\begin{array}{l}\text { atuação do } \\
\text { mandatário em }\end{array}$ & $\begin{array}{l}149, \\
150\end{array}$ & & $\begin{array}{l}2939 \\
\left(5^{\circ}\right)\end{array}$ & $\begin{array}{l}2279, \\
2280\end{array}$ & 1071 & & 1516 & 1307 & 1307 & 1307 & 36 & 39 & 39 & & & 662 & 672 & 663 \\
\hline
\end{tabular}




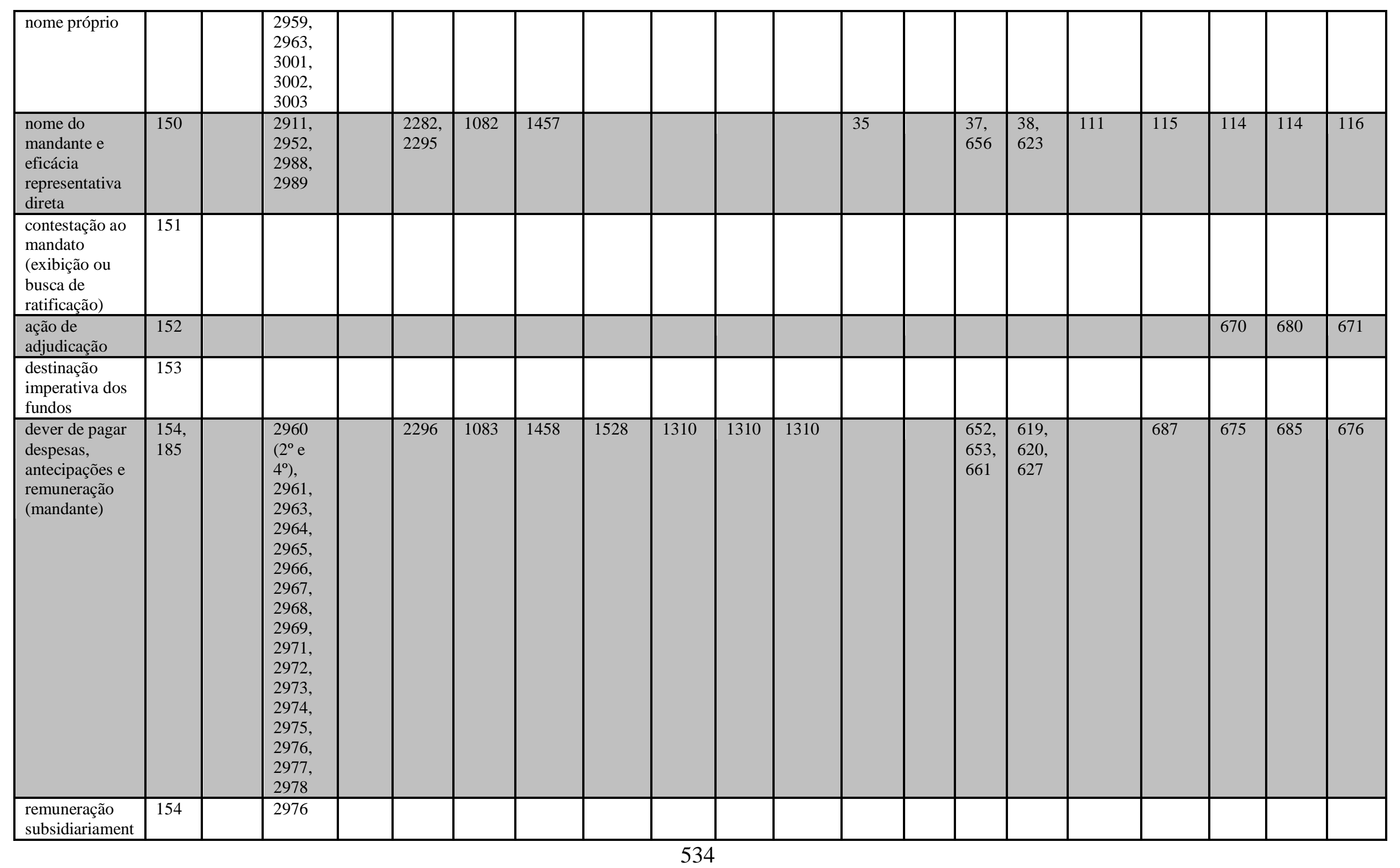




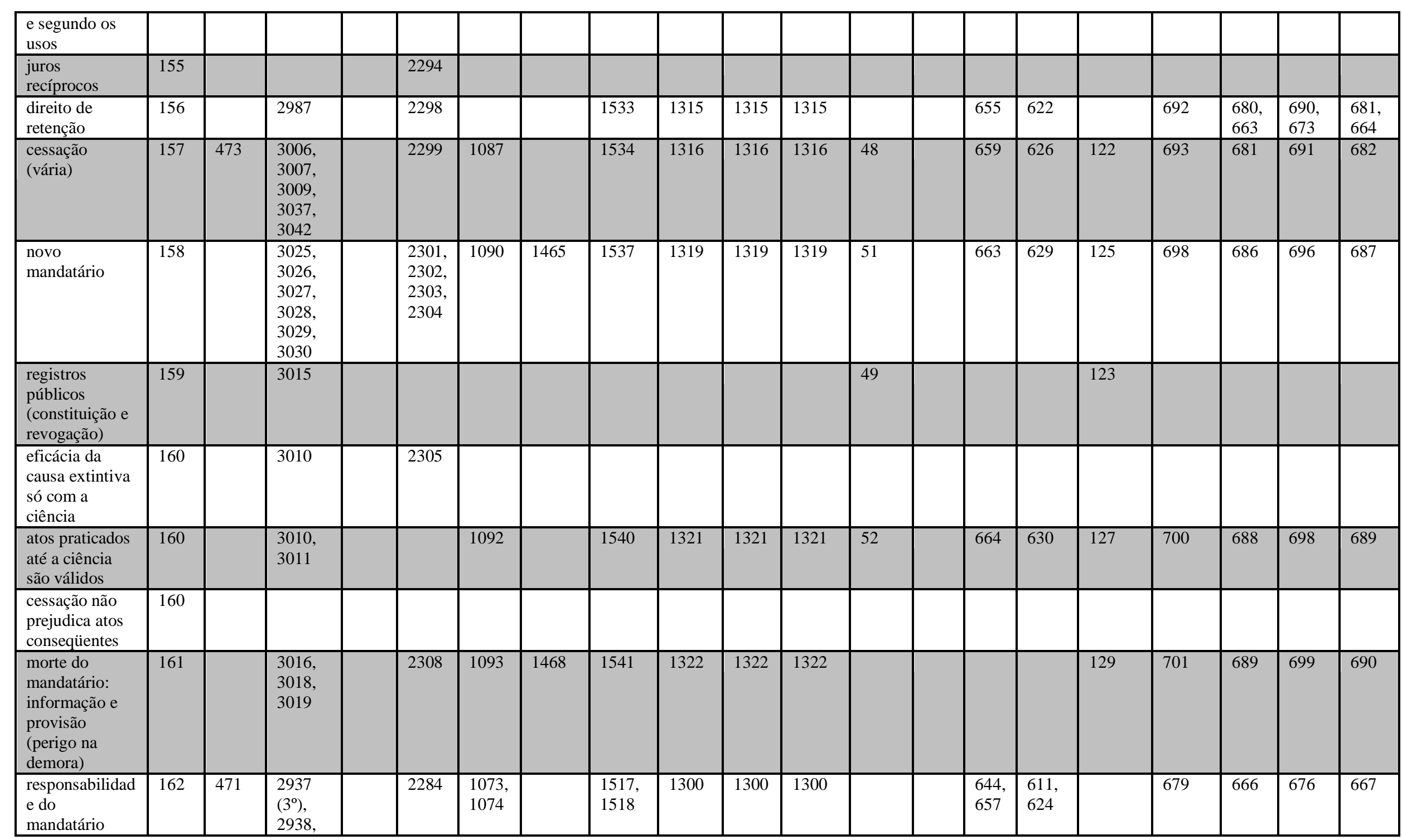




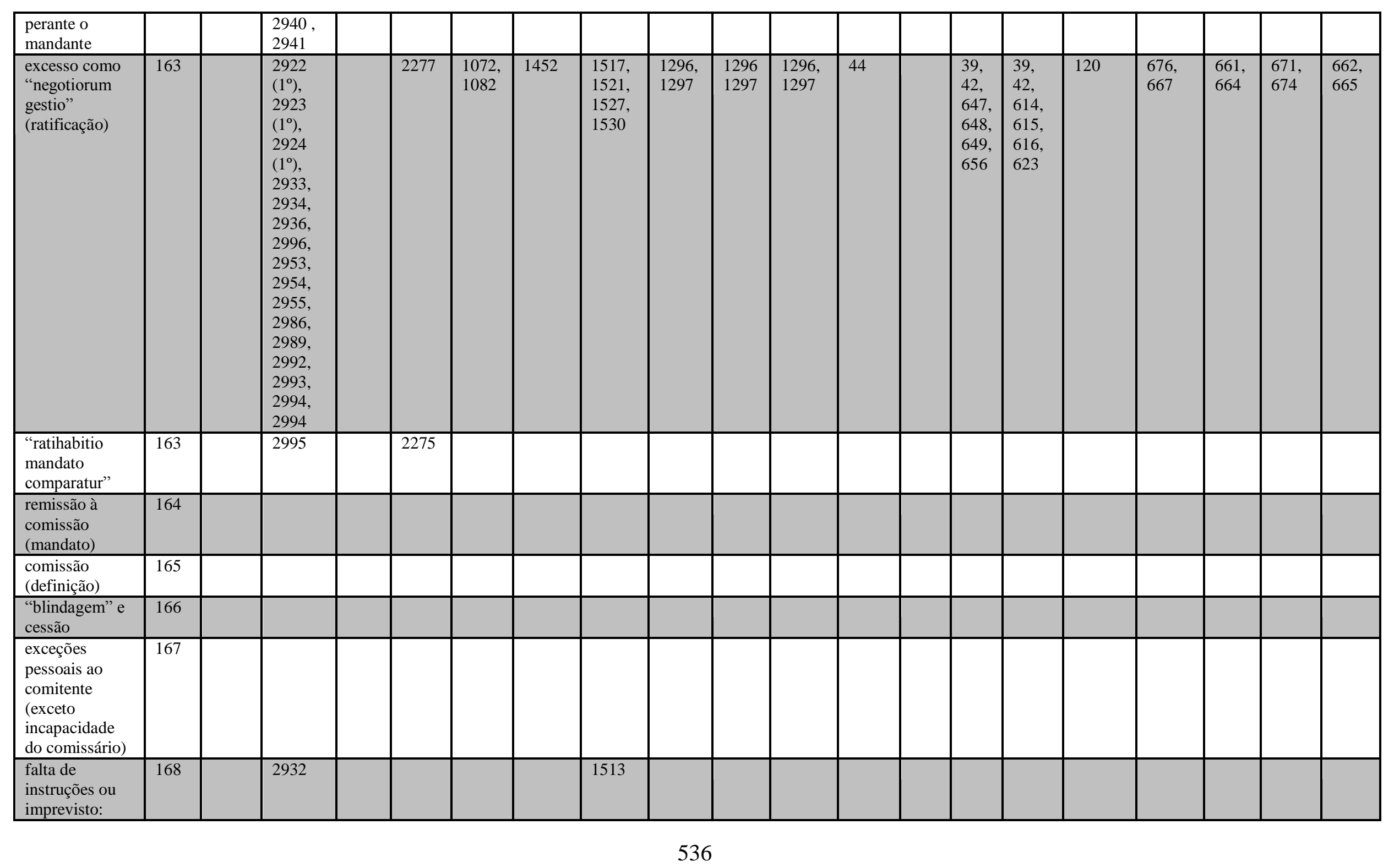




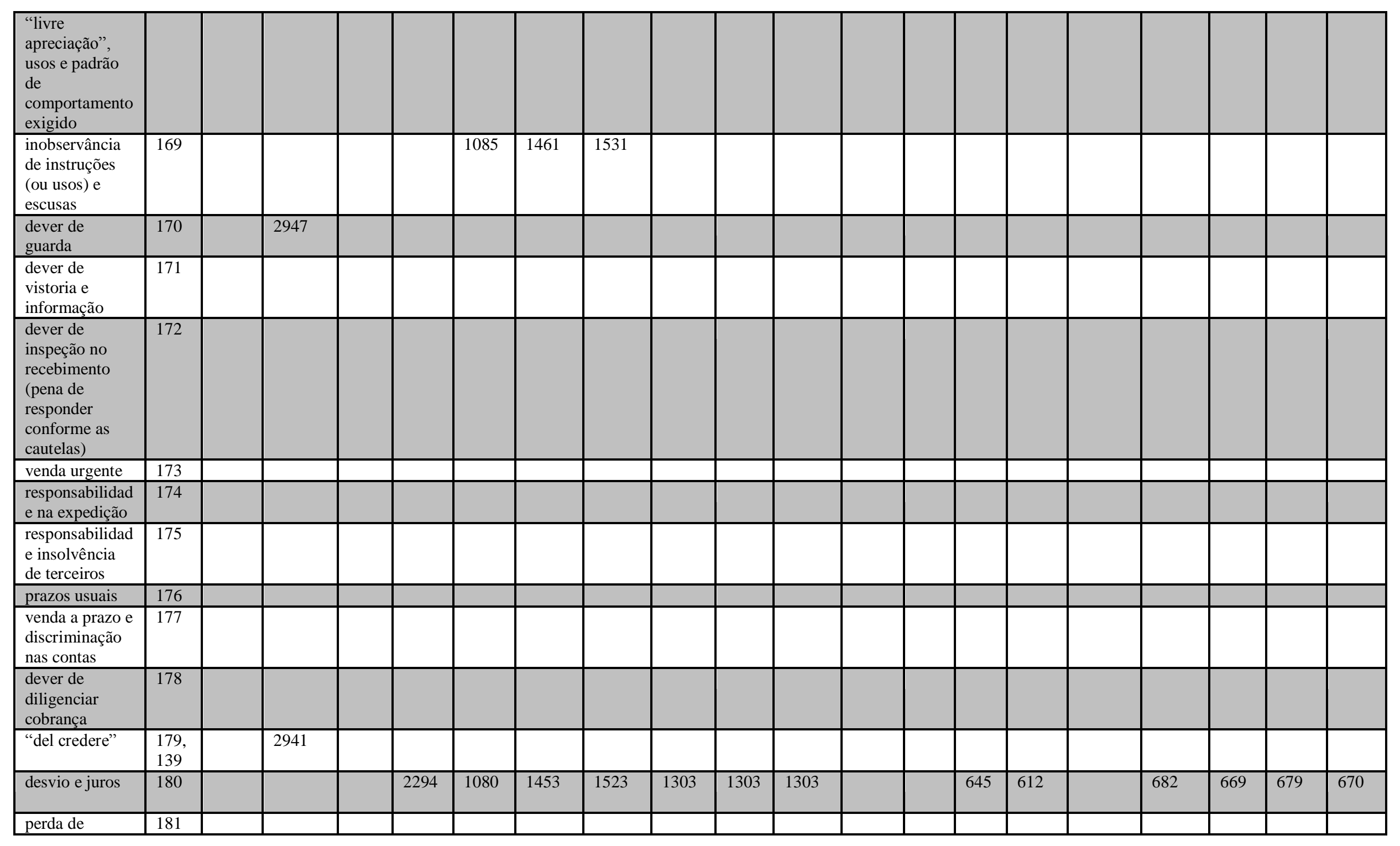




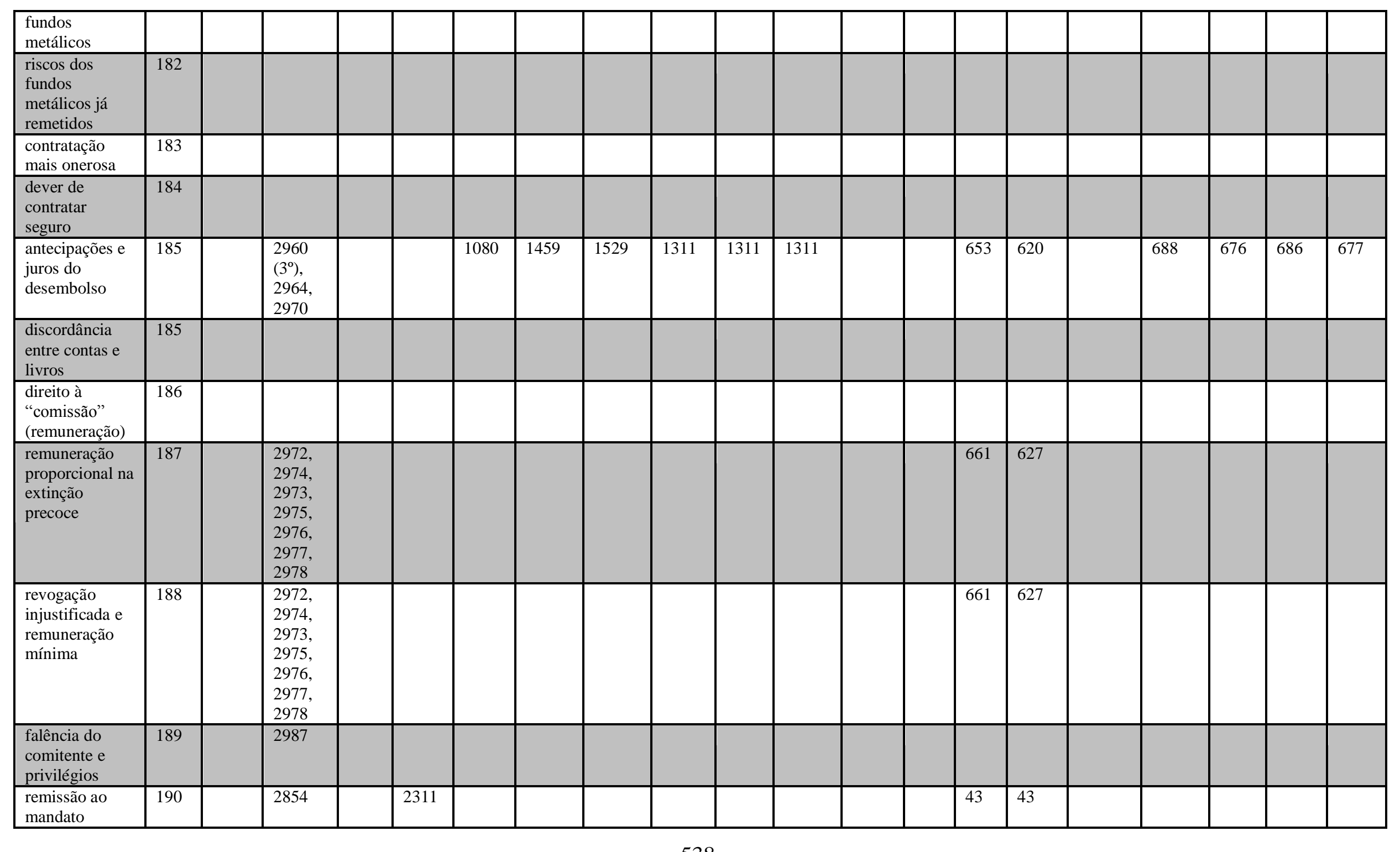




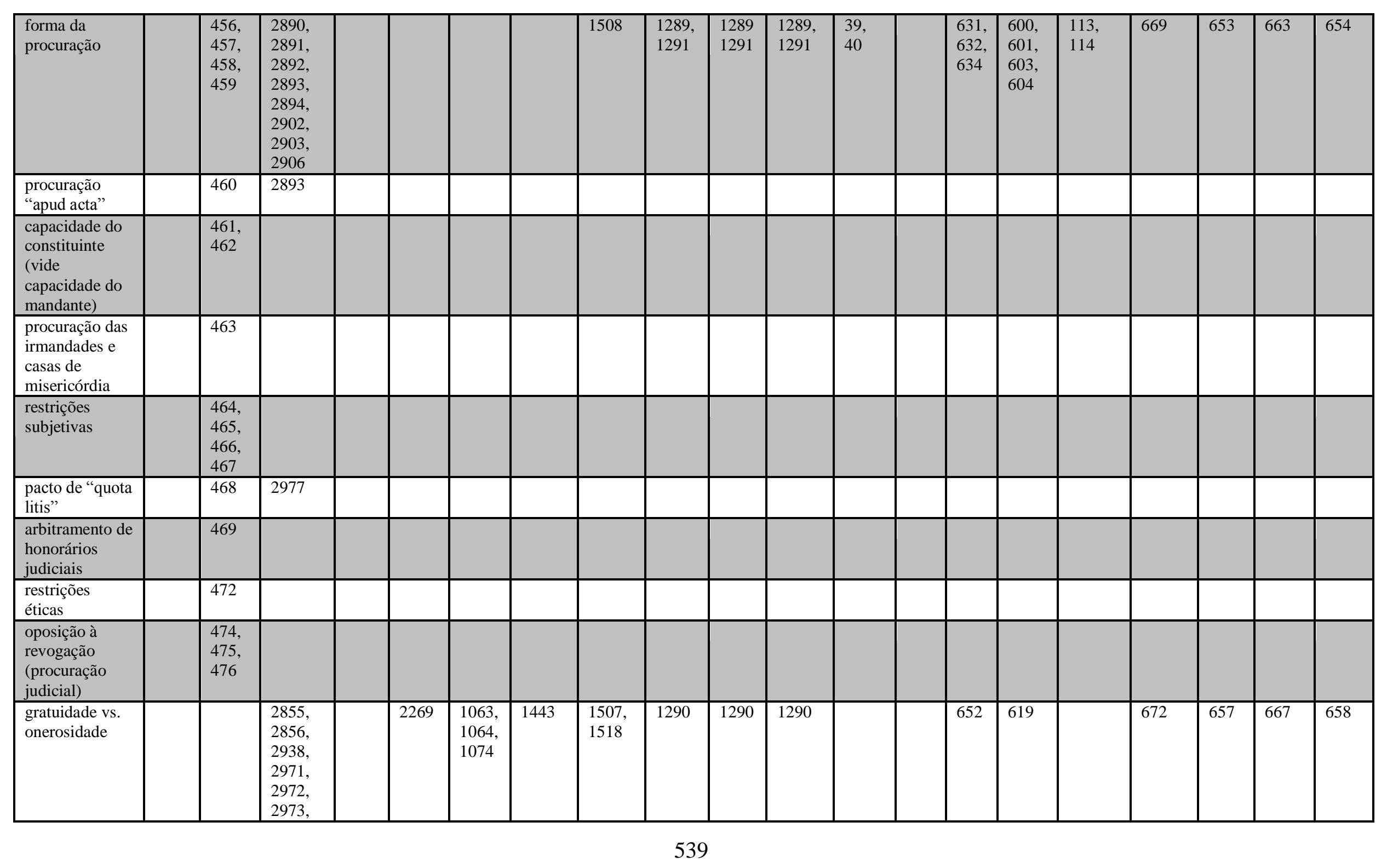




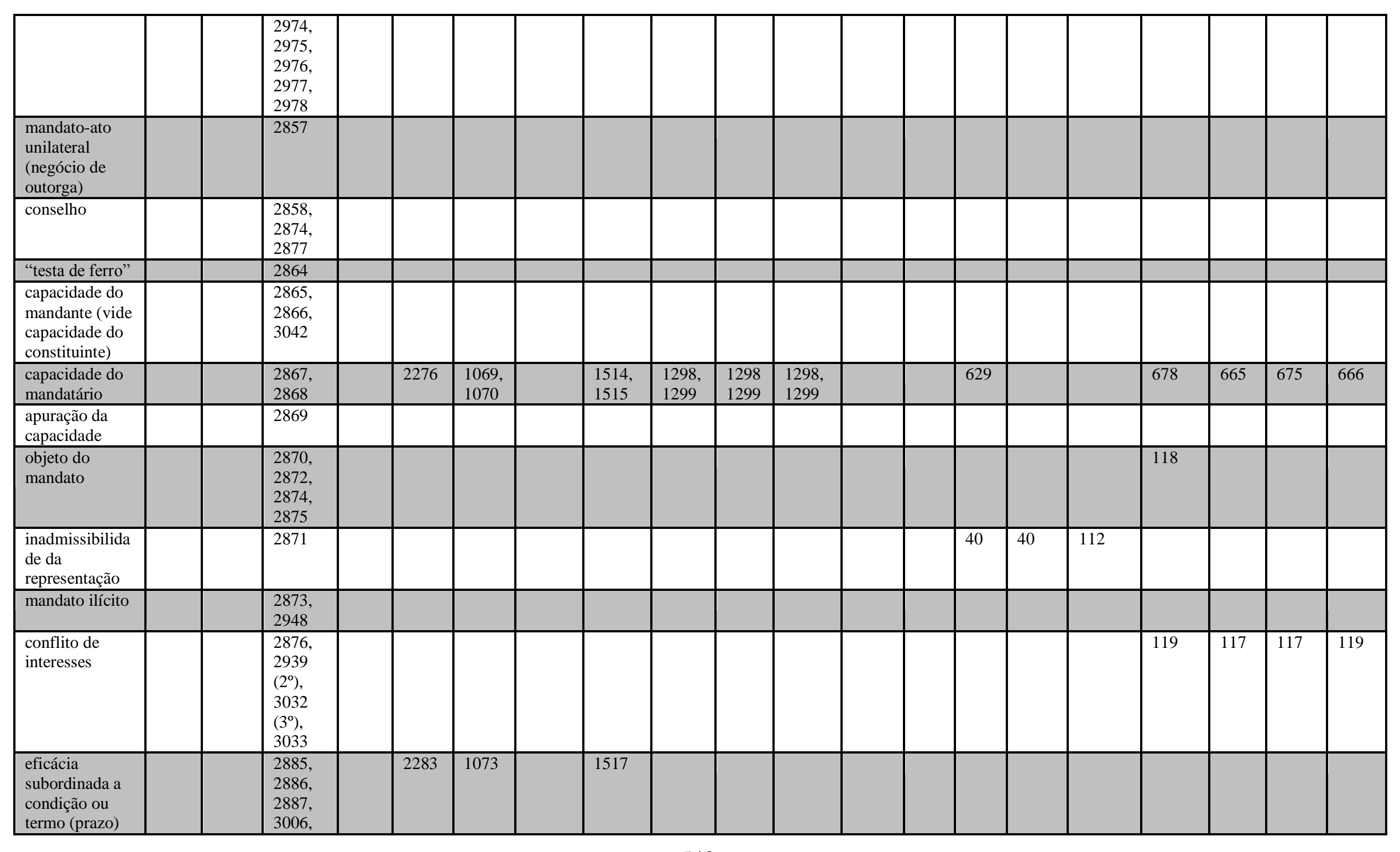




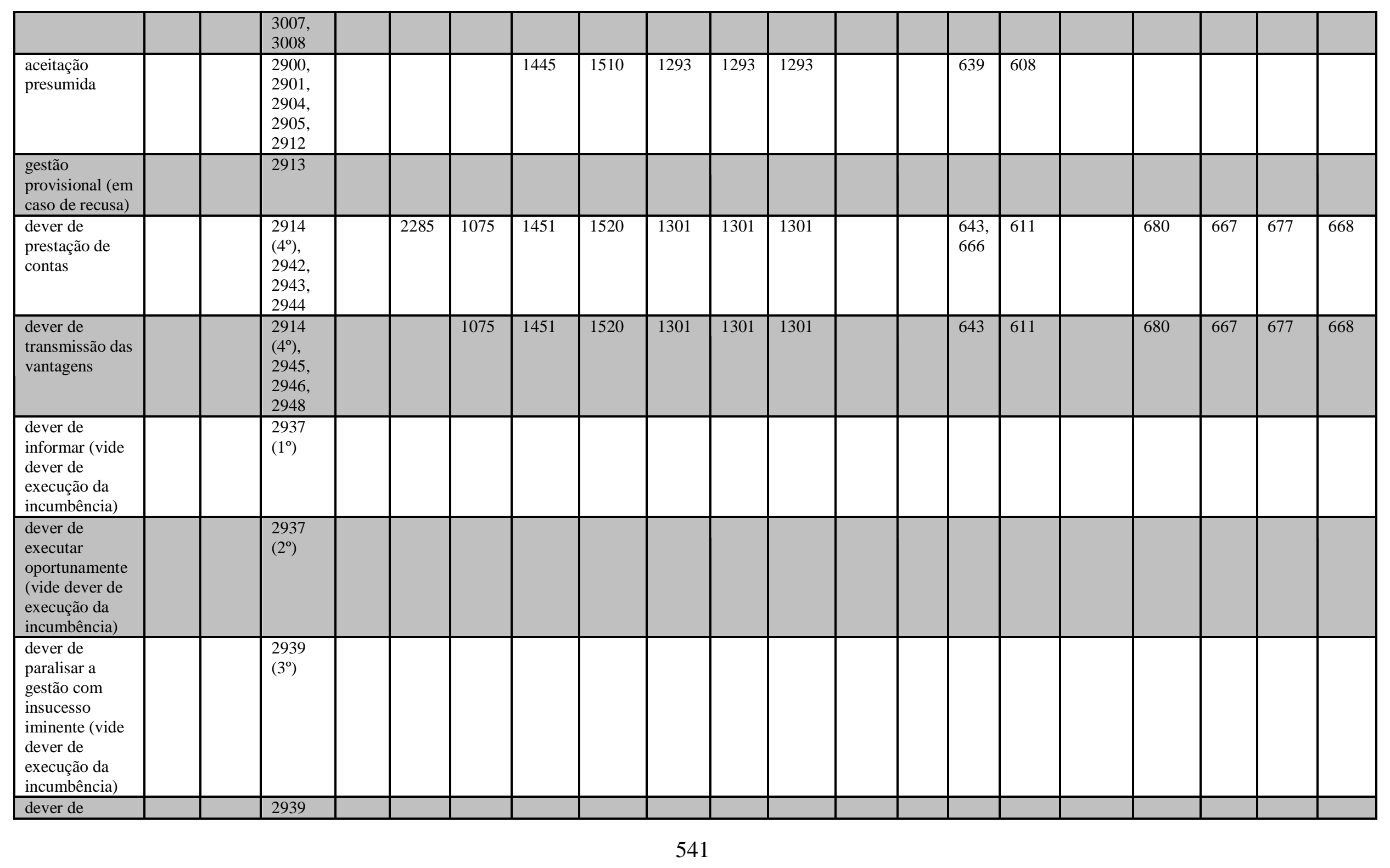




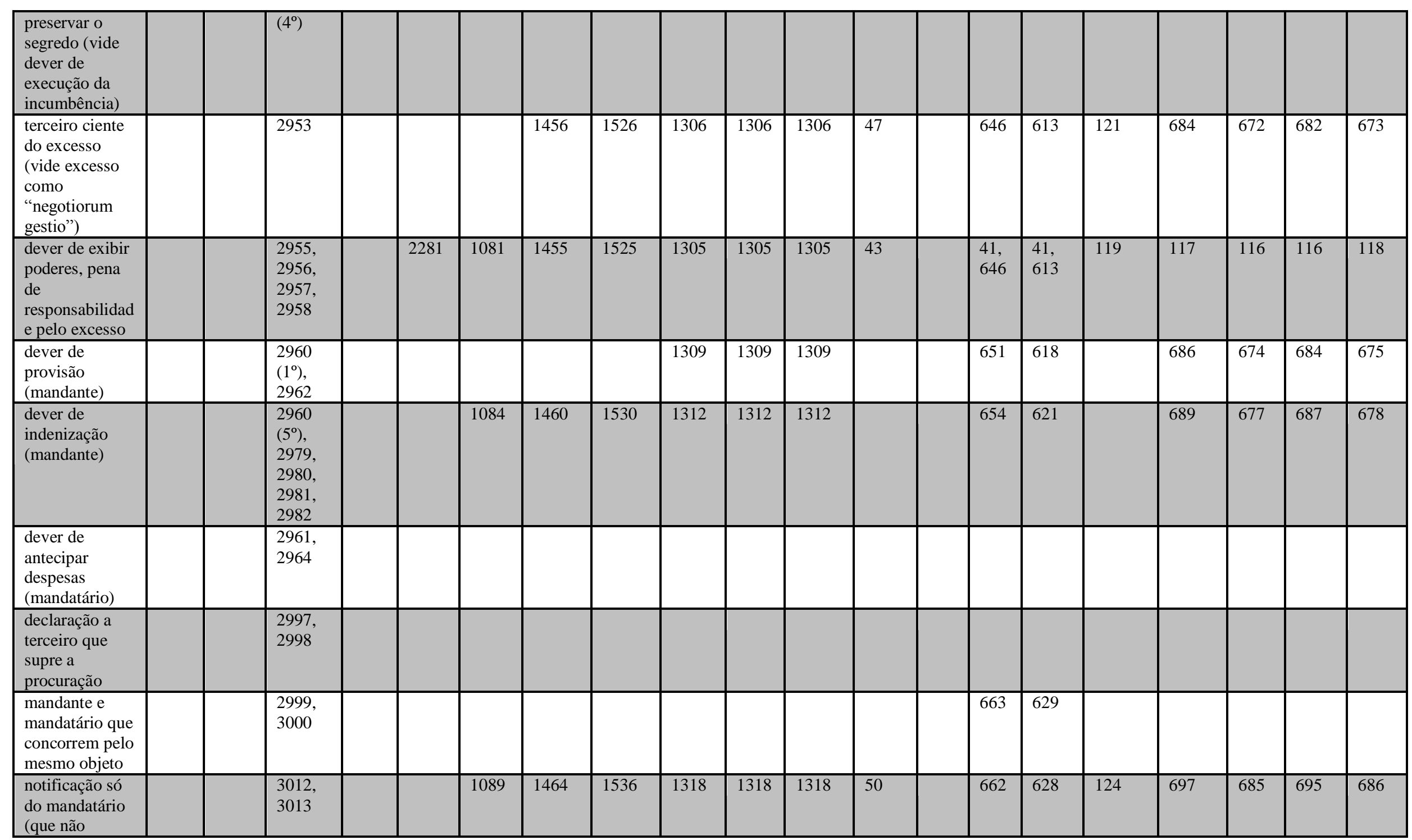




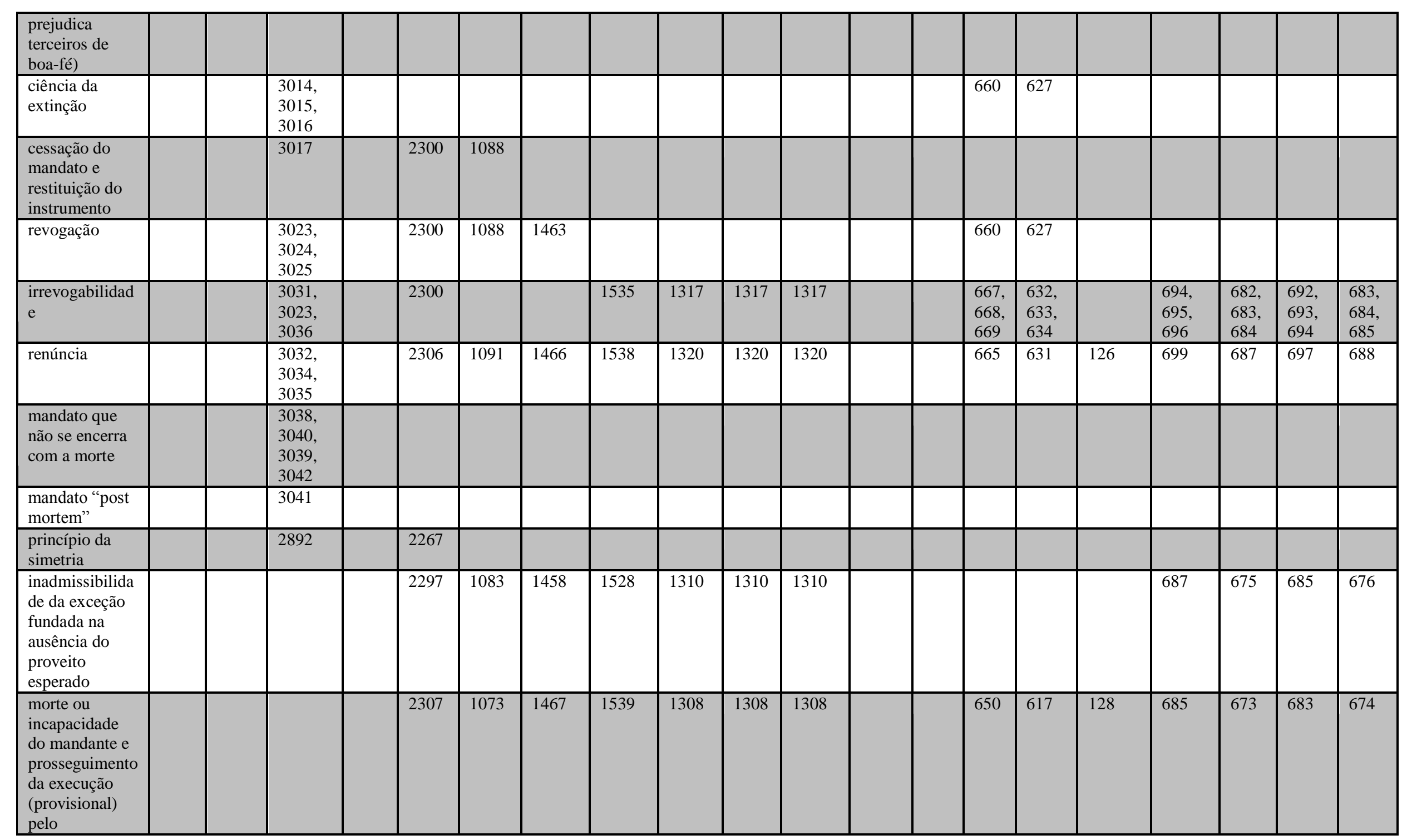




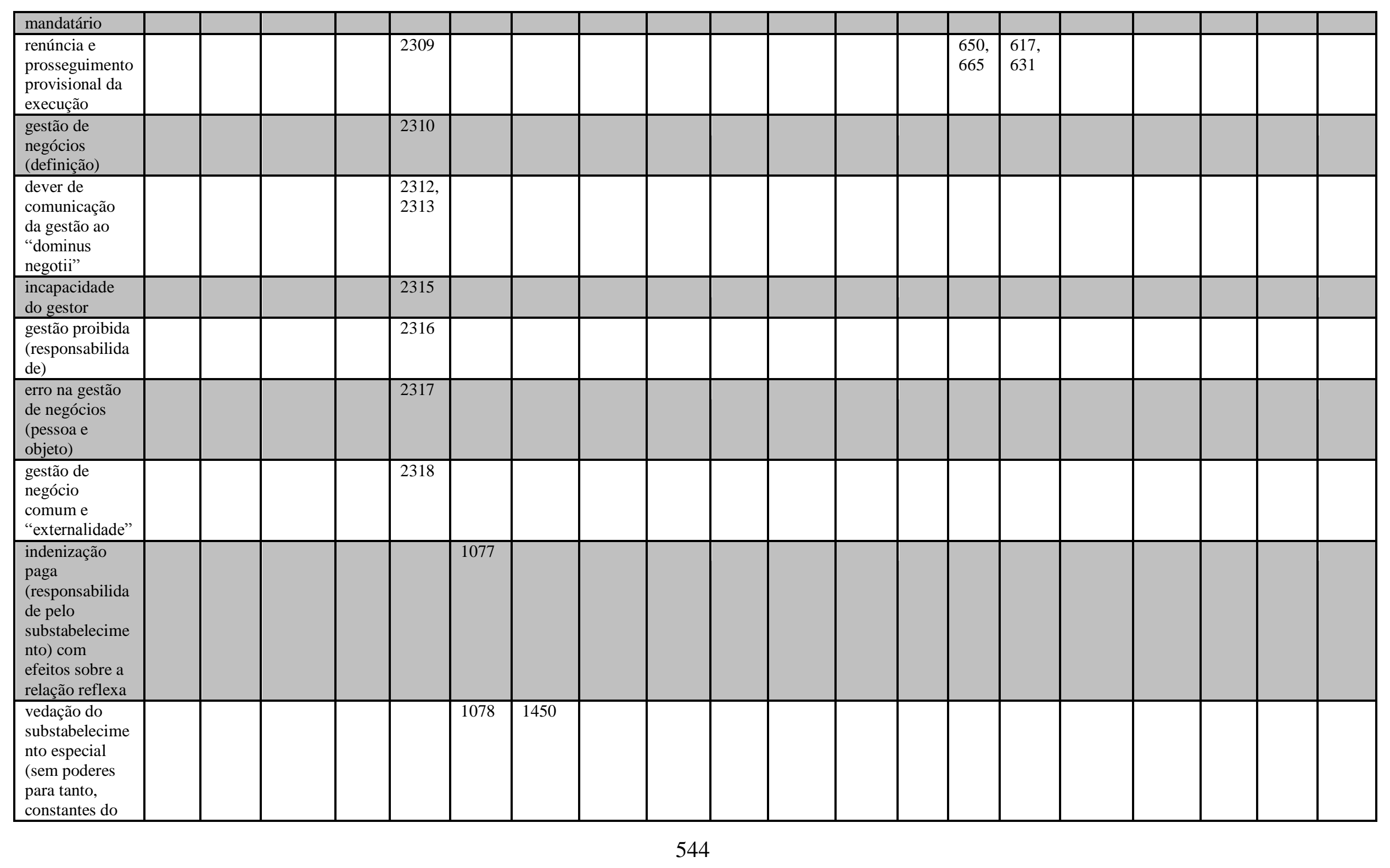




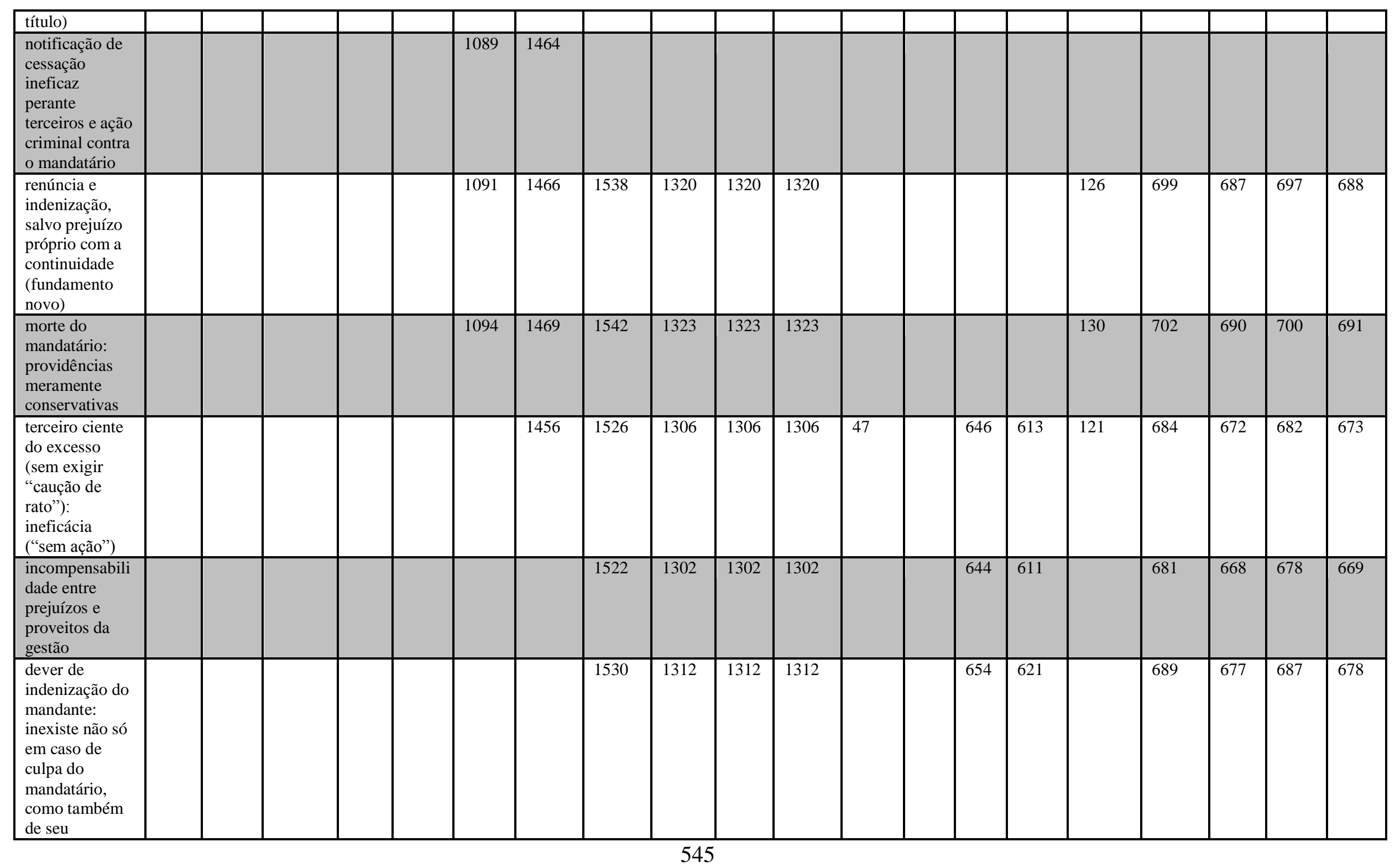




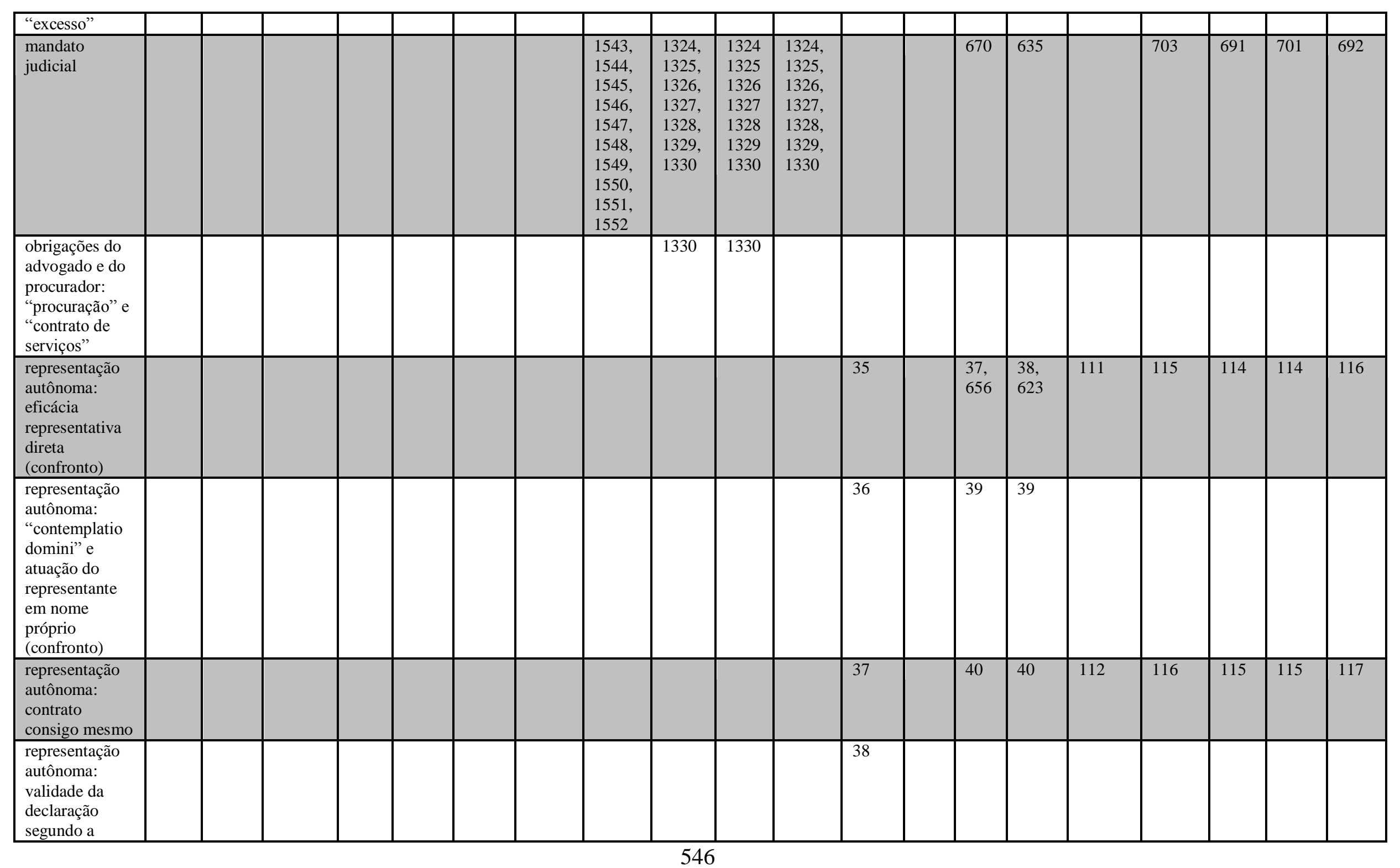




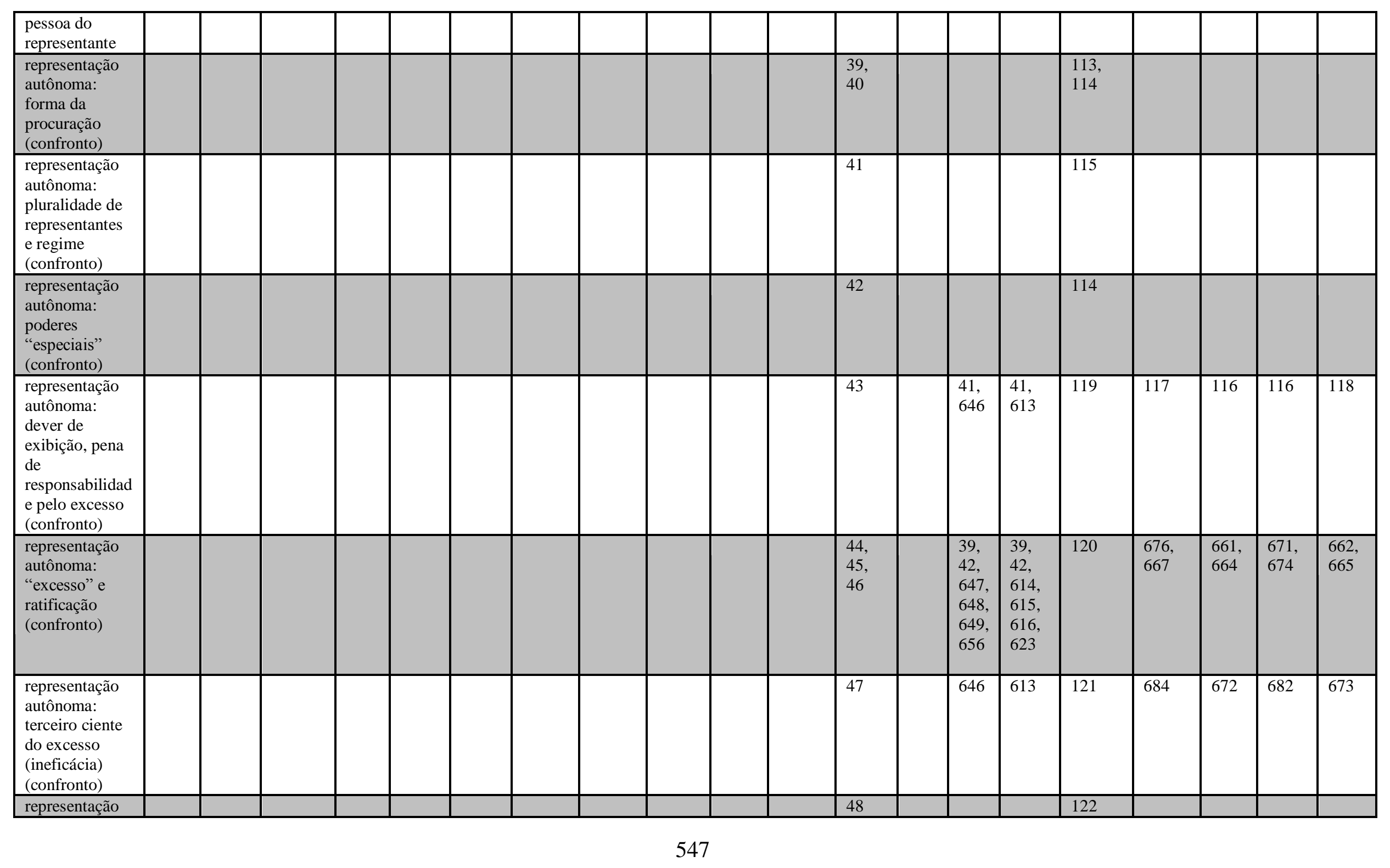




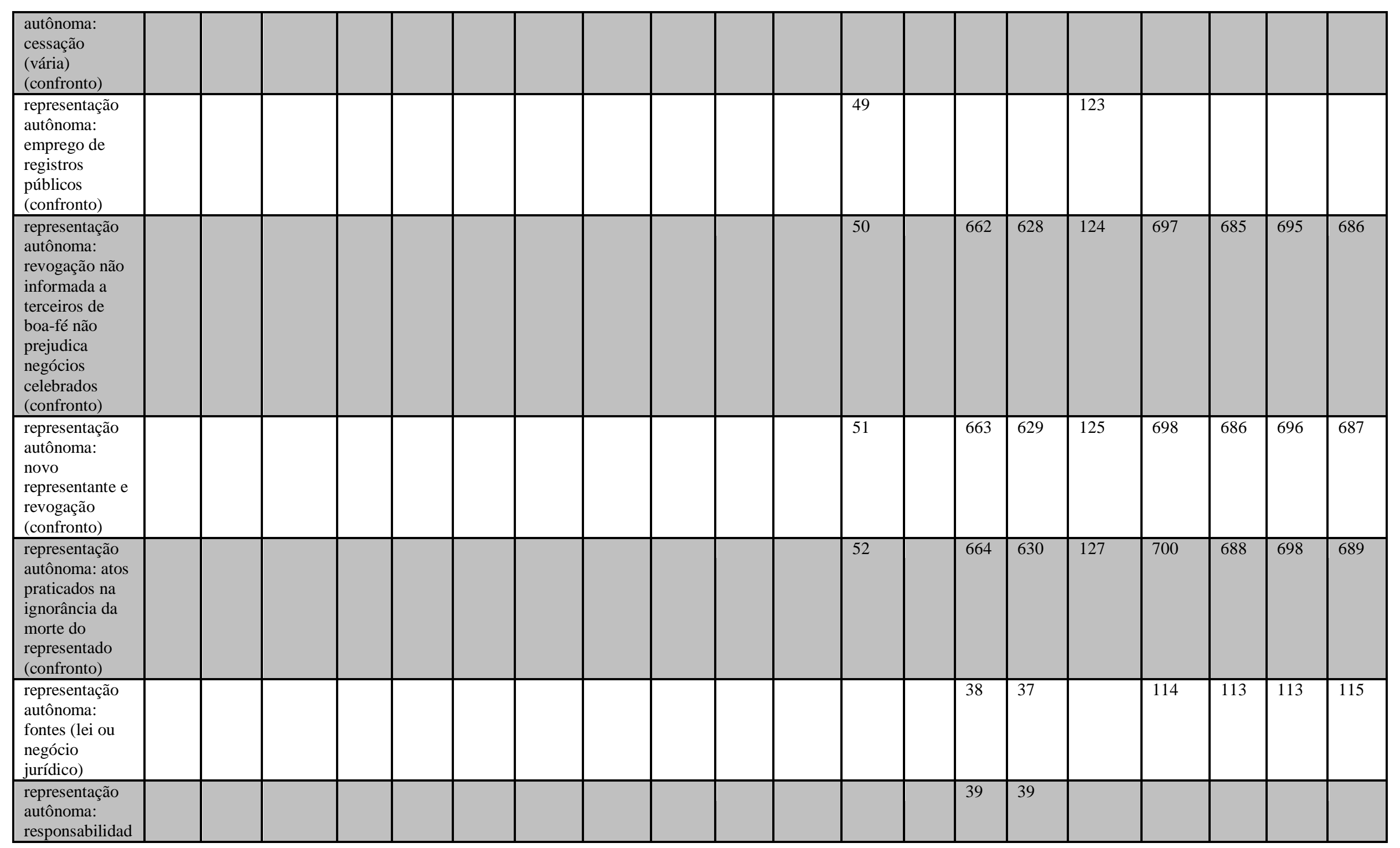

548 


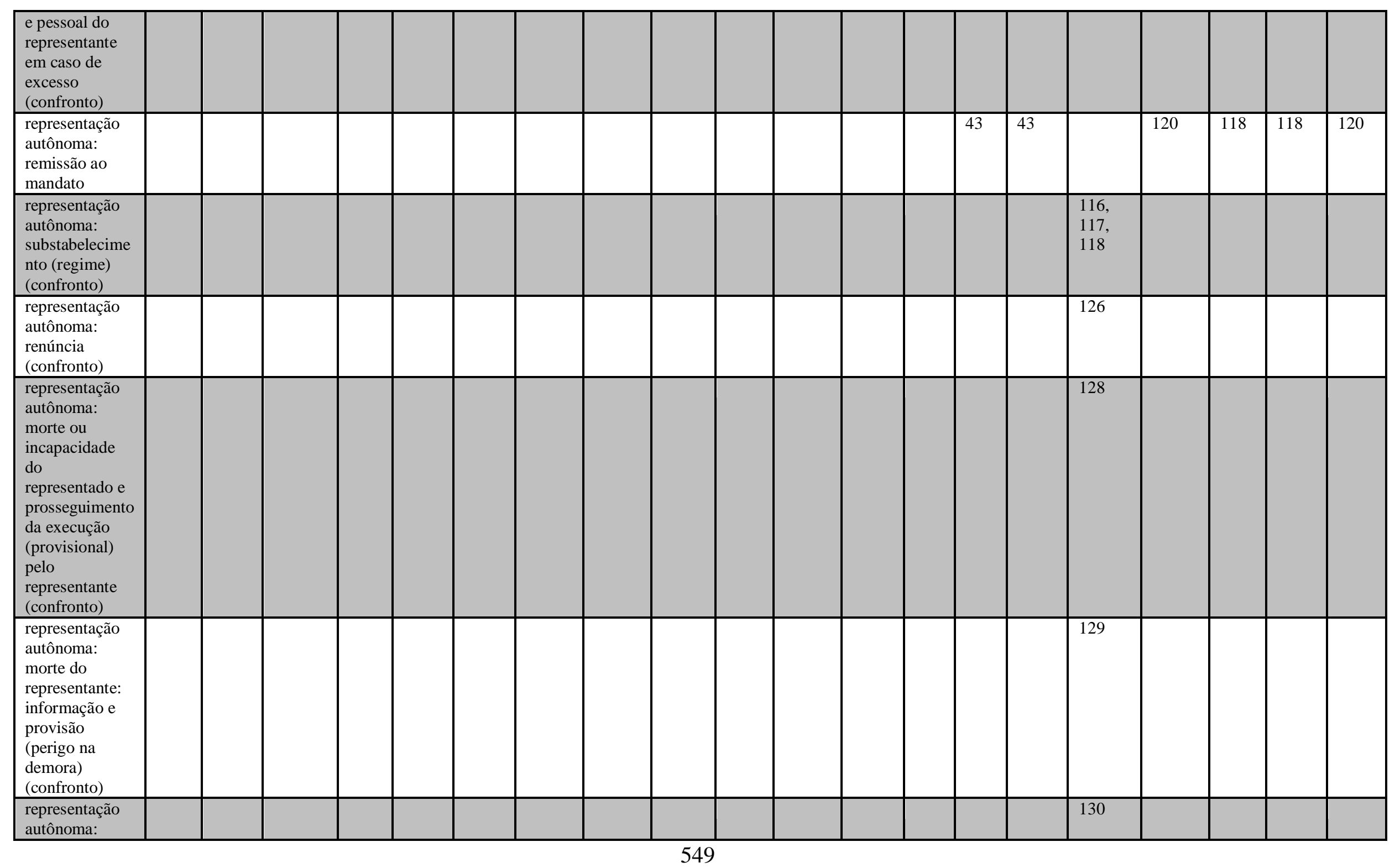




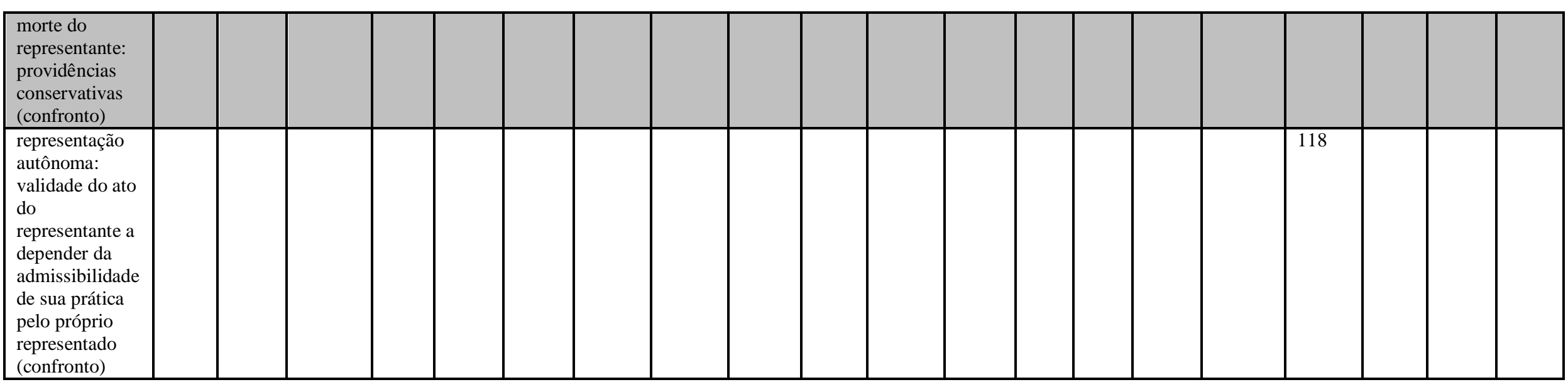




\section{ANEXO VI \\ DOCUMENTO “ANTEPROJETO DE PARTE GERAL DO CÓDIGO CIVIL" (1970) - DE JOSÉ CARLOS MOREIRA ALVES (EXTRATO)}

\section{“Capítulo II}

\section{$\underline{\text { Da representação }}$}

Artigo 111 - A declaração de vontade pelo representante, nos limites de seus poderes, produz efeitos em relação ao representado.

Artigo 112 - Salvo se o permitir a lei ou o representado, é anulável o negócio jurídico que o representante, no seu interesse ou por conta de outrem, celebrar consigo mesmo.

Parágrafo único. Para êsse efeito, considera-se celebrado pelo representante o negócio realizado por aquêle em quem tiverem sido substabelecidos os poderes de representação.

Artigo $113\left(1289, \S 3^{\circ}\right)$ - A outorga da representação não está sujeita à forma exigida para $\mathrm{o}$ ato que o representante deva realizar, mas tem que ser feita por escrito se aquêle exigir instrumento público ou particular.

Parágrafo único. O reconhecimento de firma no instrumento particular é condição essencial à sua validade em relação a terceiros.

Artigo $114\left(1295, \S \S 1^{\circ}\right.$ e $\left.2^{\circ}\right)-A$ procuração, que é o instrumento pelo qual a representação é outorgada, deve conter a data e o lugar em que fôr passada, a designação do outorgado e bem assim o objeto da outorga, a natureza e a extensão dos poderes conferidos.

Parágrafo primeiro. Para alienar, hipotecar, transigir, ou praticar quaisquer atos, que exorbitem da administração ordinária, precisa o representante de poderes especiais e expressos.

Parágrafo segundo. O poder de transigir não importa o de firmar compromisso.

Artigo 115 (1304) - Sendo dois ou mais os representantes nomeados no mesmo instrumento, todos podem exercer os poderes outorgados, se não forem expressamente declarados conjuntos, ou especìficamente designados para atos diferentes, ou subordinados a ordem sucessiva

Artigo $116\left(1289, \S 2^{\circ}\right)$ - Ainda quando se outorgue representação por instrumento público, pode substabelecer-se mediante instrumento particular. 
Artigo 117 - Quem, autorizado a fazê-lo, substabelecer, sòmente responde pelos atos do substabelecido se tiver agido com culpa na escolha, ou nas instruções que lhe deu.

Parágrafo único. Se a procuração fôr omissa sôbre o substabelecimento, o procurador será responsável, também, se o substabelecido proceder culposamente.

Artigo 118 - Se, apesar de proibição expressa, o procurador substabelecer, responde êle até pelo dano resultante da fôrça maior, salvo se provar que o prejuío ocorreria ainda quando não tivesse havido substabelecimento.

Artigo 119 (1305) - O representante é obrigado a provar às pessoas, com quem tratar em nome do representado, sua qualidade e a extensão de seus poderes, sob pena de, não o fazendo, responder pelo atos que a êstes excederem.

Artigo 120 (1296) - Pode o representado ratificar ou impugnar os atos praticados em seu nome sem poderes suficientes.

Parágrafo único. A ratificação há de ser expressa, ou resultar de ato inequívoco, e retroagirá à data do ato.

Artigo 121 (1306) - O terceiro que, depois de conhecer os poderes do representante, com êle celebrar negócio jurídico para o qual eram insuficientes aquêles poderes, não tem ação contra o representado, salvo se êste lhe prometeu a ratificação, ou se responsabilizou pessoalmente.

Artigo 122 (1316) - Cessa a representação:

I. Pela revogação ou renúncia.

II. Pela morte ou interdição de uma das partes.

III. Pelo implemento de condição resolutiva ou de têrmo final.

IV.Pela conclusão do negócio jurídico.

V. Pela extinção do ato em que ela se funda, ou pelo término da situação que a determinou.

Artigo 123 - Ressalvada a boa fé de terceiros, a revogação pode fazer-se por aviso na imprensa, sendo averbada à margem das notas públicas, quando delas constar a outorga. 
Artigo 124 (1318) - Se notificada sòmente ao representante, não se pode opor a revogação aos terceiros que, ignorando-a, com êle trataram; mas ficam asseguradas ao constituinte as ações que, no caso, lhe possam caber contra o procurador.

Artigo 125 (1319) - Tanto que fôr comunicada ao representante a nomeação de outro, para o mesmo negócio, considerar-se-á revogada a representação anterior.

Artigo 126 (1320) - A renúncia da representação será comunicada ao representado, que, se fôr prejudicado pela sua inoportunidade, ou pela falta de tempo, a fimd e prover à substituição do proucurador, será indenizado pelo representante, salvo se êste provar que não podia continuar a representá-lo sem prejuízo considerável.

Artigo 127 (1321) - São válidos, a respeito dos contraentes de boa fé, os atos com êstes ajustados pelo representante, enquanto êste ignorar a morte do representado, ou a extinção, por qualquer outra causa, da representação.

Artigo 128 (1308) - Embora ciente da morte ou interdição do representado, deve o representante concluir o negócio já começado, se houver perigo na demora.

Artigo 129 (1322) - Se falecer o representante, pendente o negócio a êle cometido, os herdeiros, tendo ciência da representação, avisarão o representado, e providenciarão a bem dêle, como as circunstâncias exigirem.

Artigo 130 (1323) - Os herdeiros, no caso do artigo antecedente, devem limitar-se às medidas conservatórias, ou continuar os negócios pendentes, que se não possam demorar sem perigo, regulando-se os seus serviços, dentro nesse limite pelas mesmas normas, a que os do representante estão sujeitos." 


\section{RESUMO.}

Este estudo se volta às fontes primárias do "mandato luso-brasileiro". Para que a tarefa se mostrasse bem-sucedida, pareceu indispensável ao pesquisador a realização de um esforço investigativo preparatório, comprometido com uma abordagem panorâmica da relação mantida entre os institutos da "procuração", do "mandato" e da "representação" - sob a perspectiva de uma historiografia geral.

Atento a tal objetivo, este esforço assentou em uma abordagem voltada a quatro contextos fundamentais: a) o direito romano (em que se destacam a "procuratio", o "mandatum" e uma eficácia representativa direta excepcional); b) o direito canônico (associado ao desenvolvimento da representação direta); c) a praxe notarial relacionada ao direito comum; e d) o influxo iluminista (considerado vetor indispensável à "essencialização" da representação no contexto do contrato de mandato).

Em seguida, passa-se ao confronto direto das fontes primárias do direito luso-brasileiro. Neste ponto, inicia-se o estudo pela investigação em meio às fontes do direito visigótico (Código de Eurico, "Lex Romana Visigothorum", Código Revisto de Leovigildo e "Liber Iudiciorum"). Em seguida, passa-se às fontes castelhanas do direito justinianeu: sejam de viés doutrinário ("Flores de Derecho", "Dotrinal" e "Los Noue Tienpos Delos Pleytos"); sejam de origem legislativa ("Fuero Real", "Espéculo" e "Siete Partidas"). Após, aborda-se o tema junto às fontes medievais ("Livro das Leis e Posturas" e “Ordenações de D. Duarte”) e modernas do direito lusitano - estas representadas pelas sucessivas "Ordenações do Reino de Portugal”. Ainda durante o período luso-brasileiro, é investigada a ascensão e o declínio do direito justinianeu em Portugal - e neste particular o impacto das Reformas Pombalinas da aplicação e do ensino do direito.

Já sob a perspectiva exclusivamente portuguesa, o mandato é estudado cronologicamente - em meio às codificações do século XIX: o "Código Civil" de 1867 e as codificações comerciais de 1833 e 1888. Em seguida, é abordada a "viragem" sistemática empreendida pelo "Código Civil" de 1966.

O trabalho se encerra com um estudo sobre o tema à luz das fontes genuinamente nacionais: o "Código Comercial” (1850); a "Consolidação das Leis Civis"; e os "Códigos Civis" de 1916 e 2002. Entremeada, exsurge ainda uma abordagem dos principais Anteprojetos que redundaram nestes dois últimos diplomas. O estudo é encerrado por uma conclusão - e pela divulgação a público de excerto do "Anteprojeto de Parte Geral do Código Civil” (1970), da autoria de José Carlos Moreira Alves. 


\section{RIASSUNTO.}

Questo studio si riferisce alle fonti primarie del "mandato luso-brasiliano". Affinché l'operazione avesse successo, sembrava indispensabile al ricercatore svolgere un lavoro preparatorio d'indagine, impegnato in una prospettiva d'approccio panoramico del rapporto mantenuto tra gli istituti della "procurazione", del "mandato" e della "rappresentanza" - sotto la prospettiva di una storiografia generale.

Attento di questo obiettivo, questo sforzo si è basato su un approccio incentrato su quattro contesti fondamentali: a) il diritto romano (che elenca la "procuratio", il "mandatum" e una efficacia rappresentativa diretta eccezionale), b) il diritto canonico (associato con lo sviluppo della rappresentanza diretta), c) pratiche notariali relativi al diritto comune; e d) l'influenza illuminista (vettore considerato indispensábile all' "essenzializzazione" della rappresentanza nel contesto del contratto di mandato).

Poi si passa al confronto diretto delle fonti primarie del diritto lusobrasiliano. A questo punto, iniziasi lo studio con la ricerca tra le fonti dei visigóti ("Código de Eurico", "Lex Romana Visigothorum", "Código Revisto de Leovigildo" e "Liber Iudiciorum"). Si passa quindi alle fonti castigliane del diritto giustinianeo: siano di origine dottrinale ( "Flores de Derecho", "Dotrinal" e "Los Noue Tienpos Delos Pleytos"), siano di origine legislativa ( "Fuero Real", "Espéculo" e "Siete Partidas"). Dopo, sono esaminate le fonti medievali ( "Livro das Leis e Posturas" e "Ordenações de D. Duarte") e moderne del diritto lusitano - rappresentate nelle successive "Ordenações do Reino de Portugal". Anche durante il periodo luso-brasiliano, abbiamo studiato l'ascesa e il declino del diritto di Giustiniano in Portogallo - ed in particolare l'influsso della Riforma Pombalina nell'applicazione e nel'insegnamento del diritto.

Sotto una prospettiva soltanto portoghesa, il mandato è studiato - in ordine cronologico - fra i codici del diciannovésimo secolo: il "Código Civil” del 1867 e le codificazioni commerciali di 1888 e 1833. Poi, discutiamo "la svolta" sistematica intrapresa dal "Código Civil" del 1966.

Il lavoro si chiude con uno studio su questo tema alla luce delle fonti genuinamente nazionali: il "Código Comercial" (1850); a "Consolidação das Leis Civis" e i "Códigos Civis" di 1916 e 2002. Intervallato, surge ancora un approccio dei principali progetti che hanno risultato in questi ultimi due diplome. Lo studio è chiuso con una conclusione - e la divulgazione al pubblico di un estratto del "Anteprojeto de Parte Geral do Código Civil" (1970), di José Carlos Moreira Alves. 


\begin{abstract}
.
This study refers to the primary sources of the "Luso-Brazilian mandate". For the task to prove successful, it seemed essential for the researcher to carry out a preparatory investigative effort, committed to an overview approach of the relationship maintained between the institutes of "power of attorney," "mandate" and "representation" from a standpoint of general historiography.

Mindful of this goal, this effort was based on an approach focused on four key concepts: a) Roman law (which features the "procuratio", the "mandatum" and an exceptional directly representative effectiveness), b) canon law (associated with the development of direct representation), c) notary practice related to common law, and d) the Enlightenment influx (considered as an essential vector for "essentializing" the representation in the context of mandate contract).

Then, we go on to the direct confrontation of the primary sources of LusoBrazilian law. At this point, we begin the study by researching among the sources of the Visigothic Law (“Código de Eurico", "Lex Romana Visigothorum”, “Código Revisto de Leovigildo" and "Liber Iudiciorum"). We then proceed to the Castilian sources of Justinian law: whether of a doctrinal bias ("Flores de Derecho", "Dotrinal" and "Los Noue Tienpos Delos Pleytos"); or of legislative origin ("Fuero Real", "Espéculo" and "Siete Partidas"). Next, we discuss the matter with the medieval sources ("Livro das Leis e Posturas" and "Ordenações de D. Duarte") and modern sources of Lusitanian law - the latter represented by the successive "Ordenações do Reino de Portugal". Still during the Luso-Brazilian period, we investigate the rise and decline of the Justinian law in Portugal and the impact of the Pombal Reform in the implementation and teaching of law.

From a solely Portuguese standpoint, the mandate is studied chronologically - in the midst of encodings of the nineteenth century: the "Código Civil" of 1867 and the commercial codifications of 1833 and 1888. Next, we discuss the systematic "turning point" undertaken by the "Código Civil" of 1966.

The work ends with a study on the subject in light of the genuine Brazilian sources: the "Código Comercial" (1850), the "Consolidação das Leis Civis" and the "Códigos Civis" of 1916 and 2002. Interspersed, there is also a discussion of the principal Drafts that resulted in these two pieces of legislation. The study is closed with a conclusion - and by the public disclosure of the excerpt from "Anteprojeto de Parte Geral do Código Civil " (1970), by José Carlos Moreira Alves.
\end{abstract}

